-tis Room

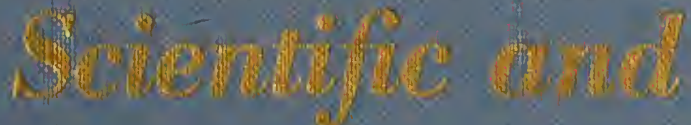

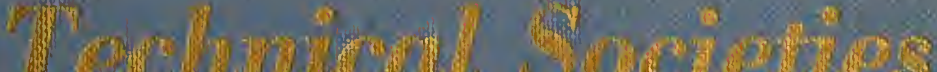
a)

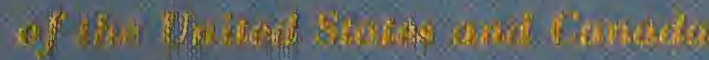





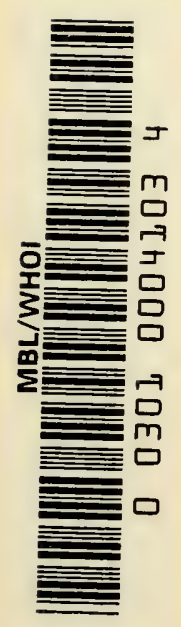



SCIENTIFIC AND TECHNICAL SOCIETIES OF THE UNITED STATES AND CANADA

Seventh Edition

1960-1961 



\title{
SCIENTIFIC AND TECHNICAL SOCIETIES OF THE
}

\author{
UNITED STATES AND CANADA
}

SEVENTH EDITION

Part I

Scientific and Technical Societies of the United States

Compiled in the Library

NATIONAL ACADEMY OF SCIENCES-

IATIONAL RESEARCH COUNCIL

Part II

Scientific and Technical Societies of Canada

Compiled in the Public Relations Office

NATIONAL RESEARCH COLNCIL, CANADA

\section{Publication 900}

National Academy of Sciences-National Research Council

$$
\text { WASHington, D. C. }
$$

1961 
Library of Congress Catalog Card Number:27-21004

Copyright (C) 1961 by the National Academy of Sciences 
This edition of Scientific and Technical Societies of the United States and Canada presents information collected during the summer and fall months of 1960 . As in earlier editions, the preparation of the United States section took place in the Library of the National Academy of Sciences-National Research Council in Washington, while the Canadian section was compiled at the National Research Council in Ottawa.

Entries are limited to professional and selected amateur societies in scientific and technical fields. Both national and local membership societies are included, but the following are excluded : trade associations; institutions composed principally of paid staffs; most county and smallcity medical and engineering societies; most local clapters of national societies; strictly undergraduate groups; voluntary health agencies whose sole membership activity is the raising of money for research or therapy; and societies whose primary interest in a subject is not scientific or technical. The last named category causes to be excluded from the directory those flower-growing societies which have no real involvement in scientific horticulture, and also "nature study" groups whose members are principally interested in the recreational or entertainment values of the subject. In general, the attempt was made to exclude those societies whose members are not personally involved in the scientific and technical aspects of a subject field.

Approximately 2500 questionnaires were mailed to societies in the United States and Canada, and 2037 were returned. From these returns, a total of 1836 were accepted for listing in the seventh edition. Although this represents a slight increase over the sixth edition, the figures for the two editions are not strictly comparable, since the inclusion-exclusion criteria described above are partially new. Although the attempt was made to identify and list as many scientific and technical societies as possible, the present compilation should not be considered a population subject to statistical analyses. The questionnaire method may, in itself, introduce unknown biases. The National Academy of Sciences-National Research Council and the National Research Council of Canada can accept no responsibility for the accuracy of the information contained herein. Furthermore, the listing of a society does not imply that it is approved by the National Academy of Sciences-Nationa! Research Council or by the National Research Council of Canada, nor does omission of a society imply disapproval.

This work could not have been compiled without the support of many persons. Thanks must be given, first of all, to Mr. Robert A. Lay of the National Research Council of Canada for assuming complete editorial responsibility for the Canadian section, and for his cooperation in solving joint editorial problems. With respect to the United States section, the skillful assistance of Mrs. Mary G. Flannery is gratefully acknowledged. Other persons who contributed to the compilation of the United States section included: Mrs. Luisa F. Marshall, Mrs. Harriet J. Myers, Mr. Page Kilgore, Mr. John Meid, and Mr. Frank M. Holz. Finally, appreciation is expressed to the hundreds of society officers who supplied the information which made this compilation possible.

\author{
John H. Gribis \\ Librarian \\ National Academy of Sciences- \\ National Research Council
}





\title{
CONTENTS
}

\author{
PART I
}

Scientific and Technical Societies of the United States

PART II

Scientific and Technical Societies of Canada

\section{INDEXES}





\section{PART I \\ UNITED STATES \\ SCIENTIFIC AND TECHNICAL SOCIETIES}

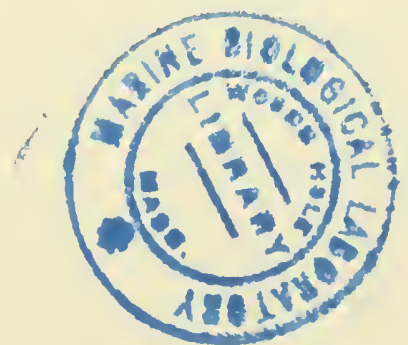





\title{
SCIENTIFIC AND TECHNICAL SOCIETIES
}

\author{
OF THE
}

\section{UNITED STATES}

\author{
Seventil Edition
}

1. Abilene Geological Society. P. O. Box 974,

Abilene, Tex. President: Louis A. Williams, Sun Oil Company, P.O. Box 240, Abilene Tex. Term expires January 1, 1961. Secretary: Frank L. Schatz. Term expires January 1. 1961.

\section{History: Organized 1946.}

Purpose: To promote sciences of petroleum geology and technology in West Central Texas; to foster scientific spirit in these fields; to encourage professional cooperation among geologists and associated scientists.

Membership: Persons engaged or interested in geological or allied problems, and who are members of or qualified for membership in the American Association of Petroleum Geologists, or who, in the opinion of the Executive Committee, would be desirable members. Total membership 292.

Meetings: Biweekly.

Professional activities: Scholarship Award of $\$ 100$ to outstanding science student for the year at Abilene High School; Monroe G. Cheney Memorial Award of $\$ 100$ savings bond to outstanding science student at Coleman High School; cash award of $\$ 50$ to outstanding geology student at Hardin-Simmons University; cash award of $\$ 50$ to outstanding science student at McMurray College; cash award of $\$ 50$ to outstanding science student at Abilene Christian College; Honorary Life Membership award.

Publications: Newsletter, monthly, free to members. Editor: Elton E. Rodgers.

2. Aboriginal Research Club. President: Darrel J. Richards, 6584 Balfour Street, Allen Park, Mich. Term expires December 31, 1960. Executive Secretary: Edward J. Wahla, 17846 Peters Avenue, Roseville, Mich. Term expires December 31, 1960.

History: Organized November 23, 1935. While not affiliated with any other organization, keeps close contact with the University of Michigan, Cranbook lnstitute of Science, and the Detroit Historical Museum.

Purpose: To promote the study of American archaeology and to encourage the collecting and preserving of prehistoric artifacts.
Membership: Active, 90, actively interested in any phase of archaeology, anthropology, ethnology, or history; Institutional, 20.

Mectings: Monthly, October through June.

Publications: The Totem Pole, monthly, nine times per year to coincide with meetings, current volume: $43, \$ 1.50$. Editor: D. J. Richards.

3. Academy of Applied Osteopathy. President: S. M. Pugh, 3010 Hoyt Avenue, Everett, Wash. Term expires January 1962. Secretary: Margaret W. Barnes, P. O. Bin 1050, Carmel, Calif. Term expires January 1962.

History: Founded 1937 as the Osteopathic Manipulative Therapeutic and Clinical Research Association; incorporated 1944 under present title. Fourteen component societies representing state or regional distribution. Committees: Graduate Instruction; Structural Consultation; College Assistance; Fellowship Program; Clinical Observation.

Purpose: To develop the science and art of osteopathic manipulative therapy; to encourage physicians toward greater proficiency in the distinctive skills of osteopathic, diagnostic, and therapeutic procedures.

Membership: Regular, 900 ; based on membership in the American Osteopathic Association and legal requirements as demanded at the site of practice; Honorary Life, 20, awarded; Life, 21 , conferred upon all past presidents as well as qualifying candidates; Associate, 7. Total membership 948.

Meetings: Annual.

Professional activities: Sponsorship of graduate instruction seminars and courses; sponsorship of undergraduate courses at osteopathic colleges; Andrew Taylor Still Medallion of Honor; Academy Lecturer Award; Yearbook Dedication Award.

Publications: Yearbook, current volumes are unnumbered, $\$ 5$ to nonmembers. Directory, annual, current volumes are unnumbered, free. Newsletter, bimonthly, current volume: 15, free. Editor: M. W. Barnes.

4. Academy of Denture Prosthetics. 807 Medical Arts Building, Salt Lake City 11, Utah. President: A. IV. Sears, 2705 Atlantic Boule- 
vard, Jacksonville 7, Fla. Term expires May 12, 1961. Secretary-Treasurer: IV. Les Warburton. Term indefinite.

History: Organized 1918 as National Society of Denture Prosthetists; name changed to present title 1940; incorporated 1951.

Purpose: To promote the science and art of denture prosthetics as a specialty of dentistry; to provide for the dissemination of knowledge of this specialty throughout the dental profession; to encourage study and investigation of its various phases and related subjects.

Membership: By invitation only, after having made a presentation before the Academy. Active Fellows, 49; Associate Fellows, 10; Life Fellows, S. Total membership 67.

Mectings: Annual.

Professional activities: Educational and Research Fund, initiated February 1960.

Publications: Journal of Prosthetic Dentistry (cosponsored with two other denture societies), bimonthly, current volume: $10, \$ 12$. Editor: Carl O. Boucher, Ohio State University, Columbus, Ohio. Newsletter, irregular, free, for Fellows only. Editor: W. Les Warburton.

5. Academy of Medicine of Cincinnati. 320 Broadway, Cincinnati 2, Ohio. President: Robert E. Howard, 2600 Union Central Building, Cincinnati 2, Ohio. Term expires September 19, 1961. Executive Secretary: Edward F. Willenborg. Term indefinite.

History: Organized March 5, 1857; incorporated March 6, 1869; Cincinnati Medical Society, organized 1851, merged with Academy February 13, 1893.

Purpose: The interchange of ideas in medicine and surgery and the maintenance of a central information bureau for the public on medical questions.

Membership: Senior Active in practice more than 3 years, 901 ; Senior Active not in private practice, 104; Junior Active in practice less than 3 years, 75; Junior Active not in private practice, 13; Associates, 13; Nonresident, 191 ; Intern-Resident, 178; Retired, 75. Total membership 1,550 .

Meetings: Annual, third Tuesday in September; monthly, third Tuesday, October through May.

Professional activities: Health campaigns, scientific programs, awards to past presidents upon retirement from Presidency, awards to members in medical practice for fifty years.

Publications: Cincinnati Journal of Medicine, monthly, current volume: 41 , domestic $\$ 4.00$, foreign $\$ 5.00$. Editor-in-Chief: George $X$. Schwemlein.
6. Academy of Medicine of Cleveland. 2009 Adelbert Road, Cleveland 6, Ohio. Presidcnt: P. J. Robechek, 10300 Carnegie Avenue, Cleveland, Ohio. Term expires May 1961. Executive Secretary: Robert A. Lang. Term indefinite.

\section{History: Organized 1824.}

Purpose: To promote the interests of the medical profession and the general welfare of the community, and to foster the prosecution of medical research.

Membership: Requires degree of M. D. from accredited medical school, license for the practice of medicine in the State of Ohio, membership in American Medical Association, and active medical practice. Total membership 2,200 .

Mectings: Annual and monthly.

Professional activities: Fifty-year awards are presented to those who have been practicing medicine for that period; Health Education Foundation, \$10,000; Lower Fund Lectures, for continuance of a scientific educational program for nembers.

Publications: Bulletin, monthly, current volume: $45, \$ 3$. Editor: Leon H. Dembo.

\section{Academy of Medicine of Washington, D. C.} Cosmos Club, 2121 Massachusetts Avenue, N. IV., Washington, D. C. President: Joseph Hyram Roe, George Washington University Medical School, Washington, D. C. Term expires December 1962. Secretary: Angus M. Griffin. Term expires December 1962.

History: Incorporated February 1935 as the Washington Academy of Medicine; name changed to present title November 1935.

Purpose: To advance the science and art of medicine, and to promote the mutual exchange of knowledge between medical and other scientific groups.

Membership: Limited to leading clinicians, medical research scientists, and medical administrators of Washington, D. C. Total membership 150.

Mcetings: Three times a year.

8. Academy of Motion Picture Arts and Sciences. 9038 Melrose Avenue, Hollywood 46, Calif. President: B. B. Kahane. Term expires July 1961. Secretary: Hal Elias. Term expires July 1961.

History: Organized May 1927.

Purpose: To advance the arts and sciences of motion pictures.

Membership: Active, Honorary, and Life Members; must be sponsored by two Academy 
members and be voted on by the Board of Governors. Total membership 1,760.

Mcetings: Annual.

Professional activities: Annual Awards of Merit, for outstanding achievement; special awards voted by the Board of Governors.

Library: 3,000 volumes.

9. Academy of Natural Sciences of Philadelphia. 19th Street and Parkway, Philadelphia 3, Pa. President: M. Albert Linton. Director: $\mathrm{H}$. Radclyffe Roberts. Term indefinite.

History: Founded 1812, incorporated 1817; oldest center for natural science research in the western hemisphere; has complete facilities for basic taxonomic research, study collections; has active research projects in malacology, ornithology, entomology, limnology, geology, and ichthyology.

Purposc: Research in the natural science field.

Membership: Open to any person interested in the program of the Academy. Annual Individual Members, Junior Members, Family Members, Contributing Members, Life Members, Sustaining Members, Benefactors, and Patrons. Total membership 2,600.

Mectings: Annual.

Professional activities: Jessup Fund Grant, awarded to college or graduate students, men or women, for special projects; Hayden Memorial Geological Award, for geological or paleontological research; Leidy Medal and Richard Hopper Day Memorial Medal, for outstanding work in natural science.

Publications: Proceedings, annual. Editor: C. IV. Hart, Jr., Frontiers, five times yearly, $\$ 2.50$, free to members. Editor: M. E. Drinker.

Library: 140,000 volumes. Subject emphasis : natural sciences.

\section{Academy of Psychosomatic Medicine.} President: George F. Sutherland, 3700 North Charles Street, Baltimore 18, Md. Term expires October 15, 1961. Secretary: Bertram B. Moss, 55 East Washington Street, Chicago 2, I11. Term expires October 15, 1961.

History: Organized March 28, 1952.

Purpose: To advance scientific knowledge and practice of medicine relating to interaction of mind, body, and environment.

Membership: Requires membership in the medical profession or in related disciplines in the psychosomatic field. Total membership 515.

Meetings: Annual.

Professional activities: Annual award for best paper presented at meeting.

Publications: Psychosomatics, bimonthly, current volume: $3, \$ 10$; Meeting Abstracts, annual, current volume : $2, \$ 5$. Editor: Wilfred Dorfman.
11. Academy of Religion and Mental Health. 16 East 34th Street, New York 16, N. Y. President: Harvey J. Tompkins, Reiss Mental Health Pavilion, St. Vincent's Hospital, New York, N. Y. Term expires June 1962. Executive Secretary: George C. Anderson. Term expires June 1962.

History: Former name: National Academy of Religion and Mental Health. Incorporated in 1955 and had its first offices in the New York Academy of Medicine.

Purpose: Education and research in relation between religion and health, especially mental health.

Membership: Requires affiliation with professional groups involved in Academy's program; primarily clergymen, psychologists, psychiatrists, physicians, cultural anthropologists, sociologists, and social workers. Total membership 2,700.

\section{Meetings: Annual.}

Professional activities: Grants in aid; research grants.

Publications: Academy Reporter, monthly (to members only), current volume: 5 .

Library: 2,000 volumes. Subject emphasis: religion and mental health.

\section{Academy of Science and Art of Pittsburgh.} Carnegie Museum, 4400 Forbes Avenue, Pittsburgh 13, Pa. President: O. E. Jennings. Term expires February 1961. Executive Secretary: H. E. Phifer, 1104 La Clair Avenue, Pittsburgh 18, Pa. Term expires February 1961.

History: Organized 1889; incorporated March 10, 1890. Sections: Astronomical, Photographic.

Purpose: Advancement of science and art through lectures and the work of the sections.

Membership: Open to persons with interest in the purpose of this Academy. Total membership 1,700 .

Mectings: Weekly, October to April.

Professional activities: Walter B. Scaife Nature Lectureship, capital $\$ 10,000$; geographical lectures; Annual Photographic Salon, conducted by Photographic Section; laboratory construction of telescopes and participation in satellite observations by Astronomical Section.

13. Academy of Science of St. Louis. 2 Oak Knoll Park, St. Louis 5, Mo. President: Stratford Lee Morton, 1825 Boatmen's Bank Building, St. Louis 2, Mo. Term expires January 1961. Executive Secretary: Roy W. Jordan, 8224 Forsyth Boulevard, Clayton 5, Mo. Term expires January 1961. 
History: Organized March 10, 1856; incorporated January 17, 1857.

Purpose: To encourage interest in and understanding of the sciences, and, as a means to this end, to develop and maintain a museum and library, to hold meetings, to sponsor lectures, and to engage in any other appropriate scientific activities.

Hembership: An interest in the purposes of the Academy. Total nembership 1,100.

Meetings: Monthly.

Professional activities: Maintains a museum of science, a science school service, and a science career program for promising young people.

Publications: Your Museum, monthly, free to nembers. Editor: Sally Haven.

Library: 75,000 Volumes.

14. Acoustical Society of America. 335 East 45th Street, New York 17, N. Y. President: Robert WV. Young, United States Navy Electronics Laboratory, San Diego 52, Calif. Term expires May 1961. Secretary: Wallace Waterfall. Term expires May 1961.

History: Organized May 10, 1929. СHAPTERS : Delaware Valley; Los Angeles; Michigan; Northwest; San Diego; Washington, D. C. Commitrees: Architectural Acoustics; Audio Engineering and Electroacoustics; Musical Acoustics; Noise; Physical Acoustics; Psychological and Physiological Acoustics; Slock and Vibration; Sonic and Ultrasonic Engineering; Speech Communication; Underwater Acoustics. The Society is a founder and Member Society of the American Institute of Plyysics and participates in the managenent of the Institute through representation on its Governing Board.

Purpose: To increase and diffuse the knowledge of acoustics and to promote its practical applications.

Hembership: Associate: open to any person interested in acoustics; Active: open to any person active in acoustics, who has an academic degree or its equivalent in scientific or professional experience in acoustics or in a closely related field; Fellow: based on assessment of the candidate's contributions to the advancement of acoustical science and teclmology; Sustaining: available for corporations and other organizations interested in materially supporting the publications and activities of the Society; Honorary. Total membership 2,814.

\section{Mectings: Semiannual.}

Professional activities: The Society is an agency in the management of the Acoustical Standards Board of the American Standards Association and various committees and subcommittees reporting to that Board; the Society contributes to the development and maintenance of standards for acoustical devices affecting health and industrial efficiency; to encourage professional activity on a local scale, the Society has sponsored several regional chapters and has provided for more as needed; the Society's ten techrical committees assist and cooperate with local program chairmen in the arrangement of meetings, the promotion of new developments in their respective fields, the representation of the Society in joint sponsorship of meetings with other organizations, responsibility for adequate coverage of subject matter in the publications of the Society; the committees also pronote improved educational facilities for the study of acoustics in technical schools; each conmittee publishes in the Journal an annual report of its membership and activities; Biemnial Award of $\$ 100$ and a bound set of the Journal is made in the spring of each even-numbered year to a nember of the Society not over thirty-five years of age who has made outstanding research contributions to acoustics; Gold Medal, awarded in the spring of each oddnumbered year to a member, without respect to age, whose services to the science of acoustics and to the Society have been unusually distinguished; Wallace Clement Sabine Medal, awarded at fall meetings every two to three years to a member who has made outstanding contributions in the field of architectural acoustics; Underwater Acoustics Medal, awarded at fall meetings to a member who lras made outstanding contributions in the field of underwater acoustics.

Publications: Journal, monthly, current volume : $32, \$ 18$, free to members. Editor: R. Bruce Lindsay. Noise Control, bimonthly, current volune: 6, \$8. Managing Editor: Herbert A. Erf.

15. Aerospace Medical Association. Washington National Airport, Washington 1, D. C. President: George J. Kidera, United Air Lines, Inc., 5959 South Cicero Avenue, Chicago 38, I11. Term expires April 1961. Executive Vice President: William J. Kennard. Term expires April 1961.

History: Organized 1928; formerly Aero Medical Association.

Purpose: To promote the science and art of aerospace medicine by stimulating investigation and study and disseminating knowledge; to establish and maintain cooperation between the medical and other sciences concerned with aeronautical development and progress; and to promote, protect, and maintain safety in aviation and astronautics.

Membership: Open to physicians licensed in country of residence, or designated as aviation medical examiner, flight surgeon, or aviation medical director, past or present, by government of nation of citizenslip; to allied scientists or 
engineers concerned with life sciences as related to aviation or astronautics; to workers in, or contributors to, aerospace medicine, if college graduates or commissioned in the armed services with equivalent qualifications; to those persons connected with commercial airline or aerospace industry; and to those persons engaged in teaching of research in aerospace or related medicine. Corporate membership is authorized for companies supporting the Association and its objectives. Total membership 2,420.

\section{Meetings: Annual.}

Professional activities: Theodore C. Lyster Award, annual, established 1947, for outstanding achievement in the general field of aviation medicine; Raymond F. Longacre Award, annual, for outstanding accomplishment in psychological and psychiatrical aspects of aviation medicine; Arnold D. Tuttle Award, annual, established 1952, to individual or group for the most significant contribution toward solution of a challenging problem in aviation medicine by original research, and which has been published in Aerospace Medicine during the previous two years; Eric Liljencrantz Award, annual, established 1957, to individual for the best paper on basic research in problems of acceleration and altitude.

Publications: Aerospace Medicine, monthly, current volume: $31, \$ 10$, free to members. Editor: John P. Marbarger.

16. Agricultural History Society. Room 3446, South Agriculture Building, U. S. Agricultural Marketing Service, Washington 25, D. C. President: Gilbert C. Fite, University of Oklahoma, Norman, Okla. Term expires spring 1961. Secretary-Treasurer: Wayne D. Rasmussen. Term indefinite.

History: Founded February 14, 1919; incorporated June $6,1924$.

Purpose: To stimulate interest in the history of agriculture, to promote its study and to facilitate research and publication.

Membership: Based on interest in the history of agriculture. Total membership 725.

Mectings: Semiannual.

Professional activities: Everett E. Edwards Memorial Awards, $\$ 50$ each, awarded annually for (1) the best manuscript article on agricultural history submitted by an author in the course of taking a degree and (2) the best article published in Agricultural History. In cooperation with the University of Illinois Press, an annual award for the best book manuscript dealing with a subject in agricultural history.

Publications: Agricultural History, quarterly, current volume: $34, \$ 5$. Editor: C. Clyde Jones.
17. Agricultural Research Institute. 2101 Constitution Avenue, N. W., Washington 25, D. C. President: C. H. Mahoney, National Canners Association, 1133 20th Street, N. W., Washington 6, D. C. Term expires October 1961.Secretary: R. E. Krauss. Term indefinite.

History: Organized December 1951. The Institute was conceived by industrial scientists as a supporting organization for the Agricultural Board of the National Academy of Sciences-National Research Council in promotion of the kinds of research and policies needed to insure the long-time utilization of agricultural resources for the national welfare. The Institute operates under the Division of Biology and Agriculture of the National Academy of Sciences-National Research Council.

Purpose: To promote the objectives of the Agricultural Board: namely, to advance and interpret scientific knowledge pertaining to agriculture; to initiate and provide recommendations relative to the science of agriculture based on objective analysis, and to disseminate the facts and conclusions by publication or otherwise among those agencies and population groups, including industry, where appropriate utilization and implementation can be effected; to aid the Agricultural Board in the selection, initiation, and interpretation of its studies; and to provide financial support to the Board.

Membership: Class A, 68, corporations and individuals who are interested in the industrial applications of scientific agriculture; Class B, 100, experiment stations, academic institutions, scientific societies, and other associations, organizations, or individuals who are engaged in activities related to the science of agriculture and who are nominated by the National Research Council and elected by the Governing Board of the Institute. Total memberslip 168.

\section{Mectings: Annual.}

Publications: Reporter, bimonthly, current volume: 1, free; Proceedings, annual, free. Editor: LeRoy Voris.

18. Air Pollution Control Association. 4400 th Avenue, Pittsburgh 13, Pa. President: Harry A. Belyea, Chief Air Pollution Control Officer, Municipality of Metropolitan Toronto, Department of Works, 55 Eglinton Avenue, East Toronto 12, Canada. Term expires June 1, 1961. Executive Secretary: Arnold Arch. Term indefinite.

History: Organized 1906 as International Association for the Prevention of Smoke; name changed to Smoke Prevention Association in 1915; incorporated in 1923; name changed to Smoke Prevention Association of America in 
1940 ; name changed to Air Pollution and Smoke Prevention Association of America in 1950; name changed to present title in 1952. SECTIons: Central States; East Central; MidAtlantic States; Mid-West. Committees: Auditing; Awards; By-Laws; Entertainment; Finance; Incinerator; Ladies Entertainment; Management; Marine; Membership; Meteorological; Nominating; Program; Public Relations; Railroad Smoke; Research and Development; Resolutions; Standardization; Standards for Dust Emission; Standards for Emission of Solids; Vapors, Fumes, and Noxious Gases; Ways and Means.

Purpose: To improve air sanitation and foster control of atmospheric pollution affecting health and/or causing damage to property, nuisance to the public, and waste of natural resources; to encourage public acceptance of the necessity for atmospheric pollution prevention and assist governmental units toward a solution of this problem; to encourage the development and adoption of apparatus, equipment, and operating procedures that will economically prevent pollution of the atmosphere; to encourage the participation, cooperation, assistance, and support of medical societies, health associations, and other organizations in air pollution prevention activities; to encourage industrial, manufacturing, producing, and distributing firms and transportation agencies and associations of such firms to contribute knowledge and effort to promote experimentation and application of methods towards the reduction of atmospheric pollution; to encourage the development and adoption of engineering standards of performance on a national and international scale that are workable and reasonable; to promote research in the solution of problems embracing all sources of atmospheric pollution; to aid municipalities and public bodies in adopting regulations controlling the discharge into the atmosphere of harmful contaminants; to prepare and distribute literature and publications pertaining to the problems involved in providing cleaner air; and to maintain a library and information service of professional papers, technical articles and publications, and descriptive material pertaining to cause, effect, and remedy of processes involving atmospheric pollution.

Membership: Any person of good character, and firms and/or organizations, interested in accomplishing the purposes of this Association. Total membership approximately 2,000 .

\section{Meetings: Annual.}

Professional activities: Frank A. Chambers Award. Richard Beatty Mellon Award. Honorary lifetime membership.

Publications: Journal, bimonthly, current volume: 10, free to members. APCA Abstracts, monthly, current volume: 5 , free to members. Editor: Arnold Arch.

19. Airlines Medical Directors Association. President: G. Earle Wight, Room 501, Windsor Station, Montreal, Canada. Term expires April 24, 1961. Secretary: James N. IVaggoner, 9851 Sepulveda Boulevard, Los Angeles 45, Calif. Term expires April 24, 1961.

History: Organized 1946; affiliate, Aerospace Medical Association.

Purpose: To improve practice and standards of aviation and industrial medicine, particularly pertaining to airline operations, and to encourage research and study of medical problems in these fields.

Membership: Physicians and surgeons of medical departments of commercial airlines, and other persons who have contributed to the practice of aviation medicine in civil airlines. Total membership 85.

Mectings: Semiannual.

20. Alabama Academy of Science, Inc. Department of Forestry, Auburn University, Auburn, Ala. President: James R. Goetz, 2101 6th Avenue, N., Birmingham, Ala. Term expires April 1961. Secretary: W. B. De Vall. Term expires March 1962.

History: Organized April 1924. Sections: Biological Sciences; Chemistry; Geology and Anthropology ; Forestry, Geography, and Conservation; Physics and Mathematics; Industry and Economics; Science Education; Social Sciences; Medical Sciences.

Purpose: To encourage scientific research, promote diffusion of useful scientific knowledge, and unify scientific interests of the State.

Membership: Individual, 535, persons in the State of Alabama actively engaged in science who have four-year college degrees or ten years of professional experience; Collegiate, 63, college students interested in promotion of science in Alabama; Complimentary, 61; Life, 5; Industrial, 6 , firms and corporations interested in advancement of science in Alabama; Sustaining, 11. Total unduplicated membership 664.

\section{Meetings: Annual.}

Professional activities: Student research awards; research grants; various awards through Junior Academy include individual and school awards and awards for best scientific papers and best science exhibits.

Publications: Journal, quarterly, current volume: 31. Editor: A. T. Hansen, P. O. Box 2982, University of Alabama, University, Ala. 
21. Alabama Pharmaceutical Association. 304

Thomas Jefferson Hotel, Birmingham, Ala.

President: M. G. Mullendore, 2911 Highland

Avenue, Birmingham, Ala. Term expires June 1961. Executive Secretary: Thelma Morris Coburn. Term indefinite.

History: Organized 1881.

Purpose: To improve science and art of pharmacy.

Memberslip: Active Members. Total membership 700 .

Mectings: Annual.

Professional activities: Administration of Pharmacy Scholarship Foundation.

22. Alabama Psychological Association. President: Neil B. Sims, Veterans Administration Hospital, Birmingham, Ala. Term expires July 1, 1961. Secretary: Paula McKinney Brown, Tuskegee Institute, Tuskegee, Ala. Term expires July 1, 1963.

History: Organized 1950.

Purpose: To advance psychology as a science, a profession, and a means for promoting human welfare.

Menbership: Membership in American Psychological Association, or equivalent qualification. Total nembership 83.

Meetings: Annual.

23. Alabama Society of Anesthesiologists. 115 Jordan Lane, Spring Hill Station, Mobile, Ala. President: Vernon N. Balovich. Term expires April 1961. Secretary-Treasurer: Joyce R. Chapman, 1804 12th Avenue South, Birmingham 5, Ala. Term expires April 1961.

History: Organized May 4, 1948.

Purpose: To advance the science of anesthesiology in Alabama.

Membership: Active and Junior Members, 30; membership in the State Society and in the County Society.

Mectings: Quarterly.

24. Alabama Society of Professional Engineers. P. O. Box 1325, Birmingham, Ala. President: Henry R. Hudson, P. O. Box 7062, Montgomery, Ala. Term expires May 31, 1961. Secretary: R. T. Moore, 312 Moore Building, Montgomery, Ala. Term indefinite.

History: Founded 1952 and affiliated with National Society of Professional Engineers. Chapters: Birmingham; Montgomery; Auburn; Northeast Aiabama (Huntsville).

Purpose: The advancement of the public welfare and the promotion of the professional, social, and econonic interest of the professional engineer.

Membcrstip: Requires registration by State Board of Registration for Engineers, or that engineers in training and graduate engineers (or equivalent) be working to become registered. Total membership 300.

Mectings: Semiannual.

25. Alaska Society of Professional Engineers, Inc. 2508 Eide Street, Anchorage, Alaska. President: Arthur R. Jacobs, 835 9th Avenue, Anchorage, Alaska. Term expires December 31, 1960. Secretary: James R. Clinton. Term expires December 31, 1960.

History: Founded 1957. Incorporated and affiliated as member, National Society of Professional Engineers, 1958.

Purpose: The advancement of the public welfare and the promotion of the professional, social, and economic interest of the professional engineer; cooperation with national, state, and local societies.

Membership: Active, 55; Engineer in Training, 1. Requirements: Active, registration as professional engineer; Engineer in Training, registration as such, or qualification to become so registered. Total membership 56.

Meetings: Monthly.

Professional activities: Armco national scholarships (sponsored by National Society of Professional Engineers).

26. Alaska State Medical Association. $718 \mathrm{~K}$ Street, Anchorage, Alaska. President: Benjamin E. McBrayer, P. O. Box 637, Mt. Edgecumbe, Alaska. Term expires May 1961. Secretary-Treasurer: Robert B. Wilkins. Term expires May 1961.

History: Organized 1930; incorporated 1947 as Alaska Territorial Medical Association; name changed to present title March 1959. CoMPONENT Societies: Anchorage Medical Society; Fairbanks Medical Association; Juneau Medical Society; Ketchikan Medical Society; Sitka-Mt. Edgecumbe Medical Society.

Purpose: To promote the art and science of medicine and the betterment of public health.

Membership: Requires M. D. degree from accredited institution, license for practice of medicine and surgery issued by Alaska Board of Medical Examiners. Regular members, 103; Associate, 12. Total membership 115.

Mectings: Annual.

Publications: Alaska Medicine, quarterly, current volume: 2, \$6. Editor: William Mills. 
27. Albany Society of Engineers. 25 South Allen Street, Albany 8, N. Y. President: Louis B. Calcagni, East Greenbush. N. Y. Term expires December 31, 1960. Exccutive Secretary: John F. McColl, 20 Glendale Avenue, Delmar, N. Y. Term expires December 31, 1960.

History: Organized 1905-06 as Albany Society of Civil Engineers; name changed to present title April 25, 1922.

Purpose: Advancement of engineering knowledge and practices, maintenance of high professional standards, and welfare of engineers.

Mcmbership: Requires active engagement in engineering or kindred professions. Total membership 320 .

Meetings: Monthly.

Publications: Yearbook, biannual. Editor: John F. McColl.

\section{Alexander Graham Bell Association for the}

Deaf, Inc. Volta Bureau, 1537 35th Street, N. W., Washington 7, D. C. President: George T. Pratt, Clarke School for the Deaf, Northampton, Mass. Term expires January 1961. Executive Secretary: Jeanette Ninas Johnson. Term expires January 1961. Secretary: June Miller, University of Kansas Medical Center, Kansas City 12, Kans. Term expires January 1961.

History: Organized and incorporated 1890 as American Association to Promote the Teaching of Speech to the Deaf. National Forum on Deafness and Speech consolidated with the Association. Name changed to present title June 1953.

Purpose: To promote the teaching of speech to the deaf and to help educators of the deaf in their efforts to teach speech and lip reading; to furnisin information to those interested in any of the problems occasioned by deafness.

Mcmbership: Regular, Sustaining, and Life menbers, 4,000; open to all who are interested in the objectives of the Association.

Mectings: Business meetings, annual; National Program meetings, biennially in even years; Regional Program meetings in odd years.

Publications: Volta Review, monthly except July and August, current volume: $62, \$ 5$, free to nimenbers. Editor: Jeanette Ninas Johnson.

Library: The 20,000 volume John Hitz Memorial Library.

29. Alpha Chi Sigma Fraternity. 5503 East Washington Street, Indianapolis 19, Ind. President: Frank J. Zvanut, Country Club Road, St. Charles, Mo. Term expires June, 1962. National Secretary: Roy W. Loan. Term permanent.
History: Founded 1902 at the University of Wisconsin. At first a professional collegiate organization, it was divided in 1922 into collegiate and professional branches: forty-nine chapters in universities or colleges; thirty-one professional chapters. Incorporated under the laws of Wisconsin. An associate of the American Association for the Advancement of Science.

Purpose: To advance chemistry as a science and profession; to aid members by every honorable means in the attainment of their ambitions as chemists throughout life.

Mcmbership: Satisfaction of academic degree and competence in chemistry and/or chemical engineering, with the usual personality requirements of fraternities. Total membership, Collegiate and Professional, 29,750.

\section{Meetings: Biennial.}

Professional activities: National fund to finance grants-in-aid; local awards, usually for scholarships, anong various chapters; two national traveling efficiency cups are awarded biennially to outstanding collegiate chapters that best represent the organization's ideals as well as its value to the chemistry department and institution; a traveling scholarship is awarded biennially to the highest-rated collegiate chapter; the Reserve Trust Funds approximate $\$ 141,000$; the professional branch of the organization finances annually the American Chemical Society Award in Pure Chemistry, $\$ 1,000$, to be given to a chemist not over thirty-five years of age who contributes to the literature the most outstanding researcl in pure chemistry; the collegiate branch of the organization operates a national safety program in the interest of safe practice in chemical laboratories, in conjunction with the National Safety Council, with which the national fraternity and all of its collegiate chapters are associated.

Publications: Hexagon, quarterly, current volume: $50, \$ 1.25$ to professional members. Proceedings, annual, free to members.

30. Alpha Epsilon Delta. 7 Brookside Circle, Bronxville, N. Y. President: Norman F. Witt, University of Colorado, Boulder, Colo. Term expires 1962. Secretary: Maurice L. Moore. Term expires 1962.

History: Founded April 28, 1926; incorporated August 2, 1949. Seventy-five chapters in accredited colleges throughout the United States.

Purpose: To encourage excellence in premedical scholarship; to stimulate appreciation of importance of premedical education in study of medicine; to promote cooperation and contacts between medical and premedical students and educators in developing an adequate program 
of premedical education; to bind together similarly interested students.

Membership: Active, 18,721, students engaged in courses leading to study of medicine who have completed at least three semesters or five quarters of work with general scholastic standing of 80 percent and average of 80 percent in sciences, and who rank in upper 35 percent of class in general scholarship; Active Alumni, 180, those deemed worthy by chapter; Honorary, 739, deemed worthy by chapter and approved by National Officers. Total membership 19,630.

\section{Meetings: Biennial.}

Professional activities: Distinguished Service Award, presented to outstanding leader in premedical education. Alumni Award, recipient nominated by chapter and selected by National Officers. Chapter Activity Award, presented to chapter at biennial convention for most constructive program of activities during biennium.

Publications: Scalpel, quarterly, current volune: $30, \$ 2.50$. Editor: Maurice L. Moore.

\section{American Academy for Cerebral Palsy.} 1520 Louisiana Avenue, New Orleans 15, La. President: G. W. N. Eggers, 2201 Market Street, Galveston, Tex. Term expires November 11, 1961. Secretary: J. D. Russ. Term expires November 11, 1961.

History: Organized 1948; incorporated 1952. Commitees: Brain Registry; Evaluation of Therapy; Audio-Visual; Research.

Purpose: To foster and stimulate interest in cerebral palsy and correlate all aspects of work for welfare of its victims.

Membership: Active, 253, on specialty boards working in cerebral palsy, and with M. D. degree; Associate, 11, working in cerebral palsy with doctorate other than M. D., or physicians not qualified for active membership; Honorary, 5 , with M. D. or other doctorate, preeminent in fields allied to cerebral palsy; Foreign Corresponding, 14, with M. D. or other doctorate, preeminent in field of cerebral palsy and residing outside Western Hemisphere; Emeritus, 3, active members past age 70 or retired from practice. Total membership 286.

Meetings: Annual.

Publications: Annual Proceedings.

32. American Academy of Allergy. 756 North Milwaukee Street, Milwaukee 2, Wis. President: Bram Rose, McGill University Clinic, Royal Victoria Hospital, Montreal, Canada. Term expires March 7, 1961. Executive Secretary: James $\mathrm{O}$. Kelley. Term indefinite.

History: Organized December 4, 1943, through merger of two parent societies, the Society for the Study of Asthma and Allied Conditions, founded March 7, 1923, and the American Association for the Study of Allergy, founded June 25, 1923.

Purpose: Advancement of knowledge and practice of allergy by discussion at meetings, by fostering education of students and public, by encouraging cooperation among those engaged in this field, and by promoting and stimulating research and study in allergy.

Membership: Members, 652, minimum of five years from graduation from medical school; Fellows, 391, proficiency in research in profession of allergy; Foreign Members, 41 ; Foreign Fellows, 10; Emeritus Members and Fellows, 37; Honorary Fellows, 18: Affiliate Fellows, 53. Total membership 1,202.

Meetings: Annual.

Publications: Membership directory, biennially. Journal of Allergy, bimonthly, current volume: 31, \$8.50. Editor: Francis C. Lowe11, Massachusetts General Hospital, Boston, Mass.

33. American Academy of Applied Nutrition. 10651 West Pico Boulevard, Los Angeles 64, Calif. President: WVeston IV. Shay, 5514 IVilshire Boulevard, Los Angeles 36. Calif. Term expires May 1961. Erecutive Secretary: Donald B. Haynie. Term indefinite.

History: Organized and incorporated 1936.

Purpose: To promote and advance by educational means the science and art of nutrition, especially as it pertains to prevention and treatment of disease.

Membership: Professional, 265, dentists, physicians, chemists, nutritionists, agriculturists, or veterinarians, with doctors' degrees or equivalent, who are proficient in nutrition; nonprofessional, 1,222. Total membership 1,487.

Meetings: Annual.

Publications: Journal of Applied Nutrition, quarterly, current volume: $13, \$ 5$. Editor : Granville F. Knight. Modern Nutrition, monthly, current volume: $13, \$ 5$. Editor: Margaret Haake.

34. American Academy of Arts and Sciences. 280 Newton Street, Boston 46, Mass. President: Kirtley F. Mather, 3 Concord Avenue, Cambridge 38, Mass. Term expires May 1961. Executive Secretary: Ralph IV. Burhoe. Term expires May 1961.

History: Chartered in 1780 under Acts of the Legislature of the Province of Massachusetts. Committees: Special committees are established for promotion of knowledge in various projects in highly specialized fields of study.

Purpose: To cultivate every art and science which may tend to advance the interest, honor, 
dignity and happiness of a free, independent, and virtuous people.

Mcmbership: Election is based on nomination by members and not on application by nominee. It implies recognition of scholarship or professional eminence. There are two groups of members: Fellows, elected from citizens or residents of the United States; Foreign Honorary Members. On January 1, 1960, there were 1.385 Fellows, 64 Fellows Emeriti; 187 Foreign Honorary Members. Total membership 1,636.

Mcetings: Monthly, October through May.

Professional activities: Permanent Science Fund $(\$ 382,471)$. Cyrus M. Warren Fund $(\$ 18,405)$, established in 1891 by the will of Cyrus M. Warren. From the income, grants are made for encouragement and advancement of research in chemistry. Rumford Fund $(\$ 86,819)$, established 1796 by Benjamin Thompson, Count Rumford. The income is used for awarding of the Rumford premium, consisting of a gold and a silver medal, to authors of any important discovery or useful improvement in light or heat which shall have been made in any part of America. It is also used to make grantsin-aid of research along these lines. Francis Amory Fund $(\$ 53,759)$, established by will of Francis Amory, is to be used for a Septennial Prize for outstanding work with reference to alleviation or cure of diseases affecting human genito-urinary system. Publication Fund $(\$ 42,887)$, established for publication of results of research contributed by members of the Academy, and other proceedings.

Publications: Daedalus, quarterly, current volume : $89, \$ 4.50$. Records annual, current volume: 2, \$2.30. Bulletin, monthly, October-May, current volume: 14, \$1. Editor: Gerald Holton.

\section{American Academy of Child Psychiatry.} Prcsidcnt: Marion Kenworthy, 1035 5th Avenue, New York, N. Y. Term expires 1961. Sccretary: Reginald S. Lourie, 2125 13th Street, N. W., Washington 9, D. C. Term expires 1961 .

\section{History: Organized February 22, 1953.}

Purpose: To provide a forum for free and full discussion of matters relevant to advancement of child psychiatry; to delineate the scope of practice of this specialty and to encourage recognition of this practice among psychiatrists and other members of the medical profession; to encourage and support high standards of training and practice; to stimulate physicians to enter this field; to promote and advance activities in areas of prevention, treatment, research, and teaching in child psychiatry; and to honor physicians who have made considerable contributions to this subject and activity.
Membership: Fellows must be members of American Psychiatric Association, certified by American Board of Psychiatry and Neurology in psychiatry, or eligible to take examination of this Board. Associates must be physicians not eligible for Fellowship, but who have made outstanding contributions in child psychiatry. Membership by invitation. Total membership 196.

Meetings: Semiannual.

Publications: Journal, quarterly.

\section{American Academy of Compensation Medi-} cine, Inc. 221 West 57th Street, New York 19, N. Y. President: Donald A. Covalt, 400 East 34th Street, New York 16, N. Y. Term expires May 1961. Secretary: William T. Foley, 441 East 68th Street, New York 21, N. Y. Term expires May 1961.

History: Organized and incorporated June 22, 1946.

Purpose: To establish standards of practice and to promote education and research in workmen's compensation and industrial medicine; to encourage, foster, and promote advancement of medicine and surgery in relation to industrial medicine; to develop medical criteria for the determination of causal relationship between injury, disease, and disability ; to serve as a forum for exchange of ideas and discussion of problems.

Membership: Fellows, 209, licensed physicians who are members of their county and state medical societies and the American Medical Association and who are diplomates in a specialty, or Fellows of the American College of Surgeons, or Fellows of the American College of Physicians, or who have special qualifications acceptable to the Board of Governors; Associate Fellows, 6, licensed physicians whose training and qualifications indicate meeting requirements for fellowship within five years; Members, licensed physicians in good standing. Total membership 225.

Mectings: Annual.

Professional activities: Postgraduate courses are held in cooperation with New York University Post-Graduate Medical School and with other postgraduate medical schools by invitation; lectures with county medical societies.

Publications: Compensation Medicine, quarterly, current volume: 11 , domestic $\$ 5$, foreign \$7. Editor: Samuel M. Peck.

\section{American Academy of Dental Medicine.}

President: Hermann Becks, University of California Medical Center, San Francisco, Calif. Term expires June 1961. Secretary: George F. Clarke, 554 Franklin Street, Melrose, Mass. Term expires June 1961. 
History: Organized 1946; incorporated in New York. Sections: Connecticut; Maryland; Massachusetts; Michigan; Missouri; Montreal; New Jersey; New York; Pennsylvania; South Carolina; Texas.

Purpose: To promote study and dissemination of knowledge of cause, prevention, and control of diseases of the teeth, their supporting structures, and adnexa and of related subjects; to promote better scientific understanding between fields of medicine and dentistry.

Membership: Active members, 905, members of dental profession who have been graduated from college for at least five years and who are members of representative national societies and qualified by special interest or accomplishment in field of dental medicine; Associate members, 53, from allied professions; Honorary members, 22, nonmembers of outstanding service in field of dental medicine. Total membership 980.

Meetings: Semiannual.

Professional activities: Endowment and Research Fund, for dento-medical research projects.

Publications: Journal of Dental Medicine, quarterly, current volume: $15, \$ 5$. Editor: I. Yudkoff.

\section{American Academy of Dermatology and} Syphilology. First National Bank Building, Rochester, Minn. President: Francis IV. Lynch, 350 St. Peter Street, St. Paul 2, Minn. Term expires December 1960. SecretaryTreasurer: Robert R. Kierland, Mayo Clinic, Rochester, Minn. Term expires December 1962.

\section{History: Organized 1936.}

Purpose: Education in dermatology and syphilology.

Membership: Fellows, 1,637, certified by American Board of Dermatology and Syphilology; Associates, 384, three years full-time training in dermatology and syphilology: Affiliates, 61, three years part-time in dermatology and syphilology, public health, education, or research in connection with this specialty; Non-resident Fellows, 46, approximately equivalent requirements to those for certification by the Board; Special, 49, retired, in the Armed Forces, etc. Total membership 2,177.

Meetings: Annual.

Professional activities: Earl D. Osborne Fellowship in dermal pathology at the Armed Forces Institute of Pathology, Washington, D. C.

\section{American Academy of General Practice.} Volker Boulevard at Brookside Street,
Kansas City 12, Mo. President: John G. Walsh, 2901 Capitol Avenue, Sacramento, Calif. Term expires April 1961. Executive Director: Mac F. Cahal. Term indefinite.

History: Organized June 1947. Incorporated in Illinois, November 1947. Commissions: Education; Hospitals; Legislation and Public Policy; Membership. Committees: Finance; Publication; Insurance; Scientific Assembly; Constitution and By-Laws; Mental Health; Industrial Health; Rural Health; National Defense; Voluntary Prepaid Medical Care.

Purpose: To promote and maintain high standards of general practice of medicine and surgery; to encourage and assist young men and women in preparing, qualifying, and establishing themselves in general practice; to preserve the right of the general practitioner to engage in medical and surgical procedures for which he is qualified by training and experience; to assist in providing postgraduate study courses for general practitioners, and to encourage and assist practicing physicians and surgeons in participating in such training; to promote the science and art of medicine and surgery and the betterment of public health, and to preserve for the patient the right of free choice of physician.

Membership: Eligibility: Active members must be physicians engaged in the general practice of medicine and surgery. A general practitioner is defined as one who does not limit himself to one field of medicine or surgery. He must have graduated from a medical school approved by the American Medical Association. He must be duly licensed to practice in the state or province in which he practices, and must be a member of the constituent state or provincial medical society of the American Medical Association or Canadian Medical Association of the state, territory, or province in which he practices, or hold membership in the recognized medical society of the country of his residence. A candidate for membership who was graduated from medical school after January 1, 1950, must have had at least one year of rotating internship at a hospital approved for internship training by the Council on Medical Education and Hospitals of the American Medical Association. In addition, he must have completed one of the following: two years of graduate training acceptable to and approved by the Commission on Education, one year of such training followed by two years of general practice, or three years of general practice. Total membership 25,842.

\section{Meetings: Annual.}

Publications: GP, monthly, current volume: $21, \$ 10$, members $\$ 5$. Managing Editor: Walter H. Kemp. 
40. American Academy of Implant Dentures.

2120 Ocean Avenue, Brooklyn 29, N. Y. President: Arthur C. Jermyn, 240 Danbury Circle, N., Rochester, N. Y. Term expires October 1961. Secretary: A. Norman Cranin. Term expires October 1961.

\section{History: Organized 1951.}

Purpose: To promulgate the art and science of implantodontology; to influence standards of practice and elevate the theoretical and clinical science of implant dentistry.

Membership: Requires affiliation with American Dental Association or National Dental Association and local constituent society. IV ritten and oral examination must be passed. Total nembership 150.

Mectings: Annual.

Professional activities: An annual President's plaque is presented. Periodic awards are made to deserving scientists or officers of the Academy for achievement in its ficld.

Publications: Journal of Implant Dentistry, semiannual, current volume: $6, \$ 2.50$. Editor: A. C. Jermyn. Newsletter, monthly, current volume: 1, free to members. Editor: A. N. Cranin.

\section{American Academy of Microbiology, Inc.} 900 Market Street, Wilmington, Del. Chairman: C. A. Evans, Department of Microbiology, University of Washington, Seattle 5, Wash. Term expires May 2, 1961. Executive Secretary: G. I. Wallace, 232 Burrill Hall, University of Illinois, Urbana, Ill. Term expires May 2, 1961.

History: Organized September, 1955; sponsored by the Society of American Bacteriologists.

Purpose: To promote the highest professional standing of microbiologists; to carry on professional activities on behalf of the science of microbiology; to promote programs of recognition, certification and/or accreditation of microbiologists where needed to accomplish the aforesaid purposes.

Membership: Active Fellows, 515, a doctor's degree, a minimum of seven years full-time post doctorate experience in microbiology, membership in good standing in at least one scientific society, high ethical standards and professional excellence and experience; Emeritus Fellows, 24 , fellow who is retired because of age.

\section{Mectings: Annual.}

Professional activities: Certification and accreditation programs for microbiologists. Conferences on Educational and Professional Standards in Microbiology.

\section{American Academy of Neurological Sur-} gery. President: George S. Baker, Mayo Clinic, Rochester, Minn. Term expires October 1960. Secretary-Treasurer: Robert L. McLaurin, Cincinnati General Hospital, 3231 Burnet Avenue, Cincinnati 29, Ohio. Term expires October 1960.

\section{History: Organized 1938.}

Purpose: To promote scientific intercourse among members, and knowledge and skill of those devoted to neurological surgery.

Membership: Requires graduation from accredited colleges and acceptable postgraduate training in neurology, neurological surgery, and related fields. Total membership 69.

\section{Meetings: Annual.}

Professional actizities: American Academy of Neurological Surgery Award, annual, to a neurosurgeon in training, for original investigation.

\section{American Academy of Neurology. 4307}

East 50th Street, Minneapolis 17, Minn. President: Augustus S. Rose, Division of Neurology, UCLA Medical Center, Los Angeles 24, Calif. Term expires April 1961. Executive Secretary: Mrs. J. C. McKinley. Term indefinite.

History: Organized and incorporated 1948.

Purpose: To promote and encourage interest in the field of neurology through education and research.

Membership: Fellows, 348, diplomates of American Board of Psychiatry and Neurology or certified in neurology by Royal College of Physicians and Surgeons of Canada, predominantly interested in organic neurology, practicing chiefly in neurology and having made personal contributions to advancement of scientific knowledge of their profession; Active, 463, diplomates of American Board or certified by Royal College; Associates, 815, those in field related to neurology; Junior, 367, graduates of Class A medical schools and engaged in postgraduate training for neurological specialty; Honorary-Corresponding, 50, persons outside of United States and Canada, who have distinguished themselves in neurology; Honorary, 8, not diplomates of American Board but having rendered distinguished service to neurology. Total membership 2,051.

Mectings: Annual.

Professional actirities: S. WVeir Mitchell Award by Women's Auxiliary to the American Acadeny of Neurology, $\$ 200$, awarded annually to junior nember of the AAN who submits the most commendable manuscript in the field of neurology. 
Publications: Neurology, monthly, current volume: $10, \$ 12, \$ 9$ to junior members. Editor : Russell N. DeJong, Ann Arbor, Mich.

\section{American Academy of Occupational Medi-} cine. President: Joseph A. Quigley, National Lead Co., P. O. Box 158, Mt. Healthy Station, Cincinnati 31, Ohio. Term expires February 9, 1961. Secretary: Paul J. Whitaker, AllisChalmers Manufacturing Co., P. O. Box 512, Milwaukee 1, Wis. Term expires February 9, 1961.

History: Organized April 26, 1946.

Purpose: Maintenance and improvement of the health of industrial workers.

Mcmbership: Full-time practice in occupational medicine. Total membership 350 .

Meetings: Annual.

Professional activities: Award of Honor.

Publications: Archives of Environmental Health.

45. American Academy of Ophthalmology and Otolaryngology. 15 2nd Street, S. W., Rochester, Minn. President: Dean McAllister Lierle, Iowa City, Iowa. Term expires December 31, 1960. Executive Secretary: William Lemuel Benedict. Term expires December $31,1960$.

History: Organized in 1896 as the Western Ophthalmological, Otolaryngological and Rhinological Association; name changed to WVestern Ophthalmologic and Otolaryngologic Association in 1899, and to present title in 1903. ComMitTeEs: Conservation of Hearing; Standardization of Tonometers; Optics and Visual Physiology; Ophthalmic Pathology; Otolaryngologic Pathology: Reconstructive Plastic Surgery; Audio-Visual Education; Implants and Implant Techniques; Use of Diagnostic Procedures and Therapy in Uveitis; Research in Otolaryngology.

Purpose: To promote and advance the science and art of medicine appertaining to the eye, ear, nose, and throat; to encourage the study of the relationship of these specialties to surgery, general medicine, and hygiene.

Membership: A candidate for Active Fellowship shall be a member in good standing of a local and national medical society and shall be certified and approved by a national examining and certifying specialty board acceptable to the Council. Active Fellows shall automatically become Life Fellows after twenty-five consecutive years in good standing. Active Fellows, 5,797; Life, 938; Inactive, 130; Honorary, 29; Associate, 10. Total membership 6,904.

Meetings: Annual.
Professional actizities: Wherry Memorial Lecture Fund; Educational Trust Fund; scholarships in ophthalmic and otolaryngic pathology; awards for research in otolaryngology; awards for theses.

Publications: Transactions, bimonthly, current volume: $64, \$ 2$; Orthoptic Journal, annual, current volume: 10, \$2. Editor: William L. Benedict.

46. American Academy of Optometry. 1506 Foshay Tower, Minneapolis 2, Minn. President: Lawrence Fitch, Pennsylvania State College of Optometry, 12th and Spencer Streets, Philadelphia, Pa. Term expires December 1960. Secretary: Carel C. Koch. Term expires December 1960.

History: Founded 1921.

Purpose: To support research on vision and to promote postgraduate education.

Membership: Members must be optometrists in practice, faculty teachers of professional optonetric courses, or research workers in vision. Total membership 920.

Mectings: Annual.

Professional activitics: Grants in aid for research projects.

Publications: American Journal of Optometry, monthly, current volume: $37, \$ 8$. Editor: Carel C. Koch.

47. American Academy of Oral Pathology. Presidcut: Robert Colby, School of Dentistry, Georgetown University, Washington, D. C. Term expires April 4, 1961. SecretaryTreasurer: Robert J. Gorlin, University of Minnesota, Minneapolis, Minn. Term indefinite.

History: Founded 1947. Founded the American Board of Oral Pathology 1948.

Purpose: To stimulate study and research in oral pathology; to advance the understanding of the application of scientific procedures to dentistry; to promote and assist a certification board in oral pathology ; to encourage the establishment of fellowships; to aid in the maintenance of the Registry of Dental and Oral Pathology of the American Dental Association.

Membership: Interest in oral pathology. Total membership approximately 350 .

Mectings: Annual.

Professional activities: Helen McLain Lecture, annual.

Publications: Oral Surgery, Oral Medicine, Oral Pathology, monthly, current volume: 13, \$12. Editor: K. Thome. 
48. American Academy of Orthopaedic Surgeons, Inc. 29 East Madison Street, Chicago 29, 111. President: Hugh Smith, 869 Madison Avenue, Memphis 3, Tenn. Term expires January 1961. Executize Secretary: John K. Hart. Term indefinite.

History: Organized 1933; incorporated.

Purpose: Advancement of all phases of orthopaedic surgery.

Mcmbcrship: Members must have been graduates of medical school for seven years, practiced othopaedic surgery for three years, and been certified by American Board of Orthopaedic Surgery. Active, 2,442; Associate, 7 ; Honorary, 34; Emeritus, 157; Corresponding, 37. Total membership 2,677.

Mectings: Annual.

Professional activities: Kappa Delta Award for research; certificates are awarded for scientific exhibits.

Publications: Bulletin, quarterly. Editor: Willian A. Larmon.

49. American Academy of Pediatrics. 1801 Hinman Avenue, Evanston, I11. President: William W. Belford, 420 Walnut Street, San Diego 3, Calif. Term expires October 1960. Excutive Director: E. H. Christopherson. Term indefinite.

History: Organized 1930. Geographic SECTIONS: Nine districts covering United States and Canada; District X covering Spanishspeaking Latin America; District XI covering Brazil. Committees: Thirty scientific committees and five sections of the Academy, including Allergy, Cardiology, Diseases of the Chest, Military Pediatrics, and Surgery.

Purpose: To foster and stimulate interest in pediatrics and in all aspects of work for welfare of children.

Membership: Requires certification by American Board of Pediatrics, and other professional qualifications. Total membership 6,270.

Mectings: Semiannual.

Professional activities: Residency fellowships in pediatrics; Mead Johnson Research Grants in pediatrics; Borden Award; Mead Johnson Awards for research in pediatrics.

Publications: Pediatrics, monthly, current volume: 25, \$12. Editor: Charles D. May.

\section{American Academy of Periodontology.}

President: B. O. A. Thomas, 668 Homer Avenue, Palo Alto, Calif. Term expires October 1961. Secretary: Clarke E. Chamberlain, 1101 North North Street, Peoria, I11. Term expires October 1960.
History: Organized February 21, 1914 ; incorporated in Michigan. Commitrees: Membership; Constitution and ByLaws; Education; Research in Periodontology; Nomenclature and Classification; Scientific Sessions; Ethics.

Purpose: To advance the art and science of periodontology, and by its application to improve and maintain public health.

Membership: Requires affiliation with American Dental Association or a recognized dental association, with periodontics as a major part of practice. Active, 285; Associate, 304; NonResident, 17; Academic, 17; Honorary, 10; Fellows, 14; Retired, 11. Total membership 640.

\section{Mectings: Annual.}

Professional activities: Sponsoring Graduate Workshop for Teachers in Periodontology, University of Minnesota, 1960.

Publications: Journal of Periodontology, quarterly, \$8, free to members. Editor: Maynard K. Hine, 1121 West Michigan Street, Indianapolis, Ind.

\section{American Academy of Physical Medicine} and Rehabilitation. 30 North Michigan Avenue, Chicago 2, 111. Executive Secretary: Dorothea C. Augustin. Term indefinite.

History: Organized September 1938 as American Society of Physical Therapy Physicians; name later changed to American Society of Physical Medicine and Rehabilitation, and, still later, to present title. Committees: Advisory for Advancement of Physical Medicine and Rehabilitation; Membership Nominating; Scientific Program.

Purpose: To promote the art and science of medicine and the betterment of public health through understanding and utilization of functions of physical medicine and rehabilitation.

Membership: Active members, must be certificants of American Board of Physical Medicine and Rehabilitation; Senior, active members for fifteen years and over sixty-five years of age; Corresponding, doctors of medicine from countries other than the United States and Canada with recognition, training, and experience comparable to Diplomates of American Board of Physical Medicine and Rehabilitation; Honorary, for unusual contribution to this field of medicine. Total membership approximately 300 .

\section{Mectings: Annual.}

Professional activities: Seminars in physical medicine, sponsored periodically through grants by American Rehabilitation Foundation.

Publications: Archives of Physical Medicine and Rehabilitation, monthly, current volume: 41, \$8.50. Editor: Paul A. Nelson. 
52. American Academy of Restorative Dentistry. President: Carlisle C. Bastian, 22 Central Park, S., New York 19, N. Y. Term expires February 5, 1961. Secretary: Morton H. Mortonson, Jr., 735 North Water Street, Milwaukee 2, Wis. Term expires February 5,1961 .

History: Organized 1928.

Purpose: To promote the art and science of dentistry, especially as it applies to use of natural teeth in restoring and maintaining a healthy, functioning mouth; to disseminate among its members and to the profession the knowledge gained.

Membership: Active (limited to 165), 156; Associate, 10, dental graduates not in restorative work, and full-time teachers; Honorary, 20, chiefly former active members no longer in practice. Total membership 186.

Mectings: Annual.

Publications: Journal of Prosthetic Dentistry, bimonthly, current volumes: 17-18, \$9. Editor: C. O. Boucher, Ohio State University, Columbus, Ohio. The Journal is cosponsored with other dental organizations.

\section{American Academy of Sanitary Engineers. Sec American Sanitary Engineering Intersociety Board, Inc.}

53. American Academy of the History of Dentistry. President: Van B. Dalton, 116 Garfield Place, Cincinnati, Ohio. Term expires 1961. Exccutive Secretary: Milton B. Asbell, 25 Hadden Avenue, Camden, N. J. Term expires 1961.

History: Organized as a national society in IV ashington, D. C., 1950.

Purpose: Research activities in the history of dentistry.

Membership: Limited to individuals interested in the purpose of the organization. Total membership approximately 125 .

Mcetings: Annual.

Publications: Bulletin, monthly.

54. American Academy of Tuberculosis Physicians. P. O. Box 7011, Denver 6, Colo. Secretary: George P. Bailey. Term indefinite. Mo.

History: Organized June 1935 at Kansas City,

Purpose: To alleviate the sufferings of the tuberculous and eradicate tuberculosis through scientific pursuits; to elevate the standard of physicians specializing in tuberculosis and allied diseases and to designate those qualified according to the best scientific and practical information available.
Membership: Graduation from Class A medical school, experience and training in tuberculology, thoracology, and allied diseases.

Meetings: Annual.

Professional activitics: Gold Key awards. Certificates of Honor. Excellate awards to very select group.

Publications: Tuberculology, irregular, $\$ 6$. Editor: H. J. Corper.

55. American Alpine Club. 113 East 90th Street, New York 28, N. Y. President: Robert H. Bates, 153 High Street, Exeter, N. H. Term expires December 1961. Executive Secretary: Lawrence G. Coveney, 199 Oak Ridge Avenue, Summit, N. J. Term expires December 1961.

History: First meeting, Washington, D. C., January 2, 1903: incorporated in Pennsylvania, December 30, 1915.

Purpose: Scientific exploration and study of higher mountain elevations and of regions within or about the Arctic and Antarctic Circles; cultivation of mountain craft; promotion and dissemination of knowledge regarding such regions.

Membership: Requirements: Active, mountain ascents acceptable to Board of Directors; exploration in Arctic or Antarctic; contributions to the science of mountaineering, recent glaciology, or alpine art, considered by Board of Directors to be of permanent importance in advancing knowledge of these subjects; minimum age twenty years. Honorary, preeminent distinction in mountaineering, exploration, or research; election by unanimous vote of Board of Directors. Honorary members exempt from dues and assessments but possess privileges of active memberhip except right to vote, propose or second candidates, or hold office unless elected from active membership. Active members, 527; Honorary, 8. Total membership 535.

Meetings: Annual.

Profcssional activities: Assistance given to various expeditions in respect to mountain exploration and geological research.

Publications: American Alpine Journal, annual, current volume: $12, \$ 3$, members $\$ 2$. Accidents in American Mountaineering, annual, $\$ 0.25$, free to members. American Alpine Club News, bimonthly, $\$ 1.50$, free to members. Editor: Adams H. Carter.

Library: 6,600 volumes. Subject emphasis: Mountaineering.

56. American Animal Hospital Association. President: Wayne H. Riser, 3511 Kent Street, Kensington, Md. Term expires April 1961. Executive Secretary: Frank R. Booth, 3920 East Jackson Boulevard, Elkhart, Ind. Term indefinite. 
History: Founded 1933 as an association of animal hospitals.

Purpose: To provide the best possible veterinary service and hospital facilities for the care and treatment of animal pets; to advance the professional interests of veterinarians engaged in hospitalization of animals; to maintain high standards of hospital facilities.

Membership: Requirenents: A hospital building, suitably constructed and maintained for proper housing of small animals, subject to annual inspections to guarantee proper maintenance, and managed by a director complying with Code of Ethics of the profession.

Mectings: Annual.

Professional activities: Annual scientific convention, six regional scientific meetings; Moss Essay Award to senior veterinary student; Morris Memorial Animal Foundation Award for research; Veterinarian of the Year Award; special awards.

Publications: Bulletin, bimonthly, members only. Editor: Frank R. Booth.

\section{American Anthropological Association. 1530}

P Street, N. W., IVashington 5, D. C. President: Margaret Mead, American Museum of Natural History, 77th Street and Central Park West, New York 24, N. Y. Term expires November 20, 1960. Exccutive Secretary: Betty J. Meggers. Term indefinite.

History: Incorporated 1902, at Washington, D. C. ; reorganized 1947, as a professional association.

Purpose: To advance all branches of science of anthropology and further professional interest of American anthropologists.

Membcrship: No requirements for members except dues payments; Fellows must be professional anthropologists with qualifications approved by Executive Board. Fellows, 771; Members, 2,130; Library Subscribers, 1,050. Total nembership 3,951.

\section{Mectings: Annual.}

Publications: American Anthropologist, bimonthly, current volume: $62, \$ 8.50$ to members, institutional subscribers $\$ 11.75$. Editor: Edward H. Spicer. Fellow Newsletter, ten annually, current volume: 1, \$2. Editor: Betty J. Meggers.

\section{American Association for Cancer Research,}

Inc. President: Murray J. Shear, National Cancer Institute, Bethesda 14, Md. Term expires April 8, 1961. Exccutiz' Secretary: Iunh J. Creech, Justitute for Cancer Research, 7701 Purholme Avenue, Fox Chase, Philadelphia 11, Pa. Term indefinite.
History: Organized May 7, 1907 ; incorporated 1940 in New York. Two local sections, Southwest and Chicago.

Purposc: Association of research workers for presentation and discussion of new and significant observations and problems in cancer; to foster cancer research.

Membership: Active: persons having at least two years of meritorious research resulting in publications clearly relevant to cancer, residence in the Americas. Honorary: distinguished scientists and others contributing significantly to advance of cancer research. Emeritus: those sixty-five years of age, active members ten years or longer. Corresponding membership open to qualified persons not residents of the Americas. Active, 1,011; Honorary, 9; Emeritus, 39; Corresponding, 7. Total membership 1,066 .

Mectings: Annual.

Publications: Cancer Research, monthly, current volume: $20, \$ 15$. Editor: Harold P. Rusch, University of $\mathrm{W}$ isconsin, Madison, Wis.

59. American Association for Cleft Palate Rehabilitation. President: Samuel Pruzansky, University of Illinois, 840 South Wood Street, Chicago 12, I11. Term expires May 1961. Sccretary-Treasurer: Betty Jane McWilliams, Children's Hospital, Pittsburgh 13, Pa. Term expires May 1961.

IIistory: Organized 1942 ; incorporated October 8, 1951. Committees: Medical; Dental; Para-Medical-Dental.

Purpose: To promote the science and art of relabilitation of persons with cleft palate and associated deformities; to encourage scientific research in the causes of cleft palate and cleft lip; to encourage cooperation among and stimulation of specialists interested in rehabilitation of cleft palate persons; to stimulate public interest in and support of this activity.

Membership: Open to persons possessing degrees in dental surgery, dental medicine, medicine, philosophy, or education, and possessing recognized professional certificates in this field. This is an inter-disciplinary organization, made up of qualified people concerned with patient nanagement. Total membership 600 .

Mectings: Annual.

Publications: Cleft Palate Bulletin, quarterly, \$3. Editor: Ernest H. Hixon, State University of Iowa, Iowa City, Iowa.

60. American Association for Health, Physical Education, and Recreation. 1201 16th Street, N. M.. Mashington 6, D. C. President: Minnie I. Lymn, Bouve Boston School, Tufts Uni- 
versity, Bedford, Mass. Term expires March 1961. Exccutive Secretary: Carl A. Troester, Jr. Term indefinite.

History: Organized 1885 as Association for the Advancement of Physical Education; name changed in 1886 to American Association for the Advancement of Physical Education, in 1903 to American Physical Education Association, in 1937 to American Association for Health and Physical Education, and in 1938 to present title. Association is a department of National Education Association. Sections: Six District Associations: Central ; Eastern; Midwest ; Northwest: Southern; Southwest. State Associations in fifty States, Puerto Rico, and the District of Columbia. Drvisions: Health Education; Physical Education; Recreation Education: Girls' and W'omen's Sports; Men's Athletics; Safety and Driver Education; General. Forty-eiglit sections based on special interest groups.

Purpose: To promote and improve education in health, safety, physical training, athletics, and recreation in schools, colleges, and communities; to interpret the ains and purposes of these areas to teachers, allied professional groups, and the public; to raise standards of preparation and encourage and assist in research; to encourage national and international cooperation in the subject fields.

Mcmbership: Professional, 13,000, and Life, 200, professionals in subject fields; Student, 7,000 , enrolled for professional preparation in subject fields. Total membership, including institutional subscriptions, 25.000.

Mectings: Annual.

Professional actiarities: Funds are allocated in varying amounts to the Research Council of the Association and to other sections. Honor Awards: William G. Anderson Award: Luther H. Gulick Award.

Publications: Journal, monthly except June, July, and August, current volume: 31 , free to menhers: subscription $\$ 10$, available to institutions and libraries only. Research Quarterly, current volume: 31, free to members; subscription $\$ 5$, available to institutions and libraries only. Editor: Nancy H. Rosenberg.

\section{American Association for Rehabilitation}

Therapy, Inc. 12020 Joan Drive, Pittsburgh 35, Pa. President: Robert B. Miller, 362 East Loucks Street, Sheridan, Wyo. Term expires July 15, 1961. Policy Board Chairman: Joseph H. MacQueen. Term expires July 15, 1961.

History: Organized September 14, 1950 at Topeka, Kans. Sections: Manual Arts Therapy; Educational Therapy; Industrial
Therapy; Medical Coordinators or Directors; Recreation Therapy; Volunteer Directors; Special Teachers. Nineteen chapters throughout the United States, National Boards: Convention; Editorial: Fiscal; History; Policy; Rehabilitation Careers. Natronal CommitTEEs :Editorial ; Education; Legislation; Liaison; Membership; Nominations; Public Relations Research.

Purpose: To promote the use of curative and technical modalities within the scope, philosopluy, and approved medical concepts of rehabilitation; to advance its practice; to establish and advance the standards of education and training of rehabilitation therapists; to encourage and further research; to cooperate with other organizations in the realization of common objectives.

Membership: Active: bachelor's degree or equivalent in a field applicable to rehabilitation therapy, and work as reluabilitation personnel under the direction of a plysician in pursuance of a medical objective as prescribed and supervised by him, or work in an administrative, advisory, or therapeutic capacity; physicians qualify as active members. Student: enrollnent in an accredited college in a course applicable to rehabilitation therapy. Associate members, those not qualified for active or student memberslip. Active. 473; Student, 3; Associate, 43. Total nembership 519.

Mectings: Annual; biannual meetings in each cliapter.

Professional actirities: Joseph F. Harris Award, aunual, presented to the member who does the most for professional advancement of the Association: Long Term Service Award, anmual, Edgar E. Best Award, annual, for best scientific exhibit in Manual Arts Therapy; "Wise Owl" Award, for best professional paper published by a member; Registry of Medical Rehabilitation Therapists and Specialists (chartered).

Publications: American Archives of Rehabilitation Therapy, quarterly, current volunse: \&, \$3. Editor: Hollis J. McCoy, 3725 West 10th Street, Topeka, Kans. Rehabilitation Therapy Bulletiu, four to eight times per year, current volume: 10, free to members. Editor: Joseph H. MacQueen. Directory of Registered Rehabilitation Therapists and Specialists, annual. current volume: $6, \$ 2$. Registrar: Joseph F. Harris.

62. American Association for Textile Technology, Inc. Presidcnt: Cameron A. Baker, Better Fabrics Testing Bureau, 101 West 31st Street. New lork 1, N. Y. Term expires January 1961. Exccutive Secretary: Bernice S. Bronner, 100 West 55th Street, New York 19, . \. I. Term indefinite. 
History: Organized 1934; incorporated 1945.

Purpose: To encourage in the broadest and most liberal manner the advancement of textile technology in all its branches; to promote interchange of professional knowledge among members of this Association and between this Association and other technical societies, associations, and organizations; to stimulate fraternal intercourse among technologists; to provide means for the diffusion of the knowledge of textile technology; to consider the establishment and promulgation of standards.

Membership: Regular membership, open to those graduates of accredited colleges or textile technical schools of collegiate rank who are engaged in the technical branches of the textile and affiliated industries, who at time of application for membership are pursuing the profession of technologist and have had two years of textile technical experience. In lieu of graduation from a college or textile technical school of collegiate rank, applicant must have had at least five years of practical experience in the technical branch of the textile or affiliated industries and must be qualified as a technologist at the time of application for membership. Total membership 944.

Mectings: First Wednesday of each month, except July and August.

Professional activities: Plaques awarded annually in June to the best textile graduate in each of ten accredited textile schools.

\section{American Association for the Advancement}

of Science. 1515 Massachusetts Avenue, N. W., Washington 5, D. C. President: Thomas Park, University of Chicago, Chicago, 111. Term expires December 1961. Executive Officer: Dael Wolfle. Term indefinite.

Mistory: Founded 1848 in pursuance of a resolution adopted at Boston, September 1847, by the Association of American Geologists and Naturalists to resolve itself into the American Association for the Advancement of Science; incorporated March 1874. Sections: A, Mathematics; B, Physics; C, Chemistry; D, Astronomy; E, Geology and Geography; F, Zoological Sciences; G, Botanical Sciences; $H$, Anthropology; I, Psychology; K, Social and Economic Sciences; L, History and Philosophy of Science; M, Engineering; N, Medical Sciences; Nd, Dentistry; Np, Pharmacy; O, Agriculture; P, Industrial Science; Q, Education. Divisions: Alaska Division, members resident in Alaska, and others who meet the Division's requirements; Pacific Division, members resident in British Columbia, IVashington, Oregon, California, Idaho, Nevada, Utah, Hawaiian Islands, and Montana west of the Continental Divide; Southwestern and Rocky
Mountain Division, members resident in Arizona, New Mexico, Colorado, Sonora, Chihuahua, Texas west of the 100th meridian, Wyoming, and Montana east of the Continental Divide.

In June 1960, there were two hundred and ninety-one scientific organizations which were officially affiliated with the Association. Affiliated organizations have representatives in the council of the Association and take part in the direction of its affairs. Of the affiliated organizations, forty-six are academies of science, two hundred and forty-five are other societies.

Purpose: To further the work of scientists, to facilitate cooperation among them, to improve the effectiveness of science in the promotion of human welfare, and to increase public understanding and appreciation of the importance and promise of the methods of science in human progress.

Membership: Sustaining members; Life menbers; Annual members, separated into Members and Fellows, the latter being those who have made meritorious contributions to science. Total membership about 60,000 .

Mectings: Annual. The Southwestern and Rocky Mountain Division annual meeting is held in the Spring; the Pacific Division annual meeting is held in June; and the Alaska Division annual meeting is usually held in September. The AAAS Gordon Research Conferences are held each Summer at the Colby Junior College, New London, N. H., New Hampton School, New Hampton, N. H., and Kimball Union Academy, Meriden, N. H., to stimulate research in universities, research foundations, and industrial laboratories.

Professional activities: General Endowment Fund, capital in 1960 about $\$ 506,000$, income approximately $\$ 39,000$. Newcomb Cleveland Prize of $\$ 1,000$, established in 1923 , is awarded each year to a person presenting a noteworthy contribution to science at the annual meeting of the Association. This paper must be presented at the meeting, though the author need not be a member of the Association. AAAS Prize in Sociology of $\$ 1,000$, funds provided for this purpose by an anonymous friend of the Association, to be awarded annually for a paper or book using successfully methods of the natural sciences in the field of sociology. Theobald Smith Award of $\$ 1,000$, established in 1937 by Eli Lilly and Company, for a distinguished contribution to medical science by a person under 35 years of age. Other grants awarded through state academies of science.

Publications: Science, weekly, current volume: $131-132, \$ 8.50$, free to members. Editor: Graham DuShane. 
64. American Association for the History of Medicine, Inc. Smithsonian Institution, Washington 25, D. C. President: Chauncey D. Leake, Ohio State University, Columbus 10, Ohio. Term expires 1962. Secretary: John B. Blake. Term expires 1961.

History: Founded 1925 ; incorporated in New lork State as nonprofit membership corporation; acts as United States and Canadian Section of International Society of the History of Medicine. Sections: Twenty-seven constituent societies. Committens: Bibliography; Teaching of History of Medicine; Research in American Medical History.

Purpose: To encourage a high standard of interest in the history of medicine, including the history of public health, dentistry, pharmacy, nursing, medical social work, and allied subjects.

Membership: Active: requires residence in the United States or Canada, and interest in history of medicine. Active Members, 550 ; Nonresident Members, 20; Honorary, 8; Constituent Societies, 27.

\section{Meetings: Annual.}

Professional activities: William H. Welch Medal, for contributions of outstanding scholarly merit in medical history; William Osler Medal, for student prize essay; Fielding $H$. Garrison Lecture; preparation of annual bibliography in history of medicine in United States and Canada.

Publications: Bulletin of the History of Medicine, bimonthly, current volume: 34 , free to members. Editor: Owsei Timken, Johns Hopkins School of Medicine, Baltimore 5, Md.

65. American Association for the Study of Neoplastic Diseases. President: Norman N. Steinberg, Royal Oak, Mich. Term expires July 1961. Executive Secretary: Bruce H. Sisler, National Cancer Institute, Research Grants Branch, Bethesda, Md. Term expires July 1961.

History: Organized in 1932 at Johns Hopkins University.

Purpose: To bring together the pathologists, radiologists, surgeons, and other members of the specialties most concerned in the treatment of neoplastic diseases; to continue the study of such diseases.

Membership: Limited to individuals with degrees of doctor of medicine or doctor of dental surgery, with an interest in the scientific study of neoplasia. Total membership 160.

Mectings: Annual.

Professional activities: Maintains a tumor registry; holds the Joseph Colt Bloodgood Lecture annually.
66. American Association for the Surgery of Trauma. President: Harrison L. McLaughlin, 180 Fort Washington Avenue, New York 32, N. Y. Term begins October 1960.

History: Organized June 14, 1938, at San Francisco, Calif.

Purpose: Cultivation and improvement of the science and art of surgery of trauma and allied sciences.

Membership: Members of state or provincial societies with ten years' practice limited to surgery or allied specialties, certified by American Board of Surgery or specialty board with which identified, who are Fellows of American College of Surgeons or of one of the Royal Colleges, and have contributed to medical literature. Active members, 250; Senior, 140; Honorary, 16. Total membership 406.

\section{Meetings: Annual.}

Publications: Journal of Surgery, bimonthly. Editor: Charles G. Johnston, 1401 Rivard Street, Detroit, Mich.

\section{American Association for Thoracic Surgery,}

308 Carondelet Building, 7730 Carondelet Avenue, St. Louis 5, Mo. President: John H. Gibbon, Jr., Philadelphia, Pa. Term expires April 1961. Secretary: Hiran T. Langston.

Term expires April 1961.

History: Organized 1917 in New York City at a meeting of the New York Society for Thoracic Surgery.

Purpose: To encourage and stimulate investigation and study that will increase the knowledge of intrathoracic physiology, pathology, and therapy; to correlate and disseminate such knowledge.

Membership: Active: individuals who have been associate members, elected for distinction in thoracic field or meritorious contribution to knowledge pertaining to thoracic disease and surgical treatment. Associate: individuals having an active interest in thoracic disease as a practitioner, teacher, or investigator. Senior: individuals who have been active members for not less than ten years, active members who have passed the age of sixty or who have become incapacitated by illness. Honorary: persons who have rendered distinguished service to the profession. Active, 271; Associate, 176; Senior, 86; Honorary, 9. Total membership 542.

Meetings: Annual.

Professional activities: Sponsorship and support of the Evarts A. Graham Memorial Traveling Fellowship, open to young thoracic surgeons from Europe, to bring a well trained thoracic surgeon from abroad to this country for additional experience and training in a center of his choice. 
Publications: Journal of Thoracic and Cardiovascular Surgery, monthly, current volume: 39, $\$ 20$. Editor : Emile Holman.

68. American Association of Anatomists. President: Edward W. Dempsey, School of Medicine, Washington University, 4580 Scott Avenue, St. Louis 10, Mo. Term expires March 24, 1961. Secretary-Treasurer: Louis B. Flexner, Department of Anatomy, School of Medicine, University of Pennsylvania, Philadelplia 4, Pa. Term expires spring 1964.

History: Organized September 17, 1888 at Washington, D. C. as the Association of American Anatomists, in affiliation with the Congress of American Physicians and Surgeons; name changed to present title December 29, 1909. Committees: Motion Pictures; Journal Trust Fund; Anatomical Nomenclature.

Purpose: Advancement of anatomical science. Mcmbership: Members must be engaged in the investigation of anatomical or cognate sciences, with the equivalent of an M.D. or Pl.D. degree, and at least one publication on an anatomical subject. Total membership 1300.

Mectings: Annual, each year at a different medical school, at the invitation of a department of anatomy or biology.

Professional activitics: Journal Trust Fund, approximately $\$ 19,800$, for assistance in publication or original research in anatony.

Publications: American Journal of Anatomy, bimonthly, current volume: 105-106, \$15. Editor: Donald Duncan. Anatomical Record, montlily, current volume: 134-136, \$22.50. Editor: Charles M. Goss.

69. American Association of Bioanalysts, 490 Post Street, San Francisco 2, Calif. President: William G. Gilleland, 1216 Pennsylvania Avenue, Fort Worth, Tex. Term expires July 1, 1961. Excutive Secretary: Lucien D. Hertert. Term expires July 1, 1961.

History: Formed 1956 by a merger of The Council of American Bioanalysts and The National Association of Clinical Laboratories. Incorporated under the laws of California. Organized into four regions, each of which holds scientific meetings throughout its geographic area.

Purpose: To provide for a common meeting place of individuals teaching and applying the bioanalytical sciences; to encourage research into all phases of bioanalytical tests and testing; to diffuse analytical knowledge that student, teacher, analyst, and the health of the general public be benefited by these efforts.

Membership: Active, open to scientistdirectors of clinical laboratories, 480 ; Honorary, 3. Total membership 483.
Mectings: Annual, rotating through the four regions.

Professional activities: Margaret Beattie Lecture, annual; Herbert Johnstone Memorial Fund; maintenance of Central Standards Laboratory.

Publications: Abstracts of Bioanalytic Technology, quarterly, current volume: 8, \$9. Editor : H. B. McDaniels. Bulletin, quarterly, current volume: 4, free. Editor: Lucien D. Hertert.

Library: A slide library of permanent specimens.

70. American Association of Blood Banks. 30 North Michigan Avenue, Chicago 2, 111 . President: John R. Schenken, Nebraska Methodist Hospital, 3612 Cuning Street, Omaha, Nebr. Term expires October 27, 1961. Manager. Central Office: Miss Lois I. James. Term indefinite.

History: Founded November 19, 1947, at Dallas, Tex. Central Office established in Chicago March 3, 1958.

Purpose: To furnish guidance and advice on problems in establislment and administration of blood banks, provide information regarding schools offering blood bank training, and distribute informative material on blood banking.

Mcmbcrship: Individual memberslip open to any person interested in blood banking and transfusion therapy. Associate institutional nembership open to hospitals and clinics which do not operate blood banks. Institutional membership open to ethical institutions, including those operated by American Medical Association registered hospitals engaged in blood banking. Total membership, including both individual and institutional, approximately 3,000 .

Mectings: Annual.

P'rofessional activities: John Elliott Award; Landsteiner Award.

Publications: Bulletin, monthly current volume: 13, \$5. Editor: Kurt Stern. In January 1961 the Bulletin will be discontinted and replaced by a new scientific journal, Transfusion, bimonthly, members $\$ 6$, nonmembers $\$ 8$. Editor: T. J. Greenwalt.

\section{American Association of Botanical Gardens} and Arboretums. 1632 Chestnut Street, Philadelphia 3, Pa. President: John E. Voight, Nlfred L. Boemer Botanic Garden, 5819 Soutl 92nd Street, Hales Corners, WVis. Term expires Octoher 1961. Secretary: Carl IV. Fenninger, P. O. Box 216, Lima, Pa. Term expires October 1961.

History: Organized September 1940.

Purpose: To promote the interests of botan- 
ical gardens and arboretums, and public, including municipal, interest in living plants.

Mcmbcrship: Requirement for voting memberslip: association with a botanic garden or arboretum. Associate membership: no special requirement. Total membership 160 .

Mectings: Annual.

Publications: Newsletter, quarterly, free to nembers.

\section{American Association of Cereal Chemists,} Inc. 1955 University Avenue, St. Paul 4, Minn. President: John A. Johnson, Kansas State University, Manhattan, Kans. Term expires April 1961. Executive Secretary: Raymond Tarleton. Term indefinite.

History: Founded May 8, 1915, at Kansas City, Mo. Merged with the American Society of Milling and Baking Technology March 28, 1923. Sections: Northwest; Pioneer; Kansas City; Nebraska; Central States; Niagara Frontier; Pacific Northwest; Midwest; New York; Lone Star; Toronto; Cincinnati; Canadian Prairie; Northern California; Southern California; Chesapeake. Commitrees: Fifteen Association Committees, thirty-five Technical Comnittees.

Purpose: To encourage and advance scientific and technical research in cereals and their products, particularly milling and baking, but including other industries utilizing cereals and products; to study analytical methods used in cereal chemistry and develop and adopt uniform or standard methods of examination and analysis; to promote spirit of scientific cooperation among workers in field of cereal knowledge and maintain high professional standards in Association as conditions of membership; to encourage more general recognition of the chemist and biologist as essential factors in development of cereal industries.

Membcrship: Active: Individuals having B.S. degree or four years in recognized institution, or minimum of two years chemistry and four years practical experience; Sustaining: individuals interested in or concerned with use of cereals or cereal products; Corporate: corporations interested in or concerned with use of cereals or cereal products. Total membership 1,300 .

\section{Meetings: Annual.}

Professional activities: Thomas Burr Osborne Medal, awarded at irregular intervals for distinguished contributions to field of cereal chemistry; established 1926.

Publications: Cereal Chemistry, bimonthly, current volume: $37, \$ 15$. Editor: $\mathrm{W}$. F. Geddes. Cereal Science Today, monthly except June and August, current volume: 5, \$3. Editor: Paul E. Ramstad.
73. American Association of Clinical Chemists, Inc. Lebanon Hospital, New York 57, N. Y. President: Arnald 11 are, Los Angeles County Hospital, Los Angeles, Calif. Term expires June 30, 1961. Executioc Secretary: Robert L. Dryer. State University of lowa, lowa City, Iowa. Term expires June 30 , 1962.

History: Organized December 15, 1948; incorporated in New York State. Sections: Metropolitan New York; Boston; Philadelphia; Chicago; Washington - Baltimore - Richmond; Southern California; Midwest; Upper New York.

Purpose: To raise the level of clinical chemistry, stimulate development of new methods, and maintain a forum for discussion and exchange of ideas.

Membership: Fellows, 145, require certification by American Board of Clinical Chemistry; Members, 650 , require $\mathrm{Ph} . \mathrm{D}$. degree and one year's experience, or Master's degree with three years' experience, or Bachelor's degree with five years' experience: Associate members, 144: Honorary, 6, by vote of Executive Committee. Total membership 875 .

Mectings: Anuual.

Professional activities: Ames Award, formerly the Ernst Bischoff Award, annual, $\$ 1,000$, scroll, and medal.

Publications: Clinical Chemist, bimonthly, current volume: $12, \$ 5$. Editor: H. D. Appleton.

\section{American Association of Colleges of Chiro-} pody-Podiatry. 926 IVest Lehigh Avenue, Philadelphia 33, Pa. President: Donald V. Anderson. Term expires August 1961. Executive Secrctary: L. C. Numbers. Term expires August 1961.

History: Founded August 2, 1232, by representatives of California College of Chiropody, Chicago College of Chiropody, Illinois College of Chiropody, First Institute of Podiatry, Ohio College of Chiropody, and School of Chiropody of Temple University.

Purpose: To improve the quality of chiropodical education.

Mcmbership: Colleges must be accredited by the Council on Education of the American Podiatry Association.

Metings: Annual.

Publications: Journal, monthly, current volume: 50, \$10. Editor: A. Rubin.

Library: 3301 16th Street, N. IN., Washington, D. C. 1,000 volumes. Subject emphasis: chiropody. 
75. American Association of Colleges of Pharmacy. 833 South Wood Street, Chicago 12, 111. President: Henry M. Burlage, University of Texas, College of Pharmacy, Austin, Tex. Term expires July 1961. Secretary-Treasurer: Charles W. Bliven, George Washington University, School of Pharmacy, IVashington 6, D. C. Term expires July 1961.

History: Organized May 1900 as the American Conference of Pharmaceutical Faculties; name changed to present title August 1924.

Purpose: To promote pharmaceutical education and research.

Membership: Active, 76: college must have its full curriculum in operation and must be accredited by the American Council on Pharmaceutical Education; affiliate, 3: must be a nember of the Canadian Conference of Pharnraceutical Faculties.

Mectings: Annual.

Professional activities: Annual seminar for teachers in the professional areas of instruction, with a general teaching seminar every third year.

Publications: American Journal of Pharmaceutical Education, quarterly, current volume: 24, \$5. Editor: Melvin R. Gibson, Washington State University, Pullman, Wash.

76. American Association of Correctional Psychologists. President: Raymond R. Gilbert, Massachusetts Department of Correction, 120 Tremont Street, Boston 8, Mass. Term indefinite. Executive Secretary: Sheldon B. Peizer, Federal Correctional Institution, Ashland, Ky. Term indefinite.

History: Organized September 1953 as a special interest group under Division 18 (Psychologists in Public Service) of the American Psychological Association, with the name Socity of Correctional Psychologists. Name changed to present title in 1957 and the Association became an affiliate of the American Correctional Association.

Purpose: To further application of psychological knowledge to solution of correctional problems, and to work toward improved standards for psychological services in the correctional field.

Membership: Professional: Members of American Psychological Association presently employed in correctional work; Affiliate: psychologists, not members of American Psychological Association, who are employed or interested in field of correction. Professional members, 78; Affiliate members, 38. Total membership 116

Meetings: Annual.
Publications: Journal of Correctional Psychology, quarterly, current volume: $4, \$ 5$ (included in dues). Editor: Sheldon B. Peizer.

77. American Association of Cost Engineers. c/o University of New Hampshire, Durham, N. H. President: Bernard J. Gaffney, Wood Conversion Co., St. Paul, Minn. Term expires December 31. 1960. Executive Secretary: Edward D. Shanken, 32 Garden Lane, Durham, N. H. Term permanent.

History: Founded June 2, 1956 at a meeting at the University of New Hampshire. CommitTEES : Admissions; Awards; Bibliography; Capital Cost Control; Capital Cost Estimating; Coordinating; Cost Index; Education; Membership; Operating Cost Estimating and Control; Planning; Profitability; Publications; Publicity; Regional Activities. Sections: Boston; Chicago; Cleveland; Houston; New York; Philadelphia; Pittsburgh; San Francisco; Baton Rouge; Detroit; Kansas City; Los Angeles; Miami; Seattle; South Charleston, W. Va.; St. Paul; Montreal; Ontario; Essex, England.

Purpose: To advance the science and art of cost engineering; to provide forums and media through which experiences with the principles and techniques of cost engineering may be reported, discussed, and published for the common good; to promote standardization of terminology in cost engineering and so far as practicable develop standard methods; to encourage instruction in cost engineering in standard engineering curricula; to cooperate with other organizations having common interests.

Membership: Members, 807, engaged in cost engineering and either graduates of a recognized engineering curriculum, with at least five years of experience in a responsible position, or holders of a license to practice Professional Engineering, or having had at least ten years of experience in the engineering profession, at least seven of which were in a responsible position; Associates, 64, persons interested in cost engineering who do not qualify for membership; Students, 6, engineering students regularly enrolled in a college or university. Total membership 877.

\section{Mectings: Annual.}

Professional activities: AACE Award of Merit, to recognize outstanding service in cost engineering; active encouragement and participation in undergraduate and graduate courses in cost engineering in colleges and universities.

Publications: Bulletin, quarterly, current volume: $2, \$ 5$, free to members. Editor: Edward D. Shanken. 
78. American Association of Criminology, Inc. P. O. Box 5, Hanover, Mass. President: John D. Allan, 13 Lewis Park, Rockland, Mass. Term expires November 1961. Secretary: Wayne A. Laitinen. 894 Main Street, RFD 2. Hanover, Mass. Term expires November 1961.

History: Organized in 1953 as a private voluntary socicty; enlarged in 1955 and chartered as a private non-profit professional organization; affiliated with the International Criminological Society; holds membership in the Fourth International Criminological Congress; has affiliated chapters in the United States and in foreign countries.

Purpose: The adrancentent of the science of criminology.

Mcmbership: Must be actively engaged in some field of criminology as a full-time profession, or must be a graduate of an accredited institution of higher learning with a major in criminology. Total membership approximately 500 .

Mectings: Anuual.

Publications: Registered Criminologist Newsletter, irregular, free to members.

Library: Approximately 1,000 rolumes.

79. American Association of Dental Schools.

840 North Lake Shore Drive. Chicago 11,

I11. President: Raymond J. Nagle, College of Dentistry, New York University, 421 1st Avenue, New York 10, N. Y. Term expires March 1961. Secretary-Treasurer: Reginald H. Sullens. Term indefinite.

History: Organized 1923 hy amalgamation of the American Institute of Dental Teachers, the National Association of Dental Faculties, the Faculties' Association of American Universities, and the Canadian Faculties' Association.

Purpose: To promote dental education and research.

Membership: Requirements: Active, any dental school in the United States or Canada classified as approved school by Council on Dental Education of either the American or the Canadian Dental Association. Provisional, any newly established dental school which is an integral part of an accredited college or university in the United States, including Puerto Rico, or Canada. Associate, any cducational institution which regularly offers a course in any or all auxiliary aids to dentistry, but does not offer course of instruction leadiug to dental degree, provided offered courses are approved by Councils on Dental Education of American and Canadian Dental Associations; entitled to all privileges of Association except right to vote. Affiliate, U. S. Air
Force, Army, Navy, Public Health Service, and Veterans Administration, and comparable agencies of Canadian Government, provided agency gives regular postgraduate courses of instruction duly authorized by law or regulation and maintained by duly appropriated Government funds, and further provided such courses do not lead to degree in dentistry. Honorary, for outstanding service to mankind or contributions to art and science of dentistry, or exceptional service to Association. Active members, 48: Provisional, 5; Associate, 5; Affiliate, 5. Total membership 63.

Mectings: Annual.

Professional actizities: Honorary Membership Award.

Publications: Journal of Dental Education, quarterly, current volume: 24, \$3. Editor: Marion $\mathrm{W}$. McCrea. Proceedings, annual, current volume: $37, \$ 2$. Editor: R. H. Sullens.

80. American Association of Endodontists. President: Paul P. Sherwood, 2165 Adelbert Road, Cleveland 6, Ohio. Term expires February 1961. Secretary: Edwin C. Van Valey, 9 Rockefeller Plaza, New York 20, N. Y. Term expires February 1961.

History: Organized 1943; incorporated 1955 in Illinois. Sections: United States; Canada : Mexico; Cuba; Chile; Argentina; Brazil ; England; France; Israel; Switzerland. Conmittees: Research; Nomenclature; Essay; Clinic; Library. Sponsors: American Board of Endodontics.

Purpose: To promote interchange of ideas on methods of pulp conservation and endodontic treatment; to stimulate research; to help maintain high standards of endodontic practice in the dental profession.

Membership: Dentists who are menbers of a recognized national dental association in their country of residence and who have proved interest in endodontics. Total membership 675 .

Mcetings: Annual.

Publications: Newslctter, quarterly, subscription included in annual dues. Editor: Harry J. Healey, 1121 West Michigan St., Indianapolis, 2. Ind. Section in Journal of Oral Pathology, Oral Surgery and Oral Medicine.

81. American Association of Engineers. 8 South Michigan Avenue, Cliicago 3, I1l. President: Patrick J. Lucey, 216 South LaGrange Road, LaGrange, Ill. Term expires October 1960. Exccutive Secretary: M. E. McIver. Term expires October 1960.

History: Founded June 1915.

Purpose: To promote the social and economic wclfare of the professional engineer. 
Hembership: Open to any engineer in any field, or of any grade; student engineers. Total memberslip 6,490 .

Mectings: Monthly.

Professional activitics: Scholarships; student boans. Clausen Medal awarded to person contributing the most to the engineering profession during a specified time.

Publications: Professional Engineer, quarterly, \$1.50. Editor: M. E. McIver.

Library: Over 1,800 volumes on engineering.

82. American Association of Feed Microscopists. c/o Missouri Department of Agriculture, Jefferson City, Mo. President: Mlbert J. Gehrt, Moorman Manufacturing Co., Quincy, I11. Term expires June 1961. Secretary-Treasurer: G. M. Barnhart. Term inrlefinite.

History: Organized 1953 at the University of Kentucky. Distributed throughout the United States, Canada, and Mexico. Committees include: Check Sample; Methods; Publications ; Controversial Sample.

Purpose: To study and advance the science of feed nicroscopy.

Membership: Open to qualified feed microscopists or to persons showing an interest in feed microscopy. State Control Departments, 30: Feed and other Industrial Manufacturers, 100.

Mectings: Annual.

\section{American Association of Genito-Urinary}

Surgeons. President: Carl Rusche, 1400 Nortl Vermont Avenue, Los Angeles 27, Calif. Term expires 1961. Secretary-Treasurer: William J. Engel, Cleveland Clinic, 2020 East 93rd Street, Cleveland 6, Ohio. Term expires 1961.

\section{History: Organized October 16, 1886.}

Purpose: To promote scientific advancement in treatment of diseases of the genito-urinary tract.

Membership: By invitation to urologists who have demonstrated leadership in study of genitourinary diseases. Active members, 66; Fellows, 40. Total nembership 106.

\section{Meetings: Annual.}

Professional actiritics: Keyes Medal, for outstanding contribution to urology; Parringer Medal, for outstanding contribution to control of malignant diseases of genito-urinary tract.

Publications: Transactions, annual, current volume: 51. Editor: J. A, C. Colston.

84. American Association of Immunologists. President: Albert H. Coons, Harvard Medical
School, 25 Shattuck Street, Boston 15, Mass. Term expires 1961. Secretary-Treasurer: Calderon Howe, Columbia University College of Physicians and Surgeons, 630 West 168th Street, New York 32, N. Y. Term expires 1962.

\section{History: Organized 1914.}

Purpose: To advance knowledge of inmunology and related disciplines, and to facilitate interchange of ideas and information among investigators in the various fields.

Membership: Open to any qualified person engaged in the study of problems related to the purpose of the Association. Ictive members, 543; Emeritus, 31.

\section{Mectings: An11ual.}

Publications: Journal of Immunology, monthly, current volume: $84, \$ 15$.

\section{American Association of Industrial Dentists.}

Pennsylvania Department of Health, P. O. Box 90, Harrisburg, Pa. President: Robert B. Nemeroff, 475 th Avenue, New York N. Y. Term expires April 26, 1961.

History: Organized February 1943. Fostered by, and cooperating closely with, the American Dental Association. Closely allied with other national industrial health organizations: American Association of Industrial Physicians and Surgeons, American Industrial Hygiene Association, American Association of Industrial Nurses, Anerican Conference of Government Industrial Hygienists.

Purpose: To sponsor the study and discussion of oral health as related to industrial health, productivity, and safety; to promote standardization of methods for conservation or improvement of oral health among persons in industries; to initiate preventive industrial dental procedures; to promote a more general understanding of purposes and results of dental health care of persons in industry; to encourage development of new industrial oral health programs and promote mutual understanding witl other industrial hygiene persomnel.

Mcubcrhip: Active: dentists who are members of the American Dental Association officially engaged in practice or promotion of an industrial dental program and wlio devote a substantial part of their practice to treatment of industrial injuries. Associate: persons engaged in investigation, consultation, or promotion in connection with industrial health. Sustaining: any individual, group, association, company, corporation, or agency who displays interest in the improvement of industrial dental health by contributing financial support to the Association. Total membership 148 . 
Meetings: Semiannual in December and April.

Publications: Transactions of annual meetings, which include all scientific papers presented during the sessions.

86. American Association of Industrial Nurses, Inc. 170 East 61st Street, New York 21, N. I. President: Margaret L. Steele, 2838 Lawndell Drive, Brentwood 17, Mo. Term expires April 1961. Exccutive Dircctor: Ella G. Casey. Term indefinite.

History: Organized 1942. Seventy-eight local and State constituent associations in the United States. Several permanent and various special committees.

Purpose: To constitute the professional association of nurses engaged in industrial practicc: to maintain the honor and character of the nursing profession; to improve community healtl by bettering nursing service to workers: to develop and promote standards for industrial nurses and nursing services; to stimulate interest in and provide a forum for discussion of problems in the subject field; to stimulate nembership participation in all nursing activities, local, State, and national.

Membership: Active: registered nurses en ployed full time in commerce, industry, or in conserving the health of employed workers, or nursing consultants and nurse educators who devote full time to field of industrial nursing. Inactive: former Active Members who have retired from industrial nursing and are not engaged in other nursing activity. Associate: nurse educators, nurse editors, nurse writers, or other nurses who evidence sufficient interest in industrial nursing. Patron: persons, agencies, organizations, or companies interested in promoting the purpose of this Association. Active Members, approximately 4,400; Inactive and Associate Members, approximately 100 . Total membership approximately 4,500 .

Mcetings: Annual.

Professional activitics: Margaret Currie Achievement Award and Christina Sinkula Achievement Award, presented amually for outstanding educational programs and community activities; Winifred Hardiman Scholarship Fund, maintained to provide loans for graduate industrial nurses desiring courses in nursing leading to baccalaureate or higher degrees.

Publications: Journal, monthly, current volume: 8, \$6. Editor: Gertrude A. Stewart.

\section{American Association of Jesuit Scientists} (Eastern States Division). Presidcnt: Clarence Schubert, Fordham University, New Jork 58, N. Y. Term expires September 1961. Scrotary: Joln Kinnier, Boston College,
Chestnut Hill 67, Mass. Term expires Septeniber 1963.

History: Organized 1922. Sectıons: Biology, Chemistry, Mathematics, Physics, Science, and Philosophy.

Purpose: To promote the study and teaching of science in Jesuit high schools, colleges, and universities.

Membership: Open to Jesuits teaching the sciences or otherwise engaged in scientific work in the eastern Atlantic states. Total membership 271.

\section{Mectings: Annual.}

Publications: Bulletin, quarterly, current volmue: 37 , free. Editor: Bernard A. Fiekers.

\section{American Association of Medical Clinics.} P. O. Box 58, Charlottesville, Va. President: Russel V. Lee, Palo Alto Medical Clinic, 300 Homer Avenue, Palo Alto, Calif. Term expires October 1960. Executive Director: Edwin P. Jordan. Term indefinite.

\section{History: Founded 1949.}

Purpose: To elevate standards of practice, improve graduate medical education, pronote research and exchange of ideas and experiences.

Membership: A clinic, for full membership, must lave seven or more full-time physicians in different specialties, two of which shall be internal medicine and general surgery. Total membership 135 clinics, with approximately 3,000 physicians.

Meetings: Annual.

Publications: Group Practice, monthly, current volume: 8 , \$8. Editor: Edwin P. Jordan.

89. American Association of Medical Milk Commissions, Inc. 405 l.exington Avenue, New York 17, N. Y. Prosident and Chairman of the Council: James P. Conway. Term expires May 1961. Secretary: Charles Speaks. Term expires May 1961.

History: Organized 1907. CommitteEs: Methods and Standards for Production of Certified Milk; Containers and Closures; Research.

Purpose: To provide methods and standards for the production of milk as fine, nutritious, and clean as possible, approved by the medical profession. Methods and standards are changed annually to keep current with nutritional science and dairy technology.

Membership: Open to Medical Milk Comnussions appointed by county or state medical societies or by public health officials. Total memhership approximately 450.

Mectings: Annual.

Publications: Methods and Standards for Production of Certified Milk, annual. Certified Milk Magazine, every other month, $\$ 1.50$. 
90. American Association of Medical Record Librarians. 840 North Lake Shore Drive, Chicago 11, 111. President: Elizabeth Price, Presbyterian-St. Luke's Hospital, Chicago, 111. Term expires October 1960. Executive Director: Doris Gleason. Term indefinite.

History: Organized October 1928, in Boston, Mass., under sponsorship and guidance of Imerican College of Surgeons.

Purpose: To improve quality and efficiency of medical records in hospitals, clinics, and other health and medical institutions; to establish standards and criteria of competency and promote the education of medical record librarians; to improve and develop teaching and practice of medical record library science.

Membership: Active: registered medical record librarians. Associate: persons engaged in medical record work who are unregistered, or student medical record librarians, or student medical record technicians. Inactive: members no longer engaged in medical record work. Honorary. Total membership 4,486.

\section{Meetings: Annual.}

Professional activities: Institutes for medical record personnel approximately six times a year ; annual workshop for directors of approved schools.

Publications: Journal, bimonthly, current volune: 31 , one year $\$ 3$, two years $\$ 5$. Editor: Doris Gleason.

91. American Association of Museums. Sinithsonian Institution, Washington 25, D. C. President: Froelich G. Rainey, University Museum, Philadelphia, $\mathrm{Pa}$. Term expires May 1961. Director: Joseph A. Patterson. Term indefinite.

History: Organized May 1906 in New York; headquarters established at Smithsonian Institution, Washington, D. C., May 1923. Six regional conferences.

Purpose: To promote the welfare of museums and the the museum profession; to increase and diffuse knowledge relating to them, and to provide national representation; to provide useful services for the membership and for those interested in museums.

Membership: Institutional nembership, 711, includes all types of museums, art centers, historic houses and societies, planetariums, zoos, aquariums, botanical gardens, and libraries holding special collections and exhibitions other than books. Individual membership, 1,679, open to museum trustees, members of the museum profession, and individuals interested in ninuseums.

Meetings: Annual.
Publications: Museum News, ten issues annually, \$10. Editor: Edward T. McClellan.

\section{American Association of Neuropathologists.}

President: Richard Richter, Division of Neurology, University of Chicago, Chicago 37, Ill. Term expires June 1961. SecretaryTreasurer: Leon Roizin, 722 West 168th Street, New York 32, N. Y. Term expires June 1961.

History: Organized 1924 as the Club of Neuropathologists, name changed to present title 1932.

Purpose: To advance the science of neuropathology.

Membersiip: Active, 130, graduates in medicine who have specialized in neuropathology and who have contributed meritorious work in neuropathology; Associates, 16, persons who, though not graduates in medicine, lave meritoriously contributed to the scientific field of neuropathology; Honorary, 1 distinguished investigator in neuropathology. Total membership 147.

Meetings: Annual.

93. American Association of Nurse Anesthetists. 3010 Prudential Plaza, Chicago 1, I11. President: Mrs. Evelyn E. Auld, 1800 Forest Road, Durham, N. C. Term expires September 1961. Secretary: Florence A. McQuillen. Term indefinite.

History: Organized June 1931, in Cleveland as the National Association of Nurse Anesthetists; incorporated in Ohio March 1932. Headquarters moved from Cleveland to Clicago in 1937. Incorporated in Illinois and name changed to present title in 1939. Comprises forty-nine state associations and eight assemblies, following groupings of the Hospital Association Assemblies.

Purpose: To advance the science and art of anesthesiology and to develop educational standards and techniques in the administration of anesthetics.

Membership: Active, 8,841, active registered nurses who have taken a 12-montl course with qualifying examination; inactive, 1,205, with the qualifications for active membership but not engaged in work with anesthetics; lonorary nember, 1. Total membership 10,047.

Meetings: Annual, concurrently with American Hospital Association.

Publications: Journal, bimonthly, current volume: 28, \$5. News Bulletin, bimonthly, current volume: 14. Editor: Bernice O. Baum. 
94. American Association of Obstetricians and Gynecologists. Secretary: Clyde L. Randall, 100 Meadow Road, Buffalo 16, N. Y. Term expires 1962.

\section{History: Organized 1888.}

Purpose: The cultivation and promotion of knowledge in whatever relates to obstetrics and gynecology.

Membership: Fellows, must be citizens of a country in the Western Henisphere and have completed medical school training and one year's internship at least ten years prior to election; nust be recommended by one or more of the Fellows, and have read an original paper or formally discussed a paper at an annual session by invitation of the Executive Council; Enseritus Fellows, any Fellow who has served the Association as an Active Fellow for twenty ycars or more. Total nembership 200 .

Mcetings: Annual, in September; Clinical, i11 March.

Professional activities: Association Foundation Prize, awarded for the gathering, promotion and dissemination of theoretical and practical knowledge upon subjects of obstetrics and gynecology, capital $\$ 20.000$.

Publications: Transactions, annual, current volume: 70 (1959), \$13.50. Editor: Clayton T. Beecham, Assistant Secretary, 105 Schoolhouse Lane, Philadelpliia $14, \mathrm{~Pa}$.

95. American Association of Orthodontists. 225 South Meramec Avelue, Clayton 5, Mo. President: William R. Humphrey, 1232 Republic Building, Denver, Colo. Term expires April 16, 1961. Secretary-Treasurer: Earl E. Shepard. Term expires April 1962.

History: Organized 1900 as American Society of Orthodontists and incorporated February 1917: present name adopted 1937. Cosstituext Societies: General Section, Great Lakes, Middle Atlantic, Northeastern, Pacific Coast, Rocky Mountain, Southern, Southwestern.

Purpose: To promote the art and science of orthodontics; to adopt rules and regulations for their government and code of ethics.

Membership: Persons in exclusive practice of orthodontics who are members of local, State, and national dental organizations, have practiced five years, and have completed orthodontic courses of 1.500 or more hours. Total membership 2,084 .

Meetings: Annual.

Professional activities: Milo Hellman Award; Ketcham Award; Mershon Award.

Publications: American Journal of Orthodontics, monthly, current volume: $46, \$ 10$. Editor: H. C. Pollock.
96. American Association of Orthoptic Technicians. University of California at Los Angeles, Medical Center, Los Angeles 24, Calif. President: Miss Frances Fowler. Term expires October 1960. Executive Secretary: Miss Julie Mimms, Mississippi Optical Dispensary, Medical Arts Building, Jackson, Miss. Term expires October 1961.

History: Organized 1940.

Purpose: To maintain orthoptic standards and promote related knowledge.

Membership: Requires certification by American Orthoptic Council. Total membership 265.

Meetings: Annual.

Professional actizities: Malter B. Laucaster Award, established 1953, in recognition of outstanding contribution to ortloptics, for a technique, paper, or book, or for teaching or leadership.

Publications: American Orthoptic Journal, annual, current volume: $9, \$ 2$.

97. American Association of Osteopathic Colleges. Kirksville College of Osteopathy and Surgery, Kirksville, Mo. President: Joseph M. Peach, Kansas City College of Osteopathy and Surgery, 2105 Independence Avenue, Kansas City 24, Mo. Term expires July 1961. Secretary: J. S. Denslow. Term expires July 1961.

History: Established in June, 1898, in Kirksville, Mo., as The Associated Colleges of Osteopathy; name changed in 1941 to present title.

Purpose: To established and maintain a high standard of osteopathic education and to advance osteopathic knowledge.

Membership: Accreditation as an osteopatlic college by the American Osteopathic Association. Total nembership six colleges.

Metings: Semiannual.

98. American Association of Pathologists and Bacteriologists. President: Douglas H. Sprunt, Institute of Pathology, University of Tennessee, 858 Madison Avenue, Memphis, Tenu. Term expires December 31, 1960. Assistant Secretary: Jack P. Strong, School of Medicine, Louisiana State University, New Orleans, La. Term indefinite.

History: Organized 1900.

Purpose: Advancement of the knowledge of disease.

Membership: Active members must be $110 m i-$ nated by two members of the Association, accompanied by evidence of accomplishment of creditable research in pathology or bacteriology. 
Active, 960; Emeritus, 20. Total memberslip 980.

Mcctings: Annual, usually in April.

Professional activities: Gold-Headed Cane, awarded to members distinguished in their fields and held for life or until the holder desires to pass it on.

Publications: American Journal of Pathology, monthly, current volume: $36, \$ 10$. Editor: Edward A. Gall, Department of Pathology, Cincinnati General Hospital, Cincinnati 29, Ohio.

99. American Association of Petroleum Geologists. P. O. Box 979, Tulsa 1, Okla. President: Ben H. Parker, 4040 East Louisiana Avenue, Denver, Colo. Term expires April 27, 1961. Executive Director: Robert H. Dott.

History: Organized at Tulsa, February 10, 1917, as the Southwestern Association of Petroleum Geologists; name changed to present title in 1918; incorporated in Colorado, April 1924; domesticated in Oklahoma, February 1925. SEcTions: Pacific, Rocky Mountain, Eastern. Divisions: Paleontology and Mineralogy.

Purpose: To promote the science of geology, especially relating to petroleum and natural gas ; to promote technology of petroleum and natural gas, and to encourage improvements in methods of exploring for and exploiting these substances: to foster spirit of scientific research among members; to disseminate facts relating to the Association's fields of interest.

Membership: Active members, 10,687, must be college graduates with majors in geology and must have 3 years experience in petroleum geology or in application of geology to exploration, development, research or other phases of petroleum technology: Associate, 1,001, college graduates in allied sciences with 3 years experience; Junior. 3,658, must have one-half year of graduate study in geology as regularly enrolled student, or bachelor's degree plus 1 year experience, and be engaged in graduate studies, teaching, or petrolum exploration or research: Honorary, 36; Life, 38. Total membership 15,420.

Mectings: Annual.

Professional activitics: Funds specially allocated as needed. Powers Medal. awarded for outstanding achievement in petrolenm geology. President's Award, $\$ 100$, to author, under 35 year of age, of most significant article in the monthly Bulletin during year. Distinguished Lectures, bringing outstanding speakers on geology to affiliated societies on self-supporting, nonprofit basis.

Publications: Bulletin, monthly, current volume: $44, \$ 18$, free to members. Editor: Grover E. Murray, Louisiana State University, Baton Rouge, La.
100. American Association of Physical Anthropologists. President: Walter IV. Greulich, Stanford University, Palo Alto, Calif. Term expires 1961. Secretary-Treasurer: T. Dale Stewart, United States National Museum, Washington. D. C. Term expires 1964.

\section{History: Organized 1928.}

Purpose: To promote research, publication, teacling, and study in physical anthropology; to encourage cooperation with anatomists, physiologists, biologists, plysicians, dentists, and scholars in various brances of anthropology in this and other countries.

Membership: Candidates must be sponsored by two members and must have a scientific background and training applicable to the study of biological man. Total membership over 400 .

\section{Meetings: Annual, in the spring.}

Professional acticities: Viking Fund Medal and Prize in Physical Anthropology, $\$ 1,000$ per year; to be discontinued after 1961.

Publications: American Journal of Physical Anthropology, quarterly, current volume: 18, $\$ 10$ domestic, $\$ 11$ foreign, free to nembers. Editor: IV. S. Laughlin, Department of Anthropology, University of $\mathrm{W}$ isconsin.

\section{American Association of Physics Teachers.}

American Institute of Physics, 335 East 45th Street, New Jork 17, N. I. President: I. O. Olsen, Case Institute of Technology, Cleveland, Ohio. Term expires February 1961. Secretary: Frank Verbrugge, University of Minnesota. Term expires February 1961.

History: Organized December 1930. SEcTIons: Appalachian; Central Pennsylvania; Chesapeake; Chicago; Colorado-IVyoming; Eastern Pennsylvania; 11linois; Indiana; Kentucky; Michigan; Minnesota; New England; Northern California; Oregon; Southern California; Texas; Western Pennsylvania; Mashington; Wisconsin; Puerto Rico. CommitTEES: Awards; Taylor Memorial; Visual Aids; Relations with Secondary Schools; Physics in Engineering Education.

Purpose: Advancement of teaching of physics and furtherance of appreciation of the role of physics in our culture.

Membership: Regular nembership restricted to teachers of physics in institutions of college and university grade, and teachers of physics in secondary schools who have demonstrated an active interest in the objectives of this Association, and such other persons as the council may deem likely to contribute materially to its objectives. There may be elected as junior members only college or university students who have a major interest in physics and who have completed at least two 1-year college physics 
courses. Regular members, 3,945; Junior, 921 ; Emeritus, 48; Honorary, 5. Total membership 4,919.

Meetings: Annual, in January or February. Summer, in June. Regional meetings.

Professional actizitics: Oersted Medal, awarded for notable contributions to teacling of physics. Richtmyer Memorial Lecture. Stbsidy for annual lecturer selected each year by Committee action. Award to high schools for superior physics teaching.

Publications: American Journal of Physics, monthly, current volume: 28, $\$ 7.50$. Editor: IV. C. Michels.

\section{American Association of Plastic Surgeons.}

President: Herbert Conway, 525 East 68th Street, New York 21, N. Y. Term expires May 21. 1961. Secrefary-Treasurer: Thomas D. Cronin, 6615 Travis Street, Houston 25. Tex. Term expires May 21, 1961.

History: Organized July 28, 1921, as American Association of Oral Surgeons; name clianged in 1934 to American Association of Oral and Plastic Surgeons, and in 1942 to present title. Sections in the Uniterl States and Canada.

Purposc: To stimuate and advance knowledee of the science and art of plastic surgery and thereby to improve and elevate the standard of practice of this specialty.

Mcmbership: Active Fellows. S\&, by invitation only, must be certified by American Roard of Plastic Surgery; Senior Fellows, 30, all Ictive Fellows who have attained the age of sixty-five, and Active Fellows who have been members for twenty years and are recommended by Board of Trustees and confirmed by members: Honorary Fellows, 7. Total nembership 125.

Mectings: Annual.

103. American Association of Psychiatric Clinics for Children. 250 west 57 th Street, New York 19. N. Y. President: Othilda Krug. 3140 Harvey Avenue, Cincinnati 29, Ohio. Term expires spring 1961. Secretary: Mrs. Geraldine J. Korda, 322 West 21st Street. Los Angeles 7, Calif. Term expires spring 1961.

History: Organized 1946. Charter member clinics formally ratified plan for national association, 1948. Organization stemmed from former Division of Community Clinics of the National Committee for Mental Hygiene. CosrMitTtees: Maintenance of Membership Standards, Membership. Training in Child Psychiatry.

Purpose: To provide coordination of activities of psychiatric clinics serving children in the United States, its territories, and Canada.

Mcmbership: Active members, 117 ; Associate, 11; Inactive, 1. Of total number of nember clinics (active), 54 are approved training centers. In Active member shall be a clinic whose basic service is psychiatric work with children and whose basic discipline is psychiatry, working in collaboration with psychiatric social work and psychology, and which meets standards set up for this classification of membership by the Association. An Associate member shall be elected for a period not to exceed 3 years, during which it shall have opportunity to qualify, by developing its standards, for Active nembership. An lnactive member shall be a clinic which has been found by the Committee on Maintenance of Membership Standards to have ceased to meet membership qualifications. Total membership 129 clinics.

Mectings: Annual.

Publications: Newsletter, quarterly. Editor Phyllis D. Schaefer.

\section{American Association of Public Health} Dentists. President: David B. Ast, New York State Health Department, 84 Holland Avenue. Albany 8, N. Y. Term expires October 15. 1960. Secretary-Treasurer: Charles L. Howell, 1330 West Michigan Street, Indianapolis, Ind. Term expires 1961.

\section{History: Organized 1937.}

Purpose: To promote dental public health, maintain the ideals of organized dentistry in all public health projects, and afford opportunity for constructive discussion of administrative problems of dental health programs.

Nombership: Requires interest and engagement in dental public health. Total nembership 178.

Meetings: Annual.

Publications: Bulletin, quarterly, current volume: $20, \$ 2$. Editor: Harry Draker.

105. American Association of Railway Surgeons. 5800 Stony Island Avenue, Chicago 37, I11. President: Walter D. Abbott, 900 Des Moines Building, Des Moines, Iowa. Term expires April 15, 1961. Secretary: Carl I. Werelius. Term expires April 15, 1961. Executive Secrctary: Frank Parker, 59 East Van Buren Street, Chicago 5, Ill. Term indefinite.

History: Founded June 28, 1888, as National Association of Railway Surgeons; incorporated in Illinois, April 13, 1897 ; membership enlarged in 1898 to include surgeons in Canada and Mexico, and name changed to International Association of Railway Surgeons, which in turn was changed to present title. 
Purpose: Promotion and improvement of railway surgery.

Mcmbership: Active nembers, degree of doctor of medicine, membership in American or Canadian Medical Associations, and professional activity in some pluase of medicine or surgery for the railroad industry. Total membership 3,100 .

Mcctings: Annual.

Publications: Industrial Medicine and Surgery, monthly, current volume: 29 , free to memhers. Editor: Carey P. McCord, 605 North Michigan Avenue, Chicago, 111.

106. American Association of State Highway Officials. 917 National Press Building. Washington 4, D. C. Presidcnt: David H. Stevens, Chairman, State Highway Commission of Maine, Augusta, Me. Term expires December 2. 1960. Exccutive Secretary: A. E. Johnson. Term indefinite.

History: Founded 1914. Organized in four sections by geographical regions. CommıtTeE: Standards.

Purpose: To foster the development, operation, and maintenance of a nation-wide integrated system of highways to serve adequately the transportation needs of the country.

Mcmbership: Membership is by Highway Department. Full-time employees of a member department are termed active members. Member departments, 53.

Mcctings: Annual.

Professional activities: George Bartlett Award, given in cooperation with the American Road Builders' Association and the Highway Research Board, to some individual who has made an outstanding contribution to highway progress. Twenty-Five Year Award of Merit, given to employees nominated by the Chief Administrative Officer of the member Departments, who have completed twenty-five years of service. Thomas H. MacDonald Award, to a person having been employed by one or more member organizations of the Association for a period of at least five years who has rendered continuous outstanding service over an extended period of time or has made some exceptional contribution to the art and science of highway engineering.

Publications: American Highways, quarterly, current volume: 39 , domestic $\$ 2$, foreign, $\$ 3$. Editor: A. E, Johnson.

107. American Association of Texile Chemists and Colorists. Exccutive Sccretary: George P. Paine, A ATCC National Headquarters, P. O. Box 28, Lowell, Mass. Term permanent.

Mistory: Organized November, 1921 ; incorporated (Massachusetts) $1929 . \quad$ SECTions :
Northern New England; Rhode Island: Western New England; Metropolitan New York: Hulson-Molnawk: Mestern New York: Delaware Valley : IV ashington; Piedmont : South Central; Southeast: Midwest; Pacific Northwest: Pacific Southwest. Student Chapters: Lowell Technological Institute; Philadelphia Textile Institute: North Carolina State College; New Bedford Institute of Textiles and Technology: Auburn University: Georgia Institute of Technology: Clemson College: Bradford Durfee Technical Institute. CommitteE: Research.

Purposc: To promote the increase of knowledge of the application of dyes and chemicals in the textile industry: to encourage in any practical way research work on chemical processes and materials of importance to the textile industry : to establish for the members clannels by which interchange of professional knowledge among them may be increased.

Mcmborship: Senior members, twenty-six years or over and with five years experience in the industry: Junior members, lacking the required years but connected with the industry: Associate members; Student menhers, enrolled in a course of study leading to Senior requirements: Corporation members, supporting the research of the Association. Senior, 5765; Junior, 153: Associate, 928; Student, 172; Corporations, 298. Total membership 7316.

Mectings: Annual general meetings; section meetings.

Professional actiritics: Olney Medal, awarded ammually for achievement in textile chemistry; American Dyestuff Reporter Award, annual, $\$ 200$, for published paper.

Publications: American Dyestuff Reporter, fortnightly, free to members. Technical Manual, $\$ 6.50$, free to members.

Library: 2,000 volumes.

108. American Association of Variable Star Observers. 4 Brattle Street, Cambridge 38 , Mass. Prcsidcut: Ralph N. Puckstaff, 2119 Main Street, Oshkosh, Wis. Term expires October 1960. Dircctor: Mrs. Margaret II. Mayall. Term indefinite. Exccutiz' Secretary: Clinton B. Ford, Loomis Road, Suffield, Conn. Term indefinite.

History: Organized in 1911, incorporated in 1917. Committees and Divisions : Nova Search, Occultations, Photoelectric Photometry, Solar.

Purpose: To promote the study of variable stars, astronomy, and kindred subjects.

Membership: Annual, 380; Students, under twenty-one years of age; honorary, 8 , outstanding service to the Association; Patron, 2; Sustaining, 39; Life, 61; Library and Observatory 
Subscriptions, 27; Observing Contributors and Exchanges, 180. Total membership 697.

Metings: Semiannual.

Professional activities: Nova Medal, for the discovery of a nova by visual methods; Merit Award, for outstanding work for the Association; researcl headquarters maintained in Cambridge with staff of three.

Publications: Reports of Variable Star Observations, quarterly, current volume: $24, \$ 2.50$. Editor: Margaret IV. Mayall. Solar Bulletin, monthly, \$5. Editor: Harry L. Bondy.

Library: 2,000 volumes. Subject emphasis: Astronomy.

\section{American Association of Veterinary} Nutritionists. President: Roy E. Nichols, Veterinary Science Department, University of Visconsin, Madison, Wis. Term expires August 1961. Secretary: Spencer H. Morrison, 515 Woodlands Drive, Clinton, Iowa. Term expires August 1961.

\section{History: Organized 1956.}

Purpose: To promote veterinary interest in and understanding of animal nutrition, provide a concerted means for discussion and exchange of information, and promote cooperation between veterinarians and others who share responsibility for maintaining optimum animal health through adequate nutrition.

Mcmbcrship: Full members, 125, actively engaged in field of nutrition; Associate, 27, open to all interested members of American Veterinary Medical Association; membership in latter organization is prerequisite to all membership in this Association. Total membership 152.

Meetings: Annual.

\section{American Association of Zoological Parks} and Aquariums. Executive Secretary: Alfred B. LaGasse, Oglebay Park, Wheeling, W. Va. Term permanent.

History: Organized October 1942. Affiliated with American Institute of Park Executives. Committees: Importations, Exportations, and Quarantine; Aquariums; Health and Welfare; Planning and Construction.

Purposc: To promote zoological parks, aquariums, and conservation; to aid in the exchange and importation of zoological specimens; to provide exhibits for scientific and recreational purposes; to aid in the preservation of wild life.

Membership: Senior officer of public zoo or aquarium; owner of private animal park. Total membership 200.

Mectings: Annual.

Publications: Parks and Recreation, monthly,
\$3. Editor: Alired B. LaGasse. Newsletter, monthly.

111. American Association on Mental Deficiency, Inc. P. O. Box 96, Willimantic, Conn. President: Edward L. Johnstone, Woods School, Langhorne, Pa. Term expires May 1961. Secretary-Treasurer: Neil A. Dayton, Mansfield Training School, Mansfield Depot, Conn. Term indefinite.

History: Organized June 1876 ; name clanged 1933 from American Association for Study of the Feebleminded to present title. Eleven geographic regions in the United States and Canada.

Purpose: To study all phases of cause, care, treatment, and prevention of mental deficiency, and education of the mentally deficient.

Membership: Fellows, Active Members, Associate Members, Affiliate Members, Students. Total membership 5,017.

Mectings: Annual, in May; regional, in fall.

Publications: American Journal of Mental Deficiency, bimonthly, current volume: $65, \$ 14$. Editor: II illiam Sloan.

112. American Astronautical Federation. President: Norris R. Peery, P. O. Box 487, Fairbanks, Alaska. Term expires 1961. Executive Secretary: Leon M. Slawecki, office of Senator Joseph Clark, Washington 25, D. C. Term expires 1961 .

History: Organized July 4, 1954. Member societies: Chicago Rocket Society; M. I. T. Rocket Research Society; Pacific Rocket Society, Los Angeles; Detroit Rocket Society; Philadelphia Astronautical Society; Reaction Research Society, Glendale, Calif.; member societies also in Boise, New Orleans, Salt Lake City.

Purpose: To advance space flight in the United States by furthering technical cooperation among member societies, aiding them to educate public in accepting space flight as a rational and necessary project.

Mcmbership: Active members, approximately 400 ; Associates, approximately 600; Subscribers, approximately 500 . Requirements and dues set by individual societies. Total membership approximately 1,000 .

\section{Mectings: Annual.}

Professional activities: Publication of results of research conducted by members. CommitTEE: Technical Coordination; furnishes general assistance to members.

Publications: Journal of Space Flight, quarterly. Editor: Gary L. Bennett, 1107 North 16th Street, Boise, Idaho. 
113. American Astronautical Society. 516 th Avenue, New York 36, N. Y. President: George Arthur, General Electric Company, 3198 Chestnut Street, Philadelphia, Pa. Term expires December 31, 1960. Exccutive Secretary: Fernand F. Martin, Radio Corporation of America, Front and Cooper Streets, Camden, N. J. Term expires December 31, 1960.

History: Organized January 22, 1954 ; incorporated February 17, 1954, in New York.

Purpose: To promote and support scientific research in the varied scientific and engineering fields related to astronautics, and to present findings to the public.

Membership: Fellows, persons at least twenty-five years of age with college degree or large amount of relevant scientific or industrial experience or who have made a contribution to the subject; Members, minimum eighteen years of age; Student Members, less than eighteen years of age. Total membership 1,000.

Mectings: Semiannual.

Publications: Journal of the Astronautical Sciences, quarterly, \$5. Editor: R. E. Roberson. Astronautical Sciences Review, quarterly, \$4. Editor: R. Merrick. Proceedings. Editor Horace Jacobs.

114. American Astronomical Society. Dearborn Observatory, Northwestern University, Evanston, 111. President: Lyman Spitzer, Jr., Princeton University Observatory, Princeton, N. J. Term expires August 1962. Secretary: J. Allen Hynek. Term expires Jnne 1961.

History: Organized 1897 as a conference of astronomers; name changed 1899 to the Astronomical and Astrophysical Society of America; name changed to present title 1914.

Purpose: Advancement of astronomy and closely related branches of science.

Membership: Open to any person deemed capable of preparing an acceptable paper upon some subject of astronomy or related branch of science; however, membership is generally limited to second year graduate students and professional people. A subscription to the Astronomical Journal or the Astrophysical Journal is required of all menbers over twentyseven years of age. Life Membes ship has been discontinued and no more are elected to this category; Corporate Members (two types, Regular and Sustaining), open upon invitation to organizations whose activities are related to astronomy; Emeritus Membership, open to any member on retiring from his academic or other duties. Members, approximately 1,100; Life, 150 ; Corporate, 20; Emeritus, 3. Total membership approximately 1,273.

Mectings: Normally three national meetings per year, usually at a college or an observatory.

Professional activities: Ernest IV. Brown Fund, in support of the Astronomical Journal; Dorothea K. Roberts Fund and the Kovalenko Fund, used as specified by the Council; Annie J. Cannon Prize, established 1933, awarded every three years to women for distinguished contribistions to astronomy or closely related sciences. open to women of all countries; Henry Norris Russell Lectures, annual, first given December, 1946; Helen B. Warner Prize, to encourage research by younger members of the Society. awarded annually unless a suitable candidate is not found.

Publications: Astronomical Journal, irregular, \$8. Society is also associated with the Astrophysical Journal, bimonthly, \$15.

\section{American Automatic Control Council.} President: John C. Lozier, Bell Telephone Laboratories, Whippany, N. J. Term expires June 1961. Secretary-Treasurcr: William E. Vannah, Editor, Control Engineering, 330 IVest 42nd Street, New York 36, N. I. Term expires December 1960.

History: Formed in 1956. Commitees: Applications, Bibliography, Components, Education, Publicity, Terminology, and Steering Committee for annual Joint Automatic Control Conference.

Purpose: To promote cooperation among the various technological societies in the United States that have an active interest in theory and practice of control engineering; to provide representation in affairs of the International Federation for Antomatic Control which will faithfully reflect technical opinion and society policy in the United States.

Mcmbcrship: Requires that organization be a professional scientific or engineering society in which a division or group is actively engaged in control engineering, that its request for membership be approved by at least two thirds of the delegates representing the constituent societies of the Council, and that its headquarters be in the continental United States. Total membership 5 societies.

\section{Meetings: Quarterly.}

Professional activitics: A $\$ 100$ award for best presentation of a suitable paper at the Joint Automatic Control Conference.

116. American Blood Irradiation Society. President: R. C. Olney, 4740 F Street, Lincoln 10, Nebr. Term expires May 31, 1961. SecretaryTreasurer: H. T. Lewis, Jr., 1241 Peermont Avenue, Pittsburgh 16, Pa. Term expires May 31, 1961. 
History: Organized June 8, 1947; incorporated September 13, 1948, in Delaware.

Purpose: To encourage the study, maintain and improve the standards, and advance the knowledge of ultraviolet blood irradiation in accordance with the Knott technique.

Membership: Open to members of American Medical Association, or corresponding associations of other countries. Total nembership approximately 70 .

Meetings: Annual.

Publications: News Letter, quarterly, free to nembers. Editor: H. T. Lewis, Jr.

\section{American Board for Psychological Ser-} vices, Inc. Glendale, Ohio. President: Karl F. Heiser, 10 East Sharon Avenue, Glendale, Ohio. Term indefinite. Secretary-Treasurer: W'endell S. Dysinger, MacMurray College, Jacksonville, 11t. Term indefinite.

History: Established 1954 by the American Psychological Association as an independent body with the functions of recommending standards of competence and quality for agencies and individuals who offer psychological services to the public, publishing a directory of voluntary applicants who meet the Board's standards, and evaluating and certifying agencies and individuals who seek registration with the Board.

Purpose: To inform the public how to discriminate between competent and well-qualified psychological services, and those which do not meet professional and scientifically acceptable standards; and to inform the public and the related professions through the Director where the services of competence and quality may be obtained.

Membership: Six elected members. Services of 201 agencies and individuals in the United States and Canada have been evaluated and approved. Agency requirements: must have chief psychologists who have doctoral degrees in psychology and four years of approved, supervised experience in professional work. Individuals in private, independent practice must be Diplomates of the American Board of Examiners in Professional Psychology; Diplomate must have been examined by that Board in the field of his specialized knowledge, and must have had extensive experience as a psychologist.

Meetings: Semiannual.

Publications: Directory of American Psychological Services, biennial, $\$ 1.50$.

118. American Board of Bio-Analysts. 81 East Front Street, Red Bank, N. J. President: Melvin S. Chuker, 2530 East Broadway, Tucson, Ariz. Term expires June 15, 1963. Secretary: IVilliam H. Krieger, 5407 56th Place, East Riverdale, Md. Term indefinite.
History: Incorporated in New Jersey, August 18, 1959. Registered at Washington, D. C., October 20, 1959.

Purpose: To certify qualified bio-analysts in one of 13 sciences pertinent to practice of bioanalysis; to conduct seminars and publish scientific papers.

Mcmbership: Requires baccalaureate degree and ten years' practice. Admission by examination only. Total membership 272.

Mectings: Annual.

Professional activities: American College of Bio-Analysts. Awards: Dean Emeritus, Professor Emeritus, Philosopher Emeritus.

\section{American Board of Laboratory Animal} Medicine. President: B. D. Fremming, 1887 Saw Mill Run Boulevard, Pittsburgh, Pa. Term expires December 31, 1962. SecretaryTreasurer: R. J. Flynn, Argonne, 111. Term expires December 31, 1962.

History: Incorporated 1957. Affiliated with the Animal Care Panel 1960.

Purpose: To encourage education, training, and research in Laboratory Animal Medicine; to establish standards of training and experience for qualification of specialists in Laboratory Animal Medicine; and to further the recognition of such qualified specialists by suitable certification and other means.

Membership: Fellows, 51, veterinarians of good moral character who meet the requirements, training, and experience set by the Board, and who have satisfactorily completed the Board examination and been elected by a majority vote of all Council members; Associate, 14, veterinarians who have had at least three years postgraduate experience in Laboratory Animal Medicine and who can meet all prerequisites for the Board examination excepting the advanced training and experience requirements.

Mectings: Annual.

Professional activities: Examination and certification of specialists.

\section{American Board of Neurological Surgery.}

300 Longwood Avenue, Boston 15, Mass. Chairman: E. Jefferson Browder, 200 Hicks Street, Brooklyn 1, N. Y. Term expires September 1962. Secretary-Treasurer: Donald D. Matson. Term expires September 1964.

History: Incorporated 1940.

Purpose: To conduct investigations and examinations to determine the competence of voluntary candidates for certificates issued by the Board; to grant and issue certificates of qualification to candidates successful in demonstrating proficiency; to stimulate development 
of adequate training facilities; to aid in evaluating residencies and fellowships under consideration by the Council on Medical Education and Hospitals of the American Medical Association; to advise physicians desiring certification as to course of study and training to be pursued.

Membership: Published once a year in detail in the Internship and Residency Number, Journal of the American Medical Association. Total membership 875 .

Meetings: Examinations held each spring and fall.

121. American Board of Ophthalmology. P. O. Box 236, Cape Cottage Brancl, Portland, Maine. Chairman: Kenneth C. Swan, Department of Ophthalmology, University of Oregon Medical School, Portland 1, Oreg. Term expires December 1960. Executive Secretary: Merrill J. King. Term expires December 1960.

History: Organized in 1916 as the American Board for Ophthalmic Examinations, with three representatives from the American Ophthalmological Society, the Section on Ophthalmology of the American Medical Association, and the American Academy of Ophthalmology and Otolaryngology; name changed later to present title; incorporated May 1917; reorganized in 1934 so that each component society elects four members, with one elected each year to serve a four-year term.

Purpose: To elevate the standards of ophthalmology, to determine the competence of ophthalmologists who desire certification, to conduct examinations for candidates who appear before the Board and to issue certificates to those who pass, to act as advisors to prospective students of ophthalmology.

Membership: Members selected by the component societies, 12; consultants, 4; emeritus members, 4. Total membership 20.

Mectings: Semiannual.

122. American Board of Pathology. Indiana University School of Medicine, Indianapolis 7, Ind. President: William B. Wartman, 303 East Chicago Avenue, Chicago 11, I11. Term expires December 31, 1960. Secretary: Edward B. Smith, 1200 West Michigan Street, Indianapolis 7, Ind. Term expires December 31,1960 .

History: Organized and incorporated 1936 in Michigan. Initially supported by American Medical Association and American Society of Clinical Pathologists. Subsequently supported also by College of American Pathologists, American Association of Pathologists and
Bacteriologists, and American Society for Experimental Pathology.

Purpose: To determine proficiency of physicians specializing in practice of pathology.

Membcrship: Requires M. D. degree, license to practice medicine, and special training in pathology as approved by Council on Medical Education and Hospitals of American Medical Association and by this Board. Twelve members (institutions ), 4,000 diplomates.

Metings: Seniannual.

Professional activities: Awards certificates for proficiency in pathology.

\section{American Board of Preventive Medicine.} 3438 Walnut Street, Philadelphia 4, Pa. President: Ernest L. Stebbins, Dean, Johns Hopkins School of Hygiene and Public Health, Baltimore 5, Md. Term expires June 1961. Secretary-Treasurer: Tom F. Whayne, Associate Dean, School of Medicine, University of Pennsylvania, Philadelphia, Pa. Term expires June 1962.

History: A non-profit corporation formed upon recommendation of a joint committee composed of representatives from the Section on Preventive and Industrial Medicine and Public Health of the American Medical Association and the Conmittee on Professional Education of the American Public Health Association, and created in accordance with the action of the Advisory Board for Medical Specialties; incorporated in Delaware June, 1948, as the American Board of Preventive Medicine and Public Health Incorporated; in 1949 recognized and approved by the Council on Medical Education and Hospitals of the American Medical Association as a Medical Specialty Board authorized to certify properly qualified specialists in public health, specialists in aviation medicine in February 1953, and of specialists in occupational medicine in June 1955. Name changed to present title in 1952.

Purpose: To encourage the study, improve the practice, and elevate the standards and advance the cause of preventive medicine; to grant and issue to physicians, duly licensed by law to practice medicine, certificates of special knowledge in the various fields of preventive medicine: public health, aviation medicine, and occuptional medicine.

Membership: Limited to graduates from a medical school in the United States or Canada approved by the Council on Medical Education and Hospitals of the American Medical Association, or from a foreign school satisfactory to the Board, with a hospital internship of at least one year approved by the same Council and Board, witl authority to practice medicine in a State, territory, commonwealth, or possession 
of the Lnited States or in a Province of Canada; of good moral character and high ethical and professional standing. Total membership 2111 Mectings: Annual.

\section{American Board of Psychiatry and Neu-} rology, Inc. 102-110 2nd Avenue, S. II., Rochester, Minn. President: Francis M. Forster, 1300 University Avenue, Madison 6. II is. Term expires December 10, 1960. Exccutive Secretary-Trcasurer: David A. Boyd. Jr. Term indefinite.

History: Founded in 1934 following conferences of committees appointed by the American Psychiatric Association, the American Neurological Association, and the Section on Nervous and Mental Diseases of the American Medical Association.

Purpose: To determine the competence of specialists in psychiatry and in neurology; to arrange, control, and conduct investigations and examinations to test the qualifications of voluntary candidates for certificates issued by the Board; to grant and issue certificates or other recognition of special knowledge in the field of psychiatry and neurology to successful voluntary applicants therefor; to serve the public physicians, hospitals, and medical schools by preparing lists of practitioners who shall have been certified by the Board; to consider and advise as to any course of study and technical training, and to diffuse any information calculated to promote and ensure the fitness of persons desirous of qualifying for a certificate of qualifications to be issued thereby.

Membership: Diplomates, 6,815, physician duly licensed by law to practice medicine, of acceptable ethical and professional standing, a member of the American Medical Association, satisfactory completion of adequate training in psychiatry or neurology, or both, as a specialty.

Mectings: Annual, in December; another meeting in spring.

125. American Board of Surgery, Inc. 1617 Pennsylvania Boulevard, Philadelphia 3, Pa. President: J. Englebert Dunphy, University of Oregon School of Medicine, Department of Surgery, Portland 1, Ore. Term expires August 31, 1961. Exccutive-Treasurer: John B. Flick, 1617 Pennsylvania Boulevard, Philadelphia $3, \mathrm{~Pa}$. Term indefinite.

History: Organized January 9, 1937 by a committee representative of certain national and sectional surgical societies called together through the initiative of the American Surgical Association.

Purpose: To conduct examinations of eligible candidates who seek certification by the Board; to issue certificates of qualification to all those meeting the Board's requirements and satisfactorily completing its examinations; to inprove the opportunities for the training of surgeons.

Membership: Members, 18, one of whom is nominated by the Board as Secretary-Treasurer. The other seventeen are nominated as follows The American Surgical Association-4; The Section on Surgery of the American Medical Association-4; The American College of Surgeons-4; The Southern Surgical Association -1: The Western Surgical Association-1; The Pacific Coast Surgical Association-1; The New England Surgical Society-1; The Central Surgical Association-1. Term of membership is six years, except for the Secretary-Treasurer whose membership terminates with his office.

Mectings: Annual.

126. American Broncho-Esophagological Association. President: F. Johnson Putney, 1712 Locust Street, Philadelphia 3, Pa. Term expires May 25, 1961. Secretary: Daniel C. Baker, 903 Park Avenue, New York, N. Y. Term expires May 25, 1961.

History: Organized 1917 as Association of American Peroral Endoscopists; name changed in 1921 to American Bronchoscopic Society, and in 1939 to present title.

Purpose: Promotion of knowledge of diseases and injuries in respiratory and upper digestive tracts, and advancement of the art of bronchoesophagology.

Mcmbcrship: Active nembers, 177 ; Associate, 5; Corresponding, 49; Honorary, 7 ; Emeritus, 32. Membership by invitation only. Active members must submit theses on subjects pertaining to broncho-esophagology; applicants must be leaders or potential leaders in their fields. Total membership 270.

Mectings: Annual.

Publications: Transactions, annual, free to members. Editor: Stanton A. Friedberg, 122 South Michigan Avenue, Chicago, Ill.

\section{American Bryological Society. President:} Roy F. Cain, University of Toronto, Canada. Term expires August 1961. SecretaryTreasurer: William A. Weber, University of Colorado Museum, Boulder, Colo. Term expires December 1961.

History: Organized January 1, 1898 as the Sullivant Moss Chapter; title changed April 1908 to Sullivant Moss Society; changed to present title January 1949.

Purpose: To promote interest in the study of bryology and lichenology, to facilitate ex- 
cliange of specimens, and to build up reference collections of mosses, hepatics, and lichens.

Mcmbcrship: Open to individuais interested in bryology. Individual members, 283 ; institutional and commercial, 216; total nembership 499.

Mectings: Annual, with meeting of the American Institute of Biological Sciences.

Professional activities: Three herbaria: moss, Duke University; hepatics, University of Cincinnati; lichens, University of Colorado. A moss exchange is located at Syracuse University, and an hepatic exchange at Millbrook, Ontario, both under the direction of the Society.

Publications: Bryologist, quarterly, current volume: 63 , domestic $\$ 5$, foreign $\$ 5.15$. Editor: Howard Crum.

128. American Cancer Society, Inc. 521 West 57th Street, New York 19, N. Y'. President: IVarren H. Cole, 840 South Wood Street, Chicago 13, Ill. Term expires November 1, 1960. Executive Vice Prcsident: Lane W. Adams. Term indefinite.

History: Organized in 1913 as the American Society for the Control of Cancer, and incorporated as such under New York State laws in May 1922; name changed to present title in 1944. Sections: The Society has 60 organized Divisions in all the states and the District of Columbia. Technical Committees: Medical and Scientific, Public Information, Research.

Purpose: To collect, collate, and make available statistical information relative to the incidence, mortality, and curability of cancer, to investigate conditions under which cancer occurs, to encourage and foster medical and scientific research by others in the field of cancer, and to that end voluntarily to assist, by grants of money or otherwise, qualified individuals and institutions; to encourage and foster the education and training of persons to qualify them to engage in medical and scientific research in the field of cancer and in detection, diagnosis, treatment, and prevention of cancer and to that end to assist such persons and institutions qualified so to educate and train such persons, by grants of money or otherwise; to encourage, foster, and conduct programs for the continuing education and training of physicians, dentists, nurses, technicians, and others as to all matters concerned with the detection, diagnosis, treatment, and prevention of cancer; to encourage, foster, and conduct programs for the continuing education of the public concerning cancer, its symptoms and detection, so as to further the timely use of medically and scientifically recognized means for the detection, diagnosis, treatment, and prevention of cancer; to encourage and foster the establishment, and voluntarily to assist financially and otherwise the equipment, maintenance, and operation of hospitals, clinics, laboratories, and other facilities for the detection, diagnosis, treatment, and prevention of cancer; to encourage, foster, and voluntarily assist financially and otherwise the establishment and carrying out of a program of service to cancer patients; voluntarily to assist and cooperate with medical and scientific societies and other official and nonofficial organizations interested in cancer anywhere in the world; to encourage international cooperation in connection with the study and control of cancer; to carry on any other activities which may contribute to the control of cancer, except the actual treatment of cancer patients or the actual ownership and operation of hospitals, clinics, laboratories, or other facilities for the detection, diagnosis, treatment and prevention of cancer within such limitations as are provided by law.

Membcrship: Membership of the Society provides for two delegate members from each $\mathrm{Di}$ vision and the Board of Directors. There is also provision for honorary life members.

\section{Mectings: Annual.}

Professional activities: The Society makes grants for research and for personnel for research. The final authority for making grants is vested in the Society's Board of Directors or its Executive Committee, acting upon the recommendations of the Research Committee of the Board, the Research Advisory Council, and appropriate advisory committees.

The Research Committee is a standing committee of the Board of Directors and is responsible for: (a) developing plans for carrying out the research objectives of the Society; (b) setting the broad policies of the programs; (c) administering the program; (d) evaluating its results; (e) rendering reports on activities and progress; (f) providing prompt and full dissemination of knowledge gained; (g) appointing from time to time policy advisory committees of experts in the field of medical and scientific research to advise it on specific problems and undertake sucl other activities as it may consider necessary or desirable in carrying out its responsibilities.

The Research Advisory Council is composed of fifteen investigators representing the various scientific disciplines and administrative skills concerned with present day cancer research and is responsible for: (a) examining the progress and needs of all research on cancer; (b) recommending appointment of standing and, where needed, special scientific advisory committees; (c) reviewing recommendations of all such committees.

Standing scientific advisory committees are: Research on the Etiology of Cancer, Research on the Pathogenesis of Cancer, Research on the Therapy of Cancer, Institutional Researclı 
Grants, and Personnel for Research. These committees are charged with: (a) recommending approval or disapproval of applications for grants; (b) evaluating and reporting progress and initiating activity in their respective assigned areas.

Ad Hoc Scientific Review committees are appointed as advisory groups to the Research Advisory Council. Certain aspects of progress made in cancer research are evaluated, and specific recommendations are made relative to further research.

In the period 1945 to April 1960, the Society allocated $\$ 78,385,000$ to support research endeavors. During a twelve-month period in 1959-1960, expenditures for research amounted to $\$ 11,883,256$, and on March 1, 1960, there were 620 grants in effect which represented total expenditures of $\$ 16,603,693$.

Publications: Cancer, bimonthly, \$15. CA, a Bulletin of Cancer Progress, bimonthly, \$2.50. Cancer News, 3 times a year, free.

Library: 7,000 volumes.

129. American Catholic Psychological Association. Fordham University, New York 58, N. Y. President: William C. Cottle, Guidance Burtau, University of Kansas, Lawrence, Kansas. Term expires August 31, 1961. E.recutivc Sccretary: Rev. William C. Bier, S. J., Fordham University, New York 58, N. Y. Term expires August 31, 1961.

\section{History: Organized 1948.}

Purpose: To interpret to Catholics the meaning of modern psychology and to advance its acceptance in Catholic circles; to provide a forum for the discussion of psychological questions of special interest to Catholics.

Membership: Constituent members must be Fellows or members of the American Psychological Association; Associate members must be associate members of the APA or meet the same membership requirements as APA associates. Constituent members 525; Associate members 117.

Meetings: Annual, at time of the APA Convention.

Publications: Newsletter, bimonthly, current volume: 10, \$10. Editor: Rev. Willian C. Bier.

130. American Ceramic Society, Inc. 4055 North High Street, Columbus 14, Ohio. President: George Spencer-Strong, Penco Corporation, 5601 Eastern Avenue, Baltimore 24, Md. Term expires April 25, 1961. President-Elect: J. S. Nordyke, 440 Sulgrave Road, Pittsburgh 11, Pa. Term expires May 1. 1962. General Secretary: Charles S. Pearce. Term indefinite.
History: Organized 1899, incorporated 1905 , reorganized 1918. 'Twenty-four local sections. Committees: Executive; Rules; Membership; Research; Classification, Nomenclature and Glossary; Standards; Publications; Finance; Classes and Divisions; Sections; Student Branches; Trustees Nominating; Meetings ; Pension Fund; Patents; Ceramic Education. Divisions: Basic Science, Design, Electronics, Enamel, Glass, Materials and Equipment, Refractories, Structural Clay Products, White Wares.

Purpose: To promote the art, science, and technology of ceramics.

Membership: Open to any individual interested in any phase of ceramic work. Personal members, 5,178; corporation members, 309; subscriptions, 2,003. Total membership 7,490.

Meetings: Annual in spring; division meetings also annual in fall.

Professional activities: Frank Forrest Award, for the promotion of research papers in the field of glass technology; S. B. Myer, Jr. Award, for the promotion of research papers in the field of glass teclinology; Ross Coffin Purdy Award, for outstanding paper in ceramic literature; John Jeppson Medal, for scientific, technical, or engineering achievements in the ceramic field; Binns Medal, for outstanding work in ceramic design; Orton Lecture; Fellow, for broad and productive scholarship in ceramic science and technology. Honorary Membership accorded to persons of professional eminence and achievements in ceramics.

Publications: Journal, montlily, current volume: 43, \$20. Ceramic Abstracts, monthly. Bulletin, monthly current volume: 39 , free to members. Editor: C. S. Pearce.

Library: 1,100 volumes.

131. American Chemical Society, 1155 16th Street, N. W., Washington, D. C. President: Arthur C. Cope. Term expires December 31, 1961. Executive Secretary: Alden H. Emery. Term indefinite.

History: Organized April 20, 1876; incorporated 1877; reorganized 1891-1892 to secure national participation; incorporated under Federal Charter, 1937. Sections: There are 159 local sections; boundaries determined geographically. Divisions: Agricultural and Food Chemistry; Analytical Chemistry; Biological Chemistry; Carbohydrate Chemistry; Cellulose Chemistry ; Chemical Education ; Chemical Literature; Chemical Marketing and Economics; Colloid Chemistry; Fertilizer and Soil Chemistry; Gas and Fuel Chemistry; History of Chemistry; Industrial and Engineering Chemistry; Inorganic Chemistry; Medicinal Chemistry; Organic Chemistry; Organic Coatings 
and Plastics Chemistry; Petroleum Chemistry; Physical Chemistry; Polymer Chemistry; Rubber Chemistry; Water and Waste Chemistry. Commitees: Committees of the Council: Council Policy Committee; Nominations and Elections; Chemical Education; Constitution and Bylaws; Local Section Activities; Membership Affairs; National Meetings and Divisional Activities; Professional Relations and Status; Publications; Admissions; Air Pollution; Analytical Reagents; Annual Report on Atomic Weights; Nomenclature, Spelling, and Pronunciation; Professional Training; Standardization Relations; Women's Service. Committees of the Board: Awards and Recognitions; Corporation Associates; Education and Students; Finance; Grants and Fellowships; Public, Professional and Member Relations; Publications; Advisory to the Chemical Corps; Civil Defense; Clinical Chemistry; Editors, ACS Journals; Education Liaison and Advisory Panel ; Exchanges; Frasch Foundation Awards; Petroleum Research Fund Advisory Board. Special Committees: Building Committee; Investments Committee; Paper; Pension Comnittee; Planning, Building Fund Campaign.

Purpose: To encourage in the broadest and most liberal nanner the advancement of chemistry in all its branches; to promote research in chemical science and industry; to improve the qualifications and usefulness of chemists through high standards of professional ethics, education, and attainments ; to increase and diffuse chemical knowledge; and by its meetings, professional contacts, reports, papers, discussions, and publications, to promote scientific interests and inquiry, thereby fostering public welfare and education, aiding the development of the country's industries, and adding to the material prosperity and happiness of its people.

Membership: Member, Senior Grade, adequate collegiate training in chemistry or chemical engineering, or its equivalent, and five years of graduate training or experience in some form of chemical or chemical engineering work; however, only two years of postgraduate study or experience are required from those who have studied in a department of chemistry or chemical engineering approved by the ACS and who lave been certified by the head of the department as having completed the course recommended by the Society; furthermore, an uncertified graduate with a bachelor's degree from a non-approved institution who subsequently obtains a master's degree from an approved institution may be admitted to full membership at the end of two years following the granting of this degree. Member, Junior Grade, adequate basic training but insufficient graduate study and experience for Member, Senior Grade, or inadequate training but engaged in chemical work.
Eneritus, nember for thirty-five continuous years or over who is retired from active business, teaching, or professional activity or who is over seventy years of age. Student Affiliate, a student in good standing majoring in chenistry of chemical engineering and regularly matriculated in a technical school, college, or university authorized to grant degrees, who has not taken a baccalaureate degree in chemical or chemical engineering and who has been duly llominated by two members of the ACS, one of whom is an instructor in the institution he attends. Corporation Associate, any reputable firm, association, corporation, or institution or one or more subdivisions thereof desiring to support the program of the Society, particularly the expansion and improvement of the publications which are not self-supporting. Junior and Senior Grade Members, 90,011; Life Members, 11 ; Emeritus Members, 747 ; Corporation Associates, 464; Student Affiliates, 6,282. Total membership 97,515.

\section{Mectings: Semiannual.}

Professional activities: Petroleum Research Fund, $\$ 70,000,000$ charitable trust fund to support fundamental research and advance scientific education in the petroleum field, which may include any field of pure science that may afford a basis for subsequent research directly connected with the petroleum field. National, Regional, Local Section and Divisional Arards: Roger Adams Award in Organic Chemistry, to recognize and encourage outstanding contributions to research in organic chemistry, established 1959, sponsored by Organic Syntheses, Inc., Organic Reactions, lnc., and the Division of Organic Chemistry of the American Chenical Society; American Chemical Society Award for Creative Work in Synthetic Organic Chemistry, to recognize and encourage creative work in synthetic organic chemistry, established 1955, sponsored by the Synthetic Organic Chemical Manufacturers Association; American Cliemical Society Award for Nuclear Applications in Chemistry, to recognize, encourage, and stimulate isotopic applications in chemistry, established 1953, sponsored by the NuclearChicago Corporation; American Chemical Society Award in Biological Chemistry, to stimulate fundamental research in biological cliemistry by young chemists working in the colleges and universities and other nonprofit institutions of the United States, established 1934, sponsored by Eli Lilly \& Company; American Chenical Society Award in Chemical Instrumentation, to recognize and encourage achievement in origination, iniprovement, or application of instrumental methods of chemical analysis, established 1953 by Beckman Instruments, Inc., since 1959 sponsored by E. H. Sargent \& Company; American Chemical Society Award in Industrial and 
Engineering Chemistry, to stimulate fundamental research in industrial and engineering chemistry and in development and application of chemical engineering principles to industrial processes, established 1955, sponsored by the Esso Research and Engineering Company; American Chemical Society Award in Chromatography and Electrophoresis, to recognize outstanding contributions to chromatography and electrophoresis, established 1959, sponsored by Labline, Inc., American Chemical Society Award in Petroleum Chemistry, to recognize, encourage, and stimulate outstanding research achievements in petroleum chemistry in the United States and Canada, established 1948, sponsored by Precision Scientific Company; American Chemical Society Award in Pure Chemistry, to recognize and encourage fundamental research in pure chemistry carried out in North America by young men and women, established 1931, sponsored by Alpha Chi Sigma Fraternity since 1940; American Chemical Socicty Award in the Chenistry of Milk, to recognize and encourage outstanding research achievements in the chemistry of milk in the United States and Canada, established 1938, sponsored by The Borden Company Foundation, Inc.; American Chemical Society Local Section Member Relations Award, to recognize outstanding member relations activities by local sections, established 1959 by the Board of Directors of the Society; American Chemical Society Local Section Public Relations Award, to recognize outstanding public relations activities by local sections, established 1955 by the Board of Directors of the Society; Fisher Award in Analytical Chemistry, to recognize and encourage outstanding contributions to the science of analytical chemistry, pure or applied, carried out in the United States or Canada, established 1947 by the Fisher Scientific Company; Fritzsche Award, to recognize and encourage outstanding achievement in analysis, structure elucidation, chemical synthesis of essential oils, isolates, flavors and related substances, established 1948 by Fritzsche Brothers, Inc.; Garvan Medal, to recognize distinguished service to chemistry by women chemists, citizens of the United States, established 1936, financed with the income from a fund set up by Francis P. Garvan; James T. Grady Award, to recognize, encourage, and stimulate outstanding reporting which materially increases the public's knowledge and understanding of chemistry, chemical engineering, and related fields, established 1955, sponsored by the American Chemical Society; Ipatieff Prize, to recognize outstanding chemical experimental work in the field of catalysis or high pressure, carried out by men and women of any nationality and not over forty years of age, established 1943, financed by a trust established by Vladimir N. and Bar- bara Ipatieff; The Kendall Company Award in Colloid Chemistry, to recognize and encourage outstanding scientific contributions to colloid and surface chemistry in the United States and Canada, established 1952 by The Kendall Company; Charles Lathrop Parsons Award, to recognize outstanding public service by a men1ber of the American Chemical Society, established 1952, sponsored by the Society; PaulLewis Laboratories Award in Enzyme Chemistry, to stimulate fundamental research in enzyme chemistry in the United States by young men and women, established 1945 by Paul-Lewis Laboratories, Inc.; Priestley Medal, to recognize distinguished services to chemistry, established 1922, sponsored by the American Chemical Society; Scientific Apparatus Makers Award in Chemical Education, to recognize outstanding contributions to chemical education, established 1950 by the Scientific Apparatus Makers Association. Administered by Divisions: Bituminous Coal Research Award, to recognize the best paper on coal or derived products of coal presented at each meeting of the Division of Gas and Fuel Chemistry, established 1955 by Bituminous Coal Research, Inc.; Dexter Chemical Corporation Award in the History of Chemistry, to stimulate interest in the history of clemistry, established 1956 by the Dexter Chenical Corporation; Hudson Award of the Division of Carbohydrate Chemistry, to acknowledge contributions of recipient to carbohydrate chemistry, established by a vote of the Division on an action of the Executive Committee; Honor Scroll of the Division of Industrial and Engineering Chemistry, to improve the quality of the technical papers presented at sessions and to improve speaker-to-audience contact, established 1950; The Carbide and Carbon Chemicals Prize, to recognize contributions to the science or technology of paint, plastics, or printing ink chemistry, established 1953 by the Division of Organic Coatings and Plastics Chemistry; The Charles Goodyear Medal, to recognize valuable contributions to the science or technology of rubber or related products, established 1939 by the Division of Rubber Chemistry; The Edward Bartow Award, to improve the quality and manner of presentation of teclmical papers presented at meetings of the Division of Water and Waste Chemistry, established 1950; Certificates of Merit, to recognize a notable first appearance before the Division of Water and Waste Chemistry and to encourage presentation of technical papers by the new and younger members of the Division. Administered by Local Sections: Charles E. Coates Memorial Award (Baton Rouge Section), to recognize contributions to chemistry or chemical engineering, activity in the ACS or AIChE, and community activity by 
a member of the AIChE chapter or ACS section in the Baton Rouge area, established 1957 in cooperation with the local section of the ACS and the local chapter of AIChE; Gilbert Newton Lewis Medal, to acknowledge leadership in the science of theoretical chemistry, established 1951 by the California Section; California Section Award, to encourage young scientists who show promise in the field of chemistry, established 1951 by the California Section; Nillard Gibbs Medal, to recognize eminent work in and original contributions to pure or applied chemistry, founded by William A. Converse and establisbed 1910 by the Chicago section; The Eminent Chemists' Award, to recognize contributions to the betterment of mankind by a member of the Cincinnati Section of the ACS, established 1950 by the Executive Committee of the Cincinnati Section; Austin M. Patterson Award in Chemical Literature, to acknowledge meritorious contributions in the field of chemical literature and especially in the documentation of chemistry, established 1949 by the Dayton Section; Delaware Section Award, to encourage and promote the publication of scientific papers by members of the section; S. C. Lind Lectureship Award, to acknowledge leadership in chemical science, established 1948 by the East Tennessee Section; The Florida Section Award, to recognize leadership in and contributions to the advancement of the profession of chemistry, established by the Florida Section; The Herty Medal, to give recognition to the work and service of outstanding chemists who have contributed to their chosen field and are from the southeast portion of the United States, established 1933 to honor C. H. Herty, awarded by the Georgia Section of the ACS; lowa Award, to recognize meritorious achievement in fundamental or applied chemistry by a resident of Iowa, established 1949 by the Iowa Section; Charles F. Spencer Award, to recognize outstanding achievement in agricultural chemistry, established 1955 by the Kansas City Section; Remsen Memorial Lectureship Award, to recognize demonstration by the recipent of the unique qualities as chemist, educator, and administrator exemplified by Ira Remsen, established 1946 by the Maryland Section; Southern Chemist Award, to recognize and honor distinguished service to the profession of chemistry in the southern States, and to focus national attention on their scientific progress, established 1950, awarded by Southern Chemist magazine, publication of the Memphis Section; Milwaukee Section Award, to honor a Section member for outstanding service to the industry, the profession, or the Section in the Milwaukee area, established 1956 by the Milwaukee Section; Minnesota Award, to honor a Section member for outstanding contributions in chemical research or in service to the profession, established 1958, supported by the Minnesota Section; William H. Nichols Medal, to stimulate original research in chemistry, established 1902 by IVilliam H. Nichols of New York, awarded by New York Section; The Leo Hendrik Baekeland Award of the North Jersey Section, to encourage accomplishment in pure or applied chemistry among young American chemists, established 1944, supported by the Bakelite Company, a division of Carbide and Carbon Corporation; James Flack Norris Award, to recognize outstanding achievement in the teaching of chemistry, established 1929 by the Northeastern Section; Theodore William Richards Medal, to recognize conspicuous achievement in chemistry, established 1929 by the Northeastern Section; Northeastern Indiana Chemist of the Year, to recognize and encourage outstanding achievement in chemistry or chemical engineering, distinguished service to the American Chemical Society, and to the community in which recipient resides, established 1957 by the Northeastern Indiana Section; The Edgar Fahs Smith Memorial Lecture, to encourage achievement in chemistry and to honor the memory of Edgar Fahs Smith, established 1929, co-sponsored by the Philadelphia Section; Pittsburgh Award, to recognize distinglished service to chemistry in Pittsburgh, established 1933 by Pittsburgh Section; Puget Sound Award in Chemisty, to recognize distinguished work in chemistry or chemical engineering, established 1956 by the Puget Sound Section; Harrison E. Howe Lectureship, to recognize achievement in chemistry and to promote discussion of problems likely to be important in the future of chemistry, established by the Rochester Section, first awarded in 1945-46; Midwest Award, to recognize meritorious contributions to the advancement of pure or applied chemistry or chemical education by chemists in Missouri and its eight bordering States, established 1945 by the St. Louis Section ; Utah Award, to recognize outstanding contributions to chemistry while residing in the area served by the Section, established 1957 by the Salt Lake Section; Southwest Regional Award, to recognize outstanding contributions by a chemist or chemical engineer in the southwest States, established 1948, supported by twenty-one local sections of the Society; Distinguished Service Award, in recognition of outstanding contributions to the professional standing of chemists, established 1948 by the Virginia Section; Hillebrand Award, to recognize original contributions to the science of chemistry by a member of the Chemical Society of Washington, established 1925 by this Society (Washington Section, ACS) as a memorial to IV. F. Hillebrand; Jacob F. Schoellkopf Medal, to give encouragement and recognition to the spirit of 
research in industry within the territory of the Western New York Section of ACS, established 1930 by the Section.

Publications: Analytical Chemistry (formerly Analytical Edition of Industrial and Engineering Chemistry), monthly, current volume: $32, \$ 4$ members, $\$ 5$ non-members. Editor: Lawrence T. Hallett. Chemical Abstracts, semi-monthly, current volume: $54, \$ 40$ members, $\$ 200$ colleges and universities, $\$ 925$ non-members. Editor: Charles L. Bernier, Ohio State University, Columbus 10, Ohio. Chemical and Engineering News (formerly Industrial and Engineering Chemistry-News Edition), weekly, current volume: 38 , free to members, $\$ 6$ non-members. Editor: Richard L. Kenyon. Chemical Reviews, bi-monthly, current volume: $60, \$ 10$ members, $\$ 12$ non-members. Editor: Ralph L. Shriner, State University of Iowa, Iowa City, Iowa. Chemical Titles, semi-monthly, current volume: $1, \$ 50$ members, $\$ 50$ colleges and universities, $\$ 65$ non-members. Editor (Director): G. Malcolm Dyson, Chemical Abstracts Service, Ohio State University, Columbus 10, Ohio. Industrial and Engineering Chemistry, monthly, current volume: $52, \$ 4.50$ members, $\$ 5$ non-members. Editor: Will H. Shearon, Jr. Journal of Agriculture and Food Chemistry, bi-monthly, current volume : $8, \$ 10$ members, $\$ 20$ non-members. Editor: Rodney N. Hader. Journal of Chemical Documentation, bi-annual, $\$ 7$ members, $\$ 10$ nonmembers. Editor: Herman Skolnik, Hercules Powder Co., Wilnington, Del. Journal, semimonthly, current volume: $82, \$ 13$ members, $\$ 30$ non-members. Editor: IV. A. Noyes, Jr., University of Rochester, Rochester 20, N. Y. Journal of Chemical and Engineering Data (formerly Chemical and Engineering Data Series of Industrial and Engineering Chemistry), quarterly, current volume: 5, $\$ 9$ members, $\$ 18$ nonmembers. Editor: Will H. Shearon, Jr. Journal of Organic Chemistry, monthly, current volume : 25, $\$ 12.50$ members, $\$ 25$ non-members. Editor: George H. Coleman, Department of Chemistry, Wayne State University, Detroit 1, Mich. Journal of Physical Chemistry (formerly Journal of Physical and Colloid Chemistry), monthly, current volume: $64, \$ 12$ members, \$24 non-members. Editor: IV. A. Noyes, Jr., University of Rochester, Rochester 20, N. Y. Journal of Chemical Education, monthly, current volume: $37, \$ 4$ members and non-members. Editor: William F. Kieffer, Department of Chemistry, College of Wooster, Wooster, Ohio (Division of Chemical Education, ACS). Rubber Chemistry and Technology, quarterly, current volume: 33 , free to members and associates of the ACS Rubber Division, $\$ 9.50$ companies and libraries. Editor: David Craig, B. F. Goodrich Research Center, Brecksville, Ohio (Division of Rubber Chemistry, ACS).
132. American Clinical and Climatological Association. President: Marshall N. Fulton, 124 Waterman Street, Providence, R. I. Term expires October 8, 1960. Secretary: F. Tremaine Billings, Jr., 420 Medical Arts Building, Nashville, Tenn. Term indefinite.

History: Organized 1884 as the American Climatological Association; name changed 1914 to the American Climatological and Clinical Association; name changed to present title 1932.

Purpose: Clinical study of disease.

Membership: Physicians proposed by three members and voted upon by the Council. Active members, 175; Emeritus, 75; Honorary, 10. Total membership 260.

Meetings: Annual.

Professional activities: Gordon Wilson Memorial Fund, to provide an annual lectureship with an honorarium of $\$ 100$.

Publications: Transactions, annual, current volume: 72, free to members. Editor: David Strayhorn, 2212 West End Avenue, Nashville, Tenn.

\section{American College Health Association.}

President: Samuel I. Fuenning, Director of Student Health Service, University of Nebraska, Lincoln, Nebr. Term expires April 1961. Secretary-Treasurer: Norman S. Moore, Cornell University, Gannett Clinic, Ithaca, N. Y. Term indefinite.

History: Organized March 4, 1920, as the American Student Healtl Association; name changed in 1949 to present title. Affiliates: Central, District of Columbia, Indiana, Illinois, Michigan, Mid-Atlantic, New England, North Central, Ohio, Pacific, Rocky Mountain, Southern, Southwestern. Sections: Administration. Athletic Medicine, Clinical Medicine, Environmental Health and Safety. Health Education, Mental Health, Nursing Service. ComMitTeEs: Research, Tuberculosis Control.

Purpose: The maintenance of an official and authorized organization through which institutions and individuals engaged in student health service may work for the promotion of health, prevention of disease, and the care of student illness.

Membership: Institutional membership is open to institutions of higher education of recognized standing. Individual membership is open to any individual interested in college student health work whether or not affiliated with a college or university. Members, approximately, 1,000 .

Meetings: Annual.

Professional activities: Two awards annually for research design, one to a small college and one to a large college. 
Publications: Student Medicine, quarterly, current volume: 9, $\$ 5$. Editor: Ralph W. Alexander. Newsletter, quarterly, current volume: 3 , for members only. Editor: Edward Dvorak.

\section{American College of Allergists. 2160 Rand}

Tower, Minneapolis 2, Minn. Presidcnt: Giles A. Koelsche, 2001 st Street, S. W., Rochester, Minn. Term expires March 1961. Exccutiz'c l ice Presidcnt: Eloi Bauers.

History: Organized and incorporated November 23, 1942. Committees: Aerobiology, Audio-Visual, Bronchopulmonary Physiologic Therapy, Central Nervous System Allergy, Dermatology, Entomology, New and Unused Therapeutics, Ophtho-Otolaryngologic Allergy, Pediatric Allergy, Psychosomatic Allergy, Public Education, Standardization, Technology.

Purpose: The establishment of an organization of qualified physicians and scientists to meet for the purpose of promoting and advancing the study and laboratory and clinical knowledge of allergy; to advance and maintain the highest possible standards among those engaged in practice; to perpetuate the best traditions of medicine and medical ethics; to establish standards for the qualification and procedures for the certification of physicians engaged in the specialty of allergy; to maintain the dignity of this specialty in its relation to public welfare; to promote friendly intercourse and relationships between and among those engaged in the practice.

Mcmbcrship: Total membership, 1,164. Active Fellows, elected or promoted from Associate Fellows, must be certified by the Board of $E_{X-}$ aminers and meet qualifications of Credential Conmittee and the Board of Regents. Associate Fellows, subject to discretion of Board of Regents, any physician applying allergy to his practice and any scientist who contributes to the advancement of knowledge.

Mcctings: Anuual.

Professional activities: Annual graduate instructional course.

Publications: Annals of Allergy, monthly, $\$ 10.50$. Editor: E. A. Brown, 75 Bay State Road, Boston 15, Mass.

\section{American College of Anesthesiologists,} Inc. 515 Busse Highway, Park Ridge, Ill. Executive Secretary: John W. Andes. Term indefinite.

History: In 1947 the Fellowship Committee of the American Society of Anesthesiologists, Inc. was reorganized as the American College of Anesthesiologists, Inc., but remained a part of the parent organization.

Purpose: To certify qualifying members of American Society of Anesthesiologists as Fel- lows of the College. denoting competence in medical specialty of anesthesiology.

Mcmbership: Requires proof of competence in specialty by written, oral, and practical examinations; one year's formal training or five years' experience devoting fifty-one per cent of time to anesthesiology. Total membership 1,991.

Mcctings: Semiamual.

136. American College of Apothecaries. Hamilton Court, 39th and Chestnut Streets, Pliladelphia, Pa. Presidcut: Henry H. Gregg, 4954 France Avenue, South Minneapolis, Minn. Term expires September 1961. Executize Secretary: Robert E. Abrams, 405 Langford Road, Broomall, Pa. Term indefinite.

History: Organized May 10, 1940, in Richmond, Va., and incorporated January 12, 1946. in St. Louis, Mo. Divided into eight regions similar to the Federal Reserve Districts. ConMITTEES: Standard committees on both scientific and technical subjects.

Purposc: To promote public health by cooperation with other public health professions in rendering the best possible type of pharmaceutical service and to disseninate helpful information to the public concerning health matters. To provide services which will aid its fellowship in carrying out its purposes.

Menbcrship: Full Fellowship, 630, registered pharmacist operating exclusive prescription shop; Hospital Fellowship, 110, registered pharmacist; Associate Fellowship, 130, registered pharmacist; Faculty Fellowship, 60 , registered pharmacist; Honorary Fellowship, 4, at the discretion of the Board of Directors.

Mectings: Anuual, mid-year, and regional.

Professional activities: Annual survey plus other surveys either directly or by sponsoring grants.

Publications: Secretary's Newsletter, biweekly. Editor: Robert E. Abrams.

137. American College of Cardiology, Inc. Empire State Building, New York 1, N. Y. President: Louis F. Bishop, 141 East 55th Street, New York 22, N. Y. Term expires June 1, 1961. Executive Dircctor: Philip Reichert. Term indefinite.

History: Organized 1949; incorporated in District of Columbia.

Purpose: To promote and advance the science of cardiology and angiology; to make available free postgraduate training in the subjects; to create cardiological centers for clinical treatment and research in cardiovascular diseases: to publish information pertaining to the subjects.

Membership: Full Fellowship requires certification by an appropriate American Board; 
subordinate grades must show orientation toward eventual Full Fellowship within a limited time. Fellows, 1,326; Associate Fellows, 426; Members, 207. Total membership 1,959.

Msetings: Semiannual.

Professional activities: Groedel Medal, awarded annually; Personal IVorkshops, conducted throughout year.

Publications: American Journal of Cardiology, monthly, current volumes: 5-6, \$12. Editor: Simon Dack.

138. American College of Chest Physicians. 112 East Chestnut Street, Chicago 11, I11. President: J. Jay Flipse, 550 Brickell Avenue, Miami 32, Fla. Term expires June 1961. Executive Director: Murray Kornfeld. Term indefinite.

History: Founded 1935; incorporated July 31, 1942, in Illinois. GEOGRAPHICAL SECTIONs: Seventy-nine chapters in eighty-nine countries and territories. Councils: Undergraduate Medical Education (Committees on Undergraduate Medical Education, College Essay, Audiovisual Aids); Postgraduate Medical Education (Committees on Postgraduate Medical Education, Motion Pictures, Resident Loan Fund) : Public Health (Committees on Liaison with State and County Medical Societies, Air Pollution, Indian Affairs, Occupational Diseases of the Chest with sections on MedicalLegal Aspects of Pneumoconioses, Radiographic Classification of the Pneumoconioses, Prevalence and Nature of Occupational Diseases of the Chest and Educational Aspects of the Pneumoconioses) ; Pulmonary Research (Committees on Bronchoesophagology, Pulmonary Surgery, Microbiology, Non-Surgical and Drug Therapy, Chemotherapy and Antibiotics, Pulmonary Physiology with sections on Pulmonary Function Testing, Inhalation Therapy, Mechanical Aids to Respiration, Aviation Medicine, Pathology, Pulmonary Diseases in Children, Allergy); Cardiovascular Research (Committees on Hypertension, Clinical Cardiovascular Disease, Cardiovascular Roentgenology, Cardiology in Children, Cardiovascular Surgery, Electrocardiography and Vectorcardiography, Rehabilitation in Cardiovascular Diseases, Cardiovascular Physiology); Hospitals (Committees on Chest Diseases in Institutions, Standards and Accreditation, Psychosomatic Aspects of Diseases of the Chest, Rehabilitation in Pulmonary Diseases, Nurse Graduate Training in Patient Care, Resident Fellowships, Chest Roentgenology ) ; Tuberculosis.

Purpose: To further undergraduate and postgraduate medical education and research in diseases of the chest (heart and lungs) throughout the world, and to promote the highest stand- ards of scientific endeavor in the specialty of chest diseases in all countries.

Membcrship: Eligible physcians in the United States, its possessions, and Canada may apply for Fellowship, Associate Fellowship, and Asociate Membership. Fellowship and Associate Membership are avilable to eligible physicians in other countries. Total nembership 7,116.

Meetings: Annual.

Publications: Diseases of the Chest, monthly, current volume: $37, \$ 15$. Editor: J. Arthur Myers, 1316 Mayo Memorial Building, University of Minnesota, Minneapolis, Minn.

139. American College of Dentists. 4236 Lindell Boulevard, St. Louis, Mo. Executive Secretary: Otto II. Brandhorst. Term indefinite.

History: Organized August 20, 1920. Thirtytwo sections in the United States. Commitees: Conduct, Education, Growth and Aging of the Face, Health Services, Journalism, Professionai Relations, Recruitment, Research, World Relations.

Purpose: To advance the ideals of the dental profession; to advance the standards and efficiency of dentistry; to encourage graduate study and continuing education of dentists; to encourage and promote research; to increase public understanding and appreciation of oral health service; to encourage development and use of measures for control and prevention of oral disease; to cooperate with other groups for the advancement of professional relationships in the public interest.

Membership: By invitation, based on unusual services. Active and Honorary members. Total membership 2,692.

Meetings: Annual.

Professional activitics: Teacher Training Fellowships, grants-in-aid research, travel grants for research personnel, disaster aid funds for researchers.

Publications: Journal, quarterly, current volune: 27, \$5. Editor: Thomas F. McBride, Ohio State University, Columbus, Ohio.

140. American College of Foot Orthopedists, Inc. President: Murray Bromberg, 56 Broad Street, Bloomfield, N. J. Term expires August 28, 1961. National Sectrctary: Joseph R. Cinzio, 242 Lexington Avenue, Passaic, N. J. Term expires August 28, 1962.

History: Incorporated in 1llinois 1950. ComMitTees: Convention; Editorial and Public Education; Finance; Nomenclature; Qualification and Examination Board; Scientific and Research. 
Purpose: Standardization of nomenclature; surveys and compilation of statistical data; preparation of bibliographies on foot orthopedics; standardization of diagnostic procedures and continuing research.

Membership: Requires membership in American Podiatry Association, at least two years' active practice of podiatry, and presentation of twenty-five case histories and passage of written examination. Point system maintained to retain Fellowship and attain Diplomate status. Total membership 120 Fellows.

\section{Mectings: Annual.}

Publications: Newsletter, Quarterly, current volume: 3, free to members. Editor: Joseph R. Cinzio.

\section{American College of Gastroenterology,} Inc. 33 West 60th Street, New York 23, N. Y. President: Joseph Shaiken, 836 North 12th Street, Milwaukee 3, W is. Terin expires October 1960. Executive Dircctor: Daniel IVeiss. Term indefinite.

History: Incorporated 1932 as Society for the Advanvement of Gastroenterology; name changed in 1934 to National Society for the Advancement of Gastroenterology; name changed in 1938 to National Gastroenterological Issociation; name changed to present title 1954.

Purpose: Promotion and maintenance of highest standards of medical education, practice, and research in gastroenterology.

Mcmbership: Requires graduation from accredited school and membership in county medical society and in American Medical Association. Associate Fellows, Board eligible; Fellows, American Board Diplomates; Boards concerned are American Specialty Boards approved by Council on Medical Education of American Medical Association; those affecting this College generally are American Board of Internal Medicine, American Board of Pathology, American Board of Proctology, American Board of Radiology, and American Board of Surgery. Honorary Fellows, 29; Life Fellows, 36; Fellows, 376; Associate Fellows, 201 ; Members, 249. Total membership 891.

\section{Mcetings: Annual.}

Professional actiritics: Postgraduate course in gastroenterology; Ames Award, for best paper published in Journal; Henry G. Rudner, Sr., Award, for best original research work in field.

Publications: American Journal of Gastroenterology, monthly, current volume: $34, \$ 8$. Editor: Samuel Weiss.
142. American College of Hospital Administrators. 840 North Lake Shore Drive, Chicago 11, 111. Presidcnt: Melvin L. Sutley, 1601 Spring Garden Street, Pliladelphia 30, Pa. Term expires 1961. Executive Director: Dean Conley, 6253 North Sheridan Road, Chicago 40, I11. Term indefinite.

History: Organized 1933. Eighteen Geographical divisions throughout the United States and Canada.

Purposc: To elevate the standards of hospital administration; to establish a standard of competence for hospital administration to develop and promote standards of education and training for hospital administrators; to educate hospital trustees and the public to understand that the practice of hospital administration calls for special training and experience; to provide a method for conferring Fellowships in hospital administration on those who have done or are doing noteworthy service in the field of hospital administration.

Membership: Almost without exception, affiliation with a hospital approved by the Joint Commission on Hospital Accreditation is necessary; candidates must be engaged in hospital administration as a career in the United States, Canada, or other countries, in a responsible position in an approved hospital either as the administrator, assistant administrator, administrative assistant, or in a post of camparable responsibility, or may also be members of the faculty of approved courses in hospital administration; baccalaureate degree from an acceptable educational institution or its equivalent in education, experience, or both; those who have baccalaureate degrees must have had at least three years of successful experience in a responsible administrative position in an acceptable hospital, while graduates of approved courses in hospital administration who have received their master's degree must have had a minimum of one year's experience in a responsible administrative position in an acceptable hospital in addition to the year of administrative residency. Fellowship, awarded to men and women who have been Members of the College in good standing for at least five years, have been found technically eligible for advancement to Fellowship, have submitted an acceptable Fellowship Project, which may be a thesis, four case reports, a bibliography of four published articles, or any combination of case reports and bibliograpliy totaling four, and must comply in all other respects with the constitutional provisions of the College for Fellowship; Membership, granted to those persons who have been Nominees in good standing in the College for at least two years and who have fulfilled technical requirements for advancement, which include 
successfully passing both an oral and a written examination and in all other respects complying with the constitutional provisions for this status; Nomineeship, granted to those who have fulfilled all of the requirements for admission to the College. Total membership approximately 4,000 .

\section{Meetings: Annual.}

Professional activities: Anuual Congress on Administration, three-day management meeting; Annual Hospital Administrators' Award, $\$ 500$, for the best book on administration; An1utual Edgar C. Hayhow Award, for best article in Hospital Administration: Annual Article Award, for best article in eight hospital publications; Fellows' Seminar, week-long conference limited to Fellows; Preceptor Conferences.

Publications: Hospital Administration, quarterly, current volume: 5, \$5. 1960 Directory. every five years, current volume: $1, \$ 15$. News, monthly, current volume: 23, free. Editor: Dean Conley.

Library: 5,000 volumes. Emphasis, administration and management in general.

143. American College of Medical Technologists, 81 East Front Street, Red Bank, N. J. President: Leona L. Carter, 4415 Chickasaw Road, Memphis, Tenn. Term expires 1963. Secretary-Trcasurcr: C. A. Bartholomew, Term indefinite.

History: Organized March 21, 1942 at Philadelphia; incorporated (New Jersey) May 15, 1942; registered at II ashington, D. C. as a national organization July 15, 1942.

Purpose: To encourage increased scientific knowledge of its members through seminars and scientific meetings.

Membership: Baccalaureate degree, ten years of practice in medical technology, and a thesis. Fellows, 568; Associates, 372. Total membership 940.

Metings: Semiannually.

Professional activities: One full scholarship in medical technology given annually; Dean Emeritus Award for Past Presidents.

Publications: Record, annually, current volume dated 1959, free. Editor : C. A. Bartholomew.

144. American College of Obstetricians and Gynecologists. 79 West Monroe Street, Chicago 3, 111. President: C. Paul Hodgkinson, 17546 Meadowood, Lathrup Village, Mich. Term expires April 1961. Executive Secretary: Donald F. Richardson. Term indefinite.

History: Organized and incorporated in 1951 as The American Academy of Obstetrics and Gynecology. By action of the Executive Board and vote of the Fellows, the name was changed to The American College of Obstetricians and Gynecologists, May 1956. The College is comprised of eight districts including the United States, Canada, Alaska, Hawaii, Puerto Rico, and the Canal Zone.

Purposc: To establish and maintain the highest possible standards for obstetric and gynecologic education in medical schools and hospitals, obstetric and gynecologic practice and research; to perpetuate the history and best traditions of obstetrics and gynecologic practice and ethics; to maintain the dignity and efficiency of obstetric and gynecologic practice in its relationship to public welfare; to promote publications and encourage contributions to medical and scientific literature pertaining to obstetrics and gynecology.

Mcmbership: Fellows and Founding Fellows, 5,642 , graduation from a medical school which is satisfactory to the Executive Board, linitation of training and/or professional activities to obstetrics and/or gynecology for the five years immediately prior to date of application, evidence of higls ethical and professional standing; Junior Fellows, 634 ; Life Fellows, 59; Associate Fellows, 9. Total membership, 6,474.

\section{Mectings: Annual.}

Professional activities: Mead Johnson Scholarship Award, annually to worthy internes or residents in obstetrics and/or gynecology, five $\$ 1,000$ grants. Higher Education Loan Program, Emil Novak Tumor Registry, and International Federation of Obstetrics-Gynecology.

Publications: Obstetrics and Gynecology, monthly, current volume: $15, \$ 12$ per year. Editor: Ralph A. Reis.

\section{American College of Osteopathic Surgeons.}

P. O. Box 488, Coral Gables 34, Fla. President: Milton V. Gafney, 1143 South Buckner Boulevard, Dallas 17, Tex. Term expires November 1, 1960. Exccutive Secretary: Esther F. Martin. Term indefinite.

History: Organized in June 1926 by a small group of practicing surgeons during the annual American Osteopathic Association convention at Louisville, Ky.

Purpose: To encourage the study of the science of surgery, surgical diagnosis, pathology, and the application of osteopathic principles, practice, and treatment thereto.

Membership: Members, osteopathic physicians who are specializing in surgery; must be engaged in the practice of surgery or in a surgical specialty, a substantial portion of which is major surgical practice, such as ophthalmology, otolaryngology, urology, gynecology, or orthopedics. Associate Members, physicians engaged in activities directly related to the practice of surgery, such as anesthesiology, 
pathology, and radiology; must be certified by his respective specialty board. Honorary Members, may be granted to any person upon unanimous vote of the Board of Governors. Life Members, may be granted by the Board of Governors to any member who has reached the age of sixty and who has held continuous membership for the immediately preceding twenty years; to any member who has reached the age of sixty-five and who has held continuous membership for the inmediately preceding ten years; and at the discretion of the Board of Governors, to those who, for good and sufficient reason, have been forced to retire from active practice. Fellows, may be conferred on members, associate members, honorary members, and life members of the College. Candidates, osteopathic physicians as are considered intellectually and temperamentally qualified to receive it, are permitted to attend educational meetings of the College for instruction in the practice of surgery. Total membership 520; Candidates, 121.

\section{Mectings: Annual.}

Professional activities: Degree of "Fellow in the American College of Osteopathic Surgeons" conferred in recognition of outstanding accomplishments in a surgical specialty or outstanding service to the organization. Orel F. Martin Medal, awarded for distinguished service to the College.

Publications: Bulletin, quarterly. Editor: Esther F. Martin.

146. American College of Physicians. 4200 Pine Street, Philadelphia 4, Pa. President: Chester S. Keefer, 65 East Newton Street, Boston 18, Mass. Term expires May 11, 1961. Executive Director: Edward C. Rosenow, Jr., Term indefinite.

History: Chartered 1915 under the Laws of Delaware as a corporation "not for profit," designed to be an organization in which internists and allied specialists may find a common meeting ground for the discussion of the special problems that concern them and through which their interest may have proper representation. Organized at the same time was the American Congress on Internal Medicine, whose primary function was to conduct an annual Congress in which the College participated. In February 1926, the American Congress on Internal Medicine was merged with the American College of Physicians, former members of the Congress becoming Associates of the College.

Purpose: To establish an organization composed of qualified physicians of high standing who shall meet from time to time for the purpose of considering and discussing medical and scientific topics and who through their organization shall attempt to accomplish the further purposes of maintaining and advancing the highest standards in medical education, medical practice, and clinical research; perpetuating the history and best traditions of medicine and medical ethics; and maintaining both the dignity and the efficiency of internal medicine in its relationship to public welfare.

Nembership: Limited to qualified internists of high standing and those of equally high standing engaged in pediatrics, neurology, psychiatry, pathology, radiology, public health, and other related specialties. Associated, junior menbers on probation for three to ten years; Fellows, advancement from Associateship; Masters; Life members, who can be either Masters or Fellows. Total membership approximately 11,000 .

\section{Meetings: Annual.}

Professional activities: Funds from $\$ 20,000$ to $\$ 35,000$ annually for one-year research fellowships in the amount of $\$ 3,000$ to $\$ 3,500$ each, to young physicians for the purpose of promoting and advancing clinical research. Latin-American Fellowships, conducted jointly by the College and the W. K. Kellogg Foundation; $\$ 50,000$ to $\$ 60,000$ annually; 12 to 15 fellowships from Latin-American countries for training in American medicine; purpose to increase inter-American understanding by serving as a medium for the exchange of knowledge and acquaintanceships among the American Republics, to stimulate progress in the teacluing of internal medicine and in research in the Latin-American countries, to help prepare Latin-American doctors of medicine in internal medicine. Mead Johnson Postgraduate Scholarships, three of $\$ 1,000$ each annually, to help underwrite internships or residences in internal medicine, for needy students. A. Blaine Brower Traveling Scholarships, to provide opportunity for worthy young physicians, preferably Associates of the College, to spend a month as visiting fellows at institutions arranged by the College for observation and postgraduate study. John Phillips Memorial Award, founded 1929, in memory of the late Dr. John Phillips; a bronze medal given periodically, usually annually, for some outstanding piece of work in internal medicine or pediatrics; recipient required to present his paper at the annual session. James D. Bruce Memorial Lectureship, an award in preventive medicine, founded 1946, in memory of the late Dr. James D. Bruce, a bronze medal is given annually and the recipient presents the results of his research on the program of the annual session. Alfred Stengel Memorial Award, founded 1947, a merit award for loyalty and service to the College, including outstanding influence in maintaining and advancing the best standards of medical education, medical practice, and 
clinical research and in perpetuating the other objectives of the College; a special diploma award.

Publications: Annals of Internal Medicine, monthly, $\$ 10$ domestic, $\$ 12$ foreign. Editor: $M$. C. Pincoffs (until October 1960). Bulletin, 6 per year, current volume: 1, $\$ 2$. Editor: Thomas McMillan.

147. American College of Radiology. 20 North Nacker Drive, Chicago 6, Ill. President: Earl E. Barth, 670 North Michigan Avenue, Chicago 11, I11. Term expires fiebruary 1961. E.recutive Director: William C. Stronach. Term indefinite.

History: Organized June 26, 1923 ; became a regularly incorporated, non-profit organization in 1924. The College assumed all the functions formerly performed by the Inter-Society Committee for Radiology. Commissions: Hospital Standards; Public Relations; Public Health; Legislation and Public Policy; Radiologic Units, Standards and Protection. Comnittee on International Affairs; Liaison Groups with Technician Organizations; Liaison Committee to Medical Care Insurance Plans.

Purpose: To improve the distribution, quality, and availability of radiological service to the sick through the study and interpretation of socio-economic factors as they affect medicine and health; to encourage and develop improved standards and facilities for postgraduate education in radiology; to acquaint the medical profession and the public with achievements and developments in radiology and thus promote and encourage progress in this specialty.

Membership: Members, 3,839, physicians practicing the specialty of radiology who have been certified: Fellows, 806, elected from the membership on the basis of outstanding contributions and service to radiology; Associate Members in Physics, 33, physicists who have been certified by the American Board of Radiology; Associate Fellows in Physics, 39, elected from the Associate Membership on the basis of outstanding achievement; Resident Members, 379, those who occupy residencies recognized by the American Board of Radiology, but who are not yet certified; Honorary Fellows, 38, those who are ineligible for admission as members but whose standing and preeminent contributions to the science or practice of radiology entitle them to honorary recognition; Corresponding Members, 52, those physician practicing the specialty of radiology, certified by the American Board of Radiology or by the Royal College of Phyicians and Surgeons of Canada and who are not citizens of the USA or Canada, and who are in good ethical standing in their respective countries; Members Emeritus, 91, members who have retired from the practice of radiology whether because of age or physical disability and who have been elected Meinbers Emeritus by the Board of Chancellors: Fellows Emeritus, 86. fellows who have retired from the practice of radiology whether because of age or physical disability and have been elected Fellows Emeritus by the Board of Chancellors ; Retired Membership and Fellowship, may be conferred by the Board of Clancellors on application of the member or fellow who has retired from practice and who, in the judgement of the Board, should be relieved from the payment of dues.

\section{Mcctings: Anmual.}

Professional activities: A Gold Medal is presented to outstanding radiologists and scientists, and financial support is given regularly to the National Society for Medical Research, the Armed Forces Institute of Pathology, and the International Society of Radiology.

Publications: Jou Radiologist, quarterly, current volume: 3 . Editor, Nendell G. Scott. New's Bulletin, monthly, current volume: 16.

148. American College of Surgeons. 40 East Erie Street, Chicago, I11. President: Owen H. Wangensteen, Minneapolis, Minn. Term expires October 14, 1960. Dircctor: Paul R. Hawley. Term expires January 31, 1961.

\section{History: Founded 1913}

Purpose: To advance and protect the welfare of the surgical patient.

Hembership: Requires advanced graduate training in surgery and evidence of moral character and of ethical and competent practice. Total membership 24,000.

Mectings: Annual.

Professional actinitics: Approval of graduate training programs in surgery; approval of cancer programs; fellowships and scholarships awarded to promiing young surgeons.

Publications: Surgery, Gynecology and Obstetrics, monthly, current volumes: 110-111, \$15. Editor: Loyal Davis. Bulletin, bi-monthly, and Directory, every three years, both free to members.

Library: 40.000 volumes. Subject emphasis: Rare books and history of surgery.

149. American College of Veterinary Pathologists. President: E. L. Stubbs, School of Veterinary Medicine, University of Pennsylvania, Philadelphia, Pa. Term expires November 29, 1960. Secretary-Treasurer: T. C. Jones, 180 Longwood Avenue, Boston 15, Mass. Term expires November 29, 1960.

History: Organized November 29, 1948; incorporated August 1, 1949. Recognized by 
American Veterinary Medical Issociation as certifying agency for specialists in veterinary pathology, August 1951.

Purpose: To further scientific progress in specialty of veterinary pathology; to establish standards of training and experience for qualifications of specialists in veterinary pathology: to further recognition of such qualified specialists by suitable certification.

Mcmbership: Veterinarians must have minimum of five years' professional training and experience subsequent to receipt of degrees; training must be under conditions and preceptors approved by the Council of this organization; after required training candidates are admitted to examinations, scope of which includes diseases of large and small animals, clinical and experimental pathology, and, upon successful completion of examinations, are awarded certificates and membership. Members and cluater members, 89; Emeritus, 3. Total membership 92.

\section{Mectings: Semiannual.}

Professional activities: Seminars are held at least once annually, and often twice a year, for postgraduate education of members and, in some instances, of non-members. Through its conmmittees on Education, Requirements, Examination, Clinical Pathology, and Photography, continuous studies are made of needs in education and research in this organization's specialty.

\section{American Committee for International} Wild Life Protection. Chairman: Harold J. Coolidge, 2101 Constitution Avenue, Washington 25, D. C. Term expires January 1961, subject to annual re-election. Fxecutive Secretary: Lee S. Crandall, New York Zoological Park, New York 60, N. Y. Terın expires January 1961, subject to annual re-clection.

History: Organized January 1930 at annual meeting of the Boone and Crockett Club to represent that club and other important recognized institutions interested in wild life protection. Members of the first Executive Committee represented the Boone and Crockett Club, the New York Zoological Society, the American Museum of Natural History; representatives of the Museum of Comparative Zoology, Field Museum of Natural History, Snithsonian Institution, Academy of Natural Sciences of Pliiladelphia, California Acadeny of Sciences, American Society of Mammalogists, Camp Fire Club of America, and Wilderness Club were added later.

Purpose: Conservation and preservation of threatened and vanishing forms of wild life; promoting and financing research into status and ecology of threatened spccies; publishing and disseminating information dealing with current status of various forms of wild life and with scientific and esthetic value of all wild life; contributing financially to national and international organizations concerned with wild life conservation, with special reference to activities outside the United States.

Mcmbership: Open to persons having world wide interest in wild life conservation or distinguished for achievement in the general cause of nature and faunal preservation. Total menbership 44 .

Meetings: Annual.

151. American Concrete Institute. P. O. Box 4754, Detroit 19, Mich. President: Joe W. Kelly, Professor of Civil Engineering. Engineering Materials Laboratory, University of California, Berkeley 4, Calif. Term expires February 22, 1961. Executive Secretary: William A. Maples. Term indefinite.

History: Organized January 17, 1905 ; chartered December 14, 1906, under Incorporation Laws of the District of Columbia, as the National Association of Cement Users; July 2, 1913, name changed to present title. ComMITTEES: There are more than fifty committees for research on concrete products and structures.

Purpose: To organize the efforts of its members for a non-profit public service in gathering, correlating, and disseminating information for the improvement of the design, construction. manufacture, use, and maintenance of concrete products and structures.

Membership: Individual, 8,408; Corporation Member, firm, society, or government agency, 402 : Contributing, same as Corporation but with unusual interest and desire to support Institute activities, 51; Junior, under twenty-eight 939; Student, same as Junior plus enrollment in engineering school, 432; Life, paid up individual, 13; Honorary, elected by Board of Direction, 8. Total membership 10,253.

\section{Mectings: Annual.}

Professional actizitics: Wason Medal, founded by Leonard C. Wason, Boston, Mass., awarded each year to the author of the most meritorious paper published in the previous annual volume of Proceedings. Wason Research Medal, founded by Leonard C. IVason, awarded for notable contributions reporting research in the field of concrete and concrete design, Henry C. Turner Gold Medal, founded in 1927 by Henry C. Turner of New York City, awarded occasionally for notable achievement in or service to the concrete industry. American Concrete Institute Construction Practice Award, a certificate of award and bronze plaque awarded on occasion for a paper of outstanding merit on construction practice. Alfred E. Lindau Award, founded in 1947 by Concrete Reinforcing Steel Institute, awarded occasionally for outstanding contribu- 
tions to reinforced concrete design practice. Heury L. Kennedy Award, established 1958 by the Institute to be given only for outstanding technical or administrative service and is not mandatory each year.

Publications: Journal, monthly, current volume: 56, \$18. Editor: William A. Maples.

152. American Conference of Governmental Industrial Hygienists, 1014 Broadway, Cincinnati 2, Ohio. Chairnan: Allan L. Coleman, Connecticut Department of Health. 345 Main Street, Hartford 1, Conn. Term expires April 1961. Sccrctary-Trcasurcr: Charles D. Yaffe. Term indefinite.

Iistory: Organized 1938 as the National Conference of Governmental Industrial Hygienists.

Purposc: To promote industrial hygiene in all its aspects and plases; to coordinate industrial hygiene activities by official Federal, State, local, and territorial industrial hygiene agencies; to encourage the interchange of experience among industrial hygiene personnel in such official organizations ; to collect and make accessible to all governmental industrial hygienists such information and data as may be of assistance to them in the proper fulfillment of their duties; to hold annual and such other meetings as may be necessary to effectuate the purpose of this organization.

Membership: Regular members, persons professionally engaged and regualarly employed by official governmental units responsible for fulltime programs of industrial hygiene in any of its aspects and phases: Associate members, persomel of educational institutions engaged in teaching or research in industrial hygiene, and governmental personnel in allied activities but not responsible for full-time programs in industrial hygiene. Total membership 509.

Mectings: Annual.

Professional activities: Development of materials through work of numerous standing committees; annual award presented to a nrember or group of members for outstanding recent contributions to the field; development of industrial hygiene standards and technical literature in such fields as rentilation, analytical methods, air sampling, and medical and nursing records.

Publications: Transactions of Annual Meetings, \$5. Manual of Analytical Methods, \$5.

153. American Congress of Physical Medicine and Rehabilitation. 30 North Michigan Ave., Chicago 2, I1l. President: Donald A. Covalt, Institute of Physical Medicine and Rehabilitation, 400 East 34th Street, New York, N. Y.
Term begins August 1960. Exccutice Secretary: Dorothea C. Augustin. Term indefinite

History: Organized in 1921 as American Congress of Physical Therapy.

Purpose: To promote and advance the art and science of physical medicine and relubilitation through the diagnosis and treatment of disease, defects, and injury by physical means and restoration to the fullest physical, mental, social. vocational, and economic usefulness possible.

Membership: Active members: graduate in medicine and surgery, legally qualified to practice medicine in the United States or in foreign countries. Associate: physiologist, physicist, biophysicist, electrical engineer, mechanical engineer, chemical engineer, research worker, investigator, teacher, or any other expert in the field of physical medicine and rehabilitation who is invited by the nembership committee. Honorary: eminent individuals interested in physical medicine and rehabilitation who are invited by the membership comnittee or who hold the Gold Key. Affiliate: persons actively enrolled in an approved residency or fellowship in physical medicine and reliabilitation. Total nembership approximately 750 .

Mcetings: Annual.

Professional activities: Gold Key Award: annual awards for scientific exhibits; annual essay award; Baruch essay award.

Publications: Archives of Physical Medicine and Rehabilitation, monthly, current volume: 41, \$8.50. Chairman of Editorial Board: Paul A. Nelson.

154. American Congress on Surveying and Mapping. President: M. Arnold Karo, Coast and Geodetic Survey, Department of Commerce, Waslington 25, D. C. Term expires March 1961. Exccutic' Secretary: Walter S. Dix, 430 NToodward Building. WVashington 5, D. C. Term indefinite.

History: Organized June 1941. Sections: Arizona; Colorado: Great Lakes; Hawaii ; Louisiana; New Mexico; North Carolina; Northern California: Oregon; St. Louis, Mo.; Southern California; Texas; Utah. AffiliAtes: East Bay Council; Florida Society of Professional Land Surveyors; Georgia Association of Registered Land Surveyors; Illinois Register of Land Surveyors; Indiana Society of Iand Surveyors; Kansas Society of Land Surveyors; Massachusetts Civil Engineers and Land Surveyors; Michigan Society of Registered Land Surveyors; Minnesota Land Surveyors Association; Nassau-Suffolk Civil Engineers, New Tork; South Carolina Society of Land Surreyors; Survey and Map Section, Florida Engi- 
lieers; Texas Surveyors Association; Virginia Association of Surveyors; Washington Association of Land Surveyors; Wisconsin Society of Land Surveyors. Incorporated 1950, District of Columbia. Divisions: Cartography; Control Surveys; Education; Instruments ; Property Surveys; Topography.

Purpose: To advance the science of surveying and mapping in their several branches; to further the interests of both those who use maps and surveys and those who make them; to establish a central source of reference for its members; to contribute a public education in the use of maps and surveys, and to encourage the prosecution of basic mapping and surveying programs which are paid in whole or in part with public funds; to provide a much needed means or channel for the exchange of information, advancement of techniques, establishment of standards, improvement of the professional status of those engaged in the work, and the exercise of international, national, and local expression on all matters concerning the general and scientific development of surveying and mapping.

Membership: Members, any person interested or engaged in surveying and mapping. Fellow Members, any member of the Congress who has made some outstanding contribution to surveying and mapping, or to the Congress. Honorary Members, any person of national or international fame who has made some outstanding contribution to surveying and mapping. Professional and Technical Associations, any professional organization interested in surveying and mapping activities. Sustaining Members, any commercial or professional institution or individual interested or engaged in surveying and mapping, the manufacture of instruments or equipment for this work, or the reproduction or compilation of maps. Total membership: 5,000 individuals and several hundred libraries.

Mectings: Annual.

Professional activities: Wild-Heerbrugg Award, for best article on improvement of instrumentation in surveying. $K$ and $E$ Scholarship for graduate work in surveying.

Publications: Surveying and Mapping, quarterly, current volume: $20, \$ 5$. Editor: Howard S. Rappleye.

155. American Council of Independent Laboratories, Inc. President: Cecil M. Shilstone, Shilstone Testing Laboratory, 814 Conti Street, New Orleans, La. Term expires October 1960. Exccutive Secretary: Harold M. Dudley, 4302 East-West Highway, Washington 14, D. C. Term indefnite.

Mistory: Organized 1937. Divisions : Central ; Eastern; Southern; Western.
Purpose: The promotion of scientific analysis, testing, inspection, or research and the advancement of the welfare of the independent scientific laboratories which associate themselves for this purpose.

Membership: The nembership is composed of independent laboratories whose principal business is analysis, testing, inspection, and research and which are adequately equipped and organized to render reliable service in their chosen fields. Total membership 78 laboratories, 70 branches.

Hectings: Annual.

Publications: Bulletin, quarterly. Editor: $\mathrm{H}$. M. Dudley.

\section{American Council on Pharmaceutical Edu-} cation. Presidcnt: George D. Beal, 5610 Elmer Street, Pittsburgh 32, Pa. Term expires January 1961. Sccretary-Treasurer: P. H Costello, 77 West IV ashington Street, Chicago 2, I11. Term expires January 1961.

History: Established 1932; incorporated 1939. Composed of three representatives each from the American Pharmaceutical Association, American Association of Colleges of Pharmacy, and the National Association of Boards of Pharmacy, plus one representative from the American Council on Education.

Purpose: To formulate standards for an approved school of pharmacy, to revise when necessary, and to publish a list of approved schools of pharmacy.

Mcmbcrship: Appointment by sponsoring organizations. Total membership 10.

Mectings: Two per year.

Professional activitics: Accreditation of colleges of pharmacy.

\section{American Crystallographic Association.}

President: Jurg Waser, California Institute of Technology, Pasadena, Calif. Term expires December 31, 1960. Sccretary: Leroy E. Alexander, Mellon Institute, Pittsburgh 13, $\mathrm{Pa}$. Term expires December 31, 1960.

History: Organized 1949 by consolidation of the American Society for X-Ray and Electron Diffraction with the Crystallographic Society of America. Commitees: Apparatus and Standards, Crystallographic Computing, Crystallographic Data, Publications.

Purpose: To promote the study of the arrangement of the atoms in matter, the causes of such arrangement, and its consequences and of the tools and methods used in such studies.

Membership: Any person actively interested in the purposes of the Society, whose application is sponsored by two members of the Society. Total membership 900.

Meetings: Annual. 
158. American Dairy Science Association, 32 Ridgeway Circle, White Plains, N. Y. President: R. E. Hodgson, U. S. Department of Agriculture, Animal Husbandry Research Division, Beltsville, Md. Term expires July 1. 1961. Executive Secretary: H. F. Judkins. Term expires July 1, 1961.

History: Organized in 1906. Divisions : Eastern, Southern, Mestern.

Purpose: To advance the general welfare of the dairy industry by instruction in dairy science, the stimulation of scientific research, and inprovement in the methods of conducting extension work.

Membership: Those who have had technical college training in dairying or in allied fields or are filling a responsible position requiring some technical knowledge of dairy science. Total nilembership 2,550.

Mectings: Annual.

Professional activitios: Two Student Affiliate Awards for best scientific papers at annual meeting. One Student Affiliate Award for best exhibit of activities at Annual Meeting.

Publications: Journal of Dairy Science. monthly, current volume: $43, \$ 15$, members \$10. Editor: E. O. Herreid, University of lllinois.

\section{American Dental Assistants Association,}

410 First National Bank Building, La Porte, Ind. President: Mrs. Joy Phillips, 3041 West Pierson, Phoenix, Ariz. Term expires October 20, 1960. Executive Secretary: Mrs. Elma Troutman. Term indefinite.

History: During the 1923 meeting of the American Dental Association in Cleveland, Ohio, a small group of dental assistants, led by Juliette A. Southard, took the initial step to organize the American Dental Assistants Association. Organization was completed in Dallas, Texas November 13, 1924 and the Association was incorporated in 1925 .

Purpose: To aid in the advancentent and elevation of the dental profession by encouraging persons in the dental assistants vocation to form societies whereby they may secure the educational advantages of lectures, clinical demonstrations, discussions, and instructions in the details of their duties.

Membership: Active, high school graduate or its equivalent, employed in an ethical dental office, clinic, hospital, or institution, or instructor of dental assisting, and affiliated through a local and State association; Independent, dental assistants eligible for active nembership who are employed in localities where 110 local society exists; Associate, former active members of the Assuciation who have discontinued their work in dental offices; Student, high school graduates enrolled in dental assistant courses of one or more years in schools or colleges approved by the Association; Life, granted to those nembers who have maintained active, continuous membership for a period of twentyfive years; Honorary, may be conferred upon members of the dental profession and others of distinction who have aided in the promotion and weltare of dental assistants. Total membership 10,000 .

\section{Meetings: Annual.}

Professional activities: Juliette A. Southard Scholarship Award, two $\$ 100$ awards given each year to the students judged by the Scholarship Committee as being the most deserving. Relief Trust; Annual Trophy Awards for Clinics; Best Educational Essay.

Publications: The Dental Assistant, bimonthly, current volume: 29, \$3. Editor: Mrs. Violet Crowley.

160. American Dental Association, 222 East Superior Street, Chicago 11, 111. President: Paul H. Jeserich, School of Dentistry, University of Michigan, Ann Arbor, Mich. Term expires October 1960. Secretary: Harold Hillenbrand. Term expires 1962.

History: Organized August 18, 1840 as American Society of Dental Surgeons, and adjourned sine die August 6, 1856. The American Dental Convention was organized August 2. 1855 and terminated about 1882. On August 3. 1859, at Niagara Falls, New York, twenty-six delegates representing eight local societies and two dental colleges organized the American Dental Association. In 1869, as a result of the IVar Between the States, dentists who liad broken away from the parent group formed the Southern Dental Association. In 1897 the Association united with the Southern Dental Association, and the name was clianged to the National Dental Association. On June 19. 1922, the organization took its original name, the American Dental Association. There are thirteen Trustee Districts covering the United States; fifty-four State and territorial societies; and 444 city and local societies. Councils: Constitution and Bylaws; Dental Education; Dental Health; Dental Research; Dental Therapeutics; Dental Trade and Laboratory Relations; Federal Dental Services; Hospital Dental Service; Insurance; International Relations; Jourualism; Judicial ; Legislation ; Membership; National Board of Dental Examiners; Relief; Scientific Session. Bureaus: Audiovisual Service; Dental Health Education; Economic Research and Statistics ; Library and Indexing Service; Membership Records; Public Information. SEctions : Anesthesiology ; Operative Dentistry ; Oral Surgery: Orthodontics and Oral Development; 
Pedodontics; Periodontics; Practice Administration; Prosthodontics, Complete; Prosthodontics, Partial; Public Health Dentistry; Research; Roentgenology.

Purpose: To encourage the improvement of the health of the public and te promote the art and science of dentistry.

Mcmbership: Active, 77,212, licensed dentist who is a member of constituent or component society, or federal dental service; Life, 4,875, active nembers of ADA for thirty-five years, sixty-five years of age, active member in good standing at time of election by House of Delegates; Student, 12,305, undergraduate student of accredited dental school, intern, resident, or graduate student; Honorary, 37, individual who, because of outstanding contributions to the advancement of the art and science of dentistry, has been elected by House of Delegates on nomination of Board of Trustees; Affiliate, 244, ethical dentist who practices in any country other than United States, who is a member of a recognized dental organization in such country and whose application, for membership is passed on favorably by Board of Trustees; Associate, 23, nuember of an allied profession who has contributed to the advancement of dentistry. Total membership 94,696.

Mectings: Annual.

Professional activities: Awards at National Science Fair: two finalists receive expense paid trips to annual session of Association; two second-place awards of $\$ 50$ each. Council on Dental Research supports ten research associates at the National Bureau of Standards and Standards and three at the National Institutes of Health, \$150.635. Bureau of Economic Research and Statistics, $\$ 50,000$; Council on Dental Therapeutics' budget for research, $\$ 100,685$. A laboratory with a staff of four is maintained at the headquarters.

Publications: Index to Dental Literature, quarterly and annually, current volume: 11, annual subscription $\$ 20$, annual bound volume $\$ 10$. Dental Abstracts, monthly, current volume : 5 , domestic $\$ 8$, foreign $\$ 9$. Editor: Lon $W$. Morrey. Accepted Dental Remedies, annually, $\$ 3$ per copy. American Dental Directory, annually, $\$ 15$ per copy. Journal of Oral Surgery, Anesthesia and Hospital Dental Service, bimonthly, current volume: 18 , domestic $\$ 10$, foreign \$12. Editor: Fred A. Henry. Journal, monthly, current volume: 60 , domestic $\$ 7$, foreign $\$ 8$, free to members. Editor: Lon W'. Morrey. American Dental Association Specifications for Dental Materials, annually, current volume: 3, \$2.25 per volume. Newsletter, semimonthly, current volume: $13, \$ 2$. Dental Health Highlights, monthly, current volume: 16, free. Clipsheet, irregular, current volume: 10, free. Library: 13,400 volumes.
161. American Dental Hygienists' Association, Inc. 100 East Ohio Street, Chicago 11, I11. President: Miss Tillie Ginsburg, 604 North 16th Street, Milwaukee 3, Wis. Term expires October 1960. Executive Secretary: Miss Margaret E. Swanson. Term expires January 1964.

History: Organized September 11, 1923; incorporated, 1927. Twelve trustee districts, fortysix constituent associations, seventy-five component associations.

Purpose: To cultivate, promote, and sustain the art and science of dental hygiene, to represent and safeguard the common interest of the members of the dental hygiene profession, and to contribute toward the health of the public.

Menbership: Any ethical female dental hygienist who possesses a certificate or degree in dental hygiene granted by a school of dental hygiene accredited by the Council on Dental Education of the American Dental Association, and who is licensed to practice in any one of the States, districts, territories or dependencies of the United States. Active members, 4,052: Students, 1,765; Life, 30, Honorary, 14.

Mectings: Annual.

Publications: Journal, quarterly, current volume: 34 , domestic $\$ 4$, foreign $\$ 5$. Editor: Miss Belle Fiedler.

162. American Dermatological Association, Inc. President: George C. Andrews, 115 East $61 \mathrm{st}$ Street, New York 21, N. Y. Term expires June 20, 1961. Secretary: Wiley M. Sams, 308 Ingraham Building, Miami 32, Fla. Term expires April 1963.

History: Organized September 6, 1876, and incorporated in June 1930. Sections: United States; Canada; Cuba.

Purpose: The advancement of dermatologic knowledge, teaching, and research.

Mombership: By invitation; full time dermatologists with Board certification. Active members, 113; Senior, 62; Corresponding, 41 ; Honorary, 16.

Meetings: Annual.

Professional activities: Research and Educational Fund, Inc. ; Annual Essay Contest, first prize, $\$ 1,000$; second prize, $\$ 400$.

Publications: AMA Archives of Dermatology, monthly, current volume: 81. Editor: Herbert Rattner.

163. American Diabetes Association, Inc. 1 East 45th Street, New York 17, N. Y. President: Franklin B. Peck, Sr., Indianapolis, Ind. Term expires June 1961. Secretary: E. Paul Sheridan, Denver. Colo. Term expires June 
1961. Exccutive Director: J. Richard Connelly. Term indefinite.

History: Organized and incorporated 1940; forty-four affiliate associations throughout the United States. Commitrees: Affiliate Associations, Camps, Detection and Education, Emergency Medical Care, Employment, Food and Nutrition, Oral Hypoglycemic Compounds, Professional Education (Subcommittees on Speakers Bureau, Definition and Classification, Teaching of Diabetes in Hospitals, Teaching of Diabetes in Medical Schools), Research and Fellowships, Scientific Exhibits, Scientific Programs, Scientific Publications, Statistics, Therapeutic Agents and Devices.

Purpose: To promote among physicians and others the free exchange of knowledge with respect to diabetes mellitus and to improve standards of treatment; to promote medical research by individuals, hospitals, clinics, universities, and other institutions; to educate the public in the early recognition of diabetes mellitus and in the importance of medical supervision of its treatment ; to distribute accurate information respecting it to the general public by literature, meetings, and other appropriate means; to develops educational methods designed to give diabetic patients a better understanding of their disease: to encourage the formation of subsidiary groups.

Ucmbership: Active members, 2,459, graduates of medical schools approved by the American Medical Association, and other physicians and scientists interested in diabetes; Associate, 42. professional or lay people interested in objectives and activities of the Association; Sustaining Corporate, Contributing Corporate, and Corporate Members, 24, medical, welfare, civic, educational, scientific, or other business organizations; Honorary, 10. Total membership 2,535.

Meetings: Annual.

Professional activities: Research Fund, for the promotion of research, both clinical and laboratory, in the field of diabetes and for the study of diabetes. Nordisk Insulinfond Foundation for the Elliott P. Joslin Fellowship, to be applied to the study of diabetes, capital amount, \$71,712. Clinical and Research Fund, clinical and basic research including awarding of fellowships, capital amount $\$ 397,884$. Banting Medal, for distinguished service in the interest of doctor and patient. Annual Graduate and Medical Student-Intern Essay Contest, to stimulate interest in diabetes and allied diseases among medical students, interns, physicians within two years after their graduation from medical school, and graduate students in the basic sciences: (a) for the best paper reporting original studies, $\$ 250$; (b) for the best review article or case report, $\$ 100$. Annual Lilly Award. $\$ 1.000$ and a medal, to recognize demonstrated research in the field of diabetes, taking into consideration independence of thought and originality, eligibility: any investigator in the United States or Canada in an appropriate field of work related closely to diabetes who is less than forty years of age on January 1 of the year in which the award is made.

Publications: Diabetes: The Journal of the American Diabetes Association, bimonthly, current volume: 9 , free to members, domestic $\$ 9$. foreign \$10, Medical Students, Interns and Residents $\$ 4.50$. Editor: Irving Graef. ADA Forecast, bimonthly, current volume: $13, \$ 2$. Editorin-Chief: Frederick W. Williams.

164. American Dietetic Association. 620 North Michigan Avenue, Chicago 11, I11. President: Doris Johnson, Director of Dietetics, GraceNew Haven Community Hospital, New Haven 4, Conn. Term expires October 1960. Exceutize Dircctor: Ruth M. Yakel. Term indefinite.

History: Organized in 1917 in Cleveland, Ohio. Fifty affiliated State associations, plus the District of Columbia and Puerto Rico. Sections: Community Nutrition, Diet Therapy, Food Administration, and Education.

Purpose: To improve the nutrition of human beings; to advance the science of dietetics and nutrition; and to promote education in these and allied areas.

Mcmbership: Professionally qualified dietitians and nutritionists. Total membership 14,358.

\section{Mectings: Annual.}

Professional actirities: Mary Swartz Rose Fellowship, to acknowledge a nember of outstanding ability who is doing graduate study. Marjorie Hulsizer Copher Award, the highest honor to a nember for outstanding achievement in the field of dietetics. Lydia J. Roberts Essay Award, to encourage research in the feeding of infants and children. Graduate Loan Fund, available to members doing graduate study and dietetic interns. Mead Johnson Awards, ten to dietetic interns and two to members doing graduate study. Cooperates with the American Hospital Association in holding institutes in the area of Hospital Dietary Department Administration.

Publications: Journal, monthly, domestic $\$ 8$, Foreign \$9. Editor: Dorothea F. Turner. Annual Reports and Proceedings, \$1.

Library: 1,000 volumes.

165. American Documentation Institute. President: Gerald J. Sophar, Jonker Pusiness Machines, 404 North Frederick Avenue, 
Gaithersburg, Md. Term expires October 1961. Executive Director: John B. Kaiser, 1025 Connecticut Avenue, N.W., Washington 6, D. C. Term indefinite.

History: Organized 1937; affliate, American Association for the Advancement of Science. Conimittees: Auxiliary Publications, Bibliography, Distribution, Organization of Information, Reproduction, Research and Technical Developments. Training.

Purpose: Advancement of principles and techniques of conmunication of recorded knowledge.

Membership: Individual members, 350, persons subscribing to purposes of this Institute; Institutional, 12, socicties, associations, government agencies, educational institutions, industrial and business organizations interested in promoting purposes of this Institute.

Mectings: Annual.

Publications: Anerican Documentation, quarterly, current volume: $11, \$ 6.50$. Editor: Luther H. Evans.

\section{American Electroencephalographic Society.}

1420 Grattan Street. St. Louis 4, Mo. Presidcnt: Jerome K. Merlis, University Hospital, Baltimore, Md. Term expires June 1961. Secretary: George A. Ulett. Term expires June 1961.

History: Organized December 1946; incorporated December 1947. Member of International Federation of Electroencephalographers. Committees: Hospital Relations, Scientific Proceedings, Symposium, Technicians.

Purpose: To promote research and exchange of professional information on electroencephalography and related fields; to help maintain high scientific standards of clinical electroencephalographic laboratories: to set up standards for the certification of investigators or technicians to assist in training personnel; to draw up minimum specifications for apparatus; to assist in the formation of international committees for uniform standards of apparatus, techniques, and procedure throughout the world.

l/cmbership: Full members: experienced workers in electroencephalography or related fields, 127; honorary fellows: distinguished workers in the field, who shall be required to pay no fees or dues, and who shall have no vote, 19; associate: advanced workers in such fields who are not deemed qualified to be members, 104: subscribers: technicians and others not deemed qualified for any other class of membership, 107. Total nembership 358.

Mectings: Anmual.

Publications: Journal of Electroencephalography and Clinical Neurophysiology, quarterly, current volume: 12, \$10. Editor: Herbert $\mathrm{H}$. Jasper.
167. American Electroplaters' Society, Inc. 443

Broad Street, Newark 2, N. J. President: IV. Andrew Viesley, P. O. Box U, Bergen Point Station. Bayonne, N. J. Term expires Ine 23. 1961. Excoutive Sccretary: John P. Nichols. Term indefinite.

History: Organized and incorporated in New Jersey, 1909. Three branches in Australia, five in Canada, fifty-one in the United States.

Purpose: Improvement and dissemination of knowledge of the arts and sciences of electroplating, metal finishing, and allied specialties; development of cooperation and friendship among nembers.

Mcmbership: Active members, 7,200, persons interested in the object of this Society; Student, persons not over twenty-five years of age, enrolled in full time courses at accredited institutions of learning, and interested in the object of this Society; Sustaining. 350, those with interest in this Society's researcl program; Honorary, 14: Members-at-Large. 300, those not desiring membership in any branch. Total membership approximately 8,000 .

\section{Mectings: Annual.}

Professional actiritics: Research Fund, for research in electroplating and metal finishing, over $\$ 100,000$; Carl E. Heussner Award (Society's Gold Medal), $\$ 250$, annual, for best paper presented; Silver and Bronze Medals, $\$ 150$ and $\$ 50$ respectively, annual, for 2 nd and $3 \mathrm{rd}$ best papers; Robert S. Leather Mechanical Finishing Award, Chromium Plating Award, and Precious Metal Plating Award, for best papers on those subjects, $\$ 50$ each: George B. Hogaboom Memorial Nickel Plating Award, \$75; John J. Hanney Memorial Copper Plating Award, \$75; Scientific Aclievement Award, this Society's highest, $\$ 500$; Charles Henry Proctor Memorial Leadership Award, \$150.

Publications: Plating Magazine, monthly, current volume: 47 , domestic $\$ 5$, foreign $\$ 8$, free to menbers. Editor: Rodney Leeds. Technical Proceedings, annual.

168. American Entomological Society. Academy of Natural Sciences of Philadelphia, 1900 Race Street, Philadelphia, Pa. President: Neal A. Weber, Biology Department, Swarthmore College. Swarthmore, Pa. Term expires January 1961. E.recutive Secretary: Richard F. Swivel, P. O. Box 37, Penns Park, Pa. Term expires Jannary 1961.

History: Organized February 22, 1859.

Purpose: The improvement and advancement of entomology by original research, and by publication of discoveries.

Hembership: Resident members, corresponding members, honorary members. Total membership 180 . 
Meetings: Monthly, except June, July, and August.

Publications: Transactions, quarterly, current volume: 86, \$9. Editor: Margaret Smith Grant. Entomological News, monthly except August and September, current volume: $71, \$ 6$. Editor : R. G. Schmieder. Memoir Series, irregular, current volume: 17. Editor: Margaret Smith Grant.

Library: 10,000 volumes emphasizing taxonomy, morphology, physiology, and hiogeography.

169. American Epidemiological Society. President: George F. Badger, School of Medicine, W'estern Reserve University, Cleveland 6, Ohio. Term expires April 1961. SecretaryTreasurer: Robert F. Korns, New York State Department of Health, 84 Holland Aventue, Albany, N. Y. Term expires April 1961.

History: Founded in 1927 by 25 epidemiologists; informal constitution adopted April 1928.

Purpose: To promote the study and discussion of epidemiological problems; to conduct a meeting annually at which reports of current research are presented and discussed.

Membership: Open to individuals with an active interest in and who have made a worthy contribution to the field of epidemiology. Nomination by three active members, and election by at least a majority of active members; author or coauthor of at least one scientific paper of epidemiological import and distinction. Total membership approximately 100 .

Meetings: Annual.

170. American Eugenics Society, Inc. 230 Park Avenue, New York 17, N. Y. President: Harry L. Shapiro, American Museum of Natural History, 79th Street and Central Park Vest, New York, N. Y. Term expires December 1961. Secretary: Frederick Osborn. Term expires December 1961.

History: Incorporated in 1926. The Society is the successor to the Eugenics Committee of the United States and the Eugenics Society of the United States.

Purpose: To promote research on individual lutman differences, to provide authoritative information about heredity and qualitative aspects of population, and to advance scientific applications of knowledge in these and related fields. To maintain an educational membership society consisting of and directed by scientists, professionals, and laymen who are interested in furthering these purposes.

Mcmbership: Individuals interested in furthering the purposes of the Society; all nominations must be brought before the Committee on Membership of the Society. Total membership 471.

Meetings: Annual.

Professional activities: Medical Genetics Committee acts as advisory group in professional matters and encourages interest in field of medical genetics; evaluates applications for fellowships and grants received by the Society: offers recommendations to Population Council, which makes financial awards for these purposes; concentrates its efforts on methods of improving and expanding the teaching of medical genetics in the medical schools of the New York area; holds symposia in medical genetics and related fields. Heredity Counseling Referral Service refers inquiries to geneticists in the various parts of the United States.

Publications: Eugenics Quarterly, current volume: $7, \$ 5$, free to members. Editor: Helen G. Hammons.

171. American Farm Research Association. 100 Willayne Plaza, West Lafayette, Ind. President: Wayne Shidaker, Farm Bureau Cooperative Association, Inc., Columbus, Ohio. Term expires November 1960. Secretary: Roger Flemming, American Farm Bureau Federation, 261 Constitution Avenue, N. W., Washington, D. C. Term expires November 1960. Director of Research: George D. Scarseth, 1414 Ravinia Road, W'est Lafayette, Ind. Term indefinite.

History: Organized July 1, 1944. CommiтTEES: Animal Nutrition; Farm Chemicals; Petroleum; Plant Food; Seed.

Purpose: To conduct research in the production and distribution of farm commodities and supplies; to translate technical and scientific information into practical use for farmers; to assist farmer-owned cooperatives to use new technologies; to develop new research projects of special interest to farmers.

Membership: Members of the American Farm Bureau Federation, or State farmer-owned cooperatives approved by the State farm bureau. Total membership 12 organizations.

\section{Metings: Annual.}

Professional activitics: The Association sponsors research fellowships at State universities and agricultural experiment stations through State farm bureaus. The amounts granted each State vary, and may be as much as $\$ 60,000$. Agricultural Science Extension, lectures to extend knowledge and understanding of agricultural science. Several State farm bureaus own the Association's laboratories, which are associated through the committees of the Association.

Publications: Research Letter, monthly, restricted to members. Editor: George D. Scarseth. 
172. American Federation for Clinical Research. 250 West 57th Street, New York 19, N. Y. President: Arnold S. Relman, Evans Memorial Hospital, Boston 18, Mass. Term expires May 1961. Secretary-Treasurer: George E. Schreiner, Georgetown University Hospital, Washington, D. C. Term expires May 1961.

History: Organized May 7, 1941. Sections: Eastern, Southern, Midwestern, and Westeru. Fifteen organized local clubs: Albany Research Club; Ann Arbor-Detroit, Toledo Group; Boston Chapter; Chicago Group ; Greater Philadelphia Chapter; New Jersey Research Society; Northwest Society for Clinical Research; Oakland Chapter; Omaha Research Club; University of Denver Medical Research; San Francisco Branch; Syracuse Research Club; Temple Chapter; Washington, D. C. ; Westchester Chapter. Standing Committees: Executive, Publication.

Purpose: To promote and encourage original research in clinical and laboratory medicine; to welcome as members and provide an accessible forum for young persons engaged in sucl research.

Membership: Regular members, 2,123, any person under the age of forty-one who has completed and published a meritorious investigation in any field related to medicine, and whose application has been approved by the Council; Senior, 1,371, any person forty-one years of age of older, who has completed and published a meritorious investigation in any field related to medicine, and who is actively stimulating younger persons to pursue similar juvestigation, and whose application has been approved by the Council; Corporate, any corporation or foundation interested in the purposes of the Federation, which has been invited to become a Corporate member and has paid the prescribed dues. Total membership 3,494.

Meetings: Annual; four geographic meetings.

Publications: Clinical Research, quarterly, current volume: $8, \$ 8$ domestic, $\$ 9$ foreign. Editor: Morton D. Bogdonoff.

\section{American Federation of Mineralogical So-} cieties. President: Henry B. Graves, 3153 North West 27th Street, Miami 42, Fla. Term expires August 10, 1961. Secretary: Mrs. Veryle Carnahan, 9531 Mina Avenue, Whittier, Calif. Term expires August 10, 1961.

History: Organized June 12, 1947 at Salt Lake City. Members: California Federation of Mineralogical Societies; Eastern Federation of Mineralogical and Lapidary Societies; Midwest Federation of Mineralogical and Geological Societies; Northwest Federation of Mineralogical
Societies; Rocky Mountain Federation of Mineralogical Societies; Texas Federation of Mineral Societies.

Purpose: To promote popular interest and education in the various earth sciences, and in particular the subjects of geology, mineralogy, paleontology, lapidary and related subjects.

Membership: Open to organized regional federations; consists of affiliated groups of societies or associations whose objects and purposes fit within the framework of objects of this association. Total membership approximately 35,000 to 40,000 , comprising 525 societies in 6 regional federations.

Meetings: Annual.

Professional activities: Scholarship Foundation; Junior Essay Contest, five cash prizes.

Publications: Gems and Minerals, monthly, \$3. Editor: Don MacLachlan.

174. American Fern Society, Inc. President: Clair A. Brown, 1180 Stanford Avenue, Baton Rouge 8, La. Term expires December 31, 1960. Sccretary: Donald G. Huttleston, Longwood Gardens, Kennett Square, Pa. Term expires December 31, 1960.

History: Organized in 1893 as Limnaean Fern Chapter of the Agassiz Association; name changed to present title in 1905 ; incorporated in 1936.

Purpose: To affiliate those interested in ferns, to foster such an interest, to encourage correspondence and exchange of specimens between nembers, and the publication of matter pertaining to this group of plants.

Mcmbcrship: Members, 800, interest in ferns and their allies; Honorary, 5.

Meetings: Annual.

Publications: American Fern Journal, quarterly, current volume: 50, $\$ 2.35$. Editor: C. V. Morton.

175. American Fisheries Society. P. O. Box 483, McLean, Va. President: James Moffett, 1220 East Washington Street, Ann Arbor, Mich. Term expires September 1961.

History: Organized 1870 ; incorporated in the District of Columbia, 1910.

Purpose: To promote conservation, development, and wise utilization of fisheries, both recreational and commercial.

Membership: Anyone interested in fish, fishing, and fisheries is eligible for membership. Total menbership 2,100.

Mectings: Annual.

Professional activities: Annual Award for best paper printed in quarterly Transactions. 
Publications: Transactions, quarterly, current volume: 89, \$2.50. Editor: Lloyd Smith, Ir.

\section{American Forestry Association. 919 17th} Street, N. W., IVashington 7, D. C. Prcsident: Don P. Johnston. Term expires December 1960. Executive Tice-President: Fred E. Hornaday. Terin indefinite.

History: Organized April $18 S 2$ in Cincinnati, as the American Forestry Congress, joined at the Montreal meeting August 1882 by an earlier American Forestry Association organized in Chicago in 1875 ; name changed to present title 1889 ; incorporated January 1897 ; reincorporated January 1920 in the District of Columbia.

Purpose: Advancement of intelligent management and use of the country's forests and related resources of soil, water, wildlife, and outdoor recreation.

Membership: Open to persons interested in the conservation and perpetuation of Anerican forests and forest life. Subscribing. Contributing, Sustaining, Life, and Foreign nembers; Patrons. Total memberslip 30,000.

Mectings: Annual.

Publications: American Forests, monthly, current volume: $66, \$ 6$.

177. American Foundation for Homoeopathy. 1726 Eye Street, N. W., IVashington 6. D. C. President: Allan D. Sutherland, P. O. Box 678, Brattleboro, Vt. Term expires October 1962. Secretary: Mrs. Margery B. Lavelle. Term indefinite.

History: Incorporated in the District of Columbia. Jume 1924, as an educational and scientific organization. Formerly run by a Board of Trustees made up of seven physicians and five laymen: since 1954 it has been six physicians and six laymen. Conducted a PostGraduate School in Homoeopathy for Physicians since 1922, except for war years. Fcundation Course for Laymen started in 1946.

Purpose: To promote the art of healing according to the natural laws of cure from a strictly homoeopathic standpoint; to establish and direct centers for the study and understanding of homoeopathy together with research work in any correlated subject; to diffuse knowledge among the laity concerning homoeopathic principles; to serve as a reference center for all that relates to homoeopathy and to serve as a repository for homoeopathic literature and drugs.

Membership: Open to those who wish to help further the work of the Foundation. Associate, 114 ; Contributing, 110; Sustaining, 21 ; Life, 1. Meetings: Every four months.
Professional activities: Lula R. Cannon Fund for Cancer Research, \$2,000 per year. Scholarship Fund $(\$ 5,000)$ for use by student in PostGraduate School in Homoeopathy.

Publications: The Layman Speaks, A Homoeopathic Digest, monthly, current volume: 13, \$4. (\$4.50 foreign). Editor: Arthur B. Green.

Library: Approximately 5,000 volumes.

178. American Foundation for Tropical Medicine, Inc., and Liberian Institute of the American Foundation for Tropical Medicine, Inc. 551 th Avenue, New York 17, N. I: President: Max J. Miller. Term indefinite. Exccutive Secretary: Mrs. Herma H. Hoefler. Term indefinite.

History: Foundation incorporated 1940, Institute 1946, both in New lork.

Purpose: To collect, classify, and disseminate knowledge concerning tropical or geograplical medicine, public health, and prevention of human and animal diseases in warm climates; to conduct researcli and aid various educational programs for this purpose.

Membership: Open to persons interested in tropical medicine. Total nembership 79.

Meetings: Annual.

Professional activities: Research laboratory, Harbel, Liberia ; Richard Pearson Strong Medal for outstanding achievement in tropical medicine.

179. American Foundrymen's Society. Golf and Nolf Roads, Des Plaines, 111. Presidcnt: Norman J. Dunbeck, International Minerals and Chemical Corporation, Skokie, I11. Term expires May 1961. General Manager: William IV. Maloney. Term expires May 1261.

History: Organized May 12, 1896, at Philadelplisa, Pa.; incorporated July 3, 1916, under the laws of Illinois. There are forty-seven cliapters in various foundry centers in the United States, Canada, and Mexico. Divisions: Brass and Bronze, Die Casting and Permanent Mold, Ductile Iron, Education, Gray Iron, Light Metals, Malleable, Pattern, Sand, and Steel. There are eighteen general interest committees.

Purpose: To promote the arts and sciences applicable to metal casting manufacture and to improve the methods of production and the quality of castings, so that the increasing utility of all classes of castings may result advantageously to persons engaged in the foundry and related industries and to users of foundry products.

Membership: Personal members, 4,142; Company, 941; Sustaining, 136; Company affiliate, 6,276 , employees of Company or Sustaining members; Associate, 403, those engaged exclusively in education, government, or military work; Junior, 883, below age of twenty-five; 
Honorary, 92; Members in Military Service, 16. Total nembership 12,889 .

Mcetings: Annual Convention and Exhibit; Regional Technical Conferences; Monthly Technical Chapter Meetings.

Professional activities: Major research projects conducted on various aspects of the foundry industry at colleges and institutions in the United States, and by technical committees with the research work contributed by members of the Association in their plants and laboratories. Charles Edgar Hoyt Memorial Lecture, presented at the Annual Convention. Capital of $\$ 50,000$ for scholarship purposes at the secondary school level. The Society carries on educational programs at the secondary level, and in-plant programs, through its Training and Research Institute, to improve foundry teaching facilities, upgrading and technical advancement of in-plant persomnel, and recruiting; conducts safety, hygiene, and air pollution control program for the castings industry; develops engineering data for improving plant conditions. Award of Scientific Merit, for individuals who have done some singularly outstanding work. Service Citation, for continued and dedicated service to the industry and to the Society.

Publications: Transactions, annual, current volume: $67, \$ 15$ clothbound, free to Company and Sustaining members, $\$ 8$ to $\$ 10$ to members. Modern Castings, monthly, $\$ 5$, free to members. Editor: Jack H. Schaum.

Library: 2,000 volumes.

180. American Fracture Association. President: Irvin H. Scott, Scott Medical Building, Sullivan, Ind. Term expires December 31, 1960. Secretary-General: H. W. Wellmerling, 610 Griesheim Building, Bloomington, Ill. Term indefunite.

History: Organized 1941; incorporated in Illinois.

Purpose: To advance medical science through the study, investigation, and development of the various accepted types of treatment of fractures of bones.

Membership: Any person entitled to practice medicine in the territory in which he resides, and who is a member of his county and State medical society and The American Medical Association, or the equivalent thereof. Members, 331 ; Honorary, 19 ; Emeritus, 10 . Total membership 360 .

\section{Meetings: Annual.}

Professional activities: Postgraduate course in care and treatment of fractures. Sponsor and finance numerous research projects.
Publications: Clinical Orthopedics, biannual, current volume: $40, \$ 7.50$ per volume. Editor: Anthony F. DePalma.

181. American Gastroenterological Association. President: Hugh Butt, Mayo Clinic, Rochester, Minn. Term expires May 27, 1961. Secretary: IVade Volwiler, Department of Medicine, University of Washington, Seattle 5 . 11 ash. Term indefinite.

History: Organized 1897 ; incorporated. CoмMittees: Hemorrlage; Peptic Ulcer; Surgical Methods for Peptic Ulcer; Postgraduate Facilities for Training in Gastroenterology; Liver Biopsy Registry.

Purpose: Study of normal and abnormal conditions of digestive organs, and of problems connected with metabolism.

Membership: Active members, restricted to American and Canadian investigators and practitioners of medicine and surgery who lave published meritorious work on subjects pertaining to the digestive system or on problems connected with metabolism; Associate; Senior; Honorary. Total membership 316.

Meetings: Annual.

Professional activities: Julius Friedenwald Medal, awarded amnually for distinguished service in gastroenterology.

Publications: Gastroenterology, monthly, current volume: $42-43, \$ 7$, free to members. Editor : A. H. Aaron, 40 West North Street, Buffalo, N. Y. Transactions, annual, current volume: 64. American Journal of Digestive Diseases, monthly, current volume: $27, \$ 6$, free to Active and Associate members.

182. American Gastroscopic Society. Chicago, Ill. President: Paul L. Shallenberger, Guthrie Clinic, Sayre, Pa. Term expires May 24, 1961. Secretary: Arthur M. Olsen, Mayo Clinic, Rochester, Minn. Term expires May 24, 1961.

History: Organized in 1941 by Dr. Rudolf Schindler.

Purpose: The development of the gastroscopic method, and in recent years to esophagoscopy and other methods of gastro-intestinal endoscopy.

Membership: Must have Board certification, usually Internal Medicine or Surgery, or must be qualified for same. Must have had adequate training in gastroscopy and esophagoscopy and have submitted a paper suitable for publication in the Journal of the Society, or have submitted 50 case protocols of gastroscopic and esophagoscopic examinations. Total membership, 216.

Meetings: Annual. 
Professional activities: Rudolf Schindler Award, for unusual contributions to the field of gastroscopy, given annually.

Publications: Bulletin of Gastroscopy and Esophagoscopy, quarterly, current volume: 6, \$5. Editor: Roy L. Sexton.

\section{American Genetic Association. $1507 \mathrm{M}$} Street, N. IV., Washington 5, D. C. President: Samuel L. Emsweller, U. S. Department of Agriculture, Beltsville, Md. Term expires January 1961. Secretary: IV. Ralph Singleton, University of Virginia, Charlottesville, Va. Term expires January 1962.

History: Organized December 29, 1903, at St. Louis, Mo., under the auspices of the Association of American Agricultural Colleges and Experiment Stations, as the American Breeders Association; reorganized and incorporated in 1913 under the present title.

Purpose: To encourage the study of the laws of heredity, and to promote their application in the improvement of plants, animals, and human racial stocks.

Membership: Members, interest in heredity as a science, sponsored by a member; Honorary; Patrons, persons who have contributed $\$ 1,000$ or more to the objects of the Association. Total nembership 4,102.

\section{Heetings: Annual.}

Professional activities: Meyer Medal, for distinguished service in plant introduction.

Publications: Journal of Heredity, bimonthly, current volume: $50, \$ 6$, free to members and on exchange with a limited number of genetic and biological publications.

184. American Geographical Society. Broadway at 156 th Street, New York, N. Y. President: Walter A. Wood. Term expires 1962. Director: Charles B. Hitchcock. Term indefinite.

History: Organized 1851; incorporated 1852 as the American Geographical and Statistical Society; name changed to present title 1871. Departments: Cartography, Cultural Geography, Economic Geography, Glaciology, Plant Geography, Medical Geography.

Purpose: To collect and disseminate geographical information; to establish in the chief city of the United States a place where may be obtained accurate information on every part of the globe; and to encourage such exploring expeditions as are likely to result in valuable discoveries in geography and the related sciences. Society functions primarily as a research institution.

Membership: Fellowship in the Society open to individuals with an interest in exploration and travel, research, and the dissemination of geographical knowledge. Total membership approximately 4,000 .

Mectings: Annual dinner-address; lectures.

Professional activities: Cullum Geographical Meral, founded by Major-General George IV. Cullum, awarded to individuals distinguishing themselves by geographical discoveries or in the advancement of geographical science; Charles P. Daly Medal, founded by Charles P. Daly, awarded for valuable or distinguished geographical service or labors; David Livingstone Centenary Medal, founded by Hispanic Society of America, awarded for scientific achievement in field of geography of the Southern Hemisphere; S. F. B. Morse Medal, founded by Samuel F. B. Morse, March 1872, awarded for exceptionally distinguished geographical research; George Davidson Medal, founded by Ellinor Cambell Davidson in 1946, awarded for exceptional achievenent in rescarch or exploration in the Pacific area; Isaiah Bowman Memorial, awarded for presentation and publication of original lectures in geography or for geographical research. A grant of $\$ 2,500$ was made by The Asia Foundation to assist in providing copies of The Geographical Revicev to selected Asian libraries, and to permit the award of small stipends to Asian students and scholars currently in the United States to enable them to do research at the Society.

Publications: Geographical Review, quarterly, $\$ 9.50$, free to Fellows. Focus, monthly except July and August, $\$ 1$, free to Fellows. Current Geographical Publications, monthly, $\$ 8$. Soviet Geography: Review and Translation, monthly except July and August, $\$ 6$.

Library: 144,298 volumes; 274,045 n11aps; 3,838 atlases; 39,939 photographs.

185. American Geological Institute. 2101 Constitution Avenue, N. W., Washington 25, D. C. President: Ian Campbell, Department of Mines, Ferry Building, San Francisco, Calif. Term expires November 1961. Executive Director: Robert C. Stephenson. Term indefinite.

History: Organized November 1948, under National Academy of Sciences-National Research Council.

Purpose: To serve as a coordinating organization in fields of geology and solid earth geopliysics to meet need for representation on matters relating to public education, and to public, government, and professional relations.

Membership: Requires membership in one of supporting member societies. Total institutional membership 14.

Metings: Annual, of Executive Committee 
and Board of Directors only; no meetings of this Institute as a whole.

Publications: GeoTimes, eight annually, current volume: 4, \$2. Editor: Robert C. Stephenson. Directory of Geoscience Departments in Colleges and Universities of the United States and Canada, triennial, \$2. Editor: Bonnie C. Henderson. Survey of Geology-Geophysics Students in Colleges and Universities of the United States and Canada, annual, $\$ 0.50$. Editor: Bonnie C. Henderson. GeoScience Abstracts, monthly, current volume: 2 , members $\$ 15$, educational institutions $\$ 35$, non-nember public libraries $\$ 35$, others $\$ 65$. Editor: Anne C. Sangree. International Geology Review, monthly, current volume: 2 , members $\$ 15$, educational institutions $\$ 15$, non-member public libraries $\$ 55$, others $\$ 55$. Editorial Board. Izvestiya (translation from Russian of Izvestiya of Academy of Sciences of U. S. S. R., Geology Series), monthly, current volume: 58 , members $\$ 27$, educational institutions $\$ 27$; non-member public libraries and all others \$45. Editorial Board. Doklady (translation from Russian of Doklady of Academy of Sciences of U. S. S. R., Earth Science Sections), bimonthly, current volume: 124 , members and educational institutions \$27, non-member public libraries and all others $\$ 45$. Editorial Board. Managing Editor for GeoScience Abstracts, International Geology Review, Izvestiya, and Doklady: Martin Russell.

186. American Geophysical Union. 1515 Massachusetts Avenue, N.W., Washington 5, D. C. President: Lloyd V. Berkner, Associated Universities, Inc, 10 Columbus Circle, New York 19, N. Y. Term expires June 30, 1961. Executiv' Secretary: Waldo E. Smith. Term indefinite.

History: Organized tentatively June 1919 as American Section of proposed International Geophysical Union; later designated as American Geophysical Union by approval of Executive Board, National Research Council, Decenber 20, 1919. Union was made committee of Executive Board. National Research Council, February 4, 1920; since April 24, 1921, Executive Committee on Geophysics of the National Research Council. Union is American National Committee of International Union of Geodesy and Geophysics. Sections : Geodesy; Geomagnetism and Aeronony ; Hydrology ; Meteorology ; Oceanography; Seismology; Tectonophysics; Volcanology, Geochemistry, and Petrology. Branches : Revision of the Statutes and By-laws in 1945 authorized organization of regional brauches of the Union. Branches have been organized in the North Central region. Pacific Northwest, and Pacific Sonthwest.
Purposc: To assist in carrying out the objectives of the International Union of Geodesy and Geophysics, which are: To promote the study of problems concerned with the figure and physics of the earth; to initiate and coordinate researches which depend upon international cooperation and to provide for their scientific discussion and publication; to facilitate special researches, such as comparison of instruments used in different countries; and to promote and coordinate the study of the various branches of geodesy and geophysics in the United States and outlying territories.

Mcmbership: In addition to the regular membership by subscription, which totaled about 6,300 in 1960 , there are $c x$ officio members temporarily appointed, including the Chairman of the Division of Earth Sciences of the $\mathrm{Na}$ tional Research Council, and the American officers of the International Union of Geodesy and Geophysics and of its sections. The requirement for membership is active work in those fields of science relating to geophysics, or interest in geophysical research and its practical applications. There is also a student nember classification.

\section{Mectings: Annual.}

Professional activities: William Bowie Medal, awarded annually for distinguished attainment in and outstanding contribution to the advancement of cooperative research in fundamental geophysics.

Publications: Journal of Geophysical Research, monthly, current volume: $65, \$ 20$. Editors: Philip H. Abelson and James A. Peoples. Transactions, quarterly, current volume: 41, \$4. Editor: Waldo E. Smith. Izvestiya (English translation), Academy of Sciences, U.S.S.R., Geophysics Series, monthly, \$25. Geodesy and Cartography (English translation), U.S.S.R., monthly, $\$ 20$.

187. American Geriatrics Society. 2907 Post Road, Greenwood (Warwick), R. I. President: Edward L. Bortz, Lankenau Medical Building, Philadelphia 31, Pa. Term expires June 22, 1961. Executive Secretary: Richard J. Kraemer. Term indefinite.

History: Founded 1942 at Atlantic City, N. J.

Purpose: To encourage and promote the study of geriatrics.

Membership: Graduate of a recognized medical school and holding an M.D. degree; member of a State or national medical society. Membership exists throughout the United States, Canada, and several foreign countries. Total membership approximately 7,500.

Mcetings: Annual Spring meeting; sometimes a Symposium is held in the Fall. 
Professional activities: Willard O. Thompson Memorial Award, presented each June.

Publications: Journal, monthly, current volume: 8, \$10. Editor: Edward Henderson.

188. American Goiter Association, Inc. 702 Madison Avenue, Albany 8, N. Y. President: Alexander Albert, Mayo Clinic, Rochester, Minn. Term expires May 1961. Secretary: John C. McClintock. Term expires May 1961.

History: Organized December 1923 as American Association for Study of Goiter. Name changed to American Goiter Association in 1948, and to present title in 1959.

Purpose: The acquisition and dissemination of knowledge of the thyroid gland and its diseases.

Membership: Open to individuals with medical training who have demonstrated by five years of professional work an interest in the thyroid gland and its diseases. Total membership 242 (limit 250).

Mcetings: Annual.

Professional activities: Annual Van Meter award of $\$ 300$ to stimulate research, especially as to basic cause of goiter.

\section{American Group Psychotherapy Associa-} tion, Inc. 1790 Broadway, New York 19, N. Y. President: Maurice E. Linden, 500 South Broad Street, Philadelphia, Pa. Term expires 1962. Exccutive Secretary: Helene Papanek, 1 West 64th Street, New York, N. Y. Term expires 1962.

History: Organized 1942 in New York. Ten local and regional affiliate societies.

Purpose: To promote exchange of knowledge, and stimulate practice and research; to develop new methods of prevention and treatment to meet mental health needs; to formulate and support suitable standards of education and training; to unify efforts of psychiatry, psychology. and social work toward understanding and application of the therapeutic group process.

Membership: Psychiatrists, or qualified clinical psychologists and psychiatric case workers with at least three years' experience in psychotherapy under approved supervision with psychiatrists participating. Total membership approximately 1,200 .

Meetings: Annual.

Publications: American Journal of Group Therapy, quarterly, free to members. Editor: Harris Peck.

190. American Gynecological Society. President: Albert H. Aldridge, 899 Park Avenue, New York 21, N. Y. Term expires May 31. 1961. Secretary: Andrew A. Marchetti, 3800
Reservoir Road, N. II. Washington 7, D. C. Term expires May 31, 1961.

History: Organized 1876. Coxrmittees: Emil Noval Ovarian Tumor Registry; American College of Surgeons; Care of Women in the Armed Forces.

Purpose: To advance knowledge in the field of obstetrics and gynecology.

Membership: Candidates for all classes of membership must have graduated at least ten years previously from medical school, and must be proposed by two Fellows of the Society. Active Fellows, 93; Life Fellows, 34; Honorary American Fellows, 4; Honorary Foreign Fellows, 5. Total membership 136.

Mcetings: Annual.

Publications: Transactions, annually, current volume: 82, \$15. Editor: Andrew A. Marchetti.

191. American Heart Association. 44 East 23rd Street, New York 10, N. Y. President: Oglesby Paul. Term expires October 1961. Sccretary: William F. McGlone. Term expires October 1961.

History: Organized 1922; incorporated 1924. Reorganized as voluntary health agency in 1948. The Association includes fifty-five affiliates in fifty States, the District of Columbia, and Puerto Rico. These have 296 local chapters under their jurisdiction. Sections: The Assembly of the Asosciation is the national representative body composed of approximately 400 delegates elected by affiliated Heart Associations and forty chosen by the various councils of the Association. The scientific program is conducted by the Association's Councils. Their work is coordinated through the Central Committee for Medical Community Program, on which each of the eight Councils is represented. There are Councils on Arteriosclerosis, Basic Science, Cardiovascular Surgery, Circulation, Clinical Cardiology, Community Service and Education, High Blood Pressure Research, and Rheumatic Fever and Congenital Heart Disease. The latter, previously the American Council on Rheumatic Fever and Congenital Heart Disease, became an American Heart Association Council in 1944 to coordinate the Association's interests in this area with that of a number of other national medical and professional societies. The Council for High Blood Pressure Research was formerly the American Foundation for High Blood Pressure Research which merged with the American Heart Association in 1950. The Council on Arteriosclerosis, formerly the American Society for the Study of Arteriosclerosis, joined the Association in 1959.

Purpose: To support research as the principal means of expanding scientific knowledge of 
heart and circulatory diseases. More than half the funds received by the national office of the Association are currentlly expended for this purpose. Professional and lay education to facilitate the widest possible use of existing knowledge and new knowledge as it is gained through research to help dispel popular misconceptions about cardiovascular disease and to stimulate broader public support of research and other heart program activities. Development of community facilities and services related to cardiovascular problems and the needs of the cardiac patient. such as cardiac clinics, facilities for rehabilitation and vocational guidance, work simplification courses, rheumatic fever prevention, school health programs, and many other projects. Community programs are conducted by State and local Heart Associations, frequently in cooperation with other health groups in their area.

Membership: Members of affiliated Heart Associations and their chapters. Total membership about 34,500 , approximately one half being physicians.

\section{Mectings: Annual.}

Professional activities: A total of approximately $\$ 50,000,000$ has been provided by the Association and its affiliates for support of scientific research in the twelve years since it became a voluntary health agency. Research awards for studies during the 1960-61 fiscal year alloted as part of the joint research support program of the Association and its affiliates totalled approximately $\$ 9,000,000$. Affiliated Heart Associations, in addition to participating in the national program, also make research awards to support scientific investigations in their own areas. Established Investigatorships, awarded for five-year periods subject to annual review, range from $\$ 7,500-\$ 9,900$. They are available to scientists of proven ability who are engaged in a research career. Advanced Research Fellowships, awarded for one-to-twoyear periods to postdoctoral candidates with previous research training, range from $\$ 5,500-$ $\$ 6,000$ plus dependency allowances. Research Fellowships, awarded for one or two years, enable younger scientists to train for research careers under experienced supervision, range from $\$ 4,500$ plus dependency allowances. Grantsin-Aid are made to qualified investigators to help underwrite the costs of specified projects. The Career Investigatorship provides an annual award for a limited number of particularly qualified individuals throughout their productive lives. Gold Heart Award, the Association's highest honor, presented annually in recognition of outstanding individual contributions to the progress of cardiovascular medicine and the heart program. Albert Lasker Award of the American Heart Association, presented annually for distinguished achievement in the field of cardiovascular diseases. Awards of Merit, $f \circ r$ outstanding service to the Heart program. Howard W. Blakeslee Awards, presented annually to individuals whose creative efforts in any medium of mass communication are judged to have contributed most to public understanding of heart and circulatory diseases, covers several categories such as newspapers, magazines, radio and television, books, providing a minimum of $\$ 500$ for each category.

Publications: Circulation, monthly, current volume: 21, \$15. Editor: Herrman Blumgart. Circulation Research, bimonthly, current volume: 13, \$9. Editor: Carl F. Schmidt. Modern Concepts of Cardiovascular Disease, monthly, current volume: 29, \$1. Editor: E. Cowles Andrus. The Heart Bulletin, bimonthly, current volume: 9, $\$ 3.60$. Editor: Russell IV. Cumley. The American Heart, quarterly, current volume: 10, free. Staff edited. Heart Research Newsletter, quarterly, current volume: 5, free. Staff edited.

Library: 1,200 volumes.

192. American Helicopter Society, Inc. 2 East 64th Street, New York 21, N. Y. President: Lee S. Johnson. General Manager, Sikorsky Aircraft Division, Stratford, Conn. Term expires May 1961. Executive Secretary: Harry M. Lounsbury. Term indefinite.

History: Founded in 1943 to disseminate technical and nontechnical information to the helicopter industry. Society is divided into six regions of the United States, giving membership opportunity to participate in activities on the local level.

Purpose: To advance the theory and practice of the sciences of helicopters, VTOL, and similar devices.

Membership: Open to engineers, manufacturing executives, military officials, and operators in the industry, as well as to individuals demonstrating a sincere interest in furthering the rotating wing art through their contributions. Total membership 2,013.

Mcctings: Annual; regional meetings quarterly.

Professional activities: Two honorary fellowships for notable and meritorious service in the advancement of rotary wing aeronautics; Alexander Klemin Award for notable achievement in the advancement of rotary wing aeronautics; Captain William J. Kossler Award, annually, for greatest achievement in practical application or operation of rotary wing aircraft, the value of which has been demonstrated in actual service the previous year; Frederick L. Feinberg Memorial Award. 
Publications: Newsletter, monthly, current volume: 6 , domestic, $\$ 7$, foreign, $\$ 10$. Editor: Harry M. Lounsbury. Journal, quarterly, current volume: 5 , domestic $\$ 7$, foreign $\$ 10$. Editor : Brig. General William B. Bunker.

\section{American Home Economics Association.} 1600 20th Street, N. WV., Wrashington 9, D. C. President: Mrs. Dorothy S. Lyle, National lnstitute of Drycleaning, Silver Spring, Md. Term expires June 1962. Executive Secretary: Miss Mary IVarren, University of Oklahoma, Norman, Okla. Term expires June 1961.

History: Organized December 1908; incorporated in New York in 1909 and in the District of Columbia 1951. Professional Sections: Colleges and Universities; Elementary, Secondary, and Adult Education; Extension Service; Home Economists in Business; Institution Administration; Home Economists in Homemaking; Research; Health and Welfare; College Clubs. Subject-Matter Sections: Art; Family Econonics-Home Management; Family Relations and Child Development; Food and Nutrition; Housing and Household Equipment ; Textiles and Clothing.

Purpose: To provide opportunities for professional home economists and other Association members in related fields to cooperate in the attainment of the well-being of individuals and of families, the improvement of homes, and the preservation of values significant in home life.

Membership: Open to men and women trained in home economics and related fields who are engaged in professional programs of home economics: home economists who hold a bachelor's or advanced degree with a major in home economics from an accredited college or university in the United States or Canada; persons who hold a bachelor's or advanced degree in a field other than home economics from an accredited college or university in the United States or Canada and in addition have been engaged for at least three years as a part of and are currently engaged in a professional home economics program. Total membership 25,000.

Meetings: Annual.

Professional activities: Ellen H. Richards Fellowship, biennial grant of $\$ 1,000$ for advanced study in home economics; Effie I. Raitt Fellowship, biennial grant of $\$ 500$; Omicron $\mathrm{Nu}$ Fellowship, biennial grant of $\$ 1,000$ for research in home economics; AHEA Doctoral Fellowship Award, stipend of $\$ 1,400$ for study leading to a doctor's degree. Funds for the doctoral fellowship are obtained from Life Membership contributions and the grant is made whenever the accumulated sum is sufficient.

Publications: Journal of Home Economics, monthly except July and August, current volume: 52, \$6, included in membership. Editor: Mary Hawkins.

Library: 3,935 volumes.

194. American Horticultural Society, Inc. 1600 Bladensburg Road, N. E., Washington 2, D. C. President: Richard P. White, 835 Southern Building, Washington 5, D. C. Term expires November 12, 1960. Secretary: Miss Olive E. Weatherell. Term indefinite.

History: Organized 1922; united in 1926 with the National Horticultural Society; merged with American Horticultural Council in 1960.

Purpose: To promote the knowledge of horticulture.

Mombership: Corporate, 200; Individual, 4,800 , interest in horticulture.

Meetings: Annual.

Professional activities: The Society may recognize by suitable award those persons, corporations, or institutions who or which have made great contributions to world horticulture.

Publications: American Horticulture Magazine, quarterly, current volume: $39, \$ 6$, free to members. Editor: B. Y. Morrison.

Library: 1,000 volumes on horticulture.

195. American Hospital Association. 840 North Lake Shore Drive, Chicago 11, Ill. President: Frank S. Groner, Baptist Memorial Hospital, Memphis 3, Tenn. Term expires September 1961. Executive Vice-President: Edwin L. Crosby. Term indefinite.

History: Organized 1898 as the Association of Hospital Superintendents; name changed to present title in 1906; incorporated 1920. CounCILS: Administrative Practice; Association Services; Government Relations; Hospital Auxiliaries; Planning, Financing, and Prepayment; Professional Practice, Research, and Education.

Purpose: To promote the best possible hospital care for the American people and to assist in making such care available to all. The Association encourages professional, educational, and scientific research and aids in the health education of the public.

Membership: Institutional, 7,176; personal, 5,317. Total membership 12,493.

Mectings: Annual.

Professional activities: Educational institutes for hospital personnel; Hospital Research and Education Trust conducting research in hospital field; Distinguished Service Award given annually to outstanding person in hospital field.

Publications: Hospitals, semimonthly, current volume: $34, \$ 5$ annually, $\$ 12$ for three-year 
subscription; Trustee, monthly, current volume: 13, \$3; Auxiliary Leader, monthly, current volume: 1, \$2. Editor: James E. Hague.

Library: Association Library: Asa S. Bacon Memorial Library; 15,000 volumes.

\section{American Industrial Hygiene Association.}

14125 Prevost Street, Detroit 27, Mich. Presi-

dent: Jack C. Radcliffe, Ford Motor Com-

pany, The American Road, Dearborn, Mich.

Term expires May 1, 1961. Executive Secre-

tary: George D. Clayton. Term indefinite.

History: The first meeting was held as the Midwest Conference on Occupational Disease, in Detroit, Michigan, May 1937. In May 1939, at the Cleveland meeting, the Conference met jointly with the Association of Industrial Physicians and Surgeons with the name of the American Conference on Occupational Diseases and Industrial Hygiene. It was at this meeting that the American Industrial Hygiene Association was formally organized. Sections: Chicago; Georgia; Gulf Coast; Metropolitan New York; Michigan; New England; New Jersey; Northeast Michigan; Northeast Ohio; Northern California; North Texas; Ohio Valley; Pacific Northwest; Philadelphia; Pittsburgh; Rocky Mountain; Southern California; St. Louis; Tennessee Valley; Upper Midwest; Utah; Washington-Baltimore; Western Michigan; Western New York. Commintees: Air Pollution; Analytical Chemistry; Engineering; $\mathrm{Hy}-$ gienic Guides; Noise; Radiation; Respiratory Protective Equipment; Technical Publications; Toxicology.

Purpose: To increase the knowledge of industrial hygiene through interchange and dissemination of information; to promote the study and control of environmental factors affecting the health and well-being of industrial workers; to correlate such activities as are conducted by individuals and agencies throughout industrial, educational, and governmental groups; to bring together persons interested in the various phases of industrial hygiene.

Membership: Individual, 1,200, having a college degree or equivalent and three years' experience in industrial hygiene; Industrial Associate, 100 .

Meetings: Annual.

Publications: Journal, bimonthly, current volume: 21, domestic $\$ 7.50$, Canada $\$ 7.75$, foreign \$8.25. Editor: Dohrman H. Byers, U. S. Public Health Service, 1014 Broadway, Cincinnati, Ohio.

197. American Institute of Architects. President: Philip Will, Jr., 309 West Jackson Boulevard, Chicago 6, Ill. Term expires 1961. Executive Director: Edmund R. Purves, 1735
New York Avenue, N. W., Washington 6, D. C. Term indefinite.

History: Organized in 1857; incorporated. Districts: California, Central States, Great Lakes, Florida, Gulf States, Middle Atlantic, New England, New York, North Central States, Northwest, South Atlantic, Texas, IVestern Mountain.

Purpose: To organize and unite in fellowship the architects of the United States of America; to combine their efforts so as to promote the aesthetic, scientific, and practical efficiency of the profession; to advance the science and art of planning and building by advancing the standards of architectural education, training, and practice; to coordinate the building industry and the profession of architecture to insure the advancement of the living standards of our people through their improved environment; to make the profession of ever-increasing service to society.

Membership: Corporate, 13,500 , must be registered architects, acceptable both to chapter and to national body.

Meetings: Annual.

Professional activities: Gold Medal, authorized 1906; Fine Arts Medal, authorized 1919; Allied Professions Medal; Craftsmanship Medal; Industrial Arts Medal; Architectural Photography Medal; Citation of an Organization; Citation of Honor, to an individual, partnership, association, or company; Edward C. Kemper Award; Honorary Membership; Honorary Fellowship; Honor Awards for Current Work; R. S. Reynolds Memorial Award, $\$ 25,000$ and emblem; Architectural Journalism Awards, initiated 1954, \$250 each; Student Citations, initiated 1954; School Medal; Henry Adams Fellowship; Delano and Aldrich and William H. Emerson Fellowship, usually $\$ 1,200$; Edward Langley Scholarships; Milton B. Medary Scholarship; Rehmann Scholarships; National Fire Underwriters Scholarships, maximum funds $\$ 4,500$; Allied Industries Scholarships, maximum funds $\$ 750$; Matico Scholarships, $\$ 500$ each; Arnold W. Brunner Fellowship, maximum $\$ 2,400$.

Publications: Journal, monthly, current volume: 34, \$4. Editor: Joseph Watterson.

Library: 10,000 volumes.

198. American Institute of Biological Sciences. 2000 P Street, N. W., Washington 6, D. C. President: James G. Dickson, University of Wisconsin, Madison, Wis. Term expires December 31, 1960. Executive Director: Hiden T. Cox. Term indefinite.

History: Organized February 1948; incorporated January 1955 . Originally organized 
under sponsorship of National Research Council. Entirely independent since incorporation. The Institute is a voluntary association of organizations which have a common interest in the life sciences.

Purpose: Advancement of the biological, medical, and agricultural sciences and their applications to human welfare. Assistance to societies, organizations, and individual biologists in matters of common concern which can be most effectively dealt with by united action.

Membership: Member societies, 24, national organizations concerned with advancement of biological sciences; Affiliate societies, 25, local, regional, or national organizations interested in biological sciences; Associates, 19, organizations contributing to support of AIBS; individual honorary, life, supporting, professional, and associate members; members of member societies also are members of AIBS. Total membership 85,000 .

\section{Meetings: Annual.}

Professional activities: Conducts and arranges symposia, conferences, colloquia; publishes journals and monographs; translates foreign scientific journals and monographs; conducts educational studies and surveys; assists in educational activities; arranges for national meetings of biological societies; maintains speakers' visits to colleges and high schools; maintains register of biologists; provides advisory committees for government agencies; provides services to biological societies.

Publications: Bulletin, bimonthly, current volume: 10 , free to members. Editor: Hiden $\mathrm{T}$. Cox. Quarterly Review of Biology, \$10. Editor: H. Bentley Glass. In Brief, In Biology, five times annually, current volume: 1. Editor: Harold F. Osborne. Symposium Series, individual publications, various prices and editors.

\section{American Institute of Chemical Engineers.} 25 West 45th Street, New York 36, N. Y. President: Jerry McAfee, Gulf Oil Corporation, P. O. Box 1166, Pittsburgh 30, Pa. Term expires December 31, 1960. Executive Secretary: F. J. Van Antwerpen. Term indefinite.

History: Organized in 1908; incorporated in 1910.

Purpose: The advancement of chemical engineering in theory and practice and the maintenance of a high professional standard among its members.

Membership: Members, 6,901, proficient in chemical engineering and actively engaged in the practice of the profession. Associates, 11,914, $\mathrm{BS}$ in chemical engineering or an equivalent degree; $\mathrm{BS}$ in engineering other than chemical or in a physical science and having had three years' experience in chemical engineering; having had five years' experience in chemical engineering; or executives qualified to take responsible charge of an enterprise involving to an important degree the practice of chemical engineering. Affiliates, 125, engaged in an activity and possessing scientific attainments or practical experience which qualify them to cooperate with engineers in the advancement of chemical engineering knowledge and practice. Students, 22, in a curriculum leading to a degree in chemical engineering. Student Chapter members, 3,212. Total membership 18,940.

\section{Mcetings: Annual.}

Professional activities: Student Contest Problem Award; William H. Walker and Allan P. Colburn Awards; Founders Award; Professional Progress Award.

Publications: Chemical Engineering Progress, monthly, current volume: $56, \$ 6$. Editor: F. L. Resen. Journal, quarterly, current volume: 6 , \$6. Editor: Harding Bliss. Computor Program Manual, irregular. Monograph and Symposium Series, irregular.

200. American Institute of Chemists. 60 East 42nd Street, New York 17, N. Y. President: Milton Harris, The Gillette Co., Gillette Park, Boston 6, Mass. Term expires May 1961. Secretary: John Kotrady. Term expires May 1962.

History: Organized January 22, 1923 as the American Institute of Chemistry; name changed to present title September 1923. Chapters: Alabama; Baltimore; Beaver Falls, N. Y.; Chicago; Delaware; Florida; Louisiana; Middle llest (Kansas-Missouri-Nebraska); New England; New Jersey; New York; Niagara; Ohio ; Philadelphia; Piedmont (Georgia); Pittsburgh; Tennessee; Twin Cities (Minneapolis-St. Paul); Washington; Western.

Purpose: To advance the profession of chemistry in the United States.

Membership: Fellows, individuals who have a degree and ten years' experience; Members, degree and three years' experience; Associates, degree; Life members; Honorary; Emeritus. Fellows, 2,127; Members, 297 ; Associates, 244 ; Life, 36; Honorary, 47; Emeritus, 106. Total membership 2,857.

Mcetings: Annual; monthly chapter meetings.

Professional activities: Medal is given for noteworthy and outstanding service to the science of chemistry or to the profession of the chemist in America; student awards are made by the chapters.

Publications: Chemist, monthly, \$4. Editor: V. F. Kimball. 
201. American Institute of Consulting Engineers, Inc. Engineering Societies Building, 33 West 39th Street, New York 18, N. Y. President: Richard H. Tatlow III, President, Abbott, Merkt and Company, 630 3rd Avenue, New York 17, N. Y. Term expires January 1961. Secretary: T. T. McCrosky. Term expires January 1961.

History: Founded Decenber 12, 1910 as successor to the Association of Consulting Engineers, organized May 12, 1905; incorporated 1913.

Purpose: To encourage the practice of engineering as a profession; to promote ethical principles and practices; to advance the interests of engineers in all branches of the profession with particular application to those matters having a bearing on the activities and interests of consulting engineers; to increase the usefulness of the profession to the public at large.

Membership: Members, in practice as consulting engineer, of high personal character, and attainment of an honorable reputation and distinguished position in the engineering profession; at least thirty-five years of age, full member in good standing of the American Society of Civil Engineers, American Society of Mechanical Engineers, American Institute of Mining, Metallurgical and Petroleum Engineers, American Institute of Chemical Engineers, or American Institute of Electrical Engineers. Total Membership 275.

Mectings: Monthly except July and August; Annual Dinner.

Professional activities: Award of Merit, presented annually to an outstanding person in the field of engineering, pure or applied natural science, or an educator in one or more of these fields, either American or foreign.

Publications: Annual Report.

\section{American Institute of Electrical Engineers.}

33 West 39th Street, New York 18, N. Y. President: C. H. Linder, General Electric Company, 570 Lexington Avenue, New York 22, N. Y. Term expires July 31, 1961. Executive Secretary: N. S. Hibshman. Term expires July 31, 1961.

History: Organized 1884; incorporated 1896. Sections: 115 sections in cities and states throughout the United States and Canada.

Purpose: The advancement of the theory and practice of electrical engineering and of the allied arts and sciences, and the maintenance of a high professional standing among its members.

Membership: Fellows, 1,619. Members, 15,200, of electrical, teacher, inventor, working in field of electrical engineering or electrical science, thirty years of age, thirteen years of active practice with five years in a responsible position. Associate, 36,738, graduate of engineering curriculum approved by Board of Directors, or equivalent attainment, including six years engineering experience; at least twenty-one years of age. Affiliates, 1,927, interested in rendering service to electrical engineering or electrical science; at least twenty-one years of age. Honorary, 7. Total membership 55,491.

Mectings: Four annual general meetings are held: Summer, generally in June, in different sections of the country and always outside of New York City; Pacific; Midwest; Winter. The annual business meeting is held during the summer general meeting. There are also district meetings; local meetings are held frequently by sections and branches.

Professional activities: Edison Medal, awarded annually to a resident of the United States and its dependencies or the Dominion of Canada, for meritorious achievement in electrical science or electrical engineering or in the electrical arts. Lamme Medal, awarded annually to a member who has shown meritorious achievement in the development of electrical apparatus or machinery. The Institute is one of the representatives on the board of award of the John Fritz Medal and the Commission of Washington Award; a committee of the Institute awards the Charles Le Geyt Fortescue Fellowships. National and District prizes are offered annually to authors of worthy papers.

Publications: Electrical Engineering, monthly, current volume: 79, $\$ 12$ nonmembers, $\$ 6$ members. Editor: C. S. Rich.

\section{American Institute of Fishery Research}

Biologists. Secretary: F. H. Bell, International Pacific Halibut Commission, University of Washington, Seattle 5, Wash. Term indefinite.

\section{History: Incorporated December 1956 in} Olympia, Wash.

Purpose: To advance the theory, practice. and application of the science of fishery research biology; to promote the conservation and proper utilization of fishery resources; to maintain high professional standards in fishery research biology.

Membership: Limited to fishery research biologists and to teachers of fishery research biology; three grades of members. Total membership approximately 200 .

204. American Institute of Homeopathy. 1601 Chestnut Street, Philadelphia 3, Pa. Presidcnt: Elizabeth W. Hubbard, 108 East 86th Street, New York, N. Y. Term expires 1960. 
Business Manager: Garth II. Boericke. Term indefinite.

History: Organized 1844. State societies in thirty-one states and the District of Columbia.

Purpose: To further medical research and advance homeopathy.

Mcmbership: Regular members, graduates of accredited medical colleges who are registered in the state in which they practice; Associate; Honorary. Total membership 350.

\section{licetings: Annual.}

Publications: Journal, bimonthly, current volume: 52. Editor: Allan D. Sutherland.

\section{American Institute of Industrial Engineers.}

32 West 40th Street, New York 18, N. Y. President: Alex W. Rathe, New York University, New York, N. Y. Term expires May 1961. Executive Secrctary: E. P. Lange. Term indefinite.

History: Organized January 1948; incorporated September 1948 in Ohio. Offices moved to New York in 1960. Ten geographic regions and 108 chapters.

Purpose: To maintain the practice of the profession on a high level, to foster a high degree of integrity among its members, to encourage and assist education and research in the profession, and to aid in the identification of qualified industrial engineers.

Membership: Senior Members, 3,400. (1) registered professional industrial engineers, (2) registered professional engineers actively engaged in industrial engineering practice, (3) graduates of industrial engineering curriculum with five years practice, (4) graduates of engineering curriculum with six years practice, (5) other college graduates with nine years practice, (6) those with some or no college training and thirteen years practice in field; Associate Members, 5,300, graduates of industrial engineering curriculum with one year of experience, graduates of engineering curriculum with one year in industrial engineering practice, other college graduates with four years of practice, those with some or no college training and with eight years practice; Affiliates, 956. Total membership 9,656 .

Meetings: Annual.

Publications: Journal of Industrial Engineering, bimonthly, current volume: $11, \$ 10$. Editor: R. N. Lehrer, Technological Institute, Northwestern University, Evanston. Ill.

206. American Institute of Mining, Metallurgical and Petroleum Engineers, Inc. 29 West 39th Street, New York 18, N. Y. President: Joseph L. Gillson, 109 Mullin Road, Wilming- ton 3, Del. Term expires February 1961. Secretary: Ernest Kirkendall. Term expires February 1961.

History: Founded 1871 as American Institute of Mining Engineers; incorporated 1905. Name changed in 1919 to American Institute of Mining and Metallurgical Engineers Inc., and in 1956 to present title. In 1956 the Institute was reorganized into three constituent Societies and technical Divisions grouped within the Societies as follows: Society of Mining Engineers, 29 West 39th Street, New York 18, N. Y; Divisions: Coal, Industrial Minerals, Minerals Beneficiation, and Mining and Exploration. The Metallurgical Society, 29 West 39th Street, New York 18, N. Y.; Divisions: Extractive Metallurgy, Institute of Metals, and Iron and Steel. Society of Petroleum Engineers, 6300 North Central Expressway, Dallas 6, Tex., is not further subdivided. In addition the Institute has three All-Institute Councils as follows: Council of Economics, Council of Education, and Council of Section Delegates. The Institute maintains a field office at 707 Newhouse Building, Salt Lake City 11, Utah. It has local sections throughout the United States and in Venezuela, Peru, Mexico, Philippine Islands, Saudi Arabia, Sumatra. Student chapters are located throughout the United States.

Purpose: To promote the arts and sciences connected with the economic production of the useful minerals and metals; to hold meetings for the reading and discussion of professional papers and to circulate by means of publications among its members the information thus obtained.

Membership: Members, 19,882, must be at least twenty-seven years of age and must have had at least six years of employment in a field of science or engineering represented by one or more of the three constituent Societies, during at least three years of which must have held positions of responsibility. Associate, 4,838, persons whose interest or work in a field of science or engineering represented by one or more of the three constituent Societies is too limited to meet the requirements of the classification of Members. Junior, 8,658, must be qualified through education and experience to hold a subordinate position in a field of science or engineering represented by one of the three constituent Societies; shall not have passed their thirtieth birthday anniversary at the time application is received, and shall not remain Junior Members beyond their thirty-third birthday. Student, 2,332, students in good standing at a degree-granting school approved by the Board of Directors, who have been nominated by one instructor of the nominee (preferably an Institute Member). Total membership 35,710.

\section{Meetings: Annual.}


Professional activities: Several endowment funds of the Institute are designated to support The Engineering Societies Library, service to students and young engineers, technical publications, and the promotion of the sciences and the arts embraced by AIME. The Institute and particularly its Woman's Auxiliary sponsor about forty scholarships each year. James Douglas Gold Medal, to recognize distinguished aclievement in nonferrous metallurgy. IVilliam Lawrence Saunders Gold Medal, to recognize distinguished achievement in mining. Anthony F. Lucas Gold Medal, to recognize distinguished achievement in improving the technique and practice of finding and producing petroleum. Erskine Ramsay Gold Medal, to recognize distinguished achievement in coal mining. Benjamin F. Fairless Award, in recognition of distinguished achievement in iron and steel production and metallurgy. Charles F. Rand Medal, for distinguished achievement in mining administration. Robert H. Richards Award, to recognize achievement which furthers the art of mineral beneficiation. Hal Williams Hardinge Award, to recognize outstanding achievement in the field of industrial minerals. The Institute also has several best-technical-paper awards.

Publications: Mining Engineering Journal, monthly, current volume: $12, \$ 8$ to North, South, and Central America, $\$ 10$ elsewhere. Editor: R. A. Beals. Journal of Metals, monthly, current volume: 12, \$10. Editor: F. WV. Starratt. Journal of Petroleum Technology, monthly, current volume: $12, \$ 8$ to North, South, and Central America, \$10 elsewhere. Editor: R. W. Taylor. Bimonthly Transactions of the Metallurgical Society, current volume: $218, \$ 5$ to members; $\$ 20$ to nonmembers in North, South, and Central America; $\$ 25$ elsewhere. Editor: Gerhard Derge.

207. American Institute of Nutrition. President: Floyd S. Daft, Building 4, Room 313, National Institutes of Health, Bethesda 14, Md. Term expires June 30, 1961. Secretary: Arnold E. Schaefer, Building 16A, Room 100, National Institutes of Health, Bethesda 14, Md. Term expires June 30, 1963.

History: Organized with a provisional charter on September 27, 1928; with permanent charter November 16, 1934; first annual meeting held in March 1934.

Purpose: To extend the knowledge of nutrition and to facilitate personal contact between investigators in mutrition and closely allied fields of interest.

Membership: Members, 749, persons who have conducted and published as senior author meritorious original investigations in some phase of nutrition and who are presently professionally active in the field of nutrition.

Mcetings: Annual.

Publications: Journal of Nutrition, monthly, current volume: $71, \$ 8.50$ to members, $\$ 22.50$ to nonmembers. Editor: James S. Ream.

\section{American Institute of Pacific Relations,} Inc. 333 Sixth Avenue, New York 14, N. I. Chairman: Albert Mayer. Term expires October 1960. Exccutive Secrctary: William L. Holland. Term expires October 1960.

History: Founded 1925 as the American Council of the Institute of Pacific Relations, an international organization. Incorporated 1938; name changed to present title November 1946.

Purpose: To promote the study of the problems of the peoples and nations of the Pacific area and eastern and southern Asia.

Membership: Open to all persons with an interest in Asian and Pacific problems. Voting rights limited to citizens of the United States. Classes: associate, contributing, and supporting. Total nembership 480 .

Mcctings: Annual, with occasional special meetings.

Professional activities: Funds for research are appropriated from the general budget.

Publications: Far Eastern Survey, monthly, current volume: 29, \$6. Editors: Harold H. Fisher and William L. Holland.

Library: 4,500 volumes and 80 periodicals and newspapers.

209. American Institute of Park Executives, Inc. Oglebay Park, Wheeling, IV. Va. President: Daniel IV. Warren, Jr., Superintendent of Parks, Brookline, Mass. Term expires September 24, 1961. Exccutive Secretary: Alfred B. La Gasse. Term indefinite.

History: Organized 1898 as New England Association of Park Superintendents; naine changed to American Association of Park Superintendents 1904; reorganized and name changed to present title 1921 ; incorporated 1925.

Purpose: Gathering and disseminating information concerning public parks, gardens, and other recreation grounds, facilities, and programs; promotion of and cooperation toward increase of such facilities and their greater utilization.

Mcmbcrship: Fellows, 1,550, executives of public parks and recreation systems and allied organizations; Sustaining, 177, park commissions or boards whose function is correlated with work of this Institute; Associate, 139, persons interested in and contributing to the purpose of this Institute, and not qualified for other membership; Student, 67; Associate Sustaining, 
167, commercial organizations and individuals interested in contributing to the purpose of this Institute; Contributing Sustaining, qualifying as Fellows, but wishing to contribute further; Conmissioners, 851. Total membership 3,011. Mectings: Annual.

Professional actiritics: Honorary Fellowship Award, annual, for professional achievement; cooperative research program with Michigan State University.

Publications: Parks and Recreation, monthly, current volume: $43, \$ 3.75$. Editor: Alfred B. La Gasse.

Library: 23,000 volumes. Subject emphasis: Park and recreation administration.

\section{American Institute of Physics. 335 East} 45th Street, New York 17, N. Y. Chairman: Ralph A. Sawyer, University of Michigan, Ann Arbor, Mich. Term expires spring 1961. Secretary-Treasurer: Wallace Waterfall. Term indefinite.

History: Founded 1931 by the following member societies: Acoustical Society of America, American Association of Physics Teachers, American Physical Society, Optical Society of America, and Society of Rheology. Reorganized 1946 to provide membership for other organizations and for individuals.

Purpose: Advancement and diffusion of knowledge of the science of physics and its applications to human welfare.

Membership: Member Societies, 5, national organizations of at least 400 members devoted to purposes of this Institute; Associate Member Societies, 2, national organizations of at least 400 members devoted to advancement of science with interest related to physics; Corporate Associates, approximately 175 , corporations, individuals, or institutions interested in physics; Student Sections, 84, local organizations of students interested in purposes of this Institute; Affiliated Societies, 10, local, regional, and national organizations interested in physics. Total membership approximately 276.

Professional activities: Karl Taylor Compton Gold Medal.

Publications: Physical Review, semimonthly, domestic $\$ 40$, foreign $\$ 43$. Reviews of Modern Physics, quarterly, domestic $\$ 6$, foreign $\$ 6.50$. Bulletin of the American Physical Society, eight times a year, domestic $\$ 5$, foreign $\$ 6$. Physical Review Letters, semimonthly, domestic $\$ 10$, foreign $\$ 11$. Journal of the Optical Society of America, monthly, domestic $\$ 25$, foreign $\$ 28$. Journal of the Acoustical Society of America, monthly, domestic $\$ 18$, foreign $\$ 19$. Noise Control, bimonthly, domestic $\$ 8$, foreign $\$ 10$. American Journal of Physics, nine times a year, domestic $\$ 10$, foreign $\$ 10$. Astronomical Jour- nal, ten times a year, domestic $\$ 8$, foreign $\$ 8$. Review of Scientific Instruments, monthly, domestic $\$ 11$, foreign $\$ 13$. Journal of Chemical Physics, monthly, domestic \$25, foreign \$27. Journal of Applied Physics, monthly, domestic $\$ 14$, foreign $\$ 16$. Physics of Fluids, bimonthly, domestic $\$ 10$, foreign $\$ 11$. Journal of Mathematical Physics, bimonthly, domestic $\$ 10$, foreign $\$ 11$. Physics Today, monthly, domestic \$4, foreign \$5. AIP Translation Journals: Soviet Physics-JETP, 12 issues a year, domestic $\$ 75$, foreign $\$ 79$, libraries domestic $\$ 35$, libraries foreign \$39. Soviet Physics - Solid State, 12 issues a year, domestic $\$ 55$, foreign $\$ 59$, libraries domestic $\$ 25$, libraries foreign $\$ 29$. Soviet Plyysics-Technical Physics, 12 issues a year, domestic $\$ 55$, foreign $\$ 59$, libraries domestic $\$ 25$, libraries foreign $\$ 29$. Soviet Physics - Acoustics, four issues a year, $\$ 12$ domestic, $\$ 14$ foreign, no library discounts. Soviet Physics-Doklady, six issues a year, domestic $\$ 35$, foreign $\$ 38$, libraries domestic $\$ 15$, libraries foreign $\$ 18$. Soviet Physics - Crystallography, six issues a year, domestic $\$ 25$, foreign $\$ 27$, libraries domestic $\$ 10$, libraries foreign $\$ 12$. Soviet Astronomy AJ, six issues a year, domestic $\$ 25$, foreign $\$ 27$, libraries domestic $\$ 10$, libraries foreign $\$ 12$. Soviet Physics-Uspekhi, six issues a year, domestic $\$ 45$, foreign $\$ 48$, libraries domestic $\$ 20$, libraries foreign $\$ 23$. Above library prices are for libraries of non-profit academic institutions.

Library: 1,400 volumes, subject emphasis physics.

211. American Institute of Planners. Suite 410 , 2400 16th Street, N. W., Washington 9, D. C. President: Charles A. Blessing, Director of City Planning, Detroit City Planning Commission, 400 Woodward Avenue, Detroit 26, Mich. Term expires October 1960. Exccutive Director: IV. C. Dutton, Jr. Term indefinite.

History: Organized in 1917 as American City Planning Institute; name changed in 1939 to present title to reflect broader planning interests. Nineteen chapters and twenty-three sections. Committees established on variety of technical problems.

Purpose: To study and advance the science and art of planning, to further the interests of the profession, and to promote fellowship among its members.

Membership: Members, 500, eight years of professional planning experience; Associate, 880, four years; Provisional, 910, one year; Affiliate, 160 , six years professional experience in related field plus achievement; Honorary, 7 , by general election. Total membership over 2,400.

Meetings: Annual.

Professional activities: Committee studies on planning policy, technical issues, and profes- 
sional matters; annual awards; enforcement of ethics; consultation and cooperation with governments, professional societies, and related organizations; public education; informing nembership of events of interest; chapter activities.

Publications: Journal, quarterly, \$6 (menbers only). Editor: Melvin Webber. Newsletter, eight times a year. Editor: Edmund Burke Peterson. Proceedings, annual. Price varies

212. American Institute of Plant Engineers. 4 Northwest Highway, Arlington Heights, 11. President: Fred G. Fryberger, Food Machinery and Chemical Corporation, P. O. Box 1616, Baltimore 3, Md. Term expires May 31, 1961. Secretary: Joseph N. Jacques, Lakeside Laboratories, Inc., 1707 East North Avenue, Milwaukee, Wis. Term expires May 31, 1961.

History: Incorporated as a nonprofit organization in Illinois in 1954 by Richard H. Morris, S. A. Simonson, and Ted Ramond acting as agents for nineteen independent local plant engineers societies. The first national convention was held in Chicago in 1955 with nineteen chapters represented. At the beginning of 1960 there were fifty-three chapters in the continental United States, Hawaii, and Canada. Comparable organizations exist in England and Italy and are being formed in Belgium, Japan, and Mexico. Elected a member of the Engineers Joint Council in 1958.

Purpose: To advance the science of engineering, further the professional interest of plant engineers, encourage unified organizational activity, and cooperate throughout the world with compatable organizations having similar objectives.

Membership: Members, 1,618; active participation in plant engineering work, ten years' engineering experience at least two of which were in responsible charge of plant engineering activities, with four years' experience credit for a degree from an accredited engineering college or for a professional engineer's license.

\section{Mectings: Annual.}

Professional activities: Student Loan Fund, a revolving fund for short-term loans to students in engineering schools.

Publications: AIPE News, bimonthly, current volume: $5, \$ 1.50$.

213. American Institute of the City of New York. 2 East 63rd Street, New York 21, N. Y. President: Robert F. Light. Term expires February 1961. Executive Secretary: Genevieve E. Peterson. Term expires February 1961.
History: Organized and incorporated February 1828.

Purpose: To interpret the latest development in science through lectures; to encourage the youth of the country in science interest and efforts through school science fairs.

Membership: Annual members, Participating, Sustaining, Corporate, Life. Total membership 210.

Meetings: Monthly, October through May.

Professional activities: Institute receives a small grant annually from the American Association for the Advancement of Science; licensed by the State of New York to conduct science fairs in the five boroughs of the City of New York.

214. American Institute of the History of Pharmacy. President: George B. Griffenhagen, Division of Communications, American Pharmaceutical Association, 2215 Constitution Avenue, Washington 7, D. C. Term expires April 1961. Director: Glenn Sonnedecker. 357 Chemistry Building, University of IVisconsin, Madison 6, $\mathrm{W}$ is. Term expires spring 1963.

History: Founded January 1941 at Madison. Wisconsin; incorporated in Wisconsin February 1943. Represented in the House of Delegates of the American Pharmaceutical Association; a constituent society of the American Association for the History of Medicine; member, Union Mondiale des Sociétés d'Histoire Pharmaceutique; maintains informal relations with other international societies of related purpose. Committees: Executive, Membership, Exhibits and Pictorial History, Awards, Historical Markers.

Purpose: To publish research on historical or social aspects of pharmacy, to provide historical information service for members and nonmembers, to organize and sponsor historical meetings and exhibits, to grant historical awards and aid scholars in their projects, to promote the highest possible standard of teaching the history of pharmacy in American pharmaceutical education, to collect historical materials about pharmacy, to conduct research.

Membership: Individual, 616 (including 41 foreign members), any person interested in the purposes of the Institute; Institutional, 73 (2 foreign), any organization, board, school, or library; Supporting and Complimentary, 132 (29 foreign), a person, group, or firm offering special support to the objectives of the lnstitute; Honorary, person whose activities have contributed significantly to pharmacy and its service to society, or to historical endeavors in pharmacy or allied fields. Total membership 821. 
Mectings: Annual.

Professional activitics: George Urdang Medal, an international award for an outstanding publication on the history of pharmacy; award for writing on the history of hospital pharmacy.

Publications: Pharmacy in History, quarterly, current volume: 4 , free to members only. Editor: Glenı Sonnedecker.

\section{American Institute of Ultrasonics in Medi-} cine. President: David Rubin, 6360 Wilshire Boulevard, Los Angeles 48, Calif. Term expires August 1962. Secretary-Treasurer: John H. Aldes, Cedars of Lebanon Hospital, 4833 Fountain Avenue, Los Angeles 29, Calif. Term expires August 1962.

\section{History: Organized 1950.}

Purpose: To exchange clinical and laboratory information on use of ultrasonic radiation in medicine.

Membership: Requires degree of doctor of medicine or doctor of philosophy. Members must be engaged in clinical or laboratory research in use of ultrasonic radiation in medicine, or must be physicians and surgeons using ultrasonics in clinical practice. Physicians must be members of county medical societies and American Medical Association. Total membership approximately 250 .

Mectings: Annual.

Professional activitics: Certificate of Merit, awarded to participants in scientific meetings.

216. American Iron and Steel Institute. 150 East 42nd Street, New York 17, N. Y. President: B. F. Fairless. Term expires May 1961. Secretary: George S. Rose. Term expires May 1961.

History: Incorporated March 31, 1908. The American Iron Association, founded 1855, was absorbed by the American Iron and Steel Association in 1864; in 1912 the latter was absorbed by the Institute. Commitees: Manufacturing Problems; General Research; Reinforced Concrete Research; Steel Pipe Research; Building Research and Technology; General Metallurgy and Product Technology.

Purpose: To promote the interests of the iron and steel industry; to collect and publish statistics and other information concerning any matters connected with the industry; to provide a forum for the exchange of information and discussion of problems relating to the industry; to engage in activities to promote the use of iron and steel.

Membership: Companies, corporations or partnerships in the Western Hemisphere engaged directly in the production and sale of products of the iron and steel industry; Active, individuals associated with company members; Associate, individuals, suppliers of raw materials and equipment, consumers, distributors of steel, technical and research experts; Emeritus, twentyfive years as an active member and retirement from business. Company members, 102; Active individual members, 2,000; Associate members, 600; Emeritus, 157. Total membership 2,859 .

Mectings: General meeting on the fourth Vednesday and Thursday in May of each year; annual autumn regional and technical meetings.

Professional activities: Financing of various research projects pertaining to production and fabrication of iron and steel, including work on welding, slag, refractories, protective coatings, pressure vessels, light gage structural steel, plastic flow of steel, stream pollution, raw materials, reinforced concrete, air pollution, corrosion, physical chemistry of steelmaking; The Medal of the Institute, awarded the author or co-authors of a paper read before the Institute having special merit and importance in connection with iron and steel manufacture, is to perpetuate the memory of Elbert H. Gary, founder and first president of the Institute; Gary Memorial Medal, awarded for oustanding achievement in the iron and steel industry, to honor Elbert H. Gary; Charles M. Schwab Memorial Lecture, given annually to perpetuate the memory of Charles M. Schwab, one of the founders of the Institute; Regional Technical Meeting Award, for outstanding paper at regional technical meetings.

Publications: Steel Facts, bimonthly, free. Editor: Donald R. James. Steelways, bimonthly, free. Editor: John Hill. Annual Statistical Report, \$5. Yearbook. Directory of Iron and Steel Works of the United States and Canada, triannually, $\$ 10$.

Library: 6,000 volumes.

217. American Laryngological Association. President: Edwin N. Broyles, 1100 North Charles Street, Baltimore 1, Md. Term expires May 22, 1961. Exccutive Secretary: Lyman G. Richards, 12 Clovelly Road, Wellesley Hills, Mass. Term indefinite.

\section{History: Organized and incorporated 1879.}

Purpose: Advancement of research and knowledge in the fields of rhinology and laryngology.

Membership: Active Fellows, 96 (limited to 100), elected for distinguished service in research, teaching, or clinical activity; Emeritus Fellows, 22, eligible after twenty years membership and age 60 ; Honorary Fellows, 5, elected for outstanding contributions in the field; Corre- 
sponding Fellows, 14, foreign leaders in rhinology and laryngology.

Mectings: Annual.

Professional activities: Laryngological Research Fund, to further research in rhinology and laryngology. Casselberry Award, \$100 to $\$ 200$ annual cash award with certificate for original work in rhinology and laryngology. DeRoaldes Award, gold medal and certificate for unusually meritorious work or service in rhinology and laryngology. Newcomb Award, to members only, for meritorious service to the ALA or outstanding work in the field.

Publications: Annual Transactions, current volume: 80, \$8. Editor: Francis W. Davison, Geisinger Memorial Hospital, Danville, $\mathrm{Pa}$.

\section{American Laryngological, Rhinological} and Otological Society, Inc. President: Fletcher D. Woodward, Charlottesville, Va. Term expires May 1961. Secretary: C. Stewart Nash, 708 Medical Arts Building, Rochester 7, N. Y. Term expires May 1961.

History: Organized June 19, 1895; incorporated December 5, 1917.

Purpose: To promote, develop, and disseminate scientific research and clinical study or problems relating to laryngology, thinology, and otology.

Membership: Active Fellows, 603, proposed by two Fellows in good standing and preferably residing in the candidate's vicinity; candidate shall possess a certificate of qualification from the American Board of Otolaryngology or an equivalent examining body approved by the Council.

Meetings: Annual.

Professional activities: Mosher Memorial Award.

Publications: Transactions, annual, \$10. Editor: Theodore E. Walsh, 640 South Kingshighway, St. Louis, Mo.

\section{American Leather Chemists Association.}

University of Cincinnati, Cincinnati 21, Ohio.

Prcsident: Ruben Heinrich, Whiteman Lea Company, West Winfield, N. Y. Term expires June 1962. Secretary: Fred O'Flaherty. Term indefinite.

History: Organized 1903 ; incorporated August 1937 in New Jersey.

Purpose: To devise and perfect methods for analysis and testing of leathers and all materials used in connection with their manufacture; to promote the advancement of chemistry and other sciences, especially in regard to their application to problems of the leather industry; to publish results of investigations and research; to advance the professional welfare of its members.
Mcmberslip: Active members, 552, having six years of training and professional experience, two of whicl must be in the study of chemistry or chemical engineering, two in the practice of leather chemistry, and two in either field. Associate, 376, having a legitimate interest in the purposes of the Association. Student, 4, full-time students majoring in leather or tanning chemistry. Total membership 932.

\section{Mectings: Annual.}

Professional activities: Research sponsored at University of Cincinnati; Alsop Award, annual ; Moffat Medal ; Winheim Award, biannual; John Arthur Wilson Memorial Lecture, annual.

Publications: Journal, monthly, current volume: 55, \$15. Editor: Wallace Windus, 1437 Bryant Lane, Meadowbrook, Pa.

220. American Lithuanian Engineers and Architects Association, Inc. 19 Mellen Street, Boston 24, Mass. Executive Director: Bronius V. Galinis. Term indefinite.

History: Organized February 24, 1951 ; incorporated in Massachusetts, 1956. Sections: Baltimore, Boston, Chicago, Detroit, Los Angeles, New York, Philadelphia, Pittsburgh.

Purpose: To unite Lithuanian engineers and architects in the United States; to extend assistance to and foster the educational and professional training of its members.

Membership: Open to any American Lithuanian engineer or architect who has completed technical studies at an accredited institution or who has equivalent practice. Regular members, 335 ; Candidates, 24; Honorary, 4. Total membership 363.

Mectings: Biennial.

Professional activities: Scholarship fund of $\$ 1,500$ annually used to promote education.

Publications: Engineering Word, semimonthly, \$5. Editors: K. Kaunas, G. J. Lazauskas, and K. Paukštys.

221. American Malacological Union. President: Thomas E. Pulley, Director, Museum of Natural History, Houston, Tex. Term expires 1961. Exccutive Secretary: Margaret C. Teskey, Route 1, P. O. Box 318, Marinette, Wis. Term expires 1961.

History: Organized in 1931, 169 charter members. Annual meetings held with exception of four World War II years. Pacific Division has membership approximately one-fourth that of parent organization.

Purpose: To promote the science of malacology and further the interests of students and collectors.

Membership: Open to individuals with a sin- 
cere interest in mollusks and their shells on an anateur or scientific level. Total membership 750.

Meetings: Annual.

Publications: Annual Report Bulletin, current volume: $26, \$ 2$, free to members. Editor: George M. Moore.

\section{American Material Handling Society, Inc.} President: Robert Rutherford, Sun Oil Company, Marcus Hook, Pa. Term expires June 30, 1961. Executive Secretary: Robert B. Divine, Super Valu Stores Inc., 101 Jefferson Avenue, S., Hopkins, Minn. Term expires June 30, 1961. Administrative Secretary: Arthur E. Fryer.

History: Organized and incorporated January 1949. Sections: Divided into nine regions covering United States and Canada. Affiliated with: Institute of Materiais Handling in England, Arbeitsgebiet Materialfuss in RKIV Germany, Centre d'Information de la Manutention, Materials Handling and Construction Plant Association of Sotth Africa, Japanese Material Handling Society.

Purpose: To promote study and advancement of the science of material handling; to develop programs; to publish technical, statistical, and engineering data; to establish standards; to develop safety codes; to establish and encourage university material handling courses.

Membership: General members, 5,200, persons interested in promotion and operation of material handling equipment and practices and persons in field of education pertaining to subject.

Mcetings: Semiannual.

Professional activities: Clark Equipment Company Award, $\$ 2,500$ to $\$ 5,000$ annually. Silent Hoist and Crane Company, Wunsch Foundation Award, capital amount $\$ 10,000$; $\$ 350$ annually. The awards are to promote the science of materials handling.

Publications: Journal, published in Modern Materials Handling Magazine, monthly. Editor: Gordon Thomas.

223. American Mathematical Society. 190 Hope Street, Providence 6, R. I. President: E. J. McSliane, University of Virginia, Charlottesville, Va. Term expires December 31, 1960. Secretary: John W. Green, University of California, Los Angeles 24, Calif. Term expires December 31, 1960. Executive Director: Gordon L. Walker. Term expires August 31, 1961.

History: Organized November 1888, as the New York Mathematical Society; reorganized July 1894, under its present title; incorporated May 1923 in the District of Columbia.
Purpose: The encouragement and advancement of mathematical scholarship and research.

Membership: Ordinary and contributing, 7,000 , having an interest in mathematical research; endorsement by two ordinary members or by an institutional or corporate member required. Institutional, 153; Corporate, 13.

Meetings: Two national meetings and approximately nine regional meetings a year.

Professional activities: Research activities co-sponsored by the Society and supported by grants from Government agencies: Symposia in Applied Mathematics, held annually since 1948; Symposia in Pure Mathematics, held at various regular meetings of the Society; Summer Research Institute, held annually; Summer Seminars, held biannually; maintenance of the Mathematical Sciences Section of the National Register of Scientific and Technical Personnel. Bocher Memorial Prize, awarded every five years for a notable research memoir in analysis which has appeared during the preceding five years in a recognized journal published in the United States or Canada, capital about $\$ 2,000$. Frank Nelson Cole Prizes in algebra and in the theory of numbers, awarded every five years for contributions to these subjects, capital about $\$ 3,000$. Eliakim Hastings Moore Fund, used for the publication of important mathematical books or memoirs, or the award of prizes, capital about $\$ 3,000$. Marion Reilly Fund, capital $\$ 23,500$, used for the advancement of research in pure mathematics. Ernest William Brown Fund, used for the publication of mathematical books, memoirs, periodicals, and lectures to be delivered on special occasions by invited guests of the Society, capital $\$ 1,000$. Robert Henderson Fund, unrestricted, capital $\$ 1,000$. James $\mathrm{K}$. Whittemore Fund, for use in mathematical research, capital $\$ 1,000$. Geneva B. Hutchinson Fund, to be used in the advancement of mathematical research, capital $\$ 1,000$. Helen A. Merrill Fund, for mathematical research, capital $\$ 650$. Solomon A. Joffe Fund, unrestricted, capital $\$ 3,000$. Library Proceeds Fund, capital $\$ 66,000$.

Publications: Bulletin, binonthly, current volume: 66, \$7. Editor: E. E. Moise. Proceedings, bimonthly, current volume: $11, \$ 11$. Editor: R. P. Boas. 'Transactions, monthly, current volume: 95 (4 volumes annually), \$8 per volume, \$32 per annum. Editor.: Lipman Bers. Mathematical Reviews, monthly except August, current volume: $21, \$ 50$. Editor: S. H. Gould. Soviet Mathematics - Doklady, bimonthly, current volume: 1, \$17.50. Editor S. H. Gould. Notices, seven times annually, current volume: 7, \$7. Editor: Gordon L. Walker.

224. American Medical Association. 535 North Dearborn Street, Chicago 10, I11. President: 
E. Vincent Askey, 2210 IVest Third Street, Los Angeles, Calif. Term expires June 1961. Excutive Vice President: F. J. L. Blasingame. Term indefinite.

History: Organized in Philadelphia in May 1847 , to raise the standards of medical education in the United States, to combat medical quackery, and to provide an exchange of postgraduate medical educational ideas. Comprises 1.911 county and district medical societies and 53 state and territorial societies. CoUNCILS AND Commitees: Committee on Cosmetics, Council on Drugs, Committee on Pesticides, Committee on Research, Committee on Toxicology, Council on Foods and Nutrition, Council on Medical Educaiton and Hospitals, Council on Medical Physics, Council on Mental Health, Department of Investigation, Committee on Medicolegal Problems, Council on Legislative Activities, Judicial Council, Council on Industrial Health, Council on Medical Service, Council on National Defense, Council on Rural Health, Committee on Rehabilitation, Council on Scientific Assembly. Under Council on Scientific Assembly, $21 \mathrm{sec}-$ tions: anesthesiology; dermatology and syphilology; diseases of the chest; experimental medicine and therapeutics; gastro-enterology and proctology; general practice; internal medicine; laryngology, otology, and rhinology; military medicine; nervous and mental diseases; obstetrics and gynecology; ophthalmology; orthoperlic surgery; pathology and physiology; pediatrics; physical medicine and rehabilitation; preventive and industrial medicine and public health; radiology; surgery, general and addominal; urology.

Purpose: To promote the art and science of medicine and the betterment of public health.

Membership: Physicians, licensed to practice medicine. Total membership 176,000.

Meetings: Seniannual: annual in spring, clinical in fall.

Professional activities: Distinguished Service Award; General Practitioner of the Year Award.

Publications: Journal, weekly, current volume: 172, \$15. Editor : John H. Talbott. Today's Health, monthly, current volume: $5, \$ 3$. Editor : Kenneth Anderson. AMA News, biweekly, current volume: 3, \$3. Editor: James Reed. AMA Journal of Diseases of Children, monthly, current volume: 99, $\$ 8$; Archives of Neurology, monthly, current volume: $2, \$ 8 ;$ Archives of Psychiatry, monthly, current volume: 2, $\$ 8$; Archives of Dermatology, monthly, current volume: 81, \$8; Archives of Surgery, monthly, current volume: $80, \$ 8$; Archives of Ophthalmology, monthly, current volume: $63, \$ 8$; Archives of Otolaryngology, monthly current volume: 71, \$8; Archives of Pathology, month- ly, current volume: $69, \$ 8$; Archives of Internal Medicine, monthly. current volume: $105, \$ 8$; Archives of Industrial Health, monthly, current volume: $21, \$ 8$. Editor: Gilbert Cooper.

Library: Archive and Library, 6,000 volumes on medicine, medical socioeconomics, medical history.

225. American Medical Technologists, Inc., Suite 5-A, Bass Building, Enid, Okla. President: Hugh A. Woosley, 3824 Crest Court, Elkhart, Ind. Term expires June 30, 1961. Exccutive Secretary: E. IV. IVilliams. Term indefinite.

\section{History: Organized 1939.}

Purpose: To elevate standards in the field of medical technology; to maintain constant education in the field for members by means of scientific seminars and conventions.

Membership: Citizens of the United States, Canada, or Pan-America; graduates of approved high school or equivalent; graduates of a course in medical technology and/or not less than three years' experience in a clinical laboratory under proper supervision; must pass written examination for certification. Total membership 11,000 .

Meetings: Annual, national convention and five district conventions ; quarterly, State society meetings.

Professional activities: Sponsorship of State society meetings at which time scientific seminars are held.

Publications: Journals, quarterly, \$3, free to nembers. Editor: E. W. Williams.

226. American Medical Women's Association, Inc. 1790 Broadway, New York 19, N. Y'. President: Claire F. Ryder. Term expires June 1961. Executive Director: Lillian T. Majally. Term indefinite.

History: Organized in Chicago in November 1915 as the Medical Women's National Association. Incorporated in Illinois in 1916. The State of incorporation was changed to New York in February 1924. The name was changed to American Medical Women's Association in 1937. There are approximately 40 active branches located throughout the United States and Puerto Rico. Commitees: Planning; Coordinating; Archives; Constitution and ByLaws; Credentials; Finance; International Relations; Lectureship; Legislative; Liaison with American Women's Hospitals Service, Inc., and Woman's Medical College of Pennsylvania; Medical Education and Practice; Membership; Public Health; Publications; Publicity and Public Relations; Resolutions; Student Loans, Fellowships, and Grants. 
Purpose: To further the art and science of medicine; to promote interests common to women physicians and the public; to aid and encourage premedical, medical, and postgraduate medical students; to foster medical relief projects : to cooperate witl other organizations liaving comparable interests.

Membership: Limited to women physicians and women medical students who hold the degree of Doctor of Medicine from an accredited medical school, citizens and residents of the United States in good professional standing, or students who are attending an accredited medical school in the United States. Women physicians who meet the requirements except that of citizenship and United States residency nay be granted affiliate membership. Categories: active, emeritus, associate, junior, affiliate, memorial, and honorary.

Mectings: Anuual.

Professional activities: Medical education loans to women medical students who have completed successfully the first year of medical school and who need financial assistance; capital amount involved, $\$ 63,000$. Janet M. Glasgow Memorial Fund, used for medical education of women, $\$ 29,000$. Scholastic Awards: $\$ 100$ cash to each woman who graduates in first place in her class and a citation to each woman who graduates in the upper $10 \%$ of her class. Elizabeth Blackwell Medal, given anmually to a woman physician who has rendered outstanding professional service. Preceptorship prograin.

Publications: Journal, monthly, current volume: 15 , available to members only. Editor: Frieda Baumann.

\section{American Medical Writers' Association.} 209-224 W.C.U. Building, Quincy, I11. President: Theodore R. Van Dellen, 435 North Michigan Avenue, Chicago 11, I11. Term expires September 30, 1961. SecretaryTreasurer: Harold Swanberg, 510 Maine Street, Quincy, I11. Term expires September 30, 1960.

History: Organized as the Mississippi Valley Medical Editors' Association at Rock Island, I11., September 25, 1940, during the annual meeting of the Mississippi Valley Medical Society; reorganized and name changed to the American Medical Writers' Association at its Springfield, I11. meeting, September 28, 1948. A completely rewritten constitution was adopted September 19, 1951; incorporated not-for-profit in Illinois September 24, 1951. Became an affiliated society of the American Association for the Advancement of Science in 1952.

Purpose: To bring into one association all North Americans who are concerned with writ- ing, editing, publishing, or other means of communication in medicine or allied sciences; to meet from time to time to discuss medical, scientific, educational, and literary topics; to help maintain and advance high standards in communications concerning medicine and allied sciences; to foster interchange of views of the members so that they may attain such intelligent unity and harmony in every phase of their labor as will elevate and make effective the opinions of the medical and allied professions in their respective communities in relationship to the public welfare.

Membership: Active members, physicians who have had two or more articles published in a journal indexed in the Quarterly Cumulative Index Medicus; physicians and others who are actively connected with the editorial or publishing staffs of medical, dental, or kindred periodicals; medical librarians and health educators; personnel of hospitals, foundations, educational institutions, publishing and technical companies, and allied organizations who are concerned with writing, editing, publishing, or other means of communication in medicine or allied sciences; must be members of the American Medical Association or the Canadian Medical Association or constituent parts thereof, except physicians of countries other than the United States and Canada who shall be graduates of generally recognized medical colleges; those who are not physicians shall be graduates of generally recognized colleges or universities, or be similarly qualified by education, training, and experience and be sponsored by two active members or fellows of this Association. Associate members, all other individuals concerned with writing, editing, publishing, or other means of communication in medicine or allied sciences, who have been sponsored by two active members or fellows and approved for associate membership by the Executive Committee. Total membership about 1,350 .

\section{Mcetings: Annual.}

Professional activities: Endowment Fund to perpetuate the Association, about $\$ 4,000$. Medical Journalism Scholarship Fund, about \$1,500. Distinguished Service Award given amually to a member who has made a distinguished contribution to medical literature or rendered unusual service to the medical profession; Honor Award, given annually to a nonmember who has made a distinguished contribution to medical literature. Honor Awards for Distinguished Service in Medical Journalism, given annually to medical periodicals of the United States and Canada.

Publications: Quarterly Bulletin, current volume: 10, \$2. Editor: Raymond C. Pogge, Cincinnati 15 , Ohio. 
228. American Meteor Society. 521 North Wynnewood Avenue, Narberth, Pa. President: C. P. Olivier. Term indefinite.

History: Founded 1911. State sections under local directors.

Purpose: To advance meteoric astronomy, principally by making or collecting observations of meteors and fireballs.

Membership: Active members over eighteen years old; Probational, fourteen to eighteen years old. All who apply, of both classes, must prove by submitted work that they are able and capable of being useful members. Total membership about 100 .

Mcetings: Held only in connection with some larger society.

\section{American Meteorological Society. 45 Bea-} con Street, Boston 8, Mass. President: Thomas F. Malone, Director of Research, The Travelers Insurance Company, Hartford, Conn. Term expires December 1961. Executive Secrctary: Kenneth C. Spengler. Term indefinite.

History: Founded 1919. All the individuals and groups concerned with scientific and professional meteorology are provided representation and media for communication. ScIENTIFIC Committees: Agricultural Meteorology, Air Pollution, Bioclimatology, Climatology, Cloud Physics and Weather Modification, Encouragement of Meteorological Research, Forecasting, Hydrometeorology, Industrial Meteorology, Interaction of Sea and Atmosphere, Meteorological Education (College and University), Radar Meteorology, Schools (Elementary and Secondary), Severe Storms, Upper Atmosphere and Satellite Exploration. Administrative ComMittees: Admissions, Awards, Nominating, Professional Ethics and Standards, and Publications. The following boards are active within the Society: Board on Certified Consulting Meteorologists; Board on Radio and Television Weathercasting; Long Range Planning Board. Fifty-two local seminar groups in metropolitan areas meet regularly for formal and informal discussions. There are also local groups organized in Bermuda, London, Germany, Tokyo, Madrid, and Puerto Rico. Scientific activities include education guidance, abstracting and translation services, national meetings and conferences.

Purpose: Development and dissemination of knowledge of meteorology in all its phases and applications and the advancement of its professional ideals.

Membership: Membership categories are established to serve professional, nonprofessional, student meteorologists, scientist in related fields, amateur weathermen; organizational membership is open to corporations. Professional 1nembers, 3,100; Members, 2,100; Associates, 1,200; Students, 240; Corporations, 75 ; Honorary, 11.

Meetings: Ten to twelve national meetings or specialized conferences are held each year.

Professional activities: Certification of consulting meteorologists; Seal of Approval for radio and television weather presentation; employment service to members; statements to the public. Meisinger Award; Carl-Gustaf Rossby Award for Outstanding Research Contributions; Award for Applied Meteorology; Charles Franklin Brooks Award for Ottstanding Service to the Society; Award for Outstanding Services to Meteorology by a Corporation; Award for Outstanding Achievement in Bioclimatology ; Special Awards and Citations. Honorary Membership. Father James B. Macelwane Annual Student Awards in Meteorology. Sverdrup Medal in Oceanography.

Publications: Bulletin, monthly, current voltune: $41, \$ 12$. Editor: Werner A. Baum. Journal of Meteorology, bimontlly, current volume: 17, \$15. Editor: Werner A. Baum. Meteorological Abstracts and Bibliography, monthly, current volume: 11, $\$ 60$. Editor: Malcolm Rigby. Weatherwise, bimonthly, current volume: $13, \$ 4$. Editor: David M. Ludlum. Meteorological Monographs, irregular, current volume: 4, price varies. Editor Werner A. Baum.

230. American Microscopical Society. President: A. M. Elliott, Department of Zoology, University of Michigan, Ann Arbor, Mich. Term expires August 28, 1961. Secretary: G. IV. Prescott, Department of Botany, Michigan State University, East Lansing, Michigan. Term expires August 28, 1962.

IIistory: Founded as the National Microscopical Congress in 1878; changed to present title 1892.

Purpose: To encourage research with the nicroscope and accessories; to publish results of research.

Membership: Sincere interest in microscopy and its applications, especially to biology. Total members 550 .

Meetings: Annual.

Publications: Transactions, quarterly. Editor: G. W. Prescott.

231. American Mining Congress. Ring Building Washington 6, D. C. President: Raymond E. Salvati, Island Creek Coal Company, Huntington, IV. Va. Term expires December 31, 1960 (subject to re-election). Executive Vice President and Sccretary: Julian D. Conover. Term expires December 31, 1960 (subject to re-election). 
History: Organized 1898 in Denver, Colorado. Affiliated State Mining Associations are in most of the mining states. There are various committees on improved mining practices and equipment, also on Public Lands, Land and $\mathrm{W}$ ater Use, Taxation, Strategic Minerals, Safety, Radio, etc.

Purpose: The advancement of the best interests of the mining industries in the United States.

Membership: Limited to Corporate Members who are domestic producers of minerals. Total membership several thousand mining firms.

Mectings: Annual Coal Mining Convention, with exposition of mining machinery in alternate years, Cleveland, Pittsburgh, or Cincinnati ; Annual Metal Mining-Industrial Minerals Convention, with exposition of mining machinery in alternate years, in some western state; Annual Members Meeting, New York City, December.

Publications: Mining Congress Journal. Editor: R. W. Van Evera.

232. American Miscellaneous Society. Washington, D. C. Contact: Gordon G. Lill, 3111 North Pollard Street, Arlington 7, Va.

History: Organized 1952 to bring order into the miscellaneous nature of the earth sciences. Society has no formal officers.

Purpose: To sponsor worthwhile research.

Membership: Limited to scientists who have the ability to see the lighter side of heavier problems. Total membership 75 .

Mectings: Annual.

Professional activities: Drilling a hole to the Mohorovicic discontinuity, "Project Mohole".

\section{American Mosquito Control Association,} Inc. P. O. Box 278, Selma, Calif. President: D. M. Jobbins, New Jersey Agricultural Experiment Station, New Brunswick, N. J. Term expires January 31, 1961. Executive Secretary: T. G. Raley. Term expires 1961.

History: Organized 1935 as the Eastern Association of Mosquito Control Workers, name changed to present title in 1944. Geographical regions: Southeast Central, North Atlantic, South Atlantic, Northeast Central, South Pacific, North Pacific, Southwest Central, Northwest Central, Canada; Mexico, Central and South America.

Purpose: To promote closer cooperation among those concerned with or interested in mosquito control and related work.

Membership: Anyone concerned with or in. terested in mosquito control and related work. Members, 965; Life Members, 2; Exchange Accounts, 26; Honorary Members, 6; Good
Neighbors, 116; Subscribers, 445. Total membership approximately 1,100 .

Mcetings: Annual.

Publications: Mosquito News, quarterly, current volume: $20, \$ 5$. Editor: Donald L. Collins, State Education Building, Albany 1, N. Y.

234. American Nature Study Society. President: Emery E. IVill, State University Teachers' College, Oneonta, N. Y. Term expires December 1960. Secretary: Beth Schultz, Department of Biology, Western Michigan University. Kalamazoo, Mich. Term expires December 1960.

History: Organized and incorporated 1908.

Purpose: To promote nature education by means of research, publicity, and field excursions and with help, stimulation, and encouragement to nature leaders.

Membership: Open to those interested in nature and conservation. Annual, Section, Affiliate, Life, and Family memberships. Total membership 430 .

Meetings: Annual.

Publications: Newsletter, quarterly. Editor: Stanley B. Mulaik.

235. American Neurological Association. President: Harold G. Wolff, 525 East 68th Street, New York 21, N. Y. Term expires June 12, 1961. Secretary: Melvin D. Yahr, Neurological Institute, 710 West 168th Street, New York 32, N. I. Term expires June 12, 1961.

History: Organized 1875; incorporated 1947.

Purpose: The advancement of the neurological sciences.

Membership: Senior, 60; Active, 223; Associate, 67; Honorary, 30; Corresponding, 23. Total membership 403.

Meetings: Annual.

Publications: Transactions, annual, current volume: $84, \$ 6$, free to members. Editor: Melvin D. Jahr.

236. American Nuclear Society. 86 East Randolph Street, Chicago 1, I11. President: Miles C. Leverett, General Electric Aircraft Nuclear Propulsion Department, P. O. Box 132, Cincinnati 15, Ohio. Term expires June 1961. Executive Secretary: Octave J. DuTemple. Term indefinite.

History: Founded October 1954. In 19581959 three divisions authorized: Hot Laboratory Division, Isotopes and Radiation Division, and Reactor Mathematics and Computations Division. Society now has 16 local sections and 16 student branches. 
Purpose: The integration and advancement of nuclear science and technology.

Membership: Requires technical college degree and experience in some phase of nuclear science and engineering; experience indicates type of membership-member or associate. Affiliates usually not engaged in technical phase of nuclear energy. Members, 3,400; Associates, 300 ; Affiliates, 140; Students, 220. Total membership 4,060.

Nectings: Semiannual.

Professional activities: Mark Hills Student Award; local sections hold topical symposia on subjects of nationwide interest.

Publications: Nuclear Science and Engineering, monthly, current volume: $7, \$ 8$. Editor: Everitt P. Blizard. Transactions, semiannual, current volume: 3, \$8; Editor: Frank Ward. Nuclear News, monthly, current volume: $2, \$ 5$. Editor: Octave J. DuTemple.

\section{American Nurses' Association. 10 Colum-} bus Circle, New York 19, N. Y. President: Miss Mathilda Scheuer. Term expires May 1962. Executive Secretary: Mrs. Judith G. Whitaker. Term indefinite.

History: Founded 1896 as the Nurses Associated Alumnae of the United States and Canada; name changed to present title 1911. A federation of fifty-four nurses' associations in the fifty States, the District of Columbia, the Panama Canal Zone, Puerto Rico, and the Virgin Islands. These, in turn, have a total of 781 district associations.

Purpose: To foster high standards of nursing practice; to promote the professional and educational advancement of nurses and the welfare of nurses to the end that all people may have better nursing care.

Membership: Active members, registered nurses with license to practice in at least one state which license has not been revoked; Associate menbers, must meet the same requirements but do not anticipate employment in nursing during the current calendar year. Total membership more than 174,000 professional registered nurses, each belonging to one of eight sections according to area of practice: educational adninistrators, consultants, and teachers; general duty nurses; occupational health nurses; institutional nursing service administrators; office nurses; private duty nurses; public health nurses; special groups.

Meetings: National conventions, biennially, in even numbered years.

Professional activitics: Programs in the areas of Legislation, Economic Security, Intergroup Relations, International Interests, Professional Counseling and Placement Service, Research and Statistics, State Boards, Public Relations. Establishment 1955 of the American Nurses Foundation for the purpose of expanding research in nursing. Pearl Mclver Public Health Award, presented at each biennial convention to honor a public health nurse who has made an outstanding contribution to the field of public health nursing; Mary Mahoney Award, presented at each biemial convention to the person or group who, in addition to making a significant contribution to nursing generally, has been outstandingly instrumental in opening opportunities in nursing to members of all minority groups.

Publications: American Journal of Nursing, monthly. Editor: Barbara Schutt. Facts About nursing, annual.

Library: Approximately 2,500 volumes.

\section{American Occupational Therapy Associa-} tion. 250 West $57 \mathrm{tl}_{1}$ Street, New York 19, N. Y. President: Miss Helen S. Willard, Philadelphia School of Occupational Therapy, School of Allied Medical Professions, University of Pennsylvania, 3901 Pine Street, Philadelphia 19, Pa. Term expires 1961. Executive Director: Miss Marjorie Fish. Term indefinite.

History: Organized in 1917. Sections: There are 39 state and regional associations including the District of Columbia and Puerto Rico. Committees: Education; Clinical Procedures; Special Studies; International; History ; Civil Defense; Legislation and Civil Service; Registration; Recognitions; Recruitment and Publicity; Permanent Conference.

Purpose: To promote the use of occupational therapy; to advance standards of education and training in this field; to promote research; to engage in other activities advantageous to the profession and its members.

Mcmbership: Active members, registered occupational therapists in good standing; Sustaining, those eligible for active membership whose interests in the objectives of the Association prompt them to larger contributions; Associate Subscribers, those interested in the Association's journal, but not eligible for active membership; Student, those enrolled in accredited occupational therapy schools. Registered therapists must pass national registration examination. Total membership 4,694.

\section{Mectings: Annual.}

Professional activitics: Annual Award of Merit; Eleanor Clarke Slagle Lectureship, annual. Educational Fund, to promote projects for development of educational program.

Publications: American Journal of Occupational Therapy, bimonthly, domestic $\$ 6$, foreign $\$ 6.50$. Editor: Lucie S. Murphy. Newsletter, 
monthly, free to members. Editor: Helen C. Mathias. Year Book, $\$ 4$ per copy. Editor: Helen C. Mathias.

239. American Oil Chemists' Society. 35 East Wacker Drive, Chicago 1, Ill. President: Robert W. Bates, Armour and Company, 1425 West 42nd Street, Chicago 9, Ill. Term expires April 1961. Executive Secretary: Mrs. Lucy R. Hawkins. Term indefinite.

History: Organized 1909 as the Society of Cotton Products Analysts; name changed in 1920 to its present title. Committees: Bleaching Methods; Cellulose Yield: Color; Fat Analysis : Glycerin Analysis; Refining; Seed and Meal Analysis; Soap and Synthetic Detergent Analysis; Spectroscopy ; Statistical ; Technical Safety ; Uniform Methods.

Purpose: To encourage the advancement of the chemistry and technology of oils, fats, waxes. their constituents and compounds, and all allied and associated products; to promote research in these fields; to bring about standardization of analytical equipment, materials, and methods; to improve the qualifications and usefulness of oil chemists and technologists through high standards of professional ethics, education, and attainment, and by its meetings, discussions, analytical methods and publications to increase and diffuse chemical and technical knowledge. The broad objects are to assist professionally and culturally the members of this Society. to develop industry and technology in these fields, and to add to the prosperity and welfare of the nation.

Membership: Active, 2.444, must be engaged in scientific and/or technological work relating to oils, fats, waxes, their constituents or compounds, or allied or associated products, and have at least five years' scientific training or its equivalent: Honorary, 4; Emeritus, 20; Individual Associate, 153; Junior, 3; Corporation, 125. Total membership, 2,749.

Mectings: Semiannual.

Professional activities: Bond Award.

Publications: Journal, monthly, current volume: 37, \$8. Editor: A. R. Baldwin.

240. American Ophthalmological Society. President: Edwin B. Dunphy, 243 Charles Street, Boston 14, Mass. Term expires May 1961. Secretary: Joseph A. C. Wadsworth, 108 East 68th Street, New York 21, N. Y. Term expires May 1963.

History: Organized 1865.

Purpose: Advancement of the science and art of ophthalmology.

Membership: Active members, medical graduates in ophthalmology ten years, certified by the
American Board of Ophthalmology, and who write acceptable theses: Emeritus, thirty year membership or election from the membership by the Society; Honorary. Active, 199; Emeritus, 15; Honorary, 3. Total membership 217.

\section{Meetings: Annual.}

Professional activities: Howe Medal, for outstanding character and professional attainments, work in the domain of medical education and of ophthalmic practice, and original investigation in the field of ophthalmology.

Publications: Transactions, annual, current volume: 57, \$18. Editor: M. Elliott Randolph.

241. American Optometric Association, Inc. 4030 Chouteau Avenue, St. Louis 10, Mo. President: Richard C. Schiller, Medical Arts Center, 208 East Church Street, Marshalltown, Iowa. Term expires June 29, 1961.

History: Organized 1897 as the American Optical Association, name changed to present title 1918. Departments: Judicial Council; Council on Optometric Education; Department of Education; Department of Legal Affairs; Department of National Affairs; Department of Organization; Department of Public Information. Commitrees: Aid to the Partially Blind: Assistance to Graduates and Undergraduates: Civil Defense; Contact Lenses: Ethics; Insurance; International Affairs; Interprofessional Relations; Long Term Planning; Military Optometry; Motorists Vision and Highway Safety; Occupational Vision; Orthoptics and Visual Training; Practice Management; Research; Social and Health Care Trends; Standards; Vision Care of the Aging; Visual Problems of Children and Youth; Vocational Guidance.

Purpose: To unite reputable optometrists to improve the science of optometry; to elevate its standards; to restrict its practice to properly qualified optometrists.

Membership: Active members, those optometrists who are in good standing in the respective state associations which are affiliated with the American Optometric Association. Military members, those optometrists who are commissioned in the armed services of the United States. Civil Service members, those optometrists who have entered the Civil Service of the United States in the capacity of an optometrist. Distinguished members, those who have completed a term of office as president of the Association. Life members, those who have rendered long and faithful service as active members but who cannot continue as active members. Honorary nembers, those who have performed a signal service in the field of health, optometry, or optics. Student members, those who are active students in schools and 
colleges of optometry. Affiliated members, optometrists who practice and reside in foreign countries or in territories or possessions of the United States. Total membership 11,000.

\section{Mectings: Annual.}

Professional activitics: Provides funds for the promotion of research, to encourage worthy students of optometry, and to advance educational and professional standards in optometry.

Publications: Journal, monthly, current volume : $31, \$ 7.50$, free to members. Editor : Irving Bennett, 1312 7th Avenue, Beaver Falls, Pa.

\section{American Ordnance Association. 708 Mills}

Building, Washington, D. C. President: Louis Polk, Sheffield Corporation, Dayton, Ohio. Term expires December 31, 1960. Sccretary: Florence G. Ferriter. Term indefinite.

History: Organized 1919 as Army Ordnance Association; incorporated 1928 in the District of Columbia; name changed January 1948 to present title. Posts: Aberdeen, Md.; Albuquerque, N. Mex.; Birmingham, Ala.; Albany, N. Y.; Schenectady, N. Y.; Troy, N. Y.; Chicago, I1l.; Cincinnati, Ohio; Charleston, S. C.; Cleveland, Ohio; Portland, Ore.; Chambersburg, Pa.; Yorktown, Va.; Rochester, N. Y.; Buffalo, N. Y.; Jamestown, N. Y.; Utica, N. Y.; Elmira, N. Y.; Syracuse, N. Y.; Binghamton, N. Y.; Yokohama, Japan; Eglin AFB, Fla.; Hartford-Springfield; Dallas, Tex.; Los Angeles, Calif.; Shreveport, La.; Massachusetts Institute of Technology; Detroit, Mich.; Grand Rapids, Mich.; Tulsa, Okla.; Kansas City; Milwaukee, Wis.; Omaha, Nebr.; New Orleans, La.; Rutgers University and N. Y.; Minneapolis, Minn. Philadelphia, Pa.; Pittsburgh, Pa.; Seattle, Wash.; Quad Cities, Iowa; Rio Grande; Denver, Colo.; St. Louis, Mo.; San Diego, Calif.; San Francisco, Calif ; Huntsville, Ala.; Houston, Tex.; Nashville, Tenn.; IVashington; Boston, Mass. Divisions: Artillery; Bomb, Warhead and Artillery Ammunition; Combat and Tactical Vehicle; Electronics; Fire Control Instruments; Missiles and Astronautics; Small Arms and Small Arms Ammunition; Underwater Ordnance; Logistics; Materials; Packaging and Handling; Production Techniques; Research; Standards and Metrology.

Purpose: A patriotic, educational, scientific, and non-profit-making organization of American citizens dedicated to scientific and industrial preparedness.

Membership: Regular members, 40,900, must be American citizens and have an interest in advancing knowledge of scientific and industrial preparedness; Life, 1,400; Company, 1,200. Total membership 43,500 .
Mectings: Annual; frequent meetings of regions, posts, and divisions.

Professional activities: Crozier Medal, for distinguished service in the advancement of ordnance in the fighting services of the United States, ground, sea, and air. Williams Medal, for distinguished service in the field of munitions preparedness. Rice Medal, for distinguished service in ordnance engineering. Crowell Medal, for distinguished service to the American Ordnance Association. Scott Medal, for distinguished service to industrial preparedness. Campbell Medal, for distinguished service in the field of ordnance design and production. Blandy Medal, for distinguished service in the progress of armament preparedness, particularly in the utilization of atomic energy.

Publications: Ordnance, bimonthly. Editor: Roger E. Lewis. Industrial Preparedness, monthly. Editor: Maj. Gen. E. P. Mechling. Common Defense, monthly. Editor: Capt. J. M. P. Wright. Ordnance Reports. Editor: Leo A. Codd.

243. American Ornithologists' Union. President: George H. Lowery, Jr., Museum of Zoology, Louisiana State University, Baton Rouge 3, La. Term expires October 20, 1961. Secretary: Herbert G. Deignan, United States National Museum, Washington 25, D. C. Term expires October 20, 1961.

History: Organized September 26, 1883; incorporated in the District of Columbia, November 1888 .

Purpose: Advancement of ornithological science.

Membership: Requires serious interest in ornithology. Total membership 2,561.

Mcctings: Annual.

Professional activities: Brewster Memorial Medal, awarded annually for most meritorious publication on American birds; Josselyn Van Tyne Memorial Fund, for research in ornithology.

Publications: The Auk, quarterly, current volume: 77, \$5. Editor: Donald S. Farner, Washington State University, Pullman, Wash.

244. American Orthopaedic Association. 29 East Madison Street, Chicago 2, I11. President: Edwin F. Cave, 275 Charles Street, Boston 14, Mass. Term expires May 1961. Secrctary: Lee Ramsay Straub, 535 East 70th Street, New York 21, N. Y. Term indefinite.

History: Organized 1887; incorporated 1937.

Purpose: To promote and improve orthopaedic treatment, education, and research, and to provide an assembly for papers covering these fields in orthopaedic surgery. 

294.

Membership: By invitation; total membership

Mcetings: Annual.

Professional activities: Sponsorship of exchange fellowships between the United States and the British Commonwealth.

Publications: Manual of Orthopaedic Surgery; Annual Report; co-sponsorship of Journal of Bone and Joint Surgery with American Academy of Orthopaedic Surgery, 8 issues yearly. Editor: Thornton Brown.

\section{American Orthopsychiatric Association.} 1790 Broadway, New York 19, N. I. President: William S. Langford, Babies Hospital, Broadway and 167 th Street, New York 32, N. I. Term expires April 1961. Executive Secretary: Marion F. Langer. Term indefinite.

\section{History: Organized 1924.}

Purpose: To unite and provide a common meeting ground for those engaged in the study and treatment of problems of human behavior; to foster research and spread information concerning scientific work in the field of buman behavior, including all forms of abnormal behavior.

Membership: Members and Fellows: Psychiatrists with three years of approved basic training in psychiatry plus at least two years' clinical experience. Psychologists with the Ph.D. degree or its equivalent plus three years' clinical experience, or the master's degree plus one additional year of graduate work and five years' clinical experience. Psychiatric Social Workers who are graduates of accredited schools of social work with a master's degree if the date of graduation is subsequent to the date on which the school first granted the degree; graduates who majored in psychiatric social work at a school approved for such training at the time they attended, with three years' clinical experience following training; other graduates shall have had four years' clinical experience following training, one of which shall have been under the supervision of a qualified psychiatric social worker. Total membership 1,806 .

Mectings: Annual.

Publications: American Journal of Orthopsychiatry, quarterly, current volume: $30, \$ 10$. Editor: George E. Gardner, 295 Longwood Avenue, Boston 8, Mass.

246. American Osteopathic Association. 212 East Ohio Street, Chicago 11, 11l. President: Roy J. Harvey. Term expires July 1961. Executive Director: True B. Eveleth. Term indefinite.
History: Organized April 1897, as the American Association for the Advancement of Osteopathy; name changed to present name 1901. Incorporated in Illinois in 1923. Divisional societies in United States, Canada, and foreign countries. Committees: Bureau of Research; Bureau of Professional Education; Advisory Board for Osteopathic Specialists; Committee on Accreditation of Postgraduate Training.

Purpose: To promote the public health, to encourage scientific research, and to maintain and improve high standards of medical education in osteopathic colleges.

Membership: Regular members, graduates of an approved college of osteopathy, 10,516; honorary, 25 years nembership and 75 years of age; associate, executive employees of osteopatlic organizations and institutions, 45.

\section{Mectings: Annual.}

Professional activities: Basic research in laboratories, clinics, and hospitals connected with colleges of osteopathy; scholarships for undergraduate professional education; fellowships for graduate study. Distinguished Service Certificates issued for outstanding professional accomplishments.

Publications: Journal, monthly, current volume: $59, \$ 10$, free to members. Forum of Osteopathy, monthly, current volume: 34 , free to members. Health, monthly, current volume: 5, \$1.25. Editor: Raymond P. Keesecker.

Library: 3,500 volumes on osteopathy and medicine.

247. American Osteopathic College of Anesthesiologists. P.O. Box 155, Kirksville, Mo. Presidcnt: John S. Stratton, 315-B South Mission Drive, San Gabriel, Calif. Term expires October 1960. Secretary-Treasurer: Crawford M. Esterline. Term expires October 1960 .

History: Founded as American Osteopathic Society of Anesthesiologists, Detroit, Mich., 1949; incorporated 1952 as American Osteopathic College of Anesthesiologists.

Purpose: To advance the standards of practice and service in the specialty of anesthesiology ; to aid in providing opportunities for study and training in the art and science of anesthesiology; to promote the osteopathic concept of disease as related to anesthesiology; to maintain and promote the highest moral and ethical standards in the practice of anesthesiology; to establish standards for membership; to recognize outstanding accomplishment in the field of anesthesiology or outstanding service to this organization on the part of any member by conferring upon him the degree "Fellow in the American Osteopathic College of Anesthesiologists." 
Mcmbcrship: Members, 172, members in good standing of the American Osteopathic Association and of their divisional osteopathic societies, meeting such other requirements as are deternined by the Board of Governors; Candidates, 44 ; Fellows; Associates; Honorary.

Meetings: Annual.

Professional activities: Fellow in the American Osteopathic College of Anesthesiologists, for outstanding service to the College or outstanding service or accomplishment in the field of anesthesiology; named by the unanimous vote of the Board of Governors.

\section{American Osteopathic College of Radio-} logy, 2515 East Jefferson Boulevard, South Bend, Ind. President: Arthur Witthohn, 1919 Boston Street, S. E., Grand Rapids, Mich. Term expires November 1, 1960. SccretaryTreasurer: F. A. Turfler. Term expires November $1,1960$.

History: Organized 1941 ; incorporated 1953. Committees: Audio-Visual Education.

Purpose: to foster and maintain the highest standards in the specialty of radiology; to further the education of the Society's members; to recognize the osteopathic concept as it relates to the field of radiology; to stimulate and maintain high moral and ethical standards in the specialty of radiology; to promote the public health.

Membership: Active member, must hold degree of Doctor of Osteopathy, be licensed to practice in some State, certified in some phase of radiology, a member of the American Osteopathic Association, his divisional Society, and his local Osteopathic Society; Associate member, must hold degree of Doctor of Osteopathy, be licensed to practice in some State, actively engaged in some phase of radiology, a member of the American Osteopathic Association, his divisional Society, and his local Osteopathic Society; Candidate member, osteopathic physician engaged in an approved residency, preceptorship, or assistantship training program leadtoward certification in one of the branches of radiology. Active members, 109; Associate members, 55; Candidate members, 1. Total membership 165.

Meetings: Annual.

Professional activitics: Fellowships; Honorary and Life Memberships. Trenery Medal, given annually to Trenery Memorial Lecturer. Past President's Medallion.

Publications: Newsletter, issued two or three times per year, free to members. Editor: F. A. Turfler.

249. American Osteopathic Hospital Association, 4000 Brady Street, Davenport, Iowa.
President: David W. Lawrence, Long Beach Osteopathic Hospital, 2776 Pacific Avenue, Long Beach, Calif. Term expires November 2, 1960. Executive Secretary: Emil L. Herbert. Term indefinite.

History: Organized 1934 as the Associated Hospitals of Ostcopathy; name changed 1939 to present title.

Purpose: To promote the science of osteopathy; to establish and maintain high standards of medical surgical care; to promote efficient hospital administration.

Membership: Individuals who have provided accredited professional patient care on a twentyfour hour basis, have met standards of local and State health departments, and have maintained complete patient records. Total membership 255.

Mectings: Annual.

Publications: Osteopathic Hospital, monthly. Directory, annual. Editor: Don Clason.

250. American Otological Society, Inc. Presidcut: Henry L. Williams, Mayo Clinic, Rochester, Minn. Term expires June 30, 1961. Secrciary: James A. Moore, 525 East 68th Street, New York 21, N. Y. Term expires June 30, 1961.

History: Organized July 22, 1868 ; incorporated June 16, 1926.

Purpose: to advance and promote the study of otology and to engage in and encourage research with respect thereto.

Membership: Active, 111, based on contributions to otology; Senior, 20; Associate, 10; Honorary, 8. Total membership 149.

Mectings: Annual.

Professional activitics: The Central Bureau of Research encourages and supports research in otology. An Award of Merit consisting of a Citation and Honorarium is awarded at intervals.

Publications: Transactions, annually, free to members. Editor: Ben H. Senturia, 500 North Skinker Boulevard, St. Louis 30, Mo.

251. American Otorhinologic Society for Plastic Surgery. 75 Barberry Lane, Roslyn Heights, N. Y. President: Thomas E. Briant, 23 Division Street, Welland, Ontario, Canada. Term expires March 1961. Secretary: Joseph G. Gilbert. Term expires March 1961.

History: Organized June 1942.

Purpose: To further the study and practice of plastic and reconstructive surgery among otolaryngologists.

Membership: Total membership, 430, diplomates of Board of Otolaryngology (at least 
two years), who perform plastic surgery of the head and neck.

\section{Meetings: Biennial.}

Publications: Transactions, annual.

252. American Pediatric Society. Denver General Hospital, Denver 4, Colo. President: L. Emmett Holt, Jr., 550 First Avenue, New York 16, N. Y. Term expires May 1, 1961. Secretary-Treasurer: Conrad M. Riley. Term indefinite.

\section{History: Organized September 18, 1888.}

Purpose: The advancement of the knowledge of the physiology, pathology, and therapeutics ot infancy and childhood.

Membership: Active, 238, individuals active in pediatric education and research; Emeritus, 52, Active members having reached sixty-seven years of age; Honorary, 11, foreigners distinguished in pediatrics.

\section{Meetings: Annual.}

Professional activities: The John Howland Medal given ammually.

253. American Petroleum Institute. 1271 Avenue of the Americas, New York 20, N. I. President: Frank M. Porter. Term expires November 1960. Secretary: Willard M. Wilson. Term expires November 1960. Production office, Dallas, Tex. Transportation office, $1625 \mathrm{~K}$ Street, N. IV., Washington, D. C. Pacific Coast office, 510 WVest 6 th Street. Los Angeles, Calif.

History: Organized and incorporated March 20, 1919, in Washington, D. C. Divisions: Production, Refining, Marketing, Transportation, Finance and Accounting. Departments: Technical Services, Statistics. Committee on Public Affairs.

Purpose: To afford a means of cooperation with the Federal government in all matters of national concern; to foster foreign and domestic trade in American petroleum products; to promote, in general, the interests of the petroleum industry in all its branches; to promote the nutual improvement of its members and the study of the arts and sciences commected with the petroleum industry.

Membership: Individual members, engaged in petroleum or allied industry ; company members. Total membership approximately 11,000.

Meetings: Annual; also midyear meetings.

Professional activities: Funds provided for numerous fundamental research projects.

Publications: Annual and Midyear Meeting Proceedings. Statistical Bulletin, weekly, $\$ 12.50$, free to nembers.
254. American Pharmaceutical Association. 2215 Constitution Avenue, N. W., Washington 7 , D.C. President: Ronald V. Robertson, 409 West Riverside Avenue, Spokane 1, Wash. Term expires April 28, 1961. Executive Secretary: IVilliam S. Apple, 2215 Constitution Avenue, N. W., Washington 7. D. C. Term expires spring 1962.

History: Organized 1852; incorporated February 21, 1888. Local Branches: Baltimore, Central Utah (Salt Lake City), Charleston (South Carolina), Chicago, Cincinnati, District of Columbia, Fresno-Madera County (California), Greater Los Angeles, Indianapolis, Lewis \& Clark (Idaho), Memphis, Miami, Michigan (Detroit), New Orleans, New York, Northern California (San Francisco), Northern New Jersey (Newark), Northwestern (Minneapolis), Northwestern Ohio (Toledo), Oregon (Portland), Philadelphia, Pittsburgh, Puerto Rico, Puget Sourd (Seattle), St. Louis, Santa Clara County (California), Southeast Idaho (Pocatello), Southeast Texas (Houston), Southeast Wisconsin (Milwaukee), Southern New Jersey (Camden), IVestern Nebraska (Scottsbluff). Student branches in all seventy-six United States colleges and universities which have schools of pharmacy. Sections: Education and Legislation, Historical, lndustrial, Military, Pharmaceutical Econonics, Practical Pharmacy, Scientific, and Student.

Purpose: To advance the art and science of pharmacy and to improve the standards of pharmaceutical practice.

Membership: Open to all pharmacists of good moral and professional standing, whether in practice or retired, employers or employed; teachers of pharmacy, chemistry, botany, materia medica, and related subjects; editors, publishers, and writers of pharmaceutical literature; law enforcement officials, pharmaceutical chemists; retail and sales persomel as well as other officials of wholesale drug and manufacturing firms; pharmacy students and all other persons interested in the progress of the art and science of pharmacy. Active members 21,000; Associate members 12,000; Life members 633; Honorary members 8 .

\section{Meetings: Annual.}

Professional activities: Ebert Prize, a medal awarded annually to person who submits the best essay or written contribution published in the Journal of the American Pharmaceutical Association containing results of an original investigation of a medicinal substance, determining new properties, or containing other meritorious contributions to knowledge, or for improved methods of determining merit, or for the preparation of chemical or pharmaceutical products. Research Fund, capital approximately 
$\$ 108,000$, the proceeds from which are granted as honoraria or awards to encourage investigation and research upon any subject relating in any way to pharmacy or the collateral sciences. Kilmer Fund, a trust fund, the proceeds from which are used for a prize for work in pharmacognosy. Centemial Fund, about $\$ 11,000$, the income from which is used to aid the prosecution of original investigations. The Laboratory of the Association is located at the Headquarters Building in Washington, D. C., Director: Samuel W. Goldstein.

Publications: Journal: Practical Pharmacy Edition, monthly, current volume: 21, $\$ 10$. Editor: William S. Apple. Journal: Scientific Edition, monthly, current volume: $49, \$ 15$, special rates to members. Editor: Justin L. Powers. National Formulary, published every five years, \$9. Editor: Justin L. Powers. Drug Standards, bimonthly, current volume: $28, \$ 5$. Editor: Justin L. Powers.

Library: 10.500 volumes in the field of pharmacy.

255. American Philosophical Association. President: Cornelius Krusé, Wesleyan University, Middletown, Conn. Term expires December 1961. Secretary-Treasurer: Lewis E. Hahn, Washington University, St. Louis 30, Mo. Term expires June 1963.

History: Originated with the Western Philosophical Association, the present Western Division, organized in 1900, now a federation composed of three relatively autonomous Divisions: Eastern, organized in 1901, Western, and Pacific, organized in 1924, which hold separate annual meetings. Affiliated with international philosophical organizations; has participated actively in all international congresses of philosophy; also affiliated with the American Council of Learned Societies, the American Association for the Advancement of Science, the American Documentation Institute, and the Institut International de Collaboration Philosophique. ComMittees: International Cultural Cooperation, Publication, Information Service, Bibliography of Philosophy, Philosophy in Education, Advancing Original Work in Philosophy, and Carus Lectures.

Purpose: To promote a fellowship among teachers of philosophy, to exchange ideas, and to encourage a creative and scholarly interest.

Membership: Full Member, limited to persons whose training in philosoplyy has been advanced and systematic enough to make them competent to teach at the college or university level, and persons who have published contributions, whether in plilosophy or in borderline fields, which, in the opinion of the Executive Conmittee, are of substantial value to philosophy;
Associate Member, persons ineligible to full nembership, but whose interest or achievenents in philosophy are regarded by the Executive Committee as warranting their affiliation with the Association. Total membership 1,700.

Mectings: Irregular.

Publications: Proceedings and Addresses, annual, current volume: $33, \$ 2$. Editor: Lewis E. Hahn.

256. American Philosophical Society. 104 Sonth 5th Street, Philadelphia 6, Pa. President: Henry Allen Moe. Term expires September 1961. Exccutive Officer: George W. Corner. Term expires September 1961.

History: Originated in Franklin's "Junto," formed in 1727 and formally organized under the name of the American Philosophical Society in 1743. United January 1769 , under present title, with the American Society, outgrowth of the old Junto, which had still maintained its existence and whose views and ends were the same; incorporated March 1780.

Purpose: The promotion of useful knowledge. Mcmbership: Class I, Mathematical and Physical Sciences; Class II, Geological and Biological Sciences; Class III, Social Sciences; Class IV, Humanities. Members, 500 American, 75 foreign. Total membership 575.

Mcetings: Semiannual.

Professional activities: Penrose Research Fund, $\$ 175,000$ available in 1960 for grants-inaid for research; Johnson Research Fund, $\$ 52,000$ available in 1960 for grants-in-aid; Daland Fund, $\$ 27,000$ available for fellowships for research in clinical medicine; Henry M. Phillips Prize, awarded occasionally for best essay of merit on the science and philosophy of jurisprudence; John F. Lewis Prize, awarded to the American citizen who shall anmounce at any general or special meeting of the Society, and publish among its papers some truth which the Council of the Society shall deem worthy of the award.

Publications: Proceedings, annual, current volume: $104, \$ 5$. Transactions, annual, current volume: 50 , \$6. Memoirs, irregular, current volume: 50, separately priced. Year Book, \$1. Editor: IVilliam J. Robbins.

Library: 115,000 volumes on history of science and culture in America.

257. American Physical Society. Columbia University, New Jork 27, N. Y. Presidcut: V. K. Neisskopf, Massachusetts Institute of Technology, Cambridge 39. Mass. Term expires January 1961. Executice Secretary: K. K. Darrow. Term expires January 1961. 
History: Organized and incorporated 1899. Sections: New England; New York; Ohio; Southeastern. Divisions: Chemical Physics: Electron Physics; Fluid Dynamics; High-Polymer Physics; Plasma Physics; Solid State Physics.

Purpose: The advancement and diffusion of the knowledge of physics.

Membership: Total members, 16,000, individuals having an interest in physics; Fellows, about 1,700 .

Meetings: Annual meeting in January in New York; six to eight other meetings each year.

Professional activities: Oliver Ellsworth Buckley Prize, for solid state physics, awarded annually. Capital fund, $\$ 50,000$, donated by Bell Telephone Laboratories. Dannie Heinemann Prize for work in mathematical physics, supported by Heinemann Foundation. American Physical Society Prize endowed by Hughes Aircraft Company, for contributions by physicists under age of thirty-three.

Publications: Bulletin, six to eight per year, \$5. Physical Review, semimonthly, ser. 2, current volume: 120, \$40. Editor: S. A. Goudsmit. Review of Modern Physics, quarterly, current volume: 32, \$6. Editor: E. U. Condon.

\section{American Physical Therapy Association.}

1790 Broadway, New York 19, N. Y. President: Agnes P. Snyder, 162 Davis Court, San Antonio, Tex. Term expires June 1961. Exccutive Secretary: Lucy Blair. Term indefinite.

IIistory: Founded 1921 as the American Women's Therapeutic Association; name changed 1922 to American Physiotherapy Association; incorporated as a nonprofit organization in the State of Illinois in 1930; name clianged to present title 1948. Fifty-eight chapters throughout the United States and Puerto Rico; fortyeight districts within the chapters; 106 total organizational units.

Purpose: To foster the development and improvement of physical therapy service and physical therapy education through the coordinated action of physical therapists, allied professional groups, citizens, agencies, and schools to the end that the physical therapy needs of the people will be met.

Membership: Active members, graduates of programs approved by the Council on Medical Education and Hospitals of the American Medical Association, and foreign nationals who are affiliated with a member organization of the World Confederation for Physical Therapy and who fulfill other requirements as determined by the Board of Directors: Inactive, those who are no longer actively engaged in the practice of physical therapy but who wish to maintain affiliation; Life, those who upon retirement have been active members for thirty years or those who have completed twenty years as active members and reached sixty-five years of age at time of retirement; Student, persons in approved programs; Associate, nominated by a chapter and approved by the Board; Honorary, elected by the House of Delegates upon unanimous nomination of the Board of Directors. Active, 6,198; Inactive, 2,095; Life, 86; Student, 785; Associate, 40 ; Honorary, 7. Total membership 9,211 .

Meetings: Annual.

Professional activities: Cooperation with other organizations in providing for scholarship assistance for undergraduate and postgraduate work in physical therapy; awards presented in the form of honorary membership or citations to individuals for outstanding participation in matters pertaining to the growth of the profession of physical therapy and services contributing to the prevention or amelioration of disabilities in mankind. The Association promoted the founding of the Physical Therapy Fund, Inc., a tax-exempt organization dedicated to providing grants to carry out research projects and programs to improve the art and science of physical therapy.

Publications: The Physical Therapy Review, monthly, current volume: $40, \$ 7$ to nonmembers; $\$ 8$ foreign. Editor: Dorothy E. Voss.

259. American Physiological Society. 9650 Wisconsin Avenue, Washington 14, D. C. President: Julius H. Comroe, Jr., University of California Medical Center, San Francisco 22, Calif. Term expires July 1, 1961. Executive Secretary: Ray G. Daggs. Term indefinite.

History: Founded December 30, 1887 incorporated June 2, 1923. The oldest and one of the founding societies of the Federation of American Societies for Experimental Biology (founded 1913). The APS is also a founding member of the American Institute of Biological Sciences. Committees: Education; Use and Care of Animals; Placement of Senior Physiologists; Porter Fellowship; Program Advisory; International Physiology. The Board of Publications Trustees, appointed by the Council, control all activities concerned with Society publications.

Purpose: To promote the increase of plysiological knowledge and its utilization.

Membership: Active members, professional physiologists with one or more years of postdoctoral work and with continued active interest in research as evidenced by the conduction and publication of meritorious original research in physiology and/or biophysics, residents of Nortl America: Associate, advanced graduate students, 
teachers of physiology, and investigators who have not yet satisfied requirements for active membership, residents of North America; Honorary, distinguished scientists of any country who have contributed to the advance of physiology; Retired, members who have retired from employment because of ilhess or age. Active, 1,795; Associate, 76; Honorary, 16; Retired, 122. Total membership 2,009.

Mectings: April meeting with Federation of American Societies for Experimental Biology; September meeting of the APS only.

Professional attivities: Porter Fellowship, $\$ 3,600$ stipend for predoctoral student in physiology; various education activities for college teachers.

Publications: American Journal of Physiology, monthly, current volume: $198-199, \$ 40$ domestic, $\$ 41$ Canada, $\$ 42$ others. Journal of Applied Physiology, bimonthly, current volume: $15, \$ 20$ domestic, \$21 Canada, \$22 others. Physiological Reviews, quarterly, current volume: $40, \$ 10$ domestic, $\$ 10.50$ Canada, $\$ 11$ others. The Physiologist, quarterly, current volume: $3, \$ 3$ domestic, $\$ 3.50$ Canada, $\$ 4$ others. Managing Editor of all Society publications: Milton O. Lee. Menbers receive journals at reduced subscription rates and receive The Physiologist gratis. Various monographs, symposia, and special publications, irregular.

260. American Phytopathological Society. President: S. E. A. McCallan, Boyce Thompson Institute, 1086 North Broadway, Yonkers, N. Y. Term expires December 1961. Executive Secretary: George A. Zentmyer, Department of Plant Pathology. University of California, Riverside, Calif. Term expires August 1962.

History: Founded 1908; incorporated 1915. Divisions: Northeastern, Potomac. Southern, Pacific, North Central.

Purpose: To promote the study of plant diseases and of the methods by which they may be controlled; to encourage and facilitate cooperation among plant pathologists; to hold meetings for the presentation and discussion of the results of research, the exchange of ideas and experience, and the consideration of methods and means of promoting research, instruction. extension work, and practical control work in the field of plant pathology; to cooperate in all practical ways with other scientific and technical organizations and agencies for the advancement of science and its applications; to encourage and provide a channel for the publication of contributions to the world's knowledge of plant diseases and of methods for their suppression.

Mcmbcrship: Open to persons interested in the study of phytopathology, including the practical control of plant disease. Total membership 2,024.

\section{Mcetings: Annual.}

Publications: Phytopathology, monthly, current volume: $50, \$ 15$, nonmembers; $\$ 10$ members. Editor: E. E. Wilson.

261. American Plant Life Society. P. O. Box 150, La Jolla, Calif. President: Joseph C. Smith, La Mesa, Calif. Term expires October 1960. Secretary: Thomas W. Whitaker. Term expires October 1960.

History: Organized 1933; American Amaryllis Society became affiliate, 1945. CoмmitTEEs: Amaryllis, Narcissus, Alstroemerids, Allieae, Pancratieae, Hemerocallis.

Purpose: To increase and diffuse knowledge about the Amaryllidaceae.

Mcmbership: Open to those interested primarily in the plant family Amaryllidaceae. Total membership 500 .

Meetings: Annual.

262. American Podiatry Association. 3301 16th Street, N. W., Washington 10, D. C. President: Marvin D. Marr, 204 Paramount Building, Cedar Rapids, Iowa. Term expires August 1961. Secretary: A. Rubin. Term indefinite.

History: Organized in Chicago, August 1912, as National Association of Chiropodists; incorporated in New York September 19, 1912. In first several years Association consisted of individual members. In 1919 a constitution was adopted providing that this Association would be a federation of affiliated State societies. Name changed to present title January 1958.

Purpose: To enlighten the American people regarding foot health so as to prevent or reduce the great amount of suffering from foot diseases. injuries, and defects.

Membership: Requires graduation from accredited podiatry-chiropody college and membership in appropriate State society. Total membership 5,300.

Meetings: Annual.

Professional activitics: IVilliam J. Stickel Award for research in podiatry-chiropody ; Drew Awards for research in podiatry-chiropody; Scientific Exhibits Awards.

Publications: Journal, monthly, current volume : $50, \$ 10$, free to members. Editor: A. Rubin.

263. American Polar Society. President: A. J. English, 6583 Provence Road, San Gabriel, Calif. Term expires December 1960. Exccu- 
tive Secretary: August Howard, 98-20 62nd Drive, Rego Park 74, N. Y. Term expires December 1960.

History: Organized November 1934 to band together persons interested in the polar regions.

Purpose: To organize as a permanent group individuals interested in the history and exploration of the Arctic and Antarctic Regions; to act as a clearinghouse of polar information; to be of aid to organizers and members of polar expeditions; and to spread knowledge of the polar regions.

Membership: Open to all persons, institutions, and groups interested in the history and exploration of the polar regions. Total membership 1,880 .

\section{Meetings: Only regional meetings.}

Professional activities: Honorary membership - Society's highest award.

Publications: The Polar Times, semiannual, current volume: $50, \$ .50$ each. Editor: August Howard.

264. American Pomological Society. Department of Horticulture, Michigan State University, East Lansing, Mich. President: Paul Shepard, Superintendent, Missouri State Fruit Experiment Station, Mountain Grove, Mo. Term expires December 1960. Executio' Secretary: George M. Kessler. Term indefinite.

History: Organized October 10, 1848 at an American Congress of Fruit Growers representing horticultural societies from Massachusetts, Pennsylvania, New Jersey, and Connecticut. United with North American Pomological Congress in 1850. Committees: Plant Material Exchange-Tree and Small Fruits; Variety Nomenclature and Appraisal; Fruit Gardens; True-to-Name Nursery Stock: Variety Arbitration.

Purpose: To evaluate fruits, prevent duplication and misnaming of fruit varieties; to gather and disseminate pomological information with emphasis on varieties; to promote variety improvement.

Membership: Individual, 270; Individual life, 98; Affiliated Societies, 9; Industrial, 12. Total membership 389. Members must have an interest in furthering the fruit industry and fruit gardening through fruit variety improvement.

Mectings: Anmual.

Professional actizities: Marshall P. Wilder Medal; Marshall P. Wilder Certificate. Variety testing in cooperation with agricultural research stations. Sponsors inspection of fruit trees in nurseries for trueness to name.
Publications: Fruit Varieties and Horticultural Digest, quarterly, current volume: $14, \$ 2$. Editor: George M. Kessler.

265. American Proctologic Society. 7815 East Jefferson Avenue, Detroit 14, Mich. Presidcnt: Walter A. Fansler, 1829 Medical Arts Building, Minneapolis 2, Minn. Term expires June 1961. Secretary: Norman D. Nigro. Term expires June 1961.

History: Organized 1899; incorporated.

Purpose: To facilitate the dissemination and investigation of knowledge relating to the colon, rectum, and anus.

Mcmbership: Individuals with practice limited to colon and rectal surgery; diplomates of the American Board of Colon and Rectal Surgery. Affiliate Members, 216; Associate Fellows, 277; Fellows, 165; Senior Fellows, 23; Honorary Associates, 5; Honorary Fellows, 16. Total membership 702.

Mcetings: Annual.

Professional activities: American Proctologic Society Research Foundation, to further proctologic research; seven awards for research and outstanding papers.

Publications: Diseases of the Colon and Rectum, bimonthly, current volume: $3, \quad \$ 12$. Editor: Louis A. Buie.

266. American Protestant Hospital Association. 840 North Lake Shore Drive, Room 640, Chicago 11, I11. President: Frank R. Bradley, Director, Barnes Hospital, St. Louis, Mo. Term expires February 1961. Exccutive Dircctor: Leo M. Lyons. Term indefinite.

History: Organized September 12, 1921; incorporated January 3, 1924.

Purpose: To establish cooperation between the Protestant hospitals of the country; to create and stimulate interest in hospitals in the different church bodies; to promote efficiency and a right spirit of Christian service and ethics in hospitals and schools of nursing; to secure Christian nurses for Christian hospitals; to emphasize the religious spirit in hospitals and the work of the full-time chaplain in the Christian institutions.

Membership: Institutional: any Protestant hospital or any nonprofit hospital association adhering in principle to the Protestant heritage, organized for the promotion of public health or for the care or treatment of the sick or injured. Personal: any person who is a trustee or administrator or assistant administrator or a chaplain of a Protestant or nonprofit hospital, or a Protestant active in the hospital field and interested in and sympathetic with the aims 
and purposes of the Association, or a member of the staff of a Protestant hospital. Associate Institutional: organizations interested in the objectives of the Association but not eligible for Institutional membership. Associate Personal: personnel next in authority to the administrator, or trustees or members of an association whose objectives and principles are the same as those of Personal members. Sustaining: individuals, institutions, corporations, or organizations interested in the welfare of the Association. Honorary: open to any person whose services, public or private, entitle him to such recognition. Institutional, 300; Personal, 485. Total membership 785 .

Meetings: Annual.

Publications: Bulletin, quarterly, $\$ 1$, free to members. Year Book, free to members. Editor: Leo M. Lyons.

267. American Psychiatric Association. 1700 18th Street, N. IV., Washington 9, D. C. President: Robert H. Felix. Term expires May 1961. Exccutive Secretary: Mathew Ross. Term indefinite.

History: Organized October 1844, as the Association of Medical Superintendents of American Institutions for the Insane; name changed to American Medico-Psychological Association 1893 and to present title 1921. Has fifty district branches; its forty committees carry out the program of the Association.

Purpose: To further the study of subjects pertaining to the nature, treatment, and prevention of mental disorders; to further the interests, maintenance and advancement of standards of hospitals, out-patient clinics, and all other agencies concerned with medical, social, and legal aspects of these disorders; to further psychiatric education and research; and to apply psychiatric knowledge to other branches of medicine, to other sciences, and to the public welfare.

Membership: Open to doctors of medicine in Canada, the United States, Central America, and U. S. Territories. Associate Members, those with one year of experience in a a mental hospital or equivalent; Full Members, those with three years of such experience; Fellows, those with six years of such experience. Total membership approximately 12,000.

Meetings: Annual.

Professional activities: Holds conferences, institutes; has grant projects, offers consultation services, makes fellowship awards. Lester N. Hofleimer Prize, for a contribution of a research nature in the field of psychiatry or maental hygiene. Isaac Ray Award, for an outstanding contribution in the field of medical jurisprudence.
Publications: American Journal of Psychiatry, monthly, \$12. Editor: Clarence B. Farrar. Psychiatric Research Reports, irregular, monograph series, \$2. Mental Hospitals, monthly except July and August. Newsletter, monthly, except July and August, \$5.

Library: 1,000 volumes on the history of psychiatry.

See also: Arkansas District Branch; Bronx District Branch; Brooklyn District Branch (Kings County) ; Central California Psychiatric Society; Central New York District Branch; Colorado District Branch; Connecticut District Branch; Delaware Psychiatric Society; Eastern Missouri District Branch; Florida Psychiatric Society; Georgia Psychiatric Association; Hawaii Psychiatric Society; Illinois Psychiatric Society; Indiana District Branch; Indiana Psychiatric Society; Intermountain Psychiatric Association; Iowa Neuropsychiatric Society; Kansas District Branch; Kentucky District Branch; Louisiana District Branch; Maryland Psychiatric Society; Michigan District Branch; Mid-Hudson District Branch; Minnesota Psychiatric Society; Mississippi Psychiatric Society; Nassau Neuropsychiatric Society; Nebraska, North Dakota, South Dakota District Branch; Neuropsychiatric Society of Virginia; New Jersey District Branch; New York County District Branch; New York State Capitol District Branch; North Carolina District Branch; North Pacific District Branch; Northern California Psychiatric Society; Northern Indiana Psychiatric Society; Northern New England Disctrict Branch; Ohio Psychiatric Association; Oklahoma District Branch; Ontario District Branch; Pennsylvania Psychiatric Society; Quebec District Branch; Queens County Psychiatric Society; Rhode Island District Branch; South Carolina District Branch; Southern California Psychiatric Society; Suffolk County District Branch; Tennessee Psychiatric Association; Texas District Branch; Washington, D. C., Psychiatric Society; Westchester County District Branch; Western Missouri District Branch; Western New York Psychiatric Society; Wisconsin Psychiatric Association.

268. American Psychoanalytic Association, Inc. 1 East 57th Street, New York 22, N. Y. Presidcut: Jacob A. Arlow, 120 West 59th Street, New York 19, N. Y. Term expires May 1961. Executive Secretary: Mrs. Helen $\mathrm{F}$ ischer. Term indefinite.

History: Founded May 1911 as a Branch of the International Psycho-Analytical Association.

Purpose: To study and advance psychoanalysis; to advocate and maintain standards for the training of psychoanalysts and for the 
practice of psychoanalysis ; to foster the integration of psychoanalysis with other branches of medicine and to encourage research in all fields having to do with the scientific knowledge and welfare of man.

Membership: Licensed physicians graduated from an approved psychoanalytic institute or training center. Total membership 888 .

\section{Meetings: Semiannual.}

Publications: Journal, quarterly, current volume: $8, \$ 10$. Editor: John Frosch.

269. American Psychological Association, Inc. 1333 16th Street, N. IV., Washington 6, D. C. President: Neal E. Miller, Yale University, New Haven, Conn. Term expires September 1961. Executive Officer: John G. Darley. Term expires 1964.

History: Founded 1892; incorporated in the District of Columbia 1925. Divisions: Clinical and Abnormal Psychology; Consulting Psychology; Counseling and Guidance; Educational Psychology; Engineering Psychology; Esthetics; Evaluation and Measurement; Childhood and Adolescence; Experimental Psychology; General Psychology; Industrial and Business Psychology; Military Psychology; National Council on Psychological Aspects of Disability; Personality and Social Psychology; Psychologists in Public Service; Psychology of Maturity and Old Age; School Psychologists; Society for the Psychological Study of Social Issues: Teaching of Psychology.

Purpose: To advance psychology as a science and as a means of promoting human welfare by the encouragement of psychology in all its branches in the broadest and most liberal manner; by the promotion of research in psychology and the improvement of research methods and conditions; by the improvement of the qualifications and usefulness of psychologists through high standards of professional ethics, conduct, education, and achievement; by the increase and diffusion of psychological knowledge through meetings, professional contacts, reports, papers, discussions, and publications.

Membership: Members, 14,569, having a doctoral degree in psychology; Associates, 1,408, having a master's degree in psychology and one year of experience, or two years of graduate study in psychology, and at time of application devoting full time to psychological work; Fellows, 2,238, having a doctoral degree in psychology, five years' postdoctoral experience, and showing evidence of outstanding and unusual contribution to psychology. Total membership 18,215.

Metings: Annual.
Professional activitics: Three annual $\$ 1,000$ awards for outstanding contribution to scientific psychology.

Publications: American Psychologist, monthly, current volume: $15, \$ 8$ domestic, $\$ 8.50$ foreign. Contemporary Psychology, monthly, current volume: $5, \$ 8$ domestic, $\$ 8.50$ foreign. Journal of Abnormal and Social Psychology, binonthly, current volume: $60-61, \$ 16$ for 2 volumes domestic, $\$ 16.50$ foreign. Journal of Applied Psychology, bimonthly, current volume: 44 , $\$ 8$ domestic, $\$ 8.50$ foreign. Journal of Comparative and Physiological Psychology, bimonthly, current volume: $53, \$ 8$ domestic, $\$ 8.50$ foreign. Journal of Consulting Psychology, bimonthly, current volume: $24, \$ 8$ domestic, $\$ 8.50$ foreign. Journal of Educational Psychology, bimonthly, current volume: $51, \$ 8$ domestic, $\$ 8.50$ foreign. Journal of Experimental Psychology, monthly, current volume: $59-60, \$ 16$ for 2 volumes domestic, $\$ 16.50$ foreign. Psychological Abstracts, bimonthly, current volume: 34 , \$16 domestic, $\$ 16.50$ foreign. Psychological Bulletin, bimonthly, current volume: $57, \$ 8$ domestic, $\$ 8.50$ foreign. Psychological Monographs: General and Applied, irregular, current volume: $74, \$ 8$ domestic, $\$ 8.50$ foreign. Psychological Review, bimonthly, current volume: $67, \$ 8$ domestic, $\$ 8.50$ foreign.

270. American Psychopathological Association, Inc. President: William Horsley Gantt, Johns Hopkins Hospital, Baltimore 5, Md. Term expires February 1961. Exccutive Secretary: Fritz A. Freyhan, Farnhurst, Del. Term expires February 1961.

History: Founded in New York City in 1910 by a group of physicians prominent in the field of psychopathology.

Purpose: To advance the science of psychorathology.

Mcmbership: Limited to 150 , by invitation only to those individuals who have made substantial contributions in the field of psychopathology. Associate membership, those who have been active members for over 15 years and are unable to attend meetings. Honorary, former members who have made particularly distinguished contributions in the field.

Meetings: Annual.

Professional activitics: Samuel IV. Hamilton Memorial Lecture and Award: medal and $\$ 100$, to a distinguished worker in psychopathology who presents a lecture on some subject in the field; capital amounts to $\$ 3,500$. The Henry and Lillian Stratton Foundation award of $\$ 500$ for research in the field of psychopathology.

Publications: Papers presented at the Annual Meetings, published annually. Editors: Paul Hoch and Joseph Zubin. 
271. American Psychosomatic Society, Inc. 265 Nassau Road, Roosevelt, N. Y. President: Morton F. Reiser, Albert Einstein College of Medicine, New York, N. Y. Term expires April 30, 1961. Secretary-Treasurer: Eugene Meyer, Johns Hopkins Hospital, Baltimore, Md. Term expires April 30, 1961.

History: Organized 1943 as the American Society for Research in Psychosomatic Problems, Inc.; incorporated January 1944. Name changed to present title May 1948.

Purpose: To stimulate the investigation of psychosomatic problems.

Membership: Regular, scientists in biological, psychological, and sociological disciplines and workers in cognate fields who teach, practice, or participate in investigations of psychosomatic relationships and who are duly recognized and qualified representatives of their respective specialties; Emeritus, upon reaching the age of 65 , or earlier where circumstances such as retirement, illness, and the like may, in the opinion of the Council, justify such action; Corresponding, extended to outstanding leaders in the study of psychosomatic relationships in communities outside of the United States and Canada; Honorary, persons whose research and training give them exceptional eminence in the study of psychosomatic relationships from the disciplines represented in the Society. Total membership 660 .

Meetings: Anuual.

Publications: Psychosomatic Medicine, bimonthly, current volume: $22, \$ 8.50$. Editor: Carl Binger, 21 Lowell Street, Cambridge 38, Mass.

272. American Public Health Association. 1790 Broadway, New York 19, N. Y. President: Malcolm H. Merrill, San Francisco, Calif. Term expires November 4, 1960. Executive Director: Berwyn F. Mattison. Term indefinite.

\section{History: Organized April 18, 1872.}

Purpose: To promote and protect public and personal health.

Membership: Members, 9,440, persons engaged or interested in public health; Fellows, 3,339 , membership for at least two years, with an established standing in public health work; Sustaining, 52; Affiliated Societies, 48; Branches, 3. Total membership 12,937.

Meetings: Annual.

Professional activities: Sedgwick Memorial Medal for distinguished service in public health; Lasker Award for administrative and scientific achievement. Funds granted from various foundations for special projects.
Publications: American Journal of Public Health, monthly, current volume: $50, \$ 12$. Editor: George Rosen.

273. American Radio Relay League, Inc. $38 \mathrm{La}$ Salle Road, West Hartford 7, Conn. President: Goodwin L. Dosland, Moorhead, Minn. Term expires May 11, 1962. Secretary and General Manager: John Huntoon. Term indefinite.

History: Organized 1914; incorporated January 29, 1915. Divisions: Sixteen geographic divisions in the United States and Canada.

Purpose: Promotion of interest in amateur radio communication and experimentation; relaying of messages by radio; advancement of the radio art.

Membership: Full members, 77,170, licensed amateurs of the United States or Canada; Associate, 20,253 , persons anywhere who are interested in amateur radio. Total membership 97,423

Meetings: No meetings of League as a whole ; Board of Directors meets annually.

Professional activities: Annual Merit Award for outstanding contribution to amateur radio technical development.

Publications: QST, monthly, current volume: 44 , domestic $\$ 5$, Canada $\$ 5.25$, elsewhere $\$ 6$. Editor: A. L. Budlong.

274. American Radium Society. President: Jesshill Love, The Memorial Cancer Foundation, 2315 Bath Street, Santa Barbara, Calif. Term expires May 1961. Secretary: Charles G. Stetson, Englewood Hospita1, Englewood, N. J. Term expires May 1962.

History: Founded in 1916 by a pioneer group of active physicians interested in radiation therapy.

Purpose: To promote the scientific study of radium and other sources of ionizing radiation in relation to their physical properties and therapeutic application.

Membership: Members, 430, pliysicians and allied scientists who are interested in the purposes of the Society.

Meetings: Annual.

Publications: American Journal of Roentgenology, Radium Therapy and Nuclear Medicine, monthly, current volume: $83, \$ 15$. Editor : Lawrence Reyuolds, 110 Professional Building, Detroit 1, Mich.

275. American Railway Bridge and Building Association. 220 South Michigan Avenue, Chicago 4, 111. President: H. D. Curie, Master Carpenter, Baltimore \& Ohio Railroad, Gar- 
rett, Ind. Term expires September 20, 1961. Secretary: Mrs. Ruth Weggeberg. Term expires September 20, 1961.

History: Organized 1891 as Association of Railway Superintendents of Bridges and Buildings; name changed to present title 1908.

Purpose: To bring together railroad men interested in construction and maintenance of railroad bridges and buildings, and to advance their interests by increasing knowledge in this branch of engineering.

Membership: Members, persons in positions above rank of gang foremen in connection with roadway, bridge, building, and water service work, or in employ of public regulatory bodies, professors of engineering in colleges, engineering editors, or government or private timber experts; Associate, responsible persons not eligible as members, but qualified to cooperate with members in study and development of improved practices in construction and maintenance of bridges, buildings, and water facilities; Junior, graduates of recognized engineering schools, or employed at least two years in design, maintenance, or construction of railway bridges, buildings, or structures; Life ; Honorary. Total membership approximately 900 .

Mectings: Annual.

276. American Railway Engineering Association, 59 East Van Buren Street, Chicago, 111. President: E. J. Brown, Burlington Lines, Chicago, I11. Term expires March 1961. Secretary: N. D. Howard. Term indefinite.

History: Organized March 30, 1899 as the American Railway Engineering and Maintenance of Way Association; incorporated (lllinois) 1899; name changed to present title 1912.

Purpose: Advancement and dissemination of knowledge pertaining to the scientific and economic location, construction, maintenance, and operation of American railroads.

Membership: Engineer or officer in the service of a railway corporation that is a common carrier, who has had not less than five years' experience in the location, construction, operation, or maintenance of railways; dean, professor, assistant professor, or equivalent in engineering in a university or college of recognized standing, or an instructor or equivalent in such university or college, who, with an engineering degree, has had at least two years' experience in teaching engineering; engineer or member of a public board, commission, or other official agency who, in the discharge of his regular duties, deals with railway problems; editor of a trade or technical magazine who in the discliarge of his regular duties deals with railway problems and who has had the equivalent of five years' engineering or railway experience; consulting engineer, engaged in private practice, or an engineer in his employ or in the employ of a consulting engineering organization, who has had the equivalent of five years' engineering experience. Members and Associates, 2,791; Life, 481 ; Junior, 101. Total membership 3,373.

\section{Mectings: Annual.}

Professional activities: Funds for various research projects are defrayed from voluntary contributions by railroads and others.

Publications: Bulletin, seven time per year, current volume: $62, \$ 12$ to nonmembers, free to members. Proceedings, annual, current volume : $60, \$ 10-\$ 12$.

\section{American Registry of Medical Assistants.}

2 Nevins Avenue, Thompsonville, Conn. Chancellor: Mrs. Irene Talle. Term expires June 1961. Executive Secretary: C. W. Truehart, P. O. Box 507, Norwich, N. Y. Term expires June 1965.

History: Organized and chartered in Massachusetts October 1950; registered in Washington, D. C. December 1950. Chartered State affiliating societies, all operating under the National Charter.

Purpose: To qualify all medical office help, both in clinical and in secretarial duties; to establish standards of training.

Membership: Citizen of the United States, Canada, or Pan-America, and of good moral character; graduate of an approved high school or its equivalent; graduate of an accredited school for medical assistants or medical secretaries whose curriculum shall be approved by the Registry, or shall have had not less than twelve consecutive calendar months of training and experience in a physician's office or hospital under the supervision of a competent and approved physician, or shall provide evidence of license as a licensed practical nurse. Total membership 5,000.

Mectings: Annual National Seminar.

Professional activities: Outstanding Medical Assistant Award, annual; conduction of Seminars at such times and places as the best interests of the Registrants may seem to require.

Publication: ARMA, quarterly, current volume: $10, \$ 3.50$ to nonmembers. Editor: C. IV. Truehart.

278. American Rheumatism Association, Inc. 10 Columbus Circle, New York 19, N. Y. President: Edward F. Hartung, 580 Park Avenue, 
New York 21, N. Y. Term expires June 1961. Executive Secretary: Gerard W. Speyer. Term indefinite.

History: Organized June 1934 as the American Association for the Study and Control of Rheumatic Diseases; name changed to present title 1937; incorporated May 1939. Sections: Affiliated with local rheumatism societies in Akron, Atlanta, Birmingham, Boston, Buffalo, Chicago, Cincinnati, Cleveland, Dallas, Denver, Detroit, District of Columbia, Hartford, Los Angeles, Louisville, Miami, Milwaukee, New York, Oklahoma City, Onaha, Philadelphia, Pittsburgh, Reading, Portland (Oregon), St. Louis, San Francisco, Trenton, Tucson.

Purpose: To encourage study and research in the area of joint and connective tissue disease; to train and teach practicing physicians in the care of patients; to arouse in communities and governmental bodies a feeling of responsibility leading to more adequate treatment, care, and rehabilitation of arthritics.

Membership: Active members, 1,400, teachers, physicians, or investigators in good standing, qualified by investigation and research, practice, teaching, contributions to medical literature, or advancement of knowledge of rheumatic diseases.

Mcctings: Annual; interim scientific session.

Publications: Arthritis and Rheumatism, bimonthly, current volume: $3, \$ 10$. Editor: William S. Clark.

279. American Rocket Society, Inc. 5005 th Avenue, New York 36, N. Y. President: Howard S. Seifert, Stanford University, Palo Alto, Calif. Term expires December 31, 1960. Exccutive Sccretary: James J. Harford. Princeton, N. J. Term indefinite.

History: Organized March 21, 1930 and incorporated May 4, 1930. There are fifty-two sections, thirty-seven chapters, and twenty-two committees.

Purpose: The advancement of the field of astronautics and related sciences.

Membership: Individual members, 13,700, persons having a degree in engineering or science and professional activity in astronautics or related field; Fellows, elected by Board of Directors for outstanding contribution to astronautics; Associates, interested in astronautics; Students, seventeen years of age or over, enrolled full time at recognized educational institution or serving in enlisted status in Armed Forces of United States; Corporate members, 158.

Mcetings: Eiglit to twelve yearly.

Professional activitics: C. N. Hickman Award, for outstanding work in solid rockets. G. Edward
Pendray Award, for outstanding contribution to literature in rockets and astronautics. James H. Wyld Memorial Award, for outstanding application of rocket power. ARS Astronautics Award, for outstanding contribution to the advancement of space flight. ARS Liquid Rocket Engine Award, for outstanding achievements in the field of liquid rocket engine research and development. ARS High Energy Propulsion Award, for outstanding achievement in the field of nonchemical high energy propulsion systems research and development. ARS Space Technology Award, for outstanding contributions to space technology outside the propulsion field. ARS Space Flight Award, to recognize advancement in the field of manned space flight involving great personal risk, either in orbital or hypersonic flights or in terrestrial simulators or research laboratories. ARS Space Sciences Award, for outstanding achievement in scientific exploration of space and other worlds by means of rocket-powered, instrumented, or piloted spacecraft. ARS Academic Award, for outstanding contributions to the field of engineering and scientific education. ARS Thiokol Chemical Corporation Graduate Award, a $\$ 1,000$ stipend for the outstanding paper by a graduate student on astronautics or a related subject. ARS Chrysler Corporation Undergraduate Student Award, a $\$ 1,000$ stipend for the outstanding paper by an undergraduate on astronautics or a related subject.

Publications: Astronautics, monthly, current volume: 5, \$9. Editor: Irwin Hersey. Journal, monthly, current volume: $30, \$ 12.50$. Editor: Martin Sunmerfield. Roster, yearly, current volume: 29 (to members only).

280. American Roentgen Ray Society. President: Edward B. D. Neuhauser, 300 Longwood Avenue, Boston 15, Mass. Term expires September 1960. Executive Secretary: C. Allen Good, Mayo Clinic, Rochester, Minn. Term expires September 1960.

History: Organized 1900 as the Roentgen Society of the United States; name changed to present title 1906; incorporated (District of Columbia) 1922.

Purpose: Advancement of medicine through the science of radiology.

Membership: Members, persons having an M.D. from an approved school of medicine, eight years' training or experience in the United States or Canada limited to the specialty, certification by the American Board of Radiology, endorsement by two active members and two other physicians, and a thesis on a pertinent subject or reprints on previously published work acceptable to the Executive Council; A'ssociate members, recognized scientists in 
allied fields; Corresponding members. Total membership 815 .

Mectings: Annual.

Professional activities: Caldwell Lecture, delivered annually to honor the late president, Eugene IV. Caldwell, a pioneer in roentgenology; a gold, silver, and bronze medal and certificate may be given annually for original investigation of excellence of presentation of scientific exhibits.

Publications: American Journal of Roentgenology, Radium Therapy, and Nuclear Medicine, monthly, current volume: $84, \$ 15$, free to members. Editor: Lawrence Reynolds.

\section{American Sanitary Engineering Inter-} society Board, Inc. 33 WVest 39 th Street, New York 18, N. Y. President: Thomas R. Camp, 18 Tremont Street, Boston 8, Mass. Term expires October 1960. Secretary-Treasurer: R. S. Rankin, 17 Morgan Street, Stamford, Conn. Term expires October 1960.

History: In 1934 the Sanitary Engineering Division of the American Society of Civil Engineers formed a Committee on the Advancement of Sanitary Engineering. In 1952 the Joint Committee for the Advancement of Sanitary Engineering was formed to include representatives from American Society of Civil Engineers, American Public Health Association, American Water Works Association, Federation of Sewage and Industrial Wastes Associations, and American Society for Engineering Education. During the next three years it studied and formulated plans for a suitable organization to carry out a certification program by an intersociety board. In 1955, the American Sanitary Engineering Intersociety Board was incorporated and proceeded with certification of qualified applicants, those certified to become Diplomates in the American Academy of Sanitary Engineers. In 1957 the American Institute of Chemical Engineers became the sixth sponsoring society.

Purpose: To improve the practice, elevate the standards, and advance the cause of sanitary engineering; to grant and issue to engineers, duly licensed by law to practice engineering, certificates of special knowledge in the variots fields of sanitary engineering.

Membership: Diplomates, 1,016, applicants shall be of good moral character and of high ethical and professional standing, be graduates of a college acceptable to the Board, and possess an engineering degree; have a license to practice engineering in the United States or Canada; have at least eight years' engineering experience in sanitary engineering following graduation from college and successfully pass an examination.
282. American School Health Association. 515 East Main Street, Kent, Ohio. Prosident: Lyda Smiley, LaMesa-Spring Valley School District, 4750 Date, La Mesa, Calif. Term expires October 1960. Exccutive Sccrctary: A. O. DeWeese. Term expires October 1960.

History: Organized 1927 as the American Association of Sclool Physicians; name changed to present title 1938. Regional Brancin Associations: California, Michigan, New Jersey, New York. Connuttees: Appraisal of School Health Services; Health Education in Elementary and Secondary Schools; Health Problems of Physical Education and Recreation; Improvement of the Status and Functions of the School Physician; Mental Hygiene in the Classroom; School Nursing Policies and Practices; Teacher Training in Health Education; Tuberculosis Control; School Luncl Program.

Purpose: To promote comprehensive and constructive school health programs, including the teaching of health, health services, and healthful school living.

Mcmbership: Members, 7,000, school doctors, dentists, nurses, health educators, dental hygienists, and school health administrators.

Mcctings: Annual.

Professional activitics: William A. Howe Award issued annually for outstanding services in school health.

Publications: Jonrnal of School Health, 10 issues per year, current volume: $30, \$ 4$. Editor : Delbert Oberteuffer.

283. American Scientific Glassblowers Society. 309 Georgetown Avenue, Gwinlurst, Wilmington 3, Del. Presidcnt: J. Allen Alexander, 2417 Ritner Street, Philadelphia 45, Pa. Term expires May 31, 1961. Exccutive Secretary: George A. Sites. Term indefinite.

History: Organized March 14, 1952 ; incorporated in Delaware March 17, 1954. Sections: Delaware Valley, Hudson-Mohawk, Metropolitan New York, Midwest, Niagara Frontier, Pittsburgh Tri-State, San Francisco Bay Area, Southeastern, Southern California, IVashingtonBaltimore. Committees: Cooperative Testing, Methods and Materials, Safety and Hazards, Standards.

Purpose: To gather and disseminate knowledge concerning scientific glassblowing, apparatus, equipment, and materials.

Mcmbership: Regular, 453, persons who now or in the past have for five consecutive years gained the major portion of their income through the art of scientific glassblowing; Junior, 26, persons who are actively engaged in scientific glassblowing, with less than five years' expericnce: Associate, 57, persons who have a close 
affinity or association with the manufacture or use of glass or glassblowing equipment as it concerns some branch of the science. Total membership 536.

\section{Meetings: Annual.}

Publications: Fusion, quarterly, current volume: 7, \$3. Symposium Proccedings, annual. Price varies.

284. American Shore and Beach Preservation Association. 810 18th Street, N. W.. Mashington 6, D. C. President: Charles G. Holle. Term expires June 1961. Executive Secretary: Francis J. Graling. Term expires June 1961.

History: Organized October 14, 1926 at a meeting called by the Governor of New Jersey at the instigation of the Committee on Shoreline Investigations of the National Research Council, and perfected December 8, 1926 in Washington, D. C. : incorporated as a nonprofit, educationalscientific association under the laws of New Jersey.

Purpose: To bring together for cooperation and mutual helpfulness the many agencies, interests, and individuals concerned with the protection and proper utilization of shores and beaches, and in all legitimate ways to foster that sound, far-sighted, and economical development and preservation of the lands which will aid in placing their benefits within the reach of the largest possible number of people.

Membership: Individual, Sustaining, Corporate, and Sponsor.

\section{Mectings: Annual.}

Publications: Shore and Beach Magazine, semiannual, current volume: $28, \$ 4$. News Letter, monthly, \$6. Editor: Francis J. Graling.

285. American Social Health Association, Inc. 1790 Broadway, New York 19, N. Y. President: Frank H. Heller, 2100 North Akard Street, Dallas, Tex. Term expires May 1961. Executive Secretary: Conrad Van Hyning. Term indefinite.

History: Organized 1913 as American Social Hygiene Association, by the union of the American Vigilance Association, organized January 1912, with the American Federation for Sex Hygiene, organized June 1910; incorporated 1914. In 1918 absorbed the New York Social Hygiene Society, organized 1916. In January 1960 name changed to present title. Carries out program in the United States and insular possessions through State and community social hygiene societies. Its division of international services works with social hygiene groups in other countries and, through the International Union Against Venereal Diseases, of which it is the United States member-agency and regional office for the Americas, enjoys the privileges of consultant relationship with the Economic and Social Council of the United Nations.

Purpose: To inform the public abont social hygiene and needed community action; to combat syphilis and gonorrhea as dangerous communicable diseases; to fight commercialized prostitution and other conditions which lead to sex delinquency among young people; to promote and conduct demonstrations in family life education for the strengthening and improvenent of the American family.

Membership: Open to persons interested in the objectives of the Association. Total membership approximately 700 .

\section{Mectings: Annual.}

Professional actizities: William Freeman Snow Medal, awarded annually for outstanding work in the social health field.

Publications: Social Health News, 10 issues yearly, current volume: 35, free. Editor: Mary Mangan. Social Health Papers, annual, \$1. Editor: Mary Mangan.

\section{American Society for Artificial Internal}

Organs. President: Melvin H. Newman, National Jewish Hospital, 3800 East Colfax Avenue, Denver 6, Colo. Term expires April 1961. Executive Secretary: E. Converse Peirce 11, Acuff Clinic, 514 West Church Avenue, Knoxville, Tenn. Term expires April 1962.

History: Organization begun 1954 ; completed at Atlantic City, N. J., June 1955.

Purpose: To provide a flexible and current forum for physicians, physiologists, engineers, and associated investigators interested in the general field of artificial internal organs (hemodialysis, pump-oxygenators, grafts, plastics, etc.).

Membership: Open to any person who has made significant original contribution in field of artificial internal organs. Total membership 120.

Mectings: Annual.

Publications: Transactions, annual, current volume: 5, \$8. Editor: George V. Schreiner, Georgetown University, Washington 7, D. C.

287. American Society for Clinical Investigation. Secrelary: William J. Harrington, Washington University School of Medicine, St. Louis, Mo. Term expires May 1963. 
History: Organized 1908 as American Society for the Advancement of Clinical Investigation; name changed to present title 1916.

Purpose: Cultivation of clinical resaarch by methods of the natural sciences; unification of science and practice of medicine; encouragenent of scientific investigation by the practitioner; diffusion of scientific spirit among members.

Membership: Active members, 279, practicing physicians of the United States and Canada who have accomplished meritorious original investigation in clinical and allied sciences of medicine; Emeritus, 427, members past the age of forty-five. Total membership 706.

Meetings: Annual.

Publications: Journal of Clinical Investigation, monthly, current volume: $39, \$ 12$, free to members. Editor: Stanley E. Bradley, 622 West 168th Street, New York 32, N. I.

\section{American Society for Engineering Educa-} tion. President: Eric A. Walker, Pennsylvania State University, University, Pa. Term expires July 1, 1961. Executive Secretary: W. Leighton Collins, University of Illinois, Urbana, I11. Term indefinite.

History: Organized 1893 as the Society for the Promotion of Engineering Education; merged with the Engineering College Research Association June 1946 to form the present society. The Engineering College Research Council and Engineering College Administrative Council are major functioning units. SEcrions: Allegheny; Illinois-lndiana; Kansas-Nebraska; Michigan; Middle Atlantic; Missouri-Arkansas; National Capital; New England; North Midwest; Ohio; Pacific Northwest; Pacific Southwest; Rocky Mountain ; Southeast; Southwest; Upper New York. Committees: Affiliate, Annual Meeting, Awards Policy, Ceramic Engineering, Constitution and By-Laws, Curtis IV. McGraw Award, Development of Engineering Faculties, Division Activities, Editorial, Engineering School Libraries, Ethics, Financial Policy, George Westinghouse Award, Honorary Membership, lndustrial Fellowship, Industrial Membership, Instrumentation, James H. McGraw Technical Institute Award, Lamme Award, Metallurgical Engineering, National Legislation, Nominating, Nuclear, Planning, Publications, Public lnformation, Registration Law, Sections and Branches, Technical Institute Education, Technical Jnstitute Education Evaluation, Textile Engineering, Vincent Bendix Award, Visiting Engineers, Young Engineering Teachers. Divisions: Aeronautical, Architectural, Chemical, Civil, Cooperative Engineering Education, Educational Methods, Electrical, Engineering Economy, Engineering Graphics, English, Evening Engineering Education, Graduate Studies,
Humanities and Social Sciences, Industrial, Mathematics, Mechanical, Mechanics, Mineral, Physics, Relations with Industry, Technical Institute.

Purpose: The advancement of education in all its functions which pertain to engineering and allied branches of science and technology, including the processes of teaching and learning, research, and public relations.

Membership: Individual, 9,400, persons who occupy or have occupied responsible positions in engineering instruction, research, or practice, or other persons interested in engineering education; Institutional, 228, institutions having active curricula leading to baccalaureate or ligher degree in engineering and having one or more curricula accredited by Engineers' Council for Professional Development; Industrial, 196, organizations having a major interest in engineering education; Affiliate, other institutions engaged in technical instruction which are accredited by a major regional accrediting association.

Mectings: Annual.

Professional activities: Lamme Medal, for distinguished contributions as an engineering educator; George Westinghouse Award, \$1,000 for a young engineering teacher of outstanding ability; Vincent Bendix Medal, for outstanding research contributions in colleges of engineering; Curtis W. McGraw Research Award, \$1,000 for outstanding early achievement in research in colleges of engineering; James H. McGraw Technical Institute Award, \$500 for outstanding contributions to technical institute education. Special studies financed by grants from government and private foundations are carried out by special conmittees.

Publications: Journal of Engineering Education, monthly October through June with February 15 yearbook-directory, current volume: 51, $\$ 10$ in United States and Canada, \$11 foreign. Editor: Paul T. Bryant.

289. American Society for Experimental Pathology. School of Medicine, University of North Carolina, Chapel Hill, N. C. President: Jacob Furth, Roswell Park Memorial Institite, Buffalo, N. I. Term expires June 1961. Exccutive Secretary: Kenneth M. Brinkhous. Term expires June 1963.

History: Founded December 1913; incorporated August 1950. Committees: Meritorions Award or Honors, Publications, Membership Survey, Nutritional Pathology.

Purpose: To bring the productive investigators in pathology, working essentially by experimental methods, in closer affiliation with the workers in other fields of experimental medicine. 
Membership: Open to American investigators who, through the use of experimental methods, have, within three years prior to candidacy, contributed meritorious work in pathology. Active members, 679.

Meetings: Annual.

\section{American Society for Horticultural Science.}

301 Horticultural Building, Michigan State University, East Lansing, Mich. President: Vernon T. Stoutemyer, University of California, Los Angeles 24, Calif. Term expires August 1961. Sccretary-Treasurer: Roy E. Marshall. Term expires August 1961.

History: Organized 1903. Regions: New England, Southern, Great Plains, Western, Caribbean. Sections: Pomology, Vegetable Crops, Floriculture and Ornamental Horticulture, Handling and Processing. Committees: Editorial, Education, Grades and Standards of Horticultural Crops, Extension, Vegetable Breeding and Varieties, International Horticulture, Mineral Nutrition.

Purpose: To promote the science of horticulture.

Mcmbership: Active Members, 2,226, any person holding a baccalaureate degree and actively engaged in research or education; Emeritus Members, 42; Sustaining Members, 90, any corporation or company that is interested in the promotion of horticultural research. Total membership 2,358.

Meetings: Annual.

Professional activities: Awards presented at the annual meeting for the best papers published in the Proceedings during the preceding year; Leonard H. Vaughan Award in Floricultural Research; the Leonard H. Vaughan Award in Vegetable Crops Research; the Charles G. Woodbury Award in Raw Products Research; Joseph Harvey Gourley Award in Fruit Research; the Alex Laurie Award in Floriculture and Ornamental Horticulture for research papers of graduate students; L. M. Ware Award for the best paper on teaching horticulture published during the preceding three years.

Publications: Proceedings, semiannual, current volume: 75 , domestic $\$ 12$, foreign $\$ 13$. Editor: John R. Magness.

291. American Society for Metals. Metals Park, Novelty, Ohio. President: William A. Pennington, University of Maryland, College Park, Md. Term expires October 1961. Managing Director: Allan Ray Putnam. Term indefinite.

History: Founded 1920 as the American Society for Steel Treating, formed by an amalgamation of the Steel Treating Research Society and the American Steel Treating Society; name changed to present title 1935. 114 chapters in United States and Canada.

Purpose: Service of members in the metal producing and consuming industries through dissemination of technical information on the manufacture, treatment, and use of metals.

Membership: Open to anyone having an interest in the engineering aspects of metals and materials. Members; Junior Members; Sustaining Members. Total membership 31,500.

Meetings: Annual; monthly chapter meetings.

Professional activities: Henry Marion Howe Medal, awarded to the author of the best paper published in the Transactions; Albert Sauveur Achievement Award, for metallurgical research proven in time to have affected industry; Campbell Memorial Lectureship, presented during the annual convention; ASM Gold Medal, awarded to one who, having attained the age of fifty and having become recognized for his outstanding metallurgical knowledge, shall have shown great versatility in the application of science to the metal industry; ASM Medal for the Advancement of Research, awarded to an industrial organization executive who, over a period of years, has consistently sponsored metallurgical research or development and by his foresight and his influence in making available financial support has helped substantially to advance the arts and sciences relating to metals; William Hunt Eisenman Award, presented each year for outstanding contributions in the practical application of the science of metallurgy to the production of metals or their engineering use, given to that person whose achievements have accomplished significant improvement in metallurgical processing; Albert Easton White Award, for outstanding teachers of metallurgy or related sciences, presented to a teacher of long standing reputation through his ability to inspire students and impart enthusiasm and understanding; Marcus A. Grossmann Award, granted to the author(s) under age 35 of the most outstanding paper in ASM Transactions, winners also eligible for Howe Medal; Bradley Stoughton Award, presented to a teacher of metallurgy or related sciences, under age 35 , who has demonstrated excellence in his sound knowledge, enthusiasm, and ability to inspire students. ASM Foundation for Education and Research, $\$ 700,000$, supports a broad program of scholarships, fellowships, and other career activities; National Metal Congress and Exposition, annual technical sessions and exhibit; Western Metal Congress and Exposition, biennial regional sessions and exhibit; Southwestern Metal Congress and Exposition; Metals Engineering Institute, Home-study Division; ASM Documentation Service, electronic searching of current technical literature. 
Publications: Metal Progress, monthly, current volume : 77, \$9. Editor: E. E. Thum. Metals Review, monthly, current volume: $33, \$ 6$. Editor: T. C. DuMond. Transactions, annual, current volume: 52, $\$ 10$. Review of Metal Literature, monthly, current volume: 17. Metals Handbook.

Library: 4,000 volumes. Subject emphasis, metals.

292. American Society for Pharmacology and Experimental Therapeutics, Inc. 9650 IVisconsin Avenue, Washington 14, D. C. President: Alfred Gilman, Albert Einstein College of Medicine, New York 61, N. Y. Term expires June 30, 1961. Executive Sccretary: Karl H. Beyer, Merck Sharp \& Dohme Research Laboratories, IVest Point, Pa. Term expires June 30, 1961.

History: Founded December 28, 1908; incorporated 1934. The Society is one of the six member societies of the Federation of American Societies for Experimental Biology.

Purpose: To promote pharmacological knowledge and its use among scientists and to issue publications for this purpose.

Membership: Regular, qualified investigators in pharmacology, 915; Honorary, 2; Corporation Associates, 64.

\section{Meetings: Semiannual.}

Professional activities: John J. Abel Prize in Pharmacology, donated by Eli Lilly and Company, for the purpose of stimulating fundamental research in pharmacology in the United States and Canada by a young man or woman working in a college or university. Torald Sollmann Award in Pharmacology, donated by Wyeth Laboratories of Philadelphia, is awarded for significant contemporary contribution to the advancement and extension of knowledge in the field of pharmacology.

Publications: Journal of Pharmacology and Experimental Therapeutics, monthly, current volumes: $128,129,130, \$ 10$ per volume. Editor: Lawrence Peters, University of Kansas Medical Center, Kansas City 12, Kans. Pharmacological Reviews, quarterly, current volume: 12, $\$ 10$. Editor: George B. Koelle, University of Pennsylvania, Philadelphia, $\mathrm{Pa}$. The Pharmacologist, semiannual, current volume: $2, \$ 1$ per copy. Editor: Karl H. Beyer.

293. American Society for Psychical Research, Inc. 880 5th Avenue, New York 21, N. Y. Presidcnt: George H. Hyslop. Term expires January 1961. Executive Secretary: Adele WVellman. Term indefinite.
History: Formed in 1885; later became a branch of the English Society; re-established as the American Society for Psychical Research in 1905.

Purpose: The investigation of telepathy, visions and apparitions, dowsing, monitions, precognition, psychokinesis (mind over matter), automatic writing and other forms of automatism, psychometry, coincidental dreams, clairvoyance and clairaudience, predictions, the physical phenomena of mediumship and, in short, all types of "mediumistic" and unclassified psychological phenomena; the collection, classification, study, and publication of reports dealing from first-hand acquaintance with the phenomena designated above.

Membership: Approximately 900.

Mcetings: Annual; trustees meet quarterly.

Publications: Journal, quarterly, current volume: $54, \$ 1.50$ per issue, free to members. Editor: Rhea White.

Library: 6,000 volumes.

294. American Society for Quality Control, Inc. 161 West Wisconsin Avenue, Milwaukee 3, Wis. President: J. Y. McClure, Convair, a Division of General Dynamics Corporation, Fort Worth, Tex. Term expires June 30, 1961. Administrative Secretary: William P. Youngclaus, Jr. Term Indefinite.

History: Organized and incorporated in New York City on February 16, 1946. There are seventeen Districts. Divisions: Administrative Applications, Aircraft and Missile, Automotive, Chemical, Electronics, Textile. Committees: Metals Operations Research, Standards, VendorVendee.

Purpose: To create, promote, and stimulate interest in the advancement and diffusion of knowledge of the science of quality control and of its application to industrial processes.

Mcmbcrship: Members, 8,500, at least twentyone years of age and of good character, graduates in an engineering, science, mathematics, or statistics curriculum of an educational institution approved by the Board of Directors, or having equivalent attainments including at least four years of increasingly important experience in quality or inspection work or in statistical operations of a control or analytical nature. Associates, 800 , engaged in or interested in inspection or quality engineering work or in an allied field of industrial, administrative, or analytical control. Fellows, 200, at least thirty-eight years of age, engaged professionally in quality control, quality engineering, or an allied field of industrial, administrative, or analytical control, at least fourteen years of active experience in the profession, and having been in good standing in 
the grade of Senior Member for at least eight consecutive years immediately prior to the date of proposal for advancement to the grade of Fellow. Students, 55. Total membership 12,000.

\section{Mectings: Annual.}

Professional activities: Shewhart Medal, awarded not oftener than once each year, to an individual chosen for his unusual and outstanding contribution to the development of quality control principles or the practical application of those principles in industry. Brumbaugh Award, made not oftener than once a year, to the author of that paper published in Industrial Quality Control judged to have made the greatest contribution to the development of industrial application of quality control.

Publications: lndustrial Quality Control, monthly, current volume: $16, \$ 10$; free to members. Editor: M. E. Westcott.

295. American Society for Surgery of the Hand. President: Daniel C. Riordan, 1538 Louisiana Avenue, New Orleans, La. Term expires January 1961. President-elect: George Phalen, Cleveland Clinic, 2020 East 93rd Street, Cleveland, Ohio. Executive Secretary: Don L. Eyler, 1919 Hayes Street, Nashville 3, Tenn. Term expires January 1961.

History: Organized January 20, 1946; incorporated in 1947 in Ohio. Committees: Program, Publication, Memorial, Resident Training, and Auditing.

Purpose: To improve and develop surgery of the hand.

Membership: Total membership 100. Regular members, those who have contributed to the development of surgery of the hand.

Mectings: Annual.

296. American Society for Testing Materials. 1916 Race Street, Philadelphia 3, Pa. President: A. Allan Bates, Vice President of Research and Development, Portland Cement Association, 33 West Grand Avenue, Chicago 10, 111. Term expires June 1961. Executive Secretary: Robert J. Painter. Term indefinite.

History: Organized June 16, 1898, as the American Section of the lnternational Association for Testing Materials; incorporated under present title March 1902.

Purpose: The promotion of knowledge of the materials of engineering, and the standardization of specifications and methods of testing.

Membership: Total membership, 11,500; Associate, Sustaining, Company, Individual, Student, Honorary.

Meetings: Annual.

Professional activities: Research fund, capital $\$ 100,000$. Charles B. Dudley Medal, awarded annually to the author or authors of a paper presented before the Society constituting an original contribution on research in engineering materials. Max Hecht Award, annual award to be presented to a member of Committee D-19 on Industrial Water in recognition of outstanding service to the committee in the advancement of its objective. C. A. Hogentogler Award, given by Committee D-18 on Soils to the author or authors of an outstanding paper on soils for engineering purposes which has been presented at a meeting of the Society. Harold De Witt Smith Memorial Award, a medal given for outstanding achievement in the field of textile fiber utilization, by Committee D-13 on Textile Materials. Richard L. Templin Award, to stimulate papers on new testing methods and apparatus. Sam Tour Award, for papers on corrosion testing, to encourage research on improvements and evaluation of corrosion testing methods, and to stimulate preparation of technical papers in this field. Sanford E. Thompson Award for papers of outstanding merit on concrete and concrete aggregates presented at meetings of the Society; to stimulate research, to encourage the extension of knowledge of concrete and concrete aggregates, and to recognize meritorious efforts. Frank E. Richart Award, presented every three years to recognize outstanding contributions in the field of concrete and concrete aggregates. Committee D-12 Award, presented annually for outstanding achievement in the field of soap and detergent technology. Edgar Marburg Lecture, for the description of outstanding developments in the promotion of knowledge of engineering materials, by leaders in their respective professions; it carries an honorarium and a certificate. Gillett Memorial Lecture, to stimulate papers on development, testing, evaluation, and application of metals; it carries an honorarium and a certificate. Award of Merit, to recognize individuals who have rendered distinguished service to the Society.

Publications: Book of ASTM Standards, triennial, current volume: 1958, 10 parts, $\$ 116$ (each part many be purchased separately). Supplements to above in intervening years, 10 parts, \$40. Bulletin, 8 issues per year, current volume: $243-250, \$ 3.50$. Editor: R. E. Hess. Proceedings, annual, current volume: 59, $\$ 12$; free to members. Year Book, distributed to members only. Special Technical Publications, irregular.

297. American Society for the Advancement of General Anesthesia in Dentistry. President: B. J. Jacobs, 31 Lincoln Park, Newark, N. J. Term expires 1962. Exccutive Secretary: M. Hillel Feldman, 730 5th Avenue, New York, N. Y. Term expires 1962. 
History: Organized and incorporated 1929.

Purpose: Advancement of practice of general anesthesia.

Membership: Open to persons having interest and training in, and experience with, anesthetics. Total membership 500 .

Meetings: Semiannual.

298. American Society for the Study of Sterility. 920 South 19th Street, Birmingham 5, Ala. President: S. Leon Israel, 2116 Spruce Street, Philadelphia 3, Pa. Term expires April 23, 1961. Secretary: Herbert H. Thomas. Term expires April 23, 1961.

History: Organized and incorporated in California 1944. Committees covering all phases of the field of infertility. Sections: United States; Canada; Mexico.

Purpose: To extend our knowledge of all aspects of fertility and problems of infertility and mammalian reproduction, and to provide, through its meetings, a rostrum for the presentation of scientific studies dealing with all phases of these subjects, and an opportunity for formal and informal discussions among investigators in this field.

Membership: Active, 836, physicians, scientists holding a degree in one of the biological sciences, veterinarians, or individuals who are otherwise qualified, who are of high ethical standing and have evinced interest in the subject of fertility and the objectives of this Society, and who subscribe to the standards and principles of the medical profession; Honorary, 10, those who, in the opinion of the Society, are deserving of this special recognition because of exceptional contribution either to the field of fertility or to the Society; Corresponding, 47, any qualified physician or scientist outside of the United States who seeks this type of membership in preference to Active membership. Total membership 893 .

\section{Meetings: Annual.}

Professional activities: Rubin Award, to the individual contributing the outstanding article to the Fertility and Sterility Journal for the past year, as judged by the Awards Committee. Carl G. Hartman Award, given to an individual for an outstanding research project.

Publications: Fertility and Sterility Journal, bimonthly, current volume : $2, \$ 8$ domestic, $\$ 9.50$ foreign. Editor: M. Edward Davis.

299. American Society of Agricultural Engineers. 420 Main Street, St. Joseph, Mich. President: L. W. Hurlbut, Lincoln, Nebr. Term expires June 15, 1961. Executive Secretary: Jimmy L. Butt.
History: Founded December 28, 1907 at the University of Wisconsin, Madison, Wis. SECTlons: Regional: Connecticut Valley; MidCentral; North Atlantic; Pacific Coast; Pacific Northwest; Quad City; Rocky Mountain; Southeast; Southwest. State: Alabama; Florida; Georgia; Iowa; Hawaii ; Michigan; Minnesota; Kentucky; North Carolina; Ohio; Oklahoma; Pennsylvania; Soutlı Carolina; Tennessee; Virginia; West Virginia. Local Baton Rouge; Chicago; Central Illinois; Washington, D. C. Divisions: Education and Research; Farm Structures; Power and Machinery: Rural Electric; Soil and Water.

Purpose: To promote the science and art of engineering in agriculture.

Membership: Fellows, 103, engineers, may be elected but cannot apply for an honorary status; Members, 2,099, engineers with eight years active practice; Associate Members, 2,324, engineering graduates of schools of accepted standing; Affiliates, 829, qualified to cooperate with engineers; Honorary, 7 , having acknowledged professional eminence. Total membership 5,362.

Mectings: Annual meeting in June; winter neeting in December.

Professional activities: Cyrus Hall McCormick Gold Medal, awarded annually for exceptional and meritorious engineering achievement in agriculture. John Deere Gold Medal, awarded annually for distinguished achievements in the application of science and art to the soil. MBMA Award, annually for distinguished work in advancing the knowledge and science of farm buildings.

Publications: Agricultural Engineering, monthly, current volume: $41, \$ 8, \$ 4$ to members. Transactions, annual, current volune: 4 . Agricultural Engineers Yearbook, current volume: 7, \$5. Editor: James A. Basselman.

300. American Society of Agronomy. President: B. R. Bertramson, Washington State University, Pullman, Wash. Term expires November 29, 1961. Executive Secretary: L. G. Monthey, 2702 Monroe Street, Madison 5, IVis. Term indefinite.

History: Organized December 13, 1907. Incorporated April 17, 1948. Regional BranCHes: Northeastern; North-central; Southern; IVestern. Divisions: Agronomic education; Land use and management; Crop breeding, genetics and cytology; Crop physiology and ecology; Crop production and management; Forest and range soils; Seed production and technology; Soil chemistry; Soil classification; Soil conservation, drainage, irrigation, and tillage; Soil fertility; Soil microbiology; Soil physics; Turfgrass management: Weeds and weed control. 
Purpose: The increase and dissemination of information concerning crops and soils and the conditions affecting them in order to contribute to the general human welfare.

Membership: Active members, 3,600, professional agronomists and others interested in the objectives and program of the Society; Associate, 400, farm advisors and commercial men who do not desire technical journals but who wish to affiliate with the Society; Sustaining members, 95, commercial firms and associations who wish to affiliate with the Society and support its program. Total membership 4,000.

Meetings: Annual national and branch meetings, and special conferences.

Professional activitics: Annual American Society of Agronomy Awards, in recognition of outstanding work in the fields of plant science and soil science: three, $\$ 200$ each. Students Essay Awards, given annually to top six winners in the American Society of Agronomy's student essay contest: $\$ 200$ annually divided six ways. Agronomy Club Trophy, in recognition of the Society's outstanding student agronomy chapter each year.

Publications: Agronomy Journal, monthly, current volume: 52, \$15. Editor: H. L. Hamilton. Crops and Soils, nine copies annually: current volume: 12, \$3. Editor: L. G. Monthey.

301. American Society of Anesthesiologists, Inc. 515 Busse Highway, Park Ridge, I1l. President: Leo V. Hand, 1501 Centre Street, Newton Highlands 61, Mass. Term expires October 7, 1960. Executive Secretary: John IV. Andes. Term indefinite. Secretary: Robert L. Patterson, 612 Berkshire Drive, Pittsburgh 15, Pa. Term expires October 1961.

History: Organized October 1905 in Brooklyn, New York, as the Long lsland Society of Anesthetists; name changed 1912 to New York Society of Anesthetists; incorporated 1935 as The American Society of Anesthetists, Inc.; name changed to present title 1945. Component societies in forty-seven States. Committees: Annual Session Arrangements; Archives and History; Bylaws; Clinical Anesthesia Study Commissions; Credentials; Defense and Military Affairs; Equipment and Standardization; Judicial; Liaison; Medical Schools and Residencies; Membership; Postgraduate Education; Professional and Public Relations; Programs; Research; Scientific Exhibits. Special ComMitTeEs : Building Fund; Clarification of Ethics ; Consultants; Economics and Fee Schedules; Fires and Explosions; Foreign Residents; Hospital Planning and Construction; Inhalation Therapy; Legal Affairs; Liaison with the Wood Library-Museum; Maternal Welfare; Motion
Pictures; Past Presidents; Placement; Refresher Courses.

Purpose: To associate and affiliate into one organization all of the reputable doctors of medicine in the United States, its territories and possessions, who are engaged in the practice of or otherwise especially interested in anesthesiology; to encourage specialization in this field and in other ways to make available to more people the benefits to be derived from the services of qualified anesthesiologists; to raise the standards of the specialty by fostering and encouraging research and scientific progress in anesthesiology, and by establishing standards of postgraduate education for qualifications as a specialist in anesthesiology and furthermore by establishing standards for approval of postgraduate training centers; to disseminate information in regard to anesthesiology; to protect the public against irresponsible and unqualified practitioners of anesthesiology; to edit and publish publications in the field of anesthesiology and related fields; to safeguard the interests of its members, and in all ways to develop and further the specialty of anesthesiology for the general elevation of the standards of medical practice.

Mcmbership: Active, 4,602, Doctors of Medicine engaged in the practice or especially interested in the medical specialty of anesthesiology, who are graduates of medical schools approved by the Council on Medical Education and Hospitals of the American Medical Association or who have passed the ECFMG examination; whose principal professional activity is in a State, territory, possession, or the District of Columbia of the United States of America; who are licensed to practice medicine in such location; who are members of county medical society or its equivalent and are active members of component society. Junior, 1,366, Doctors of Medicine in full-time training in the specialty of anesthesiology or in full-time postgraduate medical training and have a special interest in anesthesiology, who are junior nembers of a component society. Scientific Associates, 65, Doctors of Medicine or other scientists who contribute to the advancement and progress of anesthesiology but are not engaged in the clinical practice of anesthesiology. Federal Associates, 55, Doctors of Medicine engaged in the practice or especially interested in the medical specialty of anesthesiology and who are members of the Armed Forces or Public Health Services of the United States. Foreign Associates, 553, Doctors of Medicine engaged in or especially interested in the medical special of anesthesiology whose location is outside United States, its territories and possessions, and who are licensed to practice medicine in their locations. Life, 21, nembers enrolled 
as Life members prior to July 1, 1947 and retiring Presidents who may be granted Life membership by the House of Delegates. Retired, 40 , Doctors of Medicine who previously held active membership for ten or more years and have retired completely from professional activity. Honorary, 24, physicians or scientists who have attained exceptional eminence in anesthesiology or related fields. Total membership 6,726.

Meetings: Annual.

Publications: Anesthesiology, bimonthly, current volume: 21, \$10. Editor: James E. Eckenhoff. News Letter, monthly, current volume: 24, \$3. Editor: J. Earl Remlinger.

Library: 3,000 volumes in the official repository at Wood Library-Museum in Anesthesiology.

\section{American Society of Animal Production.}

President: J. K. Loosli, Cornell University, Ithaca, N. I. Term expires November 25, 1960. Secretary-Treasurer: C. E. Terrill, Animal Husbandry Research Division, Agricultural Research Center, Beltsville, Md. Term expires December 31, 1962.

History: Organized 1908 as the American Society of Animal Nutrition; name changed to present title 1912. Sections: North Atlantic, Southern, Western.

Purpose: To afford opportunity for the exchange of ideas in the field; to bring about improvement and unification of methods of investigation, instruction, and extension in animal production; to arrange for cooperation and avoid duplication in investigational work; to recommend the adoption of new practices; to publish educational and scientific material of value to members and other workers in the animal industry field.

Membership: Open to all persons engaged or previously engaged in investigation, instruction, or extension in animal production, or in the production of livestock products; membership must be applied for and sponsored by two members of the Society. Total membership 2,000.

Mectings: Annual.

Professional activities: Morrison Award, established by Professor and Mrs. F. B. Morrison to annually honor a nember who has done outstanding recent research of direct importance in livestock production: $\$ 1,500$, a gold watch, and a scroll. American Feed Manufacturers Award, established by the American Feed Manufacturers' Association to honor a member affiliated with a public institution for outstanding livestock nutrition research work, the results of which have been published during the three years immediately preceding the year of recognition: $\$ 1,000$ and a scroll. American Society of Animal Production Extension Award, established by the Society to recognize outstanding achievement in Animal Husbandry Extension; Charles Pfizer \& Company, Inc. awards $\$ 1,000$ to the recipient. Distinguished Teacher Award of the American Society of Animal Production, established by the Society to recognize distinguished undergraduate teachers in Animal Husbandry. Swift and Company awards $\$ 1,000$ and a plaque. Fellows of the American Society of Animal Production, established by the Society to honor members who have rendered distinguished service to the field of animal industry over a period of at least twenty-five years. Five categories are recognized: Teaching, Extension, Research, Administration, Industry. The award consists of a life membership in the Society and a plaque.

Publications: Journal of Animal Science, quarterly, current volume : 19, $\$ 7$ domestic, $\$ 7.50$ for North and South America, $\$ 8$ foreign, free to nembers. Editor: W. D. Gallup, Oklahoma State University, Stillwater, Okla.

303. American Society of Anthropometric Medicine and Nutrition. 2810 1st Street, N., St. Petersburg 4, Fla. President: Frank G. Biedka, St. Paul Medical Center, 6710 West North Avenue, Chicago 35, I11. Term expires May 1961. Executive Secretary: Melvin E. Page. Term expires May 1961.

\section{History: Founded 1952.}

Purpose: To promote research into the cause, cure, and prevention of degenerative diseases. Emphasis is put upon the biochemical and nutritional approach.

Membership: High professional esteem in the fields of dentistry, medicine, osteopathy, or teaching; strong interest in contributing to the Society's purpose. Total membership 110.

Meetings: Annual.

Library: 1,500 volumes. Emphasis on nutrition, endocrinology, and related areas.

304. American Society of Bakery Engineers. Room 1354, LaSalle-IV acker Building, 121 West IVacker Drive, Chicago 1, 111. President: Clayton C. Daley, Drake Bakeries, Inc., 350 Madison Avenue, New York 17, N. Y. Term expires March 6, 1961. Executive Secretary: Victor E. Marx. Term expires March 6, 1961.

History: Founded March 1924; incorporated 1952. Chapters: Southern California, Oregon, Western Washington, Inland Empire, British Chapter Affiliate.

Purpose: The greater development of the baking industry: by bringing together for conference and discussion the men in the industry responsible for production; by educating the 
industry to a better appreciation of the importance of trained bakery production superintendents; by setting standards of education and training which will bring to bakery production superintendents the recognition to which they are entitled as engineers.

Membership: Open to all who are engaged in bakery production or engineering work, and to all those whose interests touch bakery production problems; by recommendation of two members in good standing. Total membership 3,100 .

Mectings: Annual.

Professional activities: Exchange Student Program sponsored jointly with British Chapter Affiliate; sponsorship, with other industry groups, of the Baking Industry Sanitation Committee.

Publications: Annual Proceedings. Technical bulletins to membership only.

\section{American Society of Biological Chemists,} Inc. President: Fritz Lipmann, Rockefeller Institute, New York, N. Y. Term expires June 30, 1961. Secretary: Frank WV. Putnam, Department of Biochemistry, College of Medicine, University of Florida, Gainesville, Fla. Term expires June 30, 1961.

History: Organized December 26, 1906, incorporated September 12, 1919.

Purpose: To further the extension of biochemical knowledge and to facilitate personal intercourse between American investigators in biological chemistry.

Membership: Qualified investigators who have conducted and published meritorious original investigations in biological chemistry. Total membership 1,666.

Mectings: Annual, with the Federation of American Societies for Experimental Biology.

Professional activities: Travel Fund, to support travel of younger biochemists to international biochemical congresses; amount varies.

Publications: Journal of Biological Chemistry, monthly, current volume: $235, \$ 45$. Editor: John T. Edsall, Harvard University Biological Laboratories, Cambridge, Mass.

306. American Society of Body Engineers. 100 Farnsworth Street, Detroit 2, Mich. President: R. L. Logue, 8 Cherry Hill Court, Dearborn 7, Mich. Term expires February 1961. Secretary: Dale K. Pettry, 15476 Vaughan Street, Detroit 23, Mich. Term expires February 1961 .

IFistory: Established 1945. Has expanded its scope from a local organization to include reciprocal agreements with similar foreign organizations, and has many foreign members.
Purpose: To advance the profession of body engineering, its allied arts and sciences.

Mcmbership: Regular Member, a person who has attained his 21st birthday, and who is either a graduate of a school legally authorized to confer a bachelor's degree in engineering, or the allied arts and sciences; or who through practical experience has acquired an equivalent technical knowledge; or who has regularly engaged in the direction or prosecution of engineering or the allied arts and sciences, as related to body engineering. Resident Member is a member in good standing in the Engineering Society of Detroit. Associate Member, a person who is a graduate of a school legally authorized to confer a bachelor's degree in engineering or the allied arts and sciences in the field of, or closely identified with, body engineering. Regular Resident Members, 400; Regular Non-Resident Members, 50; Associate Resident Members, 40 ; Associate Non-Resident Members, 10. Total nembership 500 .

Mectings: Monthly, except summer months.

Professional activities: Annual Technical Convention, regular educational counselling, Annual High School Drafting Contest.

Library: 10,000 volumes on general engineering.

307. American Society of Brewing Chemists, Inc. President: George E. Bredt, 9400 Quincy Avenue, Cleveland 6, Ohio. Term expires May 3, 1961. Executive Secretary: B. A. Burkhart, P. O. Box 2146, Madison 5, Wis. Term indefinite.

History: Organized as the Malt Analysis Standardization Committee; incorporated in Illinois, December 1935, under the present title.

Purpose: To study, develop, and adopt uniform or standard methods for the analysis of raw materials, supplies, and products of brewing, malting, and related industries; to secure uniformity in the statement of analytical results; to conduct, promote, and encourage scientific and technical research in brewing and related industries; to promote the spirit of scientific cooperation among all workers in the field of the industries concerned; to maintain high professional standards as requirements for membership in the Society; to encourage a more general recognition of the chemist and biologist as essential factors in the development of the brewing and related industries; and to communicate and cooperate with other organizations having similar or kindred purposes.

Memberslip: Active members, 580, bachelor's degree in chemistry, chemical engineering, or the biological sciences and actively engaged in brewing or related industries; Associate, 200, engaged in work related to brewing or related 
industries; Corporate, 110 , brewing, malting or related conpanies. Total membership 890 .

Mectings: Annual.

Publications: Brewing Chemists Newsletter. quarterly, current volume: 20 , free to members. Editor: B. A. Burkhart. Proceedings, annual. current volume: $19, \$ 5$ to members, $\$ 7.50$ to nonmembers. Editor: Earl D. Stewart.

308. American Society of Chiropodical Roentgenology. President: Joseph Healy, 30 Court Street, Westfield, Mass. Term expires 1961. Executive Secretary: Joseph L. Starr, 1115 Main Street, Bridgeport 3, Conn. Term expires 1961.

History: Founded 1946 by a group of podiatrists interested in setting up a standard for podiatric roentgenology and the research and dissemination of knowledge along these lines.

Purpose: To encourage and develop the interest in podiatric roentgenology, roentgenological interpretation, and research as it relates to the practice of podiatry.

Mcmbership: Must be a practicing podiatrist, a member of his State and the American Podiatry Association. For Associateship, must submit to the Qualifying Board credentials, radiographs, and case histories (sixty days prior to the anmual meeting) for five traumatic cases, five pathological, five orthopaedic, five orthodigital, five weakfoot conditions. For Fellowship: in addition to the above, the following is required: ten additional pathological cases including a differential diagnosis demonstration of arthritis, fifteen additional different orthopaedic cases other than weakfoot. All cases must have affidavit certifying that case reports and radiographs are original with the applicant. Total membership 150.

Mectings: Quarterly.

Professional activitics: Research in podiatric roentgenology. Sponsorship of study groups. Contribution of lecturers for regional and national scientific meetings. Awards for research in roentgenology to graduating student from colleges. Provides post-graduate courses in podiatric roentgenology.

309. American Society of Cinematographers, Inc. 1782 North Orange Drive, Hollywood, Calif. President: Walter Strenge. Term ex. pires 1961. Secretary: Charles Clarke. Term expires 1961.

History: Organized and incorporated January 1919 as the indirect outgrowth of two previous cinematographers' groups, dating back to 1911.

Purpose: To further the artistic and scientific advancement of the cinema and its allied crafts through research and experimentation, and through fellowship between the artists and the scientists of cinematography.

Mcmbership: Active Members, directors of photography; Associate; Inactive; and Honorary. Total membership 282.

Mectings: Monthly.

Professional actizities: Research projects conducted in connection with practical studio problems.

Publications: American Cinematographer, inonthly, current volume: $41, \$ 4$.

310. American Society of Civil Engineers. 33 West 39th Street, New York 18, N. Y. President: Frank A. Marston. Metcalf \& Eddy, 1300 Statler Building. Boston 16, Mass. Term expires October 1960. Exccutive Secretary: IIilliam H. Wisely. Term indefinite.

History: Instituted November 5, 1852, as the Anerican Society of Engineers and Architects; inactive 1855-1867; name clianged to present title March 4, 1868 ; incorporated April 17, 1877. There are 143 Sections and Branches and 140 Student Chapters. Technical Divisions: Air Transport, City Planning, Construction, Engineering Mechanics, Highways, Hydraulics, Irrigation and Drainage, Pipeline, Power, Sanitary Engineering, Soil Mechanics and Foundations, Structural, Surveying and Mapping, Waterways.

Purpose: The advancement of the science and profession of engineering.

Membership: Fellows, 10,933; Members, 15,880; Associate Members, 18,016; Affiliates, 94; Honorary Members, 47. Total membership 44,970 .

Mcetings: Three times per year.

Professional actirities: Norman Medal, awarded for first paper of merit in Engineering Science. J. James R. Croes Medal, awarded for second paper of merit in Engineering Scicnce. Thomas Fitch Rowland Prize, awarded for first paper of merit on Construction. James Laurie Prize, awarded for second paper of merit on Construction. Arthur M. Wellington Prize, awarded to the author of a paper on transportation. Collingwood Prize for Juniors, papers describing engineering works or investigations. Rudolph Hering Medal, awarded to the author of a paper on sanitary engineering. Karl Emil Hilgard Hydraulic Prize, awarded to the author or authors of a paper of superior merit dealing with a problem of flowing water. Construction Engineering Prize, awarded to the author or authors of the best original scientific or education paper on Construction. J. C. Stevens Award, to the writer of the best discussion in the field of 
hydraulics. Moisseiff Award, to the author of an important paper dealing with the broad field of structural design. Rickey Medal, to the author of the best paper in the general field of hydroelectric engineering. Research Program Prize, for basic research in civil engineering. Daniel WV. Mead Prizes, for Juniors and Students for papers dealing with ethics. Ernest E. Howard Award, for advancement in structural engineering. Thomas A. Middlebrooks Award, for the paper published in Transactions on Soil Mechanics and Foundation Engineering. Research Fellowship, for new knowledge for the advancement of the science and profession of civil engineering. Harza Latin-American Junior Awards, for selected qualified engineer graduates of Latin-American universities. Freeman Fund, income to be used in the aid and encouragement of young engineers for research in engineering. J. Waldo Smith Hydraulic Fellowships, awarded to a graduate student and restricted to research in the field of hydraulics. Professional Recognition Award, to the member judged to have contributed substantially to the status of the engineering profession. The Society also participates in the following Joint Awards of Engineering Societies: John Fritz Medal, for scientific or industrial achievement; Hoover Award, for distinguished public service; Alfred Noble Prize, for publication of Technical paper; Charles Franklin Kettering Award, for creative accomplishments for the benefit of mankind within the relationship of materials and energy; Washington Award, for accomplishments which promote happiness, comfort and well-being of humanity.

Publications: Civil Engineering, monthly, current volume: $30, \$ 5$. Directory, annually, $\$ 2$. Proceedings (Journals of the Technical Divisions), monthly, current volunie: $86, \$ 40$. Transactions, annually, \$12.

\section{American Society of Clinical Pathologists.}

President: John J. Clemmer, Bender $\mathrm{Hy}$ gienic Laboratory, 136 South Lake Avenue, Albany 3, N. Y. Term expires September 1960. Executive Secretary: Claude E. IVells, American Society of Clinical Pathology, 445 Lake Shore Drive, Chicago 11, I1l. Term indefinite.

History: Organized 1922. The Society sponsors the American Board of Medical Technology.

Purpose: To promote the practice of scientific medicine by a wider application of clinical laboratory methods to the diagnosis of disease; to stimulate original research in all branches of clinical laboratory work; to establish from time to time standards for the performance of various laboratory examinations; to elevate the scien- tific and professional status of those specializing in this branch of medicine; to encourage a closer cooperation between the practitioner and the clinical pathologist.

Membership: Fellow, legally qualified physician, devoting major part of practice to pathology, or a branch thereof; must hold one or more of the certificates of the American Board of Pathology; must hold membership in the American Medical Association or any one of its constituent associations; in Canada, Fellows must hold membership in either of the two national Medical Associations or in one of the provincial divisions; shall have the same American Board qualifications or Canadian equivalent as other applicants for Fellowship. Associate member, physician in good standing who is ineligible for Fellowship, but whose membership would advance the purposes of this Society, or a non-physician scientist of such outstanding attainments in science that his membership would further the objects of the Society. Corresponding member, an ethical, qualified physician residing in a country other than the United States or Canada, who devotes the major portion of his practice to pathology. Junior Member, a qualified physician actively training for a career in pathology, must have completed two years of training recognized by the American Board of Pathology. Total membership 2,563.

Mectings: Annual.

Professional activities: Ward Burdick Research Award, gold medal presented annually for the outstanding piece of research by a Fellow; Scientific Exhibits Award for Excellence, gold and silver medal; Sanford-Sheard Education and Research Fund, for grants-in-aids of individual research problems.

Publications: American Journal of Clinical Pathology, monthly, curreut volume: $33, \$ 10$ members, $\$ 12$ non-members. Editor: Parker Beamer.

312. American Society of Criminology. President: Marcel Frym, Hacker Clinic, 160 Lasky Drive, Beverly Hills, Calif. Term expires December 1960. Executive Secretary: Donald E. J. MacNamara, New York School of Criminology, 115-117 West 42nd Street, New York 36, N. Y. Term expires December 1960.

History: Organized in 1940 as Society for the Advancement of Criminology. Sections: East, Middle, South, West.

Purpose: To bring together persons actively engaged, or who have been actively engaged, in teaching and/or practice in the field of criminology; to foster training and research in criminology in institutions of higher learning and in law enforcement and correctional agen- 
cies; to encourage understanding and cooperation among those engaged in criminology; to serve as a clearing house for collection and dissemination of criminological knowledge and skills.

Membership: Active, those engaged in teaching, research, and administration in criminology ; Associate, such other persons as the Executive Committee shall find to be eligible; Student, those studying in criminology in institutions of higher learning; Honorary, those persons wlo make outstanding contributions to criminology. Total membership, 250.

\section{Mectings: Annual.}

Publications: Newsletter, quarterly. Editor : Howard R. Leary, Deputy Police Commissioner, Philadelphia Police Department, Philadelphia, $\mathrm{Pa}$.

\section{American Society of Danish Engineers.}

Room 2734, 17 Battery Place, New York 4, N. Y. President: Anker Hansen. Term expires January 1961. Secretary-Treasurer: Peer Wintersoe. Term expires January 1961.

History: Founded in 1930 by a group of Danish engineers who were graduated fron the Technical University of Copenhagen.

Purpose: To further and maintain collegiate and social relations between the members.

Membership: 200, graduation from the Technical University of Denmark or other technical training that qualifies the engineer as a professional engineer of high standing.

Meetings: Quarterly.

Publications: ASDE News, semiannual. Editor: Axel Brix-Andersen.

\section{American Society of Dentistry for Chil.} dren. President: William E. Brown, 705 North University Avenue, Ann Arbor, Mich. Term expires October 15, 1960. Exccutive Secretary: C. F. Tuma, 13201 Miles Avenue, Cleveland 5, Ohio. Term indefinite.

History: Founded 1927.

Purpose: Education of profession and lay public in all phases of dentistry for children.

Membership: 6,800, must be member of a dental organization recognized by American Dental Association, interested or employed in related field, or dental student.

Mectings: Annual.

Professional activities: Certificate of merit to outstanding dental student in dentistry for children.

Publications: Journal of Dentistry for Children, quarterly, current volume: $27, \$ 5$. Editor : Alfred E. Seyler.
315. American Society of Heating, Refrigerating and Air-Conditioning Engineers, Inc. 234 Fifth Avenue, New York 1, N. Y. President: Robert H. Tull, Westinghouse Electric Corporation, 300 Phillippi Road, Columbus, Ohio. Term expires June 1961. Presidentelect: John Everetts, Jr., Charles S. Leopold Engineers, 215 South Broad Street, Philadelphia 7, Pa. Term June 1961-June 1962. Secretary: Robert C. Cross. Term indefinite.

History: American Society of Heating and Air-Conditioning Engineers organized in 1894 and incorporated in 1895 as the American Society of Heating and Ventilating Engineers; name changed to American Society of Heating and Air-Conditioning Engineers in December 1954. The American Society of Refrigerating Engilieers organized in 1904. The two organizations merged in January 1959 to form present society. Eighty chapters in the United States, eight in Canada, and a special branch in Switzerland and one in the Pananıa Canal Zone.

Purpose: To advance the arts and sciences of heating, refrigeration, air conditioning, and ventilation, and the allied arts and sciences for the benefit of the general public.

Membership: Honorary Member, 6, any notable person of preeminent professional distinction. Presidential Member, 51, upon installation of his successor, the outgoing president of Society shall become a Presidential Member, and past presidents of either predecessor society shall become Presidential Members. Life Menber, 411, persons who hive rendered distinguished service to the Society, have been members in good standing for thirty years, and who have attained the age of sixty-five years, shall retain all rights and privileges of former membership grade. Fellow, 30, a member who has attained unusual distinction in the arts relating to the sciences of heating, refrigeration, air conditioning, or ventilation, or the allied arts and sciences, or in the teaching of major courses in said arts and sciences, or who by reasons of invention, research, original work, or as an engineering executive on projects of unusual or important scope, has made substantial conbership grade. Fellow, 30, a member who has attained the age of forty-five years, and has been in good standing as a member for a period of at least ten years prior to date of his proposal for Fellow grade. Member, 7,230, a graduate of an engineering curriculum accredited by the Engineers Council for Professional Development and approved by the Board of $\mathrm{Di}$ rectors, or approved by the Board of Directors, and with no less than six years active practice in the professions of engineering or teaching or both, of which five years has been spent in responsible charge of such teaching or engineering work, and qualified to direct such work or 
carry on important research or design in engineering field; or, if not such a graduate, has equivalent attainments including at least twelve years active practice in the professions of engineering or teaching or both, of which five years has been spent in responsible charge of such teaching or engineering work, all of a character satisfactory to the Board of Directors. A license to practice professional engineering issued by a legally authorized body whose requirements as to education and active practice are considered satisfactory and adequate by the Board of Directors may be considered equivalent to 50 per cent of active practice requirements. Associate Member, 6,861 (over 30), 931 (under 30), a graduate of an engineering curriculum accredited by the Board of Directors, or approved by the Board of Directors, or equivalent attainments including at least eight years of engineering experience, all of a character satisfactory to Board of Directors. Affiliate, 3,376, experience in technical matters, design, operation, or maintenance in heating, refrigerating, air conditioning, or ventilating fields, or an interest in the advancement of the Society's aims, with sufficient qualifications to cooperate with heating, refrigerating, air conditioning, or ventilating engineers in the advancement of knowledge. Student, 405, a person matriculated in a degreegranting or graduate school with a curriculum accredited by the Engineers Council for Professional Development, or the Engineering Institute of Canada, or in a school with a curriculum recommended by the Education Committee and approved by the Board of Directors, and pursuing a course of study in preparation for the engineering profession.

Professional activities: A research laboratory is maintained in Cleveland, Ohio, with a staff of approximately twenty persons, which cooperates with universities, colleges, and other organizations in programs of research in areas of interest to the Society; F. Paul Anderson Award Medal, awarded to a member of the Society in recognition of outstanding work done or services performed in field of heating, refrigerating, and air conditioning. Other awards are made relating to papers published in Society's Journal; several other awards of specific purpose and aim.

Publications: Journal, monthly, current volume: $2, \$ 5$. Editor: E. R. Searles. Guide, annual, current volume: $38, \$ 12$. Editor: C. H. Flink.

316. American Society of Hospital Pharmacists. 2215 Connecticut Avenue, N. W., Washington 7, D. C. President: Clifton J. Latiolais, Ohio State University Health Center, Columbus 10 , Ohio. Term expires April 1961. Executive
Secretary: Joseph A. Oddis. Term expires spring 1963

History: Organized 1942; affiliate, American Pharmaceutical Association; associate, American Association for the Advancement of Science. Fifty-four chapters.

Purpose: To improve qualifications and usefulness of hospital pharmacists; to assist in providing future supply of these specialists; to promote research in hospital pharmacy practices, and in all pharmaceutical problems; to increase dissemination of pharmaceutical knowledge by interchange of information.

Membership: Open to members, American Pharmaceutical Association, providing periods of membership coincide. Total membership 3,300 .

\section{Mectings: Annual.}

Professional activities: Whitney Spease Award; H. A. K. Whitney Lecture Award; funds for research grants; institutes on hospital pharmacy; cooperation with American Pharmaceutical Association in maintenance of Division of Hospital Pharmacy.

Publications: American Journal of Hospital Pharmacy, monthly, current volume: $17, \$ 4.50$. Editor: Don E. Francke.

\section{American Society of Human Genetics.}

President: L. C. Dunn, Columbia University, Department of Zoology, New York, N. Y. Term expires December 31, 1961. Executive Secretary: IV. J. Schull, Department of $\mathrm{Hu}$ man Genetics, 1133 East Catherine Street, Ann Arbor, Mich. Term expires December 31 , 1962.

History: Organized 1948.

Purpose: To advance the science of humanl genetics.

Membership: 650 , active in the field of human genetics; nomination by two active members. Mectings: Annual.

Publications: American Journal of Human Genetics, quarterly, current volume: $12, \$ 10$. Editor: Arthur G. Steinberg, Department of Biology, Western Reserve University, Cleveland 6, Ohio.

318. American Society of Ichthyologists and Herpetologists. Biology Department, San Fernando Valley State College, Northridge, Calif. President: George A. Moore, Oklahoma State University, Stillwater, Okla. Term expires December 31, 1961. Secretary: James A. Peters. Term expires December 31, 1961.

History: Founded February 1916 as the American Society for the Study of Fish and Reptiles; name changed to present title March 
2, 1916; incorporated (Washington, D. C.) 1950. Divisions: Western, Southeastern.

Purpose: To promote the study of coldblooded vertebrates.

Membership: Anyone who is interested in the study of cold-blooded vertebrates or in the general fields of vertebrate zoology, ecology, evolution, physiology, morphology, etc. Active members, Foreign, Honorary, Life, Honorary Foreign. Total membership 1,115.

Meetings: Annual.

Professional activities: Endowment Fund, used to print special articles or illustrations; Revolving Research Fund, used for interestfree loans to foster research; Special Gift Fund, accumulating only during the life time of the donor, about $\$ 3,000$; prizes of $\$ 25$ and $\$ 15$ each given at the annual meeting for the best student papers in ichthyology, and two similar prizes in herpetology.

Publications: Copeia, quarterly, volumes are unnumbered, $\$ 8$ domestic, $\$ 6$ foreign. Managing Editor: David L. Jameson, Biology Department, San Diego State College, San Diego, Calif.

\section{American Society of Internal Medicine. 350}

Post Street, San Francisco 8, Calif. President: Stewart P. Seigle, 85 Jefferson Street, Hartford, Conn. Term expires May 4, 1961. Executive Director: G. Tod Bates. Term indefinite.

History: Founded April 15, 1956 in Los Angeles, Calif.; close liaison with the American College of Physicians; federation of forty-seven component societies. Standing and Special Committees: Bylaws, Finance, Legislature, Medical Services, Membership, Public Relations, Annual Meeting and Credentials, Liaison with American College of Physicians, Labor Relations and Secretaries Advisory.

Purpose: To create a federation of State, District of Columbia, United States Territorial, United States Conmonwealth, and Canadian Provincial societies of qualified internists for the coordination of their efforts in furthering the practice of internal medicine; to study the scientific, economic, social, and political aspects of medicine at a national level in order to secure and maintain the best patient care and the highest standard of practice in internal medicine; to encourage the development of strong State, District of Columbia, United States Territorial, United States Commonwealth, and Canadian Provincial societies of internal medicine; to complement and supplement the aims and activities of The American College of Physicians.

Membership: 47 component societies with a total of 6,500 members. Those State, Dis- trict of Columbia, United States Territorial, United States Commonwealth, and Canadian Provincial societies of internal medicine which have applied for membership in proper form. have been accepted by a two-thirds affirmative vote of the Board of Trustees or House of Delegates at any meeting or by mail ballot of the Delegates and have agreed to the stipulations of the Articles of Incorporation and Bylaws. Minimum qualifications for admission to membership in a component Society: a physician who either is certified by the American Board of Internal Medicine or who is a member of the American College of Physicians, or, in exceptional circumstances, a physician who has limited his practice exclusively to internal medicine for five years must, if he be graduated after 1936, include credit for at least three years of approved hospital training suitable for accreditation in internal medicine after internship and, in addition, show evidence of at least two years of exclusive practice in internal medicine, and who has sufficient training, experience, and ethical qualities, limits his practice to internal medicine and who is recognized in his conlmunity as a specialist in internal medicine.

Meetings: Annual.

Publications: Newsbulletin, bi-monthly. Editor: G. Tod Bates.

\section{American Society of Landscape Architects,} Inc. 9 Park Street, Boston 8, Mass. President: Norman T. Newton, Robinson Hall, Cambridge 38, Mass. Term expires 1961. Sccretary: Eldridge Lovelace, 317 North 11th Street, St. Louis 1, Mo.

History: Organized 1899; incorporated 1916. Chapters: Boston, Chicago, Connecticut, Florida, Hawaii, Kentucky-Ohio, Michigan, Missouri Valley, New York, Northern California, Pacific Northwest, Pennsylvania, Potomac, Rocky Mountain, Southeastern, Southern California, Southwest, Upstate New York. ComMitreEs: City and Regional Parks and Playgrounds; City, Regional, and National Planning; Civil Service; National and State Parks and Forests; Public Roads, Controlled-Access Highways, and Parkways; Professional Service; Education; Housing; National Capital; Research.

Purpose: The advancement of education and skill in the art of landscape architecture as an instrument of service in the public welfare.

Membership: Members, 848, satisfactory professional qualifications; Associates, 567, less experienced recent graduates; Fellows, 108, Landscape Architects who have made an outstanding contribution; Honorary, 24, distinguished persons who have performed notable service; Corresponding, 9, distinguished foreign 
Landscape Architects; Student Affiliates, 191, students of Landscape Architecture in professional courses. Total membership, 1,747.

Mectings: Annual.

Professional activities: Certificates of Merit, annually recognizing outstanding performance by students in schools of Landscape Architecture accredited by the Society.

Publications: Landscape Architecture, quarterly, current volume: 50, $\$ 4$. Associate Editor: Grady Clay.

\section{American Society of Limnology and} Oceanography. Department of Zoology, University of Michigan, Ann Arbor, Mich. President: W. Thomas Edmondson, Department of Zoology, University of Washington, Seattle, Wash. Term expires September 1, 1961. Secretary-Treasurer: George H. Lauff, Department of Zoology, University of Michigan, Ann Arbor, Mich. Term expires September 1, 1961.

History: Organized as the Limnological Society of America in 1936; expanded in scope to become in 1948 the American Society of Limnology and Oceanography (ASLO), in recognition of the complementary nature of these two branches of hydrospheric science; the Oceanographic Society of the Pacific became the Pacific Section of ASLO in 1949; ASLO incorporated in Visconsin in 1956.

Purpose: To promote interest in limnology and oceanography and related sciences, and to further investigations dealing with these subjects.

Membership: Open to persons actively interested in any aspect of limnology or oceanography. Candidates for membership must be nominated by two active members of the Society. Total membership 925.

Mectings: Annual.

Publications: Limnology and Oceanography, quarterly, current volume: 5, \$10. Editor: K. M. Rose, A \& M College of Texas, College Station, Tex.

\section{American Society of Lubrication Engineers.}

5 North Wabash Avenue, Chicago 2, Ill. President: L. O. Witzenburg, Cleveland Worm and Gear Company, 3249 East 80th Street, Cleveland 4, Ohio. Term expires April 1961. Executive Secretary: Calvert L. Willey. Term expires April 1961.

History: Organized and incorporated March 3, 1944. Thirty-nine geographic sections. GENeral Technical Committees: Bearings and Bearing Lubrication; Engine Lubrication; Fluids for Metalworking; Gears and Gear
Lubrication; Hydraulics and Hydraulic Machinery; Lubricating Equipment; Lubricating Fundamentals; Lubricating Practices; Lubrication Reconditioning and Disposal; Properties of Lubricants; Seals and Packing. Industry Councils: Aviation; Machine Tool; Marine; Mining; Mobile Equipment ; National Railroad; Non-Ferrous Materials; Paper; Petroleum and Chemistry; Power; Steel; Textile.

Purpose: A non-profit society to encourage the active cooperation of industry and the professions in advancing the knowledge of the science of lubrication.

Membership: Members, persons not less than 24 years of age who have an engineering or science degree, or lacking the degree but having, as evidenced by their experience, the knowledge and skill approximating that of an engineer qualified to practice lubrication engineering, and a record of ten or more years in active practice; Associate Members, those who do not meet the qualification outlined above; Sectional Sustaining Members, organizations contributing to the support of sections; Industrial Members, organizations contributing to the support and purpose of the Society; Honorary and Life Members, elected by Board of Directors. Total membership, 3,100.

\section{Meetings: Annual.}

Professional activities: National Award, signifying honorary membership in the Society; presented for an outstanding contribution to the furtherance of the science and practice of lubrication engineering. Capt. Alfred E. Hunt Award, presented for best paper given at any Sectional or National meeting, or published in ASLE Official Journals. Walter D. Hodson Award, presented to an ASLE member of thirty years of age or less for best paper presented as noted in Hunt award. Wilbur Deutsch Memorial Award, to an ASLE member for the best paper on practical aspects of lubrication presented as above.

Publications: Lubrication Engineering, monthly, current volume: $16, \$ 6$ domestic, $\$ 7$ foreign. Editor: John Boyd. Transactions, biannual, current volume: $3, \$ 5$ to members only. Editor: John Boyd.

323. American Society of Mammalogists. Zoology Department, Oklahoma State University, Stillwater, Okla. President: Stephen D. Durrant, Department of Zoology, University of Utah, Salt Lake City, Utah. Term expires June 1962. Executive Secretary: Bryan P. Glass. Term expires June 1962.

History: Organized 1919; incorporated 1920.

Purpose: Promotion and publication of knowledge concerning mammals. 
Mcmbcrship: lnterest in mammalogy and nomination by two members. Annual, Honorary, Life, Emeritus. Total membership 1,765.

\section{Mcetings :Annual.}

Professional activities: Two $\$ 100$ competitive honor awards each year for predoctoral research papers. One of these is designated the A. B. Howell Award.

Publications: Journal of Manmalogy, quarterly, current volume: 41, $\$ 7$. Editor: R. H. Manville.

324. American Society of Maxillofacial Surgeons. P. O. Box 20068, Houston 25, Tex. President: D. McCullagh Mayer, 12 East 87th Street, New York 28, N. I. Term expires May 1961. Secretary-Treasurer: Edward C. Hinds. Term expires May 1961.

History: Organized and incorporated May 1947 in the State of Illinois.

Purpose: To stimulate and advance knowledge of the science and art of maxillofacial surgery and thereby to improve and elevate the standard of practice of this specialty.

Membership: Active, 69, limited to those candidates who have successfully completed all work for the degree of doctor of medicine and doctor of dental surgery and who shall have had such degrces conferred, fully qualified in maxillofacial surgery, with at least five years of acceptable and recognized graduate training and at least two years' practice of this specialty; Senior, 7; Honorary, 1; Foreign, 3. Total membership 80 .

\section{Mcetings: Annual.}

Professional activities: Essay contest.

325. American Society of Mechanical Engineers.

29 West 39th Street, New York 18, N. Y.

President: Walker L. Cisler. Term expires

November 28, 1960. Secretary: O. B. Schier

II. Term expires 1961.

History: Organized 1880; incorporated 1881. There are ninety-six Sections (one in Canada and one in Mexico). Divisions: Applied Mechanics, Aviation, Fuels, Gas Turbine Power, Heat Transfer, Hydraulic, Instruments and Regulators, Lubrication, Machine Design, Maintenance and Plant Engineering, Management, Materials Handling, Metals Engineering, Nuclear Engineering, Oil and Gas Power, Petroleum, Power, Process Industries, Production Engineering, Railroad, Rubber and Plastics, Safety, Textile Engineering, and Wood Industries.

Purpose: To promote the art and science of mechanical engineering and the allied arts and sciences; to encourage original research; to foster engineering education; to advance the standards of engineering; to promote the intercourse of engineers among thenselves and with allied technologists; and severally and in cooperation with other engineering and technical societies to broaden the usefulness of the engineering profession.

Membership: Honorary, 72, distinctive accomplishment in engineering, science, industry, research, or public service, and those allied pursuits beneficial to the engineering profession. Members, 16,68t, a graduate of an engineering curriculum approved by the Council, and in addition shall have had not less than six years active practice in the profession of engineering or teaching, five of which sliall have been in a position of responsible charge of engineering work. If not such a graduate, he shall have equivalent attainments, including not less than twelve years active practice in the profession of engineering or teaching, five years of which shall have been in a position of responsible charge of engineering work. Associates, 30,082, a graduate of an engineering currictlum approved by the Council. If not, he shall have equivalent attainments including at least eight years of engineering experience of a character satisfactory to the Council. Student, 11,307, a student regularly enrolled for and pursuing an approved engineering curriculum in a school having a student branch of the Society. Total membership 47,564.

\section{Mcetings: Twice a year.}

Professional activities: The Research Executive Committee supervises all of the research activities of ASME. Under it, a Research Planning Committee, having representatives from every technical interest in the Society, organizes, fosters, reviews, and coordinates the activities of the 24 Researci Committees (18 active, 6 inactive): Behavior of Pressure Vessel Materials, Boiler Feedwater Studies, Condenser Tubes, Contact Fatigue of Rolling Elements, Corrosion and Deposits from Combustion Gases, Critical Tables, Effect of Radiation of Materials for Nuclear Installations, Effect of Temperature on the Properties of Metals, Flow of Bulk Materials, Fluid Meters, Furnace Performance Factors, High Temperature Steam Generation, Lubrication, Mechanical Pressure Elements, Plastic Flow of Metals, Prevention of Fracture in Metals, Properties of Steam, and Randon Vibration. Each of these committees directs and supervises the investigation, collection, tabulation, and correlation of existing data and information in its field, and when the need is sufficient to warrant research, it plans and directs technical programs which are conducted under contract at various colleges, universities, and other organizations having laboratories for cooperative research work. The cost 
of such research is underwritten by contributions, mostly from industry and trade associations, and, to a lesser degree, from government agencies. Over $\$ 2,600,000$ has been contributed to this research committee program since 1922 and current annual expenditures on all projects average $\$ 150,000$.

ASME Medal, established by the Society in 1920 to be presented annually, together with an engrossed certificate, for distinguished service in science and engineering. May be awarded for general service in science having possible application in engineering. Holley Medal, established in 1924 by George I. Rockwood, to be bestowed, together with an engrossed certificate, for some great and unique act of genius of an engineering nature that has accomplished a great and timely public benefit. ASME George Westinghouse Gold Medal, established and endowed in 1953 by the Westinghouse Educational Foundation, to be bestowed annually, if warranted, together with an engraved certificate, for eminent achievement or distinguished service in the power field of mechanical engineering. Worcester Reed Warner Medal, established in 1930 at the bequest of WVorcester Reed IVarner, a gold medal to be bestowed, together with an engrossed certificate, for an outstanding contribution to permanent engineering literature. Spirit of St. Louis Medal, established by an endowment fund created in 1929 by Philip D. Ball, ASME Members, and citizens of St. Louis, Mo., to be awarded, with an engrossed certificate, for meritorious service in the advancement of aeronautics. Timoshenko Medal, established in 1957 by the ASME Applied Mechanics Division to honor Stephen P. Timoshenko and to commemorate his contributions to applied mechanics as author and teacher. The medal may be bestowed annually, together with an engrossed certificate, in recognition of distinguished contributions to applied mechanics. Machine Design Medal, established by the ASME Machine Design Division, to be bestowed annually, if warranted, together with an engrossed certificate, in recognition of eminent achievement or distinguished service in the field of machine design. Melville Prize Medal for Original Work, established in 1914 at the bequest of Rear Admiral George W. Melville, to be presented, together with an engrossed certificate, for the best original paper or thesis on any mechanicalengineering subject, by a corporate nember of the ASME, presented for the first time at a meeting of the Society for discussion and publication during the calendar year previous to the year of award, to encourage excellence in papers. Blackall Machinc Tool and Gage Award, established in 1954 and named for Frederick S. Blackall, Jr., to be awarded annually, if warranted, in the form of a plaque and an honorarium, for the best paper (s) submitted to ASME, on a subject clearly concerned with or related to the design or application of machine tools, gages, or dimensional measuring instruments, for presentation and publication by single or multiple authors. Prime Movers Committee Award, established in 1954 by the Prime Movers Committee of Edison Electric Institute, for recognition of outstanding individual or multiple author contributions to the literature of thermal electric-station practice or equipment. Junior Award, annual cash award of $\$ 50$, established in 1914 by Henry Hess, to be presented, together with an engrossed certificate, for the best paper presented for the first time at a meeting of the Society during the calendar year previous to the year of the award, by an Associate Member of the Society not more than thirty years of age at the time the paper was presented. Spirit of St. Louis Junior Award, established in 1938 by an endowment fund created by the General Committee for the 1935 Aeronautic Meeting in St. Louis, Mo., a cash award of $\$ 50$ and engrossed certificate to be awarded for the best paper on an aeronautical engineering subject presented for the first time at an ASME meeting during the three-year period prior to the year of award, by an Associate Member of the Society under thirty years of age at the time paper was presented. Richard Memorial Award, established in 1944 by $\mathrm{Pi}$ Tau Sigma, national honorary mechanical engineering fraternity, consists of a cash award, an engraved certificate and monetary supplement to cover travel expenses to and from the ASME meeting at which the award is to be given. It is presented to a mechanical engineering graduate for outstanding achievement in engineering within twenty to twenty-five years after graduation from a regular four-year mechanical engineering course of a recognized college or university. $\mathrm{Pi}$ Tau Sigma Gold Medal Award, established in 1938 by Pi Tau Sigma, the national honorary mechanical engineering fraternity, to be presented annually, together with an engraved certificate and monetary supplement to cover expenses to and from the ASME meeting at which the award is to be given, to a young mechanical engineer for outstanding achievement in engineering within ten years after graduation from a regular four-year mechanical engineering course of a recognized college or university. Arthur L. Williston Medal and Award, established in 1954 by Arthur L. Williston, consists of a medal, an engraved certificate, and a cash award of $\$ 200$. It is granted to the undergraduate student in the junior or senior class in a course of mechanical engineering, or to a junior engineer who has had professional experience and who has received a baccalatureate degree within two years prior to May 1 of the year of award. Charles T. Main 
Award, annual cash award of $\$ 150$, established in 1919 by Charles T. Main, to be awarded, together with an engrossed certificate, to a Student Member of the Society for the best paper which deals generally with the influence of the engineering profession upon public life. Student Awards, two annual cash awards of $\$ 25$ each, established in 1914 by Henry Hess, to be presented, together with engrossed certificates, for the best papers submitted by Student Members of the Society.

Publications: Mechanical Engineering, monthly, current volume: $82, \$ 7, \$ 3.50$ to members. Editor: J. J. Jaklitsch, Jr. Transactions (5 subdivisions), quarterly, current volume: 82. Editor: J. J. Jaklitsch, Jr. Applied Mechanics Reviews, monthly, current volume: $13, \$ 25$ Editor: Stephen Juhasz. PMM-Journal of Applied Mathematics and Mechanics (translation of Russian Journal), bimonthly, $\$ 35$.

\section{American Society of Medical Tech-} nologists. 25 Hermann Professional Building, Houston 25. Tex. President: Nellie May Bering, P. O. Box 955, Benjamin Franklin Station, Washington 4, D. C. Term expires June 1961. Executive Secretary: Rose Matthaei. Term indefinite.

History: Organized 1932; incorporated July 2. 1936.

Purpose: To promote higher standards in clinical laboratory methods and research; to elevate the status of those specializing in medical laboratory technique; to create mutual understanding and cooperation between medical technologist and physician and all others who are employed in the interest of individual or public health.

Membership: Active members, 6,280, must be certified by the Registry of Medical Technologists of the American Society of Clinical Pathologists or hold at least a master's degree in one of the major fields of medical technology; or hold a certificate in chemistry or microbiology from the Registry of the American Society of Clinical Pathologists : or hold a limited certificate in histologic technique from the Registry and have ninety or more semester credit hours from an accredited college of which at least twenty-seven hours are in science including chemistry or biology, with lecture and laboratory in each, and be an active member of the constituent society of the geographical area in which he is employed or resides. Affiliate members, 122. any person certified by the Registry, but not meeting the Active membership requirements, and member of a constituent society in geographical area of employment or residence. Honorary members, 11, any person who has made an outstanding contribution to the field of laboratory medicine by research or by his service to the profession of medical technology. Student members, 590, any person enrolled in an approved School of Medical Technology or in an undergraduate program whicl is prerequisite to enrollment in an approved school. Corresponding nembers, 10 , any person who is resident of and employed as a medical technologist in a foreign country, who is a member of a recognized association of medical technologists in that country. Total membership 7,013 .

\section{Mcetings: Annual.}

Professional activities: First, Second, and Third awards, $\$ 100, \$ 50$, and $\$ 25$, given to active or affiliate members for best papers presented at annual convention. Education and Research Fund.

Publications: The American Journal of Medical Technology, bimonthly, current volume: 26, \$5. Editor : Rose Matthaei.

\section{American Society of Naturalists. Presi-} dcnt: L. C. Dunn, Department of Zoology, Schermerhorn Hall, Columbia University, New York 27, N. Y. Term expires December 31, 1960. Secretary: Earl L. Green, Roscoe B. Jackson Memorial Laboratory, Bar Harbor, Maine. Term expires December 31, 1961.

History: Organized 1883 as the Society of Naturalists of the Eastern United States; name changed December 29, 1885 to present title.

Amalgamated 1902 with the Naturalists of the Central States (organized 1901), the latter society becoming the Central Branch of the general society. Eastern and Central Branches merged in 1913.

Purpose: The association of working naturalists for the discussion, advancement, and diffusion of knowledge concerning the broader biological problems, including organic evolution, thus serving to correlate the various biological sciences into a common philosophy of biology.

Membership: By invitation, limited to persons professionally engaged in some branch of natural history. Active, 500; Emeritus, 125; Honorary, 10. Total membership 635.

\section{Mcetings: Annual.}

Publications: Records, triennial, current volume: 93, free to members. Editor: Earl L. Green.

328. American Society of Naval Engineers, Inc. 1012 14th Street, N. W., Washington, D. C. President: Robert E. Cronin. Term expires December 1960. Secretary-Treasurer: James E. Hamilton. Term indefinite. 
History: Founded in 1888.

Purpose: To foster naval engineering.

Membership: Naval members, commissioned officers of the Navy, Coast Guard, and Marine Corps of the United States, active or retired, 1,556 ; civil members, 8 years in the engineering field (five years of important work), 1,289; associate members, commissioned officers of U. S. Army, U. S. Air Force, and foreign military and naval services, and persons interested in naval matters, 529; junior members, undergraduates from accredited schools, 8 .

Mectings: Annual.

Professional activities: American Society of Naval Engineers Award, for an outstanding contribution in naval engineering; Brand Award, for Massachusetts Institute of Technology postgraduate student who stands first in Course 13 A ; student awards for service academy graduates.

Publications: Journal, quarterly, current volume: 72 , domestic $\$ 12$, foreign $\$ 20$. Editor: J. E. Hamilton.

\section{American Society of Ophtalmologic and}

Otolaryngologic Allergy. President: Walter E. Owen, 1105 North Street, Peoria 2, I11. Term expires October 8, 1960. Secretary: Daniel S. DeStio, 121 South Highland Avenue, Pittsburgh 6, $\mathrm{Pa}$. Term expires October 8,1960 .

History: Organized October 1940. Organization consists of eye, ear, nose, and throat specialists whose practice is concerned greatly with allergy.

Purpose: To advance the study of allergic conditions of the eye, ear, nose, and throat.

Membership: Regular members, 325, physician specializing in ophthalmology or otolaryngology and having taken postgraduate work in allergy. Honorary nembers, 30. Total membership 355 .

Meetings: Semiannual.

Publications: Annual Bulletin.

330. American Society of Parasitologists. President: Harold IV. Brown, School of Public Health, Columbia University, New York 32, N. Y. Term expires December 31, 1960. Secretary: Francis J. Kruidenier, Zoology Department, University of Illinois, Urbana, I11. Term expires December 31, 1961.

History: Established February 21, 1925. AFfiliate Organizations: Southern California Parasitologists, 1958; Midwestern Conference of Parasitologists, 1959; Helninthological Society of Washington, 1960.

Purpose: To foster association of persons interested in parasitology, to improve teaching, promote investigation, and advance knowledge of this and related sciences.

Mcmbership: Total membership, 1,102, any person with educational or other qualification and activity within the field.

Mcctings: Annual.

Publications: Journal of Parasitology, bimonthly, current volume: $46, \$ 9.50$. Editor: $\mathrm{E}$. R. Becker.

331. American Society of Pharmacognosy. Secretary: Rolf S. Westby, Eli Lilly and Company, 740 South Alabama Street, Indianapolis, Ind. Term expires August 1962.

History: Plant Science Seminar founded 1923 at the University of Minnesota. Name changed to present title 1959 .

Purpose: To promote the growth and development of pharmacognosy, to provide the opportunity for association among the workers in that science and related sciences, to provide opportunities for presentation of research achievements and to promote the publication of meritorious research.

Membership: Active, 118, open to pharmacognosists of all nations; Associate, 12, open to graduate students; Patron, 3, person or organization. Total membership 133.

Mectings: Annual.

332. American Society of Photogrammetry. 1515 Massachusetts Avenue, N. IV., Washington 5, D. C. President: G. C. Tewinkel. Term expires March 1961. Secretary-Treasurer: C. E. Palmer. Term indefinite.

History: Organized August 1934; incorporated October 1934. Sections: Chattanooga, Northern California, Rocky Mountain, Columbia River, Central New York, Rolla, Puget Sound, St. Louis, Southern California, Ohio, Metropolitan New York, Virginia. Commettees: Research, Nomenclature, Photo Interpretation, Map Specification and Tests, Professional Stature, Geographic Exploration, Aerial Photography, Specifications for Highways, Weather Research. The Society is a member of the International Society of Photogrammetry.

Purpose: To advance knowledge in the science and art of photogrammetry; to provide means for the dissemination of new knowledge and information and thus to encourage the free exchange of ideas and intercourse among those contributing to the advancement of the art; to stimulate student interest in the field of photogrammetry by advocating a strengthening of college curricula; to hold meetings for the presentation of symposia, panels, papers and discussions; to exert its efforts toward the improvement of standards and the betterment of 
ethics ; to maintain the dignity of the profession ; and to foster a spirit of understanding and cooperation among photogrammetrists in the United States and throughout the world.

Membership: Total membership, 3,600, any person who is actively engaged in the practice of photographic mapping, or who, by reason of education or profession, is interested in the application or development of photogrammetry.

Meetings: Annual.

Professional activities: Talbert Abrams Award, \$100 annually, to encourage recording of current and historical engineering and scientific developments in photogrammetry, given to member whose article appears in Photogrammetric Engineering. Photogrammetric Award, to stimulate development of the art of aerial photogrammetry in the United States, is given, annually, to an individual member of the Society; Fairchild Camera and Instrument Corporation maintains this award and underwrites expenses connected with it. Ford Bartlett Award, to stimulate interest in the Society. Bausch and Lomb Photogrammetric Award, annually, to stimulate an interest in photogrammetry in college students and to recognize meritorious students who display outstanding ability in the field: First prize, $\$ 100$ plus three-year paid-up membership in Society, and two $\$ 50$ prizes plus one year membership.

Publications: Photogrammetric Engineering, quarterly, \$6. Editor: T. IV. Norcross.

\section{American Society of Planning Officials.}

1313 East 60th Street, Chicago 37, I11. Presidcnt: Harold S. Shefelman, Weter, Roberts and Shefelman, 1612 Northern Life Tower, Seattle, Wash. Term expires May 1961. Executive Director: Dennis O'Harrow. Term indefinite.

History: Organized and incorporated 1934.

Purpose: To improve standards and techniques; to promote efficiency in the making or administration of national, State, regional or local plans for land use and community development.

Membership: Open to all who wish to advance their knowledge of planning. Active membership, open to officers, members, staff, or consultants of an official planning body, or an unofficial planning body primarily engaged, on a nonprofit basis, in the field of land or community planning, and to faculties of schools granting degrees in planning; Associate membership, open to all others; Sponsoring membership, for those wishing to contribute to the work of the Society; Student membership, open to persons who will be enrolled in school full time for at least six months after payment of membership dues. Total membership approximately 4,000.

\section{Meetings: Annual.}

Professional activities: Annual award of silver medal, for leadership in and contribution to planning; annual award for public service rendered in the advancement of city and regional planning through outstanding journalism; maintenance of inquiry service.

Publications: Newsletter, monthly, current volume: 26. Jobs in Planning, semimonthly. Information Reports, monthly. Planning (yearbook). Editor: Dennis O'Harrow. Zoning Digest, monthly, current volume: 12. Editor: Jack Noble.

Library: 30,000 to 35,000 volumes. Subject emphasis: Planning, zoning, urban renewal.

334. American Society of Plant Physiologists. President: R. H. Burris, University of IVisconsin. Madison, IV is. Term expires December 31, 1960. Executive Secretary: G. R. Noggle, University of Florida, Gainesville, Fla. Term indefinite.

History: Organized 1924. Sections: Northeastern; Mid-IVestern; Southern; IVestern; Washington, Smithsonian Institution, Washington, D. C.

Purposc: To encourage and promote the growth and development of plant physiology as a pure and applied plase of botanical science, to publish the results of meritorious research in plant physiology, and to promote the general welfare and good fellowship of plant physiologists.

Mcmbership: Regular members, 1,321; Life, 35 ; Corresponding, elected by Executive Committee, 19; Student, 140; Emeritus, 11. Total membership 1,526 .

\section{Mcctings: Annual.}

Professional activitics: Stephen Hales Prize, awarded biennially to residents of North America who have served the science of plant physiology in some noteworthy manner. Charles Reid Barnes Life Membership Award, given annually to members or non-members of the Society, every fifth award to be made to a foreign member.

Publications: Plant Physiology, bimonthly, current volume: $35, \$ 12$. Editor: Allan $H$. Brown, Department of Botany, University of Minnesota, Minneapolis, Minn.

335. American Society of Plant Taxonomists. President: Lyman Benson, Department of Botany, Pomona College, Claremont, Calif. Term expires December 31, 1960. Secretary: C. Ritchie Bell, Department of Botany, University of North Carolina, Chapel Hill, N. C. Term expires December 31, 1960. 
History: Founded in 1937. Member society of American Institute of Botanical Sciences and affiliate of American Association for the Advancement of Science.

Purpose: To broaden the base of knowledge upon which taxonomy rests and to lead in the integration of taxonomy with other branches of botany.

Mcmbcrship: Total membership, 550, any person with an interest in plant taxonomy.

Mectings: Annual.

Professional activitics: Cooley Award of $\$ 500$ for best taxonomic paper dealing with plants of the Southeast United States published each year. Cooley Award of $\$ 100$ for best taxonomy paper given at annual meeting.

Publications: Brittonia, quarterly, current volume: $12, \$ 6.50$. Editor: Rogers McVaugh. Taxonomic Index, irregular. Editor: IV. $H$. Camp.

336. American Society of Plastic and Reconstructive Surgery. President: Kenneth L. Pickrell, Duke University Hospital, Durham, N. C. Term expires October 1960. Secretary: Thomas Ray Broadbent, 508 East South Temple Street, Salt Lake City, Utah. Term expires October 1960.

History: Organized October 1931 as Society of Plastic and Reconstructive Surgery. Name changed to present title in 1931. Incorporated in New York, 1945. Sections: United States and Canada.

Purpose: To promote medical and surgical research on the study and treatment of congenital and acquired deformities; to keep the medical profession informed of the scientific progress and the possibilities of plastic and reconstructive surgery; to stress the social, economic, and psychologic importance of this specialty.

Membership: Active, 368, certification by the American Board of Plastic Surgery; Candidate, 165 , completion of training acceptable for Board certification, Board qualified; Corresponding, 34, foreign plastic surgeons of renown; Life, 11 , retirement or limitation of practice; Honorary, 6, plastic surgeons, United States and Canada, of high accomplishment and renown.

\section{Mectings: Annual.}

Professional activitics: Essay contest in clinical and experimental research, traveling fellowships, financial, certificate, and medal awards.

Publications: Journal of Plastic and Reconstructive Surgery, monthly, current volume : 25 , $\$ 12$. Editor: Robert Ivy, 1930 Chestnut Street, Philadelphia, $\mathrm{Pa}$. Transplantation Bulletin, quarterly, current volume: 5. Editor E. J.
Eichwald, Deaconess Hospital, Great Falls, Montana.

337. American Society of Professional Biologists, Inc. President: Charles C. Croft, Ohio Health Department Laboratory, Columbus, Ohio. Term expires July 1, 1961. Executive Sccrctary: Elmer L. Shaffer, 213 Buckingham Avenue, Trenton, N. J. Term indefinite.

History: Organized September 1947; incorporated 1948. Sections: Western, Central, Southern, Eastern.

Purpose: To promote the professional welfare of biologists through coordinated group action guided by highest professional standards and ethics, and through constructive action in the field of education of biologists.

Mcmbcrship: Members, doctor's degree and at least one year of professional experience in biological sciences, or master's degree and at least five years of education or professional experience, or bachelor's degree in biological field and at least eight years of education or professional experience; Affiliates, academic degree with major work in a biological field from a department of recognized standing. Total membership 350 .

Mectings: Annual.

Publications: News, quarterly, current volume: 13. Editor: A. Dickman.

\section{American Society of Range Management.}

P. O. Box 5041, Portland 13, Oreg. President: Fred H. Kennedy, U. S. Forest Service, New Federal Building, Albuquerque, N. Mex. Term expires January 31, 1961. Exccutive Secretary: John G. Clouston. Term indefinite.

History: Organized 1947; incorporated in State of Wyoming, June 1949, Sections organized $1948 ; 18$ sections in operation covering Western States, Southeastern States, Mexico and Canada. Six student chapters within Sections. One large committee on cooperation with scientific organizations with individual representatives assigned each of ten other organizations. CommitTEEs: Range Research Methods, lnventory of Range Research, Pasture and Range Research Techniques, Range Management Bibliography, Professional Standards.

Purpose: To foster advancement in the science and art of grazing land management, to promote progress in the conservation and greatest sustained use of forage and soil resources, to stimulate discussion and understanding of scientific and practical range management problems, to provide a medium for exchange of ideas and facts among Society members and with allied technicians, and to encourage professional improvement of members. 
Hembership: Regular, 2,952, persons who are interested or engaged in practicing range or pasture management or animal husbandry, administering grazing lands, teaching, conducting research, or engaged in extension activities in range or pasture management or related subjects ; Life, 28 ; Students, 258. Total membership 3.238 .

\section{Mectings: Annual.}

Professional activitics: Publication of text on range research methods and techniques and range handbook for youth; cooperation with U. S. Civil Service Commission on preparation of standard educational requirements for range management positions; awards to college teams for range plant identification contest; two scholarship awards by Sections; five State range youth camps or range judging contests by Sections; conduct by each Section of range demonstration field trips; cooperation with International Cooperation Administration in memberships for foreign range students and in their recognition while in this country; sponsorship of medal awards to youth for range management projects.

Publications: Journal of Range Management, bimonthly, current volume: $13, \$ 8$. Editor: E. J. Woolfolk.

339. American Society of Safety Engineers, Inc. 5 North Wabash Avenue, Chicago 2, Ill. President: John F. Jones, Commonwealth Edison Company, 72 West Adams Street, Chicago 90, Ill. Term expires October 1960. Secretary and Managing Director: A. C. Blackman. Term expires October 1960.

History: Organized 1911; present name adopted 1914; incorporated as non-profit organization 1915; merged with National Safety Council as Engineering Section of that organization in 1924; returned to independent status 1948; moved to own offices 1959. Organized into eight regions and seventy-five chapters in United States and Canada. Twelve standing committees, including General and Technical Publications, Cooperation with Engineering Societies and Colleges, Safety Standards, Research, and Laws and Regulations.

Purpose: To promote the arts and sciences in the prevention of accidents, and the conservation of life, health and property ; to attain a high standard in safety engineering, and to encourage the development of safety engineering as a profession.

Membership: Members, 3,407, thirty years of age, degree in engineering or registration as professional engineer plus six years qualifying experience, other degree plus eight years qualifying experience, or no degree plus ten years qualifying experience; Associate, 2,959, degree in engineering or registration as professional engineer plus one year experience, or other degree plus three years qualifying experience, or no degree plus five years qualifying experience; Affiliate, 814 , twenty years of age plus one year of qualifying experience, or twenty-five years of age plus three years in related field; Honorary, 10; Life, 150.

Mectings: Annual.

Professional activities: Technical paper award for best technical article published in Journal of the Society from members of the Society and Veterans of Safety. Courses and seminars in accident prevention sponsored by chapters in their localities. Underwriting research on "Human Factors in Occupational Injuries" by New York University Center for Safety Education.

Publications: Engineering for Safety, monthly, current volume: 24 . Editor : Robert E. Beighley. Journal, quarterly, current volume: 5 , published as a bound-in section of National Safety News. Editor: Robert E. Beighley.

\section{American Society of Sanitary Engineering.} 228 Standard Building, Cleveland 13, Ohio. President: Arthur E. Whitney, 3181 Watson Road, St. Louis 39. Mo. Term expires October 1960. Secretary: Sanford Schwartz. Term expires October 1960.

History: Organized 1906; incorporated. SECTrons: United States, Canada, Australia, South Africa, England. Сoмmitrees: Research; Pipe Corrosion; Atmospheric and Ground Pollution; National Safety; Disease Research; Code; American Standards Association Sectional, Examination and Educational Standards; Mechanical Sanitation and Inspectors; National Water Conservation; Research Endowment Foundation.

Purpose: Research in plumbing engineering, water supply, sewage disposal, and fixture design.

Membership: Those who have been or are responsible for protecting and safeguarding health. Total membership 2,200.

Mectings: Annual.

341. American Society of Sugar Beet Technologists. P. O. Box 538, Fort Collins, Colo. President: Dewey Stewart, Sugar Beet Section, U. S. Department of Agriculture, Agricultural Research Service, Plant Industry Station, Beltsville, Md. Term expires December 31, 1961. Secretary-Treasurer: James H. Fischer. Term expires December 31, 1961.

History: Organized January 7, 1937, in Fort Collins, Colo. Geographic Sections: Canada, 
Eastern Slope, Eastern United States, Intermountain, West Coast. Technical Sections: Agricultural Engineering, Agronomy, Chemistry and Factory Operation, Entomology and Plant Pathology, Genetics and Variety Improvement, Physiology.

Purposc: To foster sugar beet and beet sugar research, and to act as a clearing house for the exchange of ideas resulting from such work.

Membership: Active members, 600, all persons, associations, corporations, and other organizations interested in the advancement of knowledge concerning sugar beet production or beet sugar processing.

Meetings: Biennial.

Professional actizitics: Meritorious Service Awards, Forty-Tear Veteran Awards, Honorary Memberships.

Publications: Journal, quarterly, current volume: 11, $\$ 4.50$ domestic, $\$ 5$ foreign. Editor: James H. Fischer.

342. American Society of Swedish Engineers. 235 West 46th Street, New York 19, N. I. President: Nils R. Bernz, 4 Peter Cooper Road, New York 10, N. Y. Term expires December 1962. Secretary: Ray U. Strandberg, 555 Ocean Avenue, Brooklyn 26, N. Y. Term expires December 1962.

Hisłory: Organized February 11, 1888; incorporated July 14, 1890.

Purpose: Promotion of arts and sciences connected with engineering and mechanical construction, and of scientific progress by readings, lectures, and discussions.

Membership: Active members, residing within radius of thirty miles of Columbus Circle, New York, N. Y.; Passive members, residing in the United States outside of above indicated zone; Corresponding members, located in other countries, including Sweden. Total membership 302.

Meetings: Monthly.

Professional activities: John Ericsson Gold Medal, awarded biennially in recognition of extraordinary merit in technical or scientific fields, alternately to Swedish subjects and American citizens of Swedish descent; Annual Award, to an outstanding graduating engineer, alternately in the United States and Sweden, $\$ 300$.

Publications: Bulletin, annual, current volume: 54, free to members. Editor: Edwin W. Dutcher.

343. American Society of Tool and Manufacturing Engineers. 10700 Puritan Street, Detroit 38, Mich. President: H. Dale Long, 1901
South Rockwell Street, Chicago 8, 111. Term expires May 1961. Executive Secretary: H. E. Conrad, 6050 Tripp Road, Holly, Mich. Term indefinite.

History: Founded January 1932 as American Society of Tool Engineers; name later changed to present title. 167 senior chapters in the United States, Canada, Australia, the Philippines, and Mexico. 31 student chapters in universities, colleges, and technical institutes of the United States.

Purposc: To advance scientific knowledge in the field of tool and manufacturing engineering and, through its members, engage in research, writing, publishing, and disseminating such information.

Membership: Senior nember, five years experience and proven ability to plan the order of operations layout or supervise the design and manufacture of tools and equipment; must be qualified to recommend correct tools and equipment for manufacturing processes; may also be executive personnel directing manufacturing operations. Total membership 40,700.

Mectings: Annual.

Professional actizitics: Student scholarships given at chapter and national level; Research Fund; national and local seminars, technical sessions, and conferences; equipment and processing exhibitions; standards research; educational activities; Progress Award; Engineering Citation; Joseph A. Siegel Memorial Award; Education Award; Gold Medal; Research Medal; Eli Whitney Award; publication of technical handbooks and manuals.

Publications: Tool Engineer, monthly, current volume: 44, free to members. Editor: Jack Greve. Scope, bimonthly, current volume: 69, free to chapter officers. Editor: Mel Stone. News for Metalworking Executives, monthly, free. Editor: Ted Black.

Library: 2,000 volumes. Subject emphasis: Tool and manufacturing engineering.

\section{American Society of Tropical Medicine} and Hygiene. 3575 Saint-Gaudens Road, Miami 33, Fla. President: Willard H. Wright. Term expires November 1960. SccrctaryTreasurer: Rolla B. Hill. Term expires November 1960.

History: Organized November 17, 1951; incorporated in Delaware on January 21, 1952. Formed by amalgamation of American Society of Tropical Medicine (founded 1903) and National Malaria Society (founded 1916).

Purpose: The advancement of tropical medicine and hygiene in its various branches and fields. 
Membership: Active, 1,150, interest in tropical medicine or hygiene; Honorary, 12, eminent contributions to tropical medicine or hygiene, non-Americans only; Emeritus, 6, retired from active work; Life, 3. Total membership 1,171.

Meetings: Annual.

Professional activities: C. F. Craig Lecture, annual reviews by authorities. Walter Reed Award, biennial, for meritorious achievement in tropical medicine, medal and certificate. J. A. LePrince Award, triennial, for achievement in malariology, medal and certificate. Bailey $\mathrm{K}$. Ashford Award, biennial, for research in tropical medicine, $\$ 1,000$, medal and certificate.

Publications: American Journal of Tropical Medicine and Hygiene, bimonthly, current volume: 8, \$10. Editor: Paul C. Beaver, Tulane University, New Orleans, La. Tropical Medicine and Hygiene News, bimonthly, current volume: 8, free. Editor: IVilliam H. DelVitt, National Institutes of Health, Bethesda, Md.

\section{American Society of X-Ray Technicians.} 16 14th Street, Fond du Lac, IVis. President: Marjorie Cook Tolan, Emory University Hospital, Atlanta 22, Ga. Term expires June 29, 1961. Executize Secretary: Genevieve J. Eilert. Term indefinite.

History: Organized in Chicago, 1920, as American Society of Radiographers; name changed to present title May 25, 1934. Fortyseven state and ten local affiliated societies. Connimtees: Affiliation: Careers; Catholic Hospital Association Joint ; Civil Defense; Education; Membership; Public Relations; Publication and Essay Awards; Radiation Safety; Resolutions and By-Laws. Commission on Technicians' Affairs, appointed by American College of Radiology.

Purpose: To promote the science and art of radiography.

Membership: Must be certified with American Registry of X-ray Technicians. Active members, 8,442; Inactive status, 441; Associate, 92; Fellows, 20; Life, 4; Honorary, 8. Total membership 9,007 .

Mectings: Annual.

Professional activities: Jerman Memorial Lecture, to perpetuate memory of Edward C. Jerman.

Publications: X-Ray Technician, bimonthly, current volume: 31 , non-members $\$ 2.50$, members of affiliated societies $\$ 1.50$, free to members. Editor: Jean I. Widger, 640 Delaware Avenue, Detroit 2, Mich.

346. American Society of Zoologists. President: Emil Witschi, Department of Zoology, State University, Iowa City, Iowa. Term expires
December 30, 1960. Secretary: Gairdner B. Moment, Department of Biology, Goucher College, Baltimore 4, Md. Term expires December 30, 1960.

History: Founded in 1902 as the result of the fusion of three older societies, the oldest of which was established in 1890. Divisions: Animal Behavior, Comparative Endocrinology, Comparative Physiology, and Developmental Biology.

Purpose: The association of workers in the field of zoology for the presentation and discussion of new or important facts and problems in that science and for the adoption of such measures as shall tend to the advancement of zoological science.

Membership: Members, 1,920, those actively engaged in the field of zoology who have training in that science equivalent to that required for doctorate degree.

Mectings: Semiannual.

Professional activities: Organizes symposia and brief refresher courses, sponsors summer institutes for college teachers, publishes a careers-in-animal-biology leaflet.

Publications: Newsletter, semiannual.

\section{American Specification Institute. 134 North}

La Salle Street, Chicago 2, I1l. Chairman, Board of Governors: Rollo E. Gilmore, 80 East Jackson Boulevard, Chicago, Ill. Secretary and Technical Dircetor: Gerald L. Palmer. Term expires June 1961.

\section{History: Organized March 17, 1921.}

Purpose: To increase and distribute the knowledge and to improve the method of writing specifications for architectural and engineering materials, equipment and structures.

Membership: Persons who devote all or part of their time to the writing of specifications. Total membership approximately 500 .

Mectings: Board of Directors meet every two months; also committee meetings.

Publications: Bulletins, irregular, free to members. Editor: G. L. Palmer.

\section{American Speech and Hearing Association.}

1001 Connecticut Avenue, N. W., Washington 6, D. C. President: Stanley H. Ainsworth, Director, Speech and Hearing Clinic, University of Georgia, Athens, Ga. Term expires December 31, 1960. Executive Secrctary: Kenneth O. Johnson. Term indefinite.

History: Organized 1925 as American Acadcmy of Speech Correction; title changed in 1927 to American Society for the Study of Disorders of Speech; changed in 1934 to Ameri- 
can Speech Correction Association; changed to present title in 1947. Incorporated.

Purpose: To encourage basic scientific study of the processes of individual human speech and hearing, promote investigation of speech and hearing disorders, and foster improvement of therapeutic procedures with such disorders; to stimulate exchange of information among persons thus engaged, and to disseminate such information.

Membership: Members, 4,946, bachelor's degree or higher in field of interest; Associates, 369 , undergraduates in field of interest.

\section{Meetings: Annual.}

Professional activities: American Speech and Hearing Foundation, to advance scientific and educational endeavor in speech pathology and audiology.

Publications: Journal of Speech and Hearing Disorders, quarterly, current volume: $25, \$ 5$. Editor: Mary IV. Huber. Journal of Speech and Hearing Research, quarterly, current volune: 3, \$5. Editor: Dorothy Sherman. Asha, monthly, current volume: $2, \$ 7$. Editor: Kenneth O. Johnson.

349. American Standards Association, Inc. 10 East 40th Street, New York 16, N. Y. President: John R. Townsend. Managing Director: George F. Hussey, Jr. Term indefinite.

History: Organized 1918 as the American Engineering Standards Committee by five engineering societies, to act as a clearinghouse for their standardization work; reorganized under present title 1928.

Purpose: To provide systematic means by which organizations concerned with standardization work may cooperate in establishing American standards in those fields in which engineering methods apply to avoid duplication of work and promulgation of conflicting standards; to serve as a clearinghouse for information on standardization work in the United States and foreign countries; to further the standardization movement as a means of advancing national economy; to promote knowledge and use of approved American industrial and engineering standards; and to act as the authoritative American channel in international cooperation in standardization work.

Mcmbership: Open to any national group or industrial organization with a substantial interest in standardization problems: includes 123 organizations-trade associations, techuical societies, and consumer groups, and 2,300 companies holding membership either individually or by group arrangement through respective trade associations; Member-bodies, Company Members, Associate Members.
Mectings: Annual.

Publications: Magazine of Standards, current volume: 24 , free to members.

Library: 70,000 volumes, including file of approved national standards from thirty-nine other countries.

350. American Statistical Association. $1757 \mathrm{~K}$ Street, N. W., IVashington 6, D. C. Prcsident: Morris H. Hansen, Bureau of the Census, Washington 25, D. C. Term expires December 1960. Executive Secretary: Donald C. Riley. Term expires October 1960.

History: Organized 1839; incorporated 1841. Chapters in most major cities in the United States, divided into ten districts. Various technical committees and advisory committees to the Federal government. Sections: Business and Economic Statistics, Training of Statisticians, Biometrics, Social Statistics, Statistics in the Physical and Engineering Sciences.

Purposc: To encourage the improvement of basic statistical data and statistical methods in many fields of knowledge; to foster contacts and discussions among individuals concerned with statistical material, problems, and methods ; to encourage use of statistics in research and practical affairs.

Mcmbcrship: Regular nembers, student menbers, family members, fellows, honorary, senior, institutional. Total membership 7,200.

\section{Meetings: Annual.}

Publications: Journal, quarterly, current volume: $55, \$ 8$. Editor: Clifford G. Hildreth. The American Statistician, five times annually, current volume: 14, $\$ 1.50$; Editor: Morris Hamburg. Technometrics, quarterly, current volume: 2, \$8. Editor: J. Stuart Hunter.

351. American Surgical Association. President: John D. Stewart, 180 Soldiers Place, Buffalo 9. N. Y. Term expires March 24, 1961. Secretary: W. A. Altemeier, Cincinnati General Hospital, Cincinnati 29, Ohio. Term indefinite.

History: Organized May 1880, as American Surgical Society; name changed to present title May 1882.

Purpose: The cultivation and improvement of the science and art of surgery, the elevation of the medical profession, and such other matters as may come legitimately within the sphere of this Association.

Membership: Active members, 250, thirty years of age and graduate of five years' standing from a recognized medical college, established reputation as a practitioner, author, teacher, or 
original investigator; Senior, 187. Total membership 437 .

Mectings: Annual.

Publications: Transactions, annual, current volume: 78, free to members. Editor: J. E. Dunphy. Annals of Surgery, semiannual. Editor: J. H. Mulholland.

352. American Technical Education Association. President: Laurence E. Spring, Erie County Technical Institute, Buffalo, N. Y. Term expires December 6, 1960. Executive Secretary: William N. Fenninger, 22 Oakwood Place, Delmar, N. Y. Term indefinite.

History: Founded in 1928 as American Association of Technical High Schools and Institutes; name changed to present title in 1949.

Purpose: To promote technical education in high schools.

Membership: Members, 600, all engaged in technical education or interested in its promotion.

Metings: Annual.

Publications: Newsletter, bimonthly, members only. Editor: W. N. Fenninger.

\section{American Therapeutic Society. 915 19th} Street, N. W., Washington 6, D. C. President: Harry E. Ungerleider, 161 East 42nd Street, New York, N. Y. Term expires June 1961. Secretary: Oscar B. Hunter, Jr. Term expires June 1961 .

History: Founded May 1900, and incorporated in the District of Columbia July 1904.

Purpose: To encourage, foster, and promote greater interest and research in the field of therapeutics; to print publications to promote the interests of the Society and the practice of therapeutics; to promote and help maintain the highest standards in teaching, practice, and research in this field.

Membership: Open to qualified practitioners of medicine, teachers, or research workers holding a doctor of medicine degree, who are graduates of approved medical schools, and, if in private practice, members of their local or county medical societies. Active, 267; Fellows, 26; Emeritus, 6; Honorary, 1. Total membership 300.

Meetings: Annual.

Professional activitics: Oscar B. Hunter Memorial Award in therapeutics, with honorarium; Lewis Harvie Taylor Lectureship.

Publications: Clinical Pharmacology and Therapeutics, bimonthly, current volume: 1, $\$ 12.50$. Editor: Walter Modell.

354. American Thoracic Society. President: William B. Tucker, 1790 Broadway, New
York 19, N. Y. Term expires May 23, 1961. Secretary-Treasurer: Frederick C. WVarring. Jr. Term expires May 1961. Executive Secretary: Frank W. Webster. Term indefinite.

History: Organized 1905 as American Sanatorium Association; name changed to American Trudeau Society in 1939; changed to present title May 17, 1960. Society is Medical Section of National Tuberculosis Association.

Purpose: Epidemiological, clinical, pathological, surgical and medical educational aspects of pulmonary diseases.

Membership: Active Members, 5,220, must have degrees of doctors of medicine, doctors of philosophy, or equivalents.

Mcctings: Annual.

Professional activities: Fellowships for medical education and grants for medical and social research.

Publications: American Review of Respiratory Diseases, monthly, $\$ 15$. Editor: Walsh McDermott.

355. American Translators Association. P. O. Box 489, Madison Square Station, New York 10, N. Y. President: Alexander Gode, Interlingua Division of Science Service, 80 East 11 th Street, New York 3, N. Y. Term expires May 1961. Executive Secretary: Miss Ruth Levy, Research Information Service, 40 East 29 th Street, New York 10, N. Y. Term expires May 1961.

\section{History: Founded 1960.}

Purpose: To promote the service efficiency of translation in America under changing and more exacting conditions and to assure American translators as a professional group a voice in international translators' conclaves.

Membership: Active member, status of professional translator; Associate member, interest in the objectives of the Association. Total membership 70.

Professional activities: Registry of translators.

Publications: Notes, weekly, free to members. Editor: Alexander Gode.

356. American Urological Association, Inc. 1120 North Charles Street, Baltimore 1, Md. President: John E. Heslin, 75 Willett Street, Albany 10, N. Y. Term expires May 25, 1961. Executive Secretary: William P. Didusch. Term indefinite.

History: Organized on February 22, 1902. Sections: Mid-Atlantic, New England, New York, North Central, Northeastern, South Central, Southeastern, Western.

Purpose: To encourage the study, improve the practice, and elevate the standards of urology. 
Membership: Active members, 1,577, trained in all phases of urology and limitation of practice to that specialty for two years; Senior, 231, twenty-five years' active membership and age of sixty-five; Associate, 9, scientists who have worked in the interest of urology; Honorary, 9; Inactive, 26, active members who are incapacitated by illness or accident or otherwise from the practice of their profession; Corresponding, 26. Total membership 1,878.

Meetings: Annual.

Professional activities: Yearly appropriation for the recording and special study of all tumors of the genito-urinary tract at the Tumor Registries maintained in the Army Medical Museum, Washington, D. C. Three prizes, consisting of certificates and money, are awarded annually for the best scientific exhibits of original research, clinical research, or instruments, at the annual meeting, $\$ 50$ first prize in each category. Annual Prize Essay Competition, limited to residents in urology in recognized hospitals and to urologists who have been practicing for not more than five years; $\$ 1,000$ available to be given at the discretion of the Committee on Research as follows: $\$ 500$ first prize, $\$ 300$ second, \$200 third. Ramon Guiteras Lecture, established in honor of a founder and first president of the Association, given at the annual meeting by any physician, surgeon, or scientist who has made a noteworthy contribution to urology either within the field of urology or in some related field.

Publications: Journal of Urology, monthly, current volume: $84, \$ 6.50$ members, $\$ 12$ nonmembers. Editor: J. A. Campbell Colston.

357. American Vacuum Society Inc. P. O. Box 1282, Boston, Mass. President: Wilfrid G. Matlieson, Sylvania Electric Products, Inc., 60 Boston Street, Salem, Mass. Term expires October 1960. Secretary: Harold C. Weingartner, Arthur D. Little, Inc., 35 Acorn Park, Cambridge 40, Mass. Term expires October 1960.

History: Society is the successor to the Committee on Vacuum Technique which was organized in 1953 to sponsor symposia on vacuum technology, and to assist in the dissemination of related knowledge. A non-profit organization.

Purpose: To promote communication among people interested in vacuum science and engineering.

Membership: Open to any individual with expressed interest in vacuum science or engineering. Total membership 800 .

Mectings: Annual.

Publications: Transactions, annual, current volume: 6, \$15. Editor: Robert Meissner.
American Venereal Disease Association. See Addenda No. 1588.

358. American Veterinary Medical Association. 600 South Michigan Avenue, Chicago 5, I11. President: E. E. Leasure, School of Veterinary Medicine, Kansas State University, Manhattan, Kans. Term expires August 1961. Exccutive Secretary: H. E. Kingman, Jr., American Veterinary Medical Association, 600 South Michigan Avenue, Chicago 5, Ill. Term indefinite.

History: Organized as United States Veterinary Medical Association in 1863. Name changed to present title 1898. Councils: Judicial, Biologic and Therapeutic Agents, Education, Public Health and Regulatory Medicine, Research, and Veterinary Service.

Purpose: To advance the science and art of veterinary medicine, including its relationship to public health and agriculture.

Membership: Open to graduates of accredited veterinary colleges. Total membership 14,753.

\section{Mectings: Annual.}

Professional activities: Research Fund to promote postgraduate study by veterinary graduates; Twelfth International Veterinary Congress Prize awarded annually for noteworthy contributions to the advancement of veterinary science; AVMA Award for meritorious service; Borden Award administered by the Association, the recipient being selected annually for outstanding research in diseases of dairy cattle; Practitioner Award in recognition of research work by a practitioner.

Pubications: Journal, semimonthly, current volume: 136, \$15. Editor: Donald A. Price. American Journal of Veterinary Research, bimonthly, current volume: $21, \$ 5$ to members, $\$ 10$ to non-members.

359. American Water Works Association, Inc. 2 Park Avenue, New York 16, N. Y. President: C. F. Wertz, Department of Water, Miami, Fla. Term expires June 1961. Secretary: Raymond J. Faust. Term indefinite.

History: Organized 1881; incorporated 1912. Thirty-two geographic sections in the United States, Canada, and Cuba. Sections: Water Works Administration, with nineteen committees; Water IVorks Practice, with forty-six committees and twelve task groups.

Purpose: Advancement of knowledge of design, construction, operation, and management of water works.

Membership: Requires interest in public water supply. Active members, 10,850; Corporate, 1.300 ; Associate, 350; Student, 70; Honorary, 50 ; Life, 370. Total membership approximately 13,000 . 


\section{Mectings: Annual.}

Professional activities: John M. Diven Memorial Medal, awarded annually to member who has rendered most outstanding service to Association during year; Publications Prize, certificate and $\$ 50$, awarded annually to nember who has made most notable contribution to science or practice of water works development; George Warren Fuller Memorial Award, annual, to members designated by geographic sections for distinguished service in water supply field; Harry E. Jordan Achievement Award, established 1951, for recognition of distinguished public service outside line of duty.

Publications: Journal, month!y, current volume: 52, \$8. Editor: E. F. Johnson. Willing Water, monthly, current volume: 4 .

360. American Welding Society. 33 West 39th Street, New York 18, N. Y. President: R. D. Thomas, Jr., President, Arcos Company, 1500 South 50th Street, Philadelphia 43, Pa. Term expires May 31, 1961. Exccutive Secretary: Fred L. Plummer. Term indefinite.

History: Organized March 1919. Sections: Eighty-four, covering most of the large industrial cities in the United States. TECHNICAL Committees: Symbols; Definitions and Charts; Filler Metal; Safety Recommendations; Methods of Inspection; Standard Qualification Procedures; Resistance IVelding; Metallizing; Brazing and Soldering; Building Codes; Welded Bridges; Marine Construction; Field Welding of Storage Tanks; Field Welding of Steel Water Pipe Joints; Automotive Welding; Welding Iron Castings; Nelding Concrete Reinforcing Steel; Missiles and Rockets; Railway Welding; Piping and Tubing; and seventy subcommittees, covering various phases of the foregoing.

Purpose: To advance the science and art of welding; to afford its members opportunities for the interchange of ideas with respect to welding and for the publication of information thereon; to sponsor or conduct welding research cooperating with other societies, associations, and governmental departments for the benefit of industry in general.

Membership: Sustaining Members, Members, Associate, Student, Honorary, and Life. Total membership 13,000.

Meetings: Annual Meeting and Welding Exposition, fall technical meeting.

Professional activities: Samuel Wylie Miller Memorial Medal, awarded to a person who, in the judgement of the Board of Trustees of the Medal has contributed conspicuously to the advancement of the welding or cutting of metals. Adams Lecture Certificate and Honorarium, awarded to an outstanding scientist or engineer for his lecture, presenting some new and distinctive development in the field of welding. Honorary Membership, awarded to person of acknowledged eminence in the welding profession, or to one accredited with exceptional accomplishments in the development of the welding art. Lincoln Gold Medal awarded to the author of the paper published in the IVelding Journal which has contributed most to the advancement and the use of welding. A. F. Davis Silver Medals (3), awarded to authors of papers published in the Welding Journal and judged best in fields of (a) machine design, (b) maintenance and hard facing, and (c) structural design.

Publications: Welding Journal, monthly, current volume: 39 , \$8. Editor: B. E. Rossi.

361. Animal Care Panel, Inc. Argonne, I1l. President: Bennett J. Cohen, University of California Medical Center, Los Angeles 24, Calif. Term expires December 31, 1960. Secretary-Treasurer: Robert J. Flynn. Tern expires December 31, 1960.

History: Founded in Chicago, 1949; incorporated 1953; membership made available to institutions, and local branches authorized, 1956; affiliate sub-societies by profession or industry authorized 1959; technicians' certification program authorized and initiated 1960.

Purpose: To serve as medium for exchange of scientific information on all phases of laboratory animal care.

Membership: Requires professionally active engagement in care, production, or use of laboratory animals. Total membership 765 .

Meetings: Annual.

Professional activities: Griffin Award, for outstanding contribution in field of laboratory animal care; Animal Technician certifying program.

Publications: Proceedings, quarterly, current volume: 10, domestic $\$ 8$, foreign $\$ 10$. Editor: N. R. Brewer.

362. Animal Nutrition Research Council. Chairman: Douglas V. Frost, Abbott Laboratories, North Chicago, I1l. Term expires October 1960. Secretary: Philip H. Derse, Wisconsin Alumni Research Foundation, Madison, Wis. Term expires October 1960.

History: Organized November 1939 as the Animal Vitamin Research Council; name changed to present title October 1946. Sections: United States and Canada.

Purpose: To stimulate interest in research in animal nutrition; to promote collaborative studies of assay methods for nutritional factors; 
to provide a medium for the discussion of assay technics and results; to plan and administer projects for the advancement and application of knowledge in animal nutrition and for the betterment of assay technics; to cooperate with control officials and associations to help accomplish these objectives.

Mcmbership: Professional training in nutrition and biochemistry, or active interest in bioassay procedures. Total membership 310 .

Mectings: Annual, second or third Wednesday in October.

Professional activities: Technical Projects Fund, $\$ 5,000$, for the support of collaborative assay studies.

364. Anthropological Society of Hawaii. Department of Anthropology, University of Hawaii, Honolulu 14, Hawaii. President: Samuel H. Elbert. Term expires June 1961. Secretary: Mrs. Tamme Wittermans. Term expires June 1961.

History: Organized 1926; affiliated with American Anthropological Association, 1947; Member, Inter-Society Education Council and Hawaiian Academy of Sciences since 1958.

Purpose: To further the science of anthropology in Hawaii by presentation of reports and papers dealing with anthropology of Pacific area, by informal discussion, and by encouragement of research.

Membership: Open to professional anthropologists and others interested in anthropological study and research. Full members, 54; Student, 13; Subscribers, 30. Total membership 97.

Meetings: Monthly, September to May.

Professional activities: Award for best anthropological exhibit at Annual Hawaiian Science Fair.

Publications: News of the Pacific, quarterly, current volume: $11, \$ 1.50$. Editor: Mrs. Frances Tamanaha.

365. Anthropological Society of Washington. Division of Archaeology, Smithsonian Institution, Washington 25, D. C. President: Harvey C. Moore. Term expires May 1961. Secretary: Frank Anderson. Term expires May 1962. Treasurer: Clifford Evans. Term expires May 1965.

History: Organized February 10, 1879; incorporated December 13, 1887.

Purpose: To encourage the study of the natural history of man, especially with reference to America.

Membership: Requires interest in anthropology, especially in the study of man as found in America. Active members, 145 ; Life, 1. Total membership 146.

Meetings: Monthly, October through May.

366. Appalachian Geological Society. President: H. Douglas Preble, P. O. Box 873, Charleston, W. Va. Term expires May 1961. Executive Secretary: Duncan C. Malcolm, P. O. Box 1913, Charleston, W. Va. Term expires May 1961.

\section{History: Grganized 1930.}

Purpose: The study of geological problems, both practical and technical, as they affect oil and gas operations in the Appalachian area.

Membcrship: Active members, 161, residents of the Appalachian District who are actively engaged in any of the various phases of geology or petroleum engineering in senior capacities; Associate, 105, as above, but in junior capacities or engaged in development or production of oil or gas. Total membership 266.

Meetings: Second Monday in each month except June through August.

367. Appalachian Mountain Club. 5 Joy Street, Boston 8, Mass. President: Kenneth A. Henderson, 29 Agawam Road, Waban 68, Mass. Term expires January 1, 1961. Executive Director: C. Francis Belcher. Term indefinite.

History: Organized January 1876; incorporated in Massachusetts in 1878 and in New Hampshire in 1935. Chap'TERs: Berkshire (Springfield and western Massachusetts); Connecticut; Narrangansett (Rhode Island); New Hampshire; New York; Portland (southern and western Maine); and Worcester (Massachusetts). Operates and maintains eight unit mountain hut system open to public in summer in White Mountains of New Hampshire. Maintains 370 miles of trails and 20 free shelters for public use in Maine and New Hampshire. Prints guide books and maps of New Hampshire and Maine mountain country and distributes same to members and public.

Purpose: To explore the mountains of New England and adjacent regions, both for scientific and artistic purposes, and in general to cultivate an interest in geographical studies.

Membership: Open to persons interested in supporting public service work of Club; sponsorship by two current members is required. Regular, Life, and Junior members. Membership also includes a limited number of Honorary and Corresponding members elected from persons who have distinguished themselves in the fields of mountaineering, exploration and geographical sciences. 


\section{Meetings: Monthly, October through May.}

Professional activities: Annual fellowship for graduate study in forestry at the University of Maine, known as the Evelyn H. Murphy Appalachian Mountain Club Fellowship. Annual clinic or workshop for Camp Counsellors and Scout Leaders in hiking and climbing.

Publications: Appalachia, semiannually, current volume, $34, \$ 2.50$, free to members.

Library: 3,500 volumes emphasizing mountaineering and geographical sciences.

368. Archaeological Institute of America. 5 Washington Square North, New York 3, N. Y. President: George E. Mylonas, Washington University, St. Louis, Mo. Term expires December 31, 1960. General Secrctary: LeRoy A. Campbell. Term expires December 31, 1960.

History: Founded in 1879 by a group of scholars who shared an interest in reconstructing the story of man's climb through the centuries; incorporated in 1906 by an act of Congress as a non-profit organization. The Institute acted as founder or co-sponsor of schools of archaeological research in Rome. Athens, Jerusalem, Baghdad, Cairo, and Santa Fe. Local Socieries: forty-seven, located in major cities of the United States and Canada.

Purpose: Provides a means for both the professional scholar and the interested layman to keep abreast of the latest archaeological discoveries and their interpretation and significance, thus forging a link between the schools in the field and the American community at home.

Membership: Life members; Fellows; Contributing; Sustaining; Annual Members; Associates; Students; Patrons. Total membership 2,500

\section{Meetings: Annual.}

Professional activities: Norton Lectureship, to an outstanding scholar; given annually: 2 years to a foreign scholar, one year to an American scholar.

Publications: American Journal of Archaeology, quarterly, current volume: $64, \$ 10$. Editor: Richard Stillwell. Archaeology, quarterly, current volume: 13, \$5. Editor: Mrs. Gladys D. Weinberg.

369. Archaeological Society of Delaware. President: Richard C. Quick, Assistant to the Director of the Library, University of Delaware, Newark, Del. Term expires June 1962. Secretary: Mrs. Marianna Akernan, Landenburg, $\mathrm{Pa}$. Term expires June 1962.

History: Founded 1933.

Purpose: To promote and encourage the study of archaeology; to encourage careful scientific research and excavation; to preserve important archaeological sites and artifacts; to preserve and record important data relative to any of these.

Membership: With the approval of the Board of Directors, membership open to those persons interested in archaeology. Total membership 135.

Mcetings: Five times per year.

Professional activities: Gathering local Indian artifacts; Archibald Crozier Award presented for distinguished achievements in the archaeology of Delaware.

Publications: Inksherds, five times per year, current volume: 5, included in membership. Editor: Charles F. Kier, Jr. Bulletins, irregular. Papers, irregular.

370. Archaeological Society of New Mexico.

President: IV. J. Keller, 124 East Lupita Road, Santa Fe, N. Mex. Term expires January 1962. Executive Secretary: Frederick Worman, Los Alamos, N. Mex. Term expires January 1962.

History: Organized in 1879 as Santa Fe Archaeological Society; name changed to present title 1909; incorporated June 1938.

Purpose: To conserve the scientific resources of New Mexico; to preserve historic and prehistoric remains, ancient monuments and noted landmarks, and to make them known; to promote ethnological and archaeological research; to promote movements whose objects are to advance knowledge of, and interest in, New Mexico's past; to cooperate in the conservation of native arts and crafts of the southwest; to aid the program of the Museum of New Mexico.

Membership: Open to persons in sympathy with the purposes of the Society. Members, Life Members, and Honorary Members. Total membership 658 .

Meetings: Biennial.

Professional activities: Annual scholarship to student in anthropology at the University of New Mexico (full tuition for one year) ; annual certificate for outstanding work by an amateur.

Publications: E1 Palacio, monthly, current volume: 67, \$5. Editor: Wayne Mauzy.

371. Archaeological Society of North Carolina.

Research Laboratories of Anthropology, University of North Carolina, Chapel Hill, N. C. President: F. S. Barkalow, Jr., P. O. Box 5215, State College Station, Raleigh, N. C. Term expires December 1960. Executive Secretary: Joffre L. Coe, P. O. Box 561, Chapel Hill, N. C. Term expires December 1960.

History: Organized 1933.

Purpose: To pronote study of archaeology 
and anthropology, particularly in relation to Indians of North Carolina; to strive for proper conservation and exploration of archaeological sites.

Membership: Prospective members should demonstrate scholarly interest in and support of aims and objectives of this Society. Active members, 174; Sustaining, 35. Total membership 209.

Meetings: Semiannual.

Professional activitics: Merit Award, annual, to a Society member.

Publications: Newsletter, irregular, current volume: 38, free to members. Editor: Joffre L. Coe. Southern Indian Studies, annual, current volume: 10 , free to members. Editor: Joffre L. Coe.

\section{Archaeological Society of Ohio. 65 North}

Foster Street, Norwalk, Ohio. Presidcnt: Harley W. Glenn, 2011 West Devon Road, Columbus 12, Ohio. Term expires May 1961. Executive Secrctary: Arthur George Smith. Term indefinite.

History: Organized by group from the Ohio Indian Relic Collectors Society, whose membership was absorbed; incorporated March 1955; has several small chapters. Technical committee: Fraudulent Artifacts.

Purpose: To discover and conserve archaeological sites and material within the state of Ohio; to seek and promote a better understanding among students and professional and amateur collectors of such material.

Membership: Active, 530, professional and nomprofessional persons interested in archaeology, of good character, over eighteen years of age; no residence requirements; Junior, 37, fifteen to eighteen years of age; Institutional, 30 ; Honorary, by vote of trustees in token of outstanding service to archaeology. Total membership 597.

Mcctings: Five meetings a year, three indoor, and two at some large site.

Publications: Ohio Archaeologist, quarterly, current volume: 10, \$1. Editor: E. W. Atkinson, 420 Chatham Road, Columbus 14, Ohio.

373. Archeological Society of New Jersey. New Jersey State Museum, Trenton, N. J. President: Donald Dilatush, Robbinsville, N. J. Term expires January 1962. Secretary: Mrs. Kathryn B. Greywacz. Term expires January 1962.

History: Organized November 1931, incorporated May 1940. Committee: Research.

Purpose: To promote and encourage the study of arclieology; to preserve important archeol- ogical sites, monuments, and artifacts; to assist in the development of a museum for display and preservation of archeological materials; to record and preserve data on the foregoing and to exchange archeological information with other organizations.

Membership: Open to persons interested in the purposes of the Society. Total membership 432.

Meetings: Quarterly.

Profossional activities: Archeological field work.

Publications: Bulletin, semiannual, current volume: $15-16, \$ 1.50$, free to members; News Letter, quarterly, current volume: $51, \$ .25$, free to members. Editor: J. Alden Mason.

374. Arctic Institute of North America. 3485 University Street, Montreal 2, Que. United States offices: 2 East 63rd Street, New York 21, N. Y.; 1530 P Street, N. W., Washington 5, D. C. Chairman: C. S. Lord, Geological Survey of Canada, Ottawa, Ont. Term expires December 1960. Secretary: M. J. Dunbar, McGill University, Montreal 2, Que. Term expires December 1962.

\section{History: Organized 1944.}

Purpose: To encourage and promote scientific research in the polar regions and to act as a coordinating center for polar research in North America.

Membership: 2,400. Members must have a general interest in polar regions.

Meetings: Monthly, October to May.

Professional actizitics: Approximately 350 research projects supported since 1945.

Publications: Arctic, quarterly, current volume: 13, \$5. Editor: P. F. Bruggemann.

Library: 4,000 volumes on polar regions and related topics.

375. Arizona Academy of Science. c/o Edwin B. Kurtz, Department of Botany, University of Arizona, Tucson, Ariz. President: William H. Woodin, P. O. Box 5602, Tucson, Ariz. Term expires April 1961. Sccrctary: Edwin B. Kurtz. Term expires April 1961.

History: Founded 1956. Supports a Junior Academy. Sections include: Anthropology, Biology, Geography, Geology, Physics, Astronomy; affiliated societies of state scientific organizations. Affiliated with the American Association for the Advancement of Science.

Purposc: To stimulate scientific research and edlucation, encourage publication, and unify the scientific interests of the state.

Mcmbership: Interest in the Academy's objectives and sponsorship by two regular members. 
Members, 450; Junior members, 200. Total membership 650 .

Mectings: Annual, usually in April.

Professional activities: Undergraduate college scholarship; merit awards to outstanding teachers; merit award for outstanding paper appearing in the Academy Journal ; grants-in-aid to Senior and Junior members.

Publications: Journal, quarterly, current volume : 1, \$3. Editor: R. M. Harris.

\section{Arizona Archaeological and Historical So-} ciety. c/o Arizona State Museum, University of Arizona, Tucson, Ariz. President: Bernard L. Fontana, Box 618, Route 3, Tucson, Ariz. Term expires May 1961. Secretary: Mrs. Ann Johnson. Term expires May 1961.

History: Organized 1916.

Purpose: Education of interested persons in the history and archaeology of the southwest.

Membership: Open to anyone interested in the aims of the Society and its programs. Total membership approximately 200 .

Meetings: Monthly, October to May.

Publications: Kiva, quarterly, current volume: $25, \$ .50$. Editor: Alfred Johnson.

377. Arizona Foundation for Neurology and Psychiatry. 5055 North 34th Street, Phoenix, Ariz. President: IVilliam McGrath, Professional Building, Phoenix, Ariz. Term expires August 1962. Executive Secretary: Frank J. Dunning. Term expires August 1962.

History: Established with the support of the local psychiatrists, Camelback Hospital, and the Phoenix Institute of Neurology and Psychiatry. Non-profit Arizona corporation.

Purpose: Maintenance and operation of research; acquisition and dissemination of knowledge in the fields of neurology, psychiatry, and medicine; maintenance, sponsorship, and promotion of research, investigation, and experimentation with respect to nervous, emotional, and physical disorders.

Membership: Association with medical facility; interest in medical research. Total membership 20 .

Mectings: At least four times per year ; special meetings called at any time by request of member or members.

Professional activities: Sponsorship of research in the field of tranquilizing drugs, and in the general field of psychiatric and nervous disorders.

378. Arizona Geological Society. P. O. Box 4443, Tucson, Ariz. President: James L. Kelly, 1414 East 8th Street, Tucson, Ariz.
Term expires May 1961. Secretary: Spence Titley, University of Arizona Geological Department, Tucson, Ariz. Term expires May 1961.

History: Organized informally 1947 ; constitution adopted 1950.

Purpose: To promote interest in the geology of Arizona.

Membership: Open to those professionally interested in Arizona geology. Regular members; graduate students. Total membership 150.

Meetings: Monthly.

Publications: Digest, annual, current volume: 3, free to members. Editor: J. W. Anthony.

379. Arizona Medical Association, Inc. Suite 1021 Central Towers Building, 2727 North Central Avenue, Phoenix, Ariz. President: Lindsay E. Beaton, 1650 North Campbell Avenue, Tucson, Ariz. Term expires 1961. Executive Secretary: Robert Carpenter. Term indefinite.

History: Organized 1892; incorporated June 19, 1960.

Purpose: To bring into one organization the entire medical profession of the State of Arizona; to promote the science and art of medicine; to promote and elevate the standards of medical ethics and medical education; to promote public health and in all instances and manners to operate as a non-profit business league and scientific and educational organization for the above stated purposes.

Membership: Members, 1,038 ; requires active membership in good standing in a county society.

Mectings: Annual.

Publications: Arizona Medicine, monthly, current volume: $17, \$ 5$. Editor: Darwin IV. Neubauer.

380. Arizona Pharmaceutical Association. 1028 East McDowell Road, Phoenix, Ariz. President: Jack Knowles, Moore Drug Company, 2 North San Francisco Street, Flagstaff, Ariz. Term expires April 1961. Exccutive Secretary: Alfred J. Duncan. Term indefinite.

History: Organized 1910; reorganized and incorporated 1933. Local Associations: Tucson Pharmaceutical Association; Maricopa County Pharmaceutical Association.

Purpose: To advance the science of pharmacy and to promote scientific research; to enact laws for the prevention of adulteration of food and medicines; and to confine compounding and sale of medicines to regularly licensed pharmacists. 
Membership: Pharmacists, store owners, college students, sustaining members. Total membership 700 .

Meetings: Annual.

Professional activities: Evelyn Mills Scholarship.

Publications: Arizona Pharmacist, monthly, \$3. Editor: Alfred J. Duncan.

381. Arizona Public Health Association. P. O. Box 6515, Phoenix, Ariz. President: George W. Marx, State Department of Health, Capitol Annex Building, Phoenix, Ariz. Term expires May 1961. Executive Secretary: Joseph J. Weinstein. Term expires May 1961.

History: Organized 1926. Sections: Clerical, Health Education, Nursing, Sanitation, and Services.

Purpose: To promote public health in Arizona.

Membership: Open to all persons engaged in practice, or interested in advancement of, public health. Total membership approximately 250.

Meetings: Annual.

382. Arizona Radiological Society. President: Robert E. Flynn, 550 West Thomas Road, Phoenix, Ariz. Term expires May 1961. Secretary-Treasurer: Don E. Matthiesen, 926 East McDowell Road, Phoenix, Ariz. Term expires May 1961.

History: Organized 1942 as Arizona Society of Radiologists and Pathologists; pathologists and radiologists separated, latter separately organized and name changed to present title, April 1951.

Purpose: To establish closer association of radiologists of $A$ rizona for advancing the science of radiology and maintaining a high standard of medical practice.

Membership: Requires membership, Arizona Medical Association, active practice of radiology in Arizona for two years, and membership, American College of Radiology. Total membership 30 .

Mcetings: Seniannual.

383. Arizona Science Teachers Association. 1119

East 4th Street, Mesa, Ariz. President: Don C. Lillywhite. Term expires November 5, 1960. Executive Secretary: August Bergdorf, Gilbert High School, Gilbert, Ariz. Term expires November 5, 1960.

History: Organized about 1938.

Purpose: Coordination and education of science teachers throughout the state of Arizona.
Membership: Approximately 350 , must be a science teacher in a school in Arizona.

Meetings: Annual.

384. Arizona Society of Anesthesiologists. 402 Craycroft Medical Center, Tucson, Ariz. President: Fred H. Landeen. Term expires May 1961. Secretary: Allan B. Carter. Term expires May 1961.

History: Organized and incorporated 1948 as Arizona State Society of Anesthesiologists; name subsequently changed to present title.

Purpose: To advance the science and art of anesthesiology.

Membership: Open to doctors of medicine interested in anesthesiology. Total membership 43.

Meetings: Quarterly.

385. Arizona Society of Professional Engineers. President: Lloyd E. Martin, 1513 West Edgemont, Phoenix, Ariz. Term expires June 1961. Secretary-Treasurer: Harold F. Hudson, 1222 North 3rd Street, Phoenix, Ariz. Term expires June 1961.

History: Organized in January 1949, and incorporated in Arizona in April 1950. Became a member of the National Society of Professional Engineers in 1950. Society comprises 5 chapters : Central, Cochise, Eastern, Northern, and Southern. Has one special group-Functional Group for Engineers in Private Practice.

Purpose: The advancement of the public welfare and the promotion of the professional, social, and economic interests of the professional engineer.

Membership: Professional Engineer: open to any individual who is a professional engineer registered under the law of any state, territory, possession, or district of the United States; Junior Member: open to any individual who holds a valid certificate as an Engineer-inTraining granted by a duly constituted board of registration, pursuant to the laws of any state, territory, or district of the United States. Meetings: Annual.

Professional activities: Engineer-of-the-Year Award.

Publications: Arizona Professional Engineer, 10 issues yearly, current volume: 12, no subscription price. Editor: L. E. Martin.

386. Arizona State Dental Association. 2727 North Central Avenue, Phoenix, Ariz. President: Frank R. Scanlon, 1640 North Norton Avenue, Tucson, Ariz. Term expires April 1961. Executive Secretary: Helen M. Pugh. Term indefinite. 
History: Organized April 1951; incorporated a constituent society of, and chartered by, the American Dental Association. Component societies: Northern Arizona Dental Society, Central Arizona Dental Society, Southern District Dental Society, and any additional dental societies as may be established by the Arizona State Dental Association. Commitrees: Convention, Judicial, Prosecution, Relief, Nominating, Vacancies, and Privileges.

Purpose: To encourage the improvement of the health of the public and to promote the art and science of dentistry; to encourage dental and oral research; to disseminate to the profession knowledge of dental discoveries and inventions; to advance the standard of dental education; to promote the usefulness, honor, and interests of the members of the dental profession; to enlighten and direct public opinion in regard to the duties, responsibilities, and requirements of the dental profession; and to secure the maintenance of a high order of professional excellence among its members.

Membership: Active Member, a dentist legally licensed by the Arizona State Dental Board and ethically practicing his profession in the state of Arizona, or a dentist who is licensed in another state, who is engaged as a full-time teacher in a dental school, or as an administrative officer in any activity associated with the ethical dental profession within the state of Arizona, and in good standing in one of the component societies; Honorary Member, a person who has made valuable contributions to the science and art of dentistry or has rendered marked service to the profession and is elected by the House of Delegates on nomination of the Board of Trustees; Life Member, a dentist who has been an active member of the Association in good standing for thirty-five years, who has attained the age of sixty-five, may at his request be transferred to life membership. Total membership 375 .

Mectings: Annual.

Publications: Arizona Dental Journal, quarterly, current volume: 2, \$2. Editor: G. H. Chiles.

387. Arizona State Psychological Association. President: Neil R. Bartlett, University of Arizona, Tucson, Ariz. Term expires April 1961. Secretary-Treasurer: Muriel N. Gurr, 6802 North Grace Lane, Phoenix, Ariz. Term expires April 1961.

History: Organized in 1950.

Purpose: To further contributions of psychologists to society and to provide a professional organization for psychologists in Arizona.

Membership: Members, 73, Associates, Members, or Fellows of the American Psychological
Association who reside in or are employed in the State of Arizona; Associates, 17, those who are presumably eligible but not Associates, Members, or Fellows of the American Psychological Association; Affiliates, 7, Student Journal Club Members of the American Psychological Association, or those eligible for membership as Student Journal Club Members of the American Psychological Association, or other interested persons who are found to be eligible by the membership of the Arizona State Psychological Association.

Meetings: Semiannual.

388. Arkansas Academy of Science. University of Arkansas, Fayetteville, Ark. President: Herman L. Bogan, Arkansas State College, Jonesboro, Ark. Term expires April 1961. Executive Secretary: R. Reece Corey. Term expires April 1961.

History: Organized 1917 as the Arkansas Academy of Science, held one meeting and disbanded because of the war. Reorganized in 1932 and held first meeting in spring of 1933; name changed to Arkansas Academy of Science, Arts and Letters in 1934; and to present title in 1941. Sections: Agriculture, Biology, Chemistry, Geography, Geology, History and Government, Mathematics, Medicine, Physical Sciences, Psychology, Sociology.

Purpose: The promotion and diffusion of knowledge in the field of science and the unification of these interests in the state.

Membership: Senior members, 200 ; collegiate academy, 30; junior academy, 60 . Total regular membership 200.

Mectings: Annual.

Professional activities: Research grant from the American Association for the Advancement of Science to assist in a research project, $\$ 50$. Sponsors Collegiate Academy, Junior Academy, Arkansas Science Fair.

Publications: Proceedings, annual, current volume: $14, \$ 3$. Editor: W. K. Noyce.

389. Arkansas Archeological Society. University Museum, University of Arkansas, Fayetteville, Ark. President: S. C. Dellinger, 537 Grey Street, Fayetteville, Ark. Term expires December 1960. Secretary: Charles R. McGimsey III. Term expires December 1964.

History: Organized in January 1960, incorporated April 1960; two local chapters, Northeast Arkansas Archaeological Society and the Western Arkansas Chapter.

Purpose: To unite all persons interested in the archeology of Arkansas for the study and preservation of Indian prehistory; to foster and 
encourage a constructive public attitude toward the archeology of the state.

Membership: Open to any person interested in archeology. Active Members, 166; Family Members, 34; Institutional Members, 12; Life Members, 1; Supporting Members, 44; Contributing Members, 3. Total membership 260.

Mectings: Annual.

Professional activitics: Preliminary archeological research under guidance of professional archeologists.

Publications: Newsletter, ten times a year, current volume: 1 , free to members. Editor: C. R. McGimsey III.

390. Arkansas District Branch of the American Psychiatric Association. President: Granville L. Jones, Arkansas State Hospital, Little Rock, Ark. Term expires April 1961. Executive Secretary: IVilliam O. Young, 112 $\frac{1}{2}$ East Seventh Street, Little Rock, Ark. Term expires April 1961.

History: Organized 1950.

Purpose: To stimulate the study and advance the interest of psychiatry.

Membership: Open to members or fellows of the American Psychiatric Association residing or practicing in the state of Arkansas; 53 full members; 3 affiliate members.

Meetings: Quarterly.

391. Arkansas Medical Society. President: J. J. Monfort, Batesville, Ark. Term expires April 19, 1961. Executive Secretary: Paul C. Schaefer, P. O. Box 1345, Fort Smith, Ark. Term indefinite.

History: Organized, Little Rock, Ark., 1875. Sixty component (county), and ten district societies. Committees: Aging, Annual Session, Cancer Control, Hospitals, Insurance, Medical Education, Medical Legislation, Public Health, Public Relations, Traffic Safety, Veterans Administration Affairs.

Purpose: To organize the physicians of Arkansas, improve medical education and public health, maintain medical ethics, and foster relations among physicians.

Membership: Requires degree of Doctor of Medicine from approved medical school and license to practice medicine and surgery. Total membership 1,250 .

Meetings: Annual.

Professional activities: Medical Education Foundation for Arkansas.

Publications: Journal, monthly, current volume: 57, \$3. Editor: Alfred Kahn, Jr., 1300 West 6th Street, Little Rock, Ark.
392. Arkansas Radiological Society. President: J. B. Scruggs, Arkansas Baptist Hospital, Little Rock, Ark. Term expires April 1961. Secretary: Charles W. Anderson, 11081/2 Poplar Street, Pine Bluff, Ark. Term expires April 1961.

History: Organized 1940; recognized, since 1955, as section of Arkansas Medical Society.

Purpose: To promote recognition of radiology as a medical specialty in Arkansas; to exchange ideas and conduct scientific programs.

Menbership: Physicians engaged in full time practice of radiology. Total membership 33 .

\section{Mectings: Semiannual.}

Professional activities: D. A. Rhinehart Memorial Trophy for outstanding film exhibit at annual meeting, Arkansas Society of X-ray Technicians.

393. Armed Forces Chemical Association. 2025 I Street, N. W., Washington 6, D. C. President: Wendell F. Jackson, Explosives Department, E. I. du Pont de Nemours \& Company, Inc., IVilmington 98, Del. Term expires May or June 1961. Secretary-Treasurcr: O. E. Roberts, Jr. Term expires May or June 1961.

History: Organized February 6, 1946, as Chemical Warfare Association; name changed to Chemical Corps Association, June 1, 1947, and to present title, May 1948; incorporated in the District of Columbia.

Purpose: Promotion of national defense through use of chemical and physical sciences.

Membership: Open to Armed Forces Personnel and all others interested in promoting national defense. Individual, Group, Sustaining, Student, Life members. Total membership 3,280 .

\section{Mectings: Annual.}

Professional activitics: ROTC Student Awards.

Publications: Armed Forces Chemical Journal, bimonthly, current volume: $14, \$ 6$. Editor: John C. MacArthur.

394. Armed Forces Communications and Electronics Association. 1624 Eye Street, N. W., Washington 6, D. C. President: Benjamin H. Oliver, Jr., 158 State Street, Albany 1, New York. Term expires June 1961. General Manager: W. J. Baird. Term expires June 1961.

History: Organized May 1946 as the Army Signal Association; name changed to Armed Forces Communications Association in 1948 after unification of Armed Forces. At the request of the industrial members who felt that 
their scope of operations was larger than communications, name was changed in 1955 to present title. SECTIONs: six geographical sections; 49 chapters both nationally and internationally.

Purpose: To maintain and improve the cooperation between the Armed Forces and industry in communications, and in the design, production, maintenance, and operation of communication, electronic, and photographic equipment in time of peace or war, and to preserve and foster the spirit of fellowship among former, present, and future service and industrial personnel in the field.

Membership: Open to industrial organizations and to men and women who are interested in furthering the objectives of the Association. provided, however, that full membership shall be available only to citizens and industrial organizations of the United States. Allied membership shall be available to the citizens and industrial organizations of the free world. Total membership 10,000 .

Mectings: Annual.

Professional activities: Amateur radio; scholarships; Recruits for Science program; medals and certificates presented to outstanding ROTC, NROTC, AFROTC students in the fields of communications and electronics.

Publications: Signal, monthly, $\$ 7, \$ 5$ to nembers. Editor: W. J. Baird.

395. Associated Engineers of Spokane. East 1411 Mission Street, Box 1445, Spokane, Wash. President: J. Byron Barber, West 933 3rd Avenue, Spokane, Wash. Term expires January 31, 1961. Exceutive Secretary: IVilbur L. King. Term expires January 31, 1961.

History: Organized about 1912. Sections: Eastern Washington and Northern Idaho.

Purpose: Coordination of engineering societies, service to the community, the maintenance of professional standards, and the development of acquaintances.

Membership: Members, 128, active member of a parent society; Associates, 29. Total membership 167.

Mectings: Weekly.

396. Association for Applied Psychoanalysis, Inc. President: Harry Slochower, 46 East 73rd Street, New York 21, N. Y. Term expires May 1961. Executive Secretary: Peter Beron, 103 East 86th Street, New York 28, N. Y. Term expires May 1961.

History: Incorporated (New York State) 1955. Committees: Research, Education (two), Publication, Industry and Psychoanalysis.
Purpose: To facilitate and promote training andl research in the field of applied psychoanalysis; to advance the application of psychoanalytic theories to industry, education, the social sciences, the arts, religion. science, philosophy, and human relations.

Membership: Personal psychoanalysis, 300 hours minimum; membership in professional organization related to applied psychoanalysis; superior personal qualities. Members, 95; Fellows, 5; Professional, 30; Associate, 50; Student, 10. Total membership 190.

\section{Meetings: Annual.}

Professional activities: Professional meetings for nembers; public workshops participated in by nembers.

\section{Association for Applied Solar Energy.}

Arizona State University, Tempe, Ariz. President: H. Walmsley, 1444 East Roma Street, Scottsdale, Ariz. Term indefinite. Executive Secretary: Frank Snell, 400 Security Building, Phoenix, Ariz. Term indefinite.

History: Founded in Phoenix on March 17, 1954 by a group of leaders of southwestern agriculture, education, finance, and industry; incorporated as a non-profit educational and scientific institution. The Association is the world headquarters for the coordination of the heretofore scattered and unrelated research in solar energy utilization.

Purpose: To gather, compile, and disseminate information relating to solar energy; to foster research and education in fields related to solar energy; to encourage the expansion and development of the applications of solar energy.

Membership: By invitation; members from fifty nations. Total membership 1,000.

Meetings: Annual.

Publications: Solar Energy: The Journal of Solar Energy Science and Engineering, quarterly, current volume: $4, \$ 10$. Editor: A. Stafford. The Sun At Work, quarterly, current volume: $5, \$ 2.50$. Editor: Sydney Wilcox.

Library: Solar energy and allied fields ; 5,000 volumes.

398. Association for Computing Machinery. 2 East 63rd Street, New York 21, N. Y. President: H. D. Huskey, Department of Mathematics, University of California, Berkeley, Calif. Term expires 1962. Executive Secretary: Mrs. Irene Hollister. Term indefinite.

History: Organized 1947. Sections: Great Lakes, Mid-Atlantic, New York, Northeast, Northwest, South Atlantic, South Central, Southeast, Southwest, Europe. CHAPtERs: 
Arrowhead (Calif.), Cleveland, Dallas-Fort Worth, Delaware Valley, Houston, HudsonMohawk (N.Y.), Kansas City, Kingston (N.Y.), Long Island, Los Angeles, Mid-Southeast, Milwaukee, Orange County (Calif.), Pittsburgh, Rio Grande, Rocky Mountain, St. Louis, San Diego, San Francisco Bay Area, Shreveport, Southeastern, Syracuse, Tulsa, Utah, Washington (D.C.), Western Carolinas.

Purpose: To advance the sciences, study, design, development, construction, and application of modern machinery, computing techniques, and appropriate languages for general information processing, for scientific computation, for the recognition, storage, retrieval, and processing of data of all kinds, and for the automatic control and simulation of processes; to promote free interchange of information about the sciences and arts of information processing, both among specialists and the public.

Membership: Open to persons interested in this Association and its purposes. Total membership 6,000 .

Meetings: Annual.

Publications: Journal, quarterly, current volume : 7, $\$ 10$. Editor: W. F. Bauer. Communications, monthly, current volume: $3, \$ 10$. Editor: Alan J. Perlis.

399. Association for Physical and Mental Rehabilitation. 105 St. Lawrence Street, Rehoboth Beach, Del. President: Carl Haven Young, 3231 Coolidge Avenue, Los Angeles 66, Calif. Term expires June 30, 1961. President-elect and Interin Executive Director: Richard G. Fowler, 3586 Tilden Avenue, Los Angeles 34, Calif.

History: Organized at Topeka, Kans., 1946.

Purpose: To provide a dynamic concept and practice of ancillary service in medical treatment and rehabilitation made possible by new and improved medical and surgical techniques.

Membership: Requires bachelor of science degree in physical education, with courses in psychology, pathology, anatomy, physiology, and therapeutic exercise, and one year of clinical experience under a physician. Total membership 800.

Meetings: Annual.

Professional activities: Scholarships in corrective therapy; John Eisele Davis Award, Corrective Therapy Award.

Publications: Journal, bimonthly, current volume: 14, \$5. Editor: Roger H. Wessel, P. O. Box 473, Montrose, N. Y.

400. Association for Research in Nervous and Mental Disease, Inc. 700 West 168th Street, New York 32, N. Y. President: Clarence C.
Hare. Term expires 1961. SecretaryTreasurer: Rollo J. Masselink. Term indefinite.

History: Organized in 1920 as the Neuropsychiatric Research Society; name changed to present title in 1922.

Purpose: The exchange and dissemination of the products of research in the field of nervous and mental disease.

Membership: Members, 920, individuals who are engaged in the practice of clinical neurology, neurosurgery or psychiatry and who are members of neurologic or psychiatric societies in the United States and Canada.

\section{Meetings: Annual.}

Professional activities: Award given for outstanding contribution in the field of neurology and/or psychiatry.

\section{Association for Research in Ophthalmol-} ogy, Inc. 10515 Carnegie Avenue, Cleveland 6, Ohio. Chairman-Elect: V. Everett Kinsey, Kresge Eye Institute, 690 Mullett Street, Detroit 26, Mich. Term expires December 31, 1961. Secretary-Treasurer: Lorand V. Johnson. Term expires December 31, 1961.

History: Organized 1929; incorporated July 20, 1936. Sections: Eastern, East Central, Southeastern, Midsouthern, Midwestern, Western.

Purpose: To promote and further research in ophthalmology and related sciences.

Membership: Active members, 1,169; Educational, 142; Sustaining, 68; Honorary, 22 ; Life, 2. Total membership, 1,403 .

Professional activities: Proctor Medal, awarded annually for outstanding research in ophthalmology and/or related sciences; Friedenwald Memorial Lectureship, awarded annually for outstanding contributions to ophthalmology and/or related sciences.

402. Association for Symbolic Logic. 190 Hope Street, Providence 6, R. I. President: Frederic B. Fitch, 1834 Yale Station, New Haven, Conn. Term expires January 1962. SecretaryTreasurer: Theodore Hailperin, Lehigh University, Bethlehem, $\mathrm{Pa}$. Term expires January 1963.

History: Organized and incorporated in 1936.

Purpose: To promote research and critical studies in the field of mathematical logic and immediately related fields; to provide a meeting ground for mathematicians and philosophers; and to encourage cooperation and mutual criticism among various groups.

Membership: Open to those individuals interested in symbolic logic upon vote by the Execu- 
tive Committee. 600 members; 25 institutional members.

Mectings: Annual, alternately with American Mathematical Society and the American Philosophical Association.

Publications: Journal of Symbolic Logic, quarterly, current volume: $24, \$ 6.50$. Managing Editor: A. Borgers.

403. Association for the Advancement of Psychoanalysis. 329 East 62nd Street, New York 21, N. Y. President: Louis E. DeRosis, 815 Park Avenue, New York 21, N. Y. Term expires May 31, 1961. Secretary: Jack L. Rubins, 1148 5th Avenue, New York 28, N. Y. Term expires May 31, 1961.

\section{History: Organized in 1941.}

Purpose: To foster psychoanalytic training, encourage investigation and research, further discussion of psychoanalytic subjects along liberal and scientific lines, and dissemate to the medical-psychiatric profession and to the general community those psychoanalytic principles which might be useful to them.

Membership: Members, 26, graduation from a Class A Medical school, one year's internship in general medicine in an approved hospital, one year's residence or internship in an approved psychiatric hospital or psychiatric division in an approved general hospital, and approved training in psychoanalysis. After having completed a period of two years as associate nember may be elected to full membership. Associate, 30; Honorary, 2. Total membership 58.

Meetings: Monthly.

Professional activitics: Contribution of $\$ 5,000$ to the American Institute for Psychoanalysis for research. Horney Award for research, \$150. Karen Horney Lectureship, \$100.

Publications: American Journal of Psychoanalysis, semiannual, current volume: $20, \$ 4$. Editor: Harold Kelman.

Library: 3,000 volumes on psychoanalysis.

404. Association for the Advancement of Psychotherapy, Inc. 15 West 81 st Street, New York, N. Y. President: Joseph Wilder, 1150 5th Avenue, New York, N. Y. Term expires December 31, 1960. Secretary-Treasurer: Stanley Lesse. Term expires December 31, 1960.

History: Organized 1939.

Purpose: To advance methods of psychotherapy among members of the medical profession and to familiarize members with progress in the field.

Membership: Full members must be practicing physicians; Associate membership is open to non-physicians who have done outstanding clinical or research work. Total membership 330.

Meetings: Monthly, October through May.

Publications: American Journal of Psychotherapy, quarterly, current volume: $14, \$ 12$. Editor: Stanley Lesse.

405. Association for the Education of Teachers in Science. Teachers College, Columbia University, New York 27, N. Y. President: George Zimmer, State University of New York, State College of Education, Fredonia, N. Y. Term expires November 1, 1960. Secretary: Willard J. Jacobson. Term indefinite.

History: Organized 1930. Affiliated in 195960 with the National Science Teachers Association and Association of Organizations for Teacher Education.

Purpose: To promote improved programs of education and training for science teachers.

Membership: College staff membership; requires some relationship to teacher education in science. Total membership 400.

Mectings: Three times a year.

406. Association of Allergists for Mycological Investigations, Inc. P. O. Box 901, Crockett, Tex. President: Homer E. Prince. Term indefinite. Secretary-Treasurer: Sim Hulsey. 701 5th Avenue, Fort Worth, Tex. Term indefinite.

History: Organized 1938, incorporated in Texas 1950.

Purpose: Research in mold allergy.

Membership: Open to any physician interested in mold allergy on either experimental or clinical basis. Total membership 50 .

\section{Meetings: Annual.}

Professional activities: Assisting members in studying problems pertaining to mold allergies; affording similar assitance to interested nonmembers insofar as facilities permit; central laboratory maintained at Crockett, Tex., for preparations of experimental mold allergens.

\section{Association of American Feed Control}

Officials, Inc. University of Maryland, College Park, Md. President: Marvin H. Snyder, Charleston, W. Va. Term expires October 1960. Secretary: Bruce Poundstone, Lexington, Ky. Term expires October 1960.

History: First meeting held in January 1910 as Association of Feed Control Officials; name changed to present title in 1929.

Purpose: To promote uniformity in legislation, definitions, and rulings, and the enforce- 
ment of laws relating to the manufacture, sale, and distribution of feedingstuff and livestock remedies in North America.

Membcrship: Composed of the officers charged by law with the execution of state, dominion, and federal laws regulating the sale of commercial feedingstuffs and livestock remedies; the Secretary of the United States Department of Agriculture; the heads of chiefs of experiment stations, bureaus, divisions, sections, and laboratories charged by law with the examination of feedingstuffs and livestock remedies; and such deputies as shall be duly designated by the above officials. Total membership 80 .

Meetings: Annual.

Publications: Official Publication, annual, \$5. Editorial Committee: Chairman, P. B. Curtis, Lafayette, Ind.

408. Association of American Fertilizer Control Officials. President: S. B. Randle, Rutgers University, New Brunswick, N. J. Term expires October 14, 1960. Secretary-Treasurer: B. D. Cloaninger, Clemson Agricultural College, Clemson, S. C. Term indefinite.

\section{History: Organized 1947.}

Purpose: To stimulate interest and uniformity in promulgating and enforcing the fertilizer laws of the nation.

Membership: Open to state or federal control officials. Total membership 49.

Meetings: Annual.

Publications: Official Publication, annual, \$1.

\section{Association of American Geographers.}

1785 Massachusetts Avenue, N. W., Washington 6, D. C. President: Jan O. M. Broek, Department of Geography, University of Minnesota, Minneapolis, Minn. Term expires September 1, 1961. Secretary: Meredith F. Burrill, Office of Geography, U. S. Department of the Interior, Washington 25, D. C. Term expires September 5, 1963.

History: Organized December 29, 1904; incorporated 1937. Sections: New England; New York-New Jersey; Middle Atlantic; Southeast; East Lakes; West Lakes; Great Plains-Rocky Mountains; Southwest; Pacific Coast. Commiteess: Cartography; Geography of the Americas; National Atlas; Political Geography; Trends in Training and Placement of Geographers.

Purpose: To further professional investigations in geography and to encourage the application of geographic findings in education, government, and business. The Association shall support these objectives by promoting acquaintance and discussion among its members and with scholars in related fields, by stimulating research and scientific exploration, by encouraging the publication of scholarly studies, and by performing services to aid the advancement of its members and the field of geography.

Membership: Members, 1,500, those with a $\mathrm{Ph} . \mathrm{D}$. degree in geography, or equivalent education, or a masters degree in geography, followed by at least one year's work as a professional geographer, or an undergraduate degree in geography and at least three years' full-time service as a professional geographer, or significant professional contributions to the field of geography; Associate Members, 500, persons actively interested in geography, but not meeting the above requirements. Total membership 2,000 .

\section{Mcctings: Annual.}

Professional activities: Joint Research Fund, to assist publication of The Annals of The Association of American Geographers. Wallace W. Atwood Research Fund, to encourage field studies in physical geography. General Research Fund, for research contemplated, or to ensure the completion of a research project and perhaps provide for proper and appropriate publication of the results of research. A. S. Nystrom Fellowship of $\$ 2,400$ for graduate research in educational geography. Three fellowships given in 1960 to authors under 36 years of age preparing the best papers for presentation at the Nineteenth International Geographical Congress in Stockholm, August 5-13, 1960.

Publications: Annals, quarterly, current volume: 50, \$10. Editor: Walter Kollmorgen, University of Kansas, Lawrence, Kans. Professional Geographer, bi-monthly, \$5. Editor: Phyllis Griess, Pennsylvania State University, University Park, Pa. Monograph Series, irregular, current volume: $1, \$ 5$. Editor: Andrew Clark, University of Wisconsin, Madison, Wis.

\section{Association of American Medical Colleges.}

2530 Ridge Avenue, Evanston, III. President: Thomas H. Hunter, University of Virginia School of Medicine, Charlottesville, Va. Term expires October 1960. Executive Director: Ward Darley. Term indefinite.

\section{History: Organized 1876.}

Purpose: The improvement and advancement of medical education by developing increasingly effective means of selecting the most able students for the study of medicine, by encouraging experimentation in curriculum development and medical teaching methods, by supporting experimentation, studies, and programs aimed at improving the ability of students to learn and teachers to teach, by supporting efforts to improve the hospital internship and residency as 
educational experiences, by supporting efforts to improve and broaden the influence of continuing medical education, by developing the knowledge and leadership necessary to provide for the long-range progress and stability of medical education and by creating and maintaining effective avenues of communication between medical educators and the American public.

Membership: Individual, 2.500, medical school and university faculty members and administrators, the administrators and staffs of affiliated hospitals, and any other individuals who wish to be active in matters relating to medical education; Emeritus, 6, faculty members, deans, and other administrative officers of medical schools and universities who have demonstrated unusual capacity and interest in dealing with the problems and in contributing to the progress of medical education and who, because of retirement, are no longer active; Sustaining, 28, and Contributing, 40, any person, corporation, or agency that has demonstrated over a period of years a serious interest in medical education and wishes to make annual contributions to the financial support of the Association; Institutional, 85, the accredited medical schools of the United States and its possessions, the American University of Beirut and the Mayo Foundation for Medical Education and Research, Graduate School of the University of Minnesota; Affiliate Institutional, 13, the accredited medical schools of Canada and the University of the Philippines.

\section{Mcetings: Annual.}

Professional activities: Borden Award, annually in medical sciences, $\$ 1,000$ and a gold medal. Abraham Flexner Award, annually for distinguished service to Medical Education.

Publications: Journal of Medical Education, monthly, current volume: $35, \$ 7$. Editor: John Z. Bowers.

\section{Association of American Pesticide Control} Officials, Inc. Box $\mathrm{HH}$, University Post Office, College Park, Md. President: J. D. Patterson, Department of Agriculture, Salem, Oregon. Term expires October 1960. Secretary: Albert B. Heagy. Term expires October 1960 .

History: Organized January 21, 1947 ; incorporated 1951. Committees: Toxicity and Antidotes; Investigators for Compiling Data on Pesticide Chemicals.

Purpose: To promote uniform and effective legislation, definitions, rulings, and enforcement of laws relating to the control of sale and distribution of insecticides, fungicides, and other economic poisons (pesticides).
Membership: Membership includes all officials from thirty-nine states, Canada and Hawaii working in the field.

Meetings: Annual.

412. Association of American Physicians. President: Cecil J. Watson, University Hospitals, Minneapolis 4, Minn. Term expires May 1961. Secretary: Paul B. Beeson, Yale University School of Medicine, New Haven 11, Conn. Term indefinite.

\section{History: Organized 1886.}

Purpose: To advance scientific and practical medicine.

Membership: Nomination by two members of the Association. Total active membership limited to 250. Eneritus members, elected at age sixty-five, or after ten years as active members at candidate's request.

\section{Meetings: Annual.}

Professional activities: George M. Kober Medal, from income of $\$ 1,000$, awarded annually to members who have contributed to the progress and achievement of the medical sciences or preventive medicine. George M. Kober Lectureship, from income of $\$ 10,000$, awarded annually for lectures by men who have contributed to the progress and achievement of the medical sciences or preventive medicine. Lecturers are to be chosen in the following manner: First year, from members of the Association of American Physicians, designated by the Council of the said Association. Second year, from members of the Washington Acadeny of Sciences, the National Tuberculosis Association, the Medical Society of the District of Columbia, and the Washington Anthropological Society. The lecturer is to be designated by the Executive Committee of the Medical Society of the District of Columbia. Third year, from members of the Medical Corps of the Army, the Navy, the U.S. Public Health Service, and members or fellows of the American Public Health Association. The lecturer is to be selected by the Executive Council of the Association of Military Surgeons of the United States.

Publications: Transactions, annual, current volume: 73 , price variable-usually $\$ 7$, free to members. Recorder: A. McGehee Harvey, Johns Hopkins Hospital, Baltimore 5, Md.

413. Association of American State Geologists. President: John C. Frye, Illinois State Geological Survey, Natural Resources Building, Urbana, I1l. Term expires 1962. SecretaryTreasurer: Carlyle Gray, Topographic and Geologic Survey, Department of Internal Affairs, Harrisburgh, Pa. Term expires 1962. 


\section{History: Organized 1908.}

Purpose: To discuss mutual problems involving conservation and development of mineral resources.

Membership: Members must hold official positions as State geologists. Total membership 46.

Meetings: Annual.

Professional activities: Special field trips.

Publications: Journal, semiannual, current volume: $12, \$ 5$, free to members. Editor: Ian Campbell, Division of Mines, Department of Natural Resources, San Francisco 11, Calif.

\section{Association of Asphalt Paving Technolo-} gists. 1224 East Engineering Building, Ann Arbor, Mich. President: James E. Ward, Barber-Greene Company, Aurora, Ill. Term expires January 1, 1961. Secretary-Treasurer: Ward K. Parr. Term indefinite.

History: Organized 1924; incorporated 1959 as a non-profit organization under the laws of the State of Michigan.

Purpose: To advance the technology of asphalt pavement construction, including production and testing of materials, and control of production and laying of such pavements; to encourage intercourse between men charged with technical responsibility; to exchange ideas related to technology of asphalt pavement.

Mcmbership: Active members, open to those with three to ten years experience in responsible positions; Life, thirty years continuous membership; Honorary. Total membership 495.

Meetings: Annual.

Publications: Proceedings, annual, current volume: 29, \$6.50. Editor. W. K. Parr.

\section{Association of Bone and Joint Surgeons,} Inc. President: Frederick R. Thompson, 16 East 90th Street, New York 28, N. Y. Term expires March 1961. Exccutive Secretary: Milton C. Cobey, 1726 Eye Street, N. W., Washington, D. C. Term expires March 1961.

History: Incorporated in Oklahoma in 1947 after the initial meeting in Oklahoma City as guests of Dr. Earl McBride.

Purpose: To stimulate development and advancement of Orthopaedic Surgery and to exchange information pertaining to orthopaedics, especially to stimulate clinical investigation in orthopaedic surgery and to develop leadership.

Membership: Active limited to 75; Emeritus, 17; Honorary, 14; by invitation and certification of The American Board of Orthopaedic Surgery.

Mectings: Annual.

Professional activities: Nicholas Andry Award for Clinical Research in Orthopaedic Surgery.
Publications: Clinical Orthopaedics, quarterly, current volume: 15, \$6. Editor: Anthony DePalma.

\section{Association of Consulting Chemists and} Chemical Engineers, Inc. President: Carl Bussow, c/o A. W. Dow, 801 Second Avenue, New York 17, N. Y. Term expires October 1960. Secretary: Emerson Venable, 6111 Fifth Avenue, Pittsburg 32, Pa. Term expires October 1960.

History: Organized and incorporated October 1928. The Association maintains the Clearing House for Consultants, to serve industry as well as government agencies and individuals in referring their inquiries to professional men experienced in the particular field.

Purpose: To advance the science and practice of consulting chemistry and chemical engineering; to improve the service of the profession and to assist in the dissemination of useful information to its clients, to the public, and to branches of the Government; to promote friendly intercourse and cooperation among the members of the profession in order to further their welfare and to maintain the highest standards of ethics and courtesy; to own and operate buildings, laboratories, instruments, equipment, and facilities for the members in the practice of their profession.

Membership: Members, consulting chemists or chemical engineers actively furnishing professional service as individuals or partners or executives in organizations whose business it is to furnish such service; or qualified persons in responsible control of the chemical business of organizations furnishing general engineering or laboratory service; or qualified chemists and chemical engineers who are employed but practice professionally independently of such employment, maintaining the practice as a separate enterprise under its own distinctive name; members must be at least thirty years of age; Honorary members. Total membership 145.

Meetings: Annual; two additional general meetings.

Publications: Your Consultant, bimonthly, current volume: 11, \$1. Consulting Services, annual, current volume: $17, \$ 1.50$. Editor: C. d'Alexandre.

417. Association of Consulting Foresters. President: Seymour I. Somberg, 100 Rogers Court, Williamsburg, Va. Term expires March 1962.

History: Organized and incorporated 1948.

Purpose: To assure forest owners of competent professional service through maintenance of high standards of performance by consulting 
foresters; to promote the most economical and most scientific management of forest resources.

Membership: Recognized professional training in forestry, plus five years experience, at least one of which has been in consulting work. Total membership 103.

Meetings: Semi-annual.

Professional activities: Award to outstanding forester.

Publications: The Consultant, quarterly, current volume : 2, \$2. Editor: Seymour I. Somberg.

\section{Association of Consulting Management} Engineers, Inc. 347 Madison Avenue, New York 17, N. Y. President: H. B. Maynard, 718 Wallace Avenue, Pittsburgh 21, Pa. Term expires January 1961. Executive Dircctor: Philip W. Shay. Term indefinite.

History: Organized 1929; incorporated 1933. Purpose: To develop, maintain, and enforce high standards of ethical professional practice and rigorous membership requirements, which will make membership in the Association a recognized mark of experience, stability, competence, and reliability; to develop and improve the art and practice of management consultation.

Mcmbership: Open to any management consulting firm in the United States or Canada which has recognized standing in the profession and whose practice conforms to the high standards of ethical and professional practice prescribed by the Association. Total membership 40.

Mectings: Three or more, held annually in New York, Chicago, and Hot Springs, Virginia.

\section{Association of Deans of American Colleges} of Veterinary Medicine. President: E. E. Leasure, School of Veterinary Medicine, Kansas State University, Manhattan, Kans. Term expires August 1961. Secretary- Treasurer: A. H. Groth, School of Veterinary Medicine, University of Missouri, Columbia, Mo. Term expires August 1961.

History: Organized 1937.

Purpose: To discuss mutual problems and to improve the level of training in veterinary medicine.

Membership: Anyone holding the position of Dean or Principle of a School of Veterinary Medicine in the United States and Canada. Deans of Latin American schools were invited to become associate members in 1959. Total membership 20.

Mectings: Annual.

420. Association of Federal Communications Consulting Engineers. President: Robert M. Silliman, 1405 G Street, N. W., Washington
5, D. C. Term expires April-May 1961. Executive Secretary: David L. Steel, Sr., 1413 K Street, N. W., Washington 5, D. C. Term expires April-May 1961.

History: Organized 1948 as an association of consulting engineers practicing before the Federal Communications Commission in matters dealing with radio and television allocations.

Purpose: To aid and promote the proper Federal administration and regulation of the engineering and technical phases of radio communications; to uphold the honor and dignity of engineers before the FCC; to provide for the mutual improvement and social intercourse of the members of the Association.

Membership: Qualified professional radio engineer who devotes a major portion of his time to radio engineering. Must be sponsored by two members who will vouch for his integrity and professional qualifications and must qualify under a point system based upon education and professional experience. A limited number of associate members are admitted from companies interested in radio and television allocation. Active members 40; Associate members 26.

Mcctings: Annual. Additional monthly meetings called by President.

Professional activities: One full engineering scholarship to American University.

421. Association of Food and Drug Officials of the United States. P. O. Box 9095, Austin 17, Tex. President: Evan Wright, Food and Drug Division, State Board of Health, Topeka, Kans. Term expires June 1961. Secretary-Trcasurcr: J. F. Lakey. Term expires June 1963.

History: Organized 1896. Sections: New England, Southern, Central Atlantic States, Central States, North Central States, MidContinental, Western States.

Purpose: To promote enactment and enforcement of uniform legislation for protection of public health and prevention of fraud and deception in the production, distribution, and sale of food products and drugs; to secure adoption of uniform administrative procedure and encourage cooperation among federal, state, county, and municipal officials.

Membership: Regular members, approximately 250, food, drug, and cosmetic enforcement officials; Associate, approximately 200 , persons interested in food and drug work. Total membership approximately 450 .

Mcetings: Annual.

Publications: Quarterly Bulletin, current volume: $24, \$ 3$, free to members. Editor: William Reindollar, Maryland Department of Health, Baltimore, Md. 
422. Association of Iron and Steel Engineers. 1010 Empire Building, Pittsburg 22, Pa. President: S. C. Read, Director Construction and Maintenance, Jones \& Laughlin Steel Corporation, 3 Gateway Center, Pittsburgh, $\mathrm{Pa}$. Term expires December 31, 1960. Managing Director: T. J. Ess. Term indefinite.

History: Organized 1907 as the Association of Iron and Steel Electrical Engineers; name changed August 1936 to present title. Sections : Birmingham, Buffalo, Canton, Chicago, Cleveland, Colorado, Detroit, Los Angeles, Philadelphia, Pittsburgh, St. Louis, San Francisco, Utah, Youngstown.

Purpose: The advancement of the technical and engineering phases of the production and processing of iron and steel.

Membership: Active members, persons engaged in or identified with engineering or operation of the iron and steel or allied industries; Associate; Junior; Honorary. Total membership 8,900.

Meetings: Annual meeting in September; spring conference; western meeting; each section holds monthly meetings October through April.

Profcssional activitics: Funds are appropriated for specific research and educational projects, as approved by the Board of Directors. Kelly Award, a certificate and monetary prize given for the best papers published in the Association's magazine during the year. AISE Merit scholarships.

Publications: Iron and Steel Engineer, monthly, current volume: $37, \$ 7.50$. Editor: T. J. Ess. Proceedings, annually.

423. Association of Life Insurance Medical Directors of America. P. O. Box 594, Newark 1, N. J. President: Ennion S. Williams, Life Insurance Company of Virginia, Richmond, Va. Term expires October 1960. Sccrctary: Royal S. Schaaf. Term expires October 1960.

History: Organized December 6, 1889 ; incorporated July 9, 1902. Sections in the United States and Canada.

Purpose: Promotion of medical science as applied to life insurance.

Membership: Open to medical directors of insurance companies and their medical associates and assistants. Active members; Emeritus; Honorary. Total membership 527.

Mectings: Annual.

Publications: Proceedings, annual, current volume: $44, \$ 5$, free to members.

424. Association of Medical Illustrators. President: Mrs. Angela B. Mailer, Veterans
Administration Research Hospital, 333 East Huron, Chicago, Ill. Term expires October 1, 1960. Corresponding Secretary: Rose M. Reynolds, University of Nebraska College of Medicine, 42nd Dewey Avenue, Omaha 5, Neb. Term expires October 1, 1960.

History: Organized July 1945; incorporated in Illinois.

Purpose: To promote the study and to encourage the advancement of medical illustration and allied fields of visual education; to advance medical education and to promote understanding and cooperation with the medical and related professions.

Membership: Active, 142, medical illustrators who have met and maintained standards approved by this Association; Associate, 20, persons engaged in allied pursuits contributing to the advancement of visual education in the broad field of medicine; Life, any Active members or Associate members who upon election shall make a payment of $\$ 250$; Honorary, 2, persons of distinction who are interested in the welfare of this organization; Emeritus, active members of the Association who shall have reached the age of sixty years and shall have been a member since its organization or for a period of twenty-five years; Benefactor, persons who have rendered illustrious service or notable aid to the Association; Contributing, members of the Association in any category who give financial aid to the Association in addition to the payment of annual dues; Sustaining, 3, societies, firms and foundations which further the work of the Association by financial contributions annually. Total membership 167.

\section{Mcetings: Annual.}

Professional activitics: Association work carried through Commitrees: Professional Relations and Ethics, Council on Education (supervises furnishing of information to those seeking career of medical illustrator and investigates areas related to training), Liason (makes contact with illustrators in medical field throughout the world). Cooperates with American Medical Association in their award for best exhibit presented by medical illustrator at annual American Medical Association meetings. At instigation and with and of the journal, Postgraduate Medicine, the Association presented an exhibit "Medical Illustration Today" at 1958 Association of Medical Illustrators meeting. and subsequently sent to many national and regional meeting at request of various organizations.

Publications: Journal, annual, current volume: 12, \$2. Editor: William A. Osburn, 20 Miller Avenue, Berwyn, $\mathrm{Pa}$. 
425. Association of Military Surgeons of the United States. 1726 Eye Street, N. W., Washington 6, D. C. President: Richard A. Kern, Temple University Hospital, $3+01$ North Broad Street, Philadelphia 40, Pa. Term expires December 1960. Executive Sccretary: George M. Beam. Term indefinite.

History: Organized September 1891, as the Association of Military Surgeons of the National Guard; name changed 1892 to present title. Incorporated by Act of Congress, approved January 1903, authorizing creation of an advisory board consisting of the Secretaries of the Treasury, War and Navy, and the Surgeons General of the three government medical services. Advisory board now consists of Secretaries of Defense, Health, Education and Welfare, Army, Navy, Air Force, the Surgeons General of the four goverment medical services, and the Chief Medical Director of the Veterans Administration.

Purpose: To increase the efficiency of the medical service of the Army, Navy, Air Force, Public Health Service, National Guard, the Reserves of all branches of the medical services of the United States, and Medical Officers of the Veterans Administration by mutual association and the consideration of matters pertaining to medico-military service of the United States both in peace and war.

Membership: Open to those who are or have been at any time commissioned officers (either Regular, Reserve or National Guard) of the Federal Medical Services; duly appointed fulltime civil members of the professional medical staffs of the Army, the Navy, the Air Force, the U. S. Public Health Service, and the Veterans Administration. (Professional medical staffs include physicians, dentists, veterinarians, nurses, dietitians, occupational therapists, physical therapists, and other allied medical professional personnel, including administrators.) Also open to officers of the military medical services of other countries. Classes of membership: active, life, ex-officio, honorary, and sustaining. Total membership 7,000.

\section{Meetings: Annual.}

Professional activities: Sir Henry Wellcome Medal and Prize, awarded annually by the Trustees of the IVellcome Foundation in London for the best essay on a military medical subject submitted in the competitive contest; established in 1916 by Sir Henry Wellcome; consists of a Silver Medal, a scroll, and an honorarium of $\$ 500$. Gorgas Medal, established in 1942 by Wyeth Laboratories of Philadelphia in memory of Major General William Crawford Gorgas; presented annually for distinguished work in preventive medicine for the Armed Forces; consists of a Silver Medal, a scroll, and an honorarium of
\$500. Stitt Award, established in 1954 by the Pfizer Laboratories Division, Charles Pfizer and Company, Inc., in memory of Rear Admiral Edward Rhodes Stitt; made for some meritorious work in the field of antibiotics; consists of life membership in the Association, a bronze plaque, and an honorarium of $\$ 500$. Major Louis Livingston Seaman Prize, established by Major Seaman in 1900; given annually for some notable article published in Military Medicine during the past year; consists of a scroll and an honorarium of $\$ 160$, a sum made possible by funds left to the Association by Major Seaman. The McLester Award, established in 1954 by J. B. Roerig Company Division, Charles Pfizer and Company, Inc. to honor the memory of Colonel James Somerville McLester; presented annually to the person who is, or has been, at any time a commissioned officer, or of relative status in the federal Medical Service, and who has done outstanding work in the field of Nutrition and Dietetics ; consists of a bronze plaque and an honorarium of $\$ 500$. Founder's Medal, authorized by the Executive Council of the Association in May, 1941, to commemorate the 50th anniversary of the founding of the Association; given for outstanding contribution to military medicine and for meritorious service to the Association; recipients chosen by the Executive Council. Sustaining Membership Award, established in 1957, awarded annually to an individual in any of the U. S. Government Medical Services who has made some outstanding contributions in the field of medical research. The Andrew Craigie Award, established in 1959 by the Lederle Laboratories, Division of American Cyanamid Company, to honor the memory of Andrew Craigie, first Apothecary General of the Military forces of United States; unade for outstanding accomplishment in the advancement of professional pharmacy in the federal government.

Publications: Military Medicine, monthly, current volume: $25, \$ 7.50, \$ 6$ to members, plus $\$ 1$ for foreign postage (formerly The Military Surgeon). Editor: Robert E. Bitner.

426. Association of Official Agricultural Chemists of North America, Inc. P. O. Box 540, Benjamin Franklin Station, Washington 4, D. C. President: John B. Smith, Agricultural Experiment Station, Kingston, R. I. Term expires October 1960. Executive Secretary: William Horwitz. Term expires October 1960.

History: Organized September 1884 at Philadelphia, Pennsylvania.

Purpose: To secure, devise, test, and adopt uniform and accurate methods for the analysis of fertilizers, foods, feeding stuffs, dairy products, economic poisons, and other materials relating 
to agricultural pursuits; also medicinal products; cosmetics; and caustic poisons; to secure uniformity in the statement of analytical results; to conduct, promote, and encourage research in chemistry in its relation to agriculture; and to afford opportunity for the discussion of matters of interest to agricultural chemists.

Membership: Active, open to chemists and other workers in analysis and research in the areas mentioned in the Purpose, connected with the following institutions of North America: U. S. Department of Agriculture; any national, state, or provincial experiment station, college, or body engaged in research in agricultural chemistry, or charged with official control of any of the materials named in the Purpose; Associate, open to chemists and other workers in analysis and research in the areas mentioned in the Purpose, connected with municipal laboratories in North America charged with control of any of the materials or subjects named in the Purpose. Chemists engaged in research in agricultural chemistry who are not eligible to active membership, and active members who lose their right to such membership by retiring from the positions indicated as requisite for eligibility, may be elected to associate membership upon recommendation of the Executive Committee. Honorary, upon recommendation of the Executive Committee and two-thirds vote of those present at any regular meeting. Over 100 institutional members; approximately 1,000 attend meetings.

Meetings: Annual.

Publications: Journal, quarterly, current volume: 43, \$10. Editor: Paul A. Clifford. Official Methods of Analysis of the Association, Revised every 5 years, current volume: 8th edition, $\$ 12$. Editor: William Horwitz.

427. Association of Official Seed Analysts. President: C. M. Bass, State Department of Agriculture, 1112 State Office Building, Richmond 19, Va. Term expires June 1961. Secretary-Treasurer: Dwight D. Forsyth, Agronomy Building, Madison 6, Wis. Term expires June 1962.

History: Organized December 31, 1908 at Washington, D. C. Commitrees: Legislative; Referee (promote uniformity among seed laboratories); Research; Rules (development of Rules for Testing Seed); Standardized Tests (for seed analysis).

Purpose: To improve seed testing in all its branches and to make it more useful to agriculture and society.

Membership: Members, 68, official state seed laboratories; associate members, 425 , those who work in such laboratories; Honorary members, 23.

\section{Mectings: Annual.}

Professional activities: Award of Merit, to those individuals who have done outstanding work with seed in research, teaching and technology, and for the Association.

Publications: Proceedings, annual, current volume: 49, \$3.25. Editor: O. L. Justice. News Letter, quarterly, current volume: $34, \$ 2$. Editor: Dan Niffenegger.

428. Association of Pacific Coast Geographers. President: Marion E. Marts, Department of Geography, University of Washington, Seattle 5, Wash. Term expires June 1961.

History: Organized 1935. The Association is the Pacific Coast affiliate of the Association of American Geographers.

Purpose: The promotion of geographic research and the diffusion of geographic knowledge.

Membership: Professional geographers actively engaged in teaching or research in geography, and located in the Pacific Coast area. Total membership 160.

Meetings: Annual.

Publications: Yearbook, current volume: 25, \$2. Editor: Frances Earle.

429. Association of Professional Photogrammetrists. 1346 Connecticut Avenue, N. W., Washington 6, D. C. Executive Secretary: John G. Ladd. Term indefinite.

History: Organized 1951.

Purpose: To promote the science and standards of photogrammetry.

Membership: Must own photogrammetric equipment and employ personnel capable of producing topographic maps, and also own allied equipment such as precision cameras and surveying apparatus; a member company must have produced at least ten accepted topographic maps or allied products by stereo-photogrammetric means, and must employ at least one registered professional engineer full time. Total membership 20 companies.

Meetings: Semiannual.

430. Association of Research Directors. President: Enil Schlittler, Douglas Road, New Vernon, N. J. Term expires May 1961. Secretary-Treasurer: Saul H. Rubin, 62 Beech Street, Nutley, N. J. Term expires May 1961.

History: Organized April 12, 1945.

Purpose: To promote a spirit of professionalism and mutual helpfulness among directors of research and give opportunity for discussion of problems. 
Membership: Requires active direction of research in industrial research organizations or institutes representing industry, with supervision of minimum of ten graduate personnel. Total membership 100.

Meetings: Eight annually.

431. Association of Senior Engineers of the Bureau of Ships. President: Walter W. Kinsinger, Navy Department, Bureau of Ships, Code 456B, Washington 25, D. C. Term expires June 1961. Secretary: J. Lamar Cochran, Navy Department, Bureau of Ships, Code 660M, Washington 25, D. C. Term expires June 1961.

History: Organized in 1946 by and exclusively for civilian engineers of the Bureau of Ships; organizing chairman, Albert A. Smith; first president, John C. Niedermair.

Purpose: To promote and protect the best interests of the government of the United States at all times; to promote the general welfare of the membership professionaily and socially; to foster a spirit of good fellowship and cooperation; and to maintain high standards of professional ethics and competence.

Membership: Full members, male civilian engineers of Grade GS 12 and over, 305; Associate, male individuals of GS 11 and over who are not qualified for full membership, 44; Junior, all requirements of full membership except for grade which shall be at least GS 5, 0; Honorary, granted to engineers of outstanding ability, who are elected by the nembership, 5 . Total membership 354 .

Meetings: Annual and monthly.

Professional activities: Senior Engineer Award for professional achievement (not limited to members of Association, but limited to employees of Bureau of Ships).

Publications: The Senior Engineer, monthly. Editor: Frank Lindenberger.

432. Association of Southeastern Biologists. President: Victor A. Greulach, Department of Botany, University of North Carolina, Chapel Hill, N. C. Term expires April 22, 1961. Secretary: Harold J. Humm, Department of Botany, Duke University, Durham, N. C. Term expires April 22, 1961.

History: Organized in 1937 as a result of an invitational meeting held at the University of Georgia called by Dr. George H. Boyd.

Purpose: To encourage in the broadest and most liberal manner the advancement of biology as a science by the promotion of research in biology ; by the increase and diffusion of knowledge of biology; by emphasis of the relation of fundamental knowledge of biology to the solu- tion of biological problems; by the preservation of biological resources; and by its meetings, reports, discussions and publications to promote scientific interests and inquiry, thereby adding to the health, happiness and knowledge of all peoples.

Membership: Any person who is engaged in (a) biological research, (b) the teaching of biological subjects (c) graduate study in the biological sciences, or (d) work in the various fields of applied biology. Members, in general, shall be residents of the Southeastern States. Total membership 800 .

\section{Meetings: Annual.}

Professional activities: Carolina Biological Supply Company Research Award, to encourage biological research, $\$ 100$; Southern Scientific Supply Company Meritorious Award, for the recognition of outstanding biology teachers in Southeast, \$100; Phipps and Bird Fellowship to Mount Lake Biological Station, to help biology investigators, $\$ 200$; Goethe Travel Awards, to graduate students for payment of expenses of attending annual meetings.

Publications: ASB Bulletin, quarterly current volume: 7, \$2. Editor: C. IV. Hart, Jr., The Academy of Natural Sciences of Philadelphia, 19th and the Parkway, Philadelphia 3, Pa.

\section{Association of Southern Feed, Fertilizer} \& Pesticide Control Officials. President: Bruce Poundstone, Department of Feed and Fertilizer, Kentucky Agricultural Experiment Station, University of Kentucky, Lexington, Ky. Term expires June 1961. SecretaryTreasurer: Maurice B. Rowe, FertilizerMotor Fuels, Division of Chemistry and Foods, Virginia Department of Agriculture, Richmond 19, Va. Term expires June 1961.

History: Organized April 26, 1938 as the Southern Feed Control Officials; name changed to present title June 8, 1950.

Purpose: To promote uniformity in legislation, definitions, standards, rules and regulations governing enforcement of laws relating to manufacture, sale and distribution of feeding stuffs, mineral feeds, livestock remedies and all forms of fertilizers and pesticides in the Southern States.

Membership: Confined to representatives of the federal agencies engaged in feed, fertilizer and pesticide control work, and the states of Alabama, Arkansas, Florida, Georgia, Kentucky, Louisiana, Mississippi, New Mexico, North Carolina, Oklahoma, South Carolina, Tennessee, Texas, Virginia, and West Virginia; the memberships shall be confined to those representatives of the above federal agencies and states charged by law with execution of the laws relating to the manufacture and sale of feeding 
stuffs, mineral feeds, livestock remedies, pesticides and fertilizers; officials of state and federal experiment or research agencies and such deputies as shall be duly designated. Total membership 60 .

Mectings: Annual.

\section{Association of State and Territorial Health}

Officers. 1330 West Michigan Street, Indianapolis 7, Ind. President: Wilson T. Sowder, State Health Officer, State Board of Health, P. O. Box 210, Jacksonville 1, Fla. Term expires October 1960. Secretary-Treasurer: A. C. Offutt, State Health Commissioner, Indiana State Board of Health, 1330 IVest Michigan Street, Indianapolis 7, Ind. Term expires October 1962.

History: Organized March 23, 1942. ComMitTEES: Federal Relations; Environnental Sanitation; Infectious Diseases; Long Term Illness; Maternal and Child Health; Special Health and Medical Services.

Purpose: To facilitate compliance with the statutory requirement that the Surgeon General of the United States Public Health Service and the Chief of the Children's Bureau shall confer with said executive officers at least once each year; and, further, to facilitate consideration of policies of any public or private agency dealing with human health, especially in its interstate or federal relationships.

Membership: Members, 54, executive officers of the departments of health of the several states, territories, and possessions of the United States.

Meetings: Annual.

Professional activities: McCormick Award.

Publications: Proceedings, annual. Editor: A. C. Offutt.

\section{Association of State and Territorial Public} Health Nutrition Directors. President: Frances Shoun, State Department of Public Health, Nashville, Tenn. Term expires 1961. Executive Secretary: Margaret A. Dunham, Division of Health Education, State Board of Health, Indianapolis, Ind. Term expires 1961.

\section{History: Organized December 9, 1952.}

Purpose: To constitute an official body with whom other professiona! groups in public health and related fields can work on nutrition problems and programs of mutual concern, and to serve as a channel through which directors of nutrition programs of the states, territories and possessions of the United States may exchange and share methods, techniques and information for the improvement of public health nutrition services.
Membership: Members, 45, limited to the directors of nutrition in the health departments of the states, territories and the District of Columbia.

\section{Mcctings: Biennial.}

436. Association of Teachers of Mathematics in New England. President: Rev. Stanley J. Bezuszka, S. J., Boston College, Chestnut Hill 67, Mass. Term expires May 1961. Secretary: Barbara B. Betts, D. C. Heath and Company, 285 Columbus Avenue, Boston 16, Mass. Term expires May 1961.

\section{History: Organized April 1903.}

Purpose: To increase interest in the science of mathematics; to secure improvements in the methods of mathematical teaching and in the selection of subject matter; and to establish close relations with cognate lines of work.

Membcrship: Interest in mathematics and in the teaching of mathematics at any level, elementary through college. Total membership 1,050.

Mectings: Five meetings during the school year and a week-long Institute in August.

Publications: Newsletter, 5 times a year. Editor: Geraldine D. Smith.

\section{Association of Teachers of Preventive}

Medicine. President: William L. Fleming, University of North Carolina School of Medicine, Chapel Hill, N. C. Term expires October 1960. Sccretary-Treasurer: Milton Terris, Tulane University School of Medicine, New Orleans, La. Term expires October 1960.

History: Founded in 1942 as the Conference of Professors of Preventive Medicine; name changed in 1954 to present title. Committees: Medical Care Teaching; Research and Training.

Purpose: The development of instructional and scientific skills and knowledge in the field of preventive medicine.

Membership: Members, 382, persons who are engaged in instruction of medical students, or who have interest, skill, or special training in preventive medicine.

Meetings: Annual.

Publications: Newsletter, 3 times a year, current volume : 7. Editor: Duncan Clark.

438. Association of the Schools of Public Health, Inc. President: James Crabtree, Graduate School of Public Health, University of Pittsburgh, Pittsburgh, Pa. Term expires April 1961. Secretary-Treasurer: Vlado Getting, 3520 School of Public Health, University of Michigan, Ann Arbor, Mich. Term expires April 1961. 
History: Organized 1941; incorporated 1959. Committees: Health Education; Research.

Purpose: The exchange of information of mutual interest concerning the graduate education of professional personnel for service in public health, and the promotion and improvement of the education and training of such personnel.

Membership: Open to institutions which are conducting schools or departments devoted to graduate teaching in public health. Total membership 13.

Mectings: Annual.

439. Association of Universities for Research in Astronomy, Inc. 950 North Cherry Avenue, Tucson, Ariz. President: C. D. Shane, Lick Observatory, Mt. Hamilton, Calif. Term expires December 1961. Secretary: James M. Miller, Assistant Vice President, Governmental Relations and Projects, University of California, Berkeley 4, Calif. Term expires December 1961.

History: Originally financed as a National Science Foundation grant to the University of Michigan. Corporation formed October 27, 1957 by the following universities: California, Chicago, Harvard, Indiana, Michigan, Ohio State, IV isconsin. Princeton University and Yale University subsequently joined the Corporation. Financed under contract between Association of Universities for Research in Astronomy, Inc. and the National Science Foundation, original contract signed December 1957.

Purpose: To install and operate the Kitt Peak National Observatory, Arizona, funded by the National Science Foundation.

Membership: Limited to (a) those universities offering the doctorate in astronomy and (b) by invitation of the Corporation. Board of Directors consists of 18 members, plus 3 Directors-at-Large.

Mectings: Annual.

Library: 2,250 volumes; subject emphasis: astronomy, with minor in mathematics and physics.

440. Association of Vitamin Chemists. 2549 West 63rd Street, Chicago 29, I11. President: Buford H. Barrows, Hales and Hunter Company, 140th Street and Stewart Avenue, Riverdale 27, I11. Term expires May 1961. Secretary: H. F. Bernholdt, Swift and Company, Research Laboratories, Chicago 9, Ill. Term expires May 1961.

History: Incorporated as a non-profit scientific organization in 1944.

Purpose: To provide a medium for the interchange of ideas and information pertinent to vitamin chemistry and technology; to stimulate the study of vitamin methodology; and to increase the fund of knowledge pertaining to vitamins.

Membership: Must have an academic degree in the basic or applied sciences or the equivalent in experience, and two years experience in the field of vitamin chemistry, technology, nutrition or related fields. Total membership 150 .

Publications: Vitamin Abstracts, quarterly, current volume: $13, \$ 4$ members, $\$ 6$ non-members. Editor: O. F. Hixson.

\section{Astronomical League. Science Service} Building, Washington 6, D. C. President: Norman C. Dalke, 8017 Stroud Avenue, Seattle 3, Wash. Term expires September 1, 1961. Executive Secretary: Wilma A. Cherup, 4 Klopfer Street, Millvale, Pittsburgh 9, Pa. Term expires September 1, 1962.

History: Organized July 1946; incorporated in the District of Columbia 1948. Sections: Great Lakes, Middle East, Mid-States, Mountain Astronomical Research Society, North Central, Northeast, Northwest, Southeast, Southwest. CommitteEs: Book Service, Education, Instruments Section, Junior Activities, Observing, Slide and Tape Service.

Purpose: To promote the science of astronony ; to encourage and coordinate activities of amateur astronomical societies; to foster observational and computational work and craftsmanship opportunities in various fields of astronomy; to correlate amateur activities with professional research.

Membership: Meinber organizations, 133, with bona fide interest in astronomy; Junior member organizations, 16, of high school age or younger, with interest in astronomy; Members-at-Large, 34 , open to those from areas where no societies exist; Affiliates, 2, vational astronomical societies; Patrons, individuals and organizations; Supporting, commercial corporations. Total membership 149 organizations, comprising approximately 7,500 individuals.

Meetings: Annual.

Professional activities: Astronomical League Award to persons who have furthered the interest of amateur astronomy.

Publications: Reflector, five issues annually, current volume: 10, free to members. Editor: Christine H. MacGill, 3776 Southwest 28th Street, Miami 34, Fla. Convention Proceedings, annual, current volume: $14, \$ 1.50$. Editor: Edwin F. Bailey.

442. Astronomical Society of the Pacific. Golden Gate Park, San Francisco, Calif. President: Seth B. Nicholson, Mt. IVilson and Palomar Observatories, Pasadena, Calif. Term expires 
February 1961. Secretary-Treasurer: Sturla Einarsson, Leusehner Observatory, University of California, Berkeley, Calif. Term indefinite.

History: Founded in 1889.

Purpose: To promote the science of astronomy and to spread astronomical information through its publications, lectures, and meetings.

Membership: Open to anyone interested in astronomy. Lay Members, 500; Astronomers, 300 ; Institutional Members, 500. Total membership 1,300 .

Meetings: Annual.

Professional activities: Catherine Wolfe Bruce Gold Medal, awarded annually for distinguished services to astronomy; public lectures within the state of California, supported by income from the Alexander F. Morrison Foundation.

Publications: Publications, bimonthly, current volume: 72, $\$ 6.50$. Editor William P. Bidelman. Leaflet, monthly, current volume: 8. Editor: Alfred H. Joy.

443. Atlanta Radiological Society. 300 Boulevard, N. E., Atlanta 3, Ga. President: James V. Rogers, 2461 Tanglewood Road, Atlanta, Ga. Term expires April 1961. SecretaryTreasurer: Wilson T. Edenfield, 2021 Continental Drive, Atlanta 6, Ga. Term expires April 1961.

History: Organized September 8, 1950.

Purpose: To advance the quality of radiology in the Atlanta area.

Membership: Active, 38, those in practice of radiology or radiologic physics; Associate, 12, those in resident training in radiology.

Meetings: Monthly.

444. Atlantic Deeper Waterways Association. Bourse Building, Philadelphia 6, Pa. President: E. M. Keely, P. O. Box 58, Lederach, $\mathrm{Pa}$. Term expires August 31, 1962. Executive Secretary: W. A. Glenn, P. O. Box 1261, Camden 5, N. J. Term expires August 31, 1962.

\section{History: Organized 1907.}

Purpose: Development and improvement of inland waterways.

Membership: Only requirement is interest in purpose of this Association. Total membership 75.

Meetings: Annual.

445. Atomic Industrial Forum, Inc. 3 East 54th Street, New York 22, N. Y. President: Francis K. McCune, General Electric Company, 570 Lexington Avenue, New York 22, N. Y. Term expires December 15, 1960.
Executive Manager and Secretary: Charles Robbins. Term expires December 15, 1960.

History: Incorporated April 10, 1953.

Purpose: To foster the development and utilization of the constructive applications of atomic energy in accordance with the best traditions of American democracy and free competitive enterprise.

Membership: Available to organizations and citizens of the United States and other countries. Organization members, 454, business organizations engaged in all phases of atomic energy research, development and application, plus other agencies or groups interested in the nuclear field, such as educational institutions, labor unions and government agencies; Individual members, 1,645 .

Meetings: Annual.

Publications: Memo to Members, monthly, current volume: $7, \$ 15$ (members only). Editor: J. R. Barlow.

Library: Official Atomic Energy Commission depository of industrial information, with more than 25,000 AEC reports, and an extensive collection of atomic energy literature and periodicals.

446. Audio Engineering Society. P. O. Box 12, Old Chelsea Station, New York 11, N. Y. President: Harry L. Bryant, Radio Recorders, 7000 Santa Monica Boulevard, Hollywood 38, Calif. Term expires October 1960. Secretary: C. J. LeBel. Term expires October 1960.

History: Organized 1948. Sections: Central New York, Japan, Los Angeles, New York, Pittsburgh, San Francisco. Student Sections: Indiana Technical College, Rensselaer Polytechnic Institute, Southern University.

Purpose: The advancement of the theory and practice of audio engineering and its closely related arts, and the dissemination of important information in this field.

Membership: Members, 1,164, persons active in audio engineering who have academic degrees, or the equivalent in scientific or professional experience in the field of audio engineering and its allied arts, and who are familiar with the application of engineering principles and data in that field; Associates, 730, persons interested in the objectives of the Society; Students, 235, those interested in audio engineering and enrolled in a recognized school, college or university; Honorary, 25; Fellows, 96. Total membership 2,250.

Meetings: Semiannual.

Professional activitics: John $\mathrm{H}$. Potts $\mathrm{Me}-$ morial Award, for outstanding work in the field of audio engineering. Emile Berliner 
Award, to recognize outstanding developments in audio engineering. Audio Engineering Society Award, to the person whose work has helped most the advancement of the Society.

Publications: Journal, quarterly, current volume: 8, \$8. Editor: Walter H. Erikson.

447. Avicultural Society of America. President: Rae V. Anderson, 13339 Marjay Drive, Lakeside, Calif. Term expires December 31, 1960. Secretary: Otis IVade, 1806 Redesdale Avenue, Los Angeles 26, Calif. Term expires December 31, 1960.

\section{History: Founded October 19, 1927.}

Purpose: To encourage study, care, and breeding of desirable foreign aviary birds and dissemination of knowledge so gained.

Membership: Open to persons actively interested in the purpose of this Society. Total membership approximately 200 .

Mectings: Monthly.

Publications: Avicultural Bulletin, monthly, free to members. Editor: Mrs. Kay W'agner.

448. Battle Creek Engineers' Club. President: Roger B. Miller, 627 Eastfield Drive, Battle Creek, Mich. Term expires August 1961. Secretary-Treasurer: William C. Storey, 177 Lincoln Hill Drive, Battle Creek, Mich. Term expires August 1961.

History: Founded 1938; affliated with Michigan Engineering Society 1942; incorporated as a non-profit organization in 1949. CommitteE: Vocational Guidance.

Purpose: To promote the social, economic and technical interests of its membership, and to promote civic activity and public service among its members.

Membership: Regular Members, 328, open to persons over 21 years of age, with bachelor's degree in engineering, architecture, or allied arts and sciences, or who, through practical experience, have acquired equivalent technical knowledge, or who are legally registered professional engineers, architects, or land surveyors, or who are regularly engaged in direction or prosecution of engineering, architecture, or allied arts and sciences; Life Members, 2, persons who, by their efforts in the interest of the organization, have contributed to its growth and prestige, have raised the standards of the engineering profession in the community, and have contributed to the welfare of the community, who have reached the age of 50 and have been members ten consecutive years; Retired Members, 8, persons who have been retired from active participation in their profession, have reached the generally accepted retirement age, and have been members five consecutive years; Honorary
Members, 3, persons whose attainments in engineering, architecture, chemistry or allied arts and sciences have given them acknowledged eminence. Total membership 341 .

Meetings: Monthly.

Professional activities: Engineering refresher course; Jetts Clubs; awards scholarship to a student at Kellogg Community College who is interested in science.

449. Beaumont Geological Society. P. O. Box 2831, Beaumont, Tex. President: IV. IV. Rangeler. Term expires June 1961. Executive Secretary: A. M. Borland. Term expires June 1961.

History: Founded May 19, 1954.

Purpose: Dissemination of knowledge to those interested in oil industry.

Membership: Persons actively engaged in geological or geophysical professions, or engaged in related activities. Total membership 67.

Meetings: Monthly except summer.

450. Beta Beta Beta. President: H. P. Sturdivant, Western Maryland College, Westminster, Md. Term expires January 1962. Secretary: Mrs. Frank G. Brooks, P. O. Box 515, Ansonia Station, New York 23, N. Y. Term expires January 1962.

History: Organized 1922 as an honorary biological society. 135 chapters.

Purpose: To stimulate sound scholarship, disseminate scientific knowledge, and promote biological research.

Membership: Active and Honorary members.

Total membership 23,650.

Meetings: Biennial.

Professional activities: McClung Research Award, for undergraduate competition; Frank G. Brooks Essay Awards. Both awards annual.

451. Bibliographical Society of America. P. O. Box 397, Grand Central Station, New York 17, N. Y. President: Frederick B. Adams, Jr., Pierpont Morgan Library, New York, N. Y. Term expires 1964. Secretary: Edwin Wolf II, Library Company of Philadelphia, Philadelphia, Pa. Term expires 1964.

History: Organized 1904 as successor to Bibliographical Society of Chicago, which was organized in 1899; incorporated 1927.

Purpose: To promote bibliographical research and to issue bibliographical publications.

Membership: Open to any individual interested in bibliographical research. Total membership 1,100 .

Meetings: Semiannual. 
Publications: Papers, quarterly, \$7. Editor: Robert F. Metzdorf, Yale University Library, New Haven, Conn.

\section{Billings Geological Society. President:} James H. Clement, P. O. Box 2547, Billings, Mont. Term expires October 5, 1960. Executive Secretary: Clarence L. Harr, P. O. Box 844, Billings, Mont. Term expires October 5, 1960.

History: Organized 1950, at Billings, Mont.; incorporated in Montana 1955. Membership covers all of Montana. Committees: Advisory, to Montana Gas and Oil Commission; Boy Scout; Education; Employment Counseling; Geological Field Conference; Oil and Gas Field of Montana; Stratigraphic and Nomenclature.

Purpose: To promote interest and research in geology and allied sciences, and in their practical application, and to encourage cooperation among members.

Membership: Active members must be college graduates with majors in geology, and must have three years'experience in petroleum geology or in application of geology to exploration and development, research, or other phases of petroleum technology; Junior, must have one half year of graduate study in geology as regularly enrolled student, or bachelor's degree plus one year's experience and be engaged in graduate studies, teaching, or petroleum exploration or research. Total membership 300 .

Meetings: Weekly, September through May.

Professional activities: Vernon Gilles Memorial Fund, Montana School of Mines (in conjunction with Northern Pacific Railway).

Publications: Guidebook, annual, current volume : $11, \$ 8.50$.

\section{Bio-Dynamic Farming and Gardening}

Association, Inc. Threefold Farm, Spring Valley, N. Y. President: Ralph Courtney, Hungry Hollow Road, Spring Valley, N. Y. Term expires July 1961. Secretary: Mrs. J. I. Porter, R.F.D. 1, Dover Plains, N. Y. Term expires July 1961.

History: Organized January \&, 1938; incorporated in New York, 1938.

Purpose: To promote research in soils, humus and compost; to further soil conservation and increased fertility to improve nutrition and health; to spread accurate knowledge and correct application of the bio-dynamic method through lectures, agricultural courses, literature, consultation with farmers.

Membership: Active members, working with any phase of agriculture, applied or scientific, soil and crop improvement; Supporting members. Total memberslip approximately 1,000.

\section{Mectings: One to three annually.}

Professional activities: Research Laboratory: Soil microbiology, humus, plant growth, nutritious value of crops, protein and amino acids, basic research, budget $\$ 25,000$ to $\$ 35,000$.

Publications: Bio-Dynamics, quarterly, current volume: $54, \$ 2$. Editor : Frederick Heckel.

Library: 1,000 volumes. Subject emphasis: Chemistry, biochemistry, plant sciences.

454. Biological Photographic Association, Inc. President: Verlin Y. Yamamoto, Medical Illustration Service, Veterans Administration Center, Des Moines, Iowa. Term expires December 31, 1960. Executive Secretary: Mrs. Jane W. Crouch, P. O. Box 1668, New York 17, N. Y. Term expires December 31, 1960.

History: Founded at New Haven, September 1931. Chapters: Boston, Charleston (S. C.), Chicago, Cleveland, Detroit, Indianapolis, Kansas City (Kans.), Los Angeles, Memphis, Milwaukee, Montreal, New York, Philadelphia, Rochester (Minn.), Rochester, (N. Y.), Salt Lake City, San Francisco, Seattle, Washington (D. C.).

Purpose: To advance the technique of biological photography and foster exchange of ideas among members.

Membership: Requires interest in photography of medical or biological material. Active members, 800 ; Fellows, 76; Sustaining members, 19. Total membership 895.

\section{Meetings: Annual.}

Professional activities: Louis Schmidt Award, annual, to outstanding member for contributions to progress of biological and medical photography and for valued service to Association. Awards of merit are made for medical motion pictures, black and white and color photographs of medical and biological subjects.

Publications: Journal, quarterly, current volume : 28, United States and Canada $\$ 9$, foreign \$9.50. Editor: Leo C. Massopust, Sr.

455. Biological Society of Washington. Presidcnt: David H. Johnson, Division of Mammals, U. S. National Museum, Washington 25, D. C. Term expires June 1961. Secretary: John L. Paradiso, Room 61, U. S. National Museum, Washington 25, D. C. Term expires June 1961.

\section{History: Organized 1880.}

Purpose: The increase and diffusion of biological knowledge.

Mcmbcrship: Persons who are interested in biological science. Total membership 435 .

Meetings: Irregular. 
Publications: Proceedings, irregular, current volume: 72, \$5. Editor: Henry IV. Setzer.

456. Biological Stain Commission, Inc. University of Rochester Medical Center; Rochester 20, N. Y. President: R. D. Lillie. Term expires Spring 1961. Secretary: Victor M. Enmel. Term expires Spring 1961.

History: Organized November 5, 1921, as a Committee of the Division of Biology and Agriculture of the National Research Council; reorganized in 1922 as a separate body, and name changed to Commission on Standardization of Biological Stains; incorporated under University of the State of New York and name changed to present title in 1944.

Purpase: Standardization of biological stains; to this end Commission carries on investigations looking toward perfecting of supply of biological stains and development of new uses for them; brings about cooperation between manufacturers, dealers, and users of stains; publishes scientific data relating to nature and use of biological stains; issues statements of certification to manufacturers and conducts investigations in related fields.

Membership: Regular, on invitation only, 100 ; Delegates, by appointment from other scientific organizations, 15. Total membership 115.

Meetings: Annual.

Professional actizities: Principal funds are obtained from fees charged dye manufacturers. Research and Assay Laboratory maintained at University of Rochester Medical Center.

Publications: Stain Technology, bimonthly, current volume: $35, \$ 6.50$.

457. Biometric Society. President: Leopold Martin, 165 Avenue du Domaine, Brussels, Belgium. Term expires December 31, 1960. Secretary: M. J. R. Healy, Rothamsted Experiment Station, Harpenden, Hertfordshire, England. Term expires December 31, 1960. Treasurer: A. W. Kimball, P. O. Box 10088, Knoxville, Tenn. Term expires December 31, 1960.

History: Organized September 6, 1947, at an International Biometric Conference arranged by a committee of the Biometrics Section of the American Statistical Association, formed in 1938. The Society has official relations with the World Health Organization and consultative status with the Economic and Social Council of the United Nations. It is affiliated with the International Statistical Institute and the International Union of Biological Sciences, in which it constitutes the Section on Biometry. Regions : Eastern North American, including Canada (see below); Western North American, including Canada (see below); Australasian; Belgian;
Brazilian; British; Région Française; German ; Italian; Japanese; At Large. National secretaries serve India, Denmark, Netherlands, Sweden, and Switzerland.

Purpose: The advancement of quantitative biological science through development of quantitative theories, and the application, development, and dissemination of effective mathematical and statistical techniques.

Membership: Total membership approximately 1,900 .

Mcetings: Quinquennial.

Publications: Biometrics, quarterly, current volume: 16, \$7. Editor: R. A. Bradley.

\section{Eastern North American Region}

President: W. T, Federer, Warren Hall, Cornell University, lthaca, N. Y. Term expires December 1960. Secretary-Treasurer: M. A. Kastenbaum, P. O. Box 2017, Oak Ridge, Tenn. Term expires December 1960.

History: Organized December 30, 1947. The Region is an affiliated society of the American Association for the Advancement of Science, and is a member of the Division of Biology and Agriculture and of the Division of Mathematics of the National Research Council. It comprises areas east of the Rocky Mountains in the United States and Canada.

Membership: Members, 821; Sustaining, 10. Total membership 831 .

Meetings: Annual.

\section{Western North American Region}

President: William F. Taylor, School of Public Health, University of California, Berkeley, Calif. Term expires December 1960. Secretary: Walter A. Becker, Western Washington Experiment Station, Puyallup, Wash. Term expires December 1960. Treasurer: Mrs. Bernice Brown, 3732 Beethoven Street, Los Angeles 66, Calif. Term expires December 1960 .

History: Organized June 1948. The Region comprises the areas of the United States and Canada west of the Rocky Mountains.

Membership: Total membership 160.

Meetings: Annual.

458. Biophysical Society. President: Ernest C. Pollard, Department of Biophysics, Yale University, New Haven 11, Conn. Term expires February 1961. Executive Secretary: Samuel A. Talbot, Biophysical Division, Department of Medicine, Johns Hopkins Hospital, Baltimore 5, Md. Term expires February 1961. 
History: Formed Columbus, Ohio, 1957.

Purpose: To encourage development and dissemination of knowledge in biophysics.

Memborship: Requires interest in biophysics, and sponsorship by two members as a scientist with experience in biophysics or allied fields. Total nembership 800 .

Mcetings: Annual.

Professional activities: Educational lectureships, placement bureau.

Publications: Biophysics Journal, bimonthly, current volume: 1 , \$6. Editor: F. Brink.

459. Blood Transfusion Association. 139 East 23rd Street, New York, N. Y. President: Murray Sargent, 21 East 89th Street, New York, N. Y. Term expires 1961. Secretary: John H. Hayes, 181-40 Kruger Road, Jamaica 3, N. Y. Term expires 1961. Exccutive Director: Jacob Geiger, 1070 Park Avenue, New York, N. Y. Term indefinite.

History: Incorporated 1929 as Blood Transfusion Betterment Association; name changed to present title 1941. Committees: Board of Medical Control; Research Grants.

Purpose: Advancement of science of blood transfusion and blood banking; supply of properly processed blood from carefully selected donors to hospitals in metropolitan area; preparation and distribution of grouping and anti-Rh sera, and human precipitin sera; preparation and distribution of fresh frozen plasma for treatment of hemophilia for which license was issued by National Institutes of Health 1954.

Membership: Active and Associate members, and Patrons. Total membership ten hospitals in New York metropolitan area.

\section{Mectings: Annual.}

Professional activitics: Research grants are made for study projects in field of blood and substitutes. Laboratory maintained at organization address, with staff of thirty-two.

460. Boston Society of Architects. President: Edwin T. Steffian, 11 Beacon Street, Boston 8, Mass. Term expires May 1961. Executive Secretary: Francis B. Sellew, 283 Dartmouth Street, Boston, Mass. Term expires May 1962.

History: Founded 1867. Chartered by American Institute of Architects 1870; incorporated 1889; relinquished Institute charter to Massachusetts State Association of Architects, 1948; has since carried on independently.

Purpose: To unite architects of Boston area and combine efforts to promote artistic, scientific, and administrative efficiency of profession.
Mcmbership: Requires practice of profession in accordance with standards set by American Institute of Architects; Emeritus, age 70, with at least ten years' membership; Honorary, nonarchitect of esteemed character who has rendered distinguished service to profession or allied arts and sciences. Regular, 192; Emeritus, 22; Honorary, 5. Total membership 219.

\section{Meetings: Three annually.}

Professional activities: Rotch Travelling Scholarship to send competent students to Europe for travel and study; B. S. A. Travelling Scholarship for students of Boston Architectural Center; Harleston Parker Medal for most beautiful building in Boston area. All awards annual.

Publications: Bulletin, five annually, current volume: 45. Editor: James C. Hopkins.

461. Boston Society of Civil Engineers. 20 Pemberton Square, Boston 8, Mass. President: Arthur T. Ippen, Hydrodynamics Laboratory, Massachusetts Institute of Technology, Cambridge 39, Mass. Term expires March 15, 1961. Secretary: Charles O. Baird, Jr., Northeastern University, Boston 15, Mass. Term expires March 15, 1961.

History: Organized July 3, 1848 ; incorporated April 24, 1851. Sections: Sanitary; Structural; Transportation; Hydraulics; Surveying and Mapping; Construction.

Purpose: Professional improvement of members, encouragement of social intercourse among engineers and men of practical science, and the advancement of engineering.

Membership: Member, four years of active practice in an engineering or technical profession, minimum age 24 years; Junior Member, engaged in active practice of some branch of engineering or other technical profession, or graduate of a school of engineering of recognized standing, minimum age 20 years; Student Member, student in school of engineering of recognized standing. Resident members, 795; Non-Resident, 200 ; Resident Junior, 66; Non-Resident Junior, 14 ; Associate, 6; Student, 9. Total membership 1,100 .

Mcetings: Monthly, except July and August. Professional activities: John R. Freeman Fund, Scholarship Award, for encouragement of younger engineers, capital $\$ 25,000$. Desmond Fitzgerald Medal, awarded for best paper presented during year. Clemens Herschel Award, for commendable papers presented during year.

Publications: Journal, quarterly, current volume: $47, \$ 6$, free to members. Editor: Charles E. Knox. 
462. Boston Society of Psychiatry and Neurology. Massachusetts General Hospital, Boston 14, Mass. President: H. Thomas Ballantine. Term expires January 1961. Executive Secretary: E. P. Richardson, Jr. Term expires January 1961.

\section{History: Organized 1880.}

Purpose: Promotion of study of all subjects pertaining to science of psychiatry and neurology.

Membership: Active membership limited to persons whose interests and activities are in psychiatry, neurology, or associated fields, presumed in permanent practice or other activity in general vicinity of Boston. Regular members, 147; Life, 16; Honorary, 9; Out-of-State, 7; Associate, 1. Tota! membership 180.

Mectings: Monthly, October through May.

463. Boston Surgical Society, Inc. President: Robert R. Linton, 1180 Beacon Street, Boston, Mass. Term expires January 1, 1961. Secretary: John J. Byrne, 818 Harrison Avenue, Boston 18, Mass. Term expires January 1, 1961.

History: Incorporated November 25, 1914, under laws of Massachusetts.

Purpose: To advance the science and art of surgery, and to create intellectual and social relationship between members.

Membership: Requires certification by American Board of Surgery or American Board in specialty selected; must be Fellow of American College of Surgeons; must have unqualified professional record in his community and have made significant contribution to advancement of art of surgery in a Boston hospital or medical school. Total membership 315 .

Mectings: Five annually, November through April.

Professional activities: Henry Jacob Bigelow Fund, capital $\$ 5,234$. Henry Jacob Bigelow Medal.

464. Botanical Society of America, Inc. President: Kenneth V. Thimann, Biological Laboratories, Harvard University, Cambridge, Mass. Term expires December 31, 1960. Secretary: B. L. Turner, Botany Department, University of Texas, Austin 12, Tex. Term expires December 31, 1964.

History: Organized 1906; incorporated 1939. Geographic Sections: Northeastern; Central States; Southeastern; Pacific. Topical SecTrons: Developmental; General; Microbiological ; Paleobotanical; Phycological; Physiological; Systematic; Teaching. Committees : Edu- cation; Guidance and Counseling; Use of Botanists in National Emergency.

Purpose: Scientific and educational advancement in field of botany.

Membership: Requires interest in field of botany, professional or otherwise. Corresponding members elected by society as distinguished botanists. Active members, about 2,000 ; Retired, about 350, Corresponding, 36. Total membership about 2,400.

\section{Meetings: Annual.}

Professional activities: Meritorious Awards, annual, to one or two American botanists of outstanding calibre. Support, every one or two years, of a Summer Institute of Botany for Teachers at Small Colleges.

Publications: American Journal of Botany, monthly except July and August, current volume: $47, \$ 12$, free to members. Editor H. C. Bold. Year Book, biennial, \$5, free to members.

465. Botanical Society of Washington. Cosmos Club, Washington 7, D. C. President: Harold T. Cook, Agricultural Marketing Service, U. S. Department of Agriculture, Washington 25, D. C. Term expires December 31, 1960. Secretary: Muriel J. O'Brien, Agricultural Research Service, Crops Research Division, U.S. Department of Agriculture, Washington 25, D. C. Term expires December 31, 1960.

History: Organized November 1901 by union of Botanical Seminar, organized 1893, and Washington Botanical Club, organized 1898.

Purpose: Exposition and discussion of botanical investigations, cultivation of social relations among members, and promotion of botanical activities in Washington metropolitan area.

Menbership: For residents of Washington or vicinity. Active members, 187; Honorary, 84; on Absentee list, 132. Total membership 403.

Meetings: Monthly, October through May.

466. Botanical Society of Western Pennsylvania. Herbarium Room, Carnegie Museum, Pittsburgh 13, Pa. President: O. E. Jennings. Term expires October, 1960. Corresponding Secretary: L. K. Henry. Term expires October, 1960.

History: Organized October, 1886; incorporated.

Purpose: To bring together people who are interested in botany.

Membership: Requires interest in botany and recommendation by two members. Total membership 160 .

Meetings: Monthly except July and August. 
Publications: Trillia, infrequent, price varies. Editor: L. K. Henry.

467. Branner Geological Club of Southern California. President: Wayne Loel, 1505 Chelsea Road, San Marino, Calif. Term expires Spring 1961. Secretary-Treasurer: Lucy E. Birdsall, U. S. Geological Survey, 215 West 7th Street, Los Angeles, Calif. Term expires Spring 1961.

History: Organized July 1921.

Purpose: To foster study of geology, cooperate with kindred associations, and promote fellowship among geologists.

Membership: Active nembers, recognized geologists or petroleum engineers; Honorary. Total membership 200.

Mectings: Two or three annually.

468. Bronx District Branch, American Psychiatric Association. President: William E. Sorrel, 263 West End Avenue, New York 23, N. Y. Term expires May 31, 1961. Excutive Secretary: Hiland Flowers, 2780 Arlington Avenue, Bronx, N. Y. Term expires May 31, 1961.

\section{History: Organized 1946.}

Membership: Requires membership in American Psychiatric Association, medical practice limited to psychiatry, diplomate of American Board of Neurology and Psychiatry, or certified as qualified psychiatrist by New York State Departinent of Mental Hygiene. Total membership 90.

Meetings: Bimonthly.

Professional activities: Scientific lectures to the medical profession.

469. Bronx Society of Neurology and Psychiatry, Inc. President: William E. Sorrel, 263 West End Avenue, New York 23, N. Y. Term expires May 31, 1961. Executive Secretary: Hiland Flowers, 2780 Arlington Avenue, Bronx, N. Y. Term expires May 31, 1961.

History: Chartered in 1946.

Mcmbership: Requires practice limited to neurology, psychiatry, or neurosurgery, part of practice being in Bronx, N. Y., or on staffs of Bronx hospitals. Total membership 92.

Mectings: Bimonthly.

Professional actizities: Lectures on psychiatry to laiety.

470. Brooklyn Engineers' Club. 117 Remsen Street, Brooklyn 1, N. Y. President: Raymond Mirrer. Term expires May 1961. Executize
Secretary: Steve S. Freeman. Term expires May 1961.

History: Organized October 9, 1896; incorporated December 29, 1896.

Purpose: To promote social and professional intercourse, to advance engineering knowledge and practice, and to maintain a high standard of professional procedure.

Membership: Requires engagement in engineering, construction, manufacturing, or any allied science or profession. Corporate members, 290 ; Fellows, 55 ; Life members, 22 ; Non-resident, 5. Total membership 372.

Meetings: Monthly, October through May.

Professional activities: Engineer of the Year Award; professional engineering licensure training course; presentation of technical papers at monthly meetings.

Publications: Brooklyn Engineer, monthly, current volume: 64 , free to selected list. Editor : Nicholas Arteca.

Library: 4,000 volumes. Subject emphasis: Varied technical.

471. Brooklyn Entomological Society. Engineers' Club, 117 Rensem Street, Brooklyn 2, N. Y. President: Harry Betros, 280 Brighton Street, Tottenville, Staten Island, N. Y. Term expires May 1961. Secretary: Miss Anna M. Flaherty, 69-51 62nd Street, Ridgewood 27, N. Y. Term expires May 1961.

History: Organized 1872; incorporated January 1885; reincorporated February 1936.

Purpose: To promote the science of entomology.

Menbership: Requires interest in the science of entomology and all its branches. Total membership 34 .

Mectings: Monthly October to May.

Publications: Bulletin, five annually, current volume: 60, \$4. Editor: John Hanson, University of Massachusetts, Amherst, Mass. Entomologica Americana, annual, current volume: 40, \$6. Editor: James Slater, University of Connnecticut, Storrs, Conn.

472. Brooklyn Psychiatric Society (Brooklyn District Branch, American Psychiatric Association). President: Abbott A. Lippman, 929 Albemarle Road, Brooklyn 18, N. Y. Term expires May 1, 1961. Secretary: Morton M. Golden, 7 Montague Terrace, Brooklyn 1, N. Y. Term expires May 1, 1961.

History: Founded 1949.

Purpose: To promote highest scientific standards among Brooklyn physicians qualified to engage in practice of psychiatry. 
Membership: Requirements: Associate member, at least one year residency in psychiatry; Full member, three years residency plus three years full time practice of psychiatry. Total memberslip 149.

Meetings: Four annually.

Professional activities: Scientific forums, speakers for laity, seminars for general practitioners, liaison with mental health agencies, consultants with Kings County Medical Society.

Publications: Directory of Psychiatrists, quinquennial, current volume: 2, \$1. Editor: Milton Kurian, 33 East 16th Street, Brooklyn 26, N. Y.

\section{Brooklyn Psychological Association. Exec-} utive Secretary: Irene H. Impellizzeri, 205 Clinton Avenue, Brooklyn 5, N. Y. Term expires September 1961.

History: Incorporated (New York) September 16,1954 . Generally patterned along the lines of the New York State Psychological Association.

Purpose: In cooperation with the State, regional, and national associations, to unite the psychologists of Brooklyn and its environs; to promote the development of psychology as a science and a profession.

Membership: Full membership, completion of two years of graduate work in psyclology in a recognized graduate school, or one year of study plus one year of experience in professional work of psychological nature; Affiliate, students who have completed eighteen points of graduate study in psychology. Total membership approximately 150 .

Meetings: Five or six annually.

Publications: Brooklyn Psychologist, current volume: 2, free to members. Editor: Emerson Coyle.

474. Building Research Institute, Division of Engineering and Industrial Research, National Academy of Sciences-National Research Council. 2101 Constitution Avenue, N. W., Washington 25, D. C. President: Harold L. Humes, Baldwin-Ehret-Hill, Inc., 500 Breunig Avenue, Trenton 2, N. J. Term expires July 1, 1961. Executive Director: Milton C. Coon, Jr. Term indefinite.

History: Organized 1952 as a unit of $\mathrm{Di}$ vision of Engineering and Industrial Research of the National Academy of Sciences-National Research Council. Activities are directed by a Board of Governors appointed by the National Research Council. The Chairman of the National Research Council and the Chairman of the Division of Engineering and Industrial Research serve as ex officio members of the Board. Committees: Executive, Finance, Education
Liaison, Membership, Publications and Publicity, Research, Programs. A number of technical committees work under the direction of the Programs Committee.

Purpose: To promote the advancement of the science of building and the arts and technologies which it comprises through the collaboration of individuals and organizations of business and professional nature in all sectors of the building industry.

Membership: Firm, organization, or individual must be engaged in, or connected with, research in building; new nembers approved by Board of Governors. 485 memberships, amounting to approximately 1,200 participating members.

\section{Meetings: Semiannual.}

Publications: Building Science Directory, quarterly, $\$ 20$ for basic Directory, $\$ 5$ for quarterly supplements. Other publications available to members only.

475. California Academy of Preventive Medicine, Inc. School of Public Health, University of California at Los Angeles, Los Angeles, Calif. President: Merle E. Cosand, San Bernardino County Health Department, San Bernardino, Calif. Term expires February 28, 1961. Secretary-Treasurer: Gerald A. Heidbreder, 241 North Figueroa Street, Los Angeles 12, Calif. Term expires February 28, 1961.

History: Organized 1956; incorporated 1958. Purpose: Educational and scientific.

Membership: Requires physician's license in California, and residence or work there; certification by American Board of Preventive Medicine in a specialty of preventive medicine. fellowship in American College of Preventive Medicine desirable. Total membership 107.

Mectings: Annual.

476. California Academy of Sciences. Golden Gate Park, San Francisco 18, Calif. Director: Robert C. Miller. Term expires October 15, 1960. Secretary: Siemon IV. Muller. Term expires October 15, 1960.

History: Organized May 16, 1853, as the California Academy of Natural Sciences; name changed 1868 to present title; incorporated January 16, 1871; public museum opened January 28, 1874; destroyed by earthquake and fire April 18, 1906; reopened in Golden Gate Park September 22, 1916. Sections: Astronomy; Aquatic Biology; Botany; Entomology; Geology ; Ichthyology ; Herpetology ; Ornithology; and Mammalogy. 
Purpose: Scientific research, the promotion of science, public education, and the maintenance of the Science Museum, Steinhart Aquarium, Morrison Planetarium, and Mailliard Memorial Library.

Membership: Anyone interested in the advancement of science. Regular members, 1,212; Student, 67 ; Life, 223 ; Honorary, 21 ; Fellows, 161; Patrons, 63 ; Associate, 17; Corresponding, 8; Benefactor, 1. Total membership 1,773.

Meetings: Monthly.

Publications: Academy News Letter, monthly, free to all members. Pacific Discovery, bimonthly, $\$ 3$.

Library: 100,000 volumes.

477. California Arboretum Foundation, Inc.

301 North Baldwin Avenue, Arcadia, Calif. President: Ralph D. Cornell, 3723 Wilshire Boulevard, Los Angeles 5, Calif. Term expires May 17, 1961.

\section{Ilistory: Incorporated February 20, 1948.}

Purpose: To conduct special historical, horticultural, and botanical research and educational projects at Los Angeles State and County Arboretum; to publish botanical and horticultural papers.

Membership: Requires interest in supporting aims and objectives of Los Angeles State and County Arboretum. Total membership 650.

\section{Meetings: Annual.}

Professional activities: Annual contribution to arboretum library; grants in support of arboretum research, and of development of special arboretum facilities (greenhouses for orchid propagation, etc.).

Publications: Lasca Leaves, quarterly, current volume: 10, free to members. Editor: Louis B. Martin. Lasca News, quarterly. Editor: Elsie L. Murray. Lasca Miscellanea, current volume: 8.

Library: 15,767 volumes on botanical and horticultural subjects. Cooperatively held and maintained by California Arboretum Foundation and Los Angeles State and County Arboretum.

478. California Botanical Society. Department of Botany, University of California, Berkeley 4, Calif. President: H. G. Baker. Term expires January 1961. Corresponding Secretary: Francia Chisaki. Term expires January 1961.

History: Organized 1916; incorporated 1935. Committee on publication.

Purpose: To promote botanical study and investigation of plants and to disseminate knowledge concerning them.
Membership: Open to all persons interested in botany; activities are such that membership is very largely composed of professional biologists. Total membership 569.

Meetings: Annual and monthly, October through May.

Profession activities: Field excursions; Symposia with emphasis on taxonomic botany, plant geography, and ecology.

Publications: Madroño, quarterly, current volume : 15, \$6. Editor: Herbert L. Mason.

479. California Federation of Mineralogical Societies, Inc. P. O. Box 687, Mentone, Calif. President: Mrs. Veryle Carnahan, 9531 Mina Avenue, Whittier, Calif. Term expires June 1961. Secretary: Mrs. Marge IVakeman, 10129 Hildreth Avenue, South Gate, Calif. Term expires June 1961.

History: Organized January 1936; incorporated 1946. Member of American Federation of Mineralogical Societies.

Purpose: To disseminate knowledge of mineralogy and the earth sciences, and to advance the lapidary art.

Membership: Open to any gem and mineral society, subject to approval of Board of Directors of the Federation. Member societies, 166; individual members, 11,617.

Mectings: Semiannual.

Professional activities: Ribbons awarded 1st, 2nd, and 3rd places in competitive exhibits at annual show, participating in scholarship fund to be awarded to student specializing in earth science courses.

Publications: Gems \& Minerals, monthly, members $\$ 1.50$, others $\$ 4.20$. Editor: Don MacLachlan.

480. California Horticultural Society. California Academy of Sciences, San Francisco 18, Calif. President: Thomas IV. Russ, 7169 Sayre Drive, Oakland, Calif. Term expires January 1961. Secretary: Elizabeth McClintock. Term expires January 1961.

History: Organized February 25, 1934 ; incorporated.

Purpose: Stimulation of greater interest in plants and furtherance of horticultural knowledge.

Membership: Open to all interested in the aim of the society. Total membership 450 .

Mcetings: Monthly, except July and December.

Professional activities: Annual awards of merit for new and unusual plant material.

Publications: Journal, quarterly, current volume: $21, \$ 2.50$, free to members. Editor: 
Donald Pratt, 7227 Geary Boulevard, San Francisco 21, Calif.

481. California Medical Association. 693 Sutter Street, San Francisco 2, Calif. President: Paul D. Foster, 1216 Wilshire Boulevard, Los Angeles, Calif. Term expires May 3, 1961. Executize Secretary: John Hunton. Term indefinite.

History: Organized March 12, 1856, as Medical Society of the State of California ; reorganized 1870; name changed to present title 1923.

Purpose: To advance scientific medicine.

Membcrship: Requires authentic degree of doctor of medicine, and license to practice as physician and surgeon in California. Active menbers, 17,000 .

Mectings Annual.

Publications: California Medicine, monthly, \$6. Editor: D. L. Wilbur.

482. California Pharmaceutical Association. 701 South St. Andrews Place, Los Angeles 5, Calif. President: Nat Lippman, 7200 Pacific Boulevard, Huntington Park, Calif. Term expires May 31, 1961. Executize Secretary: Cecil A. Stewart. Term indefinite.

History: Organized 1868; reorganized 1906; incorporated 1933. Composed of two metropolitan and thirty-seven county and local pharmaceutical associations.

Purpose: Securing of higher professional standing for pharmacists; support and encouragement of pharmaceutical education by more thorough preliminary schooling, and of greater scientific requirements for practice of pharmacy; dissemination of information pertaining to pharmaceuticals and drug laws.

Membership: Requires registration as pharmacist licensed to practice in State of California. Full Members, pharmacists, 4,000; Associate Members, pharmacy school students, members of women's auxiliaries, and pharmaceutical salesmen, 500. Total membership 4,500.

Mectings: Annual.

Professional activities: Scholarship Loan Fund, to render assistance to worthy applicants attending pharmacy schools, available to sophomore, junior, and senior students, capital $\$ 7,200$. $\$ 500$ cash scholarship awarded to a high school senior who will attend pharmacy school.

Publications: California Pharmacy, monthly, current volume: $6, \$ 3$. Editor: James W. Gentry.

483. California Science Teachers Association, Northern Section. 2082 Center Street, Berkeley 4, Calif. President: William F. Dresia,
107 Santa Margarita Drive, San Rafael, Calif. Term expires June 1961. Secretary: IV. Keith MacNab, 10 Morningside Drive, San Anselmo, Calif. Term expires June 1961.

History: Organized 1941. Affiliated with American Association for the Advancement of Science and National Science Teachers Association.

Purpose: To stimulate, improve, and coordinate science teaching at all levels of instruction.

Membership: Open to all science teachers. Total membership approximately 400 .

Mectings: Semiannual.

Professional activitics: Northern California Science Curriculum Committee.

484. California Society of Anesthesiologists, Inc. 39 North San Mateo Drive, San Mateo, Calif. President: John P. Howard, 3585 4th Avenue, San Diego 3, Calif. Term expires 1961. Executive Secretary: Norman Catron. Term indefinite. Secretary-Treasurer: Charles D. Anderson, 439 30th Street, Oakland, Calif. Term expires 1962.

History: Organized 1948; incorporated 1954.

Purpose: To advance science and art of anesthesiology, and to stimulate interest and promote progress in scientific, cultural, and economic aspects of the specialty.

Mcmbership: Active Members, physicians licensed to practice in California, who are members of American Society of Anesthesiologists, Inc.; whose specialization or special interest is i1 practice of anesthesiology; who are members in county medical society. Total membership 789.

Mcctings: Annual.

Professional activities: Residents Award.

Publications: Bulletin, quarterly, \$4. Editor: T. IV. Mclntosh.

485. California Society of Professional Engineers. 22639 Main Street, Hayward, Calif. President: Willard A. Holt, 1759 Claridge Avenue, Arcadia, Calif. Term expires June 1, 1961. Executive Secretary: Leroy Martin. Term expires June 1, 1961.

History: Incorporated September 18, 1947. Twenty-seven active chapters.

Purpose: To advance public welfare; to unite all professional engineers of the State in one organization; to advance interests of engineers, professional and in training; to promote high standards of engincering education, ethics, and practice; to improve public relations and develop civic consciousness in the profession. 
Membership: Regular, registered engineer in State of California; Associate, registered engineer from other States; Junior, engineer-intraining. Total membership 1,456.

Mectings: Annual, in May.

Professional activities: Armco-NSPE Scholarship.

Publications: Newsletter, quarterly, Editor: Willard A. Holt.

486. California State Psychological Association. 4596 Van Dyke Avenue, San Diego 16, Calif. President: James F. T. Bugental, 1314 Westwood Boulevard, Los Angeles 24, Calif. Term expires June 30, 1961. Secretary: Irving R. Stone. Term expires June 30, 1961.

History: Organized December 18, 1948. Committees for development of standards, training in school psychology and in civil service, and establishment of working relationships with medical profession.

Purpose: To advance psychology as science and as means for promoting human welfare in the State of California.

Membership: Requires membership in American Psychological Association. Total membership approximately 1,000 .

\section{Mcetings: Annual.}

Publications: California State Psychologist, bi-monthly, current volume: $2, \$ 2$, free to members. Editor: George Lehner.

487. Calorimetry Conference. Chairman: Darrell W. Osborne, Argonne National Laboratory, P. O. Box 299, Argonne, I11. Term expires September 1961. Chairman-elect: J. E. Kunzler, Bell Telephone Laboratories, Inc., Murray Hill, N. J. Term expires September 1962. Secretary: George T. Furukawa, Division of Heat and Power, National Bureau of Standards, Washington 25, D. C. Term expires September 1963.

Ilistory: Organized 1945. Commitrees: Publication of Calorimetric Data, Calorimetric Standards, Machine Computation of Data.

Purpose: To advance the science of calorimetric measurement with emphasis on experimental devices and procedures.

Membership: Experience or interest in calorimetric research. Courtesy membership extended to scientists from abroad. Total membership approximately 400 .

\section{Meetings: Annual.}

Professional activities: Plans and promotes testing of new calorimetric and thermometric devices.
488. Cambridge Entomological Club. 16 Divinity Avenue, Cambridge 38, Mass. President: Herbert Levi, Museum of Comparative Zoology, Cambridge, Mass. Term expires May 1961. Executive Secretary: Guy Buch. Term expires May 1961.

History: Organized 1874; incorporated 1877.

Purpose: The study of entomology.

Membership: Open to anyone interested in entomology. Total membership 75.

Mectings: Monthly, October through May.

Publications: Psyche, quarterly, current volume: 66, \$5. Editor: F. M. Carpenter.

489. Carolina Geological Society. Department of Geology, Duke University, Durham, N. C. President: Owen Kingman, Tennessee Copper Company, Ducktown, Tenn. Term expires October 9, 1960. Secretary: E. W. Berry, P. O. Box 6665, College Station, Durham, N. C. Term indefinite.

History: Organized 1937.

Purpose: Study of the earth.

Membership: Open to those interested in earth sciences. Total nembership 80 .

\section{Meetings: Annual.}

Professional activitics: Prize of $\$ 25$ for best geological exhibit in Science Fairs in both Carolinas.

\section{Catalysis Club of Metropolitan New York.} President: Ernest Solomon, M. W. Kellogg Company, Foot of Danforth Avenue, Jersey City 3, N. J. Term expires July 1, 1961. Executive Secretary: Kenneth Kearby, Esso Research and Engineering Company, P. O. Box 51, Linden, N. J. Term expires July 1, 1961.

\section{History: Formed in 1959.}

Purpose: To study the science of catalysis and related fields with particular emphasis on aspects of surface chemistry.

Membership: Members, 107; an interest in the field of catalysis.

Meetings: Four times a year.

491. Catalysis Club of Philadelphia. President: Harold Shalit, P. O. Box 427, Marcus Hook, Pa. Term expires June 1961. Secretary-Treasurer: Walter H. Seitzer, P. O. Box 426, Marcus Hook, Pa. Term expires June 1961.

History: Organized July 1950.

Purpose: To further the science of catalysis; to advance knowledge in the field of catalysts and reaction mechanisms; to provide opportunity for discussion of work of members. 
Membership: Open to all persons genuinely interested in the purpose of the society. Total membership 275.

Metings: Four to six annually.

Professional activities: Sponsored First International Congress on Catalysis.

492. Catholic Anthropological Conference. Catholic University of America, Washington 17, D. C. President: Allen Spitzer, Department of Sociology and Anthropology, St. Louis University, St. Louis, Mo. Term expires May 1961. Secretary: Regina Flannery Herzfeld. Term expires May 1961.

History: Founded 1926; incorporated 1928. Purpose: Advancement of anthropological sciences through promotion of anthropological research and publication by missionaries and professional anthropologists, and through anthropological training among candidates for mission work.

Membership: Open to those interested in the aims of the Conference. Members, 94; Life Members, 4. Total membership 98.

\section{Meetings: Annual.}

Professional activities: Grants-in-aid for anthropological research.

Publications: Anthropological Quarterly, current volume: 33, \$4. Editor: Regina Flannery Herzfeld.

493. Catholic Hospital Association of the United States and Canada. 1438 South Grand Boulevard, St. Louis 4, Mo. President: Rt. Rev. Msgr. A. W. Jess, 130 Evesham Road, Runnemede, N. J. Term expires June 1961. Executive Director: Rev. John J. Flanagan, S.J. Term indefinite.

History: Organized 1915. Sections: Regional, State, and Provincial Conferences, United States and Canada. Canadian activity is directed by the Catholic Hospital Association of Canada.

Purpose: Promotion and realization of progressively higher ideals in the religious, moral, medical, nursing, educational, social, and all other phases of hospital and nursing endeavor, especially in the Catholic hospitals and schools of nursing in the United States and Canada.

Membership: Constituent Members, 1,250. Each Catholic hospital may appoint one constituent member; under certain conditions, persons affiliated with ecclesiastically sponsored institutions not conforming to the definition of a "Catholic hospital" are granted constituent membership. Represented institutions: 1,050. Associate Members, 150 , interested persons, institutions, or agencies. Total membership : 1,400.
Professional activities: Approximately forty conferences and workshops.

Publications: Hospital Progress, monthly, current volume: 41, \$4. Editor: Rev. John J. Flanagan, S. J.

Library: 6,500 volumes on hospital administration.

494. Central Association of Electroencephalographers. President: Francis J. Millen, 208 East Wisconsin Avenue, Milwaukee 2, Wis. Term expires November 1960. SecretaryTreasurer: Pauline M. Cooke, 1018 North State Street, Chicago 10, I1l. Term expires November 1961.

\section{History: Organized 1947.}

Purpose: To further research and to establish and promote communication among persons in the mid-central states interested in this specialty.

Membership: Requires clinical interest or research activity in electroencephalography or related fields. Total membership approximately 300.

Mectings: Semiannual.

495. Central Association of Obstetricians and Gynecologists. President: Isadore Dyer, 1521 Delachaise Street, New Orleans 15, La. Term expires October 8, 1960. Secretary-Treasurer: Herman L. Gardner, 6436 Fannin Street, Houston, Tex. Term expires October 8, 1960.

History: Organized December 1929 at St. Louis.

Purpose: Encouragement and promotion of the study and practice of obstetrics and gynecology.

Membership: Limited to physicians resident in the central states in good professional standing who have been graduated for five years, who have had special training in obstetrics and gynecology, and whose major interests are in the specialty. Total membership 699.

Meetings: Annual.

Professional activities: Prize Award of $\$ 250$ offered annually for best investigative or clinical work in the field of obstetrics and/or gynecology submitted by any accredited physician, research worker or medical student.

496. Central Association of Science and Mathematics Teachers, Inc. P. O. Box 108, Bluffton, Ohio. President: James H. Otto, Washington High School, Indianapolis, Ind. Term expires November 25, 1960. Secretary: Joseph W. Kennedy, Indiana State Teachers College, Terre Haute, Ind. Term expires June 30, 1963. 
History: Organized about 1900; incorporated in 1928. Sections: Biology and Conservation, Chemistry, Elementary Mathematics, Elementary Science, General Science, Mathematics, Physics.

Purpose: To facilitate exchange of ideas among science and mathematics teachers, to establish professional standards, and to stimulate research.

Membership: Members, 1,500, teachers and other persons interested in the teaching of science and mathematics; student members.

Meetings: Annual.

Publications: School Science and Mathematics, 9 issues per year, current volume: 60 , $\$ 6$, free to members. Editor: George G. Mallinson, Western Michigan University, Kalamazoo, Mich.

497. Central California Psychiatric Society, District Branch of American Psychiatric Association. President: Z. O. Young, 2720 Capitol Avenue, Sacramento 16, Calif. Term expires May 1961. Sccretary: John A. Stroud, 1431 22nd Street, Sacramento, Calif. Term indefinite.

History: Organized 1950.

Purpose: To advance psychiatric knowledge and practice.

Membership: Requires degree of doctor of medicine and membership in American Psychiatric Association. Total membership 50.

Meetings: Quarterly.

Professional activities: Scientific presentations by noted speakers; papers by members.

\section{Central Neuropsychiatric Association.} 473 West 12th Avenue, Columbia 10, Ohio. President: Martin H. Hoffman, 1311 David Whitney Building, Detroit, Mich. Term expires October 14, 1960. Secretary-Treasurer: Ralph M. Patterson. Term expires October 14, 1960.

History: Organized 1922 by a group of neurosurgeons, neurologists, and psychiatrists.

Purpose: To encourage the study and practice of neuropsychiatry through clinical and scientific meetings and exchanges.

Membership: Outstanding professional ability in neurology, neurosurgery, or psychiatry; sponsorship by two members; attendance at two meetings before application is considered. Total membership 250.

Meetings: Annual.

Professional activities: Contribution to the National Society for Medical Research.
499. Central Neuropsychiatric Hospital Association. President: Marvin L. Adland, Chestnut Lodge, Rockville, Md. Term expires March 1961. Secretary: Ralph S. Green, The Haven Sanitarium. Rochester, Mich. Term expires March 1961

\section{History: Organized October 9, 1927.}

Purpose: To foster improvement in professional care, education, research, and administrative problems in small private psychiatric hospitals.

Membership: Hospitals must be approved by the American Hospital Association, and directors must be physicians and members of the American Psychiatric Association. Total membership 21 .

Mcetings: Annual.

500. Central New York Psychiatric Society, District Branch of American Psychiatric Association. 501 East Avenue, Newark, N. Y. President: Roy B. Greer, 233 Alexander Street, Rochester, N. Y. Term expires December 31, 1960. Secretary-Treasurer: Murray Bergman. Term expires December 31, 1960.

History: Founded in December 1949, as the Finger Lakes Neuropsychiatric Society, became an affiliate of the American Psychiatric Association in 1953, and a District Branch in 1956. The affiliate continued to be known as the Finger Lakes Neuropsychiatric Society while the District Branch became identified as the Central New York Psychiatric Society.

Purpose: To foster the progress of psychiatry; to represent psychiatry in its designated area; to assist the American Psychiatric Association in promoting its aims and objectives; to maintain relations with other organized psychiatric, professional, and lay groups in the area. including joint scientific meetings, etc.; and to advocate and uphold the interests of its members whenever or wherever indicated.

Membership: Active Members, members or fellows of the American Psychiatric Association; Affiliate Members, physicians practicing psychiatry or in training in psychiatry who do not meet the requirements for active membership; Honorary Members, individuals who have rendered some signal service in the interest of psychiatry. Total membership, 90.

\section{Meetings: Quarterly.}

Professional activities: Liaison with medical societies, legislatures, public agencies, etc. regarding all phases of psychiatric practices; special interest in mental health.

Publications: NewsLetter, quarterly. 
501. Central Society for Clinical Research. 2065 Adelbert Road, Cleveland 6, Ohio. President: John H. Dingle, Western Reserve University, 2019 Adelbert Road, Cleveland 6, Ohio. Term expires November 5, 1960. Secretary: Austin S. Weisberger. Term expires November 5, 1960.

History: Organized 1928. Sections: Minnesota, Wisconsin, Michigan, lowa, Illinois, Ohio, Indiana, Kentucky, Missouri, Kansas, Nebraska, Colorado, Tennessee, Alabama, Mississippi, Louisiana, Texas, Arkansas, Oklahoma, North Dakota, South Dakota, Montana.

Purpose: The promotion of clinical research and the development of the younger men in the profession.

Hembership: Active Members, 475, practicing physicians who are members of county or state medical society, or engaged in closely allied science of medicine, and not over forty-five years of age; Adjunct Members, 55, those over fortyfive years of age recommended by the Council, who are engaged in research or teaching in the medical and allied sciences but not active in clinical medicine; Emeritus Members, 270, upon application to the Council, after having been active members in good standing for ten years. Total membership 800 .

Meetings: Annual.

Publications: Journal of Laboratory and Clinical Medicine, monthly, current volume: 55 , $\$ 6.50$. Editor: William D. Robinson, Ann Arbor, Mich.

502. Central States Anthropological Society. President: Alan Merriam, Department of $\mathrm{An}$ thropology, Nortliwestern University, Evanston, 111. Term expires May 1961. SecretaryTreasurer: Bernice A. Kaplan, 2636 IVebb Avenue, Detroit 6, Mich. Term expires May 1961.

History: Organized in 1924; affiliated with the American Anthropological Association in 1952.

Purpose: To promote the dissemination of anthropological knowledge in the area of the central states, to encourage the growth of academic departments of anthropology, and to excliange research findings.

Membership: Regular Members, members of the American Anthropological Association resident in the central states; Associate Members, all others supporting the purposes of the Society. Total membership 325 .

Meetings: Annual.

Professional activities: Prize awarded for the best paper presented at the annual meeting.
503. Central States Society of Industrial Medicine and Surgery. Room 1312, 28 East Jackson Boulevard, Clicago 4, Ill. President: Paul J. Whitaker, Allis-Chalmers Manufacturing Co., Milwaukee 1, Wis. Term expires June 30, 1961. Executive Secretary: Allan P. Skoog. Term expires June 30, 1961.

History: Organized 1916 as the Illinois State Society of Industrial Medicine and Surgery: name changed 1922 to present title; eight conponent societies.

Purpose: Scientific advancement in the art of industrial medicine and surgery; encouragement of research; promotion of the interests of the medical profession.

Membcrship: Active Members, 490, doctors of medicine who are members of their local county medical societies and/or active members of the American Medical Association, and who have an interest in industrial medicine; Fellows, by examination and review, 158: Honorary and Retired, 29. Total membership 677.

Mectings: Two or three annually.

Publications: Journal of Occupational Medicine, monthly, \$10. Editor: A. G. Kammer.

504. Central Surgical Association. President: Robert T. Tidrick, University Hospital, Iowa City. Iowa. Term expires February 18, 1961. Secretary: A. D. McLachlin, Victoria Hospital, London, Ontario. Term expires February $20,1961$.

History: Organized May 1940, at the annual meeting of the American Surgical Association at St. Louis, Mo.; incorporated in Ohio, January $15,1941$.

Purpose: To further the practice of surgery in its various departments and to study surgical problems.

Membership: Active Menbers, must have nembership in State or provincial society and certification by American Board or Royal College; Senior Members, active members fifty years of age, or membership in senior surgical society. Total nembership 422 .

Mcetings: Annual.

505. Central Virginia Engineers' Club. President: Robert Juer, c/o Nitrogen Division, Allied Chemical Corporation, Hopewell, Va. Term expires June 30, 1961. Exccutive Secretary: Edward H. Bryant, c/o Richmond Engineering Co., 7 th and Hospital Streets, Richmond, Va. Term expires June 30, 1961.

History: Organized March 27, 1935.

Purpose: To unite engineers from the various branches of the profession into one organization for fellowship and for the exchange of ideas. 
Mcmbership: No formal requirements; an interest in engineering. Total membership 260. Mectings: Monthly, September through June. Professional activities: Sponsorship of Annual Engineers Week, in February.

506. Ceramic Association of New Jersey. P. O. Box 444, New Brunswick, N. J. President: John C. Elder, Robertson Manufacturing Company, Trenton, N. J. Term expires December 31, 1960. Secretary: John H. Koenig, School of Ceramics, Rutgers, The State University, New Brunswick, N. J. Term expires December 31, 1960.

II istory: Organized June, 1914 as the New Jersey Clay IVorkers Association; name changed 1932 to present title. Committees: Enamels; Glass; Refractories; Whitewares; Structural Clay Products.

Purpose: Advancement and diffusion of knowledge relating to the ceramic industries.

Membership: Engaged in technical and/or executive capacity in ceramics field. Individual Members, 391, those engaged in ceramics and related industries in New Jersey and adjacent territory ; Corporation Members, 50. Total membership 441 .

Meetings: Annual; other meetings in the fall, spring and summer.

Professional activities: Two scholarships at Rutgers, The State University; Annual Award to an outstanding member.

507. Ceramic Association of New York. President: Louis Navias, Research Laboratories, General Electric Company, Schenectady, N. Y. Term expires October 1960. Secretary-Treasurer: J. F. McMahon, State University of New York College of Ceramics at Alfred University, Alfred, N. Y. Term indefinite.

History: Organized 1934. Committees: Research and Education.

Purpose: To promote technical progress in ceramic manufacture and advance the ceramic industries of New York State.

Membership: Corporation, 91 ; Personal, 111. Total membership 202.

Meetings: Annual.

Professional activities: M. E. Holmes Thesis Prize, to promote undergraduate research; Citizenship Award, presented to "Citizen of the Year" at State University of New York College of Ceramics, Alfred University.

508. Chattanooga Engineers Club. President: Perry V. Lane, Lennon Company, Chattanooga, Tenu. Term expires December 1960. Exccutive Secretary: Robert J. Bradshaw, Jr.,
2209 Vance Avenue, Chattanooga 4, Tenn.

Term expires December 1960.

\section{History: Organized 1924.}

Purpose: To promote the dissemination of engineering and scientific knowledge; to discuss matters of an engineering and scientific nature at meetings; to participate in civic problems requiring engineering knowledge; to arrange for inspection by the members of engineering works; to develop and/or sponsor the organization and development of scientific, technical and/or engineering clubs in junior and senior high schools in order to interest students in scientific and technical study.

Membership: Full Members, 330, professional engineers, architects, or scientists with four years active work in the field of engineering, two of which are in responsible supervisory work; Associates, 28, non-professional engineers qualified by scientific knowledge or practical experience to work with engineers; Students, 6, not less than eighteen years of age who have completed their second year of college work in engineering; Junior, 6 , individuals not less than eighteen years of age who have had at least two years of practice in engineering; Honorary Members, 3, those who have rendered eminent service to the profession. Total membership 367.

Mectings: Weekly.

509. Chemical Society of Washington. President: Allen L. Alexander, Naval Research Laboratory, Washington 25, D. C. Term expires December 31, 1960. Sccretary: John L. Torgesen, National Bureau of Standards, Washington 25, D. C. Term expires December $31,1960$.

History: Organized January 31, 1884 ; incorporated March 25, 1926. The Society is a local section of the American Chemical Society.

Purpose: To encourage in the broadest and most liberal manner the advancement of chemistry in all its branches; to promote research in chemical science and industry; to improve the qualifications and usefulness of chemists through high standards of professional ethics, education, and attainments; to increase and diffuse chemical knowledge; and by its meetings, professional contacts, reports, papers, discussions, and publications, to promote scientific interests and inquiry, thereby fostering public welfare and education, and aiding the devclopment of industries.

Membership: Membership in the American Chemical Society and residence in the Washington, D. C. metropolitan area. Member, Junior Member, Student Member. Total membership, 2,312 . 
Mectings: Monthly, September through May.

Professional activities: Hillebrand Prize, awarded annually, \$200. Junior Memberships, awarded to outstanding junior in each of the several colleges and universities in area. The Society contributes support to the high school Science Fair and awards magazine subscriptions to winners in chemistry group.

Publications: Capital Chemist, monthly, current volume: 10, \$2. Editor: Samuel B. Detwiler, Jr.

510. Chemists' Club. 52 East 41 st Street, New York 17, N. Y. President: Lincoln T. Work, 36 West 44th Street, New York 36, N. Y. Term expires May 1961. Secretary: Paul B. Slawter, Jr., G. M. Basford Co., 60 East 42nd Street, New York 17, N. Y. Term expires May 1961.

History: Incorporated December 30, 1898.

Purpose: To advance the science and application of chemistry, and to promote good fellowship among its members.

Mcmbcrship: Those interested in the science, practice, and applications of chemistry and chemical engineering. Resident Members; Suburban; Non-Resident; Junior ; Foreign; Life; Honorary; Emeritus. Total membership 3,349 .

\section{Metings: Annual.}

Professional activities: Bloede-Hoffman Scholarship.

Publications: The Percolator, bi-monthly; Yearbook, bi-annually; free to nembers.

Library: 60,000 volumes on chemistry and chemical engineering.

511. Chi Epsilon Fraternity. President: Paul Hartman, Chemical Engineering Department, City College of New York, Convent Avenue and 139th Street, New York 31, N. Y. Term expires March 1962. Secretary-Treasurer: John A. Focht, University of Texas, University Station, Austin 12, Tex. Term indefinite.

History: Organized as a non-profit corporation in 1923 in the state of Illinois. Chapters: Fifty in continental United States, one outside United States, located in the following districts: Western, Mid-IVestern, Southwestern, Southeastern, North Central, Mid-Atlantic and New England. Three Alumni Chapters: New York City, Chicago, and Los Angeles.

Purposc: To recognize the fundamental characteristics of the successful civil engineer, and to aid in the development of those characteristics.

Membership: Selection of members based upon scholarship, character, practicality and sociability; undergraduates and alumni; civil engineering students; Honor Members, prominent civil engincers. Total membership 14,680.

Meetings: Semiannual.

Publications: The Transit, annually, current volume: $31, \$ 1.50$. Editor: Michael A. Spronck, Martinsville, N. J.

512. Chicago Academy of Sciencies. 2001 North Clark Street, Chicago 14, 111. President: Leslie B. Arey, Anatomy Department, Northwestern University, 303 East Chicago Avenue, Chicago 11, I11. Term expires 1961. Executive Secretary: Richard Edgren, Research Department, G. D. Searle \& Company, P. O. Box 5110, Chicago 80, 111 . Term expires 1961.

History: Organized 1856, founded 1857. Chicago Junior Academy of Sciences organized 1959 for students.

Purpose: To increase and disseminate scientific knowledge by maintenance of a museum and such other means as may be adopted from time to time to stimulate scientific investigation.

Membership: Open to individuals seriously interested in science and conservation: Sustaining, Corresponding, Student/Teacher, Patron, Contributor, Life, Honorary Life, Fellows, Industry. Total membership 250.

Meetings: Annual.

Professional activities: Laboratories maintained with professional research; American Association for the Advancement of Science grants for student projects; student science fair projects; student independent research and seminars; student and adult science clubs with lectures and field trips; teacher workshops.

Publications: Bulletin, irregular, current volume: 11. Natural History Miscellanea, irregular, current volume: 172. Special Publications, irregular, current volume: 14. Price varies per issue. Science Notes, irregular, current volume: 8, free to students and public.

Library: Approximately 7,000 volumes on natural history.

513. Chicago Dental Society. 30 North Michigan Avenue, Chicago 2, I1l. Presidcnt: James N. Lynch, 1580 Sherman Avenue, Evanston, III. Term expires May 31, 1961. Executive Secretary: Karl S. Richardson. Term indefinite.

History: Organized May 1878.

Purpose: To promote the public welfare by the improvement and advancement of the dental profession in education, science, and professional service; to engage in charitable, scientific, literary, and educational undertakings. 
Mcmbership: Open to any licensed dentist conducting an ethical practice in Cook, Lake, or Du Page Counties. Total membership 3,682.

Mectings: Monthly.

Professional activities: Midwinter meeting.

Publications: Fortnightly Review, $\$ 2.50$, free to members. Editor: Edward J. Sullivan, 1911 Central Street, Evanston, Ill.

514. Chicago Diabetes Association, Inc. 620 North Michigan Avenue, Chicago 11, I11. President: James B. Hurd, 679 North Michigan Avenue, Chicago 11, I11. Term expires February 1961. Executize Secretary: Eleanor H. Dice. Term indefinite.

History: Incorporated November 1948, in Illinois. Affiliate of American Diabetes Association, New York, N. Y.

Purpose: To disseminate knowledge and information concerning diabetes mellitus to the profession and public; to conduct an annual summer camp for diabetic children.

Membership: Professional members, 166, membership in Chicago Medical Society: Lay, 250; Associate, members of allied professions, 34. Total nembership 450.

Mectings: Bi-monthly.

Professional activities: Summer Camp for Diabetic Children.

515. Chicago Medical Society. 86 East Randolph Street, Chicago 1, I11. President: Theodore R. Van Dellen. Term expires June 30, 1961. Secretary: Allison L. Burdick, Sr. Term expires June 30, 1961. Exccutive Secretary: Mrs. E. A. Fraser. Term indefinite.

History: Organized 1850; incorporated in lllinois. Committees: Postgraduate; Clinical Conference.

Purpose: Cultivation of the science and art of medicine, and professional intercourse anong members.

Mcmbership: Open to any physician who is duly licensed and registered in Illinois, a graduate of a reputable medical school, resident in Cook County or approved adjoining counties, of good moral and professional standing, and a citizen of the United States; also, physicians who are full time employees of the American Medical Association headquarters; or duly licensed physicians otherwise eligible but not licensed in the State of Illinois, employed in an allied medical activity not requiring licensure, resident in Cook County, by special recommendation; also, physicians serving as medical officers of the United States Army, United States Navy, and the United States Public Health Service, or serving full time in the Veterans
Administration if engaged actively in their respective service. Total membership 6,507.

Mectings: Annual and monthly.

Publications: Bulletin, weekly, \$4. Editor: Allison L. Burdick, Sr.

516. Chicago Neurological Society. President: Joseph P. Evans, 950 East 59th Street. Chicago, I11. Term expires June 1961. Secretary: Ernst Haase, 25 East Washington Street, Chicago 2, I11. Term expires June 1961.

\section{History: Organized 1898.}

Purposc: To promote the study of neurology in all its branches.

Mcmbership: Active Members, 94, chosen from physicians and scientists who are interested in the study of nervous and mental diseases, and who are residents of Chicago and its immediate area; Associate Members, 7; Corresponding Members, 17; Retired Members, 4. Total membership 118 .

Mectings: Monthly, October to May.

517. Chicago Pathological Society. President: Paul B. Szanto, Cook County Hospital, Chicago 12, 111. Term expires June 1, 1961. Secretary: Lester S. King, 11linois Masonic Hospital, Chicago 14, I11. Term expires June $1,1961$.

History: Founded 1878 as the West Chicago Medical Society; present name adopted in 1881. Since 1898 the Society has formed the pathology section of the Chicago Medical Society.

Purpose: The cultivation of the science and art of medicine with special reference to pathology and morbid anatomy.

Mcmbership: Must have medical degree and an interest in pathology. Active members, 195; Emeritus, 26.

Mectings: Monthly.

518. Chicago Roentgen Society. 5145 North California Avenue, Chicago 25, 111. President: George B. Cahill, 802 Burns Avenue, Flossmoor, I11. Term expires April 1961. Secretary: William F. Hutson. Term expires April 1962.

History: Organized 1913, incorporated 1937. Committees: Awards: Blue Cross and Blue Shield; City Code; Ethical Relations; History of Radiology; Hospital Plyysicians; Membership: Nominating; Nomination of Fellows of Chicago Roentgen Society for Fellowship in American College of Radiology; Program; Reference; Special Museum Exhibit.

Purpose: To promote the study of radiology in all its aspects; to disseminate information; to 
promote closer cooperation between radiology and other branches of medicine.

Membership: Fellows, physicians licensed in lllinois, in good standing in Chicago Medical Society, whose practice has been limited to radiology for at least five years, who are diploinates of American Board of Radiology, 105; Residents, above qualifications except diplomate of The American Board of Radiology, 64 ; Non-Residents, 46; Associates, those in allied sciences closely related to radiology, 4; Honorary nembers, 6. Total membership 225.

Mectings: Six times yearly.

519. Chicago Society of Internal Medicine. 720 North Michigan Avenue, Chicago 11, 111. President: Robert M. Kark, 840 South IVood Street, Chicago 12, I11. Term expires May 1961. Secretary Treasurer: Walter A. Rambach. Term expires May 1961.

History: Organized January 8, 1915 ; affiliated with the Institute of Medicine of Chicago.

Purpose: To further the correlation of clinical and experimental research in internal medicine and its allied branches.

Membership: Open to members of the medical profession whose interests are centered primarily in the area of internal medicine, eligible after three years from date of graduation from a medical school; Associate membership, open to those who qualify for Board examinations in internal medicine; Active nembership open to Diplomates of the American Board of Internal Medicine, or outstanding teachers in fields related to internal medicine. Active $\mathrm{Mem}^{-}$ bers, 292; Associate Members, 47; Emeritus Members, 14; Non-resident Members, 15. Total membership 368.

Mectings: Monthly, October through May.

520. Chicago Urological Society. President: J. Kenneth Sokol, 251 East Chicago Avenue, Chicago, I11. Term expires April 1961. Sccretary: James H. McDonald, 840 South Wood Street, Chicago, I11. Term expires April 1961.

History: Organized April 23, 1903.

Purpose: Cultivation and improvement of the science and art of urology; study of the genital tract and the urinary tract.

Mcmbership: Active Members, 60, graduates of approved medical schools, certified by the American Board of Urology, or with equivalent training in the subject, who have practiced urology exclusively for three years, are members of the Anerican Medical Association, and present a thesis; Associate Members, 9, same requirements as for active members except requirement for practice is one year, and no thesis is required; Non-resident Mem- bers, 28 , same requirements as for active membership; Emeritus Members; Honorary Members, individuals whose distinguished service to the science of urology makes such notice desirable. Total membership 105.

Mectings: Annual; four other meetings.

Professional actirities: William T. Belfield Memorial Lecture, given in honor of the founder of the Society at the October meeting by a distinguished scientist.

521. Cincinnati Dermatological Society. President: Robert Brandt, 259 Doctors' Building, Cincinnati, Ohio. Term expires September 1961. Executive Secretary: Mitcliell Ede, 1219 Carew Tower, Cincinnati, Ohio. Term expires September 1961.

\section{History: Organized October 1925.}

Purpose: Promotion of the scientific study of dermatology and syphilology.

Membership: Open to physicians in good standing in the American Medical Association, to diplomates of the American Board of Dermatology and Syphilology, and to any qualified dermatologists meeting the requirements of the American Board of Dermatology and Syphilology who have been in active dermatologic practice for twenty years or more. Total menibership 40.

Meetings: Monthly, except July, August, and September.

522. Cincinnati Pediatric Society. President: Carl Ochs, 2727 Madison Avenue, Cincinnati 9, Ohio. Term expires October 1960. Secretary-Treasurer: Irvin Dunsky, 5316 Reading Road, Cincinnati 37, Ohio. Term expires October 1960.

\section{History: Incorporated 1954.}

Purpose: Promotion of health and welfare of children.

Membership: Consists of doctors who are interested in practice and teaching of pediatrics, and who are certified or eligible to become members of Academy of Medicine of Cincinnati, or of their local medical societies. Total membership 99.

\section{Mectings: Quarterly.}

Professional activities: Teacher-of-the-Year Award, in conjunction with Cincinnati Public Schools; Annual Award for Best Essays, to residents of Children's Hospital; A. Graeme Mitchell Memorial.

523. Cincinnati Society of Anesthesiologists. 3077 Queen City Avenue, Cincinnati 38, Oliio. President: Glenn Hattendorf, 1728 Chase Avenue, Cincinnati 23, Ohio. Term expires 
January 1961. Secretary: Nicholas G. Amato. Term expires January 1961.

History: Organized November 23, 1937. Sections: Southwestern Ohio; Northern Kentucky.

Purpose: To evaluate methods and techniques of anesthesia; to bring before the group individuals with new ideas, techniques, or social adjustments; to foster a better understanding between anesthetists and the public, surgeons, and hospitals.

Membership: Physicians and dentists who have been licensed by their respective state boards and who desire to promote knowledge in all that pertains to the art and science of anesthesiology, to advocate all measures and procedures for the safety and best interests of all patients, to establish cordial and scientific relations with surgeons, hospital management, and anesthesiologists, and to disseminate knowledge among the laity to the end that they may have a proper concept of the work of the anesthesiologist, and who belong to their respective Academies. Total membership 50.

Mectings: Annual ; monthly, the third Thursday of each month.

\section{Cincinnati Society of Neurology and Psy-} chiatry. President: Louis A. Gottschalk, Department of Psychiatry, College of Medicine, University of Cincinnati, Cincinnati 29, Ohio. Term expires September 1960. Executive Secretary: William Hillard, 2314 Auburn Street, Cincinnati, Ohio. Term expires September 1961.

History: Founded 1940 by a group of Cincinnati neurologists, psychiatrists, and neurosurgeons.

Purpose: To promote social and scientific intercourse among its members; to promote the welfare of those who devote themselves to neurology, psychiatry, and neurological surgery, in accordance with the ethics and ideals of the medical profession.

Membership: Active Members, physicians who are members of the Cincinnati Academy of Medicine, or members of the American Medical Association, with the major part of their practice in neurology, psychiatry, or neurological surgery; Associate, residents and fellows in hospitals, and those interested in fields related to neurology, psychiatry, or neurological surgery; Emeritus Members, physicians who have been active members for a period of years and desire to be transferred to Emeritus status; Honorary Members, physicians deemed worthy by the Society to be elected to such membership. Total membership 120.

Meetings: Monthly, October through May.
Professional activities: Active interest in all neuropsychiatric and neurosurgical activities in the city; public participation in society programs.

525. Civil Aviation Medical Association (Domestic \& International). Presidcnt: Delbert F. Rey, 300 Homer Avenue, Palo Alto, Calif. Term expires April 26, 1961. SecretaryTreasurer: Joel H. Fisher, 1001 Connecticut Avenue, N. W., Washington 6, D. C. Term expires April 26, 1961.

History: Organized 1947 as Airline Medical Examiners Association; incorporated in the District of Columbia January 31, 1955; name subsequently changed to present title.

Purpose: To establish and maintain effective medical standards for persons engaged in civil aviation, and to improve the conditions of practice of civil aviation medicine.

Membership: Open to any licensed physician who is a member in good standing of his local, county, State, and national medical societies and who is actively engaged in practice of aviation medicine; also open to any scientist engaged in aviation medical research, the teaching of aviation medicine, or the authorship of scientific aviation information. Total membership 391.

Meetings: Annual.

Professional activities: Yearly scientific programs.

526. Cleveland Engineering Society. 3100 Chester Avenue, Cleveland 14, Ohio. Executive Director: Donald H. Cornish. Term indefinite.

History: Founded 1880 as Civil Engineers Club of Cleveland; incorporated and name changed to present title 1909. Divisions: Construction, Fuels, Machine Design, Management, Manufacturing, Marketing, Power Plant, Process Industries, Public Utilities. Twentythree committees.

Purpose: To promote educational and professional improvement of members, to make available to the public scientific and technical knowledge, and to advance the fields of engineering, architecture, and applied science.

Membership: Active (1), degree from recognized technical college and six years in practice or teaching of engineering, architecture, or applied science, three years of which must have been in a position of responsibility; Active (2), eight years in practice or teaching of engineering, architecture, or applied science, three years of which must have been in a position of responsibility; Professional, must be registered professional engineer in Ohio; Associate, engaged in engineering, architecture, or applied science, or actively associated in business with those 
professions; Junior, under thirty years of age, two years' experience in engineering, architecture, or applied science, or degree from recognized technical college; Student, under thirty years of age, regularly enrolled full time junior, senior, or graduate student, in recognized technical college; Sustaining, any member who desires to assume a larger share in fianancial responsibilities of this Society than required by regular dues; Service, any member on active duty with armed forces of the United States; Non-Resident, any Active, Associate, or Professional member residing and principally employed outside Cuyahoga County. Total membership 2,900.

Meetings: Annual, monthly division meetings.

Professional activities: Foundation Fund, to provide financial reserve to assure continuation of essential services of the Society; Student Loan Fund, to make loans to students of scientific and technological colleges for educational purposes. $\$ 3.50$.

Publications: Cleveland Engineering, weekly,

Library: 14,000 volumes: engineering, architecture, and applied science.

527. Cleveland Physics Society. Case Institute of Technology, Cleveland 6, Ohio. President: R. L. Cummerow, National Carbon Research Laboratory, 12900 Snow Road, Parma 29, Ohio. Term expires May 1961. Secretary: Andrew Tasch. Term expires May 1961.

\section{History: Organized March 1945.}

Purpose: The advancement and dissemination of the knowledge of physics.

Membership: Full Member, professional physicist; Associate Member, college student having a major or minor in plysics. Total membership about 265 .

Meetings: Monthly, October through May.

528. Clinical Orthopaedic Society. 122 South Michigan Avenue, Chicago, Ill. President: Fred C. Reynalds, 4960 Audubon Avenue, St. Louis, Mo. Term expires October 1960. Secretary-Treasurer: Charles H. Frantz, 1810 Wealthy Street, S. E., Grand Rapids 6, Mich. Term expires October 1960.

History: Organized 1912 as Central States Orthopaedic Club; name subsequently changed to present title.

Purpose: Discussion of clinical material and problems relative to orthopaedic surgery.

Membership: Geographically limited to Central States, and provinces of Manitoba and Saskatchewan; members required to be Diplomates of American Board of Orthopaedic Surgery, and to have made contributions to orthopaedic surgery. Regular Members, 204; Senior Members, 152. Total membership 356.

Meetings: Annual.

Professional activities: Endorsement and support of Orthopaedic Research and Education Foundation.

529. Clinical Society of Genito-Urinary Surgeons. President: Carl F. Rusche, 1400 North Vermont Avenue, Los Angeles 27, Calif. Term expires February 1961. Secretary-Treasurer: Ormond S. Culp, Mayo Clinic, Rochester, Minn. Term expires February 1961.

\section{History: Founded in 1921.}

Purpose: To promote keener interest in problems of the genito-urinary system by visiting such clinics as its members designate.

Membership: Senior Members, 21, chosen from among those who are contributing to the advancement of genito-urinary surgery and who have facilities for clinical demonstrations; Junior Members, 22, limited to 25, become Senior Members upon reaching the age of 63 .

Mectings: Annual.

530. Coblentz Society, Inc. President: R. A. Friedel, Central Expcriment Station, Bureau of Mines, 4800 Forbes Avenue, Pittsburgh 13, Pa. Term expires June 1962. SecretaryTreasurer: Raymond R. Sawyer, P. O. Box 54, Norwalk, Conn. Term expires June 1961.

History: Established 1955; incorporated December 1958 in Connecticut. TeChNiCAL CommitTeEs: Collection of Infrared Spectra, Infrared Analytical Methods.

Purpose: To foster understanding and application of infrared spectra.

Membership: Open to persons with interest in infrared spectroscopy. Total membership 424.

Meetings: Semiannual.

Professional activities: Publication of infrared analytical methods in Analytical Chemistry; collection and editing of infrared spectra material published through Sadtler Research Laboratories.

531. College of American Pathologists. Suite 2115, Prudential Plaza, Chicago 1, I1l. President: Frank C. Coleman, Des Moines, Iowa. Term expires December 31, 1961. Executive Director: Arthur H. Dearing. Term indefinite.

History: Organized and incorporated May 14, 1947. Seven sections. Committees: Clinical 
Pathology Standards; Evaluation of Laboratories; Forensic Pathology; Governmental Pathology; Hospital and Institutional Relations; Prepayment Health Plans.

Purpose: To foster highest standards in education, research, and practice of pathology; to advance science of pathology through study, education, and improvement of economic aspects of practice, and to improve medical laboratory service to physicians, hospitals, and public.

Mcmbcrship: Members, 721, open to Diplomates of American Board of Pathology; Fellows, 512, eight years experience in pathology; Founding Fellows, 240; Emeritus, 47; Juniors, 226, two years in pathological training. Total membership 1,746 .

\section{Mectings: Annual.}

Professional activitics: Scholarships, laboratories, hospital and pathologist placement bureau.

Publications: Bulletin, monthly, current volune : 14. Editor: S. E. Gould.

532. College of Physicians of Philadelphia. 19 South 22nd Street, Philadelphia 3, Pa. President: Jonathan E. Rhoads, 3400 Spruce Street, Philadelphia 4, Pa. Term expires January 1961. Secrctary: Thomas E. Machella. Term expires January 1961.

History: Instituted January 1787, incorporated March 1789. Sections : Ophthalmology; Otolaryngology; General Medicine; Public Health; Preventive and Industrial Medicine; and Medical History.

Purpose: To advance the science of medicine and thereby to lessen human misery.

Membership: By invitation only, physicians of good character and professional standing who have graduated from a reputable medical school at least five years previous to election. Fellows, 1,058; Non-resident Fellows, 140; Honorary Fellows, 8; Honorary Associate Fellows, 2. Total membership, 1,208.

Mcetings: Monthly, except June to September.

Prafessional activitics: Pedro Francesco DaCosta Alverenga Prize awarded annually on July 14, to some outstanding worker in the broad field of medicine, income about $\$ 250$; Mutter Museum containing pathological and anatomical preparations and specimens, drawings, models, and casts illustrative of surgery and medicine; eight to fifteen lectures given annually, supported in part by endowed lectureship funds.

Publications: Transactions \& Studies, current volume: $27, \$ 5$. Editor: Fred B. Rogers.

Library: Contains 204,843 volumes on medicine and allied sciences.
533. Colorado Archaeological Society. University of Colorado, Boulder, Colo. President: Leo Koenig, Greeley, Colo. Term expires October 1961. Executive Sccrctary: Omer C. Stewart. Term indefinite.

History: Organized April 23, 1935; incorporated November 2, 1936. Sections: EastCentral, Gumnison and Uncompahgre Valleys, North-Central, Rio Arkansas, Rio Colorado, San Luis Valley. Chapters: Boulder, Denver, Greeley, Loveland, Montrose, Pueblo, Saguache.

Purpose: To develop interest and stimulate research in Colorado archaeology.

Mcmbership: Open to anyone interested in archaeology. Total membership approximately 500 .

Mectings: Annual.

Publications: Southwestern Lore, quarterly, current volume: $26, \$ 2.50$, free to members. Editor: John Greenway.

534. Colorado District Branch, American Psychiatric Association. President: Franklin Ebaugh, 1801 High Street, Denver 18, Colo. Term expires 1961. Prcsident-Elcct: Frederick A. Lewis, Jr., Denver General Hospital, Denver, Colo. Sccretary-Treasurer: F. Bruce Merrill, 1750 East 19th Avenue, Denver 18, Colo. Term expires 1961.

535. Colorado Engineering Council. 1380 South Santa Fe Drive, Denver 23, Colo. President: Herbert E. Prater, 2001 South Madison Street, Denver 10, Colo. Term expires June 1961. Secretary: John E. Martin, Public Service Company of Colorado, 900 15th Street, Denver 2, Colo. Term expires June 1961.

History: Organized 1919. Composed of representatives of State and national engineering societies.

Purpose: To coordinate and promote professional interest of constituent organizations and of individual members.

Mcmbership: Consists of one member and one alternate representative of local sections of national professional engineering societies, and other qualified engineering, scientific, or technical associations. Total membership 20 societies.

Mectings: Monthly, October through June.

Professional activitics: Sponsorship of Science Fair; Honor Awards to individual students throughout Rocky Mountain area.

536. Colorado Forestry and Horticulture Association. 909 York Street, Denver 6, Colo. President: Scott Wilmore, P. O. Box 382, 
Denver 1, Colo. Term expires February 1961. Executive Secretary: Helen M. Vincent. Term indefinite.

History: Organized 1884 as the Colorado State Forestry Association; consolidated with the Denver Ormamental Horticulture Society, February 1944, to form the present organization.

Purpose: To preserve the natural beauty of Colorado; to protect the forests; to encourage proper maintenance and additional planting of trees, shrubs, and gardens; to make available correct information regarding forestry, horticultural practices, and plants best suited to the climate; to coordinate the knowledge of foresters, horticulturists, and gardeners for their mutual benefit; and to establish a botanical garden in or near Denver.

Membership: Supporting, Active, Contributing, Patron, Donor, Life, Complimentary and Exchange Members, persons desiring to support the program. Total membership, 2,700.

Meetings: Annual.

Publications: Green Thumb, monthly, current volume: 17, free to nembers. Editor: Patrick J. Gallavan.

Library: Contains 3,000 volumes on horticulture, forestry, and related subjects.

537. Colorado Pharmacal Association. 306 Kittredge Building, Denver 2, Colo. President: Ralph Lent. Term expires July 1, 1961. Executive Secretary: Jack Simmons. Term indefinite.

History: Organized 1890; incorporated.

Purpose: To unite pharmacists of Colorado for mutual advancement, assistance, and improvement; to encourage scientific research, develop pharmaceutical talent, restrict practice of pharmacy to properly qualified persons; and to procure legislation to protect the public and the profession.

Membership: Active Members, registered pharmacists or assistant pharmacists of Colorado; Associate Members, those engaged in manufacture or sale of drug store merchandise; Honorary Members, elected by two-thirds majority. Total membership approximately 2,500.

Meetings: Annual.

538. Colorado Psychological Association. President: Ear1 E. Swartzlander, PBMI Building, 333 West Colfax Street, Denver, Colo. Term expires June 30, 1961. Secretary: S. G. Santostefano, University of Colorado Medical Center, 4200 East 9th Avenue, Denver, Colo. Term expires June 30, 1961.

History: Incorporated in Colorado as a nonprofit organization May 6, 1955.
Purpose: To advance psychology as a science, as a profession, and as a means of promoting human welfare in the State of Colorado.

Membership: General requirements same as for American Psychological Association with degree of doctor of philosophy in psychology from a recognized university, with some exceptions involving experience in professional psychology. Total membership 200.

Mectings: Two to four times per year.

Professional activities: Sponsorship of State legislation efforts.

Publications: Newsletter, monthly, free to members. Editor: Leonard Krause, Veterans Administration Hospital, 1055 Clermont Street, Denver, Colo.

\section{Colorado Public Health Association.}

President: John Anderson, Pueblo City and County Health Department, Pueblo, Colo. Term expires May 1961. Secretary: Miss Alice de Bruyn Kops, 4660 South Delaware Strcet, Englewood, Colo. Term expires May 1961.

History: Organized 1946; incorporated. Committees: Education, Sanitarians.

Purpose: To promote public health, provide for scientific advancement of members, and extend and develop the public health movement.

Membership: Open to all professional people allied with welfare of public health, including official and voluntary agency personnel. Total membership 600, all Active Members.

Meetings: Annual.

Professional activities: Florence R. Sabin Award, \$25, annual, to person making greatest contribution to public health in Colorado.

540. Colorado Scientific Society. P. O. Box 7752, Denver 15, Colo. President: Dwight R. Crandell, U. S. Geological Survey, Building 25, Federal Center, Denver, Colo. Term expires December 1960. Secretary: Robert E. Davis, U. S. Geological Survey, Building 25. Federal Center, Denver, Colo. Term expires December 1960.

History: Organized December 1882, incorporated January 1885.

Purpose: The promotion of scientific intercourse, observation, and record in the State of Colorado.

Membership: Regular and Honorary; any person who by knowledge and experience has general interest in science. Total membership 219.

Meetings: Monthly, October through May.

Professional activities: Earth science awards given at Colorado-Wyoming Science Fair. 
541. Colorado Society of Engineers. 1380 South Santa Fe Drive, Denver 23, Colo. President: Fred Dumler. Term expires March 1961. Managing Secretary: James Eitzen. Term indefinite.

History: Incorporated August 4, 1916 as Colorado Society of Civil Engineers; name changed to Colorado Society of Engineers, January 11, 1919; largest professional organization for engineers in Colorado; recently completed Engineers Building in Denver to serve as engineering and scientific headquarters for the State.

Purpose: To broaden the social and business relationships of engineers and those in allied interests; to provide an employment service for engineers and employers of engineers; to maintain and improve the full professional status of engineers; to promote the advancement of engineering knowledge and education; to promote full and complete engineering knowledge and participation in civic affairs, particularly those of an engineering or public works nature; to maintain a publication of engineering interest; to provide an engineering center for correlating and unifying the activities of all local branches of engineering, architectural, and scientific organizations.

Membership: Registered Member, registered professional engineer; Member, eligible for registration as professional engineer; Junior Member, less than thirty-three years of age, either a junior or senior undergraduate in an engineering school of recognized standing, or a person engaged in active engineering work and study for not less than three years, ineligible for full membership; Associate, twenty-five years of age, interested in the advancement of engineering, or technical and scientific knowledge, and ineligible for other grades of membership.

Mectings: Annual.

Professional activities: Annual awards to high school students outstanding in the field of mathematics or science (participates through Colorado Engineering Council in most activities of this type).

Publications: Engineers' Bulletin, monthly, current volume: $43, \$ 3.50$. Editor: James Eitzen.

542. Colorado State Medical Society. 835 Republic Building, Denver 2, Colo. President: Cyrus W. Anderson. Term expires September 21, 1961. Executive Secretary: Harvey T. Sethman. Term indefinite.

History: Organized 1871 as Colorado Territorial Medical Society; affiliated with the American Medical Association, 1872; incorporated 1875; name changed to present title 1876; incorporated October 31, 1888. Twenty-seven component medical societies, each representing one or more countries. Committees: Blood Banks, Health Education, Medical Education and Hospitals, Medical Service, Medicological, Public Health.

Purpose: To promote the science and art of medicine, the betterment of public health, and the welfare of the medical profession, and the similar interests of its component county and district societies.

Membership: Active Members (Senior, Junior, and Emeritus), 2,031; Associate Members, 408 , so classified by component societies as ineligible for or not desiring Active membership; Honorary Members, 7, distinguished persons who have made outstanding contribution to the purposes of this Society. Total membership 2,446 .

\section{Meetings: Semiannual.}

Professional activities: Colorado Medical Foundation, to endow purposes of the Society; Certificate of Service, annual, to an individual for outstanding public service in medicine or public health.

Publications: Rocky Mountain Medical Journal, monthly, current volume: 57, \$5. Editor: Harvey T. Sethman. Colorado Medicine (newsletter), monthly, current volume: 13 , free to members.

Library: Joint, with Denver Medical Society ; 61,409 volumes on medicine.

\section{Colorado-Wyoming Academy of Science.}

President: Sam Shushan, Department of Botany, University of Colorado, Boulder, Colo. Term expires May 1961. Secretary: Richard G. Beidleman, Colorado College, Colorado Springs, Colo. Term expires May 1963.

History: Organized 1927. Sections: Anthropology, Bacteriology, Chemistry, Physics, Social Sciences, Psychology, Plant Science, Zoology.

Purpose: To encourage scientific investigation in the Rocky Mountain region.

Membership: Open to any individual interested in science. Total membership 400.

\section{Mcetings: Annual.}

Professional activities: Cosponsor of Colorado-Wyoming Bistate Science Fair; sponsor of high school lectureship program (National Science Foundation grant); Research Awards, one or more $\$ 50$ grants annually to high school, college, or graduate students.

Publications: Journal, annual, current volume: 4, free to members. Editor: R. G. Beidleman.

544. Columbus Technical Council. President: Owen E. Buxton, Department of Mechanical 
Engineering, The Ohio State University, Columbus 10, Ohio. Term expires June 30, 1961. Secretary: Robert D. Williams, Battelle Memorial Institute, 505 King Avenue, Columbus 1, Ohio. Term expires June 30, 1961.

\section{History: Incorporated 1948.}

Purpose: To coordinate activities of local sections of technical and engineering societies in the area of Columbus and Franklin County; to enhance the prestige and public appreciation of the engineering and technical professions; to act for the common good of all society members.

Membership: Society Members, 24, representing approximately 3,000 individuals, any local section or chapter of a national engincers' society, or other engineering, scientific, or technical association in good standing; Organization Members, 7, any company in good standing located or doing business in Ohio. Total membership 31.

Meetings: Bi-monthly.

Professional activities: Technical Man of the Year Award to local engineer or scientist; vocational guidance to local grade and high school students.

Publications: Tech Topics, monthly, current volume: 16, \$3. Editor: Jack Kelly.

545. Combustion Institute. Union Trust Building, Pittsburgh 19, Pa. President: Bernard Lewis, Combustion and Explosives Research, Inc., 1007 Oliver Building, Pittsburgh 22, Pa. Term expires September 1961. Exccutive Secretary: Mrs. Helen G. Barnes. Term indefinite.

History: Incorporated July 1, 1954 in the State of Delaware as a result of three symposia sponsored by the Standing Committee on Combustion Symposia. Two working committees: The Executive Committee and The Combustion Institute Committee, comprised of representatives from industry, government and universities in Australia, Austria, Belgium, Canada, France, Germany, Great Britain, India, Italy, Japan, the Netherlands, Spain, Sweden, Switzerland, and the United States. Seventeen International sections.

Purpose: To promote the science and application of combustion, and to disseminate knowledge in this field.

Membership: Open to physicists, chemists, and engineers of all countries actively engaged or interested in the field of combustion. Total membership 1,400; 900 in the United States; and 500 in twenty-five other countries.

Mectings: Semiannual.

Professional activities: Sir Alfred C. Egerton Medal, in recognition of long endeavors in the field of combustion; Bernard Lewis Medal, for outstanding research of major scope and import; Combustion Institute Medal, for an exceptional paper delivered at previous symposium.

Publications: Combustion and Flame, quarterly, current volume: 4, \$16. Editors: Bernard Lewis (U. S.) and F. H. Garner (U. K.). Symposium (International) On Combustion, biennial, current volume: $8, \$ 25-\$ 28$.

\section{Committee to Protect Our Children's} Teeth, Inc. 105 East 22nd Street, New York 10, N. Y. Secretary: Winslow Carlton, 221 4th Avenue, New York 10, N. Y. Term indefinite.

\section{History: Incorporated April, 1956.}

Purpose: To advance understanding of preventive dental health, and to disseminate reliable information on fluoridation of public water supplies as a preventive health measure.

Membership: By invitation. Total membership 825 .

\section{Meetings: Annual.}

Professional activities: Collaboration with professional societies and citizen organizations; information and publications made available upon request.

\section{Conference for Health Council Work.} President: N. H. Cooper, 44 East 23rd Street, New York 10, N. Y. Term expires November 1960. Secretary: Richard Warfield, Philadelphia, Pa. Term expires November 1960.

History: Organized 1926; formerly National Committee of Health Council Executives.

Purpose: To provide for the exchange of experiences, to review problems of mutual interest, to improve the work of health councils, and to stimulate the extension of the health council idea.

Membership: Professional workers of health councils, departments of health, and interested lay members. Total membership 100.

Meetings: Semiannual; one in conjunction with the National Conference of Social Work meeting, and one during the annual meeting of the American Public Health Association.

548. Conference of Executives of American Schools for the Deaf. 1200 East 42nd Street, Indianapolis 5, Ind. President: William J. McClure. Term expires June 30, 1963. Executive Secretary: Ben E. Hoffmeyer, School for the Deaf, Morganton, N. C. Term expires June 30, 1963.

History: Founded 1868 as Conference of Superintendents and Principals of American Schools 
for the Deaf ; name clianged to present title and incorporated in Maryland 1931.

Purpose: To promote management and operation of schools for the deaf along broadest and most effective lines, and to further and promote general welfare of the deaf.

Membership: Regular Members, 92, executive heads of schools for the deaf in the United States or Canada; Associate Members, approximately 100, assistant superintendents, principals, or other administrative persomel in such schools; Honorary Members, 30. Total membership approximately 222.

Mectings: Annual.

Professional activities: Edgar Allen Fay Award for outstanding literary effort.

Publications: American Annals of the Deaf, five issues annually, current volume: $105, \$ 4$. Editor: Powrie V. Doctor.

\section{Conference of Municipal Public Health} Engineers. President: Tom S. Gable, National Sanitation Foundation, University of Michigan, Ann Arbor, Mich. Term expires November 1, 1960. Secretary-Treasurer: Eric W. Mood, New Haven Health Department, 161 Church Street, New Haven 10, Conn. Term expires November 1, 1960.

History: Organized 1939. Committees: Swimming Pools and Bathing Places, Administration of Air Pollution Control Programs, Accident Prevention, Hospital and Institutional Sanitation, Housing and Urban Renewal.

Purpose: To improve and encourage greater use of the science and practice of environmental sanitation in community life.

Membership: Professional or graduate engineers engaged in or officially concerned with inunicipal public health engineering or teaching of public health engineering. Total membership 220.

\section{Meetings: Annual.}

Publications: Newsletter, quarterly, free to members. Proceedings, annual, free to members. Publications to non-nembers, $\$ 3$.

550. Conference of Public Health Veterinarians.

2 East 63rd Street, New York 21, N. Y. President: Robert K. Anderson, College of Veterinary Medicine, University of Minnesota, St. Paul 1, Minn. Term expires November 2, 1960. Secretary-Treasurer: Joe W. Atkinson, National lnstitutes of Health, Bethesda, Md. Terin expires November 2, 1960.

History: Organized 1946. Committees : Legislation, Resolutions, Communicable Diseases, Research, and Membership.
Purpose: To further educational and scientific progress in the specialized field of veterinary public health; to encourage education, training, and research in veterinary public health programs and practices; to exchange scientific information; to develop a cooperative working relationship among those engaged in veterinary and other public health programs.

Mcmbcrship: Active Members, graduate veterinarians engaged in other than full-time clinical practice in a formal activity related to public health; Associate Members; Sustaining Members. Total membership 300.

Mectings: Annual, in conjunction with American Public Health Association; a second business meeting held at time of annual meeting of American Veterinary Medical Association.

Publications: Newsletter, quarterly, free to members. Editor: J. D. Salisbury.

551. Conference of Research Workers in Animal Diseases. President: Cecil Elder, University of Missouri, Columbia, Mo. Term expires December 1960. Secretary-Treasurer: Alfred G. Karlson, Mayo Clinic, Rochester, Minn. Term expires December 1960.

\section{History: Organized in 1920.}

Purpose: To promote interest and maintain high standards in the field of research in animal disease.

Mcmbcrship: Limited to research workers actually engaged in research in animal diseases in governmental or endowed institutions. Total membership 400 .

Mcetings: Annual.

\section{Conference of State and Provincial Public} Health Laboratory Directors. P. O. Box C, University Station, Grand Forks, N. Dak. President: Francis C. Lawler, Chief Bureau of Laboratories, State Health Department, Burlington, Vt. Term expires October 31, 1960. Secretary: Melvin E. Koons. Term indefinite.

History: Organized March, 1921 at Atlanta as the Southern Public Health Laboratory Association; name changed 1927 to State Laboratory Directors Conference; name changed 1939 to present title. Secrions: United States; Territories; Canada.

Purpose: To promote the development, improvement, and effectiveness of public health laboratory service; to coordinate public health laboratory activities; to stimulate the interchange of experience among directors of official public health laboratories; to develop and maintain adequate standards for the professional 
training of public health laboratory personnel; to encourage constant effort toward the improvement and standardization of technical methods; to collect and make accessible to all persons in official administrative positions in public health laboratories such information and data as might be of assistance to them in the proper fulfillment of their duties.

Membership: Members, representatives from State, Provincial, Territorial, and Federal governments of the United States and Canada, and directors, or responsible assistants to directors, of official public health laboratories; Associate Members, teachers in institutions of higher learning engaged in training of laboratory personnel; Affiliated Members, same requirements as for Members, except from countries other than the United States and Canada. Total membership over 400 .

Mectings: Annual.

Professional activities: Kimble Methodology Award, presented for fundamental contribution published, for development of diagnostic methods which fall within the province of the public health laboratory, or the adaptation of a fundamental contribution to make it of use in a diagnostic laboratory, $\$ 1000$ and suitable engraved plaque.

Publications: Public Health Laboratory, bimonthly, \$2, free to members. Editor: Francis C. Lawler.

553. Conference of State Sanitary Engineers. Kentucky State Department of Health, Louisville 2, Ky. President: Dwight F. Metzler, State Board of Health, Topeka, Kans. Term expires May 1962. Executive Secrctary: Ralph C. Pickard. Term indefinite.

History: Organized 1920. Committees: Air Pollution; Accidents; Environmental Problems in Metropolitan Areas; Migrant Labor; Milk and Food Sanitation; National Water Policy; Radiological Health; Recruitment and Training; School Sanitation; Sewage and Waste Disposal; Swimming Pools and Bathing Places; Vector Control; Water Supply; and Long Range Planning.

Purpose: To promote public health in all phases; to coordinate public health engineering activities of official State and territorial health organizations; to encourage interchange of experience among State sanitary engineers in official administrative positions; to make available to all such officials information and data which might assist them in fulfillment of their duties.

Membership: Members, 51, chief sanitary engineering officials of the States, territories, and possessions of the United States, and the Chief Sanitary Engineering Officer of the U. S. Public Health Service; Associate Members,
125, persons employed in responsible positions as assistants or colleagues of Members; Affiliated Menbers, 9, representatives from other countries engaged in sanitary engineering in executive capacities under official health departments. Total membership 185.

Mectings: Biennial.

Publications: Transactions, biennial, current volume: 36 , free to members.

554. Conference of Utility Commission Engineers. President: Frederick M. Hoppe, Michigan Public Service Commission, Lansing, Mich. Term expires May 1961. Secretary-Trcasurcr: R. L. Lloyd, National Bureau of Standards, Washington 25, D. C. Term expires May 1961.

History: Founded 1923; adopted first constitution 1950. Sponsored by the National Bureau of Standards 1923 to 1959 ; currently sponsored by the National Association of Railroad and Utility Commissioners.

Purpose: To promote effective and fair utility regulation in the public interest.

Membership: Technical staff persomnel of commissions and regulatory bodies which may be Federal, State, or of the Provinces of Canada. Total membership approximately 300 .

Mcetings: Annual.

555. Conference on Electrical Insulation. 2101 Constitution Avenue, N. IV., IVashington 25, D. C. Chaiman: S. I. Reynolds, General Electric Company, P. O. Box 1088, Schenectady, N. Y. Term expires October 31, 1961. Sccretary: J. Sticher, Detroit Edison Conıpany, 2000 2nd Avenue, Detroit, Mich. Term expires October 31, 1961.

History: Established within the Division of Engineering and Industrial Research, National Academy of Sciences-National Research Council, in 1920.

Purpose: To promote fundamental knowledge of the properties of electrical insulation and to maintain a digest of the scientific literature on this subject.

Membership: Individuals engaged in research or development in the fields of dielectrics and insulation. Membership application subject to approval by the Membership Committee. Total membership 400.

Meetings: Annual.

Publications: Digest of Literature on Dielectrics, annual, current volume: $23, \$ 8$. Annual Report, \$4.

556. Conferences of the Surgeon General, Public Health Service, with the State and 
Territorial Health Officers, the State and Territorial Hospital and Medical Facilities Construction Authorities, and the State and Territorial Mental Health Authorities. President: Wilson T. Sowder, State Board of Health, 1217 Pearl Street, Jacksonville 1, Fla. Term expires October 1960. Exccutive Secretary: Andrew C. Offutt, Indiana State Board of Health, 1330 WVest Michigan Street, Indianapolis 7, Ind. Term expires October 1962.

History: First Conference of State and Territorial Health Officers held 1903 in accordance with the Act of Congress, July 1, 1902. First Conference of State Hospital Survey and Construction Authorities held 1947 in accordance with the Act of Congress, August 13, 1946. First Conference of State Mental Health Authorities held 1947 in accordance with the Act of Congress, July 3, 1946. Committees: Environmental Sanitation; Federal Relations; Hospital and Mental Health; Infectious Diseases; LongTerm Illness and Health of the Aging; Maternal and Child Health; Research; Special Health and Medical Services.

Purpose: To maintain effective working relationships between the Surgeon General and the State and Territorial Health Officers, State and Territorial Hospital and Medical Facilities Construction Authorities, and State and Territorial Mental Health Authorities and their respective organizations.

Membership: All State and Territorial Health Officers, State and Territorial Hospital and Medical Facilities Construction Authorities, and State and Territorial Mental Health Authorities are members ex officio. Total membership approximately 79 .

Mectings: Annual; at other times when deemed necessary by the Surgeon General or at the request of five or more States.

557. Congress of Neurological Surgeons. 20 South Dudley Street, Memphis 3, Tenn. President: Thomas M. Marshall, 326 Fincastle Building, Louisville 2, Ky. Term expires October 1960. Secretary-Treasurcr: Richard L. De Saussure. Term expires October 1960.

\section{History: Organized 1951.}

Purpose: To exchange views, technical information, and experience on various aspects of principles and practice of neurological surgery; to join in study and discussion of developments in allied scientific fields; and to honor living leaders in neurosurgery.

Mcmbership: Must limit practice to neurological surgery, and be either Board certified or have equivalent in neurosurgical training, and must be members of local and county medical societies. Total membership 502.

Meetings: Annual.

Professional activities: Residents in neurological surgery invited to attend annual meetings.

Publications: Clinical Neurosurgery, annual, current volume: 6, $\$ 7.50$. Editor : Robert Fisher.

558. Connecticut Academy of Arts and Sciences. 5 Sheffield Hall, Yale University, New Haven, Conn. President: IV. H. Dunham, Jr., Jonathan Edwards College, Yale University, New Haven, Conn. Term expires October 1960. Secretary: Dorothea Rudnick, Albertus Magnus College, New Haven, Conn. Term expires October 1960.

History: Organized March 4, 1799; incorporated October, 1799.

Purpose: To cultivate every art and science which may tend to advance the interest and happiness of a free and virtuous people; to publish Memoirs and Transactions; and to hold meetings where scholarly addresses are presented.

Membership: Election by the members. Total membership approximately 330 .

Meetings: Approximately eight times per year.

Professional activities: Joint sponsorship of the Connecticut Science Talent Search for high school seniors.

Publications: Transactions, irregular, current volunie: 42, price varies. Memoirs, irregular, current volume: 14, price varies. Editor: Dorothea Rudnick.

559. Connecticut Botanical Society, Inc. Osborn Botanical Laboratory, Yale University, New Haven, Conn. President: Leonard J. Bradley, Wilton, Conn. Term expires December 1960. Corresponding Secretary: Mrs. Esther B. Lindquist, Guilford, Conn. Term indefinite.

History: Organized January 24, 1903; incorporated January 10, 1921. Committees: Bryophytes, Herbariums, Phanerogams, and Pteridophytes.

Purpose: To secure a thorough knowledge of the flora of the State; to accumulate, hold, and maintain such specimens and documents as necessary for permanent records.

Membership: Total membership 200.

Mectings: Annual.

Professional activities: Field trips, ten to twelve annually.

Publications: Yearbook, annual, free to members. 


\section{Connecticut District Branch-American} Psychiatric Association. President: Duncan C. Stephens, Ituri Towers, Greenwich, Conn. Term expires May 1961. Secretary: George S. Hughes, 11 Sunset Road, Darien, Conn. Term expires May 1961.

History: Organized in 1934 as the Connecticut Society for Psychiatry and Neurology by a group of psychiatrists and neurologists in practice in Connecticut. Affiliate of the American Psychiatric Association, and, with the reorganization of the APA with District Branches and an Assembly of District Branches, the Connecticut Society for Psychiatry and Neurology went out of existence in 1956 to be re-constituted as the Connecticut District Branch of the American Psychiatric Association.

Purpose: To foster the progress of psychiatry, to represent psychiatry in the Connecticut area, and to assist the American Psychiatric Association in promoting its aims and objectives.

Membership: Physicians licensed to practice in Connecticut who are also members of the American Psychiatric Association. Total membership 160.

Mectings: Quarterly.

561. Connecticut Forest and Park Association. 322 North Main Street, Wallingford, Conn. President: James L. Goodwin. 15 Lewis Street, Hartford, Conn. Term expires April 1961. Secretary: Archibald W. Hurford. Term indefinite.

History: Organized 1895; incorporated 1928.

Purpose: The promotion of forestry, State forests and parks, roadside improvement, nature study, outdoor recreation, and other phases of conservation of natural resources.

Membership: Open to anyone interested in conservation in Connecticut. Annual Members; Sustaining; Contributing; Business; Commercial; Industrial; Special Contributing; Life; Patron; Benefactor; Founder. Total membership 1,350 .

Meetings: Annual; two field meetings each year.

Publications: Connecticut Woodlands, bimonthly, current volume: $25, \$ 1.25$, free to members. Editor: Archibald IV. Hurford.

562. Connecticut Pharmaceutical Association.

1804 East Main Street, Waterbury, Conn.

President: Daniel Leon, 50 Main Street, Norwich, Conn. Term expires June 1961. Secretary: Paul J. Kunkel. Term indefinite.

History: Organized February 1876; incorporated.
Purpose: To promote pharmacy, work with others toward that end, and cooperate with all branches of the health professions.

Membership: Active Members must be registered pharmacists; Life Members; Honorary Members. Total membership 1,065.

Meetings: Semiannual.

Professional activities: Garvin Memorial Prize, \$25; two scholarships, University of Connecticut College of Pharmacy.

Publications: Connecticut Pharmacist, monthly, current volume: 17 , free to members. Editor : Raymon Mercier.

563. Connecticut Science Teachers Association. Stratford High School, Stratford, Conn. President: Richard F. Blake. Term expires June 1961. Executive Secretary: Angela Trovato, Branford High School, Branford, Conn. Term expires June 1961.

History: Organized May 24, 1952.

Purpose: To encourage and promote better science teaching in the State.

Membership: Open to persons actively interested in the teaching of science in the State. Total membership 500.

Mectings: Semiannual.

Publications: Newsletter CSTA, monthly, current volume: 7. Editor: Robert Zwilling, Bedford Junior High School, Westport, Conn.

\section{Connecticut Society of Civil Engineers,}

Inc. P. O. Box 5176, Hamden 18, Conn. President: Robert G. Mitchell, King Street, Warehouse Point, Conn. Term expires April 1961. Secretary-Treasurer: Edgar B. Vinal. Term expires April 1961.

History: Organized January 15, 1884, as Conmecticut Civil Engineers' and Surveyors' Association; name changed to present title 1902; incorporated 1920. CommitteEs: Planning and Zoning, Surveying and Mapping, Subdivision Development.

Purpose: To promote advancement of engineering in all branches; and to stimulate personal growth and advancement of members.

Membership: Members, 907, must be at least twenty-one years of age, and must have had at least two years' actual experience in some branch of engineering, or must have graduated from an engineering course in a college or university of recognized standing; Associates, 83, must be eighteen years of age and interested in engineering. Total membership 990.

Mectings: Eight annually.

Professional activities: Annual awards for best papers submitted in intermediate, junior, and senior classes.

Publications: Annual Report, current volume: 76. Editor: Edgar B. Vinal. 
565. Connecticut Society of Gerontology. 165 Capitol Avenue, Hartford, Conn. President: Harold S. Barrett. Term expires January 1, 1961. President-Elect: Miss Ruth Olson, Superintendent, New Britain Memorial Hospital, 2050 Corbin Avenue, New Britain, Conn. Term begins January 1, 1961.

History: Organized November 1953 as first state society in its field.

Purpose: To stimulate awareness, interest, and community activity in the problems of an aging population; to foster scientific investigation of these problems; to provide for an exchange of knowledge and information pertaining to gerontology; to give advisory and consultant services to interested organizations and agencies.

Membcrship: Open to any professional or non-professional person interested in the aims of the organization. Regular Members, persons elected by the council upon the recommendation of the Membership Committee; Sustaining Members, groups, unions, or corporations elected by a three-fourths vote of the council. Total membership 160.

\section{Meetings: Annual.}

Professional activities: Annual conferences planned for senior citizens of Connecticut; periodic conferences and meetings held for professional workers from organizations and agencies serving senior citizens; sponsors conferences to assist in the preparation of needed legislation.

566. Connecticut Society of Pathologists. President: George B. McAdams, Hartford Hospital, Hartford, Conn. Term expires September 1961. Secretary-Treasurer: Donald King, Brady Laboratory, Grace-New Haven Hospital, New Haven, Conn. Term expires September 1961.

\section{History: Organized 1935.}

Purpose: To maintain and improve service of pathologists to physicians and patients; to provide periodic conferences for mutual assistance.

Membership: Graduates from recognized medical schools specializing in practice or teaching of pathology. Active members, 48 . Total membership 60.

Mectings: Bimonthly.

567. Connecticut Society of Professional Engineers. P. O. Box B, Devon, Conn. President: Stefan L. Grapnel, Putnam, Conn. Term expires June 1, 1961. Executive Secretary: Llewelyn M. Reed. Term indefinite.
History: Incorporated 1934; one of first four State Society members of the National Society of Professional Engineers.

Purpose: Advancement of the public welfare and promotion of the professional, social, and economic interests of the professional engineer.

Membership: Open to registered professional engineers in the United States or its territories, or Canada; open also to registered engineersin-training. Total membership 700 .

Mectings: Two or three a year.

Professional activitics: Scholarships in engineering; Engineer of the Year Award; twenty and twenty-five year membership awards; awards for outstanding service.

Publications: New England Professional Engineer Magazine, bi-monthly, published jointly by all six New England State Societies.

568. Connecticut State Medical Society. 160 St. Ronan Street, New Haven, Conn. President: Jolnn N. Gallivan, 400 Main Street, East Hartford, Conn. Term expires April 1961. Secretary: Orvan W. Hess, 79 Trumbull Street, New Haven, Conn. Term expires April 1961.

History: Incorporated May 1792. СoмMitTeEs: Arrangements; Postgraduate Education; Hospitals; Industrial Health; Medical Education and Licensure; Program; Public Health; State Legislation; Public Relations; Cancer Coordinating; Professional Relations; Mental Health; Third Party Payments; Eye Care; Editorial Board of Journal.

Purpose: To extend medical knowledge and advance medical science, to promote friendly intercourse among physicians, to enlighten and direct public opinion in prevention and care of disease, and in prolonging life.

Membership: Members, 3,243, licensed to practice medicine and a years residence in Connecticut; Associates, 12, not licensed to practice medicine; Student Members, 500, candidates for degrees of Doctor of Medicine, whose families reside in Connecticut, or those in that State's medical schools, or interns and residents in Connecticut hospitals. Total membership 3,755 .

Mectings: Annual.

Publications: Connecticut Medicine, monthly, current volume: 24, \$10. Editor: Denis S. O'Connor.

569. Connecticut State Psychological Society, Inc. University of Connecticut, Storrs, Conn. President: Philip W. Morse, 560 South Main Street, Hartford, Conn. Term expires August 31, 1961. Secretary-Treasurer: Edith S. Lisansky, 134 Wakefield Street, Hamden, Conn. Term expires August 31, 1962. 
History: Organized 1944; incorporated March 1, 1946.

Purpose: To further development and usefulness of psychology as a science and profession; to establish and maintain high standards of professional competence, service, and conduct; and to safeguard interests of the profession and public.

Membership: Members and Associates: must be either Members or Associates of American Psychological Association and live or have principal employment in Connecticut. Total membership 183.

Meetings: Annual.

Publications: Connecticut Psychologist, quarterly, current volume: 13. Editor: Jane Torrey.

\section{Connecticut State Society of Anesthesiol-} ogists. President: Edwin Platz, Manchester, Conn. Term expires May 1962. Secretary: S. A. Chait, 411 New Harwinton Road, Torrington, Conn. Term expires May 1961.

History: Organized 1937; became chapter of American Society of Anesthesiologists, 1946.

Purpose: To associate and affiliate all reputable doctors of medicine in Connecticut who are engaged in practice of, or otherwise especially interested in, anesthesiology; to encourage specialization in this field and make available to more people benefits derived from services of qualified anesthesiologists; to raise standards by fostering and encouraging research and scientific progress in this specialty, and by establishing standards of postgraduate education for qualifications as specialist, and to establish standards of approval for postgraduate training centers.

Membership: Requires active practice of anesthesiology in Connecticut, and membership in both American Society of Anesthesiologists and American Medical Association. Total membership 125 .

Mectings: Quarterly.

Professional activities: Biennial postgraduate seminar.

571. Connecticut Technical Council, Inc. P. O. Box 265, New Haven 2, Conn. Presidcrit: James C. Beach, P. O. Box 236, New Haven 2, Conn. Term expires May 31, 1961. Secretary-Treasurer: Roy L. Parsell. Term expires May 31, 1961.

History: Organized 1935 ; composed of member societies, and branches, chapters, or sections of national societies.

Purpose: To provide a common meeting ground and clearing house for the promotion of closer cooperation among technical societies in Connecticut; to harmonize and coordinate the activities of such societies in matters of common concern; to further the solution of public problems of a technical nature; and to represent the societies before the Legislature.

Membership: Open to engineering and allied technical societies or associations only. Seven member bodies composed of approximately 7,000 individuals.

Meetings: Quarterly, and on special occasions.

572. Conservation Council for Hawaii. Bishop Museum, Honolulu 17, Hawaii. President: Richard H. Cox. Term expires February 1961. Secretary: Herbert R. Welder, Jr., P. O. Box 3440, Honolulu 1, Hawaii. Term expires February 1961.

History: Organized August 1950, under auspices of Pacific Science Association, Pacific Science Board, and Bishop Museum. ComMitTeES : Land, Water, Flora, Fauna, and Sites.

Purpose: To further conservation in its various aspects in the State of Hawaii.

Membership: Requires active interest in conservation. Total membership: Organizations, 30 ; Individuals, 80 .

Mectings: Annual.

Publications: Summary of Committee Reports, annual. Bulletin, bi-monthly, current volume, 3 . Editor: Herbert R. Welder, Jr.

573. Constantinian Society. 3620 Douglas Road,

Toledo 13, Ohio. President: Phil B. Bleecker, 1024 Madison Avenue, Memphis 4, Tenn. Term expires October 29, 1960. SecretaryTreasurer: Charles F. Shook. Term expires October 29, 1960.

History: Originated during World War II as informal society of chiefs and assistant chiefs of medicine from units in the Mediterranean Theatre. Reorganized under present name April 1947; named in honor of famous Afro-Italian physician, Constantinius Africanus.

Purpose: To promote educational programs along medico-military lines.

Membership: Requires eighteen months' service in Mediterranean Theatre during World War II as chief or assistant chief of medicine in a military hospital. Total membership approximately 80 .

Meetings: Annual.

Professional activities: Fred Fitz Chair, or Cardiac Award, Passavant Memorial Hospital, Chicago, Ill.

574. Construction Specifications Institute, Inc. 632 Dupont Circle Building, Washington 6, D. C. President: Glen H. Abplanalp, Havens \& Emerson, 233 Broadway, New York 7, 
N. Y. Term expires May 31, 1961. Executive Secretary: Ronald S. Ryner. Term indefinite.

History: Organized 1948. Forty-six chapters throughout the United States.

Purpose: To foster and promote the interests of persons, firms, groups, associations, corporations, and others engaged in any phase of the business of writing, preparing, compiling, or in any way utilizing specifications in the construction and allied industries; to promote improved specification practices in the construction and allied industries; to gather, compile, and analyse statistics and information relating to or useful in the conduct of such activities; to engage in research and study of any and all problems and aspects of specification writing; to establish and maintain the Institute as a clearinghouse of technical information on specifications for the fabrication and installation of construction materials and equipment; to promote closer relations and cooperation among its members and chapters.

Menbership: Active Members, individuals concerned professionally with specifications and documents used in connection with the design, construction, maintenance, and equipment for construction projects; Associate Members, persons using specifications in purchasing or procuring construction materials and equipment, or engaged in selling construction materials and equipment, or in mining, processing, or manufacture of such products, or individuals engaged in contracting in construction or related enterprises; Junior Members, individuals such as draftsmen, clerks, and others interested in specification writing, but not in responsible charge of work; Student Members, graduate or undergraduate students in recognized architectural or engineering schools; Honorary Members. Total membership 4,600.

Mectings: Annual.

Professional activities: Honorary memberships; fellowships to members; awards for numerous activities, such as specifications competitions.

Publications: Construction Specifier, monthly, current volume: 13, \$12. Editor: Carl J. Ebert.

575. Construction Surveyors Institute. 101 Park Avenue, New York 17, N. Y. Executive Secretary: G. Szmak. Term indefinite.

History: Organized in Chicago, June 1926, as American Institute of Quantity Surveyors; name changed to present title 1946.

Purpose: To unite professional surveyors and their associates for scientific development, promotion, preparation, and performance of surveying services.
Membership: Fellows, professionally engaged in consultation, instruction, or practice of surveying, analyzing, appraising, attesting, and supervising construction; Associates, students, apprentices, or mechanics indirectly or subordinately engaged in tabulating, measuring, assaying, accounting, auditing, estimating, or evaluating of construction. Total membership approximately 100.

Meetings: Annual.

576. Consulting Engineers Association of New Mexico. 13130 Central Street, E., Albuquerque, N. Mex. President: Fred J. Fricke. Term expires April 30, 1961. Secretary-Treasurer: Robert Uhl, 213 Truman Street, N. E., Albuquerque, N. Mex. Term expires April 30, 1961.

History: Organized November 8, 1956. Became member of Consulting Engineer's Council (National) May 1957.

Purpose: To develop high standards of professional performance and ethics, and to advance professional and economic welfare of members, and their value to the public.

Membership: Principals in consulting engineering firms. Total membership 11.

Meetings: Monthly.

577. Consulting Engineers Council. 322 Reisch Building, Springfield, Ill. President: Hueston M. Smith, 4010 Lindell Boulevard, St. Louis 8, Mo. Term expires April 1961. Exccutive Secretary: Larry N. Spiller. Term indefinite.

History: Founded July 1956; incorporated February 1958. Council is active member of Fédération internationale des ingénieursconseils, National Council of State Boards of Engineering Examiners, and Engineers Joint Council.

Purpose: To enhance the professional and economic status of individual engineers in private practice and to protect the public.

Membership: Open to registered professional engineers who are owners, partners, or participating principals in private firms offering engineering services on a fee basis with no commercial affiliations. Total membership 1,621.

\section{Mectings: Semiannual.}

Professional activities: Publication of standard documents and forms for use of consulting engineers; promotion of engineering registration through model registration law; and publication of a Manual of Practice for the professional guidance of engineers in private practice. Sponsorship in member associations of annual Engineer of the Year awards. 
Publications: Newsletter, monthly, current volume: 4 , \$3. Editor: Larry N. Spiller. Legislative Action Bulletin, irregular, free to members. Editor: James N. DeSerio.

\section{Convention of American Instructors of the} Deaf. President: Richard G. Brill, California School for the Deaf, Riverside, Calif. Term expires June 1961.

History: Founded in 1850 and incorporated by Act of Congress in 1897 .

Purpose: To promote the education of the deaf on the broadest, most advanced, and practical lines, and to secure the harmonious union in the organization of all persons actually engaged in educating the deaf in America.

Membership: Open to qualified teachers of the deaf. Total membership 2,400.

Meetings: Biennial.

Publications: American Annals of the Deaf, bimonthly, September through May, current volume: 105, \$5. Editor: Powrie V. Doctor, Gallaudet College, Washington, D. C.

579. Cooper Ornithological Society. Museum of Vertebrate Zoology, University of California, Berkeley, Calif. President: WV. J. Sheffler, 4731 Angeles Vista Boulevard, Los Angeles 43, Calif. Term expires April 1961. Secretary: John Davis, University of California, Hastings, Reservation, Carmel Valley, Calif. Term expires April 1961.

History: Organized June 1893 in San Jose, California; incorporated December, 1934. DIvisions: Northern and Southern.

Purpose: The study of birds and the diffusion of the knowledge so gained.

Membership: Candidates must be proposed and recommended by a member in good standing; if the Secretary receives no objection to the proposed member within thirty days after the name has been read at a regularly scheduled monthly meeting, membership is automatically conferred. Total membership 1,665.

Mectings: Annual.

Professional activities: A Brazier Howell Award for most meritorious paper presented at annual meeting by non-holder of $\mathrm{Ph}$. D., in biology, \$150. Harry R. Painton Award, biannual, for author of most meritorious paper published in the Condor in previous four years, $\$ 500$.

Publications: Condor, bimonthly, $\$ 1$, free to members. Editor: Alden H. Miller.

580. Coordinating Research Council, Inc. 30 Rockefeller Plaza, New York 20, N. Y. President: G. J. Huebner, Jr., Chrysler Cor- poration, Detroit, Mich. Term expires January 1961. Secretary: Miss Genevieve Walmsley. Term indefinite.

History: Organized May 1942, incorporated 1943. Commitrees: Aviation, Diesel and Motor Fuel, Lubricant, and Equipment Research.

Purpose: To encourage and promote the arts and sciences by directing scientific cooperative research in developing the best possible combinations of fuels, lubricants, and the equipment in which they are used, and to afford a means of cooperation with the government on matters of national interest within this field.

Membership: Open to representatives of participating companies and organizations. Committee and working group members, 700; Research, 14; Sustaining, 2. Total membership 700 .

Meetings: Annual.

581. Corpus Christi Geological Society. P. O. Box 1068, Corpus Christi, Tex. President: C. M. Baker, Continental Oil Company, 601 Oil Industries Building, Corpus Christi, Tex. Term expires May 1961. Secrctary: Mary Catherine Magaw, Shell Oil Company, P. O. Box 1861, Corpus Christi, Tex. Term expires May 1961.

History: Organized June 8, 1942.

Purpose: To promote the science of geology, especially as it relates to development of oil, gas, and other resources of Southwest Texas.

Mcmbership: Members must be qualified for or ethically engaged in practice of petroleum geology; Associate Members must be engaged in some related branch of the petroleum industry.

Mectings: Twice monthly, September through May.

Professional activitics: Robert A. Janosky Scholarship in geology.

582. Council for Agricultural and Chemurgic Research. 350 Fifth Avenue, New York 1, N. Y. President: Dwayne O. Andreas, P. O. Box 750, Mankato, Minn. Term expires April 1961. Treasurer: John IV. Ticknor. Term expires April 1961.

History: Formed 1935 in Dearborn, Michigan; incorporated 1936 as the Farm Chemurgic Council; reincorporated 1937 as the National Farm Chemurgic Council; name changed to present title May 1, 1955. Committees: Technical Advisory; Swine; Starch.

Purpose: To further the industrial use of agricultural produce; to devise and promote the raising of new crops for industry.

Membership: Interest in furthering industrial use of American products of the soil. Associate 
Members, approximately 2,000 ; Corporate Members, 129; Affiliate Members, 13. Total membership approximately 2,200.

\section{Mectings: Annual.}

Publications: Chemurgic Digest, eleven times per year, current volume: $19, \$ 5$, free to members.

583. Council of Engineering Society Secretaries. President: O. B. Schier Il, American Society of Mechanical Engineers, 29 IVest 39th Street, New York, N. Y. Term expires May 1961. Secretary: Colin Campbell, P. O. Box 1536, Tulsa 3, Okla. Term expires May 1961.

History: Organized 1920 as Council of Secretaries; present name adopted 1948.

Purpose: Mutual interchange of information on policies and procedures for guidance of principal administrative officers of engineering societies.

Membership: Must be principal administrative officers or appointed representatives of recognized engineering and related scientific societies. Total membership approximately 75 .

Mcetings: Annual.

584. Council on Arteriosclerosis of the American Heart Association, Inc. President: Forrest E. Kendall, Chairman, Goldwater Memorial Hospital, Welfare Island, New York 17, N. Y. Term expires October 21, 1960. Secretary: O. J. Pollak, 9 Kings Highway, Dover, Del. Term expires October 21,1960 .

History: Organized June 9, 1947, as American Society for the Study of Arteriosclerosis; subsequently was merged with American Heart Association and name changed to present title.

Purpose: To improve methods of diagnosis and treatment, and to work toward prevention of arteriosclerosis; to further and coordinate research and dissemination of information.

Mcmbership: Active, linited to scientists making meritorious contributions to subject of arteriosclerosis; Associate, persons exhibiting special interest in subject; Corresponding, requirements of Active, but residing outside North America; Honorary, scientists who have made outstanding contributions in this field. Total membership approximately 280 .

Meetings: Annual.

585. County Engineers Association of California. Richmond Field Station, 1301 South 46th Street, Richmond, Calif. President: R. P. O'Neill, Court House, Oroville, Calif. Term expires November 19, 1960. Secretary:
William A. Jones, P. O. Box 1157, Fairfield, Calif. Term expires November 19, 1960.

History: Founded in 1916. Committees: Highways, Legislative Activities, Radio, and Standards.

Purpose: Improvement of county public works operations and the dissemination of information to members and other interested persons.

Membership: Any county engineer, county surveyor, coul1ty road commissioner, or county director of public works, plus one deputy for each office. Total membership 125.

Meetings: Semiannual.

Publications: Public Works Guide, irregular, \$10. Editor: Paul Kilkenny, Deputy Director of Public Works, County of Conta Costa, P. O. Box 509, Martinez, Calif.

586. Cranbrook Institute of Science. Bloomfield Hills, Mich. Chairman: James A. Beresford, 2500 Buhl Building, Detroit 26, Mich. Tern expires June 1961. Director: Robert T. Hatt. Term indefinite.

History: Founded 1930.

Purpose: Education and research in the natural sciences, including anthropology.

Membership: Open to persons with an interest in the purpose of the Institute. Annual Members, 892; Junior, 594; Sustaining, 157; Supporting, 5; Honorary Life, 7; Life, 58; Patrons 11; Fellows, 19. Total membership 1,743.

Professional activitics: Mary Soper Pope Medal, for notable achievement in plant science; Billington Lectures, education in natural sciences; maintenance of a laboratory and museum.

Publications: Bulletin, irregular, current volume : 39, $\$ 10.50$; News Letter, monthly, current volume: 29, \$2; Annual Report, current volume: $29, \$ .25$.

Library: 9,800 volumes on natural sciences.

587. Cranial Academy. 3829 Troost Avenue, Kansas City 9, Mo. President: Viola M. Frymann, 7754 Ivanhoe Street, La Jolla, Calif. Term expires January 1962. Executive Secretary-Treasurer: Rachel $\mathrm{H}$. IVoods. Term expires July 1962.

History: Organized by a group of the Academy of Applied Osteopathy particularly interested in teclnics for the treatment of the head.

Purpose: To promote a clearer understanding and a wider knowledge and application of the principles of ostcopathy in general, and of the cranial-sacro mechanism in particular; to stimulate further investigation, research, evolution, and clarification. 
Membership: Open to members of the Academy of Applied Osteopathy who are sponsored by two nembers. Total membership 284 .

Mcetings: Semiannual.

Professional activitics: Honorary memberships for outstanding service, and awards for special efforts of the members.

Publications: News Letter, quarterly.

588. Crop Science Society of America. Acting Secretary-Trcasurcr: L. G. Monthey, 2702 Monroe Street, Madison 5, Wis. Term indefinite.

History: Founded 1954; affiliated with American Society of Agronomy.

Purpose: To promote scientific principles in crop improvement.

Membership: Limited to professional agronomists and others interested in crop improvement. Total membership approximately 1,200.

Meetings: Annual.

Publications: Agronomy Journal, monthly, \$14. Editor: L. G. Monthey.

589. Dallas-Fort Worth Radiological Society, Inc. President: John T. Mallams, Baylor University Hospital, Dallas, Tex. Term expires January 1961. Sccreiary-Treasurer: W. H. Neil, 1217 IVest Cannon Street, Fort Worth, Tex. Term expires January 1961.

History: Founded 1955; incorporated in Texas. Formerly Dallas-Fort Worth Radiological Club.

Purpose: To discuss mutual problems confronting radiologists in the Dallas-Fort Worth area; to hold film reading sessions regularly.

Membership: Open to doctors of medicine in radiological practice in the Dallas-Fort Worth area, who are members in the county medical society. Total membership 70.

Mectings: Monthly, except July and August.

590. Dallas Geological Society. P. O. Box 253, Southern Methodist University Station, Dallas 22, Tex. President: Edgar Kraus, P. O. Box 2819, Dallas, Tex. Term expires June 1961. Secretary: Claude M. Burnett, 1301 Mercantile Securities Building, Dallas 1, Tex. Term expires June 1961.

\section{History: Organized 1919.}

Purpose: To bring together persons interested in the sciences of geology, geophysics, and engineering, especially as they relate to the discovery and production of petroleum and natural gas.

Membership: Open to persons in the fields of geology, geophysics, or petroleum exploration or technology interested in furthering the objects of this Society. Total membership 602.

Mectings: Monthly, September through May.
591. Dallas Southern Clinical Society. 433 Medical Arts Building, Dallas, Tex. Presidcnt: Frank H. Kidd, Jr., 4000 Junius Street Dallas, Tex. Term expires April 1961. Executive Officer: Millard J. Heath. Term indefinite.

\section{History: Organized April 1929.}

Purpose: To make available to the medical profession of the South the postgraduate teaching material of Dallas.

Membership: By invitation only, to qualified physicians who are members of their county medical societies. Total membership 490 .

Mectings: Annual.

Professional activities: Marchman Award. annual, for meritorious contribution to medical science.

592. Delaware Academy of Medicine, Inc. Lovering Avenue and Union Street, Wilmington 6, Del. President: George A. Zurkow, Medical Arts Building, Wilmington, Del. Term expires 1962. Secretary: Leonard P. Lang, 1009 Park Place, Wilmington, Del. Term expires 1962. Exccutive Director: Eugene C. Syrovatka. Term indefinite.

History: Organized and incorporated 1930.

Purpose: To sponsor scientific meetings in medical and allied sciences for professional and non-professional groups.

Membcrship: Regular members, 350, degrees in medicine or dentistry; Associates, 150; Total membership 500 .

Mcetings: Annual.

Library: 6,000 volumes. Subject emphasis: Medicine.

593. Delaware Council of Engineering Societies.

P. O. Box 1212, IVilmington, Del. President:

Ralph W. Smith, Engineering Department, E. I. duPont de Nemours \& Company, Wilmington 98, Del. Term expires May 1961. Secretary-Treasurer: Richard R. Zolnick. Term expires May 1961.

History: Organized as Delaware Engineering Association May 1949; name changed to present title June 1956. Committees:Professional Development, Civic Affairs, Program, Student Guidance, Publicity, and Facilities. Affiliates: American Society of Civil Engineers, American Institute of Chemical Engineers, American Institute of Electrical Engineers, American Institute of Plant Engineers, and American Society of Mechanical Engineers.

Purpose: To create and maintain cooperative action of affiliated engineering societies in the State of Delaware. 
Membership: Council members, representatives of affiliated societies. Total membership 2,300 .

Meetings: Monthly, except July and August.

Professional activitics: Engineers' Week activities coordination in Delaware.

594. Delaware Pharmaceutical Society, Inc. R. F. D. 2, Milford, Del. President: IV. Lemar Pierce, 535 North American Avenue-Extension, Dover, Del. Term expires June 30, 1961. Secrctary-Treasurer: Harry C. Zeisig. Term expires June 30, 1961.

History: Organized June 5, 1886.

Purpose: Advancement of the profession of pharmacy; professional, social, and economic advancement of members.

Membership: Active members, pharnacists registered in Delaware and over twenty-one years of age; Associate, registered pharmacists from other States; Honorary, persons who have performed outstanding service to this Society or to the profession of pharmacy; Affiliate, nonregistered pharmacists in Delaware and other persons having proprietary or managerial interests in pharmacies; Wholesalers and Manufacturers, people who serve pharmacy in those capacities; Student, persons who have completed one year at recognized colleges of pharmacy. Total membership 228.

Meetings: Monthly except July, August, and December.

Publications: Delaware Pharmacist, monthly, free to members. Editor: John C. Craig, 1213 Delaware Avenue, Wilnington 6, Del.

595. Delaware Psychiatric Society. President: Kurt Anstreicher, Delaware State Hospital, Farnhurst, Del. Term expires 1961. Secretary-Treasurer: Albert L. Ingram, Jr., 1403 North Rodney Street, Wilmington 6, Del. Term expires 1961.

596. Delaware Psychological Association. 216 Beverly Road, Newark, Del. President: Robert Ziller, University of Delaware, Newark, Del. Term expires October 1960. Secretary-Trcasurcr: Zona K. MacPhee. Term expires October 1960.

History: Organized March 3, 1947.

Purpose: To advance psychology as a science, as a profession, and as a means of promoting human welfare.

Membership: Member, Fellow or Member of American Psychological Association, or qualified for associate membership in that organization; Affiliate, student or other person interested in psychology. Members and Affiliates must reside or be employed in Delaware. Total membership 60 .

Meetings: Three annually.

Publications: Newsletter, irregular.

597. Delaware Society of Professional Engineers, Inc. P. O. Box 1848, Wilmington 99, Del. President: Earl D. Krapf, Delaware Power \& Light Company, 600 Market Street, Wilmington 99, Del. Term expires June 1961. Secretary: John T. Kephart, Jr., Engineering Department, E. I. du Pont de Nemours \& Company, Inc., Wilmington 98, Del. Term expires June 1961.

History: Organized 1950; charter received from National Society of Professional Engineers January 11, 1951.

Purpose: Promotion and protection of engineering profession as social and econmic influence vital to welfare of the community and of mankind.

Membership: Full Members, 271, holders of valid licenses or certificates of registration as professional engineers from any State or other subdivision of the United States; Junior Members, 17 , holders of valid certificates of registration as engineers-in-training; Land Surveyor Members, holders of valid licenses or certificates of registration as land surveyors from any State or other subdivision of the United States. Total membership 288.

Meetings: Monthly.

Professional activitics: Engineer-of-the-Year Award, annual, for outstanding contribution to profession.

Publications: Delaware Engineer, monthly, current volume: 8, free to members. Editor James H. Baltisberger.

598. Diabetes Association of the District of Columbia, Inc. President: William Kurstin, 915 19th Street, N. IV., Washington, D. C. Term expires June 30, 1961. SecretaryTreasurer: Louis K. Alpert, $2300 \mathrm{~K}$ Street, N. IV., IVashington, D. C. Term expires June 30,1961 .

\section{History: Founded 1948}

Purpose: Dissemination of knowledge of diabetes mellitus, and diabetes detection.

Mcmbership: Clinical section requires degree of doctor of medicine; lay section open to all persons interested in diabetes mellitus. Physician members, 50 ; Associate, 150. Total membership 200.

Mectings: Annual.

Professional activitics: Lectures for physicians and diabetics; annual diabetes detection drive. 


\section{District of Columbia Council of Engineer-} ing and Architectural Societies. Chairman: Leland B. Sponholtz, 3202 Fayette Road, Kensington, Md. Term expires May 1961. Sccretary-Treasurcr: Lowell E. Campbell, 10100 Riggs Road, Adelphi, Md. Term expires May 1961.

\section{History: Organized April 17, 1936.}

Purposc: To enable the architectural, engineering, and allied technical organizations in the District of Columbia to render more effective public service, and to contribute to the advancement of these professions.

Mcmbership: Any duly organized and recognized engineering, architectural, or allied technical organization in the metropolitan area of the District of Columbia. Total membership 30 societies.

\section{Meetings: Five annually.}

Professional activities: Sponsorship, jointly with the Washington Academy of Sciences, of the Engineers, Scientists, and Architects Day, which includes National Capital Awards to outstanding scientists under thirty-five years of age, and Citation Awards to outstanding science teachers in the District of Columbia area secondary schools; sponsorship, with the District of Columbia area Joint Board of Science Education, of various activities, including Science Fairs.

\section{District of Columbia Pharmaceutical} Association, Inc. President: Charles N. Grubb, 326 East Capitol Street, Washington 3, D. C. Term expires June 1961. Executive Secretary: Miss M. Eileen Brooks, 145 Kennedy Street, N. W., Washington 11, D. C. Term expires June 1963.

History: Organized 1852; incorporated 1940. Purpose: To improve the profession in order to fulfill health needs of the public and the needs of allied health professions; to promote pharmaceutical education and research; to aid in regulation of employment and apprenticeship training of pharmacists; to promote the interests of members.

Membership: Store members, 175, owners or managers of pharmacies; Active, 120, registered pharnacists; Associate, 50 , interested in pharmacy, non-registered; Travelers, 155 , representatives of pharmaceutical manufacturers and wholesalers. Total membership 500 .

Meetings: Quarterly.

Professional activities: Scholarship Fund, awarded annually to outstanding high school student desiring to study pharmacy, $\$ 500$; Augustus C. Taylor Memorial Trophy, awarded annually to winner of local pharmacy week window display.
Publications: National Capital Pharmacist, monthly, current volume: $21, \$ 2$. Editor: Miss M. Eileen Brooks.

601. District of Columbia Psychological Association, Inc. President: H. Max Houtchens, Department of Medicine and Surgery, Veterans Adninistration, Washington, D. C. Term expires January, 1961. Secretary: Bertha Harper Cory, P. O. Box 4300, Upper Marlboro, Md. Term expires January, 1962.

History: Organized 1946; incorporated 1952. Purpose: To advance psychology as a science, as a profession, and as a means of promoting human welfare; to foster and maintain high standards of professional competence, service and conduct; to make available to the general public information regarding psychology.

Membership: Requires residence or employment in the metropolitan area of the District of Columbia and training and experience equivalent to that required for membership in American Psychological Association. Total membership 352 .

Meetings: Monthly except June, July, August, and December.

602. District of Columbia Society of Anesthesiologists. 3601 Davis Street, N. W., Washington 7, D. C. President: Thomas F. McDermott, Chief of Anesthesiology, Georgetown University Medical Center, Washington 7, D. C. Term expires June 30,1961 . SecretaryTreasurer: Ervin N. Chapman. Term expires June 30, 1961.

History: Founded April 17, 1951 ; component, American Society of Anesthesiologists.

Purpose: To stimulate interest and encourage specialization in anesthesiology; to make available to more people the benefits derived from the services of qualified anesthesiologists; to disseminate information regarding, protect the public against irresponsible and unqualified practitioners of, and advance the specialty of anesthesiology.

Membership: Active members, physicians licensed in Washington, D. C., and practicing anesthesiology in the metropolitan area; Junior, physicians in full-time training in anesthesiology; Honorary, physicians, dentists, and other scientists who have rendered years of faithful service to this Society, or who have made significant contributions in anesthesiology; Associate, physicians interested in anesthesiology who are not engaged in its practice. Active, 64 ; Junior, 36; Associate and Honorary, 8; Retired, 2. Total membership 110 .

Meetings : Four annually. 
Professional actiritics: Sponsors annual competition among residents-in-training for best scientific paper.

\section{District of Columbia Society of Profes-} sional Engineers, Inc. President: Leonard T. Crook, 5409 Yorktown Boulevard, Arlington 7, Va. Term expires June 30, 1961. Executive Sccretary: Louis M. Tierney, 9408 Saybrook Avenue, Silver Spring, Md. Term expires June 30, 1961.

History: Established September 13, 1935; affiliate, National Society of Professional Engineers. Secured enactment of District of Columbia Professional Engineers Registration Act, September 19, 1950. Employment Groups: Government, Private Practice, Industry, Education.

Purpose: Service to society, state, and profession by promotion and protection of engineering as a vital social and economic influence; provision of effective forums for engineers grouped by employment as above indicated.

Membership: Requires license or registration certificate as professional engineer or engineerin-training issued by a lawfully constituted registration board of a State or other subdivision of the United States or of a province of Canada ; Introductory Members have fulfilled all requirements but have not applied for Society membership. Professional Engineers, 450; Engineersin-Training, 50; Introductory Members, 60. Total nembership 560.

Mectings: Monthly, winter only.

Professional activitics: Annual award to promising high school graduate who plans to study engineering; awards for outstanding service to this Society.

Publications: Metropolitan Washington Professional Engineer, monthly, current volume: 15 , free to members.

604. Duodecimal Society of America, Inc. 20 Carlton Place, Staten Island 4, N. Y. Presidcnt: Kingsland Camp, Hotel Shelton Towers, New York 17, N. Y. Term indefinite. Executive Secretary: Ralph H. Beard. Term indefinite.

History: Organized 1935; incorporated 1944 in New York.

Purpose: To educate the public and conduct 1 esearch in the use of the 12-base in numeration, mathematics, weights, and measures, and other branches of pure and applied science.

Membership: Open to all who demonstrate competence in duodecimal calculations. Total membership approximately 100 .

Mectings: Annual.
Professional activities: An Annual Award (scroll) is conferred upon any person who has made a significant contribution to the progress and development of duodecimals, and of this Society.

Publications: Duodecimal Bulletin, semiannual, current volume: $14, \$ 2$, free to members. Editor: Ralph H. Beard.

Library: 5,000 volumes. Subject emphasis: Mathematics and Esperanto.

605. East Bay Psychiatric Association. President: Dora Fishback, 2000 Dwight IVay, Berkeley 4, Calif. Term expires April 1961. Secretary: Richard E. Turk, 2000 Dwight Way, Berkeley 4, Calif. Term expires April 1961.

History: Organized September 21, 1951, at the suggestion of the chairman of the Mental Health Committee of the Alameda-Contra Costa Medical Association.

Purpose: To speak for East Bay psychiatrists and to promote fellowship among them.

Membership: Active members must have specialized in psychiatry for three years. Associate members must be practicing or training in psychiatry. Honorary members must have rendered some signal service in the interest of psychiatry. Total membership 116.

Mcctings: Monthly except during summer.

606. East Texas Geological Society. Tyler, Tex. President: Paul H. Nichols, P. O. Box 2037. Tyler, Tex. Term expires April 1, 1961. Exccutive Sccretary: Jack G. Goodwin, P. O. Box 480, Tyler, Tex. Term expires April $1,1961$.

History: Organized September 10, 1931.

Purpose: To promote the science of geology as related to East Texas and adjacent regions, and to promote fellowship and cooperation among geologists resident therein.

Mcmbership: Total members, 243, participating geologists or persons who are actively engaged in some phase of the petroleum industry.

Mcctings: Semi-monthly.

607. Eastern Missouri Psychiatric Society, District Branch of the American Psychiatric Association. 5400 Arsenal Street, St. Louis 9, Mo. President: Bernard A. Cruvant, 915 North Grand Boulevard, St. Louis 6, Mo. Term expires May 1961. Exccutive Secretary: Shael S. Bronson, 100 North Euclid Street, St. Louis 8, Mo. Term expires May 1961.

History: Organized 1938 as the St. Louis Society of Neurology and Psychiatry as suc- 
cessor to the St. Louis Society of Mental Hygiene. Became the Eastern Missouri District Branch of the American Psychiatric Association and until recently continued as two organizations with almost identical membership, but different constitutions and slightly different requirements for membership.

Purpose: To promote the science, art and practice of psychiatry in cooperation with, and as a constituent part of, the American Psychiatric Association, and to serve as an influence for the maintenance of high professional and administrative standards in the field.

Mcmbership: Associate Members, at least one year of residency training in psychiatry; Full Members, at least three years of residency training; Fellows, at least six years of training and experience, approval by the Board of Examiners, and meritorious contribution to psychiatry; Honorary Members, those persons who have contributed substantially to further the purposes of the Society or psychiatry in general. Total membership 140.

Mcetings: Six to seven meetings a year between October and April.

Professional activities: Montlly scientific programs for nembers; participation in postgraduate education courses for general practitioners.

608. Eastern Nevada Geological Society. President: Edward Phelps, P. O. Box 269, Ely, Nev. Term expires September 1961. Secretary: Richard Breitrick, 855 Park Avenue, East Ely, Nev. Term expires September 1961.

History: Organized July 1950.

Purpose: To further interests of geological endeavor in the Great Basin, and to promote fellowship within the geological fraternity.

Mcmbership: Active Members, must be college graduates with majors in geology and must have three years' experience in petroleum geology or in application of geology to exploration, development, research, or other phases of petroleum technology, or must be college graduates in sciences closely allied to petroleum geology, exploration, or development, with three years' experience; Associate Members, persons actively engaged in petroleum exploration or who, in opinion of Executive Committee, would further aims of this Society; Honorary Members, persons who have contributed distingtished service to geological science. Total nembership 35 .

Meetings: Monthly, May through September.

609. Eastern Psychological Association. P. O. Box 252, Glenbrook, Conn. President: S. S. Stevens, Memorial Hall, Harvard University, Cambridge 38, Mass. Term expires April 1961. Secretary: Carl H. Rush. Term expires April 1961.
Ilistory: The organization grew out of meetings of the Anthropology and Psychology Section of the New York Academy of Sciences before 1900. By vote of the Council of the American Psychological Association, this Association was called the New York Branch of the American Psychological Association; name changed to present title in 1938.

Purpose: The advancement of the science of psyclology through meetings for the presentation of reports and discussion.

Membership: Member must be an Associate or Fellow of the American Psychological Association or have one full year of graduate study in psychology at an accredited university or college. A member must also reside in the territory embraced by this organization. Total membership 3,221.

Mectings: Annual.

610. Eastern States Archeological Federation. President: William J. Mayer-Oakes, Stovall Museum, University of Oklahoma, Norman, Okla. Term expires November 1960. Secretary: Mrs. Kathryn B. Greywacz, New Jersey State Museum, Trenton, N. J. Term expires November 1960.

History: Organized February 1934, incorporated November 8, 1940. The Federation is comprised of the state and provincial archeological societies from Alabana; Connecticut; Delaware; Florida; Georgia; Maine; Maryland; Massachusetts; Michigan; New Hampshire; New Jersey; New York; North Carolina ; Ontario, Canada; Pennsylvania; Quebec, Canada; Rhode Island; Virginia; West Virginia.

Purpose: To promote scientific investigation of archeological remains in the eastern states and to establish a plan for interstate cooperation in the field of archeological research.

Membership: Membership is composed of state and provincial archeological societies. Total membership, 19 member societies con1prising 4,500 individuals.

Mectinngs: Annual.

Publications: Bulletin, annual, current volume: 19, $\$ 0.50$, free to members. Editor: P. Schuyler Miller.

611. Eastern Surgical Society. President: Henry H. Hun, 149 Washington Avenue, Albany, N. Y. Term expires April 1961. Secretary: Howard Ulfelder, Vincent Memorial Hospital, Boston, Mass. Term expires April 1961.

History: Organized 1928.

Purpose: To promote interest in clinical and scientific surgery by providing opportunity at stated intervals for its members to visit, in a 
body, the clinics and laboratories situated in the cities represented.

Membership: Active, limited to 35 ; all members reaching the age of sixty automatically become senior members. Total membership approximately 60 .

Mcetings: Annual.

612. Ecological Society of America. President: Arthur D. Hasler, Department of Zoology, University of Wisconsin, Madison, Wis. Term expires August 30, 1961. Secretary: John E. Cantlon, Department of Botany and Plant Pathology, Michigan State University, East Lansing, Mich. Term expires August 30, 1961.

History: Founded 1915; incorporated 1927 ; member of American Institute of Biological Sciences since 1947. Western Section includes those members residing west of the eastern boundary of Colorado; Animal Behavior Section includes those interested in this area of study.

Purpose: To promote the scientific study of organisms in relation to their environment, both as individuals and as members of populations and communities; and to facilitate the exchange of ideas among those interested in ecology.

Membership: Persons and organizations interested in ecology and the promotion of ecological research, on the recommendation by two members and election by the Council. Associate, Active, and Sustaining Members. Total membership 2,200.

\section{Meetings: Annual.}

Professional activities: George Mercer Award, annually for outstanding paper on ecology published in English, in honor of George Mercer, killed in British Army in World War I, \$100.

Publications: Ecology, quarterly, current volume: 41, \$9. Editors: R. H. Whittaker, Review; L. C. Cole, Zoological; A. A. Lindsey, Botanical. Ecological Monographs, quarterly, current volume: $30, \$ 6$. Editors : F. C. Evans, Zoological, and II. J. Oosting, Botanical. Bulletin, quarterly, current volume: 41, \$2. Editor: J. E. Cantlon.

613. Econometric Society. P. O. Box 1264, Yale Station, New Haven, Conn. President: Lawrence Klein, Wharton School, University of Pennsylvania, Philadelphia, Pa. Term expires December 31, 1960. Secretary: Richard Ruggles. Term expires December 31, 1960.

History: Organized December 1930.

Purpose: To advance econonic theory in its relation to statistics and mathematics.

Membership: Open to any qualified individual seriously interested in the objectives of the
Society. Regular Members, 1,450; Institutional, 2; Fellows, membership in the Society for at least one year, nomination by committee, election by all Fellows, 121; Student Subscribers, 100; Subscribers, 1,350.

Meetings: Summer, winter, European, west coast (regional).

Publications: Econometrica, quarterly, current volume: 28 , domestic $\$ 14$, foreign $\$ 12$, student \$6. Managing Editor: Robert Strotz, Department of Economics, Northwestern University, Evanston, Ill.

614. Electrochemical Society, Inc. 1860 Broadway, New York 23, N. Y. President: Ralph A.Schaefer. The Bunting Brass and Bronze Company, Toledo, Ohio. Term expires spring 1961. Executive Secretary: Robert K. Shannon. Term indefinite.

History: Organized April 3, 1902. Sections: Boston, Chicago, Cleveland, Columbus, Detroit, India, Indianapolis, Midland, Mohawk-Hudson, New York Metropolitan, Niagara Falls, Ontario-Quebec, Pacific Northwest, Philadelphia, Pittsburgh, San Francisco, Southern CaliforniaNevada, Texas, Washington-Baltimore. DIvisions : Battery, Corrosion, Electric Insulation, Electrodeposition, Electronics, Electro-Organic, Electrothermics and Metallurgy, Industrial Electrolytic, Theoretical Electrochemistry.

Purpose: The advancement of the theory and practice of electrochemistry, electrometallurgy. electrothermics, and allied subjects. Among the means to this end shall be the holding of meetings for reading and discussion of professional and scientific papers on these subjects, the publication of such papers, discussions, and communications as may seem expedient. and cooperation with chemical, electrical, and other scientific and technical societics.

Membership: Active Members, 3,020, shall be interested in electrochemistry or allied subjects, be at least 25 years of age, and possess a Bachelor's or Engineering degree with a major interest in the natural sciences, and have three or more years of postgraduate experience. Election to active membership shall require the recommendation of two active members in good standing. Associate, 33, shall have received a Bachelor's or Engineering Degree with major interest in natural science, but not yet have completed the requirements of three years' experience, or have exceeded the age of twentyeight. Election to Associate Membership shall require the recommendation of two Active Members in the Society. Student, 57 , shall be at least eighteen years old, and shall be an undergraduate or graduate student registered for a degree in natural science or engineering. Election to Student Membership shall require recom- 
mendations by two Active Members and a member of the senior staff of the college of his attendance. Emeritus, 48, active members who have paid dues for twenty-five years and attained the age of sixty-five. Honorary, 7 , those individuals who by reason of valuable contributions to electrochemistry deserve special recognition by the Society, Patron, 5, and Sustaining, 160, those who through interest in electrochemistry contribute financially to the support and development of the Society. Total membership 3,182.

Meetings: Semiannual.

Professional actizities: Edward Goodrich Acheson Gold Medal and Prize, $\$ 1,000$, awarded every two years to the person who has made a distinguished contribution to the advancement of any of the objects, purposes, or activities of the Society. Palladium Medal, founded in 1950 , in recognition of outstanding accomplishments in the field of corrosion of metals and its control. F. M. Becket Memorial Award, $\$ 500$, established from a fund presented to the Society by the Electro Metallurgical Company, a division of the Union Carbide Corporation, made each year in the form of a scholarship in the field of electrochemistry. Joseph IV. Richards Memorial Lecture, established in 1929 by a group of friends and admirers of Dr. Richards; interest from the fund is used to defray the expenses incurred by inviting distinguished scientists to lecture. Young Author's Prize, \$100, established in July 1928 for the best paper printed in the yearly volume of the Journal of the Society. epen to students and graduates under thirty-one years of age. Francis Mills Turner Memorial Award, sponsored by the Reinhold Publishing Corporation, consists of $\$ 100$ worth of scientific and technical books to be given each year to an author under thirty-one years of age. Perkin Medal, an award of the Society of Chemical Industry, candidate recommended by the Socicty. Prize Essay Contest, open to students, consisting of a prize of $\$ 100$ to the First Prize and $\$ 50$ for the Second Prize. Battery Division Aivard, established 1958, for purpose of stimulating battery research and encouraging the preparation of high-quality papers for the Journal of the Society; planned to select, every two years, the author or authors of a recent paper relating to electrochemical cells or batteries published in the Journal; consists of an engraved scroll to each author of the chosen paper, and also prepaid membership in the Society and subscription to the Journal as follows: single author, life membership and subscription; two authors, ten years' prepaid membership and subscription to Journal to each; three authors, seven years' prepaid membership and subscription to each author. Electrochemical Society Assistance Award, $\$ 800$ covering the period June to September 1960, established on an experimental basis for one year, such Fellowship not to be established on a basis of need; made without regard to sex, citizenslip, race, location, or financial need to a fellow or teaching assistant pursuing work between the degree of B.S. and Ph.D. on a subject in the field of interest to the Society. The William Blum Award of the Nashington-Baltimore Section of the Society, established 1958, in recognition of outstanding contributions to electrochemistry; $\$ 100$ and a certificate given semiannually. Certificate of Appreciation to Past Presidents, voted in 1959 to approve awarding of suitable Certificates of Appreciation to all living Past Presidents of the Society.

Publications: Journal, monthly, current volume: 107, \$1.25 members (single copy); $\$ 1.75$ nonmembers (single copy). Editor: Cecil $\mathrm{V}$. King.

615. Electron Microscope Society of America. President: D. Gordon Sharp, Department of Bacteriology, University of North Carolina, Chapel Hill, N. C. Term expires January 1, 1961. Council Secretary: Miss Mary L. Rollins, P. O. Box 19687, New Orleans 19, La. Term expires January 1, 1962.

History: Organized November 1942; incorporated February 1954.

Purpose: To increase and diffuse the knowledge of electron microscopes and related instruments and results obtained through their use in whatever fields they may be found applicable.

Membership: Regular members, 884, persons interested in the use of an electron microscope.

Mcetings: Annual.

616. Elisha Mitchell Scientific Society. University of Nortl Carolina, Chapel Hill, N. C. President: Alfred T. Brauer. Term expires May 1961. Secretary-Treasurer: Melbourne R. Carriker. Term expires May 1961.

History: Organized 1883.

Purpose: To cultivate interest in natural history and general scientific subjects; to encourage individual workers in science: to increase knowledge of North Carolina and its resources.

Membership: Regular Members, 176, instructors, or higher, University of North Carolina, or persons with equivalent rank from outside the University ; Associate Members, 84, graduate students with rank less than instructor, graduate assistants, and students in the scientific professional schools with collegiate records of unusual excellence; Honorary Members, 7, nominated by executive Comnittee and approved by three-fourths of regular members. Total membership 267. 
Meetings: Montbly during two winter semesters.

Professional activities: W. C. Coker Award, annual, for best dissertation on a scientific subject, $\$ 50$.

Publications: Journal, semiannual, current volume: $76, \$ 3.50$, free to members. Editor: I. $\$. Couch.

617. Endocrine Society. 1200 North Walker Street, Oklaboma City 3, Okla. President: John Eager Howard, Johns Hopkins Hospital, Baltimore, Md. Term expires June 1961. Executive Sccrctary: Ilenry H. Turner. Term indefinite.

History: Organized 1917 in New York as Association for the Study of Internal Secretions : incorporated January 1918; name subsequently changed to present title.

Purpose: To stimulate interest in study of internal secretions, and to collect and disseminate literature on that subject.

Membership: Open to any qualified physician or biologist. Total membership 1,300.

Meetings: Annual.

Professional activities: Medal of the Endocrine Society, for work of special distinction in endocrinology, capital amount $\$ 1,000$; Ciba Award, for meritorious accomplishments of investigator under thirty-five years of age in field of clinical or preclinical endocrinology, capital amount $\$ 1,800$; Ayerst, McKenna and Harrison Fellow ship, to assist men and women of exceptional promise toward a career in endocrinology, capital amount $\$ 2,500$; Schering Scholar, and Upjohn Scholar, awarded to established investigators and teachers of endocrinology to extend their opportunities, capital amount $\$ 2,500$ each.

Publications: Journal of Clinical Endocrinology and Metabolism, monthly, current volume: $20, \$ 12$. Editor: Phebe K. Thompson, Endocrinology, monthly, current volume: 44, \$12. Editor: Roy O. Greep.

\section{Engineering and Technical Societies Coun-} cil of Delaware Valley. 1317 Spruce Street, Philadelphia 7. Pa. President: Norton H, Walton, Atlantic Refining Company, P. O. Box 8138, Philadelphia 1, Pa. Term expires May 1961. Secretary: Cliarles S. Doerr. Term indefinite.

History: Formerly called Engineering and Technical Societies Council of Philadelphia.

Purpose: To unite engineering and allied technical societies in the Philadelphia area to the end that, through unification of effort and purpose and a spirit of fraternity, there be a joint council to represent and speak for the whole; to solve problens by cooperative effort; to secure and disseminate accurate and reliable information of interest and value in the profession or otherwise related to it; to support codes of ethics for the profession; to consider legislation concerning engineers and allied interests; to take part in civic affairs of concern to the societies and the communities in which they exist; and by all legal ways and means to promote the welfare of the profession and allied interests and enhance their standing with the public.

Mcmbcrship: Engineering, technical and other societies, whose objects, activities and interests in engineering and the technical services are such that in the opinion of the Council they ean cooperate with the Council. Total nembership. 25 local sections or chapters of the national engineering societies.

Mretings: Five times a year.

619. Engineering Foundation. 29 VVest 39th Street, New York 18, N. Y. Chairman: A. M. Gaudin. Term expires May 1961. Sccretary and General Manager: S. IV. Marras. Term expires May 1961.

History: Established as a department of United Engineering Trustees, Inc., in 1914. Engineering Foundation has initiated many large research councils which are today well known throughout industry. During the years 1916 to the early 1920's, Engineering Foundation was instrumental in the establishment of the National Research Council and in its subsequent development; during its early years the entire Engineering Foundation income was used to establish the National Research Council and to maintain a joint secretariat, with the original offices being housed in Engineering Societies Btilding in New York City. Among other councils which Engineering Foundation helped establish were: Engineers' Council for Professional Development, Welding Research Council. Column Research Council, Research Council on Riveted and Bolted Structural Joints, Reinforced Concrete Research Council, Steel Structures Painting Council, Council on IVave Research, Alloys of Iron Research, Corrosion Research Council, and Thermal Resistivity Characteristics of Soils.

Purpose: The furtherance of research in science and engineering, and the advancement in any other manner of the profession of engineering and the good of mankind.

Membership: Board of 19 members, representing the five major national engineering societies : American Society of Civil Engineers; American Institution of Mining, Metallurgical and Petroleun Engineers; American Society of Mechanical Engineers; American Institute of Electrical 
Engineers; and American Institute of Chemical Engineers.

\section{Mectings: Board meets semiannually.}

Professional activitics: Sponsors the following projects: Council on Wave Research; Techniques for Forecasting Waves. Other projects sponsored through member engineering societies.

620. Engineering Societies of New England, Inc. Hotel Lenox, Room 322, 61 Exeter Street, Boston 16, Mass. President: George W. Sprague. Term expires June 1, 1961. Sccrctary: George K. Sauerwein. Term indefinite.

History: Organized June 19, 1922, as Affiliated Technical Societies of Boston; name changed June 11, 1929, to Engineering Societies of Boston; name changed to present title June 6. 1934. Affiliated Societies: Boston Society of Civil Engineers; Plant Engineers Club; American Institute of Electrical Engineers, Boston Section; American Society of Mechanical Engineers, Boston Section; American Society of Civil Engineers, Massachusetts Section; American Institute of Mining, Metallurgical and Petroleum Engineers, Boston Section; American Society of Heating, Refrigerating and Air Conditioning Engineers, Massachusetts Chapter; American Welding Society, Boston Section: Illuminating Engineering Society, New England Section; Massachusetts State Engineers' Association, Inc.; American Institute of Electrical Engineers, Lynn Section; American Society for Non-Destructive Testing, Boston Section; American Society of Safety Engineers, Boston Chapter; American Society of Tool Engineers, Boston Chapter; American Society for Quality Control, Boston Section; American Society of Lubrication Engineers, Boston Section; American Institute of Chemical Engineers, Boston Section; South Shore Industrial Engineers Association; Institute of the Aeronautical Sciences; American Institute of Industrial Engineers, Boston Chapter; Society of Women Engineers, Boston Section; American Society of Agricultural Engineers, Connecticut Valley Section; American Society of Tool Engineers, Merrimack Valley Section; Society of Fire Protection Engineers, Boston Section; American Institute of Industrial Engineers, Merrimack Valley Chapter; American Institute of Industrial Engineers, Tri-State Chapter; National Association of Corrosion Engineers, Greater Boston Section.

Purpose: To bring the technical societies of New England and their members into closer touch with one another for more effective public service, and for the advancement of scientific investigation, education, and research.
Mcmbcrship: Members, certified by the affiliated societies; Sustaining; Professional Associate. Total membership 8,900.

Mcctings: Five Council meetings per year.

Profcssional activitics: New England Award, given to a living engineer, resident in New England, who, by outstanding achievement, shall merit recognition of his accomplished work as well as of his character, by his fellow engineers of the New England States.

Publications: Journal, weekly, current volume: 29, \$1.60. Editor: IV. Colburn.

621. Engineering Society of Buffalo, Inc. Room 63, Hotel Statler Hilton, Buffalo 2, N. I'. President: Donald R. Sutton, 177 Oakridge Drive, Hamburg, N. Y. Term expires August 31, 1961. Executive Secretary: Mrs. Mildred Fritz. Term indefinite.

History: Organized 1894 as the Engineers Society of Western New York; reorganized December 20, 1912 under present title; incorporated October 13, 1920. Member of the Technical Societies Council.

Purpose: Advancement of engineering knowledge and practice; professional improvement of members by means of meetings for the reading and discussion of appropriate papers ; dissemination, in suitable manner, of facts and information brought to light through its deliberations; cooperation with the local sections of all national societies to the end that in all matters of common interest the engineering profession may take concerted action; fostering of professional and social intercourse among its members; consideration of engineering matters which may affect the general welfare of the community, and suitable action with reference thereto; creation, management and control of a scholarship fund, and for that purpose to take and acquire real and personal property or principal thereof for the advancement of engineering and practice.

Membership: Close association with the engineering profession as a result of vocation, hobby, or daily business contacts, plus sponsorship by a member of the Society. Regular members, limited to those who are interested in engineering matters and who qualify for membership in accordance with the Constitution and Bylaws of the Society; Life, members in good standing for at least five years prior to election to Life membership, limited to thirty members; Honorary, members who have performed some service of merit to the Society; Non-resident, any person who is otherwise qualified for membership and whose place of residence and business is at least fifty miles from the Society Headquarters in Buffalo, with the same rights and privileges as Regular members; Sustaining. 
Regular members, 622; Life, 25 ; Honorary, 10 ; Non-resident, 29; Sustaining, 27. Total membership 713.

Mectings: Monthly except July and August.

Professional activitics: Endowment Fund, to assure the future financial security of the Society and provide sufficient funds to promote its various objects and activities; Scholarship Fund, which provides $\$ 800$ annually to most deserving area high school graduate to the University of Buffalo Engineering College; sponsorship of engineering lectures in preparation for Professional Engineers License examinations.

Publications: Bulletin, monthly, current volume : 31 .

622. Engineering Society of Cincinnati. 1349 East McMillan Street, Cincinnati 6, Ohio. President: Reuben J. Beaman, Jr., 3045 Coral Park Drive, Cincinnati 11, Ohio. Term expires June 1, 1961. Secretary: Miss Margaret Arnold. Term indefinite.

History: Organized 1888 as the Engineers' Club of Cincinnati; name changed to present title August 17, 1943.

Purpose: To encourage the professional improvement of engineers; to advance engineering in all its branches; and to promote professional fellowship among engineers.

Membership: Active, 1,260, Qualified by one of the following: degree from an accredited engineering school or college, and a record of four years or more of active practice in the profession; or the equivalent in knowledge, skill, and longer active practice; or a Registered Professional Engineer in a state where the requirements for registration are comparable to those of the State of Ohio; or an architect, chemist, physicist, metallurgist, or a nember of other kindred technical or scientific profession with comparable qualifications. Associate, 308, inust be twenty-five years of age or over, must be or have been so connected with some branch of engineering science, or industry relating thereto, that he may be considered as qualified to cooperate with engineers in the advancement of professional knowledge; Co-Associate, same qualifications as Associate. Junior, 179, under thirty years of age, a graduate in engineering, architecture, chemistry, physics, metallurgy, or other kindred technical or scientific courses of study in a university or college of recognized standing; Honorary, 5 ; Life, 56 . Total nembership, 1,808 .

Meetings: Annual, monthly, weekly.

Professional activities: Life Members' Scholarship Fund, two scholarships of $\$ 300$ each, awarded annually to freshmen engineers at the University of Cincinuati. Carsey Memberships,
Society membership awards to fifteen senior engineers at the University of Cincinnati annually. The Engineer and Scientist of the Year, the Society cooperates with affiliate societies in the selection of the outstanding engineer or scientist of the year from this area.

Publications: Engineer and Scientist, weekly September through June, current volume: 25, free to members. Editor: Dorothy Walley.

Library: 1,940 volumes.

623. Engineering Society of Detroit. 100 Farnsworth Avenue, Detroit 2, Mich. President: Frederick Bauer, Engineering Staff, Ford Motor Company, Dearborn, Mich. Term expires June 30, 1961. Managing Director: Frank G. Horton. Term indefinite.

\section{History: Organized April 15, 1936.}

Purpose: To promote growth of engineering and allied arts and sciences; to unite for public welfare engineers and other persons interested in engineering or allied professions in Detroit and vicinity; to provide services and facilities for civic education on engineering matters.

Membership: Regular Members, 4,849, over twenty-one years of age and with bachelors' degrees in engineering, architecture, or allied arts and sciences, or equivalent technical knowledge by practical experience; Associate Members, 298, over twenty-one years of age, not eligible for regular nembership, but qualified by position or experience to cooperate with engineers in engineering work; Junior Members, 378 , over twenty-one, but not over thirty years of age, with minimum age limit waived for bachelors' degrees in engineering, architecture, or allied arts and sciences, must meet requirements for regular members or be enrolled in, and have completed, at least three years of education in one of the foregoing specialties in schools authorized to confer corresponding degrees; Senior Members, 52, over sixty-five years of age, and either have twenty-five years' nembership or are charter members; Affiliate Members, 50, societies or local sections of 11ational societies whose membership is based on interest in engineering, architecture, chemistry, or allied arts and sciences, and at least fifteen per cent of whose nembers are regular members of this Society; Sustaining Members, 178, persons or firms actively engaged in engineering, architecture, chemistry, or allied arts and sciences; Honorary Members, 5. Total membership 5,810 .

Meetings: Monthly except July and August.

Professional activities: Five $\$ 1,000$ scholarships awarded annually in connection with Metropolitan Detroit Science Fair. 
Publications: Detroit Engineer, monthly except July and August, current volume: 24, members $\$ 2$, non-members $\$ 3$. Editor: Adele Huebner.

Library: 1,200 volumes on engineering.

624. Engineering Society of Midland. P. O. Box 347, Midland, Mich. President: Frank H. Justin. Term expires June 1961. Secretary: N. R. Prott. Term expires June 1961.

History: Organized 1945; composed of members from the Saginaw Valley-Saginaw, Bay City and Midland. Society is member of the Saginaw Valley Technical Society Coordination Group representing approximately $2,500 \mathrm{mem}-$ bers of various societies.

Purpose: To promote the technical and social interests of its membership, civic activity and public service, and high professional standards.

Membership: Active Members, 400, those persons who have Bachelor's Degrees in engineering, architecture, or an allied science, or who are qualified to apply for examination for registration by Michigan State Board of Registration for Architects, Professional Engineers and Land Surveyors. Associate Members, 85 , limited to twenty per cent of active membership, those persons engaged in engineering work, or in work closely allied to engineering. Total membership 485 .

Meetings: Monthly, except summer months.

Professional activities: Sponsors Science Fair and provides two awards for best engineering exhibits. Provides a $\$ 300$ scholarship to Midland High School senior entering an accredited engineering school.

625. Engineering Society of Western Massachusetts. P. O. Box 149, Springfield, Mass. President: George A. Marston, 323 East Pleasant Street, Amherst, Mass. Term expires May 1, 1961. Secretary-Treasurer: Donald A. Bartlett, 94 Ridge Road, East Longmeadow, Mass. Term expires May 1, 1961.

History: Organized April 16, 1919.

Purpose: The professional improvement of its members; the advancement of the arts and sciences connected with the various branches of engineering.

Membership: Member, thirty years of age, has been engaged in a responsible position as engineer, architect, or applied scientist for a period of at least three years; an approved professional diploma shall be considered equivalent to two years of the required practice; or any person who has served as a teacher of applied science for more than two years. Associate, over twenty-five years of age and qualified by his business relations and practical experience to cooperate with engineers, architects and applied scientists in the advancement of professional knowledge. Junior, under twenty-five years of age, a practitioner of engineering, architecture or applied science or a graduate of an engineering school. Life, any member in good standing upon payment of $\$ 100$.

Meetings: Monthly September through May.

Publications: Year Book, free.

626. Engineering Society of York, Pennsylvania. 26 South Beaver Street, York, Pa. President: Jennings B. Grimm, R. D. 4, Dover, $\mathrm{Pa}$. Term expires March 1961. Secretary: William E. Smeigh, 2425 Auburn Road, York, Pa. Term expires March 1961.

History: Organized in 1910.

Purpose: To advance engineering knowledge and to provide means of educating the public with respect to such knowledge.

Membership: Corporate Members are civil, military, naval, mechanical, electrical, mining or other engineers, architects, surveyors or analytical chemists or persons who have taken a course in a technical school relevant to engineering. Total membership 235.

Meetings: Monthly.

Professional activities: Four $\$ 500$ and four $\$ 200$ scholarships to engineering colleges and technical schools.

Publications: York Engineer, monthly, current volume: 20 .

627. Engineers and Architects Club of Louisville, Kentucky. Henry Clay Hotel, Louisville, Ky. President: Herschel O. Smith, 3126 Horton Avenue, Louisville 5, Ky. Term expires January 1, 1961. Secretary: Herman H. Heck, 3941 Grandview Avenue, Louisville 7, Ky. Term expires January 1, 1961.

History: Organized January 1, 1891 ; incorporated June 10, 1891, and August 24, 1944.

Purpose: The professional improvement of its members; the encouragement of social intercourse among engineers and architects; and the advancement of engineering and architecture in all of their branches.

Membership: Active members, 120, engineers or architects at least twenty-three years of age, at least two years experience or a graduate of a technical school or college as an engineer or architect; Non-Resident 3; Life, 20; Other, 7. Total membership 150 .

Meetings: Monthly.

628. Engineers Club. 925 Arctic Building, Seattle 4, Wash. President: J. L. Bannon, 6851 East Marginal Way, Seattle 4, Wash. 
Term expires January 1961. Secretary: E. K. Blackford, 457 Central Building, Seattle 4, Wash. Term expires January 1961.

History: Organized January 13, 1912; incorporated January 1915.

Purpose: The promotion and advancement of the arts and sciences connected with engineering.

Membership: Engineers or closely affiliated professional persons. Total membership 348 .

Mcetings: Weekly except July and August.

Publications: Bulletin, weekly. Editor: E. K. Blackford.

629. Engineers Club of Baltimore, Inc. 6 West Fayette Street, Baltimore 1, Md. President: A. R. Vollmer, 1304 St. Paul Street, Baltimore 2, Md. Term expires January 1, 1961. Secretary: Eleanor lngram. Term indefinite.

\section{History: Organized February 24, 1905.}

Purpose: The promotion and advancement of the arts and sciences connected with engineering.

Membership: Member, any professional engineer, land surveyor or architect registered by the State of Maryland, or any other State, or a graduate of a college or university with a degree in engineering or related science, or a person engaged in engineering practice or a recognized branch of engineering and in work requiring engineering knowledge and judgment for at least seven years; Associate, a person of at least twenty-five years of age who by education and practical experience is qualified to cooperate with engineers in the advancement of their profession; Junior, any person below the age of twenty-five years who meets the requirements for either Member or $\Lambda$ ssociate Member; NonResident, a person who could otherwise qualify as a member or Associate Member, but who has neither residence nor place of business within fifteen miles of Baltimore City Post Office; Federal, a person who is an active or retired commissioned officer of the regular armed forces of the United States, and who possesses the qualifications to be a Member or Associate Member; Student, a person who is taking a full course of instruction in a technical school of collegiate grade and established reputation, satisfactory to the Board of Directors. Total membership 800 .

Mectings: Weekly.

Publications: Baltimore Engineer, monthly, free to members.

Library: 2,800 volumes.

630. Engineers Club of Bartlesville. P. O. Box 1335, Bartlesville, Okla. President: R. J. Bennett. Term expires September 30, 1960. Secretary-Treasurer: Robert A. Carle. Term indefinite.
History: Organized 1930.

Purpose: Promotion of engineering.

Membership: Members must be engineers or have interest in promoting engineering and engineering activities. Total membership 253.

Meetings: Monthly except July and August.

631. Engineers' Club of Dayton. 110 East Monument Avenue, Dayton 2, Ohio. Presidcnt: B. C. Stupp, 2680 Little York Road, Dayton 14, Ohio. Term expires June 1961. Secretary: Howard R. Palmer, 4648 Hastings Drive, Dayton 40, Ohio. Club Manager: William Siler, 2817 Colonial Avenue, Dayton 19, Ohio. Term expires June 1961.

History: Organized February 1914.

Purpose: The advancement of engineering through furnishing facilities for the educational improvement of its members.

Mcmbership: By invitation only. Active, 713; Pre-Active, 61; Associate, 167; Affiliate, 22: Non-Resident, 147; Army-Navy, 2; Military Leave, 18. Total membership 1,130.

Meetings: Annual; weekly.

Publications: The Engineer, monthly September to April, free to members.

Library: 3,500 volumes.

632. Engineers Club of Des Moines. President: L. S. Houvenagle, 27 South IVest 42nd Street, Des Moines, Iowa. Term expires January 1961. Exccutive Secretary: John Hart, Hubbel Building, Des Moines, Iowa. Term expires January 1961.

History: Established 1918.

Purpose: To provide technical and social opportunities for all types of engineers in the community.

Membership: Limited to registered professional engineers, or those with eight years experience in the practice of their profession. and of good moral character (diploma from approved school of engineering or architecture counts as two years). Total membership 225.

Mectings: Monthly.

Professional activities: Scholarship awarded annually to one male student for one year's tuition in engineering at Iowa State University or State University of Iowa. Sponsors meeting with foreign engineering students one weekend per year during their Des Moines meetings.

633. Engineers Club of Hampton Roads. P. O. Box 946, Norfolk 1, Va. President: Albert E. Rollins, P. O. Box 1778, Norfolk 1, Va. Term expires January 13, 1961. SecretaryTreasurer: Ellis B. Hilton, Jr., 3 Inland Lane, Portsmouth, Va. Term expires January 13, 1961. 


\section{History: Organized 1921.}

Purpose: To establish a forum for exchange of engineering knowledge and social intercourse; to unify and coordinate activities of various national and local societies located in the Hampton Roads district; to assist local civic organizations as advisers in engineering matters; to publish or otherwise disseminate suggestions for the improvement of the business, industrial, tranportation, recreational, or other facilities of this section, in so far as matters of engineering enter into these improvements.

Membcrship: Members, graduate or qualified engineers or architects; Associate, engineering assistant; Student. Members, 298; Associate, 61; Student, 118. Total membership 477.

Meetings: Annual; monthly, except July and August.

Professional activities: Capital Scholarship Fund, to aid in the advancement of the engineering profession through the medium of scholarships for worthy students, $\$ 25,000$ minimum goal.

634. Engineers Club of Kansas City. President Hotel, 13th and Baltimore Streets, Kansas City 6, Mo. President: IV. G. Riddle, 1009 Baltimore Street, Kansas City 5, Mo. Term expires January 1, 1961. Secretary: M. B. Hansell, Jr., 21st and Manchester Streets, Kansas City 26, Mo. Term expires January $1,1961$.

\section{History: Organized 1911.}

Purpose: The advancement of the engineering profession and its civic usefulness.

Membership: Members, 637, engineers or architects over twenty-five years of age, of good character and satisfactory professional standing; Associate, 12, persons between the ages of eighteen and thirty who are students or graduates of an engineering or arclitectural school of recognized standing or whose occupational training is in the engineering or architectural field, the pursuit of which will, in the opinion of the Board of Directors, qualify them to attain the status of Member after having completed the period of time to acquire the necessary experience; Affiliate, 112, persons who meet the qualifications for Members except that they are not engineers or architects, but who are identified with engineering work and who in the judgment of the Membership Committee and the Board of Directors would become desirable nembers of the Club; Non-Resident, 15; Non-Resident Affiliate, 1. Total membership 777.

Meetings: Annual and semimonthly.

Professional activities: Scholarships for engineering students.
635. Engineers' Club of Minneapolis. 302 Wesley Temple Building, Minneapolis 3, Minn. President: Robert A. Beveridge, 5104 39th Avenue Soutl, Minneapolis 17, Minn. Term expires May 1961. Executive Secretary: Clifford M. Bircher, Prior Lake, Minn. Term expires May 1961.

History: Founded 1883 as the Engineers' Club of Minnesota; name changed to present title in 1890. Sections: Jurisdiction covers Minnesota and surrounding states.

Purpose: To stimulate a greater interest among engineers in the welfare of the community, state and nation; to assist in the solution of public problems involving engineering and allied sciences; and to promote advancement of the arts and sciences connected with engineering.

Membership: Resident Members, 755, office or home within fifty miles of Minneapolis; Non-Resident, 54, office or lome more than fifty miles from Minneapolis; Life, 230, twentyfive years in Club; Half-Century Clıb, 3. Total Membership 1,039.

Meetings: Annual in May; monthly meetings, except June through August; weekly, October through March.

Publications: Minnesota Engineer, monthly, current volume: 11, \$3. Editor: Sydney L. Devin.

\section{Engineers' Club of Northern Minnesota.}

President: C. O. Rudstron, 703 3rd Street, N. W., Chisholm, Minn. Term expires December 1960. Secretary-Treasurcr: David Hartley, Virginia, Minn. Term expires December 1960.

\section{History: Organized 1914.}

Purpose: The promotion and advancement of engineering knowledge and the professional improvement of members.

Membership: Graduate engineer; non-graduate engineer with three years experience in any engineering works, of which one year was in a responsible position; administrative or supervisory official of mining or allied industries; or sales representative of companies serving the mining or allied industries. Total membership 640 .

Meetings: Annual; monthly except in summer months.

637. Engineers Club of Omaha. President: Ralph W. Shaw, Omaha Public Power District, 17th and Harney Streets, Omaha 2, Nebr. Term expires December 31, 1960. Secretary: William Wurgler, Wurgler Company, 313 South 14th Street, Omaha 2, Nebr. Term expires December 31, 1960. 
History: Organized in 1922.

Purposc: The professional improvement of its members, the advancement of engineering in its several branches, the enhancement of the engineering profession in the opinion of the general public, and in a dignified manner the solution of public questions involving engineering and scientific consideration.

Mcmbcrship: A person who has been in active practice of engineering or architecture or following scientific or applied scientific pursuits for at least three years; or who is a graduate of a school of engineering, architecture, science or applied science of recognized standing; or who in the judgment of the Executive Committee is fully qualified to cooperate in the advancement of engineering interest, and whose membership will, in the opinion of the Executive Committee, prove of value to the Club. Total membership 475 .

Mectings: Annual; weekly.

Professional activities: Support of Sea Scout Ship. Scholarship of $\$ 250$ per year for member of Sea Scout Ship. $\$ 200$ per year to Omaha Public Library for purchase of technical books.

Publications: Engineers News, monthly, current volume: 1. Editor: Royce Kent.

638. Engineers' Club of Philadelphia. 1317 Spruce Street, Philadelphia 7, Pa. President: William E. Hendricks, c/o Belmont Iron Works, 2215 Washington Avenue, Philadelphia 46, Pa. Term expires April 30, 1961. Exccutive Secrctary: Charles S. Doerr. Term indefinite.

History: Organized December 17, 1877.

Purpose: To promote the arts and sciences connected with engineering, by means of periodical meetings for the reading and discussion of professional papers, and the circulation by publication among its members and others of the information thus obtained.

Membership: Professional engineers, or persons who, by scientific, technical or practical experience are qualified to cooperate in the advancement of engineering. Honorary, 4, persons of broadly acknowledged eminence in the field of the activities of the Club; Active, 1,426 , shall be not less than twenty-five years of age; Junior, 200, at least eighteen years, and less than thirty-three years of age; Army-Navy, 20 , commissioned officers, in active service with the armed forces of the United States, or retired from such service for age or physical disability and not otherwise gainfully employed. Total membership 1,650 .

Meetings: Annual; monthly October to April.

Professional activitics: Charles E. Billin Award, prizes of $\$ 40, \$ 20$, and $\$ 15$ awarded to Junior members for papers on engineering subjects of their choice. Engineers' Club Speakers Medal, awarded throughout the year for presentations of papers. Lewis H. Kenney Award, for outstanding Junior member of the year. Junior Merit Award of Club membership made annually at graduation to one senior of each local engineering school based on scholarship, leadership, technical society activity and personality.

Publications: Delaware Valley Announcer, monthly, current volume: $33, \$ 4$. Editor: Charles S. Doerr. Who's Who in Engineering in The Delaware Valley.

639. Engineers' Club of St. Louis. 4359 Lindell Boulevard, St. Louis 8, Mo. President: R. J. IV. Koopman. Term expires May 31, 1961. Secretary: IV. E. Bryan. Term indefinite.

History: Organized December 2, 1868 ; incorporated May 12, 1869.

Purpose: The professional improvement of members; the advancement of engineering and the enhancement of the engineering profession in the opinion of the general public; and in a dignified manner the influencing of the solution of public questions involving engineering and scientific consideration.

Membership: Member, at least twenty-five years of age, and either a registered professional engineer or a registered architect, or having a degree in engineering or architecture from a school of engineering or architecture approved by the Board of Directors as of satisfactory standing, and not less than four years experience in the field of either professional engineering or architecture, or not less than eight years experience of responsible character in the field of either professional engineering or architecture as approved by the Board of Directors; Junior, between the ages of eighteen and thirty years who is a student or graduate of an engineering or architectural school of recognized standing, or whose occupational training is in the engineering or architectural field, the pursuit of which will, in the opinion of the Board of Directors, qualify him to become a Registered Professional Engineer or Architect after having completed the period of time to acquire the necessary experience; Affiliate, eighteen years of age, whose engineering or architectural training and experience are insufficient to entitle him to membership in the Club, or, who is not an engineer, but who is occupationally engaged in the field of engineering or architecture as a business owner, executive, manager, superintendent, salesman, purchasing agent, draftsman, etc; Sustaining, any firm in the engineering, architectural, or related fields upon payment of a sum to be stipulated in the By-Laws; Transient, a person in military service who is 
qualified and who anticipates only a temporary residence in the St. Louis area; Honorary, conferred upon a member or person who has rendered distinguished service to the Club or who is eminent in the fields of architecture, engineering, or science; Senior, members shall be designated as Senior Members in their respective classifications in the event they are not less than sixty-five years of age and have held membership in the Club for not less than twenty-five years, or those members not less than sixty years of age whose memberships have been in effect for thirty years, or those members whose meritorious services in the opinion of the Board of Directors deserve especial consideration. Total membership 2,300.

Mectings: Weekly.

Professional activities: Annual Gold Medal Award to outstanding engineer, if Board of Directors approves.

Publications: Journal, monthly. Yearbook.

640. Engineers Club of Trenton. Hotel StacyTrent, Trenton 8, N. J. President: Wilbur M. Gibbs, 3 Richmond Avenue, Mount Holly, N. J. Term expires June 1961. Secretary: Joseph P. Clark, 28 Barnsley Avenue, Morrisville, Pa. Term expires June 1961.

\section{History: Organized January 29, 1914.}

Purpose: To promote social and professional intercourse among its members, to advance engineering knowledge and practice, and to maintain a high standard of professional procedure in all respects.

Mcmbership: Corporate Members, 464, qualified engineers for at least five years; Associate, 110 , qualified engineers for at least three years; Affiliates, 93, in profession but not professional engineers. Total membership 668 .

Mectings: Eight technical meetings; cight social meetings; five to six plant trips annually.

Professional activities: Two scholarships of $\$ 500$ each, awarded annually to engineering students on basis of scholastic ability and financial need.

Publications: The Engineer, monthly October to May, current volume: 44 , free to members. Editor: Joseph P. Clark.

641. Engineers Club of Tulsa, Inc. 546 Kennedy Building, Tulsa, Okla. President: Allan A. Hardy, Director of Engineering and Researcl, IV. C. Norris, Manufacturer, Division of Dover Corporation, Tulsa, Okla. Term expires April 30, 1961. Executive Secretary: Robert E. Hedberg. Term indefinite.

History: Organized 1935; incorporated 1951. Purpose: To unify those who are interested in engincering and the application of engineering principles, to furnish wider social and professional opportunity to advance engineering in its several branches, to enhance engineering activity in the opinion of the general public, and in an effective manner to influence the solution of public questions involving scientific and engineering consideration.

Membership: Total membership 650. Engineering degree from recognized school of engineering, or engineering experience equivalent to degree.

Meetings: Weekly.

Publications: The Tulsa Engineer, monthly, current volume: 22, \$1. Editor: R. E. Hedberg.

\section{Engineers' Council for Professional De-} velopment. 29 West 39 th Street, New York 18, N. Y. President: IV. L. Everitt, 106 Civil Engineering Hall, University of Illinois, Urbana, I11. Term expires October 1960. Executive Secretary: Elsie Murray. Term indefinite.

History: Organized October 3, 1932. ComMitTeEs: Development of Young Engineers, Education and Accreditation, Ethics, Guidance, Information, and Recognition.

Purpose: To advance and promote scientific and engineering education with a view to the promotion of the public welfare through the development of better educated engineers.

Members: Eight engineering societies participate in the organization: American Institute of Chemical Engineers; American Institute of Electrical Engineers; American Institute of Mining, Metallurgical and Petroleum Engineers; American Society of Civil Engineers; American Society for Engineering Education; American Society of Mechanical Engineers: Engineering Institute of Canada; and National Council of State Boards of Engineering Examiners.

Mectings: Annual.

Publications: Annual Report, $\$ 1$.

643. Engineers Joint Council, Inc. 29 WVest 39 th Street, New York 18, N. Y. President: August B. Kinzel, Union Carbide Corporation, 30 East 42nd Street, New York 17, N. Y. Term expires January 1961. Secretary: Leroy K. Wheelock. Term indefinite.

History: Created in 1941; changed to its present organizational structure in 1952. CoMmitTEES: Automation, Engineering Manpower Commission, Honors for Engineers, International Relations, National Transportation Policy Panel, National Water Policy Panel, Nuclear Congress, Public Relations, Recognition 
of Specialties, Who's Who in Engineering, and others. Constituent Societies: American Institute of Chemical Engineers; American Institute of Electrical Engineers; American Institute of Industrial Engineers; American Institute of Mining, Metallurgical, and Petroleum Engineers; American Society of Civil Engineers; American Society for Engineering Education; American Society of Heating, Refrigerating and Air-Conditioning Engineers; American Society of Mechanical Engineers; American Water Works Association; Society of American Military Engineers.

Purpose: To advance the general welfare of mankind through the resources and creative abilities of the engineering profession, and pursuant thereto, to promote cooperation among the various branches of engineering.

Membership: Constituent Members, national engineering societies having at least 5,000 members, the majority of which are graduates of colleges of recognized standing or licensed or registered by a state board; Associated Members, national societies meeting all the requirements of constituent societies except that of 5,000 members; Affiliate Societies, those which are regional rather than national in scope, providing professional qualifications of members equal those of constituent societies. Ten constituent societies with 300,000 members.

Meetings: Monthly, except July and August.

Professional activities: Secretariat for U. S. Committee on Large Dams, U. S. National Committee, World Power Conference. International Association for the Exchange of Students for Technical Experience. Survey of the Profession, Honors for Engineers, Nuclear Congress, Engineer-Architect Relations.

Publications: Engineer, quarterly, current volume: 1, free to members. Engineering Manpower Commission Newsletter, semimonthly, free. Annual Report.

644. Engineers Joint Council of Maryland, Inc. 1021 North Calvert Street, Baltimore 2, Md. Chairman: Abbott L. Penniman, Jr., 103 West Belvedere Avenue, Baltimore 10, Md. Term expires June 30, 1961. Secretary: William R. Kahl. Term expires January 1, 1961.

History: Organized 1946. Consists of representatives of American Institute of Chemical Engineers, American Institute of Electrical Engineers, American Society of Civil Engineers, and American Society of Mechanical Engineers in Maryland.

Purpose: To develop greater confidence in, and respect for, the engineering profession; to make available for the good of society the full resources of that profession.
Membership: Members are appointed by the presidents or chairmen of the above named member societies. Total membership 4.

Mectings: Semiannual.

Professional activities: Advice and assistance to Maryland Board of Registration, State and city Boards of Health and Engineering.

645. Engineers' Society of Milwaukee. 3112 West Higliland Boulevard, Milwaukee 8, Wis. Executive Secretary: William H. Evans, Term indefinite.

History: Organized in 1904; incorporated December 1905.

Purpose: To keep engineers informed of the latest scientific, engineering, and technical developments through meetings, seminars, institutes, and short courses of study.

Nembership: Full Members, registered or graduate engineers, executives of established engineering enterprises, or persons having the duties and responsibilities of an engineer; Associate Members, persons who have a professional, technical, or business position related to engineering or to engineers in their professional pursuits. Total membership 1,250.

Mectings: Monthly.

Professional activities: ESM Engineer of the Year Award presented annually in February. Scholarship Committee awards ten scholarships to engineering students annually from funds raised from local engineering societies and industrial firms.

Publications: Milwaukee Engineering, ten a year, current volume: $40, \$ 2$. Editor: William M. Carley, Jr.

\section{Engineers' Society of Western Pennsyl-} vania. Penn Sheraton Hotel, Pittsburgh 30, Pa. President: C. A. Russell, Oliver Building, Pittsburgh 22, $\mathrm{Pa}$. Term expires December 31, 1960. Secretary: K. F. Treschow. Term expires December 31, 1960.

History: Incorporated 1880. Sections: Civil, Electrical, Industrial Management, Mechanical, Mineral Industries, Oil and Gas, Steel Works.

Purpose: Advancement of engineering knowledge and technology.

Membership: Open to persons of good moral character actively interested or engaged in the advancement of the sciences of engineering or architecture, or their several branches. Member, an engineer, arclitect, scientist, or an executive of a corporation in a field related to engincering, with responsible charge of important work for at least three years and engagement in his special pursuit for at least seven years; Associate Member, at least twenty-five years of age, with 
attainment of a position in his special pursuit qualifying him to cooperate with engineers in the advancement of professional knowledge and practice; Junior Member, at least twenty years of age, active practice in some branch of engineering or applied science for at least two years, or else student status in engineering or applied science for an equal period in a school of recognized standing; Student Junior, undergraduate in the junior or senior year at an engineering school of recognized standing. Total membership 1,800 .

Mectings: Approximately forty teclunical meetings a year.

Publications: Proceedings of Annual Water Conference, current volume: $21, \$ 10$. Editor: W. M. Porter.

647. Entomological Society of America. 4603 Calvert Road, College Park, Md. President: M. P. Jones, Extension Entomology, U. S. Department of Agriculture, Room 4150 South Building, Washington 25, D. C. Term expires December, 1960. Executive Secrctary: R. H. Nelson. Term indefinite.

History: Founded 1953 by a merger of the American Association of Economic Entomologists, organized 1889, and the former Entomological Society of America, organized 1906. Branches: Eastern, North Central, Pacific, Southeastern, Southwestern.

Purpose: To promote the science of entomology in all its branches, to assure cooperation in all measures tending to that end, and to publish the Annals of the Society, the Journal of Economic Entomology and other entomological publications.

Mcmbership: Active Members, about 3,950, all persons engaged in entomological work, or in allied fields, or persons having suitable training or interest; Student Members, about 350, persons studying entomology at the college level and enrolled in a recognized educational institution; Honorary Members, 14, by special election, limited to fifteen. Total membership about 4,300 .

Meetings: Annual and branch meetings.

Publications: Journal of Economic Entomology, six times a year, current volume: $53, \$ 15$. Editor: F. W. Poos. Annals, six times a year, current volume: 53, \$15. Editor: Roland F. Hussey. Entoma, biennially, \$2. Editor: E. H. Fisher. Index to the Literature of American Economic Entomology, annual, price varies. Compiler: Helene G. Cushman. Monographs of the Thomas Say Foundation, irregular, current volume: 9 , price varies.
648. Entomological Society of Washington. President: Patl W. Oman, Entomology Research Division, Plant Industry Station, Beltsville, Md. Term expires December 31, 1960. Corresponding Secretary: Paul A. Woke, c/o Division of Insects, U. S. National Museun, Washington 25, D. C. Term expires October 31, 1960.

\section{History: Organized March 12, 1884.}

Purpose: To promote the study of entomology.

Mcmbership: Members, interest in entomology ; Life; Sustaining; Honorary. Total membership 460 .

Mectings: Monthly, except July through September.

Publications: Proceedings, quarterly, current volume: 62, \$6. Editor: Richard H. Foote. Memoirs, irregular.

649. Erie Engineering Societies Council. President: P. J. Murray, Erie City Iron Works, 1422 East Avenue, Erie, Pa. Term expires June 1, 1961. Secretary: R. Soth, Hammermill Paper Company, East Lake Road, Erie, Pa. Term expires June 1, 1961.

History: Organized in 1951.

Purpose: To coordinate activities of engineering socicties and act as single representative of all in public affairs.

Membcrship: Total membership approximately 1,300. Various requirements for membership in component societies.

Meetings: Annual.

Publications: The Integrator, monthly, $\$ 0.60$. Editor: A. R. Davidson.

650. Eta Kappa Nu Association. President: Albrecht Naeter, School of Electrical Engineering, Oklahoma State University, Stillwater, Okla. Term expires June 30, 1961. Executive Secretary: Paul K. Hudson, Department of Electrical Engineering, University of Illinois, Urbana, I1l. Term expires June 30, 1961.

History: Founded October 28, 1904; incorporated in Delaware August 6, 1951. Fifty-six college chapters and twelve alumni chapters.

Purpose: To foster cooperation among, and mutual benefit to, students and others of demonstrated ability in electrical engineering.

Membership: Open to persons interested in purpose of this Association. Total membership 32,000 .

Meetings: Annual.

Professional activities: Annual awards to most outstanding young electrical engineer and to most active college chapter.

Publications: Bridge, quarterly, current volume : 56, \$2.50. 
651. Experimental Aircraft Association, Inc. 9711 West Forest Park Drive, Hales Corners, IVis. Presidcnt: Paul H. Poberezny. Term expires August 1963. Sccretary-Treasurer: Robert E. Nolinske, 11433 West Sunset Lane, Milwaukee 20, Wis. Term expires August 1963.

History: Organized January 1953. Association now has members in twenty-six other countries. Affiliate organizations in Canada, Australia, New Zealand, and Union of South Africa. Eighty-six chapters in the United States and Canada.

Purpose: To encourage development of any type of aircraft by individuals through experimentation and home engineering; to foster close fellowship through exchange of ideas of mutual interest; to provide our air arms with personnel having aviation incentive by encouraging youths to participate in aviation projects (model building, gliding, flying, and aircraft construction).

Membcrship: Open to any person interested in research and experimentation for improvement of any type of aircraft. Total membership approximately 8,500 .

Meetings: Annual.

Publications: Sport Aviation, monthly, current volume: 9, \$6. Editor: Paul H. Poberezny.

652. Explorers Club. 10 W'est 72nd Street, New York 23, N. Y. President: Charles B. Hitchcock, American Geographical Society, Broadway at 156th Street, New York 32, N. Y. Term expires April 1961. Sccretary: Earl R. Allyn, 14 Cathedral Avenue, Hempstead, Long Island, N. Y. Term expires April 1961.

History: Organized 1904; incorporated 1905.

Purpose: To further general exploration and spread resulting knowledge; to acquire and maintain a library for exploratory research.

Membership: Candidates for active membership are required to have contributed to advancement of knowledge of the world; Associate members shall be persons who have aided, encouraged, or taken active interest in exploration. Total membership 1,061.

Mcetings: Bimonthly, October through May.

Professional activities: Exploration Fund; Explorers Club Medal.

Publications: Explorers Journal, quarterly, current volume: $38, \$ 5$. Editor: Daniel D. Streeter.

Library: 13,000 volumes. Subject emphasis: Exploration.

653. Federal Sewage Research Association. President: Bernard B. Berger, Robert A. Taft Sanitary Engineering Center, 4676
Columbia Parkway, Cincinnati 26, Ohio. Term expires December 31, 1960. Secrctary-Treasurer: Ralph H. Holtje, Division of Water Supply and Pollution Control, U. S. Public Health Service, Washington 25, D. C. Term expires December 31, 1960.

History: Organized February 1930; affiliated with the Water Pollution Control Federation.

Purpose: To encourage the study of waste water problems and promote improved and effective water quality management.

Membership: Members, 91, must be in the employ (or on retirement status) of the Federal Government, with salary paid all or in part by Federal funds.

Meetings: Annual.

654. Federation of American Scientists. 1700 K Street, N. W., Washington 6, D. C. Chairman: M. Stanley Livingston, Cambridge Electron Accelerator, Cambridge, Mass. Term expires April 1961. General Counsel: Daniel M. Singer. Term indefinite.

History: Organized November 1945 as the Federation of Atomic Scientists; incorporated and name changed January 1946 to present title. Branches: Berkeley, Boston, Cleveland, Houston, Iowa City, Madison, New Haven, New York, Pittsburgh, Rochester, St. Louis, and Urbana. Chapters : Brookhaven, Chicago, Los Alamos, Los Angeles, Philadelphia, SchenectadyTroy, Stanford, and Washington. Committees: Atoms-for-Peace, Disarmament, Education, Loyalty-Security, Nuclear Test Ban, Outer Space, Passports, and Science Department.

Purpose: To promote the welfare of mankind and the achievement of a stable world peace; to study the implications of scientific developments; to disseminate facts necessary for intelligent conclusions concerning the social implications of new scientific knowledge; to safeguard the spirit of free inquiry; to promote public policies which will secure the benefit of science to the general welfare; and to strengthen and extend the international cooperation traditional among scientists.

Membership: Chapter members; Members-atLarge; Students; Sustaining Members; Patron Members; two-thirds of the membership must be working scientists or engineers, or students, teachers or supervisors in science or engineering; the other third must have a bachelor's degree or equivalent, but need not be closely associated with scientific fields. Total membership 2,000 .

Meetings: Council meets two or three times a year.

Publications: Newsletter, ten times a year, $\$ 2$, free to members. 
655. Federation of American Societies for Experimental Biology. 9650 Wisconsin Avenue, N. W., IVashington 14, D. C. Chairman of Board: C. C. Erickson, University of Tennessee, Institute of Pathology, Memphis, Tenn. Term expires June 30, 1961. Exccutive Officer: Milton O. Lee. Term indefinite.

History: Organized 1913. Composed of six societies: American Association of Immunologists; American Institute of Nutrition; American Physiological Society; American Society of Biological Chemists; American Society for Experimental Pathology; and American Society of Pharmacology and Experimental Therapeutics.

Purpose: To promote the interests of the member societies.

Membership: All members of the six constituent societies, 6,036 .

Mectings: Annual.

Publications: Federation Proceedings, quarterly, \$8. Managing Editor: Milton O. Lee.

656. Federation of State Medical Boards of the United States. Presidcnt: H. E. Jervey, 1515 Bull Street, Columbia, S. C. Term expires February 1961. Secretary-Treasurcr: IValter L. Bierring, 354 State Office Building, Des Moines, Iowa. Term indefinite.

History: Organized 1912.

Purpose: To promote higli standards of medical licensure and uniformity between states.

Membership: Open to all state boards of medical examiners.

Mectings: Annual.

Publications: Bulletin, monthly.

657. Fiber Society, Inc. P. O. Box 405, Athens, Ga. Exccutive Secretary: Julian S. Jacobs. Term indefinite.

History: Founded in 1941.

Purpose: The advancement of scientific knowledge pertaining to fibers, fiber products, and fibrous materials.

Membership: Members, 150, by invitation only (nomination by one member, endorsement by three members, approval by Governing Council).

Mectings: Semiannual.

658. Flight Safety Foundation. 468 Park Avenue South, New York 16, N. Y. President: John H. Cassady, 400 Northeast 5th Avenue, Boca Raton, Fla. Term expires 1961. Managing Dircctor: Jerome Lederer. Term indefinite.

History: Founded in 1945; main office in New York City; west coast office opened in
Los Angeles in 1955. In 1959 took over Cornell Aviation Crash Injury Research project in Phoenix, Arizona; now operated in Phoenix as Aviation Crash Injury Research ( $\mathrm{AvClR}$ ) Division of the Flight Safety Foundation. Affiliated with Cornell Guggenheim Aviation Safety Center.

Purpose: The furtherance of safety in all forms of air and space travel.

Membership: Members, approximately 300, affiliation with, or interest in, some area of safety in aviation or space travel.

Mectings: Annual International Air Safety Seminar; Annual lndustry Advisory Committee Meeting; Business and Private Flying Safety Seminars.

Professional activities: Administers Laura Taber Barbour Air Safety Award. Flight Safety Foundation Aviation Week Safety Awards presented annually. Certificates of Merit in recognition of outstanding safety performance.

Publications: Accident Prevention Bulletin, monthly. Air Safety Digest, bimonthly. Airport Safety Bulletin, bimontlily. Aviation Mechanics Bulletin, himonthly. Business Pilots Safety Bulletin, nonthly. Cabin Crew Safety Exchange, bimonthly. Design Notes, monthly. Human Factors Bulletin, bimonthly. Pilots Safety Exchange Bulletin, monthly. Annual Report.

659. Florida Academy of Sciences. President: Luella N. Dambaugh, University of Miami, Miami, Fla. Term expires February 1961. Secretary: James B. Lackey, University of Florida, Gainesville, Fla. Term expires February 1961.

History: Organized at Gainesville, Fla., February 6, 1935; incorporated February 24, 1935. Sections: Physical Sciences, Biological Sciences, Social Sciences, Medical, and Science Teaching.

Purpose: To promote scientific research, to stimulate interest in the sciences, to further the diffusion of scientific knowledge, to unify the scientific interests of the state, and to issue a quarterly scientific publication.

Mcmbership: Any person or organization interested in the purposes of the Academy. Patrons, Life, Sustaining, Contributing, Regular Members. Total membership 530 .

Mectings: Annual.

Professional activities: Achievement Medal, for an outstanding paper delivered at the annual meeting, a gift of the Phipps and Bird Company, Inc., of Richmond, Va. Research grant from American Association for the Advancement of Science in a variable amount, \$147 in 1960. 
Publications: Quarterly Journal, current volume: 23, free to members. Editor: J. C. Dickinson.

660. Florida Entomological Society. P. O. Box 2425, University Station Gainesville, Fla. President: Lewis Berner, Flint Hall, University of Florida, Gainesville, Fla. Term expires December 1961. Secretary: L. A. Hetrick, McCarty Hall, University of Florida, Gainesville, Fla. Term expires December 1961.

\section{History: Organized 1916.}

Purpose: To promote the study of entomology in Florida and the Southern States; to encourage research in the various phases of entomology; and to publish economic and pure science articles on entomology.

Membership: Open to persons with entomological training or with a sincere interest in entomology. Total membership 300, with 6 Honorary Members.

Mcetings: Annual.

Publications: Florida Entomologist, quarterly, current volume: 43, \$5. Editor: Lewis Berner.

661. Florida Medical Association. P. O. Box 2411, Jacksonville 3, Fla. President: Leo M. Wachtel, 2708 St. Johns Avenue, Jacksonville 5, Fla. Term expires May 28, 1961. Executive Dircctor: IV. Harold Parham. Term indefinite.

\section{History: Organized 1874.}

Purpose: To promote the science and art of medicine and the betterment of public health; to unite the medical profession of Florida into one compact organization and to federate with similar organizations in other states and territories to form the American Medical Association; to extend medical knowledge and to advance medical science; to elevate the standards of medical education; to strive for the enactment, preservation and enforcement of just medical and public health laws; to promote friendly relationships among physicians and to guard and foster their material interests; to enlighten and alert the public; to encourage similar interests and objectives in the association's component medical societies, and to carry out these objects of the association.

Membcrship: Open to members of component societies. Total membership 4,000.

Meetings: Annual.

Publications: Journal, monthly, current volume: 46, \$5. Editor: Shaler Richardson.

662. Florida Pediatric Society. President: Harry M. Edwards, 1139 South Orange Street, Ocala, Fla. Term expires November 1960. Secretary: John H. Cordes, Jr., St. Petersburg, Fla. Term expires November 1960.
History: Organized April 27, 1936; incorporated April 24, 1940.

Purpose: To provide a means of advancing the science of pediatrics.

Membcrship: Members, 170, practice limited to pediatrics.

Meetings: Semiannual.

663. Florida Psychiatric Society. President: Samuel G. Hibbs, 420 West Lafayette Street, Tampa 6, Fla. Term expires April 1961. Secrctary: M. L. Ekwall, 836 Miami Road, Jacksonville, Fla. Term expires April 1961.

History: Organized 1947 as Florida Society of Neurology and Psychiatry; name changed to present title 1957.

Purpose: To further study of subjects pertaining to mental disorders, mental defects, convulsive disorders, delinquincy, etc; to further maintenance and advancement of standards of hospitals, including out-patient clinics, for mental disorders, and of all other agencies concerned with medical, social, and legal aspects of such disorders.

Mcmbership: Doctors of medicine who are members of American Psychiatric Association and of their local medical societies. Total membership 106.

Mcetings: Semiannual.

664. Florida Psychological Association. Jacksonville University, Jacksonville 11, Fla. President: Justin E. Harlow, Psychology Department, University of Florida, Gainesville, Fla. Term expires May 1961. Secretary: Edward L. Flemming, State Board of Health, Jacksonville, Fla. Term expires May 1961.

History: Organized 1949, incorporated August, 1953.

Purposc: The advancement of psychology as a science, as a profession, and as a means of promoting human welfare.

Mcmbership: Members, 312, Fellows, Associates, or Life Members of the American Psychological Association, or persons with the doctoral degree based in part upon a psychological dissertation and conferred by a graduate school of recognized standing, or persons with two years of graduate work in psychology; Affiliate, 12; Honorary, 6.

Meetings: Annual.

Professional activities: Distinguished Service Award. Science Fair Prize.

Publications: Newsletter, three times a year, current volume: 10, free. Editor: Dell Lebo. 
665. Florida Public Health Association, Inc. President: Nathan J. Schneider, State Board of Health, Jacksonville, Fla. Term expires December 31, 1960. Secretary: Everett H. Williams, Jr., State Board of Health, Jacksonville, Fla. Term expires Decenber 31, 1960.

History: Organized 1929 as State Public Health Conference; name changed to present title 1930; incorporated. Sections: Clerical, Administrative and Fiscal; Engineering; Health Education; Health Officers; Laboratory; Mental Health; Public Health Nursing and Sanitation.

Purpose: To assist in protecting and promoting public health; to provide for scientific advancement of members; and to extend and develop the public health movement.

Membership: Active Members, all persons professionally engaged in any branch of public health work in the State of Florida. Associate, all persons in Florida who are not eligible for active membership, but who are sufficiently interested in the cause of public health to desire affiliation with this association. Honorary, may be conferred on any person, whether or not a resident of Florida, who has rendered such service to the cause of public health as to entitle him to special recognition; not over two honorary members shall be elected in any year. Life, members in good standing at the time of retirement from active service. Corporate, any board of health or other corporate health organization. Total membership 1,400.

Meetings: Annual.

Professional activities: Award for meritorious service.

666. Florida Radiological Society. President: John P. Stewart, Fort Myers, Fla. Term expires April 1961. Secretary: Alfred G. Levin, 837 Du Pont Building, Miami, Fla. Term expires April 1961.

History: Organized 1932.

Purpose: Advancement of the science of radiology in Florida.

Membership: Specialization in radiology. Total membership 115.

Meetings: Semiannual.

667. Florida Society of Anesthesiologists. P. O. Box 5666, Jacksonville 7, Fla. President: Richard S. Hodes, 1 Davis Boulevard, Medical Building, Room 407, Tampa 6, Fla. Term expires May 1961. Executive Secretary: Marshall D. Brainard. Term indefinite.

History: Organized November 26, 1949. The Society is a component society of the American Society of Anesthesiologists.
Purpose: To affiliate into one organization all of the reputable doctors of medicine and allied scientists in Florida who are engaged in anesthesiology; to make available to more people benefits to be derived from service of qualified anesthesiologists; to raise the standards of the specialty by fostering and encouraging research and scientific progress in anesthesiology; to disseminate information; to protect the public against irresponsible and unqualified practitioners of anesthesiology.

Membership: Active members, 109, Physicians in active practice of anesthesiology; Associates, physicians and other scientists interested in the subject and related subjects; Honorary, physicians who have attained exceptional eminence in the field; Junior, physicians in training. Total membership 123.

Meetings: Semiannual.

Publications: The Newsletter (a multilith letter to membership only as needed).

668. Florida State Horticultural Society. P. O. Box 2125, Manatee Station, Bradenton, Fla. President: W. L. Thompson, Citrus Experiment Station, Lake Alfred, Fla. Term expires December 1960. Secretary: Ernest L. Spencer. Term expires December 1960.

History: Organized April 1888 in Ocala, Florida. Sections: Citrus, Krome Memorial Institute (subtropical fruits exclusive of citrus), Vegetable, Ornamental, and Processing.

Purpose: The advancement of horticulture in Florida.

Membership: Open to persons with an interest in Florida horticulture. Annual Members, 992; Life Members, 46; Sustaining Members, 231; Honorary Members, 18. Total membership 1,287.

Meetings: Annual.

Professional activities: Finances graduate fellowship in virology at University of Florida; presents medal for most outstanding papers in each section as printed in the Proceedings.

Publications: Proceedings, annual, current volume: 73, \$6. Editor: W. L. Tait.

\section{Florida State Pharmaceutical Association.}

P. O. Box 631, Ft. Myers, Fla. President:

Lucien Watson, Marianna, Fla. Term expires May 1961. Secretary: R. Q. Richards, Fort Myers, Fla. Assistant Secretary: Harold C. Kinner. Term expires May 31, 1961.

History: Organized 1887; incorporated.

Purpose: To unite the reputable pharmacists and druggists of the state for mutual assistance, encouragement and improvement; to encourage scientific research; to develop pharmaceutical talent; to aid and support the College of 
Pharmacy of the University of Florida; to establish relations with the medical profession and the public.

Membcrship: Unit Members, Florida registered pharmacists; Associate Members, others not qualified as above. Total membership 1,500.

Meetings: Annual.

Professional activities: Five year scholarship annually awarded (University of Florida). Beall Award. Miskoff Award.

Publications: Journal, monthly, current volume: 24, \$1. Managing Editor: Harold C. Kinner.

670. Food and Nutrition Board. 2101 Constitution Avenue, Washington 25, D. C. Chairman: Grace A. Goldsmith, School of Medicine, Tulane University, New Orleans, La. Term indefinite. Executive Secretary: Leroy Voris. Term indefinite.

History: Established November 1940 under the division of Biology and Agriculture of the National Academy of Sciences-National Research Council. Committees, covering the various phases of human nutrition and food technology, report regularly to the Board. Activities are dependent on grants or government contracts.

Purpose: To serve as an advisory board in the field of food and nutrition. Promotes needed research in the broad field, and helps interpret nutritional science in the interests of the public welfare.

Membership: Board Members, 24, appointed by the Chairman of the Division of Biology and Agriculture, National Academy of Sciences -National Research Council. Members drawn from leaders in the sciences related to food and nutrition on the basis of their qualifications of experience and judgment to deal with the broad problems that come before the Board. Appropriate contact with Federal agencies, scientific societies, and other associations is maintained through liaison representatives appointed from their respective organizations. Panel of Consultants, 100-125.

Meetings: Semiannual.

671. Forest Products Research Society. President: Raymond H. Berry, Scott Lumber Company, Inc., Burney, Calif. Term expires June 1961. Executive Secretary: Frank J. Rovsek, P. O. Box 2010, University Station, Madison, Wis. Term indefinite.

History: Organized January 3, 1947. SeCTIONS: Northeast, Southeast, North Central, South Central, Northwest, Southwest.

Purpose: Interchange of information among individuals and organizations interested in forest products research development, production and utilization.

Membership: Professionally employed in the research, development, production, utilization and/or distribution of forest products. Total membership 4,200.

Meetings: Annual; irregular section meetings.

Publications: Forest Products Journal, monthly, $\$ 15$.

672. Fort Smith Geological Society. President: John P. Shields, 1308 South "A", Fort Smith, Ark. Term expires June 1961. Executive Secretary: James C. Perryman, P. O. Box 1307, Station A, Fort Smith, Ark. Term expires June 1961.

History: Founded 1958; became affiliated 1959 with the American Association of Petroleum Geologists. Committees: Nomenclature and Stratigraphic, Education, AAPG Statistics.

Purpose: Stimulation of interest in geology and related sciences; encouragement of scientific research among members; promotion of social and professional fellowship among members; dissemination and discussion of geological information.

Membership: Active members, persons engaged in the practice or teaching of geology or related sciences; Associate, persons interested in geology but not necessarily engaged in practice or teaching; Student, persons majoring in geological sciences in an institution of higher learning. Active, 47; Associate, 1; Student, 12. Total membership 60.

Meetings: Monthly.

673. Fort Wayne Engineers Club. Chamber of Commerce Building, Fort Wayne, Ind. President: Robert F. Rowe, 8527 Old Auburn Road, Fort Wayne, Ind. Term expires May 1961. Executive Secretary: J. L. Pawlisch, 2627 Bolton Drive, Fort IVayne, Ind. Term expires May 1961.

\section{History: Organized 1937.}

Purpose: To advance the arts and sciences of engineering; to advance the interests of individual members; to promote closer union of professional groups in the community.

Membership: Persons not under twenty-one years of age, engaged in, or qualified to practice, engineering or similarly qualified in an allied profession for at least five years. Resident members, 435; Non-resident, 54. Total membership 489.

Meetings: Monthly, except June, July, and August. 
Professional activities: Membership in, and contribution to, the Council of Indiana Engineering Societies.

Publications: News, monthly, current volume: 23, free. Editor: W. J. Hein.

674. Fort Worth Geological Society. President: Thomas F. Newman, Pan American Petroleum Corporation, P. O. Box 1410, Fort Worth, Tex. Term expires January 1, 1961. Secretary: Gerald H. Tefft, Pan Geo Atlas Corporation, Rowan Building, 6000 Camp Bowie Boulevard, Fort Worth, Tex. Term expires January 1, 1961.

History: Organized October 3, 1925 ; affiliated with the American Association of Petroleum Geologists in 1931. Joined Southwestern Federation of Geological Societies on October 21, 1957. Established the Fort Worth Earth Science Library in 1957.

Purpose: The increase and diffusion of geological knowledge and the promotion of fellowship and cooperation among geologists, petroleum engineers, and men interested in technical problems of oil production.

Membership: Active members, 175, persons of integrity and principle who are engaged or interested in technical problems, and who are members of the American Association of Petroleum Geologists or the American Institute of Mining Engineers, or any other persons who, in the opinion of the Executive Committee, would be desirable members.

\section{Mectings: Semimonthly.}

Professional activities: Support by contribution and assistance: Fort Worth Earth Science Library; Fort Worth Science Fair; Council of Scientific Societies (Dallas-Fort Worth).

Library: Fort Worth Earth Science Library, 2,000 books, 3,000 bulletins.

675. Fort Worth Surgical Society. 1009 Pennsylvania Avenue, Fort Worth, Tex. President: Charles J. Terrell, 602 West 10th Street, Fort Worth, Tex. Term expires January 1961. Executive Secretary: Frank B. Gooch. Term expires January 1961.

History: The society was founded in December 1950 by a group of twelve general surgeons, all of whom were in active practice of surgery in Fort Worth, Texas.

Purpose: The cultivation and improvement of the science and art of surgery, and the maintenance of a fraternal spirit among men who engage in the practice of surgery in Tarrant County, Texas.
Membership: Members, 35, proper training in surgery, limitation of practice to surgery, one year's active practice of surgery in Tarrant County.

Meetings: Monthly, October through June.

676. Four Corners Geological Society. President: James A. Peterson, P. O. Box 1200, Farmington, N. Mex. Term expires September, 1961. Secretary: Wilbur Reneau, Jr., 817 West Main Street, Farmington, N. Mex. Term expires September, 1961.

History: Organized September, 1952. SECtions: Arizona, Utah, Colorado, New Mexico.

Purpose: Study and dissemination of geologic knowledge, particularly of the Four Corners region.

Membership: Active members, in good standing in the American Association of Petroleum Geologists, or any professional geologist actively engaged in the petroleum industry; Associate members, geologists actively engaged in the petroleum industry but not fulfilling the above requirements. Active, 175 ; Associate, 75 . Total membership 250.

Meetings: Annual, in May; monthly meetings.

677. Franklin Institute of the State of Pennsylvania for the Promotion of the Mechanic Arts. Philadelphia 3, Pa. President: Wynn Laurence LePage. Term expires January 1961. Executive Vice President: J. G. Richard Heckscher. Term expires January 1961.

History: Founded February 5, 1824 as a society for the exchange of information among scientists, engineers, and interested laymen. Immediately established a technical library and a committee for the recognition of outstanding inventions. Within first year of Institute's history, membership exceeded 500 and a Journal was established. Institute also established first secondary public school in Philadelphia in 1828. Research for industry and government has been conducted since founding. Today, the Institute maintains a large science museum, extensive research laboratories, an outstanding technical library, a Journal, and promotes education in many areas.

Purpose: The promotion of science and the mechanic arts through the science museum and research, and by displaying industrial achievements, awarding medals, and the encouragement of youth in scientific pursuits.

Membership: Members, 7,600, persons interested in the purpose of the Institute.

Meetings: Monthly, October through May. 
Publications: Journal, monthly, current volume: 269, \$10. Editor: Mrs. Robert S. Glenn. The Institute News, monthly, current volume: 24. Editor: Mrs. Robert S. Glenn.

Library: 150,000 volumes; 50,000 pamphlets; 1,500 periodical subscriptions.

678. Franklin-Ogdensburg Mineralogical Society, Inc. P. O. Box 146, Franklin, N. J. President: Richard Hauck, 49 Montgomery Street, Bloomfield, N. J. Term expires September 30, 1960. Executive Secretary: John G. Hendricks, 121 Ely Street, Boonton, N. J. Term expires September 30, 1961.

History: Established September 30, 1959; incorporated as nonprofit organization. Area Councillors in Northeast, Midwest, South and West. Commitrees: Historical, Mineral Identification, Museum, Publications, Scientific Research, Symposium, and Technical Speakers.

Purpose: To establish, in cooperation with other interested groups, and maintain sound, permanent museum of Franklin minerals in Franklin, N. J.; to develop new information on Franklin minerals and mineralogy, through cooperative scientific programs with universities, and other organizations and individuals; to obtain and make available accurate up-to-date information on Franklin minerals and mineralogy; to facilitate collection of Franklin minerals while conserving material for future collectors; to facilitate identification of Franklin minerals; to promote fellowship and the advancement of mineralogy and geology by providing meetings of those interested in the Franklin area.

Membership: Total membership 300.

Meetings: Monthly except in winter months.

Publications: The Picking Table, quarterly, current volume: $1, \$ 2$. Editor: J. G. Hendricks.

679. Gamma Alpha. 116 Oak Avenue, Ithaca, N. Y. President A. J. Linck, University of Minnesota, St. Paul, Minn. Term expires May 1964. Secretary: David Pimentel, Cornell University, Ithaca, N. Y. Term expires May 1962.

History: Organized 1899 at Cornell University.

Purpose: To unite and promote good fellowship among men who are engaged in scientific work.

Membership: Active members, 10,344, those specializing in the study of science, holding a baccalaureate degree, or who are members of the academic staff.

Meetings: Biennial.

Publications: Gamma Alpha Record, quarterly, \$1. Editor: E. Riley.
680. Gamma Sigma Delta, The Honor Society of Agriculture. President: D. M. Hall, University of Illinois, Urbana, Ill. Term expires June 1962. National Secretary: Russell B. Dickerson, Pennsylvania State University, University Park, Pa. Term expires June 1962.

History: A professional agricultural fraternity was organized December 1, 1905, at Ohio State University; Delta Theta Sigma was organized March 30, 1908, at Iowa State College. In 1917 the Honor Society of Agriculture, Gamma Sigma Delta, was organized jointly by Iowa State College and the University of Minnesota.

Purpose: To promote scholarship.

Membership: Students, selected from seniors or postgraduates showing outstanding ability; faculty and alumni are selected from those who have made contributions to agriculture.

Mectings: Semiannual.

681. Gas Appliance Engineers Society. 18778 Hilliard Road, Rocky River 16, Ohio. President: M. J. Caparone, Robertshaw-Fulton Controls Company, Long Beach Freeway at Long Beach Boulevard, Long Beach 5, Calif. Term expires June 1, 1961. Executive Secretary: A. F. Craver, Patrol Valve Company, 2310 Superior Avenue, Cleveland, Ohio. Term expires June 1, 1961.

\section{History: Incorporated in Ohio 1954.}

Purpose: To promote the educational and professional improvement of its members and to make available to the public technical and scientific information and knowledge; the expansion, furtherance and improvement of the gas appliance industry.

Membership: Active members, 187, at least eight years experience in engineering in gas appliance industry and at least thirty years of age; Associate, 19, record of recognized leadership in a profession, industry, or science relating to gas appliance industry; Junior, 8, persons engaged in gas appliance industry who cannot qualify for regular membership due to age or lack of experience; Honorary, 4; Life, 2. Total membership 220.

\section{Mectings: Annual.}

Professional activitics: Annual Award for best technical paper in gas appliance field. Honorary membership to outstanding men in industry.

Publications: Digest, bimonthly.

682. General Science Association of New York. President: Hiram Bleecker, 67-25 Kissena Boulevard, Flushing 67, N. Y. Term expires 
1961. Secretary: Maxwell Cohen, 301 Oriental Boulevard, Brooklyn, N. Y. Term expires 1961.

History: Organized 1934. The Association is a member of Federation of Science Teacher Associations of New York City.

Purpose: To promote the professional interests of teachers of general science in the junior and senior high schools.

Membership: Members, 220, actively engaged in science teaching and affiliated with Federation of Science Teacher Associations of New York City.

Meetings: Monthly during school year.

Professional activities: Demonstrations for science teachers. Honor certificates awarded to each school for graduates. Evaluation of curriculum and materials for Board of Education.

683. Genetics Society of America. President: James F. Crow, Department of Genetics, University of $\mathrm{W}$ isconsin, Madison 6, $\mathrm{T}$ is. Term expires December 31, 1960. Secretary: W. L. Russell, Biology Division, Oak Ridge National Laboratory, Oak Ridge, Tenn. Term expires December 31, 1961.

History: Organized in New Orleans, Louisiana, in 1931, an outgrowth of the Genetics Section of the American Society of Zoologists and of the Botanical Society of America.

Purpose: To provide facilities for association and conference among students of heredity and for encouragement of close relationship between workers in genetics and those in the related sciences.

Membership: Members, 1,217, all persons actively interested in any field of genetics; Sustaining, all organizations interested in any field of genetics.

Mectings: Annual.

Publications: Records, annually, current volume: 29, \$1. Editor: W. L. Russell.

684. Geochemical Society. President: Harold C. Urey, Scripps Institution of Oceanography, University of California, La Jolla, Calif. Term expires November 1961. Secretary: Francis R. Boyd, Geophysics Laboratory. Carnegie Institution of Washington, Washington, D. C. Term expires November 1961.

History: Organized 1955.

Purpose: To advance the application of physical chemistry and physics to geology.

Mcmbership: Limited to persons with a professional interest in geochemistry. Total membership 2,400.
Publications: Geochemical News, ten times a year. Editor: E. William Heinrich, Department of Mineralogy, University of Michigan, Ann Arbor, Mich. Geochimica et Cosmochimica Acta, monthly, $\$ 17$.

685. Geological Society of America, Inc. 419 West 117th Street, New York 27, N. Y. President: Hollis D. Hedberg, Princeton University, Princeton, N. J. Term expires November 1960. Secretary: Frederick Betz, Jr. Term expires November 1960.

History: Founded 1888 as American Geological Society; name later changed to present title. Cordilleran Section, composed of Society Fellows residing west of 105 th Meridian, organized 1899. Rocky Mountain and Southeastern Sections, and Division on Engineering Geology, established 1947.

Purpose: Advancement of the science of geology in North America.

Mcmbership: Requires bachelor's degree with major in geology or related science, or equivalent training through practical experience, also active connection with geology through employment, teaching, or status as graduate student; Fellowship requires five years' professional experience or degree of doctor of philosophy in geology or related science and two years' professional experience, also contributions to geology through outstanding research, publications, administrative work, or training of other geologists. Total membership 5,341.

Mectings: Annual.

Professional activitics: Penrose Bequest, capital approximating $\$ 5,000,000$, income about $\$ 200,000$; Penrose Medal, gold, established by the late Dr. R. A. F. Penrose, Jr., awarded for distinguished attainnent in pure science, capital $\$ 5,000$; Day Medal, gold, established by Dr. Arthur L. Day, awarded for outstanding distinction in contributing to geologic knowledge through application of physics and chemistry to solution of geologic problems, capital $\$ 9,000$.

Publications: Bulletin, monthly, current volume: 71, \$15. Editor: Frederick Betz, Jr. Proceedings, annual, current volume: 28 .

686. Geological Society of Kentucky. President: George R. Thomas, United Fuel Gas Company, P. O. Box 69, Prestonsburg, Ky. Term expires June 30, 1961. Secretary: Thomas J. Crawford, Kentucky Geological Survey, 307 Mineral Industries Building, 120 Graham Avenue, Lexington, Ky. Term expires June 30, 1961.

History: Organized November 8, 1940.

Purpose: To promote the science of geology, especially as it relates to petroleum and natural gas. 
Mcmbcrship: Active, 93, residents of Kentucky or adjoining states who are actively engaged in the teaching or practice of geology or related professions in senior capacities, or professional men of the above qualifications from elsewhere, engaged in such work in Kentucky; Associate, 11 , those of similar qualifications but employed in junior capacity, or men without the above professional qualifications but engaged in the development or production of mineral products, or graduate students in geology.

Mectings: Semiannual.

687. Geological Society of Nevada. Co-Presidents: E. Richard Larson, Mackay School of Mines, University of Nevada, Reno, Nev., and Edgar L. Stephenson, 1701 Lander Street, Reno, Nev. Terms expire May 1961. Secretary: Richard H. Olson, Nevada Bureau of Mines, University of Nevada, Reno, Nev. Term expires May 1961.

History: Organized December 6, 1957.

Purpose: To meet regularly for the review of recent geological literature and for the presentation of local research.

Membership: Members, approximately 35, active interest in earth science and related research and a desire to further the aims of the society.

Mcctings: Monthly; with occasional nonscheduled meetings for visiting guest speakers.

688. Geological Society of New Jersey. President: Glenn L. Jepsen, Department of Geology, Princeton University, Princeton, N. J. Term expires April 18, 1961. Secretary: Mrs. Patricia O'Brien, New Jersey State Museum, State House Annex, Trenton 25, N. J. Term expires April 18, 1961.

History: Organized in November 1956 under joint sponsorship of the New Jersey State Museum and the Bureau of Geology.

Purpose: To bring the amateur and the professional together in such a way that authentic and reliable information on all phases of geology is easily available.

Mcmbership: Active, 152, open to all those interested in geology over the age of sixteen; Ex-Officio, 5, Governor, Commissioner of Department of Education, Commissioner of State Department of Conservation and Economic Development, Director of State Museum and State Geologist.

Meetings: Monthly, October to May except December.

Publications: Newsletter, five times per year, current volume: 10. Editor: Alan Lutz. Bulletins, six times per year, current volume: 16 . Editor: Mrs. Patricia O'Brien. Reports, current volume: $1, \$ 1.50$.
689. Geological Society of Sacramento. President: Roland J. Bain, Texaco, Inc., $1722 \mathrm{~J}$ Street, Sacramento 14, Calif. Term expires June 1961. Executive Secretary: Ed Kiessling, California Division of Mines, 1021 O Street, Sacramento 14, Calif. Term expires June 1961.

History: Organized in 1952.

Purpose: To promote and foster friendly relationships among geologists of the Sacramento area, and to hold meetings for the discussion of geological problems and the presentation of information of interest to the members.

Membership: Open to professional geologists of the Sacramento area and to any persons interested in the technical phases of geology, such as petroleum exploration, engineering geology, ground-water geology, soil mechanics, or teaching. Total membership approximately 100.

Mectings: Monthly.

690. Geological Society of the Oregon Country. President: Robert F. Wilbur, 2020 South East Salmon Street, Portland 15, Oreg. Term expires February 1961. Secretary: Mrs. Ruth E. Prentiss, 1923 North East Schuyler Street, Portland 12, Oreg. Term expires February 1961.

History: Organized March 1935; incorporated in Oregon in March 1936. Sections include Washington, Montana and Wyoming west of the Rocky Mountains, southerly part of British Columbia. Committee: Research.

Purpose: To provide facilities for the study of geology of the area; to establish and maintain a library and museum of geological works, maps, and specimens; to encourage geological study among amateurs; to designate, preserve, and interpret important geological features of the Oregon country.

Membership: Amateur and professional geologists who by their knowledge, experience, and honorable standing are qualified to advance the objectives of the Society. Adult Members, 292; Student and Junior Members, 7. Total membership 299.

Mectings: Annual.

Publications: Geological News Letter, monthly, current volume: $26, \$ 2.50$, free to members. Editor: J. R. Rentsch.

691. Geological Society of Washington. President: Harry S. Ladd, Room 405, U. S. National Museum, Washington 25, D. C. Term expires December 1960. Council Secretary: J. Thomas Dutro, Jr., Room 332, U. S. National Museum, Washington 25, D. C. Term expires December 1960. 
History: Organized February 25, 1893.

Purpose: The increase and diffusion of geological knowledge.

Membership: Active, 528, interest in geological science; Corresponding, 503; Retired, 52.

Mectings: Semimonthly October to May.

Professional activities: A sponsor of D. C. Science Fair; award to best project in the earth sciences. Annual award presented for the best paper presented at the regular meetings.

692. Georgia Academy of Science. President:

J. J. Westfall, University of Georgia, Athens, Ga. Term expires April 1961. Secretary: Romeo J. Martin, Emory University, Atlanta 22, Ga. Term expires April 1961.

History: Organized March 1922 at the University of Georgia; incorporated 1923, and again 1953. Sections: Biology, Chemistry, Earth Sciences, Physics, Mathematics and Engineering, Psychology and Medicine, Philosophy and History of Science, Science Education. The Georgia Psychological Association is an affiliate.

Purpose: The promotion of science, especially in Georgia.

Membership: Active, 408, persons interested in science; Fellows, 102, persons elected for outstanding work in science education, research, or industry. Total membership 510.

Mectings: Annual.

Professional activities: Sponsors Georgia Junior Academy of Science, and the State Science Fair; encourages high school science participation with prizes and limited research funds, $\$ 200$ to $\$ 300$ annually.

Publications: Bulletin, quarterly, current volume: 18. Editor: R. H. Fetner, Georgia Institute of Technology, Atlanta 13, Ga.

693. Georgia Engineering Society, Inc. P. O. Box 40, Atlanta 1, Ga. President: James C. Thompson, Georgia Power Company, P. O. Box 1719, Atlanta 1, Ga. Term expires December 31, 1960. Secretary: George M. Normandy. Term expires December 31, 1960.

History: Organized in 1940 as the outgrowth of the following informal groups of engineers and architects: Technical Advisory Council, 1915; Atlanta Engineering Council, 1932; Engineer's Club, 1937; each body being a logical successor to the preceding, culminating in Georgia Engineering Society, beginning formal operation January 1, 1942. One geographical chapter in Columbus, Georgia; others contemplated.

Purpose: Advancing the professions of engineering and architecturc by: promoting arts and sciences, broadening contacts of members, attracting outstanding speakers, increasing public recognition, providing governmental assistance, cooperating with educational institutions, etc.

Membcrship: Member, actively practiced profession for at least four years, at least twenty-four years of age; Junior, graduate of engineering or architectural school, or filling subordinate position in the professions, over twenty years of age; Associate, qualified by experience to assist in the professions or interested in the objectives, at least twenty years of age; Life, seventy years of age, active member ten years or longer; Honorary, acknowledged professional eminence. Total membership 1,168.

Meetings: Weekly except summer months.

Professional activities: Four awards annually at Honors Day to juniors of Georgia Institute of Technology, value $\$ 50$. One award annually to senior of Southern Technical Institute, value $\$ 50$ cash.

Publications: The Georgia Engineer, monthly, current volume : 18. Editor: Burton J. Bell. Year Book, current volume: 18 , free to members. Editor: George M. Normandy.

694. Georgia Pharmaceutical Association, Inc. President: H. D. Moseley, Dawson, Ga. Term expires April 1961. Executive Secretary: Regina Baird, 610 Grand Theater Building, Atlanta, Ga. Term expires April 1961.

History: Organized 1875; incorporated 1889.

Purpose: To unite the reputable pharmacists of the state for mutual assistance, encouragement and improvement; to encourage scientific research; to develop pharmaceutical talent; and to aid and support the colleges of pharmacy of the state.

Mcmbership: Members, 1,600, registered pharmacists or teachers in a college of pharmacy.

Meetings: Annual. District meetings semiannually.

Professional activitics: Scholarship Fund to enable deserving students to study pharmacy.

695. Georgia Psychiatric Association. President: Rives Chalmers, 2905 Peachtree Street, N. E., Atlanta, Ga. Term expires May 1961. Secretary: John Warkentin. Term expircs May 1961.

History: Organized May 23, 1955 following a meeting called by Georgia Association for Mental Health to establish better efforts toward improving mental health in Georgia.

Purpose: To serve as a district branch of American Psychiatric Association; to promote better psychiatric treatment facilities and methods, and better mental health in Georgia. 
Membership: Members, 55, membership in American Psychiatric Association, residence and practice in the State of Georgia.

Mectings: Three times a year.

Publications: Newsletter, bimonthly. Editor: L. Maholick.

696. Georgia Psychological Association. President: Cecil K. Harbin, 2278 Wineleas Road, Decatur, Ga. Term expires September 1961. Secretary: Cooper C. Clements, Department of Psychology, Emory University, Atlanta, Ga. Term expires September 1963.

History: Organized and incorporated in 1946. Purpose: To promote the science and profession of psychology in Georgia; to further the development and utilization of psychology as a science, as a profession, and as a means of promoting human welfare; to safeguard the interest of the public and of the profession, including the freedom of scientific inquiry and teaching, and the promotion of standards of competency of training, professional service, and ethical conduct; to provide opportunities for professional growth through the exchange of ideas and information and the encouragement of research in psychology.

Membership: Fellows, those persons who subscribe to the purpose of the Association, reside and/or work in the State of Georgia, maintain ethical standards of professional conduct according to the American Psychological Association's Ethical Standards of Psychologists, and have earned a doctor's degree based in part on a psychological dissertation and conferred by a graduate school of recognized standing, except when waived in special cases by a two-thirds vote of the Board of Directors on presentation of evidence of outstanding achievement in psychological service, research, or theory; and who have at least five years of acceptable professional experience subsequent to the granting of the doctor's degree. Associate Members, those persons who subscribe to the purposes of the Association, reside and/or work in the State of Georgia, maintain ethical standards of professional conduct according to the American Psychological Association's Ethical Standards of Psychologists, have earned at least a master's degree or its equivalent in psychology from a recognized college or university, and have had a minimum of one year of acceptable professional experience subsequent to the granting of the degree, or have had certain exceptions to the above made by the Board of Directors. Affiliate Members, those other interested individuals, such as qualified specialists in related sciences and professions, or members in good standing in appropriate national, regional, and/or state organizations in their own field, or graduate students in good standing in psychology recommended by the chairman of their department, or persons qualified by psychological training but who lack one year of professional experience. Fellows and Associates, 111 ; Affiliates, 15 ; Life Member, 1. Total membership 127.

\section{Meetings: Annual.}

Professional activitics: Sponsorship of workshops on topics of interest to psychologists.

Publications: Georgia Psychologist, semiannual, current volume: 14. free to members. Editor: Cooper C. Clements.

697. Georgia Public Health Association. 100 Chamber of Commerce Building, 33 Pryor Street, N. E., Atlanta 3, Ga. President: T. O. Vinson, DeKalb County Health Department, Decatur, Ga. Term expires May 1961. Secretary: Mrs. Martha C. Power, State Health Department, 47 Trinity Avenue, S. IV., Atlanta 3, Ga. Term expires May 1961.

History: Organized 1916 as the Georgia Health Officers' Association; name changed to present title May 1929. Sections: Medical Officers, Public Health Nursing, Sanitation, Laboratory, Public Health Education, Communicable Disease Investigators.

Purpose: To protect and promote public and personal health in the State of Georgia.

Membership: Open to any person interested in public health, and approved by the Executive Committee. Total membership 1,000.

Meetings: Annual.

Professional activities: Professional annual program for nine sections.

\section{Georgia Science Teachers Association.}

President: Mrs. Cora D. Middleton, Route 2, Box 398, Wilmington Island, Savannah, Ga. Term expires March 1961. Secretary-Treasurer: Mrs. Sarah R. Bradford, 629 East 46th Street, Savannah, Ga. Term expires March 1961. Vice President-President Elect: Dallas Stewart, 615 A North Cleveland Street, Albany, Ga. Term expires March 1962.

History: Affiliated with the Georgia Education Association.

Purpose: To promote better science teaching in Georgia.

Membership: Members, 756, any teacher of science or any other person engaged in the pursuit of science and desirons of cooperating in attempts to realize the objectives of the Georgia Education Association.

Meetings: Annual.

Professional activities: District and State science fairs. 
699. Georgia Society of Anesthesiologists. President: Walter F. Homeyer, 781 Spring Street, Macon, Ga. Term expires April 1961. Secretary-Treasurer: Frederick A. Carpenter, Emory University School of Medicine, 69 Butler Street, S. E., Atlanta, Ga. Term expires April 1963.

History: Organized 1948. The Society is a component of the American Society of Anesthesiologists.

Purpose: To promote the science of anesthesiology in Georgia.

Membership: Honorary, physician or other scientist who has attained eminence in anesthesiology or related fields; Active, 70, physician engaged in anesthesiology in the United States who is a graduate of an approved school, who is licensed to practice, who is a member in good standing of the county medical society and the American Society of Anesthesiologists; Junior, 16, full time trainee in anesthesiology or other specialty, with medical degree who has not been a junior nember more than three years; Associate, 1, may be a foreign, Federal (Public Health Service or Armed Forces), or scientific (physician or other scientist not in practice of anesthesiology); Retired, 3, active for at least ten years, sixty-five years or older or permanently disabled, and completely retired; Life, so designated prior to July 1, 1947.

Meetings: Quarterly.

700. Georgia Society of Professional Engineers. 230 Spring Street, N. W., Atlanta 3, Ga. President: Manon P. Phillips, City-County Municipal Building, Augusta, Ga. Term expires June 30, 1961. Exccutive Secretary: Mrs. Mildred L. Rogers. Term indefinite.

History: Founded 1944. CHAPters: Savannah, Columbus, Atlanta, Northwest Georgia, Macon, Southwest Georgia, Augusta, Southeast Georgia, Northeast Georgia, Central Georgia.

Purpose: Advancement of the public welfare; uniting of all professional engineers of the State in one organization; advancement of the professional, social and economic interests of the professional engineer; advancement and protection of the interests of the engineer-in-training ; promotion of high standards of engineering education; consideration of, and attention to, legislation affecting the profession; improvement of public relations and the cultivation of public appreciation of the work of the professional engineer; development of the civic consciousness of the members of the engineering profession; establishment and maintenance of high ethical engineering standards and practices.

Membership: Registration in any State of the United States as a professional engineer or engineer-in-training. Total membership 942.
Meetings: Annual.

Professional activities: Scholarship; GSPE Engineer of the Year.

Publications: Georgia Professional Engineer, monthly, current volume: 13, free. Editor: Robert A. Meier.

701. Gerontological Society, Inc. President: Joseph T. Freeman, Philadelphia, Pa. Term expires 1961. Secretary: R. IV. Kleemeier, IVashington University, St. Louis, Mo. Term expires 1962 .

History: Organized and incorporated 1945.

Purpose: To promote the scientific study of aging and to afford a common meeting ground for gerontologists representing various scientific disciplines, as well as those interested in and responsible for the care and treatment of the aged.

Membership: Honorary, 1, distinguished service rendered to science of gerontology or geriatrics; Fellows, 1,111, persons who in the inmediately preceding three years have engaged in the study or practice of any aspect of gerontology or geriatrics; Members, 878, persons interested in and sympathetic with the purposes of the Society; Affiliates, all voting members of an affiliate organization; Senior Members, persons who have been Fellows for preceding five years but are no longer engaged in professional work. Total membership 2,090.

Mectings: Annual.

Publications: Journal of Gerontology, quarterly, current volume: $15, \$ 10$. Editor: J. Esben Kirk. Newsletter, quarterly. Editor: O. J. Kaplan.

702. Grand Rapids Engineers' Club. President: Albertus Doornbos, 1500 Scribner Street, N. IV., Grand Rapids, Mich. Term expires May 1961. Secrctary: C. Alkema, Jr., 47 North Division Avenue, Grand Rapids, Mich. Term indefinite.

\section{History: Organized 1916.}

Purpose: To render service to community on engineering projects.

Membership: Members, 276, anyone interested in engineering; Honorary, 2, by reason of professional attainment and by recommendation of Board; Life, 64, over twenty-five years a member. 15.

Mectings: Weekly, September through June Professional activities: Loans to qualified students.

Publications: Grengineer, monthly. Editor: C. Alkema, Jr. 
703. Grassland Research Foundation, Inc. President: Barton H. Warnock, Department of Biology, Sol Ross State College, Alpine, Tex. Term expires 1961. Secretary: Harold M. Hefley, Department of Biology, Panhandle Agricultural and Mechanical College, Goodwell, Okla. Term expires 1961. Treasurer: Charles C. Carpenter, Department of Zoology, University of Oklahoma, Norman, Okla. Term expires 1961.

Histary: Incorporated October 1939.

Purpose: To sponsor and promote grassland research.

Membership: Conservationists, biologists, chemists, etc. interested in the purposes of the organization. Total membership 132.

Meetings: Annual.

704. Great Lakes Society of Orthodontists. 635 Applegate Lane, East Lansing, Mich. President: Hunter 1. Miller, 1416 Mott Foundation Building, Flint 2, Mich. Term expires December 2, 1960. Exccutive Secretary: Edward A. Cheney. Term expires January 1, 1963.

History: Organized 1926. Component of American Association of Orthodontists.

Purpose: To make readily available to practitioners of orthodontics in the Great Lakes area the current scientific approaches to growth, welfare, and health of children.

Membership: Persons devoting full time to practice of orthodontics, with certain scholastic and professional backgrounds.

Mectings: Annual.

705. Great Northern Railway Surgeons' Association. President: Ernest B. Anderson, 1849 Medical Arts Building, Minneapolis, Minn. Term expires July 1, 1962. Executive Secretary: Abbott Skinner, 1360 Lowry Medical Arts Building, St. Paul 2, Minn. Term indefinite.

\section{History: Organized 1923.}

Purpose: Promotion and discussion of matters of medical and surgical interest, more particularly subjects bearing upon duties and responsibilities of railway surgeons; cultivation of acquaintanceship among members.

Membership: Active members, regularly appointed surgeons of the Great Northern Railway; Honorary, prominent members of the medical profession not so connected. Total membership 223.

Mectings: Annual.

706. Greater St. Louis Society of Radiologists.

1465 South Grand Avenue, St. Louis, Mo. President: Charles J. Cherre, 462 North
Taylor Street, St. Louis, Mo. Term expires February 1961. Secretary-Treasurer: Armand E. Brodeur. Term expires February 1961.

History: Organized April 1923; name changed, May 1934, to St. Louis Roentgen Ray Society; changed 1938 to St. Louis Society of Radiologists; to present title, March 1954.

Purpose: The advancement of diagnostic and therapeutic radiology.

Membership: Active members, 47, radiologists certified by American Board of Radiology; Associate, 13.

Mectings: Quarterly and annual lectureship.

Professional activities: Annual Carman Lecture for the instruction of the medical profession in the latest advances of radiology.

707. Gulf Coast Association of Geological Societies. President: M. F. Kirby, 755 Milner Building, Jackson, Miss. Term expires December 1960. Secretary: William W. Woolfolk, 1417 Milam Building, San Antonio, Tex. Term expires December 1960.

History: Organized March 14, 1951. Member Societies: Texas: Beaumont, Corpus Christi, San Antonio, Houston, Tyler; Louisiana: Lake Charles, Lafayette, New Orleans, Shreveport; Mississippi: Jackson; Florida: Tallahassee.

Purpose: To provide for discussion and publication of papers on subjects and problems coming within the scope of the geological profession and with particular emphasis on Gulf Coast geology.

Membership: Total membership 4,000, membership in participating societies.

Meetings: Annual.

708. Gulf Institute of Consulting Engineers. President: Warren G. Moses, 929 Howard Avenue, New Orleans, La. Term expires December 31, 1960. Secretary: E. C. Guillot, 407 Carondelet Street, New Orleans, La. Term expires December 31, 1960.

History: Organized January 1950.

Purpose: To promote ethical principles in professional practice, and to advance interests of professional engineers engaged in the consulting practice of civil, electrical and mechanical engineering.

Membership: Open to registered professional engineers engaged in practice as consulting engineers. Total membership 53.

Meetings: Monthly.

709. Hartford Engineers Club, Inc. P. O. Box 1913, Hartford, Conn. President: Frank B. Bauer. Term expires May 1961. Business Secretary: Henning A. Thomsen. Term expires May 1961. 
History: Organized 1923; incorporated 1930.

Purpose: To encourage friendly intercourse among engineers, and to promote their professional advancement; to encourage the arts and sciences connected with various branches of engineering and to participate in matters of an engineering nature.

Membership: Open to any person connected with engineering or interested in Club purpose. Total Membership 375 .

Meetings: Monthly, September through May.

Professional activities: Slide Rule Presentation, to encourage qualified high school students to enter engineering as a profession; scholarship for engineering students.

Publications: Bulletin, monthly, current volume: 38, free to members. Year Book, biennial, current volume: 38 , free to members.

710. Harvey Cushing Society, Inc. 200 1st Street, S. W., Rochester, Minn. President: J. Grafton Love. Term expires April 1961. Secretary: H. J. Svien. Term expires April 1962.

\section{History: Founded October 10, 1931.}

Purpose: The promotion and advancement of neurological surgery and its related sciences.

Membership: Active, 674, certified by the American Board of Neurological Surgery, or Canadians who are Fellows of the Royal College of Surgeons; Associate, 22, shall be from the fields of neurology, neuroanatomy, neuro-ophthalmology, neuropathology, neurophysiology, psychiatry, psychology, roentgenology, and related fields and shall be certified by board of certification in field of primary activity; Senior, 46 , active or associate members who are sixty years of age and have served ten years of membership; Corresponding, 20, shall reside beyond the limits of the continent of North America and shall be chosen because of their devotion and contributions to neurological science; Honorary, 3, chosen from recognized leaders in field of neurological sciences.

Meetings: Annual.

Publications: Journal of Neurosurgery, bimonthly, current volume: $17, \$ 11$ domestic, $\$ 12$ foreign. Editor: Paul C. Bucy.

711. Harvey Society, Inc. President: Robert F. Pitts, Department of Physiology, Cornell University Medical College, 1300 York Avenue, New York 21, N. Y. Term expires June 31, 1961. Secretary: Alexander Bearn, Rockefeller Institute, New York, N. Y. Term expires June 31, 1961.

History: Organized 1905; incorporated 1954. Purpose: Diffusion of scientific knowledge in selected chapters in anatomy, physiology, bacteriology, pharmacology, pathology, and physiological and pathological chemistry, through medium of public lectures by workers in subjects presented.

Membership: Active members, 1,038, laboratory workers in the medical or biological sciences, residing in New York, who have personally contributed to advancement of these sciences; Associate members, 130, meritorious physicians in sympathy with objects of this Society, residing in New York; Honorary, 189. Total membership, 1,357 .

Meetings: Monthly.

Publications: Harvey Lectures, annual, current volume: $55, \$ 7.50$, free to members.

712. Hawaii Association of Plantation Physicians. 1133 Punchbowl Street, Honolulu, Hawaii. President: Richard Noda, Waipahu Sugar Company, Paia, Maui, Hawaii. Term expires November 1960. Secretary: Garton Wall, Ewa, Oahu, Hawaii. Term expires November 1960. Executive Secretary: Mrs. Betty Arnott. Term indefinite.

History: Organized 1942, as Territorial Association of Plantation Physicians; name later changed to present title; component society, Industrial Medical Association of America.

Purpose: To bring the various plantation physicians together to discuss problems, interests, ideas, needs for more rapid progress of health work on plantations.

Membership: Members, 42, interested in industrial medicine. To be active member, must work mainly in industrial medicine for at least two years and also be a member of local medical society. Total membership 42.

Meetings: Annual.

Publications: Plantation Health, quarterly, current volume: 25. Editor: Nils P. Larsen.

713. Hawaii Dermatological Society. President: Samuel D. Allison, 305 Royal Hawaiian Avenue, Honolulu 15, Hawaii. Term expires July 1961. Secretary: Wilfred H. Kurashige, 181 South Kukui Street, Honolulu 13, Hawaii. Term expires July 1961.

History: Founded February 5, 1944.

Purpose: Presenting and discussing instructive and puzzling cases.

Membership: Regular members, 8, practitioners of dermatology as approved by Honolulu County Medical Society; Associate, 16. Total nembership 24.

Mectings: Monthly. 
714. Hawaii Medical Association. 510 South Beretania Street, Honolulu 13, Hawaii. President: E. F. Cushnie, Alexander Young Building, Honolulu 13, Hawaii. Term expires May 1961. Executive Secretary: Miss Lee McCaslin. Term indefinite.

History: Formed in 1856.

Purpose: To extend medical knowledge, to advance medical science, and to promote the betterment of public health.

Mcmbership: Active, 519, license to practice medicine in Hawaii; Life, 30; Military, 2; Retired, 3; Honorary, 9; Associate, 34. Total membership 597.

Mectings: Annual.

Professional activities: Scientific fairs and essay contests.

Publications: Hawaii Medical Journal, bimonthly, current volume: $20, \$ 4$. Editor: Harry L. Arnold, Jr.

715. Hawaii Nurses Association. 510 South Beretania Street, Honolulu, Hawaii. President: Sister Maureen, St. Francis Hospital, Honolulu, Hawaii. Term expires October 1960. Exceutive Secretary: Olive C. Pridgen. Term indefinite.

History: Incorporated 1926; affiliate, American Nurses Association.

Purpose: Improvement of nursing care.

Membership: Registered nurses licensed to practice. Total membership 800.

Meetings: Annual.

Professional activitics: Margaret Jones Fund for Education and Need.

Publications: Inter Island Nurses Bulletin, bimonthly, \$2. Editor: Mrs. Rosie Kim Chang.

716. Hawaii Psychiatric Society. President: IVilliam J. T. Cody, Hawaii State Hospital, Kaneshe, Hawaii. Term expires May 1961. Secretary: K. Y. Lum, 550 Makapuu Avenue, Honolulu 16, Hawaii. Term expires May 1961.

History: Organized as Society of Neurology and Psychiatry of Hawaii in 1948; name later changed to present title; District Branch, American Psychiatric Association.

Purpose: To foster progress of psychiatry and to represent that specialty in Hawaii.

Membership: Members, 34, doctors of medicine, varying experience in psychiatry for varying levels of membership.

Mectings: Bimonthly.

717. Hawaii Psychological Association. Psychology Department, University of Hawaii, Honolulu 14, Hawaii. President: David H.
Crowell. Term expires July 1961. SecretaryTreasurer: Arthur A. Dole. Term expires July 1962.

History: Founded 1949. As a State division, the Hawaii Psychological Association has representation on the Council of Representatives of the American Psychological Association.

Purpose: To advance the interests of psychology as a science and profession in Hawaii.

Membership: Member of the American Psychological Association, or meet the requirements for membership. 46 members, 15 affiliates.

Mectings: Two to four annually.

Professional activitics: Award for best research by graduate student.

718. Hawaii State Dental Association. 291 Alexander Young Building, Honolulu 13, Hawaii. President: John Y. Kim, 212 James Campbell Building, Honolulu 13, Hawaii. Term begins October 27, 1960. Secretary: John H. Dawe. Term expires October 27, 1960.

History: Organized February 13, 1903 as Dental Society of Hawaii; reorganized 1938, name being changed to Hawaii Territorial Dental Society, with four component societies: Honolulu County Dental Society, Hawaii County Dental Society, Maui County Dental Society, and Kauai County Dental Society; name later changed to present title.

Purpose: To encourage the improvement of health of the public and promote the art and science of dentistry.

Membership: Active member, ethical practitioner of dentistry, licensed in Hawaii; other classes of membership are: Associate, Inactive, Life, and Honorary. Total membership 361.

\section{Mectings: Annual.}

Publications: Aloha-Dontia, quarterly, current volume: 8 , free to members. Editor C. T. Lee, 291 Alexander Young Building, Honolulu 13, Hawaii.

719. Hawaiian Academy of Science. P. O. Box 5081, Honolulu 14, Hawaii. President: John N. Warner, Hawaiian Sugar Planters Association, Honolulu, Hawaii. Term expires June 1961. Executive Secretary: Donald P. Gowing, Pineapple Research Institute, Honolulu, Hawaii. Term expires June 1961.

History: Organized July 23, 1925; affiliated with the American Association for the Advancement of Science in 1952. Thirteen local scientific societies with more restricted interest, which are associated societies.

Purpose: Promotion of scientific research and diffusion of scientific knowledge. 
Membership: Members, 888, scientists, teachers, businessmen and others interested in science. Total membership 888 .

Mectings: Two or three annually.

Professional activitics: American Association for the Advancement of Science-Hawaiian Academy of Science Research Grant for support of research by payment of non-salary expenses; Inter-Society Science Education Council (sponsors the Science Fair, Science Library Resources, Teachers' Science Seminars, Students' Science Seminars, Science Clubs, and teaching aids).

Publications: Proceedings, annual, current volume: 34 , free to members.

720. Hawaiian Botanical Gardens Foundation, Inc. President: IV. W. G. Moir, Experiment Station, 1527 Keeaumoku Street, Honolulu 14, Hawaii. Term expires January 1961. Secretary: Constance $\mathrm{E}$. Hartt, Experiment Station, 1527 Keeaumoku Street, Honolulu 14, Hawaii. Term expires January 1961. 1959.

History: Incorporated in Hawaii, June 29,

Purpose: To aid in the development of botanical gardens in Hawaii; to encourage research on botanical problems; to instigate the establishment of a National Tropical Botanic Garden in Hawaii.

Mcmbership: Professional botanists and entomologists, as well as non-professional individuals. Total membership approximately 150 .

Mectings: Monthly meetings of Board of Trustees.

721. Hawaiian Botanical Society. H.S.P.A. Experiment Station, Keeaumoku Street and IVilder Avenue, Honolulu, Hawaii. President: E. J. Britten, University of Hawaii, Honolulu 14, Hawaii. Term expires December 5, 1960. Executive Secretary: Charles H. Lamoureaux, University of Hawaii, Honolulu 14, Hawaii. Term expires December 5, 1960.

History: Founded May 5, 1924.

Purpose: To advance the science of botany in all its applications; to encourage research in botany in all its phases; to promote the welfare of its members and to develop the spirit of good fellowship and cooperation among them.

Membership: Regular Members, 153, interest in plant life and residence in the Hawaiian Islands; Honorary, 8, long service in the Society or achievements in the Islands in botany or related sciences.

Meetings: Monthly, except July, August and September.

Professional activities: Prizes for outstanding work in plant science by students at University of Hawaii and at the Science Fair. Support for worthy undertakings in plant science, including costs of publication of research findings.

722. Hawaiian Entomological Society. 1527 Keeaumoku Street, Honolulu 14, Hawaii. President: C. R. Joyce, U. S. Public Health Service, P. O. Box 1410, Honolulu, Hawaii. Term expires December 31, 1960. Secretary: Wallace C. Mitchell, 1673 Paula Drive, Honolulu 16, Hawaii. Term expires Decenber 31, 1960.

History: Organized December 1904.

Purpose: To promote the study of entomology, and to encourage friendly relations among those interested in the science.

Mcmbership: Active members, 105 ; Honorary,

5. Total membership 110.

Meetings: Monthly.

Publications: Proceedings, annually, current volume : 17 .

723. Hawaiian Malacological Society. 2777 Kalakaua Avenue, Honolulu 15, Hawaii. President: Clifton S. Weaver. Term expires December 31, 1960. Executive Secretary: Mrs. A. M. Harrison. Tern expires December $31,1960$.

History: Organized in October 1941; suspended during the war, reactivated October 1946.

Purpose: To study and develop interest of others in malacology, especially as it relates to the marine mollusks of the Pacific Ocean area in general and the Hawaiian Islands in particular.

Membership: Members, 440, persons interested in malacology.

Meetings: Monthly.

Professional activities: Sponsors an Annual Shell Fair and holds periodic shell auctions. Organized and sponsors the Wray Harris Memorial Library of Molluscan Literature.

Publications: Hawaiian Shell News, monthly, current volume: 8, \$4. Editor: Karl IV. Greene.

724. Hawaiian Sugar Technologists. H.S.P.A. Experiment Station, 1527 Keeaumoku Street, Honolulu, Hawaii. President: Joe T. Orrick, The Lihue Plantation Company, Ltd., Lihue, Kauai, Hawaii. Term expires December 31, 1960. Secretary-Treasurer: Fred D. Kennedy. Term expires December 31, 1960.

History: Organized in November 1902 as the Hawaiian Chemists Association; on November 15, 1922 the Association merged with the Hawaiian Engineering Association and the name changed to the Association of Hawaiian 
Sugar Technologists; May 25, 1938, the Association was reorganized and name changed to present title. Two Sections: Field and Factory.

Purpose: The study of the sugar industry, in all its aspects, and the promotion of its welfare.

Membership: Restricted to residents of the State of Hawaii. Active members, 976, those engaged in the production or processing of sugar cane; Associate, 236, any others interested in the purpose of the organization; Honorary, 69 , may be conferred upon any individual who has rendered distinguished service to the Hawaiian sugar industry. Total membership 1,281.

Meetings: Annual.

Publications: Proceedings of the Annual Meetings, annually, free to members; $\$ 8$ to nonmembers.

725. Health Physics Society. President: John S. Laughlin, 102 Brite Avenue, Scarsdale, N. Y. Term expires June 1961. Secretary: Russell F. Cowing, 1075 Commercial Street, East Weymouth, Mass. Term indefinite.

History: Organized at Ann Arbor, Michigan, June 1956; constitution and by-laws adopted at Pittsburgh, May 31, 1957. Five organized chapters.

Purpose: To aid in the work of health physics, to improve dissemination of information between individuals in this field and related fields, to improve public understanding of the problems and needs in radiation protection, and to promote and improve health physics as a profession.

Membership: Members, 1,330, persons who have been engaged in some form of health physics activities for at least one year and have been graduated from an accredited school of college grade, or have had equivalent training; Associates, 37, persons who lack the necessary qualifications for election as Members but are engaged in a field of endeavor related to health physics or whose interests in the science would make them desirable Associate Members; Affiliates, 4 , organizations approved by the affirmative vote of at least eight voting members of the Board.

\section{Meetings: Annual.}

Professional activities: American Board of Health Physics presently being organized for the purpose of certification.

Publications: Health Physics, quarterly, current volumes: $2-3$, $\$ 6$ per volume for members, $\$ 17$ per volume for non-members. Editor-inChief: K. Z. Morgan.

726. Heat Transfer and Fluid Mechanics Institute. Division of Chemical Engineering, Stanford University, Stanford, Calif. General
Chairman: Raymond C. Binder, University of Southern California, Los Angeles, Calif. Term expires September 1962.

History: 1960 Institute continues a twelveyear history.

Purpose: Presenting technical and scientific advances in fluid mechanics, heat transfer, and related fields.

Membership: Professional interest in heat transfer and fluid mechanics. Total membership 400.

Mcetings: Annual.

727. Helminthological Society of Washington. President: George IV. Luttermoser, Laboratory of Parasitic Diseases, National Institutes of Health, Bethesda 14, Md. Term expires December 1960. Corresponding SecrctaryTreasurer: Edna M. Buhrer, Plant Industry Station, Beltsville, Md. Term expires December 1960. Recording Secretary: L. A. Jachowski, Jr., Naval Medical Research Institute, Bethesda 14, Md. Term expires December 1960.

History: Organized October 8, 1910 ; affiliated with the Washington Academy of Sciences in 1923 and with the American Society of Parasitologists in 1959.

Purpose: To provide for the association of persons interested in parasitology and related sciences for the presentation and discussion of items of interest pertaining to those sciences.

Membership: Interest in parasitology or related sciences; election by vote of Society. Honorary Members, 1; Resident, 117; Life, 6; Non-resident, 261. Total membership 385.

Meetings: Monthly, October through May.

Publications: Proccedings, semiannual, current volume: 27 , domestic $\$ 3$, foreign $\$ 3.25$, free to members. Editor: G. F. Otto, Abbott Laboratories, North Chicago, I11.

728. Herb Society of America. Horticultural Hall, 300 Massachusetts Avenue, Boston 15, Mass. President: Mrs. Harry E. Ritchie, 3060 Chelsea Drive, Cleveland 18, Ohio. Term expires July 1962. Exccutize Secretary: Mrs. Robert H. Miller. Term indefinite.

History: Organized 1933; incorporated 1935. Sections: Regional units in Northern California, Southern California, New England, Connecticut, New York, Philadelphia, Western Pennsylvania, Virginia, Western Reserve (Ohio). Commıttees: Botanical and Horticultural Research; Herbarium.

Purpose: To further the knowledge of herbs and their uses. 
Membership: Open to persons with an active interest in some particular aspect of herbs. Active Members, 600.

\section{Mectings: Annual.}

Professional activities: Award of Merit, to honor members who have made outstanding contributions to the knowledge of herbs, $\$ 25$.

Publications: Herbarist, annual, current volume: 25, \$1.50. Editor Miss Madeleine Harding, 22 Robinson Street, Cambridge, Mass.

729. Herpetologists League. President: Alan Leviton, California Academy of Sciences, Golden Gate Park, San Francisco, Calif. Term expires May 1961. Exccutive Secrctary: John Legler, Department of Zoology, University of Utah, Salt Lake City 2, Utah. Term expires May 1961.

\section{History: Organized 1936.}

Purpose: The advancement of the science of herpetology.

Mcmbership: Interest in herpetology. Total membership over 700 .

Mectings: Once or twice annually with the American Association for the Advancement of Science.

Publications: Herpetologica, quarterly, current volume: 16, \$4. Editor: Wilmer IV. Tanner, Department of Zoology, Brigham Young University, Provo, Utah.

730. Highway Research Board. 2101 Constitution Avenue, N. W., Washington 25, D. C. Chairman: W. A. Bugge, Director of Highways, Transportation Building, Olympia, Wash. Term expires January 8, 1962. Director: Fred Burggraf. Term indefinite.

History: Organized 1920 as Advisory Board on Highway Research; name changed to present title 1924. The Board operates under the auspices of the Division of Engineering and Industrial Research of the National Academy of Sciences-National Research Council. DepartMENTS: Economics, Finance and Administration; Highway Design; Materials and Construction; Maintenance; Traffic and Operations; and Soils, Geology and Foundations.

Purpose: To encourage research and to provide a national clearinghouse and correlation service for research activities and information on highway administration transport and technology by means of (1) a forum for presentation and discussion of research papers and reports; (2) committees to suggest and plan research work and to correlate and evaluate results; (3) dissemination of useful information; and (4) liaison and cooperative services.
Membership: Voting membership consists of 46 technical and commercial associations; 1,700 non-voting associates.

Meetings: Annual.

Professional activities: Subscriptions and contributions from the highway departments of the States and Territories, from the Federal Government, and from technical organizations and industrial concerns, for research correlation, cooperative investigations and special researches. Highway Research Board Award was instituted in 1940 to give recognition to an author or authors of papers of outstanding merit presented at the annual meetings of the Board. Roy WV. Crum Award for Distinguished Service, instituted in 1948 as the Award to be made in recognition of outstanding achievement in the field of highway research. The George Bartlett Award, established in 1931, is given annually, in cooperation with the American Association of State Highway Officials and the American Road Builders Association, to some individual who has made an outstanding contribution to highway progress.

Publications: Proceedings, annual, current volume: $38, \$ 10$, free to members and associates. Highway Research Abstracts, monthly, except August, current volume: $29, \$ 4$, free to members and associates. Research Reports, Bulletins, Bibliographies and Special Reports published at frequent irregular intervals.

Library: 2,000 volumes.

731. History of Science Society. President: Henry Guerlac, Department of History, Cornell University, Ithaca, N. Y. Term expires December 31, 1960. Secretary: John C. Greene, Department of History, Iowa State University, Ames, Iowa. Term expires December 31, 1960.

History: Organized January 12, 1924 ; incorporated January 30, 1925.

Purpose: To foster the interest and the study of the history of science; to support a journal devoted to this subject.

Membership: Open to persons interested in the history of science. Regular members; Student members, undergraduate or graduate in accredited college or university; Sustaining members. Total membership approximately 1,200 .

\section{Meetings: Annual.}

Professional activities: George Sarton Medal, for distinguished service in history of science; Ida and Henry Schuman Prize, $\$ 250$ annual award for an undergraduate essay in the history of science; The Pfizer Award, $\$ 500$ annual award for an outstanding publication in the history of science.

Publications: Isis, quarterly, current volume: 60, \$7.50. Editor: Harry Woolf. 
732. Honolulu County Medical Society. 510 South Beretania Street, Honolulu, Hawaii. President: H. Q. Pang. Term expires December 1960. Executive Secretary: Richard M. Kennedy. Term indefinite.

\section{History: Organized 1925.}

Purpose: To bring into one organization the physicians of the City and County of Honolulu; to extend medical knowledge and advance medical science and to promote the betterment of public health; to elevate the standards of medical education and practice by assisting in the support of a medical library, and to foster the enactment and enforcement of just medical laws; to promote friendly intercourse among physicians; to guard and foster the legitimate interests of members of the medical profession and to protect them against imposition; to enlighten and direct public opinion in regard to the problens of medicine, so that the profession shall become more capable and honorable within itself and more useful to the public in the prevention and cure of disease, and in prolonging and adding comfort to life; and with other county societies form the Hawaii Medical Association, and through it, with other State associations, to form and maintain the American Medical Association.

Membership: License to practice medicine in Hawaii. Total membership 456.

Mectings: Monthly.

733. Honolulu General Surgical Society. President: Edward W. Boone, 1154 Bishop Street, Honolulu, Hawaii. Term expires March 22, 1961. Secretary-Treasurer: Frederick B. Warshauer, 1136 Union Street, Honolulu 13, Hawaii. Term expires March 22, 1961.

History: Founded in 1941 as an outgrowth of monthly meetings held in the office of Dr. Grover Batten by several Honolulu practitioners with a common interest in surgical problems. Further meetings were suspended after the December 7, 1941 attack on Pearl Harbor. Reactivated January 17, 1947.

Purpose: To further knowledge of, and kindle interest in, the specialty of general surgery among members of this community; to assist the intern-resident training programs of local hospitals.

Membership: Regular, 21, licensed resident physicians of Honolulu; certification by the American Board of Surgery, or Fellowship in the American College of Surgeons, General Surgical Section, or regular membership in Pan-Pacific Surgical Association, General Surgical Section, or satisfactory completion of training requirements of the American Board of Surgcons; Life, 2; Associate, 71. Total membership 94 .

Mectings: Bimonthly.
734. Honolulu Obstetrical and Gynecological Society. 510 South Beretania Street, Honolulu, Hawaii. President: Sidney Fujita. Term expires June 30, 1961. Secretary-Treasurer: A. Mundt. Term expires June 30, 1961.

History: Organized in 1947.

Purpose: To further scientific and educational interests in obstetrics and gynecology.

Membership: Regular members, restrict practice to obstetrics-gynecology; Associate members, all other physicians interested in obstetrics and gynecology. Total membership approximately 50 .

Meetings: Monthly.

735. Honolulu Pediatric Society. 226 North Kuakini Street, Honolulu, Hawaii. President: Harold Sexton, 1020 Ward Street, Honolulu, Hawaii. Term expires October 31, 1960. Secretary-Treasurer: Richard E. Ando, 1010 South King Street, Honolulu 14, Hawaii. Term expires October 31, 1960.

\section{History: Organized in 1946.}

Purpose: To improve the practice of pediatrics and improve the standards of infant and child care; and foster better understanding of children in Hawaii.

Membership: Active practice or research in pediatrics in Honolulu. Total membership 42. Meetings: Monthly.

Professional activities: Support of Kauikeolani Children's Hospital Visiting Professor of Pediatrics Program.

736. Horticulture Society of New York, Inc. 157 Vest 58th Street, New York 10, N. Y. President: Charles D. Webster. Term expires January 1961. Secretary: Mrs. Herman G. Place. Term expires January 1961. Executive Secretary: Richard B. Farnham. Term expires January 1961.

History: Organized 1900; incorporated 1902.

Purpose: To collect and disseminate information on topics relating to the culture and care of plants, fruits, flowers, and vegetables; and to stimulate the knowledge and love of horticulture.

Membership: Open to those persons interested in horticulture. Classes of members: Annual, Professional Gardners, Sustaining, Life, $\mathrm{Pa}$ trons, Benefactors. Total membership 5,000.

Mectings: Monthly, except March, July, August, and September.

Library: About 18,000 volumes.

737. Hospital Association of Hawaii. President: Kent Longnecker, Leahi Hospital, 3675 Kilauea Avenue, Honolulu, Hawaii. Term ex- 
pires December 31, 1960. Secretary: Lee Wheeler, P. O. Box 3378, Honolulu, Hawaii. Term expires December 31, 1960.

History: Organized in 1939.

Purpose: To promote the public health and and welfare through the development of better hospital care for all the people of Hawaii.

Membership: Membership available to organizations and individuals interested in the object of the association. Institutional, 27.

Meetings: Annual.

738. Hospital Association of Pennsylvania. President: Miss Mabel A. Barron, Ellwood City Hospital, Ellwood City, Pa. Term expires May 1961. Executive Director: John F. Worman, 610 North Third Street, Harrisburg, Pa. Term expires May 1961.

History: Founded in 1921 as a voluntary association of hospital administrators, later expanded to include hospital institutional membership, Blue Cross Plans, and hospital auxiliaries; has six regional subdivisions.

Purpose: To promote the welfare of the people through the development of hospital service, to further professional education and research.

Membership: Open to those who subscribe to the purposes of the Association. Hospital Members, 260; Auxiliaries, 193; Blue Cross Plans, 5 ; Hospital Trustees, 739 ; other members, 535. Total membership 1,727 .

Meetings: Annual.

Publications: Bulletin, monthly, current volume: 26, \$5. Editor: Harold T. Prentzel.

739. Houston Engineering and Scientific Society. President: Allen F. Rhodes, McEvoy Company, P. O. Box 3127, Houston, Tex. Tern expires May 31, 1961. Executive Secretary: Miss Edwina Provence, 2615 Fannin Street. Houston 2, Tex. Term indefinite.

History: Formed 1918.

Purpose: To promote fellowship among engineers and provide meeting facilities for technical organizations.

Membership: Member, engineer, architect, teacher of plysical science or a professional man engaged in any of the physical sciences, not less than twenty-five years of age, who either has graduated from an approved school of engineering, architecture, chemistry or physical sciences and, in addition, has had not less than two years of active practice, or has been in the active practice of his profession for not less than five years, of which not less than two years were spent in responsible charge of important work, or is a registered professional engineer, recognized as such in Texas or is a constituent of the
Engineering Joint Council; Associate, not less than twenty-five years of age, who does not meet the requirements for full membership but is actually engaged in engineering applied to physical sciences or allied to physical sciences and does cooperate with engineers in their work toward the solution of bona fide engineering problems; Student, person who is attending an approved college and is planning to become an engineer, architect, teacher of physical science, or professional man engaged in any of the sciences, not less than eighteen, and not more than twenty-four years of age; Junior, engineer, architect, teacher of physical science, or a professional man engaged in any of the physical sciences, not more than twenty-nine years of age, who either has graduated from approved school of engineering, architecture, chemistry or physical sciences, or has been engaged in engineering or related work for a period of five years or more; Academic, same qualifications as Member, and in addition must be a full time employee of a recognized educational institution ; Life, Member or Associate Member who is at least sixty-five years of age and has had a minimum of twenty years cumulative membership; Honorary, attainments in engineering, architecture, chemistry or the physical sciences shall have given a broadly acknowledged eminence; Sustaining, individual, firm or corporation who makes a substantial contribution annually; Non-Resident, member living fifty miles or more from Houston. Total membership 1,500.

Professional activities: Graduate engineering scholarships to local colleges. Conducts several seminars throughout the year for high school students interested in engincering and the sciences, and works closely with counsellors in the high schools. Sponsors industrial tours for high school students.

Publications: The Slide Rule, monthly. Editor: Elton Sterrett.

740. Houston Geological Society. 234 Esperson Building, Houston 2, Tex. President: William A. Gorman, Royal Oil and Gas Corporation, 1046 Esperson Building, Houston 2, Tex. Term expires May 1961. Secretary: Austin D. Brixey, Jr., Sinclair Oil and Gas Company, 1808 Petroleum Building, Houston 1, Tex. Term expires May 1961.

History: Founded in 1923.

Purpose: The stimulation of interest in geology, the promotion of social and professional intercourse among geologists, and the dissemination and discussion of geologic information.

Membership: Active, degree in geology or allied science, engaged in application of geology or in geological work during preceding five 
years; Associate, engaged in geological or related work. Total membership 1,464.

Meetings: Monthly.

Professional activities: Student awards and student loans to graduate students at Rice Institute, University of Houston, University of Texas, Agricultural and Mechanical College of Texas, and Lamar State College of Technology.

Publications: Houston Geological Society Buletin, monthly, current volume: $2, \$ 3$. Editor: William A. Petersen.

741. Houston Radiological Society. Texas Medical Center Library, Jesse H. Jones Library Building, Houston, Tex. President: Frank M. Windrow, Hermann Professional Building, Houston 25, Tex. Term expires December 1960. Secrctary: Lowell S. Miller, University of Texas, M. D. Anderson Hospital and Tumor Institute, Houston, Tex. Term expires December 1960.

History: Organized September 26, 1949.

Purpose: To encourage the practice of radiology according to the highest scientific and ethical standards, to make the radiological teaching material of the entire city of Houston available to all radiologists, and to promote fellowship among the radiologists of this area.

Membership: Limited to radiologists or members of allied professions who are elected in accordance with the bylaws of the organization. Active members, 39; Associate, 2.

Meetings: Monthly, except June, July, August, and December.

742. Idaho Academy of Science. 1716 East Terry Street, Pocatello, Idaho. President: Albert E. Taylor, Idaho State College, Pocatello, Idaho. Term expires April 1961. Secretary: John J. Gallagher. Term expires April 1961.

History: Founded at Boise, Irlaho, April 1958.

Purpose: To stimulate scientific education and research and diffusion of scientific knowledge; to promote fraternal relationship among those engaged in scientific work; to assist in developing and in making known the material and other resources of the State of Idaho.

Membership: Regular Members, persons interested in scientific work, 325.

Mectings: Annual.

Professional activities: Visiting Scientist Program, supported by National Science Foundation; Idaho Science Talent Search.

Publications: Journal, every 9 months, current volume: 1, \$3. Editor: Earl J. Larrison, University of Idaho, Moscow, Idaho.
743. Idaho Public Health Association. P. O. Box 563, Boise, Idaho. President: J. E. Wyatt. Term expires June 1, 1961. SecretaryTreasurer: Ralph W. Carpenter. Term expires June 1, 1963.

History: Organized June 1939; affiliate, American Public Health Association.

Purpose: Promotion of public health, scientific advancement of members, and extension and development of the health movement.

Membership: Open to persons interested in public health. Fellows, and Corporate Memberships. Total membership 927.

\section{Meetings: Annual.}

Publications: Newsletter, quarterly, current volume: 49, free to members. Editor: W. O. Young.

744. Idaho Society of Professional Engineers. President: L. F. Erickson, 216 Hillview Drive, Boise, Idaho. Term expires February 1961. Secretary: S. N. Weisberger, Jr., P. O. Box 1705, Boise, Idaho. Term expires February 1961.

History: Founded 1910 as Idaho Society of Engineers; affiliated with National Society of Professional Engineers and name changed to present title 1948. CHAPTERS: Northern, South Central, Southeast, and Southwest.

Purpose: Advancement of public health and welfare; uniting professional engineers in one organization and advancement of their social and economic interests.

Membership: Active members, 320, registered professional engineers; Junior, 26, college graduates with engineer-in-training certificates; Affiliate and Associate, 110, persons associated in business with professional engineers. Total nembership 456.

Mectings: Quarterly.

Publications: Newsletter, quarterly, current volunie: 4, free to members. Editor: C. IV. Hathaway.

745. Idaho State Medical Association. 358 Sonna Building, Boise, Idaho. President: Asael Tall, 119 North State Street, Rigby, Idaho. Term expires June 30, 1961. Executive Secretary: Armand L. Bird. Term indefinite.

\section{History: Organized 1893.}

Purpose: To promote the science and art of medicine, protection of public health, and betterment of the medical profession of Idaho.

Mcmbcrship: Limited to physicians and surgeons licensed to practice in Idaho who are members of component medical societies. Total membership 550 . 
Meetings: Anuual.

Publications: Northwest Medicine, monthly, current volume: 59, \$3. Editor: H. L. Hartley.

746. Idaho State Pharmaceutical Association, Inc. 303 McCarty Building, Boise, Idaho. President: John B. Storrs, 308 Main Street, Filer, Idaho. Term expires June 30, 1961. Secretary: J. J. Lynch. Term indefinite.

History: Organized 1906.

Purpose: To promote the general welfare of professional pharmacy.

Membership: Retail druggists, 224; Associate wholesale members, 12. Total membership 236.

Meetings: Annual.

Professional activities: Awards of: Plaque to outstanding pharmacist of year; plaque to outstanding pharmacy student, College of Pharmacy, Idaho State College, Pocatello, Idaho.

Publications: Bulletin, monthly.

747. Illinois Association for Mental Health, Inc. 7091/2 East Adams Street, Springfield, I11. President: Gerald M. O'Connor, 1135 Jefferson Building, Peoria, I11. Term expires October, 1960. Executive Director: Donald G. Wideman, 2007 Hood Street, Springfield, I11. Term indefinite.

History: Organized in 1909 as Illinois Society for Mental Hygiene; incorporated 1910; name changed to Illinois Society for Mental Health 1952 ; present name taken in 1959. Affiliated with National Association for Mental Health 1958. Thirteen county and multi-county units are presently affiliated.

Purpose: To help meet the problems of the mentally ill and to promote prevention of serious mental illness in the community.

Membership: Members, lay or professional persons interested in mental health; Delegate members, elected by the county chapters' boards of directors; At-large members, must meet geographic location, occupation, interests, and similar qualifications. Total membership 90.

Meetings: Annual.

Professional activities: Fellowships and research within State.

Publications: Newsette, monthly, current volume: 1, free to members. Editor: Mrs. C. Albrecht.

748. Illinois Association of Chemistry Teachers. President: A. J. Hoffman, Department of Chemistry, Eastern Illinois University, Charleston, I11. Term expires October 1960. Secretary-Treasurer: D. H. Dalluge, Department of Physical Science, University High School, Normal, I11. Term expires October 1960.
History: Organized 1932.

Purpose: To keep members informed on recent advances in chemistry and related sciences; to foster fellowship and professional ethics; to promote better methods and techniques in teaching chemistry.

Membership: Teachers of chemistry and others interested in that field; Honorary members, persons who have rendered meritorious service as members of this Association and have retired from active teaching. Total membership 200 .

Mectings: Semiannual.

749. Illinois Geological Society. President: Charles Bauer, P. O. Box 568, Mattoon, Ill. Term expires June 1961. Secretary-Treasurer: Wilson G. Harris, Jr., P. O. Box 389, Mt. Vernon, I11. Term expires June 1961.

History: Organized 1937, as affiliate of American Association of Petroleum Geologists.

Purpose: To promtlgate petroleum geology and emphasize professional ethics and ideals.

Membership: Active members must be college graduates with majors in geology and must have three years' experience in petroleum geology or in application of geology to exploration, development, research, or other phases of petroleum technology; Associate, college graduates in sciences allied to petroleum geology with three years' experience; Junior, must have bachelor's degree plus one year's experience and be engaged in graduate studies, teaching, or petroleum exploration or research, or must have one half year of graduate study in geology as regularly enrolled student. Total membership 128.

Meetings: Monthly.

750. Illinois Mining Institute. 102 Natural Resources Building, Urbana, Ill. President: $\mathrm{H}$. C. McCollum, Peabody Plaza, 301 Olive Street, St. Louis 8, Mo. Term expires October 21, 1960. Executive Secretary: George M. Wilson. Term expires October 21, 1960.

History: Organized 1892; inactive 1895-1911 ; again active from 1912.

Purpose: Advancement of the mining industry by encouragement and promotion of the study and investigation of mining problems, by encouraging education in practical and scientific mining, and by diffusion of information that would benefit members.

Membership: Regular, open to persons directly engaged or interested in any branch of mining, mining supplies, mining appliances, or machinery; Honorary, persons of distinction in mining; Life. Regular members, 726; Honorary, 4; Life, 85. Total membership 815.

Meetings: Annual. 
Professional activities: Four $\$ 500$ scholarships, University of Illinois, in mining engineering; $\$ 500$ scholarship, Missouri School of Mines, Rolla, Mo.

Publications: Proceedings, annual, current volume: 67, members only. Editor: George M. Wilson.

751. Illinois Psychiatric Society, District Branch, American Psychiatric Association. 6557 North Spokane Street. Chicago 46, Ill. President: Joel S. Handler, 670 North Michigan Avenue, Chicago 11, 111. Term expires May 1961. Exccutice Secretary: Harold M. Visotsky, 646 North Michigan Avenue, Chicago 11, I11. Term expires May 1961.

History: Organized October 18, 1938; became District Branch, American Psychiatric Association May 1957. Technical and Scientific Committees: Forensic Psychiatry. Medicare, Relations with Psychologists, Liaison with Council of American Psychiatric Association, Liaison with other psychiatrists in Illinois, Community Aspects.

Purpose: To consider matters relating to psychiatry, to represent that specialty in Illinois, and to assist American Psychiatric Association in promoting its aims and objectives.

Mcmbership: Regular, 273, member of American Psychiatric Association who devotes full time to practice of psychiatry; Affiliate, 21, licensed to practice medicine in Illinois, not member of the American Psychiatric Association, interested in field of psychiatry; Life, 5 , completion of twenty-five years as nember of Society; Honorary, 4, physicians and others distinguished for attainments in psychiatry or related branches of science.

Meetings: Monthly.

Professional activities: Award of $\$ 200$ annually to psychiatric resident presenting most original paper on a psychiatric research problem.

Publications: Newsletter, monthly, free to members. Editor: Harold M. Visotsky.

752. Illinois Psychological Association. President: Alan K. Rosenwald, University of Illinois College of Medicine, 912 South Wood Street, Chicago 12, I11. Term expires July 1961. Secretary: Thomas M. Kennedy, Loyola University, 6525 Sheridan Road, Chicago 26, I11. Term expires July 1961.

History: Organized and incorporated in 1935 as Illinois Association of Consulting Psychologists; name changed to Illinois Association for Applied Psychology 1943; adopted present title 1949, following merger with Illinois Association of Professional Psychologists and affiliation with American Psychological Association.
Purpose: To promote psychological services in Illinois by furthering scientific development and professional advancement of, stimulating and improving application of, and encouraging research in psychology; to establish and maintain standards of competency, service, and professional conduct.

Membership: Requires degree of doctor of philosophy in psychology. For student membership requirement is full time graduate student status in accredited institution of higher learning. 560 members with 21 student members. Total membership 581 .

Mectings: Semiannual.

Publications: Newsletter, quarterly.

753. Illinois Public Health Association. P. O. Box 870, Evanston, I1l. President: Leroy Davenport, State Health Department, Springfield, 111. Term expires April 1961. Secretary-Treasurer: Villiam J. Hixon. Term indefinite.

History: Organized December 5, 1940 ; incorporated September 19, 1950.

Purpose: To promote professional advancement of public health workers of Illinois.

Membership: Members or Fellows of American Public Health Association, and persons professionally engaged or interested in the field of public health in Jllinois. Total membership 1,099 .

\section{Meetings: Annual.}

754. Illinois Radiological Society. President: George E. Irwin, Jr., 703 North East Street, Bloomington, I11. Term expires April 1961. Sccretary-Treasurer: George A. Miller, 602 Vest University Avenue, Urbana, I11. Term expires April 1961.

\section{History: Organized 1928.}

Purpose: To study the science and practical application of radiology, and to provide assemblies for dissemination of information concerning that science and art.

Membership: Physicians licensed in Illinois who are members of county medical societies, with majority practice or continued exceptional interest in radiology. Regular members, Life, Honorary, Emeritus, Past Service. Total membership 55.

Mectings: Semiannual.

755. Illinois Society for Personality Study. President: Vin Rosenthal, 342 Beverly Drive, Wilmette. Ill. Term expires December 31, 1960. Secretary-Treasurer: Galen M. Jarvis, 1172 Walnut Avenue. Des Plaines, I11. Term cxpires December 31, 1960. 


\section{History: Founded 1932.}

Purpose: To encourage development and improvement of the study of personality in all aspects; to stimulate interest of members and public in the study and understanding of the science of human behavior and personality; to promote inquiry, research and publication in the different fields of personality study; to present the results of studies and researches by means of lectures and exhibits; to act as a consulting body to allied professional groups seeking further knowledge of human behavior.

Membership: Requires sufficient scientific qualifications to make worthwhile contributions to the purpose of this Society. Total membership 76.

Meetings: Four annually.

756. Illinois Society of Anesthesiologists. Presidcnt: Harold L. Harris, 1323 Lincoln Street, Evanston, Ill. Term expires 1961. Secretary: Forrest J. Woodman, 9317 North Harding Street, Evanston, 111. Term expires 1961.

History: Organized 1948; component society, American Society of Anesthesiologists, Inc.

Purpose: To affiliate into one organization doctors of Illinois engaged in practice of anesthesiology; to encourage specialization in this field and to make available to more people benefits derived from service of qualified anesthesiologists; to raise the standards of the specialty by fostering and encouraging research and scientific progress; to disseminate information on the subject.

Membership: Active members, 173, physicians licensed in Illinois, with practice limited to anesthesiology; Junior, 34 , residents in full time training in anesthesiology; Associate, 4, dentists and physicians in military service stationed in Illinois. Total membership 211.

Mectings: Five annually.

757. Illinois Society of Coal Preparation Engineers and Chemists. Benton Country Club, Benton, I11. President: J. Wesley Smith, 1015 Roberta Drive, Marion, Ill. Term expires December 31, 1960. Secretary-Treasurer: Frank Irwin, R.F.D. 1, Mt. Vernon, I11. Term expires December 31, 1960.

History: Organized November 1940.

Purpose: To promote the arts and sciences connected with production, preparation, and preparation control of coal, coke, and attendant products.

Membership: Members, persons interested in or connected with engineering, mining, geology, chemistry, coal preparation, or utilization; Honorary. Total membership approximately 85 . Meetings: Monthly, September through May.
758. Illinois State Academy of Science. State Geological Survey, Urbana, Ill. President: Robert A. Evers, State Natural History Survey, Urbana, Ill. Term expires April 28, 1961. Secretary: G. Robert Yohe, 322 Natural Resources Building, Urbana, Ill. Term expires April 28, 1961.

History: Organized December 7, 1907, at Springfield, Ill. Sections: Anthropology; Aquatic Biology; Botany; Chemistry; Conservation; Geography; Geology; Meteorology ; Physics; Science Education, Psychology, and Social Science; Zoology; Collegiate. CommitTEES: Animal Experimentation in Research; Archaeological and Historical Sites; Conservation; Research Grants; Science Talent Search; Teacher Training.

Purpose: Promotion of scientific research, diffusion of scientific knowledge and scientific spirit, and unification of the scientific interests of the State.

Membership: Requires sponsorship by two members. Regular annual, 1,602; Life, 40; Sustaining, 33; Patron, 46. Total membership 1,721 .

\section{Mcetings: Annual.}

Professional attivities: Research grants, $\$ 300$ to $\$ 600$ annually; award certificates to science talent search and junior academy exposition winners; Frank H. Reed Memorial, annual $\$ 50$ award to science talent search winner having best project paper.

Publications: Transactions, quarterly, current volume: 53, free to members. Editor: Paul C. Silva, 208 Harker Hall, University of Illinois, Urbana, Ill.

\section{Illinois State Archaeological Society.} President: Edward Meiners, 219 Westwood Place, East Alton, I1l. Term expires December 1961. Executive Secretary: George P. Grove, 750 Ferguson Avenue, Wood River, I11. Term expires December 1961.

\section{History: Organized May 1936.}

Purpose: To preserve the remains of prehistoric people of Illinois; to study such remains scientifically and to publish information about them; to create better understanding between amateur and professional archaeologists; to arouse public appreciation of antiquities of Illinois.

Membership: Open to persons interested in the science of archaeology. Total membership 373 .

Meetings: Quarterly.

Publications: Central States Archaeological Journal, quarterly, current volume: 7. Editor: Gray La Dassor, 3416 Lucus-Hunt Road, St. Louis 20, Mo. 
760. Illinois State Medical Society. 360 North Michigan Avenue, Chicago, I11. President: H. Close Hesseltine, University of Chicago Clinics, Chicago, I11. Term expires May 1961. Executive Secretary: Robert Richards. Term indefinite.

History: Organized at Springfield, I11, 1840 ; reorganized 1850; incorporated 1902. Eleven councilor districts, twelve scientific sections.

Purpose: To federate, in one compact organization, the medical profession of Illinois; to unite with similar societies in other States in the American Medical Association; to extend medical knowledge and advance medical science; to elevate standards of medical education; to protect the public by an educational program.

Mcmbership: Requires degree of doctor of medicine or equivalent, membership in a component society, United States citizenship, and license to practice in Illinois. Members of component societies shall be members of this organization and American Medical Association. Total membership 9,811.

Mectings: Annual.

Professional actizities: Two annual postgraduate scholarships.

Publications: Journal, monthly, current volume: 117, \$4. Editor: T. R. Van Dellen.

761. Illuminating Engineering Society. 1860 Broadway, New York 23, N. Y. President: Richard G. Slauer. Term expires October 1961. Managing Dirctor: A. D. Hinckley. Term indefinite.

History: Organized 1906: incorporated in New York. Twelve regions, with ninety-three sections and chapters, in the United States and Canada. Technical Commitees: Aviation and Signal, Color, Daylighting, Design Practice, Education, Handbook, Industrial, Institutions, Light Control and Equipment Design, Light Sources, Maintenance, Merchandising, Motor Vehicle (Exterior), Nomenclature, Office, Progress, Public Conveyances, Recommendations for Quality and Quantity of Illumination, Residence, Roadway, School, Searchlight, Sign Lighting, Sports and Recreational Areas, Testing Procedures for Illumination Characteristics, Theater Television.

Purpose: Advancement of theory and practice of illuminating engineering and dissemination of related knowledge.

Membership: Members, 2,796, not less than twenty-six years of age, eight years actively engaged in a professional or other responsible capacity in practice or teaching of illuminating engineering or in directly related fields, or equivalent standing by having made valuable contribution to the science and art of illumination, graduation from engineering school of accepted standing or technical or scientific education equivalent to three years of active practice; Associate nembers, 6,921, over eighteen years of age, interested in objects of this Society ; Student members, 137, registered in colleges or universities for study toward degrees in engineering, science, fine arts, or related curricula; Fellows, 117, over thirty-two years of age, members for three years, ten years' practice or five years' teaching of illuminating engineering, or equivalent standing by notable work, scientific attainment in this or related fields, graduates of engineering schools of accepted standing or equivalent technical or scientific education; Members Emeritus, 44 , over sixty years of age, thirty years as dues payers including fifteen as Members or Fellows; Honorary, of acknowledged eminence in branches of art or science related to illuminating engineering; Sustaining members, 469, firms, associations, or individuals interested in objects of this Society and desirous of contributing to its support. Total membership 10,015.

\section{Meetings: Annual.}

Professional activities: Illuminating Engineering Research Institute, to conduct and stimulate research in this and related fields; Illuminating Engineering Society Medal, for meritorious achievement in the art or knowledge of illuminating engineering.

Publications: Illuminating Engineering, monthly, current volume: 55. Editor: Ruby Redford.

762. Indiana Academy of General Practice. 1403 North Delaware Street, Indianapolis 2, Ind. President: Harry Pandolfo, 234 East Southern Avenue, Indianapolis 25, Ind. Term expires 1961. Errecutize Secretary: Charles G. Dosch. Term indefinite.

History: Organized 1948 as a constituent chapter of the American Academy of General Practice.

Purpose: To promote and maintain high standards of the general practice of medicine and surgery.

Membership: General Practitioners who are members of the Indiana State Medical Association and do not limit themselves to one field of medicine or surgery, and have postgraduate training according to the standards set up by the American Academy of General Practice. Total membership 855 .

\section{Mectings: Annual.}

Publications: Hoosier News Letter, nine annually, free to members. Editor: Charles G. Dosch. 
763. Indiana Academy of Science. State Library, Indianapolis 4, Ind. President: A. T. Guard, 1845 Woodland Avenue, Lafayette, Ind. Term expires December 31, 1960. Secretary: William W. Bloom, Valparaiso University, Valparaiso, Ind. Term indefinite.

History: Organized 1885; incorporated 1893 ; affiliate, American Association for the Advancement of Science; member. Academy Conference. Sections: Anthropology, Bacteriology, Botany, Chemistry, Entomology, Geology and Geography, Mathematics, Physics, Psychology, Soil Science, Taxonomy, Zoology, History of Science, Junior Academy of Science.

Purpose: To provide opportunity for direct personal exchange of ideas within the scientific disciplines.

Memberslip: Menbers, 875, persons interested in work of this Academy; Fellows, 161, selected on basis of scientific contributions. Total nembership 1,036.

Mectings: Semiannual.

Professional activitics: Science talent search; sponsorship, with National Science Foundation, of visiting scientists and a mathematical program for high schools.

Publications: Proceedings, annual, current volume: 59, free to members. Editor: $R$. Laubengayer, IVabash College, Crawfordsville, Ind.

764. Indiana-Kentucky Geological Society. President: Fred Forward, Phillips Petroleum Company, Koch Building, Evansville, Ind. Tern expires June 1961. Sccretary-Treasurer: Robert B. Sublett, 301 Court Building, Evansville, Ind. Term expires June 1961.

History: Founded 1947, affiliate, American Association of Petroleum Geologists.

Purpose: To promote the science of geology, especially as it pertains to petroleum and natural gas; to promote professional and social relationship of members; to provide meetings for presentation and discussion of subjects of mutual interest.

Mcmbership: Open to college graduates in geology and technically allied fields. Total membership 160.

Mectings: Monthly.

765. Indiana Neuropsychiatric Association. President: Elmer Hardtke, Indiana University, Bloomington, Ind. Term expires May 1961. Secretary-Treasurer: Ronald H. Hull, 723 Hume Mansur Building, Indianapolis, Ind. Term indefinite.

History: Organized in late 1930's; affiliate, American Psychiatric Association, as Indiana District Branch.
Purpose: To have scientific meetings, provide public information, and advise regarding neuropsychiatric disorders.

Mcmbership: Members, 83, physicians active in fields of neurology, psycliatry, or neurosurgery, and holding membership in American Medical Association.

Mectings: Monthly, October through May, except December.

Professional activities: Cooperative work with lay and State mental health groups; annual award to medical student for outstanding paper in this field.

766. Indiana Pharmaceutical Association. 54 Monument Circle, Indianapolis 4, Ind. President: George M. Lanigan, 2628 West 16th Street, Indianapolis, Ind. Term expires June 1961. Exccutice Secretary: L. C. Heustis. Term indefinite.

History: Organized 1882; incorporated 1912.

Purpose: To unite pharmacists of Indiana for mutual assistance and encouragement; to improve methods of pharmacy; to stimulate research and achievenent; to establish closer relations with other health professions and with the public.

Membership: Parent store membership, 730 ; Multiple store membership, 198; Individual Registered Pharmacists, 482; Associate Registered Pharmacists, 58; Travelers auxiliary, 212, salesmen, representatives, executives. Total membership 1,680 .

Mectings: Annual.

Publications: Indiana Pharmacist, monthly, current volume: 45-46, \$4. Editor: L. C. Heustis.

767. Indiana Psychological Association, Inc. 1633 North Capitol Avenue, Indianapolis, Ind. President: IV. IV. Renke, Ball State Teachers College, Muncie, Ind. Term expires April 1961. Secretary: Wynne Arnholter. Term expires April 1962.

II istory: Organized October 22, 1936, as Indiana Association of Clinical and Applied Psychologists; incorporated November 10, 1937; name changed to present title subsequently. Committees: By-laws, Ethics, Hospitality, Internship and Training, Legislative, Membership, Nominating, Program, Public Relations, Research, Workshop.

Purpose: To increase public understanding of psychology as a science, and to promote and encourage higher standards of teaching of that subject in Indiana; to establish and maintain ethical and technical standards for psychologists; to aid in establishing clinical and applied psychological services throughout the State; to stimu- 
late research and provide opportunities for exchange of ideas; to work with State, community, and civic groups in promoting mental heaith.

Membership: Members must possess degrees of doctors of philosophy, with majors in field of psychology, or certain prescribed equivalents. Total membership 211.

Meetings: Semiannual.

Publications: Bulletin, semiannual, current volume: 21. Editor: Wynne Arnholter.

768. Indiana Roentgen Society. President: C. A. Stayton, Jr., 313 Hume Mansur Building, Indianapolis, Ind. Term expires May 1961. Secretary: D. E. Wheeler, 1500 North Ritter Street, Indianapolis, Ind. Term expires May 1961.

History: Organized February 1928.

Purpose: To advance the science of radiology. Membership: Total membership 84.

Mectings: Semiannual.

769. Indiana Society of Anesthesiologists. President: Paul Littlefield. Term expires 1961. Secretary-Treasurer: M. L. Hicks, 1502 North Emerson Street, Indianapolis, Ind. Term expires 1963.

History: Organized 1948; component society, American Society of Anesthesiologists, Inc., since 1948.

Purpose: To advance and improve the specialty of anesthesiology.

Mcmbership: Active, 125, physicians licensed to practice medicine in Indiana, interested or active in practice of anesthesiology; Scientific Associate, 2, non-physicians; Junior, 13, resident physicians in specialty training.

Mectings: Semiannual.

Publications: Newsletter, quarterly, current volume: 4, free to members. Editor: M. L. Hicks.

770. Indiana Society of Professional Engineers, Inc. 1224 North Capitol Avenue, Indianapolis 2, Ind. President: R. E. Hutton, 5231 Hohman Avenue, Hammond, lnd. Term expires June 17, 1961. Exccutize Secretary: Gene IV. Baldock. Term indefinite.

History: An outgrowth of engineering clubs in Indiana, affiliated with the National Society of Professional Engineers January 8, 1937; incorporated in Indiana June 4, 1937. CHApters : Anthony Wayne, Calumet, Central Indiana, Delta, Ellakono, Francis Vigo, James B. Eads, George Rogers Clark, Lafayette, Saint Joseph Valley, and Southwestern.
Purpose: To represent the legal, professional and economic needs of the engineer in nontechnical problems in fields of education, legislation, law enforcement, ethics, public affairs, and employment.

Mcmbership: Professional Engineers, 975; Engineers-in-Training, 100; Land Surveyors, 12; Introductory members, all classes, 113. Total membership 1,200.

Mectings: Annual.

Professional activities: Armco Scholarship screening, three $\$ 5,000$ scholarships; high school counselling in cooperation with Engineers' Council for Professional Development; Engineer of the Year Award; Junior Engineer of the Jear Award.

Publications: Indiana Professional Engineer, monthly except August and September, current volume: 22, \$1. Editor: Gene IV. Baldock.

771. Indiana State Dental Association. President: IV. R. Shoemaker, 517 Citizens Bank Building, Anderson, Ind. Term expires May 1961. Secretary: Charles L. Howell, 1330 West Michigan Street, Indianapolis 7, Ind. Term expires May 1961.

History: Founded 1858; incorporated January 10, 1879.

Purpose: To encourage improvement of health of the public and to promote the art, science, and profession of dentistry.

Mcmbcrship: Requires ethical practice of dentistry. Total membership 1,750.

Mectings: Annual.

Publications: Journal, ten annually, current volume: 5, \$2. Editor: J. C. Muhler.

772. Indiana State Medical Association. President: Earl W. Mericle, 1633 North Capitol Avenue, Indianapolis, Ind. Term expires October 5, 1960. Executive Secretary: James A. Waggener, 1021 Hume Mansur Building, Indianapolis, Ind. Term indefinite.

History: Founded 1849 as Indiana State Medical Society; name changed to present title April 1926. Sections: Surgery, Medicine, Ophthalmology and Otolaryngology, Anesthesiology, General Practice, Obstetrics and Gynecology, Public Health and Preventive Medicine, and Radiology.

Purpose: To extend medical knowledge; to advance medical science; to elevate standards of medical education.

Membcrship: Physicians, 4,256, requires membership in component county medical societies.

Meetings: Annual.

Publications: Journal, monthly, current volume: $53, \$ 5$, free to members. Editor: Frank B. Ramsey, 1017 Hume Mansur Building, lndianapolis 4 , Ind. 
773. Indiana State Nurses' Association, Inc. 110 North Illinois Street, Indianapolis 4, Ind. President: Miss Florence G. Young, 615 North Michigan Street, South Bend, Ind. Term expires October 1960. Exccutive Secretary: Mrs. Helen C. Randall. Term indefinite.

\section{History: Organized 1903.}

Purpose: To promote the professional, educational, and economic advancement of nurses, maintain and improve standards of practice and education, and establish and maintain a code of ethics.

Mcmbership: Registered professional nurses licensed in at least one State. Total membership 3,984 .

\section{Mectings: Annual.}

Professional activities: Nurses Educational Foundation, Isabel Hampton Robb Scholarship Fund, Mclsaac Loan Fund, Indiana University Division of Nursing Education Scholarship Fund, Edwina MacDougall Award for district with greatest membership of potential, Frances Ott Award for district wtih greatest percentage of gain for year, three journalism awards annually.

Publications: Indiana Nurse, bimonthly, current volume: $24, \$ 1$.

774. Individual Psychology Association, New York, Inc. 333 Central Park West, New York 25, N. Y. Presidcnt: Alexandra Adler, 30 Park Avenue, New York, N. Y. Term indefinite. Executive Secretary: Mrs. Danica Deutsch. Term indefinite.

History: Organized 1943; affiliated with American Society of Adlerian Psychology.

Purpose: To promote knowledge, training, and teaching of individual psychology (teachings of Alfred Adler).

Membership: Active Members, graduates of institutions of higher learning who have successfully completed Alfred Adler Institute for Individual Psychology and have undergone didactic analysis with approved members of this Association; Associate, persons interested in individual psychology, but not meeting Active Membership requirements; Student Alumni, persons who have obtained training at the Alfred Adler Institute, but who are not eligible for Active Membership. Total membership approximately 150 .

Mectings: Annual.

Professional activities: Alfred Adler Consultation Center and Mental Hygiene Clinic; Alfred Adler Institute for Individual Psychology ; lectures to professional and lay groups; special courses for teachers, industrialists, and ministers.

Publications: Newsletter.
775. Industrial Hygiene Foundation of America, Inc. Chairman of Board: William P. Yant, 100 North Braddock Avenue, Pittsburgh 8, $\mathrm{Pa}$. Term indefinite. Managing Director: $\mathrm{H}$.

H. Sclirenck, 4400 5th Avenue, Pittsburgh 13. Pa. Term indefinite.

History: Organized 1935 as Air Hygiene Foundation; name changed to present title 1941. Commitrees: Executive, Legal, Medical, Engineering, and Chemical-Toxicological.

Purpose: Advancement of health in industry.

Membership: Only private industrial institutions and trade associations; no individual memberships. Total menibership 400 .

\section{Mectings: Annual.}

Professional activitics: Toxicological research laboratory.

Publications: Industrial Hygiene Digest, monthly, current volume: 24 , free to members. Transactions, annual, current volume: 25 , free to members.

776. Industrial Mathematics Society. 100 Farnsworth Street, Detroit 2, Mich. President: Robert Davies, 295 Harrow Circle, Birmingham, Mich. Term expires May 11, 1961. Executive Secretary: Walter Kotoucek, 9932 Heyden Avenue, Detroit 28, Mich. Term expires May 11, 1961.

\section{History: Organized 1950.}

Purpose: To extend understanding and application of mathematics in industry.

Momborship: Active nembers, must be graduates in mathematics of recognized universities or colleges, or must, by reason of experience, have attained equivalent knowledge; Associate, interest in applied mathenatics, but not qualified for active membership. Total membership approximately 200 .

Mectings: Montlly during winter.

Professional activities: Lectures by outstanding mathematicians.

Publications: Industrial Mathematics, semianmual, current volume: 10, \$4. Editor: Richard L. Justice.

777. Industrial Medical Association, Inc. President: Robert E. Eckardt, Esso Research and Engineering Company, P. O. Box 45, Linden, N. J. Term expires April 1961. Managing Dircctor: Clark D. Bridges, 28 East Jackson Boulevard, Chicago 4, III. Term indefinite.

History: Organized in 1915 as American Association of Industrial Physicians and Surgeons; name changed to present title April 1951. Component Societies: New York State Society of Industrial Medicine, Inc.; Kansas City Industrial Medical Association; Michigan Indus- 
trial Medical Association: Minnesota Academy of Occupational Medicine and Surgery; New England Industrial Medical Association; Central States Society of Industrial Medicine and Surgery: Industrial Medical Association of New Jersey: Texas Industrial Medical Association: Industrial Medical Association of Philadelphia; Kentucky Industrial Medical Association; Industrial Medical Association of Pittsburgh; Hawaii Association of Plantation Physicians; Northwest Association of Occupational Medicine; Western Industrial Medical Association; Western New York Society of Industrial Medicine and Surgery.

Purpose: To foster study and discussion of problems peculiar to industrial medicine and surgery: to unite members of the medical profession specializing in industrial medicine and surgery for mutual advancement.

Membership: Active Members, doctors of medicine who are members of local county medical societies or active members of American Medical Association or of corresponding associations in other countries, and with interest in industrial medicine: Fellows, 839. Total membership 4,000.

\section{Meetings: Annual.}

Professional activities: Knudsen Award, in recognition of outstanding contribution to industrial medicine; Meritorious Service Award, in recognition of outstanding contributions to this Association; Merit In Authorship Award, in recognition of outstanding contribution to literature in this field; Health Achievement in Industry Award, to industry providing outstanding medical service to its employees.

Publications: Journal of Occupational Medicine, monthly, current volume: $2, \$ 10$, free to members. Editor: A. G. Kammer, 2057 Beechwood Boulevard, Pittsburgh, Pa.

778. Industrial Medical Association of Philadelphia, Inc. Room 1214, Six Penn Center Plaza, Philadelphia 4, Pa. President: Walter G. Vernon, Lukens Steel Company, Coatesville, Pa. Term expires Decenber 31, 1960. E.recutive Secretary: Charles E. Rigby, Sun Oil Company, Marcus Hook, Pa. Term expires December 31, 1960. Corresponding Secretary: C. Raymond Houchins. Term expires December 31, 1960.

History: Organized 1949 as Philadelphia Interstate Industrial Medical Association; incorporated into Industrial Medical Association as component society January 1950; name changed to present title April 1952; articles of incorporation completed 1960. CoMmitTEes: Civil Defense and Mobilization, Education and Training, Physical and Chemical Agents, Public and Community Relations, Workmen's Compensation.

Purpose: To promote development of effective occupational health programs in industry and to provide continuing education and guidance for industrial physicians.

Membership: Active nembers, 123, graduates from approved medical schools, duly licensed to practice, who have shown interest in industrial medical practice by affiliation with industrial medical programs, workmen's compensation or industrial insurance, and who have been so engaged for two years; Fellows, 102, in addition to above requirements, must have been an active member five years; Honorary, 1 . Total membership 226.

Mectings: Monthly, September to May.

779. Industrial Medical Association of Pittsburgh. 525 William Penn Place, Pittsburgh 30, Pa. President: Daniel V. Dougherty, P. O. Box 309, Berea, Ohio. Term expires September 1960. Secretary-Treasurer: Merle Bundy. Term expires September 1960.

History: Formed September 30, 1954, as component society, Industrial Medical Association. Sections: IVest Virginia, Western Pennsylvania, Eastern Ohio.

Purpose: To provide organization for physicians whose interests lie in industrial medicine; to encourage development of methods to conserve and improve health of workers; to foster study of problems peculiar to practice of industrial medicine and surgery; to promote better understanding of benefits of medical services in industry; to promote cooperation between physicians and members of other professional groups concerned with occupational health.

Membership: Graduates of recognized medical schools licensed to practice in their States, who are members of State and county medical societies: Fellows, active members elevated to Fellowship in Industrial Medical Association; Active members, doctors of medicine in practice three years, the last two of which have been actively in practice of industrial medicine or surgery; Associate members, doctors of medicine qualified for active membership except for insufficient length of service; Honorary members, physicians and surgeons who have contributed distinguished service to objectives of this Association; Retired members, Fellows and active members retired from professional activity after ten or more years of membership. Total membership 258.

Meetings: Semiannual.

780. Industrial Research Institute, Inc. 100 Park Avenue, New York 17, N. Y. President: R. G. Challar, National Cash Register Com- 
pany, Main and $\mathrm{K}$ Streets, Dayton, Ohio. Term expires May 3, 1961. Secretary-Treasurer: C. G. Worthington. Term indefinite.

History: Organized as a committee of the Division of Engineering and Industrial Research, National Research Council, 1938; incorporated 1945. Conmitees: Research Management Seminar, Research Management Study Groups, Research Personnel, Vital Statistics.

Purpose: To promote, through cooperative efforts of members, improved, economical, and effective techniques of organization, administration, and operation of industrial research; to develop and disseminate information on those subjects; to stimulate and develop understanding of research as a force in economic, industrial and social activities.

Membership: Limited to companies, engaged primarily in manufacturing, which regularly maintain technical staffs and laboratories for conduct of industrial research, and their research subsidiaries or affiliates. Total membership 172 companies.

\section{Mectings: Semiannual.}

Professional activities: Industrial Research Institute Medal, established 1945, presented to recognize and honor outstanding research which contributes broadly to development of industry or public welfare.

Publications: Research Management, quarterly, current volume: $2, \$ 7.50$. Editor L. Marshall. Descriptive Booklet, annual.

781. Institute for Bio-energetic Analysis. 55 Park Avenue, New York 16, N. Y. Exccutive Director: Alexander Lowen. Term expires June 1961. Executiz'c Secretary: Betty Skalecki, 72 Barrow Street, New York 14, N. Y. Term expires June 1961.

\section{History: Organized October 1956.}

Purpose: To coordinate and further projects which relate findings of psychoanalysis to knowledge of energy principles applicable to biological structure and function.

Membership: Open to physicians, psychiatrists, psychologists, dentists, psychiatric social workers, and all qualified persons professionally engaged in any activity dealing with emotional and physical health. Total membership 26.

Mectings: Three annually.

Professional activities: Public lectures; clinical case seminars.

782. Institute of Environmental Sciences. P. O. Box 191, Mt. Prospect, I11. President: William L. Vandal, 9931 Lenore Drive, Garden Grove, Calif. Term expires April 5, 1961. Executive Secretary: Henry F. Sander. Term expires April 5, 1961.
History: Merger of Institute of Environmental Engineers and Society of Environmental Engineers in April 1959 resulted in Institute of Environmental Sciences. Chapters: Boston, Chicago, Dayton, Detroit, Los Angeles, MidAtlantic, New York City, Northern California, San Diego, Southern Tier New York.

Purpose: To provide means whereby environmental sciences can be explained, discussed, and debated, and thus aid the teclnological advances of this hemisphere.

Mcmbership: Fellow, appointed; Member, nine years experience or education; Associate nember, four years education or one year experience: Student, engineering school enrollment; Govermment member, interest in this Institute; Company menber, similar interest. Total membership 800 .

Meetings: Annual.

Professional actirities: Annual meeting technical presentation award.

Publications: Journal of Environmental Sciences, bimonthly, current volume: $3, \$ 5$. Editor: C. II. Danielson.

783. Institute of Food Technologists. 176 West Adams Street, Chicago 3, I11. President: Imri J. Hutchings, P. O. Box 57, Pittsburgh 30, Pa. Term expires May 11, 1961. Erecutive Secretary: Charles S. Lawrence. Term expires May 11, 1961.

History: Organized 1939; incorporated 1950. Sections: Ames, Ak-Sar-Ben, Australia Northern, Australia Southern, British Columbia, Chicago, Dixie, Florida, Great Lakes, Hawaii, Indiana, Japan, Kansas City, Maryland, Mexico, Minnesota, Mohawk Valley, New York, Northeast, Northern California, Ohio Valley, Oregon, Philadelphia, Pittsburgh, Puget Sound, Rocky Mountain, St. Louis, Southern California, Texas, Washington, Western New York, Wisconsin. Technical Committees: Citrus Products, Food Additives, Quality Control of Food Products, Taste Testing.

Purpose: To promote application of science and engineering to production, processing, packaging, distribution, preparation, and utilization of foods.

Membership: Professional members, bachelors' degrees in sciences or branches of engineering associated with food technology, and three years' experience; Members, qualified individuals directly associated with food technology; Student members, full time students in junior or senior years of college working toward degrees in this field. Professional members, 3,838; Members, 1,653; Student members, 223. Total membership 5,714 .

Mectings: Annual. 
Professional activities: General Foods Fund, Inc., graduate fellowships, $\$ 12,000$ annually; Florasynth Fellowship, graduate, $\$ 1,000$ annually; Samuel Cate Prescott Fellowship, graduate, $\$ 1,000$ annually; Gerber Baby Foods Fund, Inc., undergraduate awards, $\$ 6,000$ annually; Dodge and Olcott Scholarship, undergraduate, \$1,000 annually; Alexander E. Katz Memorial Scholarship, undergraduate, $\$ 1,000$ annually; Nicholas Appert Award, $\$ 1,000$ and bronze medal for pre-eminence in and contribution to field of food technology; BabcockHart Award, $\$ 1,000$ and engrossed plaque for contributions to food technology which have resulted in improved public health; Institute of Food Technologists International Award, engraved silver salver for member who has made outstanding effort to promote international exchange of ideas in field of food technology; Food Technology Industrial Achievement Award, bronze plaque to company or institution for significant advance in application of technology to food production successful in commercial operation, and engrossed plaques to individuals who have made major contributions to that achievement.

Publications: Food Technology, monthly. current volume: 14. Food Research, bimonthly, current volume: 25. Editor, both publications: M. S. Peterson.

784. Institute of Management Sciences. P. O. Box 273, Pleasantville, N. Y. President: A. Charnes, Technological Institute, Northwestern University, Evanston, Ill. Term expires December 31, 1960. Executive Sccretary: George Kozmetsky, 300 Bellino Drive, Pacific Palisades, Calif. Term indefinite.

History: Organized December 1, 1953; incorporated in California September 2, 1954. Chapters in fifteen cities, including Paris and Tokyo. Colleges: Business Computer and Data Systems, Decision Processes, Management Communications, Management Controls, Management Games, Managerial Economics, Measurements in Management, Organization Theory, Planning, Psychoanalytic Processes, Research and Development, Simulation. CommitteEs: Education, Development, Professional Relations, Publications, Research.

Purpose: To identify, extend, and unify scientific knowledge that contributes to understanding and practice of management.

Membership: Requires interest in promoting practice and growth of management sciences. Members in forty-four countries; individual members include 100 students and twenty members of the United States Armed Forces. Total membership 2,720.

Meetings: One or two annually.
Professional activitics: Research through above named colleges; financial assistance for research projects; annual methodology symposium.

Publications: Management Science, quarterly, current volume: $6, \$ 10$. Management Technology, current volume: 1. Editor, both publications: C. W. Churchman.

785. Institute of Mathematical Statistics. President: E. L. Lehman, Department of Statistics, University of California, Berkeley, Calif. Term expires August 1961. Executive Secretary: George E. Nicholson, Jr., Department of Statistics, University of North Carolina, Chapel Hill, N. C. Term expires August 1961.

History: Organized September 12, 1935, at Ann Arbor, Mich. Regrons: Central, Eastern, Western. No formal division; regional classification is only for regional meetings.

Purpose: To encourage development, dissemination, and application of mathematical statistics.

Membership: Requires interest in mathematical statistics. Present membership is representative of colleges, industry, and government, and includes people from all continents. Total membership 2,300.

Meetings: Annual. nial.

Professional activitics: Rietz Lecture, bien-

Publications: Annals of Mathematical Statistics, quarterly, current volume: 3, United States and Canada \$12, elsewhere \$10. Editor: William Kruskal, Department of Statistics, University of Chicago, Chicago 37, Ill.

786. Institute of Medicine of Chicago. 86 East Randolph Street. Chicago 1, Ill. President: Walter L. Palmer, 950 East 59th Street, Chicago 37, I11. Term expires January 1961. Exccutive Director: Edna Nicholson. Term indefinite.

\section{History: Established 1915; incorporated.}

Purpose: To serve as a nonpartisan, representative body of medical and allied persons to which profession and public can look with confidence in matters affecting mutual interests; to initiate and cooperate in medical surveys and reforms; to coordinate medical with social and civic aspects of community efforts concerned with public welfare; to encourage and promote advancement of medical sciences; to inform the public on topics of current medical interest, and to interpret to them the significance of recent developments in research. 
Membership: By invitation to pluysicians or persons engaged in allied scientific pursuits. Total membership 665.

Meetings: Quarterly.

Professional activities: Eight endowed lectureships, memorials to: Frank Billings, Charles Warrington Earle, Walter Wile Hamburger, Ludvig Hektoen, Richard H. Jaffe, Edwin R. Kretschner, Lewis Linn McArthur, and Villian, Hamlin WVilder; four special funds, honoring: George Howell Coleman, Jessie Horton Koessler, William F. Petersen, and Harry P. Weber; Joseph A. Capps Prize, for most meritorious investigation in nedicine or a fundamental science having direct bearing on a medical problem, eligibility for prize limited to graduates of medical schools in Chicago who have completed internslip or one year of laboratory work within five years immediately preceding competition; George Howell Coleman Medal, awarded to physician or kindred scientist who has rendered outstanding service above and beyond practice of profession; Edward Lorenzo Holmes Memorial Award, to young men who have contributed meritorious work in medicine, or to older men who have presented fundamentally important medical problems, with preference to work in ophthalmology; Chicago Woman's Club Fund for Research in Cancer and Allied Diseases; Edwin R. Kretschmer Meniorial Fund, for lectures or research in field of blood dyscrasia.

Publications: Proceedings, bimonthly, current volume: 23 , \$5. Editor: Edwin F. Hirsch.

787. Institute of Navigation. 711 14th Street, N. W., Washington 5, D. C. Presidcut: I. E. Rittenburg. Executive Sccretary: Alton B. Moody. Terms expire June 1961.

Mistory: Organized 1945, at Los Angeles. Regrons: Eastern, Western. Sections located in various cities, and at military installations in the United States and Japan. TechnicaL Committees: Air Navigation, Marine Navigation, Space Guidance.

Purpose: To coordinate forward strides in navigation and related arts and sciences by the Armed Services, industry, and universities; to promote and develop highest standards for navigation to insure safety.

Membership: Regular members, 1,600, interested in navigation or related arts and sciences; Student, 30, persons attending, full time, recognized colleges or universities; Honorary, 2; Library, 50; Sustaining, 3 ; Corporate, 33. Total membership 1,718 .

Mectings: Annual.

Professional activities: Thurlow Navigation Award, annual, plaque for outstanding contribution to the science of navigation; Burka Award, annual, certificate and $\$ 200$, for outstanding paper on navigation or space guidance published in journal; Gullen Award, annual, navigation watch, to person first in navigation at United States Air Force Academy.

Publications: Navigation, quarterly, current volume: 6 , free to nembers. Editor: John Dohm.

788. Institute of Radio Engineers, Inc. One East 79th Street, New York 21, N. Y. President: R. L. McFarlan. Term expires December 31, 1960. Sccrctary: Haraden Pratt. Term expires December 31, 1960. Executive Secretary: George IV. Bailey. Term indefinite.

History: Organized 1912; incorporated 1913. 107 sections in the United States, Canada, and other countries. Professional Groups: Audio, Broadcast Transunission Systems, Antennas and Propagation, Circuit Theory, Nuclear Science, Vehicular Communications, Quality Control, Proadcast and Television Receivers, Instrumentation, Radio Telemetry and Remote Control, Aeronautical and Navigational Electronics, Information Theory, Industrial Electronics, Engineering Management, Electron Devices, Electronic Computers, Microwave Theory and Techniques, Medical Electronics, Communications Systems, Ultrasonics Engineering, Conponent Parts, Production Techniques. ComMitTeEs: Antennas and IVave Guides, Audio Techniques, Circuits, Electroacoustics, Electron Devices, Electronic Computers, Facsimile, Feedback Control Systems, Industrial Electronics, Information Theory and Modulation Systems, Measurements and lnstrumentation, Mobile Communications Systems, Navigation Aids, Piezoelectric Crystals, Radio Transmitters, Receivers, Research, Sound Recording and Reproducing, Standards, Symbols, Television Systems, Video Techniques, IVave Propagation.

Purpose: To advance theory and practice of radio and allied branches of engineering, and related arts and sciences, and to maintain high professional standing among nembers.

Membership: Fellows, 823, minimum age thirty-two; Senior Members, 9,463, minimum age twenty-eight, radio engineers or scientists with eight years of active practice; Members, minimum age twenty-four, 38,977, three years' active practice as radio engineers or scientists, or as college teachers of radio or allied subjects; Associate Members, 13,165, minimum age eighteen, interest in radio engineering or allied field; Student Members, 16,738, in four year college engineering or science courses leading to degrees. Total membership 79,166 .

Meetings: Monthly.

Professional activities: Medal of Honor, in recognition of outstanding scientific and engineering achievements; Founders Award, on 
special occasions, to outstanding leaders in communications and electronics fields; Morris Liebmann Memorial Prize, for important contribution to radio art; Browder J. Thompson Memorial Prize, for published paper constituting best combination of technical contribution and presentation of subject; Harry Diamond Memorial Award, to a person in government service for outstanding contribution in field of radio or electronics; Vladimir $\mathrm{K}$. Zworykin Television Prize Award, for important technical contribution to electronic television.

Publications: Proceedings, monthly, current volume: 48 , $\$ 18$, free to members. Editor: F. Hamburger, Jr., Johns Hopkins University, Baltimore, Md.

789. Institute of Sanitation Management. 101 West 30th Street, New York 1, N. Y. President: Albert J. Burmer, Port of New York Authority, 1118 th Avenue, New York, N. Y. Term expires October 24, 1960. Exccutive Secretary: Gerard J. Riley. Term indefinite.

History: Organized October, 1957 ; incorporated in New York, through merger of three former associations: Association of Food Industry Sanitarians; Industrial Sanitation Management Association; National Association of Bakery Sanitarians. Chapters: Boston, Chicago, Cleveland, Connecticut, Detroit, Los Angeles, Minneapolis, New York, Philadelphia, Pittsburgh, St. Louis, San Francisco, and Washington, D. C.

Purpose: To maintain and improve the standards of industrial sanitation, including building maintenance; to promote industrial sanitation as a managed function in its application to work environment; to foster and engage in research and educational activities; to disseminate information pertaining to methods and costs.

Membership: Active, 815, persons of acceptable character, education, and experience who are employed as industrial or food sanitarians, or have supervisory or executive responsibility for industrial sanitation, including safety and industrial hygiene, or are engaged in building or institutional management and maintenance, or are responsibly engaged in educational research or publication activities in the field of sanitation, or are consulting sanitarians; Sustaining, 98, individuals, firms, or corporations engaged in manufacture or marketing of machinery, equipment and materials, or commercially supplying goods and services used in industrial sanitation. Mectings: Annual.

790. Institute of the Aerospace Sciences, Inc. 2 East 64th Street, New York 21, N. Y.
Executive Secretary: Robert R. Dexter. Term indefinite.

History: Incorporated in New York October 15, 1932. Geographic Sections: Antelope Valley, Atlanta, Baltimore, Boston, Central Florida, Chicago, Cleveland-Akron, Columbus, Connecticut, Dayton-Cincinnati, Detroit, Great Salt Lake, Hagerstown, Hampton Roads, Indianapolis, Kansas City, Los Angeles, New Mexico, New York, Niagara Frontier, Omaha, Philadelphia, Rocky Mountain, Sacramento, San Antonio, San Diego, San Francisco, Seattle, St. Louis, South Florida, Texas, Tullahoma, Tulsa, Twin Cities, Washington, D. C., Wichita. Student branches in seventy-eight colleges, universities, and aeronautical schools.

Purposc: To advance the arts and sciences of aero-space technology.

Membership: Honorary Members, 20; Honorary Fellows, 35; Fellows, 228; Associate Fellows, 1,725 , twelve years' professional practice, important work, responsible charge, outstanding contribution; Members, 7,075, eight years' professional work; Associate Members, 6,860, scientific or engineering work in aeronautics or allied field, or recognized standing in application, administrative, or other related positions; Corporate Members, 150; Student Members, 4,506. Total membership 15,943.

\section{Meetings: Annual.}

Professional actirities: Octave Chanute Award, for notable contribution by a pilot to aeronautical sciences; Flight Test Engineering Fellowship, value $\$ 7,800$; John Jeffries Award, to recognize importance to aviation of scientific endeavor in mediciue; Louis IV. Hill Space Transportation Award, in recognition of research in sciences relating to space travel or technology, $\$ 5,000$ for individual, or up to $\$ 10,000$ for team contribution; Robert M. Losey Award, to recognize outstanding contributions to the science of meteorology as applied to aeronautics; Minta Martin National Awards, for best graduate and undergraduate papers in aeronautical engineering; Sylvanus Albert Reed Award, for notable contribution to aeronatical sciences resulting from experimental or theoretical investigations; Lawrence Sperry Award, for notable contribution by a young man to advancement of aeronautics; Water-based Aviation Award; Wright Brothers Lecture.

Publications: Aero Space Engineering, monthly, current volume: $19, \$ 5$. Editor: Allan Bernhardt. Journal of the Aero Space Sciences, monthly, current volume: $27, \$ 15$. Editor: IV. R. Sears. Aero Space Engineering Catalog, annual, current volume: $16, \$ 7.50$. Editor: Beverly A. Dodge. Aero Space Engineering Index, annual, $\$ 15$, members $\$ 10$. Editor: John J. Glennon. 
Library: 17,000 volumes. Subject emphasis: Aeronautical science.

791. Institute of Traffic Engineers. $2029 \mathrm{~K}$ Street, N. W., Washington 6, D. C. President: Alfred F. Malo, Department of Streets and Traffic, 735 Randolph Street, Detroit 26, Mich. Term expires August 22, 1961, or, if by-laws are amended, term expires on a later date in 1961. Executive Secretary: David M. Baldwin. Term indefinite.

History: Organized 1930, in Pittsburgh, Pa; incorporated in Connecticut 1954. Fourteen local sections. Technical work carried on by a technical council and seven technical departments, including professional standards, education and administration, traffic operations measures, applications of control devices, geometric design, transportation planning, and design of devices and equipment.

Purpose: To advance the art and science of traffic engineering, and encourage intercourse between men with mutual interests in this work; to foster traffic engineering education; to stimulate original research in this field; to advance professional development of, and establish a central point of reference and union for, members.

Mcmbership: Members, 345, thirty-five years of age or over, twelve years' engineering experience including five years of traffic, responsible charge for five years, three years' important traffic engineering work; Associate, 613, over twenty-seven years of age, eight years' engineering experience including three years of traffic, one year responsible charge of traffic engineering; Junior, 299, twenty-one to thirty-five years of age, five years' engineering experience including one year in traffic; Affiliate, 53, by invitation; Honorary, 5, by invitation. Total membership 1,315.

Mcetings: Annual.

Professional activities: Technical Development and Research Fund, to assist qualified agencies in traffic engineering research; Past Presidents' Award, annual, for best traffic engineering paper by member under thirty-five years of age.

Publications: Traffic Engineering, monthly, current volume: $30, \$ 4.50$. Proceedings, annual, current volume: 29, $\$ 2$. Yearbook, $\$ 1$. Editor, all listed publications: David M. Baldwin.

792. Instrument Society of America. 313 6th Avenue, Pittsburgh 22, Pa. President: Ralph H. Tripp, Flight Test Division, Grumman Aircraft Engineering Corporation, Bethpage, N. Y. Term expires September 1961.
History: Organized August 7, 1939, as American Society of Instrument Engineers; reorganized November 1939, as American Society for Measurement and Control ; incorporated and name changed to present title 1946. 101 Geographic Sections in the United States and Canada. Commitees: Research and Development; Instrument Operation and Maintenance; Testing Instrumentation; Analysis Instrumentation; Instrumentation for Inspection and Gaging; Instrumentation for Production Processes; Instrumentation for Transportation; Medical Instrumentation; Meteorological Instrumentation: Nuclear Radiation Instrumentation; Geophysical lnstrumentation; Physical Properties Measurement.

Purpose: To advance the arts and sciences connected with theory, design, manufacture, and use of instruments in the various sciences and technologies.

Mcmbcrship: Open to any person interested in the objectives of this Society. Total membership 12,000 .

\section{Mcetings: Annual.}

Professional activitics: Fellowships and other grants to Foundation for Instrumentation Education and Research; Arnold O. Beckman Award, $\$ 1,000$, annual, to member making most important technological contribution to new principle instrument design, development, or application.

Publications: Journal, monthly, current volume: $7, \$ 4$. Editor: Charles W. Covey.

\section{Insulated Power Cable Engineers Associa-} tion. 283 Valley Road, Montclair, N. J. President: G. J. Crowdes, 79 Sidney Street, Cambridge 39, Mass. Term expires October 1, 1961. Sccretary: G. M. Haskell. Term expires October 1, 1961.

\section{History: Organized 1925.}

Purpose: To promote safety, reliability, and economy of bare, covered, and insulated conductors for transmission and distribution of electric energy.

Mcmbcrship: Must be members of technical staffs of concerns manufacturing bare, covered, and insulated conductors. Total membership 118.

\section{Mectings: Bimonthly.}

794. Inter-American Society of Psychology. President: Gustave M. Gilbert, Psychology Department, Long Island University, Brooklyn 1, N. Y. Term expires 1961. Exccutive Secretary: Samuel Pearlman, 1 Hanson Place, Brooklyn 17, N. Y. Term expires 1961. 
History: Founded 1951.

Purpose: To provide avenues of direct communication among behavioral scientists in North and South America, and to promote development of behavioral sciences in this hemisphere.

Menbership: Active members, must have academic or professional doctorates, or equivalent in training or experience; Associate, must have minimum of one year's graduate study in psychology or closely related fields. Total membership approximately 400 .

Mectings: Annual.

Professional activities: Professional literature exchange service.

Publications: News-Bulletin, quarterly, free to members. Editor: Victor D. Sanua.

795. Intermountain Association of Petroleum Geologists. President: Willard C. Gere. Term expires October 1960. Secretary: Alan C. Dille, P. O. Box 1346, Salt Lake City, Utah. Term expires October 1960.

History: Organized 1949 as affiliate of American Association of Petroleum Geologists.

Purpose: To increase and disseminate geological knowledge, especially as it relates to petroleum and natural gas.

Membership: Full membership is limited to persons who are members or associate members of American Association of Petroleum Geologists: Associate membership is open to any person actively interested in petroleum and petroleum geology. Total membership 160.

Mcctings: Weekly.

Publications: Newsletter, bimonthly, free to members.

\section{Intermountain Psychiatric Association.}

President: John K. Torrens, 3220 Silver Street, Albuquerque, N. Mex. Term expires May 1961. Secretary-Treasurcr: H. Edward Beaghler, Utah State Hospital, Provo, Utah. Term expires May 1961.

History: Organized 1951; became District Branch, American Psychiatric Association, 1958.

Purpose: To foster progress in psychiatry in Arizona, Idaho, Montana, Nevada, New Mexico, Utah, and $\mathrm{W}$ yoming.

Memhership: Physicians who have specialized in psychiatry for three or more years and are members of American Psychiatric Association. Total membership 82.

Mectings: Annual.

Publications: Newsletter, irregular, free to members. Editor: Rudolph Keene.
797. Inter-Society Color Council, Inc. President: G. L. Erikson, Braden-Sutphin Ink Co., 3650 East 93rd Street, Cleveland 5, Ohio. Term expires December 31, 1961. Secretary: Ralph M. Evans, Eastman Kodak Company, Color Technology Division, Building 65, Rochester 4, N. Y. Term expires December 31, 1961.

History: Organized 1931; incorporated in New York 1953.

Purpose: To stimulate and coordinate work being done by various societies, organizations, and associations leading to the standardization, description, and specification of color, and to promote practical application of these results to color problems arising in science, art, and industry; to provide a meeting ground for all groups having color as a common point of interest.

Membership: Members-Bodies, open to any society, association, or organization of national scope operating on a non-profit basis; Individual Members, open to any person interested in color and desirous of participating in the activities of this Council. Member-Bodies, 27, with 215 appointed delegates: Individual Menbers, 375.

Mcetings: Annual.

Publications: News Letter, bimonthly, \$4, free to members. Editor: Warren L. Rhodes, Rochester Institute of Technology, Rochester $8, N . Y$.

\section{Inter-Society Corrosion Committee. 1061} $\mathrm{M}$ and M Building, Houston 2, Tex. President: R. R. Pierce, Pennsalt Chemicals Corporation, Natrona, Pa. Term expires March 1962. Secretary: T. J. Hull. Term indefinite.

History: Organized 1939 as Advisory Committee on Corrosion of American Society for Testing Materials; separated from that Society and changed name to American Coordinating Committee on Corrosion 1940; name changed to present title, under sponsorship, National Association of Corrosion Engineers, 1948.

Purpose: To promote cooperation among technical societies working in field of corrosion; to act in advisory capacity to various technical societies interested; to recommend societies for carrying out of proposed new activities; to stimulate publication of corrosion data; to disseminate corrosion information; to promote standardization of definitions and terminology in field of corrosion.

Mcmbcrship: Linited to two representatives from any technical society and one representative from any governmental agency formerly represented on American Coordinating Committee on Corrosion or any other major governmental agency of the United States or Canada actively 
engaged in cooperation with the industry. Total membership 33 associations and organizations.

Mectings: Annual.

799. Inter-Society Cytology Council, Inc. 1101 Beacon Street, Brookline 46, Mass. President: Abraham E. Rakoff, 269 South 19th Street, Philadelphia 19, Pa. Term expires September 24, 1960. Secretary-Treasurer: Paul A. Younge. Term indefinite.

History: Organized November 15, 1951.

Purpose: To foster the cytological method so that maximum usefulness as study tool and clinical diagnostic technique may be aclieved.

Membership: Open to clinicians, pathologists, and cytologists engaged or interested in efficient utilization of cytological methods. Total membership 656 .

Meetings: Annual.

Publications: Cytology Newsletter, quarterly, current volume: 2, \$2. Editor: Emmerich von Haam. Transactions, annual, \$2.

800. Interstate Postgraduate Medical Association of North America. President: Robert M. Zollinger, University Hospitals, Columbus 10, Ohio. Term expires November 3, 1960. Executive Director: Roy T. Ragatz, P. O. Box 1109, Madison 1, IVis. Term expires November 3, 1960.

History: Founded 1916 as Tri-State Medical Association; incorporated in lllinois 1919; name changed to present title 1937.

Purpose: To promote postgraduate medical education.

Mcmberslip: Only doctors of medicine who qualify for menbership in American Medical Association are admitted. Total membership approximately 1,500 .

Mectings: Annual.

Professional activities: Annual research awards made upon recommendations of deans of medical schools in host cities of scientific assemblies (annual meetings).

Publications: Postgraduate Medicine, monthly, current volume: $27, \$ 10$. Editor : Charles Mayo.

801. Iota Sigma Pi. President: Hoylande D. Young, 620 East 83rd Place, Chicago, Ill. Term expires June 1963. Executive Secretary: Charlotte Roderuck, Department of Foods and Nutrition, Iowa State University, Ames, Iowa. Term expires June 1963.

History: Alchemia, organized in 1912 at the University of California, is considered the parent organization; organized in 1916 under present title. Nineteen active chapters.
Purpose: To promote interest in chemistry anong women students; to foster mutual advancement in academic, business, and social life; to stimulate personal accomplishment in chemical fields.

Membership: Women students in chemistry with required number of college hours in that subject, minimum "B" averages, and ranking in the highest thirty per cent of their classes; women engaged in teaching or research in chemistry or closely allied fields; graduate women chemists who have done ligh calibre work in industry or research with at least two years of professional work. Total membership $5,956$.

Mectings: Triennial.

Professional activities: Triennial research award to a woman chemist, thirty-five years of age or younger, for outstanding research achievement.

Publications: Iotan, annual, current volume: 19, \$1. Editor: Miss Peggy Dunlap.

802. Iowa Academy of Science. lowa State University, Ames, lowa. President: George C. Huff, Drake University, Des Moines, Iowa. Term expires April 1961. Secretary-Treasurer: Clarence H. Lindalil. Term expires April 1961.

History: Organized December 27, 1887, as the Iowa Association for Scientific Research; name changed to present title September 5, 1888. Sections: Botany, Inorganic Chemistry, Organic Chemistry, Geology, Mathematics, Physics, Psychology, Zoology.

Purpose: Encouragement of scientific work in Iowa.

Membership: Honorary Fellows, 2; Emeritus Fellows, 22, members for twenty-five years; Life Fellows, 11; Fellows, 493, active scientific research workers; Associate, 982, interest in science. Total membership 1,510.

Mectings: Annual.

Professional activities: Refund grant of the American Association for the Advancement of Science, $\$ 1$ for each member of this Academy who is also a nember of that Association, used for the promotion of research.

Publications: Proceedings, annual, current volume: $67, \$ 4$, free to members. Editor: $T$. Edwin Rogers, Cornell College, Mt. Vernon, Iowa.

803. Iowa Academy of Surgery. 503 Equitable Building, Des Moines, Iowa. President: Merle J. Brown, 430 Davenport Bank Building, Davenport, lowa. Term expires Spring 1961. Secretary-Treasurer: Paul B. Skelley. 615 Roshek Building, Dubuque, Iowa. Term expires Spring 1961. 
History: Organized April 26, 1954 ; incorporated May 3, 1954.

Purpose: To promote study and ethical practice of surgery.

Membership: Active members shall be graduates of recognized medical schools, members of local societies, Diplomates of American Board of Surgery, and shall have practiced surgery in Iowa for two years. Total membership 68 .

Mcctings: Semiannual.

804. Iowa Archaeological Society. Department of Sociology and Anthropology, State University, Iowa City, Iowa. Secretary: Mrs. Phil Thornton, 326 Otsego Street, Storm Lake, Iowa. Term expires June 30, 1962.

History: Founded 1951.

Purpose: To preserve archaeological sites and information; to disseminate in formation on Iowa prehistory.

Mcmbership: Open to those interested in furthering archaeological research in lowa. Total membership 195.

Meetings: Annual.

Publications: Journal, quarterly, current volume: 9, \$2. Editor: Reynold J. Ruppe.

805. Iowa Association of Pathologists. President: Regis E. Weland, Mercy Hospital, Cedar Rapids, Iowa. Term expires April, 1961. Secretary-Treasurer: Frank C. Coleman. Mercy Hospital, Des Moines 14, Iowa. Term expires April, 1961.

History: Organized May 1, 1940, in Iowa City, lowa.

Purpose: To improve standards of practice of laboratory medicine; to stimulate research in the field of pathology; to hold periodic conferences pertaining to problems of mutual interest; to promulgate ethical, friendly, and economically sound professional relationships among professors and with allied professional and lay groups.

Membership: Graduate of an approved medical school, licensed to practice in Iowa, a member of his county medical society, attainment of educational standards reasonably equivalent to requirements of American Board of Pathology, practice limited to field of pathology. Total nembership 60 .

Meetings: Semiannual.

Professional activitics: Participation in Medical Technologist Scholarship Fund Program, workshops, slide seminars, and scientific conferences for members.
806. Iowa Dental Association. 639 Insurance Exchange Building, Des Moines 9, Iowa. President: C. G. Sanner, 619 Roshek Building, Dubuque, Iowa. Term expires May 2, 1961. Secretary: Homer N. Hake. Term expires July 1, 1951.

\section{History: Organized 1863.}

Purpose: To encourage public health and promote the art and science of dentistry.

Mcmbership: Members must be graduates of recognized dental schools and licensed to practice in lowa. Total membership approximately 1,400 .

Meetings: Annual.

Professional actirities: School dental health programs.

Publications: Iowa Dental Journal, bimonthly, current volume: 46, \$2. Editor: Homer N. Hake.

807. Iowa Engineering Society. President: Arnold C. Christensen, 1016 Military Street, Council Bluffs, Iowa. Term expires February 1961. Erecutive Director: Noel T. Tweet, 411 Hubbell Building, Des Moines, Iowa. Term indefinite.

History: Organized 1889; incorporated 1896 and 1936; affiliated with National Society of Professional Engineers in 1956.

Purpose: To advance engineering knowledge, maintain a high standard of professional ethics, and foster high quality of public service; to advance the legal status, economic welfare, and professional development of engineers.

Mcmbership: Members must be registered professional engineers. Total membership 985.

Mcetings: Annual.

Professional activities: Dunlop-Woodard Award for best paper published in the Exponent; Anson Marston Award for outstanding service to this Society.

Publications: Exponent, inonthly, \$4. Editor: Sara Ann Karas.

808. Iowa Neuropsychiatric Society. 125 11th Street, N. E., Cedar Rapids, lowa. President: Paul M. Kersten, Kersten Clinic, Fort Dodge, Iowa. Term expires April 1961. SecretaryTreasurer: William D. Trumpe. Term expires April 1961.

History: Organized 1949.

Purpose: To advance the science and practice of psychiatry.

Membership: Full Members, 68, licensed physicians specializing in neuropsychiatry; Affiliate Members, 2, physicians in other branches of medicine interested in promoting purposes of 
this Society; Junior Members, 14, physicians who are preparing for practice in neuropsychiatry. Total membership 84.

Mectings: Semiannual.

809. Iowa Orthopaedic Society. President: IVillianı A. Baird, 313 5th Street, Ames, Iowa. Term expires 1961. E.recutize Secretary: John H. Kelley. Term expires 1961.

History: Organized 1939.

Purpose: Promotion of orthopaedic surgery in lowa.

Mcmbership: Members must limit practice to orthopaedic surgery. Total membership 43.

Mcctings: Three annually.

Professional actirities: Orthopaedic Research and Education Fiund.

810. Iowa Pharmaceutical Association. 540 Des Moines Building, Des Moines, Iowa. President: Max IV. Eggleston, Stauffer Pharmacy, Waverly, Iowa. Term expires March 21, 1961. Executive Secretary: Robert G. Gibbs, 924 43rd Street, Des Moines, lowa. Term expires December 1, 1962.

History: Organized 1880 as Iowa State Pharmaceutical Association; incorporated 1888; reincorporated and name changed to present title 1938.

Purpose: To unite pharmacists of Iowa for mutual assistance, encouragement, and improvement; to encourage scientific research and develop pharmaceutical talent; to elevate the standard of professional thought; to foster the spirit of interprofessional relations and cooperation in pharmacy, medicine, dentistry, nursing, and veterinary medicine.

Membership: Active members, registered pharmacists, and teachers of botany, materia medica, chemistry, pharmacy, and allied subjects; Associate members, wholesalers of drugs, pharmaceuticals, and allied lines, and unregistered proprietors of retail drug stores. Total membership 2,500.

Mectings: Annual.

Publications: Iowa Pharmacist, monthly, current volume: $15, \$ 5$, free to members. Editor: Robert G. Gibbs.

811. Iowa Psychological Association. President: Allan Frankle, 300 Des Moines Building, Des Moines, Iowa. Term expires May 1961. Exccutive Secretary: Charles F. Haner, Grinnell College, Grinnell, Iowa. Term indefinite.

History: Organized September 1948.

Purpose: To advance psychology as a science, profession, and means of promoting human welfare.

Mcmbcrship: Requires membership in American Psychological Association, or degree of doctor of philosophy in psychology, or master's or doctoral degree, including thirty hours of graduate work or its equivalent in psychology and one year of professional experience that is psychological in nature. Total membership 130 .

Mectings: Annual.

Professional activities: Awards presented at science fairs; providing information concerning psychology to interested individuals and organizations; providing psychological representation to State legislatures and other groups concerned with problems having psychological implications.

Publications: Newsletter, three annually, current volume: 5 , free to members. Editor: Charles F. Haner.

812. Iowa Public Health Association. President: Thelma Luther, State Department of Health, Des Moines, Iowa. Term expires April 1961. Secretary: Lloyd IV. Coe, 1012 Liberty Building. Des Moines, Iowa. Term expires April 1961.

History: Organized, through reorganization of Iowa Municipal Health Officers Association, 1926; affiliated with American Public Health Association 1940.

Purpose: To safeguard and promote personal and public health of Iowa residents.

Membership: Active nembers, persons engaged in public health work; Associates, persons interested in public health. Total membership 300.

Meetings: Annual.

813. Iowa Radiological Society. President: Raymond A. Berger, 125 Kirkwood Boulevard, Davenport, Iowa. Term expires April 1961. Exccutive Secretary: Louis L. Maher, 1419 Woodland Street, Des Moines, Iowa. Term expires April 1963.

History: Organized 1920 as lowa X-ray Club : incorporated 1954 under present title.

Purpose: To promote the science and practice of radiology.

Membership: Active members, 73, physicians licensed in practice of medicine and surgery and specializing in radiology, certified by American Board of Radiology, and members of county and State medical societies; Associates, 1 , physicians interested in radiology, and other scientists working in that and allied fields; Honorary, 2; Resident, physicians in resident training in radiology; Life menbers, 5. Total membership 81 .

Mcetings: Two annually. 
814. Iowa Society of Anesthesiologists. President: Albert B. Abbott, 313 5th Street, Ames, lowa. Term expires April 1961. Secretary: Robert S. Jaggard, $11 / 2$ South Frederick Street, Olwein, lowa. Term expires April 1961.

History: Organized 1944.

Purpose: To advance training of anesthesiologists in order to improve care of patients; to study causes of morbidity and mortality during and after anesthesia.

Mcmbership: Members must be doctors of medicine engaged in practice of anesthesiology in lowa. Total membership 85 .

Meetings: Eleven annually.

815. Iowa State Medical Society. 529 36th Street, Des Moines 12, lowa. President: E. F. Vau Epps, University Hospitals, lowa City, Iowa. Term expires April 27, 1961. Exccutive Director: Donald L. Taylor. Term indefinite.

History: Organized June 1850. Commitrees: Articles of lncorporation and By-laws, Health Education, Legislation, Medical Education and Hospitals, Medical Service, Necrology, Nominations, Public Health, Public Relations, Scientific Work, Grievance, Medico-Legal.

Purpose: To promote, extend, elevate and advance medical science and knowledge; to advocate measures to improve health; to organize the medical profession; to elevate standards of medical education; to enact just medical laws.

Membership: Active nembers, physicians licensed to practice in lowa, holding degrees of doctors of medicine or bachelors of medicine and active membership in component medical societies; Life members, fifty years' medical practice and thirty years' membership; Associate members, retired or incapacitated. Total membership 2,415.

Meetings: Annual.

Publications: Journal, monthly, current volume: 50, \$3. Editor: E. M. George.

816. Iowa Veterinary Medical Association.

Waukee, Iowa. Presidest: I. A. Merchant, Division of Veterinary Medicine, lowa State University, Ames, Iowa. Term expires 1961. Secretary: F. B. Young. Term expires 1961.

History: Established 1883.

Purpose: To advance the science of veterinary medicine; to elevate standards of veterinary education.

Membership: Active members are graduates of veterinary schools approved by American
Veterinary Medical Association. Total membership 840.

Meetings: Annual.

Publications: Iowa Veterinarian, bimonthly, current volume: $30, \$ 3$. Editor: F. B. Young.

817. Izaak Walton League of America. 1326 Waukegan Road, Glenview, I1l. President: Alden J. Erskine, 910 Morningside Avenue, Sioux City, Iowa. Term expires June 1961. Executive Director: Frank Gregg. Term indefinite.

History: Organized January 1922.

Purpose: To improve and perpetuate renewable resources of the country, conserve nonrenewable resources, stimulate sound land and water management practices, promote means and opportunities for the education of the public with respect to such resources, and promote opportunities for enjoyment and utilization of outdoor America.

Membership: Open to any person vouched for by two members of the League. Supporting Members, Honor Members, Members-at-Large, Master Chapter Members, Chapter Members. Total membership 600 chapters.

Mectings: Annual.

Professional activities: Membership and Conservation awards.

Publications: Outdoor America, monthly, current volume: $25, \$ 2.50$ to non-members; free to members. Editor: Frank Gregg.

Library: 1,000 volumes. Subject emphasis: Conservation.

818. Jackson County Medical Society. 3036 Gillham Road, Kansas City 8, Mo. President: John F. Bowser, 411 Nichols Road, Plaza Time Building, Kansas City 12, Mo. Term expires June 30, 1961. Executive Secretary: William H. Bartleson. Term indefinite.

History: Organized 1881; pro forma decree incorporation 1891.

Purpose: To promote the art and science of medicine.

Membership: Licensed physician of good character, graduate of an approved medical school, practicing within the county. Active, 569 ; Junior, 58; Honorary, 111 ; Corresponding, 93; Associate, 34; lnactive, 30; Military, 2. Total membership 897 .

Metings: Four tines per year.

Professional activities: Medical Foundation Fund, for public and scientific education and scholarships; Viucent Park Williams Memorial Lecture.

Publications: Greater Kansas City Medical Bulletin, weekly, current volume: $54, \$ 3$. Editor : William F. Sanders. 
Library: Over 30,000 volumes and 500 periodicals. Emphasis, all fields of medicine. Established 1889 as Medical Library for Kansas City Physicians. Kansas City Medical Library Club was organized 1910 and merged with the Society 1920.

819. Jesuit Seismological Association. St. Louis University, St. Louis 8, Mo. President: Rev. Joseph J. Lynch, S. J., Fordham University, New York 58, N. Y. Term expires summer 1961. Secretary: Rev. Bernard McConnell, S. J., Georgetown University, Washington, D. C. Term expires summer 1961.

\section{History: Organized 1925.}

Purpose: Cooperation of the nembers in the study of earthquakes and the fostering of research in seismology.

Membership: Membership is institutional and requires that members be engaged in the recording of earthquakes. Total membership 12.

Meetings: Annual.

Professional activities: A laboratory is maintained at the Institute of Technology, 3621 Olive Street, St. Louis 8, Mo. Director: Rev. William Stauder, S. J.

Publications: Preliminary Bulletin, quarterly. Editor: Rev. IVilliam Stauder, S. J.

820. Jewish Agricultural Society, Inc. 386 Park Avenue South, New York 16, N. Y. President: Robert M. Morgenthau. Term expires December 1960. Executive Secretary: William M. Heineman. Term expires December 1960.

History: Founded in 1900 as an affiliate of the Baron de Hirsch Fund.

Purpose: To assist would-be or established Jewish farmers in the United States.

Membership: Members appointed by the Directorate. Total membership about 30 .

Mectings: Annual.

Professional activities: College scholarships granted to children of Jewish farmers.

821. John A. Andrew Clinical Society. Joln A. Andrew Memorial Hospital, Tuskegee Institute, Ala. President: John IV. Chenault, Bradenton, Fla. Term expires April 1961. Secretary: Eugene H. Dibble, Jr. Term expires April 1961.

History: Organized 1912.

Purpose: To further professional advancement in medicine and surgery.

Membership: Surgeons, specialists, and dentists. Total membership 300 .

Meetings: Annual.
Professional actizities: C. V. Roman Distinguished Service Medal.

Publications: Clinical Bulletin, annual, current volume: 23,20 cents, free to members.

\section{John Burroughs Memorial Association.}

President: Richard Pough, 33 Highbrook

Avenue, Pelham, N. Y. Term expires April 1, 1961. Secretary: Farida A. Wiley, Museum of Natural History, 79th Street and Central Park West, New York 24, N. Y. Term expires April 1, 1961.

History: Organized April 1921.

Purpose: To further the principles set forth by John Burroughs, author and naturalist.

Membership: Interest in activities of the Association. Active, Associate, Junior, Sustaining, and Life. Total membership 367 individuals and 5 clubs.

Mectings: Annual, at the American Museum of Natural History; also two meetings per year held at Slabsides.

Professional activities: Burroughs Medal, awarded annually for the best paper written in the field in which John Burroughs was interested.

823. Joint Blood Council, Inc. 1832 M Street, N. W., Washington 6, D. C. President: LeRoy E. Bates, Union Memorial Hospital, 33rd and Calvert Streets, Baltimore 18, Md. Term expires June 1961. Sccretary: Frank E. Wilson. Term expires June 1961.

History: Organized 1955. Joint enterprise of American Association of Blood Banks, American Hospital Association, American Medical Association, American National Red Cross, and American Society of Clinical Pathologists. ComMitTeEs: Blood Procurement; Scientific.

Purpose: To assure an adequate supply of blood and blood derivatives to the civilian and military population at all times; to collect, study, and disseminate information on blood and blood derivatives; to encourage public to donate blood for civilian and defense needs; to establish minimal standards for voluntary accreditation of blood banks.

Membership: Limited to institutions concerned with blood programs. Total membership five institutions.

Meetings: Annual.

824. Joint Council of the Associated Engineering Societies of St. Louis. 8730 Teasdale Street, St. Louis 24, Mo. President: Clarence $\mathrm{H}$. Ax, 425 De Baliviere Avenue, St. Louis 12, Mo. Term expires June 1961. SecretaryTreasurer: George F. Herold. Term expires June 1961. 
History: Established 1914 as Associated Engineering Societies of St. Louis; name changed to present title 1927.

Purposc: To further public welfare and promote cooperation among engineering societies.

Membership: Open to any local society or local section of a national organization whose chief object is advancement of knowledge or practice of engineering or allied sciences, or the promotion of interests of engineering or allied professions. Total membership 16 societies.

\section{Mectings: Quarterly.}

Publications: Roster, annual, current volume: 9, free to nembers. Editor: George F. Herold.

825. Kansas Academy of Science. President: J. M. Jewett, State Geological Survey, University of Kansas, Lawrence, Kans. Term expires May 1961. Sccretary: G. A. Leisman, Department of Biology, Kansas State Teachers College, Emporia, Kans. Term expires May 1961.

History: Organized September 1868; name changed to present title 1871. Sections : Botany and Microbiology, Clemistry, Experimental Biology, Geography, Geology, Physics, Zoology.

Purpose: The advancement of science and the improvement of science teaching in Kansas.

Mcmbership: Honorary 4 (by election), Life 41, Sustaining 14, Annual 631, Junior Academy Clubs 30.

\section{Mectings: Annual.}

Professional actirities: Research and Junior Acadeny awards funded by Albert R. Reagan Endowment Fund, American Association for the Advancement of Science, and investment interests.

Publications: Transactions, quarterly, current volume: 63 , free to members, $\$ 3$ to non-members. Editor: Frank B. Cross, University of Kansas, Lawrence, Kans.

\section{Kansas City Southwest Clinical Society.} 3036 Gilham Road, Kansas City 8, Mo. President: Richard H. Kiene, 4312 J. C. Nichols Parkway, Kansas City 11, Mo. Term expires January 1, 1961. Exccutive Sccretary: Alta L. Binglıam. Term indefinite.

History: Organized 1923; incorporated March 14, 1960. Committees: Radio and Television; Scientific and Technical Exhibits.

Purpose: To promote, encourage, and develop educational advantages of clinical material of Kansas City; to develop and encourage medical education; to demonstrate and emphasize progress of medicine for benefit of physicians of the Southwest.

Mcmbcrship: Active nembers, 300, physicians graduated at least five years from accredited medical schools, members of medical societies of Clay or Jackson Counties. Mo., or Johnson or Wyandotte Counties, Kans., members, medical staffs of associated hospitals of Society; Associates, 450, plysicians in good standing in county medical societies: Honorary, 50, physicians retired from active practice or over sixty-five years of age; Complimentary, for internes and medical students at fall clinical conference. Total membership 750 .

Mectings: Annual.

Professional activities: Annual postgraduate medical meeting, Fall Clinical Conference.

Publications: Journal, quarterly, current volune: 36,50 cents. Editor: James R. McVay, Jr.

827. Kansas District Branch, American Psychiatric Association. President: John Grimshaw, Topeka Medical Center, Topeka, Kans. Term expires May 1961. Exccutive Secretary: R. E. Reinert, Veterans Administration Hospital, Topeka, Kans. Term expires May 1961.

History: Chartered 1955 by American Psychiatric Association.

Purpose: To promote the science and practice of psycliatry, and to support maintenance of high professional and administrative standards.

Mcmbcrship: Doctors of medicine engaged in practice of psycliatry for at least one year. Total membership 150 .

Mcctings: Semiannual.

828. Kansas Engineering Society, Inc. 1157-W State Office Building, Topeka, Kans. Presidcnt: Guy M. Shelley, Jr., 254 Laura Street, Wichita, Kans. Term expires June 30, 1961. Exccutizc Secretary: Carl D. Hultgren. Term expires June 30, 1961.

History: Organized 1909; incorporated October 26, 1915; merged with Kansas Society of Professional Engineers October 1954; affiliate, National Society of Professional Engineers, January 21, 1955. Sections: Consulting Engineers; Engineers in Government; Engineers in Industry; Young Engineers.

Purpose: Promotion and protection of the profession of engineering as a social and economic influence vital to welfare of community and mankind.

Mcmbcrship: Professional Engineer Members, 1,155 , licensed professional engineers; Associate, 74 , wot licensed, but either engineering degree or practice of engineering for four years; Engineer in Training, 77, registered engineers in training. Total membership 1,306 .

Mectings: Annual.

Professional activites: Outstanding engineer award presented annually. 
Publications: Bulletin, monthly, current volune: $10, \$ 1.50$, free to members. Editor: R. P. Slease. Year Book, annual, current volume: 52, free. Editor: Lola Mae Gibson.

829. Kansas Entomological Society. Department of Entomology, Fairchild Hall, Kansas State University, Manhattan, Kans. President: Wilbur R. Enns, Department of Entomology, University of Missouri, Columbia, Mo. Term expires December 31, 1960. Secrctary-Treasurcr: Fred A. Lawson. Term indefinite.

History: Organized under the leadership of the Popenoe Entomological Club, Kansas State College and the Entomological Club, University of Kansas.

Purpose: To collect and publish entomological literature, chiefly of the Trans-Mississippi Valley Region.

Membership: Interest in the future of entomology and desire to promote the same; open to amateurs and professional entomologists. Total membership 450.

Mectings: Annual.

Publications: Journal, quarterly, current volume: 33, \$3. Editor: Mary Michener, University of Kansas, Lawrence, Kans.

830. Kansas Geological Society. 508 East Murdock Street, Wichita, Kans. President: Melvern F. Bear. Term expires December 31, 1960. Secretary-Trcasurcr: Jack Firstenberger. Term expires December 31, 1960.

History: Organized 1920 as IVichita Geological Society; name changed to present title 1924; chartered April 15, 1925. Sections: Society sponsors Kansas Well Log Bureau and Kansas Well Sample Bureau, through which it handles collection and distribution of all well samples, drillers' logs, and electric logs for all oil tests drilled in the State of Kansas.

Purpose: Promotion of science of geology among men engaged in geology of petroleum and gas in Kansas and surrounding territory.

Membership: Active members, those engaged in geology, or those eligible for membership in American Association of Petroleum Geologists. Total membership 725 .

Mectings: Biweekly ; monthly.

831. Kansas Medical Society. 315 West 4th Street, Topeka, Kans. President: F. E. Wrightman, 1022 Main Street, Sabetha, Kans. Term expires May 3, 1961. Executive Secretary: Oliver E. Ebel. Term indefinite.

History: Organized and chartered February 10, 1859. Commitrees: Allied Groups; Anesthesiology; Auxiliary; Blue Shield Relations;
Child Welfare; Conservation of Eyesight; Conservation of Hearing and Speech; Constitution and Rules; Control of Cancer; Control of Tuberculosis; Emergency Medical Care; Endowment; Fee Schedule; General Practice Award; Gerontology; History ; Hospitals ; Industrial Medicine; Legislation; Maternal Welfare; Medical Assistants; Medical Economics; Medical Schools ; Medicare ; Membership Orientation; Mental Health; Necrology; Pathology; Prenatal IVelfare; Postgraduate Study; Public Policy: Public Relations; Relations with Bar Association; Rural Health; Safety; School Health; Stormont Medical Library; Study of Heart Disease.

Purpose: To federate and bring into one compact organization the medical profession of Kansas; to extend medical knowledge and advance medical science.

Membership: Requires United States citizenship, degree of M. D. from approved school, and favorable vote of component society in Kansas. Active members 1,448, Honorary 168 , Leave-of-Absence 43, l11-Service 5, others, 169. Total membership 1,833.

\section{Mectings: Annual.}

Professional activitics: Graduate education for members; public service projects to improve health and extend health facilities for people of Kansas.

Publications: Journal, monthly, current volume: 61, \$t. Editor: Orville R. Clark.

Library: In cooperation with Stormont Medical Library. 5,000 volumes. Subject emphasis: Medical literature.

832. Kansas Optometric Association, Inc. 201 Garlinghouse Building, Topeka, Kans. President: L. L. McCormick, 704 Wolcott Building, Hutchinson, Kans. Term expires April 1961. Administrative Director: James W. Clark, Jr. Term indefinite.

History: Organized January 1901 as Kansas Association of Optometrists; name changed to present title 1929. Six geographical zones. ComMitTeEs : Contact Lens; Subnormal Visual Aids ; $\mathrm{Visual}$ Training.

Purpose: To preserve and improve eyesight, promote science and profession of optometry and elevate its standards, and encourage scientific research.

Membership: Members nust be registered optometrists. Total membership 250.

Meetings: Annual.

Professional activities: Annual scholarship to a Kansas student for tuition and fees to school of optometry; Vision Service Award, annual, to layman for contribution to vision welfare of the public. 
Publications: Kansas Optometrist, monthly, current volume: $33, \$ 3$. Editor : F. D. Reinhardt.

833. Kansas Pharmaceutical Association. 824

Kansas Avenue, Topeka, Kans. President:

Robert Galvin, Fort Scott, Kans. Term expires March 1961. Secretary: Clara Miller. Term expires March 1961.

History: Organized 1878; incorporated.

Purpose: Educational and promotional endeavor in interest of public health.

Membership: Drug store proprietors; pharmacists, non-owners. Total membership 990.

Mectings: Annual.

Publications: KPA News, monthly, current volume: 33, \$5. Editor: Clara Miller.

834. Kansas Psychological Association. President: Herbert Schlessinger, The Menninger Foundation, Topeka, Kans. Term expires April 1961. Secretary-Treasurer: Harold J. Mand1, P. O. Box 829, Topeka, Kans. Term expires April 1961.

History: Organized 1925. Kansas Association of Consulting Psychologists absorbed into the Association 1949.

Purpose: To advance psychology as a science, as a profession, and as a means of promoting human welfare.

Membership: Residents of the State of Kansas engaged in psychological activities. Fellows, Ph.D. in psychology conferred by recognized graduate school or Diplomate status conferred by the American Board of Examiners in Professional Psychology, and prior membership as an Associate, with acceptable published research beyond the doctoral degree or four years of professional experience; Associates, Ph.D. in psychology or completion of two years of graduate study and a year of professional work of a psychological nature; Affiliates, students or other interested parties not meeting requirements for Fellows or Associates. Fellows, 60; Associates, 135; Affiliates, 68. Total membership 263.

Mectings: Annual.

Professional activities: Workshops, institutes, and programs aimed to enhance psychologists' and non-psychologists' understanding of behavior.

Publications: Newsletter, quarterly. Editor: Mrs. Leita Craig.

835. Kansas Public Health Association. 1134 Topeka Avenue, Topeka, Kans. President: A. F. Schaplowsky, Kansas State Board of Health, State Office Building, Topeka, Kans. Term expires April 1961. Secretary-Treas- urer: W. W. Wilmore. Term expires Aprit 1961.

History: Organized 1940. Sections: Health Officers; Public Health Nursing; Sanitation; Special Services.

Purpose: To bring into closer association interested persons and organizations for the purpose of aiding in promotion and protection of public health; to provide for scientific advancement of members; to extend the public health movement.

Membership: Persons professionally engaged or interested in any branch of public health work in Kansas. Total membership 265.

Mectings: Annual.

Professional activities: Samuel J. Crumbine Award, for meritorious service to public health.

836. Kansas Radiological Society. President: James R. Stark, 3244 East Douglas Street, Wichita 8, Kans. Term expires February 1961. Executive Secretary: Lewis G. Allen, 807 Huron Building, Kansas City, Kans. Term expires February 1961.

History: Organized May 11, 1948.

Purpose: To unite Kansas radiologists, and to make effective their opinions in scientific, legislative, public health, and inter-professional affairs.

Membership: Members, registered physicians. practicing in Kansas who limit their practice to radiology, and are members of American Medical Association, State and county medical societies; Associate, those with distinction in science allied to radiology; Honorary. Total membership 45.

Mectings: Three annually.

Professional activities: Financial support to annual postgraduate course in radiology at University of Kansas Medical Center; prize money for film contest at annual meeting of Kansas Society of X-ray Technicians.

837. Kansas Society of Anesthesiologists. President: Roy T. Parmley, St. Francis Hospital, Wichita, Kans. Term expires May 1961. Excutive Secretary: Robert H. Robinson, 3244 East Douglas Street, Wichita, Kans. Term expires May 1962.

History: Organized January 14, 1948. A component of American Society of Anesthesiologists, Inc.

Purpose: To advance the practice of anesthesiology.

Membership: Requires degree of M. D. from qualified medical school, Kansas State license, and membership in American Society of Anes- 
thesiologists. Regular (active) members, 40; Junior, 6. Total membership 46.

Mectings: Annual, during week of Kansas Medical Society meeting.

838. Kansas State Nurses' Association. 820 Quincy Street, Topeka, Kans. President: Mrs. Alexine Larson, 1333 Marlboro Street, Wichita, Kans. Term expires October 1961. Executive Secretary: Hulda O. Wegener. Term indefinite.

History: Organized 1912; constituent of American Nurses' Association.

Purpose: To promote professional, educational, and economic advancement of nurses, elevate standards of nursing education, and provide information about nursing.

Membership: Registered professional nurses who hold membership in district nurses' associations may be members. Total membership 2,283.

Meetings: Annual.

Professional activities: Workshops for members; annual recognition of district associations who have done outstanding work in promoting membership; honorary recognition of two individual members each year.

Publications: Kansas Nurse, monthly, current volume: 34, \$3. Editor: Hulda O. Wegener.

839. Kansas State Osteopathic Association. 121 East 8th Street, Topeka, Kans. President: Glen D. Jewett, St. John, Kans. Term expires October 6, 1961. Exccutive Secretary: Lloyd L. Hall. Term indefinite.

History: Founded 1900; incorporated 1913 in State of Kansas.

Purpose: Educational and charitable activities in health fields.

Membership: Members, 150, must be licensed to practice in the state of Kansas, meet good moral and ethical standards, and be approved by the Board.

Meetings: Annual.

Professional activities: Support of osteopathic colleges through annual dues. Encouragement of voluntary support of educational efforts through Progress Fund. Active vocational guidance for health careers.

Publications: Bulletin, quarterly, current volume: 34. Editor: Lloyd L. Hall. News Letter, bi-weekly, current volume: 6 . Editor: Lloyd L. Hall.

840. Kentucky Academy of Science. President: Pete Panzera, Murray State College, Murray, Ky. Term expires October 1960. Secretary: Gerrit Levey, College Box 1050, Berea, Ky. Term expires October 1960.
History: Organized May 8, 1914. CommitTeEs: Bacteriology and Medical Technology; Biology ; Chemistry; Engineering; Psychology.

Purpose: To encourage scientific investigation, to promote diffusion of knowledge, and to unify the efforts of the scientific talent of the State of Kentucky.

Membership: Open to persons who have an interest in the objectives of the Academy. Total membership 275.

Mcetings: Semiannual.

Professional activities: An allotment is received from the American Association for the Advancement of Science for research.

Publications: Transactions, quarterly, current volume: 20, \$2. Editor: R. IV. Barfour.

841. Kentucky Dental Association. President: Julian M. Dismukes, Jr., 1016 Citizens Bank Building, Paducah, Ky. Term expires April 1961. Secretary-Trcasurer: A. B. Coxwell, 2208 Dundee Road, Louisville 5, Ky. Term expires April 1965.

History: Organized 1860.

Purpose: To encourage improvement of public health and promote the art and science of dentistry.

Mcmbership: Dentist licensed in Kentucky may be member. Total membership 950 .

Mectings: Annual.

Professional activities: Kentucky Dental Rural Scholarship; Selden Award for Table Clinics; Student Loan Fund.

Publications: Journal, quarterly, current volume : $10, \$ 3$.

842. Kentucky Pharmaceutical Association. President: J. J. Thompson, 2506 Dixie Highway, South Fort Mitchell, Covington, Ky. Term expires 1961. Secretary: E. M. Josey, 335 West Main Street, Frankfort, Ky. Term expires 1961.

History: Organized 1878; incorporated 1888.

Purpose: To unite and promote the interests of the pharmacists in Kentucky.

Membership: Members, 1,970, pharmacists registered in Kentucky and in good standing. Meetings: Annual.

Publications: The Kentucky Pharmacist, monthly, \$2.50. Editor: E. M. Josey.

843. Kentucky Psychiatric Association. President: Harold L. McPheeters, 620 South 3rd Street, Louisville, Ky. Term expires April 1961. Secretary: Hollis Johnson, 305 West Broadway, Louisville, Ky. Term expires April 1961. 
History: Founded 1938; became District Brauch, American Psychiatric Association, 1956.

Purpose: To further knowledge of psychiatry in Kentucky; to provide forum for members.

Membership: Requires membership in American Psychiatric Association and engagement in psychiatric practice, administration, or teaching. Total membership 50.

Mectings: Semiannual.

844. Kentucky Psychological Association. President: Richard L. Blanton, Department of Psychology, University of Kentucky, Lexington, Ky. Term expires May 31, 1961. Secretary: Miss Jessie Irvine, State Hospital, Lexington, Ky. Term expires May 31, 1961.

History: Originally a section of Kentucky Academy of Science and affiliated with Kentucky Education Association. Independent since 1948, but overlapping in membership with the two parent organizations.

Purpose: Scientific and professional.

Membership: Members, working psychologists ; Associates, students, or persons interested in this field. Total membership 97.

Mectings: Semiannual.

Professional actizities: Ernest Meyers Award of $\$ 25$ for best undergraduate paper of year by a psychology major in any Kentucky four-year college.

Publications: Newsletter, three annually, free to members. Editor: Sister Agnes Lucile Raley.

\section{Kentucky Radiological Society. President:} Gerald M. Peterson, Heyburn Building, Louisville, Ky. Term expires January 1961. Secretary: Robert H. Akers, Veterans Administration Hospital, Louisville, $\mathrm{Ky}$. Term expires January 1961.

History: Organized 1930.

Purpose: Education, exchange of ideas, discussion of professional problems, and promotion of friendship and understanding.

Membership: Members must be practicing radiologists or residents in radiology. Total membership 66.

Meetings: Monthly, except June, July, and August.

846. Kentucky Society of Professional Engineers. 120 Graham Avenue, Lexington, Ky. President: James L. Knight, General Electric Company, Building 5, Appliance Park, Louisville 2, Ky. Term expires July 1, 1961. Secretary-Treasurer: C. S. Crouse. Term expires July 1, 1961.

History: Organized 1934; affiliated with National Society of Professional Engineers
July 1, 1960. Twelve chapters. Committees: Education; Employee-Engineer Relations; Legislative; Natural Resources; Industrial and Community Development; Private Practice; Violations, Engineering Act.

Purpose: Advancement of science of engineering, promotion of welfare and professional improvement of members; policing, so far as practicable, of Engineers Licensing Law.

Membership: Professional Engineer Members (legal licensure); Junior Members (hold Engineer-in-Training certificates); Associate Members; Affiliate Members; Honorary Members. Total membership approximately 1,400 .

Mectings: Annual.

Professional actionties: Future Engineers Clubs; Certificates for Distinguished Service; some chapters support scholarships.

Publications: Kentucky Engineer, quarterly, $\$ 3$.

847. Kentucky State Medical Association. 1169 Eastern Parkway, Louisville 17, Ky. Executiz'c Secretary: Joseph P. Sanford. Term indefinite.

History: Organized 1851 as Kentucky Medical Society; name changed to present title 1902; incorporated 1929. Approximately fifty committees.

Purpose: To advance medical science and medical education, work for just medical laws, and guard the interests of physicians through organization of the medical profession of Kentucky and affiliation with the American Medical Association.

Membership: Active, 2,061, doctors of medicine licensed to practice in Kentucky who are active members of component county medical societies; Associate, 59, medical officers of the United States Armed Forces, Veterans Administration, Public Health Service, or other Government services while on duty in Kentucky, and interns, residents, and teaching fellows, all of whom must be associate members of component societies, and also such dentists, pharmacists, funeral directors, and others invited by component societies to associate membership; Inactive, doctors of medicine licensed to practice in Kentucky but not so engaged, who are inactive members of component societies; Emeritus, doctors of medicine retired from active practice who have twenty years' membership; Student, 262, students in accredited medical schools in Kentucky or residents of Kentucky who are students in accredited medical schools in other States; Honorary, physicians of scientific attainments who are members of State medical associations, but who are not citizens of Kentucky. Total membership approximately 2,382 . 
Meetings: Annual.

Professional activities: Rural Kentucky Medical Scholarship Fund; Distinguished Service Award, for notable services to the medical profession; General Practitioners Award, to outstanding general practitioner.

Publications: Journal, monthly, current volume: 58, \$8. Editor: Sam A. Overstreet, Heyburn Building, Louisville, Ky.

Library: 2,000 volumes. Subject emphasis: Medicine.

848. Kings County Radiological Society. 1313 Bedford Avenue, Brooklyn, N. Y. President: Ernest I. Melton. Term expires June 1961. Secretary-Treasurer: A. Berens, 1917 Bedford Avenue, Brooklyn, N. Y. Term expires June 1961.

\section{History: Organized 1934.}

Purpose: Advancement of the science and practice of radiology in Kings County and its environs.

Membership: Active members, 36, practice limited to radiology ; Honorary. Total membership 36.

Meetings: Monthly, except June, July, and August.

849. Lafayette Geological Society. P. O. Box 1896, O. C. S., Lafayette, La. President: Samuel A. Spencer. Term expires December 31, 1960. Secretary: IV. S. McAlister. Term expires December 31, 1960.

History: Organized December 17, 1952. Member society of Gulf Coast Association of Geological Societies. Committees: Geological Names and Correlation for American Association of Petroleum Geologists; Stratigraphic and Paleontological Correlations; Type Log.

Purpose: To promote science of geology as related to South Louisiana; to promote fellowship and cooperation among geologists and others interested in geological problems.

Membership: Persons engaged in the geological profession or interested in geology. Active members, 293; Student associates, 12. Total membership 305.

Mectings: Monthly.

Professional activities: Field trips; first and second place cash awards annually for best Student geological papers prepared at Southwestern Louisiana Institute; preparation of stratigraphic type logs for South Louisiana.

850. Lake County Medical Society. 4640 IVest 5th Street, Gary, Ind. President: F. F. Boys, 4720 Magoun Aventie, East Chicago, Ind. Term expires January 1, 1961. Executive Secretary: John B. Twyman. Term indefinite.
History: Founded 1898. Committees: Indigent Medical Relief, Tuberculosis, Cancer, Public Health, Crippled Children, Mental Hygiene, Heart, Hospitals, Insurance and Welfare, Nurses, Scientific Program, Maternal and Child ITelfare, Polio, Ethics.

Purpose: To further postgraduate scientific education, public relations, and the interests of the Society's members.

Membership: American citizenship and license to practice medicine. Total membership 400 .

Mectings: Monthly.

Professional activities: Oberlin Award given annually to lay person in the community who has given outstanding service to community health.

Publications: Lake County Medical News, ten times a year, current volume: 22 , free to members. Editors: F. F. Premuda and G. N. Lewis.

851. Lepidopterists' Society. Department of Zoology, Yale University, New Haven, Conn. President: Walter Forster, Zoological Museum, Menzingerstrasse 67, Munich, Germany. Term expires December 31, 1960. Secretary: Paul R. Ehrlich, Natural History Museum, Stanford University, Stanford, Calii. Term expires December 31, 1960.

History: Organized 1947; Pacific Coast brancli founded 1954.

Purpose: To promote the science of lepidopterology in all its branches and to encourage free interchange among lepidopterists of all countries.

Membership: Honorary Life, 5, elected for important contribution to the science; Sustaining, 100; Regular, 500, interest in lepidoptera.

Mectings: Annual.

Publications: Journal, quarterly, current volume: 14. Editor: C. L. Remington. Memoirs, irregular, current volume: 1. Editor S. A. Hessel. News, eight times a year, current volume: 2. Editor: J. W. Tilden.

852. Liberal Geological Society, Inc., P. O. Box 802, Liberal, Kans. President: James R. Zimmerman. Term expires January 1961. Executive Secretary: John IV. Mason, P. O. Box 432, Liberal, Kans. Term expires January 1961.

\section{History: Organized January 5, 1954.}

Purpose: To promote, foster, and aid the science of geology and the gathering of information on various geologic subjects and problems specifically pertaining to the Anadarko Basin and its environs. 
Membership: Open to members, or those eligible for membership, in the American Association of Petroleum Geologists. Total membership 93.

Mectings: Twice monthly in winter, once monthly in summer.

Professional activities: Honorary Life Memberships awarded amnully to outstanding contributors to geology and the petroleum industry in the Liberal area.

\section{Linnaean Society of New York. President:}

Richard Edes Harrison, 313 East 51st Street, New York 22, N. Y. Term expires March, 1961. Executive Secretary: Helen Hays, 72 East 93rd Street, New York, N. Y. Term indefinite.

History: Organized March 7, 1878. CommitTEes : Program, Records, Editorial, Newsletter, Conservation, Field Work, Field Trip, Library.

Purpose: Study of natural history, particularly the study of birds; publication of scientific papers.

Mcmbership: Interest in natural history. Active members, 243; Associate, 64, must live within fifty miles of New York City; Fellows, 11, recognized for distinguished service in the Society; Honorary, 6, eminent for attainments in zoology. Total membership 324.

Mectings: Semi-monthly, October through May: monthly, June through Septenber.

Professional activities: Charles A. Urner Memorial Fund, for the promotion of field ornithology in New Jersey, New York, and Connecticut, and for publication of studies made in these areas; Linnaean Prize for Ornithological Research, $\$ 25$, awarded anmually to that member of the Society who submits the best paper embodying the results of ornithological research not undertaken in the course of professional duties.

Publications: Newsletter, October through June monthly, current volume: 14, \$2. Editors: Emanuel Levine and Miss Lisa McGaw.

854. Long Island Biological Association. Cold Spring Harbor, N. Y. President: Walter H. Page. Term indefinite. Executive Secretary: E. Carleton MacDowell. Term indefinite.

History: Organized 1890 as the Biological Laboratory of the Brooklyn Institute of Arts and Sciences; name clranged to present title 1923.

Purpose: Advancement of biology.

Menbership: Interest in the advancement of biology. Sustaining members; Patrons; Founders. Total membership 500 .

Mectings: Annual.
Professional activities: Year-round research in molecular biology; Annual Cold Spring Harbor Symposium on Quantitative Biology; specialized courses for research workers in biology; College Teachers' Conference; Nature Study Workshop for Elementary School Teachers; Nature Study Workshop for Children; undergraduate participation in research.

Publications: Cold Spring Harbor Symposia, annual, current volume: $24, \$ 8$. Editor: Clara Wooldridge. Annual Report, free. Editor: Leonora Frisch.

\section{Los Angeles Council of Engineering}

Societies. 626 North Garfield Avenue, Alhambra, Calif. President: R. Marvin Garrett, 1613 Pacific Coast Highway, Hermosa Beach, Calif. Term expires October 4, 1960. Executive Secretary: George Hallen, 1250 South Los Robles Avenue, Pasadena, Calif. Term expires October 4, 1960.

History: Formed 1946 by five founder engineering societies in the Los Angeles area; founded as the Los Angeles Engineering Council of Founder Societies. Composed of eight member societies: American Institute of Chemical Engineers; American Institute of Electrical Engineers; American Institute of Mining, Metallurgical, and Petroleum Engineers, Inc.; Petroleum Engineers; American Society of Civil Engineers; American Society of Mechanical Engineers; Society of American Military Engineers; Structural Engineers of Southern California.

Purposc: To further the public welfare wherever technical and engineering knowledge and experience are involved; to encourage public recognition of the professional status of engineers.

Membership: Engineering graduates of colleges of recognized standing, or persons licensed or registered by a state board of registration for professional engineers. Total membership at least 200 , with three delegates from each of the nember societies.

\section{Mectings: Bi-monthly.}

Professional activitics: Sponsorship of Engineers' WVeek; promotion of high school student interest in engineering; promotion, with other forces, of a Los Angeles Engineering Center Building.

856. Los Angeles Radiological Society. President: Robert E. Rickenberg, 1212 Shatto Street, Los Angeles 17, Calif. Term expires June 1, 1961. Secretary: Walter L. Stilson, 1720 Brooklyn Avenue, Los Angeles 33, Calif. Term expires June 1, 1961.

History: Organized 1921. 
Purpose: To advance the science of radiology by the interchange of scientific information and to maintain radiology as a medical specialty.

Membership: Members, 157, physicians practicing the specialty of radiology who are members of the California Medical Association and customarily members of the American Board of Radiology.

Meetings: Five times a year.

Professional activitics: Sponsoring and organizing a yearly scientific meeting, the Midwinter Meeting of the Los Angeles Radiological Society.

857. Los Angeles Society of Allergy. 1925 Wilshire Boulevard, Los Angeles 5, Calif. President: Isadore Pitesky, 2401 Atlantic Avenue, Long Beach, Calif. Term expires December 31, 1960. Secretary-Treasurer: Sheldon C. Siegel, 5830 Overhill Drive, Los Angeles 43, Calif. Term expires December 31,1960 .

\section{History: Organized January 31, 1947.}

Purpose: To unite those interested in allergy for the sharing of medical experience in this field.

Membership: Active members, must be members of California Medical Association, or certified by sub-specialty Boards of American Board of Internal Medicine or American Board of Pediatrics; Associate, members of Los Angeles County Medical Association. Total membership 48.

Meetings: Four annually.

858. Los Angeles Society of Internal Medicine. 1925 Wilshire Boulevard, Los Angeles 5, Calif. President: Joseph M. Shachtman, 9735 Wilshire Boulevard, Beverly Hills, Calif. Term expires December 31, 1960. SccretaryTreasurer: Morton Lee Pearce, Veterans Administration Center, Wilshire and Sawtelle Boulevards, Los Angeles 25, Calif. Term expires December 31, 1960.

History: Organized 1928.

Purpose: Dissemination of knowledge on internal medicine.

Mcmbership: Full membership: Certification by American Board of Internal Medicine. Associate membership: Practice limited to internal medicine. Total membership 386.

Meetings: Five annually.

859. Los Angeles Society of Ophthalmology and Otolaryngology. President: Herschel $\mathrm{H}$. Burston, 6333 Wiishire Boulevard, Los Angeles 48, Calif. Term expires 1961. Executive Secretary: Stephen John Popovich, 1915
Wilshire Boulevard, Los Angeles 57, Calif. Term expires 1961.

History: Organized 1905.

Purpose: Advancement and dissemination of knowledge of the subjects of ophthalmology and otolaryngology among members of Los Angeles County Medical Association interested in and practicing these specialties; promotion of personal and professional relationships among members.

Mcmbership: Active members, licensed plysicians, members of Los Angeles County Medical Association, who have limited their practice to the two subject specialties for at least three years; Associate, licensed physicians, members of county medical association, who have limited their practice to the two specialties for at least one year and are awaiting examination by the Board. Total membership 375.

Meetings: Annual.

860. Louisiana Academy of Science. Louisiana State University, Baton Rouge, La. President: Rene Bienvenu, Northwestern State College, Natchitoches, La. Term expires April 1961. President-Elect: Fred Deiler, Freeport Sulphur Company, Port Sulphur, La, Tern expires April 1962. Secretary: George Ware, Northwestern State College, Natchitoches, La. Term expires April 1962.

\section{History: Incorporated 1927.}

Purpose: To unite the scientists of the state, to foster scientific development, and to encourage scientific research.

Membership: Active members, 263, genuine interest in science, nomination by two members; Sustaining, 19; Honorary, 2. Total membership 284.

Meetings: Annual.

Professional activities: An annual grant of $\$ 35$ is made to the Academy by the American Association for the Advancement of Science.

Publications: Proceedings, annual current volume: 22, \$2.50. Editor: Walter Harmon, Louisiana Polytechnic Institute, Ruston, La.

861. Louisiana District Branch of the American Psychiatric Association. President: Robert G. Heath, Tulane University School of Medicine, New Orleans, La. Term expires May 1961. Secretary: Lucio E. Gatto, Louisiana State University School of Medicine, New Orleans, La.

History: Organized 1952.

Purpose: To foster the advancement, progress, and development of psychiatry in the Louisiana district, and to promote the aims and objectives of the American Psychiatric Association by 
holding joint professional meetings and developing useful relationships with other medical societies and the various communities in general.

Membership: Fellows, those with six years of experience in a mental hospital or equivalent; Full Members, those with three years of experience in a mental hospital or equivalent; Associate Members, those with one year of experience in a mental hospital or equivalent.

Mectings: Monthly.

862. Louisiana Engineering Society. 404 Baronne Street, New Orleans 12, La. President: Edward A. McLellan, P. O. Box 238, New Orleans 3, La. Term expires January 1961. Secretary-Treasurer: John P. Fernandez, 522 Crystal Street, New Orleans 24, La. Term expires January 1961.

History: Established 1898; affiliated with National Society of Professional Engineers Marcl 1958. Chapters: Baton Rouge, Lake Charles, Shreveport, Monroe, Lafayette, Alexandria. Student Chapter No. 1, Southwestern Louisiana Institute.

Purpose: Professional improvement of members, encouragement of social intercourse among engineers and men of practical science, and advancement of engineering.

Membership: Members, 1,384; Charter, 1 ; Honorary, 15; Life, 74 ; Affiliate, 139; Junior, 291. Total membership 1,904.

Mectings: Annual.

Professional actizities: $\$ 100$ scholarship annually to a senior engineering student at each of four Louisiana colleges: Louisiana State University, Tulane University, Southwestern Louisiana Institute, Louisiana Polytechnic Institute. Civic Activities Medal-Andrew M. Locket Award, annual, for outstanding service by engineer without compensation. Technological Accomplishment Medal, for technical accomplishment leading to advancement of engineering.

Publications: Louisiana Engineer, bimonthly, current volume: $46, \$ 2$. Editor: William $\mathrm{H}$. Rhodes.

863. Louisiana Psychological Association. 1528 Jackson Avenue, New Orleans 13, La. President: E. Lee Hoffman, Tulane University, New Orleans, La. Term expires March 1961. Secretary-Treasurer: G. Kinsey Stewart. Louisiana State ['niversity at New Orleans, New Orleans, La. Term expires March 1962.

Mistory: Organized March 6, 1948. Affiliated with American Psychological Association September 6, 1949.

Purpose: To advance psychology as a science, a profession and a means of promoting human welfare in Louisiana.
Membership: Residents of Louisiana with a doctor's degree in psychology, or persons who have completed at least two years of graduate work in psychology, or one year graduate study and a year of experience in professional work that is psychological in nature, and who are devoting full time to professional or graduate work in psychology. Total membership 100.

Mectings: Annual.

Publications: Newsletter, quarterly, current volume: 4, free. Editor: Ronald Pryor.

864. Louisiana Public Health Association. P. O. Box 630, State Office Building, 325 Loyola Avenue, New Orleans 12, La. President: Miss Lucille A. Godelfer. Term expires April 1961. Executize Secretary: A. G. Owens. Term expires April 1961.

History: Organized 1938. Sectons: Clerical and Statistical, Health Education, Health Officers, Laboratory, Nurses, and Sanitarians. Committees: Avards, Constitution and ByLaws, Finance, Meetings, Membership, Nominating, Public Relations, Insurance, Legislative, Program, Resolution, Reorganization.

Purpose: To foster acquaintance and mutual understanding among persons interested in public health in the State, to support and sponsor movements and policies tending to raise personnel standards and the security of workers, to stimulate progressive administration in public health work, to assist in the development of public health facilities in the state, and to contribute to the progress of public health and enhance the prestige of public health work as a career.

Membership: Active Members, persons professionally engaged in public health work who are members of the American Public Health Association, or eligible for membership; Members, persons professionally engaged in public health work but are not members of the APHA, or persons interested in public health. Total membership 719 .

\section{Mcetings: Annual.}

Professional activities: Axson-Choppin Award, and Dr. Felix Formento Memorial Award, for meritorious activity in fostering the public health program in Louisiana by an individual not in full-time employment by an official public health agency; Dr. C. B. White Memorial Award, and Agnes Morris Memorial Award, for long and diligent public health service in the state by any full-time worker in an official public health agency of the state; Dr. Edward Hall Barton Memorial Award, for significant achievement in research, scholarship or outstanding pioneering performance in public health by any person in the State. 
865. Louisiana Societies of Anesthetists. President: Calvin Cranfield, Ear, Nose and Throat Hospital, New Orleans, La. Term expires November 1960. Exccutive Secretary: Kenneth Bray, Veterans Administration Hospital, New Orleans, La. Term expires November 1960.

History: Founded 1948; a component society of American Society of Anesthesiologists.

Purpose: To further scientific aspects of anesthesiology.

Mcmbcrsip: Doctor of Medicine degree, license to practice medicine, member in good standing of American Medical Association and American Society of Anesthesiologists, practice limited to anesthesiology, or related sciences. Total menbership 60 .

Mcetings: Monthly.

866. Louisiana State Medical Society. 1430 Tulane Avenue, New Orleans 12, La. President: O. B. Owens, P. O. Box 672, Alexandria, La. Term expires May 1961. SecretaryTreasurer: C. Grenes Cole. Term expires May 1962.

History: Organized January 14, 1878 ; incorporated June 5, 1903. Committees: Accreditation of Hospitals; Aid to Indigent Members; Alcoholism; American Medical Education Foundation; Arrangements, Annual Meeting; Blood Banks; Budget and Finance; Cancer; Child Health; Chronic Diseases; Committees; Congressional Matters; Diabetes; Domicile; Federal Medical Services; Gamma Globulin and Salk Vaccine; Geriatrics; Historian: Hospitals; Industrial Health: Insurance ; Journal; Lectures for Colored Physicians; Liaison with Louisiana State Nurses Association; Louisiana Organizations for State Legislation; Maternal Welfare; Mediation; Medical Defense; Medical Education; Medical and Hospital Service in re-Insurance Contracts; Medical Testimony; Mental Health; National Emergency Medical Service; Neuropsychiatric Service at Charity Hospitals; Public Health of the State of Louisiana ; Public Policy and Legislation; Rural and Urban Health; Scientific Work; State Department of Public Welfare; State Hospital Policies and Medical Indigency; Woman's Auxiliary and Council on Medical Service and Public Relations.

Purpose: To federate and bring into one compact organization the eligible members of the medical profession of the State; to guard and foster their material interests; to enlighten and direct public opinion in regard to the great problems of state medicine.

Membership: Active members, 2,402, active members of component district and parish medical societies: Associate, 16, physicians in government agencies and services, or associate members of component district and parish societies; Intern-Resident, 96; Honorary, 5, members who have rendered meritorious service to organized medicine or contributed to advancement of scientific medicine, or non-members distinguished in medicine or the collateral branches of medicine; Military, 3; Inactive, 78, physicians who have been in active practice and members of long standing in the Society. Total membership 2,600.

Meetings: Annual.

Professional activities: Walter Reed Memorial Fund, award for thesis on tropical medicine: fifty-year pins to members who have practiced medicine for this period of time.

Publications: Journal, monthly, current volume: $116, \$ 4$. Editor: P. H. Jones.

867. Louisiana State Pharmaceutical Association. 315 St. Charles Avenue, New Orleans, La. President: R. Lewis Rieger, Rieger Pharmacies, Baton Rouge, La. Term expires June 25. 1961. Executice Secretary: Miss Joe Mary Cleaton. Term indefinite.

History: Organized 1882.

Purpose: To promote and improve the science of pharmacy: to unite fraternally all reputable pharmacists of the State of Louisiana; to improve and promote public health; to foster and encourage inter-professional relations; to support a system of education and training in science of pharmacy; to develop, maintain and enforce a code of ethics.

Membership: Active, registered pharmacists ; Associate, connected with the profession of pliarmacy but not registered pharmacists.

Mectings: Annual.

Publications: The Louisiana Pharmacist, monthly, free. Editor: Richard Drown, Jr.

868. Lubbock Geological Society. Presidcnt: Ben F. Baldwin, P. O. Box 268, Lubbock, Tex. Term expires May 1961. Executive Sccretary: B. J. Talley, Term expires May 1961.

History: Organized in 1953; member of the Soutluwestern Federation of Geological Societies and of the American Association of Petroleum Geologists.

Purpose: To promote the science of petroleum geology and technology in IVest Texas; to promote and encourage professional cooperation among geologists and associated scientists; and to foster the scientific spirit among its members.

Membership: Open to any persons of integrity and principle who are engaged or interested 
in geology or allied technical problems, and who are members, juniors, or associates, or are qualified for membership in the American Association of Petroleum Geologists, or to any persons who, in the opinion of the Executive Committee, would be desirable members. Total membership 45.

Meetings: Monthly, September through May.

Professional activitics: Award presented to the Junior Scientist of the Month in the Lubbock area.

869. Maine Medical Association. P. O. Box 637 Brunswick, Maine. President: Wilson H. McWethy, 31 Western Avenue, Augusta, Maine. Term expires June 1961. SecretaryTreasurer: Esther M. Kennard. Term expires June 1961.

History: Organized 1853; incorporated. Fifteen county medical societies. Committees : Scientific, Medical Education and Hospitals, Medical Advisory, Public Relations, Rural Health, Board of Ethics and Discipline, Credentials, Health Insurance, Legislative.

Purpase: To promote the science and art of medicine, protection of public health, and betterment of the medical profession.

Membership: Only by membership in component societies. Active members, 713; Junior, 4 ; Honorary, 46; Affiliate, 11; Senior, 49; Military Service, 5. Total membership 828.

Mectings: Semiannual.

Professional activities: Thayer Library Fund, income given to Spalding Memorial Library, Maine Medical Center, Portland, Maine; Honorary Medals: Fifty Year, Fifty-five Year, Sixty Year, and Sixty-five Year, to members in practice for those numbers of years respectively.

Publications: Journal, monthly, current volume: 51, \$3. Editor: Daniel F. Hanley.

870. Maine Medico-Legal Society. President: Wilbur Leighton. Term expires June 1961. Exccutive Secretary: Philip Wheeler, Attorney General's Office, State House, Augusta, Maine. Term expires June 1961.

History: Organized 1935.

Purpose: To improve operation of Medical Examiners' System.

Membership: Must be members of Maine Medical Association or Maine Bar Association. Total membership approximately 103.

Meetings: Annual.

871. Maine Psychological Association. President: Paul Perez, Veterans Administration Center, Togus, Maine. Term expires May 1961.
Secretary-Treasurer: Edward J. Durnall, Jr., Nasson College, Springvale, Maine. Term expires May 1961.

History: Organized May 13, 1950; incorporated April 1954. Affiliated with the American Psychological Association through the Conference of State Psychological Associations. Commitee: Psychology in the Public Schools.

Purpose: To advance psychology as a science, as a profession and as a means of promoting human welfare.

Membership: Members, 60, persons residing or employed in state, who are Fellows, Associates, or Life members of American Psychological Association or who possess equivalalent qualifications; Affiliates, 28, persons possessing a bachelor's degree with a major in psychology and employed in the field, or one year of experience in lieu of the major, and/or graduate students in psychology or students presently majoring in psychology. Total membership 88 .

Mectings: Three times a year.

Publications: Directory of Psychological and Allied Services in Maine, annually. Editor: Alan Baron.

872. Maine Radiological Society. President: Francis O'Connor, Augusta General Hospital, Augusta, Maine. Term expires June 1961. Secretary: Albert Poulin, Thayer Hospital, Waterville, Maine. Term expires June 1961.

History: Organized April 1950.

Purpose: To further the progress of science through the specialty of radiology

Membership: Active members, 20, physicians who are members in good standing of their respective county medical societies and of the Maine Medical Association, who specialize in radiology, and who are diplomates of the American Board of Radiology; Associates, 9, physicians who are members in good standing of their respective county medical societies under the Maine Medical Association and who are interested in radiology; Honorary, 3, men of outstanding merit with special interest in or contributing to radiology, or retired active members. Total membership 32.

Mectings: Annual, with Maine Medical Association; three other meetings.

Professional activitics: Awards presented to technicians annually.

873. Maine Society of Anesthesiologists. Presidcnt: Warren G. Strout, 205 French Street. Bangor, Maine. Term expires December 1960. Secretary-Treasurer: Gilbert Clapperton, 300 Maine Street, Lewiston, Maine. Term expires December 1960. 
History: Organized October 26, 1948.

Purpose: To promote interest in and recognition of anesthesiology in Maine; to encourage progress in all aspects of practice of anesthesiology; to provide opportunities for fellowship, instruction, and mutual assistance for its members.

Membership: Active members, 28, requires membership in American Society of Anesthesiologists; Junior, 5, physicians engaged in full time training in anesthesia. Total membership 33.

Meetings: Five annually.

874. Maryland Academy of Sciences. 400 Cathedral Street, Baltimore 1, Md. Director: Thomson King. Term indefinite.

History: Founded in Baltimore in 1797; incorporated as the Maryland Academy of Science and Literature in 1826; in 1867 name changed to present title.

Purpose: The collection, preservation, dissemination and interpretation of scientific information to the people of Maryland.

Membership: Open to anyone eighteen years of age and over who is interested in the program of the Academy. Total membership 1,046.

Meetings: Annual.

Profcssional activities: Three sections for specialized work in Archeology, Astronomy and Mineralogy. Award to Outstanding Young Scientist of the Year. Sponsors Westinghouse Science Talent Search. Planetarium, Thursday Night Lectures, 'Round the IVorld Adventure Lectures, Exhibit Hall, telescopes on roof, mobile exhibits loaned to schools, talks by staff members at schools and various groups, graphic time table of the heavens, excursions to visit scientific institutions, class in elementary astronomy, class in astronautics for high school teachers only.

Publications: Newsletter, nine times a year.

875. Maryland Association of Engineers, Inc. 1274 Meridene Drive, Baltimore 12, Md. President: John D. Lang, 1811 North Rolling Road, Baltimore 7, Md. Term expires January 28, 1961. Executive Secretary: Thomas A. Considine. Term expires January 28, 1961.

History: Incorporated February 8, 1934.

Purpose: To form a common meeting ground for engineers, architects, contractors, and material men; to provide a medium for interchange of technical and business information; to aid in promulgation of proper laws and their proper administration; to encourage development of civic and industrial improvements; to improve conditions surrounding practice of engineering; to aid, through proper cooperation, betterment of financial, professional, and social status of members.

Membership: Limited to corporate members. Qualifications: Adult, male persons over twentyone years of age, engaged in engineering work or allied activities. Total membership approximately 700 .

Meetings: Quarterly.

Professional actizities: Nathan L. Smith and Bernard L. Crozier Awards, made to seniors at Johns Hopkins University and University of Maryland who evidence greatest improvement in scholarship in the engineering schools.

876. Maryland Pharmaceutical Association, 650 West Lombard Street, Baltimore 1, Md. President: Harold M. Goldfeder. Term expires June 1961. Executive Secretary: Joseph Cohen. Term expires June 1961.

History: Organized 1883 as the Maryland State Pharmaceutical Association; incorporated under present title 1889.

Purpose: To advance the science of pharmacy ; to promote scientific research; to strive to have enacted just, yet stringent, laws to prevent the adulteration of foods and medicines; to confine the compounding and sale of medicine to regularly educated pharmacists.

Membership: Active, open to all registered pharmacists in good standing; Associate, those allied with the pharmaceutical profession. Active members, 600; Associate members, 200. Total membership 800 .

Meetings: Quarterly.

Professional activities: Scholarships to the University of Maryland School of Pharmacy.

Publications: The Maryland Pharmacist, monthly, current volume: $35, \$ 2$. Editor : Joseph Cohen.

Library: 1,000 volumes. Emplasis, pharmacy and allied subjects.

877. Maryland Psychiatric Society. President: Irene L. Hitchman, Springfield State Hospital, Sykesville, Md. Term expires April 1961. Secretary-Treasurer: Gerald D. Klee, Psychiatric Institute, University Hospital, Baltimore 1, Md. Term expires April 1961.

History: Organized 1949. Society is District Branch of American Psychiatric Association, and Neuropsychiatric Section of Baltimore City Medical Society.

Purpose: To promote the science, art, and practice of psychiatry.

Menberslip: Full members, 141, primarily in psychiatric practice for three years, with residence and license in Maryland; Associate, 25 , physicians in practice of psychiatry who do 
not meet requirements for regular nembership; Non-resident, 5; Affiliate, 2, physicians not specializing in psychiatry; Honorary, 3. Total membership 176.

Mectings: Monthly, October-April.

Professional activitics: Wendell Muncie Award (jointly with Maryland Association of Private Practicing Psychiatrists).

878. Maryland Society of Professional Engineers, Inc. 6 West Fayette Street, Baltimore 1. Md. President: G. Philip Stout, P. O. Box 4568, Baltimore 12, Md. Term expires May 12, 1961. Secretary: Hugh H. Hunter, 1303 Northview Road, Baltimore 18, Md. Term expires May 12, 1961.

History: Founded March 1938. Operates under constitution of National Society of Professional Engineers. Chapters: Annapolis, Baltimore, Cumberland, Frederick, Potomac, Susquehanma. Four other chapters in process of organization.

Purpose: Promotion and protection of the profession of engineering as a social and economic influence on the affairs of men and community.

Membership: Members, 700, registered engineers in any State, or the District of Columbia, in the United States, or in any possession of the United States, or in any Province of the Dominion of Canada; Junior Members, 180 , Engineer in Training certificates leading to registration in areas as indicated above. Total membership 880 .

Mectings: Annual.

Professional activities: Several fellowships supported; medals and awards presented to worthy science students at chapter, State, and national levels; "Engineers Week" sponsored.

Publications: Maryland Professional Engineer, five issues annually, current volume: 1 , free to members. Editor: Norman Emerick.

879. Massachusetts Dental Society. 227 Commonwealth Avenue, Boston 16, Mass. President: Philip H. White, 80 Boylston Street, Boston 16, Mass. Term expires May 1961. Secretary: Harold E. Tingley, 12 Bay State Road, Boston 15, Mass. Term expires May 1961. Executize Secretary: Miss Freda A. Smith. Term indefinite.

History: Founded 1864.

Purposc: To encourage improvement of public health and promote the art and science of dentistry.

Membership: Requires registered practice of dentistry in Massachusetts, or teaching, with dental degree, on staff of a dental college in Massachusetts, or internship, with dental degree, in recognized institution in that Commonwealth, or engagement in public health dentistry. Total membership 3,059.

Mectings: Semiannual.

Professional activitics: Educational and scientific programs.

Publications: Journal, quarterly, current volume: 9, \$3. Editor: Joseph A. Doherty.

880. Massachusetts Horticultural Society. 300 Massachusetts Avenue, Boston 15, Mass. President: Oliver Wolcott, Hamilton, Mass. Term expires May 1, 1961. Executive Secretary: Arno H. Nehrling, 3 Carey Road, Needham Heights, Mass. Term indefinite.

History: Organized June 12, 1829.

Purposc: Advancement of horticulture and kindred interests.

Membcrship: Requires interest in purpose of society. Annual members, 9.492; Life, 920; Honorary, 60; Corresponding. 19. Total membership 10,491 .

Mectings: Annual.

Professional activitics: Samuel Appleton Fund, $\$ 1,000$, interest devoted to flowers and food producing trees; John A. Lowell Fund, $\$ 1,000$, to perfect culture of flowers and fruits; Theodore Lyman Fund No. 1, $\$ 1,000$, for encouragement of growth of selected fruits; Josiah Bradlee Fund, $\$ 1,000$, income awarded in premiums for flowers and fruits; Theodore Lyman Fund No. 2, $\$ 10,000$, for encouragement of growth of fruits, vegetables, and other plants; Benjamin V. French Fund No. 1, \$500, for improvement of the apple; H. H. Hunnewell Fund No. 1, \$500, for introduction and cultivation of new evergreen trees and shrubs; H. H. Hunnewell Fund No. 2, $\$ 2,000$, for cultivation and development of estates of three or more acres in rare and desirable ornamental trees and shrubs; William J. Walker Fund, \$2,354.43, for introduction and cultivation of superior vegetables; Levi Whitcomb Fund, \$500, for superior potatoes; H. H. Humnewell Fund No. 3, \$1,500, for cultivation of rhododendrons and azaleas; Benjanin B. Davis Fund, $\$ 500$, for superior grapes; Marshall P. IVilder Fund, $\$ 1,000$ half for grapes of American origin, half for pears; John Lewis Russell Fund, $\$ 1,000$, for lectures on latest discoveries of connection of fungi with horticulture: Henry A. Gane Memorial Fund, $\$ 1,000$, for chrysanthemums; Francis Brown Hayes Bequest, $\$ 189.904 .54$, unrestricted; Francis Brown Hayes Fund, $\$ 10,000$, unrestricted; John S. Farlow Fund, \$2,500, for binding or purchase of books for library; John D. Williams French Fund, $\$ 12,222.23$, for purchase of books; Benjamin H. Pierce Fund, $\$ 800$, for introduction of new fruits; John C. Chaffin Fund, $\$ 1,000$, for roses of unusual merit; 
Benjanin V. French Fund No. 2, $\$ 3,000$, bequeathed to this Society by will of Charles E. French for fruit and vegetable prizes; John Allen French Fund, $\$ 5,000$, by will of Charles E. French for prizes for selected flora; George Robert White Medal of Honor Fund, $\$ 10,000$, for annual award of gold medal for advancement of horticulture in its broadest sense; Joln S. Farlow Newton Horticultural Society Fund, \$2,900.42, received from Lewis H. Farlow, for pear and foreign grape culture; Miss Helen Collamore Fund, $\$ 5,000$, at discretion of trustees of this Society; Albert Cameron Burrage Fund, 1920, $\$ 1,200$, for promotion of cranberries in Massachusetts, now unrestricted; Caroline S. Freeman Fund, $\$ 10,000$, unrestricted; Arthur F. Estabrook Legacy, $\$ 47,500$, unrestricted; Jackson Dawson Fund, $\$ 3,227$, raised through efforts of Horticultural Club of Boston, for hybridization and propagation of hardy woody plants; Thomas Roland Medal Fund, $\$ 3,000$, for medals, from time to time, for skill in horticulture; lda F. Estabrook Legacy, \$11,238.76, unrestricted; Albert Cameron Burrage Porch Fund, $\$ 1,250$, for annual award of gold medal for new porch overlooking garden; Show Fund, $\$ 47,000$, to cover possible losses on exhibitions; Albert Cameron Burrage Fund, 1930, $\$ 50,000$, for purchase of books, and for annual award of gold vase for outstanding exhibit at shows of this Society; William N. Craig Fund, $\$ 2,500$, for culture of lilies; Nathaniel T. Kidder Fund, $\$ 5.000$. for library objects; Jere A. Downs Bequest, $\$ 15,000$, for prizes as determined by trustees of this Society; Joseph Everett Chandler Fund, $\$ 19,851.84$, unrestricted; Marian Roby Case Bequest, $\$ 50,000$, unrestricted; Elizabeth Downs Wadsworth Bequest, \$19,668.19, for prizes as determined by trustees of this Society; Louisa Case Bequest, $\$ 50,000$, unrestricted.

Publications: Horticulture, monthly, current volume: $38, \$ 4$, free to members. Editor: $\mathrm{H}$. Gleason Mattoon. Yearbook, \$1, free to members.

Library: 32.000 volumes. Subject emphasis: Horticulture, landscaping, botany.

881. Massachusetts Hospital Association. 14 Somerset Street, Boston 8, Mass. President: R. D. Lowry, New England Deaconess Hospital, Boston 15, Mass. Term expires May 14, 1961. Executive Director: Henry G. Brickman. Term indefinite.

History: Organized 1936.

Purpose: Promotion of health of people of Massachusetts through development of best possible hospital care.

Membership: Requires licensed hospitals meeting Association standards. 180 member hos- pitals; 120 hospital auxiliaries; 400 personal members.

Mectings: Annual.

Professional activities: Sponsorship of educational programs for benefit of hospitals and liaison with allied health organizations.

Publications: Newsletter.

882. Massachusetts Medical Society. President: Carl Bearse. Term expires May 1961. Secretary: Robert W. Buck, 22 The Fenway, Boston 15, Mass. Term expires May 1961

History: Organized November 1, 1781. SECTIONs : Medicine, Surgery, Pediatrics, Obstetrics and Gynecology, Radiology, Physical Medicine, lndustrial Health, Psychiatry and Neurology, Physiology and Pathology, Anesthesiology, Opthalmalogy and Otolaryngology, Dermatology. Twenty county district societies.

Purpose: Elevation of the standards of medical practice; promotion and protection of public health.

Membership: Medical license in the United States; acceptable qualifications with respect to character and ethical practice. Resident members, 6,870; non-resident members, 925. Total nembership 7.795 .

\section{Mectings: Annual.}

Professional activities: Shattuck Fund, for annual lecture; awards to laymen and medical students; scholarships for medical students.

Publications: New England Journal of Medicine, weekly, current volume: $262-263, \$ 8$, foreign \$10.50. Editor: Joseph Garland.

\section{Massachusetts Psychological Association,}

Inc. 308 Bay State Road, Boston 15, Mass. President: A. H. Maslow, Department of Psychology, Brandeis University, Waltham 54. Mass. Term expires May 1962. Secretary: Irving Wolf, Department of Psychology, Boston University, Boston 15, Mass. Term expires May 1961.

History: Organized 1933 as Boston Society for Clinical Psychologists; incorporated 1941 as Massachusetts Society of Clinical Psychologists: name changed to present title May 21 , 1951, and membership extended.

Purpose: To advance psychology as a science. as a profession, and as a means of promoting human welfare.

Membership: Life members, 18, seniority in age and experience in psychology; Fellows, 237. doctoral degree in psychology, four years postdoctoral experience: Associates, 226, master's degree in psychology and two years' experience in psychological work. Total membership 481.

Meetings: Annual. 
884. Massachusetts Public Health Association, Inc. 1 Shattuck Street, Boston 15, Mass. President: Leon Sternfeld, Department of Public Health, City Hall, Cambridge, Mass. Term expires April 1961. Executize Secretary: Mrs. Elizabeth K. Caso, Term indefinite.

History: Organized 1890. Sections: Epidemiology, Food and Nutrition, Dental Health, Health Education, Health Officers, Medical Care, Maternal and Child Health, Mental Health, Public Heaith Nursing, and Sanitation.

Purpose: To provide an opportunity for persons actively engaged in or interested in public health to meet together on a multi-discipline basis to plan and initiate action to maintain or improve public health.

Membership: Members, 875, interest in public health.

Meetings: Three times a year.

Professional activities: In-Service Training; Work Projects. Lemuel Shattuck Award, for outstanding service in public health in the New England area. Paul Revere Award, for outstanding service in public health at local level in Massachusetts.

Publications: Proceedings, quarterly, current volume: 21 , free to members. Editor: Kenneth I. E. MacLeod.

885. Massachusetts Society of Anesthesiologists. President: Francis J. Audin, 53 Lowell Road, Wellesley Hills, Mass. Term expires May 1961. Secretary-Treasurer: Thomas K. Burnap, 10 Prospect Terrace, Newtonville 60, Mass. Term expires May 1961.

History: Organized May 11, 1948 and issued a charter as the state component society of the American Society of Anesthesiologists in July of 1948.

Prupose: To stimulate interest in the specialty of anesthesiology; to associate and affiliate into one organization those physicians especially interested in anesthesiology; to encourage research, teaching, and develop the specialty.

Membership: Active, 290, membership in parent society, membership in local county medical component of American Medical Association, licensed to practice in this state (exceptions for Veterans Administration and military service applicants), practice devoted entirely to anesthesiology; Junior, 70, in-training members. Total membership 360 .

Mectings: Quarterly.

Professional activities: Refresher course each March for interested physicians.

886. Massachusetts Society of Optometrists. 101 Tremont Street, Boston 8, Mass. President: Alfred D. Hanson, 303 North Main Street,
Attleboro, Mass. Term expires June 1961. Secretary: David G. MacFarlane, 412 County Street, New Bedford, Mass. Term expires June 1961.

History: Founded in 1908 as Massachusetts Optical Society; name changed to present title in 1912; incorporated in 1916.

Purpose: To advance the art and science of optometry, and interest in its kindred subjects; the promotion of good fellowship; the interchange of thought and experience pertaining to optometric theory and practice; the encouragement of research and the elevation of the profession.

Membership: Members must be registered in the State of Massachusetts and actively engaged in practice. Active, 453; Life, 34; Honorary, 7 ; Associate, 4 ; Non-resident, 2.

Mectings: Annual.

Professional activities: Annual scholarship of $\$ 800$ awarded to Massachusetts College of Optometry.

Publications: New England Journal of Optometry, monthly, free to members. Editor : William V. Emmons.

887. Massachusetts Society of Pathologists. President: Michael MacKenzic, Malden Hospital, Malden, Mass. Term expires September 1961. Executive Secretary: John M. Craig, Boston Lying-In Hospital, Boston, Mass. Term expires September 1962.

History: Founded March 20, 1958. CommitTEES : Hospital and Professional Relations, Legislation and Public Health Affairs, Autopsy and Technician Liaison.

Purpose: To foster and maintain the standards of the practice of pathology with particular interest in economic, legislative and administrative activities that effect the welfare of the pathologist ; to maintain and enhance the dignity and standing of the specialty of pathology and of the pathologist in his professional relationships with patients, hospitals, state and federal government and all other duly organized societies or organizations having reference to the practice or teaching of pathology.

Membership: Members, 147, limited to Massachusetts physicians holding membership in the New England Society of Pathologists. Regular membership, any physician of good moral character who is devoting himself primarily to the practice and/or teaching of pathology; Junior membership, any physician of good moral character who has completed one year of pathology training towards the qualification of the American Board of Pathology.

Meetings: Four per year.

Professional activities: Workshops for Massachusetts pathologists. 
888. Massachusetts Society of Professional Engineers, Inc. 79 Milk Street, Boston 9, Mass. President: David R. Bashaw, Jr., 21 Chippewa Road, Worcester, Mass. Term expires July 1, 1961. Executive Secretary: Donald C. Howard, 3 Churchill Street, Newtonville 60, Mass. Term indefinite.

History: Founded 1937; affiliated with $\mathrm{Na}$ tional Society of Professional Engineers. CHAPTERs : Metropolitan, North Shore, Central Massachusetts, Berkshire, and Connecticut Valley.

Purpose: Advancement of the public good, and the professional, social, and economic interest of the engineer.

Membership: Must be registered professional engineers. Total membership 1,600.

\section{Meetings: Annual.}

Professional activities: Engineering and Scientist's Utilization Conference; William Cunningham Press Award, for coverage of engineering news; NSPE-ARMCO Scholarship.

Publications: New England Professional Engineer, bimonthly, current volume: $13, \$ 2.50$. Editor: Norman S. Bosworth.

889. Massachusetts State Engineers' Association, Inc. 100 Nashua Street, Boston 14, Mass. President: John F. Gallagher, 25 Carroll Street, Auburn, Mass. Term expires October 31, 1960. Secretary: Benjamin P. Hill, 42 Burrell Street, Melrose 76, Mass. Term indefinite.

History: Incorporated November 6, 1925; affiliated with Engineering Societies of New England December 1, 1928.

Purpose: To improve the status and condition of engineers and members of other scientific and technical professions in the employ of the Commonwealth of Massachusetts, and the standards of loyalty and efficiency in the public service of the Commonwealth.

Membership: Engineers and other scientific and technical professionals in the service of the Commonwealth of Massachusetts. Total membership 430 .

Mectings: Annual.

890. Massachusetts State Pharmaceutical Association. 11 Beacon Street, Boston, Mass. President: Thomas A. Brady, 31 Main Street, Peabody, Mass. Term expires 1961.

History: Organized 1881.

Purpose: To increase and advance the professional knowledge of pharmacists and druggists; to promote and advance pharmacy in Massachusetts; and to advance the social commercial, and civic interests of its members.
Membership: Members, Life; Honorary.

Total membership 1,850.

Meetings: Semiannual.

891. Massachusetts Thoracic Society. President: Theodore L. Badger, 264 Beacon Street, Boston, Mass. Term expires June 30, 1961. Secretary-Treasurer: Heinz G. Lorge, Worcester County Sanatorium, IVorcester 6, Mass. Term expires June 30, 1961.

History: Formerly the Massachusetts Trudeau Society; name changed to present title June 23, 1960. The Society is the Medical Section of the Massachusetts Tuberculosis and Health League.

Purpose: To further study, research and interest in diseases of the chest.

Membership: Open to physicians having an interest in diseases of the chest. Total nembership 160 .

Meetings: Annual and quarterly.

892. Mathematical Association of America. University of Buffalo, Buffalo 14, N. Y. President: C. B. Allendoerfer, University of Washington, Seattle 5, Wash. Term expires January 1961. Sccretary: H. L. Alder, University of California, Davis, Calif. Term expires January 1965.

History: Organized December 1915; incorporated September 8, 1920. Twenty-seven geographical sections.

Purpose: The promotion of collegiate mathematics.

Membership: Members, 9,113, any person who is interested in the field of collegiate mathematics.

\section{Meetings: Semiannual.}

Professional activities: Chauvenet prize of $\$ 100$ awarded every third year for excellence in exposition. Distinguished Service Award of $\$ 500$ and certificate awarded annually for outstanding service to mathematics, other than mathematical research.

Publications: American Mathematical Month$1 \mathrm{y}, 10$ issues a year, current volume: $67 \$ 8$, free to members and on exchange. Editor: R. D. James, University of British Columbia, Vancouver, B. C., Canada.

893. Medical and Chirurgical Faculty of the State of Maryland. 1211 Cathedral Street, Baltimore 1, Md. President: Whitmer B. Firor. Term expires April 1961. Executive Secretary: John Sargeant. Term indefinite.

History: Incorporated by a Special Act of the State Legislature, 1799. One of the oldest medical societies in the United States. 
Purpose: To secure the enactment and enforcement of just laws relating to the practice of medicine and the public health.

Membership: Must be licensed physicians in the State of Maryland. Active members, 2,435, active members of component societies; Associate, 585, Doctors of Medicine or those holding academic degrees of equal rank who are not engaged in clinical practice of medicine, and Doctors of Medicine engaged in clinical practice and in full-time teaching positions in medical schools having ranks below that of Associate Professor, and Residents on hospital staffs, and members of Baltimore City Dental Society; Emeritus, 73; Fifty-Year, 28; Service, 31. Total membership 3,152.

Mectings: Semiannual.

Publications: Maryland State Medical Journal, monthly, current volume: $9, \$ 3$. Editor: George H. Yeager.

Library: 81,000 volumes. Subject emphasis: medicine.

894. Medical Association of Georgia. 938 Peachtree Street, N. E., Atlanta 9, Ga. President: Milford B. Hatcher. Term expires May 1961. Executive Secretary: Milton D. Krueger Term indefinite.

History: Organized 1849. Seventy component county medical societies. Thirty-five scientific and technical committees.

Purpose: To promote the science and art of medicine and the betterment of public health.

Membership: Active members, 2,815, Doctor of Medicine degree, United States citizen, licensed to practice medicine in Georgia, member of county medical society; Associate, 17, same as Active, but full time with State or county health department, or full time with medical school faculty; Honorary, 1, elected only by official body; Service, 54, same as active, but applies to full time medical officers with United States Government.

Meetings: Annual.

Professional activities: Distinguished Service Award, for service to Association and profession; Hardman Award, for outstanding work in public healtl, or outstanding scientific attainment in medicine or surgery; General Practitioner of the Year Award, for outstanding service to patients and public; Scientific Exhibit Awards, for outstanding exhibits portraying some aspects of medical practice at Association's annual meeting.

Publications: Journal, monthly, current volume : 49, \$5. Editor: Edgar Woody, Jr.

895. Medical Association of the State of Alabama. 19 South Jackson Street, Montgomery, Ala. President: Hugh E. Gray,
Anniston, Ala. Term expires April 1961. Secretary-Treasurer: William L. Smith. Term expires April 1961. Executive Secretary: IV. A. Dozier. Term indefinite.

History: Organized 1847; reorganized 1868. Purpose: Establishment of a high standard of professional and moral education for medical meı; enactment of wise and just laws for examination of all persons who propose to offer their services for treatment of human diseases; development of a spirit of loyalty to professional ethics.

Membership: Members of county medical societies holding charters from this Association. Total membership 2,109.

Mectings: Annual.

Publications: Journal, monthly, current volune : 29.

896. Medical Correctional Association. Presidcnt: Harry Lipton, 490 Peachtree Street, N. E., Atlanta 8, Ga. Term expires September 1961. Secretary: Ralph S. Banay, 927 Fifth Avenue, New York, N. Y. Term indefinite.

History: Founded in 1940 to bring into one organization psychiatrists, psychologists, social workers, judges, attorneys, and others interested in the scientific approach of the philosophy and practice of correctional aspects of delinquent or criminal behavior.

Purpose: To disseminate research information and improve practices in correction.

Membership: Open to individuals with active practice, sufficient background, and a sustained interest in social problems. Total membership 270.

Mectings: Annual.

Publications: Journal of Social Therapy, quarterly, current volume: $6, \$ 5$. Editor: Ralph S. Banay.

897. Medical Library Association, Inc. President: Robert T. Lentz, Jefferson Medical College Library, 1025 WValnut Street, Philadelphia 7, Pa. Term expires May 12, 1961. Secretary: Miss Ruth J. Mann, Mayo Clinic Library, Rochester, Minn. Term expires May 12,1961 .

History: Organized 1898 as Association of Medical Librarians; name clanged to present title 1907 ; incorporated 1934.

Purpose: Fostering of medical and allied scientific libraries, and exchange of medical literature among institutional menbers: improving of professional qualifications and status of medical librarians.

Membership: Institutional members, 586, medical and allied scientific libraries of not less 
than 1,000 volumes, receiving regularly not less than twenty-five medical or allied scientific serials of good standing, maintaining stated regular hours, and in charge of qualified attendants; Active, 763, persons actively engaged in library or bibliographical work in medical or allied scientific fields, or who hold this Association's Certificate of Medical Librarianship; Associate, 106, persons interested in medical or allied scientific libraries; Sustaining, 4, persons or organizations interested in support of medical or allied scientific libraries; Honorary, 3 , individuals who have made outstanding contributions to advancement of the purposes of this Association. Total membership 1,462.

Meetings: Annual.

Professional activitics: Foreign Fellowships, Scholarship Program for approved Medical Library Courses, Exchange Program of Medical Literature, Certification of Medical Librarians, Marcia C. Noyes Award, Murray Gottlieb Prize Essay Award.

Publications: Bulletin, quarterly, current volume: 48, domestic \$7, foreign \$7.50. Editor: Mrs. Mildred Crowe Langner, Jackson Memorial Library, 1000 Northwest 17th Street, Miami 36, Fla. Vital Notes on Medical Periodicals, three annually, current volume: $8, \$ 2$. Editor: William K. Beatty, Medical Library, University of Missouri, Columbia, Mo.

898. Medical Society of Delaware. 1925 Lovering Avenue, Wilmington 6, Del. President: Lemuel C. McGee. Term expires October 1961. Executive Secretary: Lawrence C. Morris, Jr. Term indefinite.

History: Founded 1776: incorporated February 1789 .

Purpose: To federate and bring into one compact organization the entire medical profession of the state; to extend medical knowledge and advance medical science; and to elevate the standard of medical education.

Membership: Open to members in good standing in the component county medical societies. Total membership 430.

Meetings: Annual.

Publications: Delaware Medical Journal, monthly, current volume: $32, \$ 5$. Editor: A. Henry Clagett, Jr.

899. Medical Society of New Jersey. P. O. Box 904, Trenton 5, N. J. President: Jesse McCall, 9 Linwood Avenue, Newton, N. J. Term expires May 1961. Executive Secretary: Richard I. Nevin. Term indefinite.

History: Organized July 23, 1766, this is the oldest medical society in the United States; recognized by law 1783; incorporated by Act of Legislature 1790 ; second act of incorporation 1816; granted authority to confer degree of Doctor of Medicine 1825 ; present charter issued 1864. Scientific Sections: Allergy, Anesthesiology, Cardiovascular Diseases, Chest Diseases, Clinical Pathology, Dermatology, Gastro-Enterology and Proctology, General Practice, Medicine, Metabolism, Neuropsychiatry, Obstetrics and Gynecology, Ophthalmology, Orthopedic Surgery, Otolaryngology, Pediatrics, Radiology, Rheumatism, Surgery, Urology.

Purpose: Advancement of the profession and promotion of the public good.

Membership: Active, 6,304, members of component county societies; Associate, 308, physicians who may be elected to active membership after a period of probation, not longer than two years; Emeritus, 119, physicians who have been members of component societies for at least twenty years, and who, by reason of age or infirmity, have retired from active practice, or members disabled in military service ; Honorary, 3, physicians and surgeons of professional distinction, or non-medical persons who have rendered signal service to this Society or have attained special eminence in scientific fields other than medicine. Total membership 6,734.

\section{Mectings: Annual.}

Professional activities: Medical Student Loan Fund, for New Jersey students; Golden Merit Awards, for physician-members in practice fifty years.

Publications: Journal, monthly, current volume: $57, \$ 3$. Editor: Henry A. Davidson. Membership News Letter, monthly, current volume: 123-134, \$6.30. Editor: Richard I. Nevin. Periodic News Letter, irregular, current volume: 26. Editor: Richard I. Nevin.

900. Medical Society of the County of Kings and Academy of Medicine of Brooklyn, Inc. 1313 Bedford Avenue, Brooklyn 16, N. Y. President: Irving M. Pallin, 555 Prospect Place, Brooklyn, N. Y. Term expires July 1961. Executive Secretary: Charles F. McCarty. Term indefinite.

\section{History: Organized 1822.}

Purpose: To provide educational opportunities for the medical profession of the community in order that the highest possible standard of practice may be attained; to maintain a medical library; to diffuse among the people knowledge of achievements of scientific medicine; to aid and conserve the public welfare by participating in all proper civic enterprises; and to fulfill the duties of a county medical society and an academy of medicine to the profession and the public.

Membership: Regular, physicians licensed to practice in the State of New York, having principal office in Brooklyn or residing in 
Brooklyn; Retired, regular members who have passed their seventieth birthday; Honorary, physicians who have been members of Kings County or another medical society in New York State for over fifty years and physicians and others who have done outstanding work for the Medical Society of the County of Kings; Corresponding, physicians who are members of a county medical society in the United States, physicians who are eligible for any other type of membership in the Medical Society of the County of Kings cannot become Corresponding Members; Associate, persons not licensed to practice medicine in the State of New York, but who are interested in the aims of the Medical Society of the County of Kings and who meet certain other requirements; Student, medical students either attending medical college in the County of Kings or those who are attending medical school outside the County of Kings and who reside in Brooklyn; Intern, interns who are serving in a Brooklyn Hospital approved for intern training, or who are serving in a county hospital which is approved for intern training, and who reside in Brooklyn; Resident, residents who are serving in a Brooklyn Hospital approved for Resident Training, or who are serving in a County Hospital which is approved for Resident Training, and who reside in Brooklyn.

Meetings: Annual; monthly October to May.

Publications: Bulletin, monthly, current volume: 39 .

Library: 200,000 volumes.

901. Medical Society of the County of New York. 10 Columbus Circle, New York 19, N. Y. President: Bernard J. Pisani, St. Vincent's Hospital, 170 West 12th Street, New York 11, N. Y. Term expires May 23, 1961. Executive Secretary: Robert D. Potter. Term indefinite.

History: Organized 1794 as Medical Society of the State of New York; incorporated 1806 under present title. The Society is a component unit of the Medical Society of the State of New York.

Purpose: To aid in regulating practice of medicine and surgery in New York County, to secure enforcement of related laws, and to assist in preservation of public health.

Membership: Requires license to practice medicine in State of New York and principal office or residence in County of New York. Active, Junior, Associate, and Life members. Total membership 6,948.

Meetings: Monthly, October through May.

Publications: New York Medicine, semimonthly, $\$ 5$, free to members. Editor: Robert D. Potter.
902. Medical Society of the District of Columbia. 1718 M Street, N. W., Washington 6, D. C. President: Victor R. Alfaro. Term expires December 31, 1960. Executive Director: Theodore Wiprud. Term indefinite.

History: Chartered by Acts of Congress February 16, 1819, July 7, 1838, and May 24, 1924. Successor, 1911, to Medical Society of the District of Columbia, founded September 26, 1817, and Medical Association of the District of Columbia, founded January 11, 1833. SECTIONs: Allergy; Anesthesiology; Dermatology and Syphilology; Gastroenterology; General Practice; Internal Medicine; Neurology and Psychiatry; Ophthalmology, Otology, Rhinology, and Laryngology ; Pathology and Laboratory Medicine; Pediatrics; Physical Medicine and Rehabilitation; Plastic Surgery; Radiology.

Purpose: To promote and disseminate medical and surgical knowledge.

Membership: Active members, 1,463, legally qualified practitioners of medicine in the District of Columbia; Life, 67, active members on roll forty years; Associate, 571, medical men not eligible for active membership, or scientists engaged in collateral lines of research; Affiliate, 36, physicians otherwise eligible for active membership in this Society, but with offices outside its jurisdiction, and who are active members of other constituent units of American Medical Association; Honorary, 29, persons who deserve recognition for eminent contributions to medical or collateral science, or for meritorious service to the medical profession; ResidentIntern, 32, hospital interns or residents, United States citizens, and not engaged in private practice. Total membership 2,198.

Meetings: Annual; monthly, October through May.

Professional activities: John Benjamin Nichols Award, to a lay person or lay organization for outstanding contribution to the health of the community.

Publications: Medical Annals of the District of Columbia, monthly, current volume : $29, \$ 4.50$. Editor: Wallace M. Yater.

903. Medical Society of the State of New York. 750 3rd Avenue, New York 17, N. Y. President: Norman S. Moore, 512 East State Street, Ithaca, N. Y. Term expires May 1961. Executive Dircctor: Herbert T. Wagner. Term indefinite.

History: Organized 1807. Seventy committees and subcommittees. Sections: Allergy; Anesthesiology; Chest Diseases; Dermatology and Syphilology; Gastroenterology and Proctology; General Practice; Industrial Medicine and Surgery; Legal Medicine; Medicine; Neur- 
ology and Psychiatry; Obstetrics and Gynecology; Ophthalmology; Orthopedic Surgery; Otolaryngology; Pathology, Clinical Pathology, and Blood Banking; Pediatrics; Physical Medicine; Preventive Medicine and Public Health; Radiology; Surgery; Urology. Sessions: History of Medicine; Public Relations.

Purpose: To federate into one organization the medical professional of the State of New York; to extend medical knowledge and advance the science and art of medicine; to promote public health and enlighten public opinion regarding problems of medicine and health.

Membership: Active, members of component county medical societies; Junior, component societies' junior members; Life, active members who have reached seventy years of age, or are permanently disabled, and are elected by the House of Delegates of this Society; Honorary, distinguished physicians residing outside New York State elected by House of Delegates of this Society. Total membership 25,056.

\section{Meetings: Annual.}

Professional activities: Merit H. Cash Prize, for best essay on such medical or surgical subject as may be designated by a committtee of this Society; Lucien Howe Prize, for best original contribution in form of essay to a branch of surgery, preferably ophthalmology; A. Walter Suiter Prize, presented for lecture at annual convention of this Society; War Memorial Fund, to assist in education of children of United States veterans who died in World War II, or as result of service connected disability from World War $1 \mathrm{I}$.

Publications: New Iork State Journal of Medicine, semimonthly, current volume: 60, $\$ 7.50$. Editor: Laurance D. Redway. Newsletter, monthly except August and September, current volume: 8 .

Library: 200,000 volumes. Subject emphasis: Medicine.

904. Medical Society of the State of North Carolina. 203 Capital Club Building, Raleigh, N. C. President: Amos N. Johnson, Garland, N. C. Term expires May 1961. Exccutive Director: James T. Barnes. Term expires May 1961.

History: Organized and chartered 1799; reorganized 1849; rechartered 1858. Sections: Practice of Medicine, Anesthesia, Internal Medicine, Neurology and Psychiatry, Obstetrics and Gynecology, Ophthalmology and Otolaryngology, Orthopaedics and Traumatology, Pathology, Pediatrics, Public Health and Education, Radiology, Surgery. Commitrees : Forty-three committees and student American Medical Association chapters.
Purpose: To bring the medical profession of the State into one compact organization; to keep abreast of medical research; to better serve the public in prevention and cure of disease and in prolonging life.

Mcmbership: Active members, 2,975, licensed to practice medicine in North Carolina, and members of component county medical societies; Honorary, 6, physicians distinguished for research and contributions in field of medicine; Life, 251; Scientific, 2. Total membership 3,227 .

\section{Meetings: Annual.}

Publications: North Carolina Medical Journal, monthly, current volume: $21, \$ 5$. Editor: IV. M. Johnson, 300 South Hawthorne Road, Winston-Salem, N. C.

905. Medical Society of Virginia. 4205 Dover Road, Richmond 21, Va. President: Allen Barker, Medical Arts Building, Roanoke, Va. Term expires October 1960. Executive Secretary: Robert I. Howard. Term expires October 1960.

History: Organized 1870; incorporated January $14,1871$.

Purpose: To promote the science and art of medicine, protection of public health, and betterment of the medical profession.

Membership: Active members, 2,700, physicians practicing in Virginia who are members of component societies; Associate, 230, previously active members moving out of the State. Total membership 2,930.

Mectings: Annual.

Publications: Virginia Medical Monthly, current volume: $81, \$ 2$, free to members. Editor: Harry J. Warthen.

906. Memphis Eye, Ear, Nose and Throat Society. Memphis Eye, Ear, Nose and Throat Hospital, 1060 Madison Avenue, Memphis 4, Tenn. Executive Secretary: IVilliam F. Murrah, Jr., 1720 Exchange Building, Memphis, Tenn. Term expires January 1961.

History: Organized September 1915.

Purpose: Presentation of interesting patients, case reports, new instruments, and specimens.

Membership: Physicians and specialists with five years' experience in the diagnosis and treatment of diseases of the eye, ear, nose, and throat, or those having completed recognized residency in ophthalmology or otolaryngology. Total membership 32.

Meetings: Monthly.

907. Metallurgical Society of the American Institute of Mining, Metallurgical and Petroleum Engineers. 29 West 39th Street, New York 18, N. Y. President: C. C. Long, 
Director of Research, St. Joseph Lead Company, P. O. Box 97. Monaca 7, Pa. Term expires February 1961. Secretary: R. W. Shearman. Term indefinite.

History: Founded in 1947 as Metals Branch of the American Institute of Mining, Metallurgical and Petroleum Engineers; name changed to present title in 1957. The Society is made up of three divisions, each comprising a number of technical and standing committees. The Extractive Metallurgy Division includes these technical committees: Electrolytic Processes; Hydrometallurgy; Physical Chemistry of Extractive Metallurgy; Pyrometallurgy; Refractories; Nuclear Fuel Processing; Copper, Nickel, and Precious Metals; Lead, Zinc, and Tin; Uranium, Rare Earths, and Minor Metals; Light Metals; and High-Temperature Metals. The Iron and Steel Division includes these technical committees: Blast Furnace, Coke Oven, and Raw Materials; National Open Hearth Steel; Electric Furnace; Acid Converter and Basic Oxygen Steel; Mechanical Working; and Physical Chemistry of Steelmaking. The Institute of Metals Division includes these technical committees: Chemistry and Physics of Metals; Ferrous Metallurgy; Heat Treating; Joining, Melting and Casting; Non-Ferrous Metallurgy; Nuclear Metallurgy; Physical Metallurgy; Powder Metallurgy; Shaping and Forming; Surface Treatment; Corrosion-Resistant Metals; Electric and Magnetic Metals; High-Temperature Alloys; Refractory Metals; Semiconductors; Structural Materials; and Titanium. Metallurgical Society standing and special committees: Education; Robert Lansing Hardy Gold Medal; Metallurgical Profession; Programs, Publications, and Engineering Management.

Purpose: To promote the advancement of metallurgical knowledge and the advancement of the metallurgical profession as a whole by: (a) Providing a medium for communication and cooperation among those interested in any phase of theoretical and applied metallurgy, including those advancing, practicing, learning, or otherwise primarily concerned with the science, engineering, economy, or technical aspects of the metal industry (both producers and consumers). The major metallurgical field cncompasses particularly the understanding and knowledge of metal behavior, the manufacturing practice for extracting, refining, and fabricating metals, and the development and application of metals and their alloys.

Providing an organization to represent the metallurgists and metallurgical engineers on matters pertaining to education, and to encourage and advance education in the broad field of metallurgical science and engineering.
Dissemination of metallurgical knowledge by the holding of professional meetings, and by the preparation, presentation, discussion, and publication of technical papers. (d) Promoting high standards in the profession of metallurgical engineering.

Membership: Members, at least twenty-seven years of age with at least six years employment in engineering or application of the sciences to any branch of the mineral industry; Associate, must be interested in metallurgy or metallurgical engineering or application of the sciences to the metals industry; Junior, not over thirty years of age and qualified to hold a subordinate engineering position; Student, must be a full-time student in good standing in an approved school. Total membership 8,377.

\section{Mcetings: Semiannual.}

Professional activities: Extractive Metallurgy Division Award. Extractive Metallurgy Division Lecture. Robert Lansing Hardy Gold Medal. Howe Memorial Lecture. Robert W. Hunt Medal and Prize Fund. Institute of Metals Division Lecture. J. E. Johnson, Jr., Award. Journal of Metals Award. Mathewson Gold Medal. F. B. McKune Memorial Award. Open Hearth Conference Award. Leo F. Reinartz-AIME-NOHC Scholarship. Student Prize Paper Awards.

Publications: Journal of Metals, monthly, $\$ 10$. Editor: F. W. Starratt. Transactions, bimonthly, \$20. Editor: Gerhard Derge. Open Hearth Proceedings, annual, current volume: 42, \$10. Blast Furnace Proceedings, annual, current volume: 18, $\$ 10$. Electric Furnace Proceedings, annual, current volume: $16, \$ 10$. Editor: E. J. Kennedy (edits all proceedings).

908. Meteoritical Society. President: John A. Russell, Department of Astronomy, University of Southern California, Los Angeles 7, Calif. Term expires 1962. Executive Secretary: Gerald L. Rowland, Long Beach City College, Long Beach, Calif. Term expires 1962.

History: Founded 1933 as the Society for Research on Meteorites; incorporated 1936; name changed to present title September, 1946.

Purpose: To promote the discovery, collection, investigation, and preservation of meteorites; to forward the observation and study of meteors and other meteoritical phenomena; to advance meteoritics and related sciences through the increase and diffusion of knowledge concerning meteorites and meteors.

Membership: Nomination and second by any two nembers of the Society. Members, 83; Fellows, 58; Life, 7. Total membership 148.

Mcetings: Annual. 
Metric Association. See Addenda, No. 1589.

909. Metropolitan Dermatological Society of Los Angeles. President: Max Popper, 105 North San Vicente Street, Beverly Hills, Calif. Term expires December 31, 1960. Secretary-Treasurer: Rose B. Saperstein, 643 South Wilton Place, Los Angeles, Calif. Term expires December 31, 1960.

\section{History: Organized December 22, 1949.}

Purpose: To unite members of the Los Angeles County and other medical societies for furtherance of practice of dermatology and syphilology as a specialty; to study scientific, economic, and social aspects of dermatology.

Membership: Fellows, members of Los Angeles or other county medical associations, diplomates of American Board of Dermatology; Associates, members of above indicated associations eligible for examination by the Board. Total membership 61.

Mectings: Monthly, except during summer.

\section{Metropolitan Microchemical Society.} Chairman: Howard J. Francis, Jr., Pennsalt Chemicals Corporation, P. O. Box 4388, Philadelphia 18, Pa. Term expires September 1961. Secretary: Louis M. Brancone, Lederle Laboratories Division, American Cyanamid Co., Pearl River, N. Y. Term expires September 1961.

History: Began as the New York-New Jersey Section of the American Chemical Society's Microchemical Section; present constitution and by-laws adopted January 1936; name changed to present title March 1938.

Purpose: To promote interest in the practice and teaching of microchemical methods and in other related fields.

Membership: Interest in microchemistry. Members, 268; Life, 2; Honorary, 30. Total membership 300 .

Meetings: Monthly.

Professional activities: Annual Microchemical Symposium each spring.

Publications: Microchemical Journal, quarterly, current volume: $4, \$ 16$. Editor: Nicholas D. Cheronis.

911. Metropolitan New York Association for Applied Psychology. President: Frederick Hauser, c/o Kenyon and Eckhardt, Inc., 247 Park Avenue, New York 17, N. Y. Term expires September 1961. Secretary: Edith MacLauchlan, 10519-192 Street, Hollis 12, N. Y. Term expires September 1961.

History: Founded in 1938.

Purpose: To provide for the cooperative association of persons who are interested in the field of applied psychology; to promote and maintain professional standards among workers in the field of applied psychology; and to further the advancement of applied psychology as a science and a profession.

Mcmbership: Full members, 115, Ph.D. or Ed.D. degree in psychology with either (a) two years of appropriate experience in applied psychology or (b) significant publications in applied psychology. Membership is limited to persons living or working within the metropolitan New York area.

Meetings: Three to five meetings per year.

Professional activities: In 1960 the Society established a graduate student award. This award will be tendered on an annual basis to graduate students in the metropolitan New York area for significant research in applied psychology.

912. Michigan Acaderay of Science, Arts, and Letters. Ann Arbor, Mich. President: Conrad R. Lam, Chief, Thoracic Surgery, Henry Ford Hospita1, Detroit, Mich. Term expire March, 1961. Executive Secretary: F. Clever Bald, Assistant Director, Michigan Historical Collections, 160 Rackham Building, University of Michigan, Ann Arbor, Mich. Term expires March, 1961.

History: Organized 1894; incorporated 1895 as the Michigan Academy of Sciences; name changed to present title 1923. Sections : American Studies, Anthropology, Botany, Economics, Fine Arts, Fish and Wildlife, Folklore, Forestry, Geography, Geology and Mineralogy, History and Political Science, Landscape Architecture, Language and Literature, Mathematics, Philosophy, Psychology, Russian Studies, Sanitary and Medical Science, Sociology, and Zoology.

Purpose: The promotion of research and the diffusion of knowledge.

Membership: Anyone interested in the discovery and dissemination of knowledge in any of the physical sciences, social sciences, arts, or humanities may become a member. Regular members, 1,300; life members, 150.

Meetings: Annual.

Professional activities: Annual Award of Honorable Mention; awards to high school students for research accomplished; support from AAAS funds to aid research activities of Junior Academy members.

Publications: Papers, annual, current volume: 45, \$10. Annual Report, current volume: 62 . Editor: Sheridan W. Baker.

913. Michigan Allergy Society. President: Robert G. Lovell, 326 North Incalls Street, Ann Arbor, Mich. Term expires June 1961. 
Secretary: Hilda H. Hensel, 12 East 4th Street, Monroe, Mich. Term expires June 1961.

History: Organized November 1936.

Purpose: The advancement of research and dissemination of knowledge pertaining to allergic disease.

Membership: Member, physician of good repute whose major practice is confined to the specialty of allergy; Associate member, any physician or member of the related scientific disciplines of good repute, who is interested in allergy. Total membership approximately 100.

Mectings: Every two months from September to May.

Professional activities: Encourages research in the field of allergy and supports such by contribution to the American Foundation for Allergic Disease.

914. Michigan Archaeological Society. President: Edward V. Gillis, 2512 Union Street, N. E., Grand Rapids 5, Mich. Term expires April, 1961. Executive Secretary: Donald R. Hayes, 1725 West Dartmouth Street, Flint, Mich. Term expires April, 1961.

History: First organized about 1925; became inactive in 1940; was reorganized in 1950. Society consists of seven chapters located in different parts of state.

Purpose: To collaborate with professional archaeologists; to record and disseminate archaeological information; to preserve Michigan's antiquities.

Membership: Regular members, 215 ; family, 13; junior, 15. Total membership 278. Applicant must uphold the purposes of the organization. Regular members must be 21 years of age. Family membership consists of wife or husband of regular member; has all Society privileges, including vote. Institutional membership, no vote privilege. Sustaining membership, all privileges. Junior membership, no vote and no privileges of office. Honorary life membership, all privileges, appointment by Executive Board.

Mectings: Annual business meeting; annual workshop conference; Semiannual meetings of Executive Board.

Professional activities: Award of Merit for extraordinary achievement in archaeology.

Publications: Michigan Archaeologist, quarterly, current volume: 6 . Editor: E. F. Greenman.

915. Michigan Basin Geological Society. President: R. David Matthews, Dow Chemical Company, 650 Building, Midland, Mich. Term expires May 1961. Secretary-Treasurer:
James H. Kent, Michigan Geological Survey Division, Conservation Department, 436 Stevens T. Mason Building, Lansing, Mich. Term expires May 1961.

History: Organized 1936 as Michigan Geological Society; name changed to present title in 1957.

Purpose: To hold meetings for the purpose of discussing the geology, technology, economics, and conservation of petroleum, natural gas, and other mineral resources of the Michigan Basin; to encourage a greater exchange of information and knowledge in the field of geology and its related earth sciences; to arrange and sponsor at least one annual field trip to an area of geological interest to the members of this Society.

Membership: Members, any person actively engaged in the work of geology or in research pertaining to "geology or related technology, graduate of an institution of collegiate standing majoring in geology or related technology and in addition has had the equivalent of one year's experience in geology or related technology, or has presented to the Society an earth science paper pertaining to the geology of the Michigan Basin; Associate, any person who is attending a reputable institution of learning with the object of taking up geology as a life profession, or any person not actively engaged in the profession, but whose interest in the earth sciences is such that he may be classified as a student of geology. Total membership 186.

Meetings: Monthly, September to May.

Professional activities: Annual Field Trips within the Michigan Basin. Symposiums on subjects of current interest.

916. Michigan Engineering Society. 100 Farnsworth Avenue, Detroit 2, Mich. President: Dudley Newton, 4095 West Buena Vista Avenue, Detroit 38, Mich. Term expires May 1, 1961. Secretary: Alfred R. Martin, 1700 IVest High Street, Jackson, Mich. Term expires May 1, 1961. Executive Secretary: Joseph E. Wilbur, P. O. Box 573, Kalamazoo, Mich. Term indefinite.

History: Organized March 25, 1880, at Lansing, Mich.; incorporated and present name adopted 1934. Committees: Building Codes, Post Graduate Engineering Study, Manpower.

Purpose: To promote social, economic, and teclnical interests of members; to promote integration of engineering and civic activity and public service among engineers in Michigan.

Membership: Requires practical experience in engineering, architecture, or land surveying; or graduation from recognized schools of engineering; or registration as architects, professional 
engineers, or land surveyors. Total membership 965.

Meetings: Annual.

Publications: Michigan Engineer, bimonthly, current volume: 78, free to members. Editor: Stewart Greer.

917. Michigan Forestry and Park Association. Wells Hall E., Michigan State University, East Lansing, Mich. President: Jack Burton, Michigan State Highway Department, Alpena, Mich. Term expires February 1961. Secretary: Arthur T. IVilcox. Term expires February 1961.

History: Organized in 1925 to bring together foresters engaged in public park, roadside development, public utility, and city forestry work in order to promote inter-agency cooperation and improve technical practices; incorporated.

Purpose: To further high standards of forestry and park work in Michigan.

Membership: Open to those individuals employed or actively interested in the stated fields. 300 members.

Mectings: Semi-annual.

Publications: Proceedings, annual, current volume: $34, \$ 1$. Editor: A. T. Wilcox.

918. Michigan Industrial Medical Association. President: Duane L. Block, Ford Motor Company, 3001 Miller Road, Dearborn, Mich. Term expires spring 1961. Executive Secretary: Robert D. McIntosh, Ternstedt Division of General Motors Corporation, 6307 West Fort Street, Detroit, Mich. Term expires spring 1961.

History: A component society of the Industrial Medical Association.

Purpose: To foster study of problems peculiar to practice of industrial medicine and surgery, and to unite into one organization members of the medical profession interested in that field; to encourage development of methods of conservation and improvement of health of workers ; and to promote understanding of purposes and results of medical care of these workers.

Membership: Active members, 119, doctors of medicine, members of local medical societies, and interested in industrial medicine; Fellows, 75, special achievement in field; Associate, 3, over three years' medical practice. Total membership 197.

Meetings: Annual.

919. Michigan Psychological Association. 535 Glenmoor Street, East Lansing, Mich. President: John Brownfain, Veterans Administration Hospital, Dearborn, Mich. Term expires
January 1961. Executive Secretary: Esther L. Belcher. Term indefinite.

History: Organized September 1935; Constitution and by-laws adopted January 11, 1941, revised 1954.

Purpose: To provide effective utilization of psychology for best interests of the public; to work for improvement of psychology as science and profession; to provide integration of activities of psychologists through exchanges of information and opportunity for cooperative action.

Membership: Members, Doctors of Philosophy, or two years' graduate work in psychology or one year's graduate work in psychology and one year's experience in professional work; Associate, graduate students, persons distinguished in allied fields. Total membership 560 .

Meetings: Annual.

920. Michigan Public Health Association. 1817 West St. Joseph Street, Lansing 15, Mich. President: Otto Engelke, Wastenaw County Health Department, Ann Arbor, Mich. Term expires May 1961. Executive Secretary: Marjorie Delavan. Term expires May 1961.

History: Organized October 1919; incorporated December 1953.

Purpose: To promote public health in Michigan.

Membership: Active members, those devoting full time to public health or public health education; Associate, interested in public health but not eligible to be members; Honorary, for outstanding contributions in field of public health. Total membership 714 .

Mectings: Annual.

Publications: Newsletter, irregular. Editor: Marjorie Delavan.

921. Michigan Society of Anesthesiologists, Inc. 504 Doctors' Building, 3919 John R Street, Detroit 1, Mich. President: F. Greifenstein, Receiving Hospital, Detroit, Mich. Term expires October 1961.

History: Organized May 5, 1941 ; incorporated December 12, 1952. Five districts.

Purpose: To affiliate physicians interested in specialty of anesthesiology; to encourage specialization and raise standards in this field; to disseminate information to members and public; to protect public against irresponsible or unqualified practice of anesthesiology.

Membership: Active members, 124, physicians engaged in practice of anesthesiology who are members of American Society of Anesthesiologists; Junior, 39, physicians training full time in anesthesiology, or in some other specialty, 
but interested in this subject; Honorary, members who have rendered years of faithful service or attained eminence in anesthesiology; Associate, scientists or others who have attained eminence in this subject. Total membership 163.

\section{Meetings: Five annually.}

922. Michigan Society of Neurology and Psychiatry and Michigan District Branch of the American Psychiatric Association. President: Eugene J. Alexander, Henry Ford Hospital, Detroit 2, Mich. Term expires May 1961. Secretary: Max L. Gardner, 19557 Mack Avenue, Grosse Pointe 36, Mich. Term expires May 1961.

History: Organized as Detroit Society of Neurology and Psychiatry in 1908, name changed to Michigan Society of Neurology and Psychiatry in 1939 . Became an affiliate society of American Psychiatric Association in 1942, with a District Branch of the APA being formed in 1953. The two organizations function as one, with most of the membership belonging to both groups.

Purpose: To further the progress of the study and practice of neurology and psychiatry.

Membership: Honorary, 4; active, 256; associate, 37 ; affiliate, 29 ; non-resident, 16; life, 9. Michigan Society of Neurology and Psychiatry (active), licensed physicians, members of American or Canadian medical associations and/or American Psychiatric Association, with three years of approved training in neurology or psychiatry, with five years (including training) practice in field, or Diplomates of the American Board of Psychiatry and Neurology; (associate) licensed physicians, members of American or Canadian medical associations and/or American Psychiatric Association, devoting full time to training in neurology or psychiatry, neurology, or neurosurgery; (affiliate) those individuals who have completed advanced training in a discipline allied to neurology or psychiatry, members of the national association of that discipline and devoting full time to that area of work. Michigan District Branch of the American Psychiatric Association, (active and associate) qualifications for membership same as for membership in American Psychiatric Association.

Meetings: Monthly, September through April, except December; annual.

Professional activities: Research award of $\$ 250$ given annually to psychiatric resident for outstanding research in psychiatry, neurology, pharmacology, and allied fields.

923. Michigan Society of Professional Engineers, Inc. 314 Townsend Street, Lansing 23,
Mich. President: Merle Powers, 6902 Clio Street, Flint, Mich. Term expires July 1, 1961. Executive Director: Richard M. Cosgrove. Term indefinite.

History: Incorporated 1946; affiliated with National Society of Professional Engineers May 10, 1946. Fifteen local chapters. FuncTIONAL Groups: Consulting Engineers Association of Michigan; Professional Engineers of Industry.

Purpose: Advancement of public welfare, and professional, social, and economic interests of engineers.

Membership: Requires registration as engineer in Michigan, or in any State or territory of the United States. Total membership 2,200.

\section{Meetings: Annual.}

Professional activities: Annual Conference on Effective Utilization of Engineering Personnel; NSPE-ARMCO Civil Engineering Scholarship; NSPE Engineer of the Year Award; Scholastic Achievement Award (High School).

Publications: Michigan Professional Engineer, monthly. Editor: Kenneth B. Fishbeck.

924. Michigan State Medical Society. 120 West Saginaw Street, East Lansing, Mich. President: Milton A. Darling, 673 Fisher Building, Detroit 2, Mich. Term expires September 28, 1960. Executive Director: IVilliam J. Burns. Term expires September 1960. Secretary: D. Bruce Wiley, 45310 Van Dyke, Utica, Mich. Term expires September 1960.

\section{History: Organized 1866.}

Purpose: To promote the science and art of medicine, to protect public health, to better the medical profession, and to unite with similar organizations to form the American Medical Association.

Mcmbership: Active member, active menber of component county society; Honorary, any person distinguished for his services or attainments in medicine or the allied sciences, or who has rendered other services of unusual value to organized medicine or the medical profession; Associate, any person not a member of the profession but engaged in scientific or professional pursuits whose principles and ethics are consonant with those of this State Society, or an intern serving the first year in any approved hospital, or an intern of longer standing, or a resident physician in training, or a teaching fellow not engaged in private practice, or a physician resident of the State of Michigan for the period of time he is in active military service previous to his engaging in active practice, or a physician not engaging in any phase of medical practice, or a commissioned medical officer of the United States Army, Navy, 
Public Health Service or physician employed by the Veterans Administration on duty in this State, who is not engaged in private practice of medicine, or an Active member, by transfer, for the period of time he is temporarily out of active practice, on account of protracted illness, or an Active Member, by transfer, for the period of one year while he is temporarily out of practice on account of postgraduate medical studies; Retired, a member who has maintained membership in a component county society of this State Society for a period of ten or more years, and has retired from practice; NonResident, physician residing and practicing outside of the county who is a member in good standing of his own component county society; Life, physician who has been a member of the Michigan State Medical Society for a minimum of five years and who has attained the age of seventy years, or has been in practice fifty years, and has maintained an active membership in good standing for twenty-five years in any constituent state society of the American Medical Association; Military, any active member in good standing who serves on active duty in the military forces during a war or similar national emergency. Total membership 6,652.

Meetings: Annual.

Professional activities: Annual award to "Michigan's Foremost Family Physician".

Publications: Journal, monthly, current volume: 59, \$6. Editor: Wilfrid Haughey, 610 Post Building, Battle Creek, Mich.

925. Michigan State Pharmaceutical Association. 1812 Michigan National Tower, Lansing 8, Mich. President: Charles W. Hahn, 1671 West Sherman Boulevard, Muskegon, Mich. Term expires June 30, 1961. Executive Secretary: John H. Butts. Term indefinite.

History: Organized November 15, 1883; incorporated August 19, 1943.

Purpose: To improve the business conditions of druggists.

Membership: Active, pharmacists registered in Michigan owning and operating a licensed drug store; or pharmacists registered in Michigan who are members of a firm or corporation operating a licensed drug store, or pharmacists registered in Michigan who are members in good standing with their local drug associations; Associate, pharmacists registered in Michigan who have been or are now actively employed in a licensed drug store and persons engaged in the teaching of pharmacy and allied sciences at colleges of pharmacy and departments of pharmacy of any college or university in the state; Travelers' Auxiliary Members, salesmen for drug and pharmaceutical manufacturers, wholesale jobbers, and those manufacturers of products directly allied with the retail drug business; Sustaining, persons, firms, or corporations directly allied with the retail drug business; Honorary, persons who shall be selected by the active members because of distinguished service rendered to pharmacy and the Association. Total membership 2,350.

Meetings: Annual Convention and semiannual meeting.

926. Mid-Central States Orthopaedic Society, Inc. 3244 East Douglas Street, Wichita 8, Kans. President: Daniel L. Yancey, 1211 South Glenstone Street, Springfield, Mo. Term expires spring 1961. Secretary-Treasurer: H. O. Marsh. Term expires spring 1961.

History: Organized April 1953; incorporated June 1954. Sections: Arkansas, Colorado, Kansas, Missouri, Nebraska, Oklahoma.

Purpose: To further observation of matters related to orthopaedic surgery, and free discussion of orthopaedic methods and teaching among members.

Membership: Senior members, those who have reached the age of sixty-five; Active, Diplomates of American Board of Orthopaedic Surgery, and those who have made outstanding contributions to this specialty; Associate, those who have successfully passed Part I of the American Board of Orthopaedic Surgery, and who have completed their formal orthopaedic training. Total membership 178.

Meetings: Annual.

927. Middle Atlantic Society of Orthodontists. President: Kyrle W. Preis, 700 Cathedral Street, Baltimore 1, Md. Term expires October 11, 1960. Secretary-Treasurer: Charles S. Jones, Mayfair Apartments, Albany and Atlantic Avenues, Atlantic City, N. J. Term expires October 11, 1960.

History: Organized and incorporated 1951. Sections: Delaware, District of Columbia, Maryland, New Jersey, Pennsylvania (east of the Alleghenies).

Purpose: To advance the science and art of orthodontics, encourage and sponsor research, strive for higher standards in education and practice, and contribute to dental health service.

Membership: Requires five years' exclusive practice of orthodontics, successfully completed orthodontic courses of 1,500 or more hours, and membership in local, State, and national dental organizations. Active members, 150; Associate; Affiliated; Honorary; Retired. Total membership 150.

Meetings: Annual. 
928. Middle States Science Teachers Association. President: William D. Fritz, 118 South 1st Avenue, Highland Park, N. J. Term expires November 26, 1960. Secretary-Treasutrer: Miss Ruth A. Welde, 220 West 19th Street, Wilmington 2, Delaware. Term expires November 26, 1960.

History: First constitution adopted November 14, 1946; current constitution and by-laws adopted November 27, 1954.

Purpose: To improve science teaching in the Middle States: New York, New Jersey, Pennsylvania, Delaware, Maryland, and the District of Columbia.

Membership: Persons interested in the teaching of science. Total membership approximately 45.

Meetings: Annual.

929. Mid-Hudson District Branch, American Psychiatric Association. President: Robert C. Hunt, Station B, Poughkeepsie, N. I. Term expires May 1961. Executive Secretary: Walter Kern, Wingdale, N. Y. Term expires May 1961.

History: Originally established as Dutchess County Psychiatric Society; name changed to present title upon official inclusion in American Psychiatric Association, May 1960.

Purpose: To foster progress of psychiatry in the Mid-Hudson area.

Membership: Requires membership in American Psychiatric Association. Total membership 60.

Meetings: Quarterly.

930. Mid-South Postgraduate Medical Assembly. 774 Adams Avenue, Memphis 5, Tenn. President: Omar Simmons, Newton Hospital, Newton, Miss. Term expires February 1961. Executive Director: Leslie H. Adams. Term indefinite.

History: Founded 1879 , as Tri-State Postgraduate Medical Assembly; present name later adopted to encompass other States.

Purpose: Bringing together physicians of the mid-South in an educational and scientific organization.

Membership: Open to any legally qualified physician. Total membership 1,600.

Meetings: Annual.

931. Midwest Group of Astronomers. Washburn Observatory, University of Wisconsin, Madison 6, Wis. Secretary: John S. Mathis. Term indefinite.

History: Organized October 1940.
Purpose: To arrange meetings for presentation of new research results and discussion of general programs for the astronomers of the Middle IVest.

Membership: Open to professional astronomers and graduate students of astronomy. Total membership 50 .

Meetings: Twice a year.

\section{Midwestern Air Pollution Prevention}

Association, Inc. 10 West 35 th Street, Chicago 16, Ill. President: Haldon A. Leedy. Term expires December, 1960. Executive Secretary: C. E. Barthel, Jr. Term expires Deccmber, 1960.

History: Organized April 13, 1951, incorporated in lllinois. Conducted research resulting in report upon which new Air Pollution Control Ordinance for city of Chicago was based.

Purpose: To reduce air pollution in Chicago and suburbs by fostering control and prevention of air pollution, by promoting study and research of air pollution, by assisting municipalities and industries, by encouraging development and adoption of apparatus and operating procedures that abate air pollution, and by educating the public, owners, and operators.

Membership: Approximately 200 members. Open to individuals having an interest in field of air pollution control.

Meetings: Annual.

Professional activities: Research and education programs in field of air pollution control.

\section{Midwestern Association of Chemistry}

Teachers in Liberal Arts Colleges. President:

Paul M. Wright, IVheaton College, Wheaton, I11. Term expires November 1, 1960. Secretary-Treasurer: William A. Deskin, Cornell College, Mt. Vernon, Iowa. Term expires December 31, 1960.

\section{History: Organized October 1953.}

Purpose: To bring together teachers of chemistry in non-tax supported liberal arts colleges in the States of Illinois, Indiana, Iowa, Michigan, Minnesota, Missouri, and Wisconsin, for exchange of ideas and mutual helpfulness.

Membership: Active members, 162, teachers in dircet charge of chemistry courses as regular faculty members in liberal arts colleges in the States above listed; Associate, 38, persons not directly engaged in teaching chemistry in colleges involved, but definitely interested in their program. Total membership 200.

Meetings: Annual. 
934. Midwestern Psychological Association. President: Marion E. Bunch, Department of Psychology, Washington University, St. Louis, Mo. Term expires May 1961. Secretary-Treasurer: I. E. Farber, Department of Psychology, State University of lowa, Iowa City, Iowa. Term expires May 1961.

History: Organized 1926.

Purpose: To promote psychology as a science. Membership: Requires membership in American Psychological Association or endorsement by member of Midwestern Psychological Association and approval by its council. Total membership 2,455.

Meetings: Annual.

935. Milwaukee Roentgen Ray Society. President: Robert WV. Byrne, 3321 North Maryland Avenue, Milwaukee 11, Wis. Term expires April 1962. Executive Secretary: Joseph F. Wepfer, St. Joseph's Hospital, Milwaukee, Wis. Term expires April 1962.

History: Organized December 1923.

Purpose: To further standards of practice of radiology for mutual benefit and education of members, and for betterment of understanding among other medical professions.

Membership: Open to those practicing radiology or roentgenology. Total membership 43 . Meetings: Monthly.

936. Mineralogical Society of America. President: Joseph Murdoch, University of California at Los Angeles, Los Angeles, Calif. Term expires November 1960. Executive Secretary: George Switzer, U. S. National Museum, Washington 25, D. C. Term indefinite.

History: Organized December 30, 1919; incorporated 1937.

Purpose: Advancement of mineralogy, crystallography, petrology, geochemistry, and allied sciences.

Membership: Open to individuals interested in mineralogy and allied fields. Honorary Fellows, 4 ; Fellows, 400; Members, 1,700. Total membership 2,100.

Meetings: Annual.

Professional activities: Roebling Medal awarded for distinguished achievement in mineralogy. Mineralogical Society of America Award in recognition of outstanding contribution within fields of interest of the Society by an individual who shall not have reached the age of 37 before January 1 of the year in which the award is made.

Publications: American Mineralogist, bimonthly, current volume: $45, \$ 6$. Editor : Lewis S. Ramsdell, University of Michigan.
937. Mineralogical Society of Utah. 129 F Street, Salt Lake City 3, Utah. President: Leon S. Stanley. Term expires February 1961. Executive Secretary: Mrs. Lester A. Larson, 1348 South 14th East, Salt Lake City 5, Utah. Term expires February 1961.

\section{History: Organized in early 1939.}

Purpose: To foster and promote the collection of minerals, rock specimens, fossils, and gem material; to instruct in the classification and labeling of same; to sponsor and promote field trips for educational purposes; and to aid in the location, development, and utilization of our mineral resources; and any other related objects.

Membership: Members, 165, screened by membership committee only.

Meetings: Monthly, October to June.

Publications: Bulletin, irregular, current volume: 9, \$1. Editor: Leon S. Stanley. Field Guides, irregular, \$.50. Editor: Leon S. Stanley.

938. Mining and Metallurgical Society of America. 11 Broadway, New York 4, N. Y. President: James Boyd. Term expires 1961. Secretary: Carroll C. Bailey. Term expires 1961.

History: Organized April 1908; incorporated December 1910.

Purpose: To discuss, digest, and formally act upon broad principles and questions affecting economic and professional sides of the mining industry. All such action is by vote of all members. Excluded from consideration: Technology, methods, detail, and special interests.

Membership: Requires eight years' professional experience, of which five shall be in charge of responsible work. Metropolitan members; Non-Metropolitan ; Life; Honorary. Total membership 450.

Meetings: Annual.

Professional activities: Gold Medal, for special achievement in mining or metallurgy.

Publications: Bulletin, semiannual, current volume: $53, \$ 4.50$. News-Letter, monthly, current volume: 18 , free to members.

939. Minnesota Academy of Medicine. Town and Country Club, St. Paul, Minn. President: Wallace H. Cole, 1360 Lowry Medical Arts Building, St. Paul 2, Minn. Term expires April 1961. Secretary: James B. Carey, Jr. University of Minnesota Hospital, Minneapolis 14, Minn. Term expires April 1961.

History: Organized October 1887.

Purpose: Educational, scientific, medical, surgical, and social; exchange of scientific ideas. Menbership: Active members, graduates of 
medicine with five years of practice; Senior, active members for twenty-five years; Honorary; Fellows, all presidents of Academy automatically become Fellows upon expiration of terms of office, but retain privileges and duties of active members. Total nembership 105.

Mectings: Monthly, October through May.

Professional activities: Fellowship, \$500 annually to each of two worthy students.

940. Minnesota Academy of Occupational Medicine and Surgery. President: Robert Goltz, Medical Arts Building, Minneapolis 2, Minn. Term expires June 1961. Secretary: Lyman Clay, Marquette National Bank Building, Minneapolis 2, Minn. Term expires June 1961.

History: Organized May 1, 1953. In 1959 it became a component part of the Industrial Medical Association.

Purpose: To bring together physicians and surgeons in Minnesota whose interests lie in development of the field of occupational medicine and surgery; to foster sound occupational medical practices and to consolidate and make more effective the influence of its members in the educational, legislative, scientific, and social aspects of occupational health.

Memberslip: Active, physician residents of the state, members in good standing in local and state medical association and/or active members iu the American Medical Association who have been licensed to practice for five years or more, who have been actively engaged in field of occupational medicine and surgery for at least three years; Associate, physician residents of state and licensed to practice in state, members in good standing in local and state medical societies and/or active members in American Medical Association, and who are actively engaged in field of occupational medicine or surgery ; Non-Resident; Senior; Honorary ; Inactive. Total membership 85.

Meetings: Annual; Quarterly meetings.

941. Minnesota Academy of Science. 51 University Avenue, St. Paul 3, Minn. President: John Rendall, Minnesota Mining and Manufacturing Company, 444 McKnight Road, St. Paul, Minn. Term expires May 1961. Secretary: Joseph P. Emanuel, State College, Winona, Minn. Term expires May 1961.

History: Organized January 1873 as Minnesota Academy of Natural Sciences. This organization was formally dissolved February 1929, and a new organization of the present title was formed November 1932; incorporated 1935. Sections: Anthropology-Social Science; Botany; Geography-Geology; Physical Science; Science Education; Zoology.
Purpose: The advancement of pure and applied science through the fostering of research, education and understanding; to provide an organization of persons interested in science; to meet, present and discuss matters of science.

Membership: Any person who subscribes to the objectives and is nominated by a member. Regular, 1,200; Corporate, 20; Collegiate, 20.

Mectings: Semiannual.

Professional activities: Scholarships (Academy-1ndustry) to high school seniors for college studies. Cedar Creek Laboratory and Forest, jointly with the University of Minnesota.

Publications: Proceedings, annual, current volume: 28, free to members. Editor: Robert F. Spencer. Minnesota Journal of Science, 3 per year, current volume: $3, \$ 3$, free to members. Editor: Harry Goehring.

942. Minnesota Psychiatric Society. President: David Boyd, Mayo Clinic, Rochester, Minn. Term expires June 1, 1961. Secretary: Richard Steinhilber, Mayo Clinic, Rochester, Minn. Term expires June 1, 1961.

\section{History: Organized 1956.}

Purpose: To foster progress of, and represent psychiatry in, the Minnesota area, and to assist the American Psychiatric Association in promoting its aims and objectives.

Membership: Open to members of American Psychiatric Association residing in Minnesota. Total membership 105.

Meetings: Biannual.

943. Minnesota Psychological Association. 814 West Lake Street, Minneapolis, Minn. Executive Secretary: William Schofield, University of Minnesota, Minneapolis, Minn. Term expires December 31, 1960.

History: Founded 1936 as Minnesota Association for the Advancement of Psychology; name later changed to Minnesota Society for Applied Psychology; name changed to present title 1948; affiliate, American Psychological Association.

Purpose: To promote psychology as a science and means of advancing human welfare.

Membership: Members, masters' degrees or equivalents, with majors in psychology, and at least twelve months' full time employment in psychological work. Affiliates, bachelors' degrees, and either engaged in full time graduate study in psychology or employed in application of psychological techniques. Members, 300; Affiliates, 9; Life members, 7. Total membership 316.

Meetings: Annual.

Professional activities: Award for distinguished service to psychology; award for 
scholastic excellence in undergraduate study of psychology.

Publications: Newsletter, quarterly.

\section{Minnesota Public Health Association.}

President: A. B. Rosenfield, Minnesota Department of Health, University Campus, Minneapolis, Minn. Term expires September, 1960. Executivc Secretary: D. S. Fleming. Term expires September, 1960.

History: Organized in 1947 as an outgrowth of State Sanitary Conference; in 1948 became affiliated with American Public Health Association. In 1959 name changed to present title.

Purpose: To protect and promote public and personal health, and to associate in one organization all individuals and organizations in Minnesota interested in public health.

Membership: Total members 900. Active, persons professionally engaged in public health work in Minnesota, or interested in public health, or who are members or eligible for membership in American Public Health Association; Honorary, elected for distinguished service in public health; Sustaining, persons or corporations or organizations interested in public health.

\section{Meetings: Annual.}

Professional activities: Annual honorary memberships.

Publications: Conference Call, quarterly newsletter to membership.

\section{Minnesota Radiological Society. President:} Dave Burlingame, 435 Lowry Medical Arts Building, St. Paul 2, Minn. Term expires May 1961. Executive Secretary: Donald H. Peterson, 1355 Lowry Medical Arts Building, St. Paul 2, Minn. Term expires May 1961.

\section{History: Organized 1928.}

Purpose: Advancement of the science and art of radiology, and stimulation of fellowship among members.

Membership: Active members must be certified by Board of Radiology and be full time practicing radiologists and radiologic physicists; Associate, physicians or other persons in radiology ; Emeritus; Honorary; Fellowship, medical graduates in training in radiology. Total membership 108.

Meetings: Three annually.

Professional activities: Carman Lecture, supported in conjunction with Minnesota State Medical Association.

946. Minnesota Society of Anesthesiologists. 412 Delaware Street, S. E., Minneapolis 14, Minn. President: Russell W. Bagley, 6738 3rd Avenue, S., Minneapolis 23, Minn. Term expires
December 31, 1960. Executive Secretary: John R. Gordon, 2831 Benton Boulevard, Minneapolis 16, Minn. Term expires December $31,1960$.

\section{History: Founded August 30, 1947.}

Purpose: To advance the science and art of anesthesiology and to stimulate interest and promote progress in various aspects of the specialty.

Membership: Active members, 68, doctors of medicine engaged or specially interested in practice of anesthesiology and holding membership in county medical societies; Junior, 48, doctors of medicine engaged in training, on full time basis, in anesthesiology, or in some other specialty with interest in anesthesiology ; Honorary, 2 , doctors of medicine who have rendered years of faithful service to this Society; Associate, scientists and others who have attained eminence in anesthesiology and related subjects. Total membership 118.

Mectings: Semiannual.

Professional activities: Lectures by authorities in anesthesiology and related fields; presentation of scientific papers by members.

Minnesota State Medical Association. See Addenda, No. 1590.

947. Minnesota State Pharmaceutical Association. 2388 University Avenue, St. Paul 14, Minn. President: Paul C. Anderson, Duluth, Minn. Term expires May 1961. Executive Secretary: Henry M. Moen. Term expires May 1961.

History: Organized 1884.

Purpose: Promotion of the science and art of pharmacy.

Membership: Proprietors and clerks who are registered pharmacists are eligible to membership. Total membership 1,927.

Mcetings: Annual.

Professional activities: A scholarship and a fellowship are maintained at the University of Minnesota.

Publications: Minnesota Pharmacist, monthly, current volume: $15, \$ 1$, free to members. Editor: Henry M. Moen.

948. Minnesota Tuberculosis and Health Association. 614 Portland Avenue, St. Paul 2, Minn. President: Herman Kleinman, Minnesota Department of Health, Minneapolis 14, Minn. Term expires March 31, 1962. Secretary: Mrs. Inez E. Anderson, Buffalo, Minn. Term expires March 31, 1962.

History: Organized 1906, as Minnesota Association for the Prevention and Relief of 
Tuberculosis; name changed in 1914 to Minnesota Public Health Association, and to present title in April 1952.

Purpose: To carry on a continuing anti-tuberculosis educational, case-finding, rehabilitation, and research program; to cooperate with the National Tuberculosis Association, and with national, regional, and State Trudeau societies; to promote public health in Minnesota, in cooperation with State and local health authorities.

Mcmbership: Presidents of county affiliates, members-at-large, Minnesota Trudeau Medical Society officers, Executive Board members, and Honorary members. Total membership 167.

Meetings: Annual.

Publications: Everybody's Health, bimonthly, current volume: 44, Minnesota $\$ 1$, elsewhere \$1.50. Editor: Geraldyn Vessels.

949. Mississippi Academy of Sciences, Inc. Mississippi State University, State College, Miss. Presidcnt: A. H. Germany, Mississippi College, Clinton, Miss. Term expires April 1961. Executive Secretary: Clyde Q. Sheely. Term expires April 1961.

History: Organized March 1930 and incorporated July 1947, with home office at Mississippi State University. Organization is composed of approximately 300 members from Mississippi colleges and universities, junior colleges, high schools, industries, and others interested in science.

Purpose: To encourage scientific research, to promote development of interest in scientific matters in the state, to render public service in scientific matters, to cooperate with scientific bodies having similar aims.

Membership: Demonstrated scientific interest. Regular members, 200 ; student members, 75; life members, 4; sustaining members, 35 .

Meetings: Annual.

Professional activities: Gulf Coast Research Laboratory; District Science Fairs involving 10,000 exhibits; Junior Academy contest program; high school science visitation program sponsored by National Science Foundation.

Publications: Journal, every 3 years, current volume: 5, \$1. Editor: Mrs. Katherine Mather.

950. Mississippi Geological Society. P. O. Box 422, Jackson, Miss. President: R. V. Ewing, Dixie Geological Service, P. O. Box 999, Jackson, Miss. Term expires May 1961. Secretary: Alan Jackson, Humble Oil and Refining Company, P. O. Box 1390, Hattiesburg, Miss. Term expires May 1961.

History: Organized November 28, 1939. Committees: Cenozoic, Mesozoic, and Paleozoic.
Purpose: To stimulate interest in the various phases of geology; to promote professional fellowship among members; and to disseminate and discuss geological information.

Membership: Open to any person who is actively engaged in geological work or associated sciences. Total membership 404.

Meetings: Bimonthly.

Publications: News Bulletin, monthly, free to members. Editor: Robert Violette.

951. Mississippi Psychiatric Society. President: Arthur J. Roberts. Term expires May 1961. Secretary-Treasurer: L. B. Lamm, Veterans Administration Hospital, Gulfport, Miss. Term expires May 1961.

History: Established March 1959, as District Branch, American Psychiatric Association.

Purpose: To foster progress of and to represent psychiatry in Mississippi, and to assist American Psychiatric Association in promoting its aims and objectives.

Menbership: Requires membership in American Psychiatric Association and residence in Mississippi. Total membership 24.

Mectings: Annual.

952. Mississippi Radiological Society. President: Robert R. Surratt, 745 North State Street, Jackson 2, Miss. Term expires February 1961. Executive Secretary: Bernard T. Hickman. Term expires February 1961.

History: Organized and incorporated November 20, 1950.

Purpose: To establish and maintain a high standard in the practice of radiology in Mississippi.

Menlbership: Open to members in county medical societies in good standing, and diplomates of American Board of Radiology. Active members, 25; resident associate members, 6.

Meetings: Monthly.

953. Mississippi Society of Professional Engineers. Barnett Building, Jackson, Miss. President: Eugene Thomas, 1059 Alta Vista Boulevard, Jackson, Miss. Term expires January 1961. Secretary-Treasurer: Fred J. Guice. Term expires January 1961.

History: Organized September 1939. Delta Chapter formed in May 1959. Functional Sections: Engineers in private practice formed in 1958; Engineers in government, being organized; Engineers in industry, under study.

Purpose: To represent the body of Engineers in Mississippi and to encourage high standards of engineering education in the State by creat- 
ing public interest in the value of engineering services; to strengthen and broaden the educational, professional, social, and economic interests of the eugineering profession through mutual aid and support, by attention to public relations, through legislation, and by the maintenance of the integrity and high standards of professional practice; to promote the advancement and protect the interest of the engineerin-training; and to create and advance public recognition of the professional status of the engineer and the value of the functions, requirements, and accomplishments of engineering.

Membership: Regular, Professional Engineer, 562; Engineers-in-Training, 21, person holding a valid certificate of registration as an Engineerin-Training, after ten years must advance to the status of Professional Engineer Member; Life, 5; Introductory, 22. Total membership 610.

Meetings: Annual; summer meeting.

Professional activities: Sponsors State Registration Law for engineers and a proposed law for registration of Land Surveyors. Legislative Committee maintains constant surveillance of proposed legislation at the state and local level. Ethics and Practices Committee controls unethical practice. Adopts and publishes schedules of recommended fees and salaries. Interprofessional Relations Committee cooperates with the American Institute of Architects to resolve problems of mutual interest. Engineers-inIndustry Committee program of service to engineering employees of industry. Education scholarships: annual award to a third year engineering student at Mississippi State University; annual award to a third year student at University of Mississippi; Herbert A. Kroeze Scholarship for graduate study in sanitary engineering; assistance in electing annual ARMCONSPE Civil Engineering Scholarship winner. Co-sponsor of annual Mississippi Highway Conference and National Engineers' Week activities in Mississippi.

954. Mississippi State Medical Association. 735 Riverside Drive, Jackson, Miss. President: G. Swink Hicks, Natchez, Miss. Term expires May 15, 1961. Secretary: R. B. Kennedy. Term expires 1963.

History: Organized December 15, 1856; incorporated 1895. Sections: Sixteen component county medical societies. Scientific Sections: Eye, Ear, Nose, and Throat; Medicine; Obstetrics and Gynecology; Pediatrics; Preventive Medicine; Surgery.

Purpose: Scientific improvement of medicine.

Membership: Must be licensed doctors of medicine in Mississippi, approved for membership in component medical societies, and mem- bers, American Medical Association. Total membership 1,400.

Meetings: Annual.

Professional activities: Annual award for scientific exhibits; refresher medical courses.

Publications: Journal, monthly, current volume: 4 , free to members. Edited by Board of Trustees.

Library: 5,000 volumes. Subject emphasis: General medical, and history of medicine.

955. Mississippi State Pharmaceutical Association. P. O. Box 246, University, Miss. President: James T. Morris, 1202 North State Street, Jackson, Miss. Term expires June 19, 1961. Secretary: Mrs. IV. W. Johnson. Term expires June 14, 1962.

History: Organized 1869; incorporated 1912. The Association is divided into twelve districts.

Purpose: To improve and regulate the drug market by preventing the importation of inferior, adulterated or deteriorated drugs; to improve the science and art of pharmacy by diffusing scientific knowledge among pharmacists; to regulate the system of apprenticeship and employment to prevent the evils of deficient training.

Membership: Members, 834, registered pharmacists in Mississippi and/or owner/manager of licensed drug stores; Life, 2; Honorary, 5. Total membership 841

Mectings: Annual.

Professional activities: Loan fund for students enrolled in the School of Pharmacy, University of Mississippi.

956. Mississippi Valley Medical Society. W. C. U. Building, Quincy, Ill. President: Arkell M. Vaughn, 2015 East 79th Street, Chicago 49, I11. Term expires November 1960. Secretary-Treasurer: Harold Swanberg. Term expires November 1960.

History: Organized April 8, 1935; incorporated November 1935; affiliate, American Association for the Advancement of Science.

Purpose: To promote the science and art of medicine, and the betterment of public health in Illinois, Iowa, and Missouri; to provide a yearly program of intense postgraduate instruction of practical work for general practitioners conducted by leading clinicians.

Membership: Requires membership in a county medical society of American Medical Association. Total membership approximately 1,100 .

Meetings: Annual.

Professional activities: Endowment Fund, $\$ 9,893$, to help perpetuate the Society; Scholar- 
ship Awards, two-year membership in Society to five graduates of medical schools in Illinois, Iowa, and Missouri, approved by medical school deans; Scientific Exhibit Award, for best exhibit at annual mecting, medal and certificate; Essay Award, for best unpublished essay of practicable and applicable value to the general practitioner of medicine, $\$ 100$ and gold medal; Distinguished Service Award, annual, to a member who has rendered unusual and distinguished service to the medical profession, gold medal; Honor Award, annual, to a non-member who has made distinguished contributions to clinical medicine; Certificates of Attendance, to active members who attend ten annual meetings.

Publications: Mississippi Valley Medical Journal, bimonthly, current volume: $81, \$ 6$. Editor: Harold Swanberg.

957. Missouri Archaeological Society, Inc., 15 Switzler Hall, University of Missouri, Columbia, Mo. President: Henry W. Hamilton, 537 Eastwood Street, Marshall, Mo. Term expires January 1961. Executive Secretary: Carl H. Chapman, 211 Edgewood Street, Columbia, Mo. Term indefinite.

History: Organized 1934; incorporated 1955. Chapters : Marion-Ralls, Hannibal; Greater St. Louis; Kansas City; Northwest, Maryville; Ozarks, Springfield; Osage, Nevada; Grand River, Trenton; Big Bend, Marshall; Maramec Springs, St. James. Committee: Preservation of Archaeological Sites.

Purpose: To preserve the remains of prehistoric peoples of Missouri; to study these remains scientifically; to publish information about them; to provide amateurs and professional archaeologists with opportunities to discuss their common interests; to stimulate public opinion to the appreciation of Missouri's antiquities.

Membership: Open to individuals with a genuine interest in archaeology and in the purpose of the Society. Active; Supporting; Contributing; Associate, under eighteen years of age; Institutional, museum, library or other organization; Life; Sustaining; Benefactor. Total membership 1,351, predominantly Active nembers.

Mectings: Twice a year.

Professional activities: Archaeological Survey of $M$ issouri, conducted in cooperation with the Division of Archaeological Research, University of Missouri; training in archaeological techniques in cooperation with the University of Missouri; annual Achievement Award, to outstanding amateur archaeologist; Jesse E. Wrench Scholarship Fund; Memoir Fund, for publication of outstanding monographs on archaeology ; Research Fund, to aid in archaeological research in Missouri; Scholarship Fund, to aid a student in anthropology at the University of Missouri.

Publications: Missouri Archaeologist, yearly, current volume: $22, \$ 2$. Editor: Robert T. Bray. Memoir, occasionally, current volume: 3, \$1. Editor: Carl H. Chapman. Newsletter, ten times per year, current volume: 142, members only. Editor: Dale R. Henning.

958. Missouri Association of Osteopathic Physicians and Surgeons. 325 East McCarty Street, Jefferson City, Mo. President: George IV. Ringland, 46 North Main Street, Cape Girardeau, Mo. Term expires October 1960. Executive Secretary-Treasurer: Paul D. Adams, Route 5, Jefferson City, Mo. Term indefinite.

History: Organized 1897. Geographic DisTRICTS: Northwest, North Central, Northeast, Central, Jackson County, West Central, Southwest, Ozark, Southeast, St. Louis, Osage, Central Ozark, Mineral Area, and West. DEPARTments: Public Affairs, Professional Affairs, Business Affairs, Twenty-eight committees. Affiliated with Missouri Osteopathic Surgical Society, Missouri Osteopathic Obstetrical and Gynecological Society, Missouri Society of Radiology, Missouri Society of General Practitioners in Osteopathic Medicine and Surgery, and Missouri Osteopathic Hospital Association.

Purpose: To promote health services through organized osteopathy.

Membership: Active, must be a graduate of an approved osteopathic college and licensed to practice osteopathy in the State of Missouri, and shall be engaged in practice in the State of Missouri; Associate, those teaching, research, administrative or executive employees of approved osteopathic colleges or of osteopathic hospitals approved by the American Osteopathic Association for intern teaching, and administrative employees of this association, or of affiliated organizations, or divisional societies; Honorary Life, granted as an award for meritorious service in the interest of osteopathy; Life, a member who has reached the age of seventy years, or who has completed forty-five years of osteopathic practice, and who is in good standing in the State Association for twenty-five years. Total membership 1,100 .

\section{Mectings: Annual.}

Professional activities: Nursing scholarships, fellowships, college support through membership dues; intern and residency training programs in affiliated hospitals.

Publications: Co-Operation, monthly, current volume: 35. Editor: Paul D. Adams. 
959. Missouri Pharmaceutical Association. Presidcnt: Jack Davidson, 2501 Jackson Street, Joplin, Mo. Term expires March 1961. Executive Secretary: Mrs. Cora D. Cox, 601 Central Trust Building, Jefferson City, Mo. Term indefinite.

\section{History: Organized October 29, 1879.}

Purpose: To improve the science and art of pharmacy by diffusing scientific knowledge among apothecaries and druggists, fostering pharmaceutical literature, developing talent, stimulating discovery, invention, stimulating inquiry as to quality of drugs and chemicals, detecting and exposing adulteration and encouraging home production and manufacture in the several departments of the drug business; to suppress empiricism, and to restrict the dispensing and sale of medicines to regularly educated pharmacists; to uphold standards of authority in the education, theory, and practice of pharmacy; to create and maintain a standard of professional honesty equal to the amount of our professional knowledge, with a view to the highest good and greatest protection to the public.

Mcmbership: Open to all registered pharmacists in the State of Missouri and to instructors who are interested in pharmacy or allied subjects; Associate, open to those who are actively engaged in the manufacture or wholesale distribution of pharmaceuticals or related materials; Student, open to those in the accredited colleges of pharmacy in Missouri; Honorary, open to those who by their efforts have contributed in an outstanding manner to the advancement of the profession of pharmacy. Total membership 1,600.

Meetings: Annual.

Publications: Missouri Pharmacist, monthly, current volume: $34, \$ 5$. Editor: Cora D. Cox.

960. Missouri Psychological Association. President: C. Kermit Phelps, Veterans Administration Regional Office, Kansas City, Mo. Term expires April 1961. Secretary: Arnold H. Hilden, Webster Groves 19, Mo. Term expires April 1962.

History: Founded February 22, 1947 ; incorporated August 26, 1954.

Purpose: To promote psychology as a profession and as a science.

Membership: Members, 101, doctoral degree, engaged in study or work primarily psychological; Fellows, 28, membership for one year, doctoral degree, outstanding performance in field of psychology ; Associates, 45, two years of graduate work, or master's degree and one year of acceptable experience in psychology. Total membership 174.
Meetings: Annual.

Publications: Missouri Psychologist, irregular, current volume: 14, free to members. Editor: Eugene Chambers.

961. Missouri Public Health Association. P. O. Box 570, Jefferson City, Mo. President: IV. G. Green, Columbia, Mo. Term expires 1961. Secretary-Treasurer: Mrs. Nadia Craver. Term expires 1961.

History: Organized 1924; incorporated July 20, 1951. Sections: Business and Statistics, Dental Health, Laboratory, Health Officer, Health Education, Public Health Nursing, Saniation, Medical Care Services.

Purpose: To promote and protect public health in Missouri.

Mcmbership: Open to any person engaged or interested in any branch of public health work in Missouri. Total membership approximately 500 .

Mectings: Annual.

Professional activities: IV. Scott Johnson Award, for outstanding contribution to public health.

Publications: News Report, three annually.

962. Missouri Society of Anesthesiologists. 1414 Vestwind Drive, Des Peres 31, Mo. President: Oral B. Crawford, 215 Professional Building, Sprinfield, Mo. Term expires April 1961. Exccutive Secretary: John F. Schweiss. Term expires April 1962.

History: Organized April 6, 1948. Component society of the American Society of Anesthesiologists.

Purpose: To advance the science and art of anesthesiology.

Membership: Active, physicians, graduates of approved medical schools or having passed the qualifying examination for Foreign Medical Graduates, licensed in the State of Missouri, membership in the American Society of Anesthesiologists and the county medical society. Active, 78; Junior, 21; Associate, 3; Retired, 3. Total membership 105.

Meetings: Two a year.

963. Missouri Society of Professional Engineers.

P. O. Box 365, Jefferson City, Mo. President:

C. W. Schemm, 1118 Syndicate Trust Building, St. Louis, Mo. Term expires June 30, 1961. Executive Director: Paul N. Doll. Term indefinite.

History: Formed January 9, 1937; affiliated July 19, 1946 with the National Society of Professional Engineers. Jurisdictional area covers the State of Missouri. Twelve chapters, whose 
jurisdictional areas likewise cover all of the State of Missouri. Twenty committees covering professional, social, and economic aspects of engineering.

Purpose: Advancement of the engineering profession in its several branches; professional improvement of its members; encouragement of social relations among its members; sponsorship of legislation protecting the public and the profession against irresponsible engineering practices.

Membership: Regular Members, registration as a Professional Engineer; Engineer-in-Training Members, enrollment as an Engineer-inTraining. Regular Members, 2,200; Engineerin-Training Members, 500. Total membership 2,700 .

\section{Meetings: Annual.}

Professional activities: Approximately twenty scholarships presented annually by the Society and its twelve chapters, all based on scholastic excellence of engineering and pre-engineering students.

Publications: Missouri Engineer, monthly, current volume: 24, \$2. Editor: Paul N. Doll.

964. Missouri State Medical Association. 634 North Grand Boulevard, St. Louis 3, Mo. President: R. O. Muether, 4161 Lindell Boulevard, St. Louis 8, Mo. Term expires March 1961. Executive Sccretary: T. R. O'Brien. Term indefinite.

History: Organized 1850.

Purpose: To promote the science and art of medicine and to improve the medical profession.

Membership: Members, 3,770, doctors of medicine licensed to practice in the State of Missouri and who are citizens of the United States.

Mectings: Annual.

Publications: Missouri Medicine, monthly, current volume: 57, \$3. Editor: Charles R. Doyle.

965. Montana Academy of Oto-Ophthalmology. President: Cecil Hall, Great Falls, Mont. Term expires 1961. Secretary: Robert Morgan, Helena, Mont. Term expires 1961.

History: Organized February 1923.

Purpose: The promotion of oto-ophthalmology.

Membership: Active, Honorary, and Life members. Total membership 36 .

Meetings: Biennial.

966. Montana Academy of Sciences. President: John H. Rumely, Montana State College, Bozeman, Mont. Term expires April 1961.
Executive Secretary: LeRoy Harvey, Montana State University, Missoula, Mont. Term expires April 1961.

History: Organized November 1940. SECTions: Zoology, Botany, Physical Sciences, Social Sciences, Teaching of Sciences.

Purpose: To encourage scientific work and facilitate the diffusion of scientific knowledge.

Membership: Open to those persons with an interest in the purposes and activities of the Academy, Regular Members, 155; Honorary Members, 14.

Meetings: Annual.

Professional activities: Supports Science Talent Search; high school science fairs. National Science Foundation Grant for "Visiting Scientists," program in Montana high schools, 1960-1961.

Publications: Proceedings, annual, current volume : $21, \$ 1.50$. Editor: Clifford V. Davis.

967. Montana Medical Association. P. O. Box 1692, Billings, Mont. President: Harold W. Fuller, 1220 Central Avenue, Great Falls, Mont. Term expires September 16, 1961. Executive Sccretary: L. R. Hegland. Term indefinite.

History: Organized January 29, 1879, as the Medical Association of Montana; name changed to present title in 1951.

Purposc: To promote and advance the science and art of medicine, to unite the medical profession, and to promote public health.

Membership: Active, 557, licensed to practice in Montana, ethical and of good moral character; inactive, 46; Honorary, 7. Total membership 610 .

Mcctings: Semiannual.

Publications: Rocky Mountain Medical Journal, monthly, free to members. Managing Editor: Harvey T. Sethman, 835 Republic Building, Denver 2, Colo. Scientific Editor for Montana: Perry M. Berg, Billings, Mont.

968. Montana Society of Engineers. Presidcnt: William J. Wenzel, IVenzel and Company, P. O. Box 2091, Great Falls, Mont. Term expires May 1961. Secretary: Arthur W. Clarkson. Term expires May 1961.

History: Organized July 1887 as the Montana Society of Civil Engineers; name changed to present title February 1897.

Purpose: The advancement of engineering and promotion of interest in the profession; unification of different branches for mutual benefit in the State of Montana.

Membership: Members, 475, registered professional engineers or eligible for registration, 
engineers in training and others working on engineering for a profession.

Mectings: Annual; chapter meetings held monthly October through April.

Professional activities: Gold Medal or engraved watch awarded annually to the outstanding member of the senior engineering class at both Montana School of Mines and Montana State College. Participate in the ARMCONSPE scholarship award.

969. Montclair Society of Engineers. President: Edward E. Mcllveen, 12 Stonehenge Road, Upper Montclair, N. J. Term expires June 1, 1961. Secretary: C. E. Parmelee, 85 Norwood Avenue, Upper Montclair, N. J. Term expires June 1, 1961.

IIistory: Organized October 1924 in Montclair, N. J.

Purpose: To unite the engineers of Montclair and vicinity, thereby promoting friendly associations and enabling them to contribute their professional knowledge and experience to the solution of community problems.

Membership: A graduate of an engineering college, or actively engaged in engineering work, or serving in an administrative or executive position in engineering work. Total membership 630 .

Meetings: Six meetings annually.

Professional activities: Scholarship Awards, loans and prizes are made annually to outstanding high school graduates to assist them in the first year's expenses at an engineering college.

Publications: Yearbook.

970. Municipal Engineers of the City of New York. 29 West 39th Street, New York 18, N. Y. President: Patrick J. O'Leary. Term expires December 31, 1960. Secretary: Lee $N$. Komiakoff. Term expires December 31, 1960.

\section{History: Organized 1903.}

Purpose: To promote and advance the various engineering sciences which are employed in the government of the City of New York, and to elevate the standard of efficiency of engineers employed in the various departments of the city.

Membership: Members, 580, licensed engineers; Associates, 70. Total membership, 650.

Meetings: Monthly from September to May.

Professional activities: A Medal is presented for the best engineering paper presented during the year.

Publications: Municipal Engineers Journal, quarterly, current volume: 45 (1959), $\$ 0.50$. Editor: Meyer F. Wiles.
971. Mycological Society of America. Rancho Santa Ana Botanic Garden, Claremont, Calif. Secretary-Trcasurer: Richard K. Benjamin. Term expires September 1, 1962.

History: Founded December 1931. Formerly the Mycological Section of the Botanical Society of America.

Purpose: To foster the study of mycology.

Membership: Open to all persons interested in the study of fungi. Total membership approximately 760 .

Mectings: Annual, usually with the American Institute of Biological Sciences.

Professional activities: Annual Mycological Society Graduate Fellowship, $\$ 750$.

Publications: Mycologia, bimonthly, current volume: 52, free to members. Editor: Donald P. Rogers. Newsletter, semiannually, current volume: 11, free. Editor: Richard K. Benjamin.

972. Nantucket Maria Mitchell Association. 1 Vestal Street, Nantucket, Mass. President: Edouard A. Stackpole. Term expires July 15, 1961. Secretary: A. P. Robbins, 52 Center Street, Nantucket, Mass. Term expires July 1961.

History: Founded 1902; incorporated 1903; observatory built 1908. Divisions: Astronomy, Memorial House, Natural Science, Scientific Library. Committees: Astronomical, Natural Science.

Purpose: To commemorate Maria Mitchell, first woman astronomer of America.

Membcrship: Professional requirements do not apply to membership, but to directors of departments, and to committee members who direct departments. Annual Members, 178; Honorary, 11; Sustaining, 39 ; Life, 261 ; Contributing, 23; Junior, 75. Total individual membership 587. Societies and Clubs: Sustaining Members, 4; Life, 5. Total institutional membership 9 .

Meetings: Annual.

Professional activitics: Research conducted in photometry of variable stars and asteroids; Astronomical Endowment Fund, for research in that field; General Endowment Fund; Mary A. Mitchell Albertson Memorial Fund, for work in natural science; laboratory maintained in Nantucket, with staff of three; astronomical observatory, with staff of two.

Library: 9,500 volumes. Subject emphasis: Astronomy and natural science.

973. Nassau Neuropsychiatric Society. President: Abraham S. Lenzner, 1 Sussex Road, Great Neck, N. Y. Term expires May 1961. Executive Secretary: Charles L. Nord, 230 
Hilton Avenue, Hempstead, N. Y. Term expires May 1961.

History: Founded 1948; assumed representational status as District Branch of American Psychiatric Association 1953.

Purpose: To advance highest standards of psychiatric and neurologic practice; to encourage research and postgraduate education.

Membership: Requires qualification for American Board of Psychiatry, or equivalent experience, or membership, American Psychiatric Association. Total membership 110.

Meetings: Monthly, for eight months annually.

974. Nassau Radiological Society. 100 Newbridge Road, Hicksville, N. Y. President: Nathaniel Robin, 520 Franklin Avenue Garden City, N. Y. Term expires June 30, 1961. Secretary: Alan E. Baum. Term expires June 30, 1961.

History: Organized November 1951; incorporated June 1953.

Purpose: To advance the science of radiology, foster interests of members, and improve plysician-patient relationship.

Membership: Full members, Board radiologists ; Associates, practicing radiologists ; Special members, related specialists. Regular members, 47 ; Corresponding, 1 ; Special, 2. Total membership 50 .

Meetings: Five annually.

\section{National Academy of Sciences-National}

Research Council. 2101 Constitution Avenue, N. IV., Washington 25, D. C. President of the Academy: Detlev WV. Bronk. Term expires June 1962. Home Secretary of the Academy: Hugh L. Dryden. Term expires June 1963. Chairman of the Research Council: (vacant). Executive Officer of the Academy-Research Council: S. D. Cornell.

History: Chartered as a private, nonprofit corporation by Act of Congress, signed by President Lincoln on March 3, 1863. Fourteen SECTIONS: Mathematics, Astronomy, Physics, Engineering, Chemistry, Geology, Botany, Zoology and Anatomy, Physiology, Pathology and Microbiology, Anthropology, Psychology, Geophysics, Biochemistry. The Council of the Academy, which is responsible for the general conduct of Academy affairs, is composed of the five elected officers of the Academy, the chairman of the National Research Council (if a member of the Academy), and six other members elected by the Academy.

In 1916 President Wilson requested the Academy to organize the research resources of the country, both because of the impending war and because of the importance of developing and utilizing science more effectively in peacetime. Accordingly, the Academy established the National Research Council as a means through which scientists generally could associate their efforts with those of the limited membership of the Academy in service to the nation, society, and science. The Academy-Research Council is now organized in eight Divisions: Anthropology and Psychology, Biology and Agriculture, Chemistry and Chemical Technology, Earth Sciences, Engineering and Industrial Research, Mathematics, Medical Sciences, and Physical Sciences. In addition, the Office of International Relations, the Office of Scientific Personnel, and the Office of Documentation deal with particular problems in their areas of interest. The Governing Board of the AcademyResearch Council is composed of the Council of the Acariemy and the chairmen of the eight Divisions.

Purpose: To promote science and its applications to human welfare, and to investigate and report upon any subject of science or technology whenever called upon by the Government of the United States.

Membership: Membership of the Academy, 615 , citizens of the United States; Members Emeriti, 11; Foreign Associates, 65. Members are elected by the Academy on nomination of the Sections or the Council of the Academy; limited to thirty-five new members annually. Foreign Associates are elected by the Academy on nomination by the Council of the Academy; limited to election of four annually.

Membership of the Research Council, 275, citizens of the United States, appointed by the President of the Academy. Membership includes 161 representatives nominated by the major scientific and technical societies of the country, 48 representatives of the Government designated by the President of the United States, and 66 members-at-large. Members are assigned to Divisions according to their scientific and technological interests. In addition, several thousand scientists and engineers take part in the work of the Academy-Research Council through membership on its various boards and committees.

Meetings: The Academy meets semiannually, in April in Washington, D. C., and in the autumn at the time and place determined by the Council of the Academy. Scientific sessions at both meetings are open to the public. The National Research Council meets each March in Washington, D. C. The Council of the Academy meets six times a year, the Governing Board five times a year, and each division at least once a year. Numerous meetings of com- 
mittees, boards, and other groups are held during the year.

Professional activities: Total expenditures for the operation of the Academy-Research Council are approximately $\$ 15$ million annually, about one third of which is from private grants and contracts and from endowment income, and the remainder from Federal Government sources by grant or contract for advisory services. These expenditures include sums for conferences and meetings of committees and boards, for the support of fellowships, for special projects, and for general administration. In addition, many millions of dollars are spent by other organizations in the support of science through fellowships, grants-in-aid of research, and basic research contracts upon advice rendered by the Academy-Research Council.

Funds for the general purposes of the Academy-Research Council have included a grant of $\$ 5$ million from the Carnegie Corporation in 1921, a part of which was used for construction of the Academy-Research Council building, the remainder serving as a permanent endowment. Other funds for general purposes are: Agassiz Fund, $\$ 50,000$, bequeathed by Alexander Agassiz, a charter member of the Academy; Billings Fund, $\$ 26,000$, bequeathed by Mary Anna Draper in 1915; and Nealley Fund, \$19,555, bequeathed by George True Nealley in 1925 .

Trust funds for the support of research or for the honoring of achievements in science are: Alexander Dallas Bache Fund, $\$ 60,000$, for researches in physical and natural sciences; John J. Carty Fund, $\$ 25,000$, to provide a gold medal and monetary award not oftener than once in two years to an individual for noteworthy and distinguished accomplishment in any field of science coming within the scope of the Academy; Cyrus B. Comstock Fund, $\$ 15,000$. to provide a prize every five years for the most important discovery or investigation in electricity, magnetism, or radiant energy, or to aid worthy investigation in these subjects; Henry Draper Fund, $\$ 10,000$, to provide a gold medal not oftener than once in two years, and support of investigations in astronomical physics; Daniel Giraud Elliot Fund, $\$ 8,000$, to provide for a gold medal and honorarium for the most meritorious work in zoology or paleontology published each year; Wolcott Gibbs Fund, \$10,545, to provide assistance in the prosecution of chemical research; Benjamin Apthorp Gould Fund, $\$ 50,000$, to provide assistance in researches in astronomy; Marcellus Hartley Fund, $\$ 1,200$, to provide a gold Public Welfare Medal for eminence in the application of science to the public welfare; Joseph Henry Fund, $\$ 47,163$, to provide assistance for meritorious investigators, especially in the direction of original research; Jessie Stevenson Kovalenko Fund,
$\$ 43,741$, to provide a gold medal and honorarium for contributions to medical science: Marsh Fund, $\$ 20,000$, for the promotion of original research in the natural sciences; Murray Fund, $\$ 10,000$, to provide for an Alexander Agassiz Gold Medal to be awarded for original contribution in the science of oceanography; J. Lawrence Smith Fund, $\$ 10,000$, to provide a gold medal to be awarded not more often than once in two years for important original investigations of meteoric bodies, and grants to aid investigations of meteoric bodies; Mary Clark Thompson Fund, $\$ 10,000$, to provide a gold medal for important services to geology and paleontology; Charles Dolittle $\mathrm{W}$ alcott Fund, $\$ 5,000$, to provide a bronze medal and honorarium for distinguished work in pre-Cambrian or Cambrian life; James Craig Watson Fund, $\$ 25,000$, to promote astronomical science and to provide a gold medal and honorarium for outstanding contributions to astronomy; Kimber Genetics Award, gold medal and honorarium, for achievement in the science of genetics; Thomas Lincoln Casey Endowment Fund, \$298,080, for use in the advancement of engineering in all its applications.

Publications: The following serial publications are available from the Printing and Publishing Office, National Academy of Sciences-National Research Council, 2101 Constitution Avenue, Washington 25, D. C.: (1) Proceedings of the National Academy of Sciences, monthly, current volume: $46, \$ 12.50$; volume 47 will be $\$ 17.50$. Managing Editor: Edwin B. Wilson. (2) News Report, bimonthly, current volume: $10, \$ 2$. Editor: IVallace W. Atwood, Jr. (3) IGY Bulletin, monthly, current issues: $31-42, \$ 1.50$ per single subscription to science teachers and students, \$2 to others. (4) Mathematics of Computation, quarterly, current volume: $14, \$ 8$. Chairman, Editorial Committee: H. Polachek. (5) Nuclear Data Sheets, six times a year, third year of publication, $\$ 20$ for card stock edition ( $\$ 34$ by first class mail), $\$ 17$ for paper stock edition ( $\$ 25$ by first class mail), air mail rates quoted on request. (6) Nuclear Theory Index Cards, six times a year, third year of publication, $\$ 7$ by first class mail in United States and territories, $\$ 8$ elsewhere, and $\$ 6$ by third class mail in United States or abroad. (7) Fire Research Abstracts and Reviews, three times a year, current volume: 2, free. Editor: Walter G. Berl. Note: Monographs in series are also published, there being approximately 800 numbers in print.

The following serial publications are available from American Geological Institute, 2101 Constitution Avenue, Washington 25, D. C.: (8) Doklady of the Academy of Sciences of the USSR, Earth Sciences Sections, six times a year, current volume: $124, \$ 27$ to members of 
AGI member societies and to educational institutions and personnel, $\$ 45$ to others. (9) Izvestiya of the Academy of Sciences of the USSR, Geology Series, monthly, current volume: 58 (1958), \$27 to members of AGI member societies and to educational institutions and personnel, $\$ 45$ to others. (10) GeoScience Abstracts, monthly, current volume: $2, \$ 15$ to members of AGI member societies, $\$ 35$ to educational institutions and personnel and public libraries, \$65 to others. Editor: Miss Anne C. Sangree. (11) GeoTimes, eight times a year, current volume: 5 , free to members, $\$ 2$ to non-members in North America, $\$ 2.50$ to non-members elsewhere. Editor: Robert C. Stephenson. (12) International Geology Review, monthly, current volume: $2, \$ 15$ to members of AGI member societies and to educational institutions and personnel, $\$ 55$ to others.

The following serial publications are available from the American Geophysical Union, 1515 Massachusetts Avenue, N. W., Washington, D. C.: (13) Izvestiya of the Academy of Sciences of the USSR, Geophysics Series, monthly, $\$ 25$. Translation editor: W. S. Jardetzky. (14) Journal of Geophysical Research, monthly, current volume: $65, \$ 20$. Editors: Philip H. A belson and James A. Peoples, Jr. (15) Transactions of the American Geophysical Union, quarterly, current volume: 41, \$4. Editor: Waldo E. Smith.

The following serial publications are available from the Highway Research Board, 2101 Constitution Avenue, Washington 25, D. C.: (16) Proceedings of the Highway Research Board, annual, current volume: 38 (1959), $\$ 10$. Editor: Herbert P. Orland. (17) Highway Research Abstracts, 11 issues a year, current volume: 30, \$4. (18) Roadside Development, annual, current volume: 1960, $\$ 1$. Note: The Highway Research Board also publishes the following monographs in series: Bulletins, Special Reports, Research Reports, Bibliographies, and Current Road Problems.

The following serial publications are available from the individual offices indicated: (19) Annual Report, National Academy of Sciences, National Research Council, current volume: 1958-1959, \$0.70, available from Superintendent of Documents, U. S. Government Printing Office, Washington 25, D. C. (20) Biographical Memoirs, irregular, current volume: $34, \$ 5$, available from Columbia University Press, 2960 Broadway, New York 27, N. Y. (21) Artificial Limbs, semiannual, current volume: Spring 1958 (Autumn 1958 in press), free, available from Committee on Prosthetics Research and Development, 2101 Constitution Avenue, Washington 25, D. C. Editor: Bryson Fleer. (22) Information on Laboratory Animals for Research, quarterly, current volume: 4, free. Editor: Berton F. Hill. Available from Executive Secretary,
Institute of Laboratory Animal Resources, 2101 Constitution Avenue, Washington 25, D. C. (23) Prevention of Deterioration Abstracts, monthly, current volume: 18, \$50. Editor: Mrs. Grace Chapman. Available from Prevention of Deterioration Center, 2101 Constitution Avenue IVashington 25, D. C.

Library: Approximately 10,000 volumes. Scientific serials and reference works; publications of the National Academy of Sciences-National Research Council; selected journals of sister academies and research councils in other countries.

See also the following separate entries for organizations established by the NAS-NRC and operating within its structure: Nos. 17, 185, 186, $474,555,670,730,1206$.

976. National Association for Research in Science Teaching. President: Clarence H. Boeck, University High School, Minneapolis, Minn. Term expires February 1961. Executive Secretary: Herman Branson, Howard University, Washington, D. C. Term expires February 1961.

History: Founded 1928.

Purpose: Promotion of research in science teaching at all levels.

Mcmbership: Requires published research relative to teaching of science. Total membership 300 .

Mectings: Annual.

Publications: Science Education, five issues annually, current volume: $44, \$ 5$. Editor: Clarence M. Pruitt.

977. National Association of Biology Teachers. President: Paul V. Webster, Bryan City Schools, Bryan, Ohio. Term expires December 31, 1961.

History: Organized in New York July 1938.

Purpose: To improve teaching of biological sciences on all levels.

Membership: Members, 5,600, requires interest in profession of biology teaching.

Meetings: Semiannual.

Professional activitics: Active in American Institute of Biological Sciences curriculum study and film series; cosponsor, National Science Foundation institutes in biology.

Publications: American Biology Teacher, eight annually, current volume: $22, \$ 6$. Editor: Paul Klinge, Indiana University, Bloomington, Ind. News and Views, semiannual, current volume: 2, free to members. Editor: Fran Gourley. 
978. National Association of Boards of Pharmacy. 77 West Washington Street, Chicago 2, 111. Secretary: P. H. Costello. Term expires 1962.

History: Organized September 1904, in Kansas City, Mo. Eight geographic districts. Purpose: Educational and legislative research for furtherance of higher standards and more uniform legislation for pharmacy, and interstate reciprocity in pharmaceutic licensure.

Membership: State boards. Members appointed by State governors.

Meetings: Annual.

Publications: Bulletin, quarterly, free to members. Editor: F. T. Mahaffey. Proceedings, annual.

Library: 1,200 volumes. Subject emphasis: Pharmaceutical.

979. National Association of Corrosion Engineers. 1061 M. \& M. Building, Houston, Tex. President: George E. Best, Manufacturing Chemists' Association, Inc., Washington, D. C. Executive Secretary: T. J. Hull. Term indefinite.

History: Organized October 11, 1943 ; incorporated in Texas October 8, 1945. Divisions: Northeast; North Central; South Central; Southeast; Western; Canadian. Committees : Six technical group committees, headed by a technical practices comnittee, under which function fifty-five units and task groups.

Purpose: To encourage and correlate special study and research to determine causes of corrosion; to promote standardization of terminology, technical equipment, and design in corrosion control; to contribute to industrial and public safety by promoting prevention of corrosion; to foster cooperation between companies and individuals in joint solution of corrosion problems.

Membership: Active members, 6,000, persons engaged in research concerning, or in development of equipment for, control of corrosion; Junior, 50, engaged or interested in corrosion or corrosion control ; Corporate, 400 , organizations engaged in production or sale of equipment or materials for control of corrosion. Total membership 6,450 .

Meetings: Annual.

Professional activities: Research on sulfide corrosion cracking at Yale University; IVillis Rodney Whitney Award, for achievement in corrosion science; Frank Newman Speller Award, for achievement in corrosion engineering; Junior Award, for best paper on corrosion by an author under thirty-five years of age published in Corrosion.

Publications: Corrosion, monthly, current volume: 16, \$11. Editor: Ivy M. Parker.
980. National Association of Dental Laboratories. 201 Mills Building, Washington 6, D. C. President: Ugo Garganese, 1792 Warwick Avenue, Warwick, R. I. Term expires January 1, 1961. Executive Secretary: Paul A. Slone. Term indefinite.

History: Founded 1951, as a federation of State-level organizations; concept was a pattern to fit that of industry's customers' organization, the American Dental Association, and thereby facilitate liaison.

Purpose: Establishment of standards and criteria for dental laboratory technology and better service to the dental profession.

Memborship: Requires membership in component organization. Total membership 44 State components, comprising 2,200 individual laboratories.

Meetings: Annual.

Professional activitics: National Board for Certification, dental laboratory technology, joint with American Dental Association.

Publications: Journal, monthly, current volume: 7, free to members. Editor: Ralph B. Rothstein.

\section{National Association of Federal Veterinar-} ians. President: Roy E. Willie, 9323 East Parkhill Drive, Bethesda, Md. Term expires November 30, 1960. Secretary-Treasurer: F. L. Herchenroeder, P. O. Box 3085, Parkfairfax Station, Alexandria, Va. Term indefinite.

\section{History: Organized 1917.}

Purpose: To promote the fraternal and educational interests of Federally employed veterinarians, and to acquaint the general public with their activities in Government.

Mcmbcrship: Members must hold degrees in veterinary medicine from accredited colleges, and be in or retired from full time employment of the Federal Government. Total membership 1,250 .

\section{Meetings: Semiannual.}

Professional activities: Contribution to research fund of American Veterinary Medical Association.

Publications: Federal Veterinarian, bimonthly, current volume: 17-2, \$1. Editor: F. L. Herchenroeder.

982. National Association of Gardeners, Inc. 194 Old Country Road, Mineola, N. Y. President: Benjamin Crowther, Old Court House Road, New Hyde Park, N. Y. Term expires August 1961. National Secretary: Edith A. Medlock. Term indefinite. 
History: Organized 1900; incorporated July 22, 1911. Fifteen branclies from Boston to Miami, mostly along eastern seaboard. One student chapter.

Purpose: To unite all professional gardeners and others interested in gardening; to promote their general welfare by furnishing information pertaining to gardening; to supply them with a medium to secure employment.

Membership: Active members, head and assistant gardeners and superintendents of private estates, parks, cemeteries, institutions, industrial plants, and persons actively engaged in business appertaining to gardening; Sustaining, others interested in gardening. Total membership 1,200.

Mectings: Annual.

Professional activities: Interest in International Peace Garden, Inc., as original sponsors; Gold Medal, for outstanding contribution to horticulture; employment service.

Publications: Professional Gardener, monthly, current volume: 12, free to members. Editor: Edith A. Medlock.

983. National Association of Geology Teachers. President: Carey Croneis, Rice Institute, Houston 1, Tex. Term expires October 31, 1960. Exccutive Secretary: Freeman Foote, Williams College, Williamstown, Mass. Term expires October 31, 1960.

History: Founded 1938 as Association of Geology Teachers; became a national association in 1951; name changed to present title since 1955. Sections: New England, Eastern, EastCentral, Central, Southeastern, Texas, Southwestern, Far Western, Pacific Northwest.

Purpose: To foster improvement in teaching of earth sciences at all levels of instruction, to emphasize their cultural significance, and to disseminate knowledge in this field to the general public.

Membership: Open to anyone concerned with geological education, formal or informal. Total membership 520 .

Mcctings: Annual.

Professional activities: Neil Miner Award, annual, to a teacher for eminence in stimulating interest in earth sciences.

Publications: Journal of Geological Education, semiannual, current volume: $8, \$ 4$. Editor: Robert L. Bates, Department of Geology, Ohio State University, 155 South Oval Drive, Columbus 10, Ohio.

984. National Association of Naval Technical Supervisors. Mare Island Naval Shipyard, Vallejo, Calif. President: Herbert L. Graybeal, Route 1, Suisun, Calif. Term expires June 30, 1961. Secretary-Treasurer:
David B. Mitchell, 537 Russell Street, Vallejo, Calif. Term expires June 30, 1961.

History: Founded 1946 as Supervisory Engineers and Naval Architects Association; name later changed to present title. Individual chapters are located in each of the following eleven naval shipyards: Boston, Mass.; Charleston, S. C.; Long Beach, Calif.; Mare Island, Calif.; New York, N. Y.; Norfolk, Va. ; Pearl Harbor, Hawaii; Philadelphia, Pa.; Portsmouth, N. H.; Puget Sound, IVash.; San Francisco, Calif.

Purpose: To promote the welfare of members, professionally, intellectually, and socially; to foster a spirit of cooperation and fellowship; to maintain ethical standards of highest order; to promote the interests of the Government.

Membership: Members, approximately 900 , present or former naval technical supervisors, employed in United States naval establishments; Honorary, 100. Total membership approximately 1,000 .

\section{Meetings: Annual.}

Professional activities: Courses in engineering and naval architecture; speakers for gatherings in schools and professional societies; advisory collaboration with national and municipal authorities.

985. National Association of Power Engineers, Inc. President: Floyd W. Cooper, 957 Humboldt Avenue, West St. Paul, Minn. Term expires June 30, 1961. Executive Secretary: Arthur B. Mitchell, 176 West Adams Street, Chicago 3, I11. Term expires June 30, 1961.

History: Organized October 25, 1882, as National Association of Stationary Engineers; incorporated and present name adopted January 1929. 186 chapters.

Purpose: To provide cooperative action on problems affecting power plant operators and executives; to broaden the engineer's ability and earning capacity by exchange of information and experience; to provide a systematic education and service program; to direct a systematic effort for enactment of engineers' license laws in all States; to promote development of a fraternal spirit.

Ucmbership: Active members, engineers and others engaged in maintenance and operation of power plants and building service plants; Associate members, sales engineers, teachers of engineering. Total membership 12,500.

Mectings: Annual.

Professional activities: University scholarship of student's own choosing.

Publications: National Engineer, monthly, current volume: $64, \$ 2$, free to members. Editor : IValter J. Banke. 
986. National Association of Practical Refrigerating Engineers, Inc. President: John N. Mariakis, Sheraton-Dallas Hotel, Dallas, Tex. Term expires December 31, 1960. Exccutive Secretary: J. Richard Kelahan, P. O. Box 1162, Oak Park, I1l. Term expires December $31,1960$.

History: Organized January 10, 1910 ; incorporated April 16, 1954. Regions: Four, each headed by a regional vice president. CHApters: Thirty-nine.

Purpose: To further the education and enlightenment of members in the art and science of refrigeration engineering.

Memborship: Active members, actually engaged in operation, servicing, or erection of refrigerating equipment; Associate, identified with refrigerating industry as owners, manufacturers, suppliers, students. Total membership 2,795 .

Mectings: Annual.

Professional activitics: H. G. Venemann Memorial Loan Fund, for assistance to students pursuing refrigeration and air conditioning subjects in trade schools, technical institutes, or engineering colleges; basic refrigeration courses by chapter instructors, or in cooperation with local high school districts, trade schools, or technical institutes.

Publications: Operating Data Monthly, current volume: $1-3, \$ 5$. Editor: J. Richard Kelahan.

987. National Association of Sanitarians. University of Denver, Denver 10, Colo. President: R. D. Kalling, 146 Forest Avenue, Fond du Lac, Wis. Term expires July 1961. Executive Secretary: Nicholas Pohlit. Term indefinite.

History: Organized as California Association of Sanitarians, 1930; name changed to present title June 25, 1937; incorporated November 5, 1937. Sixteen sections, fourteen committees, and nineteen project committees.

Purposc: To provide specific services in the field of environmental sanitation for official and voluntary agencies, and other people concerned; to uphold and increase standards of the sanitation profession; to search continually for truths, and disseminate findings; to strive for knowledge, and to be fully informed of developments in the field of public health; to cooperate fully with allied public health agencies.

Mcmbership: Active members, professionally engaged in environmental sanitation, but not certified for registration; Registered Active, professional competence certified by National Academy of Sciences; Associate, persons with interest in objects of this Association; Student, working toward degrees in public health, sanitation, or sanitary science; Sustaining, corporations wishing to contribute financially to promotion of public health. Total membership approximately 3,000 .

Meetings: Annual.

Professional activitics: Nalter S. Mangold Award, annual, for outstanding contribution to professional status of the sanitarian; scholarships, $\$ 500$ each, to junior and senior students of sanitary science.

Publications: Sanitarian, bimonthly, current volume: $22, \$ 5$. Editor: Milton M. Miller.

988. National Association of Science Writers, Inc. President: Earl Ubell, New York Herald Tribune, 229 West 41st Street, New York 36, N. Y. Term expires June 1961. Secretary: Victor Cohn, Minneapolis Tribune, Minneapolis, Minn. Term expires June 1961. Administrative Secretary: Mrs. Howard IV. Blakeslee, 5 Longview Road, Port IVashington, N. Y. Term indefinite.

\section{History: Founded September 1934.}

Purpose: To foster dissemination of accurate information regarding science, and interpretation of science to society.

Membership: Active Members, 144, actively engaged, for one year or more, in preparation and dissemination of science news; Associate Members, 218, persons who have been active members, and persons closely associated with preparation of science news; Honorary Members, 10; Lifetime Members, 10. Total membership 382 .

Mectings: Biennial.

Publications: Newsletter, quarterly, current volume: 8 , free to members. Editor: Patrick M. McGrady.

989. National Audubon Society. 1130 5th Avenue, New York 28, N. Y. President: Carl W. Buchheister. Term expires November 1961. Sccretary: Ernest Brooks. Term expires November 1960.

History: Organized 1901 as a federation of State Audubon societies; incorporated 1905 as National Association of Audubon Societies for the Protection of IVild Birds and Animals; name changed to present title 1940.

Purpose: To arouse, through education, public recognition of the value of and the need for conservation of wild birds and other animals, plants, soil, and water, and of the interdependence of these natural resources.

Membership: Open to persons with active interest in conservation of natural resources. Membership in eighty-five branches. Nearly $10,000,000$ children in Audubon Junior Clubs. 
Meetings: Annual.

Professional activities: Audubon Research Fellowships, for restoration of native species of birds and mammals, supported with cooperating universities; Audubon Medal, for outstanding accomplishment in field of conservation of natural resources; Audubon Camps, at Medomak, Maine, Norden, Calif., and Sarona, IVis.; Audubon Center, Greenwich, Conn.; Audubon Screen Tours, 1,500 annually, and Audubon Wildlife Tours, to sanctuary areas.

Publications: Audubon Magazine, bimonthly, current volume: $62, \$ 3$, free to members. Audubon Field Notes, bimonthly, current volume: 14 .

Library: 15,000 volumes. Subject emphasis: Conservation of natural resources.

990. National Board of Fire Underwriters. 85 John Street, New York 38, N. Y. President: John A. North, 61 Woodland Street, Hartford 15, Conn. Term expires May 25, 1961. Secretary: Charles P. Jervey, 700 Main Street, Hartford 15, Conn. Term expires May 25, 1961.

History: Established 1866. Committees: Executive; thirteen standing committees.

Purpose: To promote safe methods of building construction and adoption of fire protective measures; to gather statistics and publish papers.

Membership: Capital stock insurance companies writing fire insurance in the United States. Total membership 209.

Meetings: Annual.

Professional activities: Scholarships, to assist, by cash awards, worthy and needy students in accredited architectural colleges; investigation of wind resistance of roof assemblies, by Underwriters' Laboratories, Inc., capital $\$ 15,000$.

Publications: Facts and Trends, bimonthly, current volume: 16, free to members. Special Interest Bulletin, semimonthly, current volume: 8 , free to members.

991. National Conference of State Pharmaceutical Association Secretaries. President: Cecil A. Stewart, 701 South St. Andrews Place, Los Angeles 5, Calif. Term expires August 1961. Secretary: William J. Dixon, P. O. Box 119, Oak Hill, IV. Va. Term expires August 1961.

\section{History: Founded 1927.}

Purpose: To promote welfare and fraternity among members of pharmaceutical organizations by transmitting, for mutual benefit, professional executive, convention, organization, and legislative information, obtained by reciprocity and exchange of ideas; to help maintain, in each association, high ethical and efficient standards.

Membership: Active Members, 50, executive secretaries; Associate Members, 11, former secretaries; Honorary Members, 6. Total membership 67.

Meetings: Semiannual.

992. National Conference on Industrial $\mathrm{Hy}$ draulics. Technology Center, Chicago 16, I11. President: John J. Pippenger, Double A Products Company, Manchester, Mich. Term expires October 20, 1960. Secretary: LeRoy A. Wickstrom. Term expires June 10, 1960.

History: Organized 1945.

Purpose: To elevate the general level of technical knowledge in industrial hydraulics with sponsored educational programs.

Membership: Firms active in fluid power and hydraulics fields. Total membership 132 industrial sponsors.

Mectings: Annual.

Professional activities: Fellowship, annual, $\$ 2,650$, at Illinois Institute of Technology; mechanics laboratory maintained, with personnel and research equipment.

Publications: Proceedings, annual, current volume: 12, \$6. Editor: P. Chiarulli.

\section{National Conference on Weights and Measures. See Addenda, No. 1591.}

993. National Council for Geographic Education. Department of Geography, University of Texas, Austin, Tex. President: John Morris, Department of Geography, University of Oklahoma, Norman, Okla. Term expires December 31, 1960. Secretary: Lorrin Kennamer. Term expires December 31, 1961.

History: Organized December 1915 as National Council of Geography Teachers; name changed, November 1956, to present title.

Purpose: To foster geographic education and to increase effectiveness of the teaching of geography.

Membership: Members, 2,165, teachers, administrators, and others, as well as institutions interested in geographic education; Fellows, 723 , members five consecutive years; Contributing, 69 .

\section{Mectings: Annual.}

Professional activities: Distinguished Service Award, annual, to one geographer; awards to authors of best articles in regional geography, geography for primary level, geography for secondary level, political geography; award for best non-professional article in geography in a popular periodical. 
Publications: Journal of Geography, 9 issues per year, current volume: 39, \$4. Editor: Thomas F. Barton.

994. National Council of State Boards of Engineering Examiners. P. O. Drawer 752, Clemson, S. C. President: O. B. Curtis, P. O. Box 3, Jackson, Miss. Term expires August 26, 1961. Executive Secretary: James H. Sams. Term indefinite.

History: Organized November 8, 1920; now composed of the fifty-three legally constituted licensing boards of the United States, and functions through four zones, each under supervision of a director.

Purpose: To promote public welfare by improving professional engineering standards through efficient administration of engineering registration laws.

Membership: Must be active members of State boards of registration for professional engineers in the United States. Total membership 330 .

\section{Meetings: Annual.}

Professional activities: Distinguished Service Certificate, for outstanding service to this Council and to the engineering profession.

Publications: Registration Bulletin, quarterly, current volume: 83, $\$ 1.50$. Editor: James $H$. Sams. Proceedings, annual, current volume: 38, \$2. Editor: Janes H. Sams.

\section{National Council of Teachers of Mathe-} matics. President: Phillip S. Jones, Mathematics Department, University of Michigan, Ann Arbor, Mich. Term expires April 1962. Executive Secretary: M. H. Ahrendt, 1201 16th Street, N. W., Washington 6, D. C Term indefinite.

History: Organized 1920; incorporated in Illinois 1928; became department of National Education Association 1950.

Purpose: To assist in promoting interests of mathematics in America, especially in elementary and secondary fields, and to vitalize and coordinate work of local organizations of teachers of mathematics.

Membership: Open to all persons interested in mathematics, including teaching and related problems. Total membership 21,500.

Meetings: Annual.

Publications: Mathematics Teacher, monthly, October through May, current volume: 53, individuals $\$ 5$, institutions $\$ 7$, free to members. Arithmetic Teacher, monthly, October through May, current volume: 7 , individuals $\$ 5$, institutions \$7, free to members. Mathematics Student Journal, four annually, \$1.50. Yearbook, current volume: 25 .
996. National Dental Association, Inc. P. O. Box 197, Charlottesville, Va. President: IV. K. Elliott, 1609 $1 / 2$ 8th Avenue, Huntington, IV. Va. Term expires August 1961. Executive Secretary: E. N. Jackson. Term expires August 1961.

History: Organized 1913; incorporated 1932. Six geographical sections. Committees: Public Health, Research.

Purpose: To improve public health; to promote knowledge of the art and science of dentistry; to promote the ideals and ethics of the profession, and foster nutual improvement.

Membership: Member, member of local or State society; Junior, junior or senior of Howard and MeHarry Dental College. Total membership 770 .

Meetings: Annual.

Professional activities: Scholarship and Dentist of the Year Award.

Publications: Quarterly, \$5. Editor: C. O. Dummett.

997. National Eclectic Medical Association. President: J. B. Mitchell, Lonoke, Ark. Term expires June 1961. Executive Secretary: Bert D. Strang, 2510 Northeast 19th Avenue, Pompano Beach, Fla. Term indefinite.

History: Organized 1848; chartered in Ohio. Purpose: To promote the practice and research of scientific medicine.

Membership: Requires license to practice medicine. Total membership 1,000.

Meetings: Annual.

Publications: National Eclectic Medical Quarterly, current volume: 52, \$1.25. Editor: L. E. Daugherty, 7 Washington Street, Cumberland, Md.

\section{National Federation of Science Abstracting} and Indexing Services. 301 East Capitol Street, Washington 3, D. C. President: G. Miles Conrad, Biological Abstracts, 3815 Walnut Street, Philadelphia 4, Pa. Term expires between January and March 1961. Executive Secretary: Raymond A. Jensen. Term indefinite.

History: Organized January 31, 1958; incorporated in the District of Columbia April 29, 1958. Working Groups: Abstract Editorial, Index Editorial, Management Services, Manufacture and Production, Material Procurement and Assignment, Research.

Purpose: To foster, encourage, improve, and implement the documentation (abstracting, indexing, and analyzing) of the scientific and technological literature of the world; to foster interchange of scientific and technological in- 
formation among scientists and technologists in the United States and other countries, and to strive to provide for them the best possible research information services.

Membership: Voting members must be nonprofit organizations. Abstracting, indexing, and reviewing services are eligible for membership if they publish separately at planned intervals of six months or less publications covering areas of science and technology. Total membership 14.

Mectings: Annual.

Publications: Proceedings, annual, current volume: 3 , free to members.

999. National Fire Protective Association. 60 Batterymarch Street, Boston 10, Mass. President: Henry G. Thomas, 93 Cumberland Street, Hartford, Conn. Term expires June 1961. General Managcr: Percy Bugbee. Term indefinite.

History: Organized 1896; Electrical Committee took over in 1911 work of National Conference on Standard Electrical Rules, dating from 1897; Safety to Life Committee organized 1912; Marine Committee, 1922; Fire Marshals Protective Association of North America, dating from 1909, became section of this Association in 1927; Aviation Committee organized 1928; Society of Fire Protection Engineers organized as section of this Association 1950.

Purpose: To promote science and improve methods of fire protection and prevention; to obtain and circulate information on these subjects; and to secure cooperation of members in establishing proper safeguards against loss of life and property by fire.

Membership: Open to national institutes, societies, and associations of any kind, and to State associations principally concerned with fire waste. Organization members 250. Associate members 17,000 .

Meetings: Annual.

Publications: Advance Reports, annual, current volume: 64 , free to members. Editor: G. H. Tryon III. Proceedings, annual, current volume: 64, free to members. Editor: C. S. Morgan. Quarterly, current volume: 54, free to members. Editor: R. S. Moulton. Fire News, monthly, current volume: 492-502, free to members. Editor: C. S. Morgan. Firemen, monthly, current volume: $27, \$ 2$. Editor: P. R. Lyons.

Library: 2,000 volumes. Subject emphasis: Fire.

1000. National Foundation for Metabolic Research. Chairman, Board of Trustees: Howard E. Worne, 1100 Cornell Avenue, Merchantville, N. J. Term expires August 31, 1965. Executive Secretary: Willard C. ITheeler. Term expires August 31, 1961.
History: Founded 1956.

Purpose: To study diseases of metabolism, methods of diagnosis, and treatment, human and animal.

Membership: Requires doctorate in chosen field and license to practice, plus strong interest in research and one year's Associate Fellowship. Total membership 500.

\section{Mectings: Annual.}

Professional activitics: Scholarship in biological sciences; three science medals; maintenance of laboratories and clinics in the United States, Africa, and Mexico.

1001. National Geographic Society. 1146 16th Street, N. W., Washington 6, D. C. President: Melville Bell Grosvenor. Term indefinite. Executive Fice President and Secretary: Thomas IV. Mcknew. Term indefinite.

History: Founded 1888.

Purpose: The increase and diffusion of geographic knowledge.

Membership: Annual and Life members. Total membership 2,500,000.

Mectings: No meetings of Society as a whole; board of trustees meets quarterly.

Professional activities: Hubbard Medal and National Geographic Society Medal, awarded for outstanding work in research and exploration; funds for research; lectures in Washington, Friday evenings, November to April; expeditions sent out under Society auspices and in cooperation with other agencies; geographic news service for the press; geographic material for classroom and reference purposes, for use of teachers in public schools of the United States.

Publications: National Geographic Magazine, monthly, current volume: $117, \$ 6.50$, free to members. Editor: Melville Bell Grosvenor. Bulletins, weekly during school year, current volume: $38, \$ 2$ for thirty issues, sold to schools and teachers only.

Library: 22,000 volumes. Subject emphasis: Geography.

1002. National Health Council, Inc. 1790 Broadway, New York 19, N. Y. President: James E. Perkins. Term expires March 1961. Secretary: Berwyn F. Mattison. Term expires March 1961.

History: Organized 1921; incorporated 1933.

Purpose: To assist member agencies to work more effectively together in their common interest of promotion of the health of the nation.

Membership: Active, 52, national voluntary health organizations actively engaged in the public health field; Advisory, 7, national gov- 
ernmental health agencies; Associate, 7 , national civic organizations with well-cstablished health sections, and other national bodies which desire to share in work of this Council; Sustaining, 5, national business organizations with established interest in public health which wish to support aims and objectives of this Council. Total nembership 71 organizations.

Mectings: Annual.

Professional activitics: National Health Forum.

Library: 9,000 volumes. 55,000 pamphlets. Subject emphasis: Public health.

1003. National Institute of Ceramic Engineers. 4055 North High Street, Columbus, Ohio. President: E. C. Henry, 730 Crawford Avenue, Syracuse 10, N. Y. Term expires April 1961. Secretary-Treasurer: William W. Coffeen, P. O. Box 471, Rahway, N. J. Term expires April 1961.

History: Organized March 1938 as affiliate of American Ceramic Society.

Purpose: To foster development and understanding of ceramic engineering and dissemination of engineering information.

Membership: Requires membership in American Ceramic Society. Associate Members must be: (a) over twenty-one years of age, graduates in ceramics, ceramic engineering, or glass technology, with three years' experience or (b) over twenty-one years of age, graduates in engineering or physical science, with six years' experience. Members must be: Associate Members under (a) above, over thirty-five years of age, with nine to twelve years' experience, including at least five years in responsible capacity, or Associate Members under (b) above, over thirty-five years of age, with fifteen years' experience, including at least five years in responsible capacity. Total membership 1,000.

Mectings: Annual.

Publications: Newsletter, monthly, free to members. Editor: E. C. Van Schoick.

1004. National Institute of Packaging, Handling and Logistic Engineers. 402 IV ashington Building, Washington 5, D. C. President: William R. Black, 6419 Lincolnia Road, Alexandria, Va. Term expires May 1961. Corresponding Secretary: Thomas P. Wharton, 4380 MacArthur Boulevard, N. W., Washington 7, D. C. Term expires May 1961.

History: Functioned for several years as a chapter of Society of Industrial Packaging and Materials Handling Engineers: later established as separate organization.

Purpose: To promote government-industry cooperation in packaging, handling, and logistics fields.

Mcmbership: Requires interest in military packaging, handling, and logistics fields. Total membership 365.

Mectings: Monthly.

Professional activities: Annual award to individual who has made greatest contribution in each of following fields: Packaging, handling, logistics. One award in each field.

Publications: Bulletin, monthly, current volume: 5, free to members. Editor: Leonard E. Fagan.

1005. National Institute of Social and Behavorial Science. George Washington University, Washington 6, D. C. Director: Donald P. Ray. Term indefinite.

History: Organized 1959.

Purpose: To produce selective research publications and serve as a generalist organization in social and behavioral science to include economics, political science, sociology, social statistics, and interdisciplinary problems between social and natural science.

Mcmbcrship: Requires professional interest in fields and areas in which organization works. Regular nembers, 250; Library, 50. Total membership 300 .

Meetings: Annual.

Publications: Symposia Studies Series, four issues annually, current volume: $3-4$, libraries $\$ 5$, others $\$ 7.50$. Editor: Donald P. Ray.

1006. National League for Nursing, Inc. 10 Columbus Circle, New York 19, N. Y. President: Mrs. Lucile Petry Leone, United States Public Health Service, Department of Health, Education, and Welfare, Washington 25, D. C. Term expires 1961. General Director: Inez Haynes. Term indefinite.

History: Organized 1952, by joining together three national nursing organizations and four national committees: National League for Nursing Education (founded 1893); National Organization for Public Health Nursing (1912); Association of Collegiate Schools of Nursing (1933) : Joint Committee on Practical Nurses and Auxiliary Workers in Nursing Services (1945) : Joint Committee on Careers in Nursing (1948); National Committee for the Improvement of Nursing Services (1949); National Nursing Accrediting Service; Sections: Branches in fifty States, District of Columbia, and Puerto Rico.

Purpose: To foster development and improvement of hospital, industrial, public health, and other organized nursing services, and of nursing education, through coordinated activities of 
nurses, allied professional groups, and interested citizens, agencies, and schools.

Mcmbership: Individual members, 25,621, professional nurses, practical nurses, aides, members of allied professions, and interested laity, all interested in improvement of nursing education and service; Agency members, 1,083, organizations or other groups administratively engaged in providing nursing services and schools with educational programs in nursing; allied agencies and other organizations concerned with health and welfare programs in nursing; schools of nursing.

\section{Meetings: Biennial.}

Professional activities: Studies concerning various aspects of program; projects supported by funds from foundations and from National Institutes of Health of United States Department of Health, Education, and Welfare.

Publications: Nursing Outlook, monthly, current volume: 8, \$4. Editor: Mildred Gaynor. Nursing Research, four issues annually, current volume: 9, \$5. Editor: Barbara L. Tate.

1007. National Medical Association, Inc. 1108 Church Street, Norfolk, Va. President: J. T. Aldrich, 2621-A Franklin Avenue, St. Louis, Mo. Term expires August 15, 1961. Executive Secretary: John T. Givens. Term expires August 15, 1961.

\section{History: Organized 1895.}

Purpose: To promote the science and art of medicine, and to stimulate friendly intercourse among American physicians.

Membership: Members must be licensed physicians. Total membership 5,000.

Meetings: Annual.

Professional activitics: Distinguished Service Award for general practitioner of year.

Publications: Journal, bimonthly, \$4. Editor: Montague Cobb.

1008. National Medical Foundation for Eye Care. 250 West 57 th Street, New York 19, N. Y. President: Ralph O. Rychener, 130 Madison Avenue, Memphis 3, Tenn. Term expires October 9, 1960. Exccutive Secretary: James E. Bryan. Term indefinite.

History: Organized and incorporated October 1956, under the laws of New Jersey.

Purpose: To gather and disseminate information to the medical profession and the public relating to scientific eye care; to promote conservation of vision and prevention of blindness through most effective utilization of the scientific knowledge of ophthalmology and related branches of medicine.

Mcmbership: Active Membership available to physicians; Affiliate Membership available to persons other than physicians interested in the purposes of the Foundation. Total membership approximately 3,000 .

Meetings: Annual.

Professional activities: Annual presentation of Helmholtz Memorial Award for outstanding article by lay writer on eye care in public medium.

1009. National Microfilm Association. P. O. Box 386, Annapolis, Md. President: Frederic Luther, 2805 East 56th Street, Indianapolis 20, Ind. Term expires March 31, 1961. Executive Secretary: Vernon D. Tate. Term indefinite.

History: Organized 1946; incorporated in Michigan. Committees: Convention, Membership, Publications, Publicity, Standards, Technology.

Purpose: To promote lawful interests of microreproduction industry in direction of good business ethics, liberal discussion of pertinent subjects, technological improvement and research, standardization, improved methods of manufacturing and marketing, and education of consumers in use of microfilm and related techniques.

Membership: Open to anyone seriously interested in objectives of this Association. Categories of membership: Active A; Active B; Active C; Associate; Affiliate. Total membership 750 .

Meetings: Annual.

Professional activities: Award of Merit; Pioneer Medal; publication of hasic books in field of microfilm.

Publications: National Micro-News, six issues annually, current volume: 8 , free to members. Editor: Vernon D. Tate.

1010. National Noise Abatement Council. 51 East 42nd Street, New York 17, N. Y. President: E. G. Dyett, H. H. Scott, Inc., 111 Powder Mill Road, Maynard, Mass. Term expires November 1961. Executive Secretary: L. J. Buttolph. Term indefinite.

History: Organized April 4, 1941 ; incorporated in Illinois.

Purpose: To promote a national consciousness in noise abatement and control; to disseminate information to the public relating to the causes and effects of noise and the consequences of noise expressed in terms of health and efficiency; to propose various ways and means for controlling and abating objectionable noise.

Mcmbership: Open to any individual, corporation, firm or other organization desiring to par- 
ticipate in and support the activities of the Council. Sustaining members, 10; Supporting, approximately 50 . Total membership approximately 75 to 100 .

Meetings: Semiannual.

Professional activities: A certificate of merit is awarded for outstanding work in noise abatement in industries and municipalities and a bronze plaque to the latter for unusual achievement.

Publications: Noise Abatement Digest, bimonthly, current volume: $1, \$ 5$. Editor: $\mathrm{H}$. A. Brock.

1011. National Proctologic Association. 5 South Wabash Avenue, Chicago 3, Ill. President: Peggy Cornet, Chicago Heights, Ill. Term expires November 1960. Executive Secretary: George E. Mueller. Term indefinite.

Histary: Organized 1924.

Purpose: To teach and to promote interest and techniques in the diagnosis and treatment of proctologic pathology.

Membership: Members, physicians having membership in their local medical societies; Fellows, members who have made outstanding contributions to the Association. Total membership 50 .

Meetings: Annual.

Publications: Bulletin, two or more a month, free to members. Editor: George E. Mueller.

1012. National Psychological Association for Psychoanalysis. 66 th Avenue, New York 11, N. Y. President: Theodor Reik, 365 West End Avenue, New York 23, N. Y. Term expires March 31, 1961. Vice President: Jaques Palaci, 10 East 67th Street, New York 21, N. Y. Term expires March 31, 1961.

History: Organized 1947; incorporated 1950. Purpose: Advancement of psychoanalysis.

Menbership: Associate, master's degree, clinical experience, completed personal psychoanalysis, evidence of two controlled cases under supervision, completed program of thirty courses and seminar in professional school of analysis; Senior, one year as Associate, plus an original paper. Senior and Associate members, 88; Student-members, approximately 250 ; Special members, 1. Total membership approximately 339 .

Meetings: Monthly, September to May.

Professional activities: Public lectures; low cost mental health clinic for community, and as training for student-affiliates; annual scholarship of partial tuition.

Publications: Psychoanalysis and Psychoanalytic Review, quarterly, current volume: 47, \$6. Editor: Marie L. Coleman.
Library: 5,000 volumes. Subject emphasis: Psychoanalysis.

1013. National Rehabilitation Association. 1025 Vermont Avenue, N. WV., Washington, D. C. President: Miss Mary Switzer, Department of Health, Education and Welfare, Washington 25, D. C. Term expires October 1961. Executiv' Director: E. B. Whitten. Term indefinite.

History: Organized 1925; incorporated 1933 in Illinois. There are nine regions.

Purpose: To promote the rehabilitation of physically and mentally impaired persons.

Nembership: Professional members, individuals who work in rehabilitation programs; Active members. Total membership 14,000.

Meetings: Annual; regional conferences.

Publications: Journal of Rehabilitation, bimonthly, current volume: $26, \$ 0.50$ per issue. Newsletter, bimonthly, current volume: 15, $\$ 0.10$ per issue. Editor: Doris Rosenberg Margolis.

1014. National Resuscitation Society, Inc. 2 East 63rd Street, New York 21, N. Y. President: George E. Armstrong, Bellevue Medical Center, New York, N. Y. Term indefinite. Executive Director: Paluel J. Flagg. Term indefinite.

History: Organized and incorporated in New York, February 8, 1933, as Society for the Prevention of Asphyxial Death, Inc.; name changed to present title April 23, 1956.

Purpose: Instruction with resuscitators: alerting laity and profession to prevention of asphyxial accidents.

Membership: Doctors of medicine and doctors of dental surgery affiliated with recognized medical and dental societies. Total membership approximately 200 .

Meetings: Annual.

Professional activities: Monthly courses in respiro-cardiac resuscitation.

1015. National Rivers and Harbors Congress. 1028 Connecticut Avenue, N. W., Washington 6, D. C. President: Henry H. Buckman, Buckman Building, Jacksonville, Fla. Term expires May 1961. Executive Vice President: William H. Webb. Term expires May 1961.

History: Founded in October 1901, at Johns Hopkins University, Baltimore, Md.; reorganized and incorporated under the non-profit laws of the District of Columbia in January, 1932. Committees: Resolutions, Projects, Committee on Muncipal and Industrial Water Use and Pollution Abatement, Committee on Wildlife 
and Recreation, Committee on Irrigation and Reclamation.

Purpose: To collect and prepare all obtainable data regarding the improvement, development, and uses of the rivers, harbors, and waterways of the United States and other countries; to disseminate among as many of the people of the United States as possible the knowledge so collected and prepared, through the publication of the Association, its news bureau and its field representatives, to the end that the people may be educated to the importance of waterway development and informed of the benefits resulting therefrom; to seek the enactment of all laws and regulations needed to promote the maintenance and improvement of waterways, the development and protection of water transportation and its coordination with transportation by railways and highways.

Membership: Active, 675, those who believe in the purposes and contribute to the support and prosecution of the objects of this association; Associate, 680, all members of the Senate and House of Representatives, the Secretary of the Army, the Chief of Army Engineers, all members of the Army Corps of Engineers engaged in rivers and harbors work; Honorary, approximately 6,000 , those whose distinction in public affairs shall confer eligibility; Life, 6, elected by the Board of Directors, or upon the payment of dues fixed by the Board. Total membership 7,361 .

Mectings: Annual.

Professional activities: Ammual Award for Outstanding Service to the Cause of Water Resources Development in the United States.

Publications: The Monthly Reporter, monthly, current volume: $3, \$ 12$. Editor: William $H$. Webb.

Library: 3,000 volumes.

1016. National Science Teachers Association. 120116 th Street, N. W., Washington 6, D. C. President: Robert A. Rice, Berkeley High School, Berkeley, Calif. Term expires July 1961. Exccutive Secretary: Robert H. Carleton. Term indefinite.

History: Established in 1895 as the Department of Science Instruction of the National Education Association; in 1944 merged with the American Science Teachers Association of the American Association for the Advancement of Science and reorganized as the National Science Teachers Association. The Association has continued as a department of the National Education Association and an affiliate of the American Association for the Advancement of Science.

Purpose: To advance and strengthen science teaching at all educational levels and in all fields of science.
Membership: Regular, Student, Sustaining, and Life members. Total membership 14,000.

Mectings: Three per year.

Professional activities: Future Scientists of America Awards and Club Program. Conference, convention and publications program for students and teachers.

Publications: The Science Teacher, 8 times a year, free to members. Editor: Robert $\mathrm{H}$. Carleton. Elementary School Science Bulletin, 8 times a year, $\$ 1$.

1017. National Shade Tree Conference. Department of Horticulture, Ohio State University, 1827 Neil Avenue, Columbus 10, Ohio. President: J. C. Carter, 325 Natural Resources Building, Urbana, Ill. Term expires August 24, 1961. Executive Secretary: L. C. Chadwick. Term expires August 24, 1961.

History: Founded 1924. Five chapters; seven geographic divisions.

Purpose: To improve the practice of tree preservation; to cooperate in conservation of trees and beautification of the countryside.

Membership: Active membership confined to individuals actively engaged in commercial arboriculture or employed in fields, governmental or non-governmental, concerned with trees, parks, and forests; Honorary, for material contribution to advancement of arboriculture. Total membership 1,500.

Mcetings: Annual.

Professional actizities: Research fund; awards of fellowships for advanced degree study.

Publications: Arborists News, monthly, current volume: 25, \$3. Editor: Paul E. Tilford. Proceedings, annual, current volume: $35, \$ 3$. Editor: Paul E. Tilford.

1018. National Shellfisheries Association. President: L. Eugene Cronin, Director, Maryland Department of Research and Education, Solomons, Md. Term expires August 1961. Secretary-Trcasurer: John B. Glude, Chief, Branch of Shellfisheries, Bureau of Commercial Fisheries, Department of the Interior, Washington 25, D. C. Term expires August 1961.

History: Organized 1908 as an association of the state commissioners and members of the Bureau of Fisheries and Public Health Service; the membership has been broadened to include those interested in shellfish from a scientific standpoint or otherwise. The original name was the National Association of Shellfish Commissioners; changed to National Association of Fisheries Commissioners 1915, and to present title 1930 . 
Purpose: To promote interest in the study of problenis concerned with the biology of shellfish and their enemies, and to make practical suggestions of value to the industry.

Membership: State commissions; individual members, interested in shellfishery problems. Total membership 180 .

Meetings: Annual.

Publications: Proceedings, annual, free to members. Editor: J. D. Andrews.

1019. National Society for Medical Research. 920 South Michigan Boulevard, Chicago 5, I11. President: Lester R. Dragstedt, College of Medicine, Department of Surgery, University of Florida, Gainesville, Fla. Term expires February 1961. Executive Secretary: Ralph A. Rohweder. Term indefinite.

History: Founded 1946 under the sponsorship of the Association of American Medical Colleges.

Purpose: To advance and encourage research in biology, medicine, dentistry, pharmacy and veterinary medicine; to improve public understanding of the principles, methods, and needs of the biological and medical sciences; to inform the public in regard to the necessity, humane character, and accomplishments of animal experimentation.

Membership: Organizations, institutions, or individuals that have a prime interest in the field of biological and medical research. Organizational members, 550; Individual members, 300. Total membership 850 .

Meetings: Annual.

Professional activities: Public relations and public information in the field of medical and biological research; National Conference on the Legal Environment of Medical Science; annual Research Dog Hero Award.

Publications: Bulletin for Medical Research bi-monthly, current volume: $14, \$ 2$. Editor: Norman J. Kantor.

1020. National Society for the Study of Communication. Central Michigan University, Mount Pleasant, Mich. President: Thorrel B. Fest, University of Colorado, Boulder, Colo. Term expires December 1961. Executive Secretary: Carl H. Weaver. Term expires December 1962.

History: Organized in Chicago in December 1949, during the winter convention of the Speech Association of America, by about 100 members of that Association; an outgrowth of interest in, and a desire for, a broader approach to communication.

Purpose: To study and report on problems in communication; to devise and test means of overcoming or reducing barriers to communication.

Membership: Open to persons recommended by a member. Interdisciplinary and both academic and non-academic in character. Total membership 400 .

Mcetings: Semi-annual.

Professional activities: Twelve working committees which conduct and report research; international interdisciplinary conferences.

Publications: Journal of Communication, quarterly, current volume: 11, \$4. Editor: Wayne N. Thompson. Newsletter, quarterly, free to members. Editor: Carl H. Weaver.

1021. National Society of Professional Engineers. 2029 K Street, N. W., IVashington 6, D. C. President: Noah A. Hull, Hughes Tool Company, P. O. Box 2539, Houston, Tex. Term expires June 30, 1961. Executive Director: Paul H. Robbins. Term expires June 30, 1961.

History: Founded in 1934. Administratively divided into local, state, and national levels, the individual engineer being a member of each level; fifty-three affiliated state societies and over 400 local chapters.

Purpose: To promote the professional, social, and economic interests of the engineer by means of education, legislation, and public relations; to establish and maintain state professional engineering societies and chapters throughout the United States; and to advance the interests of the public in matters pertaining to engineering.

Membership: Members, registration in accordance with laws of one of states or territories of United States or province of Canada. Total membership 52,000.

Mectings: Annual.

Professional activities: Financing of research by the Professional Engineers Conference Board for Industry. Administers industrial scholarship program.

Publications: American Engineer, monthly, current volume: $31, \$ 4$, free to members. Editor : Kenneth E. Trombley. Legislative Bulletin, monthly, current volume: 15. Engineering Employment Practices Newsletter, monthly, current volume: 5. Private Practice News, monthly, current volume: 2 .

Library: 1,000 volumes.

1022. National Speleological Society, 203 Virginia Hills Avenue, Alexandria, Va. President: Brother G. Nicholas, F. S. C., Department of Biology, University of Notre Dame, Notre Dame, Ind. Term expires April 1961. Executive Secretary: Mrs. Dorothy Kincaid. Term indefinite. 
History: Organized May 1939, as the Speleological Society of the District of Columbia; reorganized and name changed to present title January 1, 1946. Local grottoes organized in thirteen areas. Commitrees: Archaeology, Commercial Caves, Fauna, Folklore, Formations and Mineralogy, Grottoes, Hydrology, Mapping Paleontology, Photography.

Purpose: Study of the origin, geology, hydrology, and biology of caves.

Membership: Eighteen years of age; adequate physical ability to explore caves; recommendation by a member in good standing. Annual members; Life; Institutional ; Honorary; Student; Sustaining; Regular; Associate; Regular family; Associate family. Total membership 1,846 .

\section{Meetings: Annual.}

Professional activities: Grants to Societysponsored research projects; awarding of honorary memberships and certificates of merit for outstanding speleological research.

Publications: Bulletin, semiannual, current volume: 22, \$4. Editor: William E. Davies. News, monthly, current volume: $18, \$ 4$. Editor: John Stellmack. Papers, irregular, \$0.50. Editor: Jerome Ludlow.

Library: 8,000 volumes.

1023. National Technical Association. Howard University, Washington, D. C. President: David Robert Byrd, 2636 12th Street, N. E., Washington 18, D. C. Term expires December 31, 1960. Executive Secretary: Maxine V. Kernodle. Term expires December 31, 1960.

History: Organized in 1926 as a unification of a number of local technical societies dating from 1920; incorporated in Illinois. Chapters are located in fifteen cities in the United States.

Purpose: The collection and dissemination of information concerning the opportunities in the technical and engineering fields, the advancement of engineering and science, and the promotion of interest in science.

Membership: Full and Associate members, 800 , must have degrees from an approved college of architecture, engineering, or related professional field.

Meetings: Annual; four executive meetings per year.

Publications: Journal, quarterly, current volume: $32, \$ 4.50$, members, $\$ 2$. Editor: J. Dewey Wilson, P. O. Box 21, Hampton, Va.

1024. National Wildlife Federation. 1412 16th Street, N. W., Washington 6, D. C. President: Claude D. Kelley, Box 600, Atmore, Ala. Term expires March 1961. Secretary: J. A. Brownridge. Term expires March 1961.
History: Organized 1936, formally chartered 1937 ; incorporated in the District of Columbia. Forty-nine state affiliates and the District of Columbia; divided into thirteen regions.

Purpose: To federate on a national scale statelevel organizations expressing an interest in the conservation of wildlife and other natural resources and representing a cross section of conservation interest within the states.

Membership: Only statewide sportsmen's groups or other conservation groups are eligible to apply and only one affiliate organization in each state. Local groups join the state organization, not the national. Member clubs of the state affiliates have a membership of 2,000,000.

Mectings: Annual.

Professional activities: Fellowship-scholarship-project grants are awarded annually in amounts from $\$ 500$ to $\$ 1,000$ each. Number of grants to be awarded determined by Board of Directors in spring meeting each year.

Publications: Conservation News, biweekly, current volume: 25, free. Editor: Louis Clapper. Conservation Report, weekly (during Congress), free. Editor: Louis Clapper.

1025. Natural History Society of Maryland. 2101-03 Bolton Street, Baltimore 17, Md. President: Elra M. Palmer, 614 Overbrook Road, Baltimore 12, Md. Term expires 1961. Executive Sccrctary: C. Haven Kolb, 5915 Meadow Road, Baltimore 6, Md. Term expires 1961.

History: Organized March 25, 1929. CoмmitTEES: Botany, Education, Entomology, Herpetology, Mineralogy, Marine Life, Paleontology, Ornithology and Mammalogy, and Photography.

Purpose: To increase and diffuse knowledge of natural history and to that end to establish and maintain in the State of Maryland a museum and reference library; to collect and preserve objects of natural history; to protect wildlife from needless destruction; to provide facilities for research, publication, and for the pursuance of allied sciences; and to offer popular instruction.

Membership: Total membership 300.

Meetings: Annual.

Publications: Maryland Naturalist, quarterly, current volume: $30, \$ 2$, free to members. Editor: John E. Cooper, 3329 Ripple Road, Baltimore 8, Md.

Library: 7,500 volumes.

1026. Natural Resources Council of America. 709 Wire Building, Washington 5, D. C. Chairman: C. R. Gutermuth. Term expires October 1961. Secretary: Joseph Penfold, 
Bond Building, IVashington, D. C. Term expires October 1961.

\section{History: Organized October 26, 1946.}

Purpose: To advance attainment of sound natural resource management, serve member organizations and effect closer cooperation between them, make available scientific data and other pertinent information, and aid in determination of conservation problems.

Membership: Open to recognized national conservation organizations and scientific societies in field of natural science. Total membership 38.

\section{Meetings: Annual.}

Publications: Legislative News Service, semimonthly, free to members. Editor: Louis S. Clapper, National Wildlife Federation, 1412 16th Street, N. W., Washington, D. C.

1027. Nature Conservancy. $2039 \mathrm{~K}$ Street, N. W., Washington 6, D. C. President: Alexander Adams, Banker's Trust Company, 16 IVall Street, New York, N. Y. Term expires August 31, 1961. Executive Director: Donald B. Stough. Term indefinite.

History: Organized in 1917 as Committee for the Preservation of Natural Conditions, under the Ecological Society of America; as Ecologists Union in 1946; as present title in 1950. Incorporated 1951 in District of Columbia. Sixteen chapters. Commitrees: Nature Preserves Inventory, Research Use of Preserves, Policies and Standards for Nature Preserves.

Purpose: To preserve wild nature, particularly to establish and protect nature preserves which will include an adequate series of natural areas of all types; to promote scientific, educational and inspirational use of such areas.

Membership: Interest in ecological research. Regular, 4,845; Life, 145; Patron, 10. Total membership 5,000 .

Meetings: Annual.

Professional activities: Land Acquisition (natural areas for scientific and educational purposes).

Publications: Nature Conservancy News, bimonthly, current volume: 10 .

1028. Nebraska Academy of Sciences, Inc. 101 Morrill Hall, University of Nebraska, Lincoln 8, Neb. President: James A. Rutledge, Department of Secondary Education, University of Nebraska, Lincoln 8, Neb. Term expires April 15, 1961. Secretary: C. Bertrand Schultz. Term expires April 15, 1961.

History: Organized 1891; incorporated 1950. Sections and Affiliated and Participating Societies: Anthropology, Biology and Medical
Sciences, Chemistry and Physics, Earth Science, Engineering, History and Philosophy of Science, Nebraska Chapter of the National Council of Geographic Education, Nebraska Ornithologists' Union, Nebraska Section of the Mathematical Association of America, Nebraska Section of the National Council of Teachers of Mathematics, Junior Academy of Sciences, Collegiate Academy of Sciences.

Purpose: To further the work of scientists, to facilitate cooperation among them, to improve the effectiveness of science in the promotion of human welfare, and to increase public understanding and appreciation of the importance and promise of science in human progress.

Membership: Individuals who are interested in science. Senior, 283; Collegiate, 61; Junior, 510.

Meetings: Annual.

Professional activities: American Association for the Advancement of Science Research Grants to high school students; Science Talent Search; Visiting Scientists Program (National Science Foundation).

Publications: Proceedings, annual, current volume: 1960 , $\$ 1$, free to members.

1029. Nebraska Dental Association. President:

H. A. Merchant, 1228 Medical Arts Building, Omaha, Neb. Term expires April 1961. Secretary: F. A. Pierson, 1112 Federal Securities Building, Lincoln, Neb. Term expires April 1961.

History: Organized as Missouri Valley Dental Association in July 1876 and included areas in Iowa and Nebraska; separate state organization formed later.

Purpose: To encourage improvement of the health of the public and to promote the art and science of dentistry.

Membership: Active members, dentists who are in good standing in a district society or association which is a component of this Association. Total membership approximately 760 .

Meetings: Annual.

Publications: Journal, quarterly, current volume: $36, \$ 1.50$. Editor: D. WV. Edwards.

1030. Nebraska Engineering Society. President: A. A. Johnson, 2020 West Division, Grand Island, Neb. Term expires May 1961. Secretary-Treasurer: Jack L. WVilkins, c/o Omaha Public Power District, 4th and Marcy Streets, Omaha, Neb. Term expires May 1961.

History: Organized 1936, incorporated. AfFiliated Societies: Engineers Club of Omaha; Engineers Club of Lincoln; Engineers Club of Grand Island; Nebraska Society of Professional Engineers; and Nebraska sections of American 
Society of Civil Engineers, American Institute of Electrical Engineers, American Society of Heating and Ventilating Engineers, Institute of Radio Engineers, American Society of Mechanical Engineers, Society of American Military Engineers, Nebraska Architects Association, Instrument Society of America. The Society sponsors the Nebraska Joint Committee on Professional Practice.

Purpose: To advance engineering knowledge, education and practice: to encourage civic activity among its members; to maintain high professional standards.

Membership: Members, 485, must be twentythree years of age with four years experience as an engineer or architect; Associates, those interested in subject; Honorary, 7. Total membership 485 .

Mectings: Semiannual.

1031. Nebraska, North Dakota, South Dakota District Branch, American Psychiatric Association. President: LaVern C. Strough, Nebraska Psychiatric Institute, Omaha, Neb. Term expires 1961. Secretary-Treasurcr: Frank Majka, Veterans Administration Hospital, Omaha, Neb. Term expires 1961.

\section{Nebraska Pharmaceutical Association,}

Inc. President: Norman A. Leuthauser, 3316 South 29th Street, Lincoln, Neb. Term expires April 10, 1961. Executive Secretary: Miss Cora Mae Briggs, 414 Federal Securities Building, Lincoln 8, Neb. Term indefinite.

History: Organized in 1881, incorporated March 1919.

Purpose: To further the advancement and improvement of pharmacy and to advance the ethics of the profession.

Membership: An owner of a retail pharmacy, a Registered Pharmacist owning or employed in a retail pharmacy, pharmacy faculty member, retired pharmacist, or sales representative serving the pharmacy. Total membership 780 .

Meetings: Annual.

Professional activitics: President's Pepsodent Scholarship for $\$ 500$ study in pharmacy is issued annually.

Publications: Nebraska Mortar and Pestle, monthly, current volume: $23, \$ 5$. Editor: Miss Cora Mae Briggs.

1033. Nebraska Psychological Association.

Presidcut: Marshall R. Jones, Department of Psychology, University of Nebraska, Lincoln 8, Neb. Term expires May 1961. SecretaryTreasurer: John C. Loehlin, Department of Psychology, University of Nebraska, Lincoln 8, Neb. Term expires May 1963.
History: Organized May 17, 1952. Affiliated with the American Psychological Association.

Purpose: To advance psychology as a science, as a profession, and as a means of promoting human welfare.

Mcmbership: Member, 72, requirements equivalent to those of the American Psychological Association, but also residence or work in Nebraska; Affiliate, 3, one year of graduate study, and employment or continuing academic work in the field of psychology.

Mectings: Semiannual.

Publications: Newsletter, semiannual. Editor : Jean C. Fitzgerald, 5815 Taylor Street, Omaha, Neb.

1034. Nebraska Society of Anesthesiologists. President: Dean C. Watland, 1739 Hillside Drive, Omaha, Neb. Term expires November 1960. Secretary-Trcasurer: James G. Carter, 728 Doctors Building, Omaha, Neb. Term expires November 1960.

History: Organized June 14, 1948 ; component of the American Society of Anesthesiologists.

Purpose: To promote practice of anesthesiology in the state.

Membership: Open to those interested and devoting part or full time to practice of anesthesiology. Active 14; Associate, 2.

Mectings: Semiannual.

\section{Nebraska Society of Medical Technolo-} gists. President: Mary Ann Steinrauf, 3135 North 49th Avenue, Omaha, Neb. Term expires June 30, 1961. Executive Secretary: Sister M. Charlotte Zingg, St. Joseph Hospital, 2305 South 10th Street, Omaha, Neb. Term expires June 30, 1961.

History: Organized December 3, 1938 ; incorporated under the State Laws of Nebraska in 1948. Affiliated with American Society of Medical Technologists. Committees: Membership, Program, and Public Relations.

Purposc: To encourage high ethical standards in this profession, and to further cooperation with the medical profession in the field of laboratory medicine.

Mcmbcrship: Active, 94, hold a certificate from the National Registry of Medical Technologists or have at least a master's degree in one of the fields of medical technology; Associate, 25, are or have been actively engaged in the profession of medical technology ; Student, enrolled in an American Medical Association approved school of medical technology.

Meetings: Annual.

Professional activities: Present awards for paper-writing contests among students in ap- 
proved schools. Conduct seminars on advances in the field of laboratory medicine.

Publications: The Filter, biannually, current volume: 14, free. Editor: Betty Beine.

\section{Nebraska State Medical Association. 1315}

Sharp Building, Lincoln 8, Neb. President:

Fritz Teal, 2300 South 13th Street, Lincoln,

Neb. Term expires May 1, 1961. Executive

Secretary: M. C. Smith. Term indefinite.

History: Organized 1868; incorporated 1919.

Purpose: To promote the science and art of medicine, elevate the standard of medical education and pronote public health.

Membcrship: Active members, physicians who are members of component societies; Associate, physicians serving as interns or residents in hospitals, or physicians residing in Nebraska and employed by the Federal Government; Service, regularly commissioned officers of the Armed Services or United States Public Health Service, or permanent medical officers of the Veterans Administration and the Indian Service; Life; Honorary. Total membership 1,229.

Mectings: Annual.

Publications: Nebraska State Medical Journal, monthly, current volume: $45, \$ 3.50$. Editor : George W. Covey.

1037. Nebraska State Radiological Society, Inc. Nebraska Methodist Hospital, Omaha, N'eb. President: Shaun Gunderson, Clarkson Hospital, Omaha, Neb. Term expires October 1960. Secretary-Treasurer: Ronald E. Waggener. Term expires October 1960.

History: Organized approximately 1930, incorporated September 28, 1950.

Purpose: The promotion of post-graduate education, public health and welfare as related to the science and practice of radiology.

Membership: Active, 36, Diplomates of the American Board of Radiology; Associate, 7, residents in radiology or those devoting most of their time to practice of radiology.

Meetings: Monthly, October through May.

1038. Neuropsychiatric Society of Virginia. Eastern State Hospital, IVilliamsburg, Va. President: IV. D. Buxton, University of Virginia Hospital, Charlottesville, Va. Term expires 1961. Secretary-Treasurcr: Howard H. Ashbury. Term expires 1961.

History: Organized May 18, 1935. District Branch, American Psychiatric Association since 1956.

Purpose: The advancement and the practice of psychiatry.

Membership: Membership in the American
Psychiatric Association, resident of state of Virginia, with the exception of Arlington and Fairfax Counties and City of Alexandria. Active, 91; Honorary, 8; Life, 2. Total membership 101 .

Meetings: Semiannual.

Publications: Newsletter, three times a year, current volume: 2. Editor: Robert Gardner, Lynchburg, Va.

1039. Neurosurgical Socicty of America. President: Carl Graf, 344 Linwood Avenue, Buffalo 9, N. Y. Term expires March 1961. Secretary: Raymond K. Thompson, 803 Cathedral Street, Baltimore 1, Md. Term expires 1962.

History: Organized and incorporated 1948 in Illinois.

Purpose: To disseminate information in the field of neurosurgery and to stimulate and promote fellowship among young neurosurgeons.

Membership: Members, 85, specialization in the field of neurosurgery.

Meetings: Annual.

1040. Nevada Academy of General Practice. President: Roy Peters, 475 South Arlington Street, Reno, Nev. Term expires May 1961. Secretary-Treasurcr: John M. Watson, 1845 Prater Way, Sparks, Nev. Term expires May 1961.

\section{History: Organized 1951.}

Purpose: To promote high standard of general practice of medicine and post graduate education.

Membership: Requires approved medical school diploma, one year of approved internship, and three years of general practice. Total membership 47.

Meetings: Annual.

Professional activities: Consultant of the Year avard to outstanding Nevada specialist.

1041. Nevada State Medical Association. President: Wesley IV. Hall, 607 North Arlington Avenue, Reno, Nev. Term expires August 1961. Executive Secretary: Nelson B. Neff, P. O. Box 2790, Reno, Nev. Term indefinite.

History: Organized 1904; incorporated 1938. Purpose: Organization and advancement of medicine.

Membership: Active members, 241, those physicians who are actively engaged in the practice of medicine; Life, 5, physicians retired from active practice and who have been members in good standing for ten years; Active Dues Exempt, 1, those who are out of state because of additional post-graduate training; Honorary, 2 , physicians within or outside the state elected 
to that status by the House of Delegates in annual meeting. Total membership 249.

Meetings: Annual.

Professional activities: Two $\$ 500$ Peter Frandsen Scholarships are awarded annually to students on the basis of scholastic ability and need, the scholarships to be considered as loans to be repaid if practice not established in Nevada after graduation; if practice is established in Nevada, the scholarships considered as grants.

Publications: Newsletter, monthly, current volume: 5, free. Editor: Nelson B. Neff.

1042. Nevada State Pharmaceutical Association. P. O. Box 2307, Reno, Nev. President: Hugh H. Densmore, 552 Richmond Avenue, Carson City, Nev. Term expires September 1960. Executive Secretary: Peter Codner. Term expires September 1962.

History: Organized September 1950; incorporated 1954. Main office in Reno with southern branch in Las Vegas.

Purpose: To bring together pharmacists, to advance pharmacy within the profession and the laity, and to increase the prestige of pharmacy.

Membership: Open to registered pharmacists actively engaged in the practice of pharmacy, and to drug firm representatives as non-voting members. Total membership 421. tion.

Meetings: Monthly meetings; annual conven-

Publications: Monthly bulletins.

1043. New England Association of Chemistry Teachers. President: Carl P. Swinnerton, Pomfret School, Pomfret, Conn. Term expires June 30, 1961. Financial Secretary: Rev. Joseph A. Martus, S. J., College of the Holy Cross, Worcester 10, Mass. Term expires June 30, 1961.

History: Organized 1898; incorporated 1910. Divisions: Northern, Southern, Western, Central.

Purpose: To promote efficiency in the teaching of chemistry.

Membership: Open to any person interested in the teaching of chemistry. Active, 824; Student, 6; Honorary, 10. Total membership 840 .

Meetings: Five per year; annual summer conference.

Publications: Report, monthly, current volume: 61. Editor: Robert D. Eddy. Newsletter, quarterly, current volume: 14. Editor: Howard I. Wagner.

1044. New England Biological Association. President: Miss Wilma Schields, North Quincy High School, North Quincy, Mass.
Term expires May 1962. Secretary: Mrs. Jean Smart, Quincy High School, Quincy, Mass. Term expires May 1962.

History: Organized May 1929.

Purpose: To promote efficiency in teaching of biology, health, and hygiene.

Membership: Open to anyone interested in biology, particularly biology teachers. Total membership 250 .

Meetings: Four annually.

1045. New England Botanical Club, Inc. Botanical Museum, Oxford Street, Cambridge 38, Mass. President: Richard Evans Schultes, 46 Hewlett Street, Roslindale 31, Mass. Term expires February 1963. Corresponding Secretary: Charles Schweinfurth, 11 Boulder Road, Wellesley Hills 81, Mass. Term expires February 1961.

History: Organized 1895, incorporated December 1920.

Purpose: To promote social intercourse and to disseminate local and general information concerning the flora of New England.

Membership: Sponsorship by two active members, recommendation by the council and election at a regular meeting. Active, 66; sustaining, 136; associate, 134.

Meetings: Monthly, October to June inclusive. Annual meeting in February.

Professional activities: Maintenance of herbarium of New England plants.

Publications: Rhodora, monthly, current volume: 66, \$6. Editor: R. C. Rollins.

1046. New England Council of Optometrists. President: Richard C. Dexter, 338 Main Street, Keene, N. H. Term expires March 1961. Executive Secretary: Stanley E. Smith, 101 Tremont Street, Boston 8, Mass. Term expires March 1961.

History: Organized 1921 and incorporated 1949. Comprises all optometrists in the six New England states who are members of their respective state societies.

Purpose: To disseminate information to the public regarding eye care, and to promote postgraduate education.

Membership: Open to members of the six New England state professional societies; must conform to a rigid code of ethics of practice. Total membership 1,000.

Mectings: Annual.

Professional activities: Scholarships to optometric students; annual Award of Merit to selected layman; annual educational courses; one, two, and three-day courses in postgraduate work. 
Publications: New England Journal of Optometry, monthly, \$3. Editor: William V. Emmens.

1047. New England Dermatological Society. President: Paul Catinella, 697 Cambridge Street, Brighton 35, Mass. Term expires April 1961. Secretary: Robert F. Tilley, 1180 Beacon Street, Brookline 46, Mass. Term expires April 1961.

History: Organized May 6, 1915 at Boston.

Purpose: To provide opportunities for the exchange of information and for the advancement of knowledge of dermatology and syphilology among New England physicians.

Membership: Regular members, diplomates of the American Board of Dermatology and Syphilology; Associate members, completion of requirements for examination of the Board; Junior members, men in training. Active, 103, including 96 diplomates; Associate, 36; Honorary, 4. Total membership 143.

Meetings: Four per year.

1048. New England Obstetrical and Gynecological Society. 1101 Beacon Street, Brookline 46, Boston, Mass. President: Clyde Swett, Island Falls, Maine. Term expires October, 1960. Executive Secretary: William A. Lynch. Term indefinite.

History: Organized 1929. Sections: Massachusetts, Maine, New Hampshire, Connecticut, Rhode 1sland.

Purpose: To improve the practice of obstetrics and gynecology in New England; to bring together specialists and general practitioners.

Membership: Open to members of state societies, general practitioners, surgeons, and others interested in or specializing in obstetrics and gynecology. Total membership 675 .

Meetings: Semi-annual.

Professional activities: Fund for education and research; awards made at appropriate sessions.

Publications: Transactions, annual, current volume: 13, \$5. Editor: Florence Gillette.

1049. New England Ophthalmological Society.

243 Charles Street, Boston, Mass. President:

David G. Cogan. Term expires 1961. Executive Secretary: Alfred Scott, 5 Bay State Road, Boston, Mass.

History: Organized 1897.

Purpose: The study and advancement of ophthalmology.

Membership: Certification by the American Board of Ophthalmology. Active members, 223; emeritus nembers, 13; honorary nembers, 2.
Meetings: Annual; monthly (NovemberApril)

Professional activities: Annual prize of $\$ 100$ to person in New England contributing most to the science of ophthalmology.

1050. New England Oto-Laryngological Society.

President: Frank Turchik, 1831 Barnum Avenue, Bridgeport, Conn. Term expires February 1961. Executive Secretary: Burton E. Lovesey, 15 IVest Central Street, Natick, Mass. Term expires February 1961.

History: Organized 1905 as the New England Otological and Laryngological Society; name changed to present title 1945.

Purpose: The study and advancement of otology, rhinology, and laryngology.

Membership: Active members, 275 , graduates in medicine who have specialized in ear, nose, and throat, and who have the certificate of the American Board of Otolaryngology; Senior Inactive; and Honorary. Total membership 300.

Meetings: Annual; also two other meetings during the year.

1051. New England Pediatric Society. 300 Longwood Avenue, Boston 15, Mass. President: David H. Clement, 240 Bradley Street, New Haven 10, Conn. Term expires March 1961. Secretary: Harry Shwachman. Term expires March 1961.

\section{History: Organized 1912.}

Purpose: To advance the study of infancy and childhood.

Membership: Active 575 ; emeritus, 18 . Total membership 593. Open to physicians with interest in pediatrics who are members of state medical society.

Meetings: Annual; with quarterly meetings.

\section{New England Roentgen Ray Society.} President: Arnold Janzen, 85 Jefferson Street, Hartford 14, Conn. Term expires May 1961. Secretary: Robert E. Wise, 605 Commonwealth Avenue, Boston 15, Mass. Term expires May 1963.

History: Organized December 19, 1919. ComMItTeEs: Executive; Councilor, American College of Radiology; Delegate, Eastern Conference; Blue Shield; Ethics; Delegate, Massachusetts Blue Shield Fee; By-Laws Revision; Legislative; Physics and Isotope; Technician Training.

Purpose: To further the science and practice of radiology in the New England States. 
Membership: Doctor of Medicine degree, membership in local medical society, diplomate of the American Board of Radiology. Active and Associate, 242; Non-Resident, 20; Honorary, 5; Senior, 16. Total membership 283.

Meetings: Monthly, October through May.

Professional activities: George W. Holmes Annual Lecture; George W. Holmes Annual Award.

1053. New England Society of Anesthesiologists. P. O. Box 81, Kenmore Station Post Office, Boston 15, Mass. President: Angus M. Brooks, School Street, Concord, N. H. Term expires September 1960. Executive Secretary: Thomas K. Burnap, 10 Prospect Terrace, Newtonville, Mass. Term expires February 1961.

\section{History: Organized May 4, 1938.}

Purpose: To advance the science and art of anesthesiology; to function primarily for educational purposes; to improve the quality of anesthesia in New England.

Membership: Active members, 261, doctors of medicine, members of local medical society, American Medical Association, or its equivalent, whose practice and/or training has been devoted at least half-time to anesthesiology for a period of two years; junior, 8 , doctors of medicine, graduates of accredited medical schools, in training in anesthesiology; honorary, 6, persons who have rendered special service to anesthesiology or allied branches of medicine. Total membership 275.

Meetings: Semi-annual, with annual meeting in February.

Professional activities: Horace E. Welles Prize Essay.

1054. New England Society of Pathologists. President: William Kaufmann, Springfield Hospital, Springfield, Mass. Term expires September 1961. Secretary: John M. Craig, Boston Lying-In Hospital, Boston, Mass. Term expires September 1962.

History: Organized November 7, 1929, as the Boston Pathological Society; became the New England Pathological Society on May 26, 1939 ; name changed to present title March 18, 1954. Sections: Connecticut, Rhode Island, Massachusetts, New Hampshire, Vermont, and Maine. Committees : Hospital and Professional Relations, Legislation and Public Health Affairs, Autopsy, Technician Liaison, Cytology, Clinical Pathology, Resident Workshops, Prize Pathology Essay.

Purpose: To foster and maintain through education and research the highest standards in practice of pathology and clinical laboratory services; to maintain the dignity and welfare of pathology as a specialty.

Membership: Regular members, 199, any physician, dentist, or veterinarian of good moral character who is devoting himself primarily to the practice and/or teaching of pathology in New England; Associates, 5, any physician, dentist, veterinarian or medical scientist holding a $\mathrm{Ph}$. D. degree who expresses his interest in pathology; juniors, 6, any physician of good moral character who has completed one year of training towards the qualifications of the American Board of Pathology. Total membership 210.

\section{Meetings: Five per year.}

Professional activities: Prize Pathology Essay for medical students, Medical Technologist A ward. Workshops for technologists and pathologists in cytology, mycology and bacteriology.

1055. New England Society of Psychiatry. President: W. Everett Glass, Taunton State Hospital, Taunton, Mass. Term expires 1961. Executive Secretary: Ruth M. Crossfield, P. O. Box 50, Hathorne, Mass. Term expires 1961.

History: Organized 1875 as New England Psychological Society; name changed to present title March 26, 1907.

Purpose: To maintain interest in psychiatry by fostering research and bringing together psychiatrists of New England.

Membership: Limited to physicians specializing in psychiatry or with practice and interests primarily psychiatric who are resident licensees of New England States. Active members, 271 ; Life, 72; Inactive, 3; Non-resident, 171. Total membership 517.

Mectings: Semiannual.

Professional activities: Annual prizes for original papers on psychiatric subjects.

1056. New England Surgical Society. President: Welles A. Standish, 85 Jefferson Street, Hartford, Conn. Term expires October 1960. Executive Secretary: J. Gordon Scannell, 275 Charles Street, Boston, Mass. Term indefinite.

\section{History: Organized January 1916.}

Purpose: To promote the science of surgery and kindred arts and the welfare of the surgical profession in New England.

Membership: Active members, 162, must be certified by appropriate surgical boards, members, American College of Surgeons, and residents of New England; Senior, 112, active members over sixty years of age; Associate, 9, former active members who have left New England. Total membership 283. 


\section{Meetings: Semiannual.}

Publications: Transactions, annual, current volume: 30 , free to members and medical libraries. Editor: Bentley P. Colcock.

1057. New England Water Works Association. President: Kenneth W. Robie, 20 Copley Street, Brookline, Mass. Term expires September 1961. Secretary: Joseph C. Knox, 73 Tremont Street, Boston 8, Mass. Term indefinite.

History: Organized June 21, 1822 in Boston.

Purpose: Advancement of knowledge relating to water works and water supply; encouragement of social intercouse among water works men.

Membcrship: Members, officers or employees of a public or private water works, engineers, chemists, or other persons qualified to aid or interested in the advancement of knowledge relating to water works; Associates, persons, firms, or corporations engaged in manufacturing or furnishing materials or supplies for the construction and maintenance of water works; Corporate members, water boards, commissions, company or municipal corporations; Junior, not less than eighteen nor more than twenty-five years of age, students in engineering schools, or in active practice in some branch of engineering or water supply works; Honorary; Life. Members, 952; Associates, 154; Corporate members, 43; Junior, 2; Honorary, 13. Total membership 1,164.

Meetings: Annual convention, September or October; monthly, November to March, in Boston; spring, April and May, one in northern and one in southern New England; June Conference.

Professional activities: Dexter Brackett Memorial Medal, for the most meritorious paper, bearing in mind its applicability to the general water works program, which has been published in the Journal for the calendar year of the award, provided that such a paper, or an important part thereof, shall not have been previously contributed to any other society, nor have appeared in print prior to its presentation to the Association; Commemorative Award, for the paper which shall be judged as next most meritorious to the one recommended and approved for the award of the Dexter Brackett Memorial Medal; Scholarships, awarded on the basis of merit, character, and need to members and junior members of the Association, with preference given to applicants whose programs are considered as beneficial to water works practice in New England.

Publications: Journal, quarterly, current volume: $74, \$ 4$, free to members. Editor: George C. Houser, 220 Clyde Street, Brookline 67, Mass.
1058. New Hampshire Academy of Science. Durham, N. H. President: Allen L. King, Department of Physics, Dartmouth College, Hanover, N. H. Term expires May 1961. Secretary-Treasurer: Glenn W. Stewart, Department of Geology, University of New Hampshire, Durham, N. H. Term expires May 1961.

\section{History: Organized 1919.}

Purpose: To advance the cause of pure and applied science and of scientific research; to cooperate with educational institutions of the State of New Hampshire for the improvement of scientific education; to encourage a closer union between science and industry.

Membership: Candidates for membership must have attained a degree of proficiency in one branch of science which will meet with the approval of the Committee on Membership. Total membership 110.

\section{Meetings: Annual.}

Professional activities: The American Assocition for the Advancement of Science grant is made annually through the Academy, and is matched by Academy funds when used by high school teachers; co-sponsorship of the New Hampshire Science Fair; The New Hampshire Academy of Science Award, a Lamp of Knowledge trophy awarded to the high school in the state with the best pair of exhibits at the Science Fair; sponsorship of a Visiting Scientists Program for secondary schools in New Hampshire, supported by the National Science Foundation.

Publications: Bulletin, semi-annually, current volumes unnumbered, price varies. Editor: Clayton E. Fisher, Colby Junior College, New London, N. H.

1059. New Hampshire Dental Society. 517

Milton Street, Manchester, N. H. President: John E. Story, 113 Locust Street, Dover, N. H. Term expires June 1961. Secretary: Floyd E. Williams. Term indefinite.

\section{History: Founded 1877.}

Purpose: To promote the best interests of the dental profession.

Membership: Ethical dentists practicing in New Hampshire. Regular, 242; Corresponding, 32; Honorary, 19; Life, 7. Total membership 300 .

Meetings: Annual, in June.

Professional activities: Smith-Holden Scholarship, annual, \$300; Dr. Winchester Loan Fund, $\$ 5,000$.

Publications: Newsletter, quarterly, free to members. Editor: Floyd E. Williams. 
1060. New Hampshire Medical Society. 18 School Street, Concord, N. H. President: Howard P. Sawyer, Sanbornville, N. H. Term expires October 9, 1960. Executive Secretary: Hamilton S. Putnam. Term indefinite.

History: Incorporated 1791.

Purpose: To promote health and medical education.

Membership: Open to those physicians listed with the Board of Registration in Medicine. Total membership 660 .

Meetings: Annual.

Publications: Quarterly Bulletin.

1061. New Hampshire Pharmaceutical Association. Peterborough, N. H. President: Charles D. Dockham, Story Drug Store, Inc., 528 Main Street, Laconia, N. H. Term expires September 1962. Secretary-Manager: Grace E. Hannan, Historical Building, Grove Street, Peterborough, N. H. Term expires October 1, 1963.

History: Organized January 30, 1874 ; incorporated June 18, 1874.

Purpose: To establish the relations between the pharmacists, medical and allied professions and the general public, upon just principles, which shall promote the public welfare and tend to mutual strength and advantage; to improve the science and art of pharmacy; to support the Commission of Pharmacy in regulating a system of apprenticeship and employment; to suppress the practice of pharmacy by persons without proper training and to restrict the dispensing and sale of medicine to legally registered drug stores and by registered pharmacists; to uphold standards of authority in education, theory and practice of pharmacy; to create and maintain a standard of professional honesty with a view to the highest good and greatest protection to the public.

Membership: Active Voting Members, 136, twenty-one years of age, owners of retail pharmacies in New Hampshire; Active Non-Voting Members, twenty-one years of age, registered pharmacists, teachers or research workers in pharmacy, editors of pharmaceutical publications, retired pharmacy owners, students of pharmacy, those actively engaged in the manufacture, distribution, packaging or sale of commodities usually sold in pharmacies; Life, 8 , any person who has made praiseworthy contribution to the science and art of pharmacy; Honorary, 15, any person who has made a praiseworthy contribution to the science and art of pharmacy; Individual, 150; Student, 21. Total membership approximately 342 .

Mectings: Annual and mid-year.
Professional activities: Fitch Pharmaceutical Scholarship. New Hampshire Pharmaceutical Association Scholarships, two to Seniors each year. Angie W. Moulton "Pharmacist of the Year" Award.

Publications: Journal, monthly, current volume: 24, free to members. Editor: G. E. Hannan.

1062. New Hampshire Psychological Association. Concord, N. H. President: Jane M. Kraus, 105 Pleasant Street, Concord, N. H. Term expires May 1961. Secretary-Treasurer: Frances L. Seaward, 259 Ashland Street, Manchester, N. H. Term expires May 1961.

History: Organized and incorporated January 1953.

Purpose: To further the development of psychology as a science and profession; to safeguard the interest of the public and of the profession, and the freedom of scientific inquiry, teaching, and professional practice; and to establish and maintain standards of competency, training, service, and professional and ethical conduct among its members.

Membership: Members must subscribe to the objectives of the association, reside or work within the boundaries of the state, maintain ethical standards of professional conduct as set forth by the association in its Code of Ethics, and have completed at least two years of graduate work in psychology in a recognized graduate school, or one year of graduate study plus one year of experience in professional work that is psychological in nature. Total membership 37.

Mectings: Semiannual.

1063. New Hampshire Roentgen Ray Society. President: Albert C. Johnston, 127 Washington Street, Keene, N. H. Term expires October 1960. Executive Secretary: Paul Y. Hasserjian, 1470 Elm Street, Manchester, N. H. Term expires October 1960.

History: Founded in December 1944 by the radiologists resident in New Hampshire.

Purpose: To establish an organization of radiologists for the purpose of advancing the science of radiology and improving the public health through better radiological service, and to protect the practice of radiology against all inimical influences likely to retard its continued progress or professional freedom.

Membership: Open to physicians specializing in radiology, eligible to membership in the American Medical Association, and eligible as diplomates of the American Board of Radiology. Total membership 22.

Meetings: Semiannual. 
Professional activities: Annual award to New Hampshire X-Ray Technicians Society for three best essays on radiography presented by that society.

1064. New Hampshire Society of Anesthesiologists. President: Agnes V. Bartlett, P. O. Box 397, Springfield, Vt. Term expires October 1961. Executive Secretary: Frank G. Dudley, 208 Main Street, Littleton, N. H. Term expires October 1961.

History: Founded at Hanover, New Hampshire, October 1, 1948; component Society of the American Society of Anesthesiologists, Inc.

Purpose: To advance the art and science of anesthesiology and to stimulate interest and promote progress in the various aspects of the specialty.

Membership: Open to physicians engaged or interested in anesthesiology, graduates of reputable medical schools and members of their county medical society. Total membership 50 .

Meetings: Semiannual.

1065. New Hampshire Society of Professional Engineers, Inc. President: Charles $\mathrm{O}$. Dawson, 21 Woodman Avenue, Durham, N. H. Term expires July 1961. Secretary: Elton N. Roberts, Davisville, P. O. Box 185, Contoocook, N. H. Term expires July 1961.

History: Organized in 1949 as the New Hampshire Society of Engineers; reorganized 1960 under present title.

Purpose: The advancement of the public welfare; the advancement of the professional, the social, and the economic interests of the professional engineer; the establishment and maintenance of high ethical engineering standards and practices.

Membership: Professional Engineer Members, 130 , limited to persons registered as professional engineers; Affiliate Members, 12; Land Surveyor Members, 10; Junior Members, 4, limited to persons with a Bachelor of Science degree in engineering or equivalent from a college or university of recognized standing, employed in professional work, who intend to prepare for and accomplish registration. Total membership 156.

Meetings: Annual.

Professional activities: Scholarships of $\$ 100$ each to engineering schools at Dartmouth College and the University of New Hampshire.

1066. New Hampshire Water Works Association. 61 South Spring Street, Concord, N. H. President: Harold Bean, Derry, N. H. Term expires November 1960. Secretary Treasurer:
William A. Healy. Term expires November 1960.

History: Organized in 1939 for the benefit of water supply departments and officials in the state.

Purpose: Improvement of water supply service through discussion and education program.

Membership: Open to any person or community interested in water supply matters; not restricted to residents. Total membership 465.

Meetings: Five meetings annually.

Professional activities: Full tuition scholarship to senior engineering student at University of New Hampshire, with selection being made by university officials according to student's need and scholarship attainment.

Publications: Journal, five issues annually, current volume: 21, No. 3, $\$ 3$. Editor: W. A. Healy.

1067. New Haven Entomological Society. President: Norman Davis, University of Connecticut, Storrs, Conn. Term expires April 1961. Secretary: William E. Waters, 335 Prospect Street, New Haven, Conn. Term expires April 1961.

History: Organized in October 1949 with thirty-one charter members.

Purpose: To serve as an association of individuals who wish to exchange ideas and experiences related to entomology.

Membership: Open to persons whose pursuits or studies are connected with entomology or natural history. Total membership 50.

Meetings: Monthly, October to May, inclusive.

1068. New Jersey Academy of Science. 361 Highland Avenue, Newark 4, N. J. President: Robert K. Zuck, Botany Department, Drew University, Madison, N. J. Term expires May 1961. Executive Secretary: Hirsch L. Silverman. Term expires May 1961.

History: Organized May 1954; affiliated with American Association for the Advancement of Science December 1959.

Purpose: To foster interdisciplinary work, to propagate information for the purpose of helping border fields, and to keep scientists aware of progress made in other disciplines.

Membership: Fellows; Members, those holding scientific degrees, or holding a position in industry or commerce, or in professional activity equivalent to same; Associates. Total membership 262.

Meetings: Semiannual.

Publications: Bulletin, semiannual, \$3. Editors: M. Lelyn Branin and Hirsch L. Silverman. 
1069. New Jersey Council for Geographic Education. President: Hugh Brooks, Newark State College, Newark, N. J. Term expires May 1961. Secretary: Miss Constance Moy, 497 South Main Street, Phillipsburg, N. J. Term expires May 1961.

History: Organized approximately 1935. Formerly known as New Jersey Geography Teachers. It is an affiliate of the New Jersey Education Association.

Purpose: To support and improve contribution of geography in education in the State.

Membership: Anyone who is interested in improving the quality of geography education. Total membership 350.

Meetings: Quarterly.

Publications: New Jersey Geography Newsletter, quarterly, current volume: $5, \$ 1$. Editor: Adelbert K. Botts, Professor of Geography, Trenton State College, Trenton, N. J.

1070. New Jersey District Branch of the American Psychiatric Association. 149 E1wood Street, Trenton, N. J. President: William E. Boutelle, 61 West Main Street, Somerville, N. J. Term expires May 1961. Executive Secretary: Mrs. M. Claire Wagner. Term indefinite.

History: Formed 1953. Committees: Child Psychiatry; Medical Education; Rehabilitation, Aging, and Cooperation with Leisure Time Activities; Therapy and Research. The Therapy and Research Committee elects a delegate to the assembly of the District Branches of the American Psychiatric Association.

Purpose: To promote the science, art, and practice of psychiatry; to serve as an influence for the maintenance of high professional and administrative standards in this field; to serve as a member of the assembly of the District Branches of the American Psychiatric Association; to help formulate procedures within the parent organization.

Membership: Members of the American Psychiatric Association or fulfillment of the requirements of membership in the organization. Total membership 248.

Meetings: Five to seven per year.

Professional activities: Beling-Englander Memorial Lecture, approximately $\$ 100$ annually for specific lecture in honor of first president, Christopher C. Beling, and past president, Charles Englander.

Publications: Newsletter, ten times per year, current volume: 1, \$2. Editors: Alvin Friedland and Martin H. Weinberg.

1071. New Jersey Pharmaceutical Association. 118 West State Street, Trenton, N. J. Presi- dent: Joseph W. Mittuch, Carteret, N. J. Term expires 1961. Secretary: John J. Debus. Term expires 1961.

History: Organized February 1870. ComMitTeEs: Pharmacopoeias and Formularies; Pharmaceutical Education and Standards; Public Health and Welfare.

Purpose: To improve the art of pharmacy; to elevate its standards; to promote original research and study; to publish and disseminate useful knowledge; and to encourage relations of good will between physicians, pharmacists, chemists, and the public.

Membership: Registered pharmacists who are owners or managers of pharmacies, 1.170 ; registered pharmacists who are not owners or managers of pharmacies, 968; pharmacists registered in other states, manufacturers, wholesalers, traveling men, pharmaceutical editors, writers, teachers and students in colleges of pharmacy, 177. Total membership 2,315.

Mectings: Semiannual.

Professional activities: Frederick B. Kilmer Cash Award for outstanding literary contribution; Frank O. Cole Trophy Award for outstanding participation in National Pharmacy IVeek; and Oscar Singer Medal Award for outstanding contribution to organized efforts.

Publications: New Jersey Journal of Pharmacy, monthly, \$2. Proceedings. Editor: John J. Debus.

1072. New Jersey Psychological Association. President: Frederick J. Gaudet, Stevens Institute of Technology, Hoboken, N. J. Term expires May 1961. Executive Secretary: Mrs. Ruth Prescott Nevius, 610 Park Avenue, East Orange, N. J. Term expires May 1962.

History: Founded 1931, as New Jersey Association of Psychologists; incorporated 1950. Affiliated with American Psychological Association.

Purpose: To advance psychology as a profession, science, and means of promoting human welfare.

Membcrship: Active members, 370, residence or professional employment in New Jersey, professional standing equivalent to requirement for membership, American Psychological Association, and active participation or employment in some professional phase of psychology; Associate, 51, two years' graduate work, or master's degree plus one year of experience; Emeritus, 10. Total membership 431.

Meetings: Three annually.

Professional activities: Professional speakers, symposia by members, Public Information Committee, regional and specialty groups. 
Publications: New Jersey Psychologist, quarterly, current volume: $11, \$ 2$, free to members. Editor: John Cogger.

1073. New Jersey Public Health Association. 118 West State Street, Trenton 8, N. J. President: Francis Elder. Term expires October 1961. Secretary: IValdo R. McNutt. Term expires October 1961.

History: Formed October 2, 1959, by a merger of the eighty-five year old New Jersey Health and Sanitary Association and the Council for Local Public Health Services; admitted as 46th State affiliate, American Public Health Association.

Purpose: To promote, local, State, and National health programs.

Membership: Both professional and lay individuals and organizations interested in public health. Total membership 1,200.

Meetings: Quarterly.

Publications: Newsletter, quarterly, free to members.

1074. New Jersey Science Teachers Association. P. O. Box 201, Montclair State College, Upper Montclair, N. J. President: Hugh Allen, Jr. Term expires May 1961. Corresponding Secretary: Miss Monica A. Richvalsky, Jonathan Dayton Regional High School, Springfield, N. J. Term expires May 1961.

History: Founded 1905. Affiliated with the New Jersey Educational Association; later affiliated with the National Science Teachers Association. Affiliated with New Jersey Association are: New Jersey Chapter, Catholic Round Table of Science; South Jersey Science Teachers Association; Science and Mathematics Society of North Jersey.

Purpose: To promote certain improvements of teaching at all educational levels insofar as such teaching involves the subject matter, the methods and the attitudes of science; to conduct meetings whereby friendly and professional relationships may be maintained and established among members; to conduct cooperative activities with New Jersey industries for mutual benefit.

Membership: Open to any person who lives or teaches in New Jersey and who is interested in teaching which employs the subject matter, the methods and the attitudes of science. Sustaining; Regular; Student; Honorary free membership for retired members of five years good standing. Total membership 800 .

Meetings: Two Annual General Meetings constitutionally required: May, and Convention in November; March Meeting has been added as a General Meeting; Executive Board meets monthly during academic year.

Professional activities: Co-sponsorship with Rutgers University of four full four-year scholarships, one each in physics, biology, chemistry, and engineering, by competitive examinations open to all secondary school students of New Jersey; sponsorship and regulation of student science fairs throughout the state; sponsorship of regional, sectional, and dinner meetings as well as industrial forums; Annual Scroll, illuminated, to the outstanding contribution within the state in either science or science teaching; Division of Fellows, established 1959 60 , for outstanding professional accomplishment and contribution to the field of science teaching by a member in New Jersey; Atkins Award, to New Jersey industries who have made outstanding contributions to the improvement of classroom science teaching in New Jersey; Certificates of Merit to the highest academic award achieved by a student in all subject areas of science in each school in New Jersey which has membership representation on staff.

Publications: Bulletin, quarterly, current volume: 9, \$1, free to members. Editor: Rev. Lucien R. Donnelly, O.S.B., Delbarton School, Morristown, N. J.

1075. New Mexico Academy of Science. P. O. Box 546, Mesilla Park, N. Mex. Presidcnt: Joseph A. Schufle, New Mexico Institute of Mining and Technology, Campus Station, Socorro, N. Mex. 'Term expires November 1, 1960. Secretary: Kennett G. Melgaard, New Mexico State University, University Park, N. Mex. Term expires November 1, 1962.

History: Organized 1915, as New Mexico Association for Science; name changed to New Mexico Association for the Advancement of Science, 1928, and to present title, 1941.

Purpose: To stimulate presentation of new discoveries in science.

Menbership: Open to any person engaged in any department of scientific work or active in the advancement of science. Total membership 232.

Meetings: Semiannual.

Publications: Bulletin.

1076. New Mexico Association of Nurse Anesthetists. President: Mrs. Vernie Bushman, Roswell, N. Mex. Term expires August 1961. Executive Secretary: Mrs. Ellen Heusinger, 2116 Bryn Mawr, Albuquerque, N. Mex. Term expires August 1961.

History: Organized 1956 in conjunction with the American Association of Nurse Anesthetists; affiliated with the New Mexico Hospital 
Association 1958. Board of Trustees consists of seven members. Commitrees: Publications and Education, Program and Social, Government and By-Laws.

Purpose: To promote the best interests of its members, to cooperate with the American Association of Nurse Anesthetists, to facilitate cooperation among nurse anesthetists, the medical profession, and hospitals, and, in general, to advance the science and art of anesthesia.

Membership: Open to those who are currently registered nurses in the State of New Mexico, certified by examination in the American Association of Nurses Anesthetists after completing a course in an approved school of anesthesia, with good moral and ethical standing in the profession. Active Members 50; Inactive 8. Total membership 58.

Meetings: Quarterly.

Professional activities: Recruitment programs with high schools and schools of nursing. Position listings and recommendations for medical institutions in New Mexico.

Publications: El Sol, quarterly, current volume : 70, free. Editor: C. Tennessen, Albuquerque, N. Mex.

1077. New Mexico Association of Osteopathic Physicians and Surgeons. President: H. D. Thomas, 3200 Silver Street, S. E., Albuquerque, N. Mex. Term expires May 1961. Executive Secretary: Joseph M. Peterson, 157 4th Street, N. W., Albuquerque, N. Mex. Term expires May 1961.

History: Organized as subsidiary of National Osteopathic Association in 1900. Associated with Central New Mexico and Southwestern New Mexico Osteopathic Associations.

Purpose: Osteopathic medical, surgical, and obstetrical care to residents of New Mexico.

Membership: Must be members, National Osteopathic Association; graduates, approved osteopathic colleges; licensed to practice in New Mexico. Active members, 106; Life, 6; Fellows,

4. Total membership 116.

Meetings: Annual.

1078. New Mexico Association of Soil Conservation Districts. President: J. L. Merritt, Yeso, N. Mex. Term expires December 3, 1960. Secretary-Treasurer: Joyce Laumbach, Solano, N. Mex. Term expires December 3, 1960.

History: Organized March 10, 1948. ComMitTEes : Convention, Education, Finance, Great Plains, Highway, Legislative, Publicity, Public Lands, Research, Small Watersheds, Soil Stewardship, Wildlife.
Purpose: To foster the conservation of soil and of water.

Membership: Open to all New Mexico Soil and Water Conservation Districts. Total membership 57.

Mectings: Annual.

Professional activities: District and State Land Judging Contests; paid trips for two teams to National Land Judging Contest, Oklahoma City, Okla.; Scholarship-Conservation Workshops; assist in number of Awards. Activities involve approximately $\$ 600$ annually.

Publications: Newsletter, monthly, current volume: 4, free to members. Editor: Clark Leedy, P. O. Box 786, University, N. M.

1079. New Mexico Dental Association. President: I. D. Johnson, P. O. Box 1077, Clovis, N. Mex. Term expires May 1961. Executive Secretary: Mrs. Jane Henry, 2917 Santa Cruz Avenue, S. E., Albuquerque, N. Mex. Term indefinite.

History: Organized in 1908. Formerly known as New Mexico State Dental Society.

Purpose: To promote the public welfare by the advancement of the dental profession in education, science, mutual fellowship and good feelings.

Membership: Members, 243, ethical dentists who are legally licensed in New Mexico.

Meetings: Annual.

Professional activities: Sponsor biennial Working Conferences, annual seminars. Provide loans to students in dentistry and dental hygiene.

Publications: New Mexico Dental Journal, quarterly, current volume: 11, \$1. Editor: William J. Hanratty, 126 Quincy Avenue, N. E., Albuquerque, N. Mex.

1080. New Mexico Geological Society. Campus Station, Socorro, N. Mex. President: Frank E. Kottlowski, New Mexico Bureau of Mines and Mineral Resources, Socorro, N. Mex. Term expires April 1961. Secretary: Elmer H. Baltz, P. O. Box 4217, Albuquerque, N. Mex. Term expires April 1961.

History: Organized April 12, 1947, as Geological Society of New Mexico; new Constitution became effective January 1, 1954.

Purpose: To promote the science of geology and related subjects, and to further the interests of the geological profession in New Mexico.

Membership: Active members, 247, practicing geologists, present or former; Associate, 11, persons interested in geology or related subjects; Student, 23, geology majors in accredited colleges; Honorary, 9, for outstanding contributions to geology or geological profession of New Mexico. Total membership 290. 
Meetings: Semiannual.

Professional activities: Scholarship fund of $\$ 750$ used annually to assist geology students; $\$ 50$ award, State Science Fair, for best geologic exhibit, Senior Division; $\$ 25$ award for Junior Division.

Publications: Guidebook, annual, current volume : $10, \$ 8.50$.

1081. New Mexico Hospital Association. President: H. L. Burgin, Los Alamos Medical Center, Los Alamos, N. Mex. Term expires May 1961. Executive Secretary: D. K. Dalager, 1118 Gold Avenue, S. E., Albuquerque, N. Mex. Term expires May 1961.

History: Incorporated October 26, 1945.

Purpose: To promote the public health and welfare through development of better hospitals and clinics.

Membership: Interest in the objects of the Association. Institutional; Personal. Total membership 43.

Meetings: Annual; two interim meetings.

Professional activities: Maintenance of institutes on management, finance, nursing, collections, supplies, insurance, etc.

Publications: Bulletin, monthly.

1082. New Mexico Medical Society. 220 First National Bank Building, Albuquerque, N. Mex. President: Allan L. Haynes, 1217 Pile Street, Clovis, N. Mex. Term expires May 1961. Secretary: Thomas L. Carr, Medical Arts Square, N. E., Albuquerque, N. Mex. Term expires May 1961. Executive Secretary: Ralph M. Marshall. Term indefinite.

History: Organized December 1881, as Las Vegas Medical Society; incorporated 1885, name changed to present title.

Purpose: To bring into compact organization the medical profession of New Mexico; to form, with similar societies in other States, the Anerican Medical Association; to extend knowledge, elevate educational standards, and advance the science of medicine; to secure enactment and enforcement of just medical laws.

Membership: Active members, 573, graduates of Class A medical schools, licensed in New Mexico, and members of county medical societies; Emeritus, 27. Total membership 600.

Meetings: Annual.

1083. New Mexico Nurses' Association, Inc. 107 Stanford Drive, S. E., Albuquerque, N. Mex. President: Mrs. Marion Fleck, 1406 Odlum Drive, S. E., Albuquerque, N. Mex. Term expires October 11, 1960. Executive Secretary: Mrs. Beatrice C. Martin, 1010 Parkland Place, S. E., Albuquerque, N. Mex. Term indefinite.
History: Organized November 22, 1921, as New Mexico State Graduate Nurses' Association.

Purpose: To promote professional and educational advancement of nurses, elevate the standard of nursing education, disseminate information, and bring into reciprocal communication nurses and nurses' associations of New Mexico.

Membership: Must be graduates of State accredited nursing schools offering not less than two years of instruction and clinical practice in hospitals and other agencies, and must be licensed in at least one State. Total membership 750.

\section{Meetings: Annual.}

Professional activities: Nursing scholarships are maintained by several district associations.

Publications: New Mexico Nurse, quarterly, current volume: 14, free to members. Editor: Mrs. Beatrice C. Martin.

1084. New Mexico Optometric Association, P. O. Box 696, Albuquerque, N. Mex. President: Leroy F. Fry, 101 North Richardson Street, Roswell, N. Mex. Term expires May 27, 1961. Executive Secrctary: L. Thomas Christison, 3612 Campus Boulevard, N. E., Albuquerque, N. Mex. Term indefinite.

History: Established 1905. Affiliated with the American Optometric Association.

Purpose: To promote and further optometry in New Mexico; to aid optometric research; to assist students interested in the profession.

Menbership: Active members, practicing optometrists in good standing; Military members, optometrists commissioned in the armed services of the United States; Civil Service members, optometrists who have entered the Civil Service of the United States; Distinguished members, those who have completed a term of office as President of the Association ; Life members, those who have rendered long and faithful service as active members but who cannot continue in this capacity; Honorary members, those who have performed a signal service in the field of health, optometry, or optics; Student members, active students in schools and colleges of optometry; Affiliated members, optometrists practicing and residing in foreign countries, and in territories or possessions of the United States. Total membership 52.

Meetings: Annual, in May.

Publications: Newsletter, monthly, current volume: 1. Editor: L. Thomas Christison.

1085. New Mexico Pharmaceutical Association, Inc. 122 Harvard Drive, S. E., Albuquerque, N. Mex. President: Herman Moneus. Term expires April 1961. Executive Secretary: Mrs. Nelda Orme. Term indefinite. 
History: Organized and incorporated May 1928. In 1953, divided into five districts.

Purpose: To further the profession of pharmacy.

Membership: Active membership consists of Registered Pharmacist members, Store members, and Life members. Any person registered as a pharmacist in New Mexico who is neither owner nor manager of a retail pharmacy is eligible for Registered Pharmacist membership. Any owner or manager of a retail pharmacy in New Mexico is eligible for Store membership. Active members who have served the profession with distinction may be elected to Life membership. Persons not eligible for active membership but interested in pharmacy are eligible for Associate membership. Honorary membership may be granted to professional and scientific workers of note and to other persons of distinction. Manufacturing and wholesaling firms are eligible for Sustaining membership. Store members, 253; Wholesale companies, 8; Registered Pharmacist employees, 227 ; Sustaining members, 30. Total membership 518 .

Mectings: Semiannual.

Professional activitics: Annual Ernie Welch Award for outstanding work in community and profession; annual award to pharmacy student for excellence in scholarship.

Publications: E1 Boticario, monthly, current volume: $7, \$ 3.50$, free to members. Editor: Mrs. Nelda Orme.

1086. New Mexico Psychological Association. President: Manuel Brown, New Mexico Board of Parole, Santa Fe, N. Mex. Term expires February 1961. Secretary: Lester Libo, P. O. Box 711, Santa Fe, N. Mex. Term expires February 1961.

History: Founded March 15, 1957. State affiliate, American Psychological Association.

Purpose: To advance psychology as a science, profession, and means of promoting human welfare.

Membership: Associates, 47, two years' graduate work, or one year academic and one year professional experience in psychology; Affiliates, 7 , candidates for the bachelor's degree, or full time work in psychology. Total membership 54.

Mcetings: Irregular; two to four annually.

Professional activities: Highway Safety Conference; Professional Certification Survey and Conmittee Work; Programs on Mental Health; psychological research activities in State.

Publications: Newsletter, quarterly, current volume: 4, free to members. Editor: Jerome Gibson, Sandia Corporation, Albuquerque, N. Mex.
1087. New Mexico Public Health Association, Inc. P. O. Box 8066, Albuquerque 'C', N. Mex. Secretary-Treasurer: Daniel T. Marley. Term expires May 1, 1961.

History: Founded 1922 ; affiliated with American Public Health Association in 1929. SEcTIons: Nursing, Sanitarians, Doctors in Public Health Administration, Office Management, and Special Services. Major technical committee is Committee on Continuing Education in Public Health and Health Careers Consultation.

Purpose: To provide for the scientific advancement of members, assist in the protection and promotion of public health, extend and develop the public health movement and aid in promulgation and enforcement of state and local legislation in the interest of good health.

Membership: Members, 175, interest in public health, lay or professional.

Meetings: Annual.

Professional activities: Educational Loan Fund. Annual Award for outstanding service over period of five years or more. Certificate for outstanding service by newer worker during current year.

Publications: Newsletter, quarterly, free.

1088. New Mexico Society for Biological and Medical Research. President: Ulrich C. Luft, 4800 Gibson Boulevard, S. E., Albuquerque, N. Mex. Term expires December 31, 1961. Secretary: Elizabeth H. Roorbach. Term expires December 31, 1961.

History: Organized February 15, 1957.

Purpose: To provide meetings and discussion among scientists in biological and medical fields in New Mexico; to maintain connections and work for eventual affiliation with National Society for Experimental Biology and Medical Research.

Mcmbership: Open to residents of New Mexico actively engaged in research in experimental biology and medicine. Total membership 106.

Mcetings: Three annually.

1089. New Mexico Society of Anesthesiologists. President: John Muxworthy, Jr., 921 Truman Street, N. E., Albuquerque, N. Mex. Term expires March 1961. Secretary-Treasurer: Honer S. Musgrave, 832 Jefferson Street, N. E., Albuquerque, N. Mex. Term expires March 1961.

History: Organized January 15, 1954 ; chartered by American Society of Anesthesiologists, February 22, 1954.

Purposc: To advance the science and art of anesthesiology, and to stimulate interest and 
promote progress in the scientific, cultural, and economic aspects of the specialty.

Memberslip: Active members, 13, doctors of medicine engaged or interested in anesthesiology, graduates of reputable medical schools, and nembers of local or county medical societies; Associate, scientists or others who have attained eminence in anesthesiology; Honorary. Total membership 13.

Meetings: Annual and quarterly.

1090. New Mexico Society of Internal Medicine. President: H. Richard Landmann, 227 East Palace Street, Santa Fe, N. Mex. Term expires June 1961. Secretary-Treasurer: Paul H. Noth, Los Alamos Medical Center, Los. Alamos, N. Mex.

\section{History: Founded February 27, 1957.}

Purpose: To unite qualified internists of New Mexico for furtherance of practice of internal medicine, and to secure and maintain highest standards of practice of this specialty through study of scientific, economic, social, and political aspects of medicine.

Membership: Physicians who are certified by American Board of Internal Medicine, or who are members of American College of Physicians ; in exceptional circumstances, a physician who has limited practice to internal medicine for five years must, if he graduated after 1936, include credit for at least three years of approved hospital training suitable for accreditation in internal medicine after internship, and, in addition, show evidence of at least two years of exclusive practice of internal medicine. Total membership 37.

Meetings: Annual.

1091. New Mexico Society of Professional Engineers. P. O. Box 457, Carlsbad, N. Mex. President: J. Caldwell Wilson, P. O. Box 676, Roswell, N. Mex. Term expires February 27, 1961. Executive Secretary: E. A. Roberts. Term indefinite.

History: Organized 1947; incorporated; affiliated with National Society of Professional Engineers. С hapters: Albuquerque, Santa Fe, Southeastern, Southwestern.

Purpose: Promotion and protection of profession of engineering as a social and economic influence vital to affairs of men and communities.

Membership: Active, 460, professional engineers registered in one of the fifty States; Engineers in Training, 63, must have passed State Board examinations; Surveyors, 20, so registered in one of the States; Associate, 22, engineers and others not registered, but working in engineering. Total membership 565 .

Meetings: Annual.
Professional activities: NSPE-ARMCO Scholarship; medals and plaques to members for society activities.

Publications: New Mexico Professional Engineer, monthly, current volume: $12, \$ 2$. Editor: E. A. Roberts.

1092. New Mexico Veterinary Medical Association. Secretary-Treasurer: Leonard Payne, Albuquerque, N. Mex. Term expires September 9, 1961 .

History: Founded 1935, in conjunction with the National Veterinary Medical Association.

Purpose: Education and unity of purpose at state level.

Membership: Licensed practitioner in New Mexico, membership in the national association and sponsorship by two active members. Total membership 70 .

Meetings: Annual.

1093. New Orleans Academy of Sciences. President: H. Dessauer, School of Medicine, Louisiana State University, 1542 Tulane Avenue, New Orleans 12, La. Term expires May 1961. Secretary: Trinidad Mares, Southern Utilization Research and Development Division, 1100 Robert E. Lee Boulevard, New Orleans 19, La. Term expires May 1961.

History: Organized March 21, 1853. SECtıons: Physical, Chemical, Biological, Medical, Social Sciences, Junior Academy.

Purpose: Advancement of science; support of the Junior Academy.

Membership: Active interest in advancement of science in the New Orleans area. Active members, engagement in scientific work; Associate, persons interested in science but not actively engaged in it; Sustaining and Life, same as for active membership; Honorary. Active, 187; Associate, 8; Sustaining, 3 ; Life, 30 ; Honorary, 7. Total membership 235.

Meetings: Monthly and annual.

Professional activities: Support, by grants, speakers, etc., of the New Orleans Junior Academy of Sciences.

Library: Approximately 1,000 volumes. Emphasis, history of science in the New Orleans area.

1094. New Orleans Geological Society. President: T. H. Philpott, Olin Oil and Gas Company, 1700 Commerce Building, New Orleans, La. Term expires October 1, 1960. Secretary: Leonard L. Limes, Kerr-McGee Oil Industries, Inc., 303 California Building, $\mathrm{New}$ Orleans, La. Term expires October 1, 1960. 
History: Organized October 3, 1941.

Purpose: To promote study of geology, especially as pertaining to oil and gas; to improve methods of exploration, foster the spirit of scientific research, and maintain high standards of professional conduct.

Membership: Must be engaged in exploration for oil and gas, research, or teaching of geological subjects. Total membership 575 .

Meetings: Monthly.

Professional activities: Student award for best paper on geology from Tulane or Louisiana State University.

1095. New Orleans Society of Neurology and Psychiatry. President: Robert G. Heath, 1430 Tulane Avenue, New Orleans, La. Term expires April 1961. Secretary-Treasurer: Lucio E. Gatto, 1542 Tulane Avenue, New Orleans, La. Term expires April 1961.

History: Organized 1938.

Purpose: Dissemination of scientific knowledge to specialists in neurology and psychiatry in the New Orleans area.

Membership: Active members, 88, physicians in active practice of neurology, psychiatry, and their branches; Associate, 29, physicians with special interest in neurology, psychiatry, and their branches; Honorary, outstanding practitioners of this specialty. Total membership 117.

Meetings: Monthly, September through May.

1096. New York Academy of Dentistry. President: Edgar S. Bacon, 9 Rockefeller Plaza, New York 20, N. Y. Term expires April 1961. Executive Secretary: Mrs. Augusta Grimm, 97 California Street, Ridgewood, N. J. Term indefinite.

History: Organized February 1921; incorporated May 1921.

Purpose: To uphold the dignity and honor of the dental profession and elevate standards of dental education; to encourage development of professionally controlled journals and other means for publication and distribution of dental literature; to place activities of members and profession on ethical and non-commercial planes.

Mcmbership: Active Fellows, 353, members of dental or allied professions, and of American Dental Association or equivalent, who have been actively identified with progress of dentistry by writing, investigating, teaching, or organizing; Associates, 78; Allied, 5; Nonresident, 88; Retired, 23; Honorary, 1. Total membership 548 .

Mectings: Annual in April ; monthly, October through April, omitting December.

Professional activities: Grants for specified research projects.
Publications: Annals of Dentistry, quarterly, current volume: 18, free to members. Editor: Edward Stroh.

1097. New York Academy of Medicine. 2 East 103rd Street, New York 29, N. Y. President: Robert L. Levey. Term expires December 1960. Recording Secretary: Frederick H. Wilke. Term expires December 1960. Execttive Secretary, Committee on Publications and Information: Robert L. Craig.

History: Founded 1847, incorporated 1851. Sectrons: Twelve, each of which represents a special branch of medicine or surgery.

Purpose: Promotion of the science and art of medicine, and of public health and medical education; maintenance of a public medical library.

Membership: Minimum of five years after receiving Doctor of Medicine degree, and nomination and election. Resident Fellows, 2,000; Non-resident, 400; Research and Teaching, 240; Associate, 400; Honorary, 20; Corresponding, 75 ; Life, 400 ; Exempt List, 200. Total membership 3,735 .

\section{Mcetings: Quarterly.}

Professional activities: Academy of Medicine Medal, for unusual medical achievement; endowed funds for medical research and scholarship.

Publications: Bulletin, monthly, current volume : 36, \$8. Editor: Robert L. Craig.

Library: 320,542 volumes. Second largest medical library in the United States.

1098. New York Academy of Sciences. 2 East 63rd Street, New York 21, N. Y. President: Frederick Y. Wiselogle, Squibb Institute for Medical Research, 3 Georges Road, New Brunswick, N. J. Term expires December 31, 1961. Executive Director: Eunice Thomas Miner. Term expires 1965.

History: Organized 1817, as Lyceum of Natural History; name changed to present title January 1876. Sections : Biological and Medical Sciences, Chemical Sciences, Geological Sciences. Divisions: Anthropology, Biochemistry, Engineering, Instrumentation, Mathematics, Microbiology, Nuclear Physics, Oceanography and Meteorology, Psychology, Space Research.

Purpose: To advance scientific research and discovery, provide a forum for presentation and discussion of scientific problems, publish and distribute results of research, and interpret them for promotion of common welfare.

Membership: Persons of scientific training, having been at any time engaged in scientific work, or otherwise engaged in advancement of science, shall be eligible for Active Membership. 
Sustaining members, 238; Annual active, 14,080; Student, 249; Corporation, 8; Life, 440 ; Benefactors, 3; Patrons, 2; Honorary Life, 83, elected in recognition of scientific achievement; Gold Card Members, 1. Total membership 15,104 .

Mectings: Annual. Monthly meetings of Divisions and Sections.

Professional activities: George Frederick Kunz Award, irregular intervals, \$300, for most acceptable paper in geology and nineralogy; A. Cressy Morrison Awards in Natural Science, annual, two, of $\$ 400$ each, for most acceptable papers in fields of science covered by Academy; Boris Pregel Award in Field of Nuclear Physics and Nuclear Engineering, \$500, for most acceptable paper embodying results of research in that field; D. B. Steinman Award for Research in Structural Engineering, \$500, for most acceptable original paper from Academy membership in field of pure or applied research in structural engineering, in related science of aerodynamics, or analysis and design of civil engineering structures. The income from all of the following list of endowment funds is used for scientific publications: John James Audubon Fund, established 1893, capital $\$ 2,500$; John Strong Newberry Fund, established 1897, capital $\$ 1,000$; Centennial Endowment Fund, established 1917, capital \$7,934; Ralph Winfred Tower Memorial Fund, established 1926, capital \$12,728; Roy Waldo Miner Memorial Publication Fund, capital \$7,753; Nathaniel Lord Britton Fund, established 1936, capital $\$ 30,039.77$; George Herbert Sherwood Memorial Fund, established 1940, capital $\$ 7,000$; Thomas Lincoln Casey Fund, established 1954, capital $\$ 213,461.99$.

Publications: Annals, irregular, current volume: 86, free to members. Monthly Program, October through May, current volume: 10, free to members. Transactions, eight annually, current volume : $22, \$ 7$, free to members.

1099. New York Association of Consulting Engineers, Inc. 115 East 40th Street, New York 16, N. Y. President: John F. Hennessy, Jr., 144 East 39th Street, New York 16, N. Y. Term expires December 1960. Exccutive Secretary: R. Joan Faherty. Term indefinite.

History: Organized December 1923; merged with Structural Engineers Society of New York 1954. Committees : Ten permanent. Divisions : Mechanical and Electrical; Structural and Civil.

Purpose: To maintain high ethical standards and practice, and to promote satisfactory business relations between members and clients; to interchange experience for mutual benefit.

Membership: Persons, firms, or corporations engaged in independent practice of professional engineering, planning and designing works for construction industry, from principal office in State of New York and within sixty miles of City Hall, New York, and so engaged for at least two years. Members must have no association involving conflict of interest with independent practice. Non-resident members, not entitled to vote or hold office because of removal from geographical limits. Life members, exempt from dues and assessments, and not entitled to vote or hold office, are retired members without other profession or business. 62 member firms.

Mectings: Annual; monthly.

1100. New York Association of Teachers of Biological Sciences. President: Stanley L. Weinberg, Biology Department, DeWitt Clinton High School, Bronx, N. Y. Term expires June 1961. Corresponding Secretary: Albert L. Goldberg, Franklin K. Lane High School, Brooklyn, N. Y. Term expires June 1961.

History: Founded 1899; affiliated with Federation of Science Teaching Associations of New York City. Commitees: Biology Charts, Biology Congress, Conservation, Science Luncheon.

Purpose: To improve methods of teaching biology; to educate the public in biological aspects of public welfare.

Membership: Open to biology teachers in New York metropolitan area; Associate membership open to college students and others interested in biology teaching. Total membership 500 .

Meetings: Eight annually.

Professional activities: Graduation awards in public high schools of New York; Paul B. Mann Biology Congress for students; publication of Adventures in Biology, a laboratory and project manual.

1101. New York Diabetes Association, Inc. 104 East 40th Street, New York 16, N. Y. President: Winifred C. Loughlin, 35 East 35 th Street, New York 16, N. Y. Term expires November 1960. Secretary: Lawrence E. Hinkle, Jr., 525 East 68th Street, New York 21, N. Y. Term expires November 1960. Executive Director: Abraham Bluestein.

Term indefinite.

History: Founded 1932, as a committee of the Committee on Public Health of the New York Academy of Medicine; name changed to present title 1934; affiliated with American Diabetes Association. Affiliated Societies: Clinical Society; Lay Society. Committees: Camp for Diabetic Children; Research; Professional Education; Hospital Clinics; Lay Education and Detection. 
Purpose: Dissemination of information on diabetes, promotion of research, and of lay and patient education, improvement of care of diabetic persons, and maintenance of a summer camp for diabetic children.

Membership: Clinical Society, 325, doctors of medicine; Lay Society, 300, open to all friends and relatives of diabetics; Camp Nyda Alumni, 400. Total membership 1,025 .

\section{Meetings: Annual.}

Professional activitics: Research fund; metabolic research on juvenile diabetes; physician education through open Clinical Society Meetings, and Annual Symposium on recent advances in diabetes; lay diabetic education by lectures to Lay Society by doctors of medicine; Medal to lay people for achievement in work for or by a diabetic.

Publications: Current Concepts in Diabetes Mellitus. Editor: Max Ellenberg. Newsletter, Clinical Society. Editor: Martin G. Goldner. Newsletter, Lay Society. Editor: Mrs. Abraham Steigerwald. NYDA News. Editor: Milton B. Handelsman.

1102. New York Entomological Society. American Museum of Natural History, New York 24, N. Y. President: Nicholas Shoumatoff, Bedford, N. Y. Term expires 1962. Executive Secretary: Raymond Brush, 1 University Place, New York, N. Y. Term expires 1962.

History: Organized June 29, 1892; incorporated February 1893; reincorporated February $17,1943$.

Purpose: Advancement and cultivation of the science of entomology.

Membership: Open to those interested in entomology. Total membership approximately 300.

Meetings: Semimonthly, October to May.

Publications: Journal, quarterly, current volume: $68, \$ 8$, members $\$ 5$. Editor: William S. Creighton.

1103. New York Microscopical Society. Central Park West at 79th Street, New York 24, N. Y. President: Burton Dezendorf, 401 Hasbrouck Boulevard, Oradell, N. J. Term expires June 30, 1961. Vice President: Miss Virginia L. Thomas, 44 Rutgers Place, Passaic, N. J. Term expires June 30, 1961.

History: Organized and incorporated 1877. Annual Members Exhibition since 1877.

Purpose: Advancement of theoretical and applied microscopy.

Membership: Annual members, 192, over twenty-one years of age, active interest in microscopy; Junior, 20, under twenty-one years of age, active interest in microscopy; Life, 39, annual member twenty-five years; Fellows, 49, honor conferred in recognition of distinctive achievement in microscopical science or of outstanding service to this Society. Total membership 300. Since World War II, membership has been composed of sixty per cent professional and forty per cent medical and amateur microscopists.

Meetings: Semimonthly, October through May.

Professional activities: Biennial Symposium on Microscopy; Ashby Award, this Society's highest; Junior Study Group; Medal for first place in Annual Members Exhibition which has been held for eighty-four consecutive years.

Publications: Yearbook, current volume: 8, free to members.

Library: 1,000 volumes. Subject emphasis: Microscopy.

1104. New York Neurological Society. 700 West 168th Street, New York 32, N. Y. President: H. Houston Merritt. Term expires 1961. Secretary-Treasurer: Rollo J. Masselink. Term indefinite.

History: Organized January 10, 1872; reorganized April 6, 1874; incorporated April 20, 1882.

Purpose: Advancement of the science of medicine in its relation to the nervous system.

Membership: Members must have graduated from approved medical schools, completed general medical or surgical internships, had adequate specialized training in neurology, psychiatry, neurosurgery, neuropathology, or their cognate sciences, and at least three years' practice or laboratory work in one of these specialties, and must be members of hospital or clinic staffs, or be engaged in teaching in subject field. Total membership 250.

Meetings: Monthly, October through May.

1105. New York Pathological Society. 2 East 103rd Street, New York 29, N. Y. President: Harry P. Zimmerman, Montefiore Hospital, New York 67, N. Y. Term expires July 1, 1961. Secretary: Hans Popper, Mt. Sinai Hospital, New York 29, N. Y. Term expires July 1, 1961.

History: Organized 1844; incorporated 1886. Purpase: Improvement of members in pathology, and in diagnosis and treatment of diseases.

Membership: Must be physicians trained in pathology at least two years, or must be engaged in such medical scientific work as bacteriology, immunology, physiology, biochemistry, or veterinary medicine for equivalent periods, or must be graduates of medicine at least four years 
with demonstrated interest in laboratory medicine. Active members, 195; Life, 97; Honorary, 4. Total membership 296.

Meetings: Monthly, October through May.

Professional activities: Middleton Goldsmith Fund, income used for payment of lecturers.

1106. New York Psychiatric Society. 121 Westchester Avenue, White Plains, N. Y. President: James H. Wall. Term expires January 1961. Secretary-Treasurer: Donald M. Hamilton. Term expires January 1961.

\section{History: Founded 1904.}

Purpose: To stimulate the study and advance the interest of psychiatry.

Membership: Psychiatrists who have made outstanding contributions to the field. Active members limited to 30; Senior, 6, former active members past age sixty-five; Non-resident, 9; Honorary, 3. Total membership 48.

Meetings: Four annually.

1107. New York Rheumatism Association, Inc. President: Ronald W. Lamont-Havers, Arthritis and Rheumatism Foundation, $10 \mathrm{Co}-$ lumbus Circle, New York 19, N. Y. Term expires April 1961. Secretary-Treasurer: Albert W. Grokoest, 622 West 168th Street, New York 32, N. Y. Term expires April 1961.

\section{History: Organized 1942.}

Purpose: To unite physicians in New York and suburbs who are interested in arthritic and rheumatic disorders, improve treatment of patients, and stimulate study and research.

Membership: Open to physicians, teachers, and investigators interested in Association's purpose. Total membership 224.

Meetings: Three annually.

1108. New York Rhino-Otolaryngological Society. President: E. Markey Pullen, 30 East 40th Street, New York 16, N. Y. Term expires May 1961. Secretary-Treasurer: S. P. Schechter, 1749 Grand Concourse, New York 53, N. Y. Term expires May 1961.

History: Organized 1934. Сомmitree: Scientific.

Purpose: Discussion of current literature in otolaryngology.

Membership: Diplomates in otolaryngology, with talents for special study in ear, nose, and throat. Total membership 19.

Meetings: Monthly, October through May.

1109. New York Roentgen Society. New York Academy of Medicine, 2 East 103rd Street,
New York 29, N. Y. President: Frank J. Borelli. Term expires July 1, 1961. Secretary: Albert A. Dunn. Term expires July 1, 1961.

History: Organized and incorporated July 1912.

Purpose: To disseminate scientific information; to promote the specialty of radiology.

Membership: Diplomates of American Board of Radiology. Active members, 229; Associate, 12; Honorary, 6; Non-Resident, 27; Retired, 22. Total membership 296.

Meetings: Monthly during winter.

1110. New York Society for Circulatory Diseases. 114-08 Linden Boulevard, Ozone Park 20, N. Y. President: Simon Dack, 1111 Park Avenue, New York 28, N. Y. Term indefinite. Secretary: Gabriel F. Greco. Term indefinite.

History: Organized 1949; incorporated in New York; affiliate, American College of Cardiology. Founded as State chapter of national organization.

Purpose: To advance and promote progress in cardiology.

Membership: Requires membership in American College of Cardiology. Total membership 500.

Meetings: Semiannual.

1111. New York Society for Clinical Psychiatry. President: S. Bernard Wortis, 410 East 57th Street, New York 22, N. Y. Term expires April 1961. Secretary-Treasurer: Marvin Stern, New York University School of Medicine, 550 1st Avenue, New York 16, N. Y. Term indefinite.

History: Organized November 9, 1924.

Purpose: Advancement of the art and science of psychiatry.

Membership: Active, physicians licensed in practice of neuropsychiatry with at least one year of resident training in accredited psychiatric hospitals or clinics, or equivalent training; Charter, founding members; Life, members for twenty-five years. Total membership approximately 600 .

Mectings: Five annually.

1112. New York Society of Electron Microscopists. President: William A. Ladd. Term expires May 1961. Secretary: Pauline E. Holbert, Rutgers University, New Brunswick, N. J. Term expires May 1961.

History: Organized 1951.

Purpose: To increase and disseminate knowledge of electron microscopy. 
Membership: Requires active interest in electron microscopy, industrial, biological, or technical. Total membership 174.

Meetings: Bimonthly.

Publications: International Bibliography of Electron Microscopy, quarterly.

Library: 8,000 volumes. Subject emphasis: Electron microscopy.

\section{New York State Archeological Associa-} tion. State Education Building, Albany 1, N. Y. President: Ralph S. Solecki, Columbia University, New York 27, N. Y. Term expires April 1, 1961. Secretary: Charles F. Hayes III, 657 East Avenue, Rochester 7, N. Y. Term expires April 1, 1961.

History: Organized 1916; absolute charter granted by Regents of University of the State of New York 1927. Chapters: Archeological Society of Western New York, Lancaster; Auringer-Seelye, Glens Falls; Chenango, Sherburne; Lewis Henry Morgan, Rochester; Long Island, Southold; Mid-Hudson, Rhinebeck; Orange County, Warwick; Van Epps-Hartley, Fonda.

Purpose: To promote scientific archeological and historical research relating to Indians of New York State; to coordinate work of amateur and professional archeologists.

Membership: Open to any person interested in archeology and willing to subscribe to objects of Association. Active members, 246; Sustaining, 23; Junior, 16, Husband and Wife, 25 couples; Honorary, 2 ; Life, 25 ; Members-atLarge, 8. Total membership 370.

Meetings: Annual.

Professional activities: Fellowship; Achievement Award.

Publications: Researches and Transactions, triennial, current volume: 14 , free to members. Editor: Alfred K. Guthe. Bulletin, three annually, current volume: 18 , free to members. Editor: Louis K. Brennan.

Library: 2,000 volumes. Subject emphasis: Anthropological.

1114. New York State Association of Public Health Laboratories. New Scotland Avenue, Albany 1, N. Y. President: Glenn J. Copeland, Clifton Springs Sanitarium and Clinic Laboratory, Clifton Springs, N. Y. Term expires May 1961. Secretary-Treasurer: Mary B. Kirkbride, 314 State Street, Albany 10, N. Y. Term expires May 1961.

History: Organized 1916; constitution adopted November 12, 1919. CommitteEs: Use of Laboratory Facilities; Laboratory Services; Postgraduate Training; Enumeration of Laboratory Examinations.
Purpose: To increase efficiency of laboratories engaged in public health work in New York State; to unify interests of their workers by stimulating a spirit of common understanding and cooperation, and to encourage constant effort toward improvement and standardization of technical methods.

Membership: Active members, 140, fully qualified representatives of laboratories approved by State Commissioner of Health; Associate, 148, qualified workers in laboratories approved by Commissioner of Health, and others actively interested in work of this Association; Honorary, 8; Emeritus, 10. Total membership 306.

Mectings: Two annually.

Publications: Proceedings, twice annually, current volume: $40, \$ 1$, free to members. Editor: Mary B. Kirkbride.

1115. New York State Capital District Branch, American Psychiatric Association, Inc. President: Santino F. Lando, Ellis Hospital, Schenectady, N. Y. Term expires May 12, 1961. Executive Secretary: Ian C. Funk, Albany Hospital, Albany, N. Y. Term expires May 12, 1961.

History: Organized February 5, 1957. District comprises following counties of New York State: Albany, Columbia, Montgomery, Otsego, Rensselaer, Saratoga, Schenectady, Schoharie, Varren, and Washington.

Purpose: To foster progress of and represent psychiatry in the New York State Capital District, and to assist in promotion of aims and objectives of American Psychiatric Association.

Membership: Members, 35, members or associates of American Psychiatric Association with three years' experience in psychiatry; Associate, associate members of American Psychiatric Association with less than three years in psychiatry; Honorary, individuals who have rendered signal service to psychiatry. Total membership 35 .

Meetings: Six annually.

1116. New York State Geological Association. Department of Geology, City College, New York 31, N. Y. President: Joseph L. Rosenholtz, Rensselaer Polytechnic Institute, Troy, N. Y. Term expires May 1961. Permanent Secretary: Kurt E. Lowe.

\section{History: Organized 1925.}

Purpose: To promote acquaintanceship and exchange of information among geologists in New York State and adjoining regions; to foster better understanding of New York geology by field meetings and publication of guide- 
books; to serve interests of advanced geology students.

Membership: Open to faculty members of colleges and universities, professional geologists in government and industry, science teachers of secondary schools, and other interested adults. Total membership: Individuals, 175; Institutions and organizations, 45.

Meetings: Annual.

1117. New York State Psychological Association. President: Max Siegel, 50 Kenilworth Place, Brooklyn 10, N. Y. Term expires May 1961. Exccutive Secretary: Samuel Pear1man, 1 Hanson Place, Brooklyn 17, N. Y. Term indefinite.

History: Founded 1921 as New York State Association of Consulting Psychologists; incorporated 1938 as New York State Association of Applied Psychology, after two other changes in title and structure; reincorporated 1948 under present title; reorganized on a divisional basis 1952. Divisions: General Psychology, Clinical Psychology, Applied Social Psychology, Personnel Psychology, School Psychology.

Purpose: To further development of psychology as a science and a profession; to safeguard interests of public and profession, and freedom of scientific inquiry, teaching, and professional practice; to establish and maintain standards of competency, training, service, and conduct.

Membership: General Member, is without divisional affiliation, subscribes to purposes of this Association, resides or works within New York State, and has completed two years of graduate study in psychology or one year of graduate study plus one year of professional work; Divisional Member, may be affiliated with one or more divisions, but must meet any additional membership requirements of these divisions; Student Affiliate, three-year status, graduate student with eighteen credits of graduate study in psychology. Total membership 1,700.

Meetings: Annual.

Professional activities: Official representation of profession in relations with State Government; liaison with regional and special interest associations in the State; active functioning in areas of legislation, ethical practices, public information.

Publications: New York State Psychologist, bimonthly, current volume: 12, free to members. Editor: Bernard Locke.

1118. New York State Public Health Association. President: V. J. Sallak, 766 Ellicott Street, Buffalo 3, N. Y. Term expires 1961. Secretary: Carlene Millican, 1090 Bay Street, Rochester 9, N. Y. Term expires 1961.
History: Organized 1950.

Purpose: To assist in protecting and promoting public health; to provide for scientific and professional advancement; to extend and develop the public health movement.

Membership: Open to public health educators, sanitation workers, physical therapists, statisticians, administrative workers. Total membership 960.

Meetings: Annual.

Publications: Newsletter, bimonthly.

1119. New York State Society for Medical Research, Inc. 2 East 63rd Street. New York 21, N. Y. President: Harold C. Hodge, University of Rochester School of Medicine, 260 Crittenden Boulevard, Rochester 20, N. Y. Term expires June 30, 1962. Executive Secretary: Ida Dailes. Term indefinite.

History: Incorporated January 1951.

Purpose: To promote high standards of medi cal and scientific research, and of methods used in such research, including humane use of animals.

Membership: Open to persons supporting objectives of this Society. Total membership approximately 2,000.

Meetings: Annual.

Professional activities: In-service institute for biology teachers in New York high schools; other institutes and courses to increase competence of biology teachers in secondary schools, modernize biology curricula, and interest young people in careers in the life sciences.

Publications: Bulletin, three or four annually.

1120. New York State Society of Anesthesiologists, Inc. 145 East 49th Street, New York 17, N. Y. President: Edwin Emma, 67 Raymond Place, Hewlett, N. Y. Term expires December 1960. Executive Secretary: Mrs. Eugenia C. Sinisi, 170 Nagle Avenue, New York 34, N. Y. Term indefinite.

History: Organized 1935. Sections: Albany, Bronx, Brooklyn, Buffalo, Long Island, Manhattan, Rochester, Syracuse.

Purpose: To advance the science and art of anesthesiology.

Membership: Doctors of medicine in specialty of anesthesiology. Active, Associate, Junior, Honorary, and Retired Members. Total membership 1,000 .

Meetings: Annual.

Professional activities: Prizes for scientific exhibits and best paper presented at annual meeting.

Publications: Bulletin, six annually, current 
volume: 13, free to members. Editor: William S. Howland.

Library: Over 2,000 volumes. Subject emphasis: Anesthesiology and related fields.

1121. New York State Society of Industrial Medicine, Inc. 30 Rockefeller Plaza, New York 20, N. Y. President: Harry E. Tebrock, Sylvania Electric Company, 730 3rd Avenue, New York 17, N. Y. Term expires December 1961. Secretary-Treasurer: Gerald J. Friedman, 850 Park Avenue, New York, N. Y. Term expires December 1961. Corresponding Secretary: Frank M. Dua. Term indefinite.

History: Organized May 6, 1935, as Association for the Advancement of Industrial Medicine and Surgery; name clianged to present title 1952; covers all New York State except western section.

Purpose: Advancement of industrial medicine through education, and through assistance to other medical societies.

Membership: Requires membership in local or county medical society or American Medical Association, three years' experience in medicine and surgery including two years in occupational health or investigation of industrial medical problems. Total membership approximately 400.

Mcetings: Three or four annually.

1122. New York State Society of Professional Engineers. 500 5th Avenue, New York 36, N. Y. President: Victor E. Hall, 1543 Glenwood Avenue, Syracuse 7, N. Y. Term expires June 30, 1961. Executive Director: Albert $\mathrm{H}$. Morgan. Term indefinite.

History: Founded 1926. Twenty-nine chapters.

Purpose: To safeguard life, health, and property by restricting practice of engineering to properly qualified persons; to establish high standards of conduct; to advocate creation and enforcement of adequate license and practice laws, and to place control of engineering projects within scope of such laws and acts; to focus public attention upon professional standing, functions, requirements, and accomplishments of engineers; to sponsor and promote honorable procedure toward emoluments, commensurate with the dignity and responsibility of this profession.

Membership: Professional engineers and land surveyors, 4,780, registered in New York State; engineers in training, 620, certified in New York State. Total membership 5,400.

Mectings: Three annually.

Professional activitics: Award to Engineer of the Year.
Publications: New York Professional Engineer, bimonthly, current volume: $17, \$ 2$. Editor : George Keates.

1123. New York State Waterways Association, Inc. 17 Battery Place, New York 4, N. Y. President: David A. Wright, 21 West Street, New York 6, N. Y. Term expires December 31, 1960. Secretary: William E. Cleary. Term indefinite.

\section{History: Organized 1908.}

Purpose: To protect, foster, and develop rivers, harbors, and waterways of the State of New York, for navigation, commerce, flood control, recreation, and related functions.

Mcmbership: Open to all individuals, corporations, government agencies, municipalities, and organizations interested in purposes of this Association. Total membership 110.

Mectings: Annual.

Publications: New York Waterways, bimonthly, current volume: 15 , free to members. Editor: Charles Godsoe.

1124. New York Zoological Society. 30 East 40th Street, New York 16, N. Y. President: Fairfield Osborn. Term expires December 1960. Secretary: George Wall Merck. Term expires December 1960.

History: Incorporated 1895; July 1, 1898, Society assumed control of grounds of South Bronx Park for development of New York Zoological Park, opened November 8, 1899; Society assumed control of New York Aquarium, Coney Island, October 31, 1902.

Purpose: Promotion of zoology through education, scientific activities, and research ; conservation of wild animal life.

Mcmbership: Annual members, 2,019; Contributing members, 1.145; Supporting members, 85; Life members, 362; Patrons, 40; Associate Founders, 11; Founders, 10; Founders-inPerpetuity, 13; Benefactors, 12; Corresponding members, 6; Fellows, 79; Honorary members, 5; Research Associates, 4. Total membership 3,791 .

Mectings: Annual.

Professional activitics: Maintenance of tropical research station in Trinidad, and of marine biochemistry and ecology laboratory at New York Aquarium; conservation research projects. Publications: Zoologica, quarterly, current volume: 45, \$6. Animal Kingdom, bimonthly, current volume: $63, \$ 3.50$. Annual Report, current volume: 64 , free. Editor, all listed publications: William Bridges.

Library: 7,100 volumes. Subject emphasis: Zoology. 
1125. Newark Museum Association. 43-49 Washington Street, Newark 1, N. J. Presidcut: Franklin Conklin, Jr. Term indefinite. Secretary-Director: Katherine Coffey. Term indefinite.

\section{History: Organized 1909.}

Purpose: To recieve and exhibit objects of art, science, history, and technology, and to encourage study of arts and sciences.

Membership: Annual members, 2,056; Subscribing, 243; Chapter, 20 ; Patrons, 51 ; Sustaining, 16; Corporate and Business, 37 ; Endowment, 6; Endowment Fellows, 9; Life, 11; Perpetuity, 9; Benefactors, 3; Ex Officio, 3; Honorary, 1. Total membership 2,465.

Mcetings: Annual.

Publications: News Notes, ten annually, current volume: $17, \$ 0.75$, free to members. Museum, quarterly, current volume: $12, \$ 2.50$, free to members. Editor: Mildred Baker.

Library: 11,000 books and periodicals, 15,000 photographs, 8,000 negatives, 12,000 pamphlets, 1,500 lantern slides, and approximately 2,000 recordings. Subject emphasis: Art, science, history, and technology.

\section{Newell Entomological Society.}

See Addenda, No. 1592.

1126. Noah Worcester Dermatological Society. President: H. Jerry Lavender, 717 Provident Bank Building, Cincinnati 2, Ohio. Term expires March 25, 1961. Secretary: Edwin L. Higgins, 802 Scott Street, Covington, Ky. Term expires March 25, 1961.

\section{History: Founded April 1958.}

Purpose: To bring together dermatologists and those in allied fields in order to stimulate interest and disseminate scientific knowledge.

Membership: Board members in dermatology or allied fields, members of local or county medical organizations. Total membership approximately 100 .

Metings: Two annually.

1127. North American Gladiolus Council. 2514 East 25th Street, Des Moines 17, Iowa. President: Henry A. Elieff, 4009 Park Avenue, Minneapolis 7, Minn. Term expires January 1961. Secretary: J. Elton Carter. Term expires January 1961.

History: Organized 1945 at Detroit, Mich.; incorporated 1947. Seventy participating societies in the United States, Canada, England, and New Zealand.

Purpose: To coordinate efforts of gladiolus societies; to promote research in elimination of diseases and insect pests; to develop an international classification; to hold international exhibitions of the flower, and to improve its health and beauty.

Membership: Individual members, approximately 3,500 , with interest in gladiolus cultivation and research; participating societies, 70.

Meetings: Annual.

Professional activities: Achievement Award, annual; gold medals for services rendered; silver and bronze medals to shows.

Publications: Council Bulletin, quarterly, current volume: $15, \$ 2$. Editor: Arthur M. Reeves, Route 2. Aberdeen, Md.

1128. North American Wildlife Foundation, Inc. 709 Wire Building, Washington 5, D. C. President: Max McGraw. Term indefinite. Secretary: C. R. Gutermuth. Term expires January 1962.

History: Organized, under a charter granted by the District of Columbia, July 22, 1935, as American Wildlife Institute; renamed American Wildlife Foundation, Inc., 1946; present name adopted February 1951.

Purpose: To attain better management of natural resources; to encourage and perpetuate training of technicians and administrators; to advance public education and knowledge, promote necessary research and its application, and effect better use of funds in fields of restoration and conservation.

Membership: Voting members, thirty elected trustees; Non-voting members, contributing supporters.

Mectings: Semiannual.

Professional activitics: Sponsorship of wildlife research, demonstration, and sound management, through cooperating agencies; ownership of property and facilities of Delta Waterfowl Research Station, Manitoba, Canada, operated by IVildlife Management Institute.

1129. North Carolina Academy of Science. President: Henry W. Jensen, Warren Wilson College, Swannanoa, N. C. Term expires May 1961. Secretary: John A. Yarbrough, Meredith College, Raleigh, N. C. Term expires May 1961.

History: Founded March 1902; reorganized May 1903. Sections: Biochemistry-Physiology, Botany, Chemistry, Geology, High School Teaching, Mathematics, Physics, Psychology, Zoology, Collegiate Academy, Junior Academy.

Purpose: To promote study and research, and to furnish means of publication of worthwhile papers.

Mcmbership: Open to any person interested in science. Members, Life Members. Total membership 500 . 
Meetings: Annual.

Professional activities: Grant of approximately $\$ 100$ from American Association for the Advancement of Science; Poteat Award, $\$ 50$, for meritorious paper presented at Academy meeting; sponsorship, through Junior Academy, of Westinghouse Science Talent Search, and local, regional, and State science fairs; winners from State fair participate in National Science Fair.

\section{North Carolina District Branch of} American Psychiatric Association. President: Marshall L. Fisher, 1618 Elizabeth Avenue, Charlotte 4, N. C. Term expires May 1961. Secrctary: Thomas E. Curtis, Department of Psychiatry, North Carolina Memorial Hospital, Chapel Hill, N. C. Term expires May 1961.

History: Organized November 1956. CoMMitTeES: Academy of General Practitioners; Technical Aspects of Psychiatry; Professional Standards: Community Aspects.

Purpose: To promote the science, art, and practice of psychiatry in North Carolina, and to serve as an influence for maintenance of high professional standards in this field.

Membership: Members or Fellows of American Psychiatric Association residing or practicing in North Carolina. Total membership 95.

Mectings: Semiannual.

Professional activities: Conference on research in psychiatry performed by residents or medical students.

1131. North Carolina Neuropsychiatric Association. President: Marshall L. Fisher, 1618 Elizabeth Avenue, Charlotte 4, N. C. Term expires October 1960. Secretary: Thomas E. Curtis, Department of Psychiatry, North Carolina Memorial Hospital, Chapel Hill, N. C. Term expires October 1960.

History: Established January 18, 1935. Commitrees: Executive, Publicity, Program, Membership, Research, Nominating, Ethics, Awards, Clinical Psychology, Cooperation with Lay Groups, Liaison with North Carolina Mental Hygiene Society, Legislative, Liaison with State Hospital Board of Control, Crime and Psychiatry for State Medical Society, Academic Educcation.

Purpose: To unite physicians interested and engaged in study and treatment of nervous and mental disorders; to foster advancement of knowledge and organize facilities for care of the nervous and mentally ill.

Membership: Members of State medical society or American Psychiatric Association. Total membership 149.

Meetings: Semiannual.
1132. North Carolina Pharmaceutical Association. President: E. R. Fuller, Salisbury, N. C. Term expires April 1961. Secretary: IV. J. Smith, Chapel Hill, N. C. Term expires April 1961.

History: Organized August 11, 1880, at Raleigh, N. C.

Purpose: To promote the interests of retail druggists of North Carolina.

Membership: Requires registration as pharmacist with North Carolina Board of Pharmacy. Total membership 1,350.

Mectings: Annual.

Publications: Carolina Journal of Pharmacy, $\$ 3$. Yearbook.

1133. North Carolina Psychological Association. President: Howard G. Miller, North Caroiina State College, Raleigh, N. C. Term expires 1961. Secretary: lla H. Gehman, Child Guidance Clinic, 2212 Erwin Road, Durham, N. C. Term expires 1962.

History: Organized 1948. Committees: Ethics, Legislation, and Professional Practices; Program; Interrelationships with Other Organizations; Executive; Information and Publications.

Purpose: To advance psychology as a science, as a profession, and as a means of promoting human welfare.

Mcmbership: Fellows, actively engaged in field with doctoral degree in psychology and three years' experience, or fellow of American Psychological Association; Associates, actively engaged in field with master's degree in psychology and two years' experience, or member, American Psychological Association; Affiliates, activities in related field. Fellows, 91; Associates, 55; Affiliates, 19. Total membership 165.

Meetings: Semiannual.

Professional activities: Sponsorship of professional legislation; appraisal of members in research and other work.

Publications: Semiannual Bulletin. Newsletter, irregular.

1134. North Carolina Public Health Association. President: Miss Grace Daniel, P. O. Box 1487, Salisbury, N. C. Term expires September 8, 1961. Secretary: R. W. Brown, P. O. Box 7525, Asheville, N. C. Term expires September 8, 1961.

History: Organized as North Carolina Health Officers' Association, in Charlotte, June 20, 1911; name changed to present title April 25, 1921. Sections: Health Directors, Health Education, Laboratory, Nursing, Nutrition, Sanitation, Secretarial and Statistical. 
Purpose: To protect and promote public and personal health of citizens of North Carolina through providing a medium whereby health workers may attend meetings and exchange ideas which will result in more effective public health services.

Membership: Active members, professional health workers actively engaged, on full time basis, in health work in North Carolina, who are members or Fellows of Anerican Public Health Association; Members, professional health workers similarly engaged in North Carolina, who are not members or Fellows of American Public Health Association, and persons in that State not actively engaged in health work, but interested in this Association and its objectives; Sustaining members, organizations or corporations in North Carolina interested in public health; Life; Honorary, for distinguished service to public health in North Carolina. Total membership 1,205.

\section{Meetings: Annual.}

Professional activities: Reynolds Award, for contribution to public health in North Carolina during past year; Rankin Award, in recognition of contribution to public health in that State over several years; Merit Award, for contributions or activities during past year for a local health department or group; Distinguished Public Health Service Award, for contribution to public health in North Carolina by a person not employed in that field; Sanitarians' Section offers award for achievenient in field of sanitation to a sanitarian or an engineer; scholarship for nine month course, School of Public Health, University of North Carolina, alternate years.

Publications: Quarterly Newsletter, to members.

1135. North Carolina Society of Anesthesiologists. President: IVilliam Homer, Mercy Hospital, Charlotte, N. C. Term expires January 1, 1961. Secretary-Treasurer: Robert H. Cole, 153+ Coventry Road, Charlotte 7, N. C. Term expires January 1, 1961.

History: Organized May 10, 1949 ; component society, American Society of Anesthesiologists.

Purpose: To advance anesthesiology in North Carolina.

Membership: Requires degree of doctor of medicine and practice of anesthesiology as full time specialty or resident-in-training.

Meetings: Annual.

1136. North Carolina Trudeau Society. 105 Harrison Avenue, Raleigh, N. C. President: A. L. Ormond, Hickory, N. C. Term expires April, 1961. Secretary-Treasurer: IV. H. Gentry, McCain, N. C. Term expires April, 1961.
History: Organized May, 1948; incorporated; Society is medical section, North Carolina Tuberculosis Association.

Purpose: To further clinical, epidemiological, and other scientific studies in tuberculosis and related conditions; to promote professional and social relations of members; to cooperate with other official and non-official agencies in control of tuberculosis.

Membership: Open to any medical doctor interested in combating tuberculosis. Regular members, 85 ; Honorary, 4. Total membership 89.

Meetings: Annual.

1137. North Dakota Academy of Science. P. O. Box 573, University Station, Grand Forks, N. Dak. President: Vera Facey. Term expires May 1961. Secretary-Treasurer: Ben G. Gustafson. Term expires May 1961.

History: Organized 1908 at Valley City, N. Dak.; incorporated 1957; officially designated by legislative action as State Academy, 1959.

Purpose: To promote scientific study and achievement in basic sciences at academic and professional levels.

Membership: Requires professional degree or evidence of professional competence. Full members, 312; Associate members, 10; Corporate members, 12. Total membership 334.

Meetings: Annual.

Professional activities: Roger A. Denison Prizes, $\$ 50, \$ 25, \$ 15$, for student research; funds for student publications; sponsorship of Statewide high school science testing program to find recipients for scholarship awards.

Publications: Proceedings, annual, current volume: 13, \$1.50. Editor: Ben G. Gustafson.

1138. North Dakota Geological Society. P. O. Box 1123, Bismarck, N. Dak. President: Howard Ellinwood. Term expires January 1, 1961. Executive Secretary: William R. Bolenbaugh. Term expires January 1, 1961.

History: Organized July 27, 1951. Sections : North Dakota, South Dakota.

Purpose: To promote the science of geology in North Dakota and surrounding territory; to encourage scientific research; to advance and uphold professional ethics and standards; to collect, disseminate, and discuss geological information.

Membership: Requires three years' study with major in geology, one year of experience in that field, and meeting of standards of American Association of Petroleum Geologists. Total membership 90 .

Meetings: Monthly. 
Professional activities: Course of instruction, Bismarck Junior College; sponsorship of merit badge work in Boy Scouts.

Publications: Geologram, monthly, free. Editor: Robert Munger.

1139. North Dakota Pharmaceutical Association. 1208 South Highland Acres Road, Bismarck, N. Dak. President: Alden L. Foss, 1101 Chautauqua Boulevard, Valley City, N. Dak. Term expires June 30,1961. Executive Secretary: Al Doerr. Term expires June 30, 1963.

History: Founded August 3, 1886 at Fargo, Dakota Territory, as Dakota Pharmaceutical Association; name subsequently changed to present title. Geographic Divisions and Chapters: Northeast Counties Drug Association; Northwest Counties Drug Association; Sixth District Pharmacy Association; Southeast Counties Drug Association; Southwest Counties Drug Association.

Purpose: To unite pharmacists of North Dakota; to improve the science and art of pharmacy; to restrict the dispensing and sale of medicine to regularly educated druggists and apothecaries.

Membership: Active members, 335, registration certificates and dues; Associate, 576, registration certificates. Total membership 911.

Meetings: Semiannual.

Professional activities: A. H. Robins Bowl of Hygeia Award for community service in pharmacy.

1140. North Dakota Public Health Association. President: William Unti, 422 2nd Avenue, N. W., Jamestown, N. Dak. Term expires April 1961. Secretary-Treasurer: Alice H. Peterson, State Department of Health, Bismarck, N. Dak. Term expires April 1962.

History: Organized May 1944. Sections: Sanitation, Nursing, General Health.

Purpose: To promote interest in public health, foster better understanding of problems and practices, facilitate interchange of ideas relating to solutions, and aid in promoting pertinent State and local legislation.

Membership: Open to physicians, dentists, engineers, public health nurses, health educators, welfare workers, and others having interest in advancement of public health. Total membership 125.

Meetings: Annual.

Professional activities: Award for outstanding contribution in field of health.

Publications: Newsletter, quarterly, current volume: 15, free to members. Editor: John K. Peterson.
1141. North Dakota Radiological Society. President: Lester Shook, Fargo Clinic, Fargo, N. Dak. Term expires May 1961. Secretary: John J. Jestadt, De Puy-Sorkness Clinic, Jamestown, N. Dak. Term expires May 1961.

History: Organized 1946.

Purpose: To advance the practice of radiology in North Dakota by exchange of ideas.

Membership: Diplomates, American Board of Radiology. Total membership 13.

Mectings: Annual.

Professional activities: Student Loan Fund, University of North Dakota Medical School; North Dakota Society of X-ray Technicians.

1142. North Dakota Society of Obstetrics and Gynecology. P. O. Box 1388, Fargo, N. Dak. President: John S. Gillam. Term expires September 16, 1961. Secretary: G. Wilson Hunter. Term expires September 16, 1961.

History: Organized 1938.

Purpose: To develop obstetrics and gynecology in North Dakota.

Membership: Requires membership, State medical association. Total membership 72 .

Mectings: Two annually.

Professional activities: L. W. Larson Lectureship on Female Cancer, and James H. Hanna Lectureship in Obstetrics, each $\$ 300$ annually; funds for securing nationally known speakers for meetings.

1143. North Dakota State Medical Association. P. O. Box 1198, Bismarck, N. Dak. President: C. M. Lund. Williston Clinic, Williston, N. Dak. Term expires May 1961. Secretary: William Buckingham, Elgin, N. Dak. Term expires May 1961. Executive Secretary: Lyle A. Limond. Term indefinite.

History: Organized June 1882 as Medical Society of the Territory of Dakota; name changed to North Dakota Medical Society 1887 , and to present title May 1904. Ten district societies.

Purpose: Promotion of the scientific and ethical practice of medicine.

Membership: Physicians who are members of district medical societies and practicing nonsectarian medicine. Total membership 447.

Mectings: Annual.

Publications: Journal-Lancet, monthly, current volume: $80, \$ 5$. Editor: J. Arthur Myers.

1144. North Dakota Water and Sewage Works Conference. President: Frank Orthmeyer, 1705 North 5th Street, Bismarck, N. Dak. Term expires November 1960. Secretary- 
Treasurer: IV. Van Heuvelen, State Capitol Building, Bismarck, N. Dak. Term indefinite.

History: Organized 1929.

Purpose: To further knowledge of water treatment and distribution, sewage treatment and collection, and development of sanitary engineering practices.

Membership: Open to any person interested in North Dakota water and sewage works problenıs. Total membership 516.

Meetings: Annual.

Professional activities: Flox Award; presentation of professional papers; sponsorship of area short courses on water and sewage treatment.

Publications: Official Bulletin, bimonthly, current volume: $27, \$ 2$. Editor: W. Van Heuvelen.

1145. North Florida Radiological Society. President: Marvin Harlan Johnston, Five Points Medical Center, Jacksonville 4, Fla. Term indefinite. Secretary: Paul A. Mori, 800 Miami Road, Jacksonville 7, Fla. Term indefinite.

History: Organized May 1954.

Purpose: Advancement of the practice of radiology.

Mcmbership: Requires professional practice limited to radiology. Total membership 35 .

Mcetings: Quarterly.

1146. North Pacific District Branch of American Psychiatric Association. President: James Shanklin, Portland Medical Center, Portland, Oreg. Term expires April 1961. Executive Sccretary: John IV. Evans, 201 Medical Arts Building, Portland 5, Oreg. Term expires April 1961.

History: Formed in the 1950's.

Purpose: To keep members better informed of national business; to keep leadership of national organization more informed of local needs.

Membership: Requires membership in American Psychiatric Association. Total membership 150.

Mectings: Biennial.

1147. North Pacific Pediatric Society. 1440 Southwest Taylor Street, Portland, Oreg. President: E. Stewart James, 5731 Cranville Street, Vancouver, B. C. Term expires September 24, 1961. Executive Secretary: John A. May. Term expires September 24, 1961.

History: Founded 1919. Covers States of ldaho, Montana, Oregon, and Washington, and the Provinces of Alberta and British Columbia.
Purpose: Advancement of pediatrics; scientific and social improvement of members.

Mcmbership: Physicians whose practice is limited to pediatrics. Total membership 280, of whom 18 are Associate.

Mectings: Semiannual.

1148. North Pacific Society of Internal Medicine. Presidcnt: Samuel M. Poindexter, 105 North 8th Street, Boise, Idaho. Term expires September 1961. Secretary: Fred E. Cleveland, 1118 9th Avenue, Seattle, Wash. Term expires September 1961.

\section{History: Organized 1927.}

Purpose: To elevate standards of internal medicine in the North Pacific area.

Membership: Active members, 105, from British Columbia, Idaho, Montana, Oregon, Washington, and Wyoming, with five years in internal medicine and certification by American Board; Senior, over sixty years of age; Inactive; Honorary.

Meetings: Semiannual.

1149. North Pacific Society of Neurology and Psychiatry. President: Peter Lehmann, 925 West Georgia Street, Vancouver 1, B. C. Term expires April 1961. Secretary-Treasurer: Thomas H. Holmes, School of Medicine, University of Washington, Seattle 5, Wash. Term expires April 1961.

History: Organized 1939. Sectrons: Washington, Oregon, Idaho, Montana, British Columbia, Alaska, Yukon.

Purpose: To advance the sciences of neurology and psychiatry.

Membership: Fellows, certified or eligible for certification by specialty boards; Associate members, limiting practice to neurology, psychiatry, neurosurgery, or allied sciences; Senior liellows; Honorary Fellows. Total membership 200.

Mcctings: Annual.

1150. North Pacific Surgical Association. President: John A. Duncan, 1630 Medical Dental Building, Seattle 1, Wash. Term expires November 1960. Secretary-Treasurer: Dean K. Crystal, 1110 Harvard Avenue, Seattle 22. Wash. Term expires November 1964.

History: Organized March 1912. Sections: Oregon, Washington, British Columbia.

Purpose: Cultivation of the science and art of surgery and promotion of highest ethical standards of surgical practice.

Mcmbership: Over thirty-five years of age, graduates of five years fron recognized schools 
of medicine, members of State or provincial medical associations, and having published papers of literary and surgical merit. Active members, 100; Senior members, 40. Total menbership 140 .

Mectings: Annual.

Professional activities: Annual Founders' Lecture.

1151. North Texas Geological Society. President: George M. Spalding, 4904 George Street, Wichita Falls, Tex. Term expires May 1961. Secretary: Harry B. Baskette, 1412 Silby Street, Wichita Falls, Tex. Term expires May 1961.

\section{History: Founded 1923.}

Purpose: Increase of geological knowledge, especially of North Texas and adjacent regions; promotion of fellowship and professional cooperation among geologists and geological workers resident in that area.

Mcmbcrship: Members, American Association of Petroleum Geologists, or eligible for membership in that organization; persons connected with the geological profession or interested in geological sciences are eligible for associate membership. Total membership 187.

Meetings: Bimonthly except June through August.

1152. Northeastern Loggers Association, Inc. President: Stanley IV. Hamilton, Mechanicville, N. Y. Term expires April 1961. E.recutive Secretary: Frank A. Reed, Old Forge, N. Y. Term indefinite.

History: Organized 1952; board of directors includes representatives of paper and lumber industries, United States Forest Service, State forestry departments, forestry colleges, and loggers. Division: Wood Utilization.

Purpose: To promote profitable utilization of low grade wood and wood waste in the interest of forestry.

Membership: Individual, 351 ; Industrial, 119 ; Associate, 3.

Meetings: Semiannual.

Professional actizities: Annual Loggers Congress; Annual Wood Utilization Conference; publication of wood utilization literature.

Publications: Northeastern Logger, special wood utilization issues, semiannual.

1153. Northeastern New York Radiological Society. President: Everett A. Jacobs, Columbia Memorial Hospital, Hudson, N. Y. Term expires June 1961. Secretary-Treasurer: Lester I. Citrin, St. Mary's Hospital, Troy, N. Y. Term expires June 1961.
History: Organized October 1950. Sections: Northeastern New York, Western Massachusetts, IVestern Vermont.

Purpose: Advancement of the science and practice of radiology.

Membership: Regular members, graduates of recognized medical schools, members of county medical societies, seventy-five percent of practice in radiology; Associate members, non-radiologists, physicians, or physicists with interest in radiology; Honorary members, for contribution to the science of radiology; Inactive members. Total membership 46.

Mectings: Five annually.

1154. Northern Arizona Society of Science and Art, Inc. P. O. Box 402, Flagstaff, Ariz. President: Harold S. Colton. Term expires January 1961. Executive Secretary: Agnes Allen. Term expires January 1961. Dircctor: Edward B. Danson. Term expires January 1961.

History: Organized 1928; incorporated 1933.

Purpose: To preserve scientific and artistic treasures and resources of Northern Arizona, both ancient and modern, and to diffuse knowledge on these subjects; to encourage art in its broadest sense; to conduct research and create an environment favorable for research.

Membership: Open to persons interested in objectives of this Society. Patron, Benefactor. Donor, Life Member, Sustaining Member, Fannily Member, Single Member, Student Member. Total membership 389.

Meetings: Annual.

Professional actizities: Geology scholarship, $\$ 1,000$ annually; Museum of Northern Arizona, and its research center.

Publications: Plateau, quarterly, current volume : 32, \$2. Editor: E. Roat. Bulletin, current volume: 35. Editor: Alan P. Olson.

1155. Northern California Geological Society. President: Stanford L. Rose, Standard Oil Company of California, 225 Bush Street, San Francisco, Calif. Term expires December 1960. Secretary: Earl IV. Hart, California State Division of Mines, Ferry Building, San Francisco, Calif. Term expires December 1960.

History: Organized 1944 ; informally affiliated with Pacific Section. American Association of Petroleum Geologists.

Purpose: To further, by discussion, field trips, and lectures, interest in and knowledge of the oil and gas provinces of Northern California.

Membership: Requires interest in petroleum geology and residence in Northern California. Total membership about 100 .

Meetings: Weekly. 
1156. Northern California Psychiatric Society. President: Maurice Grossman, 926 Addison Avenue, Palo Alto, Calif. Term expires May 1961. Secretary: Norman Graff, 34 North San Mateo Drive, San Mateo, Calif. Term expires May 1961.

History: Organized January 1954; affiliate, American Psychiatric Association. Secrions: Eighteen Northwestern California counties. Purpose: To further study of subjects pertaining to the nature, treatment, and prevention of mental disorders; to further interests, maintenance, and advancement of standards of hospitals for mental disorders, of out-patient clinics, and of all other agencies concerned with medical, social, and legal aspects of these disorders; to advance psychiatric education and research; to apply psychiatric knowledge to other branches of medicine, to other sciences, and to public welfare.

Menbership: Members of American Psychiatric Association, with residence or practice in Northwestern California. Total membership 320.

Meetings: Monthly, September to June.

Publications: Newsletter, bimonthly, free to members. Editor: Joan Davidson.

1157. Northern Indiana Psychiatric Society. President: David P. Morton, Narman Beatty Memorial Hospital, Westville, Indiana. Term expires June 1961. Executive Secretary: Theodore A. Hill, 107 North Eddy Street, South Bend 17, Indiana. Term expires June 1961.

History: Formed as branch of American Psychiatric Association, in December 1957.

Purpose: To bring psychiatrists of Northern Indiana together; to provide a meeting place where ideas can be exchanged; to provide a social climate.

Membership: Requires fulfillment of requirements for membership in American Psychiatric Association. Total membership 30.

Meetings: Monthly, except July and August. Publications: News Bulletin, monthly, free.

1158. Northern Montana Forestry Association. P. O. Box 394, Kalispell, Mont. President: J. F. Lally, Somers, Mont. Term expires April 1961. Secretary: Maurice E. Boorman. Term expires April 1961.

History: Organized May 1911.

Purpose: Prevention and suppression of forest fires.

Membership: Members, 250, owners of forest land within Association boundaries.

Meetings: Annual.

Publications: Annual statistical report.
1159. Northern New England District Branch, American Psychiatric Association. President: Peter B. Hagopian, Danvers State Hospital, Hathorne, Mass. Term expires November, 1960. Secretary-Treasurcr: Paul G. Myerson, 1093 Beacon Street, Brookline 46, Mass. Term expires November, 1960.

Purpose: Consideration of all matters relating to psychiatry, with special reference to clinical aspects.

Membership: Open to members of American Psychiatric Association. Total membership 265. Meetings: Quarterly.

1160. Northwest Arkansas Archaeological Society. President: H. R. McPherson, Route 8, Fayetteville, Ark. Term expires January 1, 1961. Sccretary: Mrs. J. C. Ferguson, Route 1, Fayetteville, Ark. Term expires January 1, 1961.

History: Organized October 1958; affiliate, Arkansas Archeological Society.

Purpose: To preserve remains of prehistoric peoples of Arkansas; to study these remains scientifically and to publish information concerning them; to arouse public opinion to appreciate these antiquities.

Membership: Requires interest in purposes of this Society. Total membership 250.

Meetings: Monthly.

Publications: Central States Archaeological Journal, quarterly, current volume: 7, \$2. Issued as cooperative effort with Illinois State Archaeological Society, Greater St. Louis Archaeological Society, and Indiana Indian Relic Collectors Society.

1161. Northwest Association of Horticulturists, Entomologists and Plant Pathologists. President: L. P. Batjer, P. O. Box 99, Wenatchee, Wash. Term expires July 1961. Secretary: C. G. Woodbridge, Washington State University, Pullman, Wash. Term expires June 1961.

History: Founded 1918 at Corvallis, Oreg. Purpose: To afford opportunity for research. teaching, and extension men of the Northwest to discuss common problems regarding research work in progress.

Membership: Open to any State, Provincial, or Federal employee interested in horticulture, entomology, or plant pathology, and residing in the Pacific Northwest; commercial men also eligible for membership if they spend fifty per cent of their time in field experimentation. Total membership 66.

Meetings: Annual. 
1162. Northwest Geological Society. President: Julian D. Barksdale, Department of Geolngy, University of Washington, Seattle 5, Wash. Term expires October 1960. Executize Sccretary: Glenn Boyd, 1007 Smith Building, Seattle 55, Wash. Term expires October 1960.

\section{History: Organized 1950.}

Purpose: Exchange of information on informal basis.

Membership: Requires professional interest in geology, especially water, minerals, oil, and gas. Total membership approximately 60 .

Mectings: Monthly except summer.

1163. Northwest Scientific Association. President: John R. Roberts, Pacific University, Forest Grove, Oreg. Term expires December 1960. Secretary-Treasurer: IVillis B. Merriam, Washington State University, Pullman, Wash. Term expires December 1960.

History: Organized 1923; incorporated 1928. Geographic Sections: British Columbia, Idaho, Montana, Oregon, IVashington. Sectrons: Botany, Chemistry, Engineering, Forestry, Geography, Geology, Mathematics, Physics, Social Science, Soil Conservation, Zoology.

Purpose: To promote scientific research and disseminate scientific knowledge.

Hembership: Open to anyone interested in the purpose of this Association. Institutional: Universities, colleges, junior colleges, and other educational institutions; Honorary Life, for unusual service to this Association and unusual attainment in its field; Sustaining, individuals, organizations, and businesses; Honorary Trustees, interest in science and ability in public affairs. Total membership 550 .

\section{Mectings: Annual.}

Professional activitics: Grants in aid from Howard Flint Memorial Fund and American Association for the Advancement of Science Research Grant, annual, to encourage research and presentation of research papers in all the sciences, maximum grant $\$ 500$.

Publications: Northwest Science, quarterly, current volume: 34 . Editor: Joseph W. Mills.

1164. Northwestern Pediatric Society. President: James Du Shane, Mayo Clinic, Rochester, Minn. Term expires September 1961. Secretary-Treasurer: George U. Lund, 4959 Excelsior Avenue, St. Louis Park 16, Minn. Term expires September 1962.

History: Organized 1912. Sections: Canada, Iowa, Minnesota, North and South Dakota, Visconsin.
Purpose: To afford a forum for reading and discussion of scientific papers, and to foster friendship among members.

Membership: Active Members, 169, physicians whose primary work is teaching, research, or practice of pediatrics; Affiliate Members, 18, plysicians who devote seventy-five per cent of time to practice, teaching, or research in pediatrics. who have not completed two years in institutions approved by American Board of Pediatrics; Honorary Members, 5, distinguished physicians and scientists; Emeritus Members, 5, retired from practice. Total memberslip 197.

1cetings: Semiannual.

1165. Odontological Society of Western Pennsylvania. 206 Jenkins Building, Pittsburgh 22, Pa. President: E. H. Glotfelty, Pittsburgh, Pa. Term expires December 1961. Secretary: Homer D. Butts, Jr. Union Trust Building, Pittsburgh 22, Pa. Term expires December 1960.

History: Organized 1881; incorporated; nine county sections. Society is a component of Pennsylvania Dental Association and a constituent of American Dental Association.

Purpose: To advance the dental profession in education and science; to encourage dental and oral research and to disseminate in the profession knowledge of dental discoveries and inventions: to enlighten the public in relation to oral hygiene.

Mcmbership: Open to licensed and ethical practitioners. Total membership 1,364.

Mcetings: Annual; monthly, except June, July, and August.

Publications: Odontological Bulletin, monthly except July and August, $\$ 1$ to members. Editor: Marvin Sniderman.

1166. Ogden Surgical Society. President: Junior Edward Rich, Eccles Building, Ogden, Utah. Term expires May 1961. Exccutive Secretary: Anthony J. Lund, 38524 th Street. Ogden, Utah. Term expires May 1965.

History: Organized in 1945.

Purpose: To bring new and better medical care to the Rocky Mountain area.

Mcmbership: Open to physicians and surgeons, licensed in Utah and members of the Weber County Medical Association. Total membership 114 .

Mcetings: Annual.

1167. Ohio Academy of Science. 505 King Avenue, Columbus 1, Ohio. President: Glenn H. Brown, Chemistry Department, Kent State 
University, Kent. Ohio. Term expires April 1961. Executive Secretary: Kenneth B. Hobbs. Term indefinite.

History: Organized December 31, 1891, as Ohio State Academy of Science. Incorporated March 1892 with 59 charter members. Name changed to present title in 1914. Field meetings each summer until 1901. Natural History Survey organized 1893. Sections organized in 1908. Sections: Zoology, Plant Sciences, Geology, Medical Sciences, Physics and Astronomy, Geography, Chemistry, Science Education, Anthropology and Sociology, Conservation, Genetics. Scientific Commitrees : Ohio Flora, Training and Certification of Science Teachers, Academy History, Trustees of Research Funds.

Purpose: To stimulate interest in science, to promote research, to improve science instruction, to disseminate scientific knowledge, to recognize merit in science.

Membership: Members, those with an interest in science; Fellows, activity in research or teaching; 1,400 Members and Fellows, 5 Honorary Fellows, 30 Corporation and Institution Members.

\section{Meetings: Annual.}

Professional activities: Preparation of "Vascular Flora of Ohio," District and State Science Days with scholarship awards, plaque awards to outstanding schools for science education, individual awards to outstanding science teachers.

Publications: Ohio Journal of Science, bimonthly, current volume: $60, \$ 6, \$ 3$ to members. Editor: Henry L. Plaine. News, three times yearly, current volume: 12, no charge. Editor: Clara Kenney.

1168. Ohio Forestry Association, Inc. Southern Hotel, Columbus 15, Ohio. President: W. H. Hildebrand, The Mead Corporation, Chillicothe, Ohio. Term expires January 1961. Executive Director: William Laybourne. Term indefinite.

History: Organized December 11, 1903 ; incorporated October 18, 1951. Committees: Conservation Awards, Conservation Education Guidebook, Convention and Summer Tour, Forest Industry, Paul Bunyan Forestry Exposition, Forestry Training Camp, School Forest, Free Farm, Woodland Owner's, Christmas Tree Growers' Council, Public Relations Advisory, Program of Work.

Purpose: To encourage and promote the sound use of Ohio's natural resources.

Membership: Active, 290, interest in purpose of association; Sustaining, 26; Contributing. 62; Participating, 74; Subscribing, 688.

Mcetings: Semiannual.
Professional activities: Youth Conservation Education - Forestry Training Camp, Conservation Chart and Guidebook. Annual Conservation Awards. School Forest Survey Program.

Publications: Resources and People, monthly, current volume: 9, free to members. Editor: William Laybourne. Forestry Marketing Bulletin. monthly, current volume: 105, free to members. Editor: Robert Paton. Christmas Tree Growers' Council Bulletin, quarterly, current volume: 24, free to members. Editor: Robert Paton.

1169. Ohio Psychiatric Association. President: Roger M. Gove, 301 Bennis Boulevard, Columbus 4, Ohio. Term expires May 1961. Executive Secretary: Irwin N. Perr, 12200 Fairhill Road, Cleveland 20, Ohio. Term expires May 1961.

History: Organized in 1951 as a District Branch of American Psychiatric Association.

Purpose: To further the study of subjects pertaining to the nature, treatment, and prevention of mental disorders; to further the interests, the maintenance, and the advancement of standards of hospitals for mental disorders, of out-patient clinics, and of all other agencies concerned with the medical, social, and legal aspects of these disorders; to further psychiatric education and research; and to apply psychiatric knowledge to other branches of medicine, to other sciences, and to the public welfare.

Membershit: Associate, one year of experience in a mental hospital or equivalent: Full Member, three years of experience in a mental hospital or equivalent; Fellow, six years of experience in a mental hospital or equivalent; open only to doctors of medicine. Active members : 232 .

Meetings: Annual.

1170. Ohio Psychological Association. Arps Hall, Ohio State University, Columbus, Ohio. President: John E. Horrocks. Term expires April 30, 1961. Corresponding Secretary: Richard R. Clampitt, P. O. Box 3646, Columbus 14, Ohio. Term indefinite.

History: Developed from Ohio Association for Applied Psychology, organized in 1938, affiliated with American Association for Applied Psychology in 1940. Present association organized in 1945; incorporated April 1949. Affiliated with American Psychological Association in 1946. Regional Organizations: Akron Psychological Association, Central Ohio Psychological Association, Cincinnati Psychological Association, Miami Valley Psychological Associa- 
tion, Cleveland Psychological Association, Northwest Ohio Psychological Association, and Southeast Ohio Psychological Association; School of Psychologists of Ohio.

Purpose: To advance psychology as a science, as a profession, and as a means of promoting human welfare.

Membership: All members must be in residence or employed in the State of Ohio. Fellow: doctoral degree in psychology and five years of acceptable full-time experience in psychology at a professional level; Member: doctoral degree or master's degree in psychology and one year professional work in psychology; Affiliate: graduate student preparing for a career in psychology. Fellows, 202; Associates, 311; Affiliates, 17.

Mectings: Semiannual.

Professional activities: Meetings for presentation of scientific papers and professional issues; workshops; public information programs.

Publications: The Ohio Psychologist, quarterly, current volume: $4, \$ 2$. Editor: Henry S. Curtis.

1171. Ohio Society of Anesthesiologists, Inc. 9710 Garfield Boulevard, Garfield Heights 25, Ohio. President: DeForest W. Metcalf, 6610 Mill Creek Boulevard, Youngstown 7, Ohio. Term expires September 1961. Secretary-Treasurer: Nicholas G. DePiero. Term expires September 1962.

History: Founded May 4, 1939; incorporated November 22, 1957.

Purpose: To contribute to the scientific and cultural progress of anesthesia, pneumatology, resuscitation and allied sciences, and to advance the economic welfare of its members.

Membership: Active, 352, must have Doctor of Medicine degree, be licensed to practice medicine in the State of Ohio, be a member of the county medical society and an Active member of the American Society of Anesthesiologists, Inc.; Junior, 84, Doctor of Medicine degree, member county medical society and Junior member of the American Society of Anesthesiologists. May be Junior member only while in residency training and not more than three years; Honorary 2; Retired, 2. Total membership 440.

Meetings: Annual.

Professional activities: Annual Resident Essay Contest with awards of $\$ 100$ and $\$ 50$.

Publications: Newsletter, bimonthly, current volume: 3, free. Editor: N. G. DePiero.

1172. Ohio State Horticultural Society. President: Paul Thornburg, Ashland, Ohio. Term expires February 1, 1961. Secretary: C. W. Ellenwood, Route 2, Wooster, Ohio. Term expires February 1, 1961.

History: Established 1847.

Purpose: To promote educational standards. Menbership: 700.

Mectings: Annual.

Publications: Annual Report, current volume: 113, \$5. Editor: C. IV. Ellenwood.

1173. Ohio State Medical Association. 1005 Hartman Theater Building, 79 East State Street, Columbus 15, Ohio. President: Edwin H. Artman, 36 North Walnut Street, Chillicothe, Ohio. Term expires April 13, 1961. Executive Secretary: Charles S. Nelson. Term indefinite.

History: Organized May 1846, as the Ohio State Medical Society ; incorporated under present title May 1904. Sections: Anesthesiology, General Practice, Internal Medicine, Neurological Surgery, Obstetrics and Gynecology, Ophthalnology, Otorhinolaryngology, Pediatrics, Physical Medicine, Radiology, Surgery, Urology.

Purpose: To promote the science and art of medicine and the protection of public health.

Membership: Open to individuals who hold degree of doctor of medicine, who are licensed in Ohio, who reside in Ohio if in practice, and who are members of a component county medical society. Total membership 9,500.

Meetings: Annual.

Publications: Ohio State Medical Journal, annual, current volume: 56, $\$ 5$. Editor: Perry R. Ayres.

1174. Ohio State Pharmaceutical Association. President: James L. Marshall, 1221 South Center Street, Springfield, Ohio. Term expires June 14, 1961. Executive Secretary: James D. Cope, 40 South Third Street, Columbus 15, Ohio. Term indefinite.

History: Organized and incorporated in 1879.

Purpose: To unite the profession of pharmacy; to encourage advancements and improvements in the practice of pharmacy.

Membership: Active Member, open to any registered pharmacist of good moral and professional standing in the State of Ohio. Total membership 2,100.

Meetings: Annual.

Professional activities: Beal Award, given annually to person who in the judgment of the committee has made the outstanding contribution to the profession of pharmacy during the association year which ends at convention time; Keys Award, given annually to person selected by the officers and members of Council who in their judgment has made the outstanding con- 
tribution for the progress of the association during the year; Abe Butnik Memorial Award, presented at discretion of Council to person who does the most to advance the cause of small business.

Publications: Ohio Pharmacist, monthly, current volume: 9, $\$ 3$, free to members. Editor: James D. Cope.

\section{Ohio Valley Air Pollution Control Asso-} ciation, Inc. President: A. T. Cheon, 1010 Sixth Street, Moundsville, W. Va. Term expires June 1961. Executive Administrator: James C. Martin, City Building, Wheeling, W. Va. Term expires June 1961.

History: Incorporated January 1958 to promote, encourage, and assist in establishing and developing air pollution control in the Upper Ohio Valley; 11 counties, 31 municipalities in Ohio and West Virginia, extending about 80 miles along both sides of the Ohio River.

Purposc: To provide an integrated study and research program to encompass the Upper Ohio Valley region in the States of Ohio and West Virginia; to survey the air pollution problem and to provide technical and engineering assistance to industry concerning air pollution.

Membership: Open to those with an interest in air pollution control. Total membership 120.

Mectings: Six to eight meetings a year.

1176. Ohio Valley Proctologic Society. 903 Carew Tower, Cincinnati, Ohio. President: J. M. McIntyre, 2901 North Meridian Street, Indianapolis, Ind. Term expires May 1961. Sccretary: Arthur H. WVells. Term expires May 1961.

History: Organized 1946. Sections: Ohio, Indiana, Kentucky.

Purpose: To provide a forum for the interchange of thought, opinion, and experience in proctology; to advance the specialty of proctology.

Membcrship: Graduate of a Class A medical school, a member in good standing of his county and State medical societies and of the American Medical Association. Active members, 35.

Meetings: Annual; three other meetings.

Professional activities: Plaque is presented every other year at the meeting of the Society for the best paper given by an affiliate member.

1177. Oklahoma Academy of Science. Department of Zoology, University of Oklahoma, Norman, Okla. Prcsident: Philip E. Smith, University of Oklahoma Medical Center, 800 Northeast 13th Street, Oklahoma City, Okla.
Term expires December 31, 1960. Permanent Secretary: J. Teague Self.

History: Organized December 30, 1909. SEcTIoNs: Biological Sciences, Geological Sciences Physical Sciences, Social Sciences, Science Education, Geography, Conservation.

Purpose: To stimulate scientific research; to promote fraternal relationship among those engaged in scientific work in Oklahoma; to diffuse among the citizens of the state a knowledge of the various departments of science; to investigate and make known the material, educational, and other resources of the state; to publish such reports, papers, or discussions as may embody the purpose of the Academy.

Membership: Fellows, special distinction in Academy activities; Regular members, interest in science; Departmental and Institutional memberships, interest in science. Total membership 350.

\section{Mectings: Semiannual.}

Professional activities: Annual research awards, $\$ 750$ to $\$ 1,000$; sponsorship of research for high school science projects; sponsorship of research for undergraduate and graduate college science students.

Publications: Proceedings, annual, current volume: 40, \$3. Editor: George A. Moore, Department of Zoology, Oklahoma State University, Stillwater, Okla.

1178. Oklahoma Anthropological Society, Inc. University of Oklahoma, Norman, Okla. Presidcnt: Sherman P. Lawton. Term expires 1961. Sccretary-Treasurer: Robert B. Hill, 3419 Soutl Birmingham Street, Tulsa, Okla. Term expires 1962.

History: Organized March 29, 1952 as the Oklahoma Anthropological Society, a revival of an organization which existed in the early and middle 1940's. Reorganized as non-profit corporation 1960. Chapters: Ft. Smith, Ark.; Oklahoma City, Tulsa, Ponca City, Okla.

Purpose: Scientific and educational projects in the preservation, display, interpretation and publication of prehistoric and ethnologic materials, especially of the American Indian.

Mcmbership: Open to any individual or institution interested in the prehistory or history of Oklahoma and in sympathy with the objectives of the Society. Active or Institutional Member; Contributing Member; Sustaining Member; Life Member; Associate Member, under sixteen years of age. Total membership 320 .

Meetings: Annual; occasional special meetings; monthly Chapter meetings.

Professional activities: Annual excavations; lectures and displays at organization meetings, museums, and other public places. 
Publications: Newsletter, nine times per year, current volume: 9, free to members. Bulletin, annual, current volume: $8, \$ 3.50$. Guide to Identification of Projectile Points, irregular, current volume: 2, \$4. Editor: Robert E. Bell.

1179. Oklahoma City Geological Society. P. O. Box 609, Oklahoma City, Okla. President: J. Durwood Pate, Davidor Building, Oklahoma City, Okla. Term expires May 31, 1961. Secretary: L. A. McCord, Superior Oil Company, 2211 Liberty Bank Building, Oklahoma City. Okla. Term expires May 31, 1961.

\section{History: Organized April 1921.}

Purpose: Improvement of professional ethics; better understanding of different types of geological work; increased knowledge of the science of geology; support of principles and work of the American Association of Petroleum Geologists.

Membership: Open to geologists and other persons engaged principally in geological work, and to any member of the American Association of Petroleum Geologists; Associate members, those whose work is related to the petroleum industry, but do not meet the requirements for active membership. Total membership 781 . May.

Meetings: Semi-monthly, September through

Professional activities: Junior Scientists Awards, presented to sixteen outstanding students from junior and senior high schools.

Publications: Shale Shaker, monthly, September through June, current volume: 10, \$5. Editor: Frederick J. Sinith.

\section{Oklahoma District of the American Psy-} chiatric Association. 625 Northeast 16th Street, Oklahoma City 4, Okla. President: John Gray, 208 Utica Square Medical Center, Tulsa, Okla. Term expires May 15, 1961. Secretary-Treasurer: Jay T. Shurley. Term expires May 15, 1961.

History: Organized August 20, 1947 as the Oklahoma Society of Psychiatrists, Neurologists and Neurosurgeons; adopted present title and new constitution 1954.

Purpose: To promote the science, art, and practice of psychiatry as a constituent part of the American Psychiatric Association.

Membership: Open to Members and Fellows of the American Psychiatric Association, living or working in Oklahoma. Total membership 56.

Mcetings: Four per year.

Publications: Newsletter, semi-annually, current volume: 1, free. Editor: Jay T. Shurley.
1181. Oklahoma Rheumatism Society. President: J. N. Owens, Jr., 605 Northwest 10th Street, Oklahoma City, Okla. Term expires June 1, 1961. Secretary: Richard W. Payne, 801 Northeast 13th Street, Oklahoma City, Okla. Term expires June 1, 1961.

History: Organized November 20, 1948. The Society is the parent organization of the Oklahoma Arthritis and Rheumatism Foundation.

Purpose: To promote interest in, and dissemination of, knowledge of arthritis and related disorders.

Membership: Doctor of Medicine degree and interest in rheumatic diseases. Total membership 50 .

Mcctings: Monthly; annual.

1182. Oklahoma Society of Anesthesiologists. University Hospitals, 800 Northeast 13th Street, Oklahoma City, Okla. President: Theodore R. Wenger, 4533 East 46th Street, Tulsa, Okla. Term expires May 1961. Secretary-Treasurer: Irvin G. Hamburger. Term expires May 1961.

History: Organized 1948. A component Society of the American Society of Anesthesiologists.

Purpose: To advance the science and art of anesthesiology.

Membership: Active member, full time anesthesiology practice; Junior member, physicians in training; Associate member, plysicians interested in anesthesiology, but without a full time practice. Active, 48; Junior, 10; Associate, 6 ; Life, 1 . Total membership 65 .

Mcetings: Semiannual.

1183. Oklahoma Society of Professional Engineers. 212 Commerce Exchange Building, Oklahoma City 2, Okla. President: George R. Benz, 948 Adams Building, Bartlesville, Okla. Term expires June 30, 1961. Executive Secretary: M. A. Woodbury. Term expires June 30, 1961.

History: Incorporated October 8, 1935. СHAPTERS: Bartlesville, Oklahoma City, Stillwater, Enid, Lawton, Tulsa. Affiliated with the National Society of Professional Engineers.

Purpose: Promotion, protection, and advancement of the profession of engineering as a social and economic influence vital to the public welfare.

Mcmbership: Professional Engineers, registration by a recognized State Board of Registration; Junior, certification as Engineer-in-Training by the Oklahoma State Board of Registration; Associate, non-registered but offering proof 
of experience in lieu of educational background. Professional Engineers, 1,159; Junior, 185; Associate, 34 . Total membership 1,378.

Meetings: Annual.

Publications: Oklahoma Professional Engineer, monthly, current volume: 14 , free to nimembers. Editor: M. A. Woodbury.

1184. Oklahoma State Medical Association. P. O. Box 9696, Oklahoma City, Okla. President: Walter E. Brown, 2020 South Xanthus, Tulsa, Okla. Term expires May 2, 1961. Permanent Secretary: R. H. Graham. Term indefinite.

History: Organized 1906, when the Oklahoma Territory and Indian Territory Medical Societies amalgamated. The Society has forty-five district and county medical societies.

Purpose: To promote the science and art of medicine.

Membership: United States citizen, Doctor of Medicine degree from an approved medical school, licensed to practice medicine in Oklahoma, and holder of Federal narcotics permit. Total membership 1,750 .

Mcetings: Annually.

Publications: Journal, monthly, current volume: 53, \$5.50. Editor: Ben H. Nicholson.

\section{Oklahoma State Psychological Associa-} tion. President: M. K. Temerlin, Guidance Service, University of Oklahoma, Norman, Okla. Term expires January 1961. SecretaryTreasurer: J. R. Morris, 1009 North Berry Road, Norman, Okla.

History: Established December 6, 1946. Affiliated with the Oklahoma Academy of Science in 1948 .

Purpose: To advance psychology as a science. a profession, and a means of promoting human welfare.

Membership: Limited to individuals with a master's degree in psychology and at least one year of professional experience. Total membership 150 .

Mectings: Annual.

1186. Old Dominion Horticultural Society, Inc. Lafayette Park, Granby and 35th Street, Norfolk, Va. President: E. T. Penzold, Custom House, Norfolk, Va. Term expires January 1961. Executive Secretary: Jesse Johnson, Cardinal Point, Norfolk, Va. Term expires January 1961.

History: Organized September 1940.

Purpose: To diffuse horticultural knowledge.
Menbership: Members, 785, interest in horticulture.

Meetings: Nine times per year.

Professional activities: Sponsors Norfolk Botanical Garden.

Publications: Bulletin, monthly, current volume: 20, \$3. Editor: Frederic Heutte, 248 North Blake Road, Norfolk, Va.

1187. Omaha Mid-West Clinical Society. 1613 Medical Arts Building, Omaha 2, Nebr. President: J. P. Tollman, University of Nebraska College of Medicine, 42 Dewey Street, Omaha, Nebr. Executive Secretary: Mrs. Reta M. Crowell. Term indefinite.

History: Constitution and by-laws adopted November 27, 1950.

Purpose: To conduct a postgraduate clinical assembly at least once a year, especially planned to meet the needs of physicians residing in the midwestern States.

Membership: Active members, 190, graduated for at least five years from accredited medical schools, active members of Omaha-Douglas County Medical Society for at least one year, members of Omaha hospital staffs approved by this Society, and actively engaged in practice of medicine, full time teaching, or full time public health service.

Meetings: Annual.

Publications: Journal, bimonthly, free to members. Editor: Herman M. Jahr.

1188. Ontario District Branch, American Psychiatric Association. 514 Jarvis Street, Toronto 5, Ontario, Canada. President: Angus M. Hood. Term expires March 1962. Executive Secretary: Henry S. Sager, 600 University Avenue, Toronto 2B, Ontario, Canada. Term expires March 1962.

History: Founded April 1960.

Purpose: To foster progress of psychiatry, and to assist American Psychiatric Association in promoting its aims and objectives.

Membership: Associate Members, Members, or Fellows of American Psychiatric Association residing in Ontario are eligible. Total membership 25 .

Meetings: Three annually.

1189. Operations Research Society of America. President: Martin L. Ernst, Arthur D. Little, Inc., 35 Acorn Park, Cambridge 40, Mass. Term expires May 1961. Secretary: Hugh J. Miser, Applied Science Division, Operations Evaluation Group, Massachusetts Institute of Technology, 292 Main Street, Cambridge 42, Mass. Term expires May 1961. 
History: Organized May 26, 1952; incorporated August 20, 1952. Sections: Chicago, Philadelphia, IVestern, Northwest.

Purpose: The advancement of the science of operations research through exchange of information, the establishment and maintenance of professional standards of competence, the improvement of the methods and techniques, and the encouragement and development of students.

Membership: Members, 944, at least two years' experience demonstrating ability to do effective and original professional work in operations research, or two years' experience in a field closely related, or management responsibility for activities embracing operations research, or academic appointment, with responsibility for operations research or related courses for at least one year, or publications on operations research; Associates, 1,792; Student Associates, 208. Total membership 2,944.

Meetings: Semiannual.

Professional activities: Johns Hopkins University Lanchester Prize of $\$ 1,000$ for the best paper in operations research each year.

Publications: Operations Research, 6 times per year, current volume; $8, \$ 10$. Editor: George Shortley. Bulletin, semiannually. Editor: Hugh J. Miser.

1190. Optical Society of America, Inc. President: James G. Baker, Harvard College Observatory, Cambridge, Mass. Term expires December 31, 1960. Executive Secretary: Mary E. Warga, Executive Office, 1155 16th Street, N. IV., Washington 6, D. C. Term indefinite.

History: Founded 1916; incorporated (New York) 1932. Sections: Rochester, Detroit, Niagara Frontier, New England, Chicago, Southwestern Connecticut, Southern California.

Purpose: To increase and diffuse the knowledge of optics; to promote the common interests of investigators of optical problems, of designers, and users of optical apparatus of all kinds; to encourage cooperation.

Membership: Regular member, open to any person who has contributed materially to the advancement of optics; Associate member, open to any person who is interested in optics; Fellow, open to any person who has served with distinction in the advancement of optics; Honorary members, open to any person who has rendered eminent service in the advancement of optics. Total membership 2,700.

Mectings: Spring and fall

Professional activities: Frederic Ives Medal, endowed 1928 by Herbert E. Ives, in honor of his father, Frederic Ives, awarded annually for distinguished work in optics; Adolph Lomb Medal, established 1939, awarded not oftener than once in two years, to a person under thirty years of age who shall have made a noteworthy contribution to optics; Edgar D Tillyer Medal, endowed 1953 by the American Optical Company, awarded not oftener than once in two years to a person who shall have performed distinguished work in the field of vision, including, but not limited to, the optics, physiology, anatomy, or psychology of the visual systenı.

Publications: Journal, monthly, current volume: $50, \$ 25$, free to members. Editor: W. R. Brode. Optics and Spectroscopy, monthly, current volume: $8, \$ 25$, free to members. Translation Editor: P. R. Wakeling.

1191. Oregon Academy of Science. Oregon State College, School of Science, Corvallis, Oreg. President: W. R. Todd, University of Oregon, Medical School, 3181 Southwest Sam Jackson Park Road, Portland 1, Oreg. Term expires February 25, 1961. Executive Secretary: F. A. Gilfillan. Term expires February 24, 1962.

History: Organized October 27, 1943; incorporated November 14, 1946. Sections: Biology, Chemistry, Geology-Geography, MathematicsPhysics.

Purpose: To promote research in the several fields of science, to stimulate science interest in the general public, to collect and preserve scientific materials and objects relating to the Oregon Country, and to disseminate scientific knowledge.

Membership: Members, 240, active interest in science and a willingness to work for the promotion of science in the Northwest.

\section{Mcetings: Annual.}

Professional activitics: Sponsor of Collegiate Academy of Science, and June Oregon Academy of Science. Cooperated with State Department of Education in determining certification requirements for elementary and secondary science teachers. Awarding of citations on outstanding scientists in the Northwest.

Publications: Proceedings, irregular, current volume: 3 .

1192. Oregon Psychological Association. President: Vincent Glaudin, Interfaith Counseling Center, Park Building, Portland, Oreg. Term expires May 1961. Secretary-Treasurer: Ronald E. Smith, Portland State College, Portland 1, Oreg. Term expires May 1961.

History: Organized 1936; reactivated December 1951. Adopted a Certification Act and established a Board of Examiners in 1955. Has 
committees currently active on: Psychology in the Schools, Mental Health, New School of Social Work, Public Information, and Marriage and Divorce Legislation.

Purpose: To advance psychology as a science, as a profession, and as a means of promoting human welfare; to foster and maintain high standards of practice in the field of psychology.

Membership: Members, 166, Fellow or Member status in American Psychological Association, or a doctoral degree and engaged in psychological study or professional work; Associates, 13, Associate status in American Psychological Association, or two years graduate work, or master's degree and a year of professional experience, and devoting full time to professional or graduate work.

Meetings: Semiannual.

Publications: Newsletter, 4 or 5 times a year, current volume: 7, free to members. Editor: Margie R. Lee, E. C. Brown Trust, 220 Southwest Alder Street, Portland 4, Oreg.

1193. Oregon Radiological Society. President: Clifford Allen, 2311 Northwest Northrup Avenue, Portland, Oreg. Term expires June 1961. Secretary-Treasurer: George Satterwhite, 1123 Southwest Yamhill, Portland, Oreg. Term expires June 1961.

History: Organized May 1947. Committees: Executive; Program; Radiation Protection, Legislation and Education; Public Relations; Technician Liaison; Radioactive Isotope; Hospital Liaison; Fee Schedule.

Purpose: To establish an organization of radiologists for the purpose of advancing the science of radiology and improving the public health through better radiological service.

Membership: Active, 46, radiologists in good standing in county medical society and certified by the American Board of Radiology; Associate, 4 , good standing in county medical society and eligible for but not certified by the American Board of Radiology, or in a practice confined to radiology; Emeritus, 1, active members who have retired; Honorary, 9, those ineligible for active or associate membership but entitled to honorary status by virtue of standing as practitioners of radiology.

Mectings: Monthly, October to June.

1194. Oregon State Horticultural Society. Presiident: IVilliam Hazeltine, Parkdale, Oreg. Term expires 1961. Secretary: C. O. Rawlings, Corvallis, Oreg. Term expires 1961.

History: Organized 1885; incorporated in 1909, successor to the Multnomah Fruit Growers Society, organized 1858.
Purpose: The promotion of the horticultural industry in Oregon.

Membership: Members, about 800 , interest in horticulture.

Meetings: Annual.

Professional activities: Sponsors the Research and Scholarship Foundation. Hartman Cup Award to one individual annually for outstanding contributions to horticulture.

Publications: Annual Report.

1195. Oregon State Pharmaceutical Association. 709 Jackson Towers, Portland, Oreg. President: Mel Peterson, Florence, Oreg. Term expires June 1961. Executive Secretary: H. A. Speckman. Term expires June 1961.

History: Organized 1889; incorporated June 5, 1933.

Purpose: To promote and maintain a high standard of professional work, and to cooperate with other medical-dental-pharmaceutical associations working for the betterment of public health and safety in Oregon and the United States.

Membership: Store owners or managers of licensed drug stores, and any registered Pharmacist licensed by the Oregon State Board of Pharmacy and holding a valid current license. Total membership 454.

Meetings: Annual.

Professional activities: A student loan fund is maintained to assist worthy pharmacy students.

Publications: Oregon Pharmacist, monthly, \$4. Editor: H. A. Speckman.

1196. Oregon Technical Council. President: John T. Merrifield, 1845 Northeast Couch Street, Portland 12, Oreg. Term expires January 1, 1961. Executive Secretary: Lester Wlolgast, Reynolds Metals Company, Troutdale, Oreg. Term expires January 1, 1961.

History: Formed in 1920 by local sections of American Society of Civil Engineers, American Institute of Electrical Engineers, American Society of Mechanical Engineers, American Institute of Mining, Metallurgical, and Petroleum Engineers, and American Institute of Architects.

Purpose: To coordinate work of various engineering and architectural societies and to foster recognition of engineering and architecture by the public.

Membership: Eleven constituent societies.

Meetings: Monthly.

Professional activities: Legislative recommendations. Support of technical division of public library. 
1197. Orleans Parish Medical Society. 1430 Tulane Avenue, New Orleans 12, La. President: Oscar Blitz. Term expires December 1, 1960. Executive Secretary: A. J. Kuhlmann. Term expires December 1, 1960.

History: Organized April 22, 1878; incorporated November 28, 1899. Committees : Special committees to cover every phase of medicine.

Purpose: For the advancement and cultivation of the science and art of medicine and surgery, and the betterment of public health of the community; the establishment and maintenance of a medical and surgical library and museum for the education and advancement of its members; the encouragement of scientific and philosophical studies and research, and the acquisition and erection of buildings suitable for such purposes; the promotion and maintenance of the ethical and harmonious relationship between members; the enlightenment and direction of public opinion in regard to the problems of medicine for the welfare of the community.

Membership: Active, 988, graduates of a class A medical school, citizens of the United States, legally qualified under the medical law of Louisiana to practice medicine and surgery and residents of at least six months; Associate, 84, M.D., (Army, Navy, Air Force, Public Health, Veterans Administration, teachers), Ph.D., and D.D.S. ; Intern/Resident, 74, physicians serving an internship or a residency in an accredited hospital of this city; Honorary, 20; Inactive, 52. Total membership 1,218.

Meetings: Nine scheduled meetings a year: eight scientific, and an annual installation.

Publications: Bulletin, monthly, current volume: 31. Editor: Edwin L. Zander.

Library: 99,436 volumes; combined with Rudolph Matas Memorial Library of the Louisiana Medical School.

\section{Pacific Coast Entomological Society.} California Academy of Sciences, San Francisco 18, Calif. President: J. W. Tilden, 125 Cedar Lane, San Jose, Calif. Term expires December 30, 1960. Secretary: F. E. Skinner, 1050 San Pablo Avenue, Albany 6, Calif. Term expires December 30, 1960.

History: Organized August 15, 1901 as California Entomological Club; name changed to present title 1902; incorporated 1940.

Purpose: The stimulation of entomological research through social and technical meetings, symposia, and authoritative lectures; the publication of the results of entomological research; the accumulation and recording of historical facts relative to entomology; and the promotion of cooperation among entomologists and scientists throughout the world.

Membership: Membership open to persons interested in insects or other Arthropoda. Regular, 223; Student, 1; Honorary, 2; Life, 16. Total membership 242.

Meetings: Monthly, September through May.

Professional activities: H. C. Fall Memorial Publication Fund for monographs.

Publications: Pan-Pacific Entomologist, quarterly, current volume: $36, \$ 4$, free to members. Editor: P. D. Hurd, Jr., Department of Entomology, University of California, Berkeley 4, Calif.

1199. Pacific Coast Obstetrical and Gynecological Society. President: George E. Judd, 2010 IVilshire Boulevard, Los Angeles 57, Calif. Term expires October 1960. Secretary-Treasurer: Keith P. Russe1l, 511 South Bonnie Brae Street, Los Angeles 57, Calif. Term indefinite.

History: Organized 1931 as the Pacific Coast Society of Obstetrics and Gynecology; name changed to present title in 1946.

Purpose: The advancement of knowledge in all matters pertaining to the practice of obstetrics and gynecology.

Membership: Active, 73, diplomate of American Board of Obstetrics and Gynecology, in practice more than ten years, practice limited to obstetrics and gynecology in the Pacific Coast area; Senior members, 37. Total membership 110.

\section{Meetings: Annual.}

Professional activities: Frank IV. Lynch Memorial Essay Prize, $\$ 100$ awarded for an essay on obstetrics or gynecology by a physician in the area who is not eligible for active membership.

Publications: Transactions, annual, free to members and medical school libraries.

1200. Pacific Coast Oto-Ophthalmological Society. President: Dohrmann K. Pische1, 490 East Post Street, San Francisco 2, Calif. Term expires May 4, 1961. Secretary-Treasurer: Alden H. Miller, 500 South Lucas Avenue, Los Angeles 17, Calif. Term expires July 1963.

History: Organized 1906. Sections: Alaska, Arizona, British Columbia, California, Colorado, Hawaii, Idaho, Montana, Nevada, Oregon, Utah, IVashington, Wyoming. Technical Sections: Ophthalmological, Otolaryngological.

Purpose: Cultivation and advancement of medical sciences, especially branches pertaining to eye, ear, nose, and throat. 
Membership: Physicians residing in above named States or Province, with practice limited to eye, ear, nose, and throat, who are members of county societies and local eye, ear, nose, and throat societies, and who have accomplished American Board examinations; Junior Members given five years to accomplish American Boards. Active Members, 723; Senior Members 42; Honorary Members, 35. Total membership approximately 800 .

Metings: Annual.

Publications: Transactions, annual. Editor: Earle H. McBain.

1201. Pacific Coast Society of Orthodontists. 2037 Irving Street, San Francisco 22, Calif. President: E. Allen Bishop, 703 Cobb Building, Seattle, Wash. Term expires August 1961. Secretary-Treasurer: Warren A. Kitchen. Term expires August 1961.

History: Organized in 1913; three component societies, Northern, Central and Southern.

Purpose: To advance the art and science of orthodontics and to promote better health.

Membership: The exclusive practice of orthodontics for five years, and completion of an orthodontic course of 1,500 hours in an accredited dental school, or a preceptorship of three years under the supervision of the membership committee, meeting certain standards prescribed by that committee. Total membership 515.

Meetings: Biennial.

Publications: Pacific Coast Bulletin, quarterly. Editor: William S. Smith.

1202. Pacific Coast Surgical Association. President: Robert A. Scarborough, 490 Post Street, San Francisco, Calif. Term expires February 22, 1961. Secretary-Treasurer: Carleton Mathewson, Jr., San Francisco-Stanford Hospital, San Francisco 15, Calif. Term expires February 22, 1961.

History: Organized April 11, 1925 in San Francisco.

Purpose: The advancement of surgery on the Pacific Coast.

Membership: Active, Senior and Honorary Members, practice limited to surgery, an established reputation as a practitioner, author, teacher or original investigator, and recommended by the Council.

Meetings: Annual.

1203. Pacific Northwest Dermatological Society, Inc. President: Joyle Dahl, Medical Arts Building, Portland, Oreg. Term expires May 1961. Secretary-Treasurer: Robert A. Pommerening, 1118 9th Avenue, Seattle 1, Wash. Term indefinite.
History: Organized October 1939. Sections : Oregon, Wrashington, British Columbia.

Purpose: To further the interests of dermatology and syphilology.

Membership: Active, 47, certified member of American Board of Dermatology and Syphilology, resident of Washington, Oregon, or British Columbia for three years; Honorary, 3 ; Nonresident, 1.

Meetings: Semiannual.

1204. Pacific Northwest Radiological Society. President: William Y. Burton, 242 Medical Arts Building, Portland, Oreg. Term expires May 14, 1961. Secretary: J. M. Burkey, 1116 Senaca Street, Seattle 1, Wash. Term expires May 14, 1961.

History: Organized at Big Four, Washington in 1947.

Purpose: To advance the art and science of radiology in the Pacific Northwest.

Membership: Specialization in X-ray diagnosis and/or therapy by qualified physicians. Total membership approximately 150 .

Meetings: Annual.

Pacific Rocket Society.

See Addenda, No. 1593.

1205. Pacific Roentgen Society. 450 Sutter Street, San Francisco, Calif. Chairman: George Jacobson, 1200 North State Street, Los Angeles, Calif. Term expires April, 1961. Secretary-Treasurer: L. H. Garland. Term expires April, 1961.

History: Founded in 1933 by medical radiologists practicing in California.

Purpose: The promotion of the public health by improving the practice of medicine, through better radiological service, and the adoption of measures designed to solve problems concerning the practice of radiology.

Membership: Physicians specializing in radiology, eligible to membership in the American Medical Association and Diplomates of the American Board of Radiology. Total membership 418.

Meetings: Annual.

Publications: Bulletin, quarterly, current volume: 3, free. Editor: L. H. Garland.

1206. Pacific Science Board. 2101 Constitution Avenue, N.W., Washington 25, D. C. Chairman: Alexander Spoehr, Honolulu, Hawaii. Term indefinite. Executive Director: Harold J. Coolidge. Term indefinite.

History: Organized by the National Academy of Sciences-National Research Council 
December 12, 1946. Committees: Conservation Committee for Micronesia; Honolulu; Invertebrate Consultants Committee for the Pacific; Southeast Asia; and IVest Coast Advisory.

Purpose: To aid the scientists of America who wish to engage in scientific investigations for which there is a need in the Pacific area; to advise governmental and other agencies on scientific matters pertaining to the Pacific; and to further international cooperation in the field of Pacific science.

Membership: Members are appointees of the National Academy of Sciences- National Research Council and the Pacific Science Board. 12 members and Executive Director (ex officio).

\section{Mectings: Annual.}

Professional activities: Financial support is derived from government contract funds, as well as private foundations, institutions, and individual donors.

1207. Paleontological Research Institution. 109 Dearborn Place, Ithaca, N. Y. President: Norman E. Weisbord, Florida State University, P. O. Box 1082, Tallahassee, Fla. Term expires October 1960. Director: Katherine Van Winkle Palmer. Term indefinite.

History: Founded in 1932 ; provisional charter granted by the University of the State of New York in 1933; absolute charter granted in 1936. Recently affiliated with the American Association for the Advancement of Science.

Purpose: To increase and disseminate knowledge in the field of invertebrate paleontology, and to collect and preserve type material for the promotion of paleontologic research.

Membership: Open to persons over 21 years of age, interested in paleontology and related subjects, both professional and amateur. Amateur membership is limited to persons sympathetic to the purposes of the Institution, whose interests lie largely in the field of invertebrate paleontology, whose ability and training enable them to pursue independent study, and whose research conforms to the high standards of the organization.

Meetings: Semiannual.

Professional activities: Laboratory maintained at headquarters; grants from the Geological Society of America, National Science Foundation, and American Philosophical Society.

Publications: Bulletins of American Paleontology, irregular, current volume: 41, $\$ 16$. Palaeontographica Americana, irregular, current volume: 4, \$20. Prices estimated. Editor: Katherine V. W. Palmer.

Library: 11,600 volumes on paleontology.

1208. Paleontological Society. President: Norman D. Newell, American Museum of Nat- ural History, New York 24, N. Y. Term expires November 1961. Secretary: H. B. Whittington, Museum of Comparative Zoology, Harvard University, Cambridge 39, Mass. Term expires November 1961.

History: Organized December 1908. Cooperates with the Society of Economic Paleontologists and mineralogists in the journal publication; publication of three issues is with the assistance of the Geological Society of America. Active Pacific Coast branch; represented on Joint Committee on Invertebrate Paleontology which is producing the Treatise on Invertebrate Paleontology.

Purpose: To further the science of paleontology.

Membership: Open to any person, professional or amateur, with an interest in paleontology. Members, 847. Correspondents, outstanding foreign paleontologists, 14. Total membership 861 .

Meetings: Annual, with the Geological Society.

Publications: Journal of Paleontology, bimonthly, current volume: $34, \$ 15$. Editor: R. V. Kesling, University of Michigan.

1209. Pan American Cancer Cytology Society. President: Robert E. L. Nesbitt, Jr., Albany Medical College of Union University, Albany, N. Y. Term expires 1962 or 1963. Exccutive Secretary: Herbert Friedman, Los Angeles, Calif. Term expires 1962 or 1963.

History: Formed in 1957 at conclusion of Pan American Cancer Cytology Congress, with representatives of fifteen countries attending.

Purpose: To develop, promote and extend the use of cytologic diagnosis, training and research.

Membership: Members, approximately 600, honorary fellowships and cytologist members elected on basis of scientific attainments.

Mectings: Every two or three years.

Professional activitics: Fellowships awarded for outstanding achievements, and awards presented for unusual service to the society.

Publications: Cancer Cytology, quarterly, current volume: 3, \$6. Editor: J. Ernest Ayre.

1210. Pan-Pacific Surgical Association. 230 Alexander Young Building, Honolulu 13, Hawaii. Director General: F. J. Pinkerton. Term indefinite. Executive Secretary: Peggie Gladding. Term indefinite.

History: Founded 1929; first Congress attended by 205 physicians from seven Pacific area countries.

Purpose: To bring together surgeons from countries bordering on the Pacific Ocean for the 
exchange and dissemination of scientific knowledge and techniques relating to medicine and surgery; to develop an acquaintanceship among the surgeons so that they may be instrumental in promoting a spirit of good fellowship among the races of the Pacific; to promote the improvement and standardization of hospitals and their services and facilities.

Membership: Regular, U.S., fellows of the American College of Surgeons or who are diplomates of the American Board of Surgery or a surgical specialty; Regular, other nationalities, members of the national surgical association or a national surgical specialty association in the country of their residence; Associate, those who do not meet the above requirements. Total membership 1,380.

Meetings: Once every three years.

1211. Pathological Society of Philadelphia. College of Physicians, 19 South 22nd Street, Philadelphia, Pa. President: Andrew J. Donnelly, Oncologic Hospital, 33rd Street and Powelton Avenue, Philadelphia, Pa. Term expires January 1962. Secretary: John W. Eiman, Abington Memorial Hospital, Abington, Pa. Term expires January 1962.

History: Founded in 1857.

Purpose: The cultivation and promotion of the study of pathology and of the medical sciences.

Membership: Members, 300, Doctor of Medicine degree from a university, medical college or medical school approved by the American Medical Association, or a degree in the natural sciences or in the sciences tributary to medicine.

Mectings: Ten times per year.

Professional activities: William Wood Gerhard Gold Medal, awarded for medical research.

1212. Pennsylvania Academy of Science. President: Kenneth Dearolf, Public Museum and Art Gallery, Reading, Pa. Term expires April 2, 1961. Secretary-Treasurer: K. B. Hoover, Messiah College, Grantham, $\mathrm{Pa}$. Term expires April, 1964.

History: Organized April 18, 1924.

Purpose: The furtherance of the scientific interests of Pennsylvania.

Membership: Members, 606, some scientific interest and recommendation by a member.

Meetings: Semiannual.

Professional activities: Cash prizes from Darbaker Fund for winning papers in microbiology. Research grants provided by the American Association for the Advancement of Science.

Publications: Proceedings, annual, current volume : 34, \$4. Editor: Robert E. Ogren. News
Letter, bimonthly, free to members. Editor: Homer C. Will.

1213. Pennsylvania Dental Association. 217 State Street, Harrisburg, $\mathrm{Pa}$. President: Robert W. McEldowney, 2448 Walnut Street. Harrisburg, Pa. Term expires May 19, 1961. Executive Secretary: Ray Cobaugh. Term indefinite.

History: Organized December 1, 1868. Committees and Councils: Annual Award Council, Annual Meeting Committee, Council on Component Societies, Council on Dental Health, Legislative and Law Enforcement Committee, Professional Liaison Committee, Dental Trade and Laboratory Relations Committee, Hospital Dental Service Committee, Committee on Cancer, Committee on Constitution and Bylaws, Dental Council and Examining Board.

Purpose: To encourage the improvement of the health of the public, and through research to promote the art and science of dentistry.

Membership: Active members, ethical dentists, whose professional address is within the Commonwealth of Pennsylvania, and who are registered with the Pennsylvania State Dental Council and Examining Board; Honorary members, individuals who have made an outstanding contribution to the advancement of the art and science of dentistry; Life members, a member of the Association in good standing who has completed thirty-five years of active membership, and whose sixty-fifth birthday occurs before December 31 of the year of his election. Total membership 5,400.

Meetings: Annual.

Publications: Pennsylvania Dental Journal, 9 times per year, \$2. Editor: Vincent G. Lawlor.

1214. Pennsylvania Forestry Association. P. O. Box 983, Harrisburg, Pa. President: Lloyd E. Partain, Curtis Publishing Company, PennMutual Building, Philadelphia, Pa. Term expires fall 1960. Executive Secretary: Ralph C. Wible. Term expires fall 1960.

History: Organized 1886; incorporated 1887. Purpose: To disseminate information regarding protection and wise use of forests and attendant soil, water, wildlife, and recreation resources; to coordinate efforts of government, business, and property owners in promoting sustained management of all forest and attendant resources.

Membership: Annual members and Student, Subscribing, Contributing, Honorary, Sustaining members. Total membership 1,300.

Meetings: Semiannual.

Professional activities: Tree farms; resource development program for Pennsylvania; educa- 
tional projects among schools, organizations, and agencies; Annual Conservation Award, in recognition of leadership; Foresters Forest, to honor leadership in forest conservation in Pennsylvania.

Publications: Pennsylvania Forests, quarterly, current volume: 49, \$3. Editor: Arthur C. McIntyre.

1215. Pennsylvania Horticultural Society. 389 Suburban Station Building, Philadelphia 3, Pa. President: Henry D. Mirick. Term expires December 31, 1962.

History: Organized November 24, 1827.

Purpose: To promote horticulture and create interest in plants and flowers.

Hembership: Open to persons interested in horticultural science. Total membership 6,000 .

Mectings: Annual.

Professional activities: Medals, certificates, and cash prizes given at flower shows, and for special work in horticulture.

Publications: Newsletter, monthly, and Year Book, both free to members.

Library: 7,000 volumes. Subject emphasis: Horticulture.

1216. Pennsylvania Medical Society. 230 State Street, Harrisburg, Pa. Prcsident: Allen W. Cowley, 1919 North Front Street, Harrisburg, $\mathrm{Pa}$. Term expires October 1960. Executive Director: Lester H. Perry. Term indefinite.

History: Founded April 11, 1848. Governed by a House of Delegates which establishes policies and a Board of Trustees and Councilors which carries out policies. The state is divided into twelve councilor districts with a trustee from each district making up the Board. Sixty county medical societies make up the twelve districts.

Purpose: To extend medical knowledge and advance medical science; to elevate and maintain the standards of medical education; to uphold the ethics and dignity of the medical profession; to advocate and support the enactment of such legislation as will accrue to the health and well being of the public, and to enlighten and direct public opinion in regard to health and hygiene.

Membership: Active, 10,776, fully licensed to practice medicine in Pennsylvania, member of one of the component county societies; Affiliate, 8 , member of one of the county societies and citizen of the United States, not fully licensed to practice medicine in Pennsylvania, engaged in Pennsylvania in teaching, public health, research or holding a position in Federal Service, administrative medicine, residency, or retired; Associate, 950, over sixty-five years of age with twenty-five years continuous membership, retired or illness or physical disability which prevents practicing medicine. Total membership 11,734

Mectings: Annual.

Professional activities: Science Fair Scholarships, four $\$ 500$ scholarships to winners of area science fairs. Benjamin Rush Award to the individual contributing most to the health welfare of the community. Benjamin Rush Award to the group contributing most to the health welfare of the community. General Practitioner of the Year, annual award to an outstanding general practitioner. Centenarian Award, plaques presented to all centenarians in Pennsylvania. Fifty-year Awards, recognition of fifty years practice. Medical Defense Fund, for expenses involved in suits for alleged mal-practice. Medical Benevolence Fund, for relief of pecuniary distress. Education Fund for worthy students.

Publications: Pennsylvania Medical Journal, monthly, current volume: $63, \$ 5$, free to members. Editor: Sam C. Price. Newsletter, monthly except July and August, current volume: 3 . Editor: Leroy C. Erickson. The Physician and Public Health, quarterly, current volume: 14 15-16-17. Editor: Leroy Elwell.

1217. Pennsylvania Optometric Association, Inc. President: Melvin D. Wolfberg, 105 West Pine Street, Selinsgrove, Pa. Term expires May 1961. Administrative Director: E. Payson Smith, P. O. Box 1201, Harrisburg, $\mathrm{Pa}$. Term indefinite.

History: Organized 1896, incorporated 1934. Fourteen affiliated societies covering Pennsylvania. Four General Departments: Organization, Education, Public Information, and State Affairs; with twenty-six standing committees in every phase of the profession, both educational and technical.

Purpose: To affiliate into one organization all of the local optometric societies in the state for the purpose of fostering the growth and disseminating optometric knowledge; to promote friendly intercourse; to safeguard the material interests of the optometric profession; to elevate the standard of optometric education and direct public opinion in regard to the importance and value of optometric science and service; to foster friendly relations between recognized professions in order that the citizens of the Commonwealth may secure the most accurate and complete eye care known to science.

Membership: Open to professional optometrists who are nembers of affiliated societies in Pennsylvania. Total membership over 700 .

Meetings: Annual.

Professional activities: Two scholarships of $\$ 3,000$ each; various honorary awards. 
Publications: POA Monthly, current volume: 9. Editor: E. Payson Smith. Pennsylvania Optometrist, bimonthly, current volume: 20 . Editor: Milton J. Eger.

\section{Pennsylvania Osteopathic Association,}

Inc. 1941 Market Street, Harrisburg, Pa. President: Henry N. Hillard, 245 East King Street, Lancaster, Pa. Term expires November 18, 1960. Executive Secretary: Thomas M. Fogarty. Term indefinite.

Purpose: To promote public health, and the science of the osteopathic school of the healing art.

Membership: Must be doctors of osteopathy licensed to practice in Pennsylvania. Pennsylvania members, 1,027; out-of-State, 95. Total membership 1,122 .

Meetings: Three annually.

Publications: Journal, quarterly, \$10. Editor: Thomas M. Fogarty. Physicians Placement Directory, annual, free to members. Editor: Henry N. Hillard.

\section{Pennsylvania Pharmaceutical Association.}

Harrisburg, Pa. President: Joseph Palchak, 825 Duquesne Boulevard, Duquesne, Pa. Term expires 1961. Secretary: Max L. Miller, 508 North Third Street, Harrisburg, Pa. Term expires 1961.

History: Organized August 26, 1878.

Purpose: To unite the educated and reputable pharmacists of the state and to improve the science and art of pharmacy.

Membership: Registered Pharmacists, 3,543; Drug Salesmen, 141; Life members, 50. Total membership 3,753.

Meetings: Annual.

Publications: Pennsylvania Pharmacist, monthly, $\$ 5$, free to members. Editor: M. I. Miller.

1220. Pennsylvania Psychiatric Society. President: Frederick L. Weniger, 3811 O'Hara Street, Pittsburgh 13, Pa. Term expires October 1961. Secretary-Treasurer: Jack A. Wolford. Term expires October 1960.

History: Founded in Pittsburgh, Pennsylvania, in October 1939.

Purpose: To further the study of subjects pertaining to the nature, treatment, and prevention of mental disorders, mental defects, convulsive disorders, delinquency, and the related conditions; to further the interests, the maintenance, and the advancement of standards of hospitals for mental disorders, of out-patient clinics, and of all other agencies concerned with the medical, social, and legal aspects of these disorders; to apply psychiatric knowledge to other branches of medicine, to other sciences, and to the public welfare; and to accept contributions, gifts, and bequests in furtherance of these purposes.

Membership: All classes of membership, except honorary and corresponding, limited to physicians who are residents of Pennsylvania at the time of their election, licensed to practice medicine in Pennsylvania, specializing in psychiatry or whose practice or professional interests are primarily psychiatric, and who have been so during the one year preceding date of their election to membership, or who are Fellows, Members, or Associate Menbers of the American Psychiatric Association. All classes of membership except Corresponding recommended by the Council. Fellows, 158, those who have specialized in the practice of psychiatry for at least six years, or are Fellows of the American Psychiatric Association in good standing; Members, 130 , those who have specialized in the practice of psychiatry for at least three years, or are members of the American Psychiatric Association in good standing; Associate Members, 28, those who have had at least one year's practice in a mental hospital, or are Associate Members of the American Psychiatric Association in good standing; Life Fellows, 12, those who have maintained thenselves in good standing as Fellows, or Members, for thirty consecutive years, or are Life Fellows of the American Psychiatric Association; Honorary Members, 3 , those who have distinguished themselves by attainments in psychiatry or related sciences or who have rendered signal service in philanthropic efforts to promote the interests of psychiatry and mental hygiene; Corresponding Members, 19, those who are qualified for Fellowship but who are not residents of Pennsylvania. Total membership 350 .

Meetings: Annual.

1221. Pennsylvania Psychological Association. President: Dora F. Capwell, 902 Park Building, Pittsburgh 22, Pa. Term expires May 1961. Secretary: John R. Barry, 3811 O'Hara Street, Pittsburgh 13, Pa. Term expires May 1961.

History: Organized March 30, 1934, as Pennsylvania Association of Clinical Psychologists; reorganized under present title May 20, 1946. Divisions: School Psychologists, Clinical Psychology.

Purpose: To advance psychology as a science, a profession, and a means of promoting human welfare.

Membership: Fellows, doctor's degree based in part upon a psychological dissertation, and conferred by a graduate school of recognized 
standing, and either acceptable published research of a psychological character beyond the doctoral degree, or four years of acceptable professional experience subsequent to the granting of the doctoral degree. Associates, doctor's degree based in part upon a psychological dissertation and conferred by a graduate school of recognized standing; or completion of at least two full academic years of graduate work in psychology in a recognized graduate school, and, at the time of application, full time occupation in graduate and/or professional work that is primarily psychological in nature; or at least one full academic year of graduate work in psychology in a recognized graduate school plus at least one full year of experience in professional work that is psychological in nature, and, at the time of application, full time occupation in graduate and/or professional work that is primarily psychological in nature; or acceptable status as a scientist, educator, or other distinguished person whom the Membership Committee may recommend for sufficient reason. Total membership 700 .

Meetings: Annual.

\section{Pennsylvania Public Health Association.}

303 North Second Street, Harrisburg, Pa. Secretary: Mrs. E. Jane Petach. Term expires August 1962.

History: Organized February 7, 1925. SECTIONS: Environmental Health, Health Education, and Medical Care. Region: Region One, covering Philadelphia and surrounding area.

Purpose: To promote and protect public health in Pennsylvania, in cooperation with official, professional, and voluntary agencies.

Membership: Open to all persons engaged or interested in any branch of public health work in Pennsylvania. Members; Corporate Members; Honorary Members, persons who have rendered such service to the cause of public health in Pennsylvania as to merit special recognition. Total membership 700 .

Mcetings: Annual.

Professional activities: Award of Merit, for outstanding contribution to advancement of public health in Pennsylvania.

Publications: Newsletter, quarterly, current volume: 8 , free to members.

1223. Pennsylvania Radiological Society. President: Carl B. Lechner, Erie, Pa. Term expires May 1961. Secretary-Treasurer: Frederick R. Gilmore, Clearfield Hospital, Clearfield, Pa. Term expires May 1965.

History: Organized 1916; incorporated November 1927. Committees: By-laws Revision, Exhibits, Membership, Memorial, Nominating,
Professional Relationships, Program, Public Relations, Publication, Technicians Advisory, Therapy Standardization.

Purpose: The advancement of medical science with reference to roentgenology and radium therapy; study of means calculated to render the medical profession more efficient and useful to the public.

Mcmbership: Active, diplomates of American Board of Radiology in active practice of radiology; Associate, graduates qualified to practice medicine, members in good standing of County and State Medical Societies, in active practice of radiology; Inactive, former active members in good standing retired from active practice of radiology; Honorary, individuals who have made a special study of radiology or one of its components and/or are actively engaged in scientific development of the work. Total membership approximately 200 .

\section{Meetings: Annual.}

Professional activitics: Prizes awarded for annual scientific exhibit. Prizes to residents in radiology in Pennsylvania hospitals for original scientific papers on radiology: First Award, $\$ 100$, two Honorable Mention Awards, \$25 each. Annual Guest Lecture.

Publications: Pennsylvania Journal of Radiology, biannual, free to members. Editor: John H. Harris, Jr., 26 Parker Street, Carlisle, Pa.

\section{Pennsylvania Society of Professional}

Engineers. 2121 North 2nd Street, Harrisburg, Pa. President: Roberts Bouson, 320 Locust Avenue, Washington, Pa. Term expires May 20, 1961. Executive Director: Clifton T. Kent. Term indefinite.

History: Formed in 1934. Twenty-nine chapters in Pennsylvania with the largest in Philadelphia, Pittsburgh, Harrisburg and in the Lehigh Valley area. The Society covers all branches of engineering and has many committees concerning themselves primarily with professional aspects of engineerings.

Purpose: To safeguard life, health and property by restricting, or encouraging the restriction by proper authorities, the practice of engineering and surveying to properly qualified persons; to focus attention upon the functions, requirements and accomplishments of engineers, and to sponsor and promote honorable procedures tending toward recognition of the profession.

Membership: Members, approximately 4,200, registered as Professional Engineers, Engineersin-Training or Surveyors.

Mectings: Annual.

Professional activitics: Participates in selecting high school seniors for engineering scholar- 
ships under ARMCO-N.S.P.E. Scholarship Program.

Publications: The Pennsylvania Professional Engineer, bimonthly, current volume: 2, \$1. Editor: Clifton T. Kent. The Pennsylvania Society Year Book, current volume: 9, free to members, $\$ 10$ to others. Editor: Clifton T. Kent.

1225. Petrologists' Club. Secretary: Sydney P. Clark, Jr., Geophysical Laboratory, 2801 Upton Street, N. W., Washington 8, D. C. Term expires 1962.

History: Organized January 1910 as Petrographic Club of Washington; name changed to present title March 1910.

Purpose: To provide a forum for informal discussion of petrological problems and to foster study of petrology.

Mcmbership: Professional interest in petrology. Total membership 100.

Meetings: Eight annually.

1226. Pharmaceutical Association of the State of South Carolina. President: Lake E. Ellis, 3210 White Horse Road, Greenville, S. C. Term expires August 1, 1961. SecretaryTreasurer: George S. Inman, 3303 Augusta Road, Greenville, S. C. Term expires August $1,1964$.

History: Chartered December 17, 1817 ; incorporated March 10, 1876.

Purpose: To promote the advancement of pharmacy and to encourage a more thorough education in the practical and theoretical knowledge of the profession; to protect the public from dangers of ignorance in sale of poisons and adulterated medicines.

Membership: Active, 466, Registered Pharmacists; Associate, 52, others interested in pharmacy; Complimentary, 34. Total membership 552.

Meetings: Annual.

Publications: Southeastern Drug Journal, monthly, current volume: $34, \$ 2$. Editor: Max Ginsberg.

1227. Pharmaceutical Society of the State of New York. 117-119 East 69th Street, New York 21, N. Y. President: Nicholas S. Dardano, 918 Albany Street, Utica, N. Y. Term expires June 1961. Secretary: Nicholas S. Gesoalde, 117 East 69th Street, New York 21, N. Y. Term expires June 1961.

History: Organized May 21, 1879.

Purpose: To disseminate information concerning scientific, professional, and business activities to members of the Society.
Membership: Full membership open to licensed pharmacists or pharmacy owners. Associate membership open to individuals connected with the pharmaceutical industry. Full members 6,029; Associate members 1,221.

Mectings: Annual.

Publications: New York State Pharmacist, monthly. Editor: David Frolich.

1228. Phi Lambda Upsilon Honorary Chemical Society. President: Thomas B. Cameron, Department of Chemistry, University of Cincinnati, Cincinnati 21, Ohio. Term expires June 30, 1963. Secretary: Alfred A. Schilt, Department of Chemistry, University of Michigan, Ann Arbor, Mich. Term expires June 30, 1963.

History: Organized March 1899 at the University of Illinois.

Purpose: The promotion of high scholarship and original investigation in all branches of pure and applied chemistry.

Membership: Election based primarily upon scholarship, scholastic average of $80 \%$ or better. Total membership 29,000.

Mectings: Triennial.

Professional activities: A loan fund is maintained for worthy students in need of help to complete their college education. Individual chapters often give awards, usually to outstanding senior students in chemistry.

Publications: The Register, biennial, current volume: 44, \$1. Editor: Robert G. Johnson.

1229. Phi Sigma Society. Department of Biology, Virginia Polytechnic Institute, 1305 Hillcrest Drive, Blacksburg, Va. President: Henry van der Schalie, Professor of Zoology, University of Michigan, Ann Arbor, Mich. Term expires September 1, 1964. Executive Secretary: Fred S. Orcutt. Term expires July 1, 1965 .

History: Organized March 17, 1915, as Phi Sigma Honorary Biological Society; name changed to present title April 1925.

Purpose: To promote interest in research in the biological sciences.

Menbership: Active members, outstanding graduates and upper class undergraduates who have shown research interest in biological sciences; Faculty, members of faculties in biological sciences in institutions supporting chapters; Honorary. Total membership 25,318.

Meetings: Biennial.

Professional activities: Scholarships established by some individual chapters, as well as local campus awards; national award certificates for one outstanding graduate and one outstand- 
ing undergraduate student in biological sciences at each institution with active chapter.

Publications: Biologist, quarterly, current volume: $42, \$ 1.50$, free to members. Editor: M. H. Hatch.

1230. Philadelphia Allergy Society. President: Charles H. Classen, Rosemont, Pa. Term expires 1961. Sccretary-Treasurer: Sonia Stupniker, 6900 Rising Sun Avenue, Philadelphia 11, Pa. Term expires 1961.

\section{History: Organized 1935.}

Purpose: To stimulate clinical and scientific research in allergy, and to promote favorable conditions for such research.

Mcmbership: Open to persons with interest in allergy diagnosis and treatment. Total membership 90 .

Mectings: Semiannual.

Professional activities: Lillian K. Snyder Fund for best paper submitted on allergy at scientific meeting, capital $\$ 500$.

\section{Philadelphia Anthropological Society.}

University of Pennsylvania Museum, Philadelphia, Pa. President: Edward Harper, Bryn Mawr College, Bryn Mawr, Pa. Term expires September 1961. Executive Secretary: Robert J. Smith, P. O. Box 14, Bennett Hall, University of Pennsylvania, Philadelphia 4, Pa. Term expires September 1961.

History: Organized informally 1912 ; reorganized 1930.

Purpose: To bring together persons with anthropological interests, in the Philadelphia area, for continued education and spread of anthropological knowledge.

Mcmbership: Open to persons with interest in purpose of this Society. Total membership 170 .

Meetings: Monthly during academic year.

Professional activitics: Honorary Publication Fund, for outstanding members.

Publications: Bulletin, three annually, current volume: 13 , free to members.

1232. Philadelphia Astronautical Society. 780 North 26th Street, Philadelphia, Pa. President: Robert Boritz. Term indefinite. Secretary: Robert Sinusas. Term indefinite.

History: Organized March 1953. СомmiтTEES : Propellant Development, Rocket Motor and Body Development, Electronics.

Purpose: To promote theoretical and experimental investigations in rocketry and the astronautical sciences; to promote astronautics through lectures, discussions and publications.
Membership: Membership open, but prefer persons with scientific or technical backgrounds. Active members, 18; Associate, 17. Total membership 35.

Mectings: Quarterly.

Publications: P.A.S. Bulletin, irregular. Editor: Jean Bogert. Book Review Editor: Rinehart S. Potts, c/o Aero Service Corporation, 210 East Courtland Street, Philadelphia 20, $\mathrm{Pa}$.

1233. Philadelphia Botanical Club. Academy of Natural Sciences, Philadelphia 3, Pa.President: Mrs. J. Norman Henry, Gladwyne, Pa. Term expires January 1961. Secretary: Waiter M. Benner, 5636 Loretta Avenue, Philadelphia 24, Pa. Term expires January 1961.

History: Organized December 1891.

Purpose: Cultivation of local botany.

Membership: Open to persons interested in botany. Active members, 110; Corresponding, 3 . Total membership 113.

Mcetings: Monthly, except June, July, and August.

Publications: Bartonia, irregular, current volume: 29, free to members. Editor: Edgar T. Wherry.

1234. Philadelphia County Medical Society. President: David A. Cooper, 1520 Spruce Street, Philadelphia 2, Pa. Term expires December 31, 1960. Executive Secretary: William F. Irwin, 301 South 21st Street, Philadelphia 3, Pa. Term indefinite.

History: Instituted 1849; incorporated 1877. Sections: Eye, Anesthesiology, Clinical Pathology, Rheumatoid and Arthritic Diseases. Forty-two committees devoted to the study of problems of medical care.

Purpose: Advancement of knowledge on all subjects connected with healing arts; organization of medical profession in connection with state and national organizations; elevation of character and protection of rights and interests of those engaged in the practice of medicine; study of means to render the medical profession most useful to the public.

Mcmbcrship: Active members, 3,100, licensed to practice in Pennsylvania, and citizens of the United States; Associate, 341, former active members elected to associate membership by reason of age and continuous years of active membership ; Affiliate, 263, dentists, non-practicing physicians and full-time physicians in government service. Total membership about 3,600.

Mectings: Annual meeting in November; stated meetings January, May and October. 
Professional activities: Strittmatter Award, gold medal and certificate awarded annually to physician rendering a service resounding to the credit of the medical profession, capital $\$ 5.000$; Da Costa Fund, provides an honorarium for a speaker on some surgical subject, capital $\$ 2,000$. Post-Graduate Institute, held four days each year to provide postgraduate instruction to physicians.

Publications: Philadelphia Medicine, weekly, $\$ 5$, free to members. Editor: Dorothy Ann Harrison.

Library: 4,250 volumes.

1235. Philadelphia Mineralogical Society. 5827 North Lawrence Street, Philadelphia 20, Pa. President: Paul Seel, 3 Cynwyd Road, BalaCyıwyd, Pa. Term expires October 1960. Secretary: David Travis. Term expires October 1960.

History: Organized 1892 as Student's Mineralogical Society; name changed to present title 1896.

Purpose: Cultivation and study of the science of mineralogy.

Membership: Open to persons with interest in field of mineralogy. Total membership 125.

Meetings: Monthly except July and August.

1236. Philadelphia Neurological Society. 19 South 22nd Street, Philadelphia 3, Pa. President: Henry A. Shenkin, Suite 111, Centennial Building, Front and Lehigh Streets, Philadelphia 24, Pa. Term expires January 8, 1961. Secretary: Richard G. Berry, 1025 Walnut Street, Philadelphia 7, $\mathrm{Pa}$. Term indefunite.

\section{History: Organized 1883}

Purpose: To promote the study of neurology.

Membership: Active, 138, physicians engaged in the study of neurological science in one of its branches; Senior, 4; Out-of-town, 13; Honorary, 19. Total membership 174.

Meetings: Monthly, October through May.

1237. Philadelphia Roentgen Ray Society. College of Physicians, 19 South 22nd Street, Philadelphia, Pa. President: Herbert Stauffer, Temple University Hospital, Broad and Ontario Streets, Philadelphia, Pa. Term expires September 30, 1960. Secretary: Robert B. Funch, Germantown Hospital, Penn and Wister Streets, Philadelphia, Pa. Term expires September 30, 1960.

History: Organized February 2, 1905. Constitution and By-laws enacted December 1, 1913; incorporated as The Philadelphia Roentgen Ray Society, Inc. on October 2, 1924.
Purpose: The friendly personal consideration of matters of mutual interest regarding medical radiology and advancement of standards in the science and practice of radiology.

Membership: Active, 205, citizens of United States licensed in medicine, members of a county medical society and diplomates of American Board of Radiology; Associate, 15, physicists, teachers and others whose vocation improves radiology ; Corresponding, 28, previous active members no longer in Philadelphia; Honorary, 4, those whose service to radiology deemed worthy of honor; Inactive, 5, previous active members retired or unable to practice because of illness.

Mectings: Monthly October through May.

Professional activities: Annual Memorial Lecture presented by an outstanding scientist in radiology or an allied field in honor of Dr. Henry K. Pancoast, or one of the founding members of the society. Support the convention of the Pennsylvania Society of X-Ray Technicians when it is held in Philadelphia.

1238. Philadelphia Tuberculosis and Health Association. 311 South Juniper Street, Philadelphia 7, Pa. President: William W. Tomlinson, Temple University, Philadelphia 22, Pa. Term expires April 1961. Director: Thomas E. Bramble. Term indefuite.

History: Organized April 1, 1919; incorporated December 1920 as Philadelphia Health Council and Tuberculosis Committee; name changed to present title 1941 ; affiliate, National Tuberculosis Association, and Pennsylvania Tuberculosis and Health Society. Commitrees: Campaign and Public Information, Case Finding, Health Education, Social and Medical Research, Special Services.

Purpose: Prevention of tuberculosis and promotion of health in Philadelphia.

Membership: Composed of Board of Directors of thirty members elected for three years. Membership self perpetuating.

Meetings: Semiannual.

Publications: Annual Report.

1239. Philosophical Society of Washington. Cosmos Club, Washington 6, D. C. President: Louis R. Maxwell, U. S. Naval Ordnance Laboratory, White Oak, Silver Spring, Md. Term expires December 1960. Corresponding Secretary: François N. Frenkiel, Applied Mathematics Laboratory, David Taylor Model Basin, Washington 7, D. C. Term expires December 1961.

History: Founded March 13, 1871; incorporated in the District of Columbia May 20 , 1901. 
Purpose: Promotion of science, advancement of learning, and free exchange of views.

Membership: Open to all persons interested in the purpose of this Society. Active members, including Life members, 773 .

Mectings: Biweekly, October through May.

Professional activities: Annual Joseph Henry Lectures, in honor of first president of this Society; Annual Christmas Lectures, primarily for high school and advanced junior high school students.

Publications: Bulletin.

1240. Philosophy of Science Association. Department of Philosophy, Michigan State University, East Lansing, Mich. Executive Secretary: Lewis K. Zerby. Term expires 1961.

History: Organized 1934; affiliate, American Association for the Advancement of Science.

Purpose: To promote philosophy of science, its study and understanding; to further ideas concerned with methods of science in the most general sense and in ways in which scientific activities are integrated with other human endeavors.

Membership: Open to persons in sympathy with objects of this Association. Total membership 2,000 .

Meetings: Annual.

Publications: Philosophy of Science, quarterly, current volume: 27 , domestic $\$ 6$, foreign $\$ 6.75$. Editor: Richard S. Rudner.

1241. Phoenix Observatory Association. Phoenix College, 1202 West Thomas Road, Phoenix, Ariz. President: Brian Stapleton. Term expires January 1, 1961. Faculty Representative: Amos H. Hoff, Phoenix College, Phoenix, Ariz. Term expires January 1, 1961.

\section{History: Organized 1948.}

Purpose: To encourage interest in amateur astronomy, particularly in construction and use of reflecting and refracting telescopes.

Membership: Open to persons interested in the purpose of this Association. Total membership 60 .

Mectings: Bimonthly during school year; twice during summer.

Publications: Newsletter, bimonthly, free to members. Editor: Ken Walko, 342 West Butler Street, Phoenix, Ariz.

1242. Phycological Society of America. President: Jack Myers, Department of Zoology, University of Texas, Austin, Tex. Term expires September 1961. Secretary-Treasurer:
William A. Daily, Department of Botany, Butler University, Indianapolis 7, Ind. Term expires September 1961.

History: Organized 1946.

Purpose: The advancement of phycology.

Membership: Individuals, 290, persons interested in phycology; Organizations, 14, organizations desiring to promote research in phycology. Total membership 304.

Mectings: Annual.

Publications: New Bulletin, irregular, current volume: 13, \$2. Editor: P. C. Silva, University of Illinois, Urbana, Ill.

1243. Physical Society of Pittsburgh. President: Philip M. Stehle, University of Pittsburgh, Pittsburgh 13, Pa. Term expires August 1961. Executive Secretary: Charles Church, Westinghouse Research Laboratory, Beulah Road, Churchill Borough, Pa. Term expires August 1961.

\section{History: Organized 1923.}

Purpose: To provide a common meeting ground for Pittsburgh physicists, industrial and academic.

Membership: Student of physics or a practicing physicist.

Mectings: Monthly except June, July, and August.

Professional activities: Medal for service to Pittsburgh physics. Award to winner of local Science Fair.

1244. Physics Club of Chicago. President: C. E. Barthel, Armour Research Foundation, Chicago, I11. Term expires May 1961. Secretary: Dwight L. Barr, 708 South Princeton Street, Villa Park, Ill. Term expires May 1961.

History: Founded 1931; incorporated April 1940; affiliate, American Institute of Physics and Chicago Technical Society.

Purpose: To disseminate educational and scientific information among physicists, research workers, and others with interest in physics, in the Chicago area.

Membership: Open to persons with interest in the purpose of this Club. Regular members, 225; Student, 7; Honorary, 3; Life, 13. Total membership 248 .

Mectings: Monthly, September through May.

Professional activities: Certificates to winners of physics section of Chicago Student Science Fair.

1245. Physics Club of New York. President: Sam Troik, 80 Strong Street, Bronx 68, N. Y. 
Term expires June 1961. Secretary: Nathan Borowsky, 69-55 178th Street, Flushing 65, N. Y. Term expires June 1961.

History: Organized approximately 1904.

Purpose: To promote and improve physics teaching; to develop a proper professional attitude; to establish mutual acquaintance and good fellowship among science teachers of New York City.

Membership: Full members, 103, members in Federation of Science Teachers Association of New York City; Associate, 37, members in one of the other member organizations of the Federation. Total membership 140.

\section{Meetings: Seven a year.}

Professional activities: Physics Award, to stimulate scholarship in and the study of physics, awarded to students in graduating class in high schools with the highest accomplishment in physics.

1246. Physiological Society of Philadelphia. President: Domingo M. Aviado, University of Pennsylvania Medical School, Philadelphia 4, Pa. Term expires October 1961. Executive Secretary: Robert E. Forster, Jr., Graduate School of Medicine, University of Pennsylvania, Philadelphia 4, Pa. Term expires October 1961.

History: Founded October 10, 1904 as the Society of Normal and Pathological Physiology ; name changed to present title December 15 , 1919.

Purpose: To encourage communications among investigators working in the five medical schools in Philadelphia, as well as those working in the various researcl institutes.

Membership: Members, 700, actively engaged in scientific research having direct or indirect bearing upon physiology, pharmacology and biochemistry.

Meetings: Monthly, September through May. Publications: Proceedings, annually, current volume: 34 , free to members.

1247. Pi Tau Sigma. President: D. S. Clark, School of Mechanical Engineering, Purdue University, Lafayette, Ind. Term expires October 1962. Executive Secretary: J. W. Bayne, Department of Mechanical Engineering, University of Illinois, Urbana, Ill. Term expires October 1962.

History: Organized 1915. Seventy active chapters distributed among three geographical divisions: East, Central, West.

Purpose: To foster the high ideals of the engineering profession, to stimulate interest in coordinate departmental activities, to promote the professional welfare of its members, and to develop in students of mechanical engineering the attributes necessary for effective leadership and the assumption of the responsibilities of citizens in a democracy.

Membership: Open to senior mechanical engineering students in highest third of class, and to junior students in highest quarter; Outstanding engineers and teachers are initiated as honorary members. Total membership approximately 29,000 , of which 2,000 are undergraduates.

\section{Meetings: Annual.}

Professional activities: Awards to the two outstanding young mechanical engineers annually at the winter meeting of the American Society of Mechanical Engineers. Gold Medal Award given within ten years after first mechanical engineering degree. Richards Memorial Award, to honor an outstanding mechanical engineer after twenty to twenty-five years after first mechanical engineering degree, \$250.

Publications: The Story of Pi Tau Sigma, every three years, current volume: 1958. Editor: David S. Clark, Purdue University, Lafayette, Ind. The Condenser, annually, current volume: 33. Editors: D. S. Clark and G. B. Thom, Newark College of Engineering, Newark, N. J.

1248. Pittsburgh Geological Society. President: A. S. Cate, Pennsylvania Topographical \& Geological Survey, State Office Building, Pittsburgh 22, Pa. Term expires 1961. Secretary: T. IV. Angerman, Huntley \& Huntley, Inc., 1208 Empire Building, Pittsburgh 22, $\mathrm{Pa}$. Term expires 1961.

History: Organized April 18, 1945.

Purpose: To stimulate geologic thought; to advance and disseminate geologic knowledge; to provide a forum for geologic problems.

Membership: Interest in purposes of the Society. Total membership approximately 200.

Meetings: Monthly.

1249. Pittsburgh Pediatric Society. 125 DeSoto Street, Pittsburgh 13, Pa. President: Bernard I. Michaels, 3500 5th Avenue, Pittsburgh 13, Pa. Term expires May 1961. Secretary: Trcasurer: James J. Reilly, 2231 Laketon Road, Pittsburgh 21, Pa. Term expires May 1961.

History: Organized September 1935. Comprises tri-state area: western Pennsylvania, eastern Ohio and northern IVest Virginia.

Purpose: To advance pediatrics among members and others in the medical profession in the Pittsburgh area.

Membership: Active, 139, resident of the TriState area, who are members of respective 
county medical society, limiting their practice to pediatrics; Affiliate, 20, meet the same requirements with the exception of practice in pediatrics; Honorary 4. Total membership 163.

Meetings: Bimonthly, September through May.

1250. Plant Propagators Society. President: Harvey Templeton, Jr., Winchester, Tenn. Term expires December 1960. Executive Secretary: K. W. Reisch, Ohio State University, Columbus 10, Ohio. Term expires December 1960.

\section{History: Organized November 1951.}

Purpose: To stimulate interest in the growing of finer plant material and to disseminate knowledge of how such material may best be propagated.

Membership: Commercial members, at least five years' actual experience as plant propagators, and a declaration of desire to share knowledge with others; Non-commercial, scientists, governmental employees, university professors; Junior. Total membership 375.

Meetings: Annual.

Publications: Proceedings, annual, $\$ 5$.

\section{Polk County Medical Society. 721} Bankers Trust Building, Des Moines 9, Iowa. President: Ralph A. Dorner, 710 Equitable Building, Des Moines 9, Iowa. Term expires January 1961. Executive Secretary: Edwin M. Kingery. Term indefinite.

History: Organized 1852; incorporated 1884; name changed to Des Moines Academy of Medicine and Polk County Medical Society, April 29, 1930; changed later to original title.

Purpose: To promote unity and harmony in every phase of medicine, and to encourage and make effective the opinions of the profession in scientific, legislative, public health, and social affairs.

Membership: Active, 252, resident of Polk County and licensed in Iowa, with more than three years practice; Junior Active, 40, not more than three years in practice; Life, 35; Non-resident, 19; Associate, 17 ; Intern, 22. Total membership 385.

Meetings: Monthly except summer.

Publications: The Bulletin, monthly, current volume: 31, free. Managing Editor: Edwin M. Kingery.

1252. Population Association of America, Inc. President: C. Horace Hamilton, Department of Rural Sociology, North Carolina State College, Raleigh, N. C. Term expires May 1961. Secretary-Treasurer: Kurt B. Mayer,
Department of Sociology and Anthropology, Brown University, Providence, R. I. Term expires May 1961.

History: Organized April 22, 1932.

Purpose: To promote progress of the human race by research concerning problems of population in both qualitative and quantitative aspects.

Membership: Open to persons who evidence interest in advancing the objectives of this Association. Regular and student members. Total membership 512.

Meetings: Annual.

Publications: Population Index, quarterly, current volume : 26 , $\$ 5$, free to members. Editor: Dorothy Good.

1253. Portland Surgical Society. 1312 Portland Medical Center, Portland, Oreg. President: Martin A. Howard, 504 Medical Arts Building, Portland, Oreg. Term expires June 1961. Secretary-Treasurer: Harvey W. Baker. Term expires June 1961.

History: Organized 1947; incorporated.

Purpose: To advance the science of surgery; to promote and maintain the ethical standards of its members.

Membership: Active, limited to 50, general surgeons in Portland certified by the American Board of Surgery or with equally acceptable qualifications; Associate, qualified members of surgical specialty groups in Portland or qualified general surgeons residing outside the Portland metropolitan area; Senior, active and associate members over fifty-five or over fifteen years membership. Total membership 111.

Meetings: Monthly; two-day annual meeting each May.

Professional activities: Annual Residents' Night, papers by surgical residents in Portland sponsored by the Society.

1254. Potato Association of America. New Jersey Agricultural Experiment Station, New Brunswick, N. J. President: Orrin C. Turnquist. Term expires August 1961. Secretary: Richard L. Sawyer, Long Island Vegetable Research Farm, Riverhead, Long Island, N. Y. Term expires August 1961.

History: Organized in 1912 as the National Potato Association; name changed to present title 1915.

Purpose: To publish original research data on all phases of research with Irish potatoes, and to promote legislation on various phases of the industry.

Membership: Open to any person or organization interested in any phase of the potato 
industry such as research, regulation, production, marketing, and processing. Total membership 2,300 .

\section{Meetings: Annual.}

Professional activities: Supported a research project on use of potatoes in a weight-reducing diet at Douglass College, New Brunswick, N. J. Honorary Life Memberships are presented to outstanding scientists and outstanding non-technical workers each year.

Publications: American Potato Journal, monthly, current volume: $37, \$ 4$. Potato Handbook, annual, current volume: $6, \$ 2$. Editor: John C. Campbell.

1255. Poultry Science Association. President: T. C. Byerly, U. S. Department of Agriculture, Washington 25, D. C. Term expires August 1961. Secretary-Treasurer: C. B. Ryan, Texas A \& M College, College Station, Tex. Term expires August 1961.

History: Organized 1908 as the International Association of Instructors and Investigators in Poultry Husbandry; name changed in 1912 to American Association of Instructors and Investigators in Poultry Husbandry; to present title 1926.

Purpose: The advancement of poultry husbandry throughout the United States and the Dominion of Canada, especially as it relates to the professions of research and teaching.

Mcmbcrship: Active members shall be college graduates engaged in instruction, investigation, or extension work in the poultry industry, regularly employed by an educational or research institution or a state (or province) or federal govermmental department; Associate members shall be persons not otherwise eligible, but whose contributions of knowledge in the poultry industry, as revealed by records of services, are such as to make them desirable members of the Association; Honorary ; Life. Total nembership 1,405 .

\section{Meetings: Annual.}

Professional activities: Poultry Science Research Prize, awarded to the Active member of the Association who, in the preceding year, has published the most outstanding piece of research. Ralston Purina Teaching Award, $\$ 1,000$, awarded for the encouragement of teaching methods and contributions to the field of teaching. The Pfizer Extension Teaching Award, $\$ 1,000$, awarded for outstanding poultry extension work. Borden Award, granted by the Borden Company of New York City, \$1,000 and a gold medal, for distinctive contributions to poultry science advancement covering a period of not more than seven years preceding the annual award. American Feed Manufacturers' Association Award, granted by the Nutrition
Council of the American Feed Manufacturers' Association, $\$ 1,000$ and a plaque, for distinctive work demonstrating sound research in poultry nutrition supplemented by capacity for research. Institute of American Poultry Industries Award, $\$ 1,000$ and a plaque, given every other year for outstanding research in the field of marketing.

Publications: Poultry Science, bimonthly, current volume: 39 . Editor: H. D. Branion, Department of Nutrition, Ontario Agricultural College, Guelph, Ontario, Canada.

\section{Professional Engineers of Colorado.} President: E. Vernon Konkel, 730 Kalamath Street, Denver 4, Colo. Term expires March 1, 1961. Secretary-Treasurer: Donald S. Rand, 1228 Reed Street, Denver 15, Colo. Term expires March 1, 1961.

History: Founded as a member state society of National Society of Professional Engineers in November 1948.

Purpose: The advancement of the public welfare and the promotion of professional, social, and economic interests of the professional engineer.

Membership: Members, 500, registration and National Society of Professional Engineers membership.

Meetings: Monthly except Summer.

Professional activities: Student Chapters. Armco Scholarship selection.

Publications: Newsletter, monthly, free. Editor: L. C. Koerwitz.

1257. Providence Engineering Society. 195 Angell Street, Providence 6, R. I. President: Raymond H. Stockhard, University of Rhode Island, Kingston, R. 1. Term expires June 1961. Secretary: R. E. Costellow, 62 Bayside Avenue, Warwick, R. I. Term expires June 1961.

History: Organized in 1894 as the Providence Association of Mechanical Engineers; name changed to present title 1916; incorporated 1923. Maintains close cooperation with local sections of national societies in Rhode Island.

Purpose: Advancement of the theory and practice of engineering and its allied arts and sciences, promotion of interchange of thought among engineers, and participation in matters affected with an engineering interest.

Mcmbership: Senior, engineer, architect, or applied scientist, at least 28 years old, in practice at least five years, a college graduate or equal experience. Associate, at least 20 years old, qualified to cooperate with engineers, architects, or applied scientists. Total membership 1,100.

Meetings: Monthly, except June-September. 
Professional activities: Provides speakers on engineering as a career for programs in secondary schools and parents' meetings; operates a scholarship fund combining gifts into bulk amounts which are turned over to the two engineering colleges in Rhode Island for student loans or grants.

Publications: Engineering, weekly (October to June), current volume: $35, \$ 1.25$ to nonmembers, $\$ .75$ to members. Editor: W. C. Russell.

Library: 1,500 volumes on hydraulics.

1258. Psychometric Society. Department of Psychology, Washington University, St. Louis, Mo. Secretary: Philip H. Du Bois. Term expires September 30, 1962.

History: Organized, and affiliated with American Psychological Association, 1935; affiliated with American Association for the Advancement of Science 1937.

Purpose: To promote development of psychology as a quantitative rational science.

Membership: Members shall be persons interested in, and able, through training and experience, to contribute to the objectives of this Society. Full Members, 668; Student, 71. Total membership 739.

Meetings: Annual.

Publications: Psychometrika, quarterly, current volume: $25, \$ 14$, free to nembers. Editor: Lyle V. Jones, Psychometric Laboratory, University of North Carolina, Chapel Hill, N. C.

1259. Psychonomic Society, Inc. University of Maryland, College Park, Md. Chairman: Clifford T. Morgan, Department of Psychology, University of Wisconsin, Madison 6, Wis. Term expires 1961. Secretary-Treasurer: William S. Verplanck, Department of Psychology, University of Maryland, College Park, Md. Term expires 1963.

History: Founded in Chicago, December 31, 1959 ; incorporated in Madison, Wisconsin, April $1,1960$.

Purpose: To promote the communication of scientific research in psychology and allied sciences.

Membership: Members, 708, persons qualified to conduct and to supervise scientific research in psychology or allied sciences, must hold the Ph. D. or equivalent, and must have published significant research other than the doctoral dissertation.

Mectings: Annual.

1260. Public Health Association of New York City. P. O. Box 476, New York 21, N. Y.
President: Morton D. Schweitzer, School of Public Health and Administrative Medicine, Columbia University, 600 West 168th Street, New York 32, N. Y. Term expires July 1, 1961. President-Elcct: George James, New York City Department of Health, 125 Worth Street, New York 13, N. Y. Secrctary-Treasurcr: Frances Ann McVey, Cornell UniversityNew York Hospital School of Nursing, 1320 York Avenue, New York 21, N. Y. Term expires July 1, 1961.

History: Organized May 18, 1936, as a local affiliate of the American Public Health Association.

Purpose: To provide a forum for discussion of public health problems and the new advances in medical and sanitary science.

Membership: Open to any person interested in public health, subject to approval by the Execu. tive Board. 'Total membership 250-300.

Meetings: Quarterly.

1261. Public Health Cancer Association of America. President: Edward M. Cohart, Associate Professor, Yale University Department of Public Health, New Haven, Conn. Term expires November 2, 1960. SecretaryTrcasurer: Lewis C. Robbins, Chief, Cancer Contro! Program, Public Health Service, Washington 25, D. C. Term expires November 2, 1960.

\section{History: Organized October 1941.}

Parpose: To serve as the national association of professional workers in cancer control; to advance the art and science of cancer control.

Membership: Active, membership limited to employees in official, tax-supported cancer programs, and instructors concerned with cancer education in schools of medicine, dentistry, nursing and public health; Associate, other individuals, professional and lay, interested in cancer control; Fellows, include Active members with five years experience as described for Active Members and selected by vote of the Executive Committee. Total membership 73.

Mectings: Annual.

1262. Public Health Federation of the Cincinnati Area. Cincinnati 2, Ohio. President: Leon Saks, 641 Doctors Building, 19 Garfield Place, Cincinnati 2, Ohio. Term expires December 31, 1960. Executive Secretary: Sewall Milliken, 312 West 9th Street, Cincinnati 2, Ohio. Term indefinite.

History: Established in 1917; program carried out by divisional councils on basis of special health interest. Present councils include Cancer Control, Community Dental Health, Health 
Education, Long Term Illness and Rehabilitation, Nutrition.

Purpose: To serve as forum for discussion of health issues, plan for and coordinate all health services of five-county area, conduct a health education program, work for legislation and quality standards in health services and promote research through studies and reports.

Membership: Public or private agency whose program is primarily health or disease centered and is extended to the Cincinnati area. Agency members, 100 ; individual, 30 .

\section{Meetings: Annual.}

Professional activities: Neoplastic Disease Registry, Cincinnati General Hospital, Cincinnati 29, Ohio. Health Award to persons of outstanding achievement in health field.

Publications: Headlines on Health, monthly, current volume: 18, free. Editor: Marvin Strauss. Annual Report, current volume: 42, free. Editor: Sewall Milliken.

\section{Puerto Rico Science Teachers Association.} Department of Education, Hato Rey, P. R. President: Josefina Martinez, Lares High School, Lares, P. R. Term indefinite. Secretary: Nereida Planell, Central High School, Santurce, P. R. Term indefinite. Consultant: Maria A. Ruiz.

History: Organized 1946. The Association is an affiliate of the National Science Teachers Association. Sections : Urban and Rural Junior High School Teachers; Senior High School Teachers; University of Puerto Rico, Teachers of Science; College of Agriculture and Mechanical Arts, Teachers of Science.

Purpose: To promote better science teaching through better facilities.

Mcmbership: Total membership 200.

1264. Quebec District Branch of the American Psychiatric Association. President: Gerald J. Sarwer-Foner, 613 Cote Saint Antoine Road, Montreal 6, Province of Quebec, Canada. Term expires July 1, 1961. Executive Secretary: Harry Grauer, 900 Sherbrooke Street, West, No. 14, Montreal, Province of Quebec, Canada. Term expires July 1, 1961.

History: Formed at the time of the organization of the Assembly of District Branches of the American Psychiatric Association.

Purpose: To promote professional and scientific interests of the members of the American Psychiatric Association living in the Province of Quebec, and to provide representation at the Assembly of District Branches.

Membership: Qualified psychiatrist living in the Province of Quebec and a Fellow, Member, or Associate Member of the American Psychiatric Association. Total membership 70.

Meetings: Monthly during academic year (September-June) in conjunction with the scientific meeting of the Section of Psychiatry of the Montreal Medico-Chirurgical Society.

Professional activitics: Loan fund for needy residents in psychiatric training in the Province of Quebec.

1265. Queens County Psychiatric Society. President: Benjamin J. Becker, 111-04 76th Drive, Forest Hills 75, N. Y. Term expires May 1961. Secretary: Paul J. Tomlinson, 80-45 Winchester Boulevard, Queens Village, N. Y. Term expires May 1961.

History: Organized 1957; constitution approved by American Psychiatric Association in May 1958; Society is District Branch, American Psychiatric Association, and Section on Neurology and Psychiatry, Queens County Medical Society.

Purpose: To foster progress of psychiatry; to represent that specialty in the County of Queens, City of New York; to assist American Psychiatric Association in promoting its aims and objectives.

Membership: Requires membership in American Psychiatric Association, and residence or practice in Queens County. Full members, 60.

Meetings: Quarterly.

Professional activities: Directory of psychiatrists in Queens County; scientific lectures.

1266. Radiation Research Society. Argonne National Laboratory, 9700 South Cass Avenue, Argonne, I11. Presidcnt: H. L. Friedell, Department of Radiology, Western Reserve University, Cleveland, Ohio. Term expires May 1961. Secretary-Treasurer: E. L. Powers. Term expires May 1961.

History: Organized and incorporated in the District of Columbia in 1952.

Purpose: To promote original research in the natural sciences relating to radiation; to facilitate integration of different disciplines in the study of radiation effects; to promote the diffusion of knowledge in these fields.

Membership: Full members, 596, those who have made meritorious contributions to the advancement of radiation physics, chemistry or biology by independent, original research, or some other special service to the cause of the natural and life sciences; Associate, 164, graduate students and others engaged in work related to above subjects and others interested in the field; Emeritus, 10. Total membership 770.

Meetings: Annual. 
Publications: Radiation Research, monthly, current volume: $12-13, \$ 4.50 /$ vol. members, $\$ 14 /$ vol. non-members. Editor: Titus C. Evans.

\section{Radio Technical Commission for Aero-} nautics. Room 1072, Building T-5, 16th and Constitution Avenue, N. W., Washington 25, D. C. Chairman: Arthur L. Lebel, Telecommunications Division, Department of State, Washington, D. C. Term expires September 30, 1961. Execulive Secretary: Lewis M. Sherer. Term indefinite.

History: Organized 1935; functioned informally until January 15, 1942 when a constitution was adopted. The Commission comprised of an Assembly which governs and directs its activities by establishing broad policies and operating procedures; an Executive Committee which meets monthly to manage the activities of the Commission; Special Committees appointed by the Executive Committee to perform the technical work; and a Secretariat. The Special Committees contain experts from government and industry who pool their knowledge and talents on a voluntary basis to arrive at solutions to specific problems. The Commission is not an official agency of the United States Government.

Purpose: To advance the art and science of aeronautics through the investigation of all available or potential applications of the telecommunication art, their coordination with allied arts, and the adaptation thereof to aeronautics; to carry out this objective, the Commission coordinates between govermment and industry on matters referred to it for consideration, and conducts studies and publishes findings and recommendations.

Membership: Voluntary and open to any United States organization actively identified with any phase of acronatical telecommunication. Total membership 131 organizations.

Mectings: Annual.

1268. Radiological Society of Greater Cincinnati. President: Car1 W. Koehler, Carew Tower, Cincinnati 2, Ohio. Term expires June 1961. Secretary-Treasurer: Donald W. Janney, 722 Scott Street, Covington, Ky. Term expires June 1961.

\section{History: Organized 1920.}

Purpose: Study of the science and economics of radiology; formation of closer fellowship and working relations among radiologists.

Membership: Diplomates, American Board of Radiology, and engaged exclusively in practice of that specialty. Total membership 43 .

Meetings: Monthly, September through June.
1269. Radiological Society of Hawaii. President: R. G. Rigler, 1020 Kapiolani Street, Honolulu, Hawaii. Term expires June 1961. Secretary: P. S. Arthur, Alexander Young Building, Honolulu, Hawaii. Term expires June 1961.

History: Organized March 14, 1952.

Purpose: To advance the science of radiology. Membership: Eighteen regular members. Members must be resident and licensed to practice medicine in Hawaii, members of local medical societies, and certified by American Board of Radiology.

Mectings: Monthly.

1270. Radiological Society of New Jersey. Secretary: Austin J. Tidaback, 912 Prospect Avenue, Plainfield, N. J. Term expires May 1961.

History: Organized and incorporated 1931.

Purpose: Mutual assistance, protection, and instruction in radiology, and in medical and legal matters pertaining to its practice.

Mcmbership: Active members, graduates of recognized medical colleges, diplomates of American Board of Radiology, with practice limited for at least three years to that specialty; Members-elect, same requirements except practice not limited; Non-resident; Associate, distinguished in allied field; Honorary; Retired. Total membership 125.

Mcetings: Semiannual.

Publications: News Letter, semiannual, free to nembers.

\section{Radiological Society of North America,} Inc. 713 East Genesee Street, Syracuse 2, N. Y. President: Theodore J. Wachowski, 310 Ellis Avenue, Wheaton, I1l. Term expires December 9, 1960. Secretary-Treasurer: Donald S. Childs. Term expires December 9 , 1960.

History: Organized December 1915 as the IVestern Roentgen Society; name changed to present title November 1918.

Purpose: To promote the study and practical application of radiology in all its aspects; to provide meetings for the reading and discussion of papers and the dissemination of knowledge ; to maintain a journal; to maintain a library and museum; to create a closer fellowship among radiologists and closer cooperation between radiologists and members of other branches of medicine and the allied sciences.

Membership: Open to persons with degree of doctor of medicine or degree which the American Medical Association recognizes as the equivalent, except Associate Members are not 
required to have such a degree. Active Members, citizens of the North American country of their residence, members of the American Medical Association or a state and/or country or national society recognized by a Board of Censors as its equivalent, or, if residents of a country other than the United States of America, members of a medical society or association ranked by the Board of Censors as equal to the American Medical Association or one of its component societies; and who, for the immediately previous three years have devoted the major portion of their time to the practice of radiology, or who have taken the prescribed period of formal training and, in addition, have spent at least one year in active practice, the nuajor portion of which was in the practice of radiology. Junior Members, those persons whose general background is such that they comply with the requirements for Active Membership, and have completed one year of traineeship in radiology, except they are not required to be members of the American Medical Association or equivalent, nor comply with the length of practice requirement. Honorary Members, persons who have distinguished themselves in medicine or its allied sciences. Associate Members, those who have especially distinguished themselves in some division of science closely related to radiology and who will contribute to the objectives of the Society. Corresponding Members, residents of foreign countries who will contribute to the objectives of the Society, with the sane qualifications as Active Members. Emeritus Members, those members of the Society whose long membership and service to radiology entitles them to such membership. Retired Members, those members of the Society who have been in good standing for a period of not less than ten years and who have retired from active practice. Active, Junior, and Associate, 3.304; Emeritus, Retired, Honorary, Corresponding, and Life, 150. Total membership 3,454.

\section{Meetings: Annual.}

Professional activities: Memorial Fund Lecture; Fellow at the American Registry of Radiologic Pathology, Washington, D. C.

Publications: Radiology, monthly, current volume: 74 , domestic $\$ 10$, foreign $\$ 12$. Editor: Howard P. Doub.

1272. Radiological Society of Southern California. President: Robert B. Engle, 2632 East Washington Street, Pasadena, Calif. Term expires June 30, 1961. Secretary- Trcasurer: Robert S. Scanlan, St. Vincent's Hospital, Los Angeles, Calif. Term expires June 30, 1961.

History: Organized May 1952.
Purpose: To advance the science of radiology; to disseminate scientific knowledge; and to improve radiologic service to the public.

Membership: Active, 123, physicians specializing in radiology; Associate, 2, physicists, radiobiologists, and other persons active in fields closely associated with radiology; Honorary, 1; Retired, 6.

Meetings: Three times per year.

1273. Raleigh Engineers Club. P. O. Box 1268, Raleigh, N. C. President: John IV. Hatcher, General Electric Company, Capitol Club Building, Raleigh. N. C. Term expires December 31, 1960. Secretary: Harry S. Whitesides, Jr., Westinghouse Electric Corporation, Meter Plant, Raleigh, N. C. Term expires December 31, 1960.

History: Organized March 10, 1926. CommitteEs: Career Guidance Committee. works primarily with the local high schools in the formation of junior engineering and science clubs or fairs; Professional Development Committee, to coordinate activities for professional engineering advancement.

Purpose: To promote the best interests of the engineering profession and of the public, and to foster and stimulate a spirit of good fellowship and cooperation within the profession.

Mcmbership: Members, 286, licensed engineers under the laws of North Carolina, graduates of recognized schools of engineering, five years of engineering experience, or record of recognized performance and leadership in some profession or branch of industry or science relating to engineering, and qualified to cooperate with engineers in the practice of their profession.

Mectings: Monthly.

1274. Ramsey County Medical Society. 1500 Lowry Medical Arts Building. St. Paul 2, Minn. President: Walter P. Gardner. Term expires December 31, 1960. Secretary: Abbott Skinner. Term expires December 31, 1960.

History: Organized 1870; incorporated May 1892. Commitees: Cancer, Education, Industrial Health, Public Health, and Workmen's Compensation.

Purpose: To advance the science and art of medicine, promote public health, foster cooperation among members, and maintain professional ethics.

Mcmbership: Open to any physician who resides in Ramsey County, has practiced medicine there for at least one year, and holds degree of doctor of medicine from school accredited by American Medical Association. Active mem- 
bers, 469 ; Affiliate, 22; Honorary ; Guest, physician of United States Armed Services, Public Health Service, or Veterans Administration; Associate, 1; Junior, 22; Life, 22. Total membership 535 .

Mectings: Monthly except June, July, and August.

Publications: Bulletin, monthly except June, July, and August, current volume: 54, free to members. Editor: Abbott Skinner.

1275. Reaction Research Society. P. O. Box 1101, Glendale 5, Calif. President: Larry L. Larson, 4535 Ellenwood Drive, Los Angeles 41, Calif. Term expires February 1961. Executive Secretary: Jim B. Humphreys, Jr. Term expires December 1961.

History: Organized January 1943. TECHNical Sections: Project Goddard, Project Spaceward.

Purpose: To aid in development of reaction propulsion and its applications, and to promote interest in this new science.

Membership: Open to persons interested in the purpose of this Society. Total membership 100.

Meetings: Monthly.

Professional activities: Static test program; Dean Haddon Awards for workmanship and for journalism.

Publications: News, irregular, $\$ 1.50$, free to members.

1276. Refrigeration Service Engineers Society.

433 North Waller Avenue, Chicago 44, 111.

President: Denver J. Wathen, Sr., 3312 South

Toledo Place, Tulsa 5, Okla. Term expires

November 1960. Secretary: H. T. McDermott.

Term expires November 1960.

History: Established 1933 as a national organization, subsequently becoming international.

Purpose: To keep membership currently informed on the mechanical advancement of the refrigeration and air-conditioning industry.

Membership: Members, 11,500. Persons engaged in the refrigeration and air-conditioning industry in any capacity.

Meetings: Annual.

Professional activities: Conducts study courses on the installation, servicing, maintenance, etc. of refrigeration and air-conditioning cquipment, awarding a Certificate of Proficiency upon successful completion of course.

Publications: Refrigeration Service and Contracting, monthly, $\$ 3$.

1277. Reno Surgical Society. President: Leo D. Nannini, 190 Mill Street, Reno, Nev. Term expires October 1961. Secretary: Donald F. Guisto, 975 Ryland Street, Reno, Nev. Term expires October 1961.

History: Founded 1948.

Purpose: To stimulate progress of medical science, particularly surgery, in the Reno area.

Membership: Requires medical license in Nevada and active practice there for one year, certification by specialty board, membership, American College of Surgeons, or comparable background in surgery or in specialties allied to surgery. Total membership 43.

Meetings: Annual.

1278. Research and Engineering Council of the Graphic Arts Industry, Inc. $1411 \mathrm{~K}$ Street, N. IV., Washington 5, D. C. President: Clifford L. Jewett, c/o Minnesota Mining and Manufacturing Co., 900 Bush Avenue, St. Paul 6, Minn. Term expires May 31, 1961. Managing Director: Robert E. Russell. Term indefinite. 1950 .

History: Incorporated (Illinois) March 22,

Purpose: To coordinate research and development activities in the graphic arts industry through the holding of discussion meetings and the publishing of reports on programs and activities; to publish technical reports on selected subjects relating to the graphic arts.

Membership: Sustaining, an association, a society, a company or corporation, an individual or consultant, etc., endorsing and supporting the policies and activities of the Council; Associate, an individual employed by a sustaining member interested in the activities of the Council; Affiliate, an association, school, college, laboratory, institute, governmental agency, individual, etc., who is interested in the activities of the Council but who is not otherwise eligible for membership; Honorary, an individual duly elected who has made an outstanding or noteworthy contribution to the advancement of research and engineering in the graphic arts industry. Total membership 288.

Meetings: Annual, in May; special meetings.

Publications: Coordinator, quarterly, current volume: 6, free to members. Editor: Robert E. Russell.

1279. Rho Chi Society. President: Lloyd M. Parks, Dean, College of Pharmacy, Ohio State University, Columbus, Ohio. Term expires August 1962. Secretary-Treasurer: Edward J. Rowe, College of Pharmacy, Butler University, Indianapolis, Ind. Term expires April 1961. 
History: Organized and incorporated in Michigan May 1922. Sixty-three active chapters located at various schools and colleges of pharmacy.

Purpose: To promote the pharmaceutical sciences through encouragement and recognition of intellectual scholarship.

Membership: Active Members, undergraduates, completion of at least 60 per cent of prescribed curriculum toward B. S. in pharmacy, and in highest 20 per cent of class; Graduates, completion of fifteen hours toward advanced degree; Faculty, on staff of school of pharmacy; Alumni; Honorary. Total membership over 11,000 .

\section{Meetings: Annual.}

Professional activities: Rho Chi Cumulative Research Fund, capital amount $\$ 16,400$. Rho Chi Chapter Award, a cash prize.

Publications: Report, annual, current volume: 25, free. Editor: Edward J. Rowe.

1280. Rhode Island Medical Society, 106 Francis Street, Providence 3, R. I. President: Earl J. Mara, 260 Lonsdale Avenue, Pawtucket, R. I. Term expires May 3, 1961. Executive Secretary: John E. Farrell. Term indefinite.

\section{History: Founded 1812.}

Purpose: To promote the science and art of medicine and the betterment of public health; to promote friendly intercourse among physicians; to enlighten and direct public opinion in regard to the problems of medicine.

Mcmbership: Active members, doctors of medicine in good standing in the county or district component medical societies. Total membership 961.

Mectings: Annual, in May; interim meeting in Fall.

Professional activities: Fiske Fund Prize Essay, approximately $\$ 300$, awarded for the best essay on a subject announced by the Trustees of the Fund; Dr. Charles V. Chapin Memorial Award, given by the City of Providence to the Chapin Orator selected by the Society annually; Dr. Charles V. Chapin Oration Lecture.

Publications: Rhode Island Medical Journal, monthly, current volume: $43, \$ 2$. Editor: John E. Donley.

Library: 43,000 volumes.

1281. Rhode Island Society for Neurology and Psychiatry; Rhode Island District Branch, American Psychiatric Association. President: David Fish, 355 Thayer Street, Providence 6, R. I. Term expires April 1961. SecretaryTreasurer: Joseph M. Zucker, 222 Gano
Street, Providence 6, R. I. Term expires April 1961.

History: Rhode Island Society for Neurology and Psychiatry founded October 1924; Rhode Island District Branch, American Psychiatric Association, established in accord with new policies of that Association.

Purpose: To promote better understanding and treatment of nervous and mental disorders.

Membership: Open to physicians in practice of neuropsychiatry and members of American Psychiatric Association. Above named Society has 50 members; above named District Branch, 45 ; most members belong to both organizations.

Meetings: Four times a year.

1282. Richmond Academy of Medicine, Inc. 1200 East Clay Street, Richmond 19, Va. President: Robert V. Terrell, Medical Arts Building, Richmond, Va. Term expires January 1961. Executive Secretary-Treasturer: Mrs. Patty Rose Boatwright. Term indefinite.

History: Organized 1866 as the Richmond Academy of Medicine; name changed 1890 to the Richmond Academy of Medicine and Surgery; name changed to present title 1923 ; incorporated 1927. Section: History of Medicine.

Purpose: To promote the scientific practice of medicine and surgery; to foster and encourage research in medicine, surgery, and the allied sciences.

Mcmbcrship: Active menbers, legally registered white physicians, residing and practicing in the city of Riclnmond, or in the county of Henrico or Chesterfield, of good moral and professional standing, and who do not practice or claim to practice any exclusive system of medicine; regular physicians employed exclusively in the teaching of medicine, hospital practice or hospital administration, located in the territory embraced by the Academy, shall also be eligible for active membership, whether registered or not. Active members, 546; Associate members, 20; Courtesy members, 2; Non-resident, 55; Life, 37. Total membership 660.

Mectings: Semimonthly, except during June, July, and August.

Professional activities: J. Shelton Horsley Memorial Lectureship, for the purpose of presenting each spring an outstanding lecturer in the field of surgery.

Library: 1,600 volumes.

1283. Rochester Academy of Science. 657 East Avenue, Rochester 7, N. Y. President: Joel T. Johnson, 118 Pontiac Drive, Rochester 17, N. Y. Term expires June 1, 1961. Corresponding Secretary: Mrs. D. E. Jensen, 199 
East Brook Road, Pittsford, N. Y. Term expires June 1, 1961.

History: Organized and incorporated 1881, an outgrowth of Rochester Microscopical Society, which was organized 1879; reorganized 1889. Sections: Astronomy, Botany, Mineralogy, Ornithology, Weather Science.

Purpose: To promote scientific study and research, and especially to gain and publish knowledge of natural history in the vicinity of Rochester.

Membership: Open to any person interested in science. Active members, 422; Honorary, 12 ; Life, 18; Student, 44. Total membership 496.

Mectings: Five to eight annually.

Professional activities: Fairchild Endowment Fund.

Publications: Proceedings, annual, current volume: $10, \$ 1.50$. Editor: H. Low Gibson.

1284. Rochester Engineering Society. Sheraton Hotel, 111 East Avenue, Rochester, N. Y. President: Charles F. Starr, Term expires June 1961. Executive Secretary: O. L. Angevine. Term indefinite.

History: Founded March 18, 1897; incorporated June 8, 1934.

Purpose: Advancement of engineering knowledge and practice, dissemination of such knowledge, and establishment of a central point of reference and union for members.

Membership: Open to persons interested in the purpose of this Society. Honorary members, 1; Resident, 484 ; Non-resident, 90; Junior, 18. Total membership approximately 590 .

Mectings: Monthly.

Publications: Rochester Engineer, monthly, current volume: 38 , free to members. July number is Yearbook.

Library: 1,200 volumes.

1285. Rochester Roentgen Ray Society. President: Charles E. Sherwood, 277 Alexander Street, Rochester, N. Y. Term expires January 1961. Secretary: Robert H. Greenlaw, 260 Crittendon Boulevard, Rochester, N. Y. Term expires January 1961.

History: Organized December 15, 1948.

Purpose: To promote professional and scientific interests of radiologists in their relations with organized medicine and the general public.

Membership: Licensed physician, recognized as a specialist in radiology. Active, 35; Honorary, 7. Total membership 42.

Mectings: Monthly.
1286. Rocket City Astronomical Association.

P. O. Box 620, Huntsville, Ala. President:

Wernher von Braun. Term expires December 31, 1960. Secretary: George A. Ferrell. Term expires December 31, 1960.

History: Organized 1954.

Purpose: To foster advancement of astronomy and associated sciences.

Membership: Open to persons interested in science and astronomy. Total membership approximately 130 .

Mectings: Bimonthly.

1287. Rocky Mountain Association of Geologists. President: William Wyman Mallory, U. S. Geological Survey, Denver Federal Center, Colo. Term expires December 31, 1960. Secretary: Richard C. Oburn, 3051 South Josephine Street, Denver, Colo. Term expires December 31, 1960.

History: Organized 1922. СоммiтteEs: Research, Field Conference, Education, Publication.

Purpose: To promote interest in, and application of, geology; to foster research; to promote cooperation and fellowship among members.

Membcrship: Full member, degree in geology or allied sciences; Associate member, interests closely associated with the geological profession; Non-resident; Honorary, outstanding contributions to geology of the Rocky Mountain Region; Student, majors in geology, petroleum engineering, or geophysics. Total membership 850.

Meetings: Weekly.

Professional activities: Annual field conference on some aspect of Colorado geology ; publishing of topical and $\log$ guidebook; annual awards to outstanding college students in geology; sponsorship of science courses in local high schools; issuing of special research publications.

1288. Rocky Mountain Federation of Mineralogical Societies. President: Mrs. Lois K. Heister, 2628 Charleston Street, N. E., Albuquerque, N. Mex. Term expires June 1961. Secretary: Mrs. Marjorie Tomingas, 409 Tennessee Street, S. E., Albuquerque, N. Mex. Term expires June 1961.

History: Organized August 9, 1941. Consists of sixty-three affiliated societies from the States of Arizona, Colorado, Iowa, Kansas, Missouri, Nebraska, New Mexico, Oklahoma, South Dakota, Texas, Utah, Wyoming.

Purpose: To promote interest and knowledge of mineralogy, geology, and the lapidary arts. 
Membership: Membership in an affiliated society. Total membership approximately 6,000 .

Mectings: Annual.

Publications: News Letter, bi-monthly. Uranium Prospector and American Outdoorsman, monthly, current volume: $6, \$ 1.50$. Editor: Wayne Winters, P. O. Box 462, Tucson, Ariz.

1289. Rocky Mountain Radiological Society. President: Peter Russo, Osler Building, Oklahoma City, Okla. Term expires August 1961. Secretary-Trcasurer: John H. Freed, 4200 East 9th Avenue, Denver 20, Colo. Term expires August 1961.

History: Organized August 1, 1941. Sections : Arizona, Arkansas, Colorado, Idaho, Kansas, Missouri, Montana, Nebraska, Nevada, New Mexico, North Dakota, Oklahoma, South Dakota, Texas, Utah, 11 yoming.

Purpose: To advance the science of radiology and improve public health through better radiological services; to protect the practice of this specialty against inimical influences.

Wentbership: Sponsorship by two members of applicant's State radiological society, or two members of the Rocky Mountain Radiological Society. Total membership 139.

Mectings: Annual.

\section{Rocky Mountain Section of the American} Association of Petroleum Geologists. Denver, Colo. President: O. E. Childs, Phillips Petroleum Co., 1160 Denver Club Building, Denver 2, Colo. Term expires 1961. Exccutive Secretary: Floyd H. Miller, Petroleum Research Corp., P. O. Box 8377, Denver, Colo. Term expires 1961.

History: Founded 1950 at Denver.

Purpose: To hold an annual technical meeting wherein geologists of the area present results of geologic study pertinent to the area; to promote advancement and aims of the American Association of Petroleum Geologists; to provide for discussion of subjects and problems within the profession: to reduce isolating effects of distance between petroleum geologists within the province by means of annual meetings.

Membership: Members of the American Association of Petroleum Geologists with residence in the states of New Mexico, Nevada, Colorado, Utah, Ityoming, Montana, Arizona, Idaho. Active: Associate; Junior. Total membership 2,500 .

Meetings: Annual.

1291. Rocky Mountain Society of Orthodontists. President: IVilliam A. Blueher, Medical Arts Square, N. E., Albuquerque. N. Mex. Term expires November 1960. Secretary-Treasurer: Eli H. Mullinax, 8790 IVest Colfax Street, Lakewood, Colo. Term expires November 1960.

History: Organized and incorporated 1921. The Society is a constituent of the American Association of Orthodontists. Sections: New Mexico, Colorado, Utah, IVyoming.

Purposc: To advance the science and art of orthodontics; to encourage and sponsor researcls: to strive for higher standards of excellence in orthodontic instruction; to contribute to dental health service.

Membership: Open to persons in exclusive practice of orthodontics who are members of local, State, and national dental organizations, have practiced five years, and have completed orthodontic courses of 1500 or more hours. Active members, 49; Associate members, 8; Honorary members, 1; Retired members, 4. Total membership 62.

Mectings: Annual.

1292. Rocky Mountain Traumatic Surgical Society. President: Ralph Stuck, 1612 Tremont Place, Denver, Colo. Term expires 1962. Secretary: Charles S. Houston, Aspen, Colo. Term indefinite.

History: Founded 1958.

Purpose: Presentation of papers on aspects of medical, surgical, and other specialties as applied to athletic and sporting events.

Mcmbcrsip: Certification by a specialty board, proposal by a member, election by the membership. Total membership limited to 100 .

Meetings: Annual.

1293. Roswell Geological Society. P. O. Box 6732, Roswell, N. Mex. President: Richard F. Mayer. Term expires May 31, 1961. Secretary: Donald B. Tait. Term expires May 31. 1961.

History: Organized May 29, 1950: affiliate, American Association of Petroleum Geologists and Southwest Federation of Geological Societies. Committee: Stratigraphic.

Purpose: To provide for discussion of subjects coming within the scope of technical branches of the oil industry.

Membershif: Active members, 230, degrees in geology, geophysics, enginecring; Associate, 20. working in oil industry. Total membership 250.

Mectings: Monthly.

Professional activities: Small contributions to graduate students in nearby schools. 
1294. St. Louis Academy of General Practice. 4 North 8th Street, Room 415, St. Louis 1, Mo. President: Eugene IV. Hall, 116a South Florissant Street, St. Louis 35, Mo. Term expires December 31, 1960. Executive Sccretary: Miss Eleanore Schmied. Term indefinite.

History: Chartered in 1948; component chapter of the American Academy of General Practice.

Purpose: Advancement of medical science, private and public health.

Membership: Candidate must be a graduate of an approved medical school with minimum of one year of rotating internship in an approved hospital. He must have completed one of the following: (1) two years approved residence training; (2) one year residence, two years practice; (3) three years active practice. He must be a member of his state medical society, licensed to practice medicine and surgery, be of high moral and ethical character, and must have shown interest in continuing his medical advancement by engaging in post-graduate education. Total membership 190.

Mectings: Quarterly.

Professional activities: Four or more programs yearly, presenting outstanding speakers chosen by the Academy and by the two local medical schools.

Publications: News and Views, monthly, current volume: 13. Editor: B. WV. Finkel.

1295. St. Louis Medical Society. 3839 Lindell Boulevard, St. Louis, Mo. President: Paul F. Max, 3720 Washington Street. St. Louis, Mo. Term expires January 3, 1961. Secretary: Charles S. Sherwin, 4660 Maryland Street, St. Louis, Mo. Term expires January 3, 1961.

History: Organized 1835; incorporated 1837.

Purpose: The advancement of medical and collateral sciences.

Membership: Active memhers, 1,003, physicians licensed and registered in Missouri, residing, or practicing in St. Louis; Junior, 153, graduates in medicine, and serving full time internship or residency in a hospital; Associate, 4. engaged in the pursuit of a medical or an allied science: Corresponding, 64, membership in medical society of county of residence, outside St. Louis : Library, 12, members of society outside St. Louis, and in affiliation with the Missouri State Medical Association or other state medical association; Students, 17, undergraduate in a recognized medical school; Honor, 22, active members who have rendered distinguished service to medicine or the community; Life, active members who for reasons of disability are withdrawing from practice, or who have been members of the
Society for forty-five years, or have reached the age of seventy; Honorary, distinguished members of the profession not residing in St. Louis; Retired, 4, members who retire from the practice or teaching of medicine for reasons other than physical disability and/or before they qualify for life membership. Total membership 1,372 .

Meetings: Monthly, September through May.

Publications: Bulletin, semi-monthly, current volume: 68. Editor: Robert IV. Kelley.

1296. St. Louis Society of Internal Medicine. President: David M. Skilling, 18 South Kingshighway, St. Louis, Mo. Term expires January 1961. Secrctary-Treasurer: Barrett L. Taussig, 4500 Olive Street, St. Louis, Mo. Term expires January 1961.

History: Organized in 1908.

Purpose: To forward the practice of internal medicine and to foster and improve the standards of internal medicine in St. Louis.

Membership: Specialists in internal medicine. Limited to 25 active members. Total membership 38 .

Meetings: Monthly.

1297. San Angelo Geological Society. P. O. Box 1668, San Angelo, Tex. President: R. D. Johnson, P. O. Box 632, San Angelo, Tex. Term expires April 1961. Executive Secretary: W. E. Schulkey, Jr., P. O. Box 1112. San Angelo, Tex. Term expires April 1961.

History: Organized in fall of 1953.

Purpose: To promote science of petroleum geology and technology in West Texas.

Membership: Degree in geology or allied science and engaged in direct application of geology, or engaged in geological work during preceding five years. Total membership 70 .

Meetings: Twice montlly.

Professional activitics: Supports $(\$ 1,000)$ American Association of Petroleum Geologists Research Fund.

1298. San Diego Society of Natural History. Balboa Park, San Diego 1, Calif. President: I. N. Lawson, 1048 Myrtle Way, San Diego 3, Calif. Term expires August 1961. Executive Director: George E. Lindsay. Term expires August 1961.

History: Organized and incorporated October 9. 1874. Sections: Mammalogy, Ornithology, Botany, Entomology, Conchology, Herpetology, and Mineralogy.

Purpose: The study of nature, the acquisition and diffusion of scientific knowledge, and the 
collection and preservation of materials pertaining thereto.

Membership: Open to persons interested in natural history. Adults, 514 ; Juniors, 693. Total membership 1,207.

Meetings: Semiannual.

Publications: Transactions, irregular, current volume: 12, Occasional Papers, irregular, current volume: 10. Memoirs, irregular, current volume: 2. Editor: Reid Moran. Bulletin, monthly, current volume: 327 , free to members. Editor: George E. Lindsay.

Library: 80,000 volumes on natural history and geology.

1299. San Francisco Radiological Society. 450 Sutter Street, San Francisco, Calif. President: J. F. Huffman, Stonestown Medical Building, San Francisco, Calif. Term expires October 1960. Executive Secretary: Merrell A. Sisson. Term expires October 1960.

History: Organized 1951.

Purpose: To promote the economic and scientific aspects of radiology.

Membership: Open to any duly licensed physician practicing in San Francisco who is an active member in good standing of the San Francisco Medical Society, and who limits his practice to radiology. Total membership 57.

Mectings: Quarterly.

1300. San Joaquin Geological Society. J. A. Dunwoody, c/o Tidewater Oil Company, 1809 19th Street, Bakersfield, Calif. Term expires November 1960. Secretary-Treasurer: J. S. Bigelow, c/o Western Gulf Oil Company, P. O. Box 1392, Bakersfield, Calif. Term expires November 1960.

History: Organized January 1941, affiliated with the Pacific Section of the American Association of Petroleum Geologists.

Purpose: To promote interest in the geological sciences.

Membership: Automatically conferred upon residents of the area who are members of the Pacific Section of the American Association of Petroleum Geologists. Total membership 200.

Meetings: Monthly.

1301. Science Service, Inc. 1719 N Street, N. W., Washington 6, D. C. President: Leonard Carmichael, Smitlısonian Institution, Washington 25, D. C. Term expires April 1961. Director: Watson Davis. Term indefinite.

History: Organized and incorporated 1921.

Purpose: The popularization of science.

Membership: Fifteen members of the Board of Trustees, nominated by the National Academy of Sciences-National Research Council, the American Association for the Advancement of Science, the E. W. Scripps Estate, and the journalistic profession.

Meetings: Annual.

Professional activities: Disseminate scientific information by providing news service to newspapers, journals, and scientific institutions. Interlingua Division devoted to promoting the international auxiliary language. Sponsors: Science Clubs of America, Westinghouse Science Scholarships and Awards, National Science FairInternational.

Publicatians: Science News Letter, weekly, current volume: $78, \$ 5.50$ a year. Chemistry, monthly September through April, current volume: 33, \$4. Editor: Watson Davis. THINGS of science, monthly, $\$ 5$. Edited by staff of Science Service.

Library: 21,000 volumes.

1302. Science Teachers Association of New York State, Inc. President: Miss Josephine Bordonaro, Onondaga Valley Academy, Syracuse, N. Y. Term expires August 31, 1961. Secretary: Mrs. Mary Archer, Monroe High School, Rochester, N. Y. Term expires August 31, 1961.

History: Organized 1896.

Purpose: To further American democratic procedures in public and private schools; to provide a forum for discussion of local, state, national, and international problems in science education; to promote research in science education, science teaching, science curricula in the schools; and training of science teachers in colleges and universities.

Membership: Open to persons engaged in science teaching in New York State, and to all persons on leave of absence, or who have retired from science teaching, or who have continued science teaching in another state, providing such persons were active members in good standing when the leave of absence, transfer, or retirement took place. Total membership approximately 1,500 .

Meetings: Semiannual.

Publications: Science Teachers Bulletin, semiannual, \$1. Editor: Robert Love, Alfred, N. Y.

1303. Science Teachers of New England. President: Frank Carroll, 7 Oakton Avenue, Dorchester, Mass. Term expires 1961. Secretary: Sister Francis Regis, Fontbonne Academy, 930 Brook Road, Milton, Mass. Term expires 1961.

History: Organized May 1952. 
Purpose: To promote the improvement of science teaching in New England.

Membership: Total membership approximately 300.

Meetings: Annual; two regional annually.

1304. Scientech Club, Inc. President: Dan Babcock, R. R. 19, P. O. Box 13, Indianapolis 8, Ind. Term expires December 31, 1960. Secretary: E. S. Hildreth, 212 Electric Building, Indianapolis 4, Ind. Term expires December 31, 1960.

History: Organized October 1918; incorporated (Indiana) June 9, 1930.

Purpose: To promote the interchange of technical and scientific knowledge and advances.

Membership: Open to professional, scientific, or technical men, and men interested in some business or calling of a scientific or technical character. Resident members, residing in Marion County, Ind. ; Non-resident ; Emeritus, continuous active membership for at least ten years, must have been an officer or member of the Board of Directors, must have retired from original profession, and be not less than sixty years of age. Total membership 203.

Meetings: Weekly.

Professional activities: Luncheon meetings with speakers from the membership or from persons of professional standing or technical background.

Publications: News Letter, weekly, current volume: 41 , free to members. Editor: E. S. Hildreth.

1305. Scientific Research Society of America. President: W. J. Coppoc, Beacon Laboratories of Texaco, Inc., Beacon, N. Y. Term expires June 1961. Director: Donald B. Prentice, 51 Prospect Street, New Haven, Conn. Term expires June 1961.

History: Organized 1947; incorporated 1948. Sixty-two branches in industrial, governmental, and educational organizations in the United States.

Purpose: To encourage original investigation in science, pure and applied.

Memberslip: Members, investigators in pure or applied natural science; Associates, junior investigators. Total membership approximately 8,000 .

\section{Meetings: Annual.}

Profesisonal activities: Proctor Memorial Fund, for support of the Proctor Prize and society activities, capital amount $\$ 94,091$. Lecture programs and grants-in-aid are shared with Society of the Sigma $\mathrm{X}_{\mathrm{i}}$, Inc.

Publications: American Scientist, quarterly, published jointly with Society of the Sigma Xi, current volume: $48, \$ 2.50$, foreign $\$ 3$.
1306. Seattle Anthropological Society. President: Mrs. Virginia Watson, 1552 Interlaken Boulevard, Seattle 2, Wash. Term expires 1960. Secretary: Lewis Langness, Department of Anthropology, University of Washington, Seattle 5, Wash. Term expires 1960.

History: Organized 1948; incorporated 1951.

Purpose: To encourage and promote the study of anthropology in all its branches, to publish and circulate anthropological literature.

Membership: Open to individuals interested in anthropology, who have been approved by the Council. Total membership 100.

Meetings: Nine or ten annually.

Professional activities: Prize of $\$ 100$ awarded to graduate student member for article published in a major journal.

Publications: Bulletin, annual, current volume : 5, free. Editor: Viola Garfield.

1307. Seismological Society of America. President: James T. Wilson, Department of Geology, University of Michigan, Ann Arbor, Mich. Term expires spring 1961. Secretary: Karl V. Steinbrugge, 465 California Street, San Francisco 4, Calif. Term expires spring 1961.

History: Organized and incorporated in San Francisco, California in fall of 1906 after earthquake of April 1906. Committee: Scientific Council. Section : Eastern.

Purpose: To promote the study of earthquakes.

Membership: Open to amateurs and professional seismologists, engineers, geologists and others, without distinction, with invitation or sponsorship customary. Regular members, 732 ; Life Members, 21; Corporate Members, 19. Total membership 772.

Meetings: Annual.

Professional activities: American Association Fund, available for field study of earthquake effects.

Publications: Bulletin, quarterly, current volume: $50, \$ 8$, free to members. Editor: Don Tochor.

1308 Sequoia Natural History Association. Ash Mountain, Three Rivers, Calif. Chairman of the Board: Aibert Marshall. Term expires February 1961. Executive Secretary: Harry B. Robinson. Term indefinite.

History: Organized 1942 ; activities supervised by a ten-member board of directors.

Purpose: Promotion of scientific, historical, educational, and interpretive activities of the National Park Service. 
Membership: Limited to members of the National Park Service.

Meetings: Annual.

1309. Shawnee Geological Society. President: VValter C. Miller, Box 1148, Shawnee, Okla. Term expires May 1961. Secretary: VTilliam V. York. Term expires May 1961.

History: Organized April 5, 1929. Affiliated with the American Association of Petroleum Geologists in December 1931.

Purpose: To advance knowledge through lectures and discussions of geological problems in Oklahoma and the surrounding area, and to promote fellowship among the geologists of that region.

Membership: Active members, geologists or students of earth science. Total membership 63.

Mectings: Monthly.

1310. Shreveport Geological Society. President: Frank S. Craver, Jr., P. O. Box 1768, Shreveport, La. Term expires May 1961. Secretary: Pat N. Mason, P. O. Box 1092, Shreveport, La. Term expires May 1961.

History: Organized December 1919, as the Shreveport Section of the South-IVestern Geological Society; reorganized October 1924 under present title.

Purpose: To increase geological knowledge, especially that of Louisiana, South Arkansas, and East Texas; and to promote fellowship among geologists in the area.

Membership: Active, open to persons engaged in the practice or teaching of geology or related sciences, also all persons who were active members in good standing on and after October 3, 1924; Associate, persons interested in geological science but not actively engaged in the practice or teaching of geology or related sciences; Honorary, elected at the discretion of the society. Total membership 450.

Meetings: Monthly, except July and August.

1311. Sigma Delta Epsilon. President: Mrs. Ethaline Cortelyou, Aeroprojects Inc., West Chester, Pa. Term expires January 1961. Executive Secretary: Elizabeth McLaughlin, 702 Butternut Street, N. IV. Washington 12, D. C. Term indefinite.

History: Organized December 1921 at Cornell University, Ithaca, New York. Eighteen Chapters in leading universities and colleges, and in large cities.

Purpose: To further interest in science, to provide a society for the recognition of women in science, and to promote friendship among women in various sciences.
Membership: Women scientists with degrees who are or have been engaged in original experimental research in natural and physical sciences. Total membership 2,000 active members.

\section{Meetings: Annual.}

Professional activities: Sigma Delta Epsilon Fellowships $(\$ 1,600)$, Grants-in-Aid $(\$ 500)$ for graduate or post-doctoral research, capital amount $\$ 5,000$. Co-sponsored First and Second Conferences on Encouraging Women to Select and Advance in Careers in Science, at annual meetings of American Association for the Advancement of Science.

Publications: News Letter, semiannual, free to members. Editor: Mrs. Mary Lou Pritchard, 6500 hnox Street, Lincoln, Nebr.

1312. Sigma Phi Delta Fraternity. President: Robert J. Beals, 1503 South Hillcrest Street, Urbana, I11. Term expires January 1, 1962. Secretary: William M. Jermain, 1908 St. Mary's Avenue, Janesville, Wis. Term expires January 1, 1962.

History: Founded at the University of Southern California in April 1924. Twelve active chapters (two in Canada) and ten alumni chapters (one in Canada).

Purpose: To promote the advancement of the engineering profession, to foster the advancement of engineering education, to instill a greater spirit of cooperation among engineering students and organizations, and to encourage excellence in scholarship.

Membership: Active, 250, undergraduate students in engineering; Alumni, 3,650; Faculty, 100; Honorary, 3. Total membership approximately 4,000 .

Mectings: Biennial in odd-numbered years.

Professional activities: Alumni chapters present scholarship awards to active chapters; Supreme Council sponsors annual Efficiency Contest; Grand President sponsors expansion award for chapter effort.

Publications: The Castle, semiannual. Editor: John Gray. The Star, three times a year. Editor: Robert J. Beals.

1313. Sigma Pi Sigma, Physics Honor Society. Physics Department, Pennsylvania State University, University Park, $\mathrm{Pa}$. President: Stanley S. Ballard, Physics Department, University of Florida, Gainesville, Fla. Term expires October 1962. Executive Secretary: Marsh W. White. Term expires October 1962.

History: Founded December 1921 at Davidson College, Davidson, N. C., as a local honor society, now national in scope with 107 chapters; asso- 
ciated with the American Association for the Advancement of Science, the American Institute of Physics, and the Association of College Honor Societies.

Purpose: To serve as a means of awarding distinction to students having high scholarship and promise of achievement in physics; to promote student interest in research and the advanced study of that subject; to encourage a professional spirit and friendship among those who have displayed marked ability in physics; and to popularize interest in physics in the general collegiate public.

Membership: Candidates selected from advanced course students and from faculty members. Primary qualifications include exceptionally high scholarship, a manifested interest in physics, and promise of achievement in extending the boundaries of human knowledge. Members classed as Active, 2,600, Alumni, Associate, Sustaining, and Honorary. Total membership 18,000 .

Meetings: A national convention is held approximately every three years.

Professional activities: Loans to advanced active student members to enable them to complete their education; assistance to local chapters by arranging for and financially assisting in lecture tours by noted speakers.

Publications: Radiations, six times yearly, current volume: 25 , free to members. Editor: Marsh W. White.

Sigmund Freud Archives, Inc. See Addenda, No. 1594

1314. Sioux Valley Medical Association. President: E. A. Kilbride, Worthington, Minn. Term expires February 1961. Secretary: E. H. Silbey, 622 4th Street, Sioux City, Iowa. Term indefinite.

History: Organized 1895.

Purpose: To conduct postgraduate work for physicians and surgeons, and to present a medium through which new ideas may be expressed.

Membership: Open to ethical physicians who are members of their county medical societies and who reside in the states of South Dakota, Minnesota, Iowa, or Nebraska. Total member ship 500 .

\section{Meetings: Annual}

1315. Soaring Society of America, Inc. President: Harner Selvidge, c/o Meteorology Research, Inc., 2420 North Lake Avenue, Altadena, Calif. Term expires December 1960. Executive Secretary: Lloyd M. Licher, P. O. Box 66071, Los Angeles 66, Calif. Term indefinite.
History: A non-profit organization governed by a board of directors elected by the membership; organized and incorporated in 1932; with 11 regions in the United States defined for purpose of electing directors. Committees: Research and Technical.

Purpose: To foster and promote all phases of gliding and soaring on a national and international basis.

Membership: Consists of charter members and all individuals whose applications have been accepted by the Society. Types of membership: Member, Associate, Student Member, Family Member, Sponsoring Member, Industrial Member, Life Member, Honorary Member. Total membership 2,752.

Meetings: Annual.

Professional activities: Paul E. Tuntland Memorial Award to the pilot who, during the preceding year, is deemed to have made a soaring flight yielding the most scientific information.

Publications: Soaring, monthly, current volume: 24 , free to members, $\$ 4$, available only to libraries and institutions. Editor: Lloyd M. Licher.

1316. Société de Chimie Industrielle, Inc., American Section. President: O. B. J. Fraser, The International Nickel Company, 67 Wall Street, New York 5, N. Y. Term expires December 1960. Executive Secretary: Pierre Bouillette, The Givaudan Corporation, 321 West 44th Street, New York 36, N. Y. Term expires December 1960. 1951.

History: Organized 1917, incorporated April

Purpose: To establish, foster, and maintain cordial personal and professional relations among French speaking scientists and other persons and organizations interested in pure and applied science, and the application of science to industry; to conduct scientific meetings, and to assist scientists and industrialists visiting the United States.

Membership: Applicant must give scholastic degree, industrial or university affiliation, and have sponsorship by two persons, including one member; individual members; corporate members. Total membership 149.

Meetings: Six to eight meetings annually.

Professional activities: The International Palladium Medal.

1317. Society for American Archaeology. President: Erik K. Reed, 238 Griffin Street, Santa Fe, N. Mex. Term expires May 1961. Secretary: Joe Ben Wheat, University of Colorado Museum, Boulder, Colo. Term expires May 1964. 
History: Founded December 1934. Preparation of a constitution and other preliminary work accomplished by the Committee on State Archaeological Surveys of the National Academy of Sciences-National Research Council.

Purpose: To promote and to stimulate interest and research in the archaeology of the American continents; to encourage a more rational public appreciation of the aims and limitations of archaeological research; to serve as a bond among those persons interested in American archaeology, both professionals and non-professionals; to publish and to encourage publication of their results.

Membership: Open to individuals who subscribe to the ideals of the Society. Total membership 1,584 .

Meetings: Annual.

Professional activities: Viking Fund Medalist in archaeology, designated annually by the Society.

Publications: American Antiquity, quarterly, current volume: $26, \$ 8$. Memoirs, irregular, current volume: 16, varying price. Editor: Raymond H. Thompson. Abstracts of New IVorld Archaeology, annual, free to subscribers of American Antiquity. Editor: Richard B. Woodbury. Archives of Archaeology, irregular, current volume: 9, varying price. Editor: David A. Baerreis.

1318. Society for Applied Anthropology. New York State School of Industrial and Labor Relations, Cornell University, Ithaca, N. Y. President: John Bennett, University of Pittsburgh, Pittsburgh 13, Pa. Term expires May 1961. Managing Editor: Marian D. Tolles. Term indefinite.

History: Incorporated April 1941, in Massachusetts. Chapters : Boston; Chapel Hill, N. C. In 1951, the Society instituted the Clearinghouse for Research in Human Organization for the purpose of collecting and disseminating information on current research in all the fields of human organization. Wilton S. Dillon, Director.

Purpose: To promote scientific investigation of the principles controlling the relations of human beings to one another, and to encourage the wide application of these principles to practical problems.

Membership: Active Members, $\mathrm{Ph} . \mathrm{D}$. or equivalent in publications and experience; Subscribing Members, persons interested in field; Student, those enrolled in recognized institutions; Honorary, founding members; Exchange, institutions and publishers. Total membership 1,750 .

Meetings: Annual.
Publications: Human Organization, quarterly, current volume: 19, \$8. Editor: William F. Whyte.

1319. Society for Applied Spectroscopy. President: Mrs. Sarah H. Degenkolb, American Steel and Wire Division, United States Steel Corporation, Wire Avenue, Cleveland, Ohio. Term expires January 1961. Executive Secretary: Rev. James J. Devlin, Boston College, Chestnut Hill, Mass. Term expires January 1962.

History: Founded November 1958 in New York with 16 local sections, formerly united in a federation. Now has 21 local sections: Baltimore-IVashington Spectroscopy Society ; American Association of Spectrographers, Chicago; Cincinnati Society for Applied Spectroscopy; Cleveland Society of Spectroscopy; Society for Applied Spectroscopy, Delaware Valley; Rocky Mountain Spectroscopy Society, Denver; Optical Society of America, Detroit; Indiana Spectrographers Society; Intermountain Society for Applied Spectroscopy, Idaho Falls; Southern California Society of Applied Spectroscopy, Los Angeles;Milwaukee Society for Applied Spectroscopy; New England Spectroscopic Society; Society for Applied Spectroscopy of New York; Optical Society of America, Niagara Frontier Section; Northern California Spectroscopy Society, San Francisco; Society for Applied Spectroscopy, Ohio Valley Section; Spectroscopy Society of Pittsburgh; San Diego Society for Spectroscopy; Southeastern Association of Spectrographers; St. Louis Society for Applied Spectroscopy; North Texas Society for Applied Spectroscopy.

Purpose: To advance and disseminate knowledge of spectroscopy in its widest sense; to advance the professional standing of its members; and to coordinate the efforts of its members individually, and in sections.

Membership: Open to those individuals with an interest in the knowledge and advancement of spectroscopy. Total membership 1,600.

Meetings: Semiannual.

Publications: Applied Spectroscopy, six times yearly, current volume: $14, \$ 3.50$. Editor : Frederick Strong III.

1320. Society for Clinical and Experimental Hypnosis (United States Division of the International Society for Clinical and Experimental Hypnosis). President: Jacob $\mathrm{H}$. Conn, Suite 812, Medical Arts Building, Baltimore 1, Md. Term expires October 1961. Executive Secretary: Milton J. Marmer, 507 North Arden Drive, Beverly Hills, Calif. Term expires October 1961. 
History: Founded in June 1949. Institute for Research in Hypnosis incorporated 1957 as the research and training branch. The American Board of Clinical Hypnosis and its 3 sub-boards, American Board of Medical Hypnosis, American Board of Hypnosis in Dentistry, and American Board of Examiners in Psychological Hypnosis, were incorporated within the Institute in 1958. In August 1959, the Society became the U. S. Division of The International Society for Clinical and Experimental Hypnosis, which has twenty-four national divisions, and is an affiliate of the World Federation for Mental Health.

Purpose: To stimulate and support the professional pursuit of research in the field and its boundary areas; to encourage cooperation among members of professional and scientific disciplines in regard to the utilization of hypnosis in both research and practice; to support communication by scientific meetings and publications; to establish standards of adequacy and ethics for use of hypnosis; to strive toward the establishment of formal and standardized training facilities for those who qualify.

Membership: Associate, a doctorate in medicine, dentistry, or psychology, an acceptable initial training course, and utilization of hypnosis in practice or research at time of application; Full Member, same requirements as for Associate membership and publication of a scientific paper, or two years of significant experience in the clinical uses of hypnosis; Fellow, recognition of exceptional service to the Society or outstanding contribution to the field of scientific hypnosis, bestowed by special action of the Executive Council. Total membership 900.

Meetings: Annual.

Professional activitics: Institute for Research in Hypnosis, a non-profit foundation serving as the training and research branch of the Society, offering courses and workshops, grantsin-aid to research, and publication of books and monographs.

Publications: International Journal, quarterly, current volume: 8, \$8. Editor: Milton V. Kline, 345 West 58th Street, New York 19, N. Y. Newsletter, quarterly, current volume: 2.

1321. Society for Economic Botany. New York Botanical Garden, Bronx Park, New York, N. Y. President: Ernest Guenther, Fritzsche Brothers, Inc., New York, N. Y. Term expires 1961. Secretary: Quentin Jones, New Crops Branch, U. S. Department of Agric11lture, Beltsville, Md. Term expires 1962.

History: Founded July 1959 with 247 charter members. Executive responsibility for Society resides in Council of six. elected by the membership.
Purpose: To foster coordination and collaboration, and to develop interdisciplinary channels of communication among the various fields of interest concerned with past, present, and future uses of plants.

Membership: Individual members: Annual, persons interested in any aspect of economic botany, 252; Life, 5; Patrons, 1. Institutional members: Sustaining, 1. Total membership 259.

Mectings: Annual.

Publications: Economic Botany, quarterly, current volume: $14, \$ 6$ to members, $\$ 8$ to nonmembers. Managing Editor: D. J. Rogers.

1322. Society for Experimental Biology and Medicine. President: Philip Bard, Department of Physiology, School of Medicine, Johns Hopkins University, Baltimore, Md. Term expires July 1961. Secretary: A. J. Goldforb, City College of New York, New York, N. Y. Term expires July 1961.

History: Established February 25, 1903. SECTIONS: New York, Western New York, Southern, Iowa, Illinois, Minnesota, Missouri, Pacific Coast. Wisconsin, Cleveland, District of Columbia, Southern California, Southwestern, Rocky Mountain, Baltimore, Ohio Valley, Southeastern, Maryland, Michigan, Northwest.

Purpose: Cultivation of the experimental method of investigation in the sciences of biology and medicine.

Membership: Open to any person who has accomplished meritorious original investigation in biology or medicine by the experimental method. Total membership 3,411.

Mectings: Each of nineteen sections holds meetings during the academic year.

Publications: Proceedings, monthly, current volume: 103, \$17, free to members. Editor: A. J. Goldforb.

1323. Society for Experimental Stress Analysis. P. O. Box 168, Cambridge 39, Mass. President: B. J. Lazan, Institute of Technology, University of Minnesota, Minneapolis, Minn. Term expires October 1960. Executive Secretary: IV. M. Murray, Massachusetts Institute of Technology, Cambridge, Mass. Term expires October 1960.

History: Organized 1943. Sixteen local sections: Central Indiana, Chicago, Delaware Valley, Hudson-Mohawk, Mid-Ohio, Milwaukee, New England, New York Metropolitan. Northern California, Northern Ohio, Pittsburgh, South Central, Southern Michigan, Southern Ohio, Southwest, Washington Area.

Purpose: To promote and encourage knowledge pertaining to experimental stress analysis; to hold conferences, meetings, and symposia for 
the exchange of ideas and exhibition of equipment; and to publish and distribute papers or articles on stress analysis.

Membership: Open to persons interested in the Society's field of activity; individual, 2,000; corporate, 80 . Total membership 2,080.

Ucetings: Semiannual.

Publications: Proceedings, biennial, current volume: $17, \$ 14.50$, free to members. Editor: C. V. Mahlmann, 35 Adams Street, Brookline 46, Mass.

1324. Society for Gynecologic Investigation. 317-325 South State Street, Dover, Del. President: James T. Bradbury, University of Iowa, Iowa City, Iowa. Term expires April 1961. Secretary-Treasurcr: J. George Moore, University of California, Los Angeles 24, Calif. Term expires 1963.

History: Organized as the Society of University Gynecologists by a group of obstetricians and gynecologists primarily concerned with research in the two fields. Incorporated in Delaware, June 1953.

Purpose: To stimulate, encourage, assist and conduct fundamental obstetrical and gynecological research, and to provide opportunities for the free exchange of ideas, knowledge, and investigative techniques in these fields.

Membcrship: Open to individuals below forty-six years of age who currently hold, and who have held for two years, a responsible position in an institution of higher learning, and who by recent and current investigations in the field of fundamental gynecic research have demonstrated promise of continuing a productive academic career. Council may make exception to such requirements in individual cases. Total nembership 68.

Meetings: Annual.

1325. Society for Industrial and Applied Mathematics. President: Brockway McMillan, Bell Telephone Laboratories, Whippany, N. J. Term expires October 1960. Secretary: Gilbert W. Kaskey, Remington-Rand Univac, Philadelphia, Pa. Term expires October 1960.

History: Organized and incorporated in Delaware, 1952. Currently has twelve sectional organizations active in different geographical areas.

Purpose: To provide media for the exchange of information and ideas among mathematicians and other scientists and engineers; to promote basic research in mathematics and its applications.

Hembership: Open to any individual or institution qualified to further the objectives of the Society. Only universities, colleges, and similar non-profit institutions may apply for academic membership. Full-time students of academic members are eligible for student membership. Industrial and other corporations are eligible for corporate membership. Individual, 1,430; corporate and industrial, 53. Total membership 1,483 .

Meetings: Annual.

Professional activities: SIAM Russian Translation Activity; SIAM Visiting Lectureships Program, by professional applied mathematicians at colleges and universities-both activities supported by National Science Foundation grants. John von Neumann Lecture given amnually by invitation at a meeting of the Society.

Publications: Journal, quarterly, current volume: 8, \$10. Editor: I. E. Block. SIAM Review, quarterly, current volume $1, \$ 10$. Editor: R. J. IVisner. (Both publications free to members.) Theory of Probability and its Application, quarterly, current volume: $4, \$ 18$.

1326. Society for Investigative Dermatology, Inc. President: Harvey Blank, University of Miami Medical School, Jackson Memorial Hospital, Miami 36, Fla. Term expires June 1961. Secretary-Treasurer: Herman Beerman, 255 South 17th Street, Philadelphia 3, Pa. Term expires June 1965.

History: Organized June 1937; incorporated May 1937.

Purpose: To publish a scientific journal, thereby fostering scientific interest in research in dermatology and syphilology, and to offer an opportunity for scientists in this field to present the results of their research at the annual meetings.

Membership: Open to any physician in good standing, or an individual engaged in teaching or in scientific research in medicine or allied subjects in a reputable university, college, laboratory, hospital, or other institution. Subscribing members, 811; non-subscribing members, 20 ; honorary members, 19 . Total membership 850 .

Meetings: Annual.

Publications: Journal, monthly, current volume: 34-35, \$12, free to members. Chairman, Editorial Board: Naomi M. Kanof.

1327. Society for Nondestructive Testing, Inc. President: D. T. O'Connor, Machlett Laboratories, Inc., Springdale, Conn. Term expires October 1960. Executive Secretary: Philip D. Johnson, 1109 Hinman Avenue, Evanston, I11. Term expires October 1960.

History: Organized October 1941 and incorporated in Massachusetts as the American Indus- 
trial Radium and X-Ray Society; name later changed to present title. Sections: Boston, New York City, Philadelphia, Pittsburgh, Connecticut Valley (Hartford), Chicago, Central New York, Milwaukee, St. Louis, Oak Ridge, Montreal, Toronto, Los Alamos, Los Angeles, San Francisco, Houston.

Purpose: To promote the art and science of nondestructive testing and to assist industry in supplying better quality products at less cost through the efficient use of nondestructive testing; and to publish material of benefit for members of the Society.

Membership: Open to individuals who have a sincere interest in the work of the Society. Individual, 3,550; Corporate, 25; Sustaining, 25. Total membership 3,600.

Mectings: Annual, held simultaneously with that of American Society for Metals. Also semiannual regional meetings.

Professional activities: Annual awards: Lester Lecture Award, Mehl Lecture Award, Coolidge Award, DeForest Award, and DuPont Award.

Publications: Nondestructive Testing, bimonthly, current volume: $18, \$ 6$. Editor : Philip D. Johnson.

Library: 1,000 volumes on radiography, magnetic testing, ultrasonics, etc.

1328. Society for Pediatric Research. President:

Gilbert B. Forbes, University of Rochester

School of Medicine, 260 Crittenden Boulevard,

Rochester 20, N. Y. Term expires May 1961.

Exccutive Secretary: Clark D. West, Chil-

dren's Hospital Research Foundation, Cincinnati 29, Ohio. Term expires May 1961.

History: Founded 1928 as the Eastern Society for Pediatric Research; name changed to present title in 1932.

Purpose: To provide a meeting place where research workers in pediatrics can present and discuss their work; to stimulate research in pediatrics.

Membership: Open to individuals actively engaged in pediatric investigation. Members automatically become emeritus after age 45 . Active Members, 198; Emeritus Members, 212. Meetings: Annual.

1329. Society for Pennsylvania Archaeology.

State Museum Building, Harrisburg, Pa.

President: John A. Zakucia, 55 Highland

Avenue, Struthers, Ohio. Term expires May 1961. Secretary-Treasurer: Vincent R. Mrozoski, 407 Phillips Street, Aliquippa, Pa. Term expires May 1961.

History: Organized 1929. Member of Eastern States Archaeological Federation and Pennsyl- vania Federation of Historical Societies. Twelve regional chapters with independent membership and programs.

Purpose: To promote the study of the archaeology of Pennsylvania and neighboring States, to encourage scientific research and excavation, to discourage careless digging without records, to promote the conservation of important archaeological sites and artifacts, to favor the passage of laws prescribing such, to oppose the manufacture and sale of fraudulent antiquities, to encourage the establishment of local archaeological museums and societies, to prevent traffic in archaeological objects for the sole purpose of financial profit, and the collecting of artifacts without proper record keeping and cataloguing, to promote the spread of archaeological knowledge by means of publications and meetings, and to serve as a bond between the individual archaeologists in the State, both non-professional and professional.

Membership: Open to any person or institution sympathetic with the ideals and objectives of the Society. Classes of membership-Active, Active Husband and Wife, Institutional, Sustaining, Life. Total membership 1,024.

\section{Meetings: Annual.}

Professional activities: Archey Awards, given annually to members who have contributed toward archaeology and for the betterment of the Society.

Publications: Pennsylvania Archaeologist, three times yearly, current volume: 30 , free to members, $\$ 3$ to institutions. Editor: Vernon $\mathrm{E}$. Leslie.

1330. Society for Projective Techniques, Inc. Adelphi College, Garden City, Long Island, N. Y. President: Bertram Forer, 2170 Live Oak Drive, East, Los Angeles 28, Calif. Term expires September 1961. Executive Secretary: Walter G. Klopfer, Department of Psychology, University of Portland, Portland 3, Oreg. Term expires September 1962.

History: Organized and incorporated 1936. Former name: Society for Projective Techniques and Rorschach Institute, Inc.

Purpose: To promote the study, research, development and application of projective methods of personality diagnosis.

Membership: Fellows, 184, limited to persons with a degree of doctor of philosophy or doctor of medicine and five years clinical experience; Associates, 570, limited to those with a master's degree and two years of clinical experience; Student Affiliates, 25, open to those with graduate standing in psychology; Affiliates, 6, persons who are qualified in their own profession and have a legitimate interest in projective techniques. Total membership 785 . 
Mcctings: Semiannual.

Publications: Journal of Projective Techniques, quarterly, current volume: $24, \$ 8$. Editor: Bruno Klopfer.

\section{Society for Promoting International Sci-} entific Relations. 206 IVest 104th Street, Suite 42, New York 25, N. Y. President: David Nachmansohn. Term expires March 1961. Executive Vice-President: Henry Goldschmiedt. Term expires March 1961.

History: Organized 1940, formerly American Society of European Chemists.

Purpose: To promote international scientific relations through exchange of visits between scientists of the United States and those of foreign institutions, to arrange lectures, and to exchange useful information.

Membership: Total membership 350.

Meetings: Five times annually.

\section{Society for Research in Child Develop-}

ment, Inc. Purdue University, Lafayette, Ind. President: W. M. Krogman, University of Pennsylvania, Philadelphia, $\mathrm{Pa}$. Term expires March 1961. Secretary: Dale B. Harris, Pennsylvania State University, University Park, Pa. Term expires March 1961.

History: Organized June 1933 at the University of Chicago, following a Conference on Child Development. Fields represented were pediatrics, psychology, psychiatry, anthropology, nutrition, physiology, sociology, and education.

Purpose: To further research in child development by means of meetings, conferences, publications, and the distribution of research information; to encourage the interdisciplinary consideration of theoretical and methodological problems of research in child development; to stimulate the exploration of implications of research findings for instruction in the area of child development.

Mcmbership: Members, 570, open to persons who are actively engaged in research in child development or any of the basic sciences related thereto, persons who are actively engaged in teaching undergraduate or graduate courses in child development and who have demonstrated their capacity for leadership in the area by publication through appropriate channels, and persons who are actively engaged in furthering the stated purposes of the Society. Student Members, 16, persons who at the time of holding membership in the Society are engaged in at least half-time graduate study relative to the purposes of the Society. Emeritus Members, 39, persons who have reached the retirement age of 65 and who have at least ten years standing in the Society.

\section{Meetings: Semi-annual.}

Publications: Child Development, quarterly, current volume: $31, \$ 8$. Child Development Abstracts and Bibliography, three times yearly, current volume: $34, \$ 6$. Monographs of the Society, irregular, current volume: $25, \$ 6$. Editor: William E. Martin.

1333. Society for Social Responsibility in Science. 900 Woods Road, Southampton, Pa. President: Victor Paschkis, 501 West 123rd Street, New York 27, N. Y. Term expires September 1961.

History: Organized September 1949. Divisions: Education, Occupation.

Purpose: To induce, by education and example, individual scientists and engineers to recognize a personal responsibility for the anticipated consequence to society of their work; to always exercise their profession for the benefit of humanity, and thus to provide opportunities for scientists and engineers to seek alternatives to violence in intergroup relations; to discuss their responsibilities, imposed by their individual consciences, with regard to refraining from the preparation and use of weapons for the destruction of human life.

Membership: Member, 475, open to men or women educated in the field of pure or applied science, including medicine and engineering; Associate, 60, open to men or women in sympathy with statement of purpose who do not necessarily subscribe to it in full; no restrictions regarding occupation or profession. Total membership 535 .

Mcctings: Annual.

Publications: Newsletter, monthly, current issues: $89-100$, free.

1334. Society for the Advancement of Space Travel. President: Rinehart S. Potts, 210 East Courtland Street, Philadelphia 20, Pa. Term indefinite. Secretary: Thomas E. Purdom, 2nd Med. Tk. Battalion, 69th Armor, 2nd Infantry Division, Fort Benning, Ga. Term indefinite.

History: Formed in 1954; joined American Astronautical Federation 1956.

Purpose: To advance space travel by study of the human factors (sociological and psychological) involved.

Membership: Ability and willingness to contribute actively of time and effort to committee work. Total membership 100.

Publications: Frontier, irregular. Editor: Dale R. Smith. 
1335. Society for the Psychological Study of Social Issues. President: Morton Deutsch, Bell Telephone Laboratories, Murray Hill, N. J. Term expires September 1961. Presidentelect: Isidor Chein, New York University, New York, N. Y. Term September 1961September 1962. Administrative Secretary: Dorothy S. Jochem, Institute for Social Research, University of Michigan, Ann Arbor, Mich. Term indefinite.

History: Organized 1936; division, American Psychological Association. Committees: CrossNational Research, Desegregation and Integration, Education, International Relations, Juvenile Delinquency, Man-in-Space, Mental Health in the Schools, Uses and Abuses of Ability Testing.

Purpose: To achieve greater effectiveness and freedom for psychology in its efforts to make society intelligible, to advance scientific knowledge regarding social change and other social processes, and to encourage application of findings of psychology to problems of society.

Membership: Two years of graduate training in social psychology or related fields, or equivalent in professional experience. Total membership approximately 1,000 .

Meetings: Annual.

Professional activities: Kurt Lewin Memorial Award, to honor those who further, in their work, the development and integration of psychological research and social action; grants-inaid research programs.

Publications: Journal of Social Issues, quarterly, current volume: $16, \$ 4$. Editor: Robert Chin, Boston University, Boston, Mass. Newsletter, quarterly, free to members. Editor: Elizabeth M. Douvan.

1336. Society for the Study of Blood. New York Academy of Medicine, 2 East 103rd Street, New York, N. Y. President: Leon Sussman, 36 East 38th Street, New York, N. Y. Term expires May 1961. SecretaryTreasurer: Ralph L. Engle, Jr., New York Hospital, 525 East 68th Street, New York 21, N. Y. Term expires June 1963.

History: Organized 1945.

Purpose: To further research and disseminate knowledge concerning the allied fields of hematology, blood grouping, and transfusion.

Membership: Open to individuals with an active interest in the field of hematology. Total membership 153.

Meetings: Quarterly.

1337. Society for the Study of Development and Growth. President: Edgar Zwilling, Brandeis University, Waltham, Mass. Term expires November 1960. Executive Secretary:
William P. Jacobs, Princeton University, Princeton, N. J. Term expires November 1960.

History: Founded August 1939.

Purpose: To hold an annual symposium on problems of development and growth.

Membership: Evidence of the candidate's contribution to the study of development and growth. Total membership 319.

Meetings: Annual.

1338. Society for the Study of Evolution. President: Alfred E. Emerson, University of Chicago, Chicago, Ill. Term expires December 1960. Secretary: Herbert H. Ross, Illinois Natural History Survey, Urbana, 111. Term expires December 1961.

History: Organized March 1946 as an outgrowth of the Society for the Study of Speciation, organized 1940, and the National Academy of Sciences-National Research Council's Committee on Common Problems of Genetics, Paleontology and Systematics, 1943.

Purpose: To promote the study of organic evolution and the integration of the various fields of science concerned with evolution.

Membership: Open to individuals with an interest in the study of evolution. Total membership 1,200.

Meetings: Annual.

Publications: Evolution, quarterly, current volume: 14, \$8. Editor: I. Michael Lerner, University of California, Berkeley, Calif.

1339. Society for Vascular Surgery. President: Julian Johnson, 555 Dulles Building, 3400 Spruce Street, Philadelphia 4, Pa. Term expires June 1961. Secretary: George $H$. Yeager, 314 Medical Arts Building, Baltimore 1, Md. Term expires June 1961.

Hisiory: Organized June 8, 1947.

Purpose: To promote scientific advancements in the field of vascular surgery; to promote and encourage research, teaching and practice in the field.

Membership: Limited to diplomates of American Board of Surgery or Royal College with special interest and training in vascular surgery who have contributed to the literature on the subject. Active Members, 138; Senior Members, 33; Foreign Corresponding Members, 5. Total membership 176.

Mectings: Annual.

1340. Society of Actuaries. President: James E. Hoskins, 1124 Farmington Avenue, West Hartford 7, Conn. Term expires September 1960. Executive Secretary: Arthur A. 
McKinnie, 208 South La Salle Street, Chicago 4, Illinois. Term indefinite.

History: Founded 1949 as the successor to The Actuarial Society of America (founded 1889) and the American Institute of Actuaries (founded 1909). Principal Technical StandING CommitteEs: Education and Examination, Mortality and Morbidity, New Recording Means and Computing Devices, Papers, Standard Notation and Nomenclature.

Purpose: To advance the knowledge of actuarial science and to promote the maintenance of high standards of competence and conduct within the actuarial profession.

Membership: Associate, 829, approval by the Board of Governors and the passing of prescribed examinations; Fellow, 1,081, Associateship and the passing of prescribed examinations. Total membership 1,900 .

Meetings: Three to five annually.

Professional activities: Co-sponsors with the Mathematical Association of America an annual High School Mathematics Contest, one $\$ 200$ and eight $\$ 100$ prizes to nine undergraduates ranking highest in the General Mathematics Examination; awards a triennial prize for the best paper presented by a member of the Society within five years after his first becoming an Associate of any recognized actuarial society; special investigative studies, the latest being the Build and Blood Pressure Study (1959).

Publications: Transactions, quarterly, current volume: 12, \$13. Editor: Alden T. Bunyan.

Library: 2,700 volumes.

1341. Society of Aeronautical Weight Engineers, Inc. President: Clarence E. Kelknap, Goodyear Aircraft Corporation, Akron, Ohio. Term expires May 1961. Executive Secretary: D. Lloyd Smith, Douglas Aircraft Company, E1 Segundo, Calif. Term indefinite.

History: Organized in 1939; incorporated in California in April 1941.

Purpose: To promote recognition of weight control as a specialized branch of aeronautical engineering; to exchange weight information for mutual benefit; to combine effort in reducing weight of purchased equipment; to promote a better understanding among weight engineers, thereby fostering a higher degree of efficiency in weight control procedure and a better informed and more cooperative personnel; to promote and enhance the professional status of weight engineers, and to encourage study of weight engineering problems in institutions of higher learning. Twenty-one chapters.

Membership: Members, persons engaged in weight engineering or allied work; Senior Members, persons who are and have been for at least five years actively engaged in responsible weight engineering or allied work, or who are at present and have been for at least three consecutive years Members of the Society, or who have been or are officers of a Society Chapter, or who at present and for at least one year past have had responsible charge of important weight engineering work (any two of the preceding qualifications required); Associate Members, persons who are engaged in related commercial, financial, or manufacturing fields which maintain relationship with weight engineers, or those who have been previously voting members of the Society; Student Members, undergraduate or graduate students attending accredited schools or universities, and who are recommended by a faculty member; Honorary Fellows, persons who have achieved outstanding recognition in weight engineering, or who have materially contributed to the advancement of the Society, and who have been elected by a three-fourths vote of the Board of the Society; Company Members, manufacturers, producers of equipment, transport operators, engineering schools, controlling agencies, or other related organizations; Benefactors, persons who have contributed the sum of not less than five hundred dollars. Total membership approximately 1,100 .

Meetings: Annual.

Professional activities: Weight Optimization Award presented periodically.

Society of Aerospace Material and Process Engineers. See Addenda, No. 1595.

1342. Society of American Bacteriologists. 19875 Mack Avenue, Detroit 36, Mich. President: Herald R. Cox, Lederle Laboratories, Pearl River, N. Y. Term expires June 1961. Secretary: E. M. Foster, 311 Bacteriology, University of Wisconsin, Madison 6, Wis. Term expires June 1961.

History: Founded 1899 at New Haven, Connecticut. Twenty-nine local branches, with one in Puerto Rico and one in Rio de Janeiro. Four Divisions: Agriculture and Industrial ; General ; Physiology; and Medical, Immunology and Virology.

Purpose: To promote scientific knowledge of bacteriology and related subjects through discussions, reports, and publications; to stimulate scientific investigations and their applications; to plan, organize, and administer projects for the advancement of knowledge in bacteriology.

Membership: Regular Member, 6,000, an interest in the Society's objectives and a bachelor's degree or equivalent in training and experience; Student Member, 20, enrollment as a bacteriology major in a school or college; Sustaining Member, 105, interest in the Society's objectives; 
Corresponding Member, 7; Emeritus Member, 120; Honorary Member, 3. Total membership 6,255 .

\section{Meetings: Annual.}

Professional activities: Eli Lilly and Company Research Award in Bacteriology and lmmunology, in recognition of outstanding work by young men and women, $\$ 1,000$, annually. Cash awards of $\$ 125$ and $\$ 75$ at National Science Fair for best microbiology exhibits.

Publications: Journal of Bacteriology, month1y, current volume: 79. Editor: J. R. Porter. Bacteriological Reviews, quarterly, current volume: 23. Editor: H. W. Scherp. Price of two, $\$ 16$. Reviews available to non-members at $\$ 4$. Applied Microbiology, bi-monthly, current volume $8, \$ 10$. Editor: H. B. Woodruff. Bacteriological News, quarterly, current volume: 26. Editor: R. W. Sarber.

1343. Society of American Foresters. 425 Mills Building, 17th Street at Pennsylvania Avenue, N. W., Washington 6, D. C. President: Charles A. Connaughton, U. S. Department of Agriculture, 630 Sansome Street, San Francisco 11, Calif. Term expires December 1961. Executive Secretary: Henry Clepper. Term indefinite.

History: Organized November 1900. Twentytwo geographic Sections, seventy local chapters, and nine subject Divisions: Forest Economics, Forest Management, Forest Recreation, Forest Utilization, Forest-IVildlife Management, Forestry Education, Range Management, Silviculture, and Watershed Management.

Purpose: To represent, advance, and protect the interests and standards of the profession of forestry; to provide a medium for exchange of professional thought ; and to promote the science, practice, and standards of forestry in America.

Membership: Open to individuals with a professional education in forestry at an accredited college or university. Total membership 12,855 .

\section{Meetings: Annual.}

Professional activities: Sir William Schlich Memorial Medal, and Gifford Pinchot Medal; Award for achievement in biological research leading to advancement of forestry.

Publications: Journal, monthly, current volume: 58, \$9. Editor: Arthur B. Meyer. Forest Science, quarterly, current volume: $6, \$ 6$. Editor: John W. Duffield.

1344. Society of American Military Engineers. 808 Mills Building, Washington 6, D. C. President: A. M. Minton, Director of Civil Engineering, Headquarters, U. S. Air Force, Washington 25, D. C. Term expires May
1961. Executive Secretary: F. H. Kohloss. Term indefinite.

History: Organized 1919, founded January, 1920; incorporated December 1925 in the District of Columbia; 114 local posts (chapters) and 60 student posts (chapters) in colleges.

Purpose: To promote the national defense by the advancement of knowledge of the science of military engineering; to increase the engineer potential of the nation for the national security.

Membership: Total individual membership 30,000. Military Engineer Member : a citizen of the United States, who holds a commission as an officer in the engineer services of the military forces of the United States, or has an honorable discharge from such engineer service, or is in the military forces of the United States, or has an honorable discharge therefrom and is a graduate of an engineering college of recognized standing, or has been in the active practice of the engineering profession for eight years, or holds a legally authorized license to practice professional engineering. Military Member: a citizen of the United States or its possessions who is serving in the military forces of the United States, or who has been honorably discharged from such forces, who has completed at least two years in the Reserve Officers' Training Corps, who is not included as Military Engineer. Engineer Member: person not eligible for either of two previous types of membership, who has graduated in engineering from a school of recognized standing, or who has been in active practice of the engineering profession for not less than eight years, or who holds a license to practice professional engineering issued by a legally authorized body, or who is a voting member of a professional engineering society, and who is a citizen of the United States or its possessions. Affiliate Member: citizen of the United States or its possessions, interested in military engineering affairs and in preparedness for national defense, who is ineligible for previous types of membership. Sustaining Member: a domestic firm, company, or corporation, or a division thereof, and other similar domestic organization which is interested in advancing the knowledge of the science of military engineering, in increasing the potential of the United States for national security, and in furthering the objectives of the Society. Student Member: Undergraduate student who is pursuing engineering courses or who is duly enrolled as a member of the Reserve Officers' Training Corps. Honorary Member : person who has rendered distinguished services to the Society, or who has otherwise attained distinction deserving of recognition by the Society. Foreign Member: national of country other than the United States who has the technical qualifications for becoming an 
officer of the engineer service of the military forces of the United States, or whose past or present service in the military or naval forces of such country corresponds to that service in the military forces of the United States which is required to qualify a citizen of the United States for military membership.

\section{Meetings: Annual.}

Professional activities: Military Engineering Achievements, Annual Medal Awards: George W. Goethals Medal, outstanding military engineering-at-large; Wheeler Medal, Army engineers; Moreell Medal, Navy engineers; Newman Medal, Air Force engineers; Colbert Medal, Coast and Geodetic Survey; Bliss Medal, military engineering education. ROTC Award of Merit, authorized in 1948 to be awarded annually to outstanding engineering students in the ROTC.

Publications: Military Engineer, bi-monthly, current volume: $52, \$ 6$ to members, $\$ 8$ to subscribers, $\$ 10$ foreign. Editor: F. H. Kohloss.

1345. Society of Automotive Engineers, Inc. 485 Lexington Avenue, New York 17, N. Y. President: Harry E. Chesebrough, Chrysler Corporation, P. O. Box 1518, Detroit 31, Mich. Term expires January 1961. Secretary: Joseph Gilbert. Term indefinite.

History: Informally organized 1904 ; formally organized 1905 as the Society of Automobile Engineers; incorporated 1909; merged with the American Society of Aeronautic Engineers and the Society of Tractor Engineers under present title in 1916. Geographic Divisions and ChapTERS: Atlanta, Baltimore, British Columbia, Buffalo, Central Illinois, Chicago, Cincinnati, Cleveland, Dayton, Detroit, Fort IVayne, Hawaii, Indiana, Kansas City, Metropolitan, MidContinent, Mid-Michigan, Milwaukee, MohawkHudson, Montreal, New England, Northern California, Northwest, Ontario, Oregon, Philadelphia, Pittsburgh, Rockford-Beloit, St. Louis, Southern California, Southern New England, Spokane-Intermountain, Syracuse, 'Texas, Texas Gulf Coast, Twin City, Virginia, Washington, Western Micligan, IVichita, Alberta Group, Colorado Group, Salt Lake Group, South Texas Group, Williamsport Group. 'TECHNICAL and Scientific Committees: Aerospacecraft, Aerospace Powerplant, Air Transport, Body, Computers, Engineering Materials, Farm, Construction and Industrial Machinery, Fuels and Lubricants, Nuclear Energy, Passenger Car, Powerplant, Production, Science-Engineering, Transportation and Maintenance, Truck and Bus.

Purpose: To promote the arts, sciences, standards and engineering practices connected with the design, construction, and utilization of self-propelled mechanisms, prime movers, components thereof, and related equipment.

Membership: Members, 15,689; Associates, 5,396; Juniors, 3,716. Total membership approximately 25,000 .

Meetings: Annual.

Professional activities: Horning Memorial Award, medal and cash award annually to author of best paper relating to the mutual adaptation of fuels to internal combustion engines, presented before the Society during the calendar year; in absence of an eligible paper, award may be presented in recognition of distinguished active service in the field of mutual adaptation of fuels and engines, provided recipient presents a Horning Memorial Lecture on an appropriate subject at a meeting of the Society. Manly Memorial Medal, medal and cash award annually to the author of the best paper relating to theory or practice in the design or construction of or research on aerospace engines, their parts, components, or accessories, presented at a meeting of the Society or any of its Sections during the calendar year. Wright Brothers Medal, medal and cash award annually to the author of the best paper on aerodynamics or structural theory or research, airplane design or construction, or any other aeronautic subject, presented at a meeting of the Society during the calendar year. L. Ray Buckendale Lecture, cash award and certificate for an annual lecture and monograph by a distinguished authority in the technical areas of commercial or military ground vehicles, directed toward filling the needs of young engineers and students for up-to-date practical knowledge. Russell S. Springer Award, certificate and cash award annually to youngest member of the Society under 33 years of age who is sole author of a paper published in SAE Transactions; if no sole author is eligible, award is made to youngest author of a twoauthored paper.

Publications: Transactions, annual, current volume: $68, \$ 3$ to members, $\$ 10$ to non-members. Editor: Kathleen Napier. Handbook, annual $\$ 3.50$ to members; $\$ 12$ to public libraries, university libraries, and United States government bureaus; $\$ 20$ to non-members. Editor: Maxine Barends. Journal, monthly, current volume: 68 , $\$ 5$ to members, $\$ 12$ to non-members. Editor: Norman G. Shidle.

1346. Society of Biological Psychiatry. President: William Horsley Gantt, Phipps Clinic, Johns Hopkins Hospital, Baltimore 5, Md. Term expires June 1961. Secretary-Treasurer: George N. Thompson, 2010 Wilshire Boulevard, Los Angeles 57, Calif. Term expires June 1961. 
History: Organized Jume 1946, incorporated January 1949.

Purpose: To study the biological basis of behavior.

Membership: Open to doctors of medicine and other scientific workers who have accomplished and published research concerning neuronal basis of human behavior, and who give promise of doing continued research. Active, 156; Senior, 21, those who have been active for teı years; Honorary, 2. Total membership 179.

Meetings: Annual.

Professional activities: A. E. Bennett Award for research; Manfred Sokel Foundation Annual Award for distinguished guest academic lecturer.

Publications: Biological Psychiatry, yearly, current volume: 2, \$9. Editor: Joseph Wortis.

1347. Society of Chemical Industry, American Section. Honorary Chairman: William $\mathrm{H}$. Lycan, 500 George Street, New Brunswick, N. J. Term indefinite. Executive Secretary: Frank C. McGrew, 13140 DuPont Building, IVilmington 98, Del. Term indefinite.

History: Organized 1894; parent society, originally English, with sections in all parts of the English-speaking world, organized 1881.

Purpose: The promotion of industrial chemistry.

Membership: Open to individuals interested and active in the chemical industry whose personal characteristics are compatible with the present membership, and who are suggested by an active nember and sponsored by two active members, at least one of whom knows the proposed new member personally. Applications are ratified by the Council of the parent Society. Total membership 874.

Meetings: Semiannual.

Professional activities: Perkin Medal, awarded annually for the most valuable work in applied chemistry; Chemical Industry Medal, awarded annually to a person making a valuable application of chemical research to industry.

1348. Society of Clinical Surgery. President: Jonathan E. Rhoads, 3400 Spruce Street, Philadelphia 4, Pa. Term expires November 1960. Secretary: J. Garrott Allen, 300 Pasteur Drive, Palo Alto, Calif. Term expires November 1960 .

Histary: Organized 1903.

Purpose: The advancement of surgery, the stimulation of members to work along lines of original thought and investigation, and the development of surgical teaching.

Membership: Active, 50, men engaged in general surgery, between the ages of thirty and fifty-five, with official connection in some medical institution, whether school, hospital, or laboratory; Senior, 50, those who are over fiftyfive years of age. Must have demonstrated by contributions to medical literature their capacity for progressive work in the field of general surgery.

Meetings: Semiannual.

1349. Society of Commercial Seed Technologists. President: Harley M. Reeder, Agricultural Seed Laboratories, P. O. Box 6363, Phoenix, Ariz. Term expires June 1961. Secretary-Treasurer: Robert G. Colborn, 2600 Woods Boulevard, Lincoln 2, Nebr. Term expires June 1961.

History: Organized June 1922 as the Association of Commercial Seed Analysts of North America. Name changed to present title July 1946.

Purpose: To maintain the highest proficiency and professional standards among members; to promote the best interests of the seed industry; and to encourage cooperation between the official seed analysts and the commercial agencies.

Membership: Registered Members, 108, those with college degrees or the equivalent of a major in the botanical sciences, and two years actual experience under supervision, or five years actual experience under supervision. Both require seed-testing courses attendance. Associate Members, 23, past members or persons associated in allied professions or work; Honorary, 10, a merit award status; Affiliates, 8. Total membership 149.

Mectings: Annual.

Publications: Seed Technologist News, quarterly, current volume: $28, \$ 2$. Editor: Charles R. Gunn, Louisville, Ky.

1350. Society of Cosmetic Chemists. 2 East 63rd Street, New York 21, N. Y. President: H. J. Amsterdam. Term expires December 1960. Secretary: Robert A. Kramer, 250 East 43rd Street, New York 17, N. Y. Term expires Deceniber 1960.

History: Founded 1945. Chapters: Chicago, California, New York, New England. Scientific Committees: Laboratory Methods, Literature Review.

Purpose: To establish a medium for the dissemination of scientific knowledge of the toilet goods industry, and to improve the professional standing of scientists in the fields of cosmetics and perfumery.

Membership: Majored in the fields of chemistry, pharmacy, chemical engineering, medicine, physics, or other related sciences, and are recipients of degrees from accredited colleges or 
universities; or matriculated for not less than two years in an accredited college or university with recognized credit in the above stated fields of science and who, thereafter, have been engaged in a technical capacity in the toilet goods industry for not less than 5 years; or have been deemed eligible upon examination of their qualifications by the Board of Directors. Active Members, 750 ; Honorary Members, 5 ; Emeritus, 5. Total membership 760 .

Meetings: Semiannual.

Professional activities: Annual Medal Award for outstanding contributions to the science of cosmetics; Special Award of $\$ 1000$ given annually to the scientist who has recently made an outstanding contribution to the cosmetic science.

Publications: Journal, bi-monthly, current volume: 11, \$18. Editor: M. G. DeNavarre.

1351. Society of Die Casting Engineers, Inc. President: Ollie Clayton, 1179 Gordon Street, Clawson, Mich. Term expires December 1960. Executive Secretary-Treasurer: Meyer R. Tenenbaum, 19364 James Couzens Highway, Detroit 35, Mich. Term indefinite.

History: Organized October 1954 in Detroit, Michigan. Chapters : Detroit; Saginaw Valley, Michigan; Grand Rapids, Mihcigan; Toledo; Cleveland; Chicago; Syracuse; New York; New England States; and Indiana.

Purpose: To advance the arts and sciences relating to die casting and utilization of die casting, and application of the science of die casting through research and education.

Membership: Enployment in and/or interest in die casting company or in any related company. Regular, 996; Sustaining, 27 ; Company, 62. Meetings: Anmual.

Publications: Die Casting Engineer, bimonthly, current volume: $3, \$ 6.50$ domestic. $\$ 8$ foreign.

1352. Society of Economic Geologists. President: Duncan R. Derry, Rio Canadian Exploration, Ltd., 335 Bay Street, Toronto, Canada. Term expires March 1961. Secretary: Harold M. Bannerman, U. S. Geological Survey, Washington 25, D. C. Term indefinite.

History: Organized 1920; incorporated 1930. Purpose: To advance the science of geology as applied to industry.

Membership: Honorable standing in the profession, a minimum of 8 years experience, including not less than 5 years at work principally devoted to economic geology, of which 3 years must have been in positions of responsibility. Application must be sponsored by three members. Total membership 1,000.

Meetings: Semiannual.
Professional activities: Penrose Medal Award for achievement and advancement of the science of economic geology

Publications: Econonic Geology, 8 issues yearly, current volume: 55 , free to members. Editor: Alan M. Bateman, Yale University, New Haven, Conn.

1353. Society of Economic Paleontologists and Mineralogists. P. O. Box 979, Tulsa 1, Okla. President: W. M. Furnish, University of lowa, Iowa City, Iowa. Term expires April 1961. Secretary: John Imbrie, Columbia University, New York, N. Y. Term expires April 1961.

History: Organized March 1926. The Society, together with the Society of Vertebrate Paleontology and the Paleontological Society, is a member of the Joint Committee on Zoological Nomenclature for Paleontology in America. Sections: Pacific, Gulf Coast, Permian Basin.

Purpose: To promote the science of stratigraphy through research in paleontology and sedimentary petrology, especially as these relate to development of knowledge of the geology of petroleum.

Membership: Active Members, 1,095, those having membership in the American Association of Petroleum Geologists; Associate Members, 374 , those engaged in studies that apply to the geology of petroleum; Correspondents, 6 ; Honorary, 6 , persons of distinguished achievement in paleontology. Total membership 1,481.

\section{Mectings: Anuual.}

Publications: Journal of Paleontology, bimonthly, current volume: $34, \$ 15$ to non-members, $\$ 8$ to members. Editors: M. L. Thompson and Charles Collinson, Illinois State Geological Survey, Urbana, Ill. Journal of Sedimentary Petrology, quarterly, current volume: $30, \$ 6$ to non-members, $\$ 5$ to members. Editor: Jack L. Hough, University of Illinois, Urbana, Ill.

1354. Society of Engineers of Eastern New York. President: John Pannenborg, Rosendale Lock 7 Road, Schenectady, N. Y. Term expires April 1961. Executive Secretary: Arthur Bibb, 475 9th Street, Troy, N. Y. Term indefinite.

\section{History: Organized 1904.}

Purpose: The advancement of engineering, the professional improvement of members, and the encouragement of social intercourse.

Membership: Open to any individual interested in engineering subjects, who is sponsored by two members. Total membership 100 .

Meetings: Monthly, October to April. 
1355. Society of Experimental Psychologists, Inc. Secretary-Treasurer: John L. Kennedy, Department of Psychology, Princeton University, Princeton, N. J. Term expires April 1962.

Histary: Organized 1904 as Experimentalists; name changed to present title 1929 ; incorporated 1936.

Purpose: To advance psychology by an annual conference of leading experimental psychologists and by an award for an outstanding contribution to research in experimental psychology.

Membership: Limited to persons engaged in the advancement of experimental psychology. A nember who has reached the age of sixty automatically becomes a Fellow. Not more than three new members elected in any one year. Total membership 75 .

\section{Mectings: Annual.}

Professional activities: Howard Crosby Warren Medal, established 1936, awarded for contributions to the advancement of experimental psychology; capital $\$ 1,000$, income $\$ 25$ annually. Howard Crosby Award, established 1946, awarded with H. C. Warren Medal for contributions to the advancement of experimental psychology; capital $\$ 10,500$, award $\$ 250$.

1356. Society of Exploration Geophysicists. President: T. O. Hall, General Geophysical Company, 750 Houston Club Building, Houston 2, Tex. Term expires November 1960. Business Manager: Colin Campbell, P. O. Box 1536, Tulsa 1, Okla. Term indefinite.

History: Organized in Houston, Texas, in 1930, as the Society of Petroleum Geophysicists. Name changed to present title 1936; incorporated in Colorado in 1937. Secrions: Shreveport, Calgary, Casper, Corpus Christi, Cochabamba, Dallas, Denver, Edmonton, Fort Worth, "Four Corners," Houston, Jackson (Miss.), Billings, Farmington (N. Mex.), Oklahoma City, Pacific Coast, Midland (Tex.), Regina, New Orleans, San Antonio, Lafayette (La.), Tulsa, Salt Lake City, and Caracas.

Purpose: To promote the science of geophysics, especially as it relates to exploration and research; to foster the common scientific interests of geophysicists ; and to maintain a high professional standing among members.

Mcmbership: Active, eight years experience; Associate, active interest in geophysics; Student, resident enrollment in a recognized college or university. Total membership 5,800.

Mectings: Annual.

Prafessional activitics: SEG Foundation, about $\$ 20,000$ annually in scholarships and fellowships. Awards: Annual Best Paper award for publication in Geophysics; Honorary Membership for outstanding contribution to geophysics; Annual Best Oral Presentations (2) for papers given at annual meeting.

Publications: Geophysics, bi-monthly, current volume: 25, \$10. Editor: Nelson C. Steenland.

\section{Society of Fire Protection Engineers. 60} Batterymarch Street, Boston 10, Mass. President: James J. Duggan, Union Carbide Chemicals Company, P. O. Box 8004, South Charleston 3, W. Va. Term expires May 1961. Executive Secretary: Robert S. Moulton. Term expires May 1961.

Histary: Organized October 1950. Incorporated as a technical section of the National Fire Protection Association under their charter. SECTIons: Chicago, Maryland, Philadelphia, Montreal-Ottawa, Boston, San Francisco, Los Angeles, New York.

Purpose: To promote the art and science of fire protection engineering and its allied fields, to maintain a high professional standing among its members, and to foster fire protection engineering education.

Mcmbership: Members, 580, engineering degree and eight years experience, or twelve years engineering experience, and, in either case, three years responsible charge; Associates, 273, engineering degree and four years experience, or eight years engineering exprience; Juniors, 204, one year active practice or study in fire protection engineering, thirty-five years of age or less; one student chapter. Total membership 1,058.

Meetings: Annual.

Publications: Year Book, biennially, current volume: 5. Bulletin, bimonthly, current volume : 60. Free to members. Editor: R. E. Stevens.

\section{Society of General Physiologists. Presi-} dent: John B. Buck, National Institutes of Health, Bethesda 14, Md. Term expires September 1961. Secretary: James W. Green, Rutgers University, New Brunswick, N. J. Term expires September 1961.

\section{History: Organized September 1946.}

Purpose: To encourage communication between biologists who are interested primarily in fundamental physiological principles rather than in application, and in phenomena common to all organisms rather than those limited to special groups.

Mcmbership: Substantial record of published basic research in general physiology. Total membership approximately 350 .

Meetings: Annual.

Professianal activitics: Annual sponsorship of a physiological symposium; symposium proceedings published. 
Publications: Journal of General Physiology, six times a year, current volume: $44, \$ 10$. Chairman of Editorial Board: Alfred Mirsky.

1359. Society of Illinois Bacteriologists, Inc. President: Z. John Ordal, University of Illinois, Urbana, Ill. Term expires December 1960. Secretary: Charles J. Rickher, 437 North Butrick Street, Waukegan, 11l. Term indefinite.

History: Organized 1935; incorporated October 1950 in Illinois. Branch of Society of American Bacteriologists.

Purpose: To further the advancement of bacteriology and to aid the Society of American Bacteriologists in extending its work.

Membership: Active, persons professionally engaged in bacteriology or in related fields, who have had at least three years of academic training beyond high school, or equivalent thereof; Associate, persons interested in the field; Student. Total membership 785 .

Meetings: Three times a year, fall, winter and spring.

Professional activities: Member of Chicago Technical Societies Council.

Publications: News Letter, six times a year.

1360. Society of Marine Port Engineers, New

York, N. Y., Inc. 114 Liberty Street, New

York 6, N. Y. President: George A. Farnsworth, P. O. Box 367, Tottenville, Staten Island, New York. Term expires January 1962. Sccretary-Treasurer: William Richards. Term expires January 1961.

History: Founded September 1946 in New York City; incorporated in New York State.

Purpose: To develop cooperative spirit among members and to protect the interests and welfare of the American Merchant Marine.

Membership: Open to members of the United States Coast Guard, Bureau of Marine Inspection, with Chief Engineer license-unlimited tonnage, ocean, steam or diesel. Total membership approximately 200.

Meetings: Monthly.

Professional activities: Engineering Award for each graduation at U. S. Maritime College, Kings Point, New York; New York State Maritime College, Fort Schuyler, New York; Maine Academy, Castine, Maine.

Publications: De Air-Ator, quarterly, current volume: 6 , free to members.

1361. Society of Medical Consultants to the Armed Forces. President: I. Ridgeway Trimble, 2947 St. Paul Street, Baltimore 18, Md. Term expires November 1960. Secretary: Tom F. IVayne, School of Medicine, Univer- sity of Pennsylvania, Philadelphia 4, Pa. Term expires November 1962.

History: Organized February 1946.

Purpose: When requested, to study and advise on medical problems in military services.

Membership: Active, 385, individuals who have served as commissioned medical officers in or consultants to the U. S. military forces; Associate, 4, regular army officers; Emeritus, 22; and Honorary, 14, officers and consultants of the armed forces of U. S. allies. Membership is limited to physicians meeting the stated criteria and who are proposed by active members. Total membership 425.

Meetings: Annual.

1362. Society of Medical History of Chicago. 55 East Washington Street, Chicago 2, 111. Prcsident: Ilza Veith, University of Chicago, Chicago 37, Ill. Term expires May 1961. Secretary-Treasurer: Leo M. Zimmerman. Term expires May 1961.

\section{History: Founded in 1910.}

Purpose: To foster interest and knowledge in the history of medicine by offering regular meetings and programs dealing with medical history in all its various aspects.

Membership: Candidates must be approved by the Council of the Society. Total membership 165.

Meetings: Monthly.

1363. Society of Medical Jurisprudence. 2 East 103rd Street, New York, N. Y. President: C. F. Weidlich, 55 Liberty Street, New York, N. Y. Term expires January 1961. Secretary: Edward B. Willing, 22 West 1st Street, Mt. Vernon, N. Y. Term expires January 1961.

History: Organized and incorporated 1883.

Purpose: The investigation, study, and advancement of the science of medical jurisprudence and the attainment of a high standard of medical testimony in courts.

Membership: Open to physicians, lawyers, and scientists. Total membership 600 .

Meetings: Annual; monthly, except June through September.

1364. Society of Mining Engineers of the American Institute of Mining, Metallurgical and Petroleum Engineers, Inc. 29 West 39th Street, New York 18, N. Y. President: Arthur B. Cummins, Johns Manville Company, Research Center, Manville, N. J. Term expires February 1961. Secretary: John C. Fox. Term expires February 1961. 
History: Organized 1957 as a semi-autonomous constituent society of the American Institute of Mining, Metallurgical and Petroleum Engineers. 100 local sections and subsections in every part of the United States and others in Mexico, Canada, Peru, Saudi Arabia, the Philippines, and Indonesia. Divisıons: Mining and Exploration, Minerals Beneficiation, Coal, and Industrial. Divisions are divided into technical or commodity committees.

Purpose: To promote the arts and sciences connected with the economic production of the useful minerals and metals; to hold meetings for social intercourse and the reading and discussion of professional papers; to circulate by means of publications among its members the information thus obtained; and to establish and maintain a place for meeting of its members, and a hall for the reading of papers and delivery of addresses, and a library of books relating to subjects cognate to the sciences and arts of mining and metallurgy.

Membership: Members: Must be at least twenty-seven years old and have had at least six years employment in engineering or application of the sciences to any branch of the mineral industry; must have held positions in responsible charge of engineering or technical work for three years. Associate Members: Persons whose interest or work in a field of science or engineering represented by one or more of the three constitutent societies is too limited to meet the requirements of the classification of Member. Junior Menbers: Must be under thirty years of age and qualified to hold a subordinate engineering position. Student Members: Students in good standing at a degree-granting school approved by the Board of Directors, who have been nominated by one instructor. Students, 500 ; Juniors, 2,000 ; Members and Associates, 10,380. Total membership 12,880.

\section{Meetings: Annual.}

Professional activities: James Douglas Gold Medal; IVilliam Lawrence Saunders Gold Medal; Charles F. Rand Memorial Medal; Erskine Ramsay Gold Medal; Robert H. Richards Award; Rossiter W. Raymond Award; Robert Peele Memorial Award; Hal Williams Hardinge Award; Daniel C. Jackling Award and Lecture; all awards presented in recoguition of achievement on a professional basis. Also an annual award in the Annual National Prize Paper Contest for students. Institute cooperates with other Founder engineering societies in presentation of other awards: John Fritz Medal, Alfred Nobel Prize, Hoover Medal, and Percy Nichols Award.

Publications: Mining Engineering, monthly, current volume: $12, \$ 6$ to members, $\$ 8$ domestic non-menbers, $\$ 10$ foreign non-members. Mining
Transactions, annual, current volume: $21, \$ 5$. Editor: R. A. Beals.

Library: 175,000 volumes; 1,500 periodicals.

\section{Society of Motion Picture and Television}

Engineers, Inc. 55 West 42nd Street, New York 36, N. Y. President: Norwood L. Simmons, Eastman Kodak Company, 6706 Santa Monica Boulevard, Hollywood 38, Calif. Term expires December 1960. Executive Secretary: Charles S. Stodter. Term indefinite.

History: Founded in 1916 by a group of twenty-four engineers as the Society of Motion Picture Engineers. Television was added to its title and objectives in 1950. Membership in more than sixty countries. Sections: New York, Rochester, Boston, Chicago, Washington, D. C., Atlanta, Nashville, Dallas-Fort Worth, Hollywood, San Francisco, and Toronto, Canada. Student Chapters : City College of New York, Rochester Institute of Technology, University of Miami, University of Southern California, and Boston University. Engineering Committees: Color, Film Dimensions, Film Projection Practice, Instrumentation and High Speed Photography, Laboratory Practice, Screen Brightness, $16 \mathrm{~mm}$ and $8 \mathrm{~mm}$ Motion Pictures, Sound, Standards, Television, Television Studio Lighting, Video-Tape Recording.

Purpose: Advancement in the theory and practice of engineering in motion pictures, television, and the allied arts and sciences; the standardization of equipment and practices employed therein; the maintenance of a high professional standing among its members; guidance of students and the attainment of high standards of education; and the dissemination of scientific knowledge by publication.

Membership: Active, an engineer or scientist or one of equivalent standing in field of motion pictures or television, over twenty-five years of age, 2,570; Associate, technical personnel interested in motion picture and television field over eighteen years of age, 3,225; Student, a person registered in college, university, or other educational institution of like scholastic standing interested in motion picture or television technology, 436; Sustaining, an individual or company or corporation contributing substantially to the financial support of the Society, 133; Honorary, 10, and Fellow, 270, are elective memberships. Total membership 6,644.

Meetings: Semiannual.

Professional activities: Annual Awards: Progress Medal, for invention, research, or development resulting in significant advance in development of motion picture or television technology; Samuel L. Warner Memorial Award, for design and development of new and improved methods and/or apparatus for sound-on- 
film motion pictures; David Sarnoff Gold Medal Award, for development of new techniques or equipment contributing to improvement of engineering phases of television; Herbert T. Kalmus Gold Medal, for development of color films, processes, techniques, or equipment useful in making color motion pictures for theater and television use; SMPTE Journal Award, for most outstanding paper published in Journal during preceding calendar year; Student Member Award, for outstanding paper prepared by a Student Member during the school year. Sponsorship of educational courses in universities and conduct of lecture series on subjects of current technological interest in motion pictures and television; of International Congress on Higl-Speed Photography; of engineering standards and recommended practices including distribution of test films, slides, and tapes.

Publications: Journal, monthly, current volune: $69, \$ 12.50$. Editor: Victor H. Allen.

1366. Society of Natural History of Delaware. IVilmington Institute Free Library, 10th and Market Streets, IVilmington, Del. President: Robert S. Howard, Department of Biological Sciences, University of Delaware, Newark, Del. Term expires June 1961. Secretary: Mrs. R. L. Hardy. Term expires June 1961.

History: Established in 1891; incorporated in 1919.

Purpose: The cultivation and study of the natural sciences.

Membership: Open to those persons interested in the natural sciences, Annual, Contributing, and Sustaining Members. Total memberslip 250.

Meetings: Monthly.

Professional activities: Publication of papers, field trips, maintenance of scientific library, and museum, including herbarium.

1367. Society of Naval Architects and Marine Engineers. President: Albert G. Mumma, 74 Trinity Place, New York 6, N. Y. Term expires December 1960. Secretary: IVilbur N. Landers. Term expires December 1960.

History: Founded and incorporated 1893. Twelve SEctions: Chesapeake, Eastern Canadian, Great Lakes, Gulf, Hampton Roads, Hawaii, New England, New York Metropolitan. Pacific Northwest, Philadelphia, Northern California, and Southern California. TECHNICAL and Research Committees: Steering Hydrodynamics, Hull Structure, Ships' Machinery and Ship Technical Operations, with appropriate panels and task groups.

Purpose: To advance the art, science, and practice of naval architecture, shipbuilding and marine engineering, both governmental and commercial, in all of their branclies and of the allied arts and sciences.

Membership: Interest and competence in Society's field of operations. Members, 3,029 Affiliates, 620; Associate Members over thirty, 2,592; Associate Members under thirty, 762; Student Members, 285; Honorary Members, 21 ; Honorary Vice-Presidents, 9; Permanent Members, 4 ; Life, 18; Special Members, 28; Foreign Affiliates, 146. Total membership 7.514.

\section{Mectings: Semiannual.}

Professional activities: Endowment Fund, capital $\$ 1,000,000$, income used for prizes, scholarship awards, publication of textbooks, and other special activities. Research Fund, supported by industry to carry on research activities of the Society. Scholarships : $\$ 9,000$ allocated annually for advanced study in naval architecture, marine engineering, and allied engineering subjects: $\$ 12,000$ allocated annually for undergraduate study in these speciaties. Awards: David IV. Taylor Medal, for notable achievement in naval architecture and marine engineering; Vice Admiral "Jerry" Land Medal, for outstanding accomplishment in the marine field; Davidson Medal, for outstanding accomplishment in scientific ship research; Captain Joseph H. Linnard Prize for the best paper contributed to Proceedings of the Society; President's Award for the best paper presented before a Section of the Society; Student Paper Awards, for the best papers by students, both graduate and undergraduate.

Publications: Journal of Ship Research, quarterly, current volume: 4, \$4. SNAME News, quarterly, current volume: 4 , free to members. Transactions, annual, current volume: $68, \$ 10$, free to members. Year Book, free to members. Index Pamphlet, annual, free to members. Editor: L. S. Blodgett.

1368. Society of Neurological Surgeons. President: James L. Poppen, 605 Commonwealth Avenue, Boston 15, Mass. Term expires April 1961. Secretary-Treasurer: Guy L. Odom, Duke University Medical Center, Durham, N. C. Term expires April 1964.

\section{History: Organized 1920.}

Purpose: Development of neurological surgery and the education of the medical profession, particularly surgeons, in the recognition that neurological surgery requires special training in addition to that of general surgery.

Membership: Open to individuals who have devoted special study to some phase of surgery of the nervous system and have demonstrated this by publications. Limited to 50 .

Meetings: Annual. 
1369. Society of Nuclear Medicine, Inc. President: Titus Evans, University of Iowa, Iowa City, Iowa. Term expires June 1961. Adninistrator: Samuel N. Turiel, 430 North Michigan Avenue, Chicago 11, I11. Term indefinite.

History: Founded 1954 in State of Washington by federating several regional groups interested in nuclear medicine. Currently has 14 accredited chapters. Commitree: Radiation Protection.

Purpose: To bring together physicians and other scientists engaged in the use of nuclear phenomena in the diagnosis and treatment of disease.

Membership: Open to scientists, including physicians, veterinarians, nurses, physicists, mathematicians, technicians, laboratory personnel. Members: persons possessing an advanced degree in the medical, biological, or physical sciences, and who have an interest and competence in the application of nuclear radiation. In exceptional cases, individuals not qualifying under the above may be accepted by reason of outstanding contributions to nuclear medicine by action of the Executive Committee. Associate: those persons interested in the utilization of radioisotopes and nuclear phenomena in the management and treatment of disease, and who have obtained a bachelor's degree in science. Total 1,625 members.

Mectings: Annual.

Publications: Journal, quarterly, current volume: 1, \$10. Editor: George E. Thoma.

1370. Society of Packaging and Handling Engineers. 14 East Jackson Boulevard, Chicago 4, 111. President: C. L. Lippman, U. S. Steel Company, 120 Montgomery Street, San Francisco, Calif. Term expires January 1962. $A d$ ministrative Secretary: Kay Crowley. Term indefinite.

History: Formed as a non-profit organization in June 1945, in Illinois; incorporated as The Industrial Packaging Engineers Association of America; name changed to present title in 1959.

Purpose: To further the application of good engineering practices in the industrial packaging and materials handling fields.

Membership: On an individual or company basis, according to the following classifications: Associate: those persons who are qualified by position or experience to cooperate with packaging and/or materials handling engineers, and those persons who, in the opinion of the Board of Directors, will further the objectives and purposes of the Society; Professional: those persons who are 26 years of age or more, and who by previous technical training or experience, or by present occupation are qualified to utilize scientific or engineering principles in the fields of packaging and/or materials handling, graduates from a recognized college or university with three years of experience acceptable to the Board of Directors, or five years experience acceptable to the Board of Directors, in the fields of packaging and/or materials handling; Fellow, those who have been members of the Society for a minimum of 5 years, who are at least 33 years of age, and who by reason of their special contributions to the fields of packaging and/or materials handling are deemed by the Board of Directors to have earned this recognition. Total membership 1,200.

\section{Meetings: Annual.}

Professional activities: National Packaging and Handling Competition; five Packaging Scholarships at Hofstra University.

Publications: Trends, bimonthly, current volume: 6 , free to members. Editor: Kay Crowley.

1371. Society of Pelvic Surgeons. President: Waring G. Cosbie, 170 St. George Street, Toronto 5, Canada. Term expires October 1960. Secretary: Laman A. Gray, 216 Heyburn Building, Louisville 2, Ky. Term expires October 1961.

History: Organized December 1952.

Purpose: To exchange ideas pertaining to various phases of pelvic surgery and related fields, and to exert influence for the betterment of the teaching and practice of pelvic surgery.

Membership: Active Members (limited to 45), graduates of recognized medical schools, licensed in United States or Canada, on staff of recognized hospital or having special interest and accomplishment in field of pelvic surgery; Senior, active members at age of 65 are transferred. Total membership 42.

Meetings: Annual.

1372. Society of Petroleum Engineers of the American Institute of Mining, Metallurgical, and Petroleum Engineers, Inc. President: Wayne E. Glenn, Continental Oil Company, P. O. Box 2197, Houston, Tex. Term expires February 1961. Executive Secretary: Joe B. Alford, 6300 North Central Expressway, Dallas 6, Tex. Term indefinite.

History: Organized in 1913 as a Committee on Oil and Gas of the AIME; expanded to become the Petroleum Division of AIME in 1922; became the Petroleum Branch of AIME in 1949, and, with the reorganization of AIME in 1957 , became the present society, a largely autonomous organization operating within the framework of AIME. Now has thirty-six sections in the United States, two in Canada, three in Venezuela, one in Saudi Arabia, and one in Sumatra; 
with six subsections in the United States, and twenty-seven student chapters. TECHNICAL Commitrees: Education, General Editorial, Production Review, Program, Symbols, Transactions Editorial.

Purpose: To furnish a medium of cooperation among those interested in the petroleum-natural gas industry, and to promote the advancement of this branch of mineral technology through meetings to stimulate the preparation, reading, discussion, and circulation of papers.

Membership: Member, 6,723, must be at least twenty-seven years old, and have had at least six years employment in engineering or application of the sciences to any branch of the mineral industry, must have held positions in responsible charge of engineering or technical work for three years; graduation from a technical college not required but is considered equivalent to two years employment. Associate Member, 1,861 , must be interested in petroleum engineering or application of the sciences to the petroleum industry, technical training or experience not required. Junior Member, 4,889, must be under thirty years of age, qualified to hold a subordinate engineering position. Student Member, 980 , must be a full-time student in good standing in an approved school. Total membership 14,453 .

Meetings: Annual.

Professional activities: Anthony F. Lucas Gold Medal, an Institute award, for distinguished achievement in improving technique of finding and producing petroleum; John Franklin Carll Award, for distinguished contribution to petroleum engineering; Cedric K. Ferguson Medal, for outstanding technical paper by a Junior Member; Certificate of Service, for outstanding contribution to the Society; local sectional sponsorship of scholarships in petroleum engineering, student paper contests, etc.

Publications: Journal of Petroleum Technology, monthly, current volume: 12 , free to members, $\$ 8$ to non-members. Petroleum Transactions, AIME, annual, current volume: 216, $\$ 4.90$ to members, $\$ 7$ to non-members. Editor: R. William Taylor.

1373. Society of Photographic Scientists and Engineers. P. O. Box 1609, Main Post Office, Washington, D. C. President: George T. Eaton, Research Laboratories, Eastman Kodak Company, Rochester 4, N. Y. Term expires May 1961. Managing Secretary: Edward S. Cobb. Term indefinite.

History: Organized June 1948, incorporated in the District of Columbia. Chapters: Binghamton, Boston, Chicago, Cleveland, Monmouth, New York, Rochester, Southern California, Washington, D. C.
Purpose: The advancement and diffusion of knowledge of the science of photography and its applications to the field of photographic engireering in industry, education, and research, without restriction by specific use or by the dimensions of materials, including the understanding, production, and improvement of the materials.

Mcmbership: Honorary, 5, a person who has performed eminent service in the advancement of photographic science or engineering; Fellow, 13 , a person who has contributed outstandingly to the technical or scientific progress of photographic science and engineering; Senior, 3, a person who has made or performed outstanding contributions and service to the Society; Regular, one with professional standing in the field of engineering or science, or administrative responsibilities in the technical photographic operations, or a teacher of technical photography in a school of recognized standing; Associate, one who is over twenty-one years of age and is engaged in or interested in work relating to some technical aspect of photography; total Regular and Associate members, 2,300; Students, 105; Sustainers, 53. Total membership 2,479.

\section{Meetings: Annual.}

Professional activities: Volunteer Satellite Tracking Project conducted under the auspices of National Aeronautics and Space Administration. Society is represented in American Standards Association, the Inter-Society Color Council, and the National Academy of SciencesNational Research Council.

Publications: Photographic Science and Engineering, bimonthly, current volume: 4 , free to members, $\$ 12$ to non-menbers. Editor: $\mathrm{T}$. Howard James.

1374. Society of Plastics Engineers, Inc. 65 Prospect Street, Stamford, Conn. President: George IV. Martin, 178 Sargeant Street, Holyoke, Mass. Term expires January 1961. Executive Secretary: Thomas A. Bissell. Term indefinite.

History: Organized December 1941, incorporated August 1942. CommitteEs: Education, Technical Advisory, Inter-Society Relations, Meetings, Publications, Administrative, Sections, Membership. Fifteen Professional Activities Groups: Plastics in Buildings, Plastics in Electrical Insulation, Extrusion, Reinforced Plastics, Injection Molding, Metal Mold Design and Construction, Castings and Plastics Toolings, Forming, Finishing, Thermosetting Molding, Vinyl Plastics, Polymer Structure and Properties, Fabricating, Standards for Reporting Properties, Plastics in the Automotive Industry.

Purpose: To promote in all lawful ways the 
scientific and engineering knowledge relating to plastics.

Membership: Senior, those qualified by previous technical training, experience, or present occupation to conduct or direct design, engineering, chemical or physical research relating to plastics, to exercise technical supervision of the production of plastics materials or products, or the manufacture of equipment connected therewith, to impart technical instruction in the chemistry, physics or engineering of plastics, or the design and fabrication of plastics products; Associate, those qualified as Senior Members except having less experience qualification, or engaged in the plastics or a related industry in a responsible commercial, financial, or manufacturing capacity, or connected with the plastics or a related industry and competent to cooperate technically with plastics engineers and scientists; Junior Member, those qualified to fill subordinate technical positions in the plastics or a related industry, and less than thirty years of age; Student Member, those regularly enrolled in a technical course at a recognized college or university, and less than twenty-six years of age; Distinguished Member, those who, at the time of election, are members in good standing who have attained professional eminence in the plastics field, who have made a significant contribution to the plastics industry, who have given outstanding devotion and service to the Society, or who have served the Society as President; Honorary Member, those who have been non-members but who, by virtue of outstanding achievement or professional eminence, may be deemed worthy of this status. Total membership 7,679.

Meetings: Annual; 7 Regional; 400 Sectional.

Publications: Journal, monthly, current volume: $16, \$ 6$, domestic, $\$ 10$ foreign. Editor: Melvyn A. Kohudic.

1375. Society of Protozoologists. President: William Trager, The Rockefeller Institute, New York 21, N. Y. Term expires December 1961. Secretary: John O. Corliss, Department of Zoology, University of Illinois, Urbana, I1l. Term expires September 1962.

\section{History: Organized December 1947.}

Purpose: To promote closer association of persons interested in research which will advance protozoological science.

Membership: Open to any individual, including non-Americans, interested in the science of protozoology. Regular Members; Graduate Student Members; Honorary Members, 10, persons who have rendered highly meritorious service in the field. Total membership 675 .

Meetings: Annual.
Publications: Journal of Protozoology, quarterly, current volume: $7, \$ 12$, free to members. Editor: William Trager.

1376. Society of Public Health Educators, Inc. President: Norbert Reinstein, 153 East Elizabeth Street, Detroit 1, Mich. Term expires October 1960. Executive Secretary: Ruth F. Richards, 42 Broadway, Room 900, New York 4, N. Y. Term expires October 1961.

\section{History: Incorporated 1952.}

Purpose: To contribute to the advancement of the health of all people by improving standards in the field of public health education.

Membership: Two years experience and master's degree in public health. Total membership 360.

\section{Meetings: Annual.}

Publications: Monograph, quarterly, current volume: 8, \$3. Editor: H. Weddle.

1377. Society of Rheology. c/o American Institute of Physics, 335 East 45th Street, New York 17, N. Y. President: John H. Elliott, Hercules Powder Company, Research Center, Wilmington, Del. Term expires November 1961. Secretary: William R. Willetts, Titanium Pigment Corporation, 99 Hudson Street. New York 13, N. Y. Term expires November 1961.

History: Organized December 1929. Member society of the American Institute of Physics.

Purpose: The development of the science of the deformation and flow of matter.

Membership: Open to chemists, physicists, engineers, and other professional scientists. Personal Members, 421 ; Company and Institutional Members, 30; Sustaining. Total membership approximately 550 .

\section{Meetings: Annual.}

Professional activities: Bingham Medal, award annually to a scientist who has made a notable contribution to rheological knowledge.

Publications: Rheology Bulletin, three times yearly. Transactions, annual, current volume: 4 , both free to members. Editor: E. H. Lee, Department of Applied Mathematics, Brown University.

1378. Society of Soft Drink Technologists. 1128 16th Street, N. W., Washington 6, D. C. President: Melvin Helin, Infilco Inc., Tucson, Ariz. Term expires April 1961. SecretaryTreasurer: Harry E. Korab. Term indefinite. 1954.

History: Organized July 1953; incorporated 
Purpose: To promote development and dissemination of the knowledge of the art, science, and technology of soft drink production and utilization, on a non-profit professional basis; to afford opportunity for the discussion of matters of interest, and to establish organized, special study of problems; to promote, assist, and encourage research in any technological problems.

Membership: Open to any person actively engaged in the scientific or technical phases of production, research, or quality control in the soft drink industry. Total membership 260.

Meetings: Annual.

1379. Society of State Directors of Health, Physical Education and Recreation. President: George H. Grover, State Department of Education, Albany 1, N. Y. Term expires May 1961. Secretary: Simon A. McNeely, Office of Education, Department of Health, Education and Welfare, Washington 25, D. C. Term indefinite.

History: Organized 1926. Constitution adopted 1944.

Purpose: To promote sound programs of health, physical education, recreation, safety, and athletics throughout the United States; to study problems in these areas; to provide a basis for exchange of ideas and programs among members; to cooperate with other professional organizations in furthering the development of programs in the above fields.

Membership: Active, state directors of departments of health, physical education, and recreation; Associate, staff members of state departments; Affiliate, former staff members of state departments, and national personnel. Total membership 108.

Meetings: Annual.

Professional activities: Annual Honor Awards for outstanding service, publications directed toward improving state leadership, study projects in the related fields, cooperative action with other disciplines.

Publications: Newsletter, quarterly, free.

Society of Systematic Zoology. See Addenda, No. 1596.

1380. Society of Technical Writers and Publishers, Inc. P. O. Box 3706, Beechwold Station, Columbus 14, Ohio. Contact: Mrs. Norma Kennedy, Office Manager. Term indefinite.

History: Society of Technical Writers and the Association of Technical Writers and Editors were each organized in 1953, and merged in November 1957 into the Society of Technical Writers and Editors, Inc. That Society merged with the Technical Publishing Society to become the present society in July 1960.

Purpose: To further the advancement of the profession of technical writing and editing by developing and establishing standards and a code of ethics, by stimulating exchange of ideas, knowledge, philosophy, and techniques, by encouraging professional development and training, and by acquainting others with the profession.

Membership: Voting membership extended to persons having or having had a major concern with technical writing or editing, with publication of technical material, or with related activities. Fellow: any person who because of his outstanding contribution to the profession or to the advancement of the Society, is selected by the Society to receive honorary recognition. Senior Member, any person qualified as a voting member and who has had six years of experience, of which three years have been spent in a responsible position. A baccalaureate degree from a school of recognized standing counts as one year of experience, but such education must include a major in science or technology, or a major in English or journalism with a minor in science. Member : any person qualified as a voting member. Affiliate Member: any person interested in the aims of the Society, and not eligible for voting membership. Student Member: any person enrolled at a school of recognized standing who is interested in the aims of the Society and not eligible for voting membership. Sustaining Member : any company, organization, or agency interested in the aims of the Society. Total membership 3,000 in the United States, Canada, and Great Britain.

\section{Meetings: Annual.}

Professional activities: Pittsburgh Chapter sponsors scholarship at Carnegie Institute of Technology; and Fort Wayne Chapter offers the Brockman award for the best paper from a student at Indiana Technical College.

Publications: Review, quarterly, current volume : 7, \$4. Editor: Allan Lytel. Newsletter, bimonthly, current volume: $6, \$ 1$. Editor: Paul S. Kennedy.

1381. Society of the Plastics Industry, Inc. 250 Park Avenue, New York 17, N. Y. President: R. C. Weigel, Polychemicals Department, E. I. duPont de Nemours \& Company, Inc., Wilmington 98, Del. Term expires May 1961. Executive Vice-President: William T. Cruse. Term indefinite.

History: Organized 1927; chartered in the State of New York 1937. Sections and CHAPTERS: Mid-West: Chicago, Detroit, Ohio; New England; Philadelphia; Western: Northern California, Southern California; Canadian: 
Montreal, Toronto. Divisions in the United States: Button, Cellular Plastics, Epoxy Resin Formulators, Fluorocarbons, Garden Hose, Housewares Manufacturers, Industrial Container, Machinery, Melamine Dinnerware, Mold Makers, Molders Management, Plastics for Tooling, Polyethylene Film, Polystyrene Wall Tile, Reinforced Plastics, Sheet Forming, Shoe, Thermoplastics Pipe, Thermoplastics Structures, Vinyl Dispersions, Vinyl Film Manufacturers, Profile Extruders, Plastic Bottle and Tube Manufacturers Institute, Vinyl-Metal Laminators Institute. Commitтees in the United States: Accounting and Financial, Code Advisory, Plastics Education, Fire Prevention, Domestic Refrigeration, Engineering and Technical, Food Packaging Materials, Injection Molding $\mathrm{Ma}$ chine Standards, International, 9th National Plastics Exposition, Plastics for Lighting Joint SPI-IES-NEMA, Public Relations, Radio Frequency Heating, Safety, Tariff, Traffic, Polyethylene Committee on Construction, Industrial and Agricultural Applications, SPI National Conference.

Purpose: To assemble and disseminate scientific, engineering, and general informative data on plastics; to cooperate with the military and allied departments of the United States and Canadian governments in the furtherance of their plastics projects; to act as an authoritative central forum for member companies; and to promote actively and advance the application and use of plastics through greater public acceptance and favorable recognition of plastics products.

Membership: Company members, 1,150 , identified with the plastics industry consistent with the by-laws of the Society; Individual members, 2,400 , must be an employee of a menber company. Total membership 3,550.

Meetings: Annual.

Library: 1,000 volumes.

1382. Society of the Sigma Xi. 56 Hillhouse Avenue, New Haven 11, Conn. President: Frank M. Carpenter, Harvard Biological Laboratories, Cambridge 38, Mass. Term expires December 1960. Exccutive Secretary: Thomas T. Holme. Term expires December 1963.

History: Founded at Cornell University 1886, incorporated October 1942. 137 chapters and more than 100 clubs in the leading universities and technical institutions in the United States and Canada, with at least one Group in each of the fifty states, the District of Columbia, Canada and Lebanon.

Purpose: To encourage original investigation in pure and applied science.

Membership: Members, any professor, instructor, or other member of the instructional or re- search staff of the institution in which the chapter is located, who has shown noteworthy achievement as an original investigator in some branch of pure or applied science; or any student in, or graduate of, the institution in which the chapter is located who has clearly demonstrated ability to pursue independent scientific research in some branch of pure or applied science; or any professor, instructor, other investigator connected with a degree-granting institution not having a chapter, who would otherwise be eligible; or any investigator connected with a non-degree-granting institution not having a chapter who would otherwise be eligible, when the nomination by the chapter's Committee on Admissions has been approved by a threefourths vote of the National Executive Committee. Associate Members : any person who is currently or was during the preceding year a student in the institution in which the chapter is located and has completed at least three years of work toward a bachelor's degree, and has shown marked excellence in his studies in at least one field of pure or applied science and given evidence of an aptitude for research in one of these fields. Total membership 100,000.

Meetings: Amual.

Professional activities: Grants-in-aid.

Publications: American Scientists, quarterly, current volume: $48, \$ 2.50$ domestic, $\$ 3$ foreign. Editor: Hugh S. Taylor.

1383. Society of University Surgeons. President: H. William Scott, Jr. Vanderbilt University Hospital, Nashville, Tenn. Term expires February 1961. Secretary: Ben Eiseman, 4200 East Ninth Avenue, Denver 20, Colo. Term expires 1962.

History: Organized February 1938; incorported 1941. CommitteE: Graduate Training in Surgery.

Purpose: To advance the art and science of surgery by encouragement of its members to pursue original investigations both in the clinic and in the laboratory, the development of methods of graduate teaching of surgery with particular reference to the resident system, and free and informal interchange of ideas pertaining to the above subjects, insofar as limited membership and common aims permit.

Membership: Open to individuals under fortyfive years of age who have occupied a faculty position in a university department of surgery and its affiliated teaching hospital for at least eighteen months following completion of a graduate unjersity residency training in surgery in a menbership hospital, and who by work as surgeon, teacher, and investigator give promise of a successful career in academic surgery. Total nembership 369 . 


\section{Meetings: Annual.}

Professional activities: Interchange of scientific information and supervision of residency training programs.

1384. Society of Vertebrate Paleontology. President: Claude W. Hibbard, Museum of Paleontology, University of Michigan, Ann Arbor, Mich. Term expires November 1960. Secretary-Treasurer: Robert $\mathrm{H}$. Denison, Chicago Natural History Museum, Chicago 5, Ill. Term expires November 1960.

History: Organized December 1940 by the group who had functioned previously as a section of vertebrate paleontology in the Paleontological Society.

Purpose: To promote the science of vertebrate paleontology, and to serve the common interest and facilitate the cooperation of all persons concerned with the history, evolution, comparative anatomy and taxonomy of vertebrate animals, as well as the field occurrence, collection and study of fossil vertebrates and the stratigraphy of the beds in which they are found.

Membership: Open to all persons who are twenty-one or more years of age, and who are interested in any aspect of the science of vertebrate paleontology. Members, 395; Foreign, 86; Honorary, 13. Total membership 494.

Meetings: Annual.

Publications: News Bulletin, three times yearly, current volume: $60, \$ 2$. Editor: Nelda E. Wright, Museum of Comparative Zoology, Harvard University, Cambridge 38, Mass. Bibliography of Vertebrate Paleontology, annual, current volume: $58-59, \$ 0.50$. Editor: Rachel $\mathrm{H}$. Nichols, American Museum of Natural History, New York 24, N. Y.

1385. Society of Woman Geographers. 1216 Connecticut Avenue, Washington 6, D. C. President: Marion I. Stirling. Term expires May 1963. Secretary: Benita S. Harris. Term indefinite.

History: Organized March 1925. Sections: New York, Chicago, Washington, San Francisco.

Purpose: To form a medium of contact between traveled women engaged in geographical work and its allied arts and sciences; to further geographical work in all its branches; to spread geographical knowledge; to encourage geographical research.

Membership: Active Members, 300, traveled women, residing in the United States and Canada, who have done distinctive work, thereby adding to the world's knowledge concerning the countries on which they have specialized, and have published or produced a record of their work; Associate, 50, widely traveled, interested in geographical research; Corresponding, 50, same as Active Members, but residing outside the United States. Total membership 400.

Mectings: Triennial.

Professional activities: Fellowship administered by Columbia University.

Publications: Bulletin, triennial.

1386. Society of Women Engineers. 29 West 39th Street, New York 18, N. Y. President: Catherine IV. Eiden, 208 West Washington Street, Chicago 6, I1l. Term expires July 1961. Secretary: Elizabeth Plunkett, 905 South 200th Street, Seattle 88, Wash. Term expires July 1961.

History: Organized 1949, incorporated in the District of Columbia February, 1952. Sections: Atlanta, Boston, Chicago, Cleveland, Connecticut, Denver, Detroit, Hartford, Houston, Los Angeles, New York, Pacific Northwest, Philadelphia, Pittsburgh, St. Louis, San Francisco Bay, Washington.

Purpose: To inform the public of the qualifications, abilities, and achievements of women engineers, to bring about the better utilization of engineering talent for the economic and social benefit of humanity, to encourage women with suitable aptitudes and interests to enter the engineering profession.

Membership: Senior Member, those with an engineering degree from a recognized engineering college or university and not less than six years of increasingly important engineering experience, or a degree in a science related to engineering from a recognized college or university and not less than eight years of increasingly important engineering experience, or not less than eleven years of increasingly important engineering experience indicating engineering competency and achievement; Member, an engineering degree from a recognized engineering college or university, or a degree in a science related to engineering from a recognized college or university and at least two years of engineering experience indicating engineering competency and achievement, or not less than five years of engineering experience indicating engineering competency and achievement; Associate, employment in or training for fields related to engineering and interest in the advancement of engineering; Student, those enrolled in a recognized college or university pursuing a course of study leading to a degree in engineering or a science related to engineering. Total membership 700.

Meetings: Annual.

Professional activties: SIVE Achievement Annual Award, Professional Guidance and Education, Lillian Moller Gilbreth Scholarship 
$(\$ 500)$; section activities: Science Fair Awards, local scholarships and prizes, career days.

Publications: Newsletter, monthly, current volume: $6, \$ 3$. Editor: Jeanne Aitchison.

\section{Society of Wood Science and Technology.} President: James S. Bethel, National Science Foundation, Washington 25, D. C. Term expires June 1961. Secretary: John Zerbe, National Lumber Manufacturers Association, Washington, D. C. Term expires June 1961.

History: Organized as American Institute of Wood Engineering, June 1958 at Madison, Wisconsin; name changed to present title 1959. Committees: Education, Visiting Scientist.

Purpose: To establish a professional basis for the pursuit of wood science and technology; to foster improvements in education in wood science and technology; to promote research in this field; and to provide a medium of exchange of ideas and technical information relating to wood science and technology.

Membership: Member, a graduate of a college or university accredited by one of the six regional associations of colleges and secondary schools, or of a curriculum in a foreign school judged by the admissions committee to be equivalent to one offered by accredited U. S. schools, Junior Member, a college graduate who does not meet all of the educational requirements for membership; Student Member, a junior, senior, or graduate student following a course of study leading to qualification for junior membership or regular membership. Total membership 200.

Mcetings: Annual.

Professional activities: Visiting Scientist Program; course and curriculum study of university-level education.

1388. Soil and Crop Science Society of Florida. Everglades Experiment Station. Belle Glade, Fla. President: J. R. Henderson, Agricultural Extension Service, Gainesville, Fla. Term expires November 1960. Secrctary-Treasurcr: R. V. Allison. Term expires November 1960.

\section{History: Organized 1939.}

Purpose: The development and application of soil and crop sciences to Florida agriculture.

Membership: Open to any individual or organization interested in the objectives of the Society. Annual Members, 842; Sustaining Members, 132; Honorary Lifetime Members, 10 ; Libraries, 87. Total membership 1,000.

Meetings: Annual.

Publications: Proceedings, annual, current volume: 19. \$1. Editor: R. T. Allison.
1389. Soil Conservation Society of America, Inc. President: E. L. Sauer, 207 Davenport, Hall, University of Illinois, Urbana, Ill. Term expires December 1960. Executive Secretary: H. Wayne Pritchard, 838 5th Avenue, Des Moines, Iowa. Term indefinite.

History: Founded 1941, incorporated 1949. 107 local chapters.

Purpose: To advance the science and art of good land use.

Membership: Open to individuals with a special interest in soil and water conservation. Total membership 11,141.

Mectings: Annual.

Professional activities: Merit Award to outstanding conservation projects.

Publications: Journals of Soil and Water Conservation, bi-monthly, current volume: 15, $\$ 7.50$. Editor: Walter E. Jeske.

1390. Soil Science Society of America. Secretary: L. G. Monthey, 2702 Monroe Street, Madison, Wis. Term indefinite.

History: Organized 1936; incorporated in Wisconsin 1952; member, American Society of Agronomy. Sections: Western Society of Soil Science; Soil Science Society of Florida. DIvisions: Soil Chemistry: Soil Conservation, Drainage, Irrigation, and Tillage; Soil Fertility; Soil Genesis, Morphology, and Cartography; Soil Physics.

Purpose: To foster all phases of fundamental and applied soil science.

Mcmbership: Active members, 1,250; Associate. 300 . Total membership 1,550.

Meetings: Annual.

Publications: Proceedings, quarterly, current volume; $24, \$ 12$, free to members. Editor: H. E. Myers.

\section{South-Atlantic Association of Obstetri-} cians and Gynecologists. President: John B. Cross, Emory University Clinic, P. O. Box 459. Atlanta, Ga. Term expires 1961. Executive Sccretary: Lawrence L. Hester, Jr., Medical College Hospital, 55 Doughty Street, Charleston. S. C. Term expires 1963.

History: Organized February, 1958; includes Virginia, North Carolina, South Carolina, Georgia, and Florida.

Purpose: To encourage the study, improve the practice, and advance the cause of obstetrics and gynecology; to promote the development of professional interest, and to encourage friendship among such specialists in this area; and through invitation to its membership, to grant recognition of special knowledge in obstetrics 
and gynecology to those who show themselves to be duly qualified.

Membership: Active Fellows must reside within territorial limits of Association and be diplomates of the American Board of Obstetrics and Gynecology, 174: Senior Fellows, 66; Emeritus Fellows; and Honorary Fellows.

Meetings: Annual.

Professional activities: Foundation Prize, awarded annually, to encourage and promote research in problems connected with obstetrics and gynecology.

1392. South Bay Radiological Society, Northern Section. Secretary: George A. Hoeffler, 109 St. Matthews Avenue, San Mateo, Calif. Term expires January 1961.

History: Organized 1947. In December 1959, split into Northern and Southern Sections.

Purpose: To promote the science of radiology ; to review problem cases studied by members in their respective activities; to discuss problems of public relationship; to keep members informed of all latest developments.

Menbership: Open to certified radiologists resident in the area. Total membership approximately 60 .

Meetings: Monthly.

1393. South Bay Radiological Society, Southern Section. Secretary: H. K. Darling, 630 East Santa Clara Street, San Jose, Calif. Term expires December 1960.

History: Organized 1947. In December 1959 split into Northern and Southern Sections.

Purpose: To promote the science of radiology ; to review problem cases studied by members in their respective activities; to discuss problems of public relationship; to keep members informed of all latest developments.

Mcmbership: Open to certified radiologists resident in the area. Total membership 27.

Mectings: Monthly.

1394. South Carolina Academy of Science. President: J. Gray Dinwiảdie, Clemson College, Clemson, S. C. Term expires June 1961. Secretary-Trcasurer: C. Stuart Patterson. Furman University, Greenville, S. C. Term expires June 1962.

History: Founded 1924.

Purpose: To encourage scientific research, to promote the diffusion of useful knowledge, to unify the scientific interest of the state. to keep the standards of teaching science high.

Membership: Open to individuals interested in science, upon recommendation by two regular members. Organizations or individuals may become patron members. Regular and Student, 445; Patron, 25. Total nembership 470.

Meetings: Annual.

Professional activitics: Junior Academy of Science, for the promotion and encouragement of science in the high schools, \$175; American Association for the Advancement of Science Grant, to promote the research of one of the members, $\$ 50$, matched by the Academy; Jefferson Award, for an outstanding paper presented at the annual meeting, $\$ 50$; State-wide program of high school science fairs.

Publications: Bulletin, annual, current volume : 21, free to members. Editor: Frank Tutwiler. Vinthrop College, Rock Hill, S. C.

1395. South Carolina District Branch of the American Psychiatric Association. President: William P. Beckman, 2214 Bull Street, Columbia, S. C. Term expires March 1961. Executive Sccrctary: Joseph J. Nannarello, 1610 Pendleton Street, Greenville, S. C. Term expires March 1961.

\section{History: Organized October 1957.}

Purpose: To foster the progress of psychiatry, to improve psychiatry in the South Carolina area, and to assist the American Psychiatric Association in promoting its aims and objectives.

Mcmbership: For associate membership applicant must have one year's experience in a mental hospital or its equivalent (by May 1st preceding an annual meeting): for full membership applicant must have fulfilled requirements for associate status plus two years' experience in full-time psychiatry. In both cases, references are required from at least two full members or fellows of the American Psychiatric Association. Total memhership 23.

\section{Mectings: Semiannual.}

Profcssional astizitics: Cooperates with the Academy of General Practice for conferences, clinics. seminars, relative to emotional and mental problems which occur in general practice and non-psycliatric specialties.

1396. South Carolina Medical Association. President: Joseph P. Cain, Jr., Mullins, S. C. Term expires May 1961. Exccutive Sccretary: M. L. Meadors, 309 WVest Evans Street, Florence, S. C. Term indefinite.

\section{History: Organized 1848.}

Purpose: To unite the medical profession of the state for social, material, and scientific betterment; to protect the interests of its members; and to enlighten and direct public opinion in regard to medical problems. 
Membership: Members of a component medical society of the South Carolina Medical Association. Full Members, 1,294; Honorary Members, 152; Honorary Fellows, 2 ; Service Members, 5; Junior Menibers, 5. Total membership 1,458 .

\section{Mectings: Annual.}

Publications: Journal, monthly, current volume: 56, \$3. Editor: J. I. Waring.

\section{South Carolina Psychological Association,} Inc. President: Elmore Martin, South Carolina State Hospital, Columbia, S. C. Term expires March 1961. Secretary: John Zuidema, South Carolina Mental Health Commission, Columbia, S. C. Term expires March 1961.

\section{History: Organized April 1954.}

Purpose: To advance psychology as a science, as a profession, and as a means of promoting human welfare.

Membership: Full Members, 40, members of American Psychological Association or those actively working in psychology subsequent to obtaining a master's degree; Professional Affiliates, 12, those interested in psychology; Life, 2; Student Affiliates, students majoring in psychology. Total membership 54 .

Meetings: Semiannual.

Professional activities: Annual Awards for outstanding theoretical papers or research by undergraduate psychology students. Self certification of members for private practice.

Publications: Feedback, quarterly, current volume: 2, free. Editors: Boris Gertz and John Zuidema.

1398. South Carolina Public Health Association. Wade Hampton Office Building, Columbia, S. C. President: Miss Betty Ficquett, South Carolina State Board of Health, IVade Hampton Office Building, Columbia, S. C. Term expires May 1961. Secretary: Miss Emily Anne Easterling, Richland County Health Department, Columbia, S. C. Term expires May 1961.

History: Organized 1921. Technical SectIons: Medical; Public Health Nursing; South Carolina Association of Sanitarians, Inc.; Public Health Education; and Clerical.

Purpose: To promote public health in South Carolina through study and discussion of health needs, and to plan ways and means of meeting those needs.

Membership: Open to individuals employed in South Carolina in any branch of public health work, either official or voluntary; open to corporations and organizations interested in public health as organization members. Total membership 803 .

\section{Mectings: Annual.}

Professional activities: Service Awards for twenty, twenty-five, or thirty years of active public health service by members of the Association.

\section{South Carolina Radiological Society.} President: William A. Matthews, 117 Dotson Street, Rock Hill, S. C. Term expires May 1961. Secretary-Treasurer: George W. Brunson, 1406 Gregg Street, Columbia, S. C. Term expires May 1961.

History: Organized June 1932 as the South Carolina X-Ray Society; name changed to present title May 1952.

Purpose: The advancement of the science of radiology and its maintenance as a specialty in medicine through a closer association of the radiologists of South Carolina, and the promotion of increasingly higher standards of radiological service.

Membership: Open to physicians licensed to practice medicine in South Carolina who devote full or part time to the specialty of radiology, and who are certified (or so qualified) by the American Board of Radiology, and members in good standing in county and state medical societies. Active, 33; Associate, 2; Retired, 1; Honorary, 2. Total membership 38 .

\section{Meetings: Semiannual.}

Professional activities: Robert B. Taft Memorial Trophy, annual award donated by the Society, awarded by the South Carolina Society of X-Ray Technicians to one of its members for the best scientific paper presented at annual meetings.

1400. South Carolina Society of Engineers, Inc. 210 Creason Building, Columbia, S. C. Presidcnt: Harry O'B. Bellinger, City Hall, Columbia, S. C. Term expires January 1961. Secretary-Trcasurer: Albert E. Johnson. Term expires January 1961.

History: Organized November 1929. Branches: Savannah River, Camden.

Purpose: To maintain a high professional standing among the members; to advance the arts and sciences; and to work for the welfare of the state.

Membership: Member, thirty-three years of age, in active practice of his profession at least twelve years, in responsible charge of work for at least five years, qualified to design, as well as direct, engineering work; Associate Member, twenty-seven years of age, in active practice of his profession for at least eight years, responsible charge of work as principal or assistant for at least one year; Junior Member, twenty years 
of age, and in active practice of his profession for four years. Total membership 690.

Meetings: Semiannual.

Professional activities: Student loan fund for scholarships.

Publications: South Carolina Engineer, semiannual, current volume: 13, free to members. Editor: L. A. Emerson, P. O. Box 1116, Columbia, S. C.

1401. South Dakota Academy of Science. President: Ernest J. Hugghins, South Dakota State College, Brookings, S. Dak. Term expires May 1961. Executive Secretary: John M. Winter, University of South Dakota, Vermillion, S. Dak. Term expires May 1961.

History: Founded November 1915; affiliated with the American Association for the Advancement of Science.

Purpose: The promotion of scientific research; the dissemination of scientific knowledge and the diffusion of scientific spirit; the unification of the scientific interests of the state.

Membership: Open to persons with an interest in scientific affairs. Total membership 228.

Mectings: Annual.

Publications: Proceedings of the Academy, annual, current volume: 38, free to nembers. Editor: Willard Read.

1402. South Dakota Pharmaceutical Association. President: Albert H. Zarecky, Pierre, S. Dak. Term expires June 1961. Secretary: Bliss C. Wilson, P. O. Box 38, Pierre, S. Dak. Term indefinite.

History: Organized October 1890, created by Act of State Legislature.

Purpose: To improve the science and art of pharmacy and restrict the sale of medicines to regularly educated and qualified persons, to report annually to the Governor of the state and to recommend the names of at least three members who are practicing pharmacists doing a retail business in the state and otherwise qualified to be appointed as members of the State Board of Pharmacy.

Membership: Registration as a pharmacist in South Dakota. Total membership 949.

Meetings: Annual.

Publications: South Dakota Journal of Medicine and Pharmacy, monthly, current volume: 13, \$2. Editor: Harold S. Bailey, Brookings, S. Dak.

1403. South Dakota Public Health Association. Capital Building, Pierre, S. Dak. President: Cecilia Schuck, State College, Brookings, S. Dak. Term expires Fall 1961. Secretary:
Alice Brady, State Department of Health, Pierre, S. Dak. Term expires Fall 1961.

History: Organized 1933 as South Dakota Health Officers Association; name changed to present title October 3, 1939.

Purpose: To promote public health in South Dakota by legislation, regulation, and development of public interest and activity.

Membership: Active nembers, 88, engaged in public health work in South Dakota; Associate members, 8, interested in public health; Active members in both American Public Health Association and this Association, 19; Sustaining members, 7, with individual representation of 35 active members. Total membership 150 .

Meetings: Annual.

1404. South Dakota Radiological Society. President: Warren Peiper, St. Joseph's Hospital, Mitchell. S. Dak. Term expires May 1961. Secretary: Donald J. Peik, 303 South Minnesota Avenue, Sioux Falls, S. Dak. Term expires May 1961.

History: Organized 1949.

Purpose: Advancement of radiology in South Dakota.

Membership: Must limit practice to radiology. Total membership 12.

Meetings: Annual, in conjunction with the South Dakota State Medical Association.

1405. South Dakota Society of Professional Engineers. Presidcnt: Marvin R. Heck, 1906 South Hawthorne Street, Sioux Falls, S. Dak. Term expires June 1961. Secretary: Duane P. Paulson, 2604 IV est 29th Street, Sioux Falls, S. Dak. Term expires June 1961.

History: Organized at Pierre, South Dakota, May 1957. Became affiliated with National Society of Professional Engineers June 1957.

Purpose: The advancement of professional, social and economic interests of the professional engineer.

Membership: Open to individuals registered as professional engineers. Professional Engineer Members, 90; Junior Members, 8. Total membership 98 .

Meetings: Annual.

1406. South Dakota State Medical Association. Presidcnt: C. Rodney Stoltz, Bartron Clinic, Watertown, S. Dak. Term expires May 1961. Executive Secretary: John C. Foster, 711 North Lake Avenue, Sioux Falls, S. Dak. Term indefinite.

History: Organized 1882, and incorporated May 29, 1891, as the South Dakota State Medi- 
cal Society; name changed to present title April 2. 1906.

Purpose: To promote the science and art of medicine, the protection of public health, and the betterment of the medical profession.

Membership: Members must be duly licensed to practice medicine in the state of South $\mathrm{Da}$ kota. Regular members, 406; government employees, 31: honorary, 24. Total membership 461.

\section{Mcetings: Annual.}

Professional activities: Spafford Memorial Fund, for fellowships at the University of South Dakota; South Dakota Medical School Endowment Association, for furtherance of medical education in South Dakota, capital $\$ 40,000$.

Publications: South Dakota Journal of Medicine and Pharmacy, monthly, current volume: 13 , free to members, \$2. Editor: Robert Vandemark. The Grab Bag, irregular, current volume : 12, free. Editor: John C. Foster.

1407. South Louisiana Geological Survey. President: Troy A. Freund, Bel Oil Corporation, P. O. Box 1442, Lake Charles, La. Term expires February 1961. Secretary: James Smith, Schlumberger Well Surveying Corporation. Box 500, Rt. 3, Lake Charles, La. Term expires February 1961.

History: Organized 1936. Member of American Association of Petroleum Geologists and Gulf Coast Association of Geological Societies.

Purpose: To promote the science of geology as it relates to South Louisiana, and to promote fellowship and cooperation among geologists, petroleum engineers, and others interested in geological problems.

Membership: Open to all persons actively engaged in the geological profession, or persons having an interest in geology. Total membership 96.

Meetings: Monthly.

1408. South Texas Geological Society. President: John S. Rives, 1610 Milam Building, San Antonio, Tex. Term expires December 1960. Executive Secretary: Charles E. Kimmell, 614 Petroleum Commerce Building. San Antonio, Tex. Term expires December 1960.

\section{History: Organized April 1929.}

Purpose: To promote the science of geology, especially as it relates to oil and gas, and other natural resources of South Texas; and to foster fcllowship among its members.

Membership: Members must be eligible for membership in the American Association of Petroleum Geologists. Active, 317; Honorary, 4: Courtesy, 15; Press, 12. Total membership 348.
Meetings: Bimonthly, except July and August. Professional activities: Cash award to best earth science exhibit, San Antonio, Texas, High Schools Science Fair.

1409. Southeastern Allergy Association. President: Susan C. Dees, Duke Hospital, Durham, N. C. Term expires October 1961. Secretary: Katharine Baylis MacInnis, 818 Albion Road, Columbia, S. C. Term indefinite.

History: Organized November 1945. SECTIoNs: Virginia, North Carolina, South Carolina, Georgia, Florida, Alabama, Tennessee, and West Virginia.

Purpose: To bring together those physicians in the southeast who are interested in allergy.

Membership: Open to those with an interest in allergy who are resident in the southeastern states. Total membership approximately 75 .

Mectings: Anuual.

1410. Southeastern Geological Society. President: Harbans S. Puri, P. O. Box 841. Tallahassee, Fla. Term expires 1961. SecretaryTreasurer: William D. Reves, P. O. Box 841, Tallahassee, Fla. Term expires 1961.

History: Organized 1944. Sections : Alabama, Florida, Georgia. Affiliated with American Association of Petroleum Geologists and member society of Gulf Coast Association of Geological Societies.

Purpose: To pronote the science of geology, especially as it relates to petroleum and natural gas in Florida, Georgia, and Alabama; to promote professional and social relationships of members; and to provide a meeting place for presentation and discussion of subjects of mutual interest.

Membership: Active, open to persons engaged in practice of the geological profession and eligible for membership in American Association of Petroleum Geologists: Associate, those interested in geological endeavors, but not eligible for AAPG membership. Total membership 134. Mectings: Monthly.

1411. Southeastern Surgical Congress. 340 Bonlevard, N.E.. Atlanta 12, Ga. President: Willard H. Parsons, 1600 Monroe Street, Vicksburg, Miss. Term expires March 1961. Sccretary-Dirccter: A. H. Letton. Term expires March 1963.

History: Organized and incorporated 1930. Territory comprises the twelve southeastern states and the District of Columbia.

Purpose: To establish and maintain an association of surgeons and allied specialists for the benefit of humanity by advancing the education 
of its membership in the science of surgery, and the ethical and competent practice of its art.

Membership: Completion of training of a minimum duration determined by date of graduation and specialty : physicians graduated prior to 1 January 1938 may be accepted for membership if they are considered to be outstanding surgeons by the Credentials Committee in their respective states; graduation prior to 1 January 1949 and completion of a residency program of at least three years duration in an institution approved for that purpose by the Conference Committee on graduate training in surgery; graduation on or after 1 January 1949 and such training as will permit the applicant to take the examination for certification by the appropriate American Boards of Surgery and Surgical Specialties for Diplomates; physicians who are in specialties other than general surgery who graduated prior to 1 January 1949 and who have completed a residency or preceptor program acceptable to their particular board of certification, and at least one year of the practice of surgery following completion of formal training. Total membership 1,834 .

\section{Meetings: Annual.}

Professional activities: Scientific Paper Award given to the residents in the territory of the Southeastern Surgical Congress for the three best papers: first prize, $\$ 100$ and expenses to annual meeting to present his paper; second prize, $\$ 50$; third prize, $\$ 25$.

Publications: American Surgeon, monthly, current volume: $26, \$ 10$. Editor: George Yeager.

1412. Southern Appalachian Botanical Club. President: Donovan S. Correll, Texas Research Foundation, Renner, Tex. Term expires December 1960. Secretary: Elizabeth Ann Bartholomew, V Vest Virginia University, Morgantown, W. Va. Term expires December 1961.

History: Organized in 1935.

Purpose: To stimulate botanical activity in the southern Appalachian region.

Membcrship: Open to persons with an intertest in botany in the southern Appalachians. Total membership 365.

Mectings: Annual, with Association of Southeastern Biologists.

Publications: Castanea, quarterly, current volume: 25, \$4. Editor: Earl L. Core.

1413. Southern Association of Science and Industry. President: IV. C. Windsor, Jr., 2828 Southland Center, Dallas 1, Tex. Term expires May 1, 1961. Executive Director: IV. R. Knight, 33 Gilmer Street, S. E., Atlanta 3, Ga. Term expires December 31, 1961.
History: Organized 1941.

Purpose: To promote economic development of the South with emphasis upon scientific approach.

Membership: Total membership 200.

Meetings: Irregular.

Publications: Newsletter, monthly, current volume: 1, free to members. Editor: W. R. Knight.

\section{Southern California Academy of Sciences.} Los Angeles County Museum, Los Angeles 7. Calif. President: Fred S. Truxal, 8820 McConnell Street, Los Angeles 45, Calif. Term expires June 1961. Sccrctary: Gretchen Sibley. Term expires June 1961.

History: Organized 1891 as the Southern California Science Association; name changed to present title 1896; incorporated 1907. SECTIONs : Conservation, Health and Sanitation, Zoological Sciences, Botanical Sciences, Agricultural Sciences, Earth Sciences, Anthropology, Physical Sciences, Junior Scientists. Affiliated with the American Association for the Advancement of Science in 1953.

Purposc: To promote intercourse among those who are cultivating science; to elicit public interest in the results of technical investigation; to study natural features and phenomena; and to conserve material illustrating all phases of science.

Mcmbership: Open to professional scientists and those with an interest in science; a junior membership established in 1950. Unlimited Senior, 141 ; Unlimited Student, 20 : Limited Senior, 29; Limited Student, 3; Life, 15; Fellows, 41 ; Honorary.

Mectings: Monthly, September to June.

Publications: Bulletin, three times a year, current volume: $51, \$ 3.50$. Editor: John Adams Comstock.

1415. Southern California Meter Association. President: J. M. Lange, P. O. Box 3249, Terminal Annex, Los Angeles, Calif. Term expires June 1961. Secretary': Glen C. Wilson. 10219 Orange Avenue, South Gate, Calit. Term expires June 1961.

History: Organized July 1927. CommitteE: Standards.

Purpose: To ascertain the facts wherever ditferences of practice, procedure, or opinion regarding fluid meters, instruments or controllers exist; to duly substantiate them by practical and scientific methods, and report them in formal papers designed to be filed among the archives of the Association to the end that the resulting material or information may be equally available to all nembers; to compile and publish a 
booklet of systematically arranged information pertaining broadly to fluid meters, instruments, or controllers.

Membership: Active, 353, those engaged in the measurement and control of fluids other than the design, manufacture, or sale thereof; Associate, 148, those connected with the design, manufacture, or sale of fluid meters, regulators, or any equipment pertaining to the measurement or control of fluids; Sustaining, 69, any firm, company, or corporation which employs individuals who are members; Affiliated, any person interested in the measurement and controls of fluids. Total membership 564.

Meetings: Monthly.

1416. Southern California Psychiatric Society. 427 North Camden Drive, Beverly Hills, Calif. President: Jack B. Lomas. Term expires May 1961. Executive Secretary: Diana Howard. Term indefinite.

History: Formed 1953 as a District Branch of the American Psychiatric Association, covering Los Angeles, San Diego, San Bernardino, Riverside, and Ventura counties; technical and scientific committees, including liaison with the general practice sections of local medical associations, and with paramedical professions associated with psychiatric need, care, and treatment of patients.

Purpose: To further the study of subjects pertaining to the nature, treatment, and prevention of mental disorders; to further the interests, maintenance, and advancement of standards of hospitals for mental disorders, of out-patient clinics, and all other agencies concerned with the medical, social, and legal aspects of these disorders; to further psychiatric education and research; to apply psychiatric knowledge to other branches of medicine, to other sciences, and to public welfare; and to serve the American Psychiatric Association as a District Branch, and to implement the work of the American Psychiatric Association in Southern California.

Membership: Open to members of the American Psychiatric Association and resident in the geographical area, with active practice or retired status in the specialty of psychiatry. Total membership approximately 500 .

Meetings: Monthly.

Publications: News, monthly, current volume: $6, \$ 2$ to non-members, free to members. Editor: Eugene Pumpian-Mindlin.

1417. Southern California Public Health Association. President: Gerald A. Heidbreder, 241 North Figueria Street, Los Angeles 12, Calif. Term expires December 1960. SecrctaryTreasurer: Dorothea Hanson, 111 East First Street, Los Angeles 12, Calif. Term expires December 1960.
History: Organized 1917, affiliated with the American Public Health Association; covers the ten southern counties of California.

Purpose: To assist in the protection and promotion of public health; and to provide for the scientific advancement of members.

Membership: Open to those with an interest in public health. Total membership 150 .

Mectings: Annual.

1418. Southern Electroencephalographic Society. President: Donald S. Bickers, 710 Peachtree Street, N. E., Atlanta 8, Ga. Term expires November 1961. Secretary-Treasurer: Simon E. Markovich, Jackson Memorial Hospital, Miami 36, Fla. Term expires November 1960.

History: Organized December 1948; incorporated April 1949.

Purpose: To promote scientific advancement in the field of electroencephalography and the developments in this field in the southern area; to encourage the development and maintenance of high scientific standards in electroencephalographic laboratories in the South; to provide information on electroencephalography.

Membership: Full Members, 133, doctors of medicine; Associate, 91, technicians. Total membership 224.

Meetings: Annual.

1419. Southern Medical Association. President: Edwin Hugh Lawson, 2700 Napoleon Avenue, New Orleans 15, La. Term expires November 1960. Executive Secretary: Robert F. Butts, 2601 Highland Avenue, Birmingham 5, Ala. Term indefinite.

History: Organized at Chattanooga, Tennessee, October 1906. Draws membership from Alabama, Arkansas, District of Columbia, Florida. Georgia, Kentucky, Louisiana, Maryland, Mississippi, Missouri, North Carolina, Oklahoma. South Carolina, Tennessee, Texas, Virginia, and West Virginia.

Purpose: To develop and foster scientific medicine.

Membership: Open to those individuals who are members of both their county and state societies. Total membership approximately 14,000. Meetings: Annual.

Publications: Southern Medical Journal, monthly, current volume: $53, \$ 10$. Editor: R. H. Kampmeier.

1420. Southern Minnesota Medical Association. President: Charles G. Sheppard, Hutchinson. Minn. Term expires October 1, 1961. Exccutive Secretary: John J. Eustermann, Mankato, Minn. Term expires October 1, 1961. 
History: The Minnesota Valley Medical Association, organized 1880, and the Southern Minnesota Medical Association, organized 1892, combined in 1911 to form the present Association.

Purpose: The interchange of ideas, the discussion of medical problems, and the dissemination of medical knowledge among physicians of southern Minnesota.

Membership: Must be licensed to practice medicine and be members in good standing of a local county medical society. Active; Nonresident; Emeritus; Honorary. Total membership 350 .

\section{Meetings: Annual.}

Professional activities: A silver medal and $\$ 100$ is awarded to the senior student at the University of Minnesota who has shown the greatest proficiency in the fields of medicine and surgery. At the annual meeting, awards are given for the best exhibit, best case presentation, and best medical paper. Scholarship funds for worthy medical students are given annually.

Publications: Minnesota Medicine, monthly, \$5. Editor: A. H. Wells.

\section{Southern Psychiatric Association. Presi-} dent: Conrad Wall, 1520 Louisiana Avenue, New Orleans, La. Term expires October 1961. Executive Secretary: Richard C. Proctor, Bowman Gray School of Medicine, WinstonSalem, N. C. Term expires October 1961.

History: Organized 1935. Secrions: Sixteen southern States and the District of Columbia.

Purpose: To further study of the nature, treatment, and prevention of mental disorders, the interests, maintenance, and advancement of standards of hospitals, out-patient clinics, and all other agencies concerned with medical, social, and legal aspects of these disorders; to advance psychiatric education and research; to apply psychiatric knowledge to other branches of medicine, to other sciences, and to public welfare.

Membership: Requires residence and medical practice in Albama, Arkansas, District of Columbia, Florida, Georgia, Kentucky, Louisiana, Maryland, Mississippi, Missouri, North Carolina, Oklahoma, South Carolina, Tennessee, Texas, Virginia, or West Virginia. Active members, 230; Honorary members; Inactive members; Corresponding members; Life Fellows.

Meetings: Annual.

1422. Southern Society for Clinical Research. President: Laurence $\mathrm{H}$. Kyle, Georgetown University Hospital, 3800 Reservoir Road, N. W., Washington, D. C. Term expires January 1961. Secretary-Treasurer: G. Watson James III, Medical College of Virginia, Richmond, Va. Term expires January 1961.
History: Organized January, 1947. Sections The 16 southern states and the District of Columbia.

Purpose: To stimulate interest in clinical research in the southern states.

Membership: Open to any doctor of medicine, doctor of philosophy, or doctor of science who has accomplished meritorious research in a branch of the medical sciences related to clinical medicine, who resides within the territorial limits of the Society, and who enjoys an unimpeachable reputation in his profession, provided he is not more than forty-five years of age. Active, 177, under forty-five and active in research; Emeritus, 97; Honorary, 5. Total menbership 279.

Meetings: Annual.

1423. Southern Society for Philosophy and Psychology. President: Rubin Gotesky, Northern Illinois University, DeKalb, Ill. Term expires April 1961. Secretary: Dan R. Kenshalo, Florida State University, Tallahassee, Fla. Term expires April 1962.

History: Founded 1904 with 36 charter members; during the 1920 s and 1930 s committees worked effectively to advance the academic status of psychology and philosophy in southern colleges and universities.

Purpose: To promote philosophy and psychology in the southern section of the United States by facilitating the exchange of ideas among those engaged in these fields of inquiry, by encouraging investigation, by fostering the educational function of philosophy and psychology, and by improving the academic status of these subjects.

Membership: Candidates must be engaged professionally in one or both of the fields of philosophy and psychology, give evidence of a substantially equivalent interest and competence, have pursued for two academic years a program of graduate study, be proposed by not fewer than two members of the Society and be recommended by the Council for election. Candidate normally should have a $\mathrm{Ph}$. D. degree and be working professionally in a teaching and/or research capacity.

Meetings: Annual.

Professional activities: Junior Award for best paper of psychological and philosophical interest by members who have had their $\mathrm{Ph}$. D. degree for less than five years.

1424. Southern Society of Anesthesiologists. President: Arthur S. Keats, Jefferson Davis Hospital, Houston, Tex. Term expires March 1961. Secretary-Treasurer: Ray T. Parmley, St. Francis Hospital, IVichita, Kans. Term expires March 1961. 
History: Organized 1946.

Purpose: To disseminate scientific knowledge concerning anesthesiology.

Membership: Qualified doctors of medicine.

Total membership approximately 750 .

Meetings: Annual.

1425. Southern Society of Clinical Surgeons. President: Hugh Trout, Jr., Jefferson Hospital, Roanoke, Va. Term expires April 1961. Secretary: G. V. Brindley, Jr., Scott and White Clinic, Temple, Tex. Term indefinite.

History: Organized April 1927.

Purpose: To continue the advance in medicine and surgery.

Membership: Open to physicians engaged in the practice of surgery, in good standing in their state associations, who reside or practice in the "south." Senior Members, 27; Members, 48. Total membership 75 .

Mectings: Annual.

1426. Southern Society of Orthodontists. President: Charles E. Harrison, 362 Sixth Street South, St. Petersburg, Fla. Term expires November 1961. Secretary: William H. Oliver, 1915 Broadway, Nashville, Tenn. Term expires November 1961.

History: Organized February 1921; incorporated. Society is a component of the American Association of Orthodontists. Committee: Research.

Purpose: To advance the science and art of orthodontics; to encourage and sponsor research; to strive for higher standards of excellence in orthodontic education and practice; and to contribute to dental health service.

Membership: Active, 224, individuals in good standing in local, state, and national organizations with accepted adequate training, now engaged in exclusive practice or teaching of orthodontics, with five years of specialization. Associate, 59, same as active except a requirement of only eighteen months specialization. Total membership 283.

Meetings: Annual.

1427. Southern Surgeons Club. President: David R. Murphy, Jr., 442 LaFayette Street, Tampa, Fla. Term expires 1961. SecretaryTreasurer: Felda Hightower, Bowman Gray School of Medicine, Winston-Salem, N. C. Term expires 1963.

History: Organized October 1940.

Purpose: Interchange of ideas and presentation and discussion of advances in the medical sciences which have surgical significance.
Membership: Members, 42, Board certification in surgery, unanimous vote of the membership. Meetings: Annual.

1428. Southern Surgical Association. President: Francis M. Massie, Lexington Clinic, 1221 South Broadway, Lexington, Ky. Term expires December 1960. Secretary: J. D. Martin, Jr., Emory University, Atlanta 22, Ga. Term expires December 1963.

History: Organized as the Southern Surgical and Gynecological Association, 1887; name changed to present title, 1916.

Purpose: To further the study and practice of surgery, especially in the southern States.

Membership: Members, 344, specialists in surgery with ten years' surgical experience.

Meetings: Annual.

Professional activities: An annual award of an Arthur M. Shipley medal for an outstanding paper presented by a newly elected member.

Publications: Transactions, annual, current volume: 71. Editor: George D. Lilly.

1429. Southwestern Association of Naturalists. Department of Botany, Oklahoma State University, Stillwater, Okla. President: Howard McCarley, Department of Biology, Southeastern State College, Durant, Okla. Term expires April 1962. Secretary-Treasurer: U. T. Waterfall. Term expires April 1962.

History: Organized May 25, 1953. СommitTEES: Conservation, Survey of Museums and Herbarium Collections, Survey of Handbooks and Manuals in Progress.

Purpose: To promote the field study of plants and animals, living and fossil, in the Southwestern United States and Mexico; and to aid the scientific activities of its members.

Membership: Members, 300, interest in the natural history of the Southwest. Membership includes college and university faculty members in the biological sciences.

Meetings: Annual.

Publications: Southwestern Naturalist, quarterly, current volume: $5, \$ 5$. Editor: Don Tinkle.

1430. Southwestern Federation of Geological Societies. P. O. Box 1819, Abilene, Tex. Chairman Executive Conmittee: IV. N. Tindell. Term expires January 1, 1961. Secretary: IV. G. McCampbell, Jr., P. O. Box 1287, Roswell, N. Mex. Term expires January 1. 1961.

History: Organized in 1958 as a Federation of the following nine Geological Societies: Abilene, Dallas, Fort Worth, San Angelo, Lubbock, 
North Texas, South Texas, West Texas, and Roswell, New Mexico.

Purpose: To provide a regional cooperative arrangement among the American Association of Petroleum Geologists' affiliated geological societies of the Southwest, for the advancement of the profession of geology, with particular emphasis on the economic geology of the southwestern region of the United States.

Membership: Nine geological societies in the Southwest affiliated with American Association of Petroleum Geologists, with a total of approximately 3,400 members.

Meetings: Annual.

1431. Southwestern Psychological Association. President: Fillmore Sanford, Department of Psychology, University of Texas, Austin 12, Tex. Term expires April 15, 1961. Secretary: Gordon Anderson, Testing and Counseling Bureau, University of Texas, Austin 12, Tex. Term expires April 15, 1962.

History: Organized in 1954 at the initiative of Texas Psychological Association. Members of American Psychological Association in the states of Arkansas, Kansas, Louisiana, Missouri, Oklahoma, and Texas were invited to form a regional association.

Purpose: To advance psychology as a science, as a profession, and as a means of promoting human welfare.

Membership: Fellows, Members, Associates or Life Members of the American Psychological Association. Total membership approximately 400.

Meetings: Annual.

1432. Southwestern Society of Orthodontists. President: Bibb Ballard, 7713 Inwood Road, Dallas, Tex. Term expires October 1961. Executive Secretary: Thomas Matthews, 8215 Westchester Street, Dallas, Tex. Term expires October 1961.

History: Organized in Dallas, Texas in 1920.

Purpose: To improve the professional ability of the members.

Mcmbership: Limited to individuals who have had five years in exclusive practice as orthodontists. Total membership 212.

Mectings: Annual.

1433. Southwestern Surgical Congress. 301 Pasteur Building, Oklahoma City 3, Okla. President: Howard D. Cogswell, 1602 North Norton Avenue, Tucson, Ariz. Term expires April 1961. Executive Secretary: Mary O'Leary. Term indefinite.
History: Organized 1948 in Oklahoma City, Okla.; includes ten states in the Southwest.

Purpose: To stimulate progress of medical science, particularly surgery, in the states conprising the organization.

Membership: Reputable and legally qualified surgeons and allied specialists, residing in the territory, who graduated from Class A medical colleges. Total membership 1,100.

Meetings: Annual.

Professional activities: Essay Award Contest.

Publications: The American Surgeon, month1y, \$12. Editor: George H. Yeager.

Special Libraries Association. See Addenda, No. 1597.

1434. Speech Association of America. Louisiana State University, Baton Rouge 3, La. Presidcnt: Kenneth G. Hance, Michigan State University, East Lansing, Mich. Term expires December 31, 1960. Secretary: Robert C. Jeffrey, Indiana University, Bloomington, Ind. Term expires July 1, 1963.

History: Organized 1914; incorporated 1950.

Purpose: To serve as a professional organization for individuals interested in speech. Included in its membership are teachers of public speaking, interpretation, drama, speech pathology, speech science, audiology, radio, and television.

Membership: Anyone with an interest in speech as an instrument of thought and social cooperation. Total membership 7,700.

Meetings: Annual.

Publications: Quarterly Journal of Speech, \$5.50. Editor: Richard Murphy. The Speech Teacher, quarterly, $\$ 5.50$. Editor: Karl Robinson. Speech Monographs, quarterly, \$7. Editor: Douglas Ehninger.

1435. Standards Engineers Society. 170 Livingston Avenue, New Providence, N. J. President: R. G. Munroe, Raytheon Company, IVayland, Mass. Term expires December 31, 1960. Sccretary: J. A. Caffiaux, Electronic Industries Association, 11 West 42nd Street, New York, N. Y. Term expires December 31, 1960.

History: Organized in 1947; incorporated in 1956.

Purpose: To provide a means by which standards engineers and others interested in standardization may, in meetings and in publications of the Society, discuss the principles, techniques, effects, and other professional aspects of standardization; to further standardization as a means of enhancing general welfare and to promote knowledge and use of approved standards issued 
by regularly constituted standardizing bodies; to encourage significant additions to the literature of standardization and its formal study; to maintain a high professional standing among standards engineers and professional criteria therefor.

Membership: Member, 795, at least twentyfour-years of age, an engineer in standardization or allied fields who has demonstrated competence in standards engineering or allied technical work of a professional character and has been in active professional practice for at least three years, or a teacher of basic or applied physical science or of industrial engineering who has occupied such position for at least three years in school of recognized standing and has contributed to standardization or the advancement of its principles, or an executive who, for at least three years, has directed important technical or research work in standardization or allied technical fields, or a person regularly employed in standardization or allied technical work for at least six years who, by experience, education, and contribution to the advancement of standardization or the technical literature thereof, has attained a standing equivalent to an engineer; Associate, 187, at least twenty-one years of age, shall be engaged in work of a type required for eventual qualification for the grade of Member; Student, 13, a registered student in basic or applied physical science, engineering, or industrial management in a school of recognized standing; Honorary Life Fellows, 4; Fellows, 18. Total membership 1,000.

Meetings: Annual.

Professional activitics: Joint Standards Engineers Society-American Society for Testing Materials award; various awards for papers on standardization; supply free subscriptions of "Standards Engineering" to colleges; preparation of a Standards Handbook.

Publications: Standards Engineering, six times a year, current volume: 12, $\$ 5$. Editor: C. J. Eiwen, 4042 North 35th Street, Arlington 7, Va. Proceedings of Annual Meetings, annual, $\$ 4.75$. Editor: C. J. Eiwen.

1436. State Medical Society of Wisconsin. 330 East Lakeside Street, Madison, Wis. President: E. D. Sorenson, 104 South Wisconsin Street, Elkhorn, Wis. Term expires May 1961. Secretary: C. H. Crownhart. Term expires January 1, 1961.

History: Established by the Territorial Legislature, 1841. Districts: The state is divided into into thirteen councilor districts, composed of several county societies. The House of Delegates is the legislative body of the Society. The Council is the Board of Trustees with full authority and power of the House of Delegates between annual sessions. Commitrees : Standing committees: Council on Scientific Work; Council on Medical Service; Committee on Medical Education and Hospitals; Committee Hospital Relations; Committee on Cancer. Council Committees: Blood Banks; Civil Defense; Military Medical Service; Veterans Medical Service.

Purpose: To federate and bring into one compact organization the entire medical profession of the State of Wisconsin, and to unite with similar societies of other states and territories of the United States to form the American Medical Association; to extend medical knowledge and advance medical science; to elevate the standard of medical education, and to secure the enactment and enforcement of just medical laws ; to promote friendly intercourse among physicians; and to enlighten and direct public opinion in regard to the great problems of state medicine, so that the profession shall become capable and honorable within itself, and more useful to the public, in the prevention and cure of disease, and in prolonging and adding comfort to life.

Membership: Members must be licensed to practice medicne in the State of Wisconsin. Full dues-paying members, including regular members, life members, affiliate members, associate members, educational members, and members whose dues are waived or remitted by official action of the Society. Total membership 3,600.

\section{Meetings: Annual.}

Professional activities: Council Award granted to physician who has distinguished himself in the field of medicine, served in some outstanding capacity or been of service to his profession through organized medicine. President's Award to outstanding non-medical person who has made a major contribution to public health. Charitable, Educational and Scientific Foundation of the State Medical Society supporting medical, scientific and socio-economic research, loans to medical students and postgraduate scientific education.

Publications: Wisconsin Medical Journal, monthly, current volume: 59, \$5. Managing Editor: C. H. Crownhart.

\section{Structural Engineers Association of Cali-} fornia. President: J. Albert Paquette, 417 Market Street, San Francisco 5, Calif. Term expires December 31, 1960. Secretary: Harold S. Kellam, 251 Kearney Street, Room 202, San Francisco 8, Calif. Term expires Decenber $31,1960$.

History: Organized 1932. Sections: Structural Engineers Association of Northern California, San Francisco; Structural Engineers Association of Central California, Sacramento; 
Structural Engineers Association of Southern California, Los Angeles.

Purpose: To promote the highest standards of structural engineering, to the end that the practice of structural engineers shall serve and advance the best interests of the client, the community, and the public.

Membership: All members of the local associations are members of the state association, and most are licensed civil or structural engineers in the state. Total membership approximately 1,200 .

Meetings: Annual.

1438. Structural Engineers Association of Oregon. 717 Board of Trade Building, Portland 4, Oreg. President: Lloyd A. Pajunen, 4129 South East McLoughlin Boulevard, Portland 2, Oreg. Term expires September 1961. Secretary-Treasurcr: Miles R. Abel, 9670 South West Eagle Lane, Beaverton, Oreg. Term expires September 1961.

History: Organized November 1949 ; active in building code changes, discussions of legislative matters affecting structural engineering, earthquake studies, studies of all types of engineering materials singly, or in manufactured or constructed forms.

Purpose: To provide an active association for better acquaintance and understanding among engineers; to encourage practice in accordance with ethical standards; to promote the highest standards of structural engineering to the end that the best interests of the client, the community, the public, and the profession will be served; and to cooperate with other professional organizations.

Membership: Corporate Member, 55, registered engineer in Oregon, in responsible charge of design, construction, or research relating to structures of major importance, or engaged in teaching the profession of structural engineering ; Affiliate Member, 12, not registered in Oregon, regularly engaged in a business relative to structural engineering, or regularly employed in the field of structural engineering; Life Member, corporate member who has brought distinction, eminence, and esteem to his profession and to the Association by virtue of his wide reputation, outstanding professional accomplishments, and his long and devoted professional life. Total membership 67.

Mectings: Monthly.

Professional activities: Sponsorship of Northwest Structural Engineers Associations Conference every third year.

1439. Structural Engineers Association of Southern California. President: Jack N. Sparling, 812 West 8th Street, Los Angeles 17, Calif.
Term expires December 31, 1960. Executive Secretary: Don Wiltse, 2808 Temple Street, Los Angeles 26, Calif. Term indefinite.

History: Organized 1929.

Purpose: Activity in technical matters in field of structural engineering.

Membership: Total membership 723.

Meetings: Monthly.

Professional activities: Stanford University scholarships.

Publications: Bulletin, monthly, free to members. Editor: Don Wiltse.

1440. Student American Medical Association. 430 North Michigan Avenue, Chicago 11, 111. President: IVilliam Waddell, 120 Newell Street, Durham N. C. Term expires May 7, 1961. Executive Director: Russell F. Staudacher. Term indefinite.

History: Organized December 29, 1950; incorporated November 23, 1951.

Purpose: To advance the profession of medicine, to contribute to the welfare and education of medical students, and to prepare members to meet the social, moral, and ethical obligations of their profession.

Membership: Limited to students, interns, and residents. Total membership 50,000 .

Meetings: Annual.

Professional activities: Annual competition for scientific exhibits and papers, and for medical photography.

Publications: New Physician, monthly, current volume: 9, free to members. Editor: Edward R. Pinckney.

1441. Suffolk County (New York) District Branch Society of the American Psychiatric Association. President: Edward H. Malone. South Oaks, Amityville, N. Y. Term expires June 1961. Executive Secretary: Henry Tanner, Northport Veterans Administration Hospital, Northport, N. Y. Term indefinite.

History: Organized in 1955; absorbed the Long Island Psychiatric Society.

Purpose: To promote the aims of the American Psychiatric Association; to disseminate factual information relating to psychiatry and mental health; to foster and encourage cooperation between the Society's physicians and the other physicians and agencies in Suffolk County; to promote scientific meetings and conferences within the Society, or in conjunction with other professional groups; to improve the standards of psychiatric professional skill in the community. 
Membership: Limited to Associate Members, Members, or Fellows of the American Psychiatric Association: Members (one class of membership only), 57. Total membership 57.

Mectings: Five times a year.

Professional activities: Frequent seminars for the profession and laity

1442. Sussex Engineering Society. P. O. Box 154, Seaford, Del. President: Stanley M. Carter. Term expires June 1, 1961. Executive Secretary: Harry L. Holman. Term expires June 1, 1961.

History: Organized March 1950. Affiliate, Delaware Council of Engineering Societies.

Purpose: To provide a medium for engineering activities.

Membership: Registered professional engineers, with engineering degrees from recognized colleges or universities, members of national engineering societies, and eight years' approved experience in engineering practice. Total membership 110.

Meetings: Monthly, September through May.

Professional activities: High school student guidance; publicity to further engineering profession.

1443. Sweadner Entomological Society. Carnegie Museum, Pittsburgh 13, Pa. President: Robert Surdick. Term expires December 31, 1960. Secretary-Treasurer: Harry Katz, 2039 5th Avenue, Pittsburgh 19, Pa. Term expires December 31, 1960.

History: Organized 1951.

Purpose: To encourage young people in the study of entomology; to stimulate amateur and professional entomologists.

Membership: Open to any person interested in entomology, professional or non-professional. Total membership 90 .

Meetings: Monthly.

1444. Swedish Engineers' Society of Chicago. 503 Wrightwood Avenue, Chicago 14, Ill. President: Earl Viking, 3645 North Wilton Avenue, Chicago, I11. Term expires May 31, 1961. Secretary: Michael J. Pasternock, 5412 West North Avenue, Chicago 39, Ill. Term expires May 31, 1961.

History: Organized October 10, 1908; incorporated in Illinois June 25, 1912.

Purpose: To promote engineering education and knowledge.

Membership: Active members, 200, Swedish descent, technical education or ability in engineering; Associate, 100, persons interested in the activities and wishing to further the aims of this Society. Total membership 300.

Meetings: Weekly.

Professional activities: Fellowship Foundation in Nuclear Sciences; monthly lectures.

Library: 3,100 volumes. Subject emphasis: Technical engineering services.

1445. Tau Beta Pi Association, Inc. Perkins Hall, University of Tennessee, Knoxville, Tenn. President: Donald A. Dahlstrom, Eimco Corporation, 301 South Hicks Road, Palatine, I11. Term expires December 1962. Secretary-Treasurer: Robert H. Nagel. Term indefinite.

History: Established at Lehigh University June 1885 as honor society in engineering colleges. 103 active chapters and 27 alumni chapters.

Purpose: To mark in fitting manner those who have conferred honor upon their Alma Mater by distinguished scholarship and exemplary character, or by attainments as alumni in the field of engineering; to foster a spirit of liberal culture in engineering colleges of America; to promote welfare and advancement of the engineering profession and of engineering education.

Membership: Undergraduates, who form the chapters, must stand in the highest fifth of their classes to be eligible; men from the first eighth are elected during their junior years, the balance of the highest fifth are eligible at the beginning of their senior years. Alumni who would have qualified had chapters existed at their colleges may be elected at any time. Alumni who may not have been eligible scholastically, but who have shown merit by their success as engineers, are elected in limited numbers. Total membership 106,000.

Mcetings: Annual.

Professional activities: Tau Beta Pi Fellowships, six to eight annually, awarded to outstanding student members for a year of graduate work; a student loan fund is available to members for undergraduate or graduate study.

Publications: Bent, quarterly, current volume: 51,1 st four years free to members, thereafter $\$ 2$. Editor: Robert H. Nagel. Council Bulletin, quarterly, current volume: 33 , free to members. Editor: Leonard A. Cohn.

1446. Technical Association of the Pulp and Paper Industry. 360 Lexington Avenue, New York 17, N. Y. President: James R. Lientz, Union Bag-Camp Paper Corporation, Savannah, Ga. Term expires February 1961. Executive Sccretary: P. E. Nethercut. Term expires February 1961. 
History: Founded 1915. Sections: Chicago, Delaware Valley, Empire State, Golden Gate, Gulf Coast, Indiana, Italian, Kalamazoo Valley, Lake Erie, Lake States, Maine-New Hampshire, New England, Ohio, Pacific, St. Louis, Southeastern, Virginia-Carolina.

Purpose: Search for and dissemination of knowledge relating to pulp and paper.

Membership: Active members, college degrees, ten years' experience in pulp and paper industry ; Associate, five years' experience in that industry. Total nembership 9,600.

Mectings: Ten annually.

Professional activities: Technical Association of the Pulp and Paper Industry Medal, for outstanding contribution to technical advancement of the industry; research funds.

Publications: Tappi, monthly, current volume : 43, free to members. Editor: R. G. Macdonald. Yearbook, free to members. Bibliography of Paper Making, annual, free to members. Editor: J. Weiner.

1447. Technical Club of Dallas, Texas. 1012 Fidelity Union Life Building, Dallas 1, Tex. President: Ronald A. Waterhouse, The Atlantic Refining Co., P. O. Box 2819, Dallas 21, Tex. Term expires December 31, 1960. Secretary: Charles S. Frazier, The A. J. Boynton Co., 1012 Fidelity Union Life Building, Dallas 1, Tex. Term expires December 31, 1960.

\section{History: Organized July 2, 1919.}

Purpose: To promote the interchange of ideas, especially as regards the social, civic, and professional advancement of the technical professions; to increase acquaintance among the members of the professions; to make available to the public the technical knowledge of the nembership.

Membership: Persons who follow one of the commonly recognized lines of applied science. Total membership 160.

Mectings: Weekly, September through May.

Professional activities: Annual full tuition award to freshman student entering the School of Engineering, Southern Methodist University ; annual gift, $\$ 500$, to Southern Methodist University, for the purchase of laboratory equipment; annual prizes awarded to the two students graduating from Southern Methodist University with the highest class standing.

Publications: Technician, weekly, volumes unnumbered, free. Editor: John A. Savage, School of Engineering, Southern Methodist University.

1448. Technical Society of Knoxville. President: J. W. Crabtree, P. O. Box 1951, Knoxville, Tenn. Term expires December 31, 1960.
Secretary: Ellsworth S. Weed, Tennessee Valley Authority, Union Building, Knoxville, Tenn. Term expires December 31, 1960.

\section{History: Organized June 6, 1921.}

Purpose: Advancement of technical and allied arts and sciences; to aid the public in solution of civic problems involving engineering or scientific phases; to facilitate social intercourse and maintenance of high professional standards of members.

Membership: Degree from accredited school of engineering, architecture, or science, or twenty-four years of age with minimum of four years' experience in a technical field. Total membership 260.

Meetings: Weekly.

Publications: Soupcon, weekly, current volume: 24, \$1. Yearbook, free to members.

1449. Technology Club of Syracuse, and Affiliated Societies. 407 James Street, Syracuse 3, N. Y. President: IVilliam E. Good, 700 Tulip Street, Liverpool, N. Y. Term expires April 1, 1961. Executive Secretary: Harry Bratt. Term expires August 31, 1961.

History: Organized October 5, 1903, as Technology Club; name changed to present title 1921. Eight technical affiliates.

Purpose: Advancement of the engineering profession.

Membership: Requires interest in technology. Regular members, 650; Non-resident, 70; Junior, 25 ; Honorary, 8. Total membership 753. Meetings: Biweekly, October to April.

Professional activities: J. E. Sweet Lecture Fund, original principal $\$ 20,000$.

1450. Teknik Club. Secretary: Alfred C. Nelson, 1021 South Clayton Way, Denver 9, Colo. Term expires May 1, 1961.

History: Organized 1911.

Purpose: To promote professional and social intercourse among men engaged in scientific and technical activities.

Membership: By invitation to men in scientific pursuits. Resident members, limited to 60 ; Non-resident, unlimited; Honorary. Total membership 103.

Meetings: Monthly, September through May.

1451. Tennessee Academy of Ophthalmology and Otolaryngology. President: D. Isbell, 535 McCallie Avenue, Chattanooga, Tenn. Term expires April 1961. Secretary: WVilliam F. Murrah, 1720 Exchange Building, Memphis, Tenn. Term expires April 1961. 
History: Organized 1915. Section of Tennessee State Medical Association.

Purpose: To promote and advance the science and art of medicine of the eye, ear, nose, and throat, and to encourage the study of the relationship of these specialties to surgery, general medicine, and hygiene.

Membership: Requires practice in above named specialties for at least one year, and membership in local, county, or State medical society. Total membership 120.

Meetings: Annual.

1452. Tennessee Academy of Science. President: C. P. Keim, Oak Ridge, Tenn. Term expires December 1960. Secretary: James L. Wilson, Belmont College, Nasbville, Tenn. Term expires December 1960.

History: Organized 1912, at Nashville, Tenn. Affiliate, American Association for the Advancement of Science. Tennessee Ornithological Society, Barnard Astronomical Club, Tennessee Science Teachers Association, and Tennessee Psychological Association are affiliated societies. Sections: Botany, Chemistry, Engineering, Geology-Geography, Mathematics, Medical Sciences, Physics-Astronomy, and Zoology.

Purpose: To promote scientific research and diffusion of scientific knowledge; to secure communication between persons engaged in scientific work, especially in Tennessee; to assist, by investigation and discussion, in developing and publicizing the resources of the State.

Membership: Open to all persons in sympathy with the purposes of this Academy. Total membership 718 .

\section{Meetings: Annual.}

Professional activities: Sponsorship of a Junior Academy of Science, and a Collegiate Division.

Publications: Journal, quarterly, current volume: $35, \$ 4$, teachers below college level $\$ 2$. Editor: Helen L. Ward.

1453. Tennessee Archaeological Society. 6 Hesler Biology Building, University of Tennessee, Knoxville, Tenn. President: H. D. Green, 1787 Peabody Street, Memphis,Tenn. Term expires October 31, 1960. SecretaryTreasurer: T. M. N. Lewis. Term indefinite.

History: Organized 1944, by Department of Anthropology, University of Tennessee.

Purpose: To foster active interest in discovery and preservation of archacological remains and data in harmony with scientific methods.

Membership: Open to persons with interest in the archaeology of Tennessee and adjacent States. Total membership 550.

Meetings: Annual.
Publications: Tennessee Archaeologist, semiannual, current volume: $15, \$ 3$. Editor: T. M. N. Lewis. Newsletter, irregular, current volume: 5, free to members. Editor: T. M. N. Lewis.

\section{Tennessee Pharmaceutical Association.} 406 Vendome Building, Nashville, Tenn. President: James H. Gentry, 602 West Main Avenue, Knoxville, Tenn. Term expires December 31, 1960. Secretary: Tom C. Sharp. Term expires December 31, 1960.

\section{History: Organized 1884.}

Purpose: To assist in educational and professional training; to secure and disseminate information; to cooperate with other organizations having similar aims; and to assist in passing legislation favorable to the profession.

Membership: Registered pharmacists or drug store owners and proprietors. Total membership 763.

Meetings: Annual.

Publications: Tennessee Pharmacist, monthly, free to members. Editor: Tom C. Sharp.

1455. Tennessee Psychiatric Association. President: Carrol C. Turner, 5650 Raleigh La Grange Road, Memphis, Tenn. Term expires 1961. Secretary-Treasurer: Bruce E. Walls, 4160 Tuckahoe Road, Memphis 17, Tenn. Term expires 1961.

History: District Branch of the American Psychiatric Association.

1456. Tennessee Psychological Association. President: George Copple, Department of Psychology, Vanderbilt University, Nashville, Tenn. Term expires October 1960. SecretaryTreasurer: Gordon N. Cantor, Psychology Department, George Peabody College, Nashville, Tenn. Term expires October 1960.

History: Organized 1948; incorporated 1954.

Purpose: To advance psychology as a science, as a profession, and as a means of promoting human welfare.

Membership: Members: (a) Membership in the American Psychological Association and residence in Tennessee; or (b) Application for membership in the American Psychological Association, residence in Tennessee, and Master of Arts degree, and one year of experience in psychology or two years graduate study in psychology. Associate members: (a) graduate students in psychology not yet eligible for membership in the American Psychological Association with residence in State; or (b) eligible psychologists not members of American Psychological Association with residence in State; or 
(c) members of related sciences and professions with residence in State. Members 141; Associate members 13 .

\section{Meetings: Annual.}

\section{Tennessee Public Health Association. 627}

Cordell Hull Building, Nashville, Tenn. President: R. B. Turnbull, 842 Jefferson Avenue, Memphis, Tenn. Term expires October 7, 1960. Secretary-Treasurer: Cecil B. Tucker. Term expires December 31, 1960.

\section{History: Organized October 4, 1939.}

Purpose: To protect and promote public and personal health in the State of Tennessee.

Membership: Active membership open to health workers connected with official agencies and to persons engaged in teaching or research in public health. Associate membership open to members of non-official agencies and to laymen interested in the promotion of public health. Honorary membership limited to individuals who have shown distinguished interest in public health, with no more than two elected by the executive committee annually. Total membership 751 .

Meetings: Annual.

1458. Tennessee Radiological Society. President: George K. Henshall, Jr., 311 Medical Arts Building, Chattanooga, Tenn. Term expires April 1961. Secretary: J. J. Range, P. O. Box 324, Johnson City, Tenn. Term expires April 1961.

\section{History: Organized April 11, 1934.}

Purpose: To organize radiologists of the State of Tennessee into a society to encourage a high standard of professional competence and ethics; to acquire, preserve and disseminate information regarding the study and practical application of roentgenology, radium therapy, nuclear medicine and other related branches.

Membership: Active members shall be graduates of recognized medical colleges, members in good standing of the Tennessee State Medical Association, and of the county medical society of the county in which they reside, and shall devote at least $80 \%$ of their practice to some phase of radiology. This shall include doctors of philosophy in physics and biophysics who are primarily engaged in medical work or research and are associated with medical doctors who are members of this Society. Honorary members are those individuals whom the Society wishes to honor and who shall be recommended by the President and Executive Committee for such honors. Regular members 62; honorary members 15 .

Meetings: Annual.
1459. Tennessee Science Teachers Association. 321 Seventh Avenue North, Nashville, Tenn. President: Joe D. Reding, Treadwell High School, Memphis, Tenn. Term expires April 1, 1961. Secretary: Mrs. Vivian Finch, Huntingdon High School, Huntingdon, Tenn. Term expires April 1, 1961.

History: Organized 1946 by the Science Section of the Tennessee Education Association. Constitution revised 1951.

Purpose: To encourage the improvement of science teaching in Tennessee; to promote mutual exchange of good teaching practices among teachers; to explore new techniques and procedures in science teaching; to discover and cultivate science talent among Tennessee youth.

Membership: Limited to members of the Tennessee Education Association in the Science Section. Total membership approximately 125 .

Mectings: Annual, at time of the Tennessee Education Association meeting in March or April.

1460. Tennessee State Horticultural Society, Inc. President: J. F. Womble, Greenfield, Tenn. Term expires November 1960. Secretary: B. S. Pickett, University of Tennessee, Knoxville, Tenn. Term expires November 1960.

History: Organized in late 1890's as the East Tennessee Horticultural Association; name changed to present title in 1905; incorporated January 1919.

Purpose: To acquire and disseminate scientific and practical horticultural information by scheduled talks, demonstrations, and publications.

Membership: Persons interested in horticulture. Total membership 285.

\section{Meetings: Annual.}

Publications: Proceedings, annual. Editor: B. S. Pickett. Tennessee Horticulture, monthly. Editor: A. N. Pratt, State Department of Agriculture, 404 State Office Building, Nashville 3, Tenn.

1461. Tennessee State Medical Association. 112 Louise Avenue, Nashville 5, Tenn. President: Ralph O. Rychener, 1720 Exchange Building, Memphis 3, Tenn. Term expires April 10, 1961. Executive Director: J. E. Ballentine. Term indefinite.

History: Organized 1830 as the Tennessee Medical Society; name changed to present title 1901. Composed of fifty county medical societies. Maintains thirty-seven standing and special committees. 
Purpose: To federate and to bring into one compact organization through the component societies, the medical profession of the State, and to unite with similar associations in other states to form the American Medical Association.

Membership: Must be certified by a component medical society and be licensed to practice medicine in Tennessee. Anyone classed as a veteran member must have passed his seventieth birthday. Total membership 2,736: active 2,501, associate 40, veteran 195 .

Meetings: Annual.

Professional activities: Award to the Outstanding Physician of Tennessee. Annual.

Publications: Journal, monthly, current volume: 53, \$5. Editor: R. H. Kampmeier.

\section{Tennessee State Society of Anesthesiolo-}

gists. Mid State Medical Center, 2012 Church

Street, Nashville 4, Tenn. President: Mary

Frances Poe, 860 Madison Avenue, Memphis,

Tenn. Term expires 1961. Secretary: J.

Sumpter Anderson, Jr. Term expires 1961.

History: Organized 1948.

Purpose: To advance the art and science of anesthesiology, and to stimulate interest and promote progress in the scientific, cultural, economic, and ethical aspects of this specialty.

Mombership: Physicians engaged in the practice of medicine who are especially interested in anesthesiology. Active members 55; Junior members 16.

Meetings: Annual.

1463. Texas Academy of Science. Department of Geography, University of Texas, Austin 12, Tex. President: Gordon K. Teal, Texas Instruments, Inc., Dallas, Tex. Term expires December 31, 1960. Secretary-Treasurer: Lorrin Kennamer, Department of Geography, University of Texas, Austin, Tex. Term expires December 31, 1960.

History: Organized 1892; reorganized and incorporated as a nonprofit organization 1929. Five Sections: Physical, Biological, Social, Geological, and Conservation. Affiliates: Texas Section of the American Association of Physics Teachers, Texas Section of the Mathematical Association of America, and the Texas Chapter of the National Council of Geology Teachers.

Purpose: To foster and encourage better science teaching and science student activities; to further the work of scientists; to facilitate cooperation among scientists.

Membership: Interest and work in science and nomination by two members. Total membership 1,000 .
Meetings: Annual.

Professional activities: Sponsors Junior Academy and Collegiate Academy as well as Science Fairs. Cooperates with the American Association for the Advancement of Science to furnish research funds for secondary and collegiate students.

Publications: Texas Journal of Science, current volume: 12, \$5. Editor: Clark Hubbs, University of Texas, Austin, Texas.

1464. Texas District Branch Society of the American Psychiatric Association. President: Clarence S. Hoekstra, 8215 Westchester, Dallas, Tex. Term expires May 1961. Secretary-Treasurer: E. Ivan Bruce, Jr., 1014 Strand, Galveston, Tex. Term expires May 1961.

History: Organized 1956 in keeping with the policy of the American Psychiatric Association to broaden representation of the membership in APA operations.

Purpose: To promote the science, art and practice of psychiatry in the State of Texas in cooperation with, and as a constituent part of, the American Psychiatric Association.

Membership: Open to members, associate members or fellows of the American Psychiatric Association who are practicing in the State of Texas. Total membership 166.

Mectings: Semiannual.

1465. Texas Herpetological Society. President: John E. Werler, Houston Zoological Gardens, 509 City Hall, Houston 2, Tex. Term expires May 1961.

History: Organized November 18, 1938; first field meet April 15-16, 1939, at San Marcos, Tex.

Purpose: To promote the discovery and dissemination of knowledge of amphibians and reptiles; to encourage the study of reptiles and amphibians in Texas; and to stimulate fellowship among herpetologists of Texas and the Southwest.

Membership: Scientific interest in herpetology. Total membership 85.

\section{Mcetings: Annual.}

1466. Texas Industrial Medical Association, Inc. P. O. Box 472, Pasadena, Tex. President: Noble B. Daniel, 317 State Line, Texarkana, Tex. Term expires April 23, 1961. SecretaryTreasurer: J. G. Burdick, Ethyl Corporation, P. O. Box 472, Pasadena, Tex. Term expires April 23, 1961.

History: Founded April 25, 1955 at Fort Worth with fifteen charter members. Com- 
ponent society of the Industrial Medical Association.

Purpose: To promote the art and science of industrial medicine and surgery; to encourage conservation and improvement of health of employees; to encourage research.

Membership: Degree of Doctor of Medicine, member of county medical society, three years experience in the practice of medicine and two years practice in industrial medicine and surgery.

Mectings: Twice per year.

1467. Texas Medical Association. 1801 North Lamar Boulevard, Austin, Tex. President: May Owen, P. O. Box 1719, Fort Worth, Tex. Term expires April 1961. Executive Secretary: C. Lincoln Williston, 1801 North Lamar Boulevard, Austin, Tex. Term indefinite.

History: Organized 1853; reorganized 1904. Chartered by the State of Texas 1901, extended for fifty years effective May 1951. 115 component county medical societies. Councils: Annual Session, Constitution and By-Laws, Medical Education and Hospitals, Medical Jurisprudence, Medical Service and Insurance, Public Relations and Public Service, Scientific Advancement.

Purpose: To federate and bring into one compact organization the entire medical profession of the State of Texas, and to unite with similar associations of other states to form the American Medical Association; to extend medical knowledge and to advance medical science; to elevate the standard of medical education; to secure the enactment and enforcement of just medical laws.

Membership: Open to physicians legally registered to practice medicine in the State of Texas. Total membership 8,206.

Meetings: Annual.

Professional activities: Sam E. Thompson, M.D. Fund for loans to needy and deserving medical students at the University of Texas Medical Branch at Galveston. Anson Jones Award for outstanding lay medical reporting in Texas.

Publications: Texas State Journal of Medicine, monthly, current volume : $56, \$ 6$. Managing Editor: Harriet Cunningham.

Library: 30,000 medical volumes.

1468. Texas Neuropsychiatric Association. President: Clarence S. Hoekstra, 8215 Westchester, Dallas, Tex. Term expires May 1961. Secretary-Treasurer: E. Ivan Bruce, Jr., 1014 Strand, Galveston, Tex. Term expires May 1961.
History: Organized October 19, 1928 as the Texas Neurological Society; name changed to present title November 1944.

Purpose: To advance scientific knowledge among the membership in the fields of psychiatry, neurology, and neurosurgery.

Membership: Physicians eligible for membership in the American Medical Association, who confine their practice strictly to neurology and/or psychiatry, neurosurgery, neuroanatomy, or neurophysiology. Total membership 266.

Meetings: Annual.

1469. Texas Pharmaceutical Association. Austin Savings Building, Austin 1, Tex. President: R. L. Brusenhan, c/o Prescription Laboratory, 500 Navarro Street, San Antonio, Tex. Term expires July 1961. Executive Secretary: C. J. M. Roesch, Austin Savings Building, Austin 1, Tex. Term indefinite.

History: Organized 1879 in Dallas.

Purpose: To attain the highest standards for professional pharmacy; to improve the quality of drug store merchandising; and to promote greater consumer acceptance of the drug store as the dependable outlet for all drug products in Texas.

Membership: Open to any registered pharmacist in State of Texas, owner or corporation in the retail drug business employing registered pharmacists, of good moral character and professional standing, who shall have attained the age of twenty-one. Total membership 4,000.

Meetings: Annual.

Professional activities: Pharmacist of Year Award, DSA Award, Scholarships for pharmacy students.

Publications: Texas Pharmacy, monthly, current volume: 90, \$3. Editor: C. J. M. Roesch.

1470. Texas Psychological Association. President: Ruth Hubbard, Veterans Administration Hospital, Waco, Tex. Term expires December 1960. Secretary-Treasurer: Gladys Guy Brown, 3520 Cedar Springs Road, Dallas 19, Tex. Term expires December 1961.

History: Organized 1947. Committees : Constitutional Revision, Ethics, Legislation, Membership, Nominations and Elections, Program, Public Relations, Publications, Relationships with Educational Agencies.

Purpose: To advance psychology as a science, profession, and means of promoting human welfare.

Membership: Requires membership in American Psychological Association. Total membership 250.

Meetings: Annual.

Publications: Newsletter, quarterly, current volume; 3 , free to members. 
1471. Texas Public Health Association. P. O. Box 5192, Austin 31, Tex. President: William S. Brumage, State Health Department, Austin, Tex. Term expires March 8, 1961. Executive Secretary: Joseph N. Murphy, Jr., P. O. Box 5192 Austin 31, Tex. Term expires March 5, 1961.

History: Organized 1925; chartered 1932. Sections : Clerical, Dental Health, Health Education, Health Officers, Laboratory, Engineering, Nursing, Sanitation, Veterinary Public Health, Vital Statistics.

Purpose: To protect and promote the health of the people of Texas.

Membership: Persons actively engaged in schools, colleges, universities, official and nonofficial public health agencies as designed by the Governing Council. Persons interested in public health are eligible for associate membership. Sustaining membership open to individuals or corporations interested in public health.

Meetings: Annual.

Professional activities: Honorary Life Membership, B.T. Bryant Memorial Award, Scholarship Award to Texas high school student.

Publications: Journal, bimonthly, current volume : $12, \$ 3$. Editor: Jeff L. Lewis.

1472. Texas Radiological Society. 1216 Pennsylvania Avenue, Fort Worth, Tex. President: Delphin von Briesen, 1501 Arizona Street, El Paso, Tex. Term expires January 21, 1961. Executive Secretary: R. P. O'Bannon, 1216 Pennsylvania Avenue, Fort Vorth, Tex. Term expires January 21, 1961.

\section{History: Organized May 1914.}

Purpose: To encourage a high standard of professional competence and ethics; to acquire, preserve and disseminate information regarding the study and practical application of roentgenology, radium therapy, nuclear medicine, and other related branches of medical physics.

Membership: Degree of Doctor of Medicine and good standing with the state and county medical society, and devote eighty per cent practice to some phase of radiology.

Meetings: Annual.

Professional activities: Annual lecture on radiology at each of the medical schools in the State.

1473. Texas Society of Anesthesiologists. The Medical Towers, Houston 25, Tex. President: Randle J. Brady, 3317 Binz Street, Houston 4, Tex. Term expires April 1961. SecretaryTreasurer: Eugene L. Slataper, The Medical Towers, Houston 25, Tex. Term expires April 1961.
History: Organized 1936; incorporated April 1948.

Purpose: To promote the highest standards of anesthesiology; to cooperate with surgeons and hospitals for betterment of the patient; to encourage specialization in anesthesiology; to cooperate with the American Society of Anesthesiologists, Inc. in furthering the development and advancement of anesthesiology.

Membership: Active membership for those doctors of medicine limiting their work to anesthesiology; Associate membership for scientists who have attained a position of eminence in this field; Junior membership for medical doctors in training in field of anesthesiology. Active members 165; Junior members 65 .

Meetings: Annual.

1474. Texas Society of Pathologists, Inc. Austin, Tex. President: O. J. Wollenman, Jr., St. Joseph's Hospital, 1401 South Main Street, Fort Worth, Tex. Term expires 1961. Secretary-Treasurer: Vernie A. Stembridge, Pathology Department, Southwestern Medical Schoo1, Dallas 35, Tex. Term expires 1963.

History: Organized 1921; incorporated 1954. Oldest state society of pathologists in the United States.

Purpose: To extend scientific knowledge in pathology, to promote higher standards, to secure enactment and enforcement of just laws concerning practice of pathology, to enlighten the public, and to cooperate with other organizations in attaining these aims.

Membership: Open to medical doctors, licensed to practice in Texas, diplomates of American Board of Pathology or members of any national society of pathologists which judges scientific quality of its members. Active members 116; Junior members 6.

Meetings: Semiannual.

Professional activities: Caldwell Award, in honor and memory of Dr. George T. Caldwell, pioneer pathologist in Texas, for outstanding work and achievement.

1475. Texas Society of Professional Engineers. 1008 San Jacinto Street, Austin, Tex. President: Olaf T. Lodal, 1411 Transit Tower, San Antonio, Tex. Term expires January 1961. Executive Secretary: Gus F. White. Term expires January 1961.

History: Founded 1936, incorporated 1937. Twenty-five local chapters.

Purpose: To secure for the engineering profession its rightful share of public esteem and for the members of the profession adequate recognition and compensation for their services to society. 
Membership: Registration as a professional engineer, certification as an engineer-in-training, or graduation from an accredited engineering course. Total membership 6,000.

Meetings: Annual.

Professional activities: Three annual scholarships of $\$ 300$ each.

Publications: Texas Professional Engineer, monthly, current volume: 19, $\$ 1.75$. Editor: Thomas A. Melody.

1476. Textile Research Institute. Princeton, N. J. President: J. H. Dillon. Term expires March 16, 1961. Secretary-Treasurer: P. C. Alford, Jr. Term expires March 16, 1961.

History: Founded 1930 as United States Institute for Textile Research and incorporated in New York; name changed to present title 1941; incorporated in New Jersey as institute of learning.

Purpose: To conduct long range fundamental research for benefit of all branches of the textile industry; to train scientists for this work and disseminate information gained.

Membership: Personal members, 250; Company members, 90 .

Meetings: Annual.

Professional activitics: Research laboratories with permanent staff of fifty; graduate educational program conducted cooperatively with Princeton University.

Publications: Textile Research Journal, monthly, current volume: $30, \$ 25$. Editor: R. K. Toner. Institute Membership News, quarterly, current volume: 14, free to members. Editor: Candida Frenking.

Library: 1,500 volumes. Subject emphasis: Chemistry, physics, engineering.

1477. Tissue Culture Association. President: Charity IVaymouth, R. B. Jackson Memorial Laboratory, Bar Harbor, Maine. Term expires April 1962. Secretary-Treasurer: Duncan C. Hetherington, Duke Hospital, Durham, N. C. Term indefinite.

History: Organized November 1946 as the Tissue Culture Commission after the Hershey Conference. Constitution adopted April 1949. Name changed to Tissue Culture Association and the first set of officers elected April 1950.

Purpose: To foster the collection and dissemination of information concerning the maintenance and experimental use of tissue cells and the evaluation and development of procedures therefor.

Membership: Open to persons who have contributed to the understanding of cell cultivation or its applications to other fields of science.
Associate members may not hold office but may participate in all other activities. Total membership 622: Honorary members 3, Associate members 30, Active members 508, Foreign members 81.

Meetings: Annual.

Professional activities: Sponsors annual summer course in tissue culture. Bibliography of Research in Tissue Culture being compiled by M. R. Murray.

1478. Topeka Engineers Club. President: John H. Anderson, 2331 Prairie Road, Topeka, Kans. Term expires December 31, 1960. Secretary: James O. Ridenour, 2520 West 9th Street, Topeka, Kans. Term expires December 31, 1960.

\section{History Organized 1919.}

Purpose: Promotion of engineering profession.

Membership: Graduate or practicing engineers. Total membership 153.

Meetings: Monthly.

1479. Torrey Botanical Club. President: Charles A. Berger, Fordham University, Bronx, New York 58, N. Y. Term expires December 1960. Secretary: Annette Hervey, New York Botanical Garden, Bronx Park, New York 58, N. Y. Term expires December 1960.

History: Founded informally about 1860 ; incorporated 1872. In its beginnings, the Club was intended primarily to establish firmer bonds of interest among botanists of the New York area. Today, however, membership includes botanists from every state in the Union and from a large number of foreign countries. In approximately a century, the Club has become a national and international organization, and its publications are standard reference works for botanists.

Purpose: To promote interest in botany, and to collect and disseminate information on all phases of plant science.

Membership: Total membership 575.

Meetings: Semimonthly from October to May.

Publications: Bulletin, bimonthly, current volume: 87, \$9. Editor: James Gunckel. Memoirs, irregularly, current volume: 21 .

1480. Tree-Ring Society. President: J. C. McGregor, Department of Anthropology, University of Illinois, Urbana, Ill. Term indefinite. Secretary: C. W. Ferguson, Department of Watershed Management, University of Arizona, Tucson, Arizona. Term indefinite. 
History: Founded 1934 at Flagstaff, Arizona.

Purpose: Discussion of problems in dendrochronology and publication of original papers.

Membership: Interest in dendrochronology. Individual members 72 (U.S. 63, Foreign 9); Institutional members 108 (U.S. 82, Foreign 26).

Mectings: Irregular.

Publications: Tree Ring Bulletin, annual, current volume: 23, \$2. Editor: Bryant Bannister

1481. Tri-State Medical Association. 122 South Green Street, Greensboro, N. C. President: Furman Wallace, Spartanburg, S. C. Term expires February 1, 1961. Secretary-Treasurer: R. B. Davis. Term expires February 1, 1961. Both offices have been extended to July, 1961.

History: Organized 1898 at Charlotte, N. C.

Purpose: Operates schools for medical doctors and technicians, dentists, and nurses.

Membership: Open to Caucasian members of state medical societies in the District of Columbia, Virginia, North Carolina and South Carolina. Total membership 650 .

Meetings: Annual.

Professional activities: Sponsors and operates medical schools in the tri-State area.

Publications: Tri-State Medical Journal, monthly. Editor: R. B. Davis.

1482. Tri-State Radiological Society. President: Robert E. Beck, 600 Mary Street, Evansville 10, Ind. Secretary: James R. Mathews, 118 Southeast 1st Street, Evansville, Ind. Terms expire 1960-61.

History: Organized 1952. Sections: Southern Indiana, Southern Illinois, Northwestern Kentucky.

Purpose: Exchange of scientific ideas, and discussion and solution of mutual problems.

Membership: Total 14.

Meetings: Quarterly.

1483. Trowel and Brush Society. President:

Robert Kiste, Department of Anthropology, Indiana University, Bloomington, Ind. Term expires August 31, 1961. Executive Secretary: Miss Pliyllis Jacobs, 2401 Cross Country Boulevard, Baltimore 9, Md. Term expires August 31, 1961.

History: Organized 1948.

Purpose: To promote good techniques in archaeological research; to maintain contact and friendly relationship between students who attend Archaeological Field School at Angel Mounds, near Newburgh, Ind.

Membership: Composed of persons who have attended the above named field school and have received acceptable grades, and who are dedicated to principles of good archaeological research. Total membership 112.

\section{Meetings: Irregular.}

Professional activitics: Key presented to each member; award for distinguished service to Indiana archaeology.

Publications: Annual News Letter, free to members. Editor: Glenn A. Black.

1484. Tulsa Geological Society. President: Bill O. Andress, c/o Blackwell Oil and Gas Company, 507 Enterprise Building, Tulsa, Okla. Term expires August 31, 1961. Secretary: James H. Moore, P. O. Box 263, Tulsa, Okla. Term expires August 31, 1961.

\section{History: Organized November 1920.}

Purpose: To increase and diffuse geological knowledge and to promote fellowship and cooperation among geologists, geophysicists, petroleum engineers, and other scientists interested in geological problems.

Mcmbership: Resident of Tulsa; completion of thirty hours of geology in college or three years of employment in geology or allied sciences. Total membership 700.

Meetings: Annual. Semimonthly technical meetings October through May.

Publications: Digest, annual, current volume: 27, $\$ 2.50$. Editor: Albert L. Kidwell.

1485. United Cerebral Palsy Associations, Inc. 321 West 44th Street, New York 36, N. Y. President: Wendell J. Brown, 704 44th Street, Des Moines, Iowa. Term expires November 1960. Secretary: Mrs. Tex Ritter, 10063 Toluca Lake Avenue, North Hollywood, Calif. Term expires November 1960. Executive Director: Samuel K. McConnell, Jr. Term indefinite.

History: Organized and incorporated August 12, 1948. Sections: Affiliates in forty-four states and the District of Columbia. CommitTEES: Medical and Scientific, Adult Activities, Research, Clinical, Service, and Special Education.

Purpose: To promote research in cerebral palsy and the treatment, education, and rehabilitation of persons with cerebral palsy, and to subsidize professional training programs of all types related to the problem of cerebral palsy; to further, by professional and public education, dissemination of information concerning all aspects of the problem of cerebral palsy; 
to promote better and more adequate techniques and facilities for the diagnosis and treatment of persons with cerebral palsy; to cooperate with governmental and private agencies concerned with the welfare of the handicapped; to promote the employment of persons with cerebral palsy; to solicit, collect and otherwise raise funds and other property for the above purposes and for endowing and supporting facilities for the care, treatment and study of persons with cerebral palsy; to establish affiliates and to cooperate with them for the above purposes.

Membership: Representative Directors, individuals who are local or state presidents; Directors-at-Large, civic or philanthropic leaders. Total membership 330.

\section{Metings: Annual.}

Professional activities: Funds allotted each year from the United Cerebral Palsy Research and Educational Foundation to universities, hospitals, and other institutions for fundamental and applied research; for post-doctoral fellowships in medical research and special education; for clinical and medical student fellowships; for scholarships to train occupational, physical, speech and hearing therapists; and for summer workshops in special education and vocational training.

Publications: Crusader. Editor: Flora Kaiser.

1486. United Engineering Trustees, Inc. 29

IVest 39th Street, New York 18, N. Y. President: Andrew Fletcher. Term expires October 1960. Secrctary: S. W. Marras. Term expires October 1960.

History: Established and incorporated in 1904 by the joint action of four national engineering societies: American Society of Civil Engineers, American Institute of Mining, Metallurgical and Petroleum Engineers, The American Society of Mechanical Engineers, and American Institute of Electrical Engineers, which are known as Founder Societies. Former name was Engineering Foundation, Inc. In 1958 the American Institute of Chemical Engineers became a fifth Founder Society. DePartments: Engineering Societies Library, Engineering Foundation, Real Estate Activities.

Purpose: The advancement of the engineering arts and sciences in all their branches, including the maintenance of a free public engineering library.

Membership: A federation of the above five national engineering societies.

Meetings: Monthly.

Professional activities: Administers trust funds for Engineering Societies Library, Engineering Foundation, John Fritz Medal Board of Award, Daniel Guggenheim Medal Board of
Award; acts as treasurer for Engineers' Council for Professional Development; custodian of grants to various research projects of Engineering Foundation.

Library: 177,000 volumes.

1487. United Epilepsy Association, Inc. 111 West 57th Street, New York 19, N. Y. President: Carl Marks, 20 Broad Street, New York 5, N. Y. Term expires May 1961. Executive Director: Meade P. Brown, 140 Kilburn Road, Garden City, Long Island, N. Y. Term indefinite.

History: Chartered by the Board of Regents April 21, 1944, as the Association to Control Epilepsy; provisional charter amended by the Regents in 1945, name changed to The National Association to Combat Epilepsy; absolute charter granted May 23, 1952; name changed to Epilepsy Association of New York October 1952; name changed to present title October 1954. Chapters : Long Island, Brooklyn, Westchester. Professional Advisory Council: a standing technical scientific committee, with a subcommittee on research and training grants.

Purpose: To support research in the field of epilepsy; to stimulate the developinent of clinical facilities for diagnosis and treatment of epilepsy; to conduct public and professional information programs; to establish voluntary health agencies in all communities; to deal with epilepsy as a major health problem.

Mcmbership: Individual members enrolled in chapters. Total membership approximately 700 .

Professional activitics: Symposia; support of laboratories for research in brain and central nervous system functions; training grants.

Publications: Epilepsy News, quarterly, current volume: 6. Editor: Nancy Davids.

1488. United Inventors and Scientists of America. President: David Resnick, 27121/2 IVest 7th Street, Los Angeles 57, Calif. Term expires January 1961. Secretary: Mrs. Julia Dunmar, 4491/2 North Stanley Street, Los Angeles 36, Calif. Term expires January 1961.

History: Organized and incorporated October 8, 1942.

Purpose: To emphasize the significant role of the inventor in the advancement of human welfare and to encourage new inventions; to encourage creative thinking among young people; to develop the inventiveness of the future inventors of the country; to focus interest on achievements of junior inventors.

Membership: Any individual holding a patent or having a patent pending. Total membership 735.

Meetings: Semiannual, in January and July. 
1489. United States Livestock Sanitary Association. President: James R. Hay, 600 South Michigan Avenue, Chicago 5, 11l. Term expires October 21, 1960. Secretary-Treasurer: Ralph A. Hendershott, 33 Oak Lane, Trenton 8, N. J. Term expires October 21, 1960.

History: Organized September 25, 1897 ; incorporated 1940. Committees: Brucellosis; Tuberculosis; Anaplasmosis ; Rabies ; Biologics ; Hog Cholera Eradication; Livestock Markets, Yards and Transportation; Exotic Diseases; Laws and Regulations; Public Health; Parasitic Disease.

Purpose: To assist in the production of healthy livestock through control and eradication of infectious communicable diseases.

Membership: Anyone interested in : control of diseases of livestock; marketing, transporting, selling, and raising of livestock; meat and milk hygiene. Total membership 1,063.

Meetings: Annual.

Publications: Proceedings, annual, current volume: $64, \$ 5$, free to members. Editor: R. A. Hendershott.

1490. United States National Committee, International Commission on Irrigation and Drainage. P. O. Box 7826, Denver 15, Colo. Chairman: C. R. Maierhofer. Term expires December 31, 1960. Executive Secretary: Stephen H. Poe. Term indefinite.

History: Organized 1952 under sponsorship of Irrigation and Drainage Division of American Society of Civil Engineers.

Purpose: To promote advances in the science of irrigation, drainage, and flood control.

Membership: Anyone interested and active in irrigation, drainage, and flood control. Total membership 300 .

Meetings: International congresses triennially.

Publications: Bulletin, annual, $\$ 2.50$. Editor: I. K. Mahajan. Transactions, triennially, price varies.

1491. United States Pharmacopoeial Convention, Inc. 46 Park Avenue, New York 16, N. Y. President: Arthur C. DeGraff, 850 Park Avenue, New York 21, N. Y. Term expires 1970. Director of Revision: Lloyd C. Miller. Term indefinite.

History: Organized January 1, 1820 ; incorporated 1900, in Washington, D. C.

Purpose: The revision and publication of the United States Pharmacopocia.

Membership: Accredited delegates of medical and pharmaceutical associations and colleges, and certain governmental agencies, to decennial meetings. Total membership 203.
Meetings: United States Pharmacopoeial Convention meets once a decade, in year ending in zero, at Washington, D. C.

Publications: Pharmacopoeia of the United States of America, every five years, with supplements as required, current volume: 16.

1492. United States Rocket Society, Inc. P. O. Box 271, Pittman, Nev. President: R. L. Farnsworth. Term indefinite. Secretary: E. H. Farnsworth. Term expires 1961.

History: Organized 1920; incorporated March 31, 1952.

Purpose: To disseminate rocket information and general matters of astronautical value; to develop a long-range program of actual flight technique.

Membership: Open to any interested person over eighteen, except citizens of communist countries. Total membership 570 .

Mectings: Annual.

Publications: Rockets, quarterly, current volume: 10, $\$ 2$. Editor: R. L. Farnsworth.

1493. Utah Academy of Sciences, Arts and Letters. President: H. Tracy Hall, Brigham Young University, Provo, Utah. Term expires April 1961. Secretary: Wilmer W. Tanner, Department of Zoology and Entomology, Brigham Young University, Provo, Utah. Term expires April 1965.

History: Organized April 3, 1908 as Utah Academy of Sciences; name changed to present title 1933; incorporated April 1959. Divisions: Biological Sciences, Physical Sciences, Social Sciences, Arts and Letters, Junior Academy.

Purpose: To promote investigation and to diffuse knowledge in all branches of science.

Membership: Open to those interested in aims of the society. Total membership 450.

Meetings: Semiannual, in autumn and spring.

Professional activities: Distinguished Service Awards; Research Funds; NSF-supported travelling lectures to high schools; State Science Fair.

Publications: Proceedings, annual, current volume: 37, \$3. Editor: Gladys L. Harrison.

1494. Utah Engineering Council. President: Milton B. Thacker, P. O. Box 898, Salt Lake City 10, Utah. Term expires December 31, 1960. Executive Secretary: Arty W. Clark, 74 West 47 th South, Salt Lake City, Utah. Term expires December 31, 1960.

History: Founded in 1948 by seven member societies. 
Purpose: To further engineering profession and ideals, to carry out civic duties requiring engineering attention.

Membership: Distinguished leaders in eleven member societies. Total membership 22.

Meetings: Monthly, except summer.

Publications: Utah Engineering and Sciences, monthly. Editor: G. H. Meyers.

1495. Utah Geological Society. 200 Mines Building, University of Utah, Salt Lake City, Utah. President: Bronson Stringham. Term expires February 1961. Secretary-Treasurer: Arthur L. Crawford. Term indefinite.

\section{History: Organized October 4, 1946.}

Purpose: The increase and diffusion of geological knowledge.

Membership: Active, 175, professional geologists in Utah; Associate, 20, college students who expect to become geologists; Corresponding, 8, professional geologists located outside of Utah.

\section{Meetings: Semiannual.}

Professional activities: Maintains geological road signs, publishes an annual guidebook and has a field trip. Participated in American Geological Institute Mission 66 program.

Publications: Annual geologic guidebook of selected areas of Utah; title of Guidebook 15 (1960) is: "Geology of the Silver Island and Adjacent Areas in the Great Salt Lake Desert Northeast of Wendover, Utah;" \$4. Editor: Fred Schaeffer.

1496. Utah Oto-Ophthalmological Society. President: David A. Dolowitz, 2000 South 9th Street East, Salt Lake City 5, Utah. Term expires September 1961. Executive Secretary: Don B. McAffee, 508 East South Temple Street, Salt Lake City, Utah. Term expires September 1961.

History: Founded in 1918 as Intermountain Oto-Ophthalmological Society.

Purpose: The cultivation and advancement of medical sciences, especially the branches which pertain to diseases of the eye, ear, nose, and throat; to cooperate with the various county and state medical associations for extension and advancement of medical knowledge.

Membership: Physicians who have special training in one or more of the aforementioned specialties-eye, ear, nose, or throat. Total membership approximately 35 .

Meetings: Monthly.

1497. Utah Pharmaceutical Association. Suite 210, Granite Mart Building, 1086 East 21st Street South, Salt Lake City, Utah. Presi- dent: Emory J. Herndon, 3924 Washington Boulevard, Ogden, Utah. Term expires May 1961. Executive Secretary: H. Ward McCarty. Term indefinite.

History: Organized in 1892.

Purpose: To render professional service in all areas and on all levels to the practice of pharmacy in the state; to gather professional and economic information in the interest of Utah pharmacy and to communicate these to the profession; to provide professional seminars and forums, to hold regional pharmaceutical meetings and panels, to encourage continuous professional education, to develop professional ethics and self-discipline: to communicate to the public a factual, realistic image of state pharmacy and also the goals and ideals of the profession; to foster inter-professional relationships with Utah's State Medical Association and other associations relating to the healing arts.

Membership: Active, 227, must be a registered pharmacist or an owner-operator of a licensed pharmacy; Non-Resident, 66, a registered pharmacist living outside the State of Utah but maintaining annual registration with the Utah State Board of Pharmacy; Associate, 53, a nonpharmacist directly connected with the business of retail pharmacy, such as a pharmaceutical manufacturer's representative or an officer or representative of a wholesale drug house; Enployed registered pharmacists who do not own pharnacies, 309. Total membership 655.

Mectings: Annual convention; one annual formal seminar; five to ten regional dinner meetings.

Professional activities: Utah Pharmaceutical Association Annual Scholarship to College of Pharmacy, University of Utah. Annual financial assistance to Student Branch, Utah Pharmaceutical Association, at College of Pharmacy. Sponsors Lever Brothers Company Annual Scholarship to College of Pharmacy, University of Utah.

Publications: Bulletin News, monthly, current volume: 69, \$5. Editor: H. Ward McCarty.

1498. Utah Psychological Association. P. O. Box 270, Provo, Utah. President: IVilliam Fawcett Hill. Term expires May 1961. Executive Secretary: Reed S. Morrill. Term expires May 1963.

History: Incorporated December 1950; subsequently affiliated with the Rocky Mountain Psychological Association, the Western Psychological Association, and the American Psychological Association.

Purpose: To help its members in Utah to advance psychology as a science, as a profession, and as a means of promoting human welfare. 
Membership: Members, limited to persons who hold a doctor of philosophy degree (based on a psychological dissertation) from a recognized graduate school and who have five years of experience in psychology; Associates, persons who have had two years of graduate work in psychology and at least one year of psychology experience. Total membership 85.

\section{Mectings: Semiannual.}

Professional activitics: Medal awarded to best psychology research at annual high school Science Fair.

Publications: Newsletter, five per year, current volume: 4 . Editor: Abe Stein.

1499. Utah Public Health Association. President: Delmar Stone, Salt Lake City Health Department, Health Education, 115 South State Street, Salt Lake City, Utah. Term expires April 1961. Secretary-Treasurer: Kathryn Brandon, P. O. Box 25, Foothill Station, Salt Lake City 8, Utal.. Term expires April 1961.

History: Organized 1937. Affiliated with the American Public Health Association and the Western Branch, American Public Health Association.

Purpose: To promote public health as a profession and to advance public health practice in Utah by all possible constructive measures.

Membcrship: Persons actively working in public health and/or having an active interest in Utah's public health. Active members, approximately 150; Corporate members, 7 .

\section{Meetings: Annual.}

Publications: Newsletter, quarterly, \$2, free to members and to other affiliates of the American Public Health Association. Editor: Frank Arnold, 932 North 10th East, Bountiful, Utah.

1500. Utah Society of Pathologists. President: Cyril D. Fullmer, Holy Cross Hospital, 1045 East 1st Street South, Salt Lake City, Utah. Term expires September 1962. Secretary: A. Peter Crane, St. Mark's Hospital, Salt Lake City, Utah. Term expires September 1962.

IIistory: Informal organization initiated about 1948; named Association of Utah Pathologists about 1952; constitution and by-laws adopted in 1959 and name changed to present title. Affiliated with Utah State Medical Association, College of American Pathologists, American Society of Clinical Pathologists.

Purpose: To elevate the standards and qualifications of physicians engaged in the practice of pathology in Utah; to elevate the standards of practice of pathology in the clinical pathology laboratories throughout Utah; to improve the quality of the practice of medicine by a wider application of clinical laboratory methods in the diagnosis, management, and prevention of disease; to develop and maintain official affiliation between this Society and other organizations; to advance the science of pathology and to improve medical laboratory service to physicians, hospitals and the public through study, education, and improvement of the economic aspects of the practice of pathology.

Mcmbcrship: Members, 16, Doctors of Medicine engaged in practice of pathology in Utah.

\section{Mectings: Biennial.}

Professional actirities: Annual High School Science Fair Award. Recruitment of medical technologists. Financial support of annual scientific meeting of Utah Society of Medical Technologists. Combined pathologist lecture series for schools of medical technology.

\section{Utah Society of Professional Engineers.}

1842 Michigan Avenue, Salt Lake City 8, Utah. President: Robert H. Dobson, 2560 East 17th Street South, Salt Lake City 8, Utah. Term expires June 1961. Secretary: John S. Duder. Term expires June 1961.

History: Founded 1907. Affiliated with the National Society of Professional Engineers.

Purpose: The advancement of engineering knowledge and practice, the maintenance of a high professional standard, and the promotion of good fellowship among its members.

Membership: Members, 185, registered engineers in the State of Utah. ,

\section{Meetings: Monthly.}

Professional activities: Sponsor of the JETS Program.

Publications: Utah Engineer, monthly. Editor: W. E. Plummer.

1502. Utah State Medical Association. 42 South 5th East Street. Salt Lake City 2, Utah. Exccutive Secretary: Harold Bowman. Term indefinite.

History: Founded October 2, 1895. CommitTEES: Blood Bank; Cancer; Fractures; Industrial Health and Labor Relations; Medical Economics; Medical Education and Hospitals; Medical Defense; Mental Health; Public Health; Rheumatic Fever; Rural Health; School Health; Sewage, Water and Air Pollution; Tubercular and Cardiovascular Disease. Nine component county societies.

Purpose: To promote the science and art of medicine, the protection of public health, and the betterment of the medical profession; to unite with similar organizations in other States and Territories of the United States to form the American Medical Association. 
Membership: Active members, 780, membership in a county medical society of Utah; Honorary, 103, continuous membership for ten years, and attainment of age sixty-five; Military Service, 3, membership in good standing to date of induction; Residency, 19, nembership in good standing to date of residency. Total nembership 905 .

Meetings: Annual.

Publications: Utah Medical Bulletin, monthly, current volume: 8, \$3. Editor: Harold Bowman. Rocky Mountain Medical Journal, monthly, $\$ 2.50$, free to members. Editor: Harvey Sethman.

1503. Utah State Radiological Society, Inc. President: Philip R. Frederick, L.D.S. Hospital, Salt Lake City, Utah. Term expires December 31, 1960. Secretary-Treasurer: Richard Y. Card, St. Mark's Hospital, Salt Lake City, Utah. Term expires December 31, 1960.

History: Organized and incorporated 1948. Purpose: To bring together its members for consideration of matters of mutual interest regarding radiology, and to promote the science of radiology.

Membership: United States citizens, graduate of a medical school recognized by Utah State Board of Medical Examiners, legally licensed to practice medicine in his commonwealth, member in good standing of State and county medical society, diplomate of American Board of Radiology and resident of Utah for one year. Total membership 22.

Meetings: Annual; three other meetings.

1504. Utah State Society of Anesthesiologists. A-28 508 East South Temple Street, Salt Lake City 2, Utah. President: Jack D. Stringham, 3005 St. Marys Circle, Salt Lake City, Utah. Term expires December 31, 1960. Secretary: Robert V. Plehn, 1111 Sonata Street, Salt Lake City 16, Utah. Term expires December 31, 1960.

History: Organized January 1947.

Purpose: The advancement of the science and art of anesthesiology.

Membership: Open to Doctors of Medicine, licensed to practice in the State of Utah, who devote all or part of their professional time to anesthesia, or who have special interests in anesthesiology. Active members, 35 ; Junior, 13 ; Honorary, 1.

Meetings: Monthly.

Professional actirities: University of Utah Anesthesiologists Student Loan Fund. Western Biennial Conference on Anesthesiology.
Publications: Newsletter, quarterly, current volume: 4, free. Editor: Leland O. Learned.

1505. Utah Statewide Archaeological Society. President: Merrill Peterson, 651 Canyon Road, Logan, Utah. Term expires May 1962. Secretary-Treasurer: Marian Pierson, P. O. Box 98, Moab, Utah. Term expires May 1962.

History: Founded March 1955 by James H. Gunnerson, Curator, Museum of Anthropology, University of Utah, Salt Lake City, Utah. Formal organization in Salt Lake City in May 1960.

Purpose: To increase and diffuse archaeological knowledge and to preserve and protect the archaeological heritage of Utah for the mutual enjoyment of all.

Membership: Open to both professional and amateur but linited to those scientifically minded and specifically interested in Utah archaeology, its preservation and interpretation. Total membership 150 .

Mectings: Biennial.

Publications: Utah Archaeology, quarterly, current volume: $6, \$ 2$. Editor: Lloyd Pierson.

1506. Vermont Pharmaceutical Association. President: Orien Johnson, IVinooski, Vt. Term expires October 1960. Secretary: Leland Chapman, Fairlee, Vt. Term expires October 1960.

History: Organized and incorporated 1894. Purpose: To promote pharmacy in the State of Vermont.

Membership: Registered pharmacist or store owner employing full-time registered pharmacist in Vermont. Pharmacies, 78; Pharmacists, 93.

Mectings: Semiannual.

Professional activities: Scholarship Fund, to assist worthy students through pharmacy college.

1507. Vermont Psychological Association. President: Mrs. Rowena R. Ansbacher, 130 East Avenue, Burlington, Vt. Term expires May 1961. Secretary: H. Beveridge Phelps, 46 Harrington Terrace, Burlington, Vt. Term expires May 1961.

\section{History: Organized 1949.}

Purpose: To advance psychology as a science, as a profession, and as a means of promoting human welfare.

Membership: Full members, 33, individuals who are members of the American Psychological Association or with equivalent qualifications; Associate, 1, individuals with B. A. degree in psychology. Total membership 34.

Meetings: Annual. 
1508. Vermont Society of Engineers. 80 Pleasant Street, Barre, Vt. President: Roderic J. Maynes, 47 Bellevue Avenue, Rutland, Vt. Term expires April 1961. Secretary: Richard J. Nicholls. Term expires April 1961.

History: Organized March 8, 1912 at Burlington, Vt. Section: Engineers Club of Rutland County. Affiliated with Engineering Societies of New England.

Purpose: The professional improvement of members, the encouragement of social intercourse among engineers and men of practical science, and the advancement of engineering.

Membership: Members, 326, civil, mechanical, mining, or electrical engineers, or other persons belonging to a technical profession, not less than twenty-four years of age, who have been in the active practice of their profession for at least four years, with graduation from an engineering school of recognized standing considered as equivalent to two years of active practice; Juniors, 3, not less than eighteen years nor more than thirty years of age, in active practice in some branch of engineering, or other technical profession, or students in, or graduates from, a school of engineering of recognized standing; Associates, 52, other persons interested in the objects of the Society; Honorary, 2; Life, 20. Total membership 403.

Mcctings: Semiannual.

Professional activities: Annual Engineering Scholarship, $\$ 300$.

Publications: Vermont Engineering, 3 times a year, current volume: 17, free. Editor: R. J. Nicholls.

1509. Vermont State Medical Society. 128 Merchants Row, Rutland, Vt. President: Frederick IV. Van Buskirk, 360 Main Street, Burlington, Vt. Term expires October 7, 1960. Excutive Secretary: Getty Page. Term indefinite.

History: Organized and incorporated 1813 by special act of the Vermont Legislature. Ten component county societies. Sections : Surgery, Internal Medicine, Radiology, General Practitioners and Pediatrics.

Purpose: To coordinate the medical activities of the State.

Membership: M. D. Degree, licensed to practice in Vermont, accepted by county society. Total membership 445.

Mcetings: Annual.

Professional activities: Clinical meeting in May for postgraduate work. Distinguished Service Award. 50-Year Club Awards. The Society finances occasional State-wide medical research projects.
Publications: News Letter, monthly, free to members. Editor: Getty Page. Annual Report, free to members.

1510. Virginia Academy of General Practice. 4205 Dover Road, Richmond 21, Va. President: Boyd H. Payne, 205 Professional Building, Staunton, Va. Term expires May 1961. Executive Secretary: Mrs. Louise B. Greiner. Term indefinite.

History: Organized in Roanoke, Virginia, October 1947. Local Chapters: Richmond Academy of General Practice, Tidewater Academy of General Practice, Northern Virginia Academy of General Practice, Hampton Roads Academy of General Practice, Blue Ridge Academy of General Practice.

Purpose: To promote and maintain high standards of the general practice of medicine and surgery in Virginia; to encourage and assist in providing postgraduate study for general practitioners in medicine and surgery, and to encourage and assist practicing physicians and surgeons to participate in such training; to encourage and assist young men and women to prepare, qualify, and establish themselves in general practice; to protect the right of the general practitioner to engage in medical and surgical procedures for which he is qualified by training and experience; to advance medical science and private and public health; and to maintain private patient-physician relationship.

Membership: Active, 372, physician engaged in the general practice of medicine and surgery duly licensed to practice in the state of Virginia, and a member in good standing of the Medical Society of Virginia; Associate, 40, graduates of approved medical schools; Inactive, 17, active members who are incapacitated by reason of illness, accident, age, or infirmity, and who for this or any other reason are unable to engage in active practice, and members who are called to temporary active duty with the Armed Forces. Total nembership 429.

Mectings: Annual.

Professional activities: Annual Scientific Assembly, fifteen total hours postgraduate study, commercial and scientific exhibits ; certificates of award to two best scientific exhibits. Lectures on general practice of medicine and surgery to medical students at two State medical schools.

Publications: Virginia General Practice News, bimonthly, current volume: 11. Chairman, Editorial Board: W. Fredric Delp, Pulaski, Va.

1511. Virginia Academy of Science. P. O. Box 1420, Richmond 11, Va. President: Wilson Bell. Term expires May 1961. Secretary: Paul M. Patterson, Hollins College, Hollins College, Va. Term indefinite. 
History: Organized at Williansburg, Va., in May 1923, as a development of the Association of Virginia Biologists. Sections: Agricultural Sciences; Astronomy, Mathematics and Physics; Bacteriology; Biology ; Chemistry; Education; Engineering; Geology; Medical Science; Psychology; Science Teachers; Statistics.

Purpose: To encourage scientific research in Virginia and to arouse public interest in science; to develop, discover and encourage scientific interest and ability among the youth of the State, by means of a Junior Academy of Science, by science clubs and by science talent searches; to cooperate with the industries in their science problems and with other scientific organizations having aims similar to those of the Academy.

Membership: Types of membership are: Patrons, Life, Business, Sustaining, Contributing, Regular, and Student. Membership is almost entirely made up of professional scientists in educational institutions, industry, agricultural experimental stations, business, and engineering. Total membership 1,050 .

\section{Meetings: Annual.}

Professional activities: Research Funds of the Virginia Academy of Science, capital $\$ 20,000$, income about $\$ 600$, for the encouragement of scientific research in Virginia. Grants are made from the Academy Trust Fund, supplemented by American Association for the Advancement of Science and gifts to members to carry on scientific investigation. J. Shelton Horsley Research Award, for a highly meritorious research paper, certificate and $\$ 100$.

Publications: Virginia Journal of Science, quarterly, current volume: 10.

1512. Virginia Pharmaceutical Association. 1105 East Clay Street, Richmond 19, Va. President: Roy P. Rhodes, 1749 Park Avenue, Lynchburg, Va. Term expires June 14, 1961. Managing Director: J. O. Hubbard, Jr. Term indefinite.

History: Organized 1882; incorporated 1886.

Purpose: To promote the progress and raise the standards of pharmacy in the State.

Membership: Active, must be a pharmacist, faculty member in a pharmacy school, representative of a drug manufacturer or drug wholesaler; Associate, those who are concerned with pharmacy but are not pharmacists. Total membership approximately 1,300 .

Meetings: Annual.

Publications: Virginia Pharmacist, monthly, current volume: 44, \$2. Editor: J. O. Hubbard, $\mathrm{Jr}$.

1513. Virginia Public Health Association. President: William A. Dorsey, 108 West Cary Street, Richmond, Va. Term expires May
1961. Secretary: Ruth Sumner, 1964 Lewis Mountain Road, Charlottesville, Va. Term expires May 1961.

\section{History: Organized 1950.}

Purpose: To assist in protecting and promoting public health in Virginia, to provide for the scientific advancement of its members, and to extend and develop the public health movement.

Membership: Active Member any person professionally engaged or actively employed in public health work in Virginia and who is a member or fellow of American Public Health Association; Member, any person who is not eligible for active membership but who is actively engaged in the field of public health, either in a voluntary or paid capacity. Total membership 490.

\section{Meetings: Annual.}

Publications: Newsletter, semiannual, current volume: 6, free to members. Editor: S. D. Sturkie.

\section{Virginia Society of Anesthesiologists.} 1200 East Broad Street, Richmond, Va. President: W. N. Holland, Lynchburg General Hospital, Lynchburg, Va. Term expires Spring 1961. Secretary: Campbell Harris, Jr. Term expires Spring 1961.

\section{History: Organized 1949.}

Purpose: To advance the science and art of anesthesiology and to stimulate interest and promote progress in the scientific, cultural and economic aspects of this specialty.

Membership: Active, 45, physicians who are in the practice of or interested in the specialty of anesthesiology, licensed to practice in Virginia, and members in good standing of local county medical society; Junior, 10.

Meetings: Semiannual, spring and fall in conjunction with State medical society.

\section{Virginia Society of Professional Engi-} neers, Inc. 609 Shirley Avenue, Norfolk 17, Va. President: Guilford L. Mattern, 1615 Franklin Road, S. W., Roanoke, Va. Term expires June 30, 1961. Secretary-Treasurer: C. D. Moore, Jr. Term expires June 30, 1961.

History: Founded 1948. Affiliated with National Society of Professional Engineers. Chapters : Blacksburg, Charlottesville, Lynchburg, Northern Virginia, Peninsula, Richmond, Roanoke, Tidewater. Functional Section for Engineers in Private Practice.

Purpose: The promotion and protection of the profession of engineering as a social and economic influence. 
Membership: Professional Engineers, 633; Engineers in Training, 40; Certified Land Surveyors, 16.

Mectings: Annual.

Publications: The Virginia Engineer, quarterly, current volume: 10, \$1. Editor: P. B. Mansfield.

1516. Virginia State Dental Association. President: William T. McAfee, 705 Colonial American National Bank Building, Roanoke, Va. Term expires May 2, 1961. SecretaryTreasurer: Myron E. Henderson, 415 Shenandoah Building, Roanoke, Va. Term expires May 2, 1961.

History: Organized 1870; successor to Virginia Society of Surgeon Dentists, founded in 1842.

Purpose: To promote the art and science of dentistry; to foster fraternal relations and intercourse among dentists; to safeguard the material interests of the profession and the public.

Membership: Graduate of an accredited dental school, and approved by the State Board of Dental Examiners. Total membership 1,170.

Mectings: Annual.

Publications: Bulletin, quarterly. Editor: $\mathrm{H}$. L. Kennett, Shenandoah Building, Roanoke, Va.

1517. Washington Academy of Sciences. 1530 P Street, N. W., Washington 5, D. C. President: Philip Abelson, c/o Geophysical Laboratory, Carnegie Institution, 2801 Upton Street. N. W., Washington 8, D. C. Term expires January 1962. Secretary: Heinz Specht, $\mathrm{Na}$ tional Institutes of Health, Bethesda 14, Md. Term expires January 1962. Executive Secretary: Mary L. Fell. Term indefinite.

History: Organized February 18, 1898, through a joint commission of scientific societies consisting of the Anthropological, Biological, Chemical, National Geographic, and Philosophical Societies. Since that time, twentyone other societies have been affiliated.

Purpose: The promotion of science.

Membership: By reason of original research or scientific attainments. Active Residents, 756; Retired Residents, 58; Active Nonresidents, 197; Retired Nonresidents, 55; Honorary, 6; Life, 3. Total membership 1,075 .

Professional activitics: Sponsors the Washington Junior Academy of Sciences to promote scientific activities, such as trips, conferences, and meetings; largest financial contributor to local science fairs; Joint Board on Science Education established in 1955 by the Academy and the District of Columbia Council of Engi- neering and Architectural Societies to coordinate the educational activities of the various technical societies represented by the founders, and to initiate and sponsor programs not feasible for a less representative group; Awards, in the form of scrolls, to the nominees of the Awards Committee for noteworthy discovery, accomplishment, or publication in the physical, biological, mathematical, and engineering sciences and the teaching of science; certificates of merit to high school students who have shown promise of original research; grants to assist high school science students to purchase equipment needs for worthwhile experiments.

Publications: Journal, monthly, current volume: 50, \$7.50. Editor: Chester Page.

1518. Washington Psychiatric Society. President: Marvin Adland, Chestnut Lodge, Rockville, Md. Term expires May 1961. Secretary: Leon Yochelson, 3000 Connecticut Avenue, N. IV., Washington 8, D. C. Term expires May 1961.

History: Organized 1949. Affiliated with the American Psychiatric Association in May 1949, and in 1953 the Society became a District Branch of The American Psychiatric Association.

Purpose: To represent psychiatry and to foster the progress of psychiatry in the Washington area.

Membership: Active, physicians who have specialized in psychiatry, or whose professional interests have been primarily psychiatric for at least three years; Associates, with practice or training in psychiatry but who do not meet above requirements; Honorary. Total membership 279.

Mectings: Monthly.

Professional activities: Annual Essay Prize of $\$ 100$ for the best psychiatric paper by a psychiatric resident.

Publications: Newsletter, monthly, free to members.

1519. Washington Society of Engineers. President: Charles Pierce, Assistant Director, U. S. Coast and Geodetic Survey, Washington 25, D. C. Term expires December 31, 1960. Secretary: William R. Ganser, Jr., 6526 Abbington Drive, Washington 21, D. C. Term expires December 31, 1960.

History: Organized 1905; incorporated 1909.

Purpose: The advancement of engineering knowledge and practice and the maintenance of high professional standards among its members.

Membership: Members, persons who are actively engaged in the practice of any of the 
various branches of engineering, or who, by reason of education or profession, are brought into active sympathy with engineering subjects; Honorary, persons of acknowledged eminence in some branch of engineering or of the sciences relating thereto, or who have rendered some special service to the profession. Total membership approximately 850 .

Meetings: Semimonthly October through April.

Professional activities: Washington Society of Engineers' Award, a certificate, to a member whose accomplishments in engineering have made an outstanding contribution to the objects of the Society. Washington Society of Engineers, Young Engineers' Prize, \$40 and membership in the Society for two years, for the most meritorious paper submitted by a member not over thirty years of age, or a student in engineering in a university located in $\mathrm{W}$ ashington, D. C., or vicinity.

1520. Washington Society of Professional Engineers. President: Paul H. Symbol, 1050 Alvarado Terrace, Walla- Walla, Wash. Term expires September 1961. Executive Secretary: David M. Lombardo, 512 1st Avenue North, Seattle 9, Wash. Term indefinite.

History: Organized and incorporated November 24, 1937 under the laws of the State of Washington. Affiliated with the National Society of Professional Engineers on December 2, 1937. Eight chapters in the State of IV ashington.

Purpose: To recognize the need of service to society, state and profession; to promote and protect the profession of engineering as a human, social and economic influence vital to the affairs of men and country.

Membership: Persons who hold a license to practice engineering. Professional Engineers, 657; Engineers in Training, 26; Introductory Members, 194.

Meetings: Annual.

1521. Washington State Medical Association. 1309 7th Avenue, Seattle 1, Wash. President: Frederick A. Tucker, 7302 Woodlawn Avenue, Seattle, Wash. Term expires September 1960. Executive Secretary: Ralph W. Neill. Term indefinite.

History: Organized 1874 as Territorial Association; name changed to present title 1894; incorporated 1909.

Purpose: To advance the science of medicine and promote the betterment of public health.
Mcmbership: Active, membership in county society, graduate of Class A medical school and licensed; Honorary; Affiliate. Total membership 2,882.

Meetings: Annual.

1522. Washington State Pharmaceutical Association. 6639 White-Henry-Stuart Building, Seattle 1, Viash. President: George E. Benson, Mission Pharmacy, 901 19th Avenue North, Seattle 2, Wash. Term expires June 20, 1961. Exccutive Secretary: Reed Bement. Term indefinite.

History: Organized 1890; incorporated 1892. Fifteen local pharmaceutical associations, State Women's Auxiliary and four local women's auxiliaries. Commitees: College of Pharmacy Recruiting and Liaison, Ned Henderson Scholarship, Professional and Interprofessional Relations, Membership, Resolutions, Advertising and Publications, Fair Trade and Public Relations, Legislative, Nominating.

Purpose: To promote the interests of pharmacy by enactment of laws of mutual advantage to pharmacists and the public, restricting to competent parties the dispensing and sale of medicines, training of assistants, and bringing the pharmacists of the State of Washington into more intimate social relations.

Membership: Active, approximately 1,000, owners of retail pharmacies, and pharmacists registered in the State of Washington.

Mectings: Annual.

Professional activities: Numerous scholarships given to students in schools of pharmacy.

Publications: Washington-Alaska Pharmacist, monthly, current volume: 12, \$4. Editor: Reed Bement.

1523. Washington State Psychological Association. President: Irwin G. Sarason, Department of Psychology, University of Washington, Seattle, Wash. Term expires May 1961. Secretary: Eldon Jacobsen, Central Washington College of Education, Ellensburg, Wash. Term expires May 1961.

\section{History: Organized 1947.}

Purpose: To advance psychology as a science, profession, and means of promoting human welfare; to foster high standards of practice; to cooperate with other agencies on problems of common concern.

Membership: Members, 182, membership in the American Psychological Association or its equivalent; Affiliates, 26, bachelor's degree in psychology or related field and a full-time position or graduate work in psychology.

Mectings: Semiannual.

Publications: Newsletter, quarterly, current volume: 10. Editor: Audrey Holliday. 
1524. Washington State Public Health Association. 1309 Smith Tower, Seattle 4, Wash. President: Vernon E. Michael, District Health Officer, Health Center, Pasco, Wash. Term expires December 31, 1960. Secretary: Caesar Branchini, City Hall, Richland, Wash. Term expires December 31, 1960.

History: Organized 1935. Sections: ClericalStatistical, Health Education, Health Officers, Laboratory, Nurses, Sanitarians, Unaffiliated.

Purpose: The protection and promotion of health in the State of Washington; the promotion of cooperation with health workers of other states and territories for the extension and development of public and personal health; mutual assistance for the improvement of the professional work and working conditions of members, and promotion of the educational advancement and scientific interests of members of the Association.

Membership: Regular, 464, persons engaged in or interested in public health; Honorary, 5; Sustaining, 17.

\section{Meetings: Annual.}

Professional activities: Annual award presented to an individual who has made a substantial contribution to the field of health in the State of Washington. Annual meritorious service pins.

Publications: Newsletter, quarterly, free to members.

1525. Washington State Radiological Society. President: Eva L. Gilbertson, 706 Summit Avenue, Seattle, Wash. Term expires 1961. Executive Secretary: Joseph Houk, 14303 Ambaum Road, Seattle, Wash. Term expires 1961.

History: Organized by radiologists who are diplomates of the American Board of Radiology and who practice in the State of Washington.

Purpose: To discuss professional and medical economic problems associated with radiology.

Membership: Diplomates of the American Board of Radiology, members of county and state medical societies. Total membership 65 .

Meetings: Monthly, September through May.

1526. Washington State Society of Anesthesiologists, Inc. President: Robert S. Fisher, 307 South 12th Avenue, Yakima, Wash. Term expires September 1961. Secretary-Treasurer: Gordon B. Clappison. Term expires September 1961.

History: Charter as a component, American Society of Anesthesiologists, Inc., approved October 9, 1948.
Purpose: To advance the science and art of anesthesiology.

Membership: Active members, 89, doctors of medicine engaged in practice of anesthesiology who are licensed to practice in the State of Washington and are members of county medical societies; Junior, 27 , doctors of medicine engaged in full time training in anesthesiology, or in some other specialty with interest in anesthesiology; Associate, 2, doctors of medicine interested in anesthesiology and related subjects, but engaged only in partial or limited practice of that specialty; Honorary, doctors of medicine or scientists who have rendered years of faithful service to this Society, have made significant contribution to anesthesiology, or who have attained eminence in that field; Provisional, doctors of medicine licensed in the State of Washington, engaged or interested in anesthesiology, who intend becoming active or associate members of this Society upon attainment of membership in county medical societies. Total membership 118.

Mcetings: Quarterly.

\section{Water Pollution Control Federation.} 4435 Wisconsin Avenue, N. W., Washington 16, D. C. President: Mark D. Hollis, Chief Engineer, U. S. Public Health Service, Washington 25, D. C. Term expires October 6, 1960. Executive Secretary: Ralph E. Fuhrman. Term indefinite.

History: Organized October 1928 as Federation of Sewage and Industrial Wastes Associations; incorporated as a non-profit organization February 1941; name changed to present title January 1, 1960. Forty-three affiliated associations.

Purpose: The advancement of fundamental and practical knowledge concerning water pollution control through the proper collection and treatment of sewage and industrial wastes, the correlation of regional and state wastewater associations and publication of a Journal.

Membership: Active, 8,438, activity or interest in the field of water pollution control ; Associate, 78 ; Honorary, 15; Corporate, 222. Total membership 8,753.

Mectings: Annual.

Professional activities: Eddy Medal for Research to recognize outstanding scientific and technical contributions as published in the Federation's Journal. The Industrial Wastes Medal for work in that field. The Emerson Medal for organizational work in the Federation. Approximately twenty-five annual certificate awards, including the Bedell Award for technical or organizational aid to a member association, and the Hatfield Award recognizing superior operation of wastewater treatment facilities. 
Publications: Journal, monthly, current volume: $32, \$ 10$ non-members, $\$ 8$ members, $\$ 11.50$ foreign non-members. Editor: Ralph E. Fuhrman.

Library: Editorial Reference Library of 1,200 volumes.

1528. Weed Society of America. c/o W. C. Jacob, Business Manager, Agronomy Department, University of Illinois, Urbana, Ill. President: K. P. Buchholtz, Agronomy Department, University of Wisconsin, Madison, Wis. Term expires December 1961. Secretary: Fred W. Slife. Term expires December 1961.

History: Organized January 1956.

Purpose: To encourage and promote the development of knowledge concerning weeds and their control.

Membership: Interest in objectives of Society as an individual or organization. Conference Members, 5; Sustaining, 36; Active, 650.

Meetings: Biennial.

Publications: Weeds, quarterly, current volume: $8, \$ 6, \$ 10$ beginning with volume 9 . Editor: C. J. Willard.

1529. West Texas Geological Society. P. O. Box 1595, Midland, Tex. President: Theodore S. Jones, Union Oil Building, Midland, Tex. Term expires January 1, 1961. Secretary: Edd Riddle, Jr., P. O. Box 4067, Midland, Tex. Term expires January 1, 1961.

History: Organized 1926. Сомmittees: Field Trip, Highway Logging, Historical and Film Record, Oil Fields of West Texas, Statistics of Exploratory Drilling, Stratigraphic Problems.

Purpose: To promote the science of geology as related to West Texas and the surrounding regions.

Membership: Any person engaged in geological or allied professions, or who is a member of the American Association of Petroleum Geology, or who is eligible for membership in that Association. Total membership 957.

Meetings: Three meetings a month, September through May.

Professional activities: Annual field trip. Ground water study. Highway Logging of Geology. Cosponsor of Southwestern Federation of Geological Societies.

Library: 10,000 volumes, with Midland Public Library.

1530. West Texas Historical and Scientific Society. President: Benjamin F. Berkeley, 301 East Avenue, East Alpine, Tex. Term expires April 1962. Secretary-Treasurer: Miss Anna D. Linn, P. O. Box 87, Alpine, Tex. Term indefinite.
History: Organized December 7, 1925 in Alpine, Texas.

Purpose: To further the study of scientific and historical matters in this Trans-Pecos Area.

Membership: Persons interested in scientific and historical matters to help promote the interest of the Big Bend Memorial Museum. Total membership approximately 125 .

Meetings: Semiannual.

Publications: Bulletins, every other year, free to members. Editor: Anna D. Linn.

Library: 2,600 volumes.

1531. West Virginia Academy of Science. President: James Hall, West Virginia University, Morgantown, W. Va. Term expires June 30, 1961. Secretary: John Daniel Draper, Bethany College, Bethany, W. Va. Term expires June 30, 1961.

History: Organized 1924; incorporated 1959. Sections: Biology, Chemistry, Geology and Mining, Psychology and Education, Mathematics and Physics, Social Sciences, Collegiate Academy, Junior Academy.

Purpose: To stimulate interest in the advancement of science within the State of West Virginia.

Membership: Regular, 354, persons interested in or engaged in any field of science; Life. 8 , regular members of academy paying fee of $\$ 50$; Institutional, 3 ; Emeritus, 18, members retired from service and elected by Executive Committee. Total membership 383 .

\section{Meetings: Annual.}

Professional activities: Awards to Junior Academy members for scientific papers, exhibits, at annual meeting, about \$685. Five Science Talent Search Awards, total of $\$ 1,250$. American Association for the Advancement of Science grant to schools applying and qualifying.

Publications: Proceedings, annual, 1960, free to members. Newsletter, quarterly, current volume : 12, free to members. Editor: A. M. Reese.

1532. West Virginia Archeological Society. President: Sigfus Olafson, 81 Chatsworth Avenue, Larchmont, N. Y. Term expires December 1960. Executive Secretary: Charles R. Lally, 314 Garfield Street, McMechen, W. Va. Term expires December 1960.

History: Organized December 1948.

Purpose: To further the study of archeology and the preservation of archeological sites in West Virginia.

Membership: Open to any individual interested in society's objectives. Total membership 139.

Meetings: Annual. 
Professional activities: Maintains archeological museum at Moundsville, W. Va.; has sponsored three major archeological projects financed by private industry, with the work being done by the Smithsonian Institution and the Carnegie Museum.

Publications: West Virginia Archeologist, irregular, current volume: 11, \$.75. Editor: Sigfus Olafson.

1533. West Virginia Coal Mining Institute. 112 Mineral Industries Building, Morgantown, IV. Va. President: S. Dunlap Brady, Jr., P. O. Box 67, Summersville, W. Va. Term expires December 31, 1960. Secretary-Treasurer: G. R. Spindler. Term indefinite.

History: Organized in 1908.

Purpose: To promote safety, efficiency, education and technical research in the coal mining industry of West Virginia.

Membership: Coal operator, manager, mine superintendent, engineer, or other person practically connected with coal mining in West Virginia. Total membership approximately 375.

Meetings: Semiannual.

Professional activities: Annual merit scholarship award in the School of Mines at West Virginia University.

Publications: Proceedings, annual. Editor: G. R. Spindler.

1534. West Virginia Optometric Association, Inc. Room 2, Strong Building. Parkersburg, W. Va. President: Mason Isiminger, 302 Jefferson Avenue, Moundsville, W. Va. Term expires June 1961. Executive Secretary: H. Eugene Merrill. Term indefinite.

History: Incorporated 1934 with four geographical divisions. TECHNICAL and ScIENTIFIC Committees: Contact Lenses, Geriatrics, Occupational Vision, Orthoptics and Visual Training, Research and Standards, and such other special committees as required.

Purpose: To unite in one association all those engaged in the profession of optometry, to advance the science of optometry, to elevate standards of optometric education so that the profession may become more capable and useful in promoting the health, comfort, and happiness of mankind.

Membership: Limited to those persons licensed to practice optometry in the State of West Virginia. Total Membership 100.

Meetings: Semiannual.

1535. West Virginia Psychological Association. IVest Virginia University, Morgantown, IV. Va. President: Julius C. Wilson, 932 Dudley
Avenue, Morgantown, W. Va. Term expires April 1961. Secretary: Robert L. Decker, Department of Psychology, West Virginia University, Morgantown, W. Va. Term expires April 1961.

History: Organized 1950.

Purpose: To advance psychology as a science and as a profession.

Membership: Master's degree in psychology and one year of experience, or two years of graduate study in psychology, and at time of application devoting full time to psychological work. Total membership 42.

Meetings: Semiannual.

1536. West Virginia Public Health Association.

State Health Department, 1800 Washington

Street, East, Charleston, W. Va. President: B. S. Brake, Clarksburg, WV. Va. Term expires May 1961. Executive Secretary: Mrs. Katherine L. Brown. Term expires May 1961.

History: Founded in 1924. Affiliated with the American Public Health Association.

Purpose: To promote a better understanding of the concepts of community health with special emphasis upon prevention of illness and promotion of well-being.

Membership: Persons engaged in the practice of public health, either directly or indirectly, as well as persons interested in the advancement of public health. Total membership 450 .

Mectings: Annual.

Professional activities: Two awards presented annually, one to citizen for public health activities, the other to a professional person who has done outstanding work in the field of public health.

Publications: The Voice, irregular, free to members. Editor: Harold T. Colley.

1537. West Virginia Radiological Society. West Virginia State Medical Association, 302 Atlas Building, Charleston, W. Va. President: John D. H. Wilson, P. O. Box 1046, Clarksburg. W. Va. Term expires August 1961. Secretary: Karl J. Myers, Myers Clinic, Philippi, IV. Va. Term expires August 1961.

History: Organized 1951.

Purpose: Improvement of the quality and status of the practice of radiology in West Virginia.

Membership: Active members, 28 , those physicians in the State of West Virginia specializing in radiology and eligible for membership in the American Medical Association.

Mectings: Semiannual, with the West Virginia State Medical Association. 
1538. West Virginia Science Teachers Association. President: IVilliam V. Brook, 1517 6th Avenue, Huntington 1, W. Va. Term expires April 1962. Executive Secretary: Rosa 1. Craig, P. O. Box 602, Sutton, IV. Va. Term indefinite.

History: Organized 1950; affiliate, National Science Teachers Association, Mest Virginia Acadeny of Science, and IVest Virginia Education Association.

Purpose: To encourage active interest in science; to exchange information regarding teaching of science; to prepare and distribute articles, reports, and aids to science teachers.

Membership: Active members, 69, those belonging to National Science Teachers Association.

Mectings: Semiannual.

Publications: "Atoms, Bees, Crystals," free to members. Editor: Mrs. Mabel H. Gorman.

1539. West Virginia Society of Anesthesiologists. President: Logan IV. Hovis, 4604 River Road, Vienna, W. Va. Term expires September 1, 1961. Executive Secretary: Harry S. WVeeks, 301 Betty Avenue, Wheeling, W. Va. Term expires September 1, 1961.

History: Organized 1948 as a component of the American Society of Anesthesiology.

Purpose: To advance the science and art of anesthesiology in Vest Virginia.

Membership: Doctors of Medicine who are licensed by the Medical Licensing Board of West Virginia, who are members in good standing of their county medical societies or equivalent organizations, and who are engaged in or especially interested in the practice of anesthesiology. Total membership 38 .

Meetings: Semiannual.

1540. West Virginia Society of Osteopathic Medicine. 313 Berman Building, Charleston, IV. Va. President: Albert Molisky, 748 Main Street, Follansbee, IV. Va. Term expires May 1961. Executive Secretary: G. D. Brooks. Term expires May 1961.

History: Formed 1920 as Vest Virginia Society of Osteopathy; name changed in 1958 to present title. Five subdivisions.

Purpose: To encourage mutual understanding and cooperation between public health agencies and osteopatlic medicine for the improvement of public health, by elevating and maintaining high standards of osteopathic hospitals and institutions within the state, and by advancing the professional knowledge of surgery, obstetrics, and the diagnosis, prevention and treatment of disease in general; by stimulating original research and investigation and by collecting and disseminating the results of such work for the education and improvement of the profession and the ultimate benefit of humanity.

Membership: Graduates of a school or college of osteopathy in good standing at the time of graduation, and who are lawfully licensed to practice osteopathy and surgery in the State of IVest Virginia ; persons may be elected to Associate or Honorary Membership. Total membership 93.

Meetings: Biennial.

Professional actizities: Support osteopathic scholarships, research and student loans.

Publications: IVest Virginia Bulletin, monthly, free to nembers. Editor: Gilbert Brooks.

1541. West Virginia State Dental Society. P. O. Box 1946, Charleston 27, IV. Va. President: John Y. Parsons, 1041 Fourth Avenue, Huntington, IV. Va. Term expires July 1961. Executive Secretary: C. T. McHenry. Term indefinite.

History: Founded in 1907; eleven component societies.

Purpose: To promote the usefulness of the science and art of dentistry, to encourage high standards in dental education and practice, to aid in the passage of just laws governing the practice of dentistry in the state, and, when requested, to assist the State Board of Dental Examiners in its efforts to enforce fully the provisions of the State Dental Practice Act.

Membership: Active Members, 490, open to ethical dentists regularly licensed to practice dentistry in West Virginia, or graduate dentists holding rank as members of the faculty of a recognized dental school within the State, or graduate dentists serving on the staffs of regularly constituted government agencies in WVest Virginia, and who are members in good standing of a component society holding a charter from this Society. Life Members, 67. Total membership 557.

Mectings: Annual.

Publications: West Virginia Dental Journal, quarterly, current volume: $34, \$ 1$. Editor: $H$. Roy Green, 701 Hawley Building, Wheeling, W. $\mathrm{Va}$.

1542. West Virginia State Medical Association. 401 Atlas Building, Charleston, WV. Va. President: John IV. Hash, 1102 Virginia Street, East, Charleston 1, IV. Va. Term expires August 1961. Executive Secretary: Charles Lively. Term indefinite.

History: Organized 1867 ; incorporated 1926.

Purpose: To federate the medical profession of the state; to extend medical knowledge and 
advance medical science; to become more useful to the public in preventing and curing disease, and in prolonging and adding comfort to life.

Membership: Active Members, licensed in West Virginia and elected by county medical society; Honorary Members, 152. Total membership 1,467.

Meetings: Annual.

Publications: West Virginia Medical Journal, monthly, current volume: $56, \$ 3.50$, free to members. Editor: Walter E. Vest, Huntington, W. Va.

\section{West Virginia State Pharmaceutical As-} sociation. Appalachian Building, Oak Hill, IV. Va. President: Minter B. Ralston, Weston, IV. Va. Term expires August 1961. Secretary-Manager: William J. Dixon, Box 119, Oak Hill, W. Va. Term indefinite.

History: Organized 1906; incorporated 1907.

Purpose: To improve the art and science of pharmacy; to restrict its practice to qualified persons; to encourage better relations among pharmacists, physicians, dentists, and the people at large; to maintain a high standard of professional honesty.

Membership: Active Members, 609, registered pharmacists; Life Members, 17; Ladies Auxiliary, 237; Travelers Auxiliary, 123. Total membership 986.

Meetings: Annual.

Publications: West Virginia Pharmacist, monthly, current volume: $13, \$ 5$. Editor: IVilliam J. Dixon.

1544. West Virginia State Society of Medical Technologists, Inc. 28 Oakwood Road, Fairmont, W. Va. President: Miss Esther Levine. Term expires June 1961. Exccutive Secretary: Miss Marie Garrett, Cabell-Huntington Hospital, Huntington, W. Va. Term expires June 1961.

History: Incorporated on March 17, 1948 as an affiliate society of the American Society of Medical Technologists.

Purpose: To promote higher standards in clinical laboratory methods and research; to elevate the status of those specializing in medical laboratory techniques; to create mutual understanding and cooperation between the medical technologists and physicians and all others who are employed in the interest of individual or public health; to promote the mutual aid and benefit of its members.

Membership: Registered and in good standing with the Registry of Medical Technologists of American Society of Clinical Pathologists. Active, 95; Affiliate, 5; Associate, 7 ; Student, 11. Total membership 118.
Mectings: Annual.

Professional activities: Active recruitment program including essay contests. Recently formed scholarship committee.

Publications: West Virginia Microscoop, quarterly, current volume: $12, \$ 0.25$. Editor: Miss Nancy Yeager.

1545. West Virginia Veterinary Medical Association, Inc. President: Leo J. Meyer, Martinsburg, W. Va. Term expires October 1961. Secretary-Treasurer: Harry J. Fallon, 200 Fifth Street West, Huntington, W. Va. Term expires October 1961.

\section{History: Organized 1903.}

Purpose: Mutual improvement of members, cultivation of fellowship among the veterinary profession, and the advancement of veterinary medicine.

Membership: Open to graduate veterinarians. Total membership 80.

Meetings: Semiannual.

1546. Westchester County District Branch of the American Psychiatric Association. President: John P. Lambert, Four Winds, Katonah, N. Y. Term expires May 1962. SecretaryTreasurer: Minette Davis, 1255 North Avenue, New Rochelle, N. Y. Term expires May 1962.

History: Organized as the Psychiatric Branch of the Westchester County Medical Society; became a District Branch of the American Psychiatric Association in 1955.

Purpose: To provide an organization for local psychiatrists and liaison with the national society.

Membership: Limited to individuals who hold membership in the Westchester Academy of Medicine and in the American Psychiatric Association. Total membership 140.

Meetings: Five times a year.

1547. Westchester Radiological Society. Purchase, N. Y. President: Clifford C. Baker, 212 Harwood Building, Scarsdale, N. Y. Term expires May 1961. Secretary: Richard P. Avonda. Term expires May 1961.

History: Organized May 1951.

Purpose: To advance the science of radiology and to maintain it as a specialty in medicine; to encourage all activities that improve the quality of specialist's care in radiology.

Membership: Members of County Medical Society, diplomates of American Board of Radiology. Total membership 31.

Meetings: Annual. 
1548. Western Association of Physicians. President: Clement A. Finch, Department of Medicine, University of Washington, Seattle 5, Wash. Term expires February 1, 1961. Secretary: Wade Volwiler. Term expires February 1, 1962.

History: Established 1956.

Purpose: To bring together, for the purpose of discussion and presentation of observations and ideas, persons playing an active and outstanding role in clinical research.

Membership: Outstanding and consistent performance in academic and investigative medicine and above thirty-eight years of age. Total membership 66.

Metings: Annual.

1549. Western Association of State Game and Fish Commissioners. President: Fred A. Thompson, New Mexico Game and Fish Department, Santa Fe, N. Mex. Term expires June 1961. Secretary: Ben Glading. California Department of Fish and Game. 722 Capital Ave., Sacramento, Calif. Term indefinite.

History: Organized 1921.

Purpose: To further game and fish interests of the West.

Membership: Western States and Provincial game and fish official organizations. Total membership 15 .

Meetings: Annual.

Publications: Proceedings of Conferences, annual, current volume: 39, \$2. Editor: Ben Glading.

1550. Western Industrial Medical Association. President: Verne G. Ghormley, 3032 Tulare Street, Fresno, Calif. Term expires October 1960. Secretary: B. M. Brundage, Medical Division, Atomics International, P. O. Box 309, Canoga Park, Calif. Term expires October 1960.

History: Organized April 25, 1940. Secrions : Arizona, California, Idaho, Nevada, Oregon, Utah, Washington. Affiliated with Industrial Medical Association.

Purpose: To foster the study and discussion of the problems peculiar to the practice of industrial medicine and surgery; to develop methods adapted to the conservation of health among workers in industries; to promote a more general understanding of the purposes and results of the medical care of employees.

Membership: Active, 320, practice in field of industrial medicine for at least three years; Fellows, 42; Honorary 3; Associate, 25. Total membership 390.

Mectings: Annual.
1551. Western Missouri District Branch of the American Psychiatric Association. President: Harold Meyers, 751 East 63rd Street, Kansas City, Mo. Term expires April 1961. Secretary: Robert S. Terrill, 208 Nichols Road, Kansas City 12, Mo. Term expires April 1961.

History: Founded 1954.

Purpose: To deal at local level with problems of national organization.

Membership: Membership in American Psychiatric Association. Total membership 48.

Meetings: Three times a year.

Publications: Newsletter, triannually, current volume: 1, free to members. Editor: G. Wilse Robinson, Jr.

1552. Western New York Psychiatric Society. President: Clarence A. Vallee, 220 Berryman Drive, Buffalo 26, N. Y. Term expires 1961. President-elect: Samuel Feinstein, Buffalo State Hospital, Buffalo, N. Y. Secretary: John Robinson, 28 Fairlawn Road, Buffalo 26, N. Y. Term expires 1961.

History: District Branch of the American Psychiatric Association.

1553. Western New York Society of Industrial Medicine and Surgery. President: James H. McDonough, Medical Director, Rome Cable Corporation, Rome, N. Y. Term expires April 1, 1961. Secretary: George A. Hardie, 343 State Street, Rochester 4, N. Y. Term expires April 1, 1961.

History: Organized in 1955; component society of the Industrial Medical Association.

Purpose: To foster the study and discussion of the problems peculiar to industrial medicine and surgery.

Membership: Active Members shall be doctors of medicine who are members of their local county medical societies and/or active members of the American Medical Association. Fellows, 40 ; Members, 107 ; Associate Members, 3; Retired, 1. Total membership 151.

Meetings: Three times a year.

1554. Western Orthopedic Association. $35421 \mathrm{st}$ Street, Oakland 12, Calif. President: Fraser L. MacPherson, Suite 610, Medico-Dental Building, San Diego, Calif. Term expires October 27, 1960. Executive Secretary: Vi Mathiesen. Term indefinite.

History: Formed by the San Francisco Orthopedic Club and the Los Angeles Orthopedic Club in 1932. Sixteen Chapters in the states of Alaska, Arizona, California, Colorado, Hawaii, Idaho, Nevada, New Mexico, Oregon, Montana, Texas, Utah, Washington, and Wyom- 
ing. Committees: By-Laws, Editorial, Membership, Resident Training, Scientific.

Purpose: The advancement of the science and art of orthopedic surgery in the Western States.

Membership: Active, 626, Diplomate of the American Board of Orthopedic Surgery; Associate, 155, passed Part $I$ of the American Board of Orthopedic Surgery and must complete Part II within three years; Honorary, 8, orthopedic surgeon not eligible for Active Membership, who has gained professional prominence by contribution to the advancement of orthopedic surgery; Emeritus, 7, retired from practice; Military, 1 , temporary service only. Total membership 802 .

Mcetings: Annual.

Professional activities: Awards given for the residents selected to present a paper at the Annual Meeting on the Resident-Training Program. Usually four are chosen and each receives $\$ 250$ and expenses.

1555. Western Psychological Association. President: David Krech, Department of Psychology, University of California, Berkeley, Calif. Term expires June 1961. Secretary: Thomas W. Harrell, 466 La Prenda Road, Los Altos, Calif. Term indefinite.

\section{History: Organized 1921.}

Purpose: To support research in scientific psychology and to hold an annual meeting for the purpose of reporting research.

Membership: Open to members of the American Psychological Association. Total membership 1,400 .

Mectings: Annual.

1556. Western Society for Clinical Research. President: Charles G. Craddock, UCLA Medical Center, Department of Medicine, Los Angeles 24, Calif. Term expires January 1961. Secretary: IVilliam N. Valentine. Term expires January 1961.

\section{History: Organized November 1, 1946.}

Purpose: The promotion of clinical investigation in the western states.

Membership: Active, 306, any qualified person who has accomplished and is conducting original investigation in the clinical or allied sciences of medicine, upon election to membership by the council of the society: Corresponding, 12, members who have taken up residence outside the western states; Emeritus, 11, active members of the society for five years and over forty-five years of age.

Mectings: Annual.
1557. Western Society of Electroencephalography. President: Richard D. Walter, Department of Neurology. University of California Medical Center, Los Angeles 24, Calif. Term expires February 1961. Secretary-Treasurer: Kenneth A. Blinn, 1250 Glendon Avenue, Los Angeles 24, Calif. Term expires February 1961 .

History: Organized May 2, 1947. Covers thirteen western States and western Provinces of Canada.

Purpose: To promote research and understanding in clinical electroencephalography and related fields; to exchange scientific and professional information; to maintain high scientific standards of clinical electroencephalographic laboratories.

Mcmbership: Active, clinical, doctors of medicine qualified in electroencephalography: Active, scientific, doctoral degrees in basic medical science, engaged in field of bioelectricity; Associate, investigators in scientific fields related to electroencephalography, and technicians in operation or manufacture of electroencephalographic equipment; Technicians, members of Western Society of Electroencephalograph Technicians. Active members, 104; Associate members, 26; Technicians, 6. Total membership 136.

Meetings: Annual.

1558. Western Society of Engineers. 84 East Randolph Street, Chicago 1, Ill. President: R. D. Maxson, 140 South Dearborn Street, Chicago 3. I11. Term expires May 31, 1961. Exccutive Secrctary: F. R. Bruce. Term expires May 31, 1961.

History: Organized 1869; incorporated 1880. Sectrons: Bridge and Structural; Chemical and Metallurgical; Communications; Electrical; Fire Protection and Safety; Gas; Fuels and Combustion: Hydraulic; Sanitary and Municipal: Mechanical: Traffic Engineering and City Planning; Transportation, Education and Research.

Purpose: The advancement of the theory and practice of engineering, the improvement of the status of engineering practice as a profession, and the maintenance of high professional standards.

Mcmbership: Full, 1,683, ten years experience with two of the ten in responsible charge; Associate, 364, six years experience, graduation from an accredited engineering college is accepted as six years of experience; Affiliate, 82; Students, 31: Honorary and Life, 299.

Mectings: Monthly; also thirty weekly meetings.

Professional activities: Washington Award, a bronze tablet, established 1916 by Past President 
John W. Alvord of the Society, awarded each year to an engineer in recognition of devoted, unselfish, and preeminent service in advancing human progress. The award is made on the recommendation of a Commission consisting of representatives of the American Society of Civil Engineers, the American Institute of Mining and Metallurgical Engineers, the American Society of Mechanical Engineers, the American Institute of Electrical Engineers, and the Western Society of Engineers; administered by this Society, income from an endowment of $\$ 13,000$. Chanute Medal, established in 1901, by Past President Octave Chanute of the Society, a separate medal to be awarded each year to the three members of the Society presenting the best papers in civil, electrical, and mechanical engineering; income from an endowment of $\$ 1,000$. Charles Ellet Award, name on loving cup, established in 1929 by E. C. Shuman, awarded each year to a Junior member for the best technical paper presented before the Junior Organization. The Alfred Nobel Prize, of which the American Society of Civil Engineers is trustee, is open to any member of this Society not over thirty years of age, or to any member of the four "founder" engineering societies.

Publications: Midwest Engineer, monthly, current volume : 12, \$4. Editor: H. K. Eaton.

1559. Western Society of Naturalists. President: Victor C. Twitty, Stanford University, Stanford, Calif. Term expires December 1960. Sccrctary: Yost U. Amrein, Pomona College, Claremont, Calif. Term expires December 1960.

History: Organized 1905 as the Biological Society of the Pacific Coast; name changed to present title in 1915.

Purpose: The advancement of the natural sciences.

Mcmbcrship: Active, 583, an interest in the biological sciences on either professional or nonprofessional level; Emeritus, 47.

Mectings: Annual.

Publications: Newsletter, three times a year. Editor: Yost U. Amrein.

1560. Western Society of Soil Science. President: Frank G. Viets, Agricultural Research Service, U. S. Department of Agriculture, P. O. Box 758, Fort Collins, Colo. Term expires June 1961. Secretary-Treasurer: Albert IV. Marsh, Agricultural Extension Service, University of California, Riverside, Calif. Term expires June 1961.

History: Organized June 1922 in Salt Lake City, Utah, as the Western Society of Soil Management and Plant Nutrition: name changed to present title 1925. In 1952 affiliated with the Soil Science Society of America and recognized as its Western Branch. In 1954 WVestern Society voted to serve also as the Soil Science Division of the Western Branch of the American Society of Agronomy.

Purpose: To promote research, teaching, and extension in soil science and plant nutrition in the geographical area of the western region of the United States and western provinces of Canada; to cooperate with other societies and organizations concerned with soil and plant nutrition problems in this area.

Mcmbership: An interest in the general objective of the society. Total membership 575 .

Mectings: Annual.

1561. Western Spectroscopy Association. Chairman: Roland C. Hawes, Applied Physics Corporation, 2724 South Peck Road, Monrovia, Calif. Term expires January 26, 1961. Recorder: Jackson M. Gordon, Shell Development Company, Emeryville, Calif. Term indefinite.

History: Organized 1952.

Purpose: To provide a form for spectroscopists to exchange ideas in their own and related fields with qualified experts; to promote this objective ample time is allowed at the annual conference for discussion.

Mcmbership: Persons who have attended any of the three meetings previous to the current year. Total membership approximately 350 .

Mectings: Annual.

1562. Western Surgical Association. President: Caleb Stone, 1118 Ninth Avenue, Seattle 1. Wash. Term expires December 1960. Secretary: John T. Reynolds, 612 North Michigan Avenue, Chicago 11, Ill. Term expires December 1960 .

Purpose: Discussion of surgical subjects.

Membership: Active Members, 225, requirements equivalent to American Board of Surgery, thirty-two years of age or over; Senior Members; Honorary Members. Total membership 362.

\section{Meetings: Annual.}

Publications: Transactions, annual, current volume: 68 , free to members.

1563. Wichita Professional Engineering Society. President: O. R. Hantla, Kansas Gas and Electric Company, P. O. Box 208, Wichita, Kans. Term expires July 1961. Secretary: Jonathan Ewert, 701 South Choutauqua Street, Wichita, Kans. Term expires July 1961. 
History: Formed 1955 as a merger of the Engineer's Club of Wichita (organized 1925) and the Wichita Society of Professional Engineers (organized 1946).

Purpose: To represent the body of professional engineers residing in the area served by the Society, and to carry out the purposes expressed by the national and state societies.

Membership: Limited to registered engineers, and those who become registered engineers within eight years after joining the Society. Total membership approximately 200 .

Meetings: Monthly.

1564. Wildlife Disease Association. c/o American Institute of Biological Sciences, $2000 \mathrm{P}$ Street, N. W., Washington 6, D. C. President: Carlton M. Herman, Patuxent Wildlife Research Center, Laurel, Md. Term expires March, 1961. Executive Secretary: Robert Holdenried, Fort Detrick, Frederick, Md. Term expires March 1962.

History: Organized March 1951 as an informal group. Constitution ratified March 1959 as a formal society. Committees: Rabies in Wildlife, Serum Exchange, Leptospirosis in Wildlife.

Purpose: The distribution of knowledge concerning parasites, diseases, physiology and other factors related to health and survival of wildlife, and the direct and indirect relations of such factors to domestic animals and man.

Membership: Persons in the fields of conservation, public and veterinary health, wildlife management, pathology, physiology, ecology, and many other diverse professional occupations. Total membership 850 .

Meetings: Annual.

Publications: Newsletter, irregular, current volume: 24, free to members. Editor: Robert Holdenried. Wildlife Disease, irregular, current issues: 4 and 5, free to members. Co-Editors: Carlton Herman and David E. Davis.

1565. Wildlife Management Institute. 709 Wire Building, Washington 5, D. C. President: Ria N. Gabrielson. Term indefinite. VicePresident: C. R. Gutermuth. Term indefinite.

History: Incorporated in State of New York, May 8, 1946.

Purpose: To promote research and scientific activities in wildlife restoration, conservation, and management, including maintenance of research projects; to develop new and improved methods thereof, and demonstrate such methods for the guidance of others; to gather basic technology and disseminate it by publications and publicity of all kinds and by personal contact, through fieldmen; to provide and maintain advisory consulting services; to promote and encourage education.

Membership: Interest in the Institute's objectives. Total membership 674 .

Mectings: Annual. The Institute sponsors the annual North American Wildlife Conferences.

Professional activitics: The Institute supports scholarships, and fellowships, and makes research grants in the field of natural resources, and helps to support Cooperative IVildlife Research Units at Land Grant Colleges in seventeen regions of the United States. Field representatives serve as liaison men between state and federal agencies and give lectures and talks on all phases of wildlife restoration and management in relation to sound land-use practices. The Institute operates waterfowl research stations at Delta, Manitoba, and Fredericton, New Brunswick, Canada.

Publications: Transactions, annual, sold on a cost basis, free to members. Editor: J. B. Trefethen. Outdoor News Bulletins, biweekly. Editor: Daniel A. Poole.

Library: 2,000 volumes

1566. Wildlife Society. President: E. L. Cheatum, Division of Game, Conservation Department, Albany 1, N. Y. Term expires March 1961. Executive Secretary: J. P. Linduska, Remington Farms, Chestertown, Md. Term indefinite.

History: Founded 1937 as the Society of Wildlife Specialists; formally organized under its present title in St. Louis, Mo., February 1937; incorporated 1948, in the District of Columbia.

Purpose: The development of all types of wildlife management along sound biological lines; the establishment of professional solidarity among conservation biologists; the maintenance of the highest possible professional standards.

Membership: Interest in wildlife. Approximately 3,000 members, including 113 Life members and 21 Honorary members.

Meetings: Annual.

Professional activities: Two publications awards. Conservation Education Award. Aldo Leopold Award for outstanding service to conservation.

Publications: Journal of Wildlife Management, quarterly, current volume: $24, \$ 6$, free to members. Editor: C. M. Kirkpatrick, Department of Forestry, Purdue University, Lafayette, Ind. Wildlife Monographs, irregular. Editor: Louis Krumholz. Newsletter, quarterly, free to members. Editor: Thomas Evans.

1567. Wilmington Organic Chemists' Club. Chairman: John F. Walker, Hercules Re- 
search Center, Wilmington, Del. Term expires April 1961. Secretary: Kenneth H. Markiewitz, Chemical Research Department, Atlas Powder Company, Wilmington, Del. Term expires April 1961.

History: Informal group founded in 1949.

Purpose: To bring outstanding workers in organic chemistry into the IVilmington area to discuss their research.

Membership: Interest in organic chemistry. In practice, membership is restricted to technically qualified persons working in organic chemistry. Total membership 500 .

Meetings: Monthly, October to April.

1568. Wisconsin Academy of Sciences, Arts and Letters. President: Merritt Y. Hughes, University of Wisconsin, Madison 6, IV is. Term expires May 1961. Secretary: Ted J. McLaughlin, University of $\mathrm{WV}$ isconsin, Milwaukee 11, Wis. Term expires May 1961.

History: Organized February 16, 1870 ; incorporated March 16, 1870.

Purpose: To promote among professional and lay scholars within the state, work and encouragement in the fields of the sciences, arts and letters; to encourage the publication of original investigations; to maintain an exchange library; and to sponsor a Junior Academy of Science.

Membership: Active members, 1,119, with an academic interest in either the sciences, arts or letters; Corresponding, 10 ; Life, 33 ; Sustaining. 27 ; Library, 94. Total membership 1,382.

Meetings: Annual.

Publications: Transactions, annual, \$3. Editor: Stanley D. Beck. Wisconsin Academy Review, quarterly, \$1. Editor: WValter E. Scott.

1569. Wisconsin Archeological Society. Milwaukee Public Museum, Milwaukee 3, Wis. President: Phillip H. WViegand, 1276 North 63rd Court, Wauwatosa 13, Wis. Term expires March 1961. Secretary: Mrs. Nona A. Wiegand. Term expires March 1961.

History: Organized June 1899 as the Archeological Section of the IVisconsin Natural History Society; incorporated March 1903 as an independent society, with name changed to present title.

Purpose: The investigation and preservation of Wisconsin Indian antiquities.

Membership: Open to persons interested in the science of archeology. Annual, Sustaining, Institutional, Life, and Endowment Members. Total membership 447.

Meetings: Monthly, except July and August.
Professional activities: Lapham Research Medal awarded for distinguished services in anthropological research.

Publications: IVisconsin Archeologist, quarterly, current volume: $41, \$ .50$, free to members. Editor: Robert Ritzenthaler.

1570. Wisconsin Pharmaceutical Association. 202 Price Place, Madison, Wis. President: Richard G. Henry. 602 Walton Place, Madison, Wis. Term expires October 4, 1960. Executive Secretary: William Allen Daniels, 4328 Regent Street, Madison, Wis. Term indefinite.

History: Organized 1880; incorporated 1881.

Purpose: The educational and scientific advancement of pharmacy in the State of IVisconsin.

Membership: Registered pharmacists. Total nembership 1,600.

Meetings: Annual.

Professional activities: Two Pharmacy R.O.T.C. Student Awards. Two Senior Pharmacy Student Awards. Association Presidential Scholarship of $\$ 500$ underwritten by Lever Brothers, Pepsodent Division.

Publications: Wisconsin Pharmacist, monthly, current volume: 28, free to members. Editor: Jennings Murphy.

1571. Wisconsin Psychiatric Association. President: Gilbert B. Tybring, Mendota State Hospital, Madison, Wis. Term expires 1961. President-elect: Harold N. Lubing, 110 East Main Street, Madison, Wis. Secretary: Charles W. Landis, Milwaukee County Institutions \& Departments, Wauwatosa, Wis. Term expires 1961.

History: District Brancl of the American Psychiatric Association.

1572. Wisconsin Psychological Association. President: M. Gertrude Reiman, Safety Building, Milwaukee, Wis. Term expires June 1, 1961. Secretary: Raymond J. McCall, Marquette University, Milwaukee 3, Wis. Term expires June 1, 1961.

History: Organized November 1938 as the Wisconsin Association for Applied Psychology; reorganized April 28, 1950, under present title.

Purpose: The advancement of psychology as a science and a profession in the State of IVisconsin.

Membership: Membership in American Psychological Association and acceptance of its ethical standards. Total membership 162.

Meetings: Semiannual. 
1573. Wisconsin Radiological Society. Secretary: Howard G. Bayley, 116 Iroquois Parkway, Beaver Dam, Wis. Term expires September 1961.

History: Organized and incorporated August 1949.

Purpose: The advancement of the science and art of medicine through the branches of roentgenology and radiology.

Membership: Limited to doctors of medicine who are Diplonates of the American Board of Radiology and in the active practice of radiology. Total membership 82.

Meetings: Annual.

1574. Wisconsin Society of Anesthesiologists. President: George C. Kreuter, 7505 Oakhill Avenue, Milwaukee 13, Wis. Term expires September 1961. Secretary: Betty J. Bamfortl, 1300 University Avenue, Madison 6, Wis. Term expires September 1960.

History: Organized December 1947.

Purpose: To foster the development and furtherance of the specialty of anesthesiology for the general elevation of the standards of medical practice and for the benefit of the public.

Membership: Active members, 65, anesthesiologists; Junior, 12, residents in training in anesthesiology; Honorary, 2, physicians who have made outstanding contributions to anesthesiology. Total membership 84 .

Meetings: Semiannual, in May and October.

1575. Wisconsin Society of Pathologists. 561 North 15th Street, Milwaukee 3, Wis. President: Paul Dietz, St. Francis Hospital, La Crosse, IVis. Term expires December 1960. Executice Secretary: Robert S. Haukohl. Term expires December 1962.

History: Organized May 15, 1932, as the Milwaukee Pathological Society; changed to present title May 16, 1942.

Purpose: To promote the practice of scientific medicine by a wider application of clinical laboratory methods to the diagnosis of disease; to stimulate research in all branches of clinical laboratory work; to establish standards for the performance of various laboratory examinations ; to elevate the scientific and professional status of those specializing in this branch of medicine.

Membership: Active, 72, Diplomates of the American Board of Pathology, members of state and county medical society; Associate, 10, graduates of recognized scientific institutions who have made significant contributions to sciences related to pathology; Junior, 12, pliysicians who have completed internships and one year training for certificate by Board; Honorary, 4 , active members who have become inactive or retired medical scientists who have distinguished themselves in research or teaching even though not engaged in practice of pathology. Total membership 98 .

Meetings: Three times a year.

1576. Wisconsin Society of Professional Engineers. 1905 Monroe Street, Madison 5, Wis. President: John Gammell, P. O. Box 512, Milwaukee 1, Wis. Term expires June 30, 1961. Secretary-Treasurer: Cass F. Hurc. Term expires June 30, 1961.

History: Organized in May 1944 by appropriate action of the IVisconsin Engineering Society; affiliated with the National Society of Professional Engineers. Standing Committees: Ethics and Practice, Education, Legislative, Membership, Program, Public Relations. Special Committees: Civil Defense, Awards, Interprofessional, Nominating, Publications, Resolutions. Functional Groups : Consulting, Education, Industrial, Public Employment.

Purpose: To advance the public welfare and the professional, social and economic interests of the professional engineer; to promote education, legislation and public relations affecting the registered engineer and the establishment and maintenance of high ethical standards in the community, state and nation.

Membership: Registration in the State of Wisconsin. Total membership 1,323.

Meetings: Monthly.

Professional activities: Assist qualified engineers throughout the State to fulfill requirements of and prepare for registration. Organize and promote annual "Engineers' Week" activity in communities throughout the State to foster better understanding by the public of the status of the profession and the role of the professional engineer. Provide career guidance to high schools and encourage capable students to plan and prepare for entering the engineering profession. Annual awards and citations to high school teachers, college students and engineers, in recognition of outstanding service and contributions to the profession.

Publications: Wisconsin Professional Engineer, ten monthly issues a year, $\$ 2$. Editor: George Sell.

1577. Wisconsin State Horticultural Society. Roon 5, Horticulture Building, University of Wisconsin, Madison 6, Wis. President: E. H. Erickson, Casco, IV is. Term expires January 1961. Executive Secretary: G. C. Klingbeil. Term expires January 1961.

History: Organized 1865. 
Purpose: The promotion and advancement of horticulture in $\mathrm{W}$ isconsin.

Membership: Open to individuals with an interest in the purposes of the Society. Total membership 1,200.

Mectings: Semiannual.

Professional activities: Two honorary recognitions.

Publications: Newsletter, eight times yearly, current volume: 3. Editor: G. C. Klingbeil.

1578. Wisconsin Surgical Society. President: Peter A. Midelfart, 314 Grand Avenue, Eau Claire, 11 is. Term expires May 1961. Secretary-Treasurer: Norman O. Becker, 104 South Main Street, Fond du Lac, Wis. Term expires May 1963.

History: Organized 1942 as $1 \mathrm{~T}$ isconsin Academy of Surgery. The Academy dissolved June 9. 1946, and the present Society was organized Septenber 14, 1946; incorporated November 1946.

Purpose: The cultivation and improvement of the science and art of surgery for the betterment of surgical care to citizens of 11 isconsin; the promotion of closer professional relations among the surgeons of the State.

Membership: Active, 140, general surgeons belonging to the State Medical Society and certified by American Board of Surgery, or fellowship in American College of Surgeons; Senior, 13, active members who have reached the age of sixty-five and who request senior membership, or members of the Society for ten years and incapacitated by chronic illness who apply for senior membership without regard to age.

Meetings: Semiannual.

Professional activities: Annual award for Prize Surgical Resident Paper.

\section{Women's Medical Society of New York}

State. President: Lois J. Plummer, 131 Linwood Avenue, Buffalo 9, N. Y. Term expires May 1962. Secretary: Harriett E. Northrup, 213 East 6 th Street, Jamestown, N. Y. Term expires May 1962.

History: Organized March 1907 ; incorporated May 2, 1908. Functions as Branch 18 of the American Medical Women's Association. Divided into eight districts. Standing CommitteEs: Legislation, Public Health and Medical Education, Scientific Program.

Purpose: To bring the Medical Women of New York State into communication with each other for their mutual advantage, to encourage social and harmonious relations within the pro- fession, to extend medical knowledge and to advance medical sciences.

Membership: Active, 250, women graduates in medicine in good professional standing and who are members of a county medical society.

Mectings: Semiannual.

Professional activities: Mary T. Greene Fund provides tuition for two women students at Vellore Medical College in India. Mathilda $\mathrm{K}$. IVallin Fund for the medical education of women.

1580. Women's Veterinary Medical Association. President: Maxine Benjamin, School of Veterinary Medicine, Colorado A. and M. College, Fort Collins, Colo. Term expires August 1962. Executioc Sccretary: Marguerite Gulick, 770 South Main Street, Great Barrington, Mass. Term expires August 1962.

History: Organized April 1947.

Purpose: To further the interests of women veterinarians and keep them informed on the activities of their colleagues.

Membership: Graduates of a recognized veterinary college. Total membership 200.

Meetings: Annual.

Professional activities: Annual $\$ 100$ award to woman graduate of the current year who has maintained highest average during four years of veterinary college. Periodic contributions to student loan fund administered by the Women's Auxiliary to the American Veterinary Medical Association. Periodic contributions to American Veterinary Medical Association Research Fund.

Publications: Bulletin, quarterly, current volume: 14. Editor: Marguerite Gulick.

1581. World Medical Association. 10 Columbus Circle, New York 19. N. Y. President: Paul Eckel, Stalstrasse 16, Hanover, Germany. Term expires September 1961. SecretaryGeneral: Heinz Lord. Term begins January 1961.

History: Organized in London in 1947.

Purpose: To protect and promote freedoms essential to effective practice of medicine; to raise the standards of medical education and health; to bring together physicians for the purpose of sharing knowledge and ideas; to provide a world forum for discussion and solution of problems common to medicine; to speak for the physician before other world organizations.

Membership: Limited to the national medical association of each country that is most representative of the medical profession. Total membership 56 national medical associations, or 700.000 physicians. 
Meetings: Annual.

Publications: World Medical Journal, bimonthly, \$7.50. Editor: S. S. B. Glider. World Medical Periodicals, $\$ 6.50$. Editor: Hugh Clegg.

Wyoming Academy of Science. See ColoradoWyoming Academy of Science.

1582. Wyoming Engineering Society. P. O. Box 2285, Airport Station, Cheyenne, Wyo. President: C. R. MacDougall, Cheyenne, Wyo. Term expires February-March 1961. Secretary-Treasurer: Malcolm D. Martin, Cheyenne, Wyo. Term expires February-March 1961.

\section{History: Organized March 1918.}

Purpose: To promote the prestige of the engineering profession in Wyoming; to standardize engineering practice and facilitate cooperation; to promote good fellowship among the members.

Membership: Members, persons with a degree in engineering, and/or four years experience in engineering work (equivalent to degree), who hold a Wyoming engineer's or surveyor's license ; Associate Members, persons who are members or representatives of contracting firms engaged in engineering work, firms or individuals supplying engineering materials; Junior Members, engineering students with one year of training, or anyone doing engineering work but not qualified by experience. Total membership 500 .

Meetings: Annual.

Professional activities: Two scholarships awarded annually to University of Wyoming engineering students.

1583. Wyoming Geological Association. P. O. Box 545, Casper, Wyo. President: James A. Barlow, Jr., 253 North Center Street, Casper, Wyo. Term expires October 1960. Secretary: Marvin A. Buskala, P. O. Box 200, Casper, Wyo. Term expires October 1960.

History: Organized February 1945; incorporated December 1950.

Purpose: To aid the industrial and productive interests of the state through scientific advancement in the science of geology as it relates to the development of petroleum and natural gas.

Membership: Open to geologists and individuals engaged in the exploration for oil and gas who meet membership requirements of the American Association of Petroleum Geologists. Total membership, 550.

Meetings: Weekly.

Professional activities: Annual Scholarship, University of Wyoming. Grants and Aid Fund, University of Wyoming.
1584. Wyoming Historical and Geological Society. President: Bruce Payne, 110 South River Street, Wilkes-Barre, Pa. Term expires February 11, 1961. Secretary: J. Campbell Collins, 74 West Ross Street, Wilkes-Barre, Pa. Term expires February $11,1961$.

History: Organized February 11, 1858, to commemorate the fiftieth anniversary of the burning of local anthracite coal in the open grate.

Purpose: The collection and maintenance of a library and museum, with special reference to literary, scientific, and historical material relating to Wyoming Valley and vicinity.

Membership: Annual members, 550; Life, 100. Mectings: Irregular.

Library: Approximately 20,000 volumes, 30,000 pamphlets, and 40,000 original manuscripts and photostats.

1585. Wyoming State Medical Society. P. O. Box 2266, Cheyenne, Wyo. President: Francis A. Barrett, 1616 East 19th Street, Cheyenne, Wyo. Term expires September 1961. Executive Secretary: Arthur R. Abbey. Term indefinite.

History: Organized 1902.

Purpose: To improve the services rendered to the people of Wyoming by the medical profession.

Membership: Limited to doctors of medicine, licensed to practice in the State of Wyoming by the State Board of Medical Examiners, who are also members of their county medical society. Total membership 265.

Meetings: Annual.

Publications: Rocky Mountain Medical Journal, monthly, free to members. Editor: Frank Barrett.

1586. Yellowstone-Bighorn Research Association, Inc. Red Lodge, Mont. President: George Darrow, 315 Securities Building, Billings, Mont. Term expires July 1961. Secretary: George McGill, Department of Geology, University of Massachusetts, Amherst, Mass. Term expires July, 1961.

History: Established 1936.

Purpose: To increase the number and quality of teachers of earth science; to recruit men qualified for future leadership and to advance the frontiers of earth science through research.

Membership: Open to those who by knowledge, experience, honorable standing and demonstrated interest in science are qualified to make effective contributions to education and 
research in earth science. Total membership 112.

Meetings: Annual.

Professional activities: Joint Fellowships with Montana Bureau of Mines; maintains field camp at Red Lodge, Mont. with library facilities and work space.

Library: 5,000 volumes.

1587. Zoological Society of San Diego, Research Council. P. O. Box 551, San Diego 12, Calif. Council Chairnan: Claude B. ZoBell, La Jolla, Calif. Term expires January 1, 1961. Secretary: Werner P. Heuschele. Term indefinite.

History: Research Council, formed in December 1916, serves as the professional scientific group within the larger Zoological Society of San Diego.

Purpose: To review research projects, assign grants-in-aid, and supervise research in zoo hospital.

Membership: Specialists in various fields of biological science who have made outstanding contributions to these fields. Total Research Council membership 24.

Meetings: Quarterly.

Professional activities: Research funds from Ellen Browning Scripps Foundation. Grants-inaid awarded by Council for biological research. Extensive laboratory facilities, zoo hospital and quarantine depot totaling 144,000 square feet available in isolated area bordering Balboa Park; Manager: Werner P. Heuschele.

Library: 60,000 volumes.

\section{ADDENDA}

1588. American Venereal Disease Association. President: S. Ross Taggart, Prince Georges County Health Department, Cheverly, Md. Term expires April 15, 1961. SecretaryTreasurer: Jules E. Vandow, 200 Central South, New York 19, N. Y. Term expires April 15, 1961.

History: Organized 1934 as American Neisserian Medical Society; name changed to present title June 1947.

Purpose: Study and control of venereal diseases.

Membership: Regular, 196, residents of the United States, Canada, Mexico, and adjacent islands, who are graduates of medical schools recognized by American Medical Association, or have been engaged for three years in bacteriological, pathological, or biochemical research, or in public health administration or other activities concerned with venereal disease con- trol; Retired, 36, twenty years' membership, or retired from active practice; Honorary, 16, Surgeons General of United States Army, Navy, Air Force, and Public Health Service, equivalent Canadian and Mexican officials, and persons who have rendered distinguished service in management of venereal diseases; Corresponding, 47, residents of countries other than above named, but otherwise, qualified for membership. Total membership 295.

Meetings: Annual.

1589. Metric Association, Inc. 502 Albee Building, $1426 \mathrm{G}$ Street, N. IV., Washington 5, D. C. President: J. T. Johnson, 694 West 11 th Street, Claremont, Calif. Term expires December 31, 1961. Executive Vice President: Robert P. Fischelis. Term indefinite. Secretary: Fred J. Helgren, 2004 Ash Street, Waukegan, I11. Term expires December 31, 1961.

History: Organized December 27, 1916, as American Metric Association; name changed to present title December 3, 1922; incorporated in District of Columbia December 1945. SECTIons: New England, Middle Atlantic, Northern, Central, Southern, North Western, Western, and South Western States.

Purpose: To secure advantages of general use of metric weights and measures.

Membership: Individual members, Firm members, Association members. Total membership approximately 200 .

Meetings: Annual.

1590. Minnesota State Medical Association. 496 Lowry Medical Arts Building, St. Paul 2, Minn. President: C. L. Oppegaard, P. O. Box 606, Crookston, Minn. Term expires January 1, 1962. Executive Secretary: Harold IV. Brunn. Term expires January 1, 1962.

History: Founded 1853 as Minnesota Medical Society; name changed to present title 1904. Thirty-three county and district medical societies.

Purpose: Scientific advancement of members, protection of medical standards, improvement of public health.

Membership: Requires graduation from Class A medical school and membership in component society. Total membership approximately 3,700 .

Meetings: Annual.

Professional activities: Rural Medical Scholarships for freshmen medical students; Distinguished Service Medal.

Publications: Minnesota Medicine, monthly, current volume: 43, \$5. Editor: Carl O. Rice. 
1591. National Conference on Weights and Measures. Office of Weights and Measures, National Bureau of Standards, Washington 25, D. C. President: A. V. Astin. Term indefinite. Secretary: II. S. Bussey. Term indefinite.

History: Organized 1905; sponsored by $\mathrm{Na}$ tional Bureau of Standards. Commitrees: Laws and Regulations; Specifications and Tolerances.

Purpose: To provide a national forum for discussion of all questions related to weights and measures; to develop a consensus on model weights and measures laws, and regulations, specifications, and tolerances for commercially used weighing and measuring devices, and testing, enforcement, and administrative procedures; to encourage and promote uniformity of requirements and methods among weights and measures jurisdictions; to foster cooperation among weights and measures officers, and between them and manufacturing, industrial, business, and consumer interests affected by their official activities.

Membership: Active members, weights and measures officers of States, counties, and cities; Associate, representatives of equipment manufacturers, business, and industry. Total membership approximately 3,500 .

Meetings: Annual.

Publications: Report of Proceedings, annual, current volume : $44, \$ 0.65$. Editor: W. S. Bussey.

1592. Newell Entomological Society. President:

Leland A. Davis, Department of Entomology, University of Florida, Gainesville, Fla. Term expires June 1, 1961. Executive Secretary: Lester E. Scherer. Term expires June 1, 1961.

History: Organized 1938.

Purpose: To serve as contact between student and professional entomologists and to encourage study of entomology.

Membership: Requires interest in entomology. Total membership 250.

Meetings: Semimonthly.

Professional activitites: Exhibits at Agricultural Fair, Florida Entomological Conference.

Publications: Journal, irregular, \$2.50. Editor: K. A. Noegel.

1593. Pacific Rocket Society, Inc. P. O. Box 15774, Del Valle Station, Los Angeles 15, Calif. President: Nicholaas Klos, 409 Glascow Avenue, Inglewood, Calif. Term expires November 1961. Secretary: Robert S. Helfman, 500 Landfair Avenue, Los Angeles 24, Calif. Term expires November 1961.

History: Founded 1944 as South Pasadena Rocket Society; incorporated under present title
1946. Branches located Inglewood, Encino, and Hollywood, Calif. Divisıons: Fuels, Facilities, Instrumentation, Clerical.

Purpose: Active research in fields of rocketry and space flight.

Membership: Requires active interest in rocketry; Full members must be over eighteen years of age; Student members must be enrolled in high school or university. 60 Full members, 50 Student members. Total membership 110.

Mectings: Biannual.

Professional activities: Laboratory maintained at Northrup Institute of Technology; static test cell, same location; forty-acre Mojave Test Area, fully equipped, in upper Mojave Desert.

1594. Sigmund Freud Archives, Inc. 300 Central Park West, New York 24, N. Y. President: Bertram D. Lewin, 32 East 64th Street, New York, N. Y. Term expires September 1960. Secretary: K. R. Eissler. Term expires September 1960.

History: Founded 1952.

Purpose: To collect and preserve all recollections, memories, correspondence, scientific and personal writings of and by Sigmund Freud; to provide a longitudinal record of the growth and development of psychoanalysis.

Membership: By invitation and election. Total membership 28.

Meetings: Annual.

Professional activites: Transmittal to Library of Congress, Washington, D. C., of all materials donated to or received by this organization. All personal papers are sealed and held confidential by the Library of Congress for periods of time specified by donors of such papers.

\section{Society of Aerospace Material and Process}

Engineers. President: Bernard Silverman, Lockheed Aircraft Corporation, 11320 Lasaine Avenue, Granada Hills, Calif. Term expires September 1, 1961. Secretary: Frank E. Robinson, General Electric Company, LJEDBuilding 700, Cincinnati 15, Ohio. Term expires September 1, 1961.

History: Organized in 1945 as the Society of Aircraft Materials and Process Engineers; name later changed to present title. CHApters: Los Angeles, San Gabriel Valley, San Fernando Valley, Southwest (Dalas-Fort Worth), Eastern (Batlimore, Washington, New York), Midwest. Steering Committee organized in October 1959 to form a national organization; first national meeting of Board of Directors in November 1960.

Purpose: To provide an opportunity for the discussion of subjects of common interest and 
importance to persons engaged in material and process engineering in the fields of airframe, missile, propulsion, and related industries, so that the members may execute their responsibilities more proficiently, may broaden their professional outlook, and may prepare for higher and more far-reaching responsibilities.

Membership: Professional, engineer or scientist with at least one year's experience in field, or the equivalent; Associate, person dealing with material and process engineers; Student, undergraduate professional student interested in field; Corporate, firms having an interest in the manufacture of aircraft, missiles, guidance and propulsion equipment, or their allied sub-contractors and suppliers, or other firms concerned with the manufacture of materials for flight systems. Total professional membership 700 .

Meetings: Annual.

Professional activities: Symposia; scholarships for needy and deserving engineering students.

Publications: News Letter, bimonthly. Editor. George Epstein.

1596. Society of Systematic Zoology. President: Curtis W. Sabrosky, Division of Insects, U. S. National Museum, Washington 25, D. C. Term expires 1962. Secretary: R. Tucker Abbott, Academy of Natural Sciences, 19th Street and Parkway, Philadelphia 3, Pa. Term indefinite.

History: Founded 1948 in Washington, D. C. ; affiliate, American Association for the Advancement of Science. Pacific Section created 1952.

Purpose: To stimulate interest and facilitate work in systematic (taxonomic) zoology.

Membership: Open to all persons interested in the purpose of this Society. Total membership 1,300 .
Meetings: Annual.

Publications: Systematic Zoology, four annually, current volume 10 , members $\$ 4$. Editor: Libbie H. Hyman.

1597. Special Libraries Association. 31 East 10th Street, New York 3, N. Y. President: Winifred Sewell, Squibb Institute for Medical Research, New Brunswick, N. J. Term expires June 1961. Executive Secretary: Bill M. Woods. Term indefinite.

History: Organized in 1909 by librarians of business, professional, governmental, and industrial organizations. Program includes an annual convention for the discussion of common problems by experts in various fields of activity; consultant services on the organization and administration of special libraries; publication of professional and bibliographical tools and manuals; and a placement service for members and employers. Thirty-one geographic chapters and sixteen subject divisions, including a ScienceTechnology Division.

Purpose: To promote the collection, organization and dissemination of information in specialized fields, and to improve the usefulness of special libraries and information services.

Membership: Sustaining, Active, Life, Associate, Affiliate, Student, and Emeritus members. Total membership 5,454.

Meetings: Annual.

Publications: Special Libraries, ten times a year, current volume: $51, \$ 7$ domestic, $\$ 7.50$ foreign. Editor: Mary L. Allison. Technical Book Review Index, ten times a year, current volume : $26, \$ 7.50$ domestic, $\$ 8$ foreign. Editor : Anthony A. Martin. 




\section{ACKNOWLEDGMENTS}

This publication forms the Canadian section of the seventh edition of Scientific and Technical Societies of the United States and Canadaa joint undertaking of the National Academy of Sciences-National Research Council in Washington, and the National Research Council of Canada.

As a result of this collaboration we have enjoyed, at every stage of the project, the advice and assistance of Mr. John H. Gribbin, Librarian of the National Academy of Sciences-National Research Council, who directed the United States compilation.

We are indebted, also, to the many scientists and technical officers who supplied the names of new societies, and to the society officers themselves, whose ready cooperation made the work possible.

Although this edition includes many groups and fields of interest not previously listed, it cannot be regarded as final and complete. The editors therefore welcome any information about societies that could be canvassed for later editions.

RoBert A. LAY

Public Relations Office

National Research Council 
1. Academy of Medicine, 288 Bloor Street, W. Toronto 5, Ont. President: Adrian Anglin. Term expires May, 1961. Honorary Secretary: T. C. Brown. Term expires May, 1961.

History: Organized May 31, 1907. Sections: medicine; surgery; paediatrics; pathology ; obstetrics and gynaecology; ophthalmology; otolaryngology; anaesthesia; preventive medicine and hygiene; urology; neurology; psychiatry; dermatology; general practice, and orthopaedic surgery.

Purpose: The advancement of the art and science of medicine with its collateral branches; the promotion and maintenance of an efficient library and museum; the improvement of the profession; the cultivation of harmony and good feeling among its fellows; and the promotion of the corporate influence of the profession in relation to the community.

Membership: 2298. Any qualified, regular medical practitioner, or anyone engaged in teaching or research work in medicine or an allied science, resident in Toronto, shall be eligible for membership.

Meetings: Monthly. Sectional meetings monthly, October to April.

Library: 60,000 volumes; medicine.

Publications: Bulletin, monthly, included in fee. Editor: J. W. Scott.

2. Acadian Entomological Society. President: F. E. Webb, Forest Biology Laboratory, Winnipeg, Man. Term expires December 31, 1961. Secretary-Treasurer: D. C. Eidt, Forest Biology Laboratory, College Hill, Fredericton, N.B. Term expires December 31, 1961.

History: Founded 1915 as Nova Scotia Entomological Society; present name adopted 1921. Disbanded 1925, reorganized 1950 and affiliated with Entomological Society of Canada.

Purpose: To bring about close association of entomologists and those interested in entomology in four Atlantic provinces and neighboring New England states, and to cooperate with and support the Entomological Society of Canada.

Membership: Anyone interested in the objects of the society may join.

Meetings: Annual.

Library: Small library founded 1960 ; regional entomological archives.
3. Agricultural Institute of Canada, 176 Gloucester Street, Ottawa 4, Ont. President: W. J. Anderson, University of British Columbia, Vancouver, B.C. Term expires June, 1961. Executive Secretary: J. E. McCannel. Term indefinite.

History: Organized June, 1920, in Ottawa, as Canadian Society of Technical Agriculturists. Name changed to present title September, 1945. Branches: Victoria \& Islands; Vancouver; Okanagan-Kootenay; Prince George; Edmonton; Calgary; Lethbridge; Vauxhall; Swift Current; Scott; Saskatoon; Regina; Indian Head; Melfort; Western Manitoba; Winnipeg; Morden; Southwestern Ontario; Western Ontario; Hamilton; Niagara; Guelph; Central Ontario; Eastern Ontario; Macdonald College; Montreal; Quebec City; New Brunswick; Nova Scotia; Prince Edward Island; Great Britain.

Purpose: To encourage agricultural research and to maintain high standards in the profession.

Membership: 3049 members; 275 student affiliates. Graduation in agriculture from a university of recognized standing required; or, graduation not in agriculture from a university of recognized standing, provided that the candidate is engaged in work of an agricultural nature.

\section{Meetings: Annual.}

Professional activities: Awards two scholarships each year for postgraduate studies at overseas universities. Value $\$ 2,000$ per academic year, renewable for 3 years; travel assistance provided. Open to all graduates whose studies are related to agriculture.

Publications: Review, bi-monthly, current volume: $15, \$ 2$. Canadian Journal of Plant Science, four yearly, current volume: $40, \$ 4$. Canadian Journal of Animal Science, twice yearly, current volume: $40, \$ 2$. Canadian Journal of Soil Science, twice yearly, current volume: 40, \$2. Editor: Miss Hilda Gray.

4. Agricultural Pesticide Technical Society, Pesticide Research Institute, University Sub Post Office, London, Ont. President: G. Friesen, University of Manitoba, Winnipeg, Man. Term expires June, 1961. SecretaryTreasurer: W. H. Minshall. Term indefinite.

History: Organized 1953 as an affiliated society of the Agricultural Institute of Canada. 
Purposc: To further the dissemination of technical information on agricultural pesticides; to encourage their research, development and proper use.

Mcmbcrship: 75 members. Members shall be persons who are qualified pesticide technologists as defined in the By-Laws. Associate Members.

Mcctings: Annual.

Publications: Proceedings of Annual Meetings, annually, current volume: $7, \$ 2$. Editor: IV. H. Minshall.

5. Alberta Association of Architects, 312 Northern Hardware Building, Edmonton, Alta. Prcsident: G. B. McAdam, 526 12th Avenue S.W., Calgary, Alta. Term expires January, 1961. Executive Sccretary: Mrs. H. L. Bond, Term indefinite.

History: Incorporated May 8, 1906.

Purpose: To protect the public interests in the erection of public and private buildings in the Province of Alberta; to enable persons requiring professional aid in architecture to distinguish between qualified and unqualified architects; and to ensure a standard of efficiency and further the advancement of art in architecture.

Membership: 156 full members. Members must be graduates of Canadian schools of architecture, associates of the Royal Institute of British Architects, or hold Certificates of Approval from the University of Alberta.

Meetings: Annual.

Publications: Newsletter, monthly.

\section{Alberta Association of Registered Nurses,} 10256 112th Street, Edmonton, Alta. Presidcnt: Mrs. D. June Taylor, 10012 112th Street, Edmonton, Alta. Term expires May, 1961. Exccutivc Secrctary: Mrs. Helen M. Sabin. Term indefinite.

History: Incorporated 1916 from existing local organizations of graduate nurses in Edmonton, Calgary, Medicine Hat and Lethbridge. Provincial act amended 1919 and association accepted as professional organization under control of University of Alberta. Thirty-eight regional chapters; specialty or interest groups such as occupational, operating room, private duty nurses; six standing committees.

Purpose: Furthering of better conditions for nurses generally in every way possible; maintaining standards of profession; offers advice and guidance to those seeking to qualify for registration.

Mcmbership: 15,417: active 4184; associate (non-practising) 1825; also inactive (non-practising). Requirements: satisfactory character; Grade XI standard or equivalent, including 85 credits; three years training in an approved school of nursing; successful completion of nurse registration examination.

\section{Meetings: Annual.}

Professional activities: Promotion of scholarships for higher education.

Publications: News Letter, 3-4 times yearly, current volume: 1 , free to active and associate members.

Library: 300 volumes related to nursing.

7. Alberta Dental Association, 835 Tegler Building, Edmonton, Alta. President: G. C. Swann, 714 Greyhound Building, Calgary, Alta. Term expires April, 1961. Exccutive Secretary: R. A. Rooney. Term indefinite.

History: Organized 1905.

Purpose: Professional administration and control in Alberta.

Membership: 415 members. Certification by the General Faculty Council, University of Alberta, required.

Mcetings: Annual.

Professional activities: Four scholarships, one prize and one medal to undergraduates of the University of Alberta.

\section{Alberta Institute of Agrologists. President:} T. C. McBeath, 1230 10th Avenue, W., Calgary, Alta. Term expires June, 1961. Registrar: J. A. Toogood, University of Alberta, Edmonton, Alta. Term indefinite.

History: Incorporated 1947. Acts as provincial counterpart of the Agricultural Institute of Canada.

Purpose: To organize and unite all workers in scientific agriculture; to maintain high standards in the profession; to encourage research.

Mcmbership: 350 (35 Agrologists-in-Training; 315 Agrologists). Graduation with B.Sc. (Agriculture) from the University of Alberta, or equivalent, required for admission as Agrologist-in-Training; three years professional experience for certification as Agrologist.

Professional activities: Annual Freshman Scholarship of $\$ 200$ to student in 1st year Agriculture at the University of Alberta. Agricultural Institute of Canada-Alberta Institute of Agrologists Gold Medal for highest standing in final year of B.Sc. (Agriculture) program.

Publications: Newsletter, quarterly, current volume: 13, free to members. Editor: J. A. Toogood.

9. Alberta Land Surveyors' Association. Presidcnt: C. W. Youngs, Edmonton, Alta. Term expires January 31, 1961. Secrctary: T. E. 
Rippon, Land Titles Office, Edmonton, Alta. Term expires January 31, 1961.

History: Organized 1910; incorporated under Alberta Land Surveyors Act.

Purpose: The licensing and professional governance of land surveyors in Alberta.

Membership: 124 : members 110; life 6; nonpractising 8 ; honorary 1 .

Mectings: Annual.

Library: 300 general reference works related to practice of land surveying.

10. Alberta Pharmaceutical Association. President: R. W. Christopherson, 86th Street and 118th Avenue, Edmonton, Alta. Term expires June, 1961. Registrar-Treasurer: D. M. Cameron, 118 5th Avenue, E., Calgary, Alta. Term indefinite.

History: Incorporated 1911 and embraced at that time all pharmacists who were in good standing with a Province or the North West Territories.

Purpose: The protection, advancement, or promotion of the interests or welfare of the members of the Association.

Membership: 790. Bachelor of Science in Pharmacy of the University of Alberta, and at least 12 months internship; or, equivalent academic standing, active membership in a recognized pharmaceutical society, and three months continuous residence in the Province required.

Meetings: Annual.

Professional activitics: One gold medal for graduating student; two gold medals for graduating nurses; two registration prizes and three scholarships; various book prizes.

Publications: Quarterly Bulletin, current volume: 11. Editor: Donald Cameron.

\section{Alberta Society of Occupational Therapists.}

President: Miss Monica McNeice, 11146 80th

Avenue, Edmonton, Alta. Term expires November, 1960. Secretary-Treasurer: Miss Frances Lyon, 8410109 Street, Edmonton, Alta. Term expires November, 1960.

History: Formed 1952 as provincial branch of Canadian Association of Occupational Therapists.

Purpose: To encourage the art of occupational therapy; to maintain professional standards; to operate a registry for Alberta occupational therapists, and to encourage formation of branches where applicable.

Membership: 15 members. Graduation from any school of occupational therapy recognized by the World Federation of Occupational Therapists required.

Meetings: Annual.
12. Alberta Society of Pathologists. President: J. H. Stirrat, Provincial Laboratory, Edmonton, Alta. Term expires September, 1960. Executive Secretary: Gordon R. MacDonald, Misericordia Hospital, Edmonton, Alta. Term indefinite.

History: Established 1950 as a non-profit professional organization under the Province of Alberta Societies Act.

Purpose: To promote the art, science and practice of the specialty of pathology.

Membership: 12. Certification of Fellowship, Royal College of Physicians and Surgeons (Canada); Specialist Certification, The Senate, University of Alberta required.

Mcetings: Annual.

Professional activitics: Trust fund recently established whose earnings will be used to aid the education of a pathologist.

13. Alberta Society of Petroleum Geologists, 401 Natural Gas Building, Calgary, Alta. President: H. W. Woodward, P.O. Box 130, Calgary, Alta. Term expires January, 1961. Exccutive Secretary: G. O. Raasch, Shell Oil Co. of Can. Ltd., 1027 8th Avenue, S.W., Calgary, Alta. Term expires January, 1961.

History: Formed 1928, and registered under the Societies Act in 1956.

Purpose: To promote the science of geology; to foster the spirit of scientific research; to encourage cooperation; to disseminate knowledge of the science.

Mcmbership: 1150 honorary and active members; 26 associate; 13 student; 39 corporate and associate corporate. University graduation with major in petroleum geology required, or qualification by nature of work.

Meetings: Twice monthly.

Professional activities: Annual Honorary Address; Medal of Merit; Link Award; Rutherford Memorial Prize in Stratigraphy; Graduate Award.

Publications: Journal, monthly, current volume: 8, \$7.50. Editor L. E. Workman. Annual Field Conference Guide Book, current volume: $10, \$ 8.50$.

14. Alberta Veterinary Medical Association, 7904148 Street, Edmonton, Alta. President: M. Hanson, 2203 Portland Street, E., Calgary, Alta. Term expires June 30, 1961. SecretaryTreasurer-Registrar: J. P. Best. Term indefinite.

History: Founded 1905.

Purpose: To safeguard the health of livestock; to further veterinary science in Alberta; to 
conduct courses of instruction in veterinary science when deemed advisable; to cooperate with other professional associations; to cooperate with Boards of Health to reduce the spread of diseases communicable from aninal to man.

Membership: 165. Requirements: degree of doctor of veterinary medicine or equivalent; Canadian citizenship; willingness to uphold the honour and dignity of the profession; willingness to practice profession in a becoming manner and in accordance with Veterinary Surgeons' Act requirements.

Metings: Twice yearly.

15. Alpine Club of Canada, Banff, Alta. President: H. A. V. Green, 252 Roslyn Road, Vinnipeg 13, Man. Term expires 1962. Secretary-Treasurer: W. C. Ledingham, 2974 II est 28th Avenue, Vancouver 8, B.C. Term indefinite.

History: Organized 1906: incorporated 1909. Iffiliated with The Mlpine Club, England, and The Ladies' Alpine Club, England. Sections: Victoria, Vancouver, Calgary, Edmonton, Winnipeg, Montreal, New York, Mid-IVestern (Chicago). Technical sections on glaciers and science.

Purpose: The promotion of scientific study and exploration of Canadian alpine and glacial regions; the cultivation of art in relation to mountain scenery; the education of Canadians to an appreciation of their mountain heritage; the encouragement of mountain craft and the opening of new regions as national playgrounds; the preservation of the natural beauties of the mountain places and of the fauna and flora in their habitat; and the interchange of literature with other alpine and geographical organizations.

Mcmbership: 1015 members. Active, nonresident, subscribing and honorary members.

Meetings: Annual.

Professional activities: The Silver Rope Award for outstanding ability in leadership and mountaincraft. Technical sections report on various glaciers; measure and record changes; cooperate with Hydrograplic Survey Branch of the Federal Department of Mines and Technical Surveys; study the botany, geology and entonlology of alpine regions.

Library: Approximately 2000 volumes on nlountaineering, skiing and allied subjects; botany, geology, maps, exploration.

\section{Anthropological and Sociological Chapter,} Canadian Political Science Association. Chairman: Nathan Keyfitz, University of Toronto, Toronto 5, Ont. Term expires June, 1961. Secretary-Treasurer: Jean Burnet, I'niversity of Toronto, Toronto 5, Ont. Term expires, June, 1961.

History: Founded 1956.

Purpose: Encouragement of research in and teaching of anthropology and sociology.

Membership: 67 nembers. Membership in the Canadian Political Science Association, and an interest in the objectives of the Chapter required.

\section{Metings: Annual.}

Professional activities: Compilation of censuses of research in sociology and social anthropology; directories of sociologists and anthropologists in Canada.

Publications: Bulletin, several times yearly. current volume: 1. Editor: S. Iási.1, 198 Macy Boulevard, Ottawa, Ont.

17. Architects Association of New Brunswick, 13 Germain Street, Saint Joln, N. B. President: W. A. Wallace, 1 Market Square, Saint John, N. B. Term expires January, 1961. Secretary-Treasurer: J. R. Myles. Term expires January, 1961.

History: Organized in Moncton, N. B., 1927, as the Maritimes Association of Architects, from which the Nova Scotia Association of Architects and the Association of Architects of New Brunswick were formed in 1932. Present title adopted, and incorporated by provincial statute in 1933.

Purpose: To govern the practice of architecture within the Province of New Brunswick and those who may legally practise that profession; to develop and maintain high standards in the architectural profession; to facilitate the acquiring and interchange of professional knowledge among its members; to enhance the efficiency of the profession in public service.

Membership: Honorary 1; regular 25; student associate 8 . Members must be permanent residents of the province of New Brunswick; either graduates of recognized schools of architecture, or have served nine years indenture to a practising registered architect and have passed examinations set by the Association.

Mectings: Annual.

18. Architectural Institute of British Columbia, 1425 West Pender Street, Vancouver 5, B. C. Presidcnt: William G. Leithead, 1920 Marine Building, Vancouver 1, B. C. Term expires December, 1960. Executive Secretary: R. B. Deacon. Term indefinite.

History: Founded 1914; incorporated 1920.

Purpose: The protection of the public interest in the erection of buildings in British Columbia, and the advancement of architecture. 
Mcmbcrship: 230 Registered Architects; 20 associate nembers; 15 student associate members; 13 undergraduate associate members. Requirements: nembership in architectural association; graduation from a recognized school of architecture; articled student having passed examinations under the National Syllabus of Study.

\section{Mcetings: Annual.}

Professional activities: $\$ 450$ award to outstanding student in Architectural Design, University of British Columbia.

19. Arctic Institute of North America, 3485 University Street, Montreal 2, Que. Chairman: C. S. Lord, Geological Survey of Canada, Ottawa, Ont. Term expires December, 1960. Secretary: M. J. Dunbar, McGill University, Montreal 2, Que. Term expires December, 1962.

\section{History: Organized 1944.}

Purpose: To encourage and promote scientific research in the polar regions and to act as a coordinating centre for polar research in North America.

Mcmbership: 2400. Members must have a general interest in polar regions.

Mectings: Monthly, October to May.

Professional activities: Approximately 350 research projects supported since 1945.

Publications: ARCTIC, quarterly, current volume: 13, \$5. Editor: P. F. Bruggemann.

Library: 4000 volumes on polar regions and related topics.

20. Association Canadienne Française pour l'Avancement des Sciences, 2900, boulevard du Mont-Royal, Montréal, Qué. President: Georges Gauthier, Service des Recherches, Ministère de l'Agriculture, Québec, Qué. Term expires October, 1960. Secretary: J. M. Beauregard. Term indefinite.

History: Founded 1924; charter granted 1931.

Purpose: The promotion of science and scientific education.

Membcrship: The Association is a federation of 50 societies: Société de Biologie de Montréal, founded 1924. Société canadienne d'Histoire naturelle et Cercles des jeunes Naturalistes, founded 1924. Société Médicale de Montréal, founded 1924. Société de Philosophie de Montréal, founded 1924. Société historique de Montréal, founded 1924. Société de Mathématiques de Québec, founded 1929. Société linnéenne de Québec, founded 1930. Société lévisenne d'Histoire naturelle, founded 1932. Société Provancher d'Histoire naturelle du
Canada, founded 1933. Société d’Etudes médiévales Albert le Grand, founded 1933. Société de Stomatologie de Québec, founded 1934. Société zoologique de Québec, founded 1934. Société agronomique de Québec, founded 1934. Société du Parler français au Canada, founded 1934. Institut de Chimie du Canada, Section de Québec, founded 1935. Société listorique et littéraire acadienne, founded 1935. Société des Sciences morales et politiques, founded 1935. Société philosophique de Québec, founded 1935. Société canadienne-française d'Electrologie et de Radiologie médicales, founded 1935. Société médicale de Québec, founded 1935. Société médicale des Hôpitaux universitaires de Québer. founded 1935. Société de Sylviculture de Québi., founded 1935. Société d'Histoire naturelle de la Pocatière, founded 1936. Société agronomique de Ste-Amne-de-la-Pocaticic suncued 1936. Société dentaire de Murtreal, founded 1936. Société thomiste de l'Université d'Ottawa, founded 1937. Société historique de Joliette, founded 1937. Société de Géographie de Québec, founded 1937. Société trifluvienne d'Histoire régionale, founded 1937. Société d'Histoire régionale de Saint-Hyacinthe, founded $193 \%$. Société de Pédagogie de Montréal, founded 1938. Société agronomique de l'Institut agricole d'Oka, founded 1939. Société médicale vétérinaire de la Province de Québec, founded 1939. Société scientifique de l'Outaouais, founded 1939. Société de Phtisilogie de Québec founded 1939. Société historique de Rigaud, founded 1940. Société de Géographie de Montréal, founded 1940. Société d'Etudes techniques de Sorel, founded 1941. Société d'Histoire régionale du nord de l'Outaouais, founded 1941. Société d'Histoire des Cantons de l'est, founded 1942. Société historique de Nouvel-Ontario, founded 1943. Centre de Québec de la Société royale d'Astronomie du Canada, founded 1944. Société des Etudes grecques de Québec, founded 1945. Association des Psychologues du Québec, founded 1946. Société de Biologie de Québec, founded 1946. Société de Chimie de Montréal, founded 1947. Société historique de Québec, founded 1948. Société de Physique de Montréal, founded 1952. Société entomologique du Québec, founded 1952. Société mathénatique de Montréal, founded 1953.

\section{Mcetings: Annual.}

Library: 2000 volumes dealing with every field of science.

Professional activitics: Médaille Léo-Pariseau awarded annually to a scientist who has distinguished himself by his scientific activities, and who has helped to promote science in French Canada. Médaille Archambault awarded annually to a French-speaking Canadian for outstanding merit in the field of applied sciences. 
Two Awards (\$200 each) to students in secondary schools and colleges.

Publications: Annales de l'Acfas, annual, current volume: 26, $\$ 2$. Bulletin de l'Acfas, monthly, current volume: 2 .

\section{Association des Biochimistes des Hôpitaux} de Québec, 202 First Street, Pont-Viau, Montréal 40, P.Q. President: Guy Nadeau, Hôpital St.-Michel Archange, Québec, P.Q. Term expires November, 1960. Executive Secretary: J. P. DuRuisseau. Term expires November, 1960.

\section{History: Organized 1958.}

Purpose: To bring together biochemists working in hospitals or engaged in the field of clinical chemistry; to promote the interests of biochemists in their professional relations with other professions and with the public.

Membership: 75. Candidates must possess a university degree in science, and must have specialized in clinical chemistry.

Mectings: Twice yearly.

Publications: Bulletin, 4 times yearly, current volume: 1, \$3. Editor: M. Bélanger.

\section{Association des Médecins de Langue Fran-} çaise du Canada, 326 est, boulevard St.-Joseph, Montréal 14, P. Q. Director-General: Emile Blain, 400 est, rue Sherbrooke, Montréal 24, P. Q. Term expires September, 1963. General Secretary-Treasurer: E.-Rolland Blais, 1779 avenue de l'Eglise, Montréal 20, P. Q. Term expires September, 1963.

History: Founded in 1902. Geographic divisions: Maritimes, Quebec, Ontario, Western Provinces. Committees include medical economics, scientific committee.

Purpose: To organize scientific congresses; to publish medical and scientific journals and periodicals; to safeguard, by the legal means at its disposal, the professional interests of its members; to encourage, maintain or establish other similar works.

Membership: 5200. Medical degree required.

Mcetings: Annual.

Publications: L'Union Médicale du Canada, monthly, current volume: $89, \$ 18$. Editor: Roma Amyot.

Library: 3000 volumes on medical subjects.

23. Association des Pathologistes et de Médecins de Laboratoire du Québec-Quebec Association of Pathologists and Laboratory Physicians. President: Jean-Louis Bonenfant, Hotel Dieu de Québec, Québec, P. Q. Term expires September, 1960. Executive-Sccretary:
Rene Lefebvre, Hotel Dieu de Montréal, Montréal, P. Q. Term expires 1962.

History: Founded 1946; incorporated by provincial statute in 1948. Membership at first limited to pathologists, but expanded in 1960 to include all laboratory physicians.

Purpose: To foster the advancement of the various specialties of the medical laboratory and of all allied sciences; to promote the welfare of its members in the Province of Quebec; to maintain the highest standards of proficiency among its members.

Membership: 88. Ordinary, associate, honorary, and junior members. Ordinary and associate members must be graduates in medicine and licensed practitioners of the Province of Quebec, specializing in one or several of the branches of laboratory medicine; they must be certified as specialists by the College of Physicians and Surgeons of the Province of Quebec, and must devote themselves primarily and principally to the practice or teaching of one or more of the laboratory specialties.

Meetings: Twice annually.

24. Association des Podiatres de la Province de Québec-Association of Podiatrists of the Province of Quebec. President: Claude Laliberté, 335 Chemin Ste. Foy, Québec, P. Q. Term expires November, 1960. ExecutiveSecretary: I. IV. Kaufman, 1396 St. Catherine Street, IV., Montreal, Que. Term expires November, 1960.

History: Founded and incorporated in 1948, to supercede a previous unchartered group known as the Association of Chiropodists and Foot Specialists of the Province of Quebec.

Purpose: To promote higher standards of education and practice for the profession of podiatry; to foster a free interchange of ideas of the art and science of podiatry among the members and the profession at large; to improve, and to develop, new techniques for the alleviation of pain and the correction of deformities within the scope of the profession.

Membership: 14. Members must be Canadian citizens, and have the degree of Doctor of Podiatry from a recognized college of podiatry ; also by "like reciprocity".

Meetings: Annual.

25. Association des Psychologues de QuébecPsychological Association of the Province of Quebec. President: Abbé Roch Duval, 71 rue d'Auteuil, Québec, P. Q. Term expires May, 1961. Secretary-Trcasurer: Marie Ange Nichols, 3750 Côte des Neiges, Montréal, Que. Term expires May, 1961. 
History: Founded 1943.

Purpose: The furtherance of psychology as a science, as a profession, and as a means of promoting human welfare.

Membership: 180. Members nust have M.A. or L.Ps. degree.

Meetings: Annual.

Professional activities: Prizes to university students in psychology at B.A. level at four universities in the province.

Publications: Bulletin, twice yearly. Editor: Aurèle Gagnon.

26. Association of Canadian Fire Marshals, Ontario Fire College, P. O. Box 830, Gravenhurst, Ont. President: K. J. Partington, Provincial Building, Hollis Street, Halifax, N. S. Term expires July 8, 1960. SecretaryTreasurer: D. E. Barrett, Ontario Fire College, P. O. Box 830, Gravenhurst, Ont. Term expires July 8, 1960.

History: Organized 1922, by Canadian members of the Fire Marshals' Association of North America.

Purpose: To promote better understanding between its members; to develop uniformity of action and legislation; generally to promote fire prevention work.

Membership: 75. Membership confined to public officials holding chief executive office in fire prevention or protection organizations. Honorary members.

Meetings: Annual.

Publications: Statistical Report of Fire Losses in Canada, annual, free. Proceedings, annual, free.

27. Association of Manitoba Land Surveyors. President: T. R. Miller, 71 Kingston Row, St. Vital, Man. Term expires January 18, 1961. Secretary-Treasurer: J. H. Bean, Civic Offices, Winnipeg, Man. Term expires January 18, 1961.

History: Incorporated 1881 by Act of Legislature as the Association of Provincial Land Surveyors; name changed to present title in 1904.

Purpose: The protection of the public from unqualified persons.

Membership: 55.

Meetings: Annual.

Library: 25 volumes on engineering and surveying.

28. Association of New Brunswick Land Surveyors, P. O. Box 22, Fredericton, N. B. President: C. R. Starkey, Cody's, N. B. Term expires January 18, 1961. Secretary-Trea- surer: R. G. Brown, R.R. No. 1, Fredericton,

N. B. Term expires January 18, 1961.

History: Organized in Fredericton, N. B., 1953 ; incorporated by provincial statute 1954.

Purpose: To promote and improve the efficiency of New Brunswick land surveyors in all matters relating to land surveying; to advance and protect the interest of New Brunswick land surveyors in their profession; to assure the general public of the professional proficiency and competency of New Brunswick land surveyors; to promote the welfare of New Brunswick land surveyors and their usefulness to the public; to protect the general public from the surveying and describing of land by unqualified persons.

Mcmbership: 88 full members, 1 honorary member. Membership restricted to those duly authorized to practise under The New Brunswick Land Surveyors Act, 1954.

Mectings: Annual.

Publications: Report, annual, current volume: 5. Editor: R. G. Brown.

29. Association of Newfoundland Land Surveyors. President: James Canning, P.O. Box H 187, St. John's, Nfld. Term expires December, 1960. Secretary-Treasurer: Gerard T. Halley, 90 Allandale Road, St. John's, Nfld. Term expires December, 1960.

History: Incorporated by Act of Legislature in 1953.

Purpose: Protection of land surveyors and encouragement of high standards in the surveying profession.

Membership: 68. Members require three years apprenticeship to a Newfoundland land surveyor and must pass examination prepared by the Association.

\section{Meetings: Annual.}

Professional activities: Scholarship, University of Newfoundland.

Publications: Newfoundland Surveyor, irregular, current volume: 3, free. Editor: W. J. Walsh, Confederation Building, St. John's, Nfld.

Library: 100 volumes on surveying and related matters.

30. Association of Nurses of the Province of Quebec, 640 Cathcart Street, Montreal 2, Que. President: Miss Eve M. Merleau, 3201 Forest Hill, Montreal, Que. Term expires November 4, 1960. Secretary-Registrar: Miss Helena F. Reimer. Term indefinite.

History: Created 1920 by provincial statute. Purpose: To regulate and control nursing profession in the province. 
Membership: Approximately 18,000. Applicants must meet nursing education requirements of Quebec Nurses' Act (1946) or equivalent thereof.

Mcetings: Annual.

Professional activitics: Four scholarships awarded annually.

Library: 800 volumes on nursing.

\section{Association of Ontario Land Surveyors, 255}

Bay Street, Toronto 1, Ont. President: H. D. G. Currie, Regional Land Surveyor, C.N.R., 151 Front Street, W., Toronto 1, Ont. Term expires February 16, 1961. SecretaryTreasurer: W. J. Baird, 6 Tinder Crescent, Toronto 16, Ont. Term expires February 16, 1961.

History: Organized 1886, by the provincial land surveyors then practising in Ontario as the Association of Provincial Land Surveyors. Incorporated 1892 under present name.

Purpose: To examine candidates for admission to the practice of land surveying in Ontario; to govern and discipline the members so admitted.

Membership: 501; registered members who have withdrawn from practice-70. Members must hold a certificate authorizing practice as land surveyors in Ontario.

Mectings: Annual.

Publications: The Ontario Land Surveyor, quarterly, current volume: 1. Editor: C. E. Stauffer.

\section{Association of Polish Engineers in Canada,} 4149 Sherbrooke Street, W., Montreal, P. Q. Presidcnt: J. Z. Sliwinski, 2541 Maplewood Avenue, Montreal, Que. Term expires May, 1961. Erecutive Secretary: F. Rudzicz, 4229 Hingston Avenue, Montreal, Que. Term expires May, 1961.

History: Organized 1941; incorporated 1944. Chapters: Montreal, Ottawa, Toronto.

Purpose: To place members in industrial enterprises, research institutes and similar establishments so as to utilize their professional abilities and improve their technical knowledge; to establish contacts with kindred Polish and Canadian corporations; to organize lectures and courses in professional subjects for members; to initiate and suggest to members proper lines of professional work; to extend assistance. by advice and otherwise, to Polish refugee workers in Canada.

Membership: 10 honorary, 449 full members. Members must be graduate engineers and technicians of Polish extraction resident in Canada.

Mectings: Annual.

Publications: Bulletin, for members only.
33. Association of Professional Chemists of Quebec. President: Claude Allard, Institut de Cardiologie de Montréal, Montréal, P. Q. Secretary-Treasurer: G. Papineau-Couture, P. O. Box 125. Station B, Montreal, P. Q.

History: Organized under authority of Quebec Legislative Assembly Bill No. 87, March 1926.

Purpose: To promote the interests of professional chemists; to advance chemistry as a science for the benefit of the public; to cooperate with organizations of chemists and chemical societies in other provinces and countries.

Membership: 500 .

Meetings: Annual.

34. Association of Professional Engineers of Alberta, 123 Commercial Building, Edmonton, Alta. President: D. C. Jones, Hudson's Bay Oil and Gas Co. Ltd., Calgary, Alta. Term expires March 25, 1961. Registrar: 1. G. Finlay, Term incuffinite.

History: Incorporated in 1920 by Act of Legislature, nam as above. One branch: Medicine Hat.

Purpose: To administer the Engineering Profession Act of Alberta; to protect the public from practice by unqualified persons.

Mcmbership: 2580 full members; 172 engineers-in-training; 72 students; 87 Canadian licensees; 40 foreign licensees; total enrollment 2951. Graduation from a recognized university in engineering, geology or geophysics plus two years experience; or Alberta High School Diploma, plus six years of suitable experience and passing of professional examinations, required.

\section{Mectings: Annual.}

Professional activitics: Two Annual Scholarships ( $\$ 200$ each) to first year students in Engineering \& Geology; Gold Medals awarded annually to top graduating students in each branch of Engineering \& Geology. Annual prizes to top students in Grade XIl Mathematics, Physics, and Chemistry.

Publications: Alberta Professional Engineer, 5 times yearly, current volume: 14, free to members. Editor: 1. G. Finlay.

\section{Association of Professional Engineers of} British Columbia, 2210 West 12th Avenue, Vancouver 9, B. C. President: H. P. J. Moorhead. Term expires December 10, 1960. Registrar: J. A. Merchant. Term indefinite.

History: Set up under Engineering Profession Act in 1920.

Purfose: To safeguard the interests of the public by ensuring that only qualified persons practise professional engineering. 
Membership: 2357. Graduation in engineering from a recognized university or equivalent, 2 years of satisfactory engineering experience, and a report on an engineering project required.

Mectings: Annual.

Professional activities: Gold Medal awarded to engineering graduate of the University of British Columbia with best record during four years. Six book prizes of $\$ 25$ awarded for best sumner essays in third year.

Publications: B. C. Professional Engineer, monthly, current volume: $11, \$ 3$. Directory, annual, \$1. Editor: J. A. Merchant.

\section{Association of Professional Engineers of} Newfoundland, P. O. Box H-183, St. John's, Nfld. President: F. Gover, Department of Mines and Resources, Harvey Road, St. John's, Nfld. Term expires October 31, 1960. Secretary-Treasurer-Registrar: F. D. Grant, 26 O'Rielly Street, St. John's, Nfld. Term indefinite.

\section{History: Incorporated 1952.}

Purpose: To pronote and improve the proficiency of professional engineers in all matters relating to the profession of engineering; to advance and protect the interests of professional engineers in their profession and their service to the public.

Membership: 155. Applicants must be residents of the province, hold a degree in engineering from a recognized college or university, and have had at least two years experience under a professional engineer.

\section{Meetings: Annual.}

Professional activities: Engineering Scholarship of $\$ 150$ donated annually to Memorial University of Newfoundland.

\section{Association of Professional Engineers of}

Saskatchewan. President: L. T. Holmes, 3057 Retallack Street, Regina, Sask. Term expires February, 1961. Secretary-TreasurerRegistrar: Reginald Bing-Wo, P. O. Box 101, Regina, Sask. Term indefinite.

History: Organized and incorporated 1930.

Purpose: To administer the Engineering Profession Act; to protect the public through a system of registration of qualified engineers.

Membership: Registered professional engineers 705; engineers-in-training 81; recorded students 245 . Registered professional engineers: graduation from an accredited university in engineering or geology, plus two years of professional experience satisfactory to the Council, or passing of Intermediate and Final Examinations set by Board of Examiners. Engineersin-training: graduation, as for professional engineers, but no experience required, or passing of Intermediate Examinations. Student: regularly enrolled at a recognized university and studying engineering or geology, or recorded with the Association for eventual qualification by examination.

Meetings: Annual.

Professional activities: Prize of $\$ 100$ avarded aunually to most deserving student in the graduating engineering class of the University of Saskatchewan.

38. Association of Professional Engineers of the Province of Manitoba, Room 418, ?65 Portage Avenue, Winnipeg 2, Man. President: W. L. Wardrop, 452 Notre Dame Avenue, Winnipeg 2, Man. Term expires January, 1961. Secretary-Treasurer-Registrar: C. S. Landon, 220 Hugo Street, Winnipeg 9, Man. Term expires January, 1961.

History: Incorporated by Act of the Legislative Assembly of the Provinre of Manitoba, March, 1920, repealed and revised in 1940.

Purpose: To protect the public from disadvantages which might be occasioned by the employment of unqualified, incompetent, or unscrupulous persons styling themselves as engineers; to secure for the Province a high standard of engineering ability; to safeguard the legally qualified engineer against usurpation of his legitimate functions by persons not qualified to practise the engineering profession.

Membership: 1167. Graduation from a university, college or engineering school, accredited by the Council of the Association, and satisfactory experience in engineering work required; or, at least six years' experience in engineering work satisfactory to the Council and examination, or credentials in lieu thereof.

Meetings: Annual.

Professional activities: Annual award of four scholarships to engineering students of the University of Manitoba.

Publications: The Manitoba Professional Engineer, quarterly, current volume: 1.

\section{Association of Professional Engineers of the} Province of New Brunswick, Room 134, Union Station, Saint John, N. B. President: K. V. Cox, c/o New Brunswick Telephone Co. Ltd., Saint John, N. B. Term expires January, 1961. Registrar: J. P. Mooney. Term indefinite.

\section{History: Formed in 1920.}

Purpose: To maintain high standards of professional ethics among professional engineers and increase their usefulness to the public; to ensure the public of the proficiency and com- 
petency of professional engineers in the practice of engineering; to promote the proficiency of professional engineers in the practice of engineering; to promote the proficiency of professional engineers in all matters relating to the engineering profession, to advance and protect the interests of professional engineers.

Membership: 450 resident members; 100 nonresident. Graduation from a college of standing, recognized by the Council of the Association, or passing of examinations set by the Association, or membership in any engineering or technical organization of standing recognized by the Council.

\section{Mectings: Annual.}

Professional activities: Two scholarships annually for third and fifth year engineering students at the University of New Brunswick.

\section{Association of Professional Engineers of} the Province of Nova Scotia. President: B. N. Cain, Acadia University. Wolfville, N. S. Term expires January, 1961. SecretaryRegistrar: G. N. Kent, P. O. Box 731, Halifax, N. S.. Term indefinite.

\section{History: Incorporated 1920.}

Purpose: To administer the engineering profession in Nova Scotia.

Membership: 650. Members must have professional engineering status.

\section{Meetings: Annual.}

Publications: The Professional Engineer, quarterly, current volume: 4, free. Editor: M. E. J. O'Loughlin.

\section{Association of Professional Engineers of} the Province of Ontario. 236 Avenue Road, Toronto 5, Ont. President: Dwight S. Simmons. Term expires December 31, 1960. Executive Director: T. M. Medland. Term indefinite.

History: Organized and incorporated 1922.

Purpose: To administer the profession of engineering in the Province.

Membership: 19,000. Graduation from an engineering school recognized by the Council of the Association, plus practical experience satisfactory to the Council.

Professional activities: Professional Engineers Medal; Professional Engineers Gold Medal. Scholarships awarded to Grade XIIl student with highest standing entering an engineering school in Ontario, and to first, second, and third year students at the University of Toronto and Queen's University. Annual award to secondary school teachers of mathematics or science.
Publications: Professional Engineer, monthly, Current volume: 21. Editor: D. L. Turner.

42. Association of Professional Engineers of the Province of Prince Edward Island. President: R. D. Donnelly, 3 Waverley Court, Charlottetown, P. E. I. Term expires December 31, 1960. Secretary-Treasurer: E. S. Chandler, 242 North River Road, Charlottetown, P. E. I. Term expires December 31, 1960.

Purpose: To promote and improve proficiency of professional engineers in all matters relating to profession of engineering.

Membership: 28 members; 16 licensed to practise; 4 student members.

Meetings: Monthly.

43. Association of Professional Engineers of the Yukon Territory, P. O. Box 812, Whitehorse, Yukon. President: G. B. Starr, P. O. Box 2365, Whitehorse, Yukon. Term expires March, 1961. Executive Secretary: J. D. Scott. Term expires March, 1961.

\section{History: Incorporated 1955.}

Purpose: To regulate the practice of engineering in the Yukon Territory.

Membership: 25. Graduation from a recognized university, plus practical experience; or membership in another recognized association required.

Meetings: 3 times yearly.

44. Association of Provincial Land Surveyors of Nova Scotia, P. O. Box 1541, Halifax, N. S. President: W. E. Servant, 21 George Dauphinee Avenue, Halifax, N. S. Term expires November, 1960. Secretary-Treasurer: H. B. Robertson, 92 Larch Street, Halifax, N. S. Term expires November, 1960.

History: Founded 1951, incorporated under Societies Act 1955; incorporated under Provincial Land Surveyors Act 1959.

Purpose: To provide for the organization of provincial land surveyors of Nova Scotia with a view to fostering and promoting the practice of land surveying; to provide for the betterment of the members of the Society; to provide for uniformity and efficiency in land surveying.

Mcmbership: 250. Members must have certificate of qualification as provincial land surveyors in the Province of Nova Scotia.

\section{Meetings: Annual.}

Publications: The Nova Scotian Surveyor, quarterly, free to members. Editor: R. E. Millard. 
45. Astronautical Society of Canada, 3644 Peel Street, Montreal 2, Que. Honorary President: Gordon R. McGregor, c/o Trans Canada Airlines, 1080 University Street, Montreal, Que. Honorary Secretary: Henri T. P. Binet, P. O. Box 67, Station "H", Montreal, Que. Term indefinite.

History: Founded 1958, as Canadian Astronautical Society; name changed to above in September of that year to avoid confusion with a society formed at approximately the same time in Downsview, Ont., and also called Canadian Astronautical Society. Both groups affiliated to the International Astronautical Federation, sharing voting rights on alternate years.

Purpose: To facilitate contacts and interchange of views between Canadians among themselves, and between Canadian citizens and other persons also interested in the advancement of astronautics and space law; to stimulate public interest in space flight; to secure, through the medium of exchange of publications, collaboration on research, dissemination of technical and other information on space-flight, etc.; to promote and stimulate the achievement of space-flight; to stimulate work on astronautical and space law subjects by international and national research or other appropriate means.

Membership: 208; includes honorary and student members. Professional or amateur interest in astronautical science or space law required. Meetings: Six annually.

\section{British Columbia Association of Chiro-} podists. President: William J. Hewitt, 2775 West Broadway, Vancouver 8, B. C. Term expires January 30, 1961. Executive Secretary: R. Hyder, 804 Robson Street, Vancouver 1, B. C. Term expires January 30, 1961.

History: Organized 1928. Presently engaged in changing name to podiatrist.

Purpose: To maintain high ethical standards and keep up to date with medical advances.

Membership: 34. Requirements: graduation from a chiropody (podiatry) college approved by committee on education.

Meetings: Quarterly.

Professional activities: Scholarship $\$ 500$ at California College of Podiatry.

Library: 35 volumes : foot and related subjects.

47. British Columbia Dental Association, 925 West Georgia Street, Vancouver 1, B. C. President: H. R. Henderson, 1564 Pandosy Street, Kelowna, B. C. Term expires June, 1961. Executive Secretary: W. Ross Upton. Term indefinite.
History: Organized 1909; incorporated 1955.

Purpose: The advancement of dentistry in all its branches, by encouraging fraternal relationships among its members, by striving for higher standards of excellence in dental practice, and by contributing to the general scheme of health service.

Membership: 568; 2 honorary. Membership consists of members of the College of Dental Surgeons of British Columbia whose applications for membership have been favorably considered by the Executive.

Meetings: Annual.

Publications: News Bulletin, bi-monthly, current volume: XIV. Editor: Hugh Munroe, 502 Birks Building, Vancouver 2, B. C.

Library: 347 volumes on all phases of dentistry.

48. British Columbia Institute of Agrologists, 1275 Burris Street, Burnaby 1, B. C. President: C. A. Hornby, University of British Columbia, Vancouver, B. C. Term expires January, 1961. Registrar: J. C. Hackney. Term indefinite.

History: Established 1947 under Agrologists Act of B. C. Provincial organization of Agricultural Institute of Canada.

Purpose: To serve agriculture and give professional status to technical agriculturists; to establish standards and ethics.

Membership: 315 . Members must graduate in science in agriculture from a Canadian university or institution with equivalent standards.

Meetings: Annual.

Professional activitics: Bursary $\$ 250$ for first year student in agriculture degree course, University of British Columbia.

Publications: News Letter, monthly.

49. British Columbia Psychological Association, P. O. Box 2583, General Post Office, Vancouver, B. C. President: E. S. W. Belyea, University of British Columbia, Vancouver 8, B. C. Term expires October 17, 1960. Secretary: D. C. G. MacKay, University of British Columbia, Vancouver, B. C. Term expires October 17, 1960.

History: Founded 1938; incorporated 1939. Initially concerned with the informal discussion of psychological issues, and presentation of papers in relatively small groups. Following World War II more emphasis was directed toward consideration of professional problems of psychologists, etc. Affiliated with Canadian Psychological Association and the British Columbia Academy of Science. 
Purpose: To promote the cooperation of those interested in the various branches of psychology; to enable members to become familiar with the latest developments in psychology and allied fields; to stimulate the ethical practice and scientific progress of psychology in British Columbia.

Membership: 28 members; 12 affiliates. Members must have a postgraduate degree in psychology (Ph.D., or M.A. or equivalent) from a recognized university, and must be, or have been, engaged in work which is, in the opinion of the Directors, that of a psychologist; subscribe to, and practise, the code of ethics of the Canadian Psychological Association. Affiliates hold university degrees based in part on psychological study, and subscribe to and practise the code of ethics of the Canadian Psychological Association.

\section{Mectings: Annual.}

Professional activities: British Columbia Psychological Association Scholarship of $\$ 75$ for a student completing third year in psychology at the University of British Columbia.

\section{British Columbia Society of Occupational}

Therapy. President: Miss Dorothy Wilson, 1345 West 14th Avenue, Vancouver, B. C. Term expires September, 1961. Secretary: Mrs. Robert H. Morris, 2276 West 20th Avenue, Vancouver 8, B. C. Term expires September, 1961.

History: Branch of Canadian Association of Occupational Therapy.

Purpose: To establish and develop occupational therapy in the province.

Membership: 57 active; 16 non-active. Members must be registered occupational therapists, members of the Canadian Association of Occupational Therapy.

Meetings: Monthly.

51. British Columbia Veterinary Association, 170 IVest 44th Avenue, Vancouver 15, B. C. President: R. E. Cranston, 2994 Douglas Street, Victoria, B. C. Term expires September, 1961. Secretary-Treasurer: H. L. Bryson. Term expires September, 1961.

History: Brought into being by passing of B. C. Veterinary Act 1911. Five subsidiary groups: Vancouver Academy, comprised of small animal practitioners in the greater Vancouver area; Fraser Valley Veterinary Association, comprised of large animal practitioners primarily in the Fraser Valley; Interior Veterinary Association, comprised of members in this region, primarily generalized practitioners; Vancouver Island Veterinary Association, com- prised of all on the Island; Public Service Veterinary Club, comprised of salaried veterinarians from the Greater Vancouver area. Constituent member of Canadian Veterinary Medical Association and American Veterinary Medical Association. Also member of Pacific North West Veterinary Medical Association with States of Washington and Oregon.

Purpose: To further the science of veterinary medicine for the betterment of the public welfare and the profession as a whole.

Membership: Life members 1; practitioners 78; Canada Department of Agriculture 19; Provincial Department of Agriculture 7 ; municipal govermment 2 ; non-resident 28; nonpractising 5; retired 3 . Graduation from a recognized school of veterinary medicine; successful completion of examination set by association required.

Mectings: Annual.

Publications: Bulletin, twice yearly, current volume: 2. Editor: K. Chester.

52. Canadian Academy of Allergy. President: Jacques Léger, 3766 Queen Mary Road, Montreal, P. Q. Term expires June, 1961. Honorary Secretary-Treasurer: Harry L. Bacal, 4640 Stanley Weir Street, Montreal 29, P.Q. Term expires June, 1961.

History: First met 1945 as Canadian Society for the Study of Allergy; present title adopted 1951. Affiliated with International Association of Allergologists.

Purpose: To serve as a forum for the presentation and exchange of scientific knowledge about allergic diseases; to educate the public, or other medical specialties, in the diagnosis and treatment of allergic disease; to encourage among its member physicians a high standard of skill and ethical conduct.

Membership: 75. Active, associate, affiliate members; Honorary Fellows. Members must be active in specialist field of allergy, either by virtue of medical practice, or by activity in medical research concerned with special problems of allergic disease.

Mectings: Annual, in conjunction with Canadian Medical Association.

53. Canadian Aeronautical Institute, 77 Metcalfe Street, Ottawa 4, Ont. President: David Boyd, Rolls-Royce of Canada Ltd., P. O. Box 1400, St. Laurent, Montreal, P. Q. Term expires May, 1961. Executive Secretary: H. C. Luttman. Term indefinite.

History: Organized 1953-54, embracing Royal Aeronautical Society and Institute of the Aeronautical Sciences interests in Canada. Incor- 
porated 8 July, 1954. Branches in Toronto, Montreal, Ottawa, Vancouver, Winnipeg, Edmonton, Cold Lake, Halifax-Dartmouth, Calgary and Quebec. Specialist sections for astronautics, propulsion and test pilots.

Purpose: To advance the art, science and engineering relating to aeronautics.

Membership: 15 Honorary Fellows; 42 Fellows; 235 Associate Fellows; 1041 members; 456 technical members; 22 junior nembers : 186 students; 67 associates; 44 sustaining members. Student-undergoing a course of study in a recognized school of engineering or technology. Junior-engaged in technical work relating to aeronautics and so engaged for not more than four years. Technical-engaged in aeronautics or fields closely related thereto for at least four years, or graduation from a university or equivalent recognized course in mathematics, science or engineering. Member-engaged in aeronautics or fields closely related thereto for at least eight years and recognized standing therein (period may be reduced to four years with graduation from a university or recognized equivalent course). Associate-engaged in work relating to aeronautics though, at the date of admission, ineligible for one of the technical grades. Associate Fellow-engaged for not less than ten years in the practice of aeronautical science or engineering, and in responsible charge of important scientific or engineering work, or original work of outstanding character, or other outstanding contributions to aeronautical science or engineering. Fellow-Associate Fellow for one year or more and a position of distinction in aeronautics, notable and valuable contributions in aeronautical science or engineering.

Meetings: Annual.

Professional activities: McCurdy Award for outstanding achievement; F. W. (Casey) Baldwin Award (best annual contribution to Journal); IV. Rupert Turnbull Lecture (premium lecture); Branch Student Competition Awards (for theses, essays, etc.).

Publications: Canadian Aeronautical Journal, monthly, current volume: $6, \$ 4$. Editor: IV. A. Chisholm.

54. Canadian Agricultural Economics Society. President: G. P. Boucher, Canada Department of Agriculture, Ottawa, Ont. Term expires June, 1961. Secretary: I. F. Furniss, Canada Department of Agriculture, Ottawa, Ont. Term expires June, 1962.

History: Organized 1930.

Purpose: To encourage and improve study and interpretation of agricultural economics with particular reference to the Canadian economy.

Membership: 454. Professional or amateur interest in agricultural economics required. Full- time university students who have not yet obtained a Bachelor's degree eligible for junior membership.

Mectings: Annual.

Publications: Canadian Journal of Agricultural Economics, twice annually, current volume : 2, \$5. Editor: P. J. Thair.

Library: Small library on agricultural economics.

55. Canadian Anaesthetists' Society, 178 St. George Street, Toronto 5, Ont. President: R. H. Meredith, 82 Old Mill Road, Toronto, Ont. Term expires May 15, 1961. SecretaryTreasurer: R. A. Gordon. Term indefinite.

History: Incorporated 1943 under letters patent of the Dominion of Canada. Affiliated with the Canadian Medical Association.

Purpose: To advance the specialty of anaesthesia in the practice of medicine in its scientific, clinical and economic spheres.

Membership: 944 . Membership in good standing in the Canadian Medical Association required.

Mectings: Annual.

Publications: Journal, quarterly, current volume: 7, \$8. Editor R. A. Gordon.

56. Canadian Association for Applied Spectroscopy. President: W. Forsyth, Aluminum Laboratories Ltd., P. O. Box 250, Arvida, Que. Secretary-Treasurer: L. R. Pittwell, Dominion Magnesium Ltd., Haley, Ont.

History: Formed 1954. Obtained Letters Patent 1957. Local sections: Toronto-Hamilton; Ottawa; Montreal; Arvida. Committees on copper and non metallic spectrographic standards.

Purpose: Advancement of the study and application of spectroscopy; the promotion of felTowship between those who in any way make use of spectroscopy in Canada and elsewhere.

Membership: 200; sustaining members 75 . Requirement: an interest in the use of spectroscopy in any form; sustaining members are corporations with an interest in spectroscopy.

Mectings: Annual.

Publications: Canadian Spectrographic News, monthly, current volume: 5, free. Editor: W. J. Bennett.

57. Canadian Association of Actuaries. President: Donald M. Ellis, Canada Life Assurance Co., Toronto, Ont. Term expires June, 1961. Secretary: Melvin C. Pryce, c/o London Life Insurance Co., London, Ont. Term expires June, 1961. 
History: Organized 1907 as the Actuaries Club; present title adopted 1946. Standing committees: education; public relations; social security; mortality; promotion of mathematical careers; expenses; papers; group matters.

Purpose: To promote actuarial knowledge among its members.

Membership: Active 411 ; retired 34. Fellowship or Associateship in one of the Institute of Actuaries (England), The Faculty of Actuaries (Scotland), or the Society of Actuaries (Canada and U.S.A.) required.

Meetings: 7 meetings yearly.

58. Canadian Association of Anatomists. President: R. Altschul, University of Saskatchewan, Saskatoon, Sask. Term expires June, 1961. Secretary: L. F. Belanger, University of Ottawa, Ottawa, Ont. Term expires 1963.

History: Founded 1956 in Montreal. Incorporated 1957 into Canadian Federation of Biological Societies.

Purpose: To advance knowledge of anatomy and to represent anatomical sciences in Canada.

Membership: 1 honorary; 83 charter and elected; 31 associate. Candidates for elected membership must be proposed by two members, and adjudged at annual meeting on basis of personal credentials. Associate membership only requires interest and good standing.

Meetings: Annual.

\section{Canadian Association of Geographers-}

L'Association Canadienne des Géographes, P. O. Box 421, Ottawa, Ont. President: E. G. Pleva, University of Western Ontario, London, Ont. Term expires June 1, 1961. Secretary: R. J. E. Brown, National Research Council, Ottawa 2, Ont. Term expires June $1,1961$.

History: Organized 1951. Geographic sections : Southern Ontario; St. Lawrence-Ottawa; British Columbia. Committees: awards; convention; editorial; education; membership; nominations. Affiliated with the International Union of the Association of Geography Teachers, and represented on the Social Science Research Council of Canada.

Purpose: The promotion of geographical study and research, especially on Canadian topics.

Menbership: Life members 7 ; full 154; associate 60 ; student 92 ; sustaining 2 . Full-a graduate degree in geography or an undergraduate degree in geography and employed as a geographer, or significant contributions in the field of geography. Associate-an active interest in geography but lacking qualifications for full membership. Student-full-time university or college student. Organizations wishing to support the Association may apply for a sustaining membership.

\section{Mectings: Annual.}

Professional activities: CAG Book Prize given annually to the best student in each department of geograpliy at Canadian universities. Sponsors Canadian Committee of the International Geographical Union.

Publications: The Canadian Geographer-Le Géographe Canadien, three yearly, current volume: 14, \$5. Editor: W. G. Dean, University of Toronto, Toronto, Ont.

\section{Canadian Association of Medical Bacteri-} ologists-Association Canadienne des Médecins Bactériologistes. President: P. H. H. Greey, University of Toronto, Toronto, Ont. Term expires December, 1960. Secretary: R. W. Reed, McGill University, Montreal, Que. Term indefinite.

History: Formed 1957 to give the medical bacteriologists of Canada an opportunity to speak with a common voice on matters of interest to the specialty.

Purpose: To assure a high degree of professional competence; to contribute to the progress of medical bacteriology, and to protect the interests of the members.

Membership: 78. A degree or other qualification in medicine from a university or other recognized institution; evidence of training and competence in bacteriology satisfactory to the Council of the Association required.

Meetings: Annual.

\section{Canadian Association of Medical Record} Librarians, 770 Glenforest Street, Oshawa, Ont. President: Rev. Sister St. Antoine, St. Michel Archange Hospital, Quebec 5, Que. Term expires September 14, 1960. Executive Secretary: Mrs. Janet Milner. Term indefinite.

History: Formed in Toronto in 1935 as the Association of Medical Record Librarians for the Province of Ontario. Present society organized 1942; obtained Dominion charter in 1949.

Purpose: To elevate the standard of clinical records in hospitals, dispensaries or other distinctly medical institutions; to provide means for acquiring and disseminating among the members facts and opinions useful to them; to provide a means for exchanging ideas and intercommunication among such members; to establish and maintain a registry of medical record librarians; to do any other things conducive to rendering intelligent service in hospitals, dis- 
pensaries or other distinctly medical institutions, or conducive to the objects aforesaid.

Membership: 457. Any and all record department personnel eligible for membership; status of membership determined by position, experience, etc. Classes of membership: active, associate, inactive, and honorary.

Meetings: Annual.

Publications: Bulletin, six yearly, current volume: 17, \$3.50. Editor: J. Milner.

\section{Canadian Association of Occupational} Therapy, 331 Bloor Street, IV., Toronto 5, Ont. President: H. Hoyle Campbell, 215 Victoria Street, Toronto 1, Ont. Term expires October, 1960. Executive Consultant and Secretary: Mrs. Ethel Smith. Term indefinite.

History: Organized 1926; Dominion Charter granted in 1934. Provincial societies: British Columbia; Alberta; Saskatchewan; Ontario (local branches: London; Hamilton; Toronto; Kingston-Brockville); Quebec; Nova Scotia. Committees : education; registration and examination; clinical training; editorial; publicity.

Purpose: To develop the science of occupational therapy; to establish and maintain proficient standards of practice; to operate a registry of qualified occupational therapists; to publish a professional journal; to disseminate knowledge of the profession.

Membership: 422 full menbers; 122 nonactive members; 21 associate members; 110 honorary members and 4 lay members. Full and associate members must be graduates of approved schools of occupational therapy in Canada or abroad; non-active-same; honorary -elected to Honorary Advisory Council; layelected to Executive Council.

Meetings: Annual.

Publications: Canadian Journal of Occupational Therapy, quarterly, current volume: 27 , \$2. Editor: Mrs. Sheila Irvine. tion.

Library: Occupational therapy and rehabilita-

63. Canadian Association of Optometrists Inc., 159 Bay Street, Toronto, Ont. President: D. L. Francis, 106 Chisholm Building. Edmonton, Alta. Term expires July, 1961. Managing Director: E. B. Higgins. Term indefinite.

History: Incorporated by Act of Parliament 1946. Represents nine of Canada's ten provinces, Newfoundland not yet being affiliated.

Purpose: To advance public knowledge of the importance of adequate vision care.

Membership: 1500. Membership in good standing in a provincial optometric association required.
Meetings: Biennial.

Publications: Canadian Journal of Optometry, quarterly, current volume: $22, \$ 3$. Editor: G. M. Belanger, 45 Rideau Street, Ottawa, Ont.

64. Canadian Association of Pathologists. President: Harold G. Pritzker, The New Mount Sinai Hospital, 550 University Avenue, Toronto, Ont. Term expires June, 1961. Secretary-Trcasurer: D. W. Penner, Winnipeg General Hospital, Minnipeg 3, Man. Term expires June, 1961.

History: Founded approximately 15 years ago.

Purpose: Advancement of pathology and its allied sciences in all aspects; promotion of the interests of pathologists and allied scientists in the Dominion of Canada; maintenance of a high standard of proficiency among the pathologists and allied scientists of Canada.

Membership: 224. Ordinary members-registered medical practitioners in good standing in one of the Provinces of Canada who specialize in pathology and who devote their time predominantly to pathology, including all medically qualified laboratory workers such as bacteriologists, virologists, biochemists; must possess qualifications equivalent to those required by the Royal College of Physicians and Surgeons of Canada for certification as a specialist in pathology. Associate members shall be physicians intending to specialize in pathology with at least two years training in a Department of Pathology in an institution of learning recognized by the Council of the Association as being competent for training in the science of pathology, or scientists with specialized training in a science allied to pathology. Honorary members-persons of distinction who have contributed to the advancement of pathology; may be elected only upon unanimous affirmative vote of the Council.

Meetings: Twice yearly.

Publications: Newsletter, monthly, free. Editor: D. IV. Penner.

65. Canadian Association of Physical Medicine and Rehabilitation. President: Talmage E. Hunt, University Hospital, Saskatoon, Sask. Term expires August, 1961. SecretaryTreasurer: Maurice Mongeau, Rehabilitation Institute of Montreal, 6265 Hudson Road, Montreal 26, Que. Term expires August, 1961.

History: Incorporated 1952.

Purpose: To establish an association of specialists in physical medicine and rehabilitation in Canada; to advance the practice of physical medicine and rehabilitation and to further the teaching of undergraduate and postgraduate stu- 
dents in this field; to represent the members of the Association in their relationships with governments, medical associations, Universities, hospitals or other organizations; to promote high standards of training for allied groups concerned with physical medicine and rehabilitation; to advise the public and the profession in their choice of appliances used in physical medicine and rehabilitation; to organize at regular intervals a Canadian Congress of Physical Medicine and Rehabilitation.

Membership: 32 active members; 22 associate. Membership limited to duly qualified medical practitioners under the heading of active members, associate members, and honorary members. Active members-accredited specialists in physical medicine and rehabilitation by the Royal College of Physicians and Surgeons of Canada, or by a comparable and acceptable licensing body in a foreign country. Associate members-duly qualified medical practitioners who are interested in physical medicine, but who are not certified. Honorary members-persons who have rendered outstanding service in physical medicine and rehabilitation.

Meetings: Annual.

66. Canadian Association of Physicists, c/o Department of Physics, McMaster University, Hamilton, Ont. President: H. E. Duckworth. Term expires June, 1961. Secretary: G. D. Scott, University of Toronto, Toronto 5, Ont. Term indefinite.

History: Organized 1946 as Canadian Association of Professional Physicists; present name adopted 1947. Incorporated 1951. Geographic districts : British Columbia and Yukon; Prairies; South-Western Ontario; Central Ontario; Ottawa Valley; Quebec; Maritimes. Committees: membership; editorial; awards; prize: congress program; lectureship; nominating; S.S. science education; "Physics in Canada"; "High Energy".

Purpose: To further advancement of science of physics; to promote use of physical discoveries in interests of mankind; to promote knowledge in physical sciences and dissemination of information leading thereto in and between all sections and regions of Canada; to advance mutual understanding and cooperation between physicists, universities, research organizations and industry.

Membership: 527 full members; 267 associate; 805 student.

Mectings: Annual.

Professional activities: C.A.P. Lectureships covering most universities in Canada; C.A.P. Medal, annual, for achievement in physics; C.A.P. Prize-cash awarded on basis of special examination to honour physics or engineering physics student; C.A.P. High School Prize awarded on basis of special examination to high school students in local areas.

Publications: Canadian Journal of Physics, monthly, current volume: $38, \$ 9$. Editor: H. E. Duckworth. Physics in Canada, quarterly, current volume: 16 . Editor: K. L. S. Gunn, McGill University, Montreal, Que.

67. Canadian Association of Radiologists, 1555 Summerhill Avenue, Montreal 25, Que. President: Arthur E. Childe, 25 Medical Arts Building, Winnipeg, Man. Term expires January, 1961. Honorary Secretary-Treasurer: Robert G. Fraser, Royal Victoria Hospital, Montreal, Que. Term expires January, 1961.

History: Organized 1937; incorporated 1948. Provincial Divisions.

Purpose: To advance the art and science of radiology, and to promote its interest in relation to medicine with particular reference to the clinical, educational, ethical and economic aspects thereof.

Membership: Qualified members 418; members-elect 69 ; associate members 17 ; life members 4 ; retired members 17 ; honorary members 8. Qualified members-certification of qualification by the Royal College of Physicians and Surgeons of Canada as a specialist in diagnostic and/or therapeutic radiology; membership in the Canadian Medical Association, or l'Association des Médecins de Langue Française du Canada. Members-elect-persons in training for the specialty. Associate members-medical practitioners registered in the Dominion of Canada, engaged, but not exclusively, in the practice of radiology; persons specially qualified in a basic science related to and closely connected with the science or practice of radiology.

Mectings: Annual.

Professional activities: Certificate of Merit presented each year for best and most original paper submitted for publication in Journal.

Publications: Journal, quarterly, current volume: XI, \$3.50. Chairman, Editorial Board: J. Scott Dunbar.

Library: Small library housed at the Library of the Academy of Medicine, Toronto, Ont.

\section{Canadian Association of Textile Colourists} and Chemists, Ontario Section. President: N. J. Mohoruk, c/o The Hamilton Cotton Co. Ltd., Hanilton, Ont. Term expires February, 1961. Secretary: S. E. Black, R.R. No. 1, Waterdown, Ont. Term expires February, 1961.

History: Organized 1935.

Purpose: To increase knowledge of the application of dyes and chemicals in the texile indus- 
try; to increase research work on chemical processes and materials of importance in the textile industry; to establish channels for increasing the interchange of professional knowledge and ideas; to sponsor and encourage technical education in the textile industry.

Membership: 175. Any person having not less than two years practical experience in bleaching, dyeing, printing or finishing of textile fibres, or suppliers of chemicals, dyestuffs and dyeing and finishing equipment, or graduates in bleaching, dyeing, printing or finishing of a recognized textile school, who are interested in promoting all or any of the objects of the Association.

\section{Meetings: Monthly.}

Professional activities: Award to outstanding student in chemistry and dyeing course at the Hamilton Institute of Technology.

\section{Canadian Association of Textile Colourists} and Chemists (Quebec Section). President: J. G. Soroka, 2100 Victoria Street, Lachine, Que. Term expires April, 1961. Secretary: T. R. Owen, 730 43rd Avenue, Lachine, Que. Term expires April, 1961.

\section{History: Organized 1936.}

Purpose: To benefit its members by increasing knowledge of the application of dyes and chemicals in the textile industry, by increasing research work on chemical processes and materials of importance in the textile industry, by establishing channels for increased interchange of professional knowledge and ideas, and by sponsoring and encouraging technical education in the textile industry.

Membership: 357. Any person having not less than two years practical experience in bleaching. dyeing, printing, or finishing of textile fibres, or suppliers of chemicals, dyestuffs, and dyeing and finishing equipment, or graduates in bleaching, dyeing, printing, and finishing of a recognized textile school, who are interested in promoting all or any of the objects of the Association, shall be eligible for membership. Membership classes: active, honorary, corporate. Active members to be 21 years of age or over.

Meetings: Monthly.

Professional activities: Whattam Award given to outstanding student in final year of class on dyeing and chemistry at Sir George Williams College, Montreal.

Publications: Canadian Textile Journal, free to members. Editor: J. Merriman.

70. Canadian Biochemical Society. President: M. Darrach, University of British Columbia, Vancouver, B. C. Term expires June, 1961. Secre- tary: H. D. Branion, Ontario Agricultural College, Guelph, Ont. Term expires June, 1961.

History: Formed 1957 in Ottawa. Constituent member Canadian Federation of Biological Societies.

Purpose: To foster science of biochemistry.

Membership: 255. Persons who through research or scholarship have demonstrated an interest in biochemistry eligible for membership.

Mectings: Annual.

71. Canadian Ceramic Society. President: R. K. Robertson, Cooksville-Laprairie Brick Ltd., 906 Shell Towers Building, 660 St. Catherine Street, Montreal, Que. Term expires January 8, 1961. General Secretary: Miss L. C. Keith, 49 Turner Road, Toronto 4, Ont. Term indefinite.

History: First meeting held in London. Ont., 1901 under original name, Ontario Clayworkers' Association. Later Canadian Clay Products Manufacturers Association, then Canadian National Clay Products Association. Present title adopted 1932. Divisions: clay; glass; pottery and whitewares; porcelain enamel; electronics. Committees: research, education. Regional sections: Quebec; Ontario; IVestern.

Purpose: To advance ceramic arts and sciences; to encourage study and research in various branches of ceramics; to establish and maintain friendly and personal contact between those interested in the ceramic industry.

Membership: 475. Corporation membersinterest in the advancement of ceramic arts and sciences, encouragement of study and research in various branches of ceramics; associate-interest in ceramic wares or in products of materials related to their manufacture; active-persons engaged in production of ceramic wares.

Mectings: Annual.

Publications: Journal, annual, current volume : 29. \$3. Editor: Miss L. C. Keith.

72. Canadian Council of Professional Engineers, 77 Metcalfe Street, Ottawa, Ont. President: J. Graham Dale, Northwestern Utilities Ltd., Edmonton, Alta. Term expires May, 1961. Executive Secretary: Leopold M. Nadeau. Term indefinite.

History: Founded in 1938 to coordinate the work of the eleven provincial and territorial associations of professional engineers in Canada. Formerly Dominion Council of Professional Engineers.

Purpose: To coordinate and standardize activities of the provincial associations, primarily in 
matters pertaining to registration, licensing and transfer of registration of professional engineers; to act on other matters of national scope concerning the profession, alone or in cooperation with other groups.

Membership: The Associations of Professional Engineers of Alberta, British Columbia, Manitoba, New Brunswick, Newfoundland, Nova Scotia, Ontario, Prince Edward Island, Saskatchewan and the Yukon Territory, and the Corporation of Professional Engineers of Quebec.

\section{Mectings: Annual.}

Publications: The Canadian Professional Engineer, annual, free to registered professional engineers of Canada. News Bulletin, 9 to 10 a year, free to Council Members of constituent bodies and a small list of individuals. Editor: L. M. Nadeau.

\section{Canadian Dental Association, 234 St. George}

Street, Toronto 5, Ont. President: James P. Whyte, Swift Current, Sask. Term expires September, 1961. Sccrctary: Don IV. Gullett. Term indefinite.

History: Organized 1902; incorporated 1942. Sections: dentistry for children; oral surgery; orthodontic; periodontology.

Purpose: To cultivate and promote the art and science of dentistry and its collateral branches.

Membership: 5780 . Classifications : individual, associate, honorary, corporate.

Meetings: Annual.

Professional activities: War Memorial Scholarship Fund inaugurated 1946; annual essay competition for final year dental students; Studentships awarded annually for training research personnel. Amount in 1959: $\$ 7000$ approx.

Publications: Journal, monthly, current volume: 26, \$5. Editor: E. R. W. Bilkey.

Library: 2500 volumes; dentistry and medicine.

74. Canadian Dermatological Association, 1390 Sherbrooke Street, W., Montreal, Que. President: S. E. Grimes, Medical Arts Building, Ottawa 4, Ont. Term expires June 17, 1961. Secretary-Treasurer: G. E. Craig. Term indefinite.

History: Founded 1926 as Canadian InterUrban Dermatological Society, a national Canadian dermatological society. This organization affiliated 1928 with British association, and name changed to British Association of Dermatologists and Syphilologists, Canadian Branch. Under this name until 1947 when present name adopted.
Membership: 118. Certification by Royal College or examination of American Board required.

Meetings: Annual.

Professional activities: Annual research award.

75. Canadian Dietetic Association, 1393 Yonge Street, Toronto 7, Ont. President: Miss E. Jean Campbell, Colonel Belcher Hospital, Galgary, Alta. Term expires June, 1961. General Secretary: Miss Joan E. Brown. Term indefinite.

History: Organized April, 1935 ; incorporated August, 1935. Provincial associations in Quebec Manitoba, Ontario, Nova Scotia, New Brunswick, British Columbia, Alberta, Saskatchewan, and Newfoundland. Committees: university education; internship; vocational guidance \& public relations; nutrition; journal; legislation.

Purpose: To promote, encourage and improve the status of dietitians in Canada by establishing standards for training dietitians, and by raising standards of dietary work.

Membership: 1140. Bachelor's degree from approved university or college course; dietetic internship approved by Board of Directors, such internship to be attested successful by a person in authority.

Meetings: Annual.

Professional activities: Annual Memorial Lecture supported by Violet Ryley-Kathleen Jeffs Foundation of $\$ 19,000$. Annual Award $\$ 175$ to graduating university student.

Publications: Journal, bi-monthly, current volume: XXII, \$3. Editor: Committee.

\section{Canadian Federation of Biological Societies.}

Chairman of the Board: R. J. Rossiter, University of IVestern Ontario, London, Ont. Term expires June 2, 1961. Honorary Treasurer: A. G. Gornall, University of Toronto. Toronto, Ont. Term expires June 2, 1961.

History: Formed October, 1957 by alliance of Canadian Physiological Society, Pharmacological Society of Canada, Canadian Association of Anatomists, and Canadian Biochemical Society.

Purpose: To bring together persons interested in teaching and research in the biological sciences; to disseminate information on the results of biological research through scientific meetings and through publication; to encourage exchange of information between the constituent societies; and to act for the member societies when concerted action is desirable.

Membership: Four societies listed under History. Membership requirements established by constituent societies. 


\section{Meetings: Annual.}

Publications: Canadian Federation News, annual, current volume: 2. Proceedings, annual, current volume: 3. Editor: P. G. Scholefield.

77. Canadian Heart Association, Inc. President: Paul David, Montreal Institute of Cardiology, 5414 Boulevard Assomption, Montreal, Que. Term expires November, 1960. Honorary Secretary: Robert S. Fraser, University of Alberta Hospital, Edmonton, Alta. Term indefinite.

History: Organized 1947; incorporated 1949.

Purpose: To promote the prevention and relief of cardiovascular disorders.

Membership: 225. Membership limited to duly qualified medical practitioners and workers in allied sciences, e.g., pathology, physiology, biochemistry, etc., specially interested in the study and treatment of cardiovascular disease.

Meetings: Annual.

78. Canadian Home Economics Association, 78 Sparks Street, Ottawa, Ont. President: Miss G. Gerlach, 108 Driveway, Ottawa, Ont. Term expires July, 1961. Exccutive Secretary: Mrs. I. I. Bruce. Term indefinite.

History: Organized 1939 in Winnipeg. Administered by elected board of 26 Directors, with at least one director from each province. Other activities carried on through committees. Affiliated groups include provincial and regional Home Economics associations, and college Home Economics clubs. Association affiliated with International Federation of Home Economics since 1948.

Purpose: To further the interests of the profession, and promote the objects of the Association.

Membership: 950: active, association, life and honorary. Associate - anyone interested in the organization.

Meetings: Annual.

Publications: Journal, quarterly, current volume: 10, \$1.50. Editor: Miss H. Janzen, 280 William Avenue, Winnipeg 2, Man.

Library: archivist library.

79. Canadian Institute of Food Technology. President: Gordon R. Maybee, Fry-Cadbury Ltd., 2050 Masson Street, Montreal 34, Que. Term expires June, 1961. Secretary-Treasurer: W. J. Eva, Ogilvie Flour Mills Co. Ltd., P. O. Box 846, IVinnipeg, Man. Term expires June, 1961.

History: Food groups formed in Winnipeg, Montreal, Toronto from 1947-51 amalgamated
1951 into Canadian Food Technologists Association. Present name adopted 1956. Incorporated 1959.

Purpose: Non-profit, scientific educational association to promote application of science and engineering to production, processing, packaging, distribution, preparation, and utilization of foods; to stimulate investigation into problems arising therefrom, and provide a medium for promulgating and discussing the results of such investigations; to stimulate and provide means for free interchange of technological information and ideas among food technologists; to promote recognition of the role of food technologists in technical direction of operations in these fields.

Membership: 515: 466 professional; associate.

Meetings: Annual.

Publications: News Letter, 4-5 annually, current volume: II. Editor: B. Berck.

80. Canadian Institute of Forestry, 10 Manor Road West, Toronto 7, Ont. President: H. J. Hodgins, Crown Zellerbach of Canada, Ltd., Burrard Building, Vancouver, B. C. Term expires 1962. Secretary-Manager: J. J. E. Dosne. Term indefinite.

History: Organized 1908 as Canadian Society of Forestry Engineers; present name adopted 1950. Twenty sections across Canada.

Purpose: To encourage wider understanding of forestry problems and improve forestry practice in Canada; to advance members' knowledge of the science and practice of forestry; to publish a technical and scientific forestry journal; to promote interests and standards of the profession.

Membership: 2100. Active - graduation with degree, or postgraduate degree, in forestry, forest engineering or applied science (forestry) from approved forestry school; or affiliate members of two or more years standing, or other persons, having sufficient experience or special qualifications, and meeting requirements of Board of Examiners. Affiliate - persons with degrees in allied sciences, or engaged or interested in forestry approved by Board of Directors. Student - registered undergraduates in forestry, forestry engineering or applied science (forestry). Honorary - for outstanding contributions to advancement of forestry.

Mectings: Annual; sections meet monthly.

Professional activities: Gold Medal Awards to university forestry faculties.

Publications: The Forestry Chronicle, 4 year1y, current volume: 36 , $\$ 6$. Editor: Harry Smith.

Library: 1000 volumes on forestry. 
81. Canadian Institute of Mining and Metallurgy, 1117 St. Catherine Street, W., Montreal 2, Que. President: II. H. Durrell, c/o Hollinger-Hanna Ltd., 810 Côte de Liesse Road, Montreal 9. Que. Term expires April, 1961. Secretary-Treasurcr: C. Gerow. Term indefinite.

History: Organized and incorporated 1898 as The Canadian Mining Institute; name changed to present title by Act of Parliament 1920. Affiliation of Mining Society of Nova Scotia arranged 1918. Six geographic districts across Canada numbered 1 to 6 from east to west; thirty-eight branches. Technical divisions: coal ; geology ; industrial minerals; metallurgy ; metal mining and petroleum; natural gas; separate committees of each for particular subjects.

Purpose: To promote arts and sciences connected with economical production of valuable minerals and metals: to maintain a central reference library; to act at all times in the interest of the mineral industry.

Membership: 5959. Members and associates 3494 ; junior and junior associates 1390; corporate 120; student 955. Members and juniors are directly connected with mineral industry with relative amounts of responsible charge; associates and junior associates are indirectly connected with the mineral industry with relative amounts of responsible charge.

Meetings: Annual.

Professional activities: Prizes for Student Essays; President's Gold Medal; Institute Medal for Distinguished Service; Past Presidents' Memorial Medal; John T. Ryan Trophies; Barlow Memorial Medal; Selwyn G. Blaylock Medal ; Medal of the International Nickel Company of Canada; Institute Medal for Bravery (to recognize great valour displayed in saving lives in mines or plants of the mineral industry).

Publications: The Canadian Mining and Metallurgical Bulletin, monthly, current volume: 53, \$10. Transactions, annual, \$10. Editor: C. Gerow.

Library: 7000 volumes on mining, metallurgy, geology, and petroleum.

82. Canadian Institute of Sanitary Inspectors. President: Thomas E. Elliott, City Hall, North Bay, Ont. Term expires September 15, 1962. Sccretary: L. A. McCrcesh, 4178 New Street, Burlington, Ont. Term expires September 15, 1962. Executive Secretary: Louis M. Berube, 1910 rue Beugrand, Montreal 5, P. Q. Term expires Septenber 15 , 1962.

History: Organized 1923 in IVinnipeg by members of Manitoba, Ontario, and Quebec sections; incorporated 1934. Branches in all provinces of Canada.
Purpose: To promote advancement of sanitary science in all or any of its branches; to raise the status and standards of the inspectors; to cooperate with other health associations in the interest of better public health programs.

Membership: 800; 34 student. Certificate in Sanitary Inspection (Canada), and reconmendation of a Branch of the Institute required.

Mectings: Annual.

Publications: Canadian Sanitarian, quarterly, current volume: 4. Editor: George Auton, P. O. Box 4006, Station D, Vancouver, B. C.

83. Canadian Institute of Surveying, P. O. Box 3151, Postal Station C. Ottawa, Ont. President: R. Thistlethwaite. Term expires February, 1961. Secretary-Trcasurer: R. J. Parlee. Term indefinite.

History: Organized 1882 as Association of Dominion Land Surveyors; name changed to Canadian Institute of Surveying 1934, then to the Canadian lnstitute of Surveying and Photogrammetry 1950; reverted to the present name 1957.

Purposc: To further the professional knowledge of its members; to promote professional interest in surveying and mapping; to enhance usefulness of the profession to the public.

Membership: 1283; honorary 9; life 16; members 881 ; associate 117; junior 260. Members are professional; associate and junior are nonprofessional but engaged in or of service to surveying and mapping.

\section{Mectings: Annual.}

Publications: The Canadian Surveyor, five yearly, current volume: $15, \$ 5$. Editor: E. J. Jones.

\section{Canadian Library Association-Association} Canadienne des Bibliothéques, 63 Sparks Street, Ottawa 4. Ont. President: Neal Harlow, University of British Columbia Library, Vancouver, B. C. Term expires 1961. Exccutice Secretary: Miss Elizabeth H. Morton. Term indefinite.

History: Organized 1946; incorporated 1947. Technical, scientific committees, sections, etc: research library: reference; cataloguing; Special Committee on Lnion List of Serials working in cooperation with the American Library Association, Library of Congress and the H. II'. IVilson Company of New York.

Purpose: To promote education, science and culture within the nation through library service; to promote high standards of librarianship and the welfare of librarians; to cooperate with library associations both within and ontside of Canada and with other organizations interested 
its the promotion of education, science and culture.

Membership: Personal 1425; institutional 501. Personal-qualified librarians; persons working as librarians in a library, or sitting as members of a library board. Institutional-giving library service, supplying books and/or library equipment.

\section{Mectings: Annual.}

Professional actizities: Microfilming of Canadian newspapers of historical interest; annual scholarship.

Publications: Canadian Index to Periodicals and Documentary Films, monthly, current volume: 5 , service basis. Editor: Miss Isabel Lee. Bulletin, bi-monthly, current volume: 16 , members free, Canada $\$ 3$, Foreign $\$ 4$. Feliciter, monthly, members only. Editor: Miss Elizabeth H. Morton.

Library: 400 volumes, librarianship and bibliography.

\section{Canadian Mathematical Congress, Ecole}

Polytechnique, 2500 Guya 1 Avenue, Montreal, Que. President: R. L. Jeffery, Queen's University, Kingston, Ont. Term expires 1961. English Secretary: R. Eric O'Connor, S. J., Loyola College, Montreal, Que. Term indefinite. French Secretary: Abel Gauthier, University of Montreal, Montreal, Que. Term indefinite. Treasurer: W. C. G. Williams, 1635 Selkirk Avenue, Montreal, Que. Term indefinite. Executive Secretary-Treasurer: L F. S. Ritcey. Term indefinite.

History: Organized 1945 by mathematicians at Canadian universities, with support from industrial and financial corporations, the National Research Council of Canada and some provinces. From beginning has had close bonds with the American Mathematical Society.

Purpose: To encourage and support mathematical research; to improve the teaching of mathematics in Canada.

Membership: 380. Members must have mathematical competence and introduction by a member.

\section{Mectings: Every four years.}

Professional activities: Biennial seminar 3-4 weeks duration; Summer Research Institute 3 months each summer at Queen's University, Kingston, Ont. Summer school for teachers each summer in one of the Maritime Provinces; annual mathematics competitions in Nova Scotia, New Brunswick, and Quebec; sponsors and fitancially supports similar competitions in other provinces.

Publications: Canadian Journal of Mathematics-Journal Canadien de Mathématiques, quarterly, current volume: $12, \$ 10$ (\$5 for in dividual members of recognized mathematical societies). Editor-in-chief: G. F. D. Duff. Canadian Mathematical BULLETIN Canadien de Mathématiques, three annually, current volume: 3, \$3. Editor-in-chief: Peter Scherk.

\section{Canadian Medical Association, 150 St.} George Street, Toronto 5, Ont. President: R. M. Parsons, P. O. Box 608, Red Deer, Alta. Term expires June, 1961. General Secretary: A. D. Kelly. Term indefinite.

History: Organized 1867; incorporated 1909. Ten provincial divisions autonomous within their provinces but closely federated with the national organization. Standing, special committees and sections representative of medical specialties.

Purpose: To promote the medical and related arts and sciences and to maintain the honour and the interests of the medical profession.

Membership: 14,000 Canadian doctors of medicine.

\section{Meetings: Annual.}

Professional activities: F. N. G. Starr Medal; Osler, Lister and Blackader Lectureships.

Publications: Journal, weekly, \$12. Canadian Journal of Surgery, quarterly, $\$ 10$. Editor: Donald C. Graham.

\section{Canadian Medical Association, Alberta Di-} vision, 503 Alexandra Block, Edmonton, Alta. President: E. F. Donald, 510 Medical Arts Building, Edmonton, Alta. Term expires September 30, 1961. Executive Secretary: IV Bramley-Moore, 503 Alexandra Building, Edmonton, Alta. Term indefinite.

History: Organized 1905 as Alberta Medical Association. Present title adopted 1935.

Purpose: To promote health and prevention of disease; to improve medical services, however rendered; to maintain the integrity and honour of the medical profession and the advancement of medical science; to perform other lawful things incidental or conducive to the welfare of the public and of the medical and allied professions.

Membership: 1200. Membership in the College of Physicians and Surgeons of Alberta required.

Meetings: Annual.

88. Canadian Medical Association, British Columbia Division, 1807 West 10th Avenue, Vancouver 9. B. C. President: E. C. McCoy. Term expires October, 1960. Executize Director: G. G. Ferguson. Term indefinite. 
History: Incorporated 1900 as British Columbia Medical Association; affiliated 1930 with Canadian Medical Association and recognized as a division of that body. Geographic divisions within province for purposes of self-government. Sections: anaesthesia; dermatology, eye, ear, nose and throat; internal medicine; general practice; general surgery; orthopaedics; neurology and psychiatry; physicians in public service; psychiatrists in private practice; radiology ; pathology; urology; obstetrics and gynaecology.

Purpose: To advance scientific, educational, professional and economic welfare of all members of medical profession in British Columbia; to serve and further interests of Canadian Medical Association in British Columbia; to act as agent or trustee or otherwise for members of medical profession, or some of them, in connection with pension or retirement savings or disability plans, or other forms of insurance; to act for members of the medical profession, or some of them, as an agent in collective bargaining in respect to conditions of medical service and remuneration; to collect fees and receive donations; to expend monies to defray expenses of association and to promote and further any of its objects; promotion of health and prevention of disease; improvement of medical services however rendered; maintenance of the integrity and honour of medical profession; performance of such other lawful things as are incidental or conducive to welfare of public and of medical and allied professions.

Membership: 1700. Every member in good standing of College of Physicians and Surgeons of B. C. and registered under Section 34 of Medical Act of B. C. eligible for membership; may become member by signing application form and delivering to secretary with initial fees.

Meetings: Annual.

Professional activities: Bursary fund.

Publications: British Columbia Medical Journal (published by Vancouver Medical Association ), monthly, current volume: 2 . Editor: J. H. MacDermot.

See also: Manitoba Medical Association; Newfoundland Medical Association; New Brunswick Medical Society; Medical Society of Nova Scotia; Ontario Medical Association.

89. Canadian Medical Association, Prince Edward Island Division. President: F. A. McMillan, Charlottetown Clinic, P. E. I. Term expires August, 1961. Secretary: C. A. Coady, Charlottetown Clinic, P. E. I. Term expires August, 1961.

Purpose: Promotion of medical science and of the interests of the medical profession.
Membership: 80. Members must be qualified medical practitioners, and licentiates of the Medical Council of Canada.

Meetings: 8-9 yearly.

90. Canadian Medical Association, Quebec Division, 2115 Drummond Street, Suite 33, Montreal 25, P. Q. President: G. IT. Halpenny, 1414 Drummond Street, Montreal 25, P. Q. Term expires June, 1961. Honorary Secretary: N. J. Belliveau. Term indefinite.

History: Started as Province of Quebec Medical Association in 1922; became Quebec Division of Canadian Medical Association in 1937 in order to extend activities beyond purely provincial level.

Purpose: Non-profit professional association.

Membership: 2100. Members must be graduates of a recognized medical school and duly licensed to practise in the Province of Quebec.

Meetings: Annual.

91. Canadian Medical Association, Saskatchewan Division. President: A. J. M. Davies, Indian Head, Sask. Term expires January, 1961. Executive Secretary: G. W. Peacock, 932 Spadina Crescent, Saskatoon, Sask. Term indefinite.

History: Formed 1937, merger of Saskatchewan Medical Association and College of Physicians and Surgeons of Saskatchewan.

Purpose: Professional and economic affairs of the profession.

Membership: 931. Registration with the College of Physicians and Surgeons of Saskatchewan required.

Mectings: Annual.

Publications: Saskatchewan Medical Quarterly, quarterly, current volume: 1200 . Editor : G. W. Peacock.

92. Canadian Neurological Society. President: C. E. C. Gould, 3195 Granville Street, Vancouver, B. C. Secrctary-Treasurer: J. Preston Robb, 1610 Pine Avenue, W., Montreal, Que.

History: Organized 1948.

Purpose: To promote prevention and relief of neurological disease and encourage study of all aspects of neurology.

Membership: 173. Certification by Royal College of Physicians and Surgeons or by a provincial College of Medicine required.

Meetings: Annual.

93. Canadian Nurses' Association, 74 Stanley Avenue, Ottawa 2, Ont. President: Miss Helen Carpenter, University of Toronto, 
Toronto, Ont. Term expires June, 1962. Executive Secretary: Miss M. Pearl Stiver. Term indefinite.

History: Founded 1908; incorporated 1925. Federation of ten provincial registered nurses' associations. Member, International Council of Nurses.

Purpose: To dignify the profession of nursing; to encourage its members to participate in affairs promoting the public welfare; to promote the best interests of nurses of Canada; to encourage an attitude of mutual understanding with nurses of other countries.

Membership: 57,150. Registration as a nurse and membership in a provincial registered nurses' association required; becomes member also of International Council of Nurses.

\section{Mectings: Biennial.}

Publications: The Canadian Nurse, monthly, in both English and French, current volume: 56. Canada and Bermuda $\$ 3, \mathrm{U}$. S. and Foreign $\$ 3.50$. Editor: Miss Margaret Kerr, Executive Director, The Canadian Nurse, 1522 Sherbrooke Street IV., Montreal, Que.

\section{Canadian Operational Research Society, c/o} Dept. of Mathematics, University of Toronto, Toronto, Ont. President: D. B. Delury, University of Toronto, Toronto, Ont. Term expires May, 1961. Secretary: W. L. Archer, 723 Courtenay Avenue, Ottawa, Ont. Term expires May, 1961.

History: Formed 1958. Cooperating arrangements with Operations Research Society of America, Institute of Management Sciences, Operations Research Society of the United Kingdom. Member of International Federation of Operational Research Societies. Operational Research Society of Toronto (founded 1955) made first local section of CORS 1958. Montreal and Vancouver sections formed 1959; Ottawa section 1960.

Purpose: Advancement of the theory and practice of operational research in Canada, by conferences, education, liaison, and development of local sections.

Membership: Technical 82; associate 122. Technical members must have demonstrated competence or be actively, professionally engaged in operational research; associates need only support the society's objects.

Meetings: Annual.

Publications: Newsletter, 3 yearly. Editor: J. R. Walter, B. A. Oil Co., 800 Bay Street, Toronto, Ont.

95. Canadian Ophthalmological Society-Société Canadienne d'Ophtalmologie. Presi- dent: Benjamine Alexander, Medical Arts Building, Montreal, Que. Term expires June, 1961. Secretary: R. G. C. Kelly, 90 St. Clair Avenue, W., Toronto 7, Ont. Term indefinite.

History: Organized 1937; incorporated 1938. Committees: editorial; Canadian National lnstitute for the Blind; certification; public relations; traffic; preschool vision.

Purpose: The cultivation and promotion of ophthalmology and the study of ophthalmic problems in relation to public health and welfare.

Membership: 237; ordinary members 228; associate 3 ; honorary 15 ; emeritus 1 . Certification in ophthalmology by Royal College of Physicians and Surgeons of Canada required. Reciprocity with American Academy of Ophthalmology.

Meetings: Annual.

Publications: Transactions, \$6. Editor: Clement McCulloch.

96. Canadian Orthopaedic Association-Association Canadienne D'Orthopédie. President: E. IV. Ewart, 83 Alma Street, Moncton, N. B. Term expires June, 1961. Secretary-Treasurer: I. W. Davidson, 130 Elm Street, E., Sudbury, Ont. Term indefinite.

Purpose: The advancement of the art and science of orthopaedic surgery in all its phases; the improvement of its practice; the elevation of its standards; the promotion of facilities for post-graduate training in orthopaedic surgery and the encouragement of orthopaedic surgeons to secure the highest qualifications.

Membership: 165; active; senior; honorary. Active members: graduation from an approved medical school; adequate training and experience in orthopaedic surgery, during a period of seven years after graduation in approved hospital or hospitals; satisfactory evidence of exclusive engagement in the study and practice of orthopaedic surgery in accordance with the purpose and objects of the association; examination approved by the association.

\section{Meetings: Annual.}

Professional activities: Contributes annually towards exchange fellowship between Great Britain, United States and Canada.

\section{Canadian Osteopathic Association, 609} Medical Arts Building, Montreal 25, Que. President: Robert H. Wettlaufer, 517 Piggot Building, Hamilton, Ont. Term expires October, 1960. Executiz' Secretary: Miss Joyce S. Currie. Term indefinite.

History: Organized with present name 1926.

Purpose: To advance healing art by the study and application of osteopathic principles; to 
stimulate original research; to elevate the standards of osteopathic education; to increase the ability of the osteopathic profession to serve the people.

Membership: 50. Graduation from a recognized college of osteopathy and license to practise in the province from which applies, or license to practise in another province, state, or country required.

Meetings: Annual.

98. Canadian Paediatric Society-Société Canadienne de Pédiatrie. President: Stanley C. Best, 2058 Montague Street, Regina, Sask. Term expires June, 1961. Secretary-Treasurcr: W. W. Tidmarsh, 79 Percival Avenue, Montreal 28, Que. Term indefinite.

History: Founded 1922 as Canadian Society for the Study of Diseases of Children.

Purpose: The betterment of Canadian paediatrics.

Membership: 400. Certified specialists in paediatrics.

Meetings: Annual.

Professional activities: Annual Mead Johnson Educational Awards.

\section{Canadian Palaeontological Association.} Secretary: L. S. Russell, National Museum of Canada, Ottawa, Ont. Term indefinite.

History: Established 1958 as an informal association of Canadian palaeontologists.

Purpose: To represent Canada on the International Palaeontological Union; to provide Canadian palaeontologists with information of national and international interest.

Membership: 46. Members should have a professional interest in palaeontology; registration with Secretary.

100. Canadian Pharmaceutical Association, Inc., 221 Victoria Street, Toronto, Ont. President: D. F. McKeague, c/o Durnford Drug Company, Greyhound Building, Calgary, Alta. Term expires August, 1961. SecretaryManager: J. C. Turnbull. Term indefinite.

History: Organized 1907, incorporated 1924. Constituent bodies are provincial statutory pharmaceutical associations, societies or colleges.

Purpose: To advance the science and practice of pharmacy in Canada.

Mcmbership: 8500 . Membership in provincial statutory pharmaceutical associations required.

Meetings: Annual.
Professional activities: Book Prize Award annually to colleges.

Publications: The Canadian Pharmaceutical Journal, monthly, current volume: 93 , Canada $\$ 3$, U. S. \$4, Foreign \$5. Editor: J. F. Henderson.

101. Canadian Physiological Society. President: F. C. McIntosh, McGill University, Montreal, Que. Term expires June, 1961. Secretary: N. B. G. Taylor, c/o D. R. M. L., P. O. Box 62, Postal Station "K", Toronto, Ont. Term expires June, 1961.

History: Organized 1935 in Toronto from joint meetings of Montreal Physiological Society and Toronto Biochemical Society. Founding constituent society of the Canadian Federation of Biological Societies 1957.

Purpose: To promote the advancement of physiology in its widest sense.

Membership: 400; emeritus 26. Memberperson who has conducted researches, publislied papers in scientific journals, and who is actively engaged in investigation, teaching, or other form of scholarship in the fields of physiology, biochemistry, pharmacology, clinical investigation or the experimental aspects of biology, pathology, therapeutics, nutrition or hygiene. Emeritus - a member retired from active employment because of age or illness. Honorary-person who has rendered distinguished service to physiology and who is not a member or emeritus member of the Society.

Meetings: Annual.

Publications: Canadian Journal of Biochemistry and Physiology, monthly, current volume: 38, \$9. Editor: J. F. Morgan (Biochemistry) ; J. A. F. Stevenson (Physiology and Pharmacology). Proceedings, annual, in Proceedings of Canadian Federation of Biological Societies.

102. Canadian Physiotherapy Association, 64 Avenue Road, Toronto 5, Ont. President: Miss Jane Hudson, 233 Poplar Plains Road, Toronto 7, Ont. Term expires April, 1962. Executive Secretary: Mrs. Curtis Millar. Term indefinite.

History: Incorporated 1920 as Canadian Issociation of Massage and Remedial Gymnastics : present name adopted 1935 . Local branches: Halifax, St. John's, Nfld., Saint John, N. B., Quebec City, Montreal, Ottawa, Kingston, London, Toronto, Hanilton, Winnipeg, Regina, Calgary, Edmonton, Vancouver and Victoria. Specialty divisions: abstetrical; private practitioners. Committees : research; public relations ; legislation and trainin.

Purpose: To form a Dominion-wide organization for the improvement of the status of 
persons engaged in the practice of physiotherapy under medical supervision.

Membership: 1030. Members must hold a diplona or degree in physiotheraphy or plyysical and occupational therapy from a Canadian university or equivalent.

Meetings: Annual.

Professional activitics: Special lectures, symposiums, etc. on new techniques; annual bursary award of $\$ 250$ for postgraduate study.

Publications: Journal, quarterly, current volume: 12, \$2.50. Editor: Mrs. P. I. Pearce.

Library: 100 volumes on plysiotherapy treatment and practice.

103. Canadian Phytopathological Society, Plant Research Institute, Central Experimental Farm, Ottawa, Ont. President: IV. E. Sackston, Canada Dept. of Agriculture, P. O. Box 6200, Winnipeg 1, Man. Term expires June, 1961. Executive Secretary: V. R. Wallen. Term expires June, 1962.

History: Founded 1929, replacing the Canadian Division of the American Phytopathological Society.

Purpose: To further plant pathology.

Membership: 220. Regular, life, student, honorary, and charter members. All persons interested in the science or practice of plant pathology eligible.

Meetings: Annual.

Publications: Proceedings, annual, current volume: $27, \$ 2$.

104. Canadian Podiatry Association, 3017 Bathurst Street, Toronto, Ont. President: Paul LaDelpha, 150 Metcalfe Street, Ottawa, Ont. Term expires October 22, 1960. Secretary: L. Hurwitz. Term expires October 22, 1960.

History: Incorporated as professional body. Formerly Canadian Association of Chiropodists; present name adopted 1957.

Purpose: Professional organization to maintain high ethical and moral standards of registered members; maintain and raise educational standards of men in practice.

Membership: Diploma of Doctor of Surgical Chiropody (or Podiatry) from approved class "A" college of chiropody or podiatry in the United States required.

Meetings: Annual.

Publications: Journal, quarterly, current volune: 16, \$3. Editor: F. WVeinstein, 240 Tegler Building, Ednonton, Alta.
105. Canadian Psychiatric Association. President: J. G. Dewan, 241 Elizabeth Street, Toronto, Ontario. Term expires June, 1961. Secretary: C. A. Roberts, 6875 Lasalle Boulevard, Verdun, Que. Term indefinite.

History: Founded 1951. Affiliated psychiatric associations in all provinces except Prince Edward Island. Committees appointed from time to time to deal with particular items of importance to the association.

Purpose: To further the increase of psychiatric knowledge and to encourage and develop research into causes, treatment, prevention of mental disorders; to establish an organization on behalf of psychiatrists of Canada for their mutual benefit, for exchange of scientific information and for promotion of professional welfare and usefulness; to represent members of the association in relationships with government of Canada, provincial and municipal governments, universities, medical associations, organizations, and bodies; to encourage psychiatric education in universities, hospitals and related institutions, and establishment of mental health clinics, demonstration units and other facilities for advancing psychiatric education and improving and extending treatment of mentally ill persons; to publish journals and other literature for dissemination of psychiatric knowledge to medical practitioners and others; to receive bequests, donations, grants of money and to raise monies by membership fees, public subscription or in any other manner not contrary to laws of Canada or any provinces for carrying out objects of the association.

Membership: Active 600 ; associate 30 ; inactive 2 ; honorary 5 ; life 8 . Active-qualified medical practitioner licensed to practise in one of the provinces and who has specialized in the practice of psycliatry for at least 3 years. Associate-qualified licensed medical practitioner with at least one year's practice in a mental hospital or equivalent, or anyone registered in an approved course in the postgraduate study of psychiatry. Inactive-any active or associate member unable to continue payment of dues due to hardship or illness. Honorary-any person nominated by two active members and confirmed by two-thirds of active nembers (restricted to 10). Life-active or associate members who were charter members and have remained continuously in good standing to age 65 or who have been in good standing for at least 10 years on reaching age 65 .

Meetings: Annual.

Publications: Journal, quarterly, \$4. Editor: F. C. R. Chalke. 
106. Canadian Psychoanalytic Society-Société Canadienne de Psychanalyse, 1637 Sherbrooke Street, W., Montreal 25, P. Q. President J. B. Boulanger, 2156 Sherbrooke Street, W., Montreal 25, P. Q. Term expires December 31, 1960. Executive Secretary: W. Clifford M. Scott, 1516 Pine Avenue, IV., Montreal 25, P. Q. Term expires December $31,1960$.

History: Formed 1952 by five members of French and British societies practising in Montreal. Elected component society of International Psycho-Analytical Association, 1957.

Purpose: To study psychoanalysis; to advocate and maintain standards for the training of psychoanalysts and for the practice of psychoanalysis; to foster the integration of psychoanalysis with other branches of medicine; to encourage research in all fields having to do with scientific knowledge and welfare of man.

Membership: Members 16; associate 8; students-in-training 19. Member-any member of the International Psycho-Analytical Association, or any member or associate member of one of its component societies resident in Canada. Associate-any associate member of one of the component societies of the International PsychoAnalytical Association resident in Canada, or any person who resides in Canada and has completed an adequate course of training.

\section{Meetings: Monthly.}

Professional activities: Canadian Psychoanalytic Society Trust-La Fondation de la Société Canadienne de Psychanalyse exists for the purpose of assisting worthy students and psychoanalysts, recommended by the Executive Council, who wish to pursue studies in psychoanalysis, by way of loans without interest, grants, bursaries, fellowships, or otherwise. Annual Françoise Boulanger Memorial Lectureship.

Publications: Canadian Psychoanalytic Review-La Revue Canadienne de Psychanalyse, current volume: 1, $\$ 2$ per copy. Editorial committee.

Library: 20 volumes on psychoanalysis.

107. Canadian Psychological Association, P. O. Box 31, Postal Station "D”, Ottawa, Ont. President: Reg. Bromiley, P. O. Box 62, Postal Station "K", Toronto, Ont. Term expires June, 1961. Secretary-Treasurer: F. R. Wake. Term indefinite.

History: Founded 1939; incorporated 1950.

Purpose: To promote by teaching, discussion and research the advancement and practical application of psychological studies in Canada.

Membership: 760. Three types: student affiliate, associate and full members.

\section{Mectings: Annual.}

Publications: Canadian Journal of Psychology, quarterly, current volume: 14, \$6. Editor: J. M. Blackburn. Canadian Psychologist, quarterly, current volume: $1, \$ 3.50$. Editor: W. R. N. Blair.

108. Canadian Public Health Association, 150 College Street, Toronto 5, Ont. President: F. B. Roth, Department of Public Health, Regina, Sask. Term expires May, 1961. Honorary Secretary: G. IV. O. Moss. Term indefinite.

History: Received province of Ontario charter in 1910 and federal charter 1912. Eight regional divisions: British Columbia Branch; Saskatchewan Branch; Alberta Division; Manitoba Public Health Association; Ontario Public Health Association; Société d'Hygiène at de Médecine Préventive de la Province de Québec; New Brunswick-Prince Edward Island Branch; Nova Scotia Branch. Association's sections: medical officers; laboratory; public health education; dental public health; environment hygiene; veterinary public health; public health nursing; medical care; public health nutrition; industrial hygiene; mental health; epidemiology and vital statistics. Also committees to study public health problems.

Purpose: Development and diffusion throughout Canada of knowledge of public health in all its branches, all other matters and things appertaining thereto, or connected therewith.

Membership: 1666. Active, associate and honorary members. Active-actively engaged in public health work.

Mectings: Annual.

Publications: Canadian Journal of Public Health, monthly, current volume: $51, \$ 5.00$. Editor: R. D. Defries.

109. Canadian Public Health Association, British Columbia Branch, President: IV. Wookey, 456 Broadway W., Vancouver 14, B. C. Term expires April, 1961. Executive Secretary: A. C. Dobson, 253 East 14th Street, North Vancouver, B. C. Term expires April, 1961.

Purpose: Association of professional public health workers.

Membership: Members nust be employed as public health workers; provision for associate members also.

Mectings: Four yearly.

Professional activities: Sponsors studies on public health matters. 
110. Canadian Public Health Association, Saskatchewan Branch, Health and Welfare Building, Regina, Sask. President: H. E. Robertson, Provincial Laboratory, Regina, Sask. Term expires April, 1962. SccretaryTreasurer: E. L. Abbott. Term expires June, 1961.

History: Formed 1926 as Saskatchewan Health Officer's Association; name changed to present title 1948.

Purpose: Development and diffusion throughout Saskatchewan of knowledge of public health and preventive medicine and all other matters and things appertaining thereto or connected therewith.

Membership: 216 active members. An active member must be engaged in public health work. Provision for associate members interested in public health work.

Meetings: Annual.

111. Canadian Rheumatism Association-La Société Canadienne de Rhumatologie, Secrétariat, Hotel-Dieu Hospital, Montreal 18, P. Q. President: J. Bruce Frain, Winnipeg Clinic, Winnipeg 1, Man. Term expires October, 1960. Sccretary: deGuise Vaillancourt. Term indefinite.

History: Organized 1936, as Canadian Branch of La Ligue Internationale Contre le Rhumatisme; known until 1947 as Canadian Rheumatic Disease Association. French title added 1956.

Purpose: Scientific society for study and control of rheumatic diseases and exchange of information.

Membership: 145 ; 13 honorary. Membersmedical doctors interested in clinical or research aspects of rheumatic disease; nomination by two members, election, required.

Mectings: Annual.

112. Canadian Society for Clinical Chemistry, The Hospital for Sick Children, Toronto 2, Ont. President: Marcel C. Blanchaer, St. Boniface Hospital, St. Boniface, Man. Term expires August 30, 1961. Secretary: D. B. Tonks. Term expires August 30, 1961.

History: Organized 1957 as Canadian Society of Clinical Chemists; present name later.

Purpose: Advancement of the practice of clinical chemistry.

Membership: 150: full members 133; associate 15; honorary 2. Members-persons engaged mainly in the practice or teaching of clinical chemistry holding degrees in science or medicine; associate-persons interested in clinical chemistry but not possessing one or both of the above qualifications; honorary-persons of great distinction who have made outstanding contributions to clinical chemistry.

Mectings: Annual.

Professional activities: Warner-Chilcott Lectureship: $\$ 150$ provided to finance travelling of invited lecturer to annual meetings.

Publications: Newsletter, 3 yearly, current volume: 1960. Editor: D. B. Tonks.

113. Canadian Society of Agricultural Engineering. President: R. F. Ford, c/o MacMillan \& Bloedel Sales, P. O. Box 40, Toronto 18, Ont. Secretary-Treasurer: C. A. Cheshire, Alberta Department of Agriculture, Edmonton, Alta. Term expires June, 1962.

History: Formed 1958 at Wolfville, N. S., as Canadian Agricultural Engineering Society. First annual meeting Winnipeg, Man., 1959, when present name adopted.

Purpose: To advance the application of engineering techniques and practices for the betterment of agriculture and allied sciences.

Membership: 240. Member-graduate of recognized college of enginecring or registered professional engineer with four years active practice, or degree other than engineering but related to agriculture and eight years practice; associate-as above, with two years active practice; junior-graduates lacking practical experience for member and associate categories; affiliate-person engaged in occupation or industry associated with agricultural engineering but not qualifying for above; student-registered undergraduate in recognized engineering or agricultural degree course.

Meetings: Annual.

Publications: Canadian Agricultural Engineering, annual, current volume: 2. Editor C. G. E. Downing.

114. Canadian Society of Agronomy. President: J. H. Mather, Line Elevators Farm Service, Grain Exchange Building, IVinnipeg, Man. Term expires June, 1961. Secretary-Treasurer: R. O. Bibbey, Ontario Agricultural College, Guelph, Ont. Term expires June, 1961.

History: Formed 1954 by amalgamation of Eastern Canadian Society of Agronomy and Field Crops Section (IVestern) of Agricultural Institute of Canada. Since inception affiliated with Agricultural Institute of Canada and meets in conjunction with it.

Purpose: To effect closer cooperation and coordination of work of agronomists in Canada ; to provide opportunity to report, exchange, and evaluate information pertinent to agronomy in Canada. 
Membership: 189. Members are graduates of recognized universities engaged in agronomic work, or former members of Field Crops Section (Western) of Agricultural Institute of Canada and Eastern Canadian Society of Agronomy who joined before June, 1955.

Meetings: Annual.

Publications: Proceedings, annual, current volume: 6 .

115. Canadian Society of Animal Production. President: W. E. Howell, University of Saskatchewan, Saskatoon, Sask. Term expires June 23, 1961. Secretary: S. L. Medland, Swift Canadian Co. Ltd., Toronto 9, Ont. Term expires June 23. 1961.

\section{History: Organized 1951.}

Purpose: To afford opportunities for discussion of problems of common interest in the animal industry; to provide avenues for improvement and coordination of research, extension and teaching related to sciences of the animal industry; to encourage publication of scientific and other educational material pertaining to the animal industry.

Membership: 400. Persons engaged or previously engaged in research, teaching, administration, extension, production, marketing, or otherwise engaged or interested in the animal industry eligible for membership.

\section{Meetings: Annual.}

Publications: Proceedings, annual, \$3. (Official journal is the Canadian Journal of Animal Science, edited and published by Agricultural Institute of Canada. See entry No. 3.)

\section{Canadian Society of Animal Production}

(Eastern Section). President: R. P. Forshaw, Ontario Agricultural College, Guelph, Ont. Term expires May 31, 1961. Secretary: D. M. Adams, Meat Packers Council of Canada, 200 Bay Street, Toronto 1, Ont. Term expires May 31, 1961.

History: Organized 1926 as Eastern Canada Society of Animal Production; name changed to present title 1931. In 1952 joined Western Section to form Canadian Society of Animal Production, for action on problems of national interest, but retains autonomy in local fields. Expected to become branch of national society in 1960 .

Purpose: To afford opportunities for discussion of problems of common interest in the animal industry; to provide avenues for improvement and coordination of research, extension and teaching related to the sciences of the animal industry; to encourage publication of scientific and other educational material pertaining to the animal industry.
Membership: 175. Persons engaged or previously engaged in research, teaching, administration, extension, production, marketing, or otherwise engaged or interested in the animal industry.

Mectings: Annual.

Publications: Proceedings, annual, consolidated with those of National Society.

\section{Canadian Society of Hospital Pharmacists.} President: I. R. Griffith, Queensway General Hospital, Toronto, Ont. Term expires August 13, 1961. Secretary: Miss Mary Gannon, Princess Margaret Hospital, Toronto 5, Ont. Term expires August 13, 1961.

History: Formed 1947; national charter granted 1950. Society given representation on council of Canadian Pharmaceutical Association 1956, and on Canadian Foundation for the Advancement of Pharmacy 1960. Branches: Alberta; Atlantic Provinces; British Columbia; Manitoba; Ontario; Quebec; Saskatchewan.

Purpose: To improve and extend usefulness of hospital pharmacists to institutions they serve and profession of pharmacy in general; to provide a means by which pharmaceutical information can be conveyed to hospital pharmacists; to take such action as may be within its power to obtain a higher standard of proficiency among hospital pharmacists in Canada.

Membership: 278. Honorary-individuals connected with health services and those who have contributed to advancement of hospital phasmacy; active-graduates of recognized schools or colleges of pharmacy, engaged in hospital, clinic or dispensary services; associate-graduate pharmacists other than those engaged in hospital pharmacy, those associated with field of pharmacy and whose application has been recommended by membership committee and approved by executive.

Meetings: Annual.

Publications: The Hospital Pharmacist, 6 times yearly; current volume: XIII, $\$ 2.50$. Editor: T. J. Quinn.

118. Canadian Society of Laboratory Technologists, 61 Victoria Avenue, N., Hamilton, Ont. President: Roy Uttley, KitchenerWaterloo Hospital, Kitchener, Ont. Term expires December 31, 1960. Executive Secretary: Miss Ileen Kemp. Term indefinite.

History: Organized 1936; incorporated 1937. Branches: Quebec; Alberta; British Columbia; Manitoba; New Brunswick; Ontario; Prince Edward Island; Saskatchewan.

Purpose: To improve the qualifications and standing of medical laboratory technologists in 
Canada; to promote research endeavor in all branches of medical laboratory work; to promote recognized professional status for medical laboratory technologists in Canada; to promote closer cooperation between the heaith field and the technician; to more efficiently aid in diagnosing and treating disease.

Membership: 2200; active 1750; associate 328; student 500 .

\section{Meetings: Annual.}

Professional activities: Annual scientific awards: Fisher Scientific Co. Award $\$ 250$ per annum in Biochemistry; Ortho Pharmaceutical (Canada) Award $\$ 250$ p.a. in Blood Bank Technique; Becton, Dickinson and Co. Award $\$ 250$ p.a. in Bacteriology ; Canadian Laboratory Supplies and Dade Reagents Award $\$ 250$ p.a. in Haematology.

Publications: Canadian Journal of Medical Technology, quarterly, current volume: $22, \$ 3$. Editor: Miss A. M. Graham.

Library: 100 volumes on science of medical teclmology.

\section{Canadian Society of Microbiologists.}

President: T. IV. M. Cameron, Macdonald College P. O., Que. Term expires June, 1961. Secretary: J. Robinson, Food and Drug Directorate, Tunney's Pasture, Ottawa, Ont. Term expires June, 1961.

History: Organized 1951; incorporated 1958. Branches: Ottawa Valley, Nova Scotia, Manitoba. Affiliate: La Société de Microbiologie de 1a. Province de Québec.

Purpose: To promote the advancement of microbiology in all its aspects and to facilitate the exchange of ideas between microbiologists.

Nembership: Honorary 4; ordinary 429. Honorary-any person who has made a distinctive contribution to microbiology (limited to 10). Ordinary-any person interested in the study of microbiology, sponsored by two members and passing assessment by membership committee.

\section{Meetings: Annual.}

Publications: Canadian Journal of Microbiology, bimonthly, current volume: 6, \$6. Published by National Research Council.

120. Canadian Society of Plant Physiologists. President: G. Krotkov, Queen's University, Kingston, Ont. Term expires June, 1961. Secretary-Treasurer: D. R. Forward, University of Toronto, Toronto 5, Ont. Term expires June, 1961.

History: Inaugurated 1958, at Saskatoon, from a series of annual research conferences on plant physiology sponsored by the National Research Council of Canada.

Purpose: To encourage research and education in the field of plant physiology and its application.

Membership: 78. A scientific interest in plant physiology required.

Meetings: Annual.

121. Canadian Society of Plastic Surgeons, 1414 Drummond Street, Montreal, Que. President: Armand Genest, 800 Cherrier Street, E.. Montreal, Que. Term expires April, 1961. Secretary-Treasurer: D. C. Robertson, 170 St. George Street, Toronto 5, Ont. Term indefinite.

History: First meeting in Montreal, November $7,1947$.

Purpose: To advance the art and science of plastic surgery; to promote its interests in relation to medicine with particular reference to clinical, educational, ethical and economic aspects thereof; to associate together in one corporate body members in good standing of the medical profession who have specialized in this particular science; to promote interest of its members and to do all such other lawful acts and things as may be incidental or conducive to attainment of above objects.

Membership: Honorary 4; active 36; associate 5. Honorary-distinguished persons who have rendered services to plastic surgery the society may desire to recognize; activeaccredited in plastic surgery by Royal College of Physicians and Surgeons of Canada, or if invited from a foreign country must be accredited by a comparable body; associatesurgeons, other than Canadians, who have attended one meeting of society and are known to the membership.

122. Canadian Society of Radiological Technicians, 2175 West 16th Avenue, Vancouver 9, B. C. President: Miss Katherine Creelman, P. O. Box 1297, Fredericton, N. B. Term expires June 29, 1961. Secretary: Mrs. E. I. Hood. Term indefinite.

History: Organized 1943. Member societies in each province except Prince Edward Island.

Purpose: To promote and encourage the science and art of radiological technique and to consider and discuss all subjects affecting it; to promote the formation of, to assist, to guide, to encourage and to form a central association for local associations of radiological technicians throughout Canada.

Hembership: Active 1500; associate 20 ; nonactive 300 ; life 4 . Active-basic training and a 
minimum of 2 years' practical experience as a radiological technician with a certified radiologist or in the X-ray department of a recognized hospital, university or other scientific institution; or license or certificate of competency as a radiological technician issued under the law of any province of Canada that has enacted legislation establishing such qualifications.

\section{Mectings: Annual.}

\section{Professional activities: Essay award.}

Publications: Focal Spot, 5 times a year, current volume: 17 , members $\$ 2$, non-members $\$ 2.50$. Editor: L. J. Cartwright, 42 Scarboro Beach Boulevard, Toronto 8, Ont.

123. Canadian Society of Soil Science. President: IT. E. Johnson, Saskatchewan Department of Agriculture, Regina, Sask. Term expires May 31, 1961. Secretary: R. L. Halstead, Central Experimental Farm, Ottawa, Ont. Term indefinite.

History: Established 1954. Soil scientists in Canada previously organized (since 1931) as the Soils Section of the Agricultural Institute of Canada.

Purpose: To encourage research and education on all phases of soil science.

Membership: Approximately 300.

Meetings: Annual.

\section{Canadian Society of Wildlife and Fishery}

Biologists, P. O. Box 195, Postal Station "D", Ottawa, Ont. President: W. Winston Mair, 271 Pleasant Park Avenue, Ottawa, Ont. Term indefinite. Secretary-Trcasurer: F. H. Schultz, 1404 Kilborn Avenue, Ottawa, Ont. Term indefinite.

History: Organized 1959; constitution officially adopted at first standing meeting January, 1960.

Purpose: To seek to estahlish and maintain the lighest possible professional standards in wildlife and fishery research and management, and to develop all phases of wildlife and fishery management along sound lines in relation to proper land use and in accordance with the best interests of the community.

Membership: About 175, composed of trained biologists who are or have been professionally engaged in practising or teaching wildlife or fishery research or management. Membersuniversity graduation with biological courses and professionally engaged in the practice and teaching of wildlife or fishery research or management. Student-enrollment in a college or university with preparation for professional work in the wildlife or fishery fields. Other persons on examination by Board of Directors.

Meetings: Biennially.

125. Canadian Thoracic Society. President: Roland Guy, Sacred Heart Hospital, Montreal, Que. Term expires June, 1961. Secretary: C. W. L. Jeanes, 265 Elgin Street, Ottawa, Ont. Term indefinite.

History: Formed 1956 as medical section of Canadian Tuberculosis Association. Affiliates: 10 provincial thoracic societies, each arranging its own program.

Purpose: To encourage clinical, epidemiological and other scientific studies in diagnosis, treatment and prevention of tuberculosis, thoracic and other diseases, and to stimulate interest in these diseases among medical practitioners and in medical schools.

Membership: 600. Any medical practitioner with an interest in thoracic diseases can be admitted to membership. Requirement of medical degree may be waived for certain workers in scientific fields closely related to society's activities.

Meetings: Annual. Provincial groups 2-3 yearly.

Professional activities: Annual scholarship award on exchange basis with British Chest and Heart Association; annual lectureship in respiratory diseases to Canadian College of General Practice. These sponsored by parent Canadian Tuberculosis Association.

126. Canadian Urological Association. President: Jean-Paul Bourque, 1025 St. Joseph Boulevard, E., Montreal 34, Que. Term expires June, 1961. Executive Secretary: Jean Charbomeau, 1025 St. Josepl Boulevard, E., Montreal 34, Que. Term expires June, 1961.

History: Founded 1944.

Purpose: To promote teaching of urology in Canada.

Mcmbership: 158. Qualified medical practitioners, members of national medical association and recognized specialists in urology.

\section{Mectings: Annual.}

127. Canadian Veterinary Medical Association, P. O. Box 416, Ottawa, Ont. President: L. P. E. Choquette, P. O. Box 92, Ste. Hyacinthe, Que. Term expires July, 1961. SecretaryTreasurer: Orlan Hall, 215 Third Avenue, Ottawa 1, Ont. Term expires July, 1961. Exccutive Secretary: Claude Kealey. Term indefinite.

History: Organized 1948. 
Purpose: To foster dissemination of information relative to veterinary medicine in Canada; to cultivate and advance art and science of veterinary medicine and surgery, and to maintain honour and interests of veterinary profession.

Membership: 1501. Menmbers must be in good standing with a provincial veterinary association.

Meetings: Annual.

Publications: Canadian Veterinary Journal, monthly, current volume: 2. Editor-in-chief : J. Archibald, Ontario Veterinary College, Guelph, Ont.

128. Canadian Welding Society, 73 Adelaide Street, IV., Toronto, Ont. President: Arthur J. Phillips, Plate and Structural Steel Ltd., 48 Abell Street, Toronto, Ont. Term expires June 1, 1961. Executive Secretary: William T. Cherry. Term indefinite.

History: Organized 1941. Chapters: Toronto; London; Hamilton; Sarnia ; Kitchener; IVelland; Brantford; Montreal; Sorel; Wimipeg; Edmonton; Vancouver.

Purpose: To advance the art and science of welding.

Membership: 1000. Members must be experienced in some phase of welding.

Mcetings: Monthly.

129. Catholic Nurses' Association of CanadaAssociation Des Infirmières Catholiques du Canada, 335 d'Aiguillon Street, Qucbec 4, Que. President: Mrs. Alma B. Lapointe. Term expires February, 1961. Exccutive Secretary: Miss Hortense Turcotte. Term expires February, 1961.

History: Catholic Nurses of the Province of Quebec, with provincial charter since 1928, obtained from federal government in October, 1936, a charter establishing a national professional association under present name.

Purpose: Union of all Catholic nurses into one professional body; preparation of a group of qualified and competent nurses, conscious of their responsibilities in care of sick, in public health fields and in practice of their profession in general; study and protection of professional, economic and moral interests of members.

Membership: 4200 ; 800 individual members. Members must be registered nurses, either lay or religious.

Meetings: Annual.

Publications: Bulletin des Infirmières Catholiques du Canada, six yearly. Bulletin of C.N.A.C., 4 yearly.
130. Central Canada Veterinary Association. President: K. E. Hartin, Richmond, Ont. Term expires June, 1961. Secretary-Treasurer: R. R. Miller, 116 Jarvis Street, Cornwall, Ont. Term expires June, 1961.

History: Formed 1903.

Purpose: Elevation of the veterinary profession; advancement of the science of veterinary medicine and surgery; protection of members.

Membership: 120. Graduation in veterinary medicine from a recognized veterinary school.

Meetings: Annual.

131. Chemical Institute of Canada, 48 Rideau Street, Ottawa 2, Ont. President: IV. N. Hall, Dominion Tar and Chemical Co., Ltd., Montreal, Que. Term expires August, 1961. General Manager and Secretary: T. H. G. Michael. Term indefinite.

History: Organized 1921 as Canadian Institute of Chemistry; present title adopted 1945. Thirty-two local sections; thirty student chapters. Ten subject divisions.

Purpose: To encourage an appreciation of and general interest in all phases of chemistry and chemical engineering; to promote increase of chemical knowledge, and facilitate its diffusion; to provide facilities for collaboration of scientists with each other, with industry, with university, and with governments in solving local and national problems; to promote establishment and maintenance of high educational, professional and ethical standards among chemists and chemical engineers; to protect and promote social and economic well-being of chemists, chemical engineers, and all those associated with the practice of chemistry; to cooperate with other scientific organizations throughout the world.

Membership: 5536: 6 Honorary Fellows, 677 Fellows; 2944 professional, 313 associate, 296 junior, 1300 student members. Junior-graduation from an accredited university course in chemistry or chemical engineering; professional -as junior plus two years acceptable professional experience; Fellow: as professional plus evidence of major contribution to chemistry; associate: interest in, or connected with, field of chemistry.

Mectings: Annual.

Professional activities: Chemical Institute of Canada Medal; Montreal Medal; R. S. Jane Memorial Lecture.

Publications: Chemistry in Canada, monthly, current volume: 12 , Canada $\$ 6$, elsewhere $\$ 8$. Editor: D. W. Emmerson. The Canadian Journal of Chemical Engineering, bi-monthly, current volume: 38 , Canada $\$ 6$, U.S. and U.K. $\$ 7$, other $\$ 7.50$. Editor: A. Cholette. 
132. Collège des Pharmaciens de la Province de Québec, 1290 St. Denis Street, Montreal, Que. President: J. C. Cusson, 1067 Laurier Street, W., Montreal, Que. Term expires July, 1961. Secretary-Registrar: Emile Coderre. Term indefinite.

History: Organized 1870 under Quebec Pharmacy Act.

Purpose: Organization of registered pharmacists as a professional body; supervision of Pharmacy Act; rulings on teaching of pharmacy; granting of diplomas to assistant pharmacists and licentiates of pharmacy.

Membership: 1400 licenciates of pharmacy (active) ; 150 assistant pharmacists; 560 students. Members must have degree of Licenciate of Pharmacy.

Meetings: Annual.

Professional activities: Prizes to successful students at universities; gold and silver medals; grants to young graduates for postgraduate studies in Canada, United States or Europe.

Publications: Report, annual.

Library: 1050 volumes on pharmacy, chemistry.

133. College of Dental Surgeons of Saskatchewan. President: R. O. Brett, Kerr Block, Regina, Sask. Term expires December 31, 1960. Secretary-Treasurer-Registrar: F. R. Smith, 606 Canada Building, Saskatoon, Sask. Term indefinite.

History: Created by Act of Legislature 1906. Purpose: To administer the Dental Profession Act.

Membership: 185. Members must be graduates in dentistry of college recognized by University of Saskatchewan and hold license to practise in the province.

Mectings: Annual.

Professional activities: Scholarships $\$ 150$ at University of Alberta and University of Manitoba.

134. College of General Practice of Canada, $150 \mathrm{~A}$ St. George Street, Toronto, Ont. President: F. Murray Fraser, 8 Prince Arthur Street, Halifax, N. S. Term expires March 29, 1961. Executive Director: W. V. Johnston. Term indefinite.

History: Founded 1954. Ten provincial chapters as well as component chapters in various cities. Committees: hospitals; education; undergraduate medical education; membership; constitution and by-laws; residency training; research; fellowship or certifica- tion; public policy; publications; scientific assemblies.

Purpose: To establish an academic body of general practitioners with broad educational aims; to promote undergraduate teaching for general practitioners; to promote residency training for general practice, research in general practice, publication of original articles by general practitioners, integration of general practitioners into general hospital staffs; to provide suitable recognition to members in the field of general practice and to do all things necessary to furnish and maintain the highest possible standard of service by general practitioners to the public.

Membership: 2000. One hundred hours postgraduate study every two years required for membership.

Meetings: Annual.

Professional activities: Ten bursaries, 18 scholarships; financial assistance for clinical days and research in general practice.

Publications: Bulletin, bi-monthly, current volume: 6 , free to members. English editors: W. V. Johnston, R. Silver. French editor: B. Fortin.

135. College of Veterinary Surgeons of the Province of Quebec. President: Lucien Cournoyer, Ecole de Médecine Vétérinaire, St. Hyacinthe, Que. Term expires December 31 , 1960. Secretary-Treasurer: Laurent Choquette, 570 Bourassa Street, St. Hyacinthe, Que. Term expires December 31, 1960.

History: Incorporated 1902 by Act of the Quebec government. Judicial districts: Quebec; Gaspé; Bonaventure; Saguenay; Chicoutimi ; Roberval ; Rimouski ; Kamouraska; Montimagny; Beauce; Three Rivers; Arthabaska; Nicolet and Abitibi. Montreal region: judicial districts of Montreal; Terrebonne; Joliette; Richelieu; Bedford; St. Hyacinthe; Iberville; Beauharnois; Hull-Pontiac; Montcalm and St. Francis. Technical, scientific committees: scientific and cultural relations; contagious diseases; professional ethics; board of governors.

Purpose: The registration of veterinarians; regulation of veterinary practice; examination of candidates to study of veterinary medicine and to practice; advancement of a veterinary science and maintenance of high professional standards.

Membership: 428. Members require diploma (Doctor's degree) in veterinary medicine from a recognized school.

Meetings: Annual.

Publications: Information Vétérinaire, bimonthly, current volume: 3 . Free to members. 
136. Community Planning Association of Canada, 425 Gloucester Street, Ottawa 4, Ont. President: Jacques Simard. Term expires October, 1960. National Director: M. L. Brennan. Term indefinite.

History: Organized in 1946 to deal with financial, social and aesthetic problems arising from the post-war building boom. Eight provincial divisions; branches.

Purpose: To foster public understanding of, and participation in, planning the orderly development of urban areas.

Membership: 2100 individuals and organizations. Honorary memberships for outstanding contributions to town planning in Canada.

Meetings: Annual.

Publications: Community Planning Review, current volume: $\mathrm{X}, \$ 3$.

Library: Town and regional planning.

137. Computing and Data Processing Society of Canada. President: C. C. Gotlieb, University of Toronto, Toronto, Ont. Term expires June, 1961. Secretary: H. J. M. Watson, Steel Co. of Canada Ltd., Wilcox Street, Hamilton, Ont. Term expires June, 1961.

History: Organized 1958. Main membership in Toronto, but chapters presently being organized in Ottawa, Montreal and Winnipeg.

Purpose: To advance computing and data processing by: sponsoring meetings and conferences; collaboration with educational institutions, research foundations and manufacturers; publication of technical and other information; exchange of information between members and between similar associations; providing a national source of information and representation.

Membership: 250. Active-those actively engaged in administration, practice, or teaching of computing and electronic data processing. Honorary-those who would further the objectives of the society and who have made a significant contribution to the advancement of the technique, and who might not otherwise qualify for membership.

Meetings: Annual.

138. Corporation des Ingénieurs Forestières de la Province de Québec, 895 d'Aigullon, Québec 4, P. Q. President: Maurice Gérin, Pruneau Ltée., 50 rue Marie de L'Incarnation, Québec, P. Q. Term expires October 27. 1960. Executive Secretary: Théo Mercier. Term expires October 27, 1960.

Histary: Formed 1916 as Association des Ingénieurs forestiers de la Province de Québec; incorporated 1921.
Purpose: To protect the public, the forest, and the members of the association.

Membership: 450. Members must be graduates in forestry of a recognized university and meet the requirements of the society.

Meetings: Annual.

139. Corporation des Ingénieurs Professionnels de Québec-Corporation of Professional Engineers of Quebec, 1600 Pine Avenue, W., Montreal 25, Que. President: Arthur Piché. Term expires April, 1961. General Secretary: Pierre Bournival. Term indefinite.

History: Constituted 1920 to control practice of engineering profession in the province. Corporation completely autonomous, but cooperates with other provincial associations of engineers through Canadian Council of Professional Engineers. Six regional representatives for districts outside cities of Montreal and Quebec. Chapters in Quebec City, Sherbrooke and Saguenay area.

Membership: 9008 . Requirements : graduation in engineering from recognized university anywhere in world; domicile in Quebec; Canadian citizenship; good character.

Meetings: Annual.

Publications: Bulletin, 10 yearly, current volume : 17 , free.

Library: 100 volumes on engineering.

140. Corporation of Land Surveyors of the Province of British Columbia, 605 Courtney Street, Victoria, B. C. President: W. N. Papove, 5174 Halifax Street, North Burnaby, B. C. Term expires January 12, 1961. Secretary-Treasurer and Registrar: H. S. Beckton. Term indefinite.

History: Incorporated 1905 to assume the government function of examining and licensing provincial land surveyors.

Purpose: To carry out the provisions of the Land Surveyors Act; to conduct examinations; to keep members informed of advances in surveying.

Membership: 215. Members required to pass preliminary examination, to serve under articles with a licensed land surveyor for a period of three years, and to pass a final examination.

Meetings: Annual.

Publications: Report, annual, current volume: 55.

Library: 350 volumes on mathematics and land surveying. 
141. Corporation of Quebec Land Surveyors. President: Marcel Ste.-Marie, P. O. Box 38, Hull, Que. Term expires 1961. Secretary: Paul Lachance, P. O. Box 152, Quebec 4, Que. Term indefinite.

History: Incorporated 1882 by provincial statute.

Purpase: To exercise control over survey of lands in the province; to issue diplomas to qualified persons, authorizing them to practise as land surveyors after examination.

Membership: 311. Examination by association required.

Meetings: Annual.

Professional activities: Annual scholarships and awards.

Publications: Annual Report, free.

Library: Textbooks, reports, etc.

142. Defence Medical Association of Canada, c/o Indian Health Services, Booth Building, Ottawa, Ont. President: R. G. C. Kelly, 90 St. Clair Avenue, W., Toronto 7, Ont. Term expires December 31, 1960. Secretary-Treasurer: H. A. Procter. Term indefinite.

History: Organized 1892 as Association of Medical Officers of the Militia of Canada. Reorganized 1907; name changed 1912 to Association of Officers of the Medical Services of Canada. Present title adopted 1937.

Purpose: To foster the development and efficiency of the medical services of the Armed Forces by: maintaining close liaison between the members of the medical service and the medical profession; the dissemination of knowledge on medical matters pertinent to the defence of Canada.

Membership: 400. Membership requirement: association with Medical Services, Armed Forces of Canada or the Commonwealth.

Meetings: Annual.

143. Dental Association of Prince Edward Island. President: W. S. MacIntyre, Montague, P. E. I. Term expires May, 1961. Secretary-Registrar: Health McIntyre, 140 Richmond Street, Charlottetown, P. E. I. Term expires May, 1961.

History: First Dental Register established in the province 1891 by Act of Parliament. Dental Society of Prince Edward Island incorporated 1902; name changed to present title 1931.

Purpose: To administer the Dental Act; to provide dental services for the public by dentists who are ethical and well qualified; to protect the public and the profession against activities of unskilled and unethical operators.
Membership: 33. Members must be graduates of a recognized dental school, pass examinations of provincial Board of Examiners or National Board of Dental Examiners of Canada.

Metings: Annual.

144. Edmonton Geological Society. President: Gunner Haugrud, Consolidated Mic Mac Oils, 11055107 Street, Edmonton, Alta. Term expires December 31, 1960. Secretary: G. W. Peterson, 9407145 Street, Edmonton, Alta. Term expires December 31, 1960.

History: Organized 1954.

Purpose: To promote the science of geology.

Membership: Active 125; honorary 1; student 4. Active-graduate in geology or related sciences who is or intends to be employed in petroleum or mining geology, or in other closely related technical capacities; honorary-any person who has contributed distinguished service to the cause of geology; student-any student who has completed first year in geology or related sciences, and who intends to continue with such course.

Meetings: Monthly.

Publications: Edmonton Geological Quarterly. Editor: John Leeson.

145. Engineering Institute of Canada, 2050 Mansfield Street, Montreal 2, Que. President: G. M. Dick, Sherbrooke, P. Q. Term expires May, 1961. General Secretary: Garnet T. Page, Sherbrooke, P. Q. Term indefinite.

History: Founded and incorporated 1887 as Canadian Society of Civil Engineers. Present name adopted 1918. Fifty branches in principal cities of Canada.

Purpase: To develop and maintain high standards in the engineering profession; to advance the welfare of its members; to encourage original research and the study, development and conservation of the resources of the Dominion.

Membership: 20,192: 8094 members; 62 affiliates ; 6590 juniors ; 5406 students ; 40 honorary. Member-engaged at least six years in some branch of engineering, position of professional responsibility for at least two years; affiliateone not an engineer by profession but admitted because of pursuits, scientific attainments or practical experience; junior-engaged at least four years in some branch of engineering; student-pursuing course of instruction at recognized engineering school, or receiving practical training.

Professional activities: Harry F. Bennett Educational Fund to establish engineering and science scholarships and fellowships and to make loans to deserving students. Leonard Medal, 
gold, annual, for a paper on a mining subject; Plummer Medal, gold, annual, for a paper on metallurgy or chemistry; Duggan Medal, silver, and Prize, annual, for a paper on metallic construction engineering subject; Gzowski Medal, gold, annual, for a paper on a civil engineering subject; Ross Medal, gold, annual, for a paper on an electrical engineering subject; Sir John Kennedy Medal; Julian C. Smith Medal for achievement in the development of Canada. Canadian Lumberman's Association Prize, $\$ 100$, annual, for a paper on the use of lumber and timber in construction and other related subjects in wood utilization; Student's Prizes $\$ 25$ each for papers on engineering; special prizes awarded by branches.

Publications: Transactions, quarterly, current volume: 4, \$4. Engineering Journal, monthly, current volume: $43, \$ 6$. Editor : Garnet T. Page.

Library: 10,000 volumes on all fields of engineering; scientific textbooks; transactions of various engineering societies; specifications; technical periodicals and government reports.

146. Entomological Society of Alberta. President: L. A. Jacobson, Research Station, Canada Agriculture, Lethbridge, Alta. Term expires December 31, 1960. Secretary: A. M. Harper, Research Station, Canada Agriculture, Lethbridge, Alta. Term expires December 31,1960

History: Organized 1952, as a regional society affiliated with Entomological Society of Canada and registered under Societies Act of Province of Alberta.

Purpose: To foster advancement, exchange, and dissemination of knowledge of insects in relation to their importance in agriculture, forestry, public health, and industry, and for its own sake, among the people of the province.

Membership: Honorary 2 ; full 76; student 11 . Honorary-conferred for long and distinguished service in entomology; full-any person interested in entomology approved by executive; student-any person studying entomology at undergraduate or high school level and enrolled in a recognized educational institution.

\section{Meetings: Annual.}

Professional activities: Annual prize $\$ 50$ to most outstanding student in entomology at University of Alberta. Society sponsors insect collection competition for Alberta school children.

Publications: Proceedings, annual, current volume: 7. Editor: M. C. McGuffin.

Library: Taxonomic entomology.

147. Entomological Society of British Columbia, c/o Department of Zoology, University of British Columbia, Vancouver 8, B. C. Presi- dent: H. R. MacCarthy, Canada Department of Agriculture Research Station, University of British Columbia, Vancouver 8, B. C. Term expires, March, 1961. SecretaryTreasurer: G. G. E. Scudder. Term expires March, 1961.

\section{History: Organized 1902.}

Purpose: To promote an interest in entomology in the region and to facilitate the exchange of material and information among workers.

Membership: 110: regular and associate 103; honorary 7.

\section{Meetings: Annual.}

Professional activities: Annual book prize $\$ 15$ to outstanding student in entomology at University of British Columbia.

Publications: Proceedings, annual, current volume: 57, \$1. Editor: H. R. MacCarthy.

Library: 700 volumes on entomology.

148. Entomological Society of Canada, K. W. Neatby Building, Carling Avenue, Ottawa, Ont. President: A. P. Arnason, Canada Department of Agriculture, Ottawa, Ont. Term expires October, 1961. Executive Secretary: L. L. Reed. Term indefinite.

History: Organized November, 1950. Associated with regional affiliated entomological soieties of Canada: Acadian Entomological Society; Entomological Society of Quebec; Entomological Society of Ontario; Entomological Society of Manitoba; Entomological Society of Saskatchewan; Entomological Society of A1berta; Entomological Society of British Columbia.

Purpose: To promote entomology in Canada and to act as a link between the regional entomological societies.

Membership: 630 regular; 7 honorary. Regular-approved by association; honorary-by election.

Meetings: Annual.

Publications: The Canadian Entomologist, monthly, current volume: 92, \$10. Editor: Eugene Munroe.

149. Entomological Society of Manitoba. President: A. G. Robinson, University of Manitoba, Winnipeg, Man. Term expires December 31, 1960. Secretary: S. R. Loschiavo, Canada Agriculture Research Station, P. O. Box 6200, Winnipeg, Man. Term expires December 31, 1960.

History: Organized 1945 : affiliation 1951 with Entomological Society of Canada. Standing committee on common names. 
Purpose: To foster the advancement, exchange and dissemination of entomological knowledge.

Hembership: 52 full members; 2 life. Professional or amateur interest in entomology required.

Meetings: Semi-annual.

Publications: Proceedings, annual, current volume: 15, free to members. Editor: W. Hanec.

Library: 30 volumes, primarily reprints on entomology.

150. Entomological Society of Ontario, Ontario Agricultural College, Guelph, Ont. President:

D. G. Peterson, Canada Dept. of Agriculture, P. O. Box 248, Guelph, Ont. Term expires November 1, 1960. Secretary-Treasurer: W. C. Allan. Term expires November 1, 1960.

History: Organized 1863 as Entomological Society of Canada; present name adopted 1870. National in character with branches in various provinces and affiliated with Entomological Society of British Columbia until forming of Entomological Society of Canada in 1950.

Purpose: The study and furtherance of entomology.

Membership: 223 nembers; 3 honorary; 7 life. Professional or amateur interest in entonology required.

Meetings: Annual.

Publications: Report, annual, current volume : 89, 65 cents. Editor: D. G. Peterson.

Library: 7500 volumes on entomology.

\section{Entomological Society of Saskatchewan,}

Canada Agriculture Research Station, c/o University of Saskatchewan Sub Post Office, Saskatoon, Sask. President: J. G. Rempel, University of Saskatchewan, Saskatoon, Sask. Term expires December, 1960. SecretaryTreasurer: C. H. Craig. Term indefinite.

History: Organized 1952 as regional affiliate of Entomological Society of Canada. Standing committee on common names of insects.

Purpose: To stimulate public awareness of the significance of entomology; to act as a local agent in the conduct of affairs of other societies having similar interests.

Membership: Combined memberships in Entomological Society of Canada and Entomological Society of Saskatchewan 19; regional memberships in Entomological Society of Saskatchewan 5. Professional or amateur interest in entomology required.

Meetings: Semi-annual.
152. Genetics Society of Canada-La Société de Génétique du Canada, Canada Department of Agriculture, Central Experimental Farm, Ottawa, Ont. President: Norma Ford Walker, University of Toronto, Toronto 5, Ont. Term expires March, 1961. Secretary-Treasurer: A. S. Johnson. Term expires March, 1963.

History: Provisionally organized 1955 at University of Alberta; inaugural meeting 1956.

Purpose: To bring about closer cooperation and coordination among genetical workers in Canada and promote improved facilities for reporting, exchanging and evaluating Canadian genetical information.

Membership: 175 regular ; 24 student ; 30 sustaining. Membership open to persons actively interested in any field of genetics; organizations admitted as sustaining members.

Mcctings: Annual.

Professional activities: Lecture tour across Canada of professionally recognized geneticists from abroad, $\$ 1000$. Huskins Memorial Lecture at annual meeting, $\$ 100$.

Publications: Canadian Journal of Genetics and Cytology, quarterly, current volume 2, \$8. Editor: A. Wilkes.

153. Geological Association of Canada, $111 \mathrm{St}$. Clair Avenue, W., Toronto, Ont. President: J. M. Harrison, Geological Survey of Canada, 601 Booth Street, Ottawa, Ont. Term expires 1961. Secretary: IValter M. Tovell, Royal Ontario Museum, 100 Queen's Park, Toronto, Ont. Term expires 1961.

\section{History: Founded 1947.}

Purpose: To investigate mineral structures of the earth; to collect, compile and disseminate geological information; to hold meetings for discussing geological subjects and for presentation and discussion of technical papers; establishment of central reference library and distribution of information gained through publications and otherwise; to establish headquarters for purposes of the organization; to encourage and promote mineral industry of Dominion of Canada by all lawful and honourable means.

Membership: 600. Fellow-engaged in the practice of geological sciences and having bachelor's degree with major work in geology and at least five years' experience, three of which have been in responsible charge of work; or master's degree, with specialization in some branch of geology and at least three years' experience in responsible charge of work; or doctor's degree with specialization in some branch of geology, and at least two years' experience in responsible charge of work. Associate-geologists in training without experi- 
ence required of a Fellow, or other scientists interested directly or indirectly in advancement of geological sciences. Honorary-persons who have distinguished themselves by technical or scientific attainments or persons eminent in development of mineral industry.

Meetings: Annual.

Publications: Proceedings, annual, current volume: 11, \$4. Editor: M. A. Fritz.

\section{Institute of Textile Science, 223 Victoria} Avenue, Westmount, Que. President: R. V. V. Nicholls, McGill University, Montreal, Que. Term expires April, 1961. Secretary: D. R. Muir, Johnson and Johnson Ltd., 7101 Notre Dame Street, E., Montreal, Que. Term expires April, 1961.

History: Founded 1955; incorporated 1956.

Purpose: To promote the development of textile science and technology by encouraging research, by facilitating the interchange of knowledge, by recognizing meritorious professional achievements, etc.

Membership: 100. Applicants for membership must have a sincere desire to further its objectives, must be graduates of a recognized university, and must be not less than 21 years old.

Meetings: At least twice yearly.

155. Manitoba Association of Architects, 518 Avenue Boulevard, Winnipeg 2, Man. President: Jas. E. Searle, 65 Dewdney Avenue, Winnipeg 2, Man. Term expires January 14 1961. Secretary: A. H. Brett. Term indefinite.

History: Incorporated 1914 by special provincial act.

Purpose: To maintain high standard of ethics in the profession; to assist in improving architectural design.

Membership: 150. Requirements: university degree comparable to University of Manitoba; two years continuous service with registered architect.

Meetings: Monthly.

Activities: Annual scholarships $\$ 300$, and book prizes $\$ 308$, University of Manitoba.

156. Manitoba Association of Chiropodists, 201 Arlington Street, Winnipeg 10, Man. President: J. E. Sinclair, 500 Boyd Building, Winnipeg 1, Man. Term expires June, 1960. Secretary-Registrar: M. A. MacTavish. Term expires June, 1960.

History: Formed 1912 as Manitoba Chiropody Association; incorporation, and present name, 1932.
Purpose: To maintain a high standard in the profession of chiropody.

Membership: 9. Requirements include satisfactory evidence of good moral character; a certificate of graduation from a recognized school, college or university; passing of examination set by association.

Meetings: Annual.

157. Manitoba Association of Registered Nurses, 247 Balmoral Street, IVinnipeg 1, Man. President: Miss Sheila M. L. Nixon, 25 Langside Street, Winnipeg 1, Man. Term expires March, 1962. Executive-Secretary: Miss Lillian E. Pettigrew, 39 Balmoral Place, Winnipeg 1, Man. Term indefinite.

History: Organized 1913 as Manitoba Association of Graduate Nurses. Present name 1929.

Purpose: Improvement of standards of nursing education for improvement of nursing service; to promote the welfare of members.

Membership: 2889 active; 311 associate. Members must be 20 years of age and provide: evidence of good character and professional reputation; Grade XI-Junior Matriculation or equivalent; a diploma showing successful completion of a course of instruction at an accredited school of nursing; success in examinations set by admission board.

Meetings: Annual.

Publications: The Nucleus, quarterly. Editor: Lillian E. Pettigrew.

Library: 300 volumes related to nursing education.

158. Manitoba Dental Association, 416 Medical Arts Building, Winnipeg 1, Man. President: F. IV. Parrott, P. O. Box 416, Portage La Prairie, Man. Term expires January, 1961. Secretary-Treasurer-Registrar: IV. G. Campbell. Term expires January, 1961.

History: Organized 1885.

Purpose: Administration of the dental act. Membership: 277.

Mectings: Annual.

159. Manitoba Institute of Agrologists, 401 Federal Building, Winnipeg 1, Man. President: J. C. Gilson, University of Manitoba, Winnipeg, Man. Term expires 1961. Secrctary-Registrar: T. O. Riecken. Term indefinite.

History: Established 1950. Affiliated with Agricultural Institute of Canada. Branches: Winnipeg; Western Manitoba; Morden.

Purpose: To make agricultural profession of increasing service to farming industry; to im- 
prove standards of excellence in research, investigation, education, extension and publicity as they pertain to agriculture and rural living; maintain high standards of professional knowledge, integrity, and ethics; to protect industry from exploitation by unqualified, dishonest or fraudulent practitioners; to promote greater coordination amongst the members in their efforts to improve conditions in the farming industry; to develop a more wide-spread appreciation of professional agriculturists by farmers and members and representatives of other professions and industries; to improve conditions under which professional agriculturists work within the province.

Membership: 307; members 305; honorary life 2. Requirements: graduation in agriculture from University of Manitoba or a university or college recognized by senate of that university; resident of the province who, by examination or otherwise, satisfies council that he has necessary qualifications.

Mectings: Twice yearly.

Publications: Newsletter, 4 yearly, current volume: 6. Editor: V. E. McNair.

160. Manitoba Medical Association (Canadian Medical Association, Manitoba Division). President: H. L. McNicol, P. O. Box 160, Flin Flon, Man. Term expires October, 1961. Honorary Secretary: F. W. DuVal, 325 Medical Arts Building, Winnipeg 1, Man. Term expires October, 1961.

History: Organized 1908. Seven district medical societies throughout the province. Eleven specialist sections; technical committees.

Purpose: Promotion of health and prevention of disease; improvement of medical services, however rendered, so that they may be available to all people; maintenance of integrity and honour of medical profession; performance of other lawful things incidental or conducive to welfare of public and of medical and allied professions.

Membership: 933 ; also 2 complimentary, 10 senior members. Duly qualified medical practitioners residing in the province and subscribing to the association's constitution, by-laws and code of ethics.

Meetings: Annual.

Professional activities: Manitoba Medical Association Medal, presented annually to student obtaining highest standing in first four years of medical course.

Publications: Manitoba Medical Review, monthly, current volume: $40, \$ 5$. Editor: S. Vaisrub.
161. Manitoba Pharmaceutical Association, 408 Confederation Building, Winnipeg 2, Man. President: J. F. Holland, 53 Maryland Street, Winnipeg 10, Man. Term expires June 20, 1962. Secretary-Registrar: M. A. Anderson. Term indefinite.

\section{History: Incorporated 1878.}

Purpose: Administration of Manitoba Pharmaceutical Act.

Membership: 550 licensed members; 10 nonpractising; 10 associate; 2 life. Members must be graduates in pharmacy from School of Pharmacy, University of Manitoba, or pass written examinations if from outside the province.

Meetings: Annual.

Professional activities: President's Prize: books to value of $\$ 15$ for highest aggregate in fourth year. Scholarship $\$ 100$ for second year; Bletcher Memorial Scholarship $\$ 100$ for first year; Dr. McDougall Memorial Scholarship $\$ 250$ for third year.

162. Manitoba Public Health Association. President: J. B. Morison, City Hall, Winnipeg, Man. Term expires December, 1960. Secretary-Treasurer: J. N. Warrener, 320 Sherbrooke Street, Winnipeg, Man. Term expires December, 1961.

History: Formed 1952; provincial branch of Canadian Public Health Association.

Purpose: An association for all professionally engaged in public health and development and diffusion of knowledge of preventive medicine and public health.

Membership: 100. Members must be professional workers in public health.

Mectings: Two annually.

163. Manitoba Veterinary Medical Association. President: V. B. Kjernisted, Stonewall, Man. Term expires March, 1961. Executive Secretary: W. L. Henry, 1235 IVarsaw Crescent, Winnipeg 9, Man. Term indefinite.

History: "Act Respecting Veterinary Surgeons" passed in 1881 and first council elected that year. New Act passed in 1890 was in force until 1957 when existing legislation assented to. Formerly Veterinary Association of Manitoba.

Purpose: To study veterinary science; to enforce code of ethics of the association; to confine practice of veterinary science in the province to properly qualified persons; to cooperate with associations, societies and organizations having objectives similar to those of the association; to cooperate for protection of the public against diseases communicable from animals to man. 
Membership: 110. Requirements: good moral character and temperate habits; graduation from a recognized veterinary college or university; Canadian citizenship or declaration of intention to become a Canadian citizen; prescribed examination.

Meetings: Two yearly.

164. Maritime Psychological Association. President: Russell Ewing, P. O. Box 3000, Charlottetown, P. E. I. Term expires 1962.

History: Formed 1948.

Purpose: To promote interests of psychology in universities in Maritime provinces.

Membership: 40. Student affiliate, associate and full members.

Meetings: Annual.

Publications: Bulletin, 2 yearly, current volume: 9. Editor: H. D. Beach.

165. Medical Society of Nova Scotia (Nova Scotia Division, Canadian Medical Association), Dalhousie Public Health Clinic, University Avenue, Halifax, N. S. President: F. J. Granvilie, Stellarton, N. S. Term expires June, 1961. Executive Secretary: C. J. IV. Beckwith, 6 Harrington Drive, Halifax, N. S. Term indefinite.

History: Founded 1854 ; incorporated 1861. Affiliated with Canadian Medical Association 1931.

Purpose: To promote health and the prevention of disease; to improve medical services however rendered; to maintain integrity and honour of medical profession; to perform other lawful things incidental or conducive to the welfare of the public and of the medical and allied professions; to promote harmony and unity of purpose between medical profession and various bodies assuming economic responsibility for care of sick or injured persons.

Membership: 570. License to practise medicine in Nova Scotia, membership in one of nine branch societies, required.

Meetings: Annual.

Publications: Nova Scotia Medical Bulletin, monthly, \$2. Editor: S. J. Shane.

166. Mineralogical Association of Canada, 300 Lebreton Street, Ottawa, Ont. President: J. S. Stevenson, McGill University, Montreal, Que. Term expires March 31, 1961. Secretary: S. Kaiman. Term expires March 31, 1961.

History: Organized 1954 for purpose of sponsoring a publication devoted to mineral sciences.
Incorporated 1955 as Canadian Association for Mineral Sciences; present name adopted 1957.

Purposc: To advance knowledge in crystallography, geochemistry, mineralogy, petrology and allied sciences.

Membership: 550: 400 ordinary or associate; 130 corporate; 20 student. Any person, corporate body or private company engaged in the study and/or use of crystallography, geochemistry, mineralogy, petrology or allied science eligible for membership. Associate membership open to anyone interested in the association.

Mectings: Annual.

Publications: The Canadian Mineralogist, annual, current volume: 6 , ordinary $\$ 2$, corporate \$5. Editor: L. G. Berry.

Library: Publications obtained by exchange.

167. Montreal Biochemical Circle-Le Cercle des Biochimistes de Montréal, 3619 University Street, Montreal 2, Que. President: JeanPaul du Ruisseau, 202 First Street, Pont-Viau, Que. Term expires June, 1961. SecretaryTreasurer: Andrew Taussig. Term expires June, 1961.

\section{History: Organized 1954.}

Purpose: To further by meetings interest in and extension of biochemical knowledge; to facilitate personal contact between investigators in biochemistry and related fields.

Membership: 48. Qualified investigators who have conducted and published meritorious original investigations in biological chemistry.

168. Montreal Physiological Society. President: Eleanor Harpur. Montreal Children's Hospital, Montreal, Que. Term expires Spring, 1961. Executive Secretary: J. M. Parker, Charles E. Frosst and Co., 350 Selby Street, Montreal, Que. Term expires Spring, 1961.

History: Founded 1925.

Purpose: To promote advance of physiology and allied sciences.

Membership: 160. Honorary-elected by society on recommendation of executive committee for reasons of outstanding scientific accomplishment; ordinary-any person who, by reason of contributions to science, is deemed worthy of election.

Meetings: 3-6 yearly.

169. National Association of Marine Engineers of Canada, 319 Pender Street, W., Vancouver 3, B. C. President: R. G. Greaves. Term expires February 22, 1963. Executive Secretary: D. Mckeown. Term expires February 22, 1963. 
History: Formed 1888 in Toronto; incorporated 1926. First local in British Columbia formed 1898 in Victoria.

Purpose: To advance the technical and economic interests of marine engineers.

Membership: 650 . Certificate of competency as a marine engineer required.

Meetings: Every four years.

Publications: N.A.M.E. News, monthly.

Library: 120 volumes on marine engineering, trade union activities.

\section{New Brunswick Association of Registered}

Nurses, 231 Saunders Street, Fredericton, N. B. President: Miss Lois O. Smith, Provincial Hospital, Lancaster, N. B. Term expires May, 1962. Executive Secretary: Miss Muriel Archibald. Term indefinite.

History: Organized 1916 as New Brunswick Association of Graduate Nurses; present name adopted 1924. Standing committees: nursing education; nursing service; legislation and bylaws; finance; public relations; advisory to schools of nursing.

Purpose: To assure qualified nursing care for the people of New Brunswick by improving and maintaining standards of nursing education and service; to participate in nursing affairs which promote public welfare; to advance professional and material welfare of members and welfare of nursing assistants.

Membership: 2991 : practising members 1974; non-practising and associate 55 ; non-active 962. Registration in the province of New Brunswick required.

Mcetings: Annual.

Professional activities: Loan fund $\$ 2000$ for student nurses.

Publications: News Bulletin, three yearly, free to members.

Library: 225 volumes on nursing.

171. New Brunswick Dental Society. President: P. M. Clarke, St. Stephen, N. B. Term expires October, 1960. Executive Secretary: R. F. Sansom, 158 Germain Street, Saint John, N. B. Term expires October, 1960.

History: Organized and incorporated 1890.

Purpose: Registration of those who wish to practise dentistry in the province; promotion of clinics and meetings for advancement of dentistry.

Membership: 115, resident and non-resident. Meetings: Annual.

Professional activities: $\$ 50$ annually to Dalhousie University dental faculty.
172. New Brunswick Medical Society (Canadian Medical Association, New Brunswick Division). President: 'T. C. Dougan, Sussex, N. B. Term expires September, 1961. Sccretary: F. L. Whitehead, East Riverside, Kings County, N. B. Term expires September, 1961.

History: Organized 1880.

Purpose: Promotion of interests of medical profession.

Membership: 445.

Meetings: Annual.

173. New Brunswick Pharmaceutical Society. President: George G. Cochrane, Plaster Rock, N. B. Term expires June, 1961. SecretaryRegistrar: E. P. Fullerton, 144 Charlotte Street, Saint John, N. B. Term expires June, 1961.

\section{History: Established 1884.}

Purpose: To govern practice of pharmacy in New Brunswick in accordance with New Brunswick Pharmaceutical Act; to establish standards of student education and examination.

Mombership: Registered pharmacists 173 : inactive 17; honorary pharmacists 3 ; certified clerks 102; inactive 11. Passing of required examinations; outside pharmacists admitted at discretion of Council.

Mectings: Annual.

174. New Brunswick Veterinary Association. President: D. B. Butterwick, Provincial Veterinary Centre, Fredericton, N. B. Term expires September 24, 1961. Secretary-Treasurcr: R. H. Henry, 1111 Main St., Moncton, N. B. Term expires September 24, 1961.

History: Formed 1919. Since forming of Canadian Veterinary Medical Association bears allegiance to it.

Purpose: To regulate the requirements of the profession for operation within the Province.

Membership: 37. Graduation from a recognized veterinary school or college, or license in another Province, required.

Meetings: Annual.

175. Newfoundland Dental Society. President: H. J. Hann, Cornwall Drug Building, St. John's, Nfld. Term expires June, 1961. Secretary: B. L. Bowden, 203 LeMarchant Road, St. John's, Nfld. Term indefinite.

History: Organized as the Newfoundland Dental Association in 1915; incorporated 1954.

Purpose: To promote the art and science of dentistry. 
Membership: 43. Members must possess qualifications acceptable to the Newfoundland Dental Board.

llectings: Annual.

176. Newfoundland Medical Association (Canadian Medical Association, Newfoundland Division), O’Mara Martin Building, Rawlins Cross, St. John's, Nfld. President: F. L. O'Dea. Term expires June, 1960. Honorary Secretary: C. U. Henderson. Term expires June 2, 1960.

History: Founded 35 years ago, comprising the St. John's Clinical Society, Central Newfoundland Medical Association and the West Coast Medical Association.

Purpose: Advancement of medical science, as laid down in constitution of Canadian Medical Association.

Membership: 155. Qualified medical doctors appearing in the Newfoundland Medical Register.

\section{Meetings: Annual.}

Publications: Newsletter, bi-monthly, current volume: 2. Editor: A. J. Neary, 10 Ordnance Street, St. John's, Nfld.

177. Nova Scotia Association of Architects, P. O. Box 173, Halifax, N. S. President: J. L. Darby, P. O. Box 190, Bedford, N. S. Term expires February, 1961. Honorary Secretary: L. J. Page, 22 Glen Drive, Wedgewood Park, Rockingham, N. S. Term expires February, 1961.

\section{History: Founded 1932.}

Purpose: To promote and increase knowledge, skill and proficiency of members in all things relating to profession of architecture.

Membership: 50. Members must have degree in architecture from recognized university or equivalent, be a British subject, and reside in province of Nova Scotia.

Meetings: Two yearly.

Professional activities: Scholarship to Nova Scotia College of Art.

Library: Recently founded; 30 technical volumes related to architecture.

178. Nova Scotia Dental Association, 353 Bayers Road, Halifax, N. S. President: IV. H. Macneil, 32 Coburg Road, Halifax, N. S. Term expires June, 1961. Executive Secretary: A. A. Dunlop. Term indefinite.

History: Founded 1893 after passing of Nova Scotia Dental Act in 1891.

Purpose: To promote art and science of dentistry, interests of public and profession.
Membership: 235. Members must be graduates of a recognized dental school in Canada or the United States.

Meetings: Annual.

Professional activities: Prizes and books to graduates of Dalhousie University dental school.

Publications: News Letter, current volume:

1, to members. Editor: J. W. Merritt.

179. Nova Scotia Institute of Agrologists, Agricultural College, Truro, Nova Scotia. President: Donald C. MacKay, Kentville, N. S. Term expires May 31, 1961. Secretary: D. G. Palfrey. Term indefinite. Registrar-Treasurer: J. R. Booker. Term indefinite.

History: Formed 1953. Performs all functions of a branch of the Agricultural Institute of Canada.

Purpose: Provides a medium through which agrologists can raise the standards of their profession and render greater service to the agricultural industry and the public.

Membership: 140. Graduation in agriculture from recognized university, or a university degree deemed equivalent, required.

Meetings: Monthly.

Professional activities: Provincial scholarship to Nova Scotia Agricultural College.

180. Nova Scotia Pharmaceutical Society, Education Building, Coburg Road, Halifax, N. S. President: J. Philip Walsh, 218 Spring Garden Road, Halifax, N. S. Term expires June 25, 1961. Secretary-Registrar: Robert G. Crowell. Term expires June 25, 1961.

History: Founded 1867; incorporated 1876.

Membership: 220 pharmaceutical chemists; 10 associate; 4 hospital pharmacists.

Meetings: Annual.

181. Nova Scotia Society of Occupational Therapy, 172 University Avenue, Halifax, N. S. President: Miss Margaret Chisholm, Canal Street, Dartmouth, N. S. Term expires September 30, 1961. Secretary: Mrs. R. S. Smith, 136 Summit Street, Halifax, N. S. Term expires September 30, 1961. Corresponding Secretary: Mrs. A. Chute.

History: Organized 1951 as Nova Scotia branch of the Canadian Association of Occupational Therapy.

Purpose: Professional society for education, growth, exchange of techniques of treatment, etc.

Membership: 16. Professional status, occupational therapy training required.

Meetings: Monthly. 
182. Nova Scotia Veterinary Medical Association. Prcsident: J. D. Smith, Kentville, N. S. Term expires October 8, 1960. SecretaryTreasurer: K. W. Trenholm, Kentville, N. S. Term indefinite.

History: Incorporated 1913 as Nova Scotia Veterinary Association.

Purpose: To promote, encourage, and develop veterinary science in the province.

Membership: 36. Members must be qualified veterinarians, have passed examinations of $\mathrm{Na}$ tional Examining Board of Canadian Veterinary Medical Association, or be members in good standing of veterinary association of another province.

Meetings: Semi-annual.

183. Nova Scotian Institute of Science. President: J. R. Dingle, Fisheries Research Board, Experimental Station, Halifax, N. S. Term expires May, 1961. Corresponding Secretary and Librarian: Evelyn M. Campbell, Nova Scotia Research Foundation, Halifax, N. S. Term indefinite.

History: Organized 1862 as Nova Scotian Institute of Natural Science; name changed to present title 1890. Origin in Halifax Mechanics Institute established 1831, from which grew Halifax Literary and Scientific Association; as interests of the members who remained were scientific, character of society changed and ultimately organized under present name.

Purpose: Publication and discussion of original research.

Membership: 300: ordinary, associate, life, student, corresponding members.

Meetings: Monthly.

Professional activities: Annual prize for student essay on original research.

Publications: Proceedings, annual, current volume: 24. Editor: L. B. MacPherson, Dalhousie University, Halifax, N. S.

Library: 8500 volumes on pure and applied science.

184. Ontario Association of Architects, 50 Park

Road, Toronto, Ont. President: James W.

Strutt, 304 Laurier Avenue, IV., Ottawa 4.

Ont. Term expires February, 1961. Secretary: John D. Miller. Term indefinite.

History: Established 1889 ; incorporated 1890 ; incorporation revised 1935.

Purpase: To promote and increase knowledge, skill and proficiency of members in all things relating to profession of architecture, and to advance and maintain a high standard in practice of architecture in Ontario; to establish and maintain or to assist in establishing and maintaining classes. schools, exhibitions or lectures in, and promote public appreciation of, architecture and allied arts and sciences.

Membership: 982 : 948 members ; 10 honorary ; 15 retired; 9 associate. Successful completion of a course at recognized university school of architecture, plus two years practical experience following graduation; or passing examination of registration board, required.

\section{Mectings: Annual.}

Professional activities: Award $\$ 200$ to second year student at University of Toronto School of Architecture with highest honour standing in architectural design. Award $\$ 100$ to student in the third year of the school obtaining highest standing in subjects related to Building Construction. General Proficiency Prize $\$ 100$ School of Architectural Technology, Ryerson Institute of Technology. Annual contribution $\$ 150$ to Scholarship Fund, Ontario College of Art.

Library: 300 volumes on architecture.

185. Ontario Association of Pathologists, 500 Sherbourne Street, Toronto 5, Ont. President: S. F. Penny, Toronto East General Hospital, Toronto, Ont. Term expires October, 1960. Secretary: T. C. Brown. Term indefinite.

History: Organized 1938, to investigate approval of pathologists for Ontario Department of Health. First annual scientific session held 1939.

Purpose: To advocate interests of pathologists in Ontario; to promote and maintain high standards of proficiency in pathological work in institutions in the province.

Membership: 142: life 12 ; ordinary 108; associate 22 . Ordinary members required to be graduates in medicine certified as specialists in pathology by Royal College of Physicians and Surgeons of Canada. Associate-graduates in medicine specializing in pathology, or graduates in a science allied to medicine.

Mectings: Annual.

186. Ontario Dental Association, $230 \mathrm{St}$. George Street, Toronto 5, Ont. President: K. M. Phillips, 13 Main Street, E., Welland, Ont. Term expires May, 1961. Secretary-Treasurer: IV. C. Durhanı. Term indefinite.

\section{History: Organized 1867.}

Purpose: To promote mutual improvement of members and advancement of science of dentistry.

Membership: Approximately 2500 active members; 6 life; 11 honorary. Any regularly qualified ethical dentist, residing in Ontario is an active annual member. 


\section{Mectings: Annual.}

Publications: Journal, monthly, current volume: 37, \$4. Editor: A. W. Lindsay.

187. Ontario Institute of Professional Agrologists, Ontario Agricultural College, Guelph, Ont. President: J. W. Huxley, MacLaren Advertising Co. Ltd., 111 Richmond Street, IV., Toronto, Ont. Term expires December 31, 1960. Executive Secretary: D. IV. Haftman. Term expires December 31, 1960.

History: Has been part of Agricultural Institute of Canada since its inception over 30 years ago. Begun to act as liaison between the provincial branches and National Council of the A.I.C. Incorporated 1960.

Purpose: To make agricultural profession of increasing service to industry and the public.

Membership: 500. Requirement: degree in agriculture from Ontario Agricultural College or equivalent.

Mectings: Annual.

188. Ontario Medical Association, 244 St. George Street, Toronto 5, Ont. President: IV. W. IVigle, Dryden, Ont. Term expires May 11, 1961. Executive-Secretary: A. K. Gillies. Term indefinite.

History: Organized 1880; incorporated 1921. Fifty-eight branch societies divided into 11 districts. Twenty-four specialty sections.

Purpose: To cultivate science of medicine and surgery; to promote public health; to elevate standard of medical and nursing education, etc.

Membership: 5900. Members must be licensed medical doctors in good standing in the province.

Meetings: Annual.

Professional activities: Scholarship $\$ 25$ to student attaining highest standing in preventive medicine in graduating year at each of four universities in the province. Bursaries and loans fund from voluntary contributions by members available for use by medical students.

Publications: Ontario Medical Review, monthly, current volume: 6881, \$4. Editor: G. Sawyer.

189. Ontario Osteopathic Association, 2920 Bloor Street, W., Toronto, Ont. President: A. Victor DeJardine, 205 Yonge Street, Toronto, Ont. Term expires May, 1961. Secretary: E. B. Johnston. Term indefinite.

History: Organized 1901 as Ontario Association of Osteopathy. From 1927-37 Ontario Association of Osteopathic Physicians and Surgeons. Name changed 1937 to Ontario Academy of Osteopathy, and to present title in 1944.
Purpose: To promote public health; to encourage scientific research; to maintain and improve high standards of medical education in osteopathic colleges.

Membership: 70. Active-license to practise osteopathic medicine in Ontario. Honorarycompletely retired from active practice.

Meetings: May and October.

190. Ontario Podiatry Association. President: J. E. Foote, 196 Brock Street, Peterborough, Ont. Term expires October, 1961. Secretary: C. IV. Morgan, 703 Spadina Avenue, Toronto, Ont. Term expires October, 1960.

Histary: Founded 1925 as Ontario Association of Chiropodists. Incorporated 1943; present title adopted 1957.

Purpose: To promote greater public understanding of foot health; to advance the profession in Ontario; to make postgraduate courses available to Ontario podiatrists.

Membership: 51. Open to those licensed to practise in Ontario and who agree to abide by by-laws and code of ethics of the association.

Meetings: Semi-annual.

Professional activities: Scholarship for first year tuition ( $\$ 400$ approx.).

191. Ontario Psychiatric Association, Thistletown Hospital, Thistletown, Ont. President: C. H. McCuaig, 117 College Street, Kingston, Ont. Term expires January, 1961. Secretary: J. W. Atcheson. Term expires January, 1963.

History: Organized 1920 as Ontario NeuroPsychiatric Association.

Purpose: To maintain an organization on behalf of psychiatrists of Ontario for exchange of scientific information and promotion of their professional welfare and usefulness.

Membership: 250 . True members-duly qualified specialist psychiatrists; junior-duly qualified medical practitioners.

Meetings: Three annually.

192. Ontario Psychological Association. President: Roger Philip, Assumption University, Windsor, Ont. Term expires February, 1961. Exccutive Secretary: R. G. Berry, 819 Kensington Drive, Peterborough, Ont. Term indefinite.

History: Organized 1947. Committees : policy and planning; legislation; professional affairs; professional training; public relations.

Purpose: To promote development of psychology as a science and as a practice.

Membership: 200. Requirement: master's degree in psychology from a recognized university. 
Meetings: Annual.

Publications: O.P.A. Quarterly, 4 per year, current volume: XIII, $\$ 3.50$. Editor: W. H. Coons, Ontario Hospital, Hamilton, Ont.

193. Ontario Public Health Association, 150 College Street, Toronto 5, Ont. President: Miss Helen Fasken, Wellington County Health Unit, Fergus, Ont. Term expires October 4, 1960. Secretary: G. K. Martin, Ontario Department of Health, 67 College Street, Toronto, Ont. Term expires October 4, 1960.

History: Established 1949 by members of Ontario Health Officers Association so that other professional groups interested in public health might combine with medical officers of health. Sections: health officers; public health nursing; dental public health; veterinary public health; environmental hygiene; plumbing inspectors'; public health education.

Purpose: To develop and diffuse in Ontario the knowledge, practice and technique of preventive medicine and public health in all their branches.

Membership: 500 . Members must be interested in public health programs in the province.

Meetings: Annual.

194. Ontario Society of Occupational Therapy. President: Mrs. D. (Jeanne) Johnstone, P. O. Box 106, Ancaster, Ont. Term expires November, 1961.

History: Incorporated 1921. Branches: Toronto; Hamilton; Kingston; London.

Purpose: Assisting occupational therapists in Ontario and furthering the cause of occupational therapy.

Membership: Registered active and non-active members of Canadian Association of Occupational Therapy resident in Ontario.

Meetings: Quarterly.

Professional activities: Book Prize to outstanding graduating student in occupational therapy at University of Toronto.

\section{Ontario Society of Radiological Tech-} nicians, 250 University Avenue, Toronto 1, Ont. President: Kenneth E. Hall, Ottawa Civic Hospital, Ottawa, Ont. Term expires June, 1961. Executive Director: Mrs. M. F. Cameron, 318 Shoreview Avenue, Burlington, Ont. Term indefinite.

History: Incorporated 1936 as Ontario Society of Radiological Technicians, changed 1940 to Ontario Society of Radiographers. Original name resumed 1960. Member, Canadian Society of Radiological Technicians. Sectional divisions : Central, Northern, Western, Lakehead, Eastern (Kingston and Ottawa) Ontario.

Purpose: To establish and maintain a profession devoted to science of radiology; to promote and encourage science of radiological technique, radiotherapy and isotopes; to consider all subjects affecting them.

Membership: Active 549 ; associate 23; student 258; non-active 149; radiological 3 . Active - persons engaged in radiological work in province of Ontario in an ethical manner under supervision of a qualified medical or dental practitioner, adequately qualified (current requirement Grade 12, after January 1, 1961, Grade 13) and passing such examinations as may be conducted and/or approved by the society. Associate - those not educationally qualified to write examinations but who through authoritative recommendation may be admitted by board of directors. Student-those who enter a training school supervised by a certified radiologist in the province and sign an agreement with the society to fulfill required period of training in radiography and/or radiotherapy (current period 2 years). Non-active-those who have worked actively but who have ceased to be engaged in radiological work and wish to continue affiliation with the society.

\section{Meetings: Annual.}

Professional activities: Educational committee sponsors and arranges week-end refresher courses, 4-5 day postgraduate course prior to annual meeting.

Publications: "Bulletin" published monthly except August, \$1. Editor: Mrs. G. Sandwell, 4 Oriole Crescent, Grimsby, Ont.

196. Ontario Veterinary Association, 97 Eglinton Street East, Toronto 12, Ont. President: T. W. Hawke, 185 Division Street, Cobourg, Ont. Term expires January 28, 1961. Secretary-Registrar: W. E. Jolliffe. Term indefinite.

History: Founded 1874; incorporated 1879.

Purpose: To establish minimum professional standards throughout the province; to encourage veterinary medicine as a profession; to protect the public from unqualified practitioners.

Membership: 771: active 674; life (retired) 25 ; absent 72. Requirements: successful graduation from Ontario Veterinary College; meeting requirements of the association.

Meetings: Annual.

Professional activities: Ontario Veterinary Association Scholarship at Ontario Veterinary College. 
197. Ottawa Biological and Biochemical Society. President: B. B. Migicovsky, Animal Research Institute, Canada Department of Agriculture, Ottawa, Ont. Term expires May, 1961. Secretary: F. Sauer, Animal Research Institute, Canada Department of Agriculture, Ottawa, Ont. Term expires May, 1961.

History: Organized 1949.

Purpose: To provide a forum for discussion of research in experimental aspects of biology.

Membership: 165. Professional or amateur interest in biological research.

Meetings: Monthly.

198. Patent and Trademark Institute of Canada. President: Eric L. Medcalf, 70 Gloucester Street, Ottawa 4, Ont. Term expires September, 1962. Honorary Secretary-Treasurer: Harvey I. Marshal, 56 Sparks Street, P. O. Box 1077, Station "B", Ottawa, Ont. Term expires September, 1962.

History: Begun 1926 with a meeting of patent solicitors at Ottawa. Organization constituted 1927 as Canadian Institute of Patent Solicitors; incorporated 1935 as Patent Institute of Canada. Present name adopted 1957.

Purpose: To form a united and representative group of persons specializing in matters pertaining to patents, trade marks, copyright and industrial designs; to study laws and practice relating to patents, trade marks, industrial designs and copyright in Canada and to promote efficient administration and development of same for protection of industrial and intellectual property in Canada; to promote and maintain high standards of training and ethics among members; to disseminate to public useful knowledge relating to protection of industrial and intellectual property; to facilitate acquirement of professional knowledge and information affecting practice and to promote interchange thereof among members.

\section{Membership: 264.}

Meetings: Annual.

Publications: Bulletin, quarterly, current volume: 4. Editor: E. G. Metcalfe. Proceedings, annual, current volume: $33 . \$ 1$.

199. Pharmaceutical Association of the Province of British Columbia, 207 West Hastings Street, Vancouver 3, B. C. President: M. S. Evers, 616 6th Street, New Westminster, B. C. Term expires June, 1961. Executive Secretary: Gibb G. Henderson. Term indefinite.

History: Established 1891.

Purpose: Administration of pharmacy act in British Columbia.
Membership: 1130; 250 students. Members require bachelor of science in pharmacy from recognized Canadian university.

Meetings: Annual.

Professional activities: Two scholarships anrually at University of British Columbia; Pharmaceutical Association of the Province of British Columbia Scholarship $\$ 100$; Dean E. L. Voods Memorial Prize $\$ 50$.

Publications: Bulletin, quarterly, current volume: 3. Editor: D. A. Denholm.

200. Pharmacological Society of Canada-La Société Pharmacologique du Canada, c/o P. O. Box 959, Montreal, Que. President: Mark Nickerson, University of Manitoba, Winnipeg, Man. Term expires June, 1961. Secretary: J. D. McColl. Term expires June, 1961.

History: Founded 1956. Charter member Canadian Federation of Biological Societies 1957.

Purpose: To promote advancement of science of pharmacology in its widest sense.

Membership: 129. Any person who has conducted research and published meritorious papers in pharmacology in the widest sense, or engaged in teaching in this field, eligible for membership.

Meetings: Annual.

201. Prince Edward Island Institute of Agrologists. President: J. D. E. Sterling, Experimental Farm, Charlottetown, P. E. I. Term expires July, 1961. Executive Secretary: David Scales, 10 Confederation Street, Parkdale, Charlottetown R. R., P.E. I. Term expires July, 1962.

\section{History: Formed 1960.}

Purpose: Promotion and maintenance of high standard of qualifications for agrologists; to unite agrologists in a society devoted to solving agricultural problems in the province.

Membership: 35. Graduation in agriculture from a recognized university required.

Meetings: Monthly.

\section{Prince Edward Island Pharmaceutical So-} ciety, Charlottetown, P. E. I. President: Derald F. MacKenzie, 197 Kent Street, Charlottetown, P. E. I. Term expires June, 1961. Secretary-Registrar: K. J. Cantwell, 175 Grafton Street, Charlottetown, P. E. I. Term indefinite.

History: Founded 1905.

Purpose: Public safety and public protection; licensing of pharmaceutical chemists; education standards of pharmacy in P. E. I. 
Membership: Eighteen certified clerks; two associate; five students; $36 \mathrm{Ph} . \mathrm{C}$.

Meetings: Annual.

Professional activitics: Prizes given to Maritime College of Pharmacy, Halifax, N. S.

\section{Prince Edward Island Veterinary Medical}

Association. P. O. Box 3000, Charlottetown, P.E.I. President: J. 1. Higgins. Secretary: G. C. Fisher, c/o Canada Packers Ltd., Charlottetown, P. E. I.

\section{History: Organized 1920.}

Purpose: To comply with Narcotic Act and afford a measure of protection to members of profession.

Membership: 14.

Mectings: Annual.

\section{Professional Institute of the Public Ser-} vice of Canada, 200 Cooper Street, Ottawa 4, Ont. President: W. M. Marshall, 109 Poweli Avenue, Ottawa, Ont. Term expires February, 1961. Executive Secretary: J. H. Leroux. Term indefinite.

History: Organized 1920. Twelve working committees. Forty-six professional groups, 29 branches across Canada.

Purpose: To enhance usefuhness of scientific, professional and technical branches of public service of Canada to the public; to maintain high professional standards; to promote welfare of members.

Membership: 5500. Membership open to persons employed by the government of Canada in a professional capacity, graduates of a recognized university or with equivalent qualifications.

\section{Mectings: Annual.}

Professional activities: Two Gold Medals presented cach year: one for achievement in pure and applied science, other for achievement outside pure and applied science.

Publications: Professional Public Service, monthly, current volume: 39 . Editor: W. S. Drinkwater.

205. Psychological Association of Alberta. President: D. B. Black, University of Alberta, Edmonton, Alta. Term expires June, 1961. Secretary-Treasurer: A. J. B. Hough, University of Alberta, Edmonton, Alta. Term expires June, 1961.

History: Constitution developed 1958. Southern Alberta division centered in Calgary and northern division centered in Edmonton. Active committees: membership and ethics; nominations; public relations and publications; professional standards and training.
Purpose: Furtherance of psychology as a science, as a profession and to promote human welfare.

Membership: 50. Full membership-doctoral degree with psychological dissertation or graduate degree in psychology plus one year experience; or through training, experience, approved by committee on membership and ethics and by executive. Associate-Master's degree, or candidate for master's degree, or honours bachelor degree.

\section{Meetings: Annual.}

Publications: Psychological Newsletter, semiannual, current volume: 2 , free to members. Editor: A. Hough.

\section{Quebec Society for the Protection of Plants} - Société de Québec pour la Protection des Plantes, Quebec Department of Agriculture, Quebec, P. Q. President: Bernard Baribeau, Qucbec Department of Agriculture, Ste-Annede-la-Pocatière, P. Q. Term expires April, 1961. Secretary: Richard Cayouette. Term indefinite.

\section{History: Organized 1908.}

Purpose: To study enemies of plant life and methods of repression.

Membership: 230: 11 honorary; 216 regular; 3 corresponding.

Mectings: Annual.

Publications: Report, annual, free to members or on exchange basis. Also supplements, irregular.

\section{Registered Nurses' Association of British} Columbia, 2524 Cypress Street, Vancouver 9, B. C. President: Miss Edna Rossiter, Shaughnessy Hospital, Vancouver, B. C. Term expires May, 1961. Executive Secretary: Miss Eleanor S. Graham. Term indefinite.

History: Established 1912 as Graduate Nurses' Association of British Columbia; present name adopted 1935. Member society of Canadian Nurses' Association.

Purpose: To maintain honour and status of nursing profession; to advance educational standards in nursing; to elevate standard of nursing practice in order to render efficient service in interest of the public; to promote and regulate sound employee-employer relations in nursing profession.

Membership: 8846; practising 6500; nonpractising 1246. Requirements: B. C. University Entrance or equivalent; graduation from recognized school of nursing, and success in B. C. nurse registration examinations ; or equivalent from outside B. C.

Mectings: Annual. 
Professional activities: Bursary/loans for post-basic study.

Publications: News Bulletin, 4-5 times yearly, unnumbered.

Library: 215 volumes on subjects allied to nursing.

208. Registered Nurses' Association of Nova Scotia, 73 College Street, Halifax, N. S. President: Miss Margaret Matheson, 3 Albion Avenue, Stellarton, N. S. Term expires June, 1961. Executive Secretary: Miss Nancy Watson. Term indefinite.

History: Organized 1909 as Graduate Nurses' Association; present name adopted 1925. Eleven branches covering the 18 counties of Nova Scotia.

Purpose: To examine and register nurses in Nova Scotia; concerned also with standards of nursing education and nursing service; approves all schools of nursing in the province (15).

Membership: 2385 active; 265 associate. Requirements: graduation from approved school of nursing; provincial Grade XI certificate or equivalent; at least 21 years of age, and provincial examinations of association. Reciprocity with other provinces and countries.

Meetings: Annual.

Publications: News Letter, quarterly.

\section{Registered Nurses' Association of Ontario,}

33 Price Street, Toronto 5, Ont. President:

Miss Ella M. Howard, New Mt. Sinai Hos-

pital, 550 University Avenue, Toronto, Ont.

Term expires April, 1962. Executive Secre-

tary: Miss Florence H. Walker. Term expires December 31, 1960.

History: Formed 1904 as Graduate Nurses' Association of Ontario ; incorporated under present name in 1925. Made registering body by Nurses' Registration Act 1951. Twelve district associations covering the province; 38 local chapters. Six standing committees: nursing service; nursing education; registration; public relations; legislation and by-laws; finance.

Purpose: To advance educational standards of nursing; to maintain honour and status of profession; to render service in interest of public. Carries responsibility, subject to Cabinet approval, for admission standards to schools of nursing, minimum curriculum, examinations, registration and discipline.

Membership: 24,030: 3 honorary; 17.682 active; 4449 associate; 1896 inactive. Honoraryfor distinguished service or valuable assistance to nursing profession; active-registration; associate-resident in Ontario but not practising; inactive-previuus registration but registration not renewed, or registered but not resident or not practising.

\section{Meetings: Annual.}

Professional activities: Permanent education fund for loans for post-basic study; annual bursary to student entering basic degree course in nursing. Maintains the 12 district associations and 38 chapters mentioned. Employs staff for educational and field programs, conferences, institutes, etc. Active voluntary committees promote professional activities, conduct workshops, etc.

Publications: News Bulletin, 6 times annually, current volume; 16 , free to members.

Library: 370 volumes on all aspects of nursing.

210. Royal Architectural Institute of Canada, 88 Metcalfe Street, Ottawa, Ont. President: Harland Steele. Term expires May, 1962. Honorary Secretary: F. Bruce Brown. Term expires May, 1962. Honorary Treasurer: R. C. Betts. Term expires May, 1962. Exccutive Director: R. L. Elliott. Term indefinite. Acting Secretary: L. E. Fallis. Term indefinite.

History: Founded 1907 as federation of nine provincial associations. Incorporated 1908; prefix "Royal" granted 1909 by King Edward VII. Incorporated under present name 1912. Patron, Her Majesty Queen Elizabeth II. Provincial associations: Alberta Association of Architects; Architectural Institute of British Columbia; Manitoba Association of Architects; Architects' Association of New Brunswick; Newfoundland Association of Architects; Nova Scotia Association of Architects; Ontario Association of Architects; Province of Quebec Association of Architects; Saskatchewan Association of Architects.

Purpose: To establish and maintain a bond between societies recognized by the Royal Institute as component associations and to promote the welfare of the architectural profession in Canada; to establish and maintain a bond between the Royal Institute and societies or institutes having similar objects; to promote a knowledge and appreciation of architecture and of the architectural profession; to promote and make available to members of Royal Institute knowledge pertaining to practice of the architectural profession; to promote encouragement and recognition of worthy aspirants to the profession.

Membership: 2200 members, Fellows, and Honorary Fellows. Limited to those holding membership in a provincial association.

Meetings: Annual.

Professional activities: College of Fellows Scholarship $\$ 2500$ awarded every second year for advancement of architectural knowledge 
through travel, study or research. Allied Arts Medal, awarded to honour outstanding achievement in arts allied to architecture, such as mural painting, sculpture, decoration, stained glass, industrial design, etc. R.A.I.C. medals, awarded yearly to outstanding student in final year of each of the five accredited Canadian schools of architecture.

Publications: Journal, nonthly, current volume: 37. Managing editor: W. B. Bowker.

Library: Miscellaneous works on architecture, building construction, etc.

211. Royal Astronomical Society of Canada, 252 College Street, Toronto 2B, Ont. President: P. M. Millman, National Research Council of Canada, Ottawa 2, Ont. Term expires 1961. National Secretary: J. E. Kennedy. Term expires 1962.

History: Incorporated 1890 as Astronomical and Physical Society of Toronto; name changed to Toronto Astronomical Society in 1900, and to present title, as Society became national in scope, in 1903. Active centres in Halifax, Quebec, Montreal (two centres: French- and English-speaking, respectively), Ottawa, Hamilton, London, Windsor, Toronto (National Headquarters), Winnipeg, Edmonton, Calgary, Vancouver and Victoria. Each centre autonomous, with own officers, constitution and by-laws, observational program and apparatus.

Purpose: To study astronomy and related subjects; to diffuse theoretical and practical information on these; to publish its work; to acquire and maintain an astronomical library.

Membership: 2000. Professional or amateur interest in astronomy.

\section{Mectings: Annual.}

Professional activities: Gold Medal awarded annually to fourth year astronomy student at University of Toronto with highest standing among those holding first class honours; Chant Medal awarded annually for distinguished work by an amateur astronomer.

Publications: Observer's Handbook, annual, \$1. Journal, bi-monthly, current volume: 54 , \$5. Editor: Ruth J. Northcott.

Library: 6400 volumes on astronomy and astrophysics.

212. Royal Canadian Geographical Society, 54 Park Avenue, Ottawa 4, Ont. President: H. A. Young, 220 Sandridge Road, Rockliffe Park, Ottawa 2, Ont. Term expires February, 1961. Executive-Secretary: WV. J. Megill. Term indefinite.

History: Established by a group of citizens in Ottawa under leadership of late Charles
Camsell, C.M.G., who become its first president. Constitution provides for Board of Directors of thirty members, of whom at least a quorum must be resident within twentyfive miles of Ottawa, and which sliall include at least one representative of each province and and one for the Yukon and Northwest Territories. Received Charter 30 May, 1929; first number Canadian Geographical Journal published May, 1930. Work recognized by Her Majesty the Queen in October 1957 by grant of the prefix "Royal" to title. Howorary $\mathrm{Pa}$ tron: His Excellency the Governor-General of Canada (since inception of society).

Purpose: Advancement of geographical knowledge and in particular the general diffusion of information of Canadian geography.

Mcmbership: 9757, 462 of whom are corporate members (Fellows). Membership open to anyone interested. Fellows are persons interested in objects of the society who have contributed to geographical research or exploration or who for other reasons are approved by Board of Directors.

\section{Meetings: Annual.}

Professional activities: Twenty-nine scholarships in geography have been awarded; research fund maintained for support of exploration and research projects. Massey Medal established by the Massey Foundation for annual presentation by the Society to a Canadian for outstanding personal achievement in exploration, development or description of geography of Canada; first award 1959.

Publications: Canadian Geographical Journal, monthly, current volume: $\mathrm{LX}, \$ 5$. Editor: W. J. Megill.

Library: 1500 volumes on geographical subjects.

\section{Royal College of Physicians and Surgeons} of Canada, 74 Stanley Avenue, Ottawa 2, Ont. President: Donald A. Thompson, 210 St. George Street, Bathurst, N. B. Term expires January, 1962. Secrelary: James H. Graham. Term indefinite.

\section{History: Incorporated 1929.}

Purpose: To promote growth and development of art and science of medicine and to offer distinguishing marks of qualification to those individuals who have attained ligh standards required in training, skill and knowledge. Certification of specialists since 1946.

Membership: 2050 Fellows. Entry by examination following five years of approved graduate training.

\section{Mectings: Annual.}

Professional activities: Annual awards in medicine and surgery; beginning 1960 will spon- 
sor an annual R. S. McLaughlin-IV. E. Gallie Visiting Professorship supported by grant from the R. Samuel McLaughlin Foundation.

Publications: Register of Fellows, annual, free to Fellows of College.

\section{Royal Society of Canada, National Research} Council Building, Sussex Drive, Ottawa 2, Ont. President: M. Y. Williams, University of British Columbia, Vancouver 8, B. C. Term expires June, 1961. Honorary Secretary: Guy Sylvestre, 355 Wilbrod Street, Ottawa, Ont. Term expires June, 1962. Associate Honorary Secretary: S. C. Robinson, Geological Survey of Canada, Ottawa, Ont. Term expires June, 1962. Exccutive Secretary: Mrs. Léa Métivier. Term indefinite.

History: Founded by His Grace the Duke of Argyle in 1882 ; incorporated by Act of Parliament, May 25, 1883. Sections: I. Humanités et sciences sociales; II. Humanities and Social Sciences; III. Mathematical, Chemical, and Physical Sciences; IV. Geological Sciences; V. Biological Sciences.

Purpose: To encourage studies and investigations in literature and science; to publish transactions annually or semiannually, containing minutes of proceedings at meetings, records of work performed, original papers and memoirs of merit, and such other documents as may be deemed worthy of publication; to offer prizes or other inducements for valuable papers on subjects relating to Canada, and to aid researches already begun and carried so far as to render their ultimate value probable; to assist in collection of specimens with a view to formation of a Canadian museum of archives, technology, archaeology, and natural history.

Membership: 530 Fellows (F.R.S.C.) must be persons resident in Canada who have published original works or memoirs of merit, or who have rendered eminent service to literature of science.

Meetings: Annual.

Professional activities: Flavelle Medal, for original work in science of conspicuous merit; Lorne Pierce Medal, for some achievement in imaginative or critical literature of special significance; Tyrrell Medal for outstanding work in history; Pierre Chauveau Medal, for outstanding work in humanities; Henry Marshall Tory Medal, for outstanding work in physical sciences; Willet G. Miller Medal, for outstanding research in geological sciences. Harrison Prize in Bacteriology.

Publications: Transactions, annual, current volume: 53, \$14. (Sectional separates available: Sections I and II combined $\$ 3$; Sections III, IV, V, \$2 each). Studia Varia, annual, current volume: 6 , prices varies.
Library: Approximately 60,000 volumes covering all branches of knowledge, particularly natural sciences; now housed in library of National Research Council, Ottawa.

215. Saskatchewan Association of Architects, 2426 Hanover Avenue, Saskatoon, Sask. President: G. H. Kerr, 102 Ross Block, Saskatoon, Sask. Term expires October, 1960. Exccutive Secretary: Mrs. E. C. Hippe. Term indefinite.

History: Organized 1909; incorporated 1911. Purpose: To control the practice and promote the study of architecture in Saskatchewan.

Membership: 54. Members must have been resident in Saskatchewan for one year, must have passed suitable training or qualifying examinations.

Metings: Semi-annual.

Professional activities: Awards one university scholarship.

216. Saskatchewan Association of Chiropodists. President: Leo Bernbaum, 720 Medical Dental Building, Regina, Sask. Secretary: Earle R. Williams, 212 MacMillan Building, Saskatoon, Sask.

\section{History: Incorporated 1943.}

Purpose: Professional association concerning practice of surgical chiropody to keep professional standards up to a high level and establish who shall have right to practise.

Mcmbership: 6. Membership gained after registration and following examination by University of Saskatchewan.

Meetings: Annual.

217. Saskatchewan Geological Society, P. O. Box 234, Regina, Sask. President: C. K. Caldwell, Financial Building, Regina, Sask. Term expires December 31, 1960. Secretary: A. Chesney, c/o Central Canada Stratigraphic Service, Regina, Sask. Term expires December 31, 1960.

\section{History: Incorporated 1951}

Purpose: To promote science of geology and geophysics, particularly as applied in petroleum, natural gas and allied industries; to promote a spirit of scientific research among members.

Membership: 90. Requirements: eligible for membership in American Association of Petroleum Geologists, Society of Exploration Geophysics, or Society of Economic Paleontologists and Mineralogists; degree in geology or science fundamental to petroleum geology and working in technical capacity in oil industry; sponsored 
by active member and unanimously approved by executive committee.

Meetings: Monthly.

Professional activities: Contributions $(\$ 1500$ to date) to geology department, University of Saskatchewan.

218. Saskatchewan Institute of Agrologists, University of Saskatchewan, Saskatoon, Sask. President: J. T. Kyle, 7 th and Hamilton Streets, Saskatoon, Sask. Term expires May 28, 1961. Registrar: E. N. Larter. Term indefinite.

History: Formed 1946; provincial division of Agricultural Institute of Canada. Six branches (locals) located throughout the province.

Purpose: To foster recognition of professional agriculture.

Membership: 500. Members must have a B.Sc. degree from recognized college, plus 3 years experience in professional agriculture.

Mectings: Annual.

Professional activities: Undergraduate scholarship $\$ 300$, Graduation Prize $\$ 50$, at College of Agriculture.

\section{Saskatchewan Land Surveyors' Association.}

President: M. Viminitz, Surveys Branch, Land Titles Office, Regina, Sask. Term expires March, 1961. Secretary-Trcasurer: A. Stewart, 2925 Wascana Street, Regina, Sask. Term expires March, 1961.

\section{History: Organized March 1910.}

Purpose: To maintain the standards of the surveying profession; protection of the public through registration of surveyors.

Membership: 80. Requirements: Grade 12 standing with three years under articles to a commissioned land surveyor and two sets of examinations (at end of $2 \mathrm{nd}$ and $3 \mathrm{rd}$ years of articles) set by the University of Saskatchewan and the S.L.S. association; or graduation as civil engineer from a recognized university, one year of articles and one set of examinations.

Meetings: Annual.

Professional activities: Annual $\$ 50$ Prize awarded to third year student in civil engincering at University of Saskatchewan for best standing in surveying.

Library: 75 volumes on surveying.

220. Saskatchewan Pharmaceutical Association, 2431 Eleventh Avenue, Regina, Sask. President: E. D. Wilkie, North Battleford, Sask.
Term expires May, 1961. Registrar: Vern Jansen. Term indefinite.

History: Organized 1911. Province divided into seven divisions with one member in each division elected to council.

Purpose: To regulate the practice of pharmacy within the province.

Membership: 330 non-practising; 522 practising. Members must be graduates of a college of pharmacy recognized by the association.

Meetings: Annual.

Professional activities: Robert Martin Prize $\$ 50$; Campbell Prize $\$ 35$. Saskatchewan Pharmaceutical Association Gold Medal.

221. Saskatchewan Psychological Association. President: C. R. Jillings, Provincial Health Building, Regina, Sask. Term expires May, 1961. Secretary: H. M. Brackman, General Hospital, Regina, Sask. Term expires May, 1961.

\section{History: Formed 1952}

Purpose: The exchange of ideas, information and methods.

Membership: $50 ; 5$ students. B. A. minimum requirement.

Meetings: Annual.

Publications: The Saskatchewan Psychologist, three yearly, current volume: $6, \$ 3$. Editor: Neil Agnew, University Hospital, Saskatoon, Sask.

\section{Saskatchewan Registered Nurses' Associa-} tion, 2066 Retallack Street, Regina, Sask. President: Miss E. Louise Miner. Term expires May, 1961. Registrar: Miss Grace Motta. Term indefinite. Executive Secretary: Miss Victoria Antonini. Term indefinite.

History: Act respecting Saskatchewan Registered Nurses' Association passed 1917; first annual convention 1918. Thirteen chapters: North Battleford, Estevan; Regina; Saskatoon; Swift Current; Humboldt; Moose Jaw; Prince Albert; Weyburn; Yorkton; Tisdale; Meadow Lake; Balcarres. Four committees: nursing education; nursing service; public relations; chapters.

Purpose: Registration (licensing) of graduate nurses; to maintain and improve the ethical and professional standards of nursing.

Membership: 3738.

Meetings: Annual.

Professional activities: Loan fund $\$ 500$ for postgraduate study.

Publications: News Bulletin, free to members. 
223. Saskatchewan Society of Osteopathic Physicians. President: Anna E. NorthupLittle, 2228 Albert Street, Regina, Sask. Term expires December 31, 1960. Executive Secretary: Doris M. Tanner, 2228 Albert Street, Regina, Sask. Term expires December $31,1960$.

\section{History: Formed 1914.}

Purpose: To coordinate members of profession; to make regulations for their practice; to maintain high ethical and professional standards.

Membership: Three. Graduation from a recognized college of osteopathy and meeting all requirements for licensure in the province required.

Mectings: Annual.

\section{Section of Pathology of the Manitoba} Medical Association. President: D. W. Penner, Winnipeg General Hospital, Winnipeg, Man. Term expires June, 1961. Secretary: C. N. Crowson, Misericordia General Hospital, Winnipeg, Man. Term expires June, 1961.

History: Founded 1949 at University of Manitoba. Provisions made for ordinary, associate and honorary membership. Meetings have been mixed scientific and business, and held 6 times annually. Annual meeting in June of each year.

Purpose: Maintenance of a high standard of proficiency in pathology; advancement of pathology; to function as representative organization of pathologists in the province.

Membership: Honorary 4; associate 11 ; ordinary 31. Requirements as for Manitoba Medical Association plus restriction of practice to pathology in any one or more of its major subdivisions.

$$
\text { Mectings: Six yearly. }
$$

\section{Société Canadienne d'Etudes et de} Recherches Psychiatriques, 2156 Sherbrooke Street, IV., Montreal 25, Que. President: Victorin Voyer, 724 Hartland Avenue, Montreal 8, Que. Term expires December 31, 1960. Secretary: J. B. Boulanger. Term indefinite.

History: Founded 1958 in Montreal by a group of Canadian psychiatrists using French as their scientific language.

Purpose: To group, in a scientific society of French expression, psychiatrists and allied workers; to encourage research and cooperation in the field of psychiatry and related science.

Membership: 18. Full membership-certification in psychiatry; associate and affiliatequalification or studies in medicine, psychology, social science, social service, sociology, anthropology, education, nursing, etc. Open to all inter- ested in psychiatric problems or fields related to psychiatry.

\section{Meetings: Quarterly.}

Publications: French section (quarterly), Journal of Canadian Psychiatric Association. (See entry 105).

\section{Société Canadienne-Française d'Electro-} radiologie Médicale. President: Paul Brodeur, Notre Dame Hospital, 1560 Sherbrooke Street, E., Montreal, Quebec. Term expires December, 1961. Secretary: A. F. Vallée, Sainte-Jeanne d'Arc Hospital, 3570 St. Urbain Street, Montreal, Que. Term expires December, 1961.

History: Founded 26 years ago, the society groups all French-speaking radiologists of the province of Quebec.

Purpose: Scientific advancement of radiology.

Mcmbership: 100. Certification in radiology, presentation of a scientific paper, and recommendation by the executive comnittee required for all members.

Meetings: Four annually.

227. Société de Biologie de Montréal. President: Jean-Marie Demers, Université de Montréal, Montréal, Qué. Term expires June, 1961. Secretary: Pierre Couillard, Université de Montréal, Montréal, Qué.

History: Organized 1922. Biological section of Association Canadienne-française pour l'Avancement des Sciences for the Université de Montréal.

Purpose: To enable biologists to learn of and discuss recent progress in biology, and to present original communications.

Membership: 90. Benefactors; titular members; active; student.

Mectings: $6-7$ yearly.

Publications: La Revue Canadienne de Biologie, \$3. Editor: Antonio d'Iorio.

\section{Société de Gastro-Enterologie de Montréal -Montreal Gastro-Enterological Society.} President: A. Cantero, Elmwood Street, Montreal, Que. Secretary: N. Renzi, 5757 Decelles Avenue, Montreal, Que.

History: Founded 1933. Affiliated with Société Médicale du Canada; merger 1958 with gastroenterological section of Montreal MedicoChirurgical Society.

Purpose: To unite all who have a special interest in gastroenterological problems.

Membership: 40. Any medical doctor with special interest in gastroenterology eligible.

Meetings: Every three months. 
229. Société d'Hygiène et de Médecine Préventive de la Province de Québec (Quebec Branch, Canadian Public Health Association), 700 Craig Street, E., Montreal 1, Que. President: C. Pomerleau, Sanitary Unit of Lévis, Lévis, Que. Term expires June, 1961. Secretary: G. Charest. Term expires June, 1961.

History: Founded 1947.

Purpose: Improvement of scientific knowledge of hygienists of the province.

Mombership: 300 . Candidates must be public health workers.

Mectings: Annual.

Publications: Bulletin, bi-monthly, current volume: 12, \$1. Editor: G. Charest.

\section{Société de Microbiologie de la Province de} Québec-Society of Microbiology of the Province of Quebec. Prcsident: Victorien Fredette, University of Montreal, P. O. Box 6128, Montreal, Que. Term expires October, 1960. Secretary: Vincent Portelance, University of Montreal, P. O. Box 6128, Montreal, Que. Term expires October, 1960.

History: Founded 1951 in Montreal. Affiliated with Canadian Society of Microbiologists.

Purpose: Joint study and discussion of problems pertaining to scientific research in all branches of microbiology and to professional interests, and promoting advancement, in that field.

Membership: One honorary member; 133 titular. Honorary-for promoting development of microbiology or having been of great help to the society; titular-persons holding scientific appointment in laboratory of microbiology or related science, or who have published papers on microbiology or related topics in scientific journals.

Meetings: 4 yearly.

231. Société Médicale de Montréal, 418 Sherbrooke Street, E., Montreal 24, Que. President: Albert Royer, 3175 St. Catherine Road, Montreal, Que. Term expires December 30. 1960. Secretary: Georges Leclerc. Term indefinite.

History: Founded 1900.

Purpose: The study of medicine, surgery, and allied subjects.

Membership: 1117: active, corresponding.

Meetings: Twice monthly.

Publications: Yearbook, free to members.

232. Society of Chemical Industry (Canadian Section), 2240 Sun Life Building, Montreal, P. Q. Chairman: C. M. Beamer, Imperial
Oil Limited, 111 St. Clair Avenue, W., Toronto, Ont. Term expires June, 1961. Honorary Secretary: D. M. Matheson, Term expires June, 1961.

History: Organized 1902. Parent Society, London, England, formed 1881; Royal Charter June 17, 1907.

Purpose: To advance applied chemistry in all its branches; to afford its members opportunities for interchange of ideas with respect to improvements in various chemical industries and for discussion of all matters bearing upon practice of applied chemistry and publication of information thereon.

Membcrship: 230. Must be members of chenical industry; no professional requirement.

\section{Mcetings: Three yearly.}

Professional activities: Society of Chemical Industry Canada Medal; university student essay prizes.

Publications: Chemistry and Industry, weekly. Journal, monthly. Annual reports on applied chemistry. Free to members.

\section{Society of Obstetricians and Gynaecolo-} gists of Canada, 280 Bloor Street, W., Toronto 5, Ont. President: Elinor F. E. Black, 226 Medical Arts Building, Winnipeg, Man. Term expires June, 1961. Secretary: F. P. McInnis. Term indefinite.

History: Incorporated 1945.

Purpose: To promote, cultivate and encourage the art and science of obstetrics and gynaecology in Canada.

Membership: Active 200 ; senior 21 ; honorary 16. Eligibility determined on basis of scientific achievement, practical experience, limitation of practice to the specialty of obstetrics and gynaecology and following presentation of a scientific communication before the society. Candidates shall be graduates of medicine of at least seven years standing.

Mectings: Annual.

Professional actizities: Society award.

234. Textile Society of Canada (Eastern Division ), 1600 Dorchester Street, W., Montreal, Que. Prcsident: E. IV. Young, 2055 Peel Street, Montreal, Que. Term expires October. 1960. Secretary: E. Dobbins, 110 Lockhart Avenue, Town of Mount Royal, Que. Term expires October, 1960.

\section{History: Organized 1937.}

Purpose: To promote knowledge and practice of textile technology; to foster lectures and encourage research and further education. 
Membership: 261. Active-persons in textile industry engaged as executives, managers, superintendents, assistant superintendents and accredited textile mill representatives; associatemembers of the allied textile trades; juniorothers actively engaged in textile industry not fulfilling qualifications of active or associate membership.

Mcetings: October, November, January, February and March in Montreal; one out of town meeting each April or May.

Professional activities: $\$ 200$ yearly given to Textile Institute of Province of Quebec, St. Hyacinthe, Que., for awards to students.

235. Textile Society of Canada (Western Division). President: IVm. Ashcroft, 99 Cameron Avenue, S., Hamilton, Ont. Term expires October 31, 1960. Secretary: A. Boothby, 175 Fennel Avenue E., Hamilton, Ont. Term expires October 31, 1960.

\section{History: Constituted 1937.}

Purpose: To promote increase of knowledge of profession and practice of textile technology; in particular, those branches related to raw materials and to manufacture of yarn and fabric of every description.

Membership: 220. Active-persons in textile industry engaged as executives, managers, superintendents, overseers. fixers, cost clerks, and those engaged in similar capacities in allied textile trades; junior-students of textile schools, but without qualifications required for active membership.

Mectings: Monthly.

236. Toronto Biochemical and Biophysical Society. President: E. A. Sellers, University of Toronto, Toronto 5. Ont. Term expires Spring, 1961. Secretary: I. G. Walker, Princess Margaret Hospital, Toronto, Ont. Term expires Spring, 1961.

History: Formed 1930 as Toronto Biochemical Society; present title adopted 1937. Society of Experimental Medicine, Toronto, 1913, precursor of present group.

Purpose: Advancement of biochemistry and biophysics.

Membership: 125. Professional or amateur interest in biochemistry or biophysics required.

Meetings: Monthly.

237. Town Planning Institute of Canada. President: Murray Zides, City Hall, Saint John, N. B. Term expires June, 1961. Secretary-Treasurer: H. T. Lemon, c/o Board of Trade of Metropolitan Toronto, 11 Adelaide
Street, W., Toronto 1, Ont. Term expires June, 1961.

\section{History: Incorporated 1923.}

Purpose: To facilitate acquirement and interchange of professional knowledge among its members; to promote professional interests; to encourage original research; to develop and maintain high standards in town planning profession; to enhance usefulness of profession to the public.

Membership: Honorary 7 ; members 70 ; associate 180 ; student 75 . Professional training and experience required.

\section{Meetings: Annual.}

Professional activities: Certificate of Distinction awarded annually to best student in planning at a Canadian university.

Publications: Plan, quarterly, current volume 1, \$2 per issue. Editor: I. O. Gertler. News, bi-monthly, current volume: 4, iree. Editor: Wm. F. H. McAdams.

238. Vancouver Medical Association, 1807 West 10th Avenue, Vancouver 9, B. C. President: C. E. G. Gould, 3195 Granville Street, Vancouver, B. C. Term expires May 21, 1961. Honorary Secretary: G. C. IIalsh, 5780 Cambie Street, Vancouver, B. C. Term expires May 21, 1961.

History: Founded 1898. Library established 1908 now main part of B. C. Medical Library Service. Specialty sections.

Purpose: To provide educational, recreational and administrative facilities for its members; to promote cultivation of art and science of medicine; to advance character and honour of medical profession; promotion of literature, science and diffusion of knowledge.

Membership: 710 : active 504; associate 160 ; senior 24; life 22. Active-practising in Vancouver, Burnaby or Richmond; associatepractising in other locations in province: senior -30 years or more continuous membership, or aged 65 or more; life-members the association wishes to honour for service. All members must be licensed in College of Physicians and Surgeons of $\mathrm{B}$. C.

\section{Meetings: Monthly.}

Professional activities: John Mawer Pearson Lectureship; Annual Osler Dinner and Lecture in honour of Sir William Osler; annual summer school - a week of postgraduate lectures by eminent lecturers; annual awarding of Prince of Good Fellows Degree-an honour for outstanding service to colleagues and city.

Publications: B. C. Medical Journal, monthly, current volume: 2, \$3. Editor: J. H. MacDermot. 
Library: 1200 volume general medical library, currently maintained by College of Physicians and Surgeons of B. C.

\section{Western Canadian Society for Horticulture}

(Prairie Group, Canadian Society for Horticultural Science). President: H. T. Allen, Experimental Farm, Lacombe, Alta. Term expires February, 1961. Secretary-Treasurer: John Walker, University of Manitoba, Winnipeg, Man. Term expires February, 1961.

History: Organized 1943 to serve geographic area including prairie provinces of Manitoba, Saskatchewan, and Alberta; later expanded to include Northwest Territories, Yukon, eastern and northern British Columbia, and northwestern Ontario. Technical and scientific committees: fruits; vegetables; ornamentals; extension; advisory. Affiliation: since 1958 repre- sents the prairie regional group of Canadian Society for Horticultural Science.

Purpose: To promote and foster science of horticulture in the prairie region.

Membership: 138: honorary life 7 ; members 79; associate 52. Also honorary and student classes. Members-graduates of recognized university whose vocation is in horticultural or related fields; or such other persons as may be adnitted by virtue of their work in technical or scientific horticulture. Associate-persons not eligible as members but who have been approved by the executive committee.

Mectings: Annual.

Professional activities: Annual horticultural merit award $\$ 25$ to three provincial universities in prairie region.

Publications: Proceedings, annual, current volume: $16, \$ 3$. 
UNITED STATES

INDEX 


\section{UNITED STATES}

\section{INDEX}

The index includes subject headings (in CAPITALS) which indicate the activities and purposes of the societies; a list of periodicals mentioned (periorlicals in ilalics) ; names of medals. prizes, awards, lectures and trust funds; and changes in the names of societies since 1955 .

-1 PCA Abstracts, 18

$A R M A, 277$

thel (John J.) prize, 292

Abrams (Talhert) award, 332

Abstracts of Bioanalytic Tcchnology, 69

Acanemies of Scance. Seo Science

Accopted Dental Remedics, 160

Accident Procention Bulletin, 658

Acheson (Edward Goodrich) medal and prize, 614

Acoustics, 14, 210

ACtUAR1AL SClence, 1340

Adams (Henry) fellowship, 197

Adams lecture certificate, 360

Adams (Roger) award, 131

Adler (Alfred) center and clinic, 774

Adler (Alfred) institute, 774

Adrcutures in Biology, 1100)

Aero Medical Association, 15

Acro Space Engincering, 790

Acro Space Enginecring Catalog. 790

Acro Space Engincering Index, 790

Aeronautics, $192,790,1267$, 1341

Medical. Sce Medicine, Iviation

Aeronomy, 186

Aerospace Mcdicinc, 15

Agassiz (Alexander) medal, 975

Igassiz fund. 975

Agricultural Chemistry". See Chemistry, Agricultural

Agricultural Engincering, 299

Agricultural Engineers Icarbook, 299

Agricultural /listory, 16

Agriculture, 17, 63, 171, 198, 299, 426, 453, 582, 680, 820. 975,1511

History, 16

See also Botany; Crops; Feeds ; liorests and forestry ; Horticulture ; Livestock: Parisitology ; Soils
Agronomy, 300, 588

Agronomy Club Tropliy, 300

Agronomy Journal, 300

Air-Conditioning. See Eigineering, Air-conditioning

Air Pollution, 18, 196, 229. 932. 1175

Air Safety Digest, 658

AIRCRAFt, 651

Airline Medical Examiners .Issociation, 525

Alaska Mcdicine, 26

Alaska Territorial Medical Issocation, 26

Albertson (Mary A. Mitchell) fund, 972

Aldrich fellowship, 197

Allergy, 32, 134, 329, 406. 857. $913,1230,1409$

Aloha-Dontia, 718

Alsop award, 219

American Academy of Obstetrics and Gynecology, 144

Ancrican Alpine Club Nezes, 55

Anerican Alpine Journal, 55

American Annals of the Deaf. 548,578

American Anthropologist, 57

American Archiaes of Rehubilitation Therapy, 61

American Association of Economic Entomologists, 647

American Biology Teacher. 977

American Board of Clinical Hypnosis, 1320

American Board of Examiners in Psychological Hypnosis, 1320

Anerican Board of Health Physics, 725

American Poard of 1 yypuosis in Dentistry, 1320

American Board of Medical Hyprosis, 1320

American Cincmatoyrapher, 309

American Dental Dircctory, 160

American Documentation, 165

- Imerican Dyestuff Reporter. 107
American Dyestuff Reporter award, 107

Ancrican Engineer, 1021

American Feed Manufacturers' Association award, 1255

American Feed Manufacturers award, 302

American Fern Journal, 174

Anerican Forcsts, 176

American Heart, 191

Amcrican Mighatays, 106

American llorticulture Ma!/Isine, 194

Imerican Institute of Mining and Metallurgical Engineers, Inc., 206

American Institute of Wood Engineering, 1387

Anerican Jommal of Anatomy, 68

Anerican Journal of Archacology, 368

American Jonrnal of Botany. 464

American Journal of Cardiology'. 137

American Journal of Clinical Pathology, 311

American Journal of Digcstiz'e Discascs, 181

American Journal of Gastrochterology, 141

American Journal of Group Therapy, 189

American Journal of IIospital Pharmacy, 316

American Journal of IIuman Genetics, 317

Ancrican Jommal of Medical Tichnology, 326

- American Journal of Mental DCficiency, 111

American Journal of Nursing. 237

Ancrican Joumal of Occupational Therapy, 238

American Ionrnal of Optomctry, 46

American Journal of Orthodontics, 95 
American Journal of Orthopsychiatry. 245

American Joumal of Pathology, 98

Amcrican Journal of Pharmaccutical Education, 75

American Journal of Physical Anthropology, 100

American Iournal of Physics. 101.210

American Journal of Physioloyy. 259

American Journal of Psychiatry'. 267

American Journal of Psychoanalysis, 403

American Journal of Psychotherapy, 404

American Journal of Public Health. 272

Anerican Journal of Rocutgenology, Radium Therapy and Nuclcar Medicine, 274. 280

American Journal of Tropical Medicine and Hygicne, 344

American Iournal of Ieterinary Rescarch, 358

American Mathematical Monthly, 892

American Mincralogist, 936

American Orthoptic Journal. 96

American Potato Journal. 1254

Amcrican Psychologists, 269

American Resica' of Respiratory Diseases, 354

American Scicntist, 1305

American Scicntists, 138?

American Social Hygiene Association, 285

American Society for the Study of Arteriosclerosis, 584

American Society of European Chemists and Pharmacists, 1331

American Society of Heating and Air-Conditionnig Engineers, 315

American Society of Physical Medicine and Reliabilitation. 51

American Society of Refrigerating Engineers, 315

American Society of Tool Engineers, 343

American Statistician, 350

American Surgcon, 1411, 1433

American Trudeau Society, 354

AMERICANA, 912

Ames award, 73, 141

Amory (Francis) fund, 34

Analytical Chemistry, 131
Anatomical Record, 68

AnAto:1Y, 68, 711

Anderson (F. Paul) medal, 315

Anderson (William G.) award, 60

Andry (Nicholas) award. 415

Anesthesiology, 23, 93, 135. $247,301,384,484,523,570$. $602,667,699,756,769,814$. $837,865,873,885,921,946$. 962, 1034, 1053, 1064, 1076 . $1089,1120,1135,1171,1182$. $1424,1462,1473,1504,1514$, $1526,1539,1574$

Dental, 297

Anesthesiology, 301

Animal Kingdom, 1124

ANIMALS, 346, 361

Diseases. Scc V'eterinary medicine

Experimentation, 1019

Hospitals, 56

Production, 302

Annals of Allergy, 134

Annals of Intcrnal Medicine. 146

Annals of Mathematical Statistics, 785

Annals of Surgcry, 351

Anthropological Quarterly, 492

ANTHROPOLOGY, 2, 20, 57, 63, 364. $365,369,370,371,372,373$, $375,492,502,586,758,763$. 912, 941, 975, 1028, 1098, $1167,1178,1231,1306,1318$

Plyysical, 100

Appalachia, 367

Appert (Nicholas) award. 783

Appleton (Samuel) funcl, 880

Applied Mechanics Reziezes, 325

Applicd Microbiology: 1342

Applicd Spectroscopy, 1319

AQuariums, 110

Arboretums, 71, 477

Arborists Nea's, 1017

ARCHAeOlogy, 2, 368, 369, 370, $371,372,373,376,389,533$, 610. 759, 804, 874, 914, 957 . $1113,1160,1317,1329,1453$. $1483,1505,1532,1569$

Archaclogy, 368

Archey awards, 1329

ArChitecture, 197, 220, 320, $460,599.627$

Landscape, 912

Naval, 984, 1367

Archives of Dermatology, 162, 224

Archizes of Eneironmental Hcalth, 44
Archizes of Industrial Hcalth, 224

Archives of Internal Medicine, 224

Archizes of Neurology, 224

Archives of Ophthalmology, 224

Archives of Otolaryngology, 224

Archives of Pathology, 224

Archiz's of Physical Ifedicine and Rchabilitation, 51, 153

Archizes of Psychiatry, 224

Archizes of Surgery, 224

Arctic, 374

Arctic and Antarctic, 263, 374

Arithmetic Tcacler, 995

Arizona Dental Journal, 386

Arizona Medicine, 379

Arizona Pharmacist, 380

Arizona Professional Engincer, 385

Arizona State Society of Anesthesiologists, 384

Arkansas Science Fair, 388

Armco scholarship, 770

Armed Farces Chemical Joumal, 393

Armed Forces Communications Association, 394

Arteriosclerosis, 584

Arthritis and Rhcumatism, 278

Artificial Internil Organs, 286

Artificial Limbs, 975

Arts and Letters. 12. 34, 912. $1154,1493,1568$

Ashby award, 1103

Ashford (Bailey K.) award, 344

Asphalt, 414

Association for the Idvancement of Industrial Medicine and Surgery, 1121

Association for the Study of Internal Secretions, 617

Association of Food Industry Sanitarians, 789

Association of Geology Teachers, 983

Association of Technical Writers and Editors, 1380

Astronautical Sciences Reriece, 113

Astronautics, 112, 113, 279, $1098,1232,1334,1492$

Astronautics, 279

Astronomical Journal, 114, 210

Astronomy, 12, 63, 108. 114 , $375,439,441.442,874,931$, $972,1167,1241,1286,1452$, 1511

Astrophysical Journal. 114

Atkins award. 1074 
Atomic Energy, 445

Atoms, Bees, Crystals, 1538

Atwood (IVallace IV.) fund, 409

Audubon camps, center, medal, fellowships, tours, 989

Audubon Ficld Notes, 989

Audubon (John James) fund. 1098

Audubon Maga:ine, 989

Auk, 243

A utomation, 115

Autriliary Leader, 195

Aviation, 325, 658

Aviation Mechanics Bullctin, 658

Aviation Medicine. See Medicine, Aviation

Avicultural Bulletin, 447

Aviculture, 447

Awards. See Fellowships and scholarships; Funds and grants; Medals and awards

Axson-Choppin award, 864

Ayerst, McKenna and Harrison fellowship, 617

Babcock-Hart award, 783

Bache (Alexander Dallas) fund, 975

Bacteriological News, 1342

Bacteriological Reviezes, 1342

Bacteriology, 41, 98, 711, 763. $840,1054,1342,1359,1511$

Baekeland (Leo Hendrik) award, 131

BAKING, 304

Baltimore Engineer, 629

Banting medal, 163

Barbour (Laura Taber) award, 658

Barnes (Charles Reid) award, 334

Barringer medal, 83

Bartlett (Ford) award, 332

Bartlett (George) award, 106, 730

Barton (Edward Hall) award, 864

Bartonia, 1233

Bartow (Edward) award, 131

Baruch award, 153

Bausch and Lomb award, 332

Beaciles. See Shores and beaches

Beal award, 1174

Beall award, 669

Beattie (Margaret) lecture, 69

Becket (F. M.) award, 614

Pieckman (Arnold O.) award, 792
Bedell award, 1527

Beet Sugar, 341

Behaytoral Science, 1005

Belfield (William T.) lecture, 520

Beling-Englander lecture, 1070

Bendix (Vincent) medal, 288

Bennett (A. E.) award, 1346

Bent, 1445

Berliner (Emile) award, 446

Best (Edgar E.) award, 61

Bibliography, 165, 451

Bibliography of Paper Making. 1446

Bibliography of Research in Tissue Culture, 1477

Bibliograpliy of Tertebrate Paleontology, 1384

Bigelow (Henry Jacob) fund, medal, 463

Billin (Charles E.) award, 638

Billings (Frank) lectureship, 786

Billings fund, 975

Billington lectures, 586

Bingham medal, 1377

Binns medal, 130

Bioanalysis, 69,118

Brochemistry, $303,305,711$, 1098

Bio-Dynamies, 453

Biographical Memoirs, 975

Biological Chemistry. See Biochemistry

Biological Psychiatry, 1346

Biological Stains, 456

Biologist, 1229

Biology, 20, 198, 203, 256, 259, $327,337,346,375,432,450$. $455,655,692,781,840,854$. 975, 1028, 1044, 1088, 1098. $1177,1191,1229,1463,1493$. 1511,1559 ,

Aquatic, 758

Education, 977, 1044, 1100

Experimental, 825, 1322

Quantitative, 457, 854

Biometrics, 457

Biophysics, 458

Biophysics Journal, 458

Biros. See Aviculture; Ornithology

Bituminous Coal Research award, 131

Plackall machine tool and gage award, 325

Blackivell (Elizabeth) inedal, 226

Blakeslee (Howard IV.) awards, 191

Plandy medal, 242
Blast Furnace Proceedings, 907

Bliss medal, 1344

Bloede - Hoffman scholarship. 510

Blood, 70, 116, 459, 823, 1336

Bloodgood (Joseph Colt) lecture, 65

Blum (IVilliam) award, 614

Bocher prize, 223

Borden award, 49, 358, 410. 1255

BoтANY, 63, 71, 260, 261, 464. 465. 466, 478, 559, 720, 721, $758,763,802,825,912,941$, $966,1025,1045,1167,1233$. $1412,1452,1479$

Economic, 1321

See also Agriculture; Bryology : Horticulture; Weeds ; and headings beginning Plant

Bowie (IVilliam) medal, 186

Bowınan (Isaiah) memorial, 184

Brackett (Dexter) medal, 105?

Bradlee (Josiah) fund, 880

Brand award, 328

BREWING, 307

Brezving Chemists Newsletter, 307

Brewster medal, 243

Bridge, 650

BRIDGES, 275

Britton (Nathaniel Lord) fund, 1098

Brittonia, 335

Brockman award, 1380

Broncho-EsophagOLOGY, 126

Brooklyn Engineer, 470

Brooklyn Psychologist, 473

Brooks (Charles Franklin) award, 229

Brooks (Frank G.) awards, 450

Brower (A. Blaine) traveling scholarships, 146

Brown (Ernest W.) fund, 114, 223

Bruce (Catherine Wolfe) medal, 442

Bruce (James D.) lectureship, 146

Prumbaugh award, 294

Brumner (Arnold W.) fellowship, 197

Bryant (B. T.) award, 1471

Bryologist, 127

Bryology, 127

Buckendale (I.. Ray) lecture, 1345

Buckley (Oliver Ellsworth) prize, 257 
Build and blood pressure study, 1340

Building Research, 216, 275 , 474,574

Building Scicnce Directory, 474

Building Scicnce Nezes, 474

Bullctin of Gastroscopy and Esophagoscopy, 182

Bulletins of American Palcontology, 1207

Burdick (Ward) award, 311

Burka award, 787

Burrage (Albert Cameron) funds, 880

Burroughs medal, 822

Business Pilots Safety Bulletin, 658

Butnik (Abe) award, 1174

Cabin Crew Safety Exchange, 658

Caldwell award, 1474

Caldwell lecture, 280

California Medicinc, 481

California Pharmacy, 482

California State Psychologist, 486

C.jorimetry, 487

Campbell lectureship, 291

Campbell medal, 242

Cancer, 58, 128, 1209, 1261

Cancer, 128

Cancer Cytology, 1209

Cancer Research, 58

Cannon (Annie J.) prize, 114

Cannon (Lula R.) fund, 177

Capital Chemist, 509

Capital scholarship fund, 633

Capps (Joseph A.) prize, 786

Carbide and Carbon Chemicals prize, 131

Cardiology, 137, 191, 584, 1110

Carll (John Franklin) award, 1372

Carmen lecture, 706, 945

Carolina Biological Supply Company a ward, 432

Carolina Journal of Pharmacy, 1132

Carsey memberships, 622

Cartography, 154, 409

Carty (John J.) fund, 975

Case (Louisa) bequest, 880

Case (Marian Roby) bequest, 880

Casey (Thomas Lincoln) fund, 975, 1098

Cash (Merit H.) prize, 903

Casselberry award, 217

Castanea, 1412

Castle, 1312
Catalysis, 490, 491

Cedar Creek laboratory and forest, 941

Centenarian award, 1216

Central States Archacological Journal, 759, 1160

Ceramic Abstracts, 130

Ceramics, 130, 506, 507, 1003

Cereal Chemistry. Sce Chemistry, Cereal

Cereal Chemistry, 72

Cerebral Palsy, 31, 1485

Certificd Milk Magazine, 89

Chaffin (John C.) fund, 880

Chambers (Frank A.) award, 18

Chandler (Joseph Everett) fund, 880

Chanute medal, 1558

Chanute (Octave) award, 790

Chapin award and lecture, 1280

Chauvenet prize, 892

Chemical Abstracts, 131

Chemical Engineering. Sec Engineering, Chemical

Chemical and Engincering Nez's, 131

Chemical Engincering Progress, 199

Chemical Industry medal, 1347

Chemical Reviezers, 131

Chemical Titles, 131

Chemist, 200

Chemistry, 20, 29, 63, 131, 200 , $393,416,509,510,692,758$, $763,801,825,840,975,1028$. $1098,1167,1191,1228,1452$. 1511

Agricultural, 426

Biological. See Biochemistry

Brewing, 307

Cereal, 72

Clinical, 73

Cosmetic, 1350

Education, 748, 933, 1043

Geological. See Geochemistry

Industrial, 1316, 1347

Inorganic, 802

Leather, 219

Oil, 239

Organic, 802, 1567

Physical, 684

Textile, 107

See also Ceramics; Crystallography; Engineering, Chemical; Microchemistry

Chemistry, 1301

Chemurgic Digest, 582

Cheney (Monroe G.) award, 1

Chicago IVoman's Club cancer fund, 786

Child Devclopment, 1332
Child Development Abstracts and Bibliography, 1332

Child Research, 1332

ChIRopody, 74

Chrysler Corporation Undergraduate Student award, 279

Ciba award, 617

Cincinnati Journal of Medicine, 5

Cinematography, 8, 309

Circulation, 191

Circulation Research, 191

City Planningo Sce Planning

Civil Engineering. Sce Engineering, Civil

Cizil Engineering, 310

Clark Equipment Company award, 222

Clausen medal, 81

Cleft Palate, 59

Cleft Palate Bulletin, 59

Cleveland Engincering, 526

Cleveland (Newcomb) prize, 63

Climatology, 229

Clinical Bullctin, 821

Clinical Chemist, 73

Clinical Neurosurgcry, 557

Clinical Orthopacdics, 415

Clinical Orthopedics, 180

Clinical Pharmacology and Therapeutics, 353

Clinical Rescarch, 172

COAL, 757, 1364, 1533

Coates (Charles E.) award, 131

Coker (IV. C.) award, 616

Colbert medal, 1344

Colburn (Allan P.) award, 199

Cold Spring Harbor Symposia, 854

Cole (Frank Nelson) prizes, 223

Cole (Frank O.) award, 1071

Coleman (George Howell) fund and medal, 786

Collamore (Helen ) fund, 880

Collingwood prize, 310

Color, 797

Colorado Medical Foundation, 542

Colorado Medicinc, 542

Colorado-Wyoming Bistate Science Fair, 543

Combustion, 545

Combustion and Flame, 545

Committee on Vacuum Technique, 357

Common Defense, 242

Communications, 394, 420, 1020,1434

Communications, 398

Compensation Medicine, 36

Compton (Karl T.) medal, 210 
COMputers, 398

Comstock (Cyrus B.) fund, 975

Concrete, 151, 216

Condenscr, 1247

Condor, 579

Conference Call. 944

Conference of Professors of Preventive Medicine, 437

Connecticut Medicine, 568

Connecticut Pharmacist, 562

Connecticut Psychologist, 569

Connecticut Science Talent Search, 558

Connecticut Society for Psychiatry and Neurology, 560

Connccticut IVoodlands, 561

Conservation education award, 1566

Conservation Nezus, 1024

Conservation of Natural ReSOURCES, 20, 338, 561, 572. $703,758,817,1017,1024-$ 1027, 1078, 1167, 1177, 1389. 1463, 1490, 1565

See also Fish and game: Forests and forestry ; Grasslands: Ornithology: Soils ; Trees; Water; Waterways: Wildlife

Conservation Report, 1024

Construction Specificr, 574

Consultant, 417

Consulting Serzices, 416

Contemporary Psychology, 269

Cooley awards, 335

Coolidge award, 1327

Co-Operation, 958

Coordinator, 1278

Copcia, 318

Copher (Marjorie Hulsizer) award, 164

Corrective Therapy award, 399

Corrosion, 798, 979

Cosmetics, 224, 1350

Council for Local Public Health Services, 1073

Council of American Bioanalysts, 69

Craig (C. F.) lecture, 344

Craig (William N.) fund, 880

Craigie (Andrew) award, 425

Cranium, 587

Criminology, 78, 312, 896

Croes (J. James R.) medal. 310

Crors, 588, 1388

Crops and Soils, 300

Crosby (Howard) award, 1355

Crowell medal, 242

Crozier (Arclibald) award, 369

Crozier (Bermard L.) award, 875
Crozier medal, 242

Crum (Roy W.) award, 730

Crumbine (Samuel J.) award. 835

Crusader, 1485

Crystallography, 157, 936

Cullum geographical medal, 184

Cumningham (IVilliam) award. 888

Current Concepts in Diabctes Mellitus, 1101

Curront Geographical Publications, 184

Currie (Margaret) award, 86

Cytology, 799, 1054, 1209

Cytology Nezesletter, 799

Da Costa Alverenga (Pedro Francesco) prize, 532

Da Costa fund, 1234

Dacdalus, 34

DAIRY SCIEnCE, 158

Daland fund, 256

Daly (Charles P.) medal, 184

Davidson (George) medal. 184

Davidson medal, 1367

Davis (A. F.) medals, 360)

Davis (Renjamin P.) fund, 880

Davis (John Eisele) award, 399

Dawson (Jackson) fund, 880

Day metal, 685

Day (Richard Hopper) medal, 9

DeAFness, 28, 548, 578

De Air-Ator, 1360

Deere (John) medal, 299

De Forest award, 1327

Delano fellowship, 197

Delazarc Enginecr, 597

Delaware Engineering Association, 593

Delazeare Medical Journal, 898

Dclazeare Pharmacist, 594

Dclazvare Valley Announccr, 638

Delta Waterfowl Research Station, 1128

Dendrochronology, 1480

Denison, (Roger A.) prize, 1137

Dcutal Abstracts, 160

Dental Assistant, 159

Dental Health Highlights, 160

Dentistry, 37, 63, 139, 159, 160. $161,386,513,718,771,806$. 841, 879, 996, 1029, 1059. $1079,1096,1165,1213,1516$, 1541

Children, 314, 546

Cleft palate, 59

Education, 79

Endodontic, 80
History, 53

Implant dentures, 40

Industrial, 85

Laboratories, 980

Orthodontic, 95, 704, 927, 1201, $1291,1426,1432$

leriodontologic, 50

Prosthetic, 4

Public lealth, 104, 546

Restorative, 52

DERMATOLOGY, 38, 162, 521, 713, $909,1047,1126,1203,1326$

De Roaldes award, 217

Detroit Engincer, 623

Deutsch (Wilbur) award, 322

Development and Growtit, 1337

Dexter Chemical Corporation award, 131

Diabetes, 163, 514, 598, 1101

Diamond (Harry) award, 788

Die Casting, 1351

Dic Casting Enginecr, 1351

Dielectrics, 555

DiEtetics, 164

Digcst of Litcrature on Diclsitrics, 555

Directory of Ancrican Psychological Scrices, 117

Discascs of the Chest, 138

Discases of the Colon and Rectum, 265

District of Columbia Science Fair, 691

Diven (John M.) medal, 359

Documentation, 165, 291, 398. 975, 998, 1009

Dodge and Olcott scholarship, 783

Doklady of the Academy of Scicuces of the USSR, Earth Scicnce Scctions, 185, 975

Douglas (James) medal, 206, 1364

Downs (Jere A.) bequest, 880

DRAINAGE, 1490

Draper (Henry) fund, 975

1) rew awards, 262

Drug Standards, 254

DRUgs. Scc Pharmacy and pharmacology

Dudley (Charles B. ) medal, 296

Dunlop- Voodard award, 807

Duodecimal Bulletin, 604

Diodecimal. Numeration, 604

Du Pont award, 1327

Dutchess County Psychiatric Society, 929

Earle (Charles Warrington) lectureship, 786 
Earth Scfences. Sec headings beginning Geo-

Ebert prize, 254

Ecological Monographs, 612

Ecology, 318, 612

Ecology, 612

Econometrica, 613

Economic Botany, 1321

Economic Gcology, 1352

E.(ONOMics, 20, 63, 613, 912, 1005

Eddy medal, 1527

Edison Electric Institute Prine Movers award, 325

Edison medal, 202

Edwards (Everett E.) awards, 16

Egerton (Sir Alfred C.) medal. 545

Eisenman (William Hunt) award, 291

El Boticario, 1085

El Palacio, 370

El Sol, 1076

Electric Furnace Procecdings, 907

Electrical Enginecring, 202

Electrochemistry, 614

Electroencephalograpiy， 166. 494. 1418,1557

Electronics, 394

Electropl.ating, 167

Elementary School Scicuce Bulletin, 1016

Ellet (Charles) award, 1558

Elliot (Daniel Giraud) fund, 975

Elliott (Jolnn) award, 70

Enerson meda1, 1527

Emerson, (William H.) fellow:ship, 197

Eininent Chemists' award, 1.31

EndocRINOLOGY, 617

Enginecr, 631, 640, 643

Engineer and Scientist, 622

Engineering, 24, 25, 27, 63, 81, 220, 313, 342, 385, 395, 448, $470,485505,508,526,535$. $541,544,567,571,583,585$. $593,597,599,603,618-646$, 649, 673, 692, 693, 700, 702, $709,739,744,770,807,824$. $828,840,846,855,862,875$, $878,888,889,916,923,953$. $963,968,969,970,975,1021$. 1023, 1028, 1030, 1065, 1091. $1098,1122,1183,1196,1224$. $1256,1273,1284,1312,1354$. $1386,1400,1405,1442,1444$. 1445. 1447-1450, 1452, 1475 , 1478, 1486, 1494, 1501, 1508, 1511. 1515, 151\%. 1520, 1558.
$1563,1576,1582$

Aeronautical, 1341, 1595

Agricultural. 299

Air-conditioning, 315, 1276

Audio, 446

Automotive, 1345

Body, 306

Ceramic, 1003

Chemical, 29, 131, 199, 416 , 975,1558

Civil, 27, 310, 461, 511, 564

Combustion, 1558

Communications, 1558

Consulting, 201, 416, 418, 420. 576, 577, 708, 1099

Corrosion, 979

Cost, 77

Die casting, 1351

Education, 288, 1312, 1445

Electrical, 202, 650, 1558

Examiners, 994

Gas appliances, 681

Fire prevention and protection, 1558

Heating, 315

Hydraulic, 1558

llluminating, 761

Industrial, 205

Logistical, 1004

Lubricating, 322, 325

Manufacturing, 343

Marine, 1360, 1367

Materials, 296, 325, 1595

Mechanical, 325, 1247, 1558

Metallurgical, 206, 325, 1558

Military, 1344

Mining, 206, 1364

Motion picture, 1365

Naval, 328, 431, 984

Nuclear, 325

Packaging and handling, 1004, 1370

Petroleum, 206, 325, 1372

Photographic, 1365, 1373

Plant, 212, 325

Plastics, 1374, 1381

Power, 325, 985

Radio, 788

Railroad, 325

Refrigerating, 315, 986, 1276

Safety, 325, 339

Sanitary, 281, 340, 553, 653 1144,1558

Standards, 1435

Structura1, 1437-1439, 1558

Television, 1365

Textile, 325

Tool, 343

Traffic, 791, 1558

Utilities, 554

W eight, 1341
Local societies, 27, 395, 448, 461, 470, 508, 526, 544, 618, 621-641, 645, 649, 673, 702, $709.739,855,969,970,1257$. $1273,1284,1354,1442,1444$. $1447-1450,1519,1563$

National societies, $81,201,202$, 205, 206, 212, 299, 310, 322, $325,328,339,343,583,619$, $642,643,985,1003,1004$. 1021, 1023, 1386, 1486

Regional societies, 620. 1558

State societies, 24, 25, 385. $485,535,541,564,567,571$. $576,585,593,597,599,603$, 644, 646, 693, 770, 807, 862, $875,878,889,916,953,963$, $968,1030,1065,1091,1099$. $1122,1183,1196,1224,1256$, $1400,1405,1475,1494,1501$. $1508,1515,1520,1576$.

Enginecring, 1257

Engineering and Technical Societies Council of Philadelphia, 618

Enginecring Employment Practices Necesletter, 1021

Engincering for Safet y', 339

Engineering Foundation, Inc., 1486

Enginecring Manpozer Commission Nerosletter, 643

Engineers Nezes, 637

Engincering IVord, 220

Enginecrs' Bulletin, 541

Engineer's Club of Wichita, 1563

Entoma, 647

Entomologica Americana, 471

Entomological Nezes, 168

Entomology, 9, 168, 471, 488. $647,648,660,720,722,763$. $829,1025,1067,1102,1161$. $1198,1443,1592$

Environmental Science, 782

EPIDEMIOLOGY, 169

EPILEPSY, 1487

Epilepsy Neros, 1487

Ericsson (John) medal, 342

Esophagoscopy, 182

Estabrook (Arthur F.) legacy, 880

Estabrook (Ida F.) legacy, 880

ETH NOLOGY, 2

EUgENics. 170

Eugenics Quarterly' 170

Ez'crybody's Health, 948

Evolution, 318, 1338

Exploration, 652

Explorers Journal. 652

Exponent, 807 
EYE CARE, 1008

See also Ophthalmology

Facts and Trends, 990

Fairchild Camera and Instrument Corporation award, 332

Fairchild fund, 1283

Fairless (Benjamin F.) award, 206

Fall (H. C.) fund, 1198

Far Eastern Survey, 208

Farlow (John S.) funds, 880

FAts. See Oils, fats and waxes

Fay (Edgar Allen) award, 548

Federal Veterinarian, 981

Federation of Sewage and Industrial Wastes Association, 1527

Feedback, 1397

FeEDs, 82, 407, 433

Feinberg (Frederick L.) award, 192

Fellowships and ScholarSHIPS

Agriculture, 171, 820

Anthropology, 370

Archacology, 957, 1113

Architecture, 197, 220, 990

Biology, 1074

Cardiology, 191

Ceramics, 506

Cerebral palsy, 1485

Chemistry, 29, 510, 1074

Cytology, 1209

Dentistry, 139, 159, 841, 996, 1059

Dietetics, 164

Electrochemistry, 614

Endocrinology, 617

Engineering, 25, 81, 206, 220, $310,343,420,461,485,567$, $622,623,624,626,632,633$, $634,637,640,700,709,739$, $740,770,862,878,888,923$, $953,963,968,969,985,986$, 1021, 1065, 1074, 1091, 1224, $1256,1257,1312,1367,1370$, $1386,1400,1439,1445,1475$, $1508,1582,1595$

Food and food technology, 783

Forestry, 367, 1017

Geography, 409, 1385

Geology, 1, 581, 1080, 1154, 1583

Geophysics, 1356

Home economics, 193

Homoeopathy, 177

Hydraulics, 992

Instruments technology, 793

Librarianship, 897

Medical journalism, 227
Medical technology, 143, 805

Medicine, 38, 146, 226, 256, $354,760,847,882,939,956$, $1041,1216,1406,1579,1590$

Mental health, 747

Metallurgy, 179, 291

Mineralogy, 173

Mines and mining, 750, 1533

Mycology, 971

Naval architecture, 1367

Nursing, 86, 773, 958, 1083

Obstetrics and gynecology, 144

Ophthalmology, 45

Optometry, 832, 886, 1046, 1217

Ornithology, 989

Orthopedics, 244

Osteopathy, 246, 958, 1540

Otolaryngology, 45

Park administration, 209

Pathology, 531

Pediatrics, 49

Pharmacy and pharmacology, $21,380,482,562,600,669$, $694,876,947,1032,1061$, $1469,1497,1506,1522,1570$

Physical therapy, 258

Physics, 1074

Physiology, 259

Psychoanalysis, 1012

Public health, 1134, 1471

Rehabilitation, 399

Sanitary science, 987

Science, 375, 941, 1301, 1311

Surgery, 67, 148

Surveying, 154

Technical writing and editing, 1380

Virology, 668

Waterworks technology, 1057, 1066

Wildlife management, 1565

See also names of individual fellowships and scholarships

Ferguson (Cedric K.) medal, 1372

Ferns, 174

Fertility and Infertility, 298

Fertility and Sterility Journal, 298

Fertilizers, 408, 433

Fibers, 657

Filter, 1035

Finger Lakes Neuropsychiatric Society of New York, 500

Fire Nczes, 999

Fire Prevention and ProtecTION, 990, 999, 1357, 1558

Fire Research Abstracts and Reviews, 975

Firemen, 999
Fish and Game, 175, 203, 912, 1018, 1025, 1549

See also Wildlife

Fisher award, 131

Fiske essay, 1280

Fitch scholarship, 1061

Fitz (Fred) chair, 573

Fitzgerald (Desmond) medal, 461

Flexner (Abraham) award, 410

Flight Test engineering fellowship, 790

Flint (Howard) fund, 1163

Flood Control, 1490

Florasynth fellowship, 783

Florida Entomologist, 660

Florida Society of Neurology and Psychiatry, 663

Flowers, 290

Flox award, 1144

Fluid Mechanics, 726

Focus, 184

FOLKLORE, 912

Food and Food Technology, 670,783

Food and Drug Pronucts, 421

Food Research, 783

Food Technology, 783

Forest Products, 671, 1152

Forest Products Journal, 671

Forest Science, 1343

Foresters Forest, 1214

Forestry Marketing Bulletin, 1168

Forests and Forestry, 20, 176, $367,417,536,561,912,917$, $1017,1152,1158,1168,1214$, 1343

Formento (Felix) award, 864

Forrest (Frank) award, 130

Fort Worth Science Fair, 674

Fortescue (Charles Le Geyt) fellowships, 202

Forum of Osteopathy, 246

Foundation for Instrument Education and Research, 792

Foundries, 179

Fractures (Bone), 180

Frandsen (Peter) scholarships, 1041

Freeman (Caroline S.) fund, 880

Freeman fund, 310

Freeman (John R.) fund award, 461

French (Benjamin V.) funds, 880

French (John Allen) fund, 880

French (John D. Williams) fund, 880 
Friedenwald (Julius) medal, 181

Friedenwald lectureship, 401

Fritz (John) medal, 202, 310, 1364,1486

Fritzsche award, 131

Frontier, 1334

Frontiers, 9

Fruit Tarictics and Horticultural Digest, 264

Fruits, 264

FueLs, 325, 580

Fuller (George Warren) award, 359

Funds And Grants

Anatomy, 68

Anesthesiology, 1504

Animal nutrition, 362

Anthropology, 492, 1231

Arboretums, 477

Archaeology, 957

Astronomy, 114, 972, 975

Biology, 69

Blood research, 459

Cancer research, 128, 177

Cardiology, 191

Cerebral palsy, 1485

Chemistry, 29, 34, 975, 1228

Dentistry, 4, 37, 139, 160, 1059 . 1096

Dermatology, 162

Diabetes, 163, 1101

Earthquake effects, 1307

Electricity, 975

Engineering, 206, 212, 325, $343,526,791,975,1367,1486$

Entomology, 1198

Exploration, 652

Geography, 409

Geology, 55, 452, 1297, 1583

Health and hygiene, 6, 11, 60

Herpetology, 318

Home economics, 193

Horticulture, 880

Hypnosis, 1320

Ichthyology, 318

Iron and steel technology, 216, 422

Magnetism, 975

Materials testing, 296

Mathematics, 223

Medical technology, 326

Medicine, 542, 786, 818, 899, $1097,1216,1467$

Meteors, 975

Mountaineering, 55

Naval architecture, 1367

Nursing, 715, 1006

Obstetrics and gynecology, 144, 1048

Occupational therapy, 238
Optometry, 46, 241

Ornithology, 243

Orthopedics, 809

Paleontology, 1207

Pathology, 311

Pediatrics, 49

Petroleum technology, 131, 253

Pharmacy and pharmacology, 254, 955, 1195, 1279

Physical therapy, 258

Physics, 34, 1313

Psychiatry, 267, 1264

Psychopathology, 270

Pulp and paper technology, 1446

Radiation, 975

Science, 9, 34, 63, 256, 659, $719,758,802,860,966,972$, $975,1028,1058,1129,1163$, 1283, 1311, 1382, 1394, 1511

Scientific publications, 1098

Speleology, 1022

Surgery, 463

Veterans' children, 903

Veterinary medicine, 56, 1580

Zoology, 1587

Sce also names of individual funds and grants

Fungicides, 411

Fusion, 283

GP, 39

Gane. See Fish and game

Gane (Henry A.) fund, 880

Gardening, 982

Garrison( Fielding H.) lecture, 64

Garvan medal, 131

Garvin prize, 562

Gary medal, 216

Gases, 18, 1558

Natural, 590, 686, 795, 915, 1410

Gastroenterology, 141, 181

Gastroenterology, 181

Gastroscopy, 182

Gems and Minerals, 173, 479

General Foods fund, 783

General Practitioner of the Year award, 224, 894, 1216

Genetics, 170, 183, 317, 683, 1167

Genito-Urinary Tract, 83, 356

Geochemical Neres, 684

Geochemistry, 186, 684, 936

Geochimica et Cosmochimica Acta, 684

GEodesy, 186

Geographical Review, 184
GEOGRAPHY, 20, 63, 184, 375, $428,758,763,825,912,941$, $975,1001,1028,1167,1177$, $1191,1385,1452$

Education, 993, 1069

National societies, 409, 1001

Regional society, 428

Geological Nerus Letter, 690

Geological Society of New Mexico, 1080

Geologram, 1138

GEOLOGY, 1, 9, 20, 63, 173, 185, $232,256,366,375,378,413$, $449,452,467,489,581,590$, $606,608,672,674,676,685-$ $692,707,740,749,758,763$, $764,802,825,830,849,852$, $868,912,915,941,950,975$, $1028,1080,1094,1098,1116$, $1138,1151,1155,1162,1167$, $1177,1179,1191,1248,1287$, $1293,1300,1309,1310,1407$, $1408,1410,1430,1452,1463$, $1484,1495,1511,1529,1583$, 1584,1586

Economic, 1352

Education, 983, 1586

Petroleum, 1, 99, 672, 674, $676,686,795,868,1155$, $1290,1293,1297,1410,1430$

Local societies, 1, 449, 452 . $467,581,590,606,608,672$, $674,689,691,740,849,852$, $868,1094,1151,1155,1179$, $1248,1293,1297,1300,1309$, $1310,1407,1408,1484,1529$

National societies, 185, 413, 685,1352

Regional societies, 366, 489, $676,690,707,764,795,1162$. $1287,1410,1430$

State societies, 378, 686, 687, $688,749,830,950,1080$, $1116,1138,1495,1583,1584$

$\mathrm{Sec}$ also Aeronomy; Geochemistry ; Geodesy, Geography ; Geomagnetism ; Geophysics; Hydrology; Meteorology; Mineralogy, Oceanography ; Petrology ; Seismology ; Tectnophysics ; Volcanology

Geology of the Silver Island, 1495

Geomagnetisal, 186

GEOPHYSICS, 185, 186, 232, 590, $975,1028,1356$

Geophysics, 1356

Georgia Association for Mental Health, 695

Georgia Engineer, 693 
Georgia Professional Engineer, 700

Georgia Psychologist, 696

Georgia State Science Fair, 692

GeoScicnce Abstracts, 185, 975

GeoTimes, 185, 975

Gerber Baby Foods fund, 783

Gerhard (IVilliam Wood) medal, 1211

Geriatrics, 187

Gerontology, 565, 701

Gibbs (Willard) medal, 131

Gibbs (Wolcott) fund, 975

Gilbreth (Lillian Moller) scholarship, 1386

Gilles (Vernon) fund, 452

Gillett lecture, 296

Gladioli, 1127

Glasgow (Janet M.) fund, 226

Glassblowing, 283

GLiding, 1315

Goethals (George W.) medal, 1344

Goethe awards, 432

Goiters, 188

Goldsmith (Middleton) fund, 1105

Goodyear (Charles) medal, 131

Gorgas medal, 425

Gottlieb (Murray) award, 897

Gould (Benjamin Apthorp) fund, 975

Gourley (Joseph Harvey) award, 290

Grab Bag, 1406

Grady (James T.) award, 131

Graham (Evarts A.) traveling fellowship, 67

Grants. See Funds and grants

Graphic ArTs, 1278

Grasslands, 703

Greater Kansas City Medical Bulletin, 818

Green Thumb, 536

Greene (Mary T.) fund, 1579

Grengineer, 702

Griffin award, 361

Grocdel medal, 137

Grossmann (Marcus A.) award, 291

Group Practice, 88

Growth AND Development, 1337

Guggenheim (Daniel) medal, 1486

Guide to Identification of Projectile Points, 1178

Guiteras (Ramon) lecture, 356

Gulf Coast Research Laboratory, 949
Gulick (Luther H.) award, 60

Gullen award, 787

Gynecology. See Obstetrics and gynecology

Haddon (Dean) awards, 1275

Hales (Stephen) prize, 334

Hamburger (Walter Wile) lectureship, 786

Hamilton (Samuel W.) award and lecture, 270

Hand Surgery, 295

Hanna (James H.) lectureship, 1142

Hanney (John J.) award, 167

HARBORS, 1015

Hardiman (Winifred) fund, 86

Hardinge (Hal Williams) award, 206, 1364

Hardman award, 894

Hardy (Robert Lansing) medal, 907

Harris (Joseph F.) award, 61

Harris (Wray) library, 723

Hartley (Marcellus) fund, 975

Hartman award, 1194

Hartman (Carl G.) award, 298

Harvey Lectures, 711

Harza Latin-American junior awards, 310

Hatfield award, 1527

Hareaii Medical Journal, 714

Hawaii Territorial Dental Society, 718

Hareaiian Shell Neres, 723

Hayden geological award, 9

Hayes (Francis Brown) bequest and fund, 880

Hayhow (Edgar C.) award, 142

Headlines on Health, 1262

IIealth, 246

Health and Hygiene, 39, 60. $133,152,161,196,282,434$. $547,556,1002,1379$

Industrial, 775

Tropical, 344

See also Public health

Health Pliysics, 725

HEARING, 45, 348

Heart. See Cardiology; Medicine, Chest diseases

Hearth Proceedings, 907

Heat Transfer, 325, 726

HeAtıNG. See Engineering, Heating

Hecht (Max) award, 296

Heinemann (Dannie) prize, 257

Hektoen (Ludvig) lectureship, 786
HeLiCOPTERS, 192

Hellman (Milo) award, 95

Helmlioltz award, 1008

HELMINTHOLOGY, 727

Henderson (Robert) fund, 223

Henry (Joseph) fund, 975

Henry (Joseph) lectures, 1239

Herlarist, 728

Herbs, 728

Heredity, 170, 183, 317, 683

Heredity Counseling Referral Service, 170

Hering (Rudolph) medal, 310

Herpetologica, 729

Herpetology, 318, 729, 1025. 1465

Herschel (Clemens) award. 461

Herty nedal, 131

Heussner (Carl E.) award, 167

Heragon, 29

Hickman (C. N.) award, 279

Highreay Research Abstracts, 730,975

Higilways, 106, 730

Hilgard (Karl Emil) prize, 310

Hill (Louis W.) award, 790

Hillebrand award, 131, 509

Hills (Mark) award, 236

Histoky, 912, 1530, 1584

Hodson (Walter D.) award, 322

Hofheimer (Lester N.) prize, 267

Hogaboom (George B.) award, 167

Hogentogler (C. A.) award, 296

Holley medal, 325

Holmes (Edward Lorenzo) award, 786

Holmes (George IV.) award and lecture, 1052

Holmes (M. E.) thesis prize, 507

HoMf. ECONOMICS, 193

Homeopathy, 177, 204

Hoosier Neze's Letter, 762

Hoover medal, 310, 1364

Horney award, 403

Horney (Karen) lectureship, 403

Horning award and lecture, 1345

Horsley (J. Shelton) award. 1511

Horsley (J. Shelton) lectureship, 1282

Horticulture, $194, \quad 290,480$, $536,668,736,880,982,1161$, $1172,1186,1194,1215,1460$, 1577

Horticulture, 880

Hospital Administration, 142 
Hospital Progress, 493

Hospitals, 142, 195, 266, 316 , 493, 499, 737, 738, 881, 1081

Animal, 56

Osteopathic, 249

Hospitals, 195

Houston Geological Society Bulletin, 740

Howard (Ernest E.) award, 310

Howe (Harrison E.) lectureship, 131

Howe (Henry Marion) medal, 291

Howe lecture, 907

Howe (Lucien) prize, 903

Howe medal, 240

Howe (IVilliam A.) award, 282

Howell (A. B.) award, 323

Howell (A. Brazier) award, 579

Howland (John) medal, 252

Hoyt (Charles Edgar) lecture. 179

Hubbard medal, 1001

Hudson award, 131

Human Factors in Occupational Injuries, 339

Human Organization, 1318

Humanities, 256

Hunnewell (H. H.) funds, 880

Hunt (Alfred E.) award, 322

Hunt (Robert $\mathrm{W}_{\text {.) }}$ medal and fund, 907

Hunter (Oscar B.) award, 353

Hutchinson (Geneva B.) fund, 223

HydRaulics, 325, 992

Hydrology, 186

Hygiene. See Health and hygiene

Hypnosis, 1320

ICHTHYOLOGY, 9, 318

Idaho science talent search, $7+2$

Illinois Society for Mental Health, 747

Illuminating Engincering. 761

IMMUNOLOGY, 84

In Bricf, In Biology, 198

Index to Dental Literature, 160

Index to the Litcurature of Amcrican Economic Entomology, 647

Indiana Nurse, 773

Indiana Pharmacist, 766

Indiana Professional Enginecr, 770

Indiana University, Division of Nursing Education, scholarship fund, 773
Industrial and Engincering

Chemistry, 131

Industrial Hygiene, 196

Industrial Hygiene Digest, 775

Industrial Mathcmatics, 776

Industrial Medicine and Surgery, 105

Industrial Packaging Engineers Association of America, 1370

Industrial Quality Control, 294

INDUStrlal Research, 20, 780. 975

Industrial Sanitation Management Association, 789

Industrial wastes medal, 1527

Information on Laboratory Animals for Rescarch, 975

INFORMATION STORAGE AND Retrieval. See Documentation

Infrared Analytical Methods in Analytical Chemistry, 530

INFRARED SPECTRA, 530

Inksherds, 369

1NSECTICIDES, 411

Institute for Research in Hypnosis, 1320

Institute of American Poultry Industries award, 1255

Institute of Environmental Engineers, 782

INSTRUMENTS AND INSTRUMENTATION, 325, 792, 1098

INSULATION, 555, 793

Integrator, 649

Inter Island Nurses Bulletin, 715

International Association of Blue Print and Allied Industries scholarships, 197

International Bibliography of Electron Microscopy, 1112

International Congress on HighSpeed Photography, 1365

International Geology Revicze, 185,975

International Journal of Clinical and Experimental Hypnosis, 1320

International Palladium medal, 1316

International Peace Garden, 982

International Relations, 975

International Society for Clinical and Experimental Hypnosis, 1320

InVENTIONS, 1488

Iotan, 801

Iore'a Dental Journal, 806
Iowa Pharmacist, 810

Iozea T'etcrinarian, 816

Ipatieff prize, 131

IroN AND STEEL, 216, 422

Iron and Stecl Engincer, 422

IRRIGATION, 1490

Isis, 731

1sotopes, 236

lves (Frederic) medal, 1190

Irestiya of the Academy of Scicnces of the USSR, Geology Series, 185, 975

Irestiya of the Academy of Sciences of the USSR, Geoplysics Series, 186, 975

Jackling (Daniel C.) award, 1364

Jaffe (Richard H.) lectureship, 786

Janosky (Robert A.) scholarship, 581

Jefferson award, 1394

Jeffries (John) award, 790

Jeppson (John) medal, 130

Jerman lecture, 345

Jessup fund grant, 9

Jobs in Planning, 333

Joffe (Solomon A.) fund, 223

Johns Hopkins University Lanchester prize, 1189

Johnson fund, 256

Johnson (J. E., Jr.) award, 907

Johnson (Mead) research grants, awards, 49, 144, 146, 164

Johnson (W. Scott) award, 961 Johnstone (Herbert) fund, 69

Jones (Anson) award, 1467

Jones (Margaret) fund, 715

Jordan (Harry E.) award, 359

Joslin (Elliott P.) fellowship, 163

Journal-Lancet, 1143

Journal of Abnormal and Social Psychology, 269

Journal of Agriculture and Food Chemistry, 131

Journal of Allergy, 32

Journal of Animal Science, 302

Journal of Applicd Nutrition, 33

Journal of Applied Physics, 210

Journal of Applied Physiology, 259

Journal of Applicd Psychology, 269

Journal of Bacteriology, 1342

Journal of Biological Chemistry. 305

Journal of Bone and Joint Surgery, $2+4$ 
Journal of Chemical and Engineering Data, 131

Journal of Chemical Documentation, 131

Journal of Chemical Education, 131

Journal of Chemical Physics, 210

Journal of Clinical Endocrinology and Metabolism, 617

Journal of Clinical Investigation, 287

Journal of Communication, 1020

Journal of Comparative and Physiological Psychology, 269

Journal of Consulting Psychology, 269

Journal of Correctional Psychology, 76

Journal of Dairy Science, 158

Journal of Dcntal Education, 79

Journal of Dental Medicine, 37

Journal of Dentistry for Children, 314

Journal of Diseases of Children, 224

Journal of Economic Entomology, 647

Journal of Educational Psychology, 269

Journal of Elcctrocncephalography and Clinical Newrophysiology, 166

Journal of Engineering Education, 288

Journal of Envirommental Sciences, 782

Journal of Experimental Psychology, 269

Journal of General Physiology, 1358

Journal of Geography, 993

Journal of Geological Education, 983

Journal of Geophysical $R_{\mathcal{E}}$ search, 186, 975

Journal of Gerontology, 701

Journal of Heredity, 183

Journal of Immunology, 84

Journal of Implant Dentistry, 40

Journal of Industrial Enginecring, 205

Journal of Laboratory and Clinical Medicine, 501

Journal of Mammalogy, 323

Journal of Mathematical Physics, 210

Journal of Medical Education, 410
Journal of Metals, 206, 907

Journal of Meteorology, 229

Journal of Neurosurgery, 710

Journal of Nutrition, 207

Journal of Occupational Medicinc, 503, 777

Journal of Oral Surgery, Anesthesia and Hospital Dental Service, 160

Journal of Organic Chemistry, 131

Journal of Paleontology, 1208, 1353

Jonrnal of Parasitology, 330

Jonrnal of Pcriodontology, 50

Journal of Petroleum Technology, 206, 1372

Journal of Pharmacology and Experimental Therapeutics, 292

Journal of Physical Chemistry, 131

Journal of Plastic and Reconstructive Surgery, 336

Journal of Projective Techniques, 1330

Journal of Prosthetic Dentistry, 4, 52

Journal of Protozoology, 1375

Journal of Range Management, 338

Journal of Rchabilitation, 1013

Joumal of School Health, 282

Journal of Sedimentary Petrology, 1353

Journal of Ship Research, 1367

Jounnal of Social Issues, 1335

Journal of Social Therapy, 896

Journal of Space Flight, 112

Journal of Specch and Hearing Disorders, 348

Journal of Speech and Hearing Rescarch, 348

Journal of Surgery, 66

Journal of Symbolic Logic, 402

Journal of the Acro Space Sciences, 790

Journal of the Astronautical Scicnces, 113

Journal of Thoracic and Cardiozascular Surgery, 67

Journal of Urology, 356

Journal of IVildlife Management, 1566

Journals of Soil and Water Conscrvation, 1389

$\mathrm{K}$ and $\mathrm{E}$ scholarship, 154

Kalmus (Herbert T.) medal, 1365
Kansas Nurse, 838

Kansas Optometrist, 832

Kappa Delta award, 48

Katz (Alexander E.) scholarship, 783

Kauikeolani Children's Hospital visiting professor of pediatrics, 735

Kelly award, 422

Kemper (Edward C.) award, 197

Kendall Company award, 131

Kennedy (Henry L.) award, 151

Kenney (Lewis H.) award, 638

Kcntucky Engineer, 846

Kentucky Pharmacist, 842

Ketcham award, 95

Kettering (Charles Franklin) award, 310

Keyes medal, 83

Keys award, 1174

Kidder (Nathaniel T.) fund, 880

Kilmer (Frederick B.) award, 1071

Kilmer fund, 254

Kimber award, 975

Kimble award, 552

Kiva, 376

Klemin (Alexander) award, 192

Knudsen award, 777

Kober (George M.) lectureship, medal, 412

Koessler (Jessie Horton) fund, 786

Kossler (William J.) award, 192

Kovalenko fund, 114

Kovalenko (Jessie Stevenson) fund, 975

Kretschmer (Edwin R.) fund and lectureship, 786

Kroeze (Herbert A.) scholarship, 953

Kunz (George Frederick) award, 1098

LABORATORIES, 155

Lamme medal, 202, 288

Lancaster (IValter B.) award, 96

Land (Jerry) medal, 1367

Landscape Architecture, 320

Landsteiner award, 70

Langley (Edward) scholarships, 197

LANGUAGE AND LiteratURE, 912

Lapham medal, 1569

Larson (L. WV.) lectureship, 1142

LARYNGOLOGY, 217, 218 
Lasca Leaves, 477

Lasca Miscellanea, 477

Lasca News, 477

Lasker (Albert) award, 191

Lasker award, 272

Laurie (Alex) award, 290

Laurie (James) prize, 310

Layman Speaks, a Homoeopathic Digest, 177

LEATHER, 219

Leather (Robert S.) award, 167

LECTURES

Agriculture, 171

Anatomy, 711

Anesthesiology, 946

Archaeology, 368

Astronomy, 114, 442

Bacteriology, 711

Biochemistry, 711

Biology, 69

Biophysics, 458

Cancer, 1142

Ceramics, 130

Dentistry, 47

Diabetes, 598, 1101

Electrochemistry, 614

Engineering, 1257, 1449

Geography, 12, 184, 1001

Geology, 99

Materials testing, 296

Mathematics, 776, 1325

Medicine, 6, 36, 51, 64, 132, 146, 344, 412, 532, 786, 818, $882,903,1294,1510$

Metallurgy, 291, 907

Metals, 179, 291

Motion picture technology, 1365

Nature, 12

Neoplastic diseases, 65

Obstetrics and gynecology, 1142

Occupational therapy, 238

Ophthalmology, 45, 401

Otolaryngology, 45

Pathology, 711, 1105, 1500

Pharmacy and pharmacology, 711

Physics, 101, 1313

Physiology, 711

Psychiatry, 468, 469, 1070, 1265

Psychoanalysis, 403, 781, 1012

Psychology, 774, 1072

Psychopathology, 270

Radiology, 280, 345, 706, 945, $1052,1237,1271,1472$

Science, 543, 586, 1239, 1304, 1305

Statistics, 785
Surgery, 1150, 1234, 1282, 1510

Television technology, 1365

Therapeutics, 353

Urology, 520

11 ildlife, 1565

Leidy medal, 9

Leopold (Aldo) award, 1566

LEPIDOPTEROLOGY, 851

Le Prince (J. A.) award, 344

Lester award, 1327

Lever Brothers Company scholarslip, 1497

Lever Brothers, Pepsodent Division, scholarship, 1570

Lewin (Kurt) award, 1335

Lewis (Bernard) medal, 545

Lewis (Gilbert Newton) medal, 131

Lewis (John F.) prize, 256

LiBRARIES, 90, 897, 1597

LiCHENOLOGY, 127

Liebmann (Morris) prize, 788

LifE INSURANCE, 423

Liljencrantz (Eric) award, 15

Lilly award, 163

Lilly (Eli) and Company award, 1342

Lim NOLOGY, 9, 321

Limnology and Oceanography, 321

Lincoln medal, 360

Lind (S. C.) lectureship award, 131

Lindau (Alfred E.) award, 151

Linnard (Joseph H.) prize, 1367

LivesTock, 407, 1489

Livingstone (David) medal, 184

Locket (Andrew M.) award, 862

LogIC, 402

LoGistics, 1004

Lomb (Adolph) medal, 1190

Long Island Psychiatric Society, $1+41$

Longacre (Raymond F.) award, 15

Los Angeles Engineering Council of Founder Societies, 855

Losey (Robert M.) award, 790

Louisiana Engineer, 862

Louisiana Pharmacist, 867

Lowell (John A.) fund, 880

LUBRICANTS, 580

Lubrication Engineering, 322

Lucas (Anthony F.) meda1, 206, 1372

Lyman (Theodore) funds, 880

Lynch (Frank IV.) prize, 1199

Lyster (Theodore C.) award, 15
MBMA award, 296

MacDonald (Thomas H.) award, 106

MacDougall (Edwina) award, 773

Macelwane. (James B.) award, 229

MaCHINES, 325

Madroño, 478

Magasine of Standards, 349

Mahoney (Mary) award, 237

Main (Charles T.) award, 325

MALACOLOGY, 9, 221, 723

Manmalogy, 323, 1025

MANAGEMENT, 418, 784

Management Science, 784

Management Technology, 784

Mangold (Valter S.) award, 987

Manly medal, 1345

Mann (Paul B.) biology congress, 1100

MaPPING. See Cartography; Photogrammetry; Surveying

Marburg (Edgar) lecture, 296

Marsh fund, 975

Marston (Anson) award, 807

Martin (Minta) awards, 790

Martin (Orel F.) medal, 145

Maryland Naturalist, 1025

Maryland Pharmacist, 876

Maryland Professional Engineer, 878

Maryland State Medical Journal, 893

Massachusetts Trudeau Society, 891

Materials Handling, 222, 325, 1370

Materials Testing, 296

Mathematical Reveizes, 223

Mathematics, 20, 63, 223, 256, $402,692,763,802,892,912$, $975,1028,1098,1191,1452$. 1511

Education, 436, 496, 995, 1028

Industrial, 776, 1325

Mathematics of Computation, 975

Mathematics Student Journal, 995

Mathematics Tcacher, 995

Mathewson medal, 907

Matico scholarships, 197

McArthur (Lewis Linn) lectureship, 786

McClung award, 450

McCormick award, 434

McCormick (Cryus Hall) medal, 299 
McGraw (Curtis W.) award, 288

McGraw (James H.) award, 288

Mclsaac fund, 773

Mclver (Pearl) award, 237

Mckune (1i. 13.) award, 907

McLain (Helen) lecture, 47

McLester award, 425

Mead (Daniel IV.) prizes, 310

Mecilanical Engineering. See Engineering, Mechanical

Mcchanical Enginecring, 325

MeCHANics, 325, 677

Fluid, 726

Medals and Awarns

Acoustics, 14

Actuarial science, 1340

Aerodynamics, 1346

Aeronautics, 192, 790

Agricultural history, 16

Agronomy, 300

Air pollution prevention, 18

Allergy research, 1230

Anesthesiology, 484, 1053, 1120,1171

Inimal care, 361

Animal production, 302

Anthropology, 100, 364, 502, 1306

Archaeology, 369-371, 914, 957, $1113,1317,1329,1483,1569$

Architecture, 197, 320, 599, 1367

Astronautics, 279

Astronomy, 108, 114, 441, 442. 975

Automation, 115

Aviation, 658

Bacteriology, 98, 1342

Biochemistry, 131, 306

Biology, 432, 450, 1229

Blood banking, 70

Botany, 464, 586, 721

Cardiology, 137, 191, 573

Ceramics, 130, 506, 507

Chemistry, 29, 131, 200, 509, 801

Agricultural, 131 ; Analytical, 131 ; Cereal, 72 ; Clinical, 73; Colloid, 131; Industrial, 131, 1347 ; Leather, 219 : Iiterature, 131: $\mathrm{Nu}$ clear, 131: Organic, 131; Petroleum, 131; Textile, 107 ; Theoretical, 131 ; Water and waste, 131

Combustion, 545

Communications, 394

Concrete research, 151
Conservation of natural resources, 817, 1168, 1389

Corrosion, 979

Cosmetics, 1350

Cytology, 1209

Dairy science, 158

Dentistry, 40, 79, 95, 159, 160 , $314,841,996$

Dermatology, 162

Diabetes, 163

Dietetics, 164

Duodecimal numeration, 604

Ecology, 612

Electricity, 975

Electrochemistry, 614

Electronics, 394

Electroplating. 167

Endocrinology, 617

Engineering, 77, 81, 201, 342, $343,385,470,535,544,567$, $577,599,603,620,622,624$, $638,639,645,700,709,770$, $807,828,862,875,878,888$, $923,968,970,994,1122,1312$, $1360,1386,1519,1558,1576$ Agricultural, 299; Air-conditioning, 315; Audio, 446; Automotive, 1345 : Chemical, 131, 199; Civil, 310, 461 ; Education, 288; Electrical, 202, 650; Heating, 315. llluminating, 761 ; Logistics, 1004 ; Lubricating, 322; Marine, 1367: Mechanical, 325, 1247: Military, 1344; Naval, 328; Nuclear, 1098; Packaging and handling, 1004 ; Petroleum, 1372; Radio, 788; Refrigerating, 315; Structural, 1098; Traffic, 791 ; W eight, 1341

Environmental science, 782

Exploration, 652

Eye care, 1008

Fertility and infertility research, 298

Fish and game, 175

Floriculture, 290

Food and food technology, 783

Forests and forestry, 417 , 1214,1343

Foundry practice, 179

Fruits research, 290

Gas appliances engineering, 681

Gastroenterology, 141, 181

Gastroscopy, 182

Genetics, 183, 975

Genito-urinary researcl, 34, 83, 356
Geography, 184, 993, 1001

Geology, 9, 99, 489, 540, 685, $091,849,852,868,975,983$. $1080,1094,1098,1287,1353$. 1408

Geophysics, 186, 1356

Geriatrics, 187

Gladioli, 1127

Goiter research, 188

Health and hygiene, 60, 152 . 282,434

Herbs, 728

Herpetology, 318

Highways, 106, 730

Horticulture, 194, 290, 480, $668,982,1194,1215$

Hospital administration, 141 . 195

lchthyology, 318

Immunology, 1342

Industrial research, 780

Instruments technology, 792

Iron and steel technology, 216. 422

Jurisprudence, 256

Laryngology, 217, 218

Magnetisn, 975

Mammalogy, 323

Materials handling, 222

Materials testing. 296

Mathematics, 223, 541, 892, 1340

Medical illustration, 424

Medical journalism, 227, 1467

Medical librarianship, 897

Medical technology, 143, 277, $326,1035,1054$

Medicine, 5, 6, 63, 64, 146, 224, 226, 412, 532, 542, 591, $786,847,866,882,894,899$, $903,924,956,975,1007$, $1040,1097,1216,1234,1280$, 1437, 1461, 1510, 1590

Aviation, 15; Clinical, 821, 956; Education, 30, 410, 800 ; History, 64; Industrial, 44, 777; Military, 425, 573; Pliysical, 153; Psychosomatic, 10; Research dog, 1019; Tropical, 178, 344, 866; Ultrasonic, 215.

Metallurgy, 206, 291, 907, 938

Meteors, 975

Microbiology, 1212

Microfilms, 1009

Microscopy, 1103

Mineralogy, 173, 206, 936, 1098

Mines and mining, 206, 938, 1364

Motion pictures, 8, 1365 
Natural history, 822

Navigation, 787

Neurology, 43, 400, 922

Noise abatement, 1010

Non-destructive testing, 1327

Nursing, 86, 237, 773

Obstetrics and gynecology, 94 , $496,1199,1391$

()ccupational therapy, 238

Oceanography, 975

Operations research, 1189

Ophthalmology, 240, 401, 903, 1049

Optics, 1190

Optometry, 832

Ordnance, 242

Ornithology, 243, 579. 853, 989

Orthoptics, 96

Osteopathy, 3, 145, 246, 247. 248,587

Otology, 218, 250

Paleontology, 9, 975

Pathology, 98, 122, 311, 1054. $1211,1474,1500$

Pediatrics, 252, 522

Pharmacy and pharmacology, $214,254,292,316,562,600$. 669, 746, 922, 1061, 1071. $1085,1139,1174,1279,1570$

Philosophy, 1423

Photogrammetry, 332

Photography, 12, 454

Physical therapy, 258

Physics, 34, 101, 210, 257, 1243-1245

Astronomical, 975; Nuclear. 1098

Planning, 333

Plant physiology, 334

Plant taxonomy, 335

Podiatry, 262, 308

Pomology, 264

Poultry science, 1255

Proctology, 265, 1176

Psychiatry, 267, 400, 403, 751, $765,877,922,1055,1346$ 1518

Psychology, 269, 664, 717, 844. $911,943,1355,1397,1423$. 1498

Psychopathology, 270

Public health, 133, 272, 539, $542,552,665,835,850,864$, $884,902,961,1087,1134$. $1140,1216,1222,1262,1398$, $1436,1471,1524,1536$

Public welfare, 975

Pulp and paper technology, 1446
Quality contro1, 294

Radiation, 975

Radio, 273

Radiography, 1063

Radiology, 147, 248, 392, 836, $872,1052,1223,1399$

Range and pasture management, 338

Reaction propulsion, 1275

Rchabilitation therapy, 61

Rheology, 1377

Rhinology, 217, 218

Roentgenology, 308

Sanitary engineering, 1144

Sanitation, 987

Science, 1, 20, 63, 256, 375, 541, 543, 616, 659, 692, 758, $825,912,975,1016,1058$, $1129,1137,1167,1177,1179$, $1305,1316,1394,1511,1517$, 1531

Education, 1074, 1167 ; History, 731; Natural, 9, 1098 ; Nuclear, 236

Seeds, 427

Soaring, 1315

Social hygiene, 285

Social psychology, 1335

Sociology, 63

Specifications, 574

Speleology, 1022

Standards, 1435

Sugar beet technology, 341

Surgery, 42, 48, 336, 415, 463. $903,1411,1428,1554,1578$

Surveying, 154

Technical writing and editing, 1380

Television, 1365

Textile technology, 62

Therapeutics, 353, 399

Tuberculosis research, 54

Urology, 34, 83, 356

V'egetables research, 290

Veterinary medicine, 56, 358, 1580

Water pollution control, 1527

VIater resources, 1015

Waterworks technology, 359, 1057

IVelding, 360

Wildlife conservation, 1566

Zoology, 975

Sec also names of individual medals and awards

Medary (Milton B.) scholarship, 197

Medical Annals of the District of Columbia, 902

Medical Foundation fund, 818
Medical Illustration, 424

Medical Journalisir, 227

Medical Jurisprudence, 1363

Medical Science. Ser Medicino

Medical Technologist award, 1054

Medical Technologist scholarship fund, 805

Medical Technology, 143, 225 , 277, 326, 840, 1035, 1544

Medicine, 5, 6, 7, 26, 39, 63, 146. $198,224,303,379,391,412$. $481,515,532,542,568,592$, $661,692,714,732,745,760$. 762, 772, 786, 815, 818, 831, $847.850,866,869,882,893-$ $905,912,930,939,954,956$. $964,967,975,997,1007,1028$, 1036. 1040, 1041, 1060, 1082, $1097,1098,1143,1167,1173$, 1184, 1197, 1216, 1234, 1251. $1274,1280,1282,1294,1295$, 1314, 1396, 1406, 1419, 1420, $1436,1452,1461,1467,1481$, $1502,1509,1510,1511,1521$, $1542,1548,1579,1581,1585$, 1590

Animal experimentation, 1019

Aviation, 15, 19, 20, 525

Chest diseases, 138, 891, 948

Clinical, 88, 132, 172, 287, 501. 591, 821, 826, 1187, 1422, 1556

Dental, 37

Education, 30, 224, 410, 800 , 1440

Experimental, 1322

History, 64, 1362

Industrial, 19, 36, 44, 152, 196 , 503, 712, 777, 778, 779, 918. $1121,1466,1550,1553$

Internal, 319, 519, 858, 1090, 1148,1296

Legal, 224, 870

Libraries, 90, 897

Licensure, 656

Life insurance, 423

Military, 425, 573, 1361

Nuclear, 274, 1369

Occupational, 940

Physica1, 51, 153

Plantation, 712

Preventive, 123, 437, 475

Psychosomatic, 10

Research, 1019, 1088, 1119, 1422, 1556

Space, 15

Tropical, 178,344

Women in, 226, 1579 
Local societies and academies, $5,6,7,515,532,732,786$, $850,1197,1234,1251,1274$, $1282,1294,1295,1420$

National societies and academies, 39, 146, 224, 226, 319. 412, 1007

Regional societies and academies, 501, 503, 956, 1314, $1419,1481,1548,1550$

State societies and academies, 26, 379, 391, 481, 542, 568, 592, 661, 714, 745, 760, 762, $772,815,831,847,866,881$, $893-895,898,899,902-905$, 924, 939, 954, 964, 967, 1036, $1040,1041,1060,1082,1097$, $1121,1143,1173,1184,1216$, $1280,1396,1406,1436,1461$, $1467,1502,1509,1510,1521$, $1542,1579,1585$

See also Allergy; Anatomy; Anesthesiology; Arteriosclerosis; Blood; Cancer; Cardiology ; Cerebral palsy ; Cranium; Dentistry; Diabetes; Electroencephalography; Epideniology; Eugenics; Fractures (Bone); Gastroenterology ; Gastroscopy ; Genetics ; Geriatrics ; Goiters; Health and hygiene ; Hospitals ; Immunology ; Laryngology ; Mental health; Metabolism; Neoplastic diseases; Neurology ; Neuropathology; Nutrition ; Obstetrics and gynecology; Physics, Health; Proctology ; Psychiatry ; Psychosomatic medicine; Public health; Resuscitation ; Rhinology ; Surgery ; Therapeutics; Thyroid gland; Trauma; Ultrasonics; Urology; Venereal diseases; Veterinary medicine

Mehl award, 1327

Meisinger award, 229

Mellon (Richard Beatty) award, 18

Melville prize medal, 325

Mental Deficiency, 111

Mental Diseases, 400

Mental Health, 11, 224, 556, 747

Mcntal Hospitals, 267

Mercer (George) award, 612

Merchon award, 95

Merrill (Helen A.) fund, 223
Metabolism, 1000

Mctal Progress, 291

Metallurgy, 206, 216, 907, 938

Metals, 167, 179, 291

Metals Branch, American Institute of Mining, Metallurgical and Petroleum Engineers, 907

Metals Engineering listitute (Home Study Division), 291

Mctals Handbook, 291

Mctals Revicze, 291

Metcorological Abstracts and Bibliography, 229

Meteorological Monographs, 229

Meteorology, 186, 229, 758, 1098

Meteors, 228, 908

Meters And Metering, 1415

Methods and Standards for Production of Certified Milk, 89

Metric Systems, 1589

Metropolitan Detroit Science Fair, 623

Metropolitan IVashington Professional Engineer, 603

Meyer medal, 183

Meyers (Ernest) award, 844

Michigan Archacologist, 914

Michigan Engineer, 916

Michigan Geological Society, 915

Michigan Professional Enginecr, 923

Microbiology, 41, 825, 1098

Microchemical Jourmal, 910

Microchemistry, 910

MiCROFILMS, 1009

Microscopy, 82, 230, 1103,

Electron, 615, 1112

Middlebrooks (Thomas A.) award, 310

Midwest Engineer, 1558

Military Engineer, 1344

Military Medicine, 425

MiLK, 89, 158

Miller (Samuel WVylie) medal, 360

Mills (Evelyn) scholarship, 380

Milwaukce Engineering, 645

Miner (Neil) award, 983

Miner (Roy Waldo) fund, 1098

Mineralogy, 99, 173, 479, 678, $874,912,915,936,937,1025$, $1235,1288,1353$

Mines ANd Mining, 206, 231, $750,938,1364,1533$

Mining Congress Journal, 231

Mining Engineering, 1364
Mining Engineering Journal, 206

Mining Transactions, 1364

Minnesota Enginecr, 635

Minnesota Journal of Science, 941

Minnesota Medicine, 1420, 1590

Minncsota Pharmacist, 947

Minnesota Public Health Conference, 944

Miskoff award, 669

Mississippi Valley Mcdical Journal, 956

Missouri Archacologist, 957

Missouri Engineer, 963

Missouri Medicine, 964

Missouri Pharmacist, 959

Missouri Psychologist, 960

Mitchell (A. Graeme) memorial, 522

Mitchell (S. Weir) award, 43

Modcrn Castings, 179

Modern Concepts of Cardiovascular Disease, 191

Modern Nutrition, 33

Modern Physics, 257

Modern Textile Magawinc, 62

Moffat medal, 219

Moisseiff award, 310

Mollusks, 723

Monographs of the Thomas Say Foundation, 647

Moore (Eliakim Hastings) fund, 223

Moreell medal, 1344

Morris (Agnes) award, 864

Morris animal foundation award, 56

Morrison (A. Cressy) awards, 1098

Morrison (Alexander F.) fou11dation, 442

Morrison award, 302

Morse (S. F. B.) medal, 184

Mosher award, 218

Mosquito Control, 233

Mosquito Neres, 233

Moss essay award, 56

Motion Pictures, 8, 309, 1365

Moulton (Angie IV.) award, 1061

Mountaineering, 55, 367

Muncie (Wendell) award, 877

Municipal Engineers Journal, 970

Murphy (Evelyn H.) fellowship, 367

Murray fund, 975

Museum Ncros, 91

Museum of Northern Arizona, 1154 
Museums, 13, 91, 1125

Mycologia, 971

Mycology, 406, 971, 1054

Myer (S. B., Jr.) award, 130

National Academy of Religion and Mental Health, 11

National Association of Bakery Sanitarians, 789

National Association of Chiropodists, 262

National Association of Clinical Laboratories, 69

National Board for Certification, dental laboratory technology, 980

National Capital Pharmacist, 600

National Conference on the Legal Environment of Medical Science, 1019

National Conference of Governmental Industrial Hygienists, 152

National Council of Geography Teachers, 993

National Eclectic Medical Quarterly, 997

National Engineer, 985

National Farm Chemurgic Council, 582

National Fire Underwriters scholarships, 197

National Formulary, 254

National Geographic Magasine, 1001

National Hcalth Forum, 1002

National Metal Congress and Exposition, 291

National Micro-Nezus, 1009

National Packaging and Handling Competition, 1370

National Safety Nezes, 339

National Science Fair, 1342

Natural History, 327, 822 , $853,1025,1298,1308,1366$, 1429,1559

Natural Resources, 20, 338, $561,572,703,758,817,1017$, 1024-1027, 1078, 1389, 1565

See also Fish and game; Forests and forestry; Grasslands ; Ornithology ; Soils ; Trees; Water; Waterways ; Wildlife

Nature Conservancy Neres, 1027

Nature Study, 234, 1429

Navigation, 787

Navigation, 787

Nealley fund, 975
Nebraska Mortar and Pestle, 1632

Nebraska State Medical Journal, 1036

Neoplastic Disease Registry, 1262

Neoplastic Diseases, 65

Nervous Diseases, 400

Neurological Surgery. See Surgery, Neurological

Neurology, 42, 43, 124, 235, 377 , $400,462,469,498-500,516$, 524, 560, 607, 765, 808, 922, $973,1095,1104,1149,1236$, 1468

Neurology, 43

Neuropathology, 92

Neurophysiology, 166

Neuropsychiatry, 765

New England award, 620

New England Journal of Medicine, 882

New England Journal of $O p$ tometry, S86, 1046

New England Professional Engineer, 888

New England Professional Engineer Magazine, 567

New Hampshire Society of Engineers, 1065

New Jersey Geography Newsletter, 1069

New Jersey Geography Teachers, 1069

New Jersey Health and Sanitary Association, 1073

Nez' Jersey Journal of Pharmacy, 1071

New Jersey Neuropsychiatric Association, 1070

Neze Jersey Psychologist, 1072

Neze Mexico Dental Journal, 1079

New Mexico Nurse, 1083

New Mexico Professional Engineer, 1091

Neze Physician, 1440

New York Medicine, 901

New York Professional Engineer, 1122

New York State Journal of Medicine, 903

Neze York State Pharmacist. 1227

New York State Psychologist, 1117

New York Waterways, 1123

Newberry (John Strong) fund, 1098

Newcomb award, 217
Newman medal, 1344

Neze's for Metal Working E.tecutives, 343

Neres of the Pacific, 364

Nichols (John Benjamin) award, 902

Nichols (Percy) award, 1364

Nichols (IVilliam H.) medal, 131

Nobel (Alfred) prize, 310, 1364, 1558

Norse Abatement, 196, 1010

Voise Abatement Digest, 1010

Noise Control, 14, 210

Non-Destructive Testing, 1327

Nondestructive Testing, 1327

Nordisk Insulinfond foundation, 163

Norfolk Botanical Garden, 1186

Norman medal, 310

Norris (James Flack) award, 131

North Carolina Medical Journal, 904

Vortheastern Logger, 1152

Northern California Science Curriculum Committee, 483

Vorthacest Medicine, 745

Northavest Scicnce, 1163

Northwest Structural Engineers Association Conference, 1438

Norton lectureship, 368

Nova medal, 108

Novak (Emil) tumor registry, 144,190

Noyes (Marcia C.) award, 897

Nuclear Data Sheets, 975

Nuclear Nezes, 236

Nuclear Science. See Science, Nuclear

Nuclear Science and Enginecring, 236

Nuclear Theory Index Cards, 975

Numeration, 604

Nursing, 237, 715, 773, 838, 1006,1083

Industrial, 86

Nursing Outlook, 1006

Nursing Rescarch, 1006

Nutrition, 33, 164, 207, 224, $303,435,670$

Animal, 109, 362

Nystrom (A. S.) fellowship, 409

Obstetrics And Gynecology, $94,144,190,495,734,1048$, 1142, 1199, 1324, 1391

Obstetrics and Gynecology, 144 
Occupational Therapy, 238

OCEANOGRAPHY, 186, 232, 321, 1098

Odontological Bulletin, 1165

Oersted medal, 101

Ohio Archacologist, 372

Ohio Indian Relic Collectors Society, 37?

Ohio Journal of Science, 1167

Ohio Pharmacist, 1174

Ohio Psychologist, 1170

Ohio State Medical Journal, 1173

Oils, Fats and WAxes, 239

Oklahoma Arthritis and Rheumatism Foundation, 1181

Oklahoma Professional Engineer, 1183

Oklahoma Society of Psychiatrists, Neurologists and Neurosurgeons, 1180

Olney medal, 107

Open Hearth Conference award, 907

Operating Data Monthly, 986

Operations Research, 1189

Operations Research, 1189

Opitinalnologr, 45, 121, 240. $329,401,859,906,1008,1049$, 1200. 1451,1496

Optics, 210, 1190

Optics and Spectroscopy, 1190

Optonietry, 46, 241, 832, 886 , 1046, 1084, 1217, 1534

Oral Surgery, Medicine. Patholoys, 47

ORDNANCE, 242

Ordnance, 242

Oregon Pharmacist, 1195

(JRNitifology, 9, 243,447, 579. 853, 989, 1025, 1028

ORthodontics. See Dentistry. Orthodontic

Orthopaedic Research and Education fund, 809

Orthupenic Surgery. Sce Surgery, Orthopedic

Orthopedics, 48, 140, 180, 244. $528,809,926,1554$

ORTIHOPSYCHIATRY, 245

Orthoptic Journal, 45

Orthoptics, 96

Orton lecture, 130

Osborne (Earl D.) fellowship, 38

Osborne (Thomas Burr) medal, 72

Osler (WVilliam) medal, 64

Osteopathic Hospital, 249
OsteopAtiry, 3, 97, 145, 246, $247,248,249,587,839,958$, $1077,1218,1540$

()TOLARYNGOLOGY, 45, 251, 329, $859,906,1050,1108,1200$, 1451,1496

() Tology, 218, 250

Oto-ophthal.mology, 965, 1200

() TORHINOLOGY, 251

Ott (Frances) award, 773

Outdoor America, 817

PMM - Journal of Applied Mathematics (translation of Russian journal), 325

Pacific Ocean Area, 208, 1206

PaCKaging and Handling, 1004,1370

Painton (Harry R.) award, 579

Palcontographica Americana, 1207

Paleontology, 9, 99, 173, 1025 , $1207,1208,1353,1384,1429$

Palladiun medal, 614

Pancoast (Henry K.) lecture, 1237

Pan-Pacific Entomologist, 1198

Parasitology, 330, 727

Parker (Harleston) medal, 460

PARKs, 209, 561, 917, 1017

Parks and Recreation, 110, 209

Parsons (Charles Lathrop) award, 131

Patilology, 98, 122, 289, 311, $517,531,566,711,805,887$, $1054,1105,1211,1474,1500$. 1575

Patterson (Austin M.) award, 131

Paul-Lewis Laboratories award, 131

Pavenents, 414

Peniatrics, 49, 252, 522, 662 , 735, 1051, 1147. 1164, 1249. 1328

Pediatrics, 49

Peele (Robert) award, 1364

Pendray (G. Edward) award, 279

Pcunsyliania Archacologist, 1329

Pennsylzania Dental Journal, 1213

Pennsyluania Forests, 1214

Pennsylzania Journal of Radiology, 1223

Pennsyliania Medical Journal, 1216

Pcunsylzania Optometrist, 1217

Pcmsylzania Pharmacist, 1219

Pennsyliania Professional Engineer, 1224
Penrose award, 1352

Penrose bequest, medal, 685

Penrose fund, 256

Pepsodent scholarship, 1032

Percolator, 510

Periodontology, 50

Perkin medal, 614, 1347

Personality, 755, 1330

Pesticines, 224, 411, 433

Peterson (William F.) fund, 786

Petroleun, 206, 253, 590, 795. 915, 1372

Petroleum Branch, American Institute of Mining, Metallurgical and Petroleum Engineers, Inc., 1372

Petrolecm Engineering. Sce Engineering, Petroleum

Petrolectm Geology. See Geology, Petroleum

Petroleum Research fund, 131

Petroleum Transactions, 1372

Petrology, 186, 936, 1225

Pfizer award, 731, 1255

Pfizer (Charles) \& Company animal husbandry award, 302

Pharmacological Reviezos, 292

Pharmacologist, 292

Pharmacopocia of the United States of America, 1491

Pharmacy and Pharmacology, 21, 63, 136, 224, 254, 292, $316,331,380,482,537,562$, 594, 600, 669, 694, 711, 746, $766,810,833,842,867,876$, $890,925,947,955,959,978$. 991, 1032, 1042, 1061, 1071, $1085,1132.1139,1174,1195$, $1219,1226,1227,1279,1402$, 1454, 1469, 1491, 1496, 1506, $1512,1522,1543,1570$

Education, 75, 156

History, 214

Pharmacy in History, 214

Philadelphia Medicine, 1234

Phillips (Henry M.) prize, 256

Phillips (John) award, 146

Pinlosopir $, 255,256,912,1239$. 1423

Philosophy of Science, 1240

Phipps and Bird fellowship, 432

Photogramuntric Engineering, 332

Photogrammetry, 332,429

Photographic Science and Engineering, 1373

Piiotography, 12, 394, 454, 1365. 1373

Pinycologi. 1242 
Physical Education, 60, 1379

Physical Review, 210, 257

Phisical Therapy, 51, 258

Physical Therapy Revicw, 258

Physicion and Public Health. 1216

Physics, 20, 63, 210, 257, 375. $527,684,692,758,763,802$, $825,975,1028,1167,1177$. $1191,1243-1245,1313,1452$, $1463,1493,1511$

Education, 101, 210

Health, 725

Medical, 224, 725

Nuclear, 1098

Physics of Fluids, 210

Physics Today, 210

Physiological Reviezes, 259

Physiologist, 259

Physiology, 259, 318, 711, 1246. 1358

Phytopathology. See Plant Pathology

Phytopathology, 260

Pi Tau Sigma medal award, 325

Picking Table, 678

Pierce (Benjamin H.) fund. 880

Pilots Safety Exchange Bulletin. 658

Pinchot (Gifford) medal, 1343

Pipe, 216

PlanniNg, 211, 333, 1558

Planning, 333

Plant Nétrition, 1560

Plant Pathology, 260, 1161

Plant Physiology, 334

Plant Physiology, 334

Plant Propagation, 1250

Plant Taxonomy, 335

Plantation Health, 712

Plastic Surgery. See Surgery, Plastic

Plastics, 325, 1374, 1381

Platean, 1154

Plating Magasine, 167

POA Monthly, 1217

Podiatry, 74, 262, 308

Poisons, 411

Polar Regions. See Arctic and Antarctic

Polar Times, 263

Political Science, 912, 1005

Pomology, 264, 290

Pope (Mary Soper) medal, 586

Population, 1252

Population Index, 1252

Porter fellowship, 259

Postgraduate Medicine, 800

Potato Handbook, 1254

Potatoes, 1254
Poteat award, 1129

Potts (John H.) award, 446

Poultry, 1255

Poultry Science, 1255

Powers medal, 99

Pregel (Boris) award, 1098

Prescott (Sanuel Cate) fellowship, 783

Prevention of Detcrioration Abstracts, 975

Priestley medal, 131

Prizes. See Medals and awards

Proctology, 265, 1011, 1176

Proctor (Charles Henry) award, 167

Proctor fund and prize, 1305

Proctor medal, 401

Professional Engineer, 81

Professional Engineers Conference Board for lndustry, 1021

Professional Gardener, 982

Professional Geographer. 409

Project Mohole, 232

Propulsion, 1275, 1595

Prosthetics, 4

Protozoology, 1375

Psychc, 488

Psychiatry, 11, 124, 189, 245. $267,268,377,390,400,403$, 404, 462, 468, 469, 472, 497. $498,499,500,524,534,560$, $595,605,607,663,695,716$. $751,765,796,808,827,843$, $861,877,883,922,929,942$. 951, 960, 973, 1031, 1038, $1055,1070,1095,1106,1115$, $1130,1131,1146,1149,1156$, $1157,1159,1169,1180,1188$, $1220,1264,1265,1281,1395$, $1416,1421,1441,1455,1464$, $1468,1518,1546,1551,1552$. 1571

Biological, 1346

Child, 35, 103

Clinical, 111

Psychical Research, 293

Psychoanalysis, 268, 396, 403, $781,1012,1594$

Psychoanalysis and Psychoanalytic Revicze, 1012

Psychological Abstracts, 269

Psychological Bulletin, 269

Psychological Monographs: General and Applied, 269

Psychological Revice, 269

Psychology, 11, 22, 63, 117, 129 , $269,387,473,486,538,569$. $596,601,609,664,692,696$, $717,752,758,763,767,794$,
$802,811,834,840,843,863$, 871, 912, 919, 934, 943, 975, $1012,1033,1062,1072,1086$, $1098,1117,1133,1170,1185$, $1192,1221,1335,1397,1423$, $1431,1456,1470,1498,1507$. $1511,1523,1535,1555,1572$ Applied, 911

Communication, 1256

Correctional, 76

Experimental, 1355

Individual, 774

Quantitative, 1258

Social, 1335

Psychometrics, 1258

Psychometrika, 1258

Psychopatilology, 270

Psychosomatic Medicine, 271

Psychosomatic Mcdicine, 271

Psychosomatics, 10

Psychot her.ipy, 189, 404

Pl'blic Henltil, 39, 196, 224, 272, 381, 435, 438, 539, 547. $549,552,556,665,697,743$, $753,812,835,864,884,920$, 944. 961, 1002, 1073, 1087, $1118,1134,1140,1222,1260$. $1262,1376,1398,1403,1417$. 1457, 1471, 1499, 1513, 1524, 1536

Cancer control, 1261

Dental, 104, 546

Laboratories, 1114

Veterinary, 550

Sec also Health and hygiene

Public IIealth Laboratory, 552

Public IVorks Guide, 585

Pulp And Paper, 1446

Purdy (Rose Coffin) award, 130

QST, 273

Quality Control, 294

Quarterly Journal of Speech, 1434

Quarterly Revicze of Biology, 198

Radiation, 196, 236, 274, 725

Radiation Rescarch, 1266

Radiations, 1313

Radio, 273, 788, 1267

RADIOGRAPHY, 345

Radiology, 147, 248, 274, 280. $308,345,382,392,443,518$, $589,666,706,741,754,768$, $813,836,845,848,856,872$, 935, 945, 952, 974, 1037, $1052,1063,1109,1141,1145$, $1153,1193,1204,1205,1223$, $1237,1266,1268-1272,1285$, 
1289, 1299, 1392, 1393, 1399 , $1404,1458,1472,1482,1503$, $1525,1537,1547,1573$

Radiology, 1271

RADIUM, 274

Railroads, 275, 276

Ralston Purina award, 1255

Ramsay (Erskine) medal, 206, 1364

Rand (Charles F.) medal, 206, 1364

Range and Pasture ManageMENT, 338

Rankin award, 1134

Ray (Isaac) award, 267

Raymond (Rossiter W.) award, 1364

Reaction Propulsion, 1275

Reactors, 236

Reagan (Albert R.) fund, 825

Recreation, 60, 209, 1379

Reed (Frank H.) memorial, 758

Reed (Sylvanus Albert) award, 790

Reed (Walter) award, 344

Reed (IValter) fund, 866

Reflector, 441

Refrigeration. See Engineering, Refrigerating

Refrigeration Service and Contracting, 1276

ReHabilitation，61，153，399, 1013

Rehabilitation Therapy Bulletin, 61

Rehmann scholarships, 197

Reilly (Marion) fund, 223

Reinartz (Leo F.) scholarship, 907

Religion, 11

Remsen lectureship award, 131

Reports of I ariable Star Observations, 108

RESEARCH, 430

Research Fundos. See Funds and Grants

Research Management, 780

Resoures and People, 1168

Resuscitation, 1014

Revere (Paul) award, 884

Review of Metal Literature, 291

Revicus of Modern Physics, 210

Review of Scientific Instruments, 210

Reynolds award, 1134

Reynolds (R. S.) award, 197

Rineology, 210, 1377

Rheology Bulletin, 1377

Rheunatism, 278, 1107, 1181

Rhinehart (D. A.) trophy, 392
Rhinology, 217, 218, 1108

Rhode Island Medical Journal 1280

Rhodora, 1045

Rice medal, 242

Richards award, 325, 1247

Richards (Ellen H.) fellowship, 193

Richards (Joseph IV.) lecture, 614

Richards (Robert H.) award, 206, 1364

Richards (Theodore William) medal, 131

Richart (Frank E.) award, 296

Richtmyer lecture, 101

Rickey medal, 310

Rietz lecture, 785

Rivers and Harbors, 1015

Roadside Dez'elopment, 975

Robb (Isabel Hampton) fund, 773

Roberts (Dorothea K.) fund, 114

Roberts (Lydia J.) award, 164

Robins (A. H.) award, 1139

Rochester Engineer, 1284

Rockets, 1492

Rockets And Rocket Propulslon, 112, 113, 279, 1492, 1593

Rocky Mountain Medical Journal, 542, 967, 1502, 1585

Rocbling medal, 936

Roland (Thomas) fund, 880

Roman (C. V.) medal, 821

Rose (Mary Swartz) fellowship, 164

Rossby (Carl-Gustaf) award, 229

Rotch scholarship, 460

Rowland (Thomas Fitch) prize, 310

RuBBer, 325

Rubber Chemistry and Technology, 131

Rubin award, 298

Rudner (Henry G., Sr.) award, 141

Rumford fund, 34

Rush (Benjamin) awards, 1216

Russell (Henry Norris) lectures, 114

Russell (Jolnn Lewis) fund, 880

Russian Studies, 912

Sabin (Florence R.) award, 539

Sabine (Wallace Clement) medal, 14

St. Louis Society of Neurology and Psychiatry, 607
Sanford-Sheard fund, 311

Sanitarian, 987

Sanitary Engineering. See Enginering, Sanitary

Sanitation, 789, 912, 987

Sarnoff (David) award, 1365

Sarton (George) medal, 731

Saunders (William Lawrence) medal, 206, 1364

Sauver (Albert) award, 291

Scaife (IValter B.) nature lectureship, 12

Scalpel, 30

Schering scholar, 617

Schindler (Rudolf) award, 182

Schlich (Sir William) medal, 1343

Schmidt (Louis) award, 454

Schoellkopf (Jacob F.) medal, 131

Scholarsimips. See Fellowships and scholarships

School Scicnee and Mathematics, 496

Schuman (Ida and Henry) prize, 731

Schwab (Charles M.) lecture, 216

Science, 12, 13, 20, 34, 63, 213, $512,540,558,616,654,677$, $679,682,692,719,742,758$, $763,802,825,840,860,874$, $912,941,949,966,975,1028$, $1058,1068,1075,1093,1098$, 1129. 1137, 1154, 1163, 1167, $1177,1191,1212,1239,1283$, $1301,1304,1305,1311,1382$, $1394,1401,1414,1452,1463$, $1493,1511,1517,1530,1531$, 1568

Abstracting and indexing, 998

Education, 20, 63, 87, 352, 383, 405, 483, 496, 563, 692, 698, $758,928,941,966,976,1016$ $1074,1167,1177,1263,1302$, $1303,1459,1511,1538$

History, 63, 692, 731, 763, 1028

Industrial, 63, 1413

International relations, 1331 , 1581

Literature, 988, 1380

Natural, 9, 586

Nuclear, 236

Personnel, 975

Philosophy, 63, 692, 1028, 1240

Physical, 256

Popularization, 1301

Social responsibility, 1333

Local academies of science, 12, 13. $512,1093,1283,1414$, 1517 
National academies of science, 34,975

Regional academy of science, 543

State acadenies of science, 20 , $375,388,476,543,558,659$, $692,719,742,758,763,802$, $825,840,860,874,912,941$, $949,966,1028,1058,1068$, $1075,1098,1129,1137,1167$, 1177, 1191, 1212, 1394, 1401, 1452, 1463, 1493, 1511, 1531, 1568

Science, 63

Science Clubs of America, 1301

Science Education, 976

Science Nere's Letter, 1301

Scicnee Teacher, 1016

Science Teachers Bulletin, 1302

Scientific Apparatus Makers award, 131

Scopc, 343

Scott medal, 242

Scripps (Ellen Browning) Foundation funds, 1587

Sea Scout ship, 637

Seaman (Louis Livingston) prize, 425

Sedgwick award, 272

Seed Technologist, 1349

SEEds, 427, 1349

Seisnology, 186, 819, 1307

Selden award, 841

Scrior Engincer, 431

Sewage, 653, 1144

Shale Shakcr, 1179

Shattuck fund, 882

Shattuck (Lemue1) award, 884

SHELLFISH, 1018

Sherwood (George Herbert) fund, 1098

Shewhart medal, 294

Shipley (Arthur D.) medal, 1428

Shore and Beach Magasine, 284

Shores and Beaches, 284

Siegel (Joseph A.) award, 343

Signal, 394

Silent Hoist and Crane Company, Wunsch Foundation award, 222

Singer (Oscar) award, 1071

Sinkula (Christina) award, 86

Slagle (Eleanor Clarke) lectureship, 238

Slide Rule, 739

Smith (Edgar Fahs) lecture, 131

Smith (Harold De Witt) award, 296
Smith-Holden scholarship, 1059

Smith (J. Lawrence) fund, 975

Smith (J. IValdo) fellowships, 310

Smith (Nathan L.) award, 875

Smith (Theobald) award, 63

SMOKE, 18

Snow (William Freeman) medal, 285

Snyder (Lillian K.) fund, 1230

SoARING, 1315

Soaring, 1315

Social Health Nerus, 285

Social Hygiene, 285

Social Issues, 1335

Social Science, 20, 63, 256, 758, 941, 966, 1177, 1463, 1493

Society for Projective Techniques and Rorschach Institue, Inc., 1330

Society for the Advancement of Criminology, 312

Society of Aircraft Materials and Process Engineers, 1595

Society of Correctional Psychologists, 76

Society of Environmental Engineers, 782

Society of Neurology and Psychiatry of Hawaii, 716

Society of Technical IVriters and Editors, 1380

Society of University Gynecologists, 1324

Sociology, 912, 1005, 1167

Soft Drinks, 1378

Solls, 176, 453, 763, 1078, 13881390,1560

Sokel (Manfred) award, 1346

Solar EnERgy, 397

Solar Energy: The Journal of Solar Energy Science and Enginecring, 397

Sollmann (Torald) award, 292

Soupçon, 1448

South Carolina Engineer, 1400

South Dakota Journal of Medicine and Pharmacy, 1402, 1406

South Dakota Medical School Endowment Association, 1406

Southard (Juliette A.) award, 159

Southcastern Drug Journal, 1226

Southern Chemist award, 131

Southern Indian Studics, 371

Southern Medical Journal, 1419

Southern Scientific Supply Company award, 432
Southwestern Lore, 533

Southwestern Naturalist, 1429

Sovict Astronomy-AJ, 210

Soviet Geography: Review and

Translation, 184

Soriet Mathematics - Doklady, 223

Sorict Physics-Acoustics, 210

Sozict Physics - Crystallography, 210

Sovict Physics-Doklady, 210

Sorict Physics-JETP, 210

Soviet Phy'sics-Salid State, 210

Sovict Physics - Technical Physics, 210

Sorict Physics - USPRKHI, 210

Space Flight. See Astronautics

Spafford fund, 1406

Spease (Whitney) award, 316

Special Libraries, 1597

SPECIFICATIONS, 296, 347, 574

Spectros copy, 530, 1319, 1561

SPeEch, 348, 1434

Speech Monagraphs, 1434

Spcech Teacher, 1434

SPELEology, 1022

Spencer (Charles F.) award, 131

Sperry (Lawrence) award, 790

Spirit of St. Louis meda1, 325

Sport Aviation, 651

Springer (Russell S.) award. 1345

Stain Technology, 456

Stains and Staining, 456

STANDARds, 296, 349, 1435

Standards Engincering, 1435

Standards Handbook, 1435

Star, 1312

Stars. See Astronomy

Statistics, 350, 613, 785, 1511

SteEl. See Iron and Steel

Steel Facts, 216

Steclicays, 216

Steinman (D. B.) award, 1098

Stengel (Alfred) award, 146

Sterility, 298

Stevens (J. C.) award, 310

Stickel (William J.) award, 262

Still (Andrew Taylor) medallion, 3

Stitt award, 425

Stoughton (Bradley) award, 291

Stratton (Henry and Lillian) award, 270

Stress Analysis, 1323

Strittmatter award, 1234

Strong (Richard Pearson) medal, 178 
Structural Engineers Society of New York, 1099

Student Medicine, 133

SugAR, 724

Sugar Beets, 341

Suiter (A. Walter) prize, 903

Sun at II ork, 397

Supervisory Engineers and Naval Architects Association, 984

Surgery, 5, 125, 148, 351, 463 $504,611,675,733,803,1056$, $1150,1166,1202,1210,1253$, $1277,1383,1411,1427,1428$, $1433,1562,1578$

Clinical, 1348, 1425

Dental, 324

Genito-urinary, 83, 529

Hand, 295

Maxillofacial, 324

Neurological, 42, 120, 557, 710 . $1039,1368,1468$

Orthopedic, 48, 415, 528, 1554

Osteopathic, 145

Pelvic, 1371

Plastic, 102, 336

Railway, 105, 705

Reconstructive, 336

Thoracic, 67

Traumatic, 66, 1292

Vascular, 1339

Surgery, Gynecology and $O b$ stetrics, 148

SURVEYING, 154, 575

Surveying and Mapping, 154

Sverdrup medal, 229

Sweet (J. E.) fund, 1449

Swift and Company animal husbandry award, 302

Symbolig Logic, 402

Symposium (International) on Combustion, 545

SyPIILOLOGY, 38, 1047, 1203

Systematic Zoology, 1596

Taft (Robert B.) trophy, 1399

Tappi, 1446

Taxonomic Index, 335

TAxonomy, 763

Plant, 335

Taylor (Augustus C.) trophy, 600

Taylor (Daniel WV.) medal, 1367

Taylor (Lewis Harvie) lectureship, 353

Tech Topics, 544

Technical Book Rcview Index, 1597

Technical Publishing Society, 1380
Technical Writing and EditING, 1380

Technician, 1447

TECH NOLOGY, 544, 571, 1023, $1196,1304,1447-1450$

Education, 352

Medical, 143, 225, 277, 326, $840,1035,1544$

Technometrics, 350

Tectonophysics, 186

TELEVISION, 1365

Templin (Richard L.) award, 296

Tennessee Archacologist, 1453

Tennessee Pharmacist, 1454

Territorial Association of Plantation Physicians, 712

Testing Methods, 296, 1327

Teras Journal of Science, 1463

Texas Pharmacy, 1469

Texas Professional Engincer. 1475

Texas State Mcdical Journal. 1467

Textile Chemistry. See Chenlistry, Textile

Textile Engineering. See Engineering, Textile

Textile Research Journal, 1476

Textiles, 62, 107, 1476

Thayer fund, 869

Theory of Probability and its Application, 1325

THERAPEUTICS, 353

Things of Scicnce, 1301

Thiokol Chemical Corporation Graduate award, 279

Thompson (Browder J.) prize, 788

Thompson (Mary Clark) fund, 975

Thompson (Sam E.) fund, 1467

Thompson (Sanford E.) award, 296

Thompson ( Willard O.) award, 187

THoRAx, 67, 354, 891

Thurlow navigation award, 787

TiIYROID GLAND, 188

Tillyer (Edgar D.) medal, 1190

Timoshenko medal, 325

Tissue Culature, 1477

Today, 72

Tool Engineer, 343

Totcm Pole, 2

Tour (Sam) award, 296

Tower (Ralph Winfred) fund, 1098

Toxicology, 196, 224, 775

TRAFFIC, 791, 1558
Traffic Engineering, 791

Transfusion, 70

Transit, 511

Translations, 355

Transplantation Bulletin, 336

TRAUMA, 66

Tree Grozers' Council bulletin. 1168

Tree Ring Bulletin, 1480

Tree-Rings, 1480

Trees, 1017

Trends, 1370

Trenery medal, 248

Trillia, 466

Tri-State Medical Joumal, 1481

Tropical Medicine and Iygicne Nezus, 344

Trustce, 195

Tuberculology, 54

Tuberculosis, 54, 354, 891, 948, 1136,1238

Tulsa Engincer, 641

Tuntland (Paul E.) award, 1315

TURBINES, 325

Turner (Francis Mills) award, 614

Turner (Henry C.) medal, 151

Tuttle (Arnold D.) award, 15

UltRASONICS, 215

Underwater Acoustics medal, 14

Upjohn scholar, 617

Uranium Prospcctor and American Outdoorsman, 1288

Urdang (George) medal, 214

Urner (Charles A.) fund, 853

UROLOGY, 83, 356, 520

Utah Archacology, 1505

Utah Engineer, 1501

Utah Enginecring and Sciences, 1494

Utah Medical Bulletin, 1502

VACUUMS, 357

Van Meter award, 188

Van Tyne (Josselyn) fund, 243

Vascular Flora of Ohio, 1167

Vaughan (Leonard H.) awards, 290

Vegetables, 290

Venemann (H. G.) fund, 986

Veneral Disease, 285, 1588

Vermont Engineering, 1508

Veterinary Medicine, 56, 109, $119,149,358,419,550,551$, $816,981,1092,1545,1564$, 1580

Viking fund medal and prize, 100,1317

V'irginia Enginecr, 1515 
I irginia Gencral Practice Nezes, 1510

Tirginia Journal of Science, 1511

Firginia Medical Monthly, 904

I irginia Pharmacist, 1512

Vision service award, 832

Fital Notes on Medical Pcriodicals, 897

Vitamin Abstracts, 440

VITAMINS, 440

Voice, 1536

Volcanology, 186

Folta Revicze, 28

Volunteer Satellite Tracking Project, 1373

Von Neumann (John) lecture, 1325

Wadsworth (Elizabeth Downs) bequest, 880

iValcott (Charles Dolittle) fund, 975

VValker (William H.) award, 199

Walker (William J.) fund, 880

Wallin (Mathilda K.) fund, 1579

Ware (L. M.) award, 290

Warner (Helen B.) prize, 114

WVarner (Samuel L.) award. 1365

Warner (IVorcester Reed) medal, 325

Warren (Cyrus M.) fund, 34

Warren (Howard Crosby) medal, 1355

If ashington-Alaska Pharmacist, 1522

IV ashington award. 310, 1558

IV ashington (Commission of) award, 202

Wason medal, 151

W ATER, 176, 1144, 1389

IVater-based Aviation award, 790

II ater Pollution, 1527

Waterfowl research stations, 1565

IV ATERWAYS, 444, 1015, 1123

IV ATER WORKS, 359, 1057, 1066

IVatson (James Craig) fund, 975

Waxes. See Oils, Fats, and Waxes

Weather. Sec Meteorology

IV catherwisc, 229
Weber (Harry P.) fund, 786

WeEDS, 1528

II'ccds, 1528

Weight optimization award, 1341

Weights and Measures, 1589, 1591

Velch (Ernie) award, 1085

Welch (IVilliam H.) medal, 64

WeLĩI G, 360

II'clding Journal, 360

IV ellcome (Sir Henry) medal and prize, 425

Velles (Horace E.) essay, 1053

Wellington (Arthur M.) prize. 310

II cst lirginia Archacologist, 1532

II cst I irginia Dcutal Journal, 1541

IV'est I'irginia Medical Journal, 1542

II'est l'irginia Microscoop, 1544

II'cst I irginia Pharmacist, 1543

Western Biennial Conference on Anesthesiology, 1504

Westinghouse awards and scholarships, 1301

Westinghouse (George) award, 288

IV estinghouse (George) medal, 325

Wrestinghouse science talent searcl, 874,1129

Wheeler medal, 1344

Wherry lecture fund, 45

Whitcomb (Levi) fund, 880

White (Albert Easton) award. 291

White (C. B.) award, 864

White (George Robert) fund. 880

II litney (Eli) award, 343

Whitney (H. A. K.) lecture award, 316

Whittemore (James K.) fund. 223

IVho's II ho in Enginecring in the Delazeare Valley, 638

Wichita Society of Professional Engineers, 1563

IVild-Heerbrugg award, 154

Vilder (Marshall P.) fund, 880

IVilder (Marshall P.) medal, 264

Wilder (William Hamlin) lectureship, 786
IVILDLIFE, 150, 176, 989, 1024 $1027,1128,1564-1566$

Sce also Fish and game

IVildlife Monographs, 1566

Villiams medal, 242

IVilliams (Vincent Park) lecture, 818

IV illing II ater, 359

Villiston (Arthur L.) medal and award, 325

Wilson (Gordon) fund, 132

IIilson (John Arthur) lecture, 219

IVinchester fund, 1059

IVinheim award, 219

II isconsin Archeologist, 1569

II isconsin Mcdical Journal, 1436

ITisconsin Pharmacist, 1570

II isconsin Professional Enginecr, 1576

II ise Owl award. 61

IVoOD

Science and technology, 1387

Utilization, 325, 1152, 1446

Moodbury (Charles G.) award, 290

World Federation for Mental Health, 1320

II orld Medical Journal, 1581

II orld Mcdical Periodicals, 1581

IVrench (Jesse E.) fund, 957

Vright Brothers lecture, 790

IVright Brothers medal, 1345

IIyld (James H.) award, 279

X-Ray Technician, 345

X-RAys, 345

York Enginecr, 626

Joung Author's prize, 614

Jour Consultant, 416

Jour Muscum, 13

Four Radiologist, 147

Zoning Digest. 333

Zoologica, 1124

ZoOLOGY, 63, 110, 318, 346, 758, $763,802,825,912,941,966$, $1124,1167,1375,1452,1587$ Systematic, 1596

Sec also Animals; Fish and game; Helminthology ; Herpetology; Nutrition, Animal; Parisitology ; Veterinary medicine; Wildlife

Zworykin (Vladimir K.) award, 788 

CANADA 


\section{CANADA}

\section{INDEX}

The index includes a subject classification of the activities and purposes of the societies (subjects appearing in CAPITALS); a list of all periodicals mentioned (periodicals in italics); names of medals prizes, lectureships and trust funds; and changes in the names of societies since 1955 as reported in their histories.

\section{Actuarial Science, 57}

AERonautics, 53

Agricultural Economics, 54

Agricultural Engineering, 113

Agricultural institute rezicae, 3

Agrieultural pesticide technical socicty proccedings, 4

Agricultural Pesticines, 4

Agriculture, 3

See also Agrology: Animal production; Entomology ; Horticulture; Phytopathology ; Plant physiology : Plant protection; Soil science; and headings beginning Agricultural

Agrology, 8, 48, 159, 179, 187. 201, 218 (Provincial societies)

AgroNOMY, 114

Alberta association of architects nezesletter, 5

Alberta association of registered nurses nezesletter, 6

Alberta institute of agrologists nezesletter, 8

Alberta pharmaceutical Association quarterly bulletin, 10

Alberta professional engineer, 34

Alberta socicty of petroleum geologists journal. 13

Alberta socicty of petroleum geologists annual ficld conference guide book. 13

Allergy, 52

Allied arts medal, 210

Anaesthesiology, 55

AN.TOMY, 58

Animal Production, 115, 116

Annales de l'acfas, 20

Annual transactions of the canadian institute of mining and metallurgy, 81

Anthropological and sociological chapter, canadian political science association, bulletin. 16
Anthropology and Soctology, 16. 214

Architecture, 210

Provincial societies, 5, 17, 18, $155,177,184,215$

See also Community planning : Town planning

Arctic, 19

Arctic, 19

Association of canadian fire marshals procecdings. 26

Association of Nero Brunswick land surveyors report, 28

Astronautics, 45

Astronomy, 211

Avancement des Sciences, 20

BACTERIOLOGIE, 60

Bacteriology, Sec Nedical bacteriology

Baldwin (F. IV. "Casey") award, 53

Barlow memorial medal. 81

$B$. C. professional engincer, 35

Becton, Dickinson and Co. award, 118

Bibliotheques, 84

Biochemistry, 70

Local societies, 167, 197

Provincial societies, 21, 236

Вiосналіе, 21, 167

BioLog1E, 227

Brology, 76, 124, 214

Local societies, 197, 227

Sec also Agrology; Anatomy : Bacteriology ; Biochemistry: Biophysics ; Entomology ; Food technology ; Microbiology : Palaeontology: Physiology: Phytopathology ; Wildlife and fishery; also headings beginning Agricultural, Plant

Biophysics, 236

Blackader lectureship, 86

Blaylock (Selwyn G.) medal, 81
Pletcher memorial scholarship, 161

Boulanger (Francoise) memorial lectureship, 106

British Columbia dental association nezes bulletin, 47

British Columbia institute of agrologists neresletter, 48

British Columbia medical journal, 238

British Columbia veterinary association bulletin, 51

Bulletin canadien de mathématiques, 85

Bulletin de l'acfas, 20

Bulletin de l'association des biochimistes des hôpitaux $d u$ Québec, 21

Bulletin de l'association des psychologues de Québec, 25

Bulletin de la corporation des ingénieurs professioncls de Québec, 139

Bulletin de la société d'hygiène et de médecine préventive de la prozince de Québec, 229

Bulletin des infirmieres catholiques du Canada, 129

Bulletin of the academy of medicine, 1

Bulletin of the association of Polish engineers in Canada. 32

Bulletin of the catholic murses association of Canada, 129

Bulletin of the Maritime psychological association, 164

Bulletin of the psychological association of the province of Quebec, 25

Campbell prize, 220

Canadian aeronautical journal, 53

Canadian agricultural engineering, 113 
Canadian anaesthetists' socicty journal, 55

Canadian association for mineral sciences, 166

Canadian association of chiropodists, 104

Canadian association of medical record librarians bullctin, 61

Canadian association of pathologists nezesletter, 64

Canadian astronautical society, 45

Canadian council of professional engineers new's bulletin, 72

Canadian entomologist, 148

Canadian fedcration nea's, 76

Canadian federation of biological societies procecdings, 76

Canadian food technologist: association, 79

Canadian geographer, 59

Canadian geographical journal, 212

Canadian geographical society, 212

Canadian home economies association journal, 78

Canadian index to periodicals and documentary films, 84

Canadian institute of food technology nezsletter, 79

Canadian institute of surveying and photogrammetry, 8.3

Canadian journal of agricultural economics, 54

Canadian journal of animal science, 3

Canadian journal of biochemistry and physiology, 101

Canadian journal of chemical enginecring, 131

Canadian journal of genctics and cytology, 152

Canadian journal of mathematics, 85

Canadian joumal of medical technology, 118

Canadian journal of microbiology, 119

Canadian journal of occupational therapy, 62

Canadian journal of optometry. 63

Canadian journal of physics, 66

Canadian journal of plant science, 3

Canadian journal of psychology, 107

Canadian journal of public health, 108
Canadian journal of soil science, 3

Canadian journal of surgery, 86

Canadian laboratory supplies and Dade reagents award, 118

Canadian library association bulletin, 84

Canadian lumbermen's association prize, 145

Canadian mathematical bulletin. 85

Canadian medical association journal, 86

Canadian mineralogist, 166

Canadian mining and metallurgical bulletin, 81

Canadian nurse, 93

Canadian operational research socicty newsletter. 94

Canadian pharmaccutical jour$n a l, 100$

Canadian podiatry journal. 104

Canadian professional engineer. 72

Canadian psychiatric assaciation journal. 105

Canadian psychoanalytic reviea, 106

Canadian psychoanalytic society trust, 106

Canadian psychologist, 107

Canadian sanitarian, 82

Canadian socicty for clinical chemistry new'sleter, 112

Canadian socicty of agronomy procecdings, 114

Canadian society of animal production procecdings. 115

Canadian spectrograplice nea's, 56

Canadian surseyor. 83

Canadian textile journal, 69

Canadian z'cterinary journal, 127

Ceramics, 71

Chant medal, 211

Chanveau (Pierre) medal, 214

Chenical Industry, 232

Chemistry, 131, 214

Provincial society, 33

Sce also Biochemistry; Clinical chemistry; Textile chemistry; also headings beginning Chemical

Chemistry and industry, 232

Chemistry in Canada, 131

Chiropony, 46, 156, 216 (Provincial societies )

See also Podiatry

Clinical Chemistry, 112

Provincial society, 23
College des pharmaciens de la prozine de Québec report, 132

College of general practice of Canada bulletin, 134

Community Planning, 136

See also Architecture; Town planning

Community planning revica, 136

Computing and Data ProcessING, 137

Corporation of land surveyors of the provines of British $\mathrm{Co}$ lumbia report, 140

Corporation of professional cugineers of Quebec bulletin, 139

Corporation of Quebec land suricyors report, 141

Dita Processing. See Computing and data processing, 137

DENTISTRY, 73

Provincial societies, $7,47,133$, $143,158,171,175,178,186$

Derm.itology, 74

Dietetics, 75

Dominion council of professional engineers, 72

Duggan medal and prize, 145

Edmonton geological quarterly, 144

Electroradiologie, 226

Exgixeerixg, 32, 72, 145

Provincial societies, 34, 35, 36, $37,38,39,40,41,42,43,139$ Sec also Agricultural engineering: Marine engineering; Mining and metallurgy ; Petroleum geology; Sanitation: Surveying

Enginecring institute of Canada transactions, 145

Enginecring journal, 145

Entomological society of Ontario report. 150

Entomology, 148

Provincial societies, 2, 146, 147. $149,150,151$

Feliciter, 84

Fellowships and ScholarSHIPS

Agriculture, 3

Agrology, 8, 48, 179, 218

Architecture, 155, 177, 184, 210,215

Chiropody, 46

Dentistry, 7, 73, 133, 143 
Engineering, 34, 36, 38, 39, 41. 145

Geography, 212

Geology, 34

Library, 84

Medicine, 88, 188

Nursing, 6, 30, 170, 207, 209, 222

Orthopaedics, 96

Pathology, 12

Petroleum geology, 13

Pharmacy, 10, 132, 161, 199

Physiotherapy, 102

Podiatry, 190

Psychoanalysis, 106

Psychology, 49

Surveying, 29, 141

Thoracics, 125

Veterinary medicine, 196

Fire Prevention and ProtecTION, 26

Fisher scientific co. award, 118

Fishery. See Wildlife and fishery, 124

Flavelle medal, 214

Focal spot, 122

Fondation de la société canadienne de psychanalyse, 106

Food Technology, 79

Forestry, 80

Provincial society, 138

Forestry chronicle, 80

Gastro-Enterologie, 228

Gastro-Enterology, 228

General Practice, 134

Genetics, 152

Genetique, 152

Genie, 139

Genie Forestiere, 138

Géographe canadien, 59

GEOGRAPHIE, 59

GEOGRAPHy, 59, 212

See also Arctic; Mountaineering

Geology, 153, 214

Local society, 144

Provincial society, 217

See also Mineralogy; Mining and metallurgy; Mountaineering; Palaeontology; Petroleum geology

Gynaecology. See Obstetrics and gynaecology, 233

Gzowski medal, 145

Harrison prize, 214

HeArt, 77

Home Economics, 78

HoRTiculture, 239

See also Agriculture
Hospital pharmacist, 117

Hospital Pharmacy, 117

See also Pharmacology; Pharmacy

Huskins memorial lecture, 152

Hygiene and Preventive MediCINE, 229

Sce also Public health

Hygiene et Medecine PrevenTIVE, 229

Information vétérinaire, 135

International nickel company of Canada medal, 81

Jane (R. S.) memorial lecture, 131

Journal canadien de mathématiques, 85

Joumal of the canadian association of radiologists, 67

Journal of the canadian ceramic socicty, 71

Journal of the canadian dental association, 73

Journal of the canadian dietetic association, 75

Journal of the canadian physiotherapy association, 102

Journal of the Ontario dental association, 186

Journal of the royal architectural institute of Canada, 210

Journal of the royal astronomical society of Canada, 211

Journal of the socicty of chemical industry, 232

Kennedy (Sir John) medal, 145

Laboratory Physicians, 23

Laboratory Technology, 118

Land Surveyors. See Surveying

LECTURESHIPS

Dietetics, 75 ,

Genetics, 152

Physics, 66

Respiratory diseases, 125

Leonard medal, 145

LIBRARY, 84

See also Medical Records

Link award, 13

Lister lectureship, 86

Manitoba institute of agrologists newusletter, 159

Manitoba medical review, 160

Manitoba professional engineer, 38
Marine Engineering, 169

Martin (Robert) prize, 220

Massey medal, 212

Mathematics, 85, 214

See also Actuarial science; Computing and data processing

McCurdy award, 53

McDougal (Dr.) memorial scholarship, 161

McLaughlin (R. S.) - Gallie (IV. E.) visiting professorship, 213

Mead Johnson educational awards, 98

Médaille Archambault, 20

Médaille Léo-Pariseau, 20

Medals and Prizes

Aeronautics, 53

Agrology, 8, 218

Architecture, 18, 155, 184, 210

Astronomy, 211

Clemistry, 131, 232

Dentistry, 7, 171, 178

Dermatology, 74

Engineering, 34, 35, 37, 41, 145

Entomology, 146, 147

Forestry, 80

Geography, 59

Geology, 217

Horticulture, 239

Mathematics, 85

Medicine 160, 213

Mining and metallurgy, 81

Obstetrics and gynaecology, 233

Occupational therapy, 194

Petroleum geology, 13

Pharmacy, 10, 100, 132, 161, 202, 220

Physics, 66

Psychology, 25

Radiology, 67, 122

Science, 20, 183, 204

Surveying, 141, 219

Textile chemistry, 68, 234

Town planning, 237

Medecine Preventive, 229

Medical Bacteriology, 60

Medical Records, 61

Medicine, 22, 86, 142, 213

Local societies, 1, 231, 238

Provincial societies, 23, 87, 88, $89,90,91,160,165,172,176$, 188

See also Allergy, Anaesthesiology; Anatomy; Dermatology; Gastroenterology ; General practice; Gynaecology; Heart; Hygiene and preventive medicine; Labor- 
atory physicians: Medical bacteriology; Neurology ; Obstetrics and gynaecology ; Ophthalmology ; Orthopaedics; Osteopathy ; Paediatrics; Pathology; Physical medicine and rehabilitation; Pliysiology; Plastic surgery; Preventive medicine; Psychiatry ; Public health; Radiology; Rheumatism; Thoracics; Urology.

Metallurgy. See Mining and metallurgy, 81

Microbiologie, 230

Microbiology, 119

Provincial society, 230

Miller (Willet G.) nedal, 214

Mineralogy, 166

Mining and Metallurgy, 81

See also Geology; Mineralogy; Welding

Montreal medal, 131

Mountaineering, 15

National association of marine enginecrs of Canada news. 169

Neurology, 92

Nerufoundland medical association newsletter, 176

Newfoundland surveyor, 29

News bulletin of the New Brunswick association of registered nurses, 170

Nova Scotia dental association newsletter, 178

Nova Scatia medical bulletin, 165

Nova Scotian institute of science proceedings, 183

Nova Scatian surveyar, 44

Nucleus, 157

Nursing, 93, 129 ,

Provincial societies, 6, 30, 157, $170,207,208,209,222$

Obstetrics and Gynaecology, 233

Occupational Therapy, 62

Provincial societies, 11,50 , 181,194

Ontario association of chiropodists, 190

Ontaria land surveyor, 31

Ontario medical revieze, 188

Ontario neuro-psychiatric association, 191

Ontario psychological association quarterly, 192
Ontaris society of radiographers, 195

Ontario society of radiological technicians bulletin, 195

Operational Research, 94

Ophthalirologie, 95

Ophthalmology, 95

OPTOMETRY, 63

Ortho pharmaceutical award, 118

OrthopaEdics, 96

OrThopedie, 96

Osler dinner and lecture, 238

Osler lectureship, 86

Osteopatнy, 97

Provincial societies, 189, 223

Paediatrics, 98

Palaeontology, 99

Patent and trademark institute of Canada bulletin, 198

Patent and trademark institute of Canada proceedings, 198

Patents And Trademarks, 198

Patent institute of Canada, 198

Pathologie, 23

Pathology, 64

Provincial societies, 12, 23, 185,224

Pearson (John Mawer) lectureship, 238

Pediatrie, 98

Petroleun Geology, 13

Pharmacentical association of the proince of British Columbia bulletin, 199

Pharmacie, 132

Pharmacologie, 200

Pharmacology, 200

See also Pharmacy, Hospital pharmacy

Pharmacy, 100

Provincial societies, 10,132 , $161,173,180,199,202,220$

See also Hospital pharmacy, pharmacology

Physical Medicine and ReHABILITATION, 65

Physics, 66, 214

Physics in Canada, 66

Physiology, 101

Local society, 168

Physiotherapy, 102

Phytopathology, 103

Pierce (Lorne) medal, 214

Plan, 237

Plant Physiology, 120

Plant Protection, 206

Plastic Surgery, 121

Plummer medal, 145

Podiatrie, 24
Podiatri, 104

Provincial societies, 24, 190

Sce also Chiropody

Preventive Medicine

See Hygiene and preventive medicine, 229

Prince of good fellows degree, 238

Prizes. See Medals and prizes

Proceedings of the canadian phytopathological society, 103

Proceedings of the entomological society of Alberta, 146

Proceedings of the cntomological saciety of British Calumbia, 147

Proceedings of the entomolagical society of Manitoba, 149

Procedings of the geological association of Canada, 153

Professional engineer (Nova Scotia), 40

Professional engineer (Ontario), 41

Professional public service, 204

Protection des Plantes, 206

Psychanalyse, 106

Psychiatrie, 225

Psycinitry, 105, 225

Provincial society, 191

See also Psychoanalysis; Psychology

Psychoanalysis, 106

See also Psychiatry: Psychology

Psychological newsletter, 205

Psychologie, 25

Psychology, 107

Provincial societies, 25, 49. $164,192,205,221$

See also Psychiatry, Psychoanalysis

Public Health, 108

Provincial societies, 109, 110. $162,193,229$

Public Service, 204

Quebec society for the protection of plants report, 206

RAdiology, 67, 122, 226

Provincial society, 195

Registered nurses' association of British Columbia news bulletin, 207

Registered nurses' associatian of Nova Scotia newsletter, 208

Registered nurses' association of Ontario nea's bulletin, 209 
Rehabilitition. See Physical medicine and rehabilitation, 65

Revne canadicune de biologic, 227

Rerue canadionns de prychanalyse, 106

RheUMATISM, 111

RHuMATOLOG1E, 111

Ross medal, 145

Royal astronomical society of Canada obscraer's handbook, 211

Royal college of physicians and surgeons register of fellow's. 213

Royal socicty of Canada tronsactions, 214

Rutherford memorial prize, 13

Ryan (John T.) trophies, 81

Ryley (Violet)-Jeffs (Kathleen) foundation, 75

Sanitation, 82

Saskatcherean medical quarterly. 91

Saskatchezan psychologist, 221

Saskatchewan registered nurses' association neas bulletin, 222
Scholarships. See Fellowships and scholarships

SCIENCE, 20, 183

Sciences, 20

Silver rope award, 15

Smith (Julian C.) medal, 145

Société de Québec pour la protection des plantes report. 206

Sociology. See Anthropology and sociology

Soll Science, 123

Space Flight, See Astronautics, 45

Spectroscopy, 56

Starr (F.N.G.) medal, 86

Statistical report of fire losses in Canada, 26

Studia raria, 214

Surveying, 83

Provincial societies, 9, 27, 28 . $29,31,44,140,141,219$

Textile Chenistry, 68, 69

Textile Science, 154, 234, 235

THORAcics, 125

Tory (Henry Marshall) medal, 214

Town Planning, 237

See also Architecture: Community planning
Tozon planning institute of Canada nezes, 237

Tranemarks. Sec Patents and trademarks, 198

Transactions of the canadian opthalmological socicty, 95

Turnbull ( $\mathrm{I}$. Rupert) lecture, 53

Tyrrell medal, 214

U'nion médicale du Canada, 22

UROLOGY, 126

Veterinary association of Manitoba, 163

Veterinary Medicine, 127

Provincial societies, 14, 51, $135,163,174,182,196,203$

Regional society, 130

Warner-Chilcott lectureship, 112

IVELDING, 128

Sce also Mining and Metallurgy

II cstcrn canadian socicty for horticulture procecdings, 239

Whattam award, 69

WILdLIFE AND FisHeRY, 124

Wroods (Dean E. L.) memorial prize, 199 







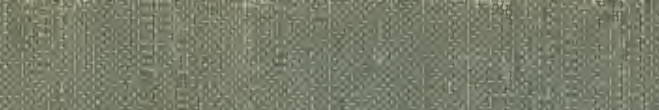

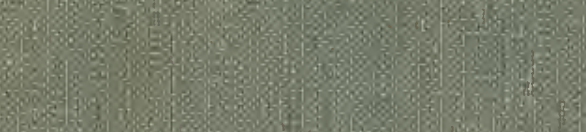
S.

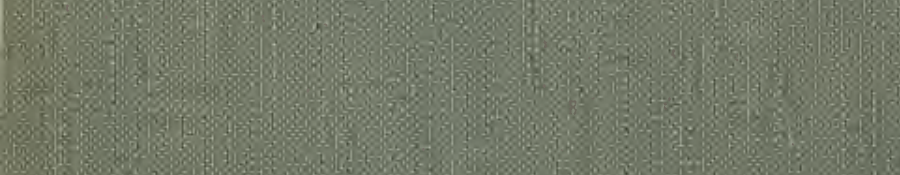

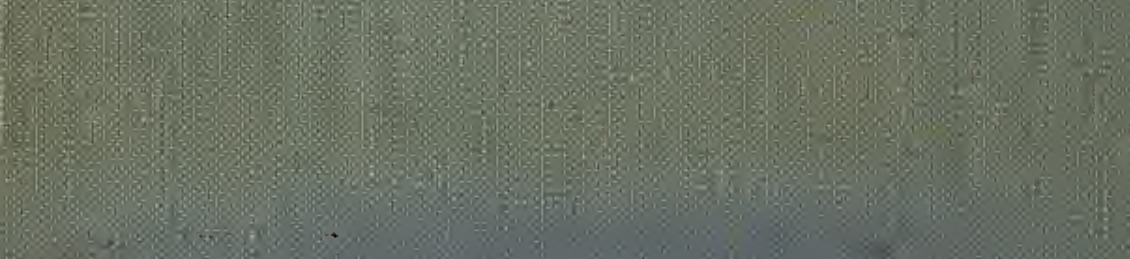

